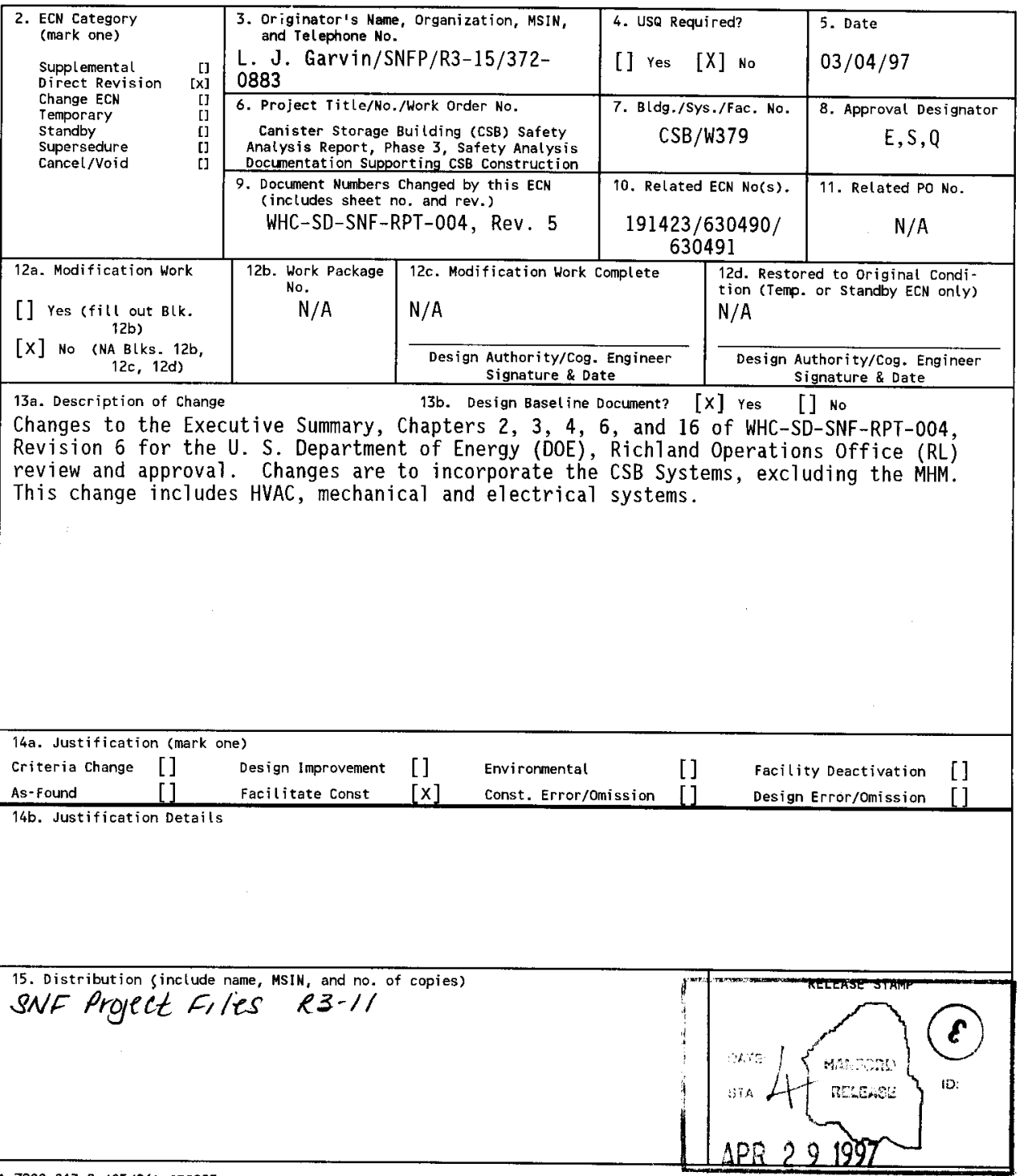




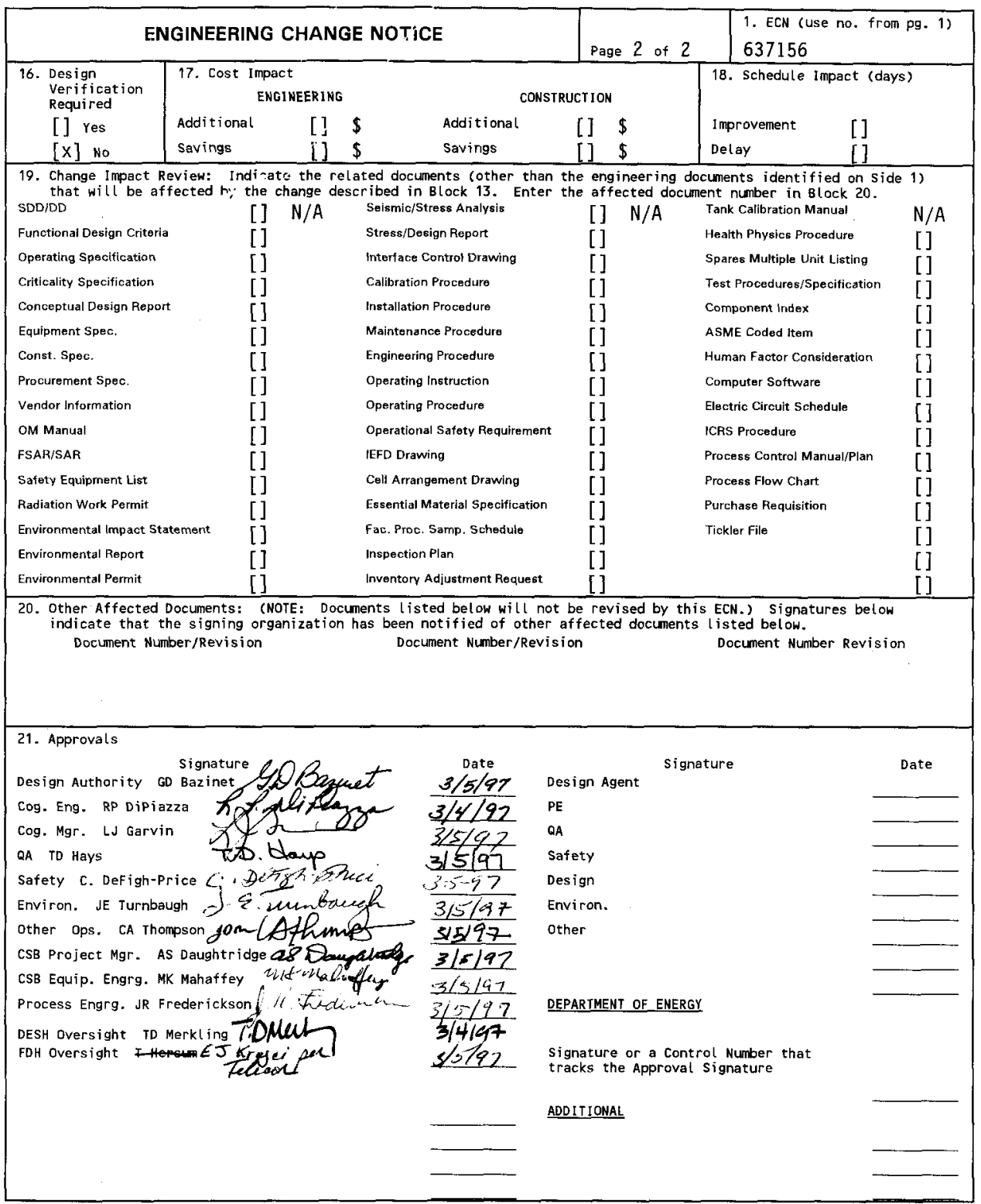




\title{
Canister Storage Building (CSB) Safety Analysis Report Phase 3: Safety Analysis Documentation Supporting CSB Construction
}

L. J. Garvin

Fluor Daniel Hanford, Richland, WA 99352

U.S. Department of Energy Contract DE-AC06-96RL13200

\author{
EDT/ECN: 637156 \\ Org Code: 2D000 \\ B\&R Code: EW31354 \\ UC: 620 \\ Charge Code: LG070 \\ Total Pages: 614702 kme $4 / 4+47$
}

Key Words: Phase 3 Safety Analys is Report (SAR), Canister Storage Building (CSB) Construction

Abstract: The purpose of this report is to provide an evaluation of the CSB design criteria, the design's compliance with the applicable criteria, and the basis for authorization to proceed with construction of the CSB.

TRADEMARK DISCLAIMER. Reference here in to any specific comercial product, process, or service by trade name, trademark, manufacturer, or otherwise, does not necessarily constitute or imply its endorsement, recomendation, or favoring by the United States Goverment or any agency thereof or its contractors or subcontractors.

Printed in the United States of America. To obtain copies of this document, contact: Document Control Services, P.0. Box 950, Mailstop H6-08, Richland WA 99352, Phone (509) 372-2420; Fax (509) 376-4989.
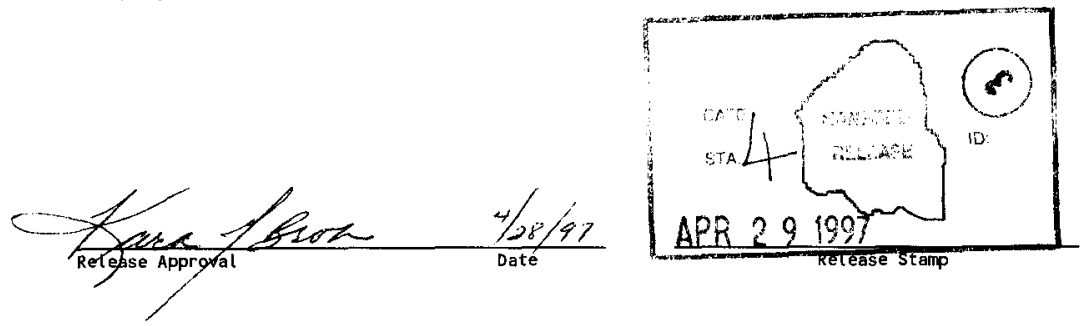

Approved for Public Release 
(2) Title

Canister Storage Building Safety Analysis Report, Phase 3, Safety Analysis

Documentation Supporting CSB Construction

CHANGE CONTROL RECORD

\begin{tabular}{|c|c|c|c|}
\hline \multirow{2}{*}{$\mathrm{R}^{\text {Revision }}$} & \multirow{2}{*}{ (4) Description of Change - Replace, Add, and Delete Psges } & \multicolumn{2}{|c|}{ Authorized for Release } \\
\hline & & (5) Cog. Engr. & (6) Cog. MgrDate \\
\hline 6 RS & $\begin{array}{l}\text { (7) Changes to the Executive Summary, } \\
\text { Chapters } 2,3,4,6 \text {, and } 16 \text { of WHC-SD- } \\
\text { SNF-RPT-004, Revision } 6 \text { for the U. S. } \\
\text { Department of Energy (DOE), Richland } \\
\text { Operations office (RL) review and } \\
\text { approval. Changes are to incorporate } \\
\text { the CSB Systems, excluding the MHM. } \\
\text { This change included HVAC, mechanical } \\
\text { and electrical systems. EOW- } 637 / 56\end{array}$ & $\begin{array}{l}\text { R. P. Dipiazza } \\
\text { PPaliogras }\end{array}$ & LIIJ Garvin \\
\hline & & & \\
\hline & & & \\
\hline & & & \\
\hline & & & \\
\hline & & & \\
\hline & & & \\
\hline & & & \\
\hline & & & \\
\hline & & & \\
\hline & & & \\
\hline & & & \\
\hline & & & \\
\hline & & & \\
\hline & & & \\
\hline & & & \\
\hline & & & \\
\hline & & & \\
\hline & & & \\
\hline & & & \\
\hline & & & \\
\hline & & & \\
\hline & & & \\
\hline & & & \\
\hline & & & \\
\hline & & & \\
\hline & & & \\
\hline & & & \\
\hline
\end{tabular}


CANISTER STORAGE BUILDIMG SAFETY ANALYSIS REPORT - PHASE 3: SAFETY ANALYSIS DOCUNENTATION SUPPORTING CANISTER STORAGE BUILDING CONSTRUCTION

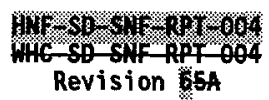

Mrow 199

December 1996 
HNF-SD-SNF-RPT-004 REV 6

This page intentionally left blank. 
HNF-SD-SNF-RPT-004 REV 6

\section{EXECUTIVE SUMMARY}

The U.S. Department of Energy established the K Basins Spent Nuclear Fuel Project to address safety and environmenta] concerns associated with deteriorating spent nuclear fuel presently stored under water in the Hanford Site's K Basins, which are located near the Columbia River. Recommendations for a series of aggressive projects to construct and operate systems and facilities to manage the safe removal of $K$ Basins fuel were made in WHC-EP-0830, Hanford Spent Nuclear Fuel Recommended Path Forward, ${ }^{1}$ and its subsequent update, WHC-SD-SNF-SP-005, Hanford Spent Nuclear Fuel Project Integrated Process Strategy for $K$ Basins Fuel. ${ }^{2}$ The integrated process strategy recommendations include the following process steps:

- Fuel preparation activities at the $K$ Basins, including removing the fuel elements from their $K$ Basin canisters, separating fuel particulate from fuel elements and fuel fragments greater than $0.6 \mathrm{~cm}(0.25 \mathrm{in.})$ in any dimension, removing excess sludge from the fuel and fuel fragments by means of flushing, as necessary, and packaging the fuel into multicanister overpacks (1) (6)

- Removal of free water by draining and vacuum drying at a cold vacuum drying foc

- Dry shipment of fue] from the Cold Vacuum Drying. rad IIII System to the Canister Storage Building (CSB), a new facility in the 200 East Area of the Hanford Site

\footnotetext{
${ }^{1}$ Fulton, J. C., 1994, Hanford Spent Nuclear Fuel Recommended Path Forward, WHC-EP-0830, Rev. 0, Westinghouse Hanford Company, Rich1 and, Washington.

${ }^{2}$ WHC, 1995, Hanford Spent Nuclear Fuel Project Integrated Process Strategy for $K$ Basins Fue 7, WHC-SD-SNF-SP-005, Rev. 0, Westinghouse Hanford Company, Richland, Washington.
} 
- Temporary staging in the CSB of MCOS-mticanister overpacks containing partially dried fuel

- Removal of the remaining absorbed water from the Mcos-mulicanister at a conditioning facility

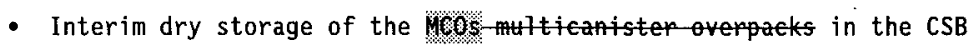
until a suitable long-term repository is established.

The purpose of this report is to provide an evaluation of the CSB design criteria, the design's compliance with the applicable criteria, and the basis

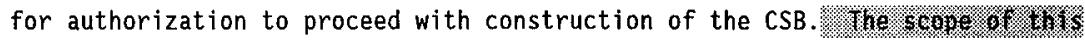

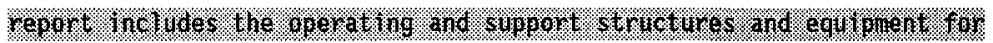

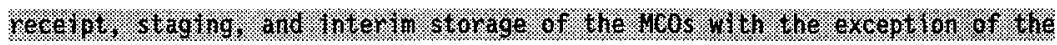

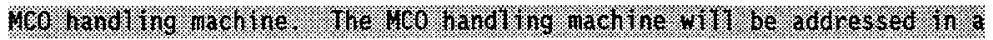

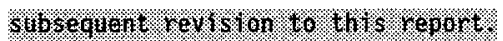

Figures ES-1 and ES-2 show the CSB vault, operating deck, superstructure, and support building. This report is based on the format of DOE-STD-3009-94, Preparation Guide for U.S. Department of Energy Nonreactor Nuclear Facility Safety Analysis Reports. ${ }^{3}$ The report includes those sections of DOE-STD-3009-94 that are applicable to the CSB based on agreement between the U.S. Department of Energy, Richland Operations Office, and Westinghouse Hanford Company, the former maintenance and operations contractor. The information provided is based on the CSB design information currently available. The information includes the identification of project requirements and criteria as applicable to the subject chapter, a summary of reference information available that documents compliance or the intent to

${ }^{3}$ DOE-STD-3009-94, 1994, Preparation Guide for U.S. Department of Energy Nonreactor Nuclear Facility Safety Analysis Reports, U.S. Department of Energy, Washington, D.C. 
HNF-SD-SNF-RPT-004 REV 6

Figure ES-1. Cutaway View of the Canister Storage Building.

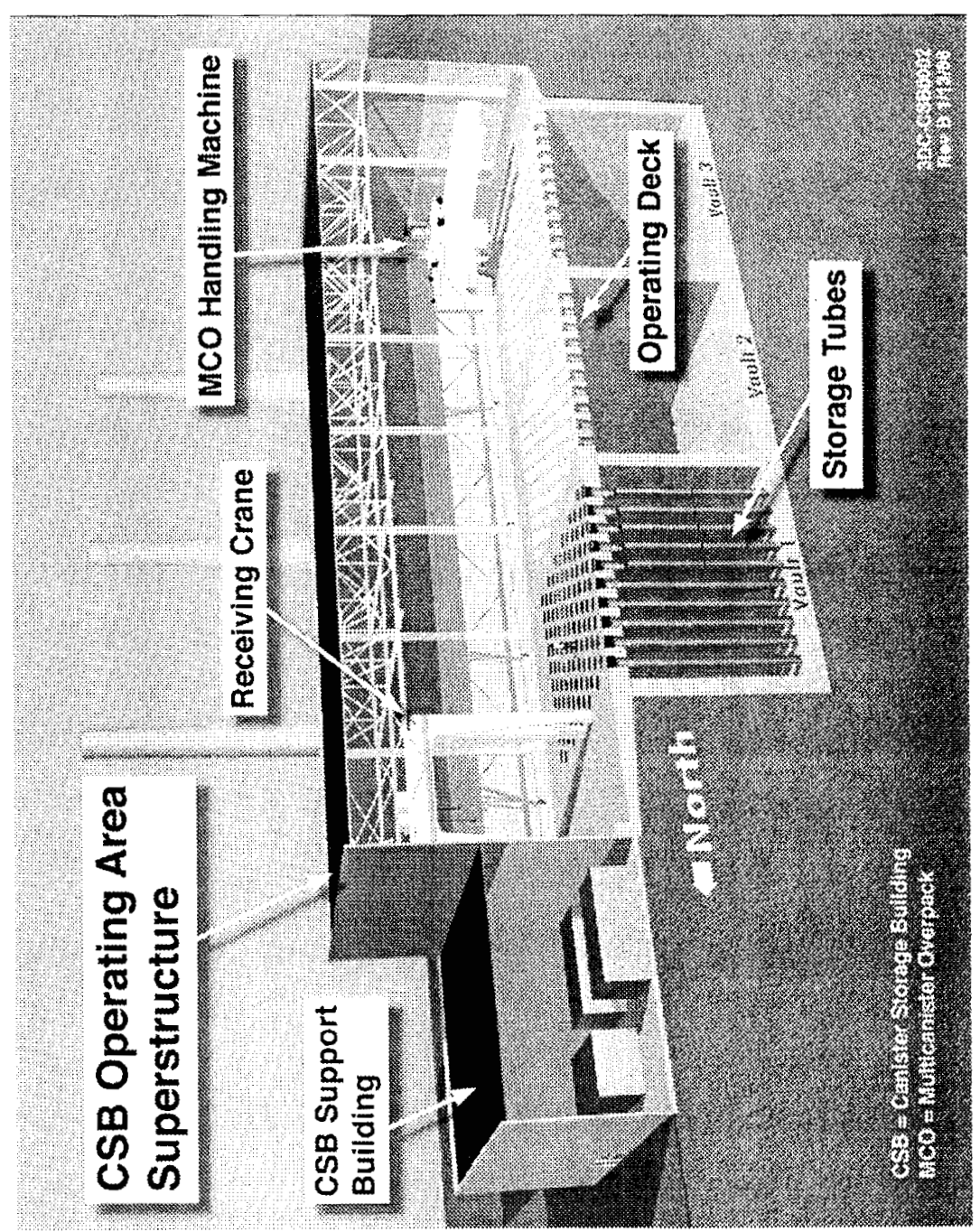


Figure ES-2. Cross Section of the Canister Storage Building through Vault 1 .

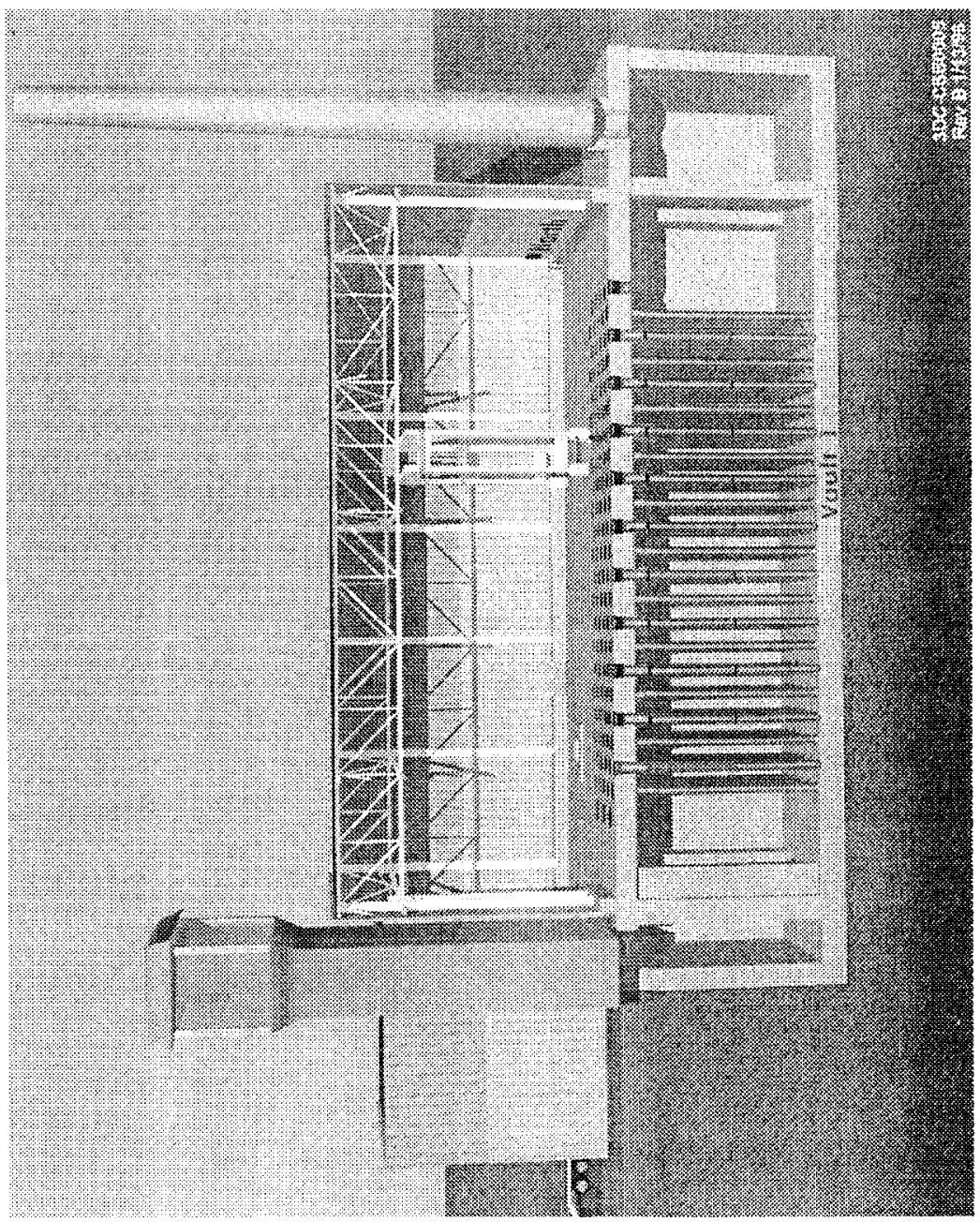


HNF-SD-SNF-RPT-004 REV 6

This page intentionally left blank. 


\section{CONTENTS}

1.0 SITE CHARACTERISTICS ................. 1- .

1.1 INTRODUCTION ................... 1-1

1.2 REQUIREMENTS ................. . . . . . . .

1.2.1 U.S. Department of Energy Orders and Standards ... 1-1

1.2.2 U.S. Nuclear Regulatory Commission Rules and

1.2.3 Guidance consensus standards and other . . . . 1-2 Documentation .............. 1-2

1.3 SITE DESCRIPTION .................. . . . . . . .

1.3 .1 Geography . . . . . . . . . . . . . . 1-3

1.3 .2 Demography ............... . 1-8

1.4 ENVIRONMENTAL DESCRIPTION ................ . . . . . . . .

1.4.1 Meteorology ............... . . 1-10

1.4 .2 Hydrology. . . . . . . . . . . . 1-31

1.4 .3 Geology . . . . . . . . . . . . . . . 1-41

1.5 NATURAL PHENOMENA THREATS $\ldots \ldots \ldots . . \ldots 1-62$

1.6 EXTERNAL HUMAN-GENERATED THREATS $\ldots \ldots \ldots \ldots . \ldots . \ldots 1-62$

1.6.1 Aircraft Activity . . . . . . . . . . . . . 1-62

1.6.2 0ther Transportation Accidents . . . . . . 1-69

1.7 NEARBY FACILITIES ................... 1- . . . . . .

1.7.1 Potential Effects from Nearby Facilities . . . . . 1-72

1.7.2 Potential Effects to Nearby Facilities . . . . . . 1-79

1.8 VALIDITY OF EXISTING ENVIRONMENTAL ANALYSES ........ $\ldots$

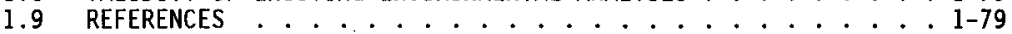

2.0 FACILITY DESCRIPTION .................. . . . .

2.1 INTRODUCTION ...................... 2-1

2.2 REQUIREMENTS $\ldots \ldots \ldots 2_{2-1}$

2.2.1 U.S. Department of Energy Orders and Standards . . 2-1

2.2.2 U.S. Nuclear Regulatory Commission Rules and

Regulations ............... 2-2

2.2.3 Industry Consensus Standards and Other

Documentation .............. 2-3

2.2.4 Contractor Requirements . . . . . . . 2-5

2.3 FACILITY OVERVIEW .............. 2-6

2.3.1 Facility Description . . . . . . . . . 2-6

2.3.2 Site Grading and Storm Drains........ 2-10

2.3.3 Facility Modifications to Hanford Waste

Vitrification Plant Canister Storage Building . . 2-11

2.4 FACILITY STRUCTURE . . . . . . . . . . . 2-15

2.4.1 Below-Grade Reinforced Concrete Structures . . . . 2-15

2.4.2 At-Grade Reinforced Concrete Structures . . . . . . 2-17

2.4.3 Stee1 Structures .............. 2-19

2.4.4 Canister Storage Building Above-Grade Structures

(Intake Structure, Exhaust Stack, Operating Area

Shelter, and Support Building) ....... . 2-29

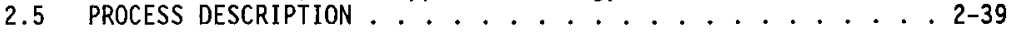

2.5.1 Baseline 0perations ............ 2-39

2.5 .2 Staging operations ............ 2-49

2.5.3 Interim Storage Operations ......... 2-52 


\section{CONTENTS (Continued)}

2.6 CONFINEMENT SYSTEMS . . . . . . . . . . . . 2-52

2.6.1 Confinement During Staging Operations . . . . . . 2-52

2.6.2 Confinement During Hot Conditioning and

Interim Storage Operations .......... 2-53

2.7 SAFETY SUPPORT SYSTEMS ............ . 2-54

2.7.1 Backup Electrical Power . . . . . . . . . . . . . . . 2-54

2.7.2 Fire Protection . . . . . . . . . . 2-54

2.7.3 Heating, Ventilating, and Air Conditioning

System ............ 2- . 256

2.7.4 Health Protection System ............ 2-57

2.8 UTILITY DISTRIBUTION SYSTEMS . . . . . . . . . 2-58

2.8.1 Backup Electrical Power and Generators . . . . . 2-58

2.8.2 Distributed Control System ......... 2-60

2.8.3 Instrument and Plant Air System .......... 2-61

2.8.4 Liquid Waste Collection ........... 2-61

2.8.5 Potable Water............... 2-62

2.9 AUXILIARY SYSTEMS . . . . . . . . . . . . . . 2-62

2.10 REFERENCES ................ 2- . . . . . .

3.0 HAZARD AND ACCIDENT ANALYSES .............. 3-1

3.1 INTRODUCTION ....................... 3-.

3.2 REQUIREMENTS ................. . . . . . . . .

3.2.1 U.S. Department of Energy Orders and Standards . . . 3-2

3.2.2 U.S. Nuclear Regulatory Commission Rules and

Documentation ............. 3-5

3.2.4 Hanford Site Requirements . . . . . . . . . . 3-5

3.3 HAZARD ANALYSIS ................. 3-5

3.3.1 Methodology . . . . . . . . . . . 3-5

3.3.2 Hazard Analysis Results............ . 3-10

3.4 ACCIDENT ANALYSIS . . . . . . . . . . . . . 3-29

3.4.1 Methodology . . . . . . . . . . . 3-29

3.4.2 Design Basis Accidents . . . . . . . . . . . 3-36

3.4.3 Beyond Design Basis Accidents ......... 3-65

3.4.4 Safety-C1ass Design Features ........ 3-66

3.5 REFERENCES .................... 3-66

4.0 SAFETY STRUCTURES, SYSTEMS, AND COMPONENTS . . . . . . . 4-1

4.1 INTRODUCTION ................... . . 4-1

4.2 REQUTREMENTS ................. . . . . . . .

4.2.1 U.S. Department of Energy Orders and Standards . . 4-2

4.2.2 U.S. Nuclear Regulatory Commission Rules and

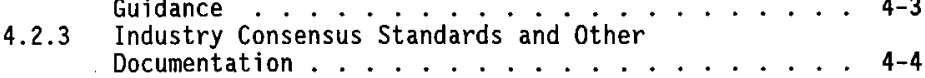

4.2.4 Hanford Site Requirements . . . . . . . . 4-5

4.2.5 Fluor Daniel, Incorporated, Requirements .... 4-6

4.3 SAFETY-CLASS STRUCTURES, SYSTEMS, AND COMPONENTS . . . . 4-6

4.3.1 Canister Storage Building Subsurface Structure . . . 4-7

4.3.2 Air Intake and Exhaust Plenums ........ 4-24 
CONTENTS (Continued)

4.3.3 Carbon Steel Base Slab Embeds .......... 4-25

4.3.4 Canister Storage Building At-Grade Structures . . . 4-26

4.3.5 Storage Tube, Bellows Assembly, Tube Plugs,

4.3.6 Impact Absorbers, and Tube Base Assemblies .... . 4-35

4.3.6 Canister Storage Building Above-Grade Structures (Intake Structure, Exhaust Stack, and Operating

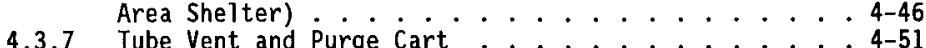

4.3.8 Multicanister 0verpack $\ldots 4-56$

4.4 SAFETY-SIGNIFICANT STRUCTURES, SYSTEMS, AND COMPONENTS $\ldots$ 4-56

4.4.1 Tube Plug Filter Media . . . . . . . . . . . 4-58

4.4.2 Multicanister Overpack Handling Machine...... 4-59

4.4.3 Backup Power System ... . . . . . . . . . 4-62

4.4.4 Tube Vent and Purge Cart ........... . 4-68

4.4.5 Receiving Crane ............ 4-71

4.4.6 Service Station - Ventilation Enclosure ..... 4-73

4.4.7 Service Station - Shield Hatch Assembly and

4.4.8 Multicanister Overpack Servicing System $\ldots$ 4-75

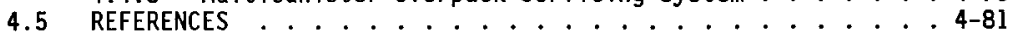

6.0 PREVENTION OF INADVERTENT CRITICALITY . . . . . . . . 6-1

6.1 INTRODUCTION .................. . . 6-1

6.2 REQUIREMENTS ............... 6-3

6.2.1 U.S. Department of Energy Orders and Standards . . . 6-4

6.2 .2 Industry Consensus Standards ........ 6-4

$6.2 .3 \quad$ U.S. Nuclear Regulatory Commission Rules . . . . 6-4

6.2 .4 Contractor Requirements . . . . . . . . 6-5

6.3 CRITICALITY CONCERNS .............. 6-5

6.3.1 Criticality Hazards ............ 6-5

6.3.2 Criticality Analysis Conditions . . . . . . . 6-9

6.3.3 Criticality Analysis Results ........... 6-12

6.4 CRITICALITY CONTROLS .............. . 6-22

6.4.1 Engineering Controls .......... 6-22

6.4.2 Administrative Controls . . . . . . . . . . 6-23

6.4.3 Application of Double Contingency Principle... 6-24

6.4.4 Beyond Design Basis Events ........ 6-25

6.5 CRITICALITY PROTECTION PROGRAM ........... 6-26

6.5.1 Criticality Safety Organization ........ 6-26

6.5.2 Criticality Safety Plans and Procedures...... 6-28

6.5.3 Criticality Safety Training ......... 6-28

6.5 .4 Operational Limits ............ 6-29

6.5.5 Criticality Safety Inspections and Audits ..... 6-29

6.5.6 Criticality Infraction Reporting and Follow-Up ... 6-30

6.6 CRITICALITY INSTRUMENTATION .......... 6-30

6.7 U.S. NUCLEAR REGULATORY COMMISSION EQUIVALENCY . . . . . 6-30

6.8 REFERENCES .................... 6-.31 
CONTENTS (Continued)

14.0 QUALITY ASSURANCE . . . . . . . . . . . . . . . 14-1

14.1 INTRODUCTION ..................... 14-1

14.2 REQUIREMENTS .................... . . . . . . . .

14.2.1 U.S. Department of Energy Rules ........ 14-1

14.2.2 U.S. Nuclear Regulatory Commission Rules . . . 14-1

14.3 QUALITY ASSURANCE PROGRAM ORGANIZATION ......... . 14-1

14.3.1 Organization ................. 14-1

14.3 .2 Program ................. 14-2

14.4 QUALITY IMPROVEMENT . . . . . . . . . . . . . . 14-3

14.4.1 Control of Nonconforming Items ......... 14-3

14.4.2 Corrective Action ............. 14-4

14.4.3 Control of Nonconformance for Purchased Items . . . 14-4

14.5 DOCUMENTS AND RECORDS .................. 14-4

14.5.1 Document Control . . . . . . . . . . 14-4

14.5.2 Records Management . . . . . . . . . . 14-5

14.6 QUALITY ASSURANCE PERFORMANCE . . . . . . . . . . . . 14-5

14.6.1 Work Processes . . . . . . . . . . . . 14-5

14.6 .2 Design ................ . 14-6

14.6 .3 Procurement ............. . . . . . . .

14.6.4 Inspection and Testing for Acceptance . . . . . 14-7

14.6 .5 Assessments . . . . . . . . . . 14-8

14.7 14.6.6 Conclusion ...................... 14-11

16.0 PROVISIONS FOR DECONTAMINATION AND DECOMMISSIONING . . . . . 16-1

16.1 INTRODUCTION ...................... . . . . . . . . . .

16.2 REQUIREMENTS . . . . . . . . . . . . . 16-1

16.2.1 U.S. Department of Energy Orders and Standards . . 16-1

16.2.2 U.S. Nuclear Regulatory Commission Rules and

Guidance ..................... 16-1

16.2.3 Industry Consensus Standards and Other

Documentation .............. 16-2

16.3 DESCRIPTION OF CONCEPTUAL PLANS . . . . . . . . 16-2

16.4 REFERENCES . . . . . . . . . . . . . . . . 16-4

17.0 MANAGEMENT, ORGANIZATION, AND INSTITUTIONAL SAFETY PROVISIONS . . . 17-1

17.1 INTRODUCTION . . . . . . . . . . . . . 17-1

17.2 REQUIREMENTS . . . . . . . . . . . . . . . . 17-1

17.2.1 U.S. Department of Energy Orders and Rules . . . . 17-1

17.2.2 U.S. Nuclear Regulatory Rules and Guidance . . . . . 17-2

17.2.3 Consensus Industry Standards ........ 17-2

17.3 ORGANIZATIONAL STRUCTURE, RESPONSIBILITIES, AND

INTERFACES . . . . . . . . . . . 17-2

17.3.1 Organizational Structure ........... 17-2

17.3.2 Organizational Responsibilities .......... 17-3

17.3.3 Staffing and Qualifications ......... 17-3

17.4 SAFETY MANAGEMENT POLICIES AND PROGRAMS . . . . . . . 17-3

17.4.1 Safety Review and Performance Assessment . . . . . 17-3

17.4.2 Configuration and Document Control ....... 17-4

17.4.3 Occurrence Reporting ............ 17-5

17.4 .4 Safety Culture ............... 17-5 
HNF-SD-SNF-RPT-004 REV 6

\section{CONTENTS (Continued)}

\section{APPENDIXES}

ES-A TECHNICAL ASSUMPTIONS AND UNCERTAINTIES ASSOCIATED WITH CANISTER STORAGE BUILDING CONSTRUCTION . . . . . . . . . . . ES-A-1

IA STRUCTURAL features OF THE COLUMBia BASIN . . . . . . . . . 1A-1

3 A CANISTER STORAGE BUILDING PRELIMINARY HAZARD ANALYSIS . . . . . . . 3A-1

4A CANISTER STORAGE BUILDING STRUCTURAL DRAWINGS . . . . . . . . . . 4A-1

4B CANISTER STORAGE BUILDING MECHANICAL DRAWINGS . . . . . . . . . . 4B-1

4C SUMMARY OF PRELIMINARY SEISMIC ANALYSIS RESULTS FOR THE MULTICANISTER OVERPACK HANDLING MACHINE . . . . . . . . . . . . . 4C-1

4D SHIELDING ANALYSIS OF THE MULTICANISTER OVERPACK HANDLING MACHINE CASK FROM APPENDIX 4, 75\% DESIGN REVIEW REPORT TO WESTINGHOUSE HANFORD COMPANY FOR THE MULTI-CANISTER HANDLING HACHINE, BY FOSTER AND WHEELER ENVIRONMENTAL CORPORATION, DATED 30 SEPTEMBER 1996 .............. 4D-1

4E CANISTER STORAGE BUILDING PIPING DRAWINGS . . . . . . . . . . . 4E-1 


\section{LIST OF FIGURES}

1-1 Location of the Hanford Site in the State of Washington ..... F1-1

1-2 The Hanford Site, Counties, and the Regional Highway Network . . F1-2

1-3 Hanford Site and Surrounding Area .............. F1-3

1-4 Hanford Site Boundaries . . . . . . . . . . . . . Fl-4

1-5 Hanford Site Topographic Map and Cross Section. . . . . . . . F1-5

1-6 Population of Cities and Counties Near the Hanford Site . . . . F1-6

1-7 Distribution of Transient Population . . . . . . . . . F1-7

1-8 Onsite Population Distribution in the 200 East Area by Zone . . . F1-8

1-9 Hanford Meteorological Network . . . . . . . . . . . F1-9

1-10 Hanford Site in Relation to Surrounding Terrain . . . . . . . F1-10

1-11 Six-Hour Precipitation Hazard Curves for the Hanford Site . . . F1-11

1-12 Greatest Depth of Snow on the Ground at Hanford from 1946-47

to $1980-81 \ldots \ldots \ldots$. . . . . . . . . F1-12

1-13 Wind Hazard Curves with Design Windspeeds . . . . . . . . F1-13

1-14 Wind Rose and Wind Speed Histogram for the 200 East Area . . . . F1-14

1-15 Location of Surface Water on the Hanford Site . . . . . . . F1-15

1-16 Location of Dams on the Columbia River . . . . . . . . . Fl-16

1-17 Extent of Probable Maximum Flood in Cold Creek Area . . . . . . . Fl-17

1-18 Characteristic Stratigraphy, Lithology, and Hydrogeologic Conditions on the Hanford Site ............. F1-18

1-19 Water Table Contours for the 200 East Areas Based on Well Data.................... F1-19

1-20 Location of the Hanford Site, Pasco Basin, and Columbia Plateau .................... F1-20

1-21 Physiographic Provinces of the Pacific Northwest, with the Columbia Intermontane Province Shown in White........ F1-21

1-22 Generalized Stratigraphy of the Pasco Basin . . . . . . . . . Fl-22

1-23 Idealized Suprabasalt Subsurface Stratigraphy of the Hanford Site .................. F1-23 
HNF-SD-SNF-RPT-004 REV 6

\section{LIST OF FIGURES (Continued)}

1-24 Annual Probability of Volcanic Ash Accumulation on the Hanford Site .................. F1-24

1-25 Structural Map of the Yakima Fold Belt .......... Fl-25

1-26 Generalized Geologic Map of the Pasco Basin . . . . . . . . F1-26

1-27 Geology of the 200 East and West Areas . . . . . . . . . . F1-27

1-28 Stratigraphy of the 200 East Area . . . . . . . . . F1-28

1-29 Generalized Location of Earthquake Swarms in the Pasco Basin . F1-29

1-30 Earthquakes at the Hanford Site 1990 through 1995 . . . . . F1-30

1-31 Top of Basalt Structure Contour Maps for 200 Areas ...... . F1-31

1-32 Seismic Hazard Curves for the Canister Storage Building Location ................... F1-32

1-33 Contribution of the Various Folds to the Mean Hazard from the Yakima Fold ................... F1-33

1-34 Contributions of the Crustal and Cascadia to the Mean Hazard at the 200 East Area ......................... F14

1-35 Contributions of the Three Crustal Sources to the Mean Hazard from Crustal Sources at the 200 East Area . . . . . . . . . F1-35

1-36 Canister Storage Building Response Spectra Compared to the Performance Category 3 Response Spectra . . . . . . . . . F1-36

1-37 Cascade Range Volcanic Ash Hazard . . . . . . . . . . F1-37

1-38 Log of Borings: Boring VP-15 . . . . . . . . . . . F1-38

1-39 Cross Section B - B': Subsurface Profile . . . . . . . F1-39

1-40 Dynamic Soil Properties of the Canister Storage Building Site . F F-40

1-41 Federal Airways and Instrument Approaches and Departures . . . F1-41

1-42 The Location of Yakima Training Center with Respect to the Hanford Site ..................... Fl-42

2-1 Canister Storage Building . . . . . . . . . F2-1

2-2 Site Plan (Water Lines; Grading and Drainage) ........ F2-7

2-3 Canister Storage Building Vault Mat Plan ........ F2-11 


\section{LIST OF FIGURES (Continued)}

2-4 Canister Storage Building Vault Cross Sections . . . . . . . F2-13

2-5 Canister Storage Building Vault Operating Floor Plan . . . . . F2-15

2-6 Canister Storage Building Standard and 0verpack Tube Plug Assemblies ................... . . F2-17

2-7 Future Service Pit in the Load-In/Load-0ut Area . . . . . . . . F2-19

2-8 Tube Base Assemblies for Standard and Overpack Storage Tubes . . F2-23

2-9 Bellows Assemblies for Standard and Overpack Storage Tubes . . . F2-25

2-10 Impact Absorbers for Standard and Overpack Storage Tube . . . . F2-27

2-11 Tube Plugs and Embed Covers for Standard and Overpack Storage Tubes....................... F2-29

2-12 Canister Storage Building Receiving Crane . . . . . . . . . . . F2-31

2-13 Shield Hatch Assembly . . . . . . . . . . . . . . . F2-33

2-14 Canister Storage Building Multicanister Overpack Handling Machine Operations Area Plan View . . . . . . . . . . . . F2-39

2-15 Canister Storage Building Multicanister Overpack Handling Machine Operations Area Elevation View ........... . F2-41

2-16 Tube Vent and Purge Cart Assembly . . . . . . . . . . . F2-43

2-17 Electrical One-Line Diagram (Backup Power) . . . . . . . . . F2-45

2-18 Support Building Emergency Power Fire Protection . . . . . . . F2-51

2-19 Heating, Ventilating, and Air Conditioning System Composite Diagram ................. . . . . . . . . . . . . . . . .

2-20 Location of Monitoring Equipment . . . . . . . . . . . F2-57

2-21 Stack Monitoring Equipment . . . . . . . . . . . . . . F2-59

2-22 Overall Canister Storage Building One-Line Diagram . . . . . . F2-65

2-23 Distributed Control System . . . . . . . . . . . . . F2-67

4-1 Air Temperature Profile . . . . . . . . . . . . F4-1

4-2 Canister Storage Building Vault, Canister Base Embeds . . . . . F4-3 


\section{LIST OF FIGURES (Continued)}

4-3 Operating Area, Storage Tube, and Vault Basemat Temperatures Expected from the Below-grade Interim Storage of Multicanister Overpacks ................ . . F4-5

4-4 Typical Configuration for Tube Plugs . . . . . . . . . . . . F4-7

4-5 Standard Tube Plug Assembly . . . . . . . . . . . . . . F4-9

4-6 Canister Storage Building Mechanical Space Allocation,

Plan View .................... F4-11

4-7 Canister Storage Building Mechanical Space Allocation, Elevations and Sections Looking North . . . . . . . . . . . F4-13

4-8 Canister Storage Building Mechanical Space Allocation, Elevations and Sections Looking East ... . . . . . . F4-15

4-9 Canister Storage Building Mechanical Space Allocation for the Multicanister Overpack Service Station, Elevations and Sections Looking North ............... F4-17

4-10 Canister Storage Building Multicanister Overpack Handling Machine's Confinement System ............. F4-19

4-11 Electrical One-Line Diagram (Backup Power) . . . . . . . . . F4-21

4-12 Location of Backup Generators in Canister Storage Building Support Building .................... F4-27

4-13 Canister Storage Building Tube Vent and Purge Cart System . . . . F4-29

6-1 Fuel Assemblies Storage Basket. . . . . . . . . . . . . . F6-1

6-2 Fuel Scrap Storage Basket. . . . . . . . . . . . . . . . F6-2

6-3 Multicanister Overpack and Storage Tube. . . . . . . . . . . . F6-3

6-4 Model A, Multicanister Overpack in the Multicanister Overpack Handling Machine ................... F6-4

6-5 Model B, Multicanister Overpacks in Vault Tubes (Finite Array)

F6-5

6-6 Model C, Multicanister Overpacks in Vault Tubes (Infinite Lattice Cell) and Mode1 D, One Multicanister Overpack Encased in Concrete .................. . F6-6

6-7 Dry Multicanister 0verpack with Mark IV Fuel, Infinite Array, Vault Flooded................... . . F6-7

6-8 Operational Criticality Safety Management Program. . . . . . . F6-8 
HNF-SD-SNF-RPT-004 REV 6

\section{LIST OF FIGURES (Continued)}

14-1 Spent Nuclear Fuels Canister Storage Building Quality

Assurance Hierarchy ... . . . . . . . . . . . F14-1

14-2 Spent Nuclear Fuel Canister Storage Building Project

Organization .......................... F14-2

17-1 Spent Nuclear Fuel Canister Storage Building Project's

Organizational Relationships ............ F17-1

17-2 Canister Storage Building Project Functions and Performing

Organizations .................... F17-2

17-3 Phased Safety Analysis Report Preparation and Review Process . F17-3

17-4 Final Safety Analysis Report Review and Approval Process . . . F17-4

17-5 Spent Nuclear Fuel Project Configuration Management Plan. . . . F17-5 


\section{HNF-SD-SNF-RPT-004 REV 6}

\section{LIST OF TABLES}

1-1 Projected Residential Population in an 80-km (50-mi) Radius of the Hanford Meteorological Station for the Period 1990

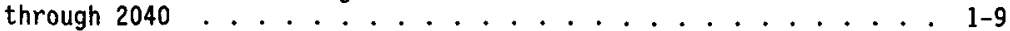

1-2 Monthly and Annual Daily Average and Extreme Temperatures at the Hanford Meteorological Station . . . . . . . . . . . 1-12

1-3 Average Number of Days at the Hanford Meteorological Station that Maximum and Minimum Temperatures were above or below Specified Limits for the Period 1945 through 1994 . . . . . . . 1-13

1-4 Monthly and Annual Average and Extreme Precipjtation in Inches at the Hanford Meteorological Station for the Period 1945 through 1994 . . . . . . . . . . . . . . . . 1-14

1-5 Extreme Precipitation Estimates for the Hanford Site . . . . . 1-15

1-6 Monthly and Seasonal Snowfall at the Hanford Meteorological Station in Inches, Average and Maximum for the Period 1945 through 1994 . . . . . . . . . . . . . . . . 1-17

1-7 Average Number of Thunderstorm Days at the Hanford Meteorological Station for the Period 1945 through 1994 . . . . . 1-18

1-8 Maximum Peak Gusts 15 Meters (50 Feet) Off the Ground at the Hanford Meteorological Station for the Period 1945 through 1994 , . 1-19

1-9 Average Number of Days of Dust or Blowing Dust at the Hanford Meteorological Station for the Period 1945 through 1994 . . . . 1-22

1-10 Monthly and Annual Number of Days with Fog and Dense Fog at the Hanford Meteorological Station for the Period 1945 through 1994 . . . . . . . . . . . . . . . . . 1-23

1-11 Average Sky Cover (Sunrise to Sunset) for the Period 1946 through 1994 and Number of Clear, Partly Cloudy, and Cloudy Days for the Period 1954 through 1994 at the Hanford Meteorological Station

1-12 Percent Frequency of Occurrence of Mixing Layer Thickness by Season and Time of Day at the Hanford Site . . . . . . . . 1-25

1-13 Percent Probabilities for Extended Periods of Surface-Based Inversions at the Hanford Site . . . . . . . . . . . . 1-26

1-14 Joint Frequency Distribution of Atmospheric Stability, Wind Direction, and Wind Speed at the 200 East Area . . . . . . . . 1-27

1-15 Percent Frequency of Occurrence of Pasqui11-Gifford Atmospheric Stability Classes A through $G$ for the 200 East Area . . . . . . 1-30 


\section{LIST OF TABLES (Continued)}

1-16 Onsite $99.5 \% \mathrm{X} / \mathrm{Qs}$ for One Fan $\left(5.66 \mathrm{~m}^{3} / \mathrm{s}\left[12,000 \mathrm{ft}^{3} / \mathrm{min}\right]\right)$

for Various Downwind Distances ............ 1-32

1-17 Onsite $99.5 \% \times / Q$ s for Two Fans $\left(11.3 \mathrm{~m}^{3} / \mathrm{s}\left[24,000 \mathrm{ft}^{3} / \mathrm{min}\right]\right)$

for Various Downwind Distances

1-18 Site Boundary $99.5 \% \times / Q$ s for One Fan $\left(5.66 \mathrm{~m}^{3} / \mathrm{s}\left[12,000 \mathrm{ft}^{3} / \mathrm{min}\right]\right)$

for the Site Boundary and Near River Shore . . . . . . . . 1-34

1-19. Site Boundary $99.5 \% \times / Q$ s for Two Fans $\left(11.3 \mathrm{~m}^{3} / \mathrm{s}\left[24,000 \mathrm{ft}^{3} / \mathrm{min}\right]\right.$ )

for the Site Boundary and Near River Shore ......... 1-35

1-20 Aquifer Properties in the 200 Areas ... . . . . . . . 1-40

1-21 Depth of Earthquakes in the Columbia Basin . . . . . . . 1-56

1-22 Principal Locations of Earthquakes in the Columbia Basin . . . 1-56

1-23 Canister Storage Building Safety-Class Natural Phenomena

Design Loads ................ . . 1-63

1-24 Airports Near the Canister Storage Building Site . . . . . . 1-65

1-25 Canister Storage Building Aircraft Risks . . . . . . . 1-68

2-1 Backup Power Load List . . . . . . . . . . . . 2-55

3-1 0ff-Normal Events at Independent Spent Fuel Storage

Installations and Similar Facilities ............ . . . . . .

3-2 Topics of Concern Requiring Further Resolution ....... 3-14

3-3 Examples of Defense-in-Depth Features for Accidents with

Potential Effects to a Collocated Worker or Offsite Receptor

(S2 and $\mathrm{S} 3$ Consequence Items) ............... 3-18

3-4 Examples of Defense in Depth for Facility Workers

(S1 Consequence Items)

3-5 Atmospheric Dispersion Coefficients Used in Accident Analyses

for the Canister Storage Building .............. 3-32

3-6 Radiological Analysis of High Burnup Mark IV Fue1 (Decayed

to January 1,1995$) \ldots \ldots$ 3-35

3-7 Safety Classification Criteria .............. 3- . . . .

3-8 Unmitigated Dose Consequences for Multicanister Overpack

Overpressurization during Handling ............. 3-43 


\section{LIST OF TABLES (Continued)}

3-9 Unmitigated Dose Consequences for Free Fall of Contents from a Sheared Multicanister Overpack . . . . . . . . . . . 3-47

3-10 Unmitigated Dose Consequences for Resuspension of Particulate from Spilled Multicanister Overpack Contents ....... . 3-48

3-11 Total Unmitigated Dose Consequences for a Single Multicanister Overpack Failure during Handling - Lateral Forces . . . . . . . 3-48

3-12 Unmitigated Dose Consequences for Failure of a Multicanister Overpacks during Handling . . . . . . . . . . . 3-60

3-13 72-Hour Temperature Changes Due to Flow Blockage in the Canister Storage Building Vault (HV-003) . . . . . . . . 3-64

3-14 Safety-Class and Safety-Significant Structures, Systems, and Components Required by Accident Analysis for the Canister Storage Building ............ . . . . . . . . . . . . . .

4-1 Canister Storage Building Safety Classification . . . . . . 4-2

4-2 Safety-Class Structures, Systems, and Components of the Below-Grade and At-Grade Reinforced Concrete Portion of the Canister Storage Building ............. 4-8

4-3 Safety-Class Structures, Systems, and Components of the Canister Storage Building. . . . . . . . . . . . 4-9

4-4 Summary of Below-Grade and At-Grade Analysis Results . . . . . 4-14

4-5 Summary of Average Clearances Resulting from Tube Plug and Multicanister Overpack Drop . . . . . . . . . . . . 4-45

4-6 Deflections at Top of Intake Structure and Exhaust Stack . . . . 4-49

4-7 Safety-Significant Structures, Systems, and Components for the Canister Storage Building ........... 4-. . . . .

6-1 N Reactor Fresh Fuel Element Description . . . . . . . . 6-6

6-2 Criticality Hazard Configurations ............. 6-10

6-3 Canister Storage Building Criticality Analysis Results - Normal Conditions .................. 6-14

6-4 Canister Storage Building Criticality Analysis Results - Flooding Conditions (Water Density Variations in Multicanister Overpacks, Tubes, or Vault Area) ............... 6-16 
HNF-SD-SNF-RPT-004 REV 6

\section{LIST OF TABLES (Continued)}

6-5 Canister Storage Building Criticality Analysis Results - Fuel Basket Misloading at the $\mathrm{K}$ Basins............. . 6-21

6-6 Canister Storage Building Criticality Analysis Results - Beyond Design Basis Accidents ............... 6- . . . . . . . . 
HNF-SD-SNF-RPT-004 REV 6

\section{LIST OF TERMS}

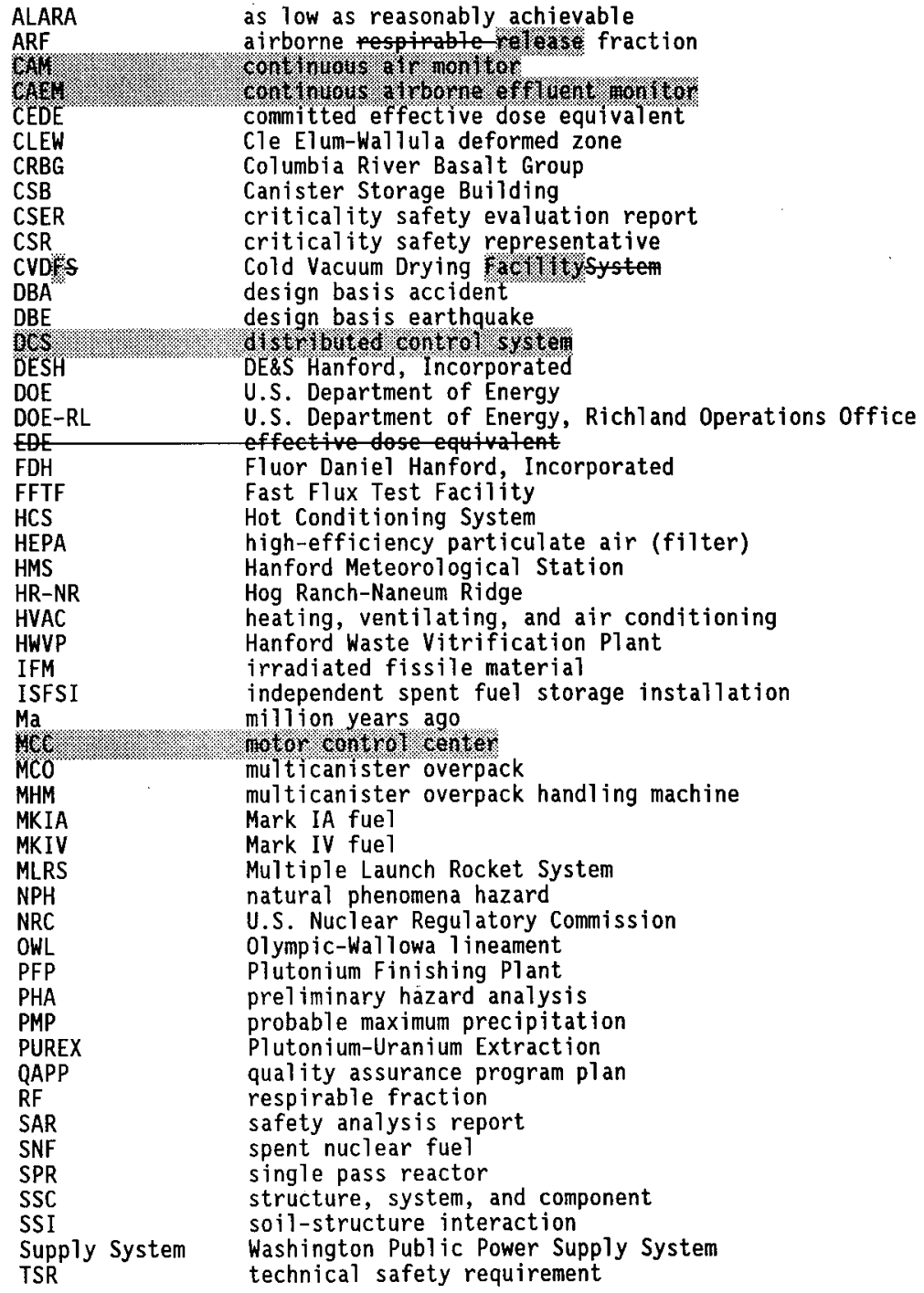




$\begin{array}{ll}\text { UCAT } & \text { United Engineers and Constructors-Catalytic } \\ \text { WESF } & \text { Waste Encapsulation and Storage Facility } \\ \text { WHC } & \text { Westinghouse-Hanford Company } \\ \text { WNP } & \text { Washington Nuclear Plant } \\ \text { YFB } & \text { Yakima Fold Belt }\end{array}$




\subsection{SITE CHARACTERISTICS}

\subsection{INTRODUCTION}

The Canister Storage Building (CSB) will be constructed in the 200 East Area of the U.S. Department of Energy (DOE) Hanford Site. The CSB will be used to stage and store spent nuclear fuel (SNF) removed from the Hanford Site $K$ Basins. The objective of this chapter is to describe the characteristics of the site on which the CSB will be located. This description will support the hazard analysis and accident analyses in Chapter 3.0.

\subsection{REQUIREMENTS}

This section lists the design codes, standards, regulations, and DOE orders that are required for establishing the safety basis for the CSB. Only the requirements that are specific to Chapter 1.0 and that pertain to the safety basis for the facility are provided.

\subsubsection{U.S. Department of Energy Orders and Standards}

The following DOE orders and standards are applicable to the safety basis for the facility.

- DOE Order 6430.1A, General Design Criteria, 1989. This order provides requirements for meteorology, hydrology, and seismology as they relate to facility siting. DOE Order 5480.28, Natural Phenomena Hazards Mitigation, provides more explicit requirements for those aspects of facility siting.

- DOE Order 5480.28, 1993, Natural Phenomena Hazards Mitigation. This Order establishes DOE facility safety requirements for dealing with natural phenomena hazards (NPHs). The Order establishes NPH mitigation requirements, performance categories, and target probabilistic performance goals for each category. DOE Order 5480.28 will be replaced by DOE Order 420.1 , which is expected to have the same NPH requirements as the implementing standards listed below.

- DOE-STD-1020-94, 1994, Natural Phenomena Hazards Design and Evaluation Criteria for Department of Energy Facilities. This standard gives design and evaluation criteria for NPH effects including guidance for defining NPH loads.

- DOE-STD-1021-93, 1993, Natural Phenomena Hazards Performance Categorization Guidelines for Structures, Systems, and Components. This standard provides guidance for assigning structures, systems, and components (SSCS) to one of five performance categories and recommends systematic procedures for implementing this guidance. 
- D0E-STD-1022-94, 1994, Natural Phenomena Hazards Site Characterization Criteria. This standard provides criteria for selecting the site-specific information needed to implement DOE Order 5480.28.

- DOE-STD-1023-95, 1995, Natura7 Phenomena Hazards Assessment Criteria. This standard provides criteria for assessing NPHs to ensure that adequate design basis load levels are estabijished for design or evaluation of DOE facilities.

The orders and standards 1 isted above were not in existence at the time the below-grade portion of the CSB was designed. The impact of these orders and standards is reflected in WHC-SD-SNF-DB-009, Canister Storage Building Natural Phenomena Hazards (Tallman 1996).

\subsubsection{U.S. Nuclear Regulatory Commission Rules and Guidance}

In Memorandum EM-36-3.1.6.7, Concurrence with K-Basins Spent Nuclear Fuel Project Policy on Nuclear Safety Requirements (Grumbly 1995), D0E established the requirement for new SNF Project facilities to achieve "nuclear safety equivalency" to comparable U.S. Nuclear Regulatory Commission (NRC)-1icensed facilities. The SNF Project identified the NRC requirements that were needed in addition to existing and applicable DOE requirements to establish nuclear safety equivalency. These NRC requirements and the process used to identify them are documented in WHC-SD-SNF-DB-003, Spent Nuclear Fuel Project Path Forward, Additional NRC Requirements (Garvin 1996), and in WHC-SD-SNF-DB-009 (Tallman 1996). These documents establish the design requirements for the CSB.

\subsubsection{Industry Consensus Standards and Other Documentation}

The following industry standards are applicable to the safety basis.

- ANSI/ANS-2.8-1992, 1992, Determining Design Basis Flooding at Power Reactor Sites. This standard provides criteria to establish design basis flooding for nuclear safety-related features at power reactor sites.

- ASCE 7-93, 1993, Minimum Design Loads for Building and Other Structures. This standard sets the minimum acceptable fastest mile wind speed.

- NFPA 780, 1995, Lightning Protection Systems. This code provides requirements for the safeguarding of persons and property from hazards arising from exposure to lightning.

- ASCE Standard 4, 1986, Seismic Analysis of Safety-Related Nuclear Structures and Commentary on Standard for Seismic Analysis of Safety-Related Nuclear Structures. This code provides guidance on seismic analysis of safety-related nuclear structures. 


\subsection{SITE DESCRIPTION}

The following sections address the geography, demography, and regional land and water use of the area encompassed by, and surrounding, the Hanford Site. Much of the information contained in this section was obtained from DOE/EIS-0245F, Management of Spent Nuclear Fuel from $K$ Basins at the Hanford Site, Richland, Washington (DOE 1996).

\subsubsection{Geography}

The Hanford Site is a $1,450 \mathrm{~km}^{2}\left(560 \mathrm{mi}^{2}\right)$ area located in the state of Washington, as shown in Figure 1-1. Principal cities and towns and prominent natural features are shown in Figure 1-1. Use of the Site is institutionally controlled by DOE for national security and health and safety reasons.

The Columbia River enters the Hanford Site at the northwest corner and flows through the northern portion of the site before turning southward to form part of the eastern boundary. The Yakima River flows from west to east, forming part of the southern boundary of the Site and empties into the Columbia River at the Tri-Cities (Richland, Kennewick, and Pasco)

(Figure 1-2). The Hanford Site is bordered on the north by the Saddle Mountains and on the west by the Umtanum and Yakima Ridges and Rattlesnake Mountain (Figure 1-3). Dominant natural features include the Columbia River, anticlinal ridges of basalt in and along the Hanford Site boundary, and sand dunes located near the Columbia River. The surrounding basaltic ridges rise to elevations as high as $1,100 \mathrm{~m}(3,600 \mathrm{ft})$.

The location of the Hanford Site with respect to local counties and regional highways is shown in Figure $1-2$. The Hanford onsite road network consists primarily of rural arterial routes. Only 104 of the $46 \mathrm{l} \mathrm{km}$ (65 of the $288 \mathrm{mi}$ ) of paved roads are accessible to the public. Most onsite employee travel occurs along Route 4, with controlled access at the Yakima and Wye Barricades, as shown in Figure 1-4. Route 4 passes within $350 \mathrm{~m}$ $(1,155 \mathrm{ft})$ of the CSB. State Route 240 is the main public route through the Site. State Routes 24 and 243 also traverse the Site. State Route 240 passes through the Hanford Site and within $8 \mathrm{~km}(5 \mathrm{mi})$ of the CSB. An additional access point to the 200 Areas from State Highway 240 (Rattlesnake Barricade), with limited hours of operation, is located near the southeastern corner of the 200 West Area (see Figure 1-4). Public access through the Hanford Site on Highways 24,240 , and 243 is not strictly controlled by DOE under normal circumstances. Large shipments, in particular components from dismantled nuclear submarines, are offloaded at the Port of Benton dock facilities discussed below. Overland wheeled trailers are then used to transport the shipments to the Site.

Onsite rail transport is provided by a short-line railroad owned and operated by DOE. This line connects just south of the Yakima River with the Union Pacific line, which in turn interchanges with the Washington Central and Burlington Northern-Santa Fe railroads at Kennewick. The mainiline of the Hanford Railroad passes $3,000 \mathrm{~m}(9,000 \mathrm{ft})$ to the north of the CSB.

There is no barge traffic on the Columbia River upstream (north) of the Port of Benton barge slip, which is just north of Richland. The barge slip is 
located near the upper end of the McNary Dam impoundment and above this location the river is too swift and shallow to allow for safe operation of barges. In addition, there are no lock facilities at Priest Rapids Dam, the next upstream dam, and there are no industrial facilities between the Port of Benton barge slip and the dam that would benefit from barge service.

There are three commercial airports within $50 \mathrm{~km}(31 \mathrm{mi})$ of the CSB. These are the Tri-Cities and Richland airports and Vista Field. They are discussed in detail in Section 1.6.1.

Traffic on the Columbia River, in the airspace over the Hanford Site, and on access routes into the areas used by U.S. Ecology, Incorporated, and the Washington Public Power Supply System (Supply System) are not subject to strict controls under normal circumstances. Under emergency plan conditions, DOE will control all road and railroad access to the Hanford Site and may close these Site routes to normal traffic. Access by the Columbia River cannot be immediately controlled, as discussed in Section 1.3.1.3.

1.3.1.1 Hanford Site Vegetation. The most broadly distributed vegetation on the Hanford Site is sagebrush, wheatgrass, blue bunch wheatgrass, cheatgrass, and other shrub plant species common to central Washington. The flora is prone to destruction by fire and can burn rapidiy. The most recent severe grass fire at the Hanford Site occurred in August 1984 as a result of a range fire that started northeast of Sunnyside, Washington (see Figure 1-1). Extremely dry vegetation, inaccessible mountain terrain, and winds up to $64 \mathrm{~km} / \mathrm{h}$ (40 $\mathrm{mi} / \mathrm{h})$ limited attempts to extinguish the fire. The fire front entered the Hanford Site adjacent to Rattlesnake Mountain, crossed Highway 240, and traveled northeast along Army Loop Road south of the 200 East Area (Figure 1-4). The fire was not controlled until it reached the Columbia River, by which time it had burned approximately $809 \mathrm{~km}^{2}$ (312 $\mathrm{mi}^{2}$ ) of range land. Hanford site facilities near the fire were protected by fire breaks cut by bulldozers and blades, and by fire-fighting tanker trucks. Vehicle access is available for the areas around all major Hanford Site facilities. For this fire, air drops of fire retardant material by U.S. Forest Service planes from the Wenatchee National Forest were used to help protect major facilities. Losses related to this severe grass fire were limited to burned railroad ties, wooden power poles, and several trailers. Severat fire-fighting vehicles also were damaged.

To protect the CSB, a clear space of at least $18.3 \mathrm{~m}(60 \mathrm{ft})$ will be provided on a11 sides of the CSB. Unpaved areas will be overlaid with a crushed rock surface. With this protection, the only potential risk to CSB operation is related to the need to maintain natural circulation in the vault. This is discussed in Section 3.4.2.6.

1.3.1.2 Hanford Site Facilities. In 1943 the U.S. Army Corps of Engineers selected the Hanford Site for construction of nuclear reactors and chemical processing facilities in support of the war effort. The current mission is environmental management of radioactive and hazardous wastes, restoration of Site land, and conversion of useable facilities for other uses. DOE nuclear facilities currently occupy approximately $6 \%$ of the total available Hanford Site land area. Site operating areas are identified by area numbers and are briefly described below. Figure 1-4 shows these numbered areas. The CSB is 
in the 200 East Area and will store spent fuel currently located in the $100 \mathrm{~K}$ Area.

Six 100 Areas border directly on the Columbia River in the northernmost portion of the Site. These areas were the locations for nine graphitemoderated plutonium production reactors. Eight of these reactors, which started operation before 1960, were shut down in the early 1970s. The ninth reactor, $N$ Reactor, became operational in 1963 and continued operating until 1986. Spent fuel from the $N$ Reactor will be stored in the CSB. The 100 Areas occupy about $11 \mathrm{~km}^{2}\left(4 \mathrm{mi}^{2}\right)$.

The CSB is located in the 200 East Area, near the center of the Hanford Site on a relatively flat terrace known as the 200 Area Plateau (Figure 1-5). In the past, the 200 East and 200 West Areas have received waste from the 100 , 300 , and 400 Areas in addition to the waste produced by 200 Area separation processes.

The 300 Area, 1ocated just north of Richland, is the site of nuclear research and development. This area covers $1.5 \mathrm{~km}^{2}\left(0.6 \mathrm{mi}^{2}\right)$.

The 400 Area is the site of the Fast Flux Test Facility (FFTF), a liquid-metal-cooled fast reactor used for testing breeder reactor fuels, materials, and components. The FFTF is currently shut down and is being defueled as part of eventual decontamination and decommissioning activities. However, the FFTF is being considered for other missions. This area covers $0.6 \mathrm{~km}^{2}\left(0.25 \mathrm{mi}^{2}\right)$.

The 600 Area includes all of the Hanford Site not occupied by the 100 , 200,300 , or 400 Areas. Land uses within the 600 Area, other than those described previously, include the following (Figure 1-4).

- An area measuring $310 \mathrm{~km}^{2}\left(120 \mathrm{mi}^{2}\right)$, known as the Fitzner-Eberhardt Arid Lands Ecology Reserve, is located along the southwest boundary of the Hanford Site (Figure 1-3). This area is a limited-access area managed by Pacific Northwest National Laboratory and has been set aside for ecological studies.

- An area measuring $4 \mathrm{~km}^{2}\left(1.5 \mathrm{mi}^{2}\right)$, located between the 200 West and 200 East Areas, is leased by Washington State. A part of this area is managed by U.S. Ecology, Incorporated, for the disposal of solid, low-level radioactive waste from commercial - not Hanford Site sources.

- An area measuring $4.4 \mathrm{~km}^{2}\left(1.6 \mathrm{mi}^{2}\right)$ is used by the Supply system for commercial nuclear power plants. This area is located approximately $17 \mathrm{~km}$ (10.5 mi) southeast of the 200 East Area and approximately $5 \mathrm{~km}(3 \mathrm{mi})$ west of the Columbia River. Three commercial nuclear power plants were originally planned for this site. Washington Nuclear Plant (WNP)-2, a boiling-water reactor, is currently in operation at this location. Construction has been terminated at the other two reactors, WNP-1 and WNP-4. Both were to be pressurized water reactors. Al so located on the Supply System leased property are the Supply System's Plant Engineering Center and Plant Support 
Facility and the Bonneville Power Administration's H. J. Ashe substation.

- An area measuring $2.6 \mathrm{~km}^{2}\left(1 \mathrm{mi}^{2}\right)$ has been transferred to Washington State as a potential site for the disposal of nonradioactive hazardous wastes. See Figure 1-4.

- About $130 \mathrm{~km}^{2}\left(50 \mathrm{mi}^{2}\right)$ of 1 and north of the Columbia River, the Saddle Mountains National Wildlife Refuge, is managed under a revocable use permit by the U.S. Fish and Wildlife Service. The U.S. Fish and Wildlife Service also manages seven islands in the Hanford Reach section of the Columbia River as part of the McNary National Wildlife Refuge.

- Another $225 \mathrm{~km}^{2}\left(87 \mathrm{mi}^{2}\right)$ of land north of the Columbia River, the Wahluke Wildlife Recreation Area, is under a revocable use permit managed by the Washington State Department Wildlife for recreational game management. Public outdoor recreational use is permitted in this area.

- Support facilities for the controlled access areas and an electrical transmission substation at Midway near the northwest corner of the Hanford Site are maintained by the Bonneville Power Administration.

1.3.1.3 Boundaries for Evaluation of Accident and Effluent Release Limits. Activities in the 200 East Area are within the DOE-controlled zone, which is surrounded by a security fence limiting general access. No special security clearance other than a Site badge is required to pass through the gates that control access to the 200 Areas. However, the DOE has the authority to determine all activities in this area including exclusion or removal of personnel and property; an exception exists relative to the Columbia River as discussed below. There are no permanent residences in this area.

Consequences of accident releases to collocated workers are calculated in Section 3.4 .2 at $100 \mathrm{~m}(328 \mathrm{ft})$ from the point of release in accordance with

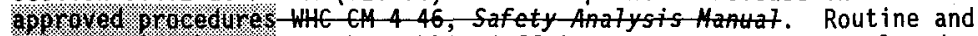
accidental releases to the public (offsite receptor) are calculated at the Site boundary shown in Figure 1-2. This is also the location of the controlled area boundary as the term is defined in Title 10, Code of Federal Regu7ations, Part 72, "Licensing Requirements for the Independent Storage of Spent Nuclear Fuel and High-Level Radioactive Waste," Section 106, "Controlled Area of an ISFSI or MRS" (10 CFR 72.106). However, for both cases, the Columbia River is taken as the location of the offsite receptor to the east as DOE does not control activities on the river. This is in accordance with DOE direction that states, "Therefore, the river must be viewed as a location of the public for safety analys is purposes" (Scott 1995). For Highway 240 to the west, DOE and its contractors can control access during emergency and accident conditions. This access control meets the requirements of 10 CFR 72.106 (b). For undetected accidents or accidents with a puff release, this control may not be effective. For the location of the offsite receptor for CSB events, this is not of concern as the Columbia River represents the more limiting case even though it is farther from the CSB site than Highway 240. 


$$
\text { HNF-SD-SNF-RPT-004 REV } 6
$$

Radiological consequences calculated in Section 3.4 .2 were developed considering only the current Hanford Site boundary (Figure 1-2) with the exception of the location of an offsite receptor on the Columbia River as discussed above. Before changes to the Site boundaries are placed into effect by the proper authorities, the calculations in this safety analysis report (SAR) will be reviewed (and reanalyzed if required) in accordance with the unreviewed safety question procedure outlined in WHC-CM-1-5, Standard operating Practices, Section 7.3, "Identifying and Resolving Unreviewed Safety Questions."

\subsubsection{Regional Land and Water Use. This section characterizes regional} 1 and and water use both inside and outside the Hanford Site boundaries based on information contained in DOE/EIS-0113, Final Environmental Impact Statement: Disposal of Hanford Defense High-Level, Transuranic, and Tank Wastes, Hanford Site, Richland, Washington (DOE 1987), Hanford Site National Environmental Policy Act (NEPA) Characterization (Cushing 1995), and DOE/EIS-0245F (DOE 1996).

1.3.1.4.1 Land Use Within the Hanford Site Boundaries. The majority of the 1 and within the Hanford Site boundary is a limited-access area under control of the DOE for use in environmental restoration and remediation efforts. A number of areas at the Hanford Site are managed under a multipurpose concept and serve as buffer zones around areas of nuclear activity. These multipurpose areas are shown in Figure 1-4.

1.3.1.4.2 Agricultural Land Use Outside Hanford Site Boundaries. Land use in the six-county region surrounding the Hanford Site (i.e., Franki in, Walla Walla, Benton, Yakima, Adams, and Grant Counties [Figure 1-2]) is predominantly agricultural. Over $75 \%$ of the 1 and area in this region is in agriculture-related use compared with less than $40 \%$ statewide. The percentage of agricultural land that is irrigated in this region varies from a $10 \mathrm{w}$ of $33 \%$ in Yakima County to a high of $73 \%$ in Grant County. However, areas of Yakima County near the Hanford Site have intensive irrigation.

Regional land used for agricultural purposes lies primarily north and east of the Columbia River and south of the Yakima River. The U.S. Bureau of Reclamation's Columbia Basin Irrigation Project is northeast of othello. Part of the farmland northeast of Priest Rapids Dam is irrigated by the Columbia Basin Project; the rest is used for dryland farming. The area from othello south to the Columbia River is irrigated farmland. The principal agricultural crops associated with the irrigated and dryland farming include hay, wheat, potatoes, corn, apples, soft fruit, and vegetables. Land in the area just outside the Hanford Site to the south and west is available for farming but is used mainly for grazing cattle and sheep. The agricultural land along the Yakima River is used for fruit orchards, grapes, hops, alfalfa, and annual row crops. Higher land away from the Yakima Valley floor is used principally for livestock grazing, dairies, and fruit orchards, with some grain crops. South and west of Kennewick, the land is used principally for dryland wheat farming, with some orchards.

1.3.1.4.3 Nonagricultural Land Use Outside Hanford Site Boundaries. The main industries in the Tri-Cities are, or are related to, agriculture and energy production. The DOE nuclear and nonnuclear industrial activities within an 8-km (5-mi) radius of the CSB are described in detail in 
Section 1.7. All industrial activities on Hanford Site leased 1 and must be compatible with DOE activities and must be approved by the DOE. These land uses are discussed in Section 1.3.2.1. The DOE retains the right to remove from lease any land not currently used or not under development by the state. The Big Bend Alberta Company owns mineral rights to several parcels of 1 and in the Arid Lands Ecology Reserve (Figure 1-4) and holds the right to perform exploratory drilling.

The U.S. Army's Yakima Training Center covers 326,000 acres just northwest of the western Hanford Site boundary (Figure 1-2). The Center is used for firing all types of ordnance, both in a direct mode and by indirect artillery and mortars. Weapons to 8-in. are fired. Firing occurs frequently. Live ordnance usage at the Center includes bombs, up to $5001 \mathrm{~b}$, delivered by high-performance aircraft; helicopter weapons, which include automatic weapons and 2.75-in. folding fin rockets; and antiaircraft missiles. The majority of the ordnance impacts a 20,000-acre area that is located in the central portion of the Center. All activities are confined to the geographical limits of the Center and/or its restricted air space unless special arrangements are made with affected agencies. Mechanized units (i.e., tanks and armored personnel carriers) from Fort Lewis and Reserve components conduct extensive maneuvers on all accessible areas of the Yakima Training Center and use specially designed ranges to practice firing their weapons. Infantry and engineering units that support the mechanized units also train at the Center. Training activity is greatest from March to November. War games sometimes involve troop and equipment deployment at the Richland airport and along Highway 243 west of the Vernita Bridge. Helicopters may fly near the Hanford Site, or military vehicles may travel over Highway 240.

1.3.1.4.4 Water Use. The major water uses, in decreasing order, are agricultural, industrial, and municipal. CSB operation will involve no water withdrawals from or direct discharges to the Columbia River. Also no liquid effluent waste streams from the CSB will be generated.

\subsubsection{Demography}

The 1990 U.S. Bureau of the Census population distribution statistics for cities within an $80-\mathrm{km}(50-\mathrm{mi})$ radius of the Hanford Meteorological Station (HMS) are shown in Figure 1-6. The HMS often serves as the center for population distribution around the 200 Areas, and its close proximity to the CSB (about $4.8 \mathrm{~km}[3 \mathrm{mi}]$ east of the HMS) warrants use of the HMS as the population distribution centerpoint for this description.

The population distribution in the area surrounding the Hanford Site is not uniform. Most of the adjacent area to the east, north, and west is farm or range land with scattered farming communities. Table 1-1 shows the actual 1990 residential population and the projected residential population within an $80-\mathrm{km}(50-\mathrm{mi})$ radius of the HMS for decennial census years through 2040 (Beck et al. 1991). The Tri-Cities are located to the south and southeast of the CSB and comprise the major population center of the area. The three cities (Kennewick, Pasco, and Richland) are estimated to have a combined population of approximately 104,000 based on 1994 estimates. The estimated unincorporated population of Benton County is 33,000 and of Franklin County is 18,000 (DOE 1996). More recent data on the Tri-Cities population are not 
available although Hanford Site and total nonfarm employment is on a downward trend. The projected increase in the total population of Franklin County from 1995 to 2005 is from 41,336 to 48,213 (8.03\%) and for Benton County from 121,328 to $136,892(6.32 \%)$ (DOE 1995).

Table 1-1. Projected Residential Population in an 80-km (50-mi) Radius of the Hanford Meteorological Station for the Period 1990 through 2040.

\begin{tabular}{|c|c|c|c|}
\hline Year & Decade & $\begin{array}{c}\text { Average annual rate } \\
\text { of growth during } \\
\text { decade (\%) }\end{array}$ & Population \\
\hline 1990 & -- & $\cdots$ & 375,860 \\
\hline 2000 & 1990 to 2000 & 0.633 & 400,346 \\
\hline 2010 & 2000 to 2010 & 0.413 & 417,200 \\
\hline 2020 & 2010 to 2020 & 0.351 & 432,062 \\
\hline 2030 & 2020 to 2030 & 0.157 & 438,909 \\
\hline 2040 & 2030 to 2040 & 0.068 & 441,911 \\
\hline
\end{tabular}

Other population centers of note within an $80-\mathrm{km}(50-\mathrm{mi})$ radius include the cities of Sunnyside, Moses Lake, and Yakima. The Yakima River Valley, stretching in an arc from the city of Yakima to the Tri-Cities, is a relatively densely populated agricultural area with a number of small towns. The nearest residence to the 200 East Area is approximately $19 \mathrm{~km}$ (11 mi) east across the Columbia River. The Richland city 1 imits are approximately $27 \mathrm{~km}$ (16 $\mathrm{mi}$ ) to the southeast.

Figure 1-7 shows the estimated populations of migrant agricultural workers and recreationists. Both are defined as transient. These estimates were developed by the Supply System in 1988 and are documented in WNP-1, 2 Ten Mile EPZ Evacuation Time Assessment Study (Mogle 1987). The center of the Supply System's 16-km (10-mi) emergency planning zone, which is located midway between WNP-1, WNP-2, and WNP-4, is the geographic point from which estimates are made. The CSB is located approximately $19 \mathrm{~km}$ (12 mi) west-northwest from the center point (see Figure 1-7). This distance from the center point is not significant to the accident analyses in Section 3.4 as the location of the offsite receptor is determined by consideration of the Site boundary and the ability to control activities within the boundary as discussed in Section 1.3.1.3.

In 1ate 1995, approximately 15,000 persons were employed on the Hanford Site. Figure 1-8 shows estimated 200 East Area employee distributions by facility. Some Hanford Site work assignments include shift and weekend coverage. The total number of persons on the Site at any one time varies with the time of day, staffing requirements for current projects, and daily fluctuations in employee work attendance. 
There are currently no hospitals, nursing homes, or penal institutions in the Supply System's 16-km (10-mi) emergency pianning zone. The closest school to the CSB site is the Edwin Markham Elementary School with a 1995-1996 enrollment of 283 students. Evacuation of the Edwin Markham School and of the nearby Country Haven and Country Christen School is provided for in the Benton and Franklin Counties Fixed Nuclear Facility Emergency Response Plan.

\subsection{ENVIRONMENTAL DESCRIPTION}

The following sections address the meteorology, hydrology, and geology of the Hanford Site.

\subsubsection{Meteorology}

This section describes the regional climatology and the meteorological conditions of the Hanford Site. Climatological data are available for the HMS, which is located between the 200 East and 200 West Areas (Figure 1-9). Data have been collected at this location since 1945. Data from the HMS are representative of the general climatic conditions for the region and describe the specific climate of the 200 Area Plateau. Information contained in this section is taken primarily from PNL-10553, Climatological Data Summary 1994 with Historical Data (Hoitink and Burk 1995), and PNL-4622, Climatological Summary for the Hanford Area (Stone et a1. 1983).

A wide range of meteorological variables is measured at the HMS and at the 125-m (410-ft) tower, which is located $492 \mathrm{~m}(1,614 \mathrm{ft})$ east of the HMS. Temperature, relative humidity, precipitation, atmospheric pressure, solar radiation, cloud cover, visibility, and subsurface temperature are parameters measured or observed at the HMS. Wind data are measured at various levels on the $125-\mathrm{m}(410-\mathrm{ft})$ tower. Three $60-\mathrm{m}(200-\mathrm{ft})$ towers, with wind and temperature measuring instruments at various levels, are located at the 300 , 400 , and $100 \mathrm{~N}$ Areas. Wind and temperature measurements also are taken on $239.1-\mathrm{m}(30-\mathrm{ft})$ towers distributed on and around the Hanford Site (see Figure 1-9). Data from all towers are telemetered to the HMS. The Hanford Meteorological Monitoring Network is described in detail in PNL-6684, The Data Collection Component of the Hanford Meteorological Monitoring Program (Glantz and Is I am 1988).

1.4.1.1 Regional Climatology. The climate of the Pasco Basin, in which the CSB is located, can be classified as midlatitude semiarid or midlatitude desert, depending on the climatological classification scheme used. Summers are warm and dry with abundant sunshine. Large diurnal temperature variation results from intense solar heating during the day and radiational cooling at night. Daytime high temperatures in June, July, and August periodically exceed $38{ }^{\circ} \mathrm{C}\left(100^{\circ} \mathrm{F}\right)$. Winters are cool with occasional precipitation. Outbreaks of cold air associated with modified arctic air masses can reach the area and cause temperatures to drop below $-18{ }^{\circ} \mathrm{C}\left(0^{\circ} \mathrm{F}\right)$. Overcast skies and fog occur periodically during the winter season (Stone et al. 1983).

Topographic features have a significant impact on the climate of the Hanford Site. All air masses that reach the Pasco Basin undergo some modification as a result of their passage over the complex terrain of the 
Pacific Northwest. The climate of the Pasco Basin is strongly influenced by the Pacific Ocean and the Cascade Range to the west. The relatively low annual average rainfall of $16.8 \mathrm{~cm}$ (6.6 in.) at the HMS is caused largely by the rain shadow created by the Cascade Range. This mountain range limits much of the maritime influence of the Pacific ocean, resulting in a more continental-type climate than would exist if the range were not present. Maritime influences are experienced in the region during the passage of frontal systems and as a result of movement through the gaps in the Cascade Range (e.g., Columbia River Gorge).

The Rocky Mountains to the east and north of the Pasco Basin also influence the climate of the region. These mountains play a key role in protecting the region from the more severe winter storms and the extremely low temperatures associated with modified arctic air masses that move southward through Canada. The Yakima Ridge, Rattlesnake Hills, and Horse Heaven Hills to the west and south of the Hanford Site, the Saddle Mountains to the north, and the Columbia River also influence the local climate (see Figure 1-10).

The position of the jet stream directs storm systems into Washington State during the cooler months. These systems cause the majority of the precipitation at the Hanford Site. The cold, or occluded, fronts associated with these storm systems originate in maritime polar, continental polar, or arctic air masses. Warm fronts occur as warmer maritime air flows over colder continental air. An average of 10 identifiable warm fronts and 52 cold fronts pass through the Pasco Basin each year (Stone et al. 1983). A majority of these passages occur during the colder months leading to increased frequency and intensity of precipitation. Periodic persistent high-pressure ridges in the upper troposphere in the cool season, which can trap cold air near the surface, lead to extended periods of wintertime stagnation.

The jet stream directs most storms north of the state of Washington during the warmer months; therefore, frontal passages are fewer and weaker than in the cooler months. High pressure with stable, subsiding air is the dominant meteorological condition during this period. Warm weather precipitation tends to be associated with convective activity and the advection of moist, maritime air into the region (Stone et a1. 1983).

1.4.1.1.1 Temperature. Monthly and annual daily average and extreme temperatures for the Hanford Site from 1961 through 1990 are given in Table 1-2. At the Hanford Site, the annual average temperature is $12{ }^{\circ} \mathrm{C}$ (53 ${ }^{\circ} \mathrm{F}$ ) (Hoitink and Burk 1995). July is typically the warmest month with an average maximum temperature of $33^{\circ} \mathrm{C}\left(91^{\circ} \mathrm{F}\right)$, an average minimum temperature of $16^{\circ} \mathrm{C}\left(61^{\circ} \mathrm{F}\right)$, and an average temperature of $25^{\circ} \mathrm{C}\left(76^{\circ} \mathrm{F}\right)$. January tends to be the coolest month with an average maximum temperature of $4^{\circ} \mathrm{C}\left(38^{\circ} \mathrm{F}\right)$, an average minimum temperature of $-4{ }^{\circ} \mathrm{C}\left(24^{\circ} \mathrm{F}\right)$, and an average temperature of $0{ }^{\circ} \mathrm{C}\left(32^{\circ} \mathrm{F}\right)$. Observed temperature extremes for the Hanford Site range from $45{ }^{\circ} \mathrm{C}\left(113{ }^{\circ} \mathrm{F}\right)$ to $-31{ }^{\circ} \mathrm{C}\left(-23^{\circ} \mathrm{F}\right)$. The highest temperature ever recorded on the Hanford Site was $46^{\circ} \mathrm{C}\left(115^{\circ} \mathrm{F}\right)$ on Ju1y 27,1939 . The lowest temperature ever recorded on the Hanford Site was $-33{ }^{\circ} \mathrm{C}\left(-27{ }^{\circ} \mathrm{F}\right)$ on December 12,1919 . These temperatures were recorded before the HMS was operational and are not included in Table 1-2. 
Table 1-2. Monthly and Annual Daily Average and Extreme Temperatures at the Hanford Meteorological Station.

\begin{tabular}{|l|c|c|c|c|c|}
\hline \multirow{3}{*}{ Month } & \multicolumn{3}{|c|}{$\begin{array}{c}\text { Average daily temperature, } \\
\text { 1961-1990 } \\
\left({ }^{\circ} \mathrm{F}\right)\end{array}$} & \multicolumn{2}{c|}{$\begin{array}{c}\text { Extreme temperature, } \\
1945-1994 \\
\left({ }^{\circ} \mathrm{F}\right)\end{array}$} \\
\cline { 2 - 6 } & Maximum & Minimum & Monthly & Maximum & Minimum \\
\hline January & 38 & 24 & 31 & 72 & -22 \\
\hline February & 47 & 29 & 38 & 72 & -23 \\
\hline March & 57 & 34 & 46 & 83 & 6 \\
\hline Apri1 & 66 & 40 & 53 & 94 & 21 \\
\hline May & 75 & 47 & 61 & 104 & 28 \\
\hline June & 84 & 55 & 70 & 111 & 37 \\
\hline July & 91 & 61 & 76 & 111 & 39 \\
\hline August & 90 & 60 & 75 & 113 & 41 \\
\hline September & 80 & 51 & 66 & 106 & 30 \\
\hline October & 66 & 40 & 53 & 89 & 12 \\
\hline November & 49 & 32 & 40 & 75 & -13 \\
\hline December & 38 & 25 & 31 & 69 & -14 \\
\hline Year & & & 53 & 113 & -23 \\
\hline
\end{tabular}

Note: Information in this table is from D. J. Hoitink and K. W. Burk, 1995, Climatological Data Summary 1994, with Historical Data, PNL-10553, Pacific Northwest Laboratory, Richland, Washington.

Table 1-3 shows the number of days per month averaged over the period 1945 through 1994 that the Hanford Site maximum and minimum temperatures were above or below specified values (Hoitink and Burk 1995). Maximum temperatures greater than or equal to $38^{\circ} \mathrm{C}\left(100^{\circ} \mathrm{F}\right)$ occur an average of 11 days a year and vary from 1 to 28 days. Maximum temperatures greater than or equal to $32{ }^{\circ} \mathrm{C}\left(90^{\circ} \mathrm{F}\right)$ occur an average of 51 days per year and vary from a low of 29 to a high of 79 days. Maximum temperatures less than or equal to $0{ }^{\circ} \mathrm{C}$ $\left(32{ }^{\circ} \mathrm{F}\right)$ occur an average of 25 days a year and vary from 2 to 58 days. Minimum temperatures less than or equal to $0{ }^{\circ} \mathrm{C}\left(32{ }^{\circ} \mathrm{F}\right)$ occur an average of 107 days per year and vary from a low of 70 to a high of 143 days. Minimum temperatures less than or equal to $-18{ }^{\circ} \mathrm{C}\left(0{ }^{\circ} \mathrm{F}\right)$ occur an average of 3 days per year and vary from 0 to 18 days. An average of 183 days a year are free of freezing temperatures, with the recorded range being 142 to 216 days. 
Table 1-3. Average Number of Days at the Hanford Meteorological Station that Maximum and Minimum Temperatures were above or below Specified Limits for the Period 1945 through 1994.

\begin{tabular}{|l|c|c|c|c|c|}
\hline \multirow{2}{*}{ Month } & \multicolumn{3}{|c|}{ Maximum temperature } & \multicolumn{2}{c|}{ Minimum temperature } \\
\cline { 2 - 6 } & $\geq 100^{\circ} \mathrm{F}$ & $\geq 90^{\circ} \mathrm{F}$ & $\leq 32^{\circ} \mathrm{F}$ & $\leq 32^{\circ} \mathrm{F}$ & $\leq 0{ }^{\circ} \mathrm{F}$ \\
\hline January & 0 & 0 & 11 & 26 & 2 \\
\hline February & 0 & 0 & 3 & 20 & $*$ \\
\hline March & 0 & 0 & ${ }^{*}$ & 14 & 0 \\
\hline Apri1 & 0 & $*$ & 0 & 4 & 0 \\
\hline May & $\star$ & 3 & 0 & $*$ & 0 \\
\hline June & 1 & 8 & 0 & 0 & 0 \\
\hline July & 6 & 19 & 0 & 0 & 0 \\
\hline August & 4 & 16 & 0 & 0 & 0 \\
\hline September & $\star$ & 5 & 0 & $*$ & 0 \\
\hline October & 0 & $*$ & $*$ & 4 & 0 \\
\hline November & 0 & 0 & 2 & 15 & $*$ \\
\hline December & 0 & 0 & 9 & 24 & 1 \\
\hline Year & 11 & 51 & 25 & 107 & 3 \\
\hline
\end{tabular}

Note: Information in this table is from D. J. Hoitink and K. W. Burk, 1995, Climatological Data Sumary 1994, with Historical Date, PNL-10553, Pacific Northwest National Laboratory, Richland, Washington.

*0enotes less than half a day.

The Hanford Site and vicinity are known for severe and abrupt temperature changes. During winter the Site frequently experiences rapid rises in temperature accompanied by moderate west winds. This phenomenon, known as a chinook wind, has produced temperature variations of up to $6{ }^{\circ} \mathrm{C}\left(22{ }^{\circ} \mathrm{F}\right)$ in 0.5 hours and is responsible for rapid melting of snow (DOE 1987).

1.4.1.1.2 Precipitation. The annual average precipitation value at the HMS is $16.8 \mathrm{~cm}(6.6 \mathrm{in}$.) with the annual precipitation value for the wettest documented year (1950) being $29.1 \mathrm{~cm}(11.45 \mathrm{in.}$ ) and for the driest year (1976) being $7.6 \mathrm{~cm}$ (2.99 in.) (Hoitink and Burk 1995). An unpublished record precipitation of $31.3 \mathrm{~cm}$ (12.3 in.) occurred in 1995 at the HMS. Monthly averaged and extreme precipitation amounts for the Hanford Site from 1945 through 1994 are given in Table 1-4. On average, 54\% of normal annual precipitation falis during November through February. December is the wettest month, receiving $2.6 \mathrm{~cm}$ (1.03 in.), and July is the driest month, receiving only $0.46 \mathrm{~cm}(0.18 \mathrm{in}$.$) . The wettest month on record is June 1950$ with $7.4 \mathrm{~cm}$ (2.92 in.); September 1991, August 1988, and August 1955 recorded no precipitation. An average of 125 days per year have a trace (less than $0.013 \mathrm{~cm}[0.005 \mathrm{in.}])$ or more of precipitation. The average number of days per month with a trace or more ranges from 16 days in January to 5 days in July. Only 24 days a year receive totals of $0.25 \mathrm{~cm}(0.1$ in.) or more. During the 49-year period of record (1945 through 1994), only 3 days have had $2.5 \mathrm{~cm}$ (1 in.) or more of precipitation. 
Table 1-4. Monthly and Annual Average and Extreme Precipitation in Inches at the Hanford Meteorological Station for the Period 1945 through 1994.

\begin{tabular}{|l|c|c|c|c|c|}
\hline \multicolumn{1}{|c|}{ Month } & Average & Maximum & Year & Minimum & Year \\
\hline January & 0.88 & 2.47 & 1970 & 0.08 & 1977 \\
\hline February & 0.62 & 2.10 & 1961 & $\mathrm{~T}^{*}$ & 1988 \\
\hline March & 0.49 & 1.86 & 1957 & 0.02 & 1968 \\
\hline April & 0.44 & 1.22 & 1969 & $\mathrm{~T}^{*}$ & 1986 \\
\hline May & 0.52 & 2.03 & 1972 & $\mathrm{~T}$ & 1992 \\
\hline June & 0.54 & 2.92 & 1950 & $\mathrm{~T}^{*}$ & 1986 \\
\hline JuTy & 0.22 & 1.76 & 1993 & $\mathrm{~T}^{*}$ & 1980 \\
\hline August & 0.25 & 1.36 & 1977 & $0^{*}$ & 1988 \\
\hline September & 0.31 & 1.34 & 1947 & 0 & 1991 \\
\hline October & 0.52 & 2.72 & 1957 & $\mathrm{~T}^{*}$ & 1987 \\
\hline November & 0.86 & 2.64 & 1973 & $\mathrm{~T}$ & 1976 \\
\hline December & 0.95 & 2.34 & 1964 & 0.11 & 1976 \\
\hline Year & 6.61 & 11.45 & 1950 & 2.99 & 1976 \\
\hline
\end{tabular}

Notes: Information in this table is from D. J. Hoitink and K. W. Burk, 1995, Climatological Data Sumary 1994, with Historical Data, PNL-10553, Pacific Northwest Laboratory, Richlond, Hashington.

* Host recent of multiple occurrences.

$T=$ trace $(0.005$ in. or less $)$.

A recent cooperative study by the National Oceanic and Atmospheric Administration, the Bureau of Reclamation, and the U.S. Army Corps of Engineers has updated the probable maximum precipitation (PMP) estimates for the Pacific Northwest (Hansen et a1. 1994). This document supersedes earlier work done by these organizations and is the source used for the PMP shown in Table 1-5. The PMP values are estimates of the maximum precipitation physically possible for both general storms (large air mass interactions) and local storms (unstable air, thunderstorms). At the Hanford Site the 6-hour local storm produces more precipitation than the 24-hour general storm. The 6-hour local storm PMP is related to the area of the storm, the smaller area yielding the most intense storm and highest precipitation. Data are presented for the $1-\mathrm{mi}^{2}$ and the $10-\mathrm{mi}^{2}$ storm. The CSB will be designed to accommodate the full range of PMP identified in Table 1-5. The effects of local PMP will be determined according to ANSI/ANS-2.8-1992 (ANSI/ANS 1992). Local

protection for run-off will be provided by earthwork and grading design and by the storm drain system consisting of culverts, ditches, channels, and catch basins as required. These features will not impact the below-grade portion of the CSB. No annual probability of exceedance is given in Hydrometeorological Report No. 57, Probable Maximum Precipitation-Pacific Northwest States (Hansen et al. 1994), for the PMP for either general or local storms. The PMP is conservatively assumed to have an annual probability of exceedance of less than $1 \times 10^{-6}$ (ASCE 1988). 


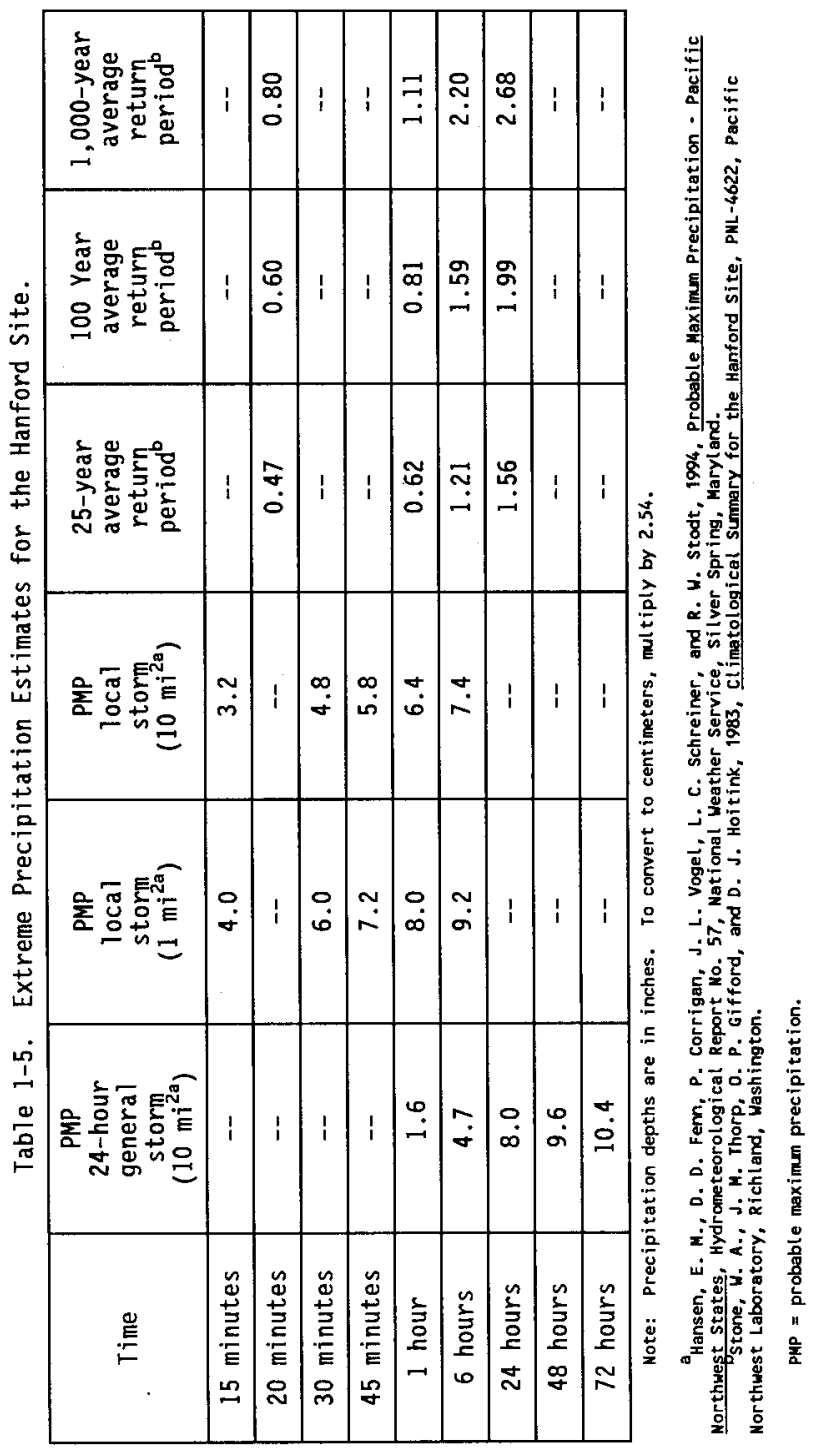


The 6-hour PMP for more frequent storms shown in Table 1-5 is from PNL-4622 (Stone et a1. 1983) and is based on the analysis of extreme values from 22 years of meteorological data from the Hanford Site. The precipitation estimates for the 100- and 1,000-year return period are based on data from the HMS. Although these values cannot be compared directly with either the $1-\mathrm{mi}^{2}$ storm or the 10-mi ${ }^{2}$ storm, they provide a data-based estimate for extreme precipitation on the 200 Area Plateau. A 6-hour precipitation hazard curve is estimated using the 100-year and 1,000-year average return period values $\left(10^{-2}\right.$ and $10^{-3}$ annual probability of exceedance respectively) of PNL-4622

(Stone et al. 1983) and the 6-hour PMP at an assumed frequency of $10^{-6}$ (Figure 1-11).

Total annual snowfall, which includes all frozen precipitation, varied for the period 1945 through 1994 from a low of $0.76 \mathrm{~cm}(0.3 \mathrm{in}$.) to a high of $142 \mathrm{~cm}$ (56.l in.) (Hoitink and Burk 1995). The average snowfall is $38 \mathrm{~cm}$ (15 in.) a year. Table 1-6 presents the monthly and annual average and extreme snowfalls. The record snow depth at the HMS is $39.6 \mathrm{~cm}$ (15.6 in.) in December 1995, but the record snow depth on the Hanford Site is $61 \mathrm{~cm}$ (24 in.) in February 1916. The record number of days with snow depth greater than or equal to $15.2 \mathrm{~cm}$ ( $6 \mathrm{in}$.$) is 43$ days in the winter of 1992-1993. The probability the depth of snow on the ground will not exceed $15 \mathrm{~cm}$ (6 in.) is $30 \%$ during the winter season (Figure 1-12).

The design ground snow load for the CSB is $98 \mathrm{~kg} / \mathrm{m}^{2}\left(20 \mathrm{lb} / \mathrm{ft}^{2}\right)$, which is the ground snow load for the NRC-1 icensed WNP-2. This value is $24 \mathrm{~kg} / \mathrm{m}^{2}$ $\left(5 \mathrm{lb} / \mathrm{ft}^{2}\right.$ ) greater than the ASCE requirement (ASCE 1993).

Glaze ice is a coating of ice formed when rain or drizzle freezes on contact with any surface having a temperature that is below freezing. The average number of days with freezing rain or freezing drizzle is six and they generally occur between November and March. The highest number of days with glaze in any winter season was 18 . The least number of days with glaze in any winter season was one. The greatest number of days with glaze in any given month was nine, in January 1970. Rime ice (i.e., supercooled droplets that freeze on contact with solid objects) is generaliy associated with supercooled fog in the nearby hills or along the banks of the Columbia River.

1.4.1.1.3 Thunderstorms. A thunderstorm day is one in which thunder is heard at the observing station one or more times during a calendar day. Table 1-7 shows the number of thunderstorm days per month and per year for the period 1945 through 1994. The average number of thunderstorm days per year is 10. The total varies from a low of 3 to a high of 23 days (Hoitink and Burk 1995). The largest number of thunderstorm days in a single month was eight. Thunderstorms can theoretically occur during any month of the year, but none have been observed in November or January. Thunderstorm season is essentially from April through September.

Thunderstorms are classified by the National Weather Service as severe when wind gusts exceed $93 \mathrm{~km} / \mathrm{h}(58 \mathrm{mi} / \mathrm{h})$ and/or hail size equals or exceeds $2 \mathrm{~cm}$ (1 in.) in diameter. Only $1.9 \%$ of all thunderstorm events observed at the HMS have been severe storms (Cushing 1995). All severe storms met the wind gust criteria, but hail was seldom observed at the HMS. The maximum recorded number of days with hail in a year is two. 
Table 1-6. Monthly and Seasonal Snowfall at the Hanford Meteorological Station in Inches, Average and Maximum for the Period 1945 through 1994.

\begin{tabular}{|l|c|c|c|c|c|}
\hline \multicolumn{1}{|c|}{ Month } & Average & Maximum & Year & $\begin{array}{c}\text { Maximum } \\
24-\text { hour }\end{array}$ & Year \\
\hline January & 5.0 & 23.4 & 1950 & 7.1 & 1954 \\
\hline February & 2.5 & 17.0 & 1989 & 10.2 & 1993 \\
\hline March & 0.5 & 4.2 & 1951 & 2.7 & 1989 \\
\hline Apri1 & $T$ & 1.0 & 1982 & $*$ & -- \\
\hline May & 0 & 0 & -- & 0 & -- \\
\hline June & 0 & 0 & -- & 0 & -- \\
\hline JuTy & 0 & 0 & -- & 0 & -- \\
\hline August & 0 & 0 & -- & 0 & -- \\
\hline September & 0 & 0 & -- & 0 & -- \\
\hline October & 0.1 & 1.5 & 1973 & 1.5 & 1973 \\
\hline November & 1.5 & 18.3 & 1985 & 8.8 & 1985 \\
\hline December & 5.3 & 21.0 & 1992 & 6.6 & 1985 \\
\hline Year & 15 & 56.1 & $1992-93$ & 10.2 & February 1993 \\
\hline
\end{tabular}

Notes: Information in this table is from D. J. Hoitink and K. W. Burk, 1995, Climatological Data Sumary 1994, with Historical Data, PNL-10553, Pacific Northwest National Laboratory, Richland, Washington.

*No value given for maximum 24-hour snowfall. 
Table 1-7. Average Number of Thunderstorm Days at the Hanford Meteorological Station for the Period 1945 through 1994.

\begin{tabular}{|l|c|}
\hline \multicolumn{1}{|c|}{ Month } & Thunderstorm Days \\
\hline January & 0 \\
\hline February & $\leq 0.1$ \\
\hline March & 0.2 \\
\hline Apri1 & 0.8 \\
\hline May & 1.6 \\
\hline June & 2.4 \\
\hline July & 2.0 \\
\hline August & 2.1 \\
\hline September & 0.8 \\
\hline October & 0.2 \\
\hline November & 0 \\
\hline December & $\leq 0.1$ \\
\hline Year & 10.1 \\
\hline
\end{tabular}

Note: Information in this table is from D. J. Hoitink and

K. W. Burk, 1995, Climatological Data Summary 1994, with Historical Data, PNL-10553, Pacific Northwest National Laboratory, Richland, Washington.

1.4.1.1.4 Extreme Winds and Tornados. Table 1-8 shows the maximum recorded peak gusts at the HMS for the period 1945 through 1994 . The highest peak gust measured at the $15-\mathrm{m}(50-\mathrm{ft})$ height was $129 \mathrm{~m} / \mathrm{sec}(80 \mathrm{mi} / \mathrm{h})$ in January 1972 (Hoitink and Burk 1995). Estimates of extreme winds, based on peak gusts observed from 1945 through 1980, are given in PNL-4622 (Stone et al. 1983). The extreme peak gust at $15 \mathrm{~m}(50 \mathrm{ft})$ for a return period of 100 years is estimated to be $137 \mathrm{~km} / \mathrm{h}(86 \mathrm{mi} / \mathrm{h})$. The return period on gusts of $114 \mathrm{~km} / \mathrm{h}(70 \mathrm{mi} / \mathrm{h})$ at $15 \mathrm{~m}(50 \mathrm{ft})$ is 10 years.

Two probabilistic wind hazard assessments have been completed for the Hanford Site. The first assessment was completed by Lawrence Livermore National Laboratory and reported in UCRL-53526, Natural Phenomena Hazards Modeling Project: Extreme Wind/Tornado Hazard Models for Department of Energy Sites (Coats and Murray 1985). This assessment was based on more than 30 years of pre-1979 Hanford Site wind data. The results are shown in Figure 1-13. The wind speeds are fastest mile and therefore, for an equivalent probability, considerably lower than the peak gusts illustrated in Table 1-8. Further, the hazard curves are based on winds at $9 \mathrm{~m}(30 \mathrm{ft})$ above ground surface and the peak gusts in Table $1-8$ were measured at $15 \mathrm{~m}(50 \mathrm{ft}$ ) above ground surface. Wind speed increases with distance above ground surface. A second study, NUREG/CR-4492, Methodology for Est imating Extreme Winds for Probabilistic Risk Assessments (Ramsdell et a1. 1986), describes a procedure for estimating extreme wind probabilities. The application of this methodology to Hanford Site data, including post-1979 data, resulted in hazard curves also shown in Figure 1-13. 
Table 1-8. Maximum Peak Gusts 15 Meters (50 Feet) off the Ground at the Hanford Meteorological Station

for the Period 1945 through 1994.

\begin{tabular}{|l|c|c|c|}
\hline \multicolumn{1}{|c|}{ Month } & $\begin{array}{c}\text { Peak gust } \\
\text { speed }\end{array}$ & $\begin{array}{c}\text { Direction of } \\
\text { peak }\end{array}$ & Year \\
\hline January & 80 & SW & 1972 \\
\hline February & 65 & SW & 1971 \\
\hline March & 70 & SW & 1956 \\
\hline April & 73 & SSW & 1972 \\
\hline May & 71 & SSW & 1948 \\
\hline June & 72 & SW & 1957 \\
\hline JuTy & 69 & WSW & 1979 \\
\hline August & 66 & SW & 1961 \\
\hline September & 65 & SSW & 1953 \\
\hline October & 63 & SSW & 1950 \\
\hline November & 67 & WSW & 1993 \\
\hline December & 71 & SW & 1955 \\
\hline Year & 80 & SW & January 1972 \\
\hline
\end{tabular}

Note: Information in this table is from D. J. Hoitink and K. W. Burk, 1995, Climatological Data Sumbry 1994, with Mistorical Data, PNL-10553, Pacific Northwest National Laboratory, Richland, Washington.

The wind hazard annual probability of exceedance for performance categories 1 and 2 is $2 \times 10^{-2}$ (DOE-STD-1020-94). On Figure 1-13, this is about $25 \mathrm{~m} / \mathrm{s}(55 \mathrm{mi} / \mathrm{h}$ ) on the Coats-and-Murray curve and about $26 \mathrm{~m} / \mathrm{s}$ ( $58 \mathrm{mi} / \mathrm{h}$ ) on the Ramsdell-et-al. curve. However, a minimum design wind speed of $31.3 \mathrm{~m} / \mathrm{s}(70 \mathrm{mi} / \mathrm{h})$ is required by the American Society of Civil Engineers in ASCE-7-93 (ASCE 1993) and recommended by DOE-STD-1020-94. Therefore, the Hanford Site design basis wind speed for performance categories 1 and 2 is $31.3 \mathrm{~m} / \mathrm{s}(70 \mathrm{mi} / \mathrm{h})$. All wind speeds are fastest mile speeds at $9 \mathrm{~m}(30 \mathrm{ft})$ off the ground.

The straight wind hazard exceedance probability for performance category 3 is $1 \times 10^{-3}$. On Figure $1-13$, this is approximately $30 \mathrm{~m} / \mathrm{s}$ $(67 \mathrm{mi} / \mathrm{h})$ on the Coats-and-Murray curve and $32 \mathrm{~m} / \mathrm{s}(72 \mathrm{mi} / \mathrm{h})$ on the Ramsde11-et-a1. curve. In DOE-STD-1020-94, the minimum straight wind speed for a performance category 3 design is $35.8 \mathrm{~m} / \mathrm{s}(80 \mathrm{mi} / \mathrm{h})$, which is higher than either of the wind hazard studies and is, therefore, the design basis for the Hanford Site.

The intersection of the straight-wind and tornado hazard curves determines whether tornadoes should be included in the design and evaluation criteria for DOE facilities, including the CSB (Coats and Murray 1985). 
If the exceedance probability at the intersection is less than $2 \times 10^{-5}$, straight winds control the design criteria. In Figure 1-13, the intersection is at $3 \times 10^{-6}$ on the Coats-and-Murray curve and $8 \times 10^{-6}$ on the Ramsdell-et-a7. curve. Therefore, following DOE guidance, the Hanford Site does not have a DOE design basis tornado.

The NRC tornado criteria will be followed at the CSB. This will be achieved by following the same requirement as the Supply System. The NRC staff have proposed dividing the United States into two regions and making the total rotational and translational wind speeds for sites west of the Rocky Mountains $322 \mathrm{~km} / \mathrm{h}(200 \mathrm{mi} / \mathrm{h})$ (NRC 1993). The basis for this consideration is a tornado hazards study, NUREG/CR-4461, Tornado Climatology of the Contiguous United States (Ramsdel1 and Andrews 1986). The Supply System requested a revision of the tornado criteria for WNP-2 (Parrish 1995) based upon the NRC staff's proposal for tornado wind speeds west of the Rocky Mountains and on the staff's acceptance of the design basis tornado characteristics in NUREG-1503, Final Safety Evaluation Report Related to the Certification of the Advanced Boiling Water Reactor Design (NRC 1994). The NRC accepted the proposed revision (Clifford 1996). These same criteria will be applied to the CSB:

- Wind speed

$$
\begin{aligned}
& -322 \mathrm{~km} / \mathrm{h}(200 \mathrm{mi} / \mathrm{h}) \text { total } \\
& -257 \mathrm{~km} / \mathrm{h}(160 \mathrm{mi} / \mathrm{h}) \text { rotational } \\
& \text { - } 64 \mathrm{~km} / \mathrm{h}(40 \mathrm{mi} / \mathrm{h}) \text { translational }
\end{aligned}
$$

- Pressure drop

$$
\text { - 6,205 Pa }\left(0.90 \mathrm{lb} / \mathrm{in}^{2}\right) \text { at } 2,068 \mathrm{~Pa} / \mathrm{s}\left(0.30 \mathrm{lb} / \mathrm{in}^{2} / \mathrm{s}\right)
$$

For the CSB the need for protection of specific targets is addressed on a risk assessment basis. By this process, an estimate is made of the probability that a tornado-generated missile will strike a particular target and fail the target in such a way that unacceptable consequences result. If the probability obtained of a missile striking and failing a target, or simply striking the target, satisfies established acceptance criteria, then no physical barriers against missiles need be provided.

The use of probabilistic risk assessment techniques to establish the need to provide tornado-generated missile protection for specific targets has been accepted by the NRC for several years and is well documented in their review and design guidance. For example, the NRC Standard Review Plan (NRC 1981), Section 3.5.1.5, "Site Proximity Missiles (Except Aircraft)," includes the following statement relative to low risk of exposure to the public.

This requirement is met if the probability of site proximity missiles impacting the plant and causing radiological consequences greater than 10 CFR Part 100 exposure guidelines is less than about $10^{-7}$ per year (see SRP Section 2.2.3).

The NRC Standard Review Plan (NRC 1981), Section 2.2.3, "Evaluation of Potential Accidents, " accepts $10^{-6}$ events/yr for offsite hazards exceeding the 
guidelines in Title 10, Code of Federal Regulations, Part 100, "Reactor Site Criteria" (10 CFR 100), if, when accompanied by reasonable qualitative arguments, the realistic value can be shown to be lower. These provisions have remained in the 1996 draft revision to Standard Review Plan 2.2.3. For the CSB, an acceptance criterion to not exceed the 5 rem ( $50 \mathrm{mSv}$ ) 1 imit of 10 CFR 72.106 at the controlled area boundary should be used.

The probability of a tornado occurring near the site and generating a missile that results in acceptable consequences can be expressed as follows:

$$
P_{T M}=P_{S} \times P_{m s} \times P_{F} \times P_{D}
$$

where

$$
\begin{aligned}
& P_{T M}=\text { The annual probability of a tornado missile striking such that an } \\
& P_{s}=\text { The tornado annual point strike frequency (events/yr) } \\
& P_{m s}=\text { The probability of a tornado-generated missile impacting a specific }
\end{aligned}
$$

The above expression is simplified in that the analyses are usually performed for a range of tornado intensities and potential missiles. The tornado intensities considered are based upon available local severe weather data. The missiles considered vary in terms of their density on the site, abjlity to be lifted by a tornado of a given intensity, and ability to damage the target. The missiles appropriate for consideration are often established by a site survey with a radius of about $600 \mathrm{~m}(2,000 \mathrm{ft})$.

It should be noted in the above equation that the missile selection is based upon identification of potential missiles based upon a site survey. The results of the tornado missile risk assessment for the CSB are provided in Letter FRF-2855, Tornado Loading Design Criteria - Revised (Jacobs 1996). This assessment has been accepted by DOF (Sellers 1996\%). The estimated frequency for a missile strike on the CSB is $4 \times 10^{-9}$ events $/ y r$, which is well below the NRC criterion of $1 \times 10^{-6}$ events/yr.

The ability of the CSB to withstand the tornado loadings is addressed in Section 4.3.

1.4.1.1.5 Dust and Blowing Dust. Dust and blowing dust are weather phenomena that occur with some frequency at the Hanford Site. Dust and 
blowing dust are recorded at the HMS when horizonal visibility is reduced to $9.65 \mathrm{~km}(6 \mathrm{mi})$ or less. Dust is carried into the area from distant sources and may or may not occur during strong winds. Dust has been observed with wind speeds ranging from $1.8 \mathrm{~m} / \mathrm{s}(4 \mathrm{mi} / \mathrm{h})$ to $13.4 \mathrm{~m} / \mathrm{s}(30 \mathrm{mi} / \mathrm{h})$. Blowing dust occurs when dust is being picked up locally and occurs with strong winds. Blowing dust has been observed with wind speeds ranging from $8.5 \mathrm{~m} / \mathrm{s}(19 \mathrm{mi} / \mathrm{h})$ to $35.8 \mathrm{~m} / \mathrm{s}(80 \mathrm{mi} / \mathrm{h})$. While both dust and blowing dust occur at the HMS, blowing dust is the most commonly observed.

Table 1-9 shows the average number of days of recorded dust or blowing dust for the period 1945 through 1994. The average number of days per year with dust or blowing dust is five. The greatest number of such days in any year is 20, while the fewest is 0 . The greatest number of days with dust or blowing dust in any month was nine in May 1980. Dust and blowing dust occur most frequentiy between March and May and again in September and occur least frequently during November and December.

Table 1-9. Average Number of Days of Dust or Blowing Dust at the Hanford Meteorological Station for the Period 1945 through 1994.

\begin{tabular}{|l|c|}
\hline \multicolumn{1}{|c|}{ Month } & $\begin{array}{c}\text { Days of dust or } \\
\text { blowing dust }\end{array}$ \\
\hline January & 0.4 \\
\hline February & 0.4 \\
\hline March & 0.5 \\
\hline April & 0.6 \\
\hline May & 0.7 \\
\hline June & 0.4 \\
\hline July & 0.4 \\
\hline August & 0.3 \\
\hline September & 0.5 \\
\hline October & 0.3 \\
\hline November & 0.2 \\
\hline December & 0.2 \\
\hline Year & 4.8 \\
\hline
\end{tabular}

Note: Information in this table is from D. J. Hoitink and K. W. Burk, 1995, Climatological Data Summary 1994, with Historical Data, PNL-10553, Pacific Northwest National Laboratory, Richland, Washington.

1.4.1.1.6 Fog and Sky Cover. Table 1-10 shows the average monthly and annual number of days with fog and dense fog for the period 1945 through 1994. Fog is reported any time horizontal visibility is reduced to $9.7 \mathrm{~km}$ ( $6 \mathrm{mi}$ ) or 
less because of suspension of water droplets in the surface layer of the atmosphere. Dense fog is reported when horizontal visibility is reduced to $0.40 \mathrm{~km}(0.25 \mathrm{mi})$ or less. Most of the fog at the HMS is radiation fog, a common type of fog that forms on nights characterized by light wind, clear sky, and moist air in the lower levels of the atmosphere. Nearly $90 \%$ of both fog and dense fog occur during the late autumn and winter months. The longest duration for fog on the Hanford Site was 114 hours in December 1985, and the longest duration for dense fog was 47 hours in December 1957.

Table 1-10. Monthiy and Annual Number of Days with Fog and Dense Fog at the Hanford Meteorological Station for the Period 1945 through 1994.

\begin{tabular}{|l|c|c|c|c|c|c|}
\hline \multirow{2}{*}{ Month } & \multicolumn{3}{|c|}{ Days with fog } & \multicolumn{3}{c|}{ Days with dense fog } \\
\cline { 2 - 7 } & Average & Maximum & Minimum & Average & Maximum & Minimum \\
\hline January & 11.2 & 25 & 0 & 6 & 15 & 0 \\
\hline February & 6.7 & 20 & 0 & 3.2 & 11 & 0 \\
\hline March & 2.1 & 10 & 0 & 0.9 & 5 & 0 \\
\hline Apri1 & 0.4 & 3 & 0 & 0.1 & 1 & 0 \\
\hline May & 0.2 & 3 & 0 & $<0.1$ & 1 & 0 \\
\hline June & 0.1 & 2 & 0 & $<0.1$ & 1 & 0 \\
\hline Ju1y & $<0.1$ & 1 & 0 & 0 & 0 & 0 \\
\hline August & 0.1 & 1 & 0 & $<0.1$ & 1 & 0 \\
\hline September & 0.3 & 2 & 0 & 0.1 & 1 & 0 \\
\hline October & 2.0 & 9 & 0 & 1.0 & 7 & 0 \\
\hline November & 9.5 & 19 & 0 & 5.3 & 13 & 0 \\
\hline December & 14.1 & 25 & 2 & 7.6 & 17 & 2 \\
\hline Year & 46.7 & 84 & 22 & 24.3 & 42 & 9 \\
\hline
\end{tabular}

Note: Information in this table is from D. J. Hoitink and K. W. Burk, 1995, Climatological Date Sumary 1994. with Historical Data, PNL-10553, Pacific Northwest National Laboratory, Richland, Washington.

\footnotetext{
${ }^{3}$ Horizontal visibility is reduced to $9.7 \mathrm{~km}(6 \mathrm{mi})$ or less.

Horizontal visibility is reduced to $0.40 \mathrm{~km}(0.25 \mathrm{mi})$ or less.
}

The term sky cover is used to express the portion of the celestial dome that is (1) covered, but not necessarily hidden by clouds or obscuring phenomena aloft; (2) hidden by an obscuring phenomenon on the ground (e.g., fog, smoke); or (3) a combination of (1) and (2). Sky cover is then determined hourly by scanning the sky and estimating the number of tenths that are covered (zero denotes clear sky and ten denotes overcast). Each day can be assigned a designation depending upon the average sky cover from sunrise to sunset. The designations are clear (zero to three tenths), partly cloudy (four to seven tenths), and cloudy (eight to ten tenths). Table 1-11 shows 
the average monthly sunrise to sunset sky values from 1946 through 1994 and the number of days of clear, partly cloudy, and cloudy days for the years 1956 to 1994. During the period of record (1954 through 1994), an average of 199 sunny days (sum of clear and partly cloudy days) were recorded per year at the HMS.

Table 1-11. Average Sky Cover (Sunrise to Sunset) for the Period 1946 through 1994 and Number of Clear, Partly Cloudy, and Cloudy Days for the Period 1954 through 1994 at the Hanford Meteorological Station.

\begin{tabular}{|l|c|c|c|c|c|c|}
\hline \multirow{2}{*}{ Month } & \multicolumn{2}{|c|}{$\begin{array}{c}\text { Average sky cover } \\
\text { (in tenths) }\end{array}$} & $\begin{array}{c}\text { Number of } \\
\text { clear days }\end{array}$ & $\begin{array}{c}\text { Number of } \\
\text { partly } \\
\text { cloudy days }\end{array}$ & $\begin{array}{c}\text { Number of } \\
\text { cloudy days }\end{array}$ \\
\cline { 2 - 7 } & Average & Maximum & Minimum & Average & Average & Average \\
\hline January & 8.0 & 9.2 & 4.3 & 3 & 5 & 22 \\
\hline February & 7.6 & 9.3 & 6.1 & 4 & 5 & 19 \\
\hline March & 6.8 & 8.5 & 4.9 & 6 & 8 & 17 \\
\hline Apri1 & 6.4 & 8.1 & 3.7 & 6 & 9 & 15 \\
\hline May & 5.9 & 8.1 & 3.6 & 8 & 11 & 12 \\
\hline June & 5.2 & 7.0 & 2.8 & 10 & 11 & 10 \\
\hline July & 3.1 & 5.0 & 0.9 & 19 & 7 & 5 \\
\hline August & 3.3 & 5.9 & 0.6 & 18 & 8 & 5 \\
\hline September & 3.9 & 6.7 & 1.4 & 15 & 8 & 7 \\
\hline October & 5.7 & 8.0 & 3.3 & 10 & 8 & 13 \\
\hline November & 7.5 & 9.1 & 5.2 & 5 & 6 & 20 \\
\hline December & 8 & 9.3 & 6.4 & 4 & 4 & 23 \\
\hline Year & 5.9 & 6.6 & 5.1 & 110 & 89 & 166 \\
\hline
\end{tabular}

Note: Information in this table is from D. J. Hoitink and K. W. Burk, 1995, Cl imatological Data Sumary 1994, with Historical Data, PNL-10553, Pacific Morthwest National Laboratory, Richland, Washington.

1.4.1.1.7 Relative Humidity. The annual mean relative humidity recorded at the HMS is $54 \%$, with the highest average monthly relative humidity ( $80 \%$ ) occurring in December and the lowest average monthly relative humidity (33\%) occurring in July. Daily relative humidity can change $20 \%$ to $30 \%$ between early morning and late afternoon, except for the winter months when changes are less pronounced (Stone et al. 1983). Higher relative humidity can be expected at locations near the Columbia River and at some locations on the Site periphery where there is increased airborne water vapor from the Columbia River, Yakima River, and irrigated land. 
1.4.1.1.8 Dispersion Climatology. Atmospheric dispersion is a function of wind speed, duration and direction of wind, atmospheric stability, and mixing depth. Dispersion conditions are generally favorable if winds are moderate to strong, if the atmosphere is of neutral or unstable stratification, and if there is a deep mixing layer. These conditions exist more than half the time at the Hanford Site in the summer. A less favorable dispersion condition may occur when the wind speed is light and the mixing Tayer is shallow. This condition is most common in the winter when moderately to extremely stable stratification exists about two-thirds of the time (Cushing 1995). Less favorable dispersion conditions also occur periodically for surface and low-level releases in all seasons from about sunset to about an hour after sunrise as a result of ground-based temperature inversions and shallow mixing layers.

Mixing layers at the HMS are estimated remotely using a Doppler acoustic sounder. Variations in the mixing layer are summarized in Table 1-12. The shallowest mixing layers are usually found in the nighttime during the winter months. Mixing layers are usually larger in the daytime during the summer months.

Table 1-12. Percent Frequency of Occurrence of Mixing Layer Thickness by Season and Time of Day at the Hanford Site.

\begin{tabular}{|l|c|c|c|c|}
\hline \multirow{2}{*}{\begin{tabular}{c} 
Mixing layer \\
\cline { 2 - 5 }
\end{tabular}} & \multicolumn{2}{|c|}{ Winter } & \multicolumn{2}{c|}{ Summer } \\
\cline { 2 - 5 } & Night & Day & Night & Day \\
\hline$<250$ & 65.7 & 35.0 & 48.5 & 1.2 \\
\hline $250-500$ & 24.7 & 39.8 & 37.1 & 9.0 \\
\hline$>500$ & 9.6 & 25.2 & 14.4 & 89.9 \\
\hline
\end{tabular}

Note: Information in this table is from C. E. Cushing, 1995, Hanford site National

Environmental Policy Act (HEPA) Characterization, PNL-6415, Rev. 7, Pacific Nor thwest Laboratory, Richland, Hashington.

Low-level inversions can also be associated with stagnant air in stationary high-pressure systems that occur primarily in the winter months. The probability of extended periods of low-level inversions is estimated in BNWL-1605, Climatography of the Hanford Area (Stone et a1. 1972). The probability of an inversion period extending more than 12 hours varies from a low of about $10 \%$ in May and June to a high of about $64 \%$ in September and october. These probabilities decrease rapidly for durations of greater than 12 hours. Table 1-13 summarizes the probabilities associated with extended surface-based inversions. 
Table 1-13. Percent Probabilities for Extended Periods of Surface-Based Inversions at the Hanford Site.

\begin{tabular}{|l|c|c|c|}
\hline \multirow{2}{*}{ Months } & \multicolumn{3}{|c|}{ Inversion duration } \\
\cline { 2 - 4 } & 12 hours & 24 hours & 48 hours \\
\hline January-February & 54.0 & 2.5 & 0.28 \\
\hline March-Apri1 & 50.0 & $<0.1$ & $<0.1$ \\
\hline May-June & 10.0 & $<0.1$ & $<0.1$ \\
\hline Ju1y-August & 18.0 & $<0.1$ & $<0.1$ \\
\hline September-October & 64.0 & 0.11 & $<0.1$ \\
\hline November-December & 50.0 & 1.2 & 0.13 \\
\hline
\end{tabular}

Note: Information in this table is from D. J. Hoitink and $K$. W. Burk, 1995 , Climatological Date Summary 1994. With Historical Data, PNL-10553, Pacific Northwest National Laboratory, Richland, Washington.

The joint frequency distribution of hourly averaged wind data from the 200 East Area meteorological tower for the 9-year period January 1982 to December 1991 are provided in Recommended Environmental Dose Calculation Methods and Hanford-Specific Parameters (Schreckhise et al. 1993) and are shown in Table 1-14. Stability class was determined using the method based on Pasquill (1961), which is a parameterization scheme based on time of year, time of day, wind speed, cloud cover, and visibility. Cloud cover and visibility were measured at the HMS, but should be representative of the 200 East Area. The percent frequency of occurrence of each of the stability classes for the 9-year period is given in Table 1-15. Stability Class D, relatively neutral dispersion conditions, occurred $28 \%$ of the time.

Conditions favorable for turbulent dispersion, represented by the unstable classes $A, B$, and $C$, occurred about $31 \%$ of the time. The stable classes, E, $F$, and $G$, indicative of conditions unfavorable for turbulent dispersion, occurred about $41 \%$ of the time.

A graphical representation of the joint frequency distribution data in the form of a wind rose and wind speed histogram is shown in Figure 1-14. The wind rose data indicate that winds from the west-northwest sector occur most frequently (nearly $20 \%$ of the time). That is, the emissions are transported toward the east-southeast sector. Winds out of the northwest and west also occur with a relatively high frequency $(12 \%$ and $11 \%$, respectively). For hours of unstable classes $A, B$, and $C$, wind directions from the west-northwest and northwest sectors occur more frequently than the other directions. Winds are more frequently from the west-northwest sector during stable conditions (classes E, F, and G). 
Table 1-14. Joint Frequency Distribution of Atmospheric Stability, Wind Direction, and Wind Speed at the 200 East Area. (3 sheets)

\begin{tabular}{|c|c|c|c|c|c|c|c|}
\hline \multirow{2}{*}{$\begin{array}{l}\text { Stability } \\
\text { class }\end{array}$} & \multirow{2}{*}{$\begin{array}{l}\text { Direction from which } \\
\text { the wind is blowing }\end{array}$} & \multicolumn{6}{|c|}{ Wind epeed claus (mi/h) } \\
\hline & & $1-3$ & $4 \cdot 7$ & $B-12$ & $13-18$ & $28-24$ & $>25$ \\
\hline A & North & 0.00008 & 0.00058 & 0.00008 & 0.00001 & 0.00000 & 0.00000 \\
\hline A & North-northesat & 0.00010 & 0.00070 & 0.00025 & 0.00003 & 0.00000 & 0.00000 \\
\hline A & Northeast & 0.00014 & 0.00073 & 0.00007 & 0.00003 & 0.00000 & 0.00000 \\
\hline A & East-northeast & 0.00012 & 0.00080 & 0.00007 & 0.00000 & 0.00000 & 0.00000 \\
\hline A & East & 0.00008 & 0.00066 & 0.00003 & 0.00000 & 0.00000 & 0.00000 \\
\hline A & East-sourtheast & 0.00014 & 0.00104 & 0.00006 & 0.00002 & 0.00000 & 0.00000 \\
\hline A & Southeast & 0.00004 & 0.00107 & 0.00029 & 0.00000 & 0.00000 & 0.00000 \\
\hline A & South-southeast & 0.00008 & 0.00082 & 0.00026 & 0.00006 & 0.00000 & 0.00000 \\
\hline A & South & 0.00009 & 0.00041 & 0.00010 & 0.00005 & 0.00000 & 0.00000 \\
\hline A & South-southwoet & 0.00004 & 0.00035 & 0.00009 & 0.00000 & 0.00000 & 0.00000 \\
\hline A & Southwest & 0.00005 & 0.00025 & 0.00017 & 0.00005 & 0.00002 & 0.00000 \\
\hline A & Wost-southwest & 0.00006 & 0.00026 & 0.00019 & 0.00020 & 0.00005 & 0.00001 \\
\hline A & Wost & 0.00006 & 0.00024 & 0.00011 & 0.00007 & 0.00001 & 0.00002 \\
\hline A & Wost-northwest & 0.00006 & 0.00033 & 0.00010 & 0.00012 & 0.00006 & 0.00000 \\
\hline A & Northwest & 0.00004 & 0.00049 & 0.00016 & 0.00014 & 0.00011 & 0.00003 \\
\hline A & North-northwest & 0.00006 & 0.00047 & 0.00005 & 0.00005 & 0.00000 & 0.00000 \\
\hline$B$ & North & 0.00269 & 0.00756 & 0.00209 & 0.00031 & 0.00002 & 0.00000 \\
\hline B & North-northoast & 0.00260 & 0.00736 & 0.00202 & 0.00045 & 0.00015 & 0.00003 \\
\hline B & Northeset & 0.00287 & 0.00570 & 0.00098 & 0.00025 & 0.00009 & 0.00002 \\
\hline 8 & East-northesat & 0.00333 & 0.00624 & 0.00039 & 0.00004 & 0.00000 & 0.00000 \\
\hline$B$ & East & 0.00280 & 0.00756 & 0.00045 & 0.00002 & 0.00000 & 0.00000 \\
\hline B & East-southeast & 0.00233 & 0.00820 & 0.00105 & 0.00002 & 0.00000 & 0.00000 \\
\hline B & Southoast & 0.00169 & 0.00820 & 0.00169 & 0.00014 & 0.00000 & 0.00000 \\
\hline B & South-southeast & 0.00094 & 0.00475 & 0.00194 & 0.00033 & 0.00000 & 0.00000 \\
\hline B & South & 0.00071 & 0.00250 & 0.00084 & 0.00020 & 0.00000 & 0.00001 \\
\hline B & South-southwest & 0.00065 & 0.00177 & 0.00062 & 0.00030 & 0.00004 & 0.00002 \\
\hline B & Southwest & 0.00077 & 0.00185 & 0.00136 & 0.00072 & 0.00036 & 0.00011 \\
\hline B & Woet-southwost & 0.00078 & 0.00227 & 0.00222 & 0.00154 & 0.00078 & 0.00033 \\
\hline 8 & West & 0.00091 & 0.00264 & 0.00186 & 0.00084 & 0.00022 & 0.00012 \\
\hline B & West-northwest & 0.00139 & 0.00451 & 0.00350 & 0.00128 & 0.00045 & 0.00007 \\
\hline B & Northwest & 0.00196 & 0.00740 & 0.00431 & 0.00141 & 0.00071 & 0.00014 \\
\hline B & North-northwest & 0.00250 & 0.00774 & 0.00197 & 0.00023 & 0.00005 & 0.00000 \\
\hline C & North & 0.00188 & 0.00528 & 0.00240 & 0.00035 & 0.00003 & 0.00000 \\
\hline$c$ & North-northeast & 0.00182 & 0.00497 & 0.00298 & 0.00049 & 0.00014 & 0.00004 \\
\hline $\mathrm{C}$ & Northosst & 0.00168 & 0.00433 & 0.00088 & 0.00032 & 0.00013 & 0.00000 \\
\hline$c$ & East-northeast & 0.00228 & 0.00387 & 0.00042 & 0,00005 & 0.00001 & 0.00000 \\
\hline$c$ & East & 0.00177 & 0.00445 & 0.00073 & 0.00002 & 0.00000 & 0.00000 \\
\hline $\mathrm{C}$ & East-southeast & 0.00175 & 0.00522 & 0.00105 & 0.00003 & 0.00000 & 0.00000 \\
\hline$c$ & Southeast & 0.00121 & 0.00548 & 0.00158 & 0.00018 & 0.00000 & 0.00000 \\
\hline C & South-southoast & 0.00099 & 0.00366 & 0.00149 & 0.00055 & 0.00002 & 0.00000 \\
\hline$c$ & South & 0.00078 & 0.00212 & 0.00091 & 0.00039 & 0.00004 & 0.00002 \\
\hline
\end{tabular}


Table 1-14. Joint Frequency Distribution of Atmospheric Stability, Wind Direction, and Wind Speed at the 200 East Area. (3 sheets)

\begin{tabular}{|c|c|c|c|c|c|c|c|}
\hline \multirow{2}{*}{$\begin{array}{l}\text { Stability } \\
\text { class }\end{array}$} & \multirow{2}{*}{$\begin{array}{l}\text { Direction from which } \\
\text { the wind is blowing }\end{array}$} & \multicolumn{6}{|c|}{ Wind epoed class $(\mathrm{mi} / \mathrm{h})$} \\
\hline & & $1-3$ & $4 \cdot 7$ & $8-12$ & $13-18$ & $19-24$ & $>25$ \\
\hline C & South-southwest & 0.00059 & 0.00178 & 0.00082 & 0.00034 & 0.00010 & 0.00007 \\
\hline C & Southwost & 0.00056 & 0.00195 & 0.00189 & 0.00079 & 0.00052 & 0.00013 \\
\hline$c$ & West-southwest & 0.00051 & 0.00252 & 0.00285 & 0.00178 & 0.00071 & 0.00026 \\
\hline$c$ & West & 0.00092 & 0.00304 & 0.00326 & 0.00131 & 0.00034 & 0.00008 \\
\hline $\mathrm{c}$ & West-northwest & 0.00129 & 0.00539 & 0.00697 & 0.00211 & 0.00053 & 0.00008 \\
\hline $\mathrm{C}$ & Northwost & 0.00193 & 0.00786 & 0.00578 & 0.00167 & 0.00080 & 0.00042 \\
\hline C & North-northwest & 0.00175 & 0.00672 & 0.00228 & 0.00028 & 0.00001 & 0.00000 \\
\hline D & North & 0.00112 & 0.00330 & 0.00204 & 0.00108 & 0.00012 & 0.00000 \\
\hline D & North-northoast & 0.00067 & 0.00285 & 0.00212 & 0.00152 & 0.00079 & 0.00006 \\
\hline D & Northeast & 0.00086 & 0.00317 & 0.00199 & 0.00098 & 0.00025 & 0.00023 \\
\hline D & East-northoast & 0.00092 & 0.00311 & 0.00080 & 0.00018 & 0.00002 & 0.00003 \\
\hline$D$ & Eost & 0.00116 & 0.00399 & 0.00133 & 0.00005 & 0.00002 & 0.00000 \\
\hline $\mathrm{D}$ & East-southesst & 0.00118 & 0.00482 & 0.00208 & 0.00017 & 0.00003 & 0.00000 \\
\hline D & Southeast & 0.00092 & 0.00587 & 0.00381 & 0.00046 & 0.00001 & 0.00000 \\
\hline D & South-southeast & 0.00098 & 0.00462 & 0.00473 & 0.00138 & 0.00013 & 0.00000 \\
\hline D & South & 0.00084 & 0.00361 & 0.00336 & 0.00134 & 0.00023 & 0.00002 \\
\hline D & South-southwost & 0.00070 & 0.00319 & 0.00243 & 0.00198 & 0.00119 & 0.00043 \\
\hline$D$ & Southwost & 0.00075 & 0.00370 & 0.00385 & 0.00457 & 0.00312 & 0.00166 \\
\hline D & Wost-southwest & 0.00092 & 0.00512 & 0.00863 & 0.00743 & 0.00456 & 0.00160 \\
\hline D & Wost & 0.00109 & 0.00735 & 0.01468 & 0.00740 & 0.00146 & 0.00037 \\
\hline D & West-northwest & 0.00113 & 0.01079 & 0.02796 & 0.02068 & 0.00790 & 0.00133 \\
\hline D & Northwost & 0.00097 & 0.00866 & 0.01272 & 0.00849 & 0.00502 & 0.00152 \\
\hline D & North-northwest & 0.00105 & 0.00500 & 0.00309 & 0.00070 & 0.00011 & 0.00002 \\
\hline $\mathbf{E}$ & North & 0.00055 & 0.00153 & 0.00102 & 0.00036 & 0.00000 & 0.00000 \\
\hline $\mathbf{E}$ & North-northeast & 0.00071 & 0.00131 & 0.00085 & 0.00031 & 0.00001 & 0.00000 \\
\hline$E$ & Northesst & 0.00039 & 0.00091 & 0.00044 & 0.00006 & 0.00000 & 0.00000 \\
\hline$E$ & East-northesst & 0.00052 & 0.00106 & 0.00016 & 0.00003 & 0.00001 & 0.00003 \\
\hline $\mathbf{E}$ & Enst & 0.00048 & 0.00129 & 0.00030 & 0.00000 & 0.00001 & 0.00000 \\
\hline$E$ & East-zoutheset & 0.00056 & 0.00242 & 0.00068 & 0.00007 & 0.00000 & 0.00000 \\
\hline $\mathrm{E}$ & Southeast & 0.00066 & 0.00331 & 0.00166 & 0.00011 & 0.00000 & 0.00000 \\
\hline $\mathrm{E}$ & South-8outhoast & 0.00076 & 0.00361 & 0.00279 & 0.00043 & 0.00004 & 0.00001 \\
\hline$E$ & South & 0.00099 & 0.00269 & 0.00163 & 0.00037 & 0.00010 & 0.00001 \\
\hline$E$ & South-southwost & 0.00063 & 0.00209 & 0.00096 & 0.00037 & 0.00012 & 0.00005 \\
\hline $\bar{E}$ & Southwest & 0.00090 & 0.00282 & 0.00142 & 0.00082 & 0.00039 & 0.00011 \\
\hline$E$ & Wost-8outhwest & 0.00077 & 0.00466 & 0.00473 & 0.00187 & 0.00067 & 0.00012 \\
\hline$E$ & West & 0.00099 & 0.00826 & 0.01244 & 0.00324 & 0.00022 & 0.00003 \\
\hline$E$ & West-northwest & 0.00091 & 0.01213 & 0.02585 & 0.00831 & 0.00157 & 0.00019 \\
\hline$\vec{E}$ & Northwest & 0.00086 & 0.00838 & 0.00752 & 0.00248 & 0.00078 & 0.00018 \\
\hline$E$ & Nonth-northwost & 0.00082 & 0.00302 & 0.00108 & 0.00009 & 0.00001 & 0.00000 \\
\hline$F$ & North & 0.00136 & 0.00240 & 0.00051 & 0.00021 & 0.00003 & 0.00000 \\
\hline$F$ & North-northeast & 0.00133 & 0.00216 & 0.00054 & 0.00019 & 0.00006 & 0.00001 \\
\hline
\end{tabular}


Table 1-14. Joint Frequency Distribution of Atmospheric Stability, Wind Direction, and Wind Speed at the 200 East Area. (3 sheets)

\begin{tabular}{|c|c|c|c|c|c|c|c|}
\hline \multirow{2}{*}{$\begin{array}{l}\text { Stability } \\
\text { class }\end{array}$} & \multirow{2}{*}{$\begin{array}{l}\text { Diroction from which } \\
\text { the wind is blowing }\end{array}$} & \multicolumn{6}{|c|}{ Wind opood clase (mi/h) } \\
\hline & & $1-3$ & $4 \cdot 7$ & $8 \cdot 12$ & $13 \cdot 10$ & $19 \cdot 24$ & $>25$ \\
\hline$F$ & Northoast & 0.00113 & 0.00234 & 0.00033 & 0.00005 & 0.00003 & 0.00000 \\
\hline $\mathbf{F}$ & East-northesst & 0.00150 & 0.00201 & 0.00013 & 0.00001 & 0.00003 & 0.00000 \\
\hline $\mathbf{F}$ & East & 0.00187 & 0.00293 & 0.00037 & 0.00004 & 0.00002 & 0.00000 \\
\hline $\mathbf{F}$ & Esst-southoost & 0.00204 & 0.00422 & 0.00069 & 0.00001 & 0.00000 & 0.00000 \\
\hline $\mathbf{F}$ & Southoast & 0.00172 & 0.00593 & 0.00143 & 0.00015 & 0.00000 & 0.00000 \\
\hline $\mathbf{F}$ & South-southeast & 0.00149 & 0.00558 & 0.00202 & 0.00026 & 0.00002 & 0.00000 \\
\hline$F$ & South & 0.00124 & 0.00335 & 0.00107 & 0.00018 & 0.00009 & 0.00000 \\
\hline $\mathbf{F}$ & South-8outhwest & 0.00122 & 0.00246 & 0.00073 & 0.00031 & 0.00013 & 0.00006 \\
\hline $\mathbf{F}$ & Southwest & 0.00157 & 0.00312 & 0.00107 & 0.00065 & 0.00040 & 0.00017 \\
\hline $\mathbf{F}$ & Woot-eouthwest & 0.00151 & 0.00509 & 0.00272 & 0.00099 & 0.00041 & 0.00007 \\
\hline $\mathbf{F}$ & Wost & 0.00192 & 0.01016 & 0.00863 & 0.00146 & 0.00010 & 0.00000 \\
\hline$F$ & Wost-northwost & 0.00238 & 0.01410 & 0.01530 & 0.00438 & 0.00080 & 0.00016 \\
\hline $\bar{F}$ & Northwest & 0.00230 & 0.00900 & 0.00427 & 0.00111 & 0.00069 & 0.00013 \\
\hline $\mathbf{F}$ & North-northwost & 0.00199 & 0.00407 & 0.00072 & 0.00009 & 0.00005 & 0.00000 \\
\hline $\mathbf{G}$ & North & 0.00110 & 0.00179 & 0.00023 & 0.00011 & 0.00000 & 0.00002 \\
\hline G & North-northesst & 0.00114 & 0.00154 & 0.00018 & 0.00006 & 0.00001 & 0.00002 \\
\hline $\mathbf{G}$ & Northeast & 0.00114 & 0.00167 & 0.00007 & 0.00003 & 0.00005 & 0.00000 \\
\hline G & East-northesst & 0.00125 & 0.00138 & 0.00005 & 0.00000 & 0.00003 & 0.00000 \\
\hline G & East & 0.00146 & 0.00219 & 0.00016 & 0.00001 & 0.00001 & 0.00000 \\
\hline G & East-southesst & 0.00166 & 0.00365 & 0.00033 & 0.00002 & 0.00000 & 0.00000 \\
\hline G & Southeast & 0.00142 & 0.00382 & 0.00078 & 0.00005 & 0.00000 & 0.00000 \\
\hline G & South-southesst & 0.00120 & 0.00392 & 0.00100 & 0.00009 & 0.00002 & 0.00000 \\
\hline G & South & 0.00099 & 0.00211 & 0.00034 & 0.00005 & 0.00002 & 0.00000 \\
\hline G & South-southwest & 0.00104 & 0.00160 & 0.00021 & 0.00005 & 0.00005 & 0.00008 \\
\hline G & Southwest & 0.00128 & 0.00166 & 0.00048 & 0.00029 & 0.00019 & 0.00008 \\
\hline G & West-southwest & 0.00133 & 0.00279 & 0.00106 & 0.00053 & 0.00030 & 0.00000 \\
\hline G & Wost & 0.00163 & 0.00436 & 0.00327 & 0.00055 & 0.00002 & 0.00000 \\
\hline G & Wost-northwest & 0.00204 & 0.00832 & 0.00602 & 0.00165 & 0.00027 & 0.00003 \\
\hline $\mathbf{G}$ & Northwest & 0.00237 & 0.00457 & 0.00167 & 0.00069 & 0.00019 & 0.00002 \\
\hline 0 & North-northwest & 0.00189 & 0.00229 & 0.00022 & 0.00008 & 0.00002 & 0.00000 \\
\hline
\end{tabular}

Note: Atmospheric stability is determined using the Pasquill method. Wind measurements were mads onsite at $10 \mathrm{~m}$ (33 $\mathrm{ft}$ ) above ground level. Data are based on measurements made from 1982 through 1989 . 
Table 1-15. Percent Frequency of 0ccurrence of Pasquil1-Gifford Atmospheric Stability $\mathrm{Cl}$ asses A through $\mathrm{G}$ for the 200 East Area.

\begin{tabular}{|l|c|}
\hline \multicolumn{1}{|c|}{ Class } & Percent occurrence per year \\
\hline A (extremely unstable) & $1.4 \%$ \\
\hline B (moderately unstable) & $15.4 \%$ \\
\hline C (slightly unstable) & $14.2 \%$ \\
\hline D (neutral) & $28 \%$ \\
\hline E (slightly stable) & $15.8 \%$ \\
\hline F (moderately stable) & $16.0 \%$ \\
\hline G (extremely stable) & $9.2 \%$ \\
\hline
\end{tabular}

To support the accident analyses of Section 3.4.2, downwind radiological exposures were calculated using a unit release dispersion parameter $(X / Q)$, which may be defined as the time-integrated air concentration at the receptor location per unit release at the source. The acute $X / Q$ s for the analyses were calculated using joint frequency distribution data so as to be exceeded only $0.5 \%$ of the time (99.5 percentile) for each sector, or to be exceeded only $5 \%$ of the time (95 percentile) for data from all sectors combined (whichever is greater). Since the downwind distance where the plume touches down from a stack release varies with stability and windspeed, a parametric study was performed to determine the distance at which the maximum onsite dose occurred. For the calculation of the CSB X/QS, the CSB's dimensions were considered to be $97.8 \mathrm{~m} \times 55.2 \mathrm{~m} \times 16.9 \mathrm{~m} \mathrm{high}(320 \mathrm{ft} \times 181 \mathrm{ft} \times 55 \mathrm{ft}$ high) with a $36.6-\mathrm{m}$ $(120-\mathrm{ft})$ stack; the inside diameter of the stack was considered to be $1.02 \mathrm{~m}$ (40 in.). The normal exhaust flow from the stack is specified to be $5.66 \mathrm{~m}^{3} / \mathrm{s}$ $\left(12,000 \mathrm{ft}^{3} / \mathrm{min}\right)$ with one fan running. In an accident situation a second fan is to start giving a specified accident flow rate of $11.3 \mathrm{~m}^{3} / \mathrm{s}$

$\left(24,000 \mathrm{ft}^{3} / \mathrm{min}\right)$. In both cases the exhaust temperature is given as $38{ }^{\circ} \mathrm{C}$ through $41{ }^{\circ} \mathrm{C}\left(100^{\circ} \mathrm{F}\right.$ through $\left.105^{\circ} \mathrm{F}\right)$. The design and operation of this ventilation system will be described in Chapter 4.0 of the final SAR as required by DOE-STD-3009-94.

$X / Q$ s are required at the worst-case onsite location and at the worst-case location on the Site boundary (see Section 1.3.1.3). Both the Site boundary, at $18.3 \mathrm{~km}$ east, and the near river shore, at $15.0 \mathrm{~km}$ east, were evaluated.

The required $X / Q$ s were calculated using the $G X Q$ code (Hey 1994) using the ISC2 momentum/buoyancy plume rise model (EPA 1992). Variation of wind speed with height, wind entrainment, initial volume rate effects, and plume downwash were accounted for. A two-dimensional parametric calculation was used to determine the worst-case onsite receptor with respect to both distance and direction. The worst-case Site boundary receptors were found by evaluating each of the 16 direction sectors around both the Site boundary and the near river shore. 
HNF-SD-SNF-RPT-004 REV 6

Using the atmospheric stabilities and wind speeds determined in the above calculations, effective plume heights were determined for onsite and Site boundary conditions. If the effective release height (stack height plus plume rise) is greater than 2.5 times the building height, the plume can be assumed to be unaffected by the building wake (EPA 1992).

The resulting parametric arrays of 99.5 percentile onsite $X / Q$ s for one fan and two fans in operation are shown in Tables 1-16 and 1-17. The maximum $X / Q$ s are indicated with asterisks.

of these two cases, the lower plume rise would be associated with the lesser exhaust flow rate (i.e., the single fan case shown in Table 1-16. The conditions that produce the worst case shown in Table 1-16 for the west sector at $230 \mathrm{~m}(755 \mathrm{ft})$ are Pasquil1 $A$ with a $2.65 \mathrm{~m} / \mathrm{s}(6 \mathrm{mi} / \mathrm{h})$ wind speed. The effective release height for these conditions was found to be $45.1 \mathrm{~m}$ (148 ft). In order to eliminate building wake effects, the effective release height must be greater than 2.5 times the building height of $16.9 \mathrm{~m}(55 \mathrm{ft})$, or $42.3 \mathrm{~m}$ $(138 \mathrm{ft})$.

The resulting $X / Q$ s for the Site boundary and near river shore are shown in Tables 1-18 and 1-19. The values shown in parentheses for the worst-case locations on the near river shore correspond to potential agricultural sites on the far river bank.

As before, the lower plume rise would be associated with the lesser exhaust flow rate (i.e., the single fan case shown in Table 1-18. The conditions that produce the worst case shown in Table 1-18 for the east sector at $18.3 \mathrm{~km}(11.4 \mathrm{mi}), 15.0 \mathrm{~km}(9.3 \mathrm{mi})$, or $15.7 \mathrm{~km}(9.7 \mathrm{mi})$ are Pasquill $\mathrm{F}$ with a $0.89 \mathrm{~m} / \mathrm{s}(2 \mathrm{mi} / \mathrm{h})$ wind speed. The effective release height for these conditions was found to be $58.0 \mathrm{~m}(190 \mathrm{ft})$.

The specific $X / Q$ values used for accident consequence analyses are provided in Section 3.4.1.2. Data are provided for ground level and stack release.

\subsubsection{Hydrology}

The primary surface water features associated with the Hanford Site are the Columbia River and its tributary, the Yakima River (Figure 1-15). West Lake, about 4 ha (10 acres) in size and less than $1 \mathrm{~m}$ ( $3 \mathrm{ft}$ ) deep, is the only natural lake on the Hanford Site. Artificial surface water bodies include ponds and ditches that were used in the past for waste water disposal.

The Hanford Site is underlain by unconsolidated to semiconsolidated sediments of the Hanford and Ringold Formations. The Columbia River Basalt Group (CRBG) and associated sedimentary interbeds lie beneath the sediments. The geology of the Hanford Site is described in Section 1.4.3.

The vadose zone at the Hanford Site is comprised mainly of unconsolidated gravels and sands. Its thickness ranges from $0 \mathrm{~m}(0 \mathrm{ft})$ at the river bank and West Lake to over $100 \mathrm{~m}(328 \mathrm{ft})$ in the 200 Areas. 
Table 1-16. Onsite $99.5 \% \times / Q \mathrm{~s}$ for One Fan $\left(5.66 \mathrm{~m}^{3} / \mathrm{s}\left[12,000 \mathrm{ft}^{3} / \mathrm{min}\right]\right)$ for Various Downwind Distances.

\begin{tabular}{|c|c|c|c|c|c|c|}
\hline \multirow{2}{*}{ Sector } & \multicolumn{6}{|c|}{$X / Q\left(\mathrm{~s} / \mathrm{m}^{3}\right)$} \\
\hline & $220 \mathrm{~m}$ & $230 \mathrm{~m}$ & $240 \mathrm{~m}$ & $250 \mathrm{~m}$ & $260 \mathrm{~m}$ & $270 \mathrm{~m}$ \\
\hline S & $4.01 \mathrm{E}-05$ & $4.06 \mathrm{E}-05$ & $3.15 \mathrm{E}-05$ & $3.35 \mathrm{E}-05$ & $3.53 E-05$ & $3.69 E-05$ \\
\hline SSW & $2.88 \mathrm{E}-05$ & 3.02 E-05 & $3.10 \mathrm{E}-05$ & 3.04 E-05 & $2.97 \mathrm{E}-05$ & $2.88 E-05$ \\
\hline SW & 2.66 E-05 & $2.91 \mathrm{E}-05$ & $2.93 \mathrm{E}-05$ & $2.93 \mathrm{E}-05$ & $2.91 E-05$ & $2.87 \mathrm{E}-05$ \\
\hline WSW & $2.90 \mathrm{E}-05$ & $3.04 E-05$ & 3.14 E-05 & $3.08 \mathrm{E}-05$ & $3.00 \mathrm{E}-05$ & $2.91 E-05$ \\
\hline$W$ & $4.12 \mathrm{E}-05$ & $* 4.18 \mathrm{E}-05 *$ & $3.15 \mathrm{E}-05$ & $3.39 \mathrm{E}-05$ & 3.60 E-05 & $3.79 \mathrm{E}-05$ \\
\hline WNW & $3.18 \mathrm{E}-05$ & 3.17 E-05 & 3.14 E-05 & $3.16 \mathrm{E}-05$ & $3.15 \mathrm{E}-05$ & $3.13 \mathrm{E}-05$ \\
\hline NW & $2.87 \mathrm{E}-05$ & 3.02 E-05 & 3.01 E-05 & $2.99 \mathrm{E}-05$ & $2.94 \mathrm{E}-05$ & $2.88 E-05$ \\
\hline NNW & $2.05 E-05$ & $2.03 \mathrm{E}-05$ & $1.99 \mathrm{E}-05$ & $1.94 E-05$ & $1.87 \mathrm{E}-05$ & $1.86 E-05$ \\
\hline$N$ & $1.99 \mathrm{E}-05$ & $1.97 \mathrm{E}-05$ & $1.94 E-05$ & $1.90 \mathrm{E}-05$ & $1.85 \mathrm{E}-05$ & $1.80 \mathrm{E}-05$ \\
\hline NNE & 2.67 E-06 & 3.15 E-06 & $3.63 \mathrm{E}-06$ & $4.10 \mathrm{E}-06$ & $4.42 \mathrm{E}-06$ & $4.29 \mathrm{E}-06$ \\
\hline NE & $1.31 \mathrm{E}-05$ & 1.32 E-05 & 1.32 E-05 & 1.31 E-05 & $1.26 \mathrm{E}-05$ & $1.25 \mathrm{E}-05$ \\
\hline ENE & 1.82 E-05 & $1.85 E-05$ & $1.87 \mathrm{E}-05$ & 1.87 E-05 & 1.74 E-05 & $1.69 \mathrm{E}-05$ \\
\hline$E$ & 2.11 E-05 & $2.13 E-05$ & $2.13 \mathrm{E}-05$ & $2.12 \mathrm{E}-05$ & $1.87 \mathrm{E}-05$ & $1.87 E-05$ \\
\hline ESE & $2.19 \mathrm{E}-05$ & $2.28 \mathrm{E}-05$ & $2.34 E-05$ & $2.38 \mathrm{E}-05$ & $1.99 \mathrm{E}-05$ & $2.02 \mathrm{E}-05$ \\
\hline SE & $2.53 E-05$ & $2.85 E-05$ & $2.81 \mathrm{E}-05$ & $2.85 E-05$ & $2.87 E-05$ & $2.87 \mathrm{E}-05$ \\
\hline SSE & $2.92 E-05$ & 3.05 E-05 & $3.09 \mathrm{E}-05$ & $3.04 \mathrm{E}-05$ & $2.97 \mathrm{E}-05$ & $2.88 \mathrm{E}-05$ \\
\hline A11 (95\%) & $3.34 E-05$ & $3.33 \mathrm{E}-05$ & $3.15 \mathrm{E}-05$ & $3.22 E-05$ & $3.28 \mathrm{E}-05$ & 3.31 E-05 \\
\hline
\end{tabular}


Table 1-17. Onsite $99.5 \% \times / Q$ s for Two Fans (11.3 $\mathrm{m}^{3} / \mathrm{s}\left[24,000 \mathrm{ft}^{3} / \mathrm{min}\right]$ ) for Various Downwind Distances.

\begin{tabular}{|c|c|c|c|c|c|c|}
\hline \multirow{2}{*}{ Sector } & \multicolumn{6}{|c|}{$\mathrm{X} / \mathrm{Q}\left(\mathrm{s} / \mathrm{m}^{3}\right)$} \\
\hline & $220 \mathrm{~m}$ & $230 \mathrm{~m}$ & $240 \mathrm{~m}$ & $250 \mathrm{~m}$ & $260 \mathrm{~m}$ & $270 \mathrm{~m}$ \\
\hline$S$ & $2.81 E-05$ & $2.90 E-05$ & $2.95 \mathrm{E}-05$ & $2.97 \mathrm{E}-05$ & $2.97 \mathrm{E}-05$ & 2.94 E-05 \\
\hline SSW & 2.24 E-05 & $2.26 E-05$ & $2.25 \mathrm{E}-05$ & $2.20 \quad E-05$ & $2.22 \mathrm{E}-05$ & $2.23 \mathrm{E}-05$ \\
\hline SW & $1.93 \mathrm{E}-05$ & $1.93 \mathrm{E}-05$ & 1.92 E-05 & $1.89 \mathrm{E}-05$ & $1.97 \mathrm{E}-05$ & $2.04 \mathrm{E}-05$ \\
\hline WSW & $2.13 \mathrm{E}-05$ & $2.15 \mathrm{E}-05$ & 2.14 E-05 & $2.20 \mathrm{E}-05$ & $2.22 \mathrm{E}-05$ & $2.23 \mathrm{E}-05$ \\
\hline$W$ & $2.86 \mathrm{E}-05$ & $2.95 \mathrm{E}-05$ & 3.01 E-05 & $* 3.04 E-05^{*}$ & $\star 3.04 \mathrm{E}-05 *$ & $3.01 \quad E-05$ \\
\hline WNW & $2.48 \mathrm{E}-05$ & $2.51 \quad E-05$ & $2.52 E-05$ & $2.50 \mathrm{E}-05$ & $2.47 \mathrm{E}-05$ & $2.42 \mathrm{E}-05$ \\
\hline NW & $2.18 \mathrm{E}-05$ & $2.20 \mathrm{E}-05$ & 2.20 E-05 & $2.20 \mathrm{E}-05$ & 2.22 E -05 & $2.23 \mathrm{E}-05$ \\
\hline NNW & $1.47 \mathrm{E}-05$ & $1.59 \mathrm{E}-05$ & $1.70 \mathrm{E}-05$ & $1.64 \mathrm{E}-05$ & $1.62 \mathrm{E}-05$ & $1.60 \mathrm{E}-05$ \\
\hline N & $1.37 \mathrm{E}-05$ & $1.44 \mathrm{E}-05$ & 1.54 E-05 & $1.53 \mathrm{E}-05$ & $1.55 \mathrm{E}-05$ & $1.59 \mathrm{E}-05$ \\
\hline NNE & $6.90 \quad E-07$ & $8.47 \quad E-07$ & $1.02 \mathrm{E}-06$ & $1.22 \mathrm{E}-06$ & $1.46 \mathrm{E}-06$ & $1.74 \mathrm{E}-06$ \\
\hline $\mathrm{NE}$ & $1.14 \mathrm{E}-05$ & $1.13 \mathrm{E}-05$ & $1.21 \mathrm{E}-05$ & 1.17 E-05 & $1.17 \mathrm{E}-05$ & $1.13 \mathrm{E}-05$ \\
\hline ENE & $1.45 \mathrm{E}-05$ & $1.58 \mathrm{E}-05$ & $1.69 \mathrm{E}-05$ & $1.54 \mathrm{E}-05$ & $1.56 \mathrm{E}-05$ & $1.57 \mathrm{E}-05$ \\
\hline $\mathrm{E}$ & $1.67 \mathrm{E}-05$ & $1.70 \mathrm{E}-05$ & $1.72 \mathrm{E}-05$ & $1.70 \quad E \sim 05$ & $1.67 \mathrm{E}-05$ & $1.61 \mathrm{E}-05$ \\
\hline ESE & $1.75 \mathrm{E}-05$ & $1.75 \mathrm{E}-05$ & $1.73 \mathrm{E}-05$ & $1.73 \quad E-05$ & $1.74 \mathrm{E}-05$ & $1.63 \mathrm{E}-0.5$ \\
\hline SE & $2.06 \mathrm{E}-05$ & $2.07 \mathrm{E}-05$ & $2.06 \mathrm{E}-05$ & $1.92 \mathrm{E}-05$ & $2.00 \mathrm{E}-05$ & $2.06 \mathrm{E}-05$ \\
\hline SSE & $2.26 \mathrm{E}-05$ & $2.29 \mathrm{E}-05$ & $2.28 \mathrm{E}-05$ & $2.25 \mathrm{E}-05$ & $2.27 \mathrm{E}-05$ & $2.26 \mathrm{E}-05$ \\
\hline A11 (95\%) & $2.56 \mathrm{E}-05$ & $2.60 \mathrm{E}-05$ & $2.62 \mathrm{E}-05$ & $2.60 \mathrm{E}-05$ & $2.57 \mathrm{E}-05$ & $2.52 \mathrm{E}-05$ \\
\hline
\end{tabular}


Table 1-18. Site Boundary $99.5 \% \times / Q$ s for One Fan $\left(5.66 \mathrm{~m}^{3} / \mathrm{s}\right.$ $\left.\left[12,000 \mathrm{ft}^{3} / \mathrm{min}\right]\right)$ for the Site Boundary and Near River Shore.

\begin{tabular}{|l|c|c|c|c|}
\hline \multirow{2}{*}{ Sector } & \multicolumn{2}{|c|}{ Site boundary } & \multicolumn{2}{c|}{ Near river shore } \\
\cline { 2 - 5 } & Distance $(\mathrm{km})$ & $X / Q\left(\mathrm{~s} / \mathrm{m}^{3}\right)$ & Distange $(\mathrm{km})$ & $X / Q\left(\mathrm{~s} / \mathrm{m}^{3}\right)$ \\
\hline S & 20.0 & $2.98 \mathrm{E}-06$ & 8.7 & $5.69 \mathrm{E}-06$ \\
\hline SSW & 17.0 & $2.22 \mathrm{E}-06$ & 8.9 & $4.95 \mathrm{E}-06$ \\
\hline SW & 18.3 & $1.82 \mathrm{E}-06$ & 8.9 & $4.98 \mathrm{E}-06$ \\
\hline WSW & 20.0 & $1.64 \mathrm{E}-06$ & 9.3 & $4.66 \mathrm{E}-06$ \\
\hline W & 19.4 & $3.73 \mathrm{E}-06$ & 11.1 & $6.32 \mathrm{E}-06$ \\
\hline WNW & 20.0 & $3.58 \mathrm{E}-06$ & 14.6 & $4.82 \mathrm{E}-06$ \\
\hline NW & 21.1 & $3.73 \mathrm{E}-06$ & 12.4 & $6.94 \mathrm{E}-06$ \\
\hline NNW & 20.9 & $4.83 \mathrm{E}-06$ & 12.0 & $8.27 \mathrm{E}-06$ \\
\hline N & 23.9 & $4.45 \mathrm{E}-06$ & 13.3 & $8.24 \mathrm{E}-06$ \\
\hline NNE & 27.4 & $2.20 \mathrm{E}-06$ & 15.2 & $3.96 \mathrm{E}-06$ \\
\hline NE & 21.6 & $2.89 \mathrm{E}-06$ & 13.7 & $4.29 \mathrm{E}-06$ \\
\hline ENE & 18.4 & $3.93 \mathrm{E}-06$ & 13.3 & $4.96 \mathrm{E}-06$ \\
\hline E & 18.3 & $* 7.14 \mathrm{E}-06^{\star}$ & 15.0 & $\star 8.31 \mathrm{E}-06 *$ \\
\hline ESE & 22.8 & $4.21 \mathrm{E}-06$ & 22.8 & $4.21 \mathrm{E}-06$ \\
\hline SE & 27.2 & $2.92 \mathrm{E}-06$ & 27.2 & $2.92 \mathrm{E}-06$ \\
\hline SSE & 22.0 & $2.84 \mathrm{E}-06$ & 11.7 & $4.67 \mathrm{E}-06$ \\
\hline
\end{tabular}


Table 1-19, Site Boundary $99.5 \% \times / Q \mathrm{~s}$ for Two Fans $\left(11.3 \mathrm{~m}^{3} / \mathrm{s}\right.$ $\left.\left[24,000 \mathrm{ft}^{3} / \mathrm{min}\right]\right)$ for the Site Boundary and Near River Shore.

\begin{tabular}{|l|c|c|c|c|}
\hline \multirow{2}{*}{ Sector } & \multicolumn{2}{|c|}{ Site boundary } & \multicolumn{2}{c|}{ Near river shore } \\
\cline { 2 - 5 } & Distance $(\mathrm{km})$ & $X / Q\left(\mathrm{~s} / \mathrm{m}^{3}\right)$ & Distance $(\mathrm{km})$ & $X / Q\left(\mathrm{~s} / \mathrm{m}^{3}\right)$ \\
\hline S & 20.0 & $2.87 \mathrm{E}-06$ & 8.7 & $4.89 \mathrm{E}-06$ \\
\hline SWW & 17.0 & $2.00 \mathrm{E}-06$ & 8.9 & $4.33 \mathrm{E}-06$ \\
\hline WSW & 18.3 & $1.68 \mathrm{E}-06$ & 8.9 & $4.35 \mathrm{E}-06$ \\
\hline W & 20.0 & $1.52 \mathrm{E}-06$ & 9.3 & $4.17 \mathrm{E}-06$ \\
\hline WNW & 19.4 & $3.36 \mathrm{E}-06$ & 11.1 & $5.63 \mathrm{E}-06$ \\
\hline NW & 20.0 & $3.26 \mathrm{E}-06$ & 14.6 & $4.20 \mathrm{E}-06$ \\
\hline NNW & 21.1 & $3.16 \mathrm{E}-06$ & 12.4 & $5.85 \mathrm{E}-06$ \\
\hline N & 20.9 & $4.12 \mathrm{E}-06$ & 12.0 & $6.59 \mathrm{E}-06$ \\
\hline NNE & 23.9 & $3.83 \mathrm{E}-06$ & 13.3 & $6.52 \mathrm{E}-06$ \\
\hline NE & 27.4 & $2.02 \mathrm{E}-06$ & 15.2 & $3.37 \mathrm{E}-06$ \\
\hline ENE & 21.6 & $2.64 \mathrm{E}-06$ & 13.7 & $3.59 \mathrm{E}-06$ \\
\hline E & 18.4 & $3.44 \mathrm{E}-06$ & 13.3 & $4.18 \mathrm{E}-06$ \\
\hline ESE & 18.3 & $\star 6.05 \mathrm{E}-06 *$ & 15.0 & $\star 7.13 \mathrm{E}-06 *$ \\
\hline SE & 22.8 & $3.60 \mathrm{E}-06$ & 22.8 & $3.60 \mathrm{E}-06$ \\
\hline SSE & 27.2 & $2.58 \mathrm{E}-06$ & 27.2 & $2.58 \mathrm{E}-06$ \\
\hline
\end{tabular}


The saturated sediments of the Hanford and Ringold Formations make up a series of aquifers and aquitards. In generat, sand- and gravel-dominated stratigraphic units form aquifers and fine-grained deposits form aquitards. The shallowest suprabasalt aquifer is unconfined beneath most of the Hanford Site. Confined aquifers are present in the sedimentary interbeds and/or interflow zones between dense basalt flows of the CRBG. The main waterbearing portions of the interflow zones are networks of interconnecting vesicles and fractures of the flow tops and flow bottoms.

The remainder of this section describes the surface water features, vadose zone, and aquifers as they relate to the 200 Areas of the Hanford Site.

1.4.2.1 Surface Water. This section describes the surface water bodies and the river flooding potential at the CSB site from the Columbia River, Yakima River, and Cold Creek. An overview of artificial surface water bodies in and near the 200 Areas is also presented.

1.4.2.1.1 West Lake. The only natural lake, West Lake, is described in Section 1.4 .2 above.

1.4.2.1.2 Columbia River. The Columbia River flows through the Hanford Site and forms part of its eastern boundary (Figure 1-15). The section of the river flowing through the Site, known as the Hanford Reach, is free-flowing and extends from Priest Rapids Dam, upstream of the Site, to the 300 Area. Flow through the Hanford Reach fluctuates significantly and is controlled by Priest Rapids Dam, Discharge ranges from lows of about $36,000 \mathrm{ft}^{3} / \mathrm{s}$ to highs around $300,000 \mathrm{ft}^{3} / \mathrm{s}$.

The Columbia River originates in the mountains of eastern British Columbia, Canada, and drains an area of approximately $70,800 \mathrm{~km}^{2}\left(27,300 \mathrm{mi}^{2}\right)$ en route to the Pacific Ocean (Figure 1-16). Flow on the Columbia River is regulated by seven upstream dams within the United States and several in Canada. The three dams with the largest reservoirs upstream from the Hanford Site are the Mica Dam and Hugh Keenleyside Dam in Canada and the Grand Coulee Dam in the United States. The dam-controlled flow of the Columbia River results in a lower flood hazard for high-probability floods (e.g., 100-year flood); however, dam-failure scenarios are significant contributors for very-low-probability floods. A flood scenario involving a $50 \%$ breach of Grand Coulee Dam (ERDA 1976) results in a flood level of about $143 \mathrm{~m}$ (470 ft) above mean sea level at Columbia River kilometer 587 (mile 365) (Figure 1-5), the closest flood route to the $200 \mathrm{Plateau}$. This flood level is about $70 \mathrm{~m}$ $(230 \mathrm{ft})$ below the ground surface at the CSB. The CSB is a flood-dry site with respect to the Columbia River (ANSI/ANS 1992).

A probabilistic flood hazard assessment of the Columbia River was performed as part of a safety evaluation of the Hanford Site $\mathrm{N}$ Reactor (McCann and Boissonnade 1988). The most extreme potential flood scenarios on the Columbia River result from dam failure. Specifically, failure of Grand Coulee Dam and Mica Dam pose the greatest threat. The results of the flood hazard assessment show that the greatest contribution to the likelihood of flooding is dam failure initiated by seismic events. Conservative estimates of the seismic capacity of upstream dams were made primarily on engineering judgment. Further, the likelihood of random dam failure was based primarily on engineering judgment and the historic frequency of dam failures. See 
UCRL-21069, Probabilistic Flood Hazard Assessment of the Department of Energy N-Reactor, Hanford, Washington (McCann and Boissonnade 1988), for a detailed discussion of the hazard assessment.

The performance category 3 flood level $\left(10^{-4}\right.$ annual probability of exceedance [McCann and Boissonnade 1988]) at river kilometer 587 (mile 365), the closest flood route to the 200 Area Plateau and the CSB (Figure 1-5), is approximately $134 \mathrm{~m}$ (435 ft) above mean sea level, which is lower than the $50 \%$ breach scenario (Tallman 1996). The 200 Areas are dry sites with respect to Columbia River flooding and such flooding need not be considered in design or accident scenarios.

Extreme flooding on the Columbia River can also occur during extreme meteorologic and hydrologic events. Historically, the largest floods have occurred when rapid snow melt was accompanied by spring rain. Such floods are controlled by the dam system and are predicted to be less severe than comparable predam record floods.

1.4.2.1.3 Yakima River. The Yakima River forms part of the southern boundary of the Hanford Site (Figure 1-15). The Yakima River is approximately $20 \mathrm{~km}(12 \mathrm{mi})$ south and more than $60 \mathrm{~m}(200 \mathrm{ft})$ below the 200 Areas. The Yakima River is not a flood hazard for the CSB site.

Cold Creek, a tributary of the Yakima River, and its tributary, Dry Creek, are ephemeral streams within the Yakima River drainage basin (Figure 1-17). The Cold Creek watershed, located in the southwestern portion of the Hanford Site, extends about $16 \mathrm{~km}$ (10 mi) up the Cold Creek and Dry Creek valleys. A flood risk analysis of Cold Creek was conducted in 1980 (Skaggs and Walters 1981) to determine the probable maximum flood for the Cold creek system (Figure 1-15). The recurrence interval is not estimated for this flood; however each occurrence would be a flash flood of short duration. The probable maximum flood reaches an elevation of about $195 \mathrm{~m}(640 \mathrm{ft})$ on the southwestern portion of 200 West Area and is not a hazard for the CSB.

1.4.2.1.4 Artificial Surface Water Bodies. In the past, numerous artificial surface water bodies were present in the 200 Areas. Effluent disposal sites (e.g., cribs, ponds, ditches) allowed waste water to infiltrate the ground and, in many cases, affect groundwater flow and chemistry. Today only $B$ Pond and the Treated Effluent Disposal Facility, both located east of 200 East Area, receive significant volumes of effluent.

1.4.2.2 Vadose Zone. The term "vadose zone" is used here to refer to unsaturated sediments between the water table and the ground surface. Flow of water through the vadose zone is a function of the moisture content, matric. potential, and unsaturated hydraulic conductivity for each hydrostratigraphic unit. In general, water flows and spreads laterally at a much greater rate in fine-grained units than in coarse-grained units. Fine-grained units in the vadose zone significantly influence the lateral distribution of water and the flux of water to the uppermost aquifer. Coarse-grained units may impede the flux of water through the vadose zone because of the formation of a capillary pressure barrier between the coarse-grained units and overlying fine-grained units. 
The vadose zone in the 200 East Area is comprised of interlayered gravel, sand, silt, and "mud" (i.e., silt and clay). In some locations the basalt has been uplifted and composes part of the vadose zone. Thickness of the vadose zone in the 200 East Area ranges from $37 \mathrm{~m}(121 \mathrm{ft})$ near B Pond to $104 \mathrm{~m}$ (341 ft) near the southern border of the area (Ford and Trent 1994). Fine-grained units in the Hanford formation and the Ringold Lower Mud unit significantly influence the lateral distribution and flux of water in the 200 East Area.

The fine-grained sedimentary units in the 200 East Area may produce perched water conditions near active waste disposal facilities. Perched water results when a discontinuous impermeable layer in the vadose zone traps discontinuous water above the saturated zone. Perched water has been observed to the east of the 24l-BY tank farm and above the Lower Mud near B Pond and the Treated Effluent Disposal Facility.

Routson and Johnson (1990) estimated the magnitude of recharge from natural precipitation on the 200 Areas plateau. Two sources of data were used in their evaluation: (1) moisture accumulated for 13 years in an 18-m(59-ft-) deep 200 East Area Tysimeter, and (2) distribution of ${ }^{137} \mathrm{Cs}$ in a 200 West Area solid-waste burial ground in which contaminated soil had been buried for 10 years. There had been no detectible moisture accumulation in the bottom of the lysimeter from 1972 to 1985 . Thus, the recharge rate was approximately zero over the 13-year period. Cesium-137 contaminated sojl was placed in a burial ground in 1970. After 10 years the distribution of ${ }^{137} \mathrm{Cs}$ was determined from core-drilled samples. No ${ }^{137} \mathrm{Cs}$ above background was detected beneath the bottom of the trench, indicating there was no measurable downward movement; however, ${ }^{137} \mathrm{Cs}$ was detected above the trench, most likely from evapotranspiration.

Routson and Johnson (1990) conclude that there appears to be very little potential for downward movement of contaminants in the upper vadose zone beneath much of the 200 Areas plateau under natural or minimally disturbed conditions. Highly disturbed sites with little vegetation (e.g., the CSB site) may allow more movement of water through the vadose zone.

PNL-10285, Estimated Recharge Rates at the Hanford Site (Fayer and Walters 1995), compiled estimates of natural recharge on the Hanford Site. Recharge through the vadose zone was $87 \mathrm{~mm} / \mathrm{yr}(3.4 \mathrm{in} / \mathrm{yr})$ in a gravel-covered, unvegetated lysimeter constructed to mimic the surface conditions at the tank farms.

Site-specific variables must be considered to estimate time for water to travel through the vadose zone. Variables include the amount of moisture infiltrating, the grain size and stratigraphy of the sediments, the amount of moisture already in each sedimentary layer, and the hydraulic conductivity. WHC-SD-EN-TI-014, Hydrogeologic Model for 200 West Groundwater Aggregate Area (WHC 1992), contains calculated travel times in four examples for the 200 West Area with steady recharge rates of 0.5 and $5 \mathrm{~cm} / \mathrm{yr}(0.2$ and $2.0 \mathrm{in} / \mathrm{yr})$. Calculated travel times range from 150 years to over 2,000 years. The methods applied in WHC-SD-EN-TI-014 (WHC 1992) are not valid for transient conditions (e.g., spills, pipe leaks). 
1.4.2.3 Aquifers. Two major aquifer systems lie beneath the 200 Areas: the suprabasalt aquifer system and the basalt and interbed aquifer system (see Figure 1-18). Stratigraphy of the 200 Areas is discussed in greater detail in Section 1.4 .3 .

1.4.2.3.1 Suprabasalt Aquifer System. The suprabasalt aquifer system under the 200 Areas occurs primarily within the sediments of the Hanford and Ringold Formations. These sediments contain interlayered coarse- and fine-grained units forming a series of aquifers and aquitards. The depth to the water table under the 200 East Area ranges from less than $40 \mathrm{~m}$ (131 ft) near B Pond to approximately $104 \mathrm{~m}(341 \mathrm{ft})$ west of the 200 East Area. The CSB site is at about $216 \mathrm{~m}(708 \mathrm{ft})$ above mean sea leve1, and the elevation of the bottom of the basemat is $201 \mathrm{~m}(659 \mathrm{ft})$ above mean sea level. The water table, at $126 \mathrm{~m}$ (413 ft) above mean sea level, is $75 \mathrm{~m}$ (246 ft) below the CSB basemat.

The suprabasalt aquifer system in the 200 East Area includes the Ringold Formation and parts of the Hanford formation. Sandy gravels dominate the saturated Hanford formation and gravels dominate the Ringold Formation. Significant silt- and clay-dominated intervals are absent except in the southwestern part of the 200 East Area and east of B Pond where the Lower Mud sequence is found. The suprabasalt aquifer system ranges in thickness from zero where basalt is present above the water table to $60 \mathrm{~m}$ (197 ft) in the south and west portions of the 200 East Area. At the CSB site the suprabasalt aquifer is about $90 \mathrm{~m}(300 \mathrm{ft})$ below surface and about $30 \mathrm{~m}$ (100 ft) thick.

Horizontal hydraulic conductivity of units within the suprabasalt aquifer system varies considerably (Table 1-20). WHC-SD-EN-TI-019, Hydrogeologic Hodel for the 200 East Groundwater Aggregate Area (Connelly et al. 1992), documents the compiled and mapped hydraulic conductivity data for the upper portion of the uppermost aquifer in the 200 West and 200 East Areas. The highest conductivity occurs in a channel stretching from northwest to southeast across the 200 East Area.

Groundwater flow beneath the 200 East Area is complex because of the convergence of flow from the west (natural groundwater flow system) and from the east (artificial recharge from B Pond and the Treated Effluent Disposal Facility) (Figure 1-19). The high transmissivity beneath most of the 200 East Area causes hydraulic gradients to be very small. It is often difficult to define groundwater flow directions from water table maps of the 200 East Area, but contaminant plume maps of the 200 Areas indicate long-term trends in groundwater flow directions (Dresel et a1. 1995). These plume maps indicate a north to northwest direction of flow in the extreme north central portion of the 200 East Area and a south to southeast direction of flow in the southeast portion of the 200 East Area.

Groundwater in the suprabasalt aquifer system is contaminated with various hazardous and radioactive constituents from waste previously discharged to the ground in the 200 Areas. The most significant contaminants include nitrate, carbon tetrachloride, tritium, and ${ }^{99} \mathrm{Tc}$. Contaminant plume maps for 1994 are presented in PNL-10698, Hanford Site Ground-Water Monitoring for 1994 (Dresel et al. 1995). 
Table 1-20. Aquifer Properties in the 200 Areas.

\begin{tabular}{|c|c|c|c|c|}
\hline Location & Interval & $\begin{array}{c}\text { Hydraulic } \\
\text { conductivity } \\
(\mathrm{m} / \mathrm{d})\end{array}$ & $\begin{array}{c}\text { Transmissivity } \\
\left(m^{2} / d\right)\end{array}$ & $\begin{array}{l}\text { Data } \\
\text { source }\end{array}$ \\
\hline \multirow{2}{*}{$\begin{array}{l}200 \text { Areas } \\
\text { (undiffer- } \\
\text { entiated) }\end{array}$} & $\begin{array}{l}\text { Elephant Mountain } \\
\text { Member interflow zone }\end{array}$ & -- & 0.7 to 569 & \multirow[t]{2}{*}{ Graham $^{2,6}$} \\
\hline & $\begin{array}{l}\text { Rattlesnake Ridge } \\
\text { interbed }\end{array}$ & -- & 0.74 to 108 & \\
\hline \multirow[t]{3}{*}{200 West } & \multirow{2}{*}{$\begin{array}{l}\text { Ringold unconfined } \\
\text { aquifer }\end{array}$} & 0.2 to 61 & -- & Last $^{c}$ \\
\hline & & 0.093 to 475 & -- & Connelly \\
\hline & Ringold Tower mud & $1.6 \times 10 \mathrm{E}-05$ & -- & Last $^{c}$ \\
\hline 200 East & $\begin{array}{l}\text { Top of unconfined } \\
\text { aquifer (Hanford and } \\
\text { Ringold) }\end{array}$ & 8 to 7,600 & - & Conne17y \\
\hline
\end{tabular}

"Graham, M. J., M. D. Hall, S. R. Strait, and H. R. Brown, 1981, Hydrology of the Separations Area, RHO-ST-42, Rockwell Hanford Operations, Richland, Washington.

Graham, M. J., G. V. Last, and K. R. Fecht, 1984, An Assessment of Aquifer Intercominication with B Pond Mountain Pond Area of the Hanford Site, RHO-RE-ST-12P, Rockwell Hanford Operations, Richland, Washington.

Clast, G. V., B. N. Bjornstad, M. P. Bergeron, D. H. Wallace, D. R. Newcomer, J. A. Schremke, M. a. Chamess, C. S. Cline, S. P. Airhart, and J. S. Wilbur, 1989, Hydrogeology of the 200 Areas Low Level Burial Grounds - An Interim Report. PNL-6820, Pacific Northwest Laboratory, Richland, Washington.

${ }^{\mathrm{C}}$ Connelly, M. P., B. H. Ford, J. W. Lindberg, S. J. Trent, C. D. Delaney, and J. V. Borghese, 1992. Hydrogeologic Model for the 200 East Groundwater Aggregate Area, WHC-SD-EN-TI-019, West inghouse Hanford Company, Richland, Washington.

1.4.2.3.2 Basalt and Interbed Aquifer System. The CRBG and associated sedimentary interbeds form a series of aquifers and aquitards. Generally the dense basalt flows form aquitards and interflow zones (fractured basalt) and the sedimentary interbeds form aquifers. The uppermost regionally extensive confined aquifer beneath the 200 Areas comprises the Rattlesnake Ridge interbed and adjacent interflow zones. The interbed is 15 to $25 \mathrm{~m}$ (49 to $82 \mathrm{ft}$ ) thick beneath the 200 Areas and generally thickens toward the west (Graham et a1. 1981 and 1984). Recharge to the Rattlesnake Ridge interbed aquifer occurs in the higher elevations to the west, north, and northeast. The flow of groundwater is generally toward the northeast beneath the 200 west Area and west to west-northwest beneath the 200 East Area (Delaney et al. 1991).

Beneath the 200 Areas the Rattlesnake Ridge interbed aquifer is generally separated from the unconfined aquifer system by the Elephant Mountain Member of the CRBG. The Elephant Mountain Member is up to $35 \mathrm{~m}$ (115 ft) thick. North of the 200 East Area the Elephant Mountain Member has been locally removed by erosion, allowing hydraulic communication between the Rattlesnake Ridge interbed aquifer and the suprabasalt aquifer system. RHO-RE-ST-12P, An Assessment of Aquifer Intercommunication with B Pond-Gable Mountain Pond Area of the Hanford Site (Graham et a1. 1984), determined that contamination found in the Rattlesnake Ridge interbed aquifer resulted from intercommunication through erosional windows between it and the overlying unconfined aquifer. Transmissivity of the Rattlesnake Ridge interbed and the Elephant Mountain interflow zone are included in Table 1-20. 


\subsubsection{Geology}

The Hanford Site lies within the Pasco Basin, and the Pasco Basin lies within the Columbia Plateau, a broad plain constructed from the Miocene CRBG and situated between the Cascade Range to the west and the Rocky Mountains to the east (Figure 1-20). The Columbia Plateau is often called the Columbia Basin because it forms a broad lowland and is surrounded on all sides by mountains. In the central and western parts of the Columbia Plateau where the Hanford Site is located, the basalt is underlain predominantly by Tertiary continental sedimentary rocks and overlain by late Tertiary and Quaternary fluvial and glaciofluvial deposits. All these deposits were folded and fauted during the Cenozoic to form the present landscape of the region.

1.4.3.1 Physiographic Setting of the Hanford site. The physiography of the Columbia Basin is controlled by the late Cenozoic faulting and folding of the CRBG and the overlying sediments of the Ringold Formation. Surface topography has been modified within the past several million years by geomorphic processes related to Pleistocene cataclysmic flooding, Holocene eolian activity, landsliding, and the Columbia River. The physiography of the Hanford Site is dominated by the low-relief plains of the Central Plains physiographic region and anticlinal ridges of the Yakima Folds physiographic region (Figure 1-21).

Cataclysmic flooding of the Hanford Site occurred when ice dams in western Montana and northern Idaho were breached allowing large volumes of water to spill across eastern and central Washington. The last major flood occurred about 13,000 years ago, during the late Pleistocene Epoch. Anastomosing flood channels, giant current ripples, bergmounds, and giant flood bars are among the landforms created by the floods and are readily seen on the Hanford Site. Most of the large landslides in the region occurred when these flood waters eroded the steep slopes of the ridges. The 200 East Area and the CSB are located on one major Pleistocene flood bar, the Cold Creek bar.

Since the end of the Pleistocene, winds have locally reworked the flood sediments, depositing dune sands in the lower elevations and loess (windblown silt) around the margins of the Pasco Basin. Generally sand dunes have been stabilized by anchoring vegetation except where they have been reactivated where vegetation is disturbed.

1.4.3.2 Stratigraphy. The stratigraphy of the Pacific Northwest is a collection of accreted terrane rocks added onto the North American craton between the Precambrian and early Cenozoic that are now mostly covered by extensive Cenozoic volcanic rocks. Intercalated with the volcanic rocks in structural basins and along the evolving continental margin are sedimentary rocks derived from eroding uplands areas.

The generalized stratigraphy of the Columbia Basin and Hanford Site is shown in Figure 1-22. The principal bedrock of the Hanford Site is the CRBG and intercalated and overlying sedimentary rocks of the Ellensburg Formation. The overlying sedimentary rocks are principally of the Ringold Formation and the Pleistocene catastrophic flood deposits of the Hanford formation (informal designation). This is the general stratigraphy present at the CSB. 
Rocks older than the CRBG are exposed primarily along the margins of the Columbia Basin and vary widely in age, lithology, and structure. It is this complex stratigraphy and structure that underlies the CRBG of the Columbia Basin and Hanford Site and that is the probable source for seismic hazards under the basalt. Because of the thick basalt cover, the exact nature of the stratigraphy and the types of the structure under the Hanford Site is uncertain.

Along the northern and northwestern margins of the Columbia Bas in in early Tertiary time, a series of sedimentary basins formed in the accreted terranes of the North Cascades (DOE 1988; Campbell 1989). These basins are now separated by tectonic "blocks" or uplifts that have a northeast- to northwest-trending structural grain and trend toward the Hanford Site. Along the northeastern and eastern margins of the Columbia Basin, the CRBG 1aps onto Paleozoic rocks and Precambrian miogeosynclinal and cratonic rocks that are interspersed with granites of the Idaho Batholith and other Jurassic and cretaceous intrusions (DOE 1988). To the south and southwest, lower- to middle-Tertiary volcanic rocks and related volcaniclastic rocks primarily of the Clarno and John Day Formations directly underlie the CRBG and overlie accreted terranes of the Blue Mountains. To the west, younger volcanic rocks that erupted from the High Cascades cover the CRBG and obscure early Cenozoic volcanic and volcanoclastic rocks of predominantly Eocene and 0ligocene age.

1.4.3.2.1 Columbia River Basalt Group. The CRBG, the principal bedrock unit in the Yakima Fold Belt (YFB) and under the Hanford Site, is a sequence of tholejitic flood basalt flows that were erupted between 17 and 6 million, years ago (Ma) (Figure 1-22). The CRBG now covers approximately $164,000 \mathrm{~km}^{2}$ $\left(63,325 \mathrm{mi}^{2}\right)$ and consists of $174,000 \mathrm{~km}^{3}\left(41,700 \mathrm{mi}^{3}\right)$ of basalt (Tolan et al. 1989). The flows were erupted from north-northwest-trending fissures or linear vent systems in north-central and northeastern Oregon, eastern Washington, and western Idaho (Swanson et al. 1975).

The CRBG has been divided into five formations (Swanson et a1. 1979a); only the Grande Ronde Basalt, the Wanapum Basalt, and the Saddle Mountains Basalt are exposed on the Hanford Site. The Imnaha Basalt occurs at the base of the CRBG under the Hanford Site (Tolan et al. 1989).

The basalt flows of the CRBG are recognized using a combination of 1ithology, chemistry, and paleomagnetic data (Swanson et al. 1979a). Chemical composition and paleomagnetic data have proven to be the most reliable criteria for flow recognition and correlation; lithology is reliable for many flows primarily within the Wanapum and Saddle Mountains Basalts, but chemical compositions are still used to confirm identifications.

Over $85 \%$ of the CRBG was erupted during the 2-million-year span of the Grande Ronde Basalt eruptions. In the field, the Grande Ronde Basalt is divided into four magnetostratigraphic units, which, from oldest to youngest are Reversed $1\left(R_{1}\right)$, Normal $1\left(N_{1}\right)$, Reversed $2\left(R_{2}\right)$, and Normal $2\left(N_{2}\right)$ (Swanson et a1. 1979a). The Grande Ronde Basalt is further subdivided into seventeen groups of flows based on chemical compositions (Reidel et al. 1989a).

The younger basalt flows of the Wanapum and Saddle Mountains Basalts on the Hanford Site have been locally eroded to varying degrees. Uplift along 
anticlinal ridges has resulted in erosion to different depths along the margins of the Pasco Basin. Within the synclines where the basalt surface is covered by sediment fill, the upper basalt flows have been locally eroded by fluvial activity and proglacial flooding. North of the 200 Areas between Gable Mountain and Gable Butte, the Saddle Mountains Basalt has been eroded down to the oldest member, the Umatilla Member. The Elephant Mountain Member is suspected of being eroded near the northeast corner of 200 East Area.

1.4.3.2.2 Intercalated and Post-Columbia River Basalt Group Sediments. The Hanford Site and CSB are situated on a sequence of sedimentary units that overlie the CRBG. These sediments are confined largely to the synclinal valleys and basins of the western Columbia Basin. The sedimentary record is incomplete, but it is a direct reflection of the structural development of the area (Fecht et a1. 1987). The upper-Miocene to middle-Pliocene (late Neogene) record of the Columbia River system in the Columbia Basin is represented by the upper Ellensburg Formation, Ringold Formation, and Snipes Mountain conglomerate. Except for local deposits (e.g., the Pliocene-Pleistocene unit and the early Palouse soil [DOE 1988]), there is a hiatus (i.e., lack of sedimentation or erosion) in the stratigraphic record between the end of the Ringold (3.4 Ma) and the Pleistocene (1.6 Ma).

Pleistocene to Recent (Quaternary) sediments overlying the CRBG at the Hanford Site include cataclysmic flood gravels and slackwater sediments of the Hanford formation; terrace gravels of the Columbia, Snake, and Yakima Rivers; and eolian deposits, including the Palouse Formation in eastern Washington.

Late Neogene Sediments. Two main late Neogene sedimentary units occur in the Columbia Basin and at the Hanford Site, the Ellensburg Formation and the Ringold Formation (Figure 1-22).

Ellensburg Formation. The Ellensburg Formation includes epiclastic and volcaniclastic sedimentary rocks that are intercalated with and overlie the CRBG (Waters 1961; Swanson et a1. 1979a). The Ellensburg stratigraphy of the Hanford Site has been discussed in RH0-BWI-ST-14, Subsurface Geology of the Cold Creek Syncline (Reidel and Fecht 1981), in Geological Society of America Special Paper 239, Volcanism and Tectonism in the Columbia River Flood-Basalt Province (Reidel et al. 1989a), and in Bulletin 77, Selected Papers on the Geology of Washington (Fecht et al. 1987). At the Hanford Site, the Ellensburg Formation is mixed with sediments deposited by the ancestral Clearwater River and Columbia River.

Ringold Formation. Sediments continued to be deposited in most synclinal valleys of the central Columbia Basin, including the Hanford Site, long after the eruptions of the CRBG; these sediments are the Ringold Formation. Although exposures of the Ringold Formation are limited to the White Bluffs on the east side of the Hanford Site, isolated exposures on the west side of the Hanford Site, and the Smyrna and Taunton Benches within the 0the1lo Basin, extensive data on the Ringold Formation have been obtained from boreholes at the Hanford Site.

The Ringold Formation at the Hanford Site is up to $185 \mathrm{~m}(607 \mathrm{ft}$ ) thick in the deepest part of the Cold Creek syncline south of the 200 West Area and $170 \mathrm{~m}(558 \mathrm{ft})$ thick in the western Wahluke syncline near the $100 \mathrm{~B}$ Area. The Ringold Formation pinches out against the Gable Mountain, Yakima Ridge, Saddle 
Mountains, and Rattlesnake Mountain anticlines. The formation is largely absent in the northern and northeastern parts of the 200 East Area but is present under the CSB.

The Ringold Formation consists of semi-indurated clay, silt, pedogenically altered sediment, fine- to coarse-grained sand, and granule to cobble gravel. Ringold strata typically are below the water table and the textural variations of the strata influence groundwater flow. The Ringold Formation historically has been divided into a variety of units, facies types, and cycles (Newcomb 1958; Myers et al. 1979; Tallman et al. 1979; Bjornstad 1984; and DOE 1988). However, these terminologies have proven to be of limited use because they are too generalized to account for significant local stratigraphic variation or because they were defined in detail for relatively small areas and do not account for basinwide stratigraphic variation (Lindsey and Gaylord 1989; Lindsey 1991a).

Recent studies of the Ringold Formation in the Hanford Area indicate it contains significant stratigraphic variations (Lindsey and Gaylord 1989; Lindsey 1991a) that are best described on the basis of sediment facies. Sediment facies in the Ringold Formation are defined on the basis of lithology, stratification, and pedogenic alteration.

- The fluvial gravel facies consists of clast-supported granule to cobble gravels with a sandy matrix and intercalated sands and muds. Clast composition is variable, but typically includes basalt, quartzite, porphyritic volcanics, and greenstone. Sands generally are quartzo-feldspathic with less than $25 \%$ basalt content. Bedforms have low angle to planar stratification, massive bedding, wide shallow channels, and large-scale cross-bedding. The facies was deposited in a gravelly fluvial braidplain characterized by wide, shallow, shifting channels.

- The fluvial sand facies consists of quartzo-feldspathic sands, cross-bedded and cross-laminated sands that are intercalated with lenticular silty sands, clays, and thin gravels. These sands usually contain less than $15 \%$ basalt lithic fragments, and fining upwards sequences are common. Strata of this type were deposited in wide, shallow channels.

- The overbank facies consists of laminated to massive silt, silty fine-grained sand, and paleosols containing variable amounts of pedogenic calcium carbonate. Overbank deposits occur as thin lenticular interbeds in the gravels and sands and as thick 1aterally continuous sequences. These sediments record deposition in proximal levee to more distal floodplain conditions.

- The lacustrine facies is characterized by plane laminated to massive clay with thin silt and silty sand interbeds displaying some soft-sediment deformation. Deposits coarsen upwards. Strata were deposited in a lake under standing water to deltaic conditions.

- The alluvial fan facies is characterized by massive to crudely stratified, weathered to unweathered basaltic detritus. These deposits generally are found around the periphery of the Pasco Basin 
and record deposition by debris flows in alluviat fan settings and in sidestreams draining into the Pasco Basin.

The lower half of the Ringold Formation is the main unconfined aquifer under the Hanford Site and contains five separate stratigraphic intervals dominated by the fluvial gravels facies. These gravels, designated units $A$, $B, C, D$, and $E$ (Figure 1-23), are separated by intervals containing deposits typical of the overbank and 1acustrine facies (Lindsey 1991a). The lowermost of the fine-grained sequences, overlying unit $A$, is designated the Lower Mud sequence. The uppermost gravel unit, unit $E$, grades upwards into interbedded fluvial sand and overbank deposits that are in turn overlain by lacustrine-dominated strata. Fluvial gravel units $A$ and $E$ correspond to the lower basal and middle Ringold units respectively as defined in DOE/RW-0164, Site Characterization Plan Reference Repository Location, Hanford Site, Washington (DOE 1988). Gravel units B, C, and D do not correlate to any previously defined units (Lindsey 1991a). The Lower Mud sequence corresponds to the upper basal unit and lower unit as defined by DOE/RW-0164 (DOE 1988).

The upper part of the Ringold Formation consists of the sequence of fluvial sands, overbank deposits, and lacustrine sediments overlying unit $E$. These sediments correspond to the upper unit as originally defined in "Ringold Formation of the Pleistocene Age in the Type Locality, The White Bluffs, Washington" (Newcomb 1958), along the White Bluffs in the eastern Pasco Basin. The fluvial sand facies is the principal facies of the upper part under the CSB.

Quaternary Stratigraphy of the Pasco Basin. Quaternary sediments, as much as $100 \mathrm{~m}$ (328 ft) thick within the Pasco Basin, overlie the Ringold Formation and are the main units at the CSB. The most extensive of these is the Pleistocene-aged Hanford formation (Figure 1-23). Locally the Hanford formation and underlying Ringold Formation are separated by several laterally discontinuous and informally defined units. These units are the Plio-Pleistocene unit, the pre-Missoula gravels, and the early Palouse soil (Figure 1-23), but they are largely absent at the CSB.

Quaternary Alluvium. Fluvial deposits from major rivers (Yakima, Snake, Columbia) are represented in the Pasco Basin ranging in age from Tertiary to present (Baker et a1. 1991). There are two main alluvial units that are recognized at the Hanford Site: the Plio-Pleistocene unit and the pre-Missoula grave]s.

Overlying the tilted and truncated Ringold Formation in an unconformable relationship in the western cold Creek syncline in the vicinity of 200 West Area is the laterally discontinuous Plio-Pleistocene unit (DOE 1988). The Plio-Pleistocene unit appears to be correlative to other sidestream alluvial and pedogenic deposits found near the base of the ridges bounding the Pasco Basin on the north, west, and south. These sidestream alluvial and pedogenic deposits are inferred to have a late Pliocene to early Pleistocene age on the basis of stratigraphic position and the magnetic polarity of interfingering loess units.

In the central Pasco Basin, mainstream alluvium lies stratigraphically between the Ringold Formation and the Hanford formation. A thick sheet of well-rounded and well-sorted quartzose to gneissic clast-supported pebble to 
cobble gravel with a quartzo-feldspathic sand matrix gravel, informally called the "pre-Missoula gravels," overlies the Ringold Formation in much of the central Pasco Basin. Based on magnetic polarity and stratigraphic position, this unit is interpreted to be early Pleistocene. Mainstream alluvium of probable early Pleistocene age is exposed along Cold Creek and the Yakima Bluffs. It is unclear whether the pre-Missoula gravels overlie or interfinger with the early Palouse soil and Plio-Pleistocene unit. The pre-Missoula gravels are interpreted as mainstream deposits in the Columbia River.

Eolian Deposits. Loess deposits at Hanford contain a detailed Quaternary record; five units are represented within the Pasco Basin (Reidel et al. 1992). These units are informally referred to as Ll through L5 and differentiated on the basis of position relative to other stratigraphic units, color, soil development, and paleomagnetic polarity.

The main eolian unit in the subsurface at the Hanford Site is referred to as the early Palouse soil. The early Palouse soil consists of up to $20 \mathrm{~m}$ $(66 \mathrm{ft})$ of massive, brown-yellow, compact, loess-like silt and minor fine-grained sand (Tallman et a7. 1979 and 1981; DOE 1988). Granule-sized grains consisting primarily of basalt are common in this unit. These deposits overlie the Plio-Pleistocene unit (Figure 1-23) in the western Cold Creek syncline around the 200 West Area but are absent in the 200 East Area. The unit is differentiated from overlying graded rhythmites (Hanford formation) by greater calcium carbonate content, massive structure, and high natural gamma response in geophysical logs (DOE 1988). The upper contact of the unit is poorly defined, and it may grade up-section into silty strata commonly found in the lower part of the Hanford formation. Because of a predominantly reversed polarity, the unit is inferred to be early Pleistocene in age.

Hanford Formation. The Hanford formation is the informal name given to all cataclysmic flood deposits of the Pleistocene. This is the main stratigraphic unit at the surface of the CSB. The Hanford formation consists of pebble to boulder gravel, fine- to coarse-grained sand, and silt. These deposits are divided into three facies: gravel-dominated, sand-dominated, and silty. These facies are referred to as coarse-grained deposits, planelaminated sand facies, and rhythmite facies, respectively, in RHO-BW-SA-563A, Quaternary Geology of the Pasco Basin, Washington (Bjornstad et al. 1987). The rhythmites also are referred to as the "Touchet Beds." The Hanford formation is thickest in the vicinity of 200 West and 200 East Areas, where it

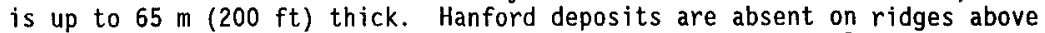
approximately $385 \mathrm{~m}(1,250 \mathrm{ft})$ above sea level, the highest level of cataclysmic flooding in the Pasco Basin (Bjornstad et a1. 1987).

- The gravel-dominated facies generally consists of coarse-grained basaltic sand and granule to boulder gravel. These deposits display massive bedding, plane to low-angle bedding, and large-scale planar cross-bedding in outcrop. The gravel facies dominates the Hanford formation in the 100 Areas north of Gable Mountain, the northern part of the 200 East and West Areas, and the eastern part of the Site including the 300 Area. The gravel-dominated facies was deposited by high-energy flood waters in or immediately adjacent to the main cataclysmic fiood channelways. 
- The sand-dominated facies consists of fine- to coarse-grained sand and granule gravel displaying plane lamination and bedding and less commonly plane bedding and channel-fill sequences in outcrop. These sands may contain small pebbles and rip-up clasts in addition to pebble-gravel interbeds and silty interbeds less than $1 \mathrm{~m}(3 \mathrm{ft})$ thick. The silt content of these sands is variable, but where it is low, a well-sorted and open framework texture is common. These sands typically are basaltic, commonly being referred to as black, gray, or salt-and-pepper sands. This facies is most common in the central Cold Creek syncline and in the central to southern parts of the 200 East and 200 West Areas. The laminated sand facies was deposited adjacent to main flood channelways during the waning stages of flooding. The facies is transitional between the gravel-dominated facies and the rhythmite facies.

- The silty facies consists of thinly bedded, plane laminated, and ripple cross-laminated silt and fine- to coarse-grained sand that commonly displays normally graded rhythmites a few centimeters to several tens of centimeters thick (Myers et a1. 1979; DOE 1988). This facies is found throughout the central, southern, and western Cold Creek syncline within and south of the 200 East and West Areas. These sediments were deposited under slackwater conditions and in back-flooded areas (DOE 1988).

Volcanic Ash Deposits. Volcanism in the Cascade Range has been active throughout the Pleistocene Epoch (approximately 2 million years before present to 10,000 years before present) and through the Holocene Epoch $(10,000$ years before present to present). The eruption history of the Holocene best characterizes the most likely types of activity in the next 100 years. Many of the volcanoes in the Cascade Range have been active in the last 10,000 years, including Mount Mazama (Crater Lake) and Mount Hood in Oregon, and Mount St. Helens, Mount Adams, and Mount Rainier in Washington State (Figure 1-24). Quaternary sediments recorded these eruptions in the form of ash deposits that are interlayered with the sediments.

The Hanford Site is approximately $150 \mathrm{~km}$ (95 mi) from Mount Adams, $175 \mathrm{~km}$ ( $110 \mathrm{mi}$ ) from Mount Rainier, and $200 \mathrm{~km}$ ( $125 \mathrm{mi}$ ) from Mount St. Helens, the three closest active volcanoes. At these distances, the tephra (ash) is the only volcanic product to reach the site and, thus, the only volcanic hazard at the Hanford Site. Mount St. Helens has been considerably more active throughout the Holocene than Mount Rainier or Mount Adams, which is the least active of the three.

1.4.3.3 History of Cataclysmic Flooding in the Pasco Basin. Cataciysmic floods inundated the Pasco Basin several times during the Pleistocene when ice dams failed in northern Washington. Net erosion by these floods was minimal and probably associated with only the earliest floods; later floods only partially incised into older flood deposits before backfilling. During the three major flood episodes there were probably numerous individual flood events. Deciphering the history of cataclysmic flooding in the Pasco Basin is complicated, not only by floods from multiple sources, but also because the paths of Missoula floodwaters migrated and changed course with the advance and retreat of the Cordilleran Ice Sheet. The best preserved record is that of the last Missoula flood, which apparently came down the Columbia River. 
Evidence for cataclysmic flooding in the Pasco Basin, besides the sediments, includes high-water marks and faint strandlines along the Basin margins. These were created by the hydraulic damming and formation of lake Lewis behind Wallula Gap. Formation of this lake and its overflow may have initiated in the columbia Gorge, as indicated by similar high-water marks both upstream and downstream of Wallula Gap. High-water mark elevations for Lake Lewis, inferred from ice-rafted erratics on ridges, range from 370 to $385 \mathrm{~m}$ $(1,213$ to $1,263 \mathrm{ft})$ above sea level. Several weak strandlines are interpreted from photolineaments between 245 and $305 \mathrm{~m}(800$ and $1,000 \mathrm{ft})$ above sea level along the northeastern flank of Rattlesnake Mountain. A flood origin is inferred based on exposures in trenches that cross these features. The lack of well developed strandlines and the absence of typical lake deposits overlying flood deposits suggests that Lake Lewis was short-lived.

The course-grained flood facies is generally confined to relatively narrow tracts in or near flood channelways. The plane-laminated sand facies, on the other hand, occurs as a broad sheet over most of the central Pasco

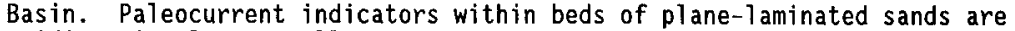
unidirectional, generally toward the south and east, within the Pasco Basin. Rhythmite facies occur in slackwater areas around the margins of the Basin and were deposited as the energy of the floodwaters decreased, including upvalley currents. Individual rhythmites become finer and thinner both laterally and vertically.

1.4.3.4 Geologic Structures of the Columbia Basin and Hanford Site. The geologic structure of the Pacific Northwest is controlled by a basement rock assemblage of accreted terranes fused onto the structurally complex North American craton from the early Mesozoic to early Cenozoic. The accreted terranes form the backbone of the Cascade Range, Okanogan Highlands, and the Blue Mountains. The terranes are now mostly covered by extensive cover of Cenozoic rocks that were folded and faulted in a north-south oriented compressive regime. North-south compression is continuing today east of the Cascades portion of the Pacific Northwest and this pattern of Cenozoic deformation is expected to continue into the future.

The Columbia Basin is a structurally and topographically low area surrounded by mountains ranging in age from the late Mesozoic to Recent (Figure 1-25). The Columbia Basin has two major structural subdivisions or subprovinces: the YFB and the Palouse Slope (Figure 1-25). The YFB is a series of anticlinal ridges and synclinal valleys in the western and central parts of the Columbia Basin. The Palouse Slope forms the eastern part of the Columbia Basin and is mainly a westward-tilting paleoslope. The Hanford Site and the CSB are in the eastern part of the YFB. The western boundary of the Palouse Slope is at the eastern boundary of the Hanford Site.

The Blue Mountains subprovince of the Columbia River flood-basalt province is a northeast-trending anticlinorium that extends $250 \mathrm{~km}$ (155 mi) from the Oregon Cascades to Idaho and forms the southern border of the Columbia Basin and the southern part of the Columbia Plateau.

1.4.3.4.1 Major Structural Features of the Columbia Basin. The main structural features of the Columbia Basin are the YFB and two major crosscutting structures: the 0lympic-Wallowa lineament (OWL) and the Hog RanchNaneum Ridge anticline (HR-NR). The OWL passes along the southern boundary of 
HNF-SD-SNF-RPT-004 REV 6

Hanford and the HR-NR anticline forms the western structural boundary of the Pasco Basin and Hanford Site.

The 01 ympic-Wallowa Lineament. The OWL (Figure 1-25) is a major topographic feature in Washington and Oregon that crosscuts the Columbia Basin and forms the southern boundary of the Hanford Site. This alignment of structural features parallels prebasalt structural trends along the northwest margin of the Columbia Basin, but it has not been linked to any individual structure (Campbel1 1989; Reidel and Campbell 1989).

The portion of the OWL that crosses the Columbia Basin is called the Cle Elum-Wallula deformed zone (CLEW) (Keinle et a1. 1977). It is a 10-km(6-mi-)wide, moderately diffuse zone of anticlines that have a $\mathrm{N} 50^{\circ} \mathrm{W}$ orientation. The CLEW consists of three structural parts: (1) a broad zone of deflected or anomalous fold and fault trends extending south from Cle Elum to Rattlesnake Mountain on the Hanford Site; (2) a narrow belt of topographically aligned domes and doubly plunging anticlines extending from Rattlesnake Mountain to Wallula Gap; and (3) the Wallula fault zone, extending from Wallula Gap to the Blue Mountains.

Northwest of the CRBG margin, numerous northwest- and north-trending faults and shear zones of the Straight Creek fault system 7 ie subparallel to the OWL. The Snoqualmie batholith intrudes these faults but is not cut by them, indicating that any possible movement along the OWL at the western margin of the Columbia Basin must be older than the batholith, 17 to $19.7 \mathrm{Ma}$ (DOE 1988).

The structural significance of the OWL has been called into question by two recent geophysical studies. Neither a seismic profiling survey by Jarchow (1991) nor a gravity survey by Saltus (1993) could find any obvious geophysical signature for the OWL below the CRBG.

Hog Ranch-Naneum Ridge Anticline. The NR-HR anticline is the western structural boundary of the Pasco Basin, the basin containing the Hanford Site (Figure 1-25). The HR-NR anticline is a broad south-trending anticline in the CRBG that crosses the YFB in a north-south direction. This south-plunging structure passes through five Yakima folds and the OWL. The HR-NR anticline was active in late to middle Miocene as demonstrated by thinning of basalt flows across it (Reidel et a1. 1989b), but the east-trending Yakima folds show no apparent offset by the cross structure (Campbe11 1989; Keinle et a1. 1977; Reidel et al. 1989b), nor is the HR-NR anticline offset where the OWL-CLEW crosses it. Growth of the HR-NR anticline continued from the Miocene to Recent and is now marked by the highest structural points along the ridges that cross it.

The Yakima Fold Belt. The YFB subprovince covers about $14,000 \mathrm{~km}^{2}$ $\left(5,400 \mathrm{mi}^{2}\right.$ ) of the western Columbia Basin (Figures $1-20$ and 1-25) and formed as basalt flows and intercalated sediments were folded and faulted under north-south directed compression. The reader is referred to Tables $1 \mathrm{~A}-1$ and 1A-2 in Appendix $1 A$ and to the compilation of structural features for the Columbia Basin by Tolan and Reidel (1989). The Hanford Site lies in the Pasco Basin, which is one of the larger structural basins near the eastern limit of the YFB. The YFB gives the Hanford Site its principal physiographic features 
and has been the primary factor influencing the geohydrologic conditions at the Hanford Site.

The YFB consists of asymmetrical anticlinal ridges and synclinal valleys. The anticlines are typically segmented and usually have a north vergence, although some folds have a south vergence. Synclines are typically asymmetrical with a gently dipping north $1 \mathrm{imb}$ and a steeply dipping south limb. Fold length is variable ranging from several kilometers to over $100 \mathrm{~km}$ (62 $\mathrm{mi}$ ); fold wavelengths range from several kilometers to as much as $20 \mathrm{~km}$ (12 $\mathrm{mi})$. Structural relief is typically about $600 \mathrm{~m}(1,970 \mathrm{ft})$ but varies along the length of the fold. The greatest structural relief along the Frenchman Hills, the Saddle Mountains, Umtanum Ridge, and Yakima Ridge occurs where these folds intersect the north-south trending HR-NR anticline (Reidel et a1. 1989b).

In general, the axial trends produce a "fanning" pattern across the fold belt (Figure 1-25). Anticlines on the western side of the fold belt generally

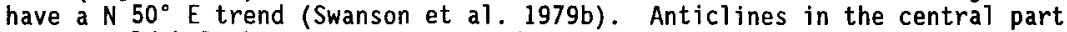
of the fold belt have east-west trends except along the $0 \mathrm{WL}$ where a $\mathrm{N} 50^{\circ} \mathrm{W}$ trend predominates.

Within the Hanford Site and surrounding area, the geometry of the anticlines typically consists of steeply dipping to overturned north flanks and gently dipping $\left(<5^{\circ}\right)$ south flanks. Exceptions, however, include the doubly plunging anticlines with in the Rattlesnake-Wallula alignment of the CLEW and the conjugate box-fold geometry of parts of the anticlines such as the Smyrna segment of the Saddle Mountains (Reidel 1984). The main variable in fold profiles is the width of the gently dipping limb. The widths of the gently dipping limbs vary from as little $5 \mathrm{~km}$ (3 $\mathrm{mi})$ to as much as $35 \mathrm{~km}$ (22 $\mathrm{mi})$.

Segmentation of the anticlines is common throughout the fold belt and is defined by abrupt changes in fold geometry or by places where regional folds die out and become a series of doubly plunging anticlines. Segment lengths are variable but average about $12 \mathrm{~km}$ ( $7 \mathrm{mi}$ ) (ranging from 5 to $35 \mathrm{~km}$ [ 3 to $22 \mathrm{mi})$ near the Hanford Site; some of the larger segments contain subtler changes in geometry, such as different amplitudes, that could also be considered segment boundaries. Segment boundaries are often marked by cross or tear faults that trend $\mathrm{N} 20^{\circ} \mathrm{W}$ to north and display a principal component of strike-slip movement (e.g., Saddle Mountains [Reidel 1984]). Near Hanford these cross faults are confined to the anticlinal folds and usually occur only on the steeper limb, dying out onto the gentler limb.

Segment boundaries may also be marked by relatively undeformed areas along the fold trend where two fold segments plunge toward each other. For example the Yakima River follows a segment boundary where it crosses the Rattlesnake-Wallula alignment at the southeast termination of Rattlesnake Mountain (Figure 1-25).

The steep limb of the asymmetrical anticlines is almost always faulted. Near the Hanford Site the steep $7 \mathrm{imb}$ is typically the northern flank, but el sewhere, as at the Columbia Hills (Swanson et al. 1979b), the south limb is faulted. Where exposed, these frontal fautt zones have been found to be imbricated thrusts as, for example, at Rattlesnake Mountain, Umtanum Ridge 
near Priest Rapids Dam (Bentley in Swanson et al. 1979b), the Horse Heaven Hills (Hagood 1986), and the Saddle Mountains near Sentinel Gap (Reidel 1984).

Yakima folds have emergent thrust faults at the ground surface. The tops of the youngest lava flows at the earth's surface serve as a plane that becomes a low angle thrust fault; the structural attitude of the surface flow controls the angle of the emergent fault plane. This type of apparent structural control led many investigators to conclude that fautts associated with the Yakima Folds are low-angle thrust faults with detachment surfaces either within the CRBG, in the sediments below the basalts, or at the basalt-sediment contact. Where erosion provides deeper exposures into the cores of folds, the frontal faults are observed to be reverse faults (e.g., the Columbia water gap in the Frenchman hills, $45^{\circ}$ south [Grolier and Bingham 1978]; the Columbia Hills at Rock Creek, Washington, $50^{\circ}-70^{\circ}$ north [Swanson et al. 1979b]).

Hydrocarbon exploration boreholes provide direct evidence for the dips of these frontal faults. Reidel et al. (1989b) have shown that the Saddle Mountains fault must dip more than $60^{\circ}$ where the She11-ARCO BN 1-9 borehole was drilled. Drilling of the Umtanum fault near Priest Rapids Dam (DOE 1988) suggests that this fault dips southward under the ridge with a dip of at least $30^{\circ}$ to $40^{\circ}$ but perhaps as high as $60^{\circ}$ (Price and Watkinson 1989).

Although it is difficult to assess, total shortening increases from east to west across the YFB. At about $120^{\circ}$ longitude, it is estimated to be greater than $15 \mathrm{~km}$ ( $9 \mathrm{mi})$ but less than $25 \mathrm{~km}$ (16 mj) (Reidel et al. 1989b) or about 5\% (Appendix 1A, Table $1 A-1$ ). Typically, shortening on an individual anticline caused by folding is approximately 1 to $1.5 \mathrm{~km}(0.6$ to $0.9 \mathrm{mi})$. The amount of shortening on faults expressed at the surface is generally unknown. Estimates range from several hundreds of meters to as much as $3 \mathrm{~km}(1.9 \mathrm{mi})$ (Appendix 1A, Table 1A-2).

1.4.3.4.2 Structure of the Hanford Site. The Cold Creek syncline (Figures 1-26 and 1-27) lies between the Umtanum Ridge-Gable Mountain upl ift and the Yakima Ridge uplift, and is an asymmetric and relatively flat-bottomed structure. The 200 Areas 7 ie on the northern flank, and the bedrock dips gently (approximately $5^{\circ}$ ) to the south. The 300 Area lies at the eastern end of the Cold creek syncline where it merges with the Pasco syncline.

The Wahluke syncline (Figure 1-26) is the principal structural unit that contains the 100 Areas. The Wahluke syncline is an asymmetric and relatively flat-bottomed structure similar to the Cold Creek syncline. The northern 1 imb dips gently (approximately $5^{\circ}$ ) to the south. The steepest $1 \mathrm{imb}$ is adjacent to the Umtanum Ridge-Gable Mountain structure.

The Umtanum Ridge-Gable Mountain structural trend is a segmented anticlinal ridge extending for a length of $110 \mathrm{~km}$ (68 $\mathrm{mi})$ in an east-west direction and passes north of the 200 and 300 Areas and south of the 100 Areas. From the west, the Umtanum Ridge plunges eastward and joins the Gable Mountain-Gable Butte segment just east of the western boundary of the Hanford Site. The easternmost segment, the Southeast anticline, trends southeast off the eastern boundary of the Gable Mountain-Gable Butte segment. 
Umtanum Ridge is an asymmetrical, north-vergent-to-locally-overturned anticline with a major thrust to high-angle reverse fault on the north side (Price and Watkinson 1989) that dies out eastward toward Gable Mountain. Gable Mountain and Gable Butte are two topographically isolated, anticlinal ridges that are composed of a series of northwest trending, doubly plunging, en echelon anticlines, synclines, and associated faults.

The Yakima Ridge uplift extends from west of Yakima, Washington, to the center of the Pasco Basin, where it forms the southern boundary of the Cold Creek syncline south of 200 West Area (Figures 1-26 and 1-27). The easternmost surface expression of the Yakima Ridge uplift is represented by an anticline that plunges eastward into the Pasco Basin (Tolan and Reidel 1989). The eastern extension of Yakima Ridge is mostly buried beneath late Cenozoic sediments and has much less structural relief than the rest of Yakima Ridge.

The 200 and 300 Areas are situated on the south flank of the UmtanumGable Mountain anticline where the Miocene-aged basalt bedrock dips to the southwest into the Cold Creek syncline. The 100 Areas lie north of the Umtanum Ridge-Gable Mountain anticline in the Wahluke syncline. The deepest parts of the Cold Creek syncline, the Wye Barricade depression and the Cold Creek depression, are approximately $12 \mathrm{~km}(7.5 \mathrm{mi})$ southeast of the 200 Areas and under the 200 West Area, respectively.

1.4.3.5 Geology of the 200 East Area Canister Storage Building. The geology of the CSB site, located in the 200 East Area, is summarized on Figures 1-27 and 1-28. The suprabasalt sediments consist of the Ringold Formation and Hanford formation. The Ringold Formation conforms to the basalt bedrock surface and tilts southeast toward the axis of the cold Creek syncline. The Ringold Formation is dominated by gravel units $E$ and $A$, which are separated by the Lower Mud unit. These are the main unconfined aquifers. The Ringold Formation thins from $50 \mathrm{~m}(164 \mathrm{ft})$ at the south end to nearly pinching out at the north end. The beds have been truncated and are unconformably overlain by the Hanford formation. The Hanford formation is mainly sands and gravelly sands that are between 75 and $100 \mathrm{~m}$ (246 and $328 \mathrm{ft}$ ) thick at the site.

During excavation of the pit for the CSB, geologic mapping showed that the foundation for the building is in the fine-grained, laminated sands of the Hanford formation. No faults were found cutting the unit but clastic dikes were observed along the south wall of the site.

1.4.3.6 Tectonic Development of the Hanford Site. A seismic hazards analysis of the Hanford Site (Geomatrix 1996) has shown that the geologic history of the Hanford Site from the Precambrian to the present and the resulting geologic structures significantly impact the hazards analysis. This section summarizes the principal geologic events in the development of the site geology.

The present structure of the Columbia Basin is the product of north-south compression that began in the early Tertiary before the eruption of the CRBG and continues today. The Columbia Basin is composed of two fundamental subprovinces, the Palouse Slope and the YFB. The Palouse Slope is a stable, undeformed area overlying the old continental craton. The YFB overlies a large pre-basalt basin that has been subsiding since the early Tertiary. The pre-CRBG sedimentary basin and CRBG basin are divided by the HR-NR anticline. 
The edge of the old continental craton lies at the junction of the two structural subprovinces and is presently marked by the Ice Harbor dike swarm of the CRBG.

The pattern of deformation in the Columbia Basin has been dominated by north-south compression and subsidence; the YFB is the principal product of these. Deformation has controlled the location of the Columbia River system since the late Miocene as well as the depositional pattern of the post-basalt sediments. The rates of deformation in the Columbia Basin have declined since the early Tertiary. The rate of regional subsidence of the basin and the rate of local uplift on the anticlinal ridges have both declined. The present rate of ridge growth is estimated at $0.04 \mathrm{~mm} / \mathrm{yr}(0.0016 \mathrm{in} / \mathrm{yr})$ and the rate of subsidence in the basin is estimated at $3 \times 10^{-3} \mathrm{~mm} / \mathrm{yr}(0.0001 \mathrm{in} / \mathrm{yr})$.

Microseismicity, high in situ stress conditions, and the geometry of Quaternary-Holocene faulting indicate that the basin is still experiencing north-south compression. Although known late Cenozoic faults are found exclusively on the anticlinal ridges, earthquake focal mechanisms and strain measurements suggest that most stress release is occurring in the synclinal areas. No earthquake events have been shown to be related to known faults. The high in situ stress in the Cold Creek syncline explains the microseismicity in the region; but the absence of microseismicity associated with the anticlinal ridges may result from weakened fault zones lubricated with groundwater that have a component of aseismic or below-detection-limit seismic slip, or the fault zones may be locked up.

1.4.3.6.1 The Pre-Miocene Columbia Basin. The beginning of the development of the Pacific Northwest can be traced to the 1ate Precambrian rifting of the Proterozoic supercontinent when plates that were to become part of either Siberia or Australia separated from North America. The western edge of the North American craton in Washington was near the present $119^{\circ}$ longitude trending north-south in the vicinity of the present Ice Harbor Dam and near the eastern border of the Hanford Site. Between the initial rifting and early Mesozoic time, eastern Washington was a passive margin accumulating sediments along the coast through most of the Paleozoic and early Mesozoic.

When Pangea began to separate in the Triassic, the western coast of North America became an active continental margin with a subduction zone forming along the cratonic boundary. By the late Jurassic, microcontinents and exotic terranes that formed at great distances from North America began to be accreted onto the old craton, expanding the North American continent westward. Washington and the west coast of North America grew by accreting other terranes until at least the Eocene. Presently these accreted terranes form the crystalline basement of the Hanford Site.

The process of subduction and accretion resulted in suturing of these exotic terranes by the intrusion of batholiths beginning in the Cretaceous and continuing into the Eocene. At the same time, most of eastern Washington was uplifted. Streams and rivers eroded these uplands and deposited the sediments along the edge of the continental shelf. The accretion also resulted in successive westward repositionings of the subduction zone until the present position was reached. 
The Cenozoic saw the initiation of extensive volcanism throughout the Pacific Northwest along north-south trending volcanic arcs and in areas where extension occurred during the Eocene. In the Columbia Basin the Eocene and early 0ligocene saw rapid subsidence caused by extension accompanied by infilling of continental sediments and volcanic rocks.

Before the eruption of the CRBG in Miocene time, the Columbia Bas in had two distinct parts: the eastern basin was underlain by ancient cratonic rocks that formed a stable gently dipping slope to the west; the western portion of the Columbia Basin was an area underlain by the accreted terranes of the Mesozoic, which were overlain by continental volcanic rocks and continental sediments that accumulated in a rapidly subsiding basin during the early part of the Cenozoic. The Hanford Site is along the boundary of these two parts of the Columbia Basin. The Journal of Geophysical Research (Catchings and Mooney 1988) interpreted the basin underlying the western part as a failed rift based on seismic refraction survey. Other studies (Rohay and Malone 1983;

Rohay et al. 1985), however, question this interpretation. These studies did not find evidence for a rift basin in the deep crust or mantle.

Tertiary sedimentary and volcaniclastic rocks extend beyond the margin of the CRBG and form part of the Cascade Range (Reidel et al. 1994); in addition, there is no known fault zone along the western margin of the bas in as suggested in the rift model. The pre-CRBG sediments that continue across the present Cascade Range were arched upward during intrusion and uplift of the Cascade Range beginning about $12 \mathrm{Ma}$ to form the present western edge of the Columbia Basin. This supports the previously mentioned geophysical studies and suggests that the Columbia Basin is not a rift basin but perhaps simply a back-arc basin. The concept of a rift basin has a significant impact on the seismic hazards of the Site (Geomatrix 1996).

1.4.3.6.2 Miocene Columbia Basin. Beginning about $17 \mathrm{Ma}$ and continuing until about $6 \mathrm{Ma}$, flood-basalt flows of the CRBG began erupting from linear vent systems in eastern Washington, northeast Oregon, and western Idaho. The greatest volume $(85 \%)$ of basalt was erupted between 16.5 and $15.5 \mathrm{Ma}$ with waning eruptions until $6 \mathrm{Ma}$. The basalt eruptions were huge by comparison to eruptions today; individual flows contained as much as $5,000 \mathrm{~km}^{3}$ (1,200 $\left.\mathrm{mi}^{3}\right)$ of basalt (Reidel et al. 1989b). The average hiatus between eruptions was as long as 20,000 years.

Borehole, geophysical, and stratigraphic data (Catchings and Mooney 1988; Reidel et a1. 1989b) indicate that the CRBG is thinner on the Palouse slope than in the YFB. The CRBG ranges from 500 to $1,500 \mathrm{~m}(1,640$ to $4,920 \mathrm{ft})$ thick on the Palouse Slope but abruptly thickens to as much as $4,000 \mathrm{~m}$ $(13,125 \mathrm{ft}$ ) in the Pasco Basin area under the Hanford Site (Reidel et al. 1989b). Regional thickness patterns for both the CRBG and underlying Tertiary sediments indicate that the pre-CRBG bas in where the Hanford Site is located began subsiding again. By far the most significant tectonic activity was continued subsidence in the basin. The subaerial nature of the CRBG indicates that subsidence continued as long as basalt was being erupted and that basalt accumulation kept pace with subsidence (Reidel et al. 1989a and 1989b). Subsidence rates from 17 to 15.6 Ma were approximately $1 \mathrm{~cm} / \mathrm{yr}(0.4 \mathrm{in} / \mathrm{yr})$ initially and decreased to $3 \times 10^{-3} \mathrm{~cm} / \mathrm{yr}(0.001 \mathrm{in} / \mathrm{yr})$ in the late Miocene (Reidel et a1. 1989b). 
During the eruption of the CRBG, the anticlinal ridges were topographic highs against which the basalt flows thinned as they were emplaced (Reidel 1984; Reidel et al. 1989b). Detailed analysis of borehole and field data (Reidel 1984; Reidel et al. 1989b) established a quantitative relationship between flow thickness and fold growth rates. During the initial eruption of the CRBG (17 to $15.6 \mathrm{Ma}$ ) the ridges grew at about $0.25 \mathrm{~mm} / \mathrm{yr}$ $(0.01 \mathrm{in} / \mathrm{yr})$, and the rate decreased to about $0.04 \mathrm{~mm} / \mathrm{yr}(0.002 \mathrm{in} / \mathrm{yr})$ during the waning phases (15.6 to $10.5 \mathrm{Ma}$ ) (Reidel 1984; Reidel et al. 1989b).

By the end of the massive eruptions of the CRBG ( $8.5 \mathrm{Ma})$, most of the Columbia Basin was a shallow, bowl-shaped, nearly featureless plain. The massive eruptions had buried most of the structural and topographic relief. In the western part of the Columbia Basin, only the anticlinal ridges that were not buried by younger flows stood above the plain. Across this plain flowed the ancestrai Columbia River and its main tributaries, including the Salmon-Clearwater, Yakima, and Palouse Rivers.

1.4.3.6.3 The Late-Miocene to Middle-Pliocene Columbia Basin. The post-CRBG tectonic history of the Columbia Basin and Hanford Site is recorded in the Yakima folds and post-CRBG sediments. Alluvial-lacustrine sediments deposited primarily by the Columbia River system show that the Yakima folds were growing and displacing river channels during the late Miocene and Pliocene (Fecht et al. 1987).

Progressive changes in the distribution of post-CRBG sedimentary facies provide one of the best records of the post-CRBG tectonic history of the Columbia Basin and Hanford Site. Ridge uplift and basin subsidence are recorded by progressive lateral shifts in these depositional environments over time (Fecht et a1. 1987; Smith 1988; Lindsey 1991b; Reidel et al. 1994).

During the waning phases of CRBG eruptions (12.5 to $8.5 \mathrm{Ma}$ ), the Columbia River flowed south across the YFB. Before approximately $8 \mathrm{Ma}$, the post-CRBG pre-Ringold channel of the Columbia River flowed across the western Pasco Basin, entering at Sentinel Gap and exiting near the southwestern side of Hanford; from there it flowed southwest toward Goldendale. About $8 \mathrm{Ma}$ the Columbia River began to shift eastward onto the Hanford Site flowing south through Gable Gap and occupying a water gap over the eastern end of Rattlesnake Mountain near Benton City, Washington (Fecht et a1. 1987). By middle Ringold time (approximately $6 \mathrm{Ma}$ ), the Columbia River shifted position again, exiting the Pasco Basin at Wallula Gap as it does now (Fecht et al. 1987).

About $3.4 \mathrm{Ma}$, regional uplift in western North America caused incision of the Columbia River system that resulted in the removal of over $100 \mathrm{~m}$ (328 $\mathrm{ft}$ ) of Ringold section across the Hanford Site and under the CSB site. This regional incision and erosion produced the White Bluffs along the Columbia River on the eastern boundary of the Hanford Site.

1.4.3.6.4 Quaternary Deformation in the Columbia Basin. Uplifted and faulted Ringold and coeval sediments flank most ridges in the central Columbia Basin (Reidel 1984; Reidel et a1. 1989b). Deformed P1 iocene-Pleistocene sediments also are found on many ridges. Younger glaciofluvial sediments of the Hanford formation locally record some of the youngest deformation in the columbia Basin. 
Evidence for continued growth of the YFB in the Quaternary is mainly restricted to the frontal fault zones. Although not common, evidence of young faulting or suspected young faulting has been found at many locations across the YFB (see Appendix IA, Tables $1 A-3$ and $1 A-4$ ). Young faults have been described at Toppenish Ridge, at Union Gap in Ahtanum Ridge, on Gable Mountain along Umtanum Ridge, in the Columbia Hills anticline, and along the CLEW. Although age relationships are not fully understood, they suggest that faulting has continued since the last cataclysmic flood (approximately 13,000 years before present).

\subsubsection{Contemporary Stress and Strain.}

1.4.3.7.1 Seismicity. Seismic monitoring at Hanford began when the U.S. Geological Survey installed a small array of seismograph stations around the Hanford Site in the summer of 1969. In 1982 a closely spaced seismic network was installed at the Hanford Site to characterize the microseismicity on the Site for a possible high-level waste repository. This operated until 1988. In 1988 the number of stations in the network was reduced. Earthquakes of magnitudes 1.0 (Coda Amplitude Magnitude) and larger currently can be detected and located at the Hanford Site and earthquakes of magnitude 2.5 and larger are detected and located throughout most of eastern Washington.

Past seismic hazard studies at the Hanford Site have shown that earthquakes can be related to three crustal layers and five general sources (Tables 1-21 and 1-22). A11 layers and sources are monitored at the Site except the Cascadia Subduction Zone, which is monitored by the University of Washington.

Table 1-21. Depth of Earthquakes in the Columbia Basin.

\begin{tabular}{|l|c|}
\hline \multicolumn{1}{|c|}{ Layer } & Depth \\
\hline Columbia River Basalt Group & $0-5 \mathrm{~km}$ \\
\hline Prebasalt sediments & $5-10 \mathrm{~km}$ \\
\hline Crystalline basement & $>10 \mathrm{~km}$ \\
\hline
\end{tabular}

Table 1-22. Principal Locations of Earthquakes in the Columbia Basin.

\begin{tabular}{|l|l|}
\hline \multicolumn{1}{|c|}{ Area } & \multicolumn{1}{c|}{ Layer } \\
\hline Major reverse faults on ridges & Mainly basalt, al so prebasalt sediments \\
\hline Secondary faults on ridges & Basalt \\
\hline Swarm area & Basalt \\
\hline Basement & Crystalline basement \\
\hline Cascadia Subduction Zone & Lithosphere - plate tectonic boundary \\
\hline
\end{tabular}


Vertical Patterns. There are three horizontal layers of seismicity (seismic stratigraphy) related to the stratigraphy of the Hanford Site and vicinity (Table 1-21): the CRBG, the prebasalt sediments, and the crystalline basement. About $75 \%$ of the earthquakes have originated in the CRBG layer. The prebasalt sedimentary layer has had $8 \%$ of the events and the crystalline basement has had $17 \%$.

Shallow Earthquakes in the Basalt. The majority of the seismicity at the Hanford Site and the surrounding area comes from the basalt layer that extends from the surface to approximately $4 \mathrm{~km}(2.5 \mathrm{mi})$ under the site.

Earthquakes in Sedimentary Rock below the Basalt. The seismicity in the pre-CRBG sedimentary rock appears to be confined to the top $3 \mathrm{~km}$ (1.9 mi). The seismicity of this sedimentary layer at the Hanford Site is relatively low when compared to the basalt layer but may be related to localized detachment zones related to the growth of the anticlinal structures.

Earthquakes in the Crystalline Basement. Deep earthquakes below $10 \mathrm{~km}$ $(6.2 \mathrm{mi})$ appear to be concentrated in the western and southwestern portions of the Hanford Site. The deepest earthquakes located below the Site are shallower than $30.0 \mathrm{~km}(18.6 \mathrm{mi})$.

Using first-motion data from the Eastern Washington Regional Network and from the Basalt Waste Isolation Project, focal mechanisms show faulting that strikes between $\mathrm{N} 30^{\circ} \mathrm{W}$ and $\mathrm{N} 80^{\circ} \mathrm{W}$. Although the strike is consistently west-northwest, the throw on the assumed faults varies. These data indicate reverse faults or strike-slip faults.

Spacial Patterns. Past studies at the Hanford Site have concluded that there are five different tectonic environments (earthquake sources) where earthquakes can occur near the Hanford Site and in the Columbia Basin of eastern Washington (Table 1-22).

1. Reverse/thrust faults in the CRBG associated with major anticlinal ridges such as Rattlesnake Mountain, Yakima Ridge, and Umtanum Ridge

2. Secondary faults occurring on the major anticlinal ridges

3. Small geographic areas of unknown geologic structure that produce clusters of events (swarms), usualiy in the CRBG in synclinal valleys

4. Basement source structures, although earthquakes cannot be directly tied to a mapped fault because very little is known about geologic structures in the crystalline basement beneath the Hanford Site

5. The Cascadia Subduction Zone, which recently has been postulated to be capable of producing a magnitude 9 earthquake.

Floating Earthquakes. A "floating" earthquake within the tectonic environment covering the entire Columbia Basin, including the Hanford Site, must be assessed. A floating earthquake is one that, for seismic design 
purposes, can happen anywhere in a tectonic province and is not associated with any known geologic structure. It can be floated anywhere in the province.

Earthquake Swarm Areas. The major source of earthquakes at the Hanford Site is swarm activity in the syncline of the YFB. There are three general areas of significant swarm activity: the Wooded Is land swarm area, Coyote Rapids swarm area, and the Saddle Mountains swarm area (Figure 1-29).

The Wooded Island swarm area, located near the 300 Area, occurs at the eastern edge of the YFB where it abuts against the Palouse siope. This boundary marks the suture zone between the old accreted terranes to the west and the stable Precambrian-Paleozoic craton to the east (Reidel et al. 1994). This zone also is marked by an abrupt increase in the thickness of the basalt and subbasalt sediment over the accreted terranes and abrupt thinning of the basalt and sediment over the craton.

The Coyote Rapids Swarm Area is located at the horn of the Columbia between $100 \mathrm{~K}$ and $100 \mathrm{~N}$ areas; it occurs over no known geologic structure. The swarm lies at the intersection of two paleoslopes that make a northeastsouthwest trough extending from Spokane, Washington, to the Columbia Gorge. This zone may be an old basement weakness zone, but there is no known reason for the swarm to occur in its present position.

The Saddle Mountains Swarm Area is located along the north side of the Saddle Mountains. The swarm area is located north of the Saddle Mountains fault zone in an area that has no mapped geologic structures. There is evidence for recent (post-13,000 years) faulting on the Saddle Mountain fault (Appendix 1A, Table $1 A-3$ ), but there is no evidence for faults at the swarm. The cause of the earthquake swarm is not known at this time.

Magnitude of Earthquakes. Earthquake activity at Hanford and in the Columbia Basin is summarized in Appendix 1A, Tables $1 A-5,1 A-6,1 A-7$, and 1A-8. Since July 1982, approximately 650 earthquakes between magnitude 0 and 3.8 have been recorded on and around the Hanford Site. The pattern of earthquake activity between 1990 and 1995 is shown in Figure 1-30. The greatest seismic activity is in the low-magnitude range, with only 5 events exceeding a magnitude of 3.0. The largest magnitude earthquake on the Hanford Site was a 3.8 magnitude earthquake on October 25, 1971, in the Coyote Rapids Swarm Area (Appendix $1 A$, Table $1 A-7$ ). The largest recent, felt earthquake was a 3.3 magnitude earthquake on June 12, 1995, in the Wooded Is land swarm area. The largest regional earthquake was the $5.7 \mathrm{Mi}$ ton-Freewater earthquake on July 16, 1936 (Appendix 1A, Table 1A-6); this earthquake occurred $100 \mathrm{~km}$ $(62 \mathrm{mi})$ southeast of the Hanford Site. The 1936 Milton-Freewater earthquake was estimated to have a peak acceleration of $0.03 \mathrm{~g}$ at the Hanford Site.

1.4.3.7.2 Contemporary Stress in the cold Creek Syncline. Contemporary stress in the cold Creek syncline is expressed principally as horizontal shortening and subsidence. Geodetic surveys (Prescott and Savage 1984) were performed across the Pasco Basin to determine rates of shortening. The data suggest north-south shortening; the rate of shortening is not statistically significant at the $95 \%$ confidence level, however, and the measurements are within the error limits of the recording instruments. 
Contemporary stress measurements were performed at the Hanford Site as part of the Basalt Waste Isolation Project. Core disking and spalling in boreholes drilled in the Cold Creek syncline indicate relatively high in situ stress (DOE 1988). Hydrautic fracturing tests were conducted in boreholes in the cold Creek syncline at a depth of about $1 \mathrm{~km}(0.6 \mathrm{mi})$ (DOE 1988). The results also indicated high in situ stress. The maximum horizontal stress ranges from 52.6 to $67.4 \mathrm{MPa}\left(7,630\right.$ to $\left.9,780 \mathrm{lbf} / \mathrm{in}^{2}\right)$ and the minimum horizontal stress ranges from 30.3 to $35.7 \mathrm{Mpa}\left(4,400\right.$ to $\left.5,180 \mathrm{lbf} / \mathrm{in}^{2}\right)$ with a mean horizontal to vertical ratio of $1.77 \pm 0.20$. The mean orientation of induced fractures, and the direction of the maximum horizontal stress, is consistent with north-south compression (DOE 1988).

1.4.3.7.3 Subsidence. Subsidence has been continuing in the Pasco Basin and Hanford Site since at least the Eocene. Estimates of subsidence since the middle Miocene $(17 \mathrm{Ma})$ indicate the rates of subsidence have declined. From 17 to about $15.6 \mathrm{Ma}$, the rate of subsidence was about 0.7 to $1 \mathrm{~cm} / \mathrm{yr}(0.3$ to $0.4 \mathrm{in} / \mathrm{yr})$. This decreased to about $0.03 \mathrm{~cm} / \mathrm{yr}(0.01 \mathrm{in} / \mathrm{yr})$ from 15.6 to $14.5 \mathrm{Ma}$. The present rate of ridge growth is estimated at $0.04 \mathrm{~mm} / \mathrm{yr}$ $(0.0015 \mathrm{in} / \mathrm{yr})$ and the rate of subsidence in the basin is estimated at $3 \times 10^{-3} \mathrm{~mm} / \mathrm{yr}(0.0001 \mathrm{in} / \mathrm{yr})$.

The pattern of subsidence in the Cold Creek syncline is shown in Figure 1-31. There are two broad areas of subsidence in the Cold Creek syncline: the Wye Barricade depression and the Cold Creek Depression. Both areas have had a long slow history of subsidence (Reidel et al. 1983); both areas are away from the 200 Areas and the CSB site.

1.4.3.8 Geologic Hazards. The geologic hazards that affect the performance of the CSB have been assessed based on the geologic data addressed in previous sections. These hazards are discussed below and, where appropriate, quantified for use in the structural evaluations and safety analyses.

1.4.3.8.1 Seismic Hazard Assessment. A seismic hazard analys is was recently completed for the Hanford Site (Geomatrix 1996). Previous seismic hazard analyses were done for Supply System WNP-1, WNP-4, and WNP-2, which also are located on the Hanford Site (Power et a1. 1981). The Supply System study was later applied to the DOE-held areas within the Hanford Site by Woodward-Clyde Consultants (WCC 1989).

The following discussion is based on the current seismic hazard analysis (Geomatrix 1996), which incorporates seismo-tectonic data and interpretations that postdate the Supply System's earlier assessment and are discussed in previous sections of this report. The details of the source models and attenuation relationships used in the hazard assessment are included in WHC-SD-W236-TI-002, Probabilistic Seismic Hazard Analysis, DOE Hanford Site, Washington (Geomatrix 1996).

The potential seismic sources determined to be the major contributors to the seismic hazard in and around the Hanford Site are crustal sources and Cascadia Subduction Zone earthquakes in western Washington State. The crustal sources are:

- Fault sources related to the Yakima folds 
- Shallow basalt sources that account for the observed seismicity within the CRBG and not associated with the anticlines

- Crystalline basement source.

The mean seismic hazard curves for the 200 East Area and the CSB site are shown in Figures $1-32$ and $1-33$ and illustrate the contributions of individual folds to the hazard. The relative contribution of crustal and Cascadia Subduction sources at the 200 East Area is illustrated in Figure 1-34 and the relative contribution of the three crustal sources for the same location is show in Figure 1-35.

Horizontal and vertical equal-hazard response spectra were developed for the CSB site. These are shown at 5\% damping for performance category 3 in Figure 1-36 (Tallman 1996). More detail and additional damping values are presented in WHC-SD-W236-TI-002 (Geomatrix 1996).

The CSB is using the design and completed portions of the subgrade construction of the canceled Hanford Waste Vitrification Plant (HWVP). The horizontal seismic response spectrum for the HWVP was a Newmark and Hall median spectra shape anchored at $0.35 \mathrm{~g}$ (Newmark and Hall 1978). The vertical spectrum is two-thirds of the horizontal. The horizontal and vertical Newmark and $\mathrm{Hall}$ response spectra envelop the horizontal and vertical equal hazards response spectra (respectively) (Figure 1-36). Therefore, use of the HWVP response spectra fulfills the requirements of performance category 3 response spectra (Tallman 1996).

The site response characteristics of the soils underlying the Hanford Site are similar to those represented in the empirical strong motion database from California. This was determined by comparing the relative response of characteristic Hanford Site soil profiles and dynamic soil properties with those of California deep soil strong-motion recording stations. Time histories representative of the events contributing to the Hanford Site hazard were used for ground motion input (Geomatrix 1996, Appendix A).

1.4.3.8.2 Volcanic Hazard Assessment. Two types of volcanic hazards have affected the Hanford Site in the past 20 million years:

- Continental flood basalt volcanism that produced the CRBG, which underlies the Hanford Site, outcropping in the surrounding ridges

- Volcanism associated with the Cascade Range.

Several volcanoes in the Cascade Range are currently considered active, but activity associated with flood basalt volcanism has ceased.

The flood basalt volcanism that produced the CRBG occurred between 17 million and 6 million years before present. Most of the lava was extruded during the first 2 to 2.5 million years of the 11 -million-year volcanic episode. Flood basalt volcanism has not recurred during the last 6 million years, suggesting that the tectonic processes that created the episode have ceased. The recurrence of Columbia River basalt volcanism is not considered to be a credible volcanic hazard (DOE 1988). 
Volcanism in the Cascade Range has been active throughout the Pleistocene Epoch (approximately 2 million years before present to 10,000 years before present) and through the Holocene Epoch (10,000 years before present to present). The eruption history of the Holocene best characterizes the most likely types of activity in the next 100 years. Many of the volcanoes in the Cascade Range have been active in the last 10,000 years, including Mount Mazama (Crater Lake) and Mount Hood in Oregon and Mount St. Helens, Mount Adams, and Mount Rainier in Washington state (Figure 1-24). The Hanford Site is approximately $150 \mathrm{~km}$ (95 mi) from Mount Adams, $175 \mathrm{~km}$ (110 mi) from Mount Rainier, and $200 \mathrm{~km}(125 \mathrm{mi})$ from Mount St. Helens, the three closest active volcanoes. At these distances, the tephra (ash) is the only hazard. Mount St. Helens has been considerably more active throughout the Holocene than Mount Rainier or Mount Adams, which is the least active of the three. Ashfall at the Hanford Site during the May 18, 1980, eruption of Mount St. Helens ranged from a trace in the southern part of the Site to about $1 \mathrm{~cm}(0.5 \mathrm{in}$. in the 100 Areas.

Probabilistic volcanic hazard studies of the Cascade Range have been completed by the U.S. Geological Survey (Hoblitt et al. 1987; Scott et al. 1995). Figure 1-24 illustrates the annual probability of exceeding $1 \mathrm{~cm}(0.4 \mathrm{in.})$ of volcanic ash accumulation in Washington and Oregon following the eruption of a major Cascade Range volcano and Figure 1-24 illustrates the annual probability of exceeding $10 \mathrm{~cm}$ (4 in.) of volcanic ash accumulation. Figure 1-37 presents this information as a volcanic ash hazard curve for the Hanford Site.

1.4.3.8.3 Subsurface Stability. The CSB is constructed in flood sediments, the youngest sediments being approximately 13,000 years old. There are no areas of potential surface or subsurface subsidence, uplift, or collapse except for the low geologic deformation discussed in Section 1.4.3.6. With the exception of the loose, surficial, wind-deposited silt, soils are competent and form good foundations. Several geotechnical studies have been completed in and around existing tank farms. Liquefaction of soils beneath the tank farms is not a credible hazard because the water table is greater than $65 \mathrm{~m}(215 \mathrm{ft})$ below ground surface. Liquefaction cannot occur in dry sediments.

A geotechnical investigation was performed at the site in 1989 (Dames and Moore 1989) to evaluate subsurface conditions for the design and construction of the HWVP. The HWVP Project was canceled and the site is being used for the CSB. Subsurface conditions were investigated by 17 borings ranging in depth from 6 to $30.5 \mathrm{~m}(20$ to $100 \mathrm{ft}$ ) at the site and in the surrounding area. Geophysical tests, including a series of downhole seismic tests, were conducted in boring VP-8, approximately $122 \mathrm{~m}(400 \mathrm{ft})$ from the CSB. Borehole VP-15 (Figure 1-38) is at the CSB site.

The 17 geotechnical investigation borings were advanced without drilling fluid by driving a 15.2-cm- (6-in.-) diameter, steel "core barrel" with a "split jar" downhole hammer. As the borings were advanced, a 20.32-cm(8-in.-) diameter steel casing was driven to prevent caving of soils above the sampling depth. Water was occasionally poured into the hole to prevent caving of the loose, dry soils and to aid in recovering samples. Slightly disturbed soil samples were taken at $1.5-\mathrm{m}(5-\mathrm{ft})$ intervals by driving a sampier using either a 320-kg (705-1b) hammer falling through a distance of $0.46 \mathrm{~m}$ (18 in.) 
or a 374-kg (825-1b) hammer falling through a distance of $0.71 \mathrm{~m}$ (28 in.). During the sampling process, resistance to penetration of the sampler, in blows per foot, was recorded.

The soil profile in the upper $30.5 \mathrm{~m}(100 \mathrm{ft}$ ) consists essentially of the three strata shown in Figure 1-39. Borehole VP-14 is approximately $70 \mathrm{~m}$ $(230 \mathrm{ft}$ ) west of the CSB. The stratigraphy in VP-15 (Figure 1-38) is the same as at VP-14 (Figure 1-39). The dynamic soil properties of the site are summarized in Figure 1-40. More detailed descriptions of the geotechnical investigations and interpretations are found in Report of Geotechnical Investigations for the Proposed Hanford Waste Vitrification Plant, Hanford Washington (Dames and Moore 1989).

\subsection{NATURAL PHENOMENA THREATS}

Table 1-23 summarizes the natural phenomena and the criteria to be used for the design of safety-class (performance category 3 ) SSCs for the CSB. Safety-significant (performance category 2) SSCs will be designed to the Uniform Building Code Zone 2B, and follow "essential facility" and "standard occupancy" rules, respectively (ICBO 1994). These SSCs also will be designed to codes, standards, regulations, and orders as listed in Section 1.2. Each of these phenomena and the bases for the analysis values have been discussed in Section 1.4.

\subsection{EXTERNAL HUMAN-GENERATED THREATS}

This section identifies and investigates specific potential humangenerated threats to CSB operation. Threats to the CSB from human activities that are not known or well characterized at this time will be evaluated by the Unreviewed Safety Question process. This also applies to those activities that have been identified, such as airport usage, but that may change significantly in terms of a potential increased risk to the facility.

\subsubsection{Aircraft Activity}

Three commercial airports and four private airports are located within $50 \mathrm{~km}(30 \mathrm{mi})$ of the CSB site. The closest commercial airport is the Richland Airport, $32 \mathrm{~km}(20 \mathrm{mi})$ southeast of the facility. This airport has two $1,220-\mathrm{m}(4,000-\mathrm{ft})$ runways, one with a $010^{\circ} / 190^{\circ}$ orientation and the other with a $070^{\circ} / 250^{\circ}$ orientation. Runway capability is about $13,600 \mathrm{~kg}$ $(30,000 \mathrm{lb})$ per point of contact. Visual flight rule 1 andings are standard Federal Aviation Administration non-control-tower patterns. In April 1996, approximately 65 aircraft were based at the airport. The projected number of operations for 1996 is 19,600. Except for two scheduled freight flights, a 11 operations in 1996 were by general aviation aircraft (Hosler 1996).

The Tri-Cities Airport is $45 \mathrm{~km}$ (28 $\mathrm{mi}$ ) to the southeast near Pasco. The Federal Aviation Administration operates the air traffic control tower and airport radar approval control facility. The airport has two $2,350-\mathrm{m}$ $(7,700-\mathrm{ft})$ crossing runways with $120^{\circ} / 300^{\circ}$ and $030^{\circ} / 210^{\circ}$ orientations. The latter has a $1,350-m(4,430-f t)$ parallel runway. Runway 30 has a 


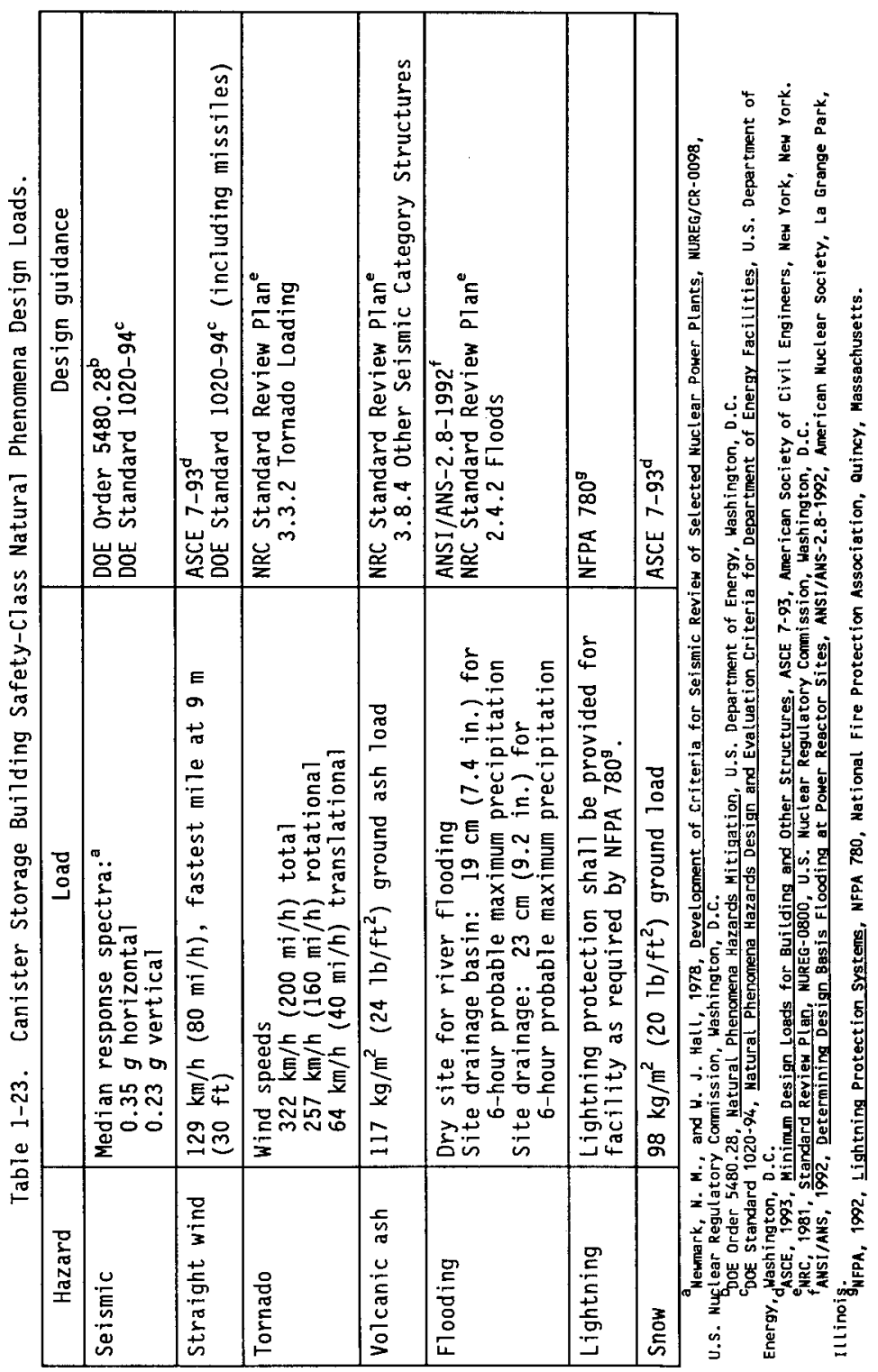


very-high-frequency omnirange instrument approach and Runway $21 R$ has an instrument landing system and is an instrument approach runway. In April 1996, about 94 aircraft were based at the airport. Total operations for 1995 were 79,000 , with $66 \%$ general aviation, $28 \%$ commercial aviation (air taxis, air carriers), $4 \%$ military aircraft, and $2 \%$ other operations (Hosler 1996). Four commercial carriers with a total of about $26 \mathrm{flights}$ per day were serving the airport in April 1996.

The Vista Airport, operated by the Port of Kennewick, is a general aviation airport located $45 \mathrm{~km}(28 \mathrm{mi})$ to the southeast. It has a $1,220-\mathrm{m}$ $(4,000-\mathrm{ft})$ runway with a $20^{\circ} / 200^{\circ}$ orientation. All operations are under visual flight rules. In April 1996, it was estimated that about 40 aircraft were based at the airport and operations averaged approximately 40 to 50 per day (Hosler 1996).

Four privately owned airstrips are within $40 \mathrm{~km}(25 \mathrm{mi})$ of the CSB. These are McWhorter (26 km [16 mi] south-southeast), Kent Farms ( $37 \mathrm{~km}$ [23 mi] southeast), Hathaway Ranch (39 km [24 mi]), and Hanford (4 km [2.5 mi] west-northwest).

NUREG-0800, Standard Review Plan, Section 3.5.1.6, "Aircraft Hazards" (NRC 1981), provides guidance to ensure that the risks from aircraft hazards are low enough for nuclear power plants. If the distance at which aircraft activity occurs meets all the criteria provided below, the probability of an aircraft accident resulting in radiological consequences greater than the exposure guideline in Title 10, Code of Federal Regulations, Section 100, "Reactor Site Criteria" (10 CFR 100), can be considered to be less than $10^{-7}$ per year and no additional analysis is required (Standard Review Plan 3.5.1.6 [NRC 1981] defines the criteria using English rather than Standard International units):

1. The plant-to-airport distance (D) is between 5 and 10 statute miles, and the projected annual number of operations is less than $500 D^{2}$, or $D$ is greater than 10 statute miles and the number of operations is less than $1,000 D^{2}$

2. The plant is at least 5 statute miles from the edge of military training routes, including low-level training routes, except for those associated with a usage greater than 1,000 flights per year or where activities (such as practice bombing) may create an unusual stress situation

3. The plant is at least 2 statute miles beyond the nearest edge of a federal airway, holding pattern, or approach pattern.

There are no active airports within 10 statute miles of the CSB site, but there are three commercial airports and three active private airports within $48 \mathrm{~km}$ (30 mi) of the site. Table 1-24 shows that the first criterion regarding the annual number of operations of less than $1,000 D^{2}$ is satisfied with a margin of more than a factor of ten. The impact of airport growth that would erase this margin would involve changes that cannot be predicted at this time. 
Table 1-24. Airports Near the Canister Storage Building Site.

\begin{tabular}{|l|l|l|l|l|l|}
\hline \multicolumn{1}{|c|}{ Airport } & $\begin{array}{c}\text { Distance (D) } \\
\text { from CSB* } \\
\text { (miles) }\end{array}$ & $\begin{array}{l}\text { Flights per } \\
\text { year }\end{array}$ & $1,000 \mathrm{D}^{2}$ & $\begin{array}{l}\text { Orientation } \\
\text { from CSB }\end{array}$ & \multicolumn{1}{|c|}{$\begin{array}{c}\text { Type of } \\
\text { operation }\end{array}$} \\
\hline Richland & 20 & 19,600 & 400,000 & Southeast & Commercial \\
\hline Tri-Cities & 28 & $\begin{array}{l}79,000 \\
5,000 / V 187\end{array}$ & 784,000 & Southeast & Commercial \\
\hline Vista & 28 & 18,250 & 784,000 & Southeast & Commercial \\
\hline Mcwhorter & 16 & & 256,000 & $\begin{array}{l}\text { South- } \\
\text { southwest }\end{array}$ & Private \\
\hline Kent Farms & 23 & & 529,000 & Southeast & Private \\
\hline $\begin{array}{l}\text { Hathaway } \\
\text { Ranch }\end{array}$ & 24 & 0 & 576,000 & East & Private \\
\hline Hanford & 2.5 & 4,000 & Northwest & $\begin{array}{l}\text { Closed since } \\
1976\end{array}$ \\
\hline
\end{tabular}

* Metric values for $D$ are not provided as the criterion is based upon $D$ in miles.

The airspace over the Hanford Site is periodically used as a marshaling area for military aircraft participating in training missions at the Yakima Training Center (Section 1.7.1.5). A low-level military training route associated with this training passes above the western edge of the Hanford Site about $14 \mathrm{~km}(8.7 \mathrm{mi})$ west of the CSB site. The traffic on this route is about 1,800 sorties per year according to the military authority responsible for the route. Military air operations may occasionally overfly the 200 East Area, but because of the proximity of Rattlesnake Mountain $(1,106 \mathrm{~m}$ $[3,629 \mathrm{ft}])$, a low approach is not routine. Aircraft tend to maintain significant altitude over the Hanford Site because of a request by the Federal Aviation Administration and because of safety considerations around the mountain (Muhlestein 1994).

Figure 1-41 shows the airports, low-level federal airways, and airport instrument approaches in the vicinity of the CSB site. Airway V187 (1ocated close to the CSB site with a minimum altitude of $1,065 \mathrm{~m}[3,500 \mathrm{ft}]$ mean sea leve1) is the only airway that can pose a potential threat to the CSB.

The Federal Aviation Administration provided a conservative estimate of 5,000 flights per year that can be expected through airway V187 (Hosler 1996). The number obtained for airway $V 187$ is for flights by aircraft that file instrument-flight-rule flight plans. Aircraft that leave the airport in the general direction of $V 187$ and that are under visual flight rules do not have to file a flight $\mathrm{pl}$ an and are not required to follow the airway. For the purpose of this evaluation, the total number of aircraft flying through airway V187 is assumed to be those constrained to the airway (i.e., 5,000 per year). Other flight paths shown on Figure 1-41 are either sufficiently far away (more than $3 \mathrm{~km}$ [2 mi]) with sufficiently low volume or are not currently active. 
HNF-SD-SNF-RPT-004 REV 6

According to the Richland airport manager, the $12 \mathrm{NM}$ and $14 \mathrm{NM}$ arc shown on Figure 1-41 is no longer used except on a rare occasion.

Standard Review Plan 3.5.1.6 (NRC 1981) provides the probability per year $\left(P_{P Y}\right)$ of an aircraft crashing into the plant as

$$
P_{P Y}=C \times N \times A_{e f f} / W
$$

where

$C=$ In-flight crash rate per mile for aircraft using airway $\left(4.0 \times 10^{-10} / \mathrm{mi}\right)$

$\mathrm{N}=$ Number of flights per year along the airway. $(5,000$, from Tri-Cities airport data)

$W=$ Width of airway in miles $(5.9 \mathrm{mi}$, see below)

$A_{\text {eff }}=$ Effective area of the plant in square miles $\left(0.068 \mathrm{mi}^{2}\right.$, see be]ow).

The width of a federal airway includes the airspace within parallel lines spaced $4 \mathrm{mi}$ each side of the centerline (14 CFR 71.75). However, Federal Aviation Administration regulations require aircraft operating under instrument flight rules to fly along the centerline of the federal airway (14 CFR 91.181) and permit a maximum error of $\pm 6^{\circ}$ in the equipment used to determine the position of the aircraft. For the CSB, located $45 \mathrm{~km}$ (28 $\mathrm{mi})$ from the airport, this results in an airway width of $9.5 \mathrm{~km}(5.9 \mathrm{mi})$ at the CSB site.

The effective area of the facility is the ground surface area covered by all flight crash trajectories that could impact the surface structure. This area is larger than the facility itself because of the possibility of the aircraft skidding across the ground before hitting the facility as well as the possibility of a direct hit on the structure before striking the ground. The effective area is the sum of the structure's area, the shadow area (behind the structure), and the aircraft skid area (in front of the structure). In UCRL-118793, Aircraft Accident Data Development for Aircraft Risk Evaluation to Ground Facilities Through the Use of a G.I.S. (Kimura et al. 1995), the components of the effective area are defined as

$$
A_{\text {eff }}=A_{\text {skid }}+A_{\text {structure }}+A_{\text {shadow }}
$$

where

$$
\begin{aligned}
A_{\text {structure }}= & \text { Ground footprint of building, } 259 \times 136=35,220 \mathrm{ft}^{2} \text { for the } \\
& \text { CSB with Hot Conditioning System (HCS) Annex } \\
A_{\text {skid }}= & \left(L+A_{w}\right) * S_{k} \\
& L=\begin{array}{l}
\text { Facility maximum dimension, } 259 \mathrm{ft} \text { for the CSB with the } \\
26 \mathrm{ft} \mathrm{HCS} \mathrm{Annex}
\end{array}
\end{aligned}
$$




$$
\begin{aligned}
& A_{w}=\text { Aircraft wingtip-to-wingtip dimension, conservatively } \\
& A_{\text {shadow }}=\left[\left(L^{2}+W_{f}^{2}\right)^{0.5}+A_{w}\right] \times Z \times \cot \phi \\
& W_{f}=\text { Facility width, } 136 \mathrm{ft} \text { for the CSB } \\
& Z \text { = Facility height, } 56 \mathrm{ft} \text { for the CSB } \\
& \phi=\text { Angle of approach (from aircraft accident data, most }
\end{aligned}
$$

As noted in Table 1-25, the CSB shadow area has been increased to include one exhaust stack that extends $75 \mathrm{ft}$ above the CSB roofline with a diameter of $7 \mathrm{ft}$ for this portion of the stack. The intake stack has very little extension above the roofline, and as such, is not addressed separately.

The effective area for the CSB for air carrier use of V187 is $0.068 \mathrm{mi}^{2}$. See Table 1-25. The probability per year, estimated by using the above equation with the input data noted, is $2.3 \times 10^{-8}$, which is sufficiently low as to screen this airway from further evaluation.

In the NRC acceptance of reduced windspeeds for design basis tornadoes (Clifford 1996), the NRC pointed out that there has been an assumption made by the NRC that protection for tornado-generated missiles provided adequate protection for general aviation light aircraft crashes and nearby explosions. However, with the reduced windspeeds, the NRC stated that new structures built to the reduced tornado criteria should be analyzed for minimum wall thickness for protection against other postulated site-specific events.

As use of the Hanford air space by general aviation is very light, it is appropriate to first investigate the potential for a crash of a general aviation light aircraft into the CSB before establishing the need to perform such analyses. The threat from general aviation, aerial applicators, aerial surveying, and military training can be estimated by assuming a certain number of aircraft in the vicinity of the CSB site, but without regard to airways, as follows:

$$
P_{p y}=C \times N \times A_{\text {eff }}
$$


Table 1-25. Canister Storage Building Aircraft Risks.

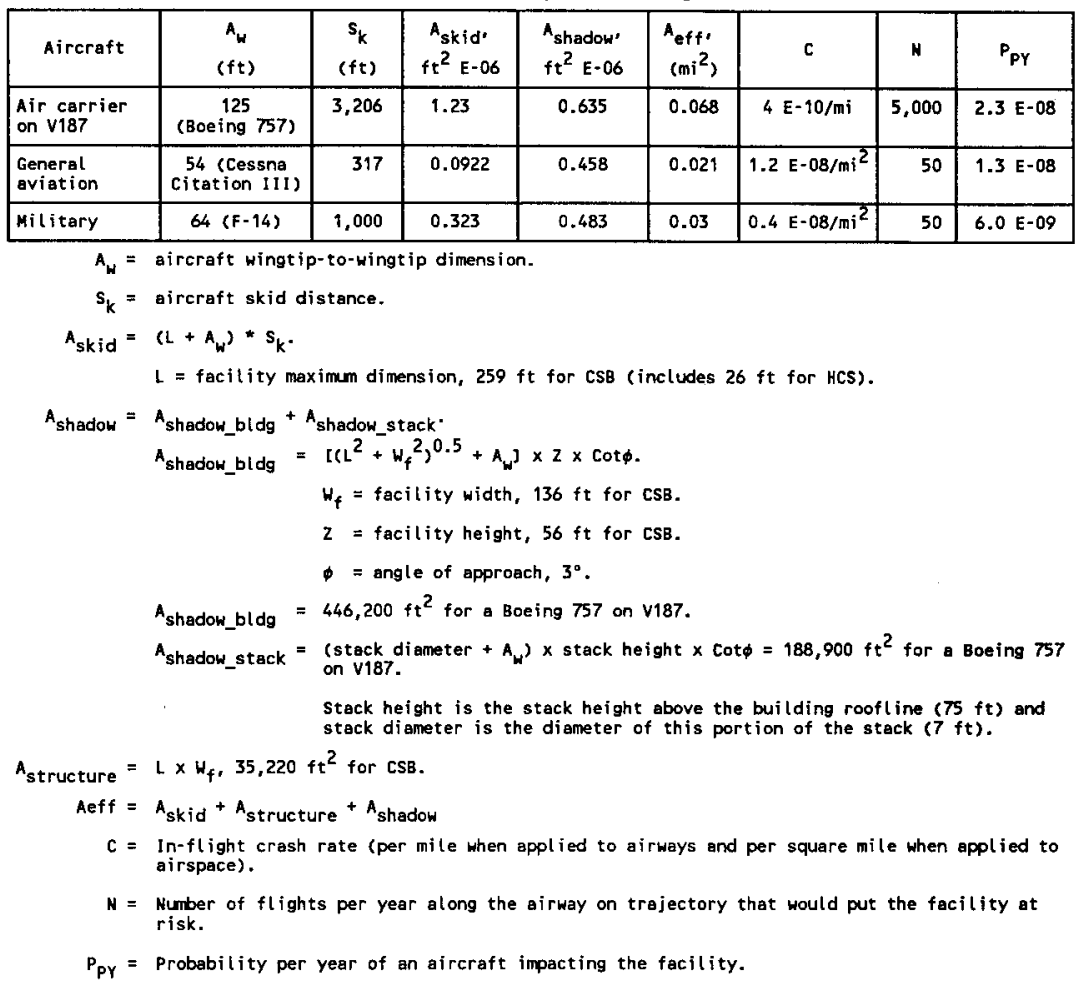




$$
\text { HNF-SD-SNF-RPT-004 REV } 6
$$

where

$$
\begin{aligned}
& P_{P Y}= \text { Probability per year of an aircraft impacting the facility } \\
& C= \text { In-flight crash frequency per square mile }\left(1.2 \times 10^{-8} / \mathrm{mi}^{2}\right. \text { for } \\
& \text { general aviation and } 0.4 \times 10^{-8} / \mathrm{mi}^{2} \text { for military } 4 \mathrm{mi} \text { or more from } \\
&\text { the end of the runway }[\mathrm{NRC} 1981])
\end{aligned}
$$

Note that Standard Review Plan 3.5.1.6 (NRC 1981) does not provide data specific to rotary wing aircraft. Such aircraft do overfly the Hanford Site. On an "accident per statute mile" basis, the accident rate for rotary and single engine fixed wing aircraft are about the same; the accident rate for reciprocating rotary wing is higher (Kimura et al. 1995):

\section{Aircraft}

Fixed wing, single engine, reciprocating Rotary wing, reciprocating and turbine Rotary wing, reciprocating only
Accident per statute mile

$$
\begin{aligned}
& 6.22 \times 10^{-7} \\
& 6.54 \times 10^{-7} \\
& 1.73 \times 10^{-6}
\end{aligned}
$$

$N=$ Number of flights per year in the vicinity of the CSB on a trajectory that puts the CSB at risk (very conservatively assumed to be 100 , evenly split between military and others)

$A_{\text {eff }}=$ Effective area of the CSB in square miles as defined above. $P_{P Y}=1.3 \times 10^{-8}$ events/yr for general aviation $P_{P Y}=6.0 \times 10^{-9}$ for military.

With these low frequencies of potential damage to the CSB, further consideration for light aircraft impact is not warranted.

DOE is currently completing a standard to address accident analysis for aircraft crash into hazardous facilities. This standard will provide a value to be used in the risk analysis as events/yr/A $/ A_{\text {eff }}$. This value will be used to assess the risk of aircraft crash for facilities away from airports independent of the use of federal airways. This standard will be addressed in the final CSB SAR.

\subsubsection{Other Transportation Accidents}

Accidents that might occur on State Highway 240, such as explosions or toxic chemical releases, are judged to present a negligible risk to the CSB because of the distance between the facility and the highway. At its closest approach, the distance is about $8 \mathrm{~km}(5 \mathrm{mi})$. NRC Regulatory Guide 1.78 , Assumptions for Evaluating the Habitability of a Nuclear Power Plant Control Room During a Postulated Hazardous Chemical Release (NRC 1974a), provides useful guidance on evaluating chemicals stored or situated at distances greater than $8 \mathrm{~km}$ ( $5 \mathrm{mi}$ ) from the facility. It states that they need not be considered because, if a release occurs at such a distance, atmospheric dispersion will dilute and disperse the incoming plume to such a degree that 
there should be sufficient time for the operators to take appropriate action. In addition, the probability of the plume remaining within a given sector for a long time is quite small.

Regulatory Guide 1.78 (NRC 1974a) also provides useful guidance for the evaluation of potential accidents involving hazardous chemicals that might be shipped past the CSB on Route 4, the Hanford Site railroad, and the Columbia River. Regulatory Guide 1.78 (NRC 1974a) does not require control room habitability analysis for shipments less frequent than 10 per year for truck traffic, 30 per year for rail traffic, or 50 per year for barge traffic. Neither the truck nor rail guidelines are exceeded for shipments of a quantity that could present a risk to the CSB. Section 1.7.1.1 discusses the process that will be used to establish whether there are critical operator actions that would require a more in-depth assessment of CSB habitability. Barge shipment on the Columbia River does not routinely occur above the Port of Benton barge facility discussed in Section 1.3.1.

Regulatory Guide 1.91, Evaluations of Explosions Postulated to Occur on Transportation Routes Near Nuclear Power Plants (NRC 1978), describes a method for determining distances from critical plant structures beyond which any explosion that might occur on a railway, highway, or navigable waterway is not likely to have an adverse effect on plant operation or to prevent safe shutdown. The method is based upon an NRC staff judgement that for structures of concern, an acceptable overpressure limit from such explosions can be conservatively chosen at $7 \mathrm{kPa}\left(1 \mathrm{lb} / \mathrm{in}^{2}\right)$. Although not stated in the Regulatory Guide, it is assumed that the $7 \mathrm{kPa}\left(1 \mathrm{lb} / \mathrm{in}^{2}\right)$ value was established for structures that are designed to withstand the severe natural phenomena loadings that are typical for safety-related structures of nuclear power plants.

For the purposes of this evaluation, the CSB critical plant structures of concern, which are similar to those in a nuclear power plant that are required for safe plant operation and shutdown, are the below-grade structure (i.e., the base slab, interior and exterior vault walls, and the intake and exhaust plenums), operating deck, and the intake and exhaust foundation bases and stacks. As described in Section 4.3.4.4, "System Evaluation," these are all. reinforced concrete structures that are designed to withstand the tornado pressure drop of $6.2 \mathrm{kPa}\left(0.9 \mathrm{lb} / \mathrm{in}^{2}\right)$. It is reasonable to assume that they would also withstand a $7 \mathrm{kPa}\left(1 \mathrm{~b} / \mathrm{in}^{2}\right)$ overpressure.

The CSB operating shelter is not considered a critical plant structure relative to the need to maintain the integrity of its shell as it is not credited for limiting offsite releases. However, as described in Section 4.3.4.4, it is also designed to withstand the tornado differential pressure of $6.2 \mathrm{kPa}\left(0.9 \mathrm{1b} / \mathrm{in}^{2}\right)$ as failure of the shelter may adversely impact safety-class SSCS. as

Regulatory Guide 1.91 (NRC 1978) defines the safe distance, $R$, in meters,

$$
R \geq 18 \times W^{1 / 2}
$$


was obtained for Hanford Site two-lane roads such as Route 4 (H\&R 1995). This risk reduction factor also would be appropriate for shipment of large quantities of explosive materials. For this analysis, it is conservatively assumed that the conditional probability that an explosion will result as a consequence of an accident is 0.1 . Therefore, the explosion rate, $n$, is $8.86 \times 10^{-9}$ explosions $/ \mathrm{km}\left(5.5 \times 10^{-9}\right.$ explosions $\left./ \mathrm{mi}\right)$.

There are currently no routine shipments of explosives on Route 4 of a quantity that would place the CSB at risk. However, such shipments could occur during the facility's lifetime. For this analysis, the number of such shipments per year, $f$, was conservatively assumed to be six. The exposure distance, $s$, for the CSB and Annex was calculated to be $0.820 \mathrm{~km}(0.51 \mathrm{mi})$ based upon a building length of $78 \mathrm{~m}(257 \mathrm{ft}$ ), a setback from Route 4 of $350 \mathrm{~m}$ $(1,155 \mathrm{ft})$, and a safe distance of $510 \mathrm{~m}(1,683 \mathrm{ft})$.

With these data, the exposure rate, $r$, was conservatively calculated to be $4.36 \times 10^{-8}$ events/yr. As this is less than $10^{-6}$ events/yr, no additional analysis is required.

Based upon the above analyses, it is concluded that explosive shipments on roadways and railways, controlled and not controlled by DOE, do not represent a risk to the CSB.

\subsection{NEARBY FACILITIES}

Accidents in certain facilities in the 200 East Area (Figure 1-8) have the potential to impact the CSB facility and its operations, as discussed in Section 1.7.1. Conversely, certain nearby facilities can potentially be affected by accidents in the CSB, as discussed in Section 1.7.2.

Threats to the CSB from nearby facilities that are not known or well characterized at this time will be evaluated by the Unreviewed Safety Question process. This also applies to those activities that have been identified but that may change significantly in terms of a potential increased risk to the facility.

\subsubsection{Potential Effects from Nearby Facilities}

Potential hazards to the CSB from onsite or offsite hazardous operations or facilities are examined under three general classifications:

- Nonreactor nuclear and nonnuclear industrial facilities within $8 \mathrm{~km}(5 \mathrm{mi})$ of the CSB including a 11 activities conducted in and near the 200 East Area

- Nuclear reactors within an $80-\mathrm{km}(50-\mathrm{mi})$ radius of the CSB

- Military activities.

1.7.1.1 Hazards to the CSB from Nonreactor Nuclear Facilities. Because SARs are being developed simultaneously for the CSB and for the Tank Waste 
Remediation System, much of the information provided in this section was prepared for both the Tank Waste Remediation System SAR and the CSB SAR.

Facilities currentiy operating, recently operating, or with potential to operate at the 200 East and 200 West Areas were screened along with the area between the 200 East and 200 West Areas. For the CSB SAR, selected facilities were those believed to pose the most risk to safe operations at the CSB. Safety analysis reports and accident analyses prepared for these facilities were reviewed to determine possible hazards, such as radiological doses to personnel resulting from direct radiation, release of airborne radioactivity, or exposure to toxic chemicals.

Considered, but not included in the SAR, were the 200 East Area Burial Grounds, the Liquid Effluent Retention Facility, and the 200 Areas Effluent Treatment Facility in the 200 East Area. In the 200 West Area, the T Plant, U Plant, Reduction-0xidation Plant, and the 222-S Laboratory were considered, but not included. These facilities have insufficient radiological or toxicological inventories in a dispersible form to represent a risk to the CSB operation.

The specific facilities discussed here include the Plutonium-Uranium Extraction (PUREX) Facility, the Grout Treatment Facility, B Plant, the Waste Encapsulation and Storage Facility (WESF), 242-A Evaporator/Crystaliizer, Plutonium Finishing Plant (PFP), and the Low-Level Waste Disposal Site. The worst-case scenarios for each of these facilities may challenge CSB habitability. This hazard is identified in Appendix $3 \mathrm{~A}$. Section 3.4 of the final SAR will document whether there are CSB operator prevention or mitigation actions required to satisfy onsite and offsite hazardous material and radiological acceptance limits. If such actions are required, CSB habitability will be addressed in the CSB emergency response procedures. During much of the CSB's 40-year 1 ife, the facility will not be particularly sensitive to these hazards as it will be simply a storage facility and will require little human supervision.

Plutonium-Uranium Extraction Facility. The PUREX Facility is located in the 200 East Area, $2.4 \mathrm{~km}(1.5 \mathrm{mi})$ east-southeast of the CSB. It is the most recently constructed of the irradiated fuel separation facilities and was used for processing $N$ Reactor fuel. The principal product was a solution of plutonium nitrate that was transferred to the PFP for further processing. Another product was uranyl nitrate solution, which was processed at the Uranium Oxide Plant. The facility is shut down and in preparation for eventual decontamination and decommissioning.

The postulated PUREX accidents having the most severe radiological consequences to a maximally exposed individual are associated with a cooling coil leaking into the 216-A-25 Pond and a fission product release from the PUREX pipe and operating gallery. After a review of these accidents and associated consequences, it was found that none of the postulated PUREX Facility accidents should impair CSB personnel in the performance of required safety actions.

Grout Treatment Facility. The Grout Treatment Facility is located on the eastern perimeter of the 200 East Area approximately $4.3 \mathrm{~km}$ (2.7 mi) east of the CSB. The Grout Treatment Facility combines tank wastes with 
grout-forming solids to form a grout slurry. The waste feed stream constituent of this slurry consists of low-level fractions of radioactive wastes. The slurry ultimately is pumped into near-surface, concrete-lined vaults for permanent disposal. Only one vault has been filled with grout (completed in 1987) even though additional vaults have subsequently been designed and constructed. This facility is currently not operational but has the potential to operate again in the future.

The maximum credible accident release postulated involves a double-ended jumper leak on the grout feed line with the pit cover blocks left off (pending a maintenance inspection) during which the Grout Treatment Facility resumes operation. This postulated release would spray low-level waste as an aerosol for a maximum period of 24 hours before detection by a visual inspection.

B Plant Facility. The B Plant is located approximately $455 \mathrm{~m}(1,500 \mathrm{ft})$ east of the CSB. Until 1952, B Plant was operated as a fuel separation facility. In 1968 it was converted to a waste fractionation plant to remove ${ }^{137} \mathrm{Cs}$ and ${ }^{90} \mathrm{Sr}$ from radioactive waste streams. This had the effect of reducing heat loads in the double-shell tanks. The B Plant now provides essential support to WESF and currently is preparing for a transition to shutdown status.

The most credible accident at B Plant, postulated in WHC-SD-WM-TI-385, B Plant Preliminary Accident Analysis (Marusich 1991), results from the simultaneous occurrence of (1) a solvent fire in which hot gases from the fire heat filters, driving off material on the filters, and (2) a blowback of process solution into the pipe gallery caused by tank pressurization. Such a scenario may result in evacuation of CSB operating personnel.

Waste Encapsulation and Storage Facility. The WESF is distinct from B Plant, even though it is located on the west end of B Plant and shares a common wall with the plant. Historically WESF was involved in converting cesium and strontium into cesium chloride and strontium fluoride salts. These materials then were encapsulated in double-walled metal containers and stored in a water-filled cooling basin. Strontium fluoride and cesium chloride capsules are still being stored in this fashion at WESF, but no new capsules are being produced.

The worst-case credible accident postulated involves a truck with a leaking gas tank that catches fire in the truck port (WHC 1996). It is assumed that this accident will result in the breaching of the truck port door and that packaged solid waste will be consumed by the fire. Radionuclides then will be transported directly to the environment via the breached truck port door.

242-A Evaporator/Crystallizer. The 242-A Evaporator/Crystallizer is located $2.4 \mathrm{~km}$ (1.5 mi) east of the CSB. The 242-A Evaporator/Crystallizer uses evaporative concentration to reduce the volume of liquid wastes (lowheat-generating tank wastes). The concentrated slurry, reduced in volume, is transferred and stored in an underground waste storage tank. The process condensate is routed to the Liquid Effluent Retention Facility for storage and treatment at the Effluent Treatment Facility. 
There were five design basis accidents (DBAs) analyzed in the 242-A Evaporator/Crystallizer SAR (Lavender 1992). Of the five accidents analyzed, the worst-case scenario involved a release from a spray leak in the pump room and a failure of the exhaust system's high-efficiency particulate air (HEPA) filters. Although this event is considered extremely unlikely, the event was analyzed for safety-class determinations at the 242-A Evaporator/ crystallizer. The release from a spray leak is comprised of a liquid component and an aerosol component. The analys is assumed that the liquid component would remain in the pump room (safety class 2); however, the aerosol component would be released to the environment via the Kl exhaust stack. The dose consequences to both the onsite maximum individual and offsite maximum individual were calculated and found to be within the risk acceptance

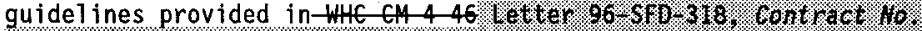

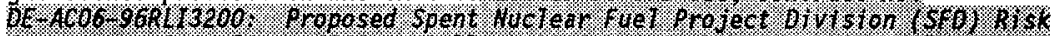

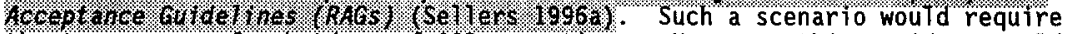
the temporary safe shutdown of CSB operations. However, this accident would not affect the intrinsic safety of CSB operations.

Plutonium Finishing Plant. The PFP is located near the western boundary of the Hanford Site in the 200 West Area, $8 \mathrm{~km}(5.0 \mathrm{mi})$ west of the CSB. It converts plutonium nitrate solution to plutonium metal and performs plutonium handling and storage operations. Contaminated liquid waste streams from the PFP are routed to the tank farms. This facility is currently in a stand-by mode and may operate again in the future.

The worst-case PFP accident scenario is associated with a fire having a postulated airborne release of $1.2 \mathrm{~g}{ }^{239} \mathrm{Pu}$ (Marusich 1990). The credible radiological hazard is defined as a consequence of respirable plutonium dispersed to the air from a fire and other material transport mechanisms. After a review of this accident and associated consequences, it has been found that an accident at this facility may require an evacuation of nearby Tank Farm facilities to reduce the consequences to tank farm personnel. Because of the distance separating the CSB from PFP, such a scenario would not adversely affect CSB operations and would not require evacuation of onsite personnel.

Low-Level Waste Disposal Site. The commercial low-level waste disposal site operated by U.S. Ecology, Inc., is the only non-DOE industrial facility within $8 \mathrm{~km}$ (5 mi) of the CSB (Figure 1-4). The disposal site is on land leased from Washington State located $1.7 \mathrm{~km}(1 \mathrm{mi})$ southwest of the CSB. The low-level waste is buried in lined containers. Monitoring of groundwater and vegetation is performed as required by the facility's NRC operating license and environmental impact statement. This facility is not likely to have a significant accidental airborne radioactive release that could adversely affect the CSB.

1.7.1.2 Hazards to the Canister Storage Building from Nonnuclear Hanford Site Facilities. A number of nonnuclear industrial facilities operating in the 200 Areas pose the potential for accidental fires, explosions, or releases of toxic fumes. These include the Essential Materials Warehouse (Building 275-EA), oil and paint storage buildings, fabrication shops, gas cylinder storage buildings, the spare parts and electrical warehouse, B Plant storage buildings, maintenance facilities, gasoline service stations, and the powerhouse complexes in each area (284-E and 284-W). Considering its 
location, Building 275-EA may have the potential to pose a risk to CSB operations and personnel and is detailed below.

Building 275-EA. Building 275-EA, the Essential Materials Warehouse, was constructed in 1955 and is located $2.4 \mathrm{~km}$ (1.5 mi) east-southeast of the CSB. It is classified as an unprotected wood frame structure and is susceptible to collapse as a result of an external event (e.g., earthquake, wind, snow, or ash loading) or an internal event (e.g., forkilift collision with a bearing wall, or fire). Building 275-EA currently stores more than 100 different types of potentially hazardous solids and liquids including acids, bases, solvents, fluorides, pesticides, and herbicides. Radioactive materials are not stored in this building.

The worst-case chemical release postulated in the safety analysis occurs following a building collapse whereupon $2,450 \mathrm{~kg}(5,445 \mathrm{lb})$ of 1,1,1-trichloroethane evaporates under adverse atmospheric conditions. The maximum concentration at the PUREX Facility gatehouse and environs is calculated to be $187 \mathrm{ppm}$, which is below the time-weighted average threshold limit value of $350 \mathrm{ppm}$ (i.e., the concentration for this chemical that an industrial worker may be repeatedly exposed to without adverse effects) as given in Threshold Limit Values and Biological Exposure Indices for 1989-1990 (ACGIH 1989). Concentration levels at the CSB would be significantly less than this because of the 2.4-km (1.5-mi) separation.

1.7.1.3 Hazards to the CSB from Nuclear Reactors. Three recentiy operating reactors, the $\mathrm{N}$ Reactor, FFIF, and the Critical Mass Laboratories, no longer pose a threat to the CSB. The $N$ Reactor and FFTF are undergoing decontamination and decommissioning, and the Critical Mass Laboratories in the 200 East Area north of the PUREX Facility are currently being used as tank farm office areas. The $\mathrm{N}$ Reactor was a 4,000 MW, dual-purpose, pressure tube, 1 ight-water cooled, graphite-moderated reactor (UNI 1978). It is located in the $100 \mathrm{~N}$ Area and is about $8.8 \mathrm{~km}(5.5 \mathrm{mi})$ from the nearest northwest Hanford Site boundary. The $N$ Reactor began operating in 1964 producing plutonium for the defense program and steam for electrical power generation. It was shut down in 1987 for safety improvements and then subsequently defueled and placed in cold standby in 1988. It is currently being decontaminated and decommissioned.

It is planned to remove the reactor building structures for the production reactors down to the reactor block and then cocoon the reactor block for 75-year safe storage. A preliminary hazard analys is (PHA) completed for a demonstration of this process for the $C$ Reactor Building (105-C) did not identify any new hazards that would result from this activity (Delphinus 1996).

The FFTF is a $400 \mathrm{MW}$, sodium-cooled, mixed-oxide-fueled, breeder reactor that is currently shut down and in the process of being defueled. It is located in the 400 Area and is approximately $7.2 \mathrm{~km}(4.5 \mathrm{mi})$ from the nearest Hanford Site boundary, which is to the east of the facility (Figure 1-4).

The only operating nuclear reactor on the Hanford Site is WNP-2. The location of this reactor is shown in Figure 1-4. WNP-2 is an operating commercial nuclear power plant using a boiling-water reactor steam supply system. The design power level was increased to 3,486 MW in 1995 (Supply 
System 1995). The reactor was designed by the General Electric Company and is designated as a BWR/5 with a Mark II containment.

By the requirements of 10 CFR 100, the following are the maximum allowable doses for WNP-2:

\begin{tabular}{lccc}
\multicolumn{1}{l}{ Location } & Duration & Whole body dose & Thyroid \\
$\begin{array}{l}\text { Exclusion area } \\
\text { boundary }\end{array}$ & 2 hours & $250 \mathrm{mSv}(25 \mathrm{rem})$ & $3,000 \mathrm{mSv}$ (300 rem) \\
$\begin{array}{l}\text { Low population } \\
\text { zone }\end{array}$ & 30 days & $250 \mathrm{mSv}(25 \mathrm{rem})$ & $3,000 \mathrm{mSv}(300 \mathrm{rem})$
\end{tabular}

The exclusion area boundary for WNP-2 is $1,950 \mathrm{~m}(1.2 \mathrm{mi})$ and the low population zone distance is $4,827 \mathrm{~m}(3 \mathrm{mi})$. The CSB is 1ocated approximately $17.6 \mathrm{~km}(11 \mathrm{mi})$ from WNP-2. Using the atmospheric diffusion guidance provided in NRC Regulatory Guide 1.3, Assumptions Used for Evaluating the Potential Radiological Consequences of a Loss of Coolant Accident for Boiling Water Reactors (NRC 1974b), to estimate the dose reduction as a function of distance, it was determined that the 2-hour and 30-day doses at the CSB would be reduced by a factor of 20 . Review of the site-specific meteorology provided in the WNP-2 Final Safety Analysis Report (Supply System 1995) shows there would be no significant reduction for the change in wind direction. The factor of 20 reduction for distance would result in a whole body dose of $12.5 \mathrm{mSv}$ (1.25 rem) and a thyroid dose of $150 \mathrm{mSv}$ (15 rem).

The expected dose that would be received at the CSB should a loss of coolant accident occur would be significantly less than this. Regulatory Guide 1.3 (NRC $1974 \mathrm{~b}$ ) requires an assumption that $25 \%$ of the radioactive iodine and all of the noble gases are released to the containment. In fact, the emergency core cooling system would prevent most of these releases as little fuel damage would occur as a result of the loss of coolant accident.

In 1998 the Supply System plans to add an independent spent fuel storage installation (ISFSI) on their leased property. The ISFSI would be licensed following the requirements in 10 CFR 72. According to 10 CFR 72.106, an individual located at the ISFSI's controlled area boundary shall not receive a dose greater than 5 rem. At the CSB, this would result in a dose not exceeding 0.25 rem.

1.7.1.4 Hazards to the Canister Storage Building from Industrial Facilities off the Hanford site. There are no oil or gas pipelines in the vicinity of the CSB. The nearest major natural gas pipeline to the CSB site is about $47 \mathrm{~km}(29 \mathrm{mi})$. A 20 -in. gas transmission line of the Northwest Pipeline corporation is located east and essentialiy parallel to U.S. Highway 395 between Pasco and Ritzville, Washington. A second pipeline system consisting of paralle $136-i n$. and 42-in. 1ines, owned by Pacific Gas Transmission Company, passes through Wallula, approximately $53 \mathrm{~km}$ ( $33 \mathrm{mi}$ ) from the site (Hosler 1996). These distances el iminate any potential hazard to plant operations from a natural gas fire or explosion. 
The nearest petroleum product storage tanks are located $61 \mathrm{~km}$ ( $38 \mathrm{mi}$ ) from the site. These are 23-million-gallon capacity tanks at the Chevron Pipeline Company, and 21-million-gallon capacity tanks at the Tidewater Barge Lines. There are no plans to use a third petroleum storage facility at the Port of Pasco (Hosler 1996).

Located within the Richland city limits is the Siemens Power Corporation's Richland Engineering and Manufacturing Facility. All operational steps for the manufacture of nuclear fuel for light water reactors are conducted within the facility including the conversion of $\mathrm{UF}_{6}$ to $\mathrm{UO}_{2}$. The most limiting postulated accident at this facility is a fire in the UF 6 cylinder storage area (Siemens 1994). Fusible plugs in twelve cylinders are assumed to melt causing the release of UF that reacts with moisture in the air to form $\mathrm{UO}_{2} \mathrm{~F}_{2}$ (solids in the form of uranyl fluoride hydrates) and $4 \mathrm{HF}$ (as hydrogen fluoride gas). UF 6 is a radiological hazard by inhalation. However, $\mathrm{UF}_{6}$ is also a concern because of its chemical toxicity and the associated HF that can cause skin and eye burns and lung impairment. This accident results in a dose that exceeds $10 \mathrm{mSv}$ (1 rem) out to $1.9 \mathrm{~km}(1.2 \mathrm{mi})$. The accident also exceeds the Emergency Response Planning Guide-2 (ERPG-2) toxicology limits out to $14.1 \mathrm{~km}(8.8 \mathrm{mi})$ (ACGIH 1989). The ERPG-2 is the maximum airborne concentration below which it is believed that nearly all individuals could be exposed for up to one hour without experiencing or developing irreversible or other serious health effects or symptoms that could impair their abilities to take protective action. The CSB is located $30 \mathrm{~km}$ (19 mi) from the Siemens facility. Therefore, CSB operators would not be placed at risk by an accident at the Siemens facility.

No other nonnuclear industrial facilities or operations have been identified that may impact CSB operations.

1.7.1.5 Hazards to the Canister Storage Building from Military Facilities. The Yakima Training Center is a subinstallation under the command of Fort Lewis (Tacoma, Washington). Further information is given in the Final Environmental Impact Statement - Ft. Lewis Military Installation (DOA 1979). The southeastern boundary of the Yakima Training Center is located about $23 \mathrm{~km}$ (14 $\mathrm{mi}$ ) from the CSB (see Figure 1-2 or 1-42). The Yakima Training Center is used for military maneuvers and weapons training and is the only significant military activity in the vicinity of the Hanford Site.

The only weapon currently in use at the Yakima Training Center known to present a hazard to the Hanford Site is the Multiple Launch Rocket System (MLRS). With a range of approximately $26 \mathrm{~km}$ (16 mi), the MLRS could potentially impact the CSB site. However, the MLRS is only fired from the perimeter of the Yakima Training Center into a centrally located impact zone. The safety fan for the MLRS is shown in Figure 1-42. The MLRS is fired away from the Hanford Site and is only fired with dummy warheads. Given this information, additional safety features, and the administrative controls in place at the Yakima Training Center, a weapons accident having an impact on the Hanford Site is very improbable.

A more probable hazard to Hanford Site facilities is a scenario in which a fire started within the Yakima Training Center boundary spreads to the Hanford Site. Exploding artillery shells, sparks from tracked vehicles or other machines, and careless smoking by troops might start brush fires that, 
under adverse meteorological conditions, could spread rapidly beyond the Yakima Training Center boundaries. The hazards associated with range fires are discussed in Chapter 3.0 .

\subsubsection{Potential Effects to Nearby Facilities}

CSB accidents with the potential to affect the maximum onsite individual (which may include persons at some of the facilities discussed above) are discussed in Section 3.4.2.3.

\subsection{VALIDITY OF EXISTING ENVIRONMENTAL ANALYSES}

No significant discrepancies have been identified between the site characteristic assumptions made in this chapter and those made in the SNF Project Environmental Impact Statement (DOE 1996).

\subsection{REFERENCES}

10 CFR 72, "Licensing Requirements for the Independent Storage of Spent Nuclear Fuel and High-Level Radioactive Waste," Code of Federal Regulations, as amended.

10 CFR 100, "Reactor Site Criteria," Code of Federal Regulations, as amended.

14 CFR 71, "Designation of Class A, Class B, Class C, Class D, and Class E Airspace Areas; Airways; Routes; and Reporting Points, "Section 71.75, "Extent of Federal Airways," Code of Federal Regulations, as amended.

14 CFR 91, "General Operating and Flight Rules," Section 91.181, "Course to be Flown," Code of Federal Regulations, as amended.

ACGIH, 1989, Threshold Limit Values and Biological Exposure Indices for 1989-1990, American Conference of Governmental Industrial Hygienists, Cincinnati, Ohio.

ANSI/ANS, 1992, Determining Design Basis Flooding at Power Reactor Sites, ANSI/ANS-2.8-1992, American Nuclear Society, La Grange Park, Illinois.

ASCE, 1986, Seismic Analysis of Safety-Related Nuclear Structures and Commentary on Standard for Seismic Analysis of Safety-Related Nuclear Structures, Standard 4, American Society of Civil Engineers, New York, New York.

ASCE, 1988, Evaluation Procedures for Hydrologic Safety of Dams, American Society of Civil Engineers, New York, New York.

ASCE, 1993, Minimum Design Loads for Building and other Structures, ASCE 7-93, American Society of Civil Engineers, New York, New York. 
Baker, V. R., B. N. Bjornstad, A. J. Busacca, K. R. Fecht, U. L. Moody, J. G. Rigby, D. F. Stradling, and A. M. Tallman, 1991, "Quaternary Geology of the Columbia Plateau," in Quaternary Nonglacial Geology; Conterminous U.S., R. B. Morrison, editor, Geological Society of America, Boulder, Colorado.

Beck, D. M., M. J. Scott, M. D. Davis, S. F. Shindle, B. A. Napier, A. G. Thurman, D. B. Pittenger, and N. C. Batishko, 1991, Hanford Area 1990 Population and 50-Year Projections, PNL-7803, Pacific Northwest Laboratory, Richland, Washington.

Bjornstad, B. N., 1984, Suprabasalt Stratigraphy Within and Adjacent to the Reference Repository Location, SD-BWI-DP-039, Rockwe11 Hanford Operations, Richland, Washington.

Bjornstad, B. N., Fecht, K. R., and Tallman, A. M., 1987, Quaternary Geology of the Pasco Basin, Washington, RHO-BW-SA-563A, Rockwell Hanford Operations, Richland, Washington.

Campbe17, N. P., 1989, "Structural and Stratigraphic Interpretation of the Rocks Under the Yakima Fold Belt Based on Recent Surface Mapping and Well Data," in Volcanism and Tectonism in the Columbia River FloodBasalt Province, S. P. Reidel and P. R. Hooper, editors, Special Paper 239, Geological Society of America.

Catchings, R. D., and W. D. Mooney, 1988, "Crustal Structure of the Columbia Plateau - Evidence for Continental Rifting," Journal of Geophysical Research, Vol. 19, no. B1, pp 459-474.

C1ifford, J. W., 1996, Revision of Tornado Design Criteria for the Washington Public Power Supply System (WPPSS) Nuclear Project No. 2 (WNP-2) (TAC No. 88626) (letter GI2-96-032 to J. V. Parrish, Washington Public Power Supply System, January 24), U.S. Nuclear Regulatory Commission, Washington, D.C.

Coats, D. W., and R. C. Murray, 1985, Natural Phenomena Hazards Modeling Project: Extreme Wind/Tornado Hazard Models for Department of Energy Sites, UCRL-53526, Rev. 1, Lawrence Livermore Laboratory, Livermore, California.

Connel1y, M. P., B. H. Ford, J. W. Lindberg, S. J. Trent, C. D. Delaney, and J. V. Borghese, 1992, Hydrogeologic Model for the 200 East Groundwater Aggregate Area, WHC-SD-EN-TI-019, Rev. 0, Westinghouse Hanford Company, Richland, Washington.

Cushing, C. E., 1995, Hanford Site National Environmental Policy Act Characterization (NEPA), PNL-6415, Rev. 7, Pacific Northwest Laboratory, Richland, Washington.

Dames and Moore, 1989, Report of Geotechnical Investigations for the Proposed Hanford Waste Vitrification Plant, Hanford Washington, Report 10805-385-016, Dames and Moore, Seattle, Washington. 
Delaney, C. D., K. A. Lindsey, and S. P. Reide1, 1991, Geology and Hydrology of the Hanford Site: A Standardized Text for Use in Westinghouse Hanford Company Documents and Reports, WHC-SD-ER-TI-003, Rev. 0, Westinghouse Hanford Company, Richland, Washington.

Delphinus, 1996, Engineering and Planning for Reactor 105-C Interim Safe Storage Project Subcontract No. 0100C-SC-G0001 Conceptual Design Report, BHI-00537, Rev. 0, prepared by Delphinus Engineering, Incorporated, for Bechtel Hanford, Incorporated, Richland, Washington.

D0A, 1979, Final Environmental Impact Statement - Ft. Lewis Military Installation, U.S. Department of Army, Headquarters, 9th Infantry Division and Ft. Lewis, with URS Company, Seattle, Washington.

DOE, 1987, Final Environmental Impact Statement: Disposal of Hanford Defense High-Level, Transuranic and Tank Wastes, Hanford Site, Richland, Washington, DOE/EIS-0113, U.S. Department of Energy, Washington, D.C.

DOE, 1988, Site Characterization Plan Reference Repository Location, Hanford Site, Washington, DOE/RW-0164, Vol. 2, U.S. Department of Energy, Washington, D.C.

DOE, 1995, Department of Energy Programmatic Spent Nuclear Fuel Management and Idaho National Engineering Laboratory Environmental Restoration and Waste Management Programs Final Environmental Impact Statement, D0E/EIS-0203-F, U.S. Department of Energy, Idaho Operations Office, Idaho Falls, Idaho.

DOE, 1996, Management of Spent Nuclear Fuel from the $K$ Basins at the Hanford Site, Richland, Washington, D0E/EIS-0245F, U.S. Department of Energy, Richland Operations Office, Richland, Washington.

DOE Order 5480.28, 1993, Natura7 Phenomena Hazards Mitigation, U.S. Department of Energy, Washington, D.C.

DOE Order 6430.1A, 1989, Genera7 Design Criteria, U.S. Department of Energy, Washington, D.C.

DOE-STD-1020-94, 1994, Natural Phenomena Hazards Design and Evaluation Criteria for Department of Energy Facilities, DOE Standard 1020-94, U.S. Department of Energy, Washington, D.C.

DOE-STD-1021-93, 1993, Natural Phenomena Hazards Performance Categorization Guidelines for Structures, Systems, and Components, DOE Standard 1021-93, U.S. Department of Energy, Washington, D.C.

DOE-STD-1022-94, 1994, Natural Phenomena Hazards Site Characterization Criteria, DOE Standard 1022-94, U.S. Department of Energy, Washington, D.C.

DOE-STD-1023-95, 1995, Natura7 Phenomena Hazards Assessment Criteria, DOE Standard 1023-95, U.S. Department of Energy, Washington, D.C. 
Drese1, P. E., P. D. Thorne, S. P. Luttre11, B. M. Gillespie, W. D. Webber, J. K. Merz, J. T. Rieger, M. A. Chamness, S. K. Wurstner, and B. E. Opitz, 1995, Hanford Site Ground-Water Monitoring for 1994, PNL-10698, Pacific Northwest Laboratory, Richland, Washington.

EPA, 1992, User's Guide for the Industrial Source Complex (ISC2) Dispersion Models, EPA-450/4-92-008a, U.S. Environmental Protection Agency, Office of Air Quality Planning and Standards, Technical Support Division, Research Triangle Park, North Carolina.

ERDA, 1976, Evaluation of Impact of Potential Flooding Criteria on the Hanford Project, RL0-76-4, U.S. Energy Research and Development Administration, Washington, D.C.

Fayer, M. J., and T. B. Walters, 1995, Estimated Recharge Rates at the Hanford Site, PNL-10285, Pacific Northwest Laboratory, Richland, Washington.

Fecht, K. R., S. P. Reidel, and A. M. Tallman, 1987, "Paleodrainage of the Columbia River System on the Columbia Plateau of Washington State - A Summary," in Selected Papers on the Geology of Washington, Bulletin 77, J. E. Schuster, editor, Division of Geology and Earth Resources, Washington State Department of Natural Resources, 01ympia Washington.

Ford, B. H., and S. J. Trent, 1994, "Hydrogeologic Setting of the 200 Areas," in Annual Report for RCRA Groundwater Monitoring Projects at Hanford Site Facilities for 1993, DOE/RL-93-88, Rev. 0, U.S. Department of Energy, Richland Operations Office, Richland, Washington.

Garvin, L. J., 1996, Spent Nuclear Fuel Project Path Forward, Additional NRC Requirements, WHC-SD-SNF-DB-003, Rev. 1, Westinghouse Hanford Company, Richland, Washington.

Geomatrix, 1996, Probabilistic Seismic Hazard Analysis, DOE Hanford Site Washington, WHC-SD-W236-TI-002, Rev, 1, prepared by Geomatrix Consultants, Incorporated, San Francisco, California, for Westinghouse Hanford Company, Richland, Washington.

Glantz, C. S., and M. M. Islam, 1988, The Data Collection Component of the Hanford Meteorological Monitoring Program, PNL-6684, Pacific Northwest Laboratory, Richland, Washington.

Graham, M. J., M. D. Ha11, S. R. Strait, and W. R. Brown, 1981, Hydrology of the Separations Area, RHO-ST-42, Rockwell Hanford Operations, Richland, Washington.

Graham, M. J., G. V. Last, and K. R. Fecht, 1984, An Assessment of Aquifer Intercommunication with B Pond-Gable Mountain Pond Area of the Hanford Site, RHO-RE-ST-12P, Rockwell Hanford Operations, Richland, Washington.

Grolier, M. J., and J. W. Bingham, 1978, Geology of Parts of Grant, Adams, and Franklin Counties, East-Central Washington, Bullet in 71, Washington State Department of Natural Resources, 0lympia, Washington. 
Grumbly, T. P., 1995, Concurrence with the K-Basins Spent Nuclear Fuel Project Policy on Nuclear Safety Requirements (Memorandum EM-36-3.1.6.7 to Manager, U.S. Department of Energy, Richland Operations Office, JuTy 20), U.S. Department of Energy, Washington, D.C.

Hagood, M. C., 1986, Structure and Evolution of the Horse Heaven Hills in South-Central Washington, RHO-BWI-SA-344 P, Rockwell Hanford Operations, Richl and, Washington.

Hansen, E. M., D. D. Fenn, P. Corrigan, J. L. Vogel, L. C. Schreiner, and R. W. Stodt, 1994, Probable Maximum Precipitation-Pacific Northwest States, Hydrometeorological Report No. 57, National Weather Service, Silver Spring, Maryland.

Hey, B. E., 1995, GXQ Program User's Guide, WHC-SD-GN-SWD-30002, Rev. 1, Westinghouse Hanford Company, Richland, Washington.

Hoblitt, R. P., R. D. Miller, and W. E. Scott, 1987, Volcanic Hazards with Regards to Siting Nuclear-Power Plants in the Pacific Northwest, Open File Report 87-297, U.S. Geological Survey, Cascades Volcano Observatory, Vancouver, Washington.

Hoitink, D. J., and K. W. Burk, 1995, Climatological Data Summary 1994, with Historical Data, PNL-10553, Pacific Northwest Laboratory, Richland, Washington.

Hosler, A. G., 1996, Contact with Local Organizations to Support CSB SAR Chapter 1 (Memo 042AGH.96 to Canister Storage Building, Safety Analysis Report File, May 6), Science Applications International Corporation, Richland, Washington.

H\&R, 1995, Recommended Onsite Transportation Risk Management Methodology, H\&R 522-1, H\&R Technical Associates, Incorporated, Oak Ridge, Tennessee.

ICB0, 1994, Uniform Building Code, International Conference of Building officials, Whittier, California.

Jacobs, E. R., 1996, Tornado Loading Design Criteria - Revised (Letter FRF-2855 to M. K. Mahaffey, West inghouse Hanford Company, September 26), Fluor Daniel, Incorporated, Richland, Washington.

Jarchow, C. M., 1991, "Investigations of Magmatic Underplating Beneath the Northwestern Basin and Range Province, and Seismic Data Acquisition and Tectonic Problems of the Columbia Plateau, Washington, and the Nature of the Mohorovic'ic' Discontinuity Worldwide," Ph. D. Dissertation, Stanford University, Stanford, California.

Keinle, C. F., R. D. Bentley, and J. L. Anderson, 1977, "Geologic Reconnaissance in the Cle Elum-Wallula Lineament and Related Structures," in Washington Public Power Supply System Nuclear Project Number 2, Preliminary Safety Analys is Report, Vol. 2A, Amendment 23, Subappendix 2R D, pp 1 to 33, Washington Public Power Supply System, Richland, Washington. 
Kimura, C. Y., C. T. Bennett, G. M. Sandquist, and S. Smith, 1995, Aircraft Accident Data Development for Aircraft Risk Evaluation to Ground Facilities through the Use of a G.I.S., UCRL-JC-118793, Lawrence Livermore National Laboratory, Livermore, California.

Last, G. V., B. N. Bjornstad, M. P. Bergeron, D. W. Wallace, D. R. Newcomer, J. A. Schremke, M. A. Chamness, C. S. Cline, S. P. Airhart, and J. S. Wilbur, 1989, Hydrogeology of the 200 Areas Low Level Burial Grounds - An Interim Report, PNL-6820, Pacific Northwest Laboratory, Richland, Washington.

Lavender, J. C., 1992, 242-A Evaporator/Crystallizer Safety Analysis Report, WHC-SD-WM-SAR-023, Rev. 1, Westinghouse Hanford Company, Richland, Washington.

Lindsey, K. A., 199la, Revised Stratigraphy for the Ringold Formation, Hanford Site, South-Centra] Washington, WHC-SD-EN-EE-004 Rev. 0, Westinghouse Hanford Company, Richland, Washington.

Lindsey, K. A., 1991b, Geologic Setting of the 200 West Area: An Update, WHC-SD-EN-TI-008, Rev. 0, Westinghouse Hanford Company, Richland, Washington.

Lindsey, K. A., and D. R., Gaylord, 1989, Sedimentology and Stratigraphy of the Miocene-Pliocene Ringold Formation, Hanford Site, South-Central Washington, WHC-SA-0740-FP, Westinghouse Hanford Company, Richland, Washington.

Marusich, R. M., 1990, Safety and Risk Assessment Technical Information to Support Plutonium Finishing Plant Restart, WHC-SD-SQA-TI-013, Westinghouse Hanford Company, Richland, Washington.

Marusich, R. M., 1991, B Plant Preliminary Accident Analysis, WHC-SD-WM-TI-385, Rev. 0, Westinghouse Hanford Company, Richland, Washington.

McCann, M. W., Jr., and A. C. Boissonnade, 1988, Probabilistic Flood Hazard Assessment of the Department of Energy N-Reactor, Hanford, Washington, UCRL-21069, Lawrence Livermore Laboratory, Livermore, California.

Mogle, R. D., 1987, WNP-1, 2 Ten Mile EPZ Evacuation Time Assessment Study, Rev. 2, Washington Public Power Supply System, Richland, Washington.

Muhlestein, L. D., 1994, Additional Analysis Related to the Multi-Function Waste Tank Facility, WHC-SD-W236A-ANAL-002, Rev. 0, Westinghouse Hanford Company, Richland, Washington.

Myers, C. W., S. M. Price, J. A. Caggiano, M. P. Cochran, W. J. Czimer, N. J. Davidson, R. C. Edwards, K. R. Fecht, G. E. Holmes, M. G. Jones, J. R. Kunk, R. D. Landon, R. K. Ledgerwood, J. T. Lillie, P. E. Long, T. H. Mitchel1, E. H. Price, S. P. Reidel, and M. Tallman, 1979, Geologic Studies of the Columbia Plateau Status Report, RHO-BWI-ST-4, Rockwell Hanford Operations, Richland, Washington. 
Newcomb, R. C., 1958, "Ringold Formation of the Pleistocene Age in the Type Locality, The White Bluffs, Washington," American Journal of Science, Vo]. 256, pp 328-340.

Newmark, N. M., and W. J. Ha11, 1978, Development of Criteria for Seismic Review of Selected Nuclear Power Plants, NUREG/CR-0098, U.S. Nuclear Regulatory Commission, Washington, D.C.

NFPA, 1995, Lightning Protection Systems, NFPA 780, National Fire Protection Association, Quincy, Massachusetts.

NRC, 1974a, Assumptions for Evaluating the Habitability of a Nuclear Power Plant Control Room During a Postulated Hazardous Chemical Release, Regulatory Guide 1.78, U.S. Nuclear Regulatory Commission, Washington, D.C.

NRC, 1974b, Assumptions Used for Evaluating the Potential Radiological Consequences of a Loss of Coolant Accident for Boiling Water Reactors, Regulatory Guide 1.3, U.S. Nuclear Regulatory Commission, Washington, D.C.

NRC, 1978, Evaluations of Explosions Postulated to Occur on Transportation Routes Near Nuclear Power Plants, Regulatory Guide 1.91, Rev. 1, U.S. Nuclear Regulatory Commission, Washington, D.C.

NRC, 1981, Standard Review P7an, NUREG-0800, U.S. Nuclear Regulatory Commission, Washington, D.C.

NRC, 1993, Policy, Technical, and Licensing Issues Pertaining to Evolutionary and Advanced Light-Water Reactor (ALWR) Designs, SECY-93-087, U.S. Nuclear Regulatory Commission, Washington, D.C.

NRC, 1994, Final Safety Evaluation Report Related to the Certification of the Advanced Boiling Reactor Design, NUREG-1503, U.S. Nuclear Regulatory Commission, Washington, D.C.

Parrish, J. V., 1995, WNP-2, Operating License NPF-21, Request for Approval to Revise Tornado Design Criteria (letter G02-95-212 to U.S. Nuclear Regulatory Commission, October 10), Washington Public Power Supply System, Richland, Washington.

Pasqui11, F., 1961, "The Estimation of the Dispersion of Windborne Material," Meteorology Magazine, Vo1. 90, pp 33-49.

Power, M. S., K. J. Coppersmith, R. R. Youngs, D. P. Schwartz, and F. H. Swan III, 1981, Amendment N.18, Final Safety Analys is Report WNP-2, Appendix 2.5K, "Seismic Exposure for the WNP-2 and WNP-1/4 Site," Washington Public Power Supply System, Richland, Washington.

Prescott, W. H., and J. C. Savage, 1984, Crustal Deformation Near Hanford, Washington, Open File Report 84-797, U.S. Geological Survey, Washington, D.C. 
Price, E. H., and A. J. Watkinson, 1989, "Structural Geometry and Strain Distribution within Umtanum Ridge, South-Central, Washington, and its Tectonic Significance," in Volcanism and Tectonism on the Columbia Plateau, Special Paper 239, S. P. Reidel and P. R. Hooper, editors, Geological Society of America, Boulder, Colorado.

Ramsdel1, J. V., and G. L. Andrews, 1986, Tornado Climatology of the Contiguous United States, NUREG/CR-4461, prepared for the U.S. Nuclear Regulatory Commission by Pacific Northwest Laboratory, Richland, Washington.

Ramsde11, J. V., D. L. Elliott, C. G. Holladay, and J. M. Hubbe, 1986, Methodology for Estimating Extreme Winds for Probabilistic Risk Assessments, NUREG/CR-4492, prepared for the U.S. Nuclear Regulatory Commission by Pacific Northwest Laboratory, Richland, Washington.

Reidel, S. P., 1984, "The Saddle Mountains: The Evolution of an Anticline in the Yakima Fold Belt," American Journal of Science, Vol. 284, pp $942-978$.

Reidel, S. P., and K. R. Fecht, 1981, "Wanapum and Saddle Mountains Basalts of the Cold Creek Syncline Area," in Subsurface Geology of the Cold Creek Syncline, C. W. Myers and S. M. Price, editors, RHO-BWI-ST-14, Rockwell Hanford Operations, Richland, Washington.

Reidel, S. P., and N. P. Campbe11, 1989, "Structure of the Yakima Fold Belt, Central Washington, "in Geologic Guidebook for Washington and Adjacent Areas, Washington Division of Geology and Earth Resources Information Circular 86, N. L. Joseph et a1., editors, Washington State Department of Natural Resources, Olympia, Washington.

Reide1, S. P., K. R. Fecht, and R. W. Cross, 1983, Constraints on Tectonic Models as Provided from Strain Rates, RHO-BWI-ST-19, Rockwell Hanford Operations, Richland, Washington.

Reidel, S. P., T. L. Tolan, P. R. Hooper, M. H. Beeson, K. R. Fecht, R. D. Bentley, and J. L. Anderson, 1989a, "The Grande Ronde Basalt, Columbia River Basalt Group - Stratigraphic Descriptions and Correlations in Washington, Oregon, and Idaho," in Volcanism and Tectonism in the Columbia River Flood-Basalt Province, Special Paper 239, S. P. Reidel and P. R. Hooper, editors, Geological Society of America, Boulder, Colorado.

Reidel, S. P., K. R. Fecht, M. C. Hagood, and T. L. Tolan, 1989b, "The Geologic Evolution of the Central Columbia Plateau," in Volcanism and Tectonism in the Columbia River Flood-Basalt Province, Special Paper 239, S. P. Reidel and P. R. Hooper, editors, Geological Society of America, Boulder, Colorado.

Reide1, S. P., K. A. Lindsey, and K. R. Fecht, 1992, Field Trip Guide to the Hanford Site, WHC-MR-0391, Westinghouse Hanford Company, Rich1and, Washington. 
Reide1, S. P., K. R. Fecht, K. A. Lindsey, and N. P. Campbel1, 1994, "Late Cenozoic Structure and Stratigraphy of South-Central Washington," in Washington Division of Geology and Earth Resources, Bullet in 80, R. Lasmanis and E. S. Cheney, editors, Washington State Department of Natural Resources, Olympia, Washington.

Rohay, A. C., and S. D. Malone, 1983, Crustal Structure of the Columbia Plateau Region, Washington, RHO-BW-SA-289P, Rockwe11 Hanford Operations, Richland, Washington.

Rohay, A. C., D. W. Glover, and S. D. Malone, 1985, Time-Term Analysis of Upper Crustal Structure in the Columbia Basin, Washington, RHO-BW-SA-435P, Rockwe 11 Hanford Operations, Richland, Washington.

Routson, R. C., and V. G. Johnson, 1990, "Recharge for the Hanford Site 200 Areas Plateau," Northwest Science, Vol. 64, no. 3, pp 150-158.

Saltus, R. W., 1993, "Upper-Crustal Structure Beneath the Columbia River Basa1t Group - Gravity Interpretation Controlled by Borehole and Seismic Studies," Geological Society of America Bulletin, Vol. 105, pp 12471259.

Schreckhise, R. G., K. Rhoads, J. S. Davis, B. A. Napier, and J. V. Ramsdell, 1993, Recommended Environmental Dose Calculation Methods and Hanford-Specific Parameters, PNL-3777, Rev. 2, Pacific Northwest Laboratory, Richland, Washington.

Scott, W. B., 1995, Clarification of Hanford Site Boundaries for Current and Future Use in Safety Analyses (Letter 9504327 to Director, Pacific Northwest Laboratory, and President, Westinghouse Hanford Company, September 23), U.S. Department of Energy, Richland Operations Office, Richland, Washington.

Scott, W. E., R. M. Iverson, J. W. Vallance, and W. Hildreth, 1995, Volcanic Hazards in the Mount Adams Region, Washington, Open File Report 95-492, U.S. Geological Survey, Washington, D.C.

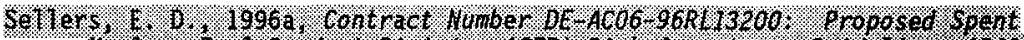

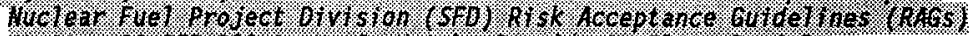

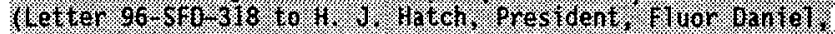

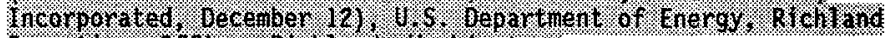

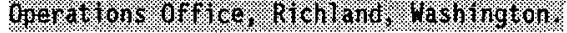

Sellers, E. D., 19966, Contract Number DE-AC06-96RL13200: Revised Tornado Criteria for the Spent Nuclear Fuel Canister Storage Building (CSB) (Letter 96-SFD-287 to H. J. Hatch, President, Fluor Daniel, Incorporated, October 10), U.S. Department of Energy, Rich1 and Operations office, Richland, Washington.

Siemens, 1994, Siemens Power Corporation Richland Engineering and Manufacturing Facility Emergency Plan, Siemens Power Corporation, Richland, Washington. 
Skaggs, R. L., and W. H. Walters, 1981, Flood Risk Analysis of Cold Creek Near the Hanford Site, RHO-BWI-C-120, Rockwell Hanford Operations, Richland, Washington.

Smith, G. A., 1988, "Neogene Synvolcanic and Syntectonic Sedimentation in Centrai Washington," Geologic Society of America Bulletin, Vol. 100, pp 1479-1492.

Stone, W. A., D. E. Jenne, and J. M. Thorp, 1972, Climatography of the Hanford Area, BNWL-1605, Pacific Northwest Laboratory, Richland, Washington.

Stone, W. A., J. M. Thorp, 0. P. Gifford, and D. J. Hoitink, 1983, Climatological Summary for the Hanford Area, PNL-4622, Pacific Northwest Laboratory, Richland, Washington.

Supply System, 1995, Final Safety Analysis Report, Washington Nuclear Power Plant No. 2, Amendment 50, Docket No. 50-397, Washington Public Power Supply System, Richland, Washington.

Swanson, D. A., T. L. Wright, and R. Helz, 1975, "Linear Vent System and Estimated Rates of Magma Production and Eruption for the Yakima Basalts," American Journal of Science, Vo1. 275, pp 877-905.

Swanson, D. A., T. L. Wright, P. R. Hooper, and R. D. Bentley, 1979a, Revisions in Stratigraphic Nomenclature of the Columbia River Basalt Group, Bulletin 1457, U.S. Geological Survey, Washington, D.C.

Swanson, D. A., J. L. Anderson, R. D. Bentley, V. E. Camp, J. N. Gardner, and T. L. Wright, 1979b, Reconnaissance Geologic Map of the Columbia River Basalt Group in Eastern Washington and Northern Idaho, Open File Report 79-1363, U.S. Geological Survey, Washington, D.C.

Tallman, A. M., 1996, Canister Storage Building Natural Phenomena Hazards, WHC-SD-SNF-DB-009, Rev. 4, Westinghouse Hanford Company, Richland, Washington.

Tallman, A. M., K. R. Fecht, M. C. Marratt, and G. V. Last, 1979, Geology of the Separations Areas, Hanford Site, South-Central Washington, RHO-ST-23, Rockwel1 Hanford Operations, Richland, Washington.

Tallman, A. M., J. T. Lillie, and K. R. Fecht, 1981, "Suprabasalt Sediments of the Cold Creek Syncline Area," in Subsurface Geology of the Cold Creek Sync7ine, RHO-BWI-ST-14, C. W. Myers and S. M. Price, editors, Rockwell Hanford Operations, Richland, Washington.

Tolan, T. L., and S. P. Reide1, 1989, "Structure Map of a Portion of the Columbia River Flood-Basalt Province," in Volcanism and Tectonism in the Columbia River Flood-Basalt Province, Special Paper 239, S. P. Reidel and P. R. Hooper, editors, Plate, scale 1:580,000, Geological Society of America, Boulder, Colorado. 
Tolan, T. L., S. P. Reide1, M. H. Beeson, J. L. Anderson, K. R. Fecht, and D. A. Swanson, 1989, "Revisions to the Estimates of the Areal Extent and Volume of the Columbia River Basalt Group," in Volcanism and Tectonism in the Columbia River Flood-Basalt Province, Special Paper 239, S. P. Reidel and P. R. Hooper, editors, Geological Society of America, Boulder, Colorado.

UNI, 1978, N-Reactor Updated Safety Analysis Report, UNI-M-90, UNC Nuclear Industries, Richland, Washington.

Waters, A. C., 1961, "Stratigraphic and Lithologic Variations in the Columbia River Basalt," American Journal of Science, Vol. 259, pp 583-611.

WCC, 1989, Evaluation of Seismic Hazard for Nonreactor Facilities, Hanford Reservation, Hanford Washington, WHC-MR-0023, prepared by Woodward-Clyde Consultants, 0akland, California, for Westinghouse Hanford Company, Richland, Washington.

WHC, 1992, Hydrogeologic Model for 200 West Groundwater Aggregate Area, WHC-SD-EN-TI-014, Rev. 0, Westinghouse Hanford Company, Richland, Washington.

WHC, 1996, Waste Encapsulation and Storage Facility Safety Analysis Report, WHC-SD-WM-SAR-005, Rev. 12, Westinghouse Hanford Company, Richland, Washington.

WHC-CM-1-5, Standard Operating Practices, Westinghouse Hanford Company, Richiand, Washington.

WHC CM-4-46, Safety Anafysis Manta?, Westinghouse-Hanford Company, Richland, Washington. 
HNF-SD-SNF-RPT-004 REV 6

This page intentionally left blank. 
Figure 1-1. Location of the Hanford Site in the State of Washington.

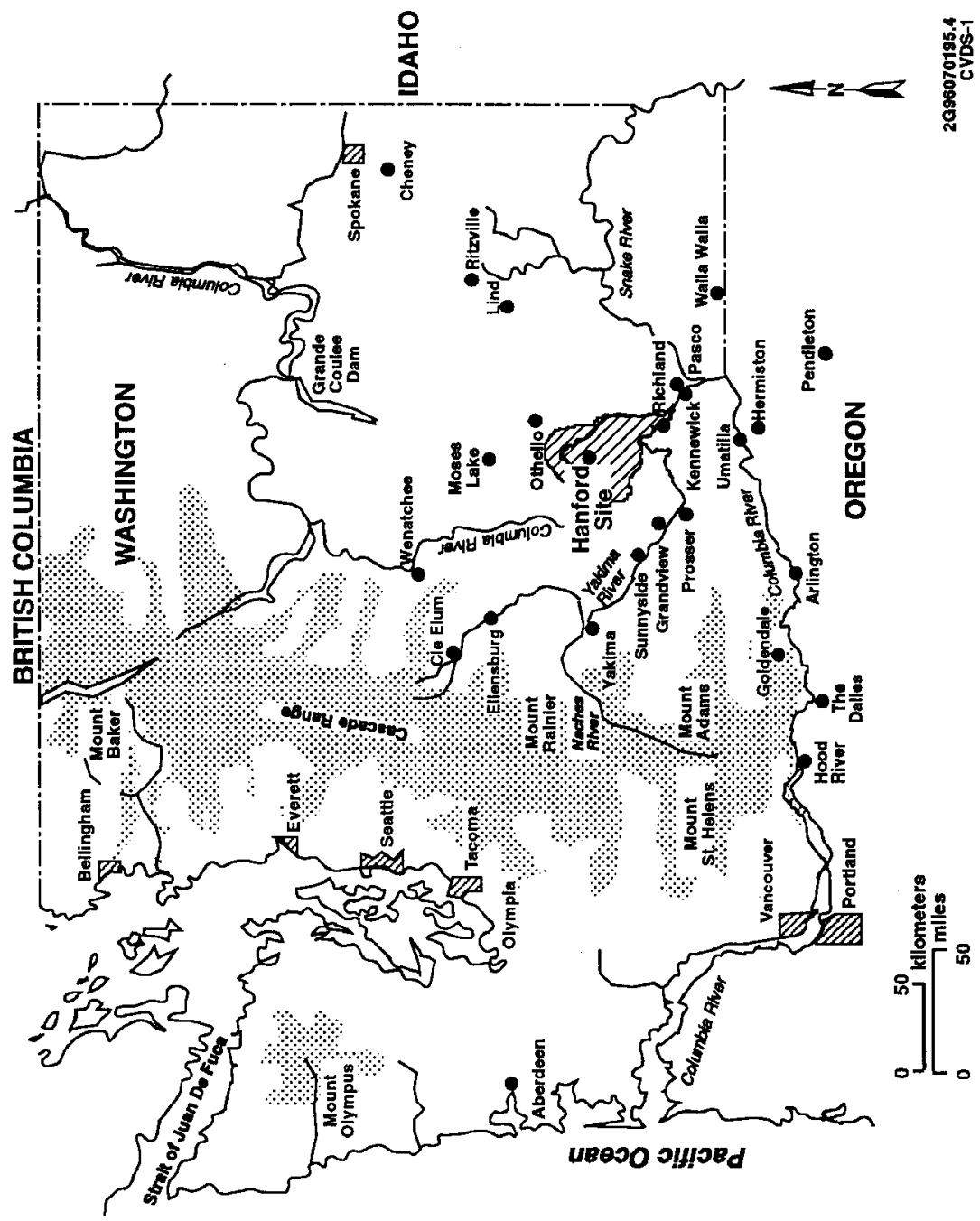


HNF-SD-SNF-RPT-004 REV 6

Figure 1-2. The Hanford Site, Counties, and the Regional Highway Network.

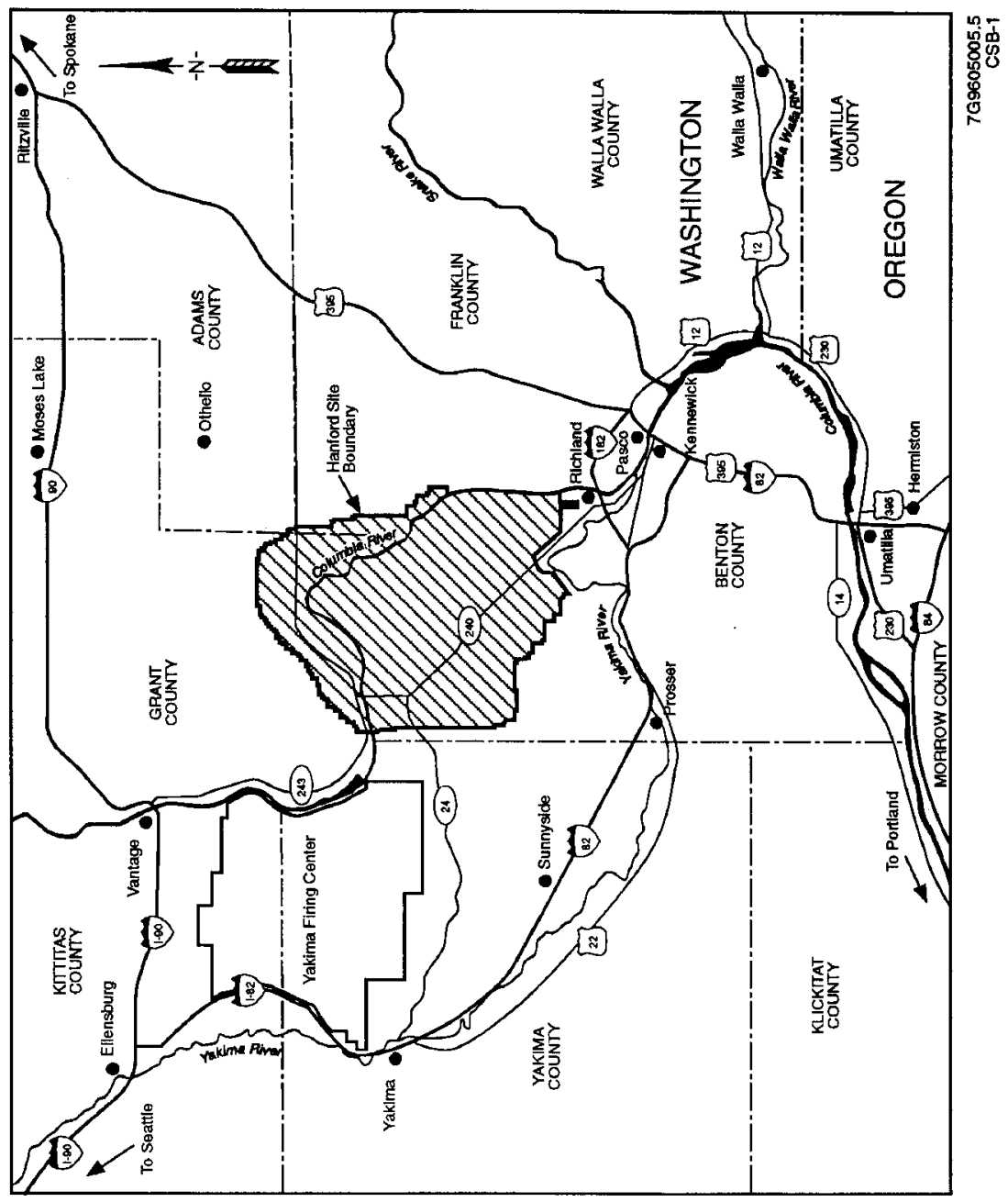


Figure 1-3. Hanford Site and Surrounding Area.

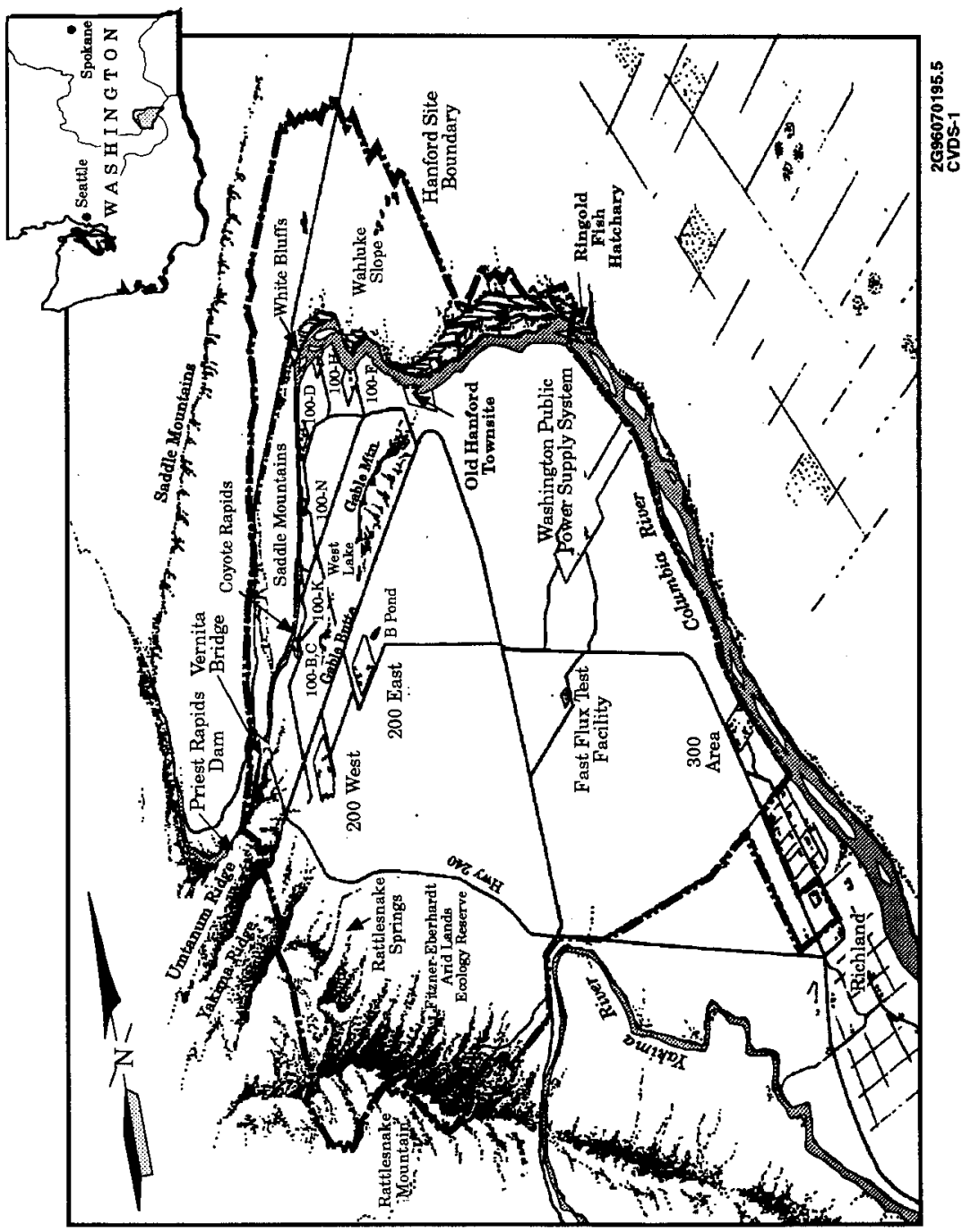


Figure 1-4. Hanford Site Boundaries.

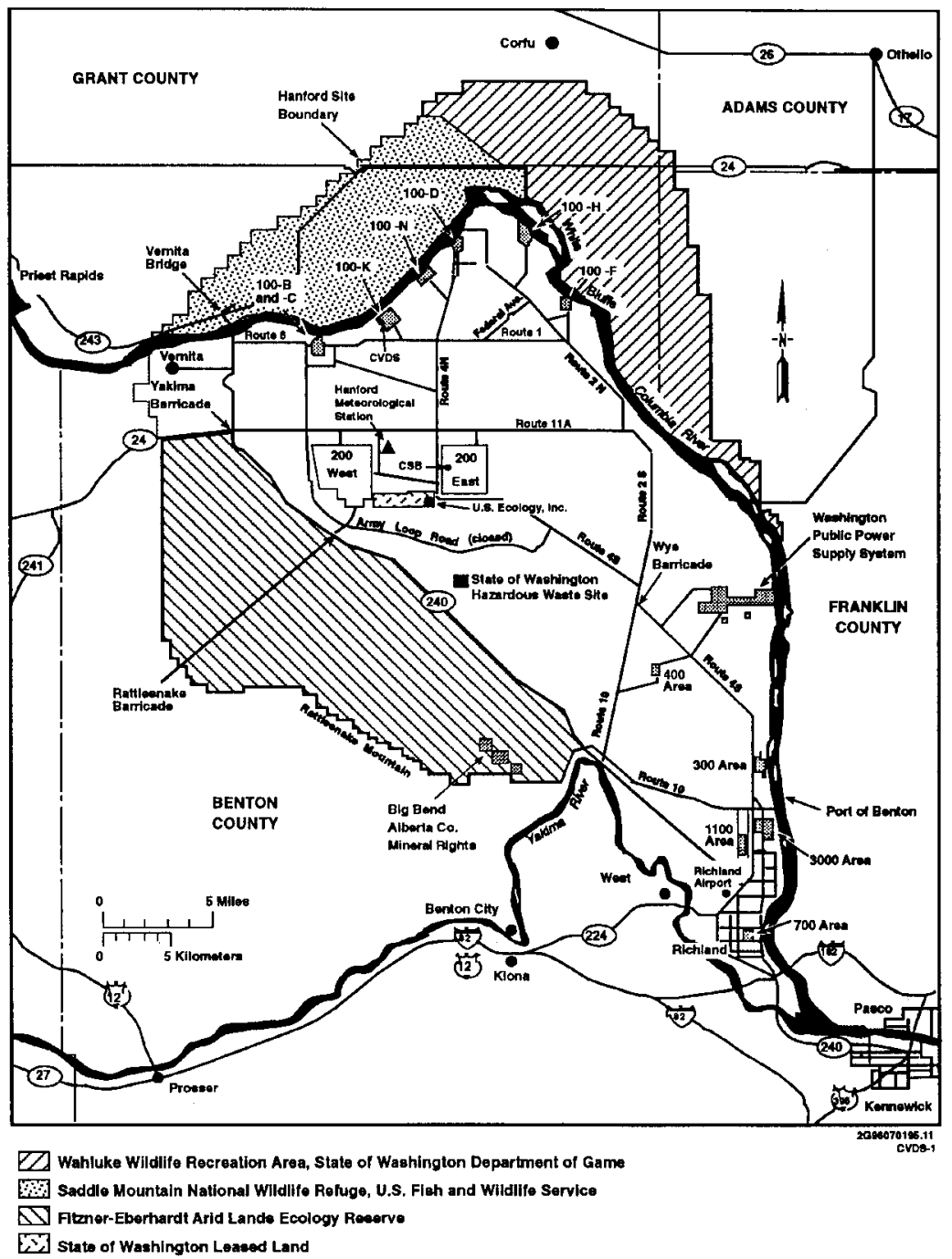


Figure 1-5. Hanford Site Topographic Map and Cross Section.

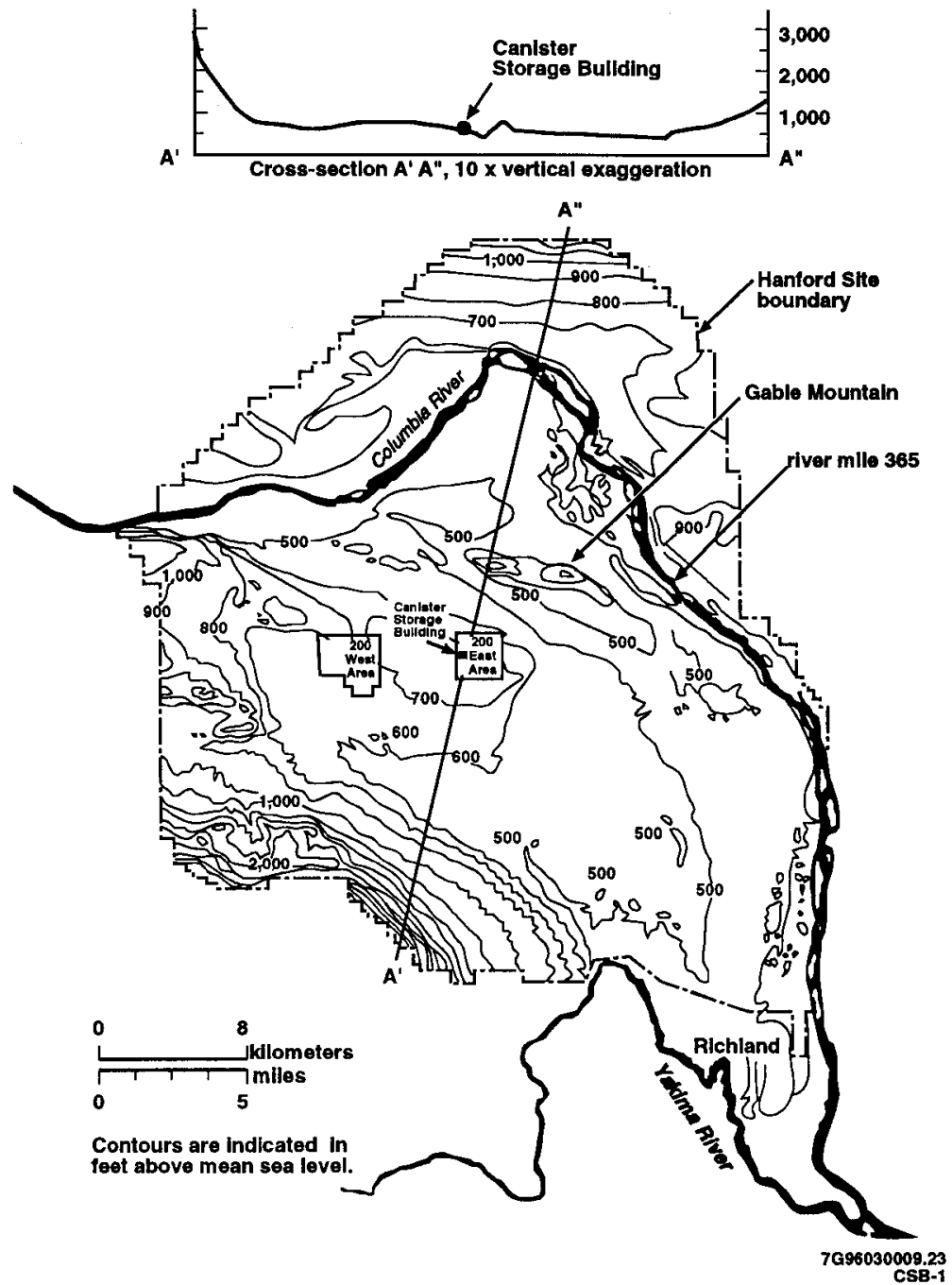


Figure 1-6. Population of Cities and Counties Near the Hanford Site.

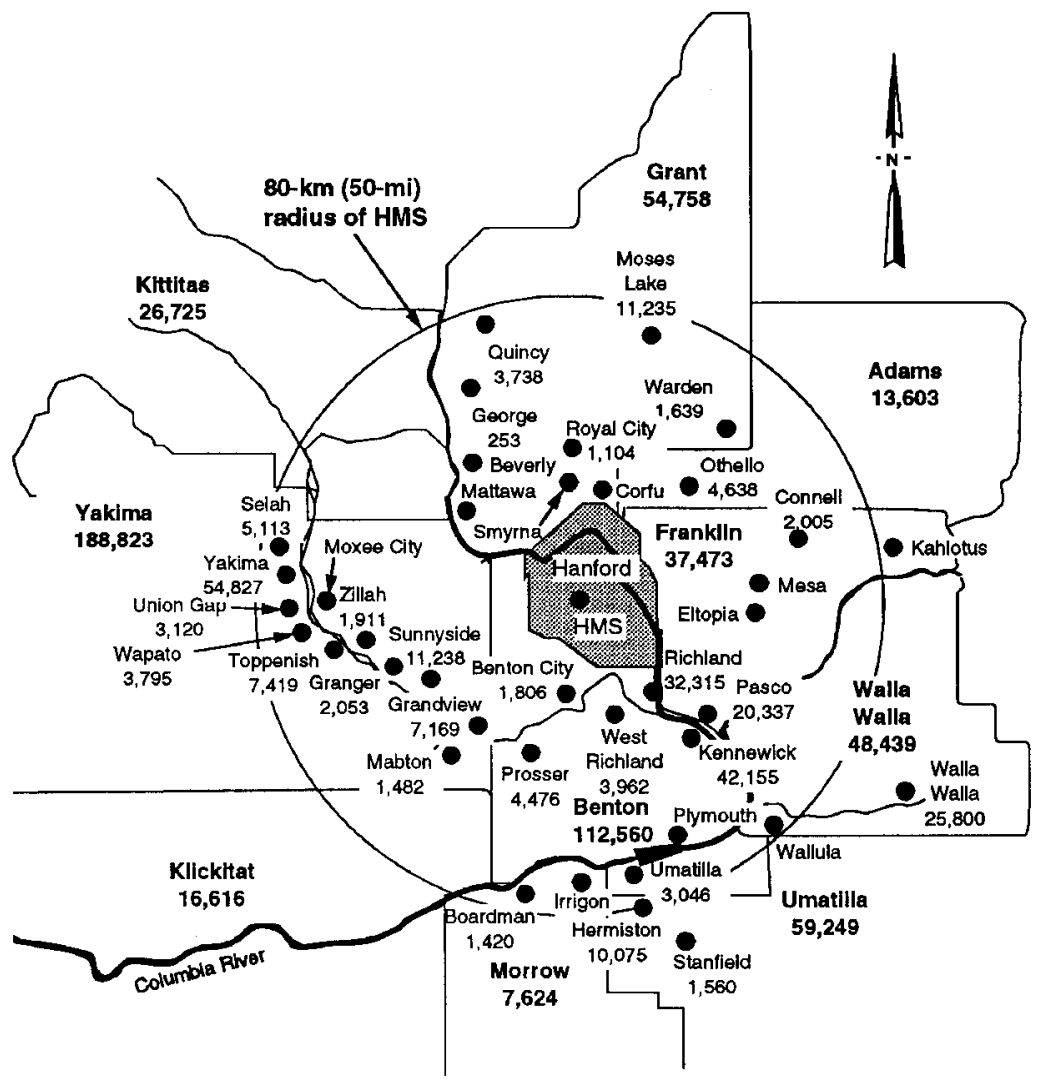

Note: If population is not listed, it is less than 1,000 .

HMS = Hanford Meteorological Station. 
Figure 1-7. Distribution of Transient Population.

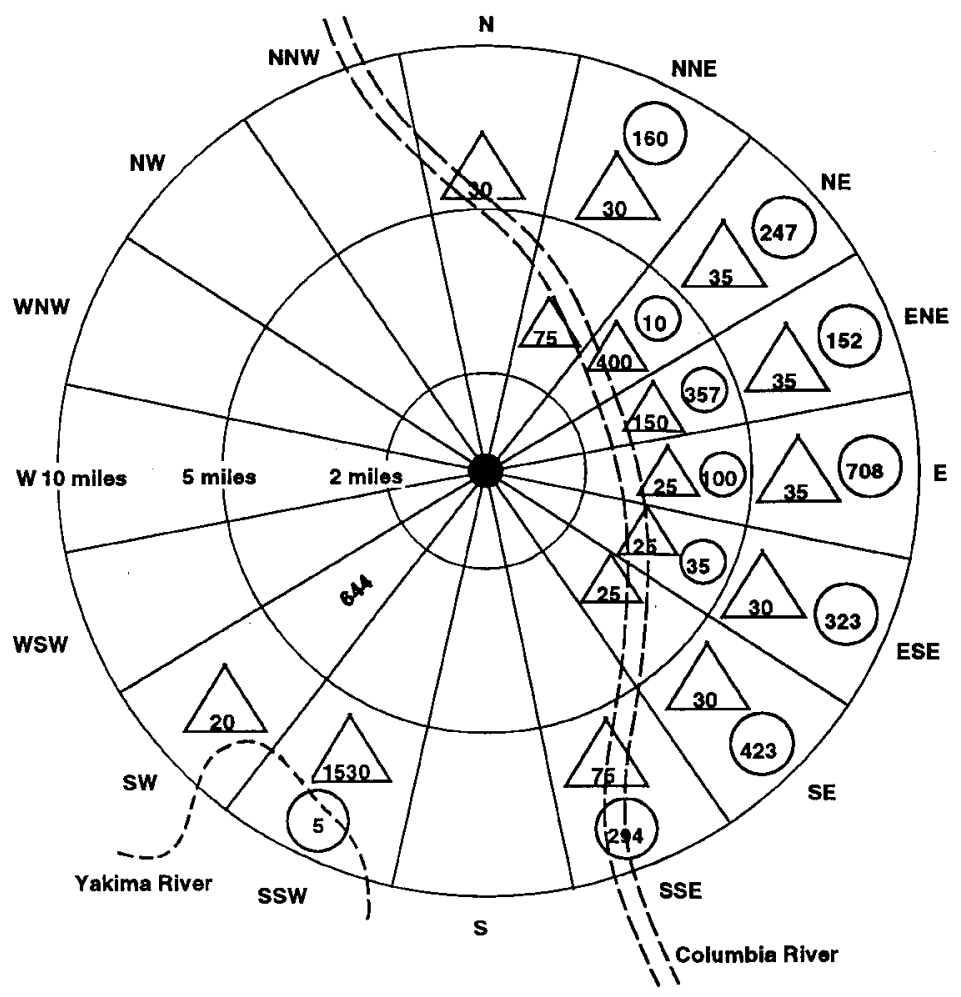

Key

midway between WNP-1, -2 , and -4

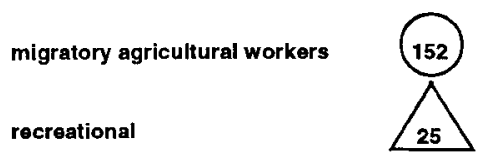

To convert miles to kilometers, multiply by 1.6093 . 
Figure 1-8. Onsite Population Distribution in the 200 East Area by Zone.

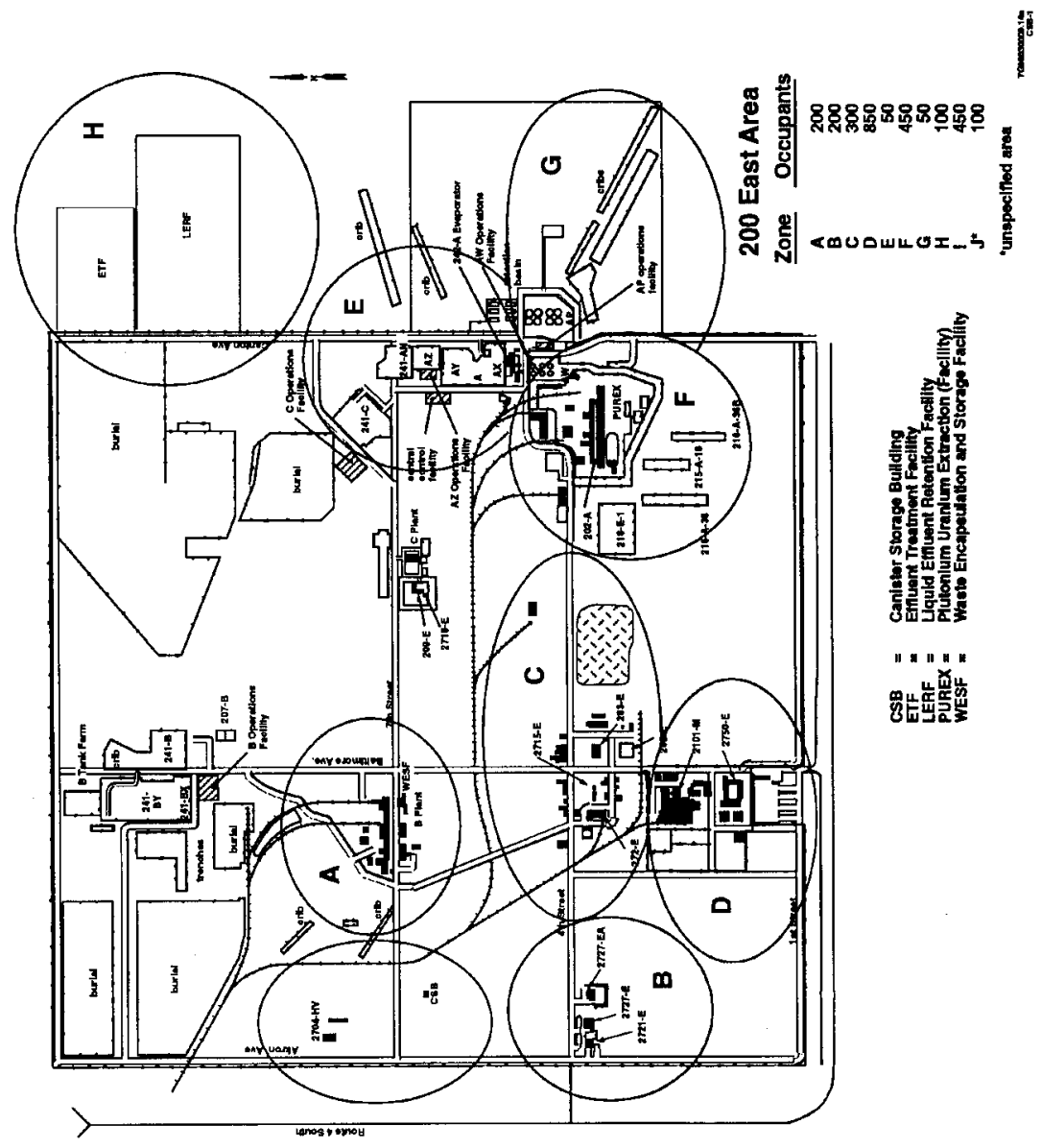


Figure 1-9. Hanford Meteorological Network.

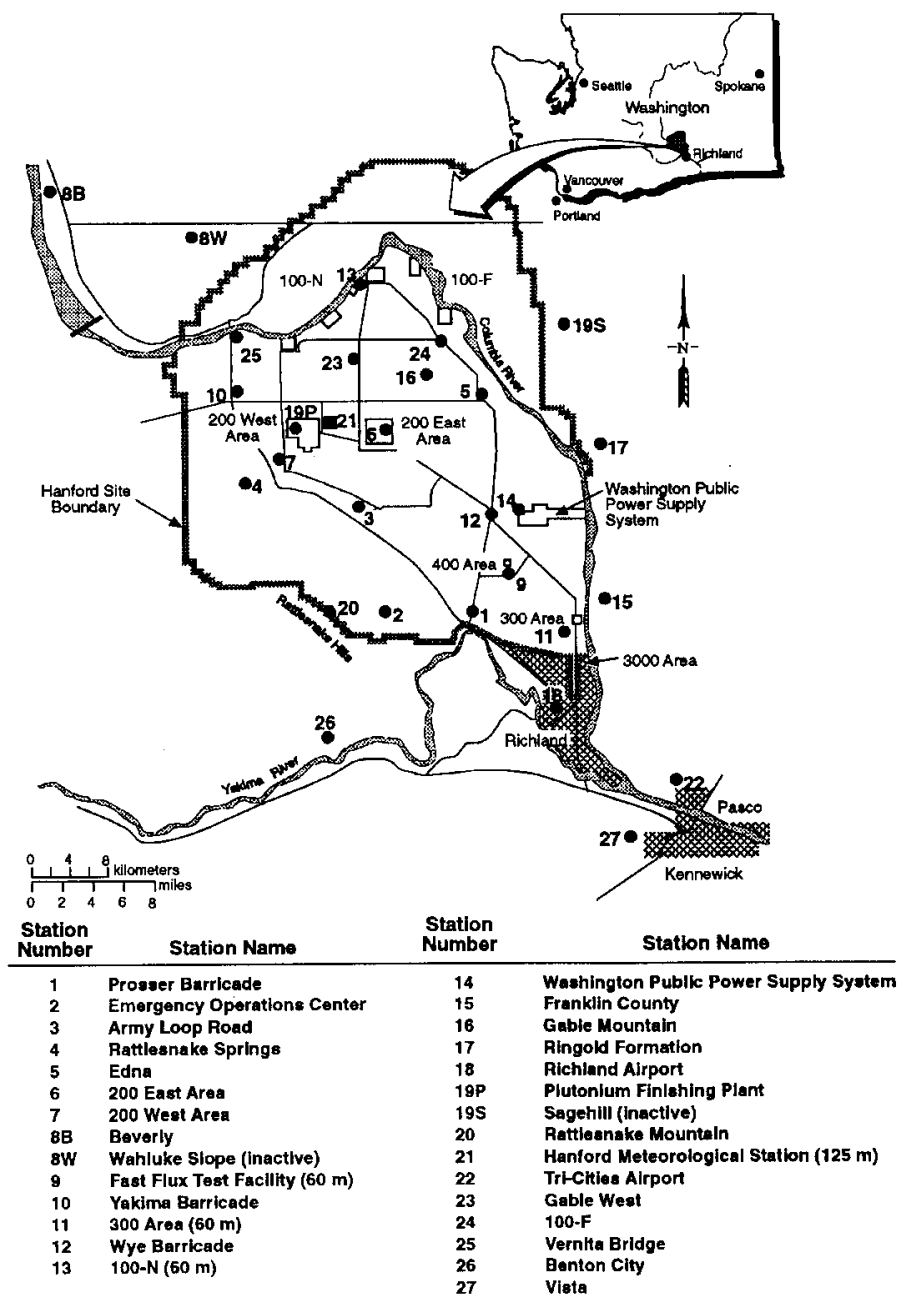

Note: All network stations are $9.1 \mathrm{~m}$ unless otherwise indicated.

To convert meters to foet, multiply by $\mathbf{3 . 2 8 1}$.

7696030009.15

CSB-1 
Figure 1-10. Hanford Site in Relation to Surrounding Terrain.

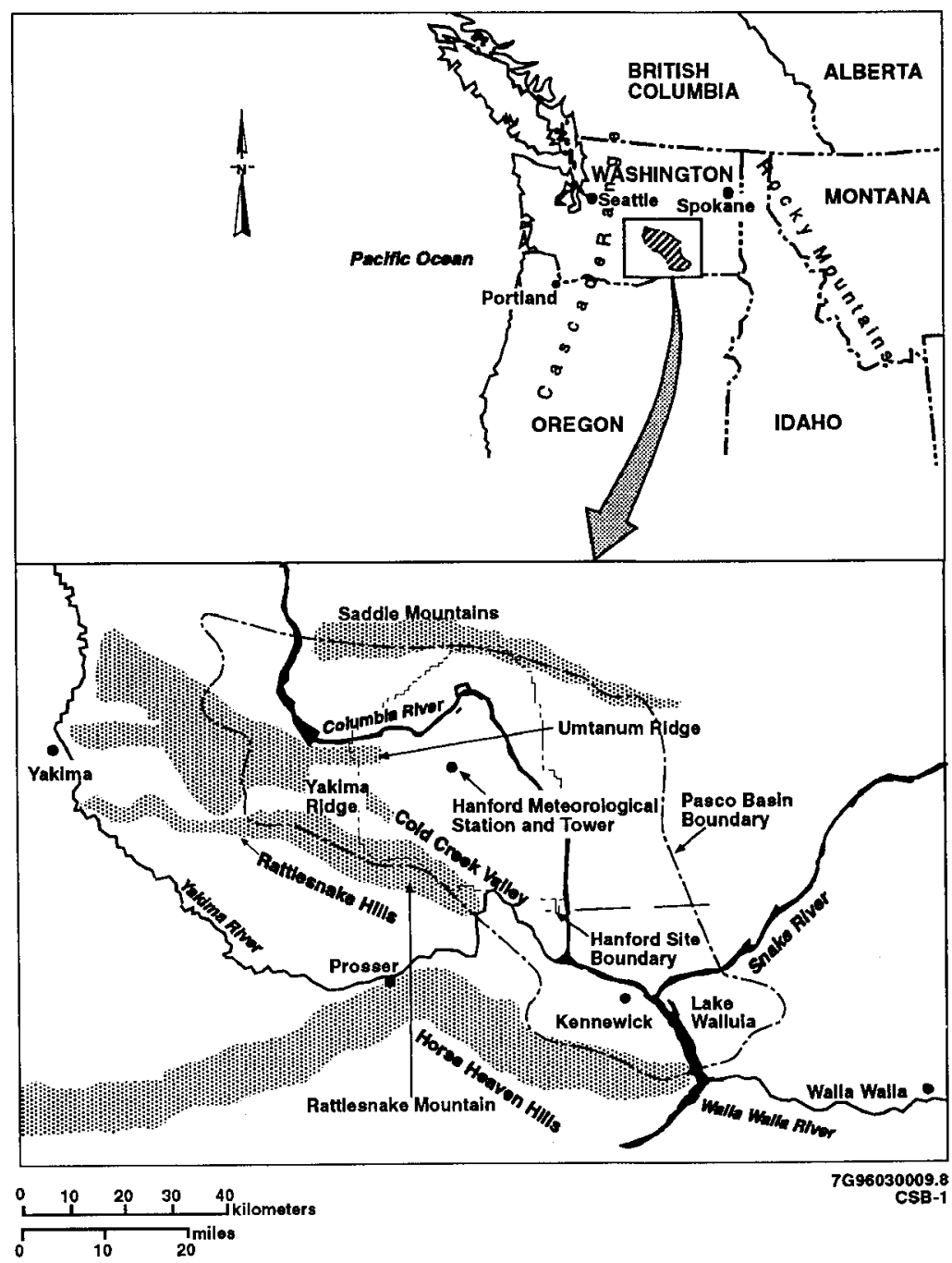


Figure 1-11. Six-Hour Precipitation Hazard Curves for the Hanford Site.

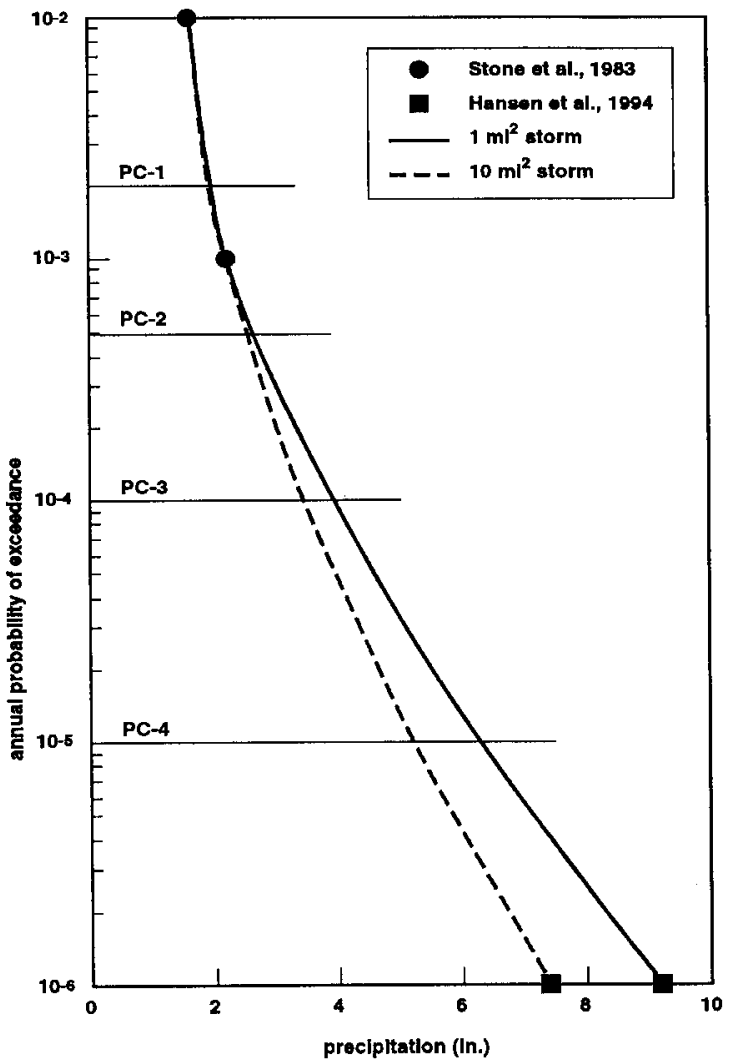

Hansen, E. M., D. D. Fenn, P. Corrigan, J. L. Vogel, L. C. Schrelner, and R. W. Stodt, 1994, Probublo Maximum Procipltation - Pacine Northmest Statea, Hydrometeorological Report No. 57, National Weather Service, sliver Spring, Maryland.

Stone, W. A., J. M. Thorp, O. P. Gifford, and D. J. Holtink, 1983, CWmatological Summary for the Hanford site, PNL-4622, Pacific Northwest Laboratory, Richiand, Washington. 
Figure 1-12. Greatest Depth of Snow on the Ground at Hanford from 1946-47 to 1980-81.

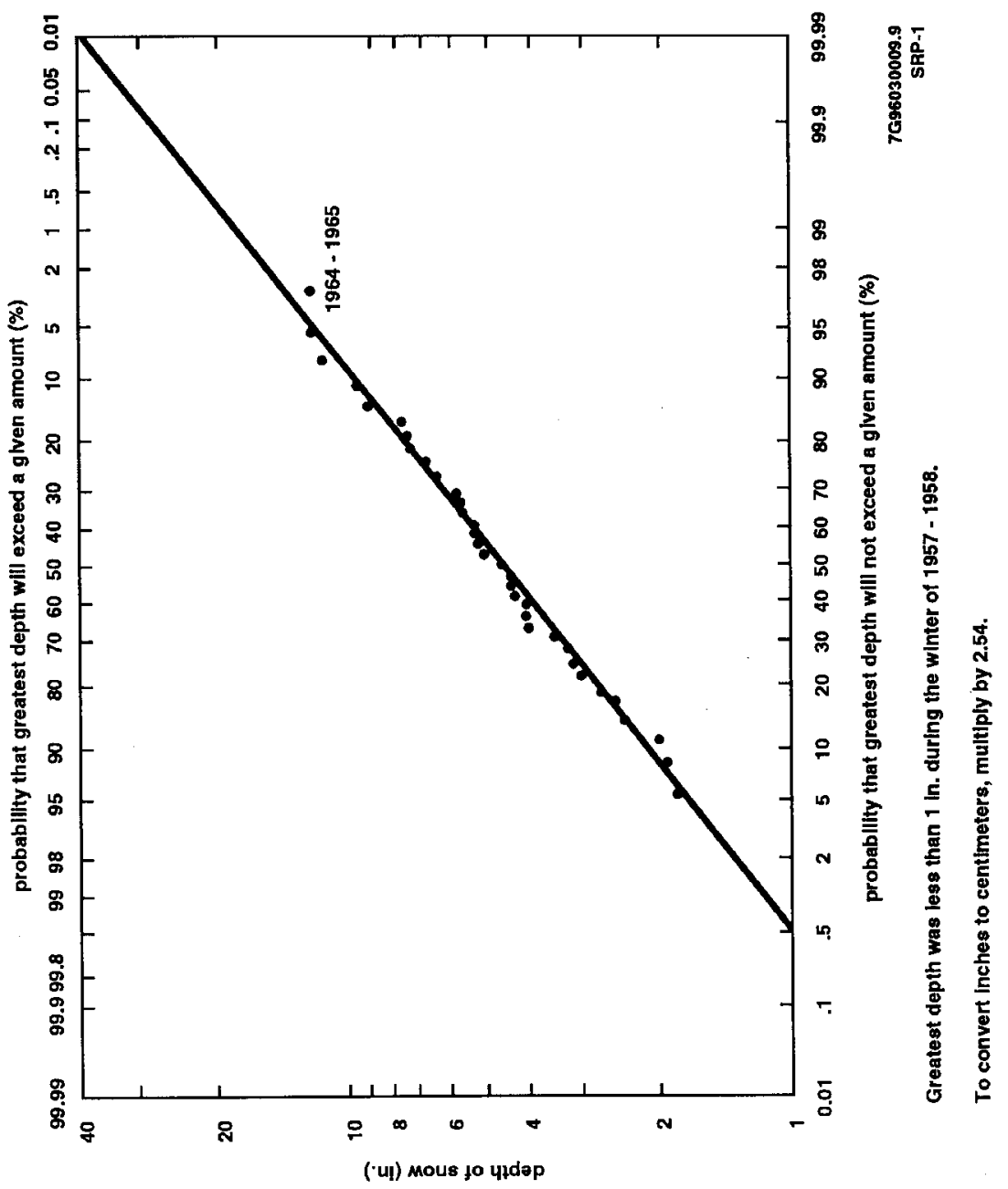


Figure 1-13. Wind Hazard Curves with Design Windspeeds (Windspeeds are Fastest Mile).

Wind Speod (moters/sec)

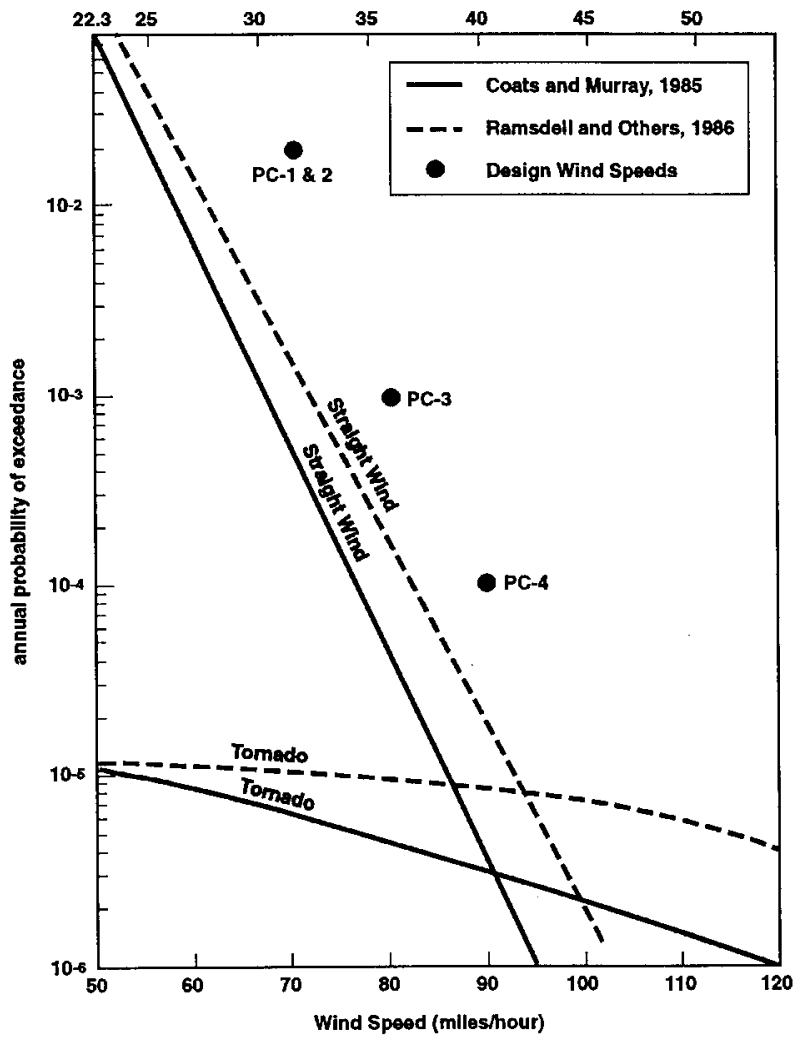

Coats, D.W., and R.C. Murray, 1985, Natural Phenomena Hazands Modeling Project Extreme Wind/Tornado Hazard Models for Departmemt of Eneryy Shes, UCRL-53526, Rev.1, Lawrence Livermore Natlonal Laboratory, Livermore, Callifomia.

Ramsdell, J.V., D.L. Elliott, C.G. Holladay, and J. M. Hubbe, 1986, Methodology for Entimating Extreme Winds for Probablitstic Alek Aeseasements, NUREG-CR-4492, prepared for the U.S. Nuclear Regulatory Commission by Paciflc Northwest Laboratory, Richland, Washington.

2095100235.2

CSB-1 
Figure 1-14. Wind Rose and Wind Speed Histogram for the 200 East Area.
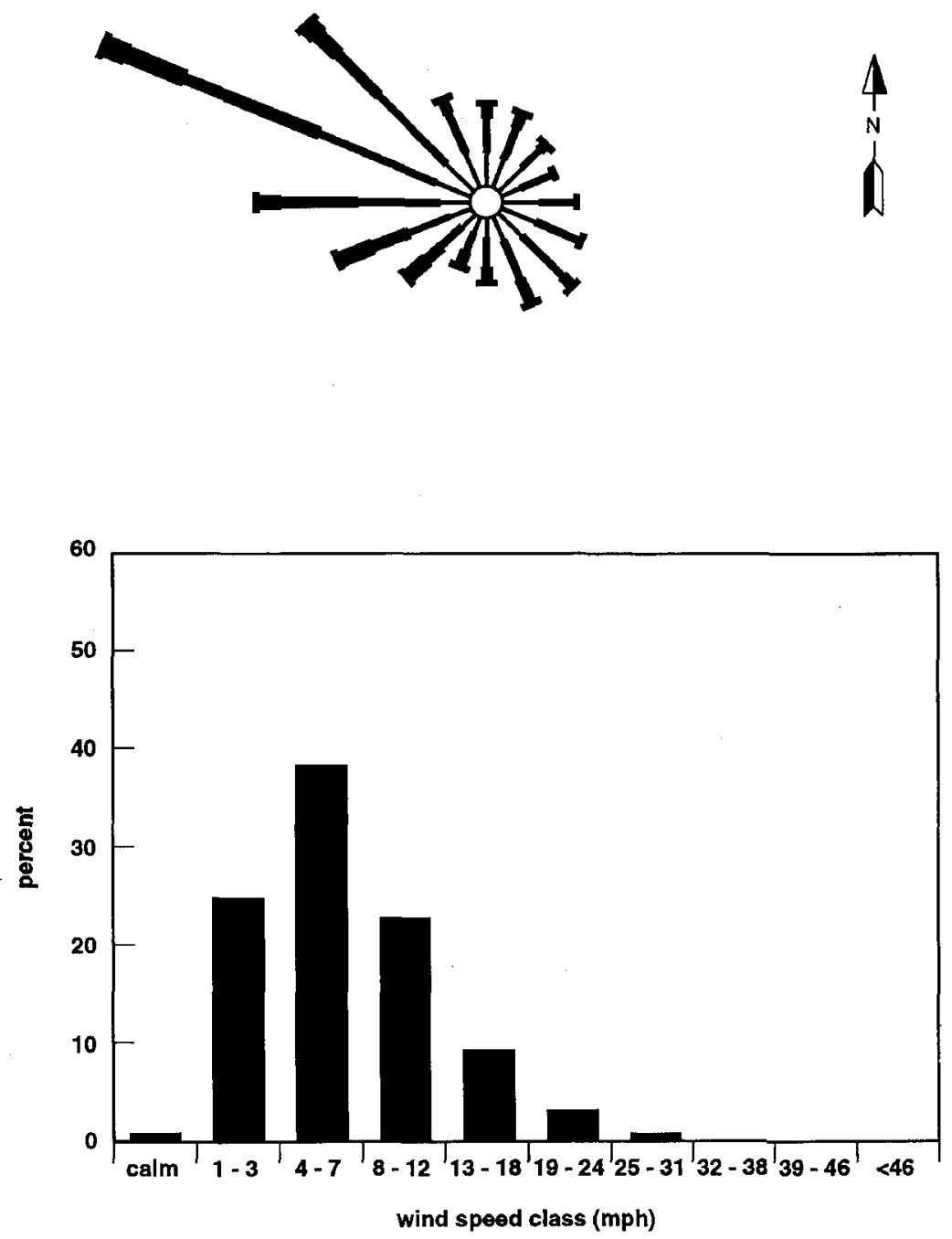

7G96030009.14 SRP-1 
Figure 1-15. Location of Surface Water on the Hanford Site.

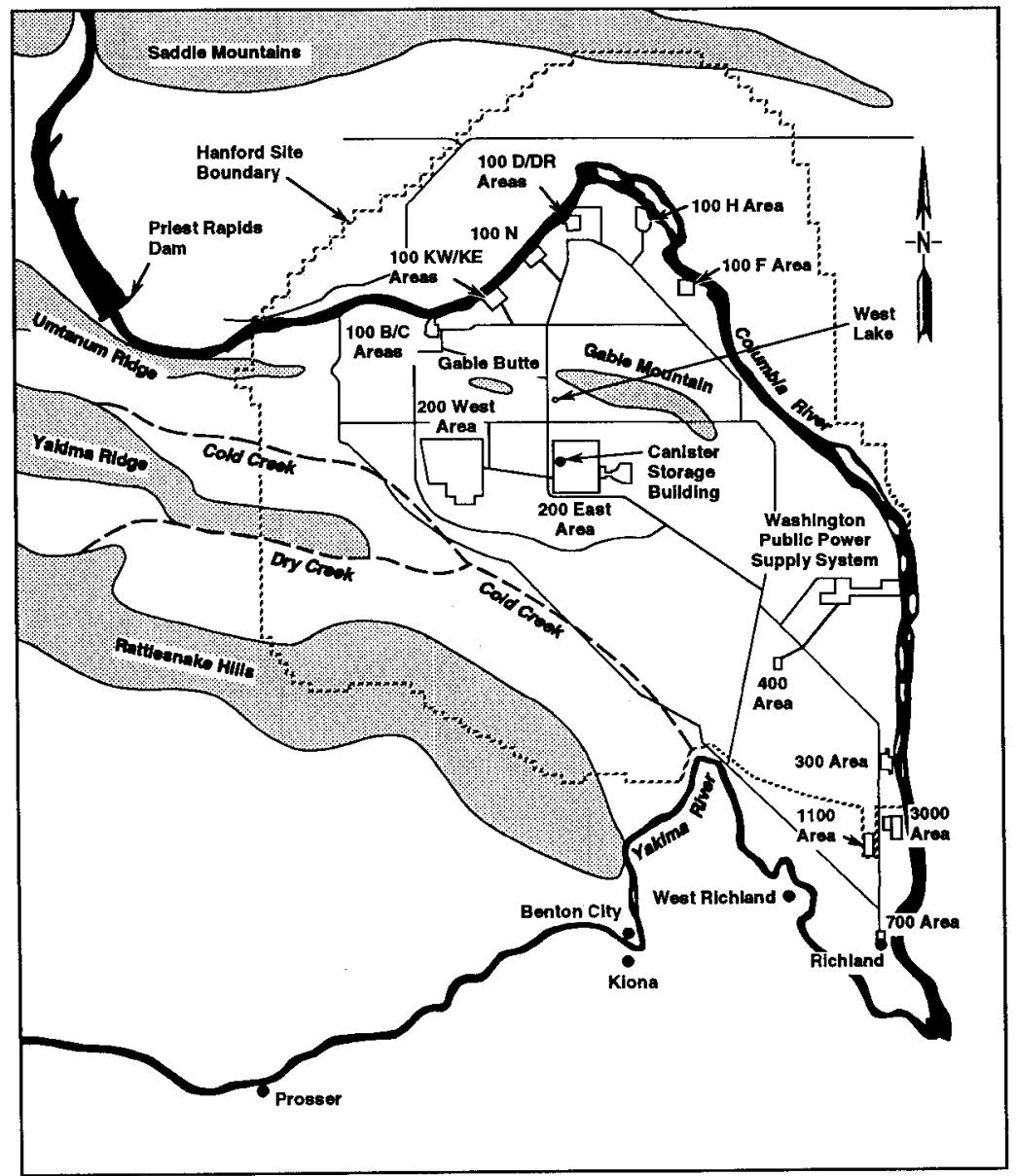

$7 \mathrm{G} 96030009.17$
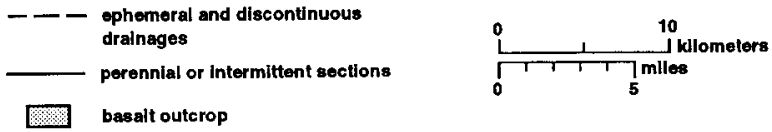
Figure 1-16. Location of Dams on the Columbia River.

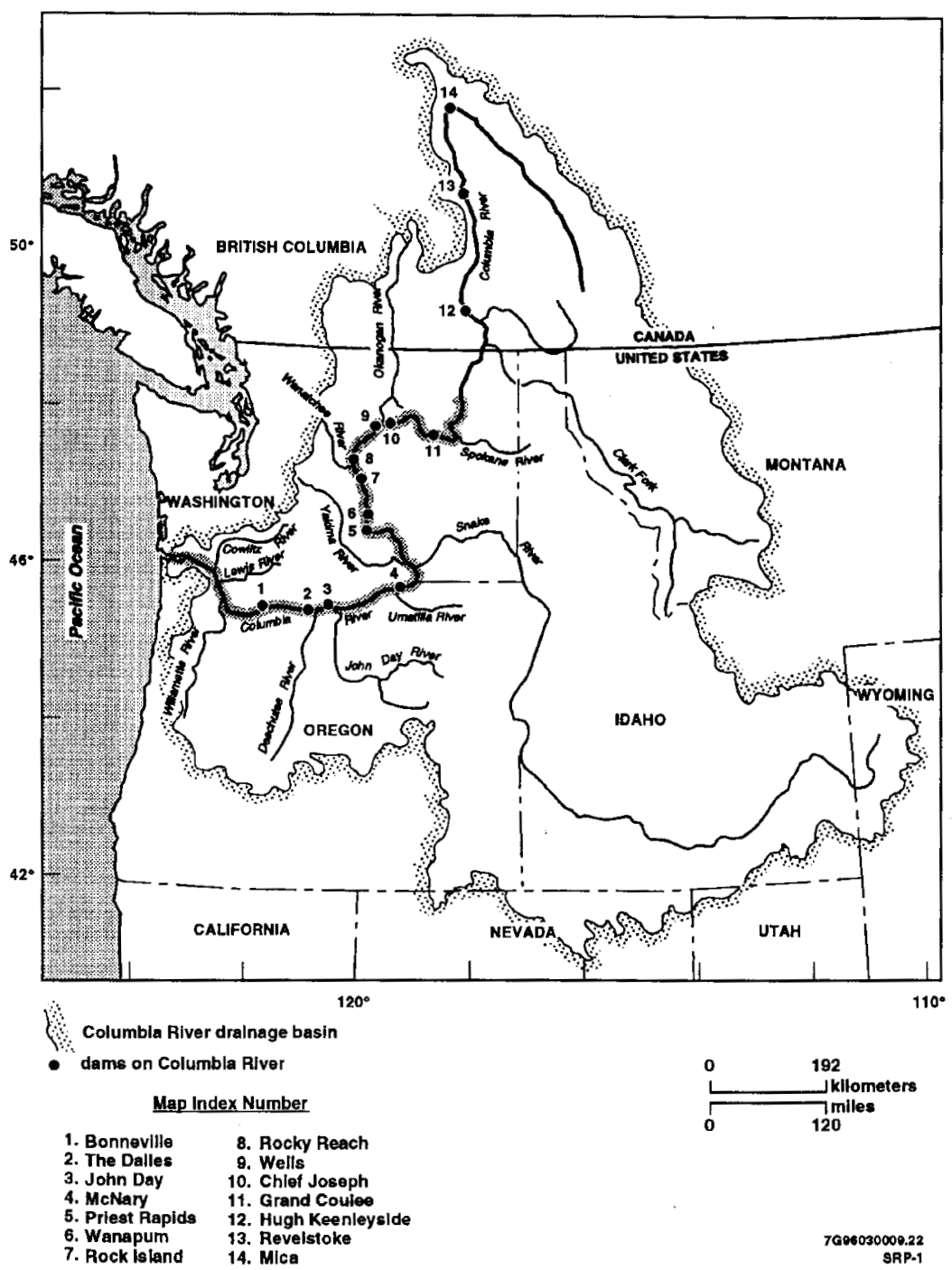


Figure 1-17. Extent of Probable Maximum Flood in Cold Creek Area.

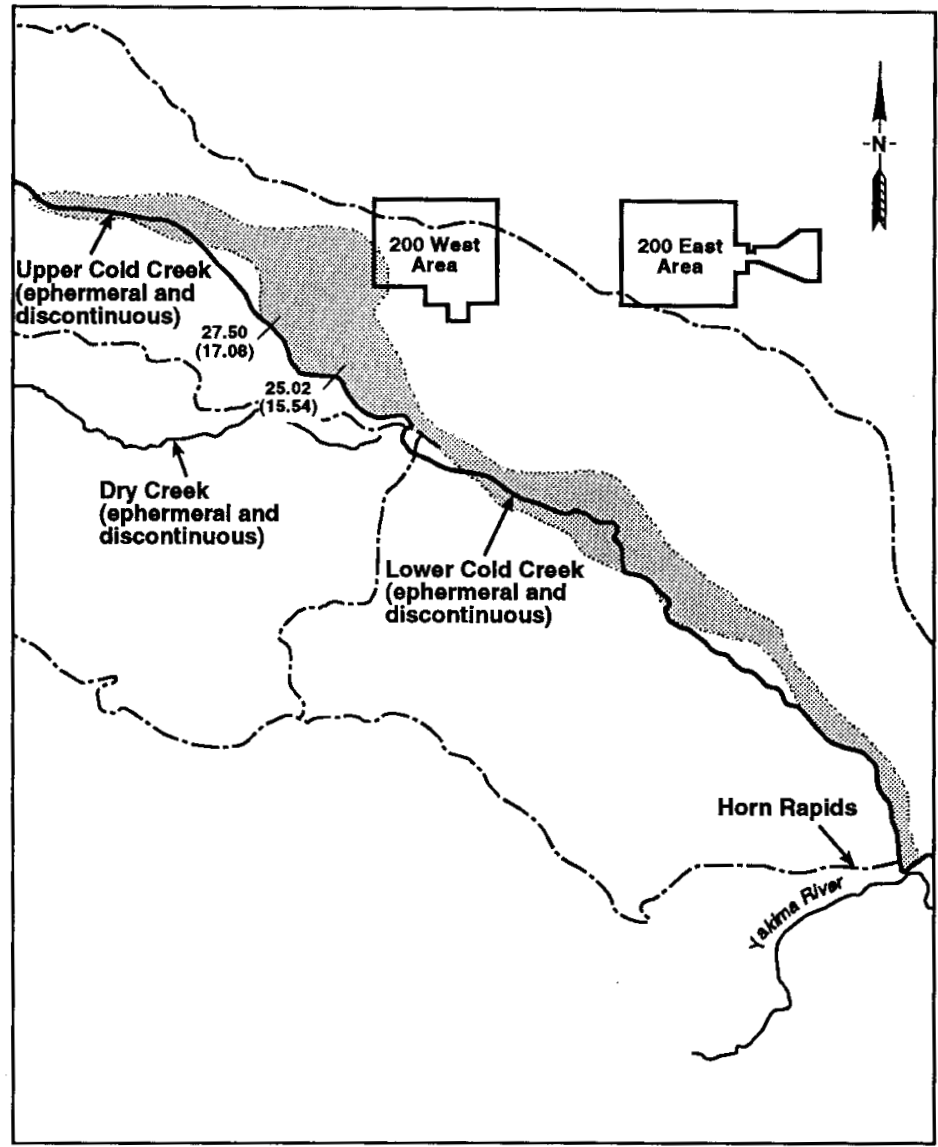

7696030009.24

7 (17.00) river allometer (mile)

SRP-1 
Figure 1-18. Characteristic Stratigraphy, Lithology, and Hydrogeologic Conditions on the Hanford Site.

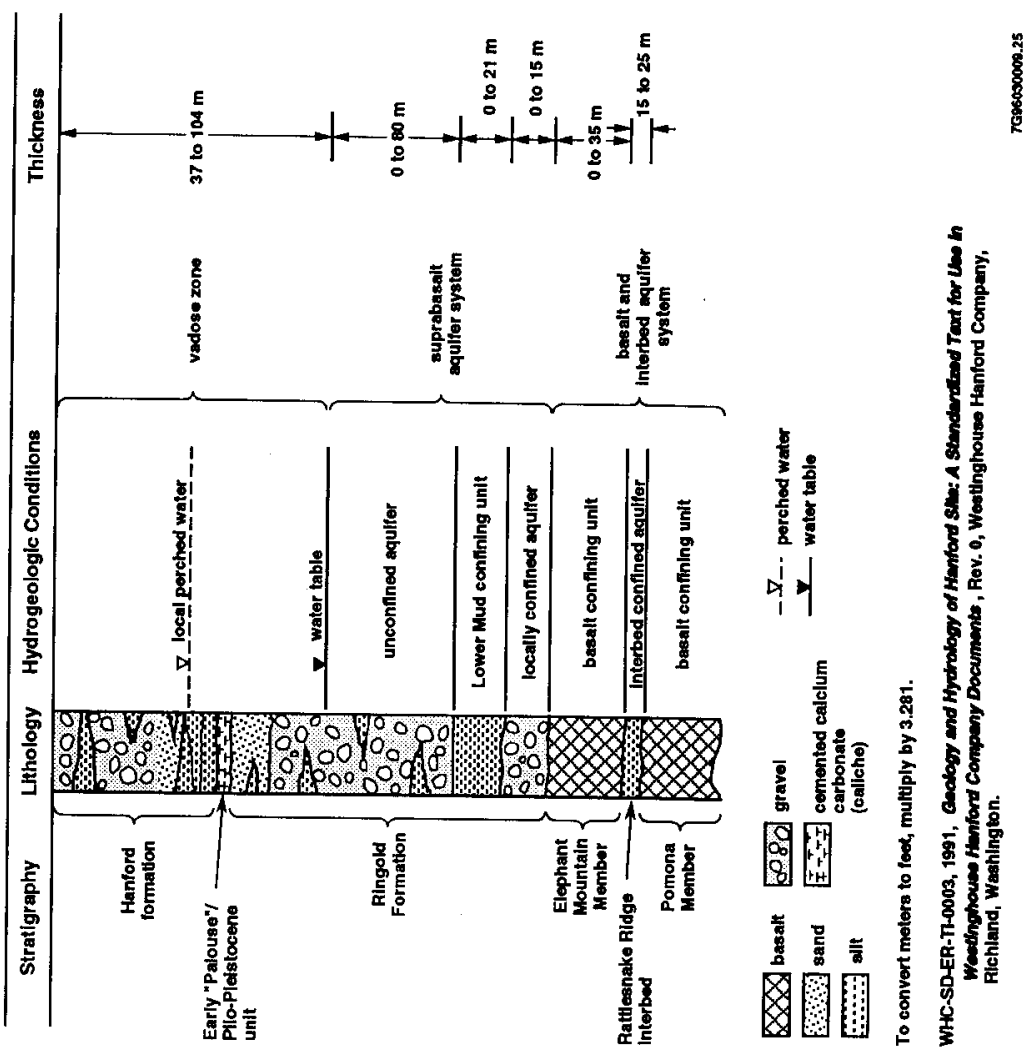


Figure 1-19. Water Table Contours for the 200 East Areas Based on Well Data.

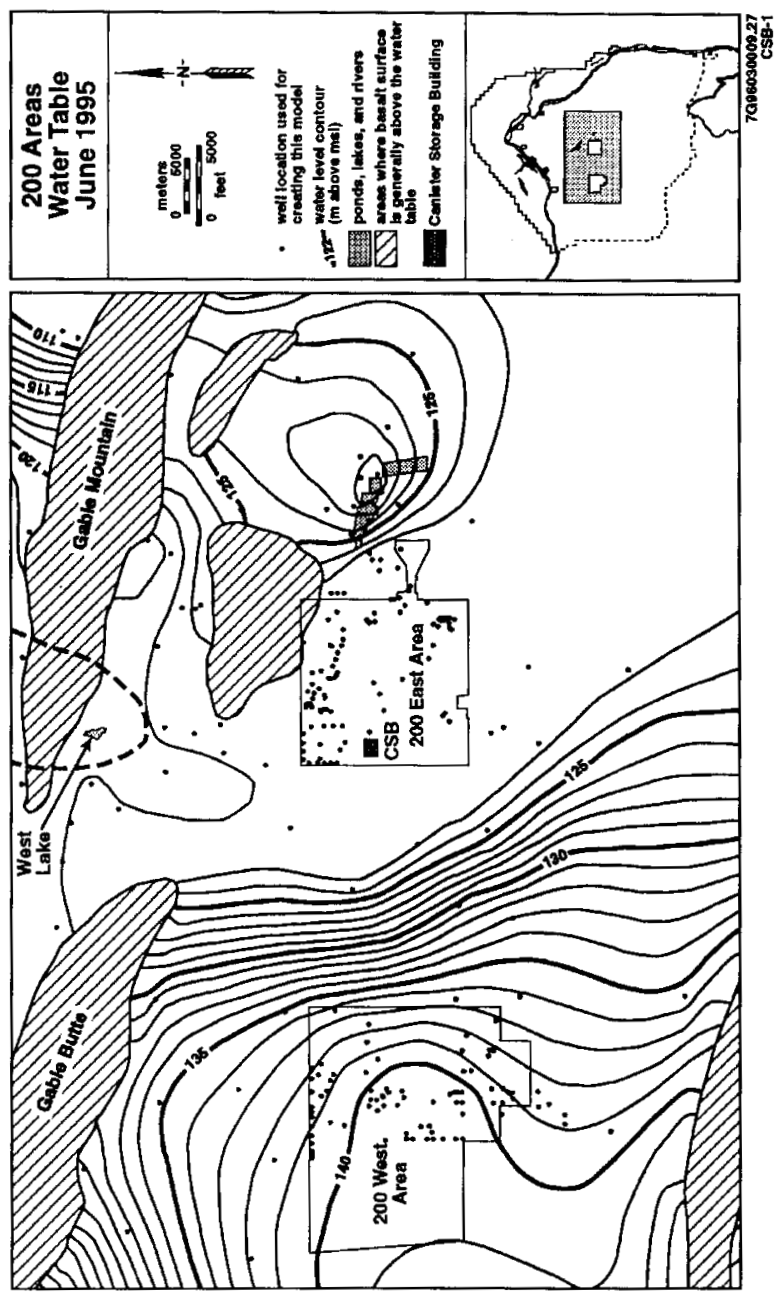


Figure 1-20. Location of the Hanford Site, Pasco Basin, and Columbia Plateau.

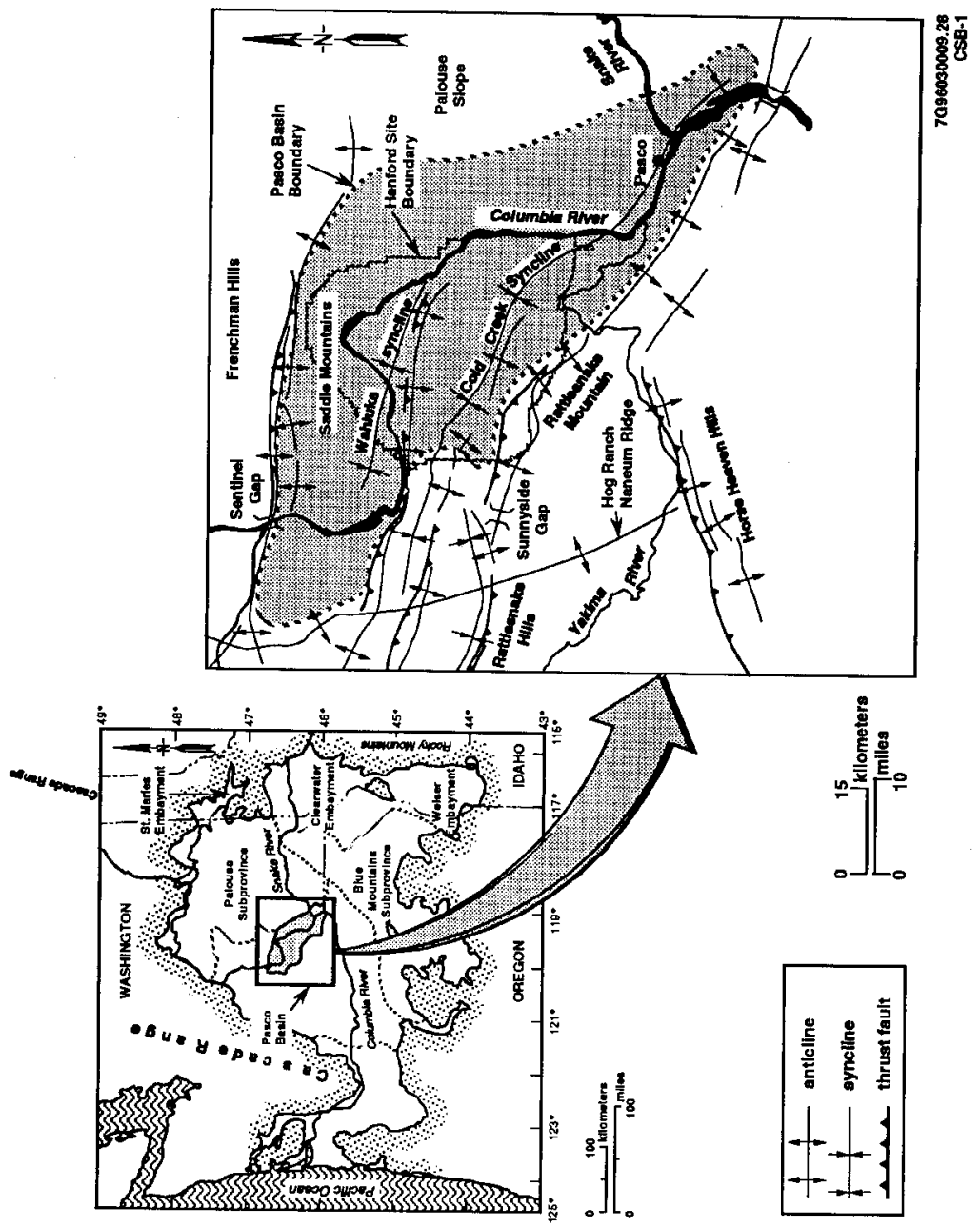


Figure 1-21. Physiographic Provinces of the Pacific Northwest, with the Columbia Intermontane Province Shown in White.
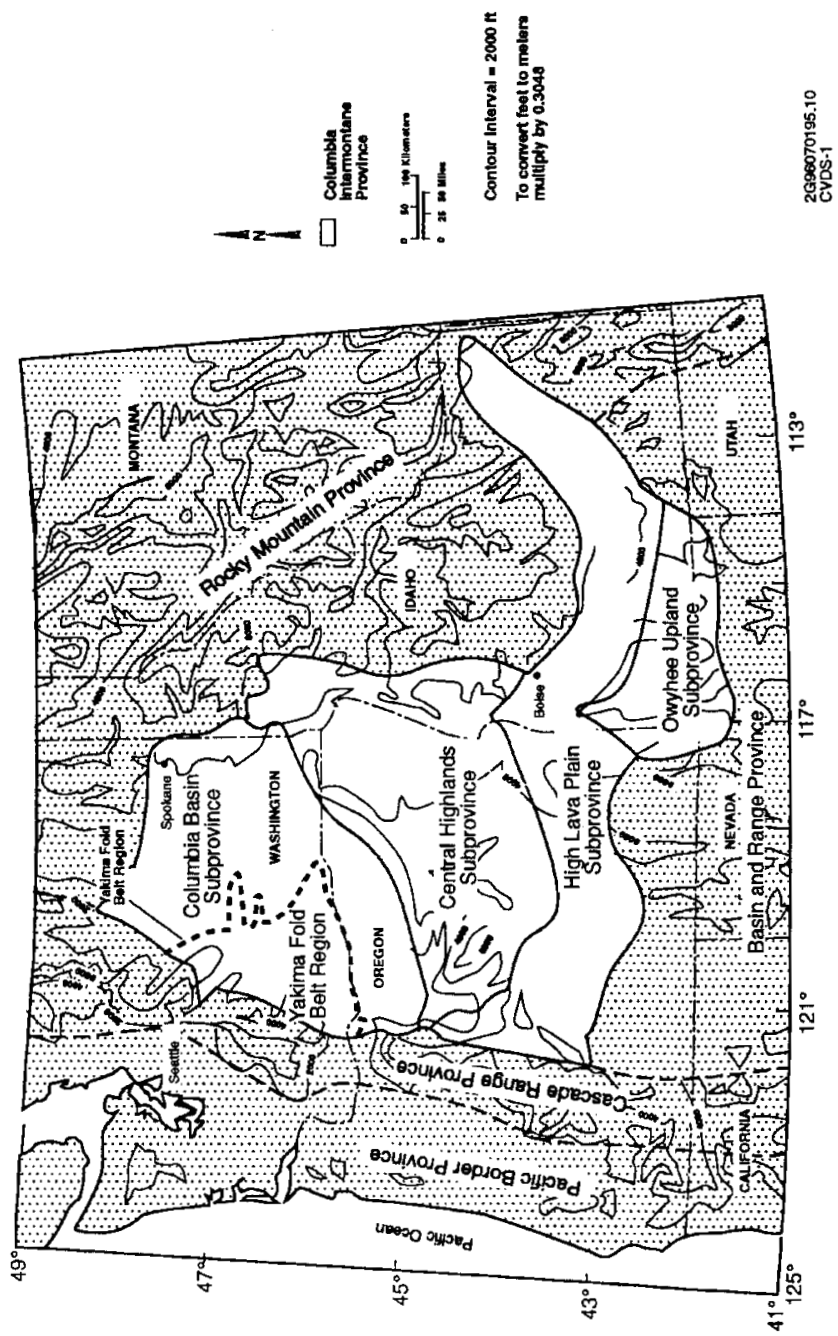
Figure 1-22. Generalized Stratigraphy of the Pasco Basin.

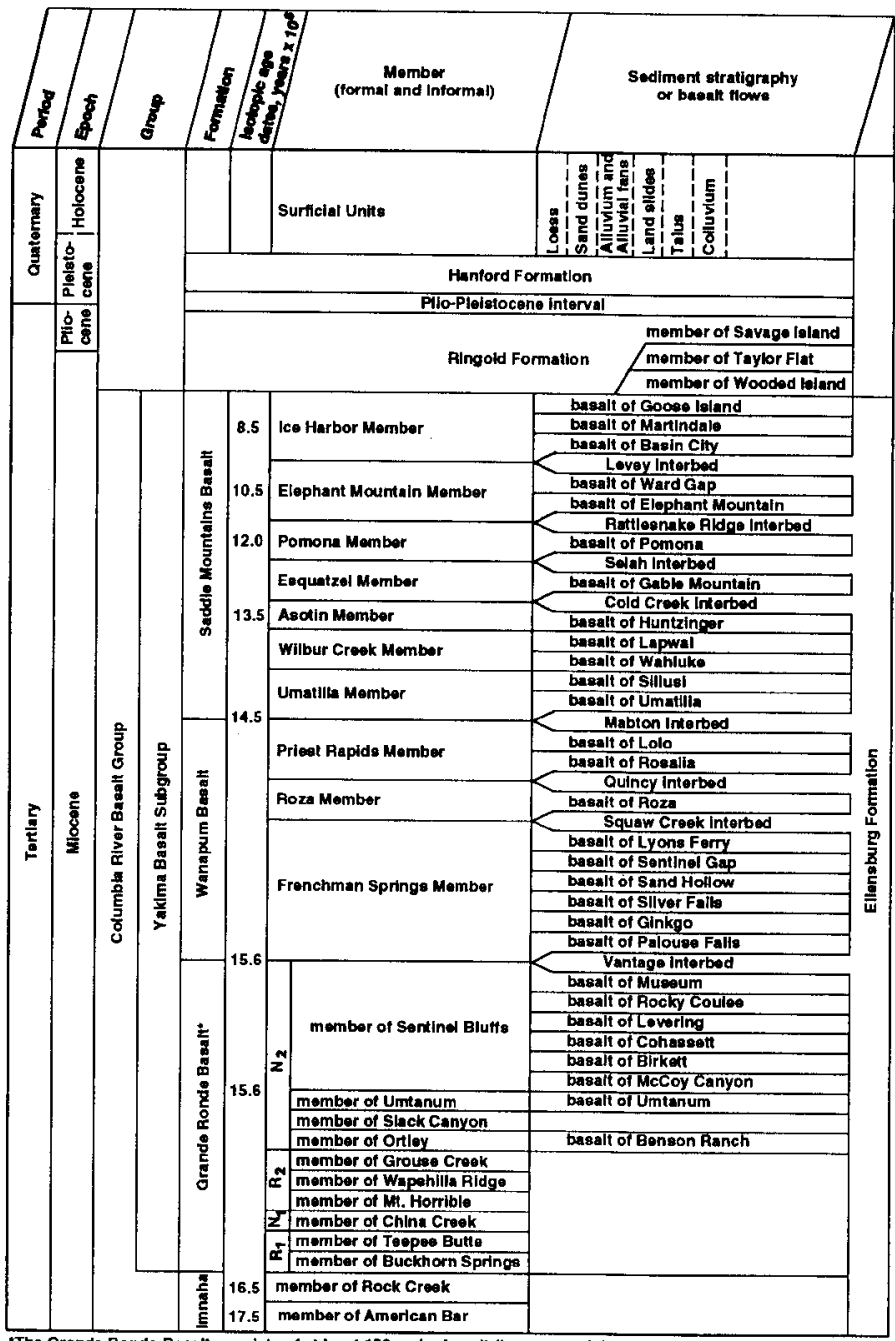

The Grande Ronde Buealt conelete of at leaet 120 malor beealt flowe comprialng 17 members.

$N_{2}, R_{2}, N_{1}$, and $R_{1}$ are magnetostratigraphic unite. 
Figure 1-23. Idealized Suprabasalt Subsurface Stratigraphy of the Hanford Site.

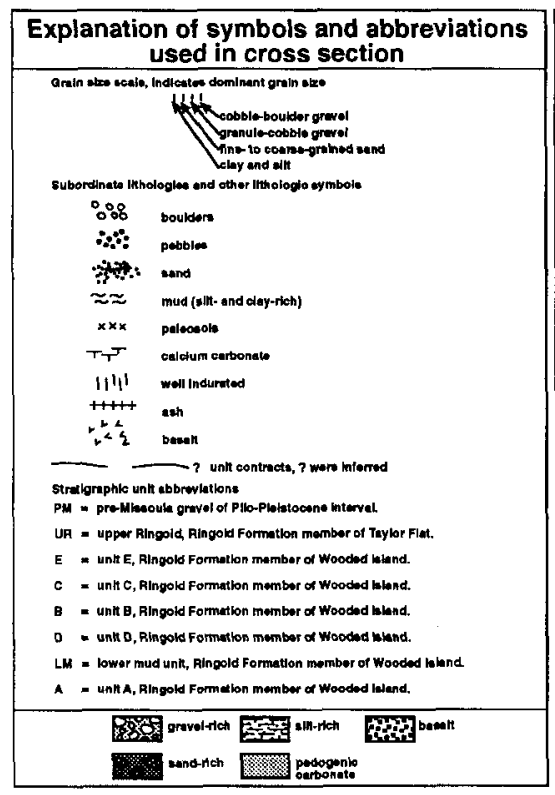

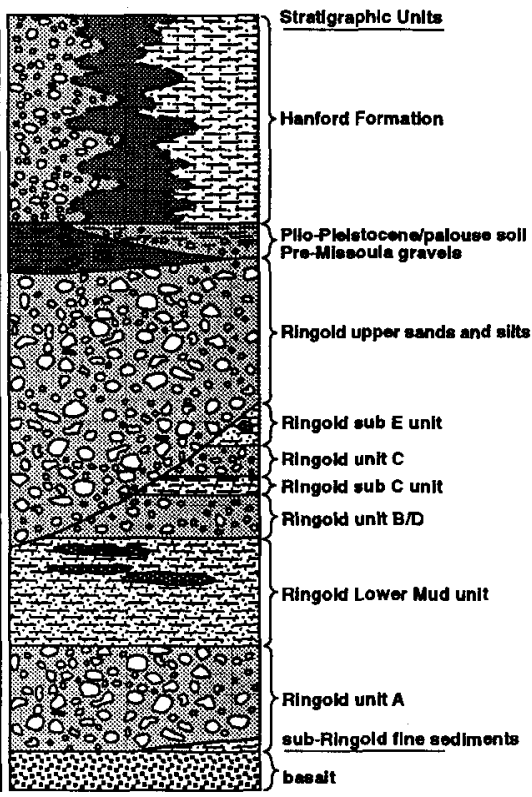

$7996030009.31 \mathrm{a}$

SRP-1 


\section{Figure 1-24. Annual Probability of Volcanic Ash} Accumulation on the Hanford Site.

\section{Greater than $1.0 \mathrm{~cm}(0.4 \mathrm{ln}$.}

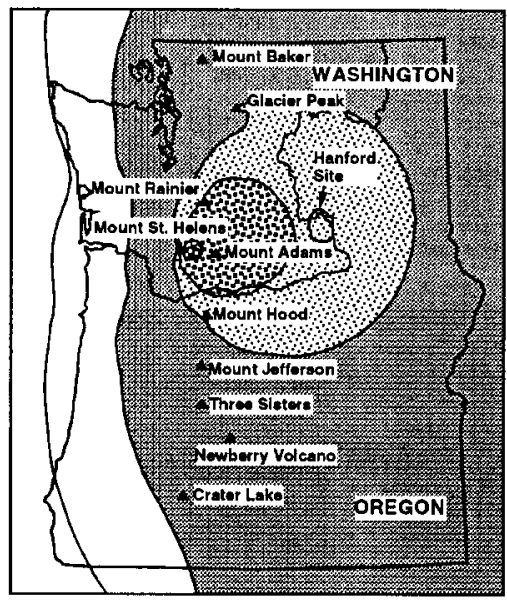

\section{Greater than $10.0 \mathrm{~cm}(4.0 \mathrm{in}$.)}

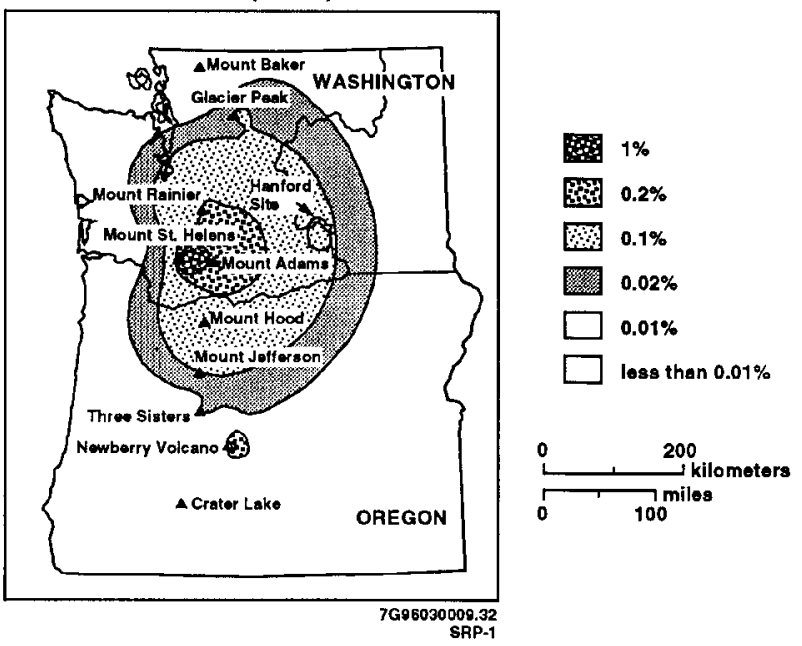

$1 \%$

E⿰马士口 $0.2 \%$

$0.1 \%$

$0.02 \%$

$\square 0.01 \%$

$\square$ lese than $0.01 \%$

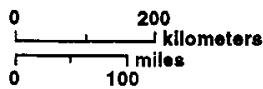


Figure 1-25. Structural Map of the Yakima Fold Belt.

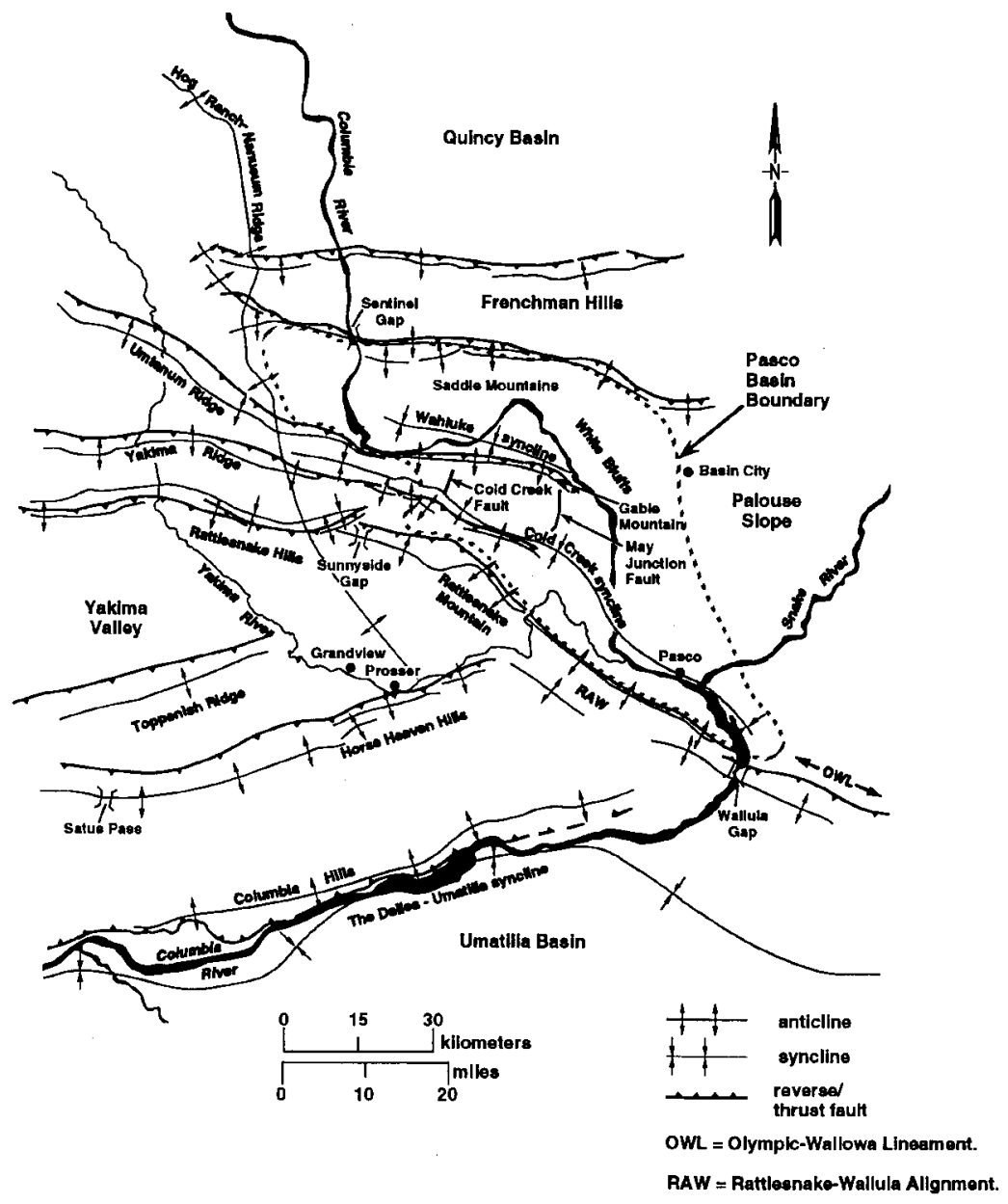

$7 \mathrm{G} 96030009.33$ 
Figure 1-26. Generalized Geologic Map of the Pasco Basin.
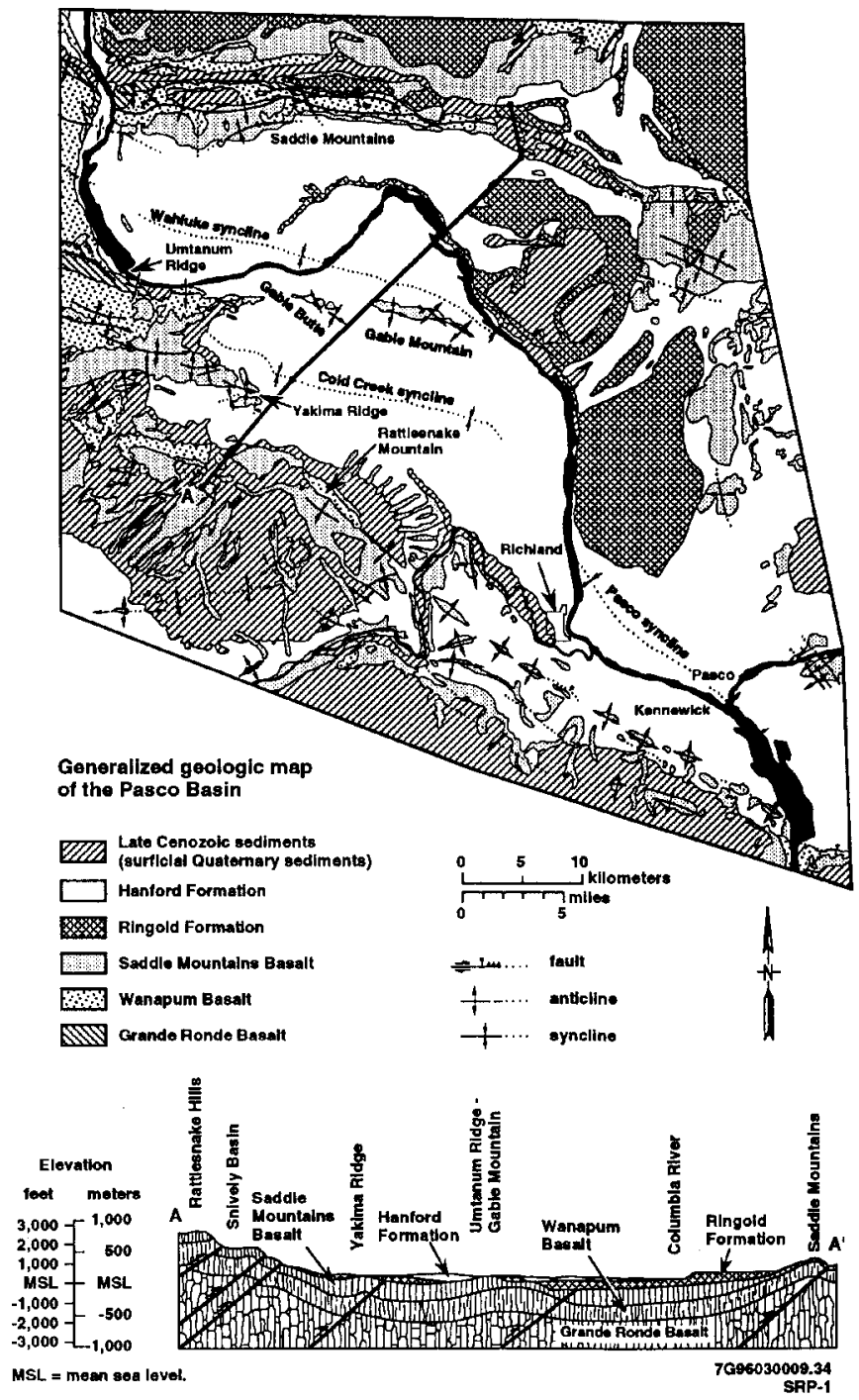
Figure 1-27. Geology of the 200 East and West Areas.

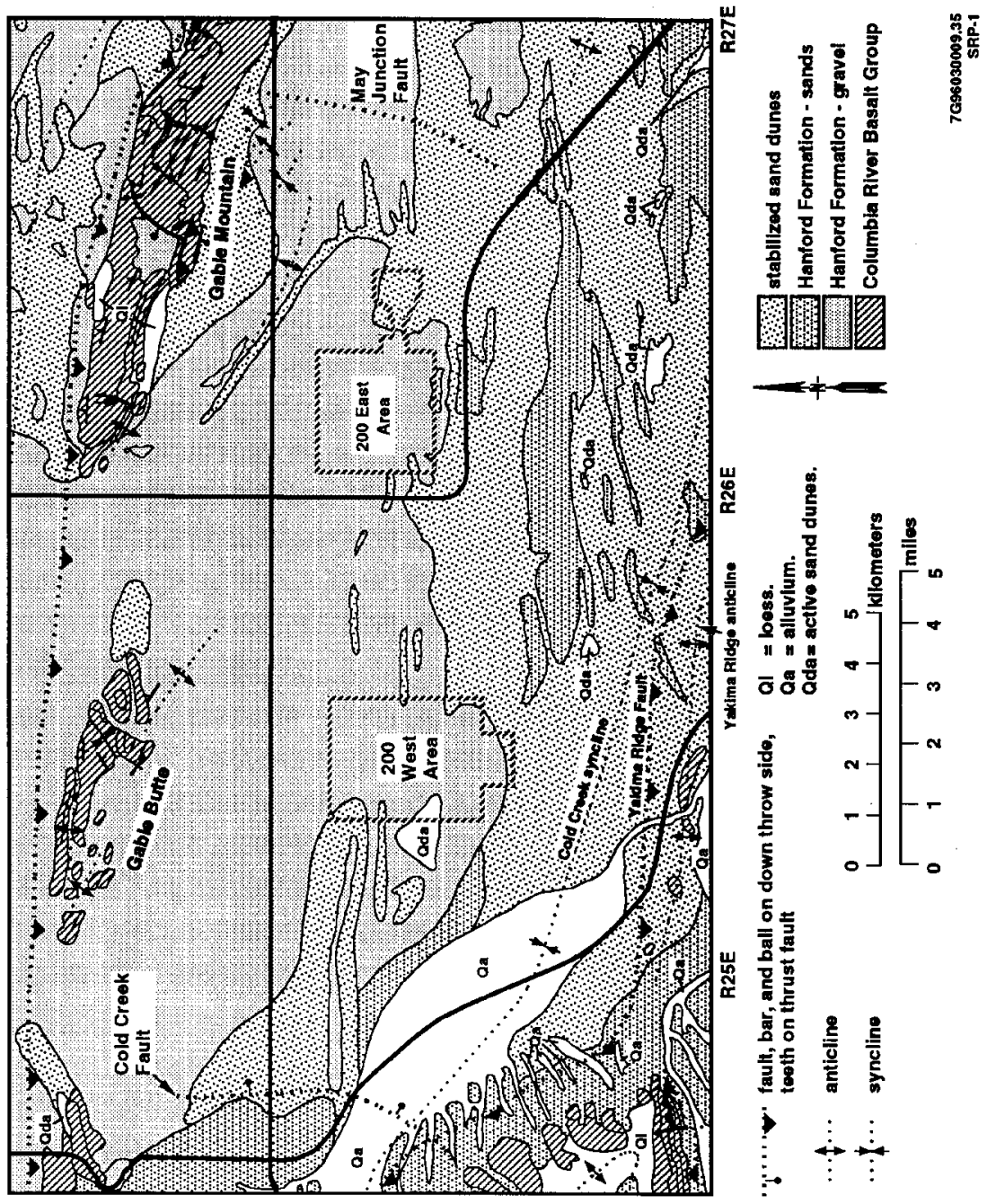


Figure 1-28. Stratigraphy of the 200 East Area.

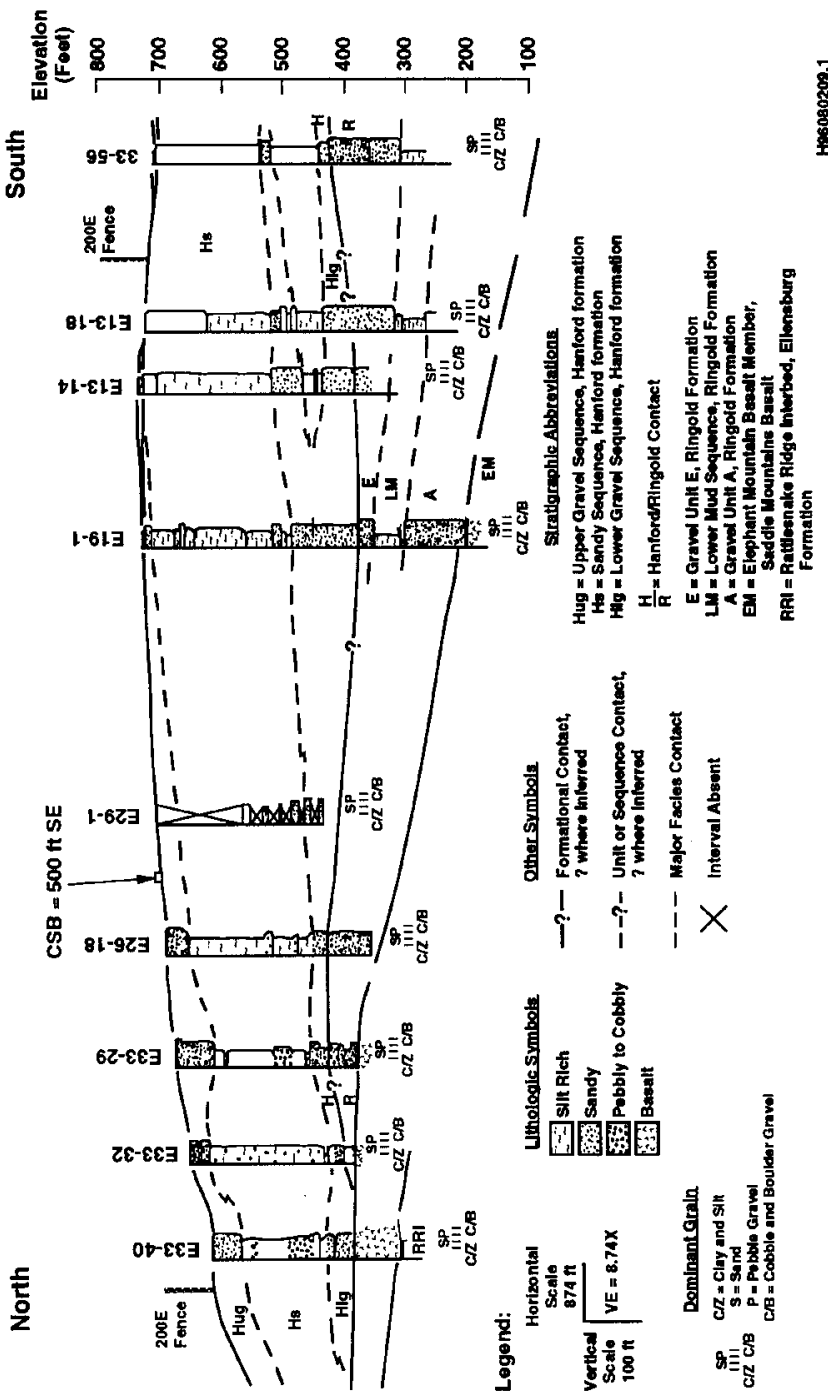

Note: Stratigraphy is for the north-south cross section shown in Figure 1-27. 
Figure 1-29. Generalized Location of Earthquake Swarms in the Pasco Basin.

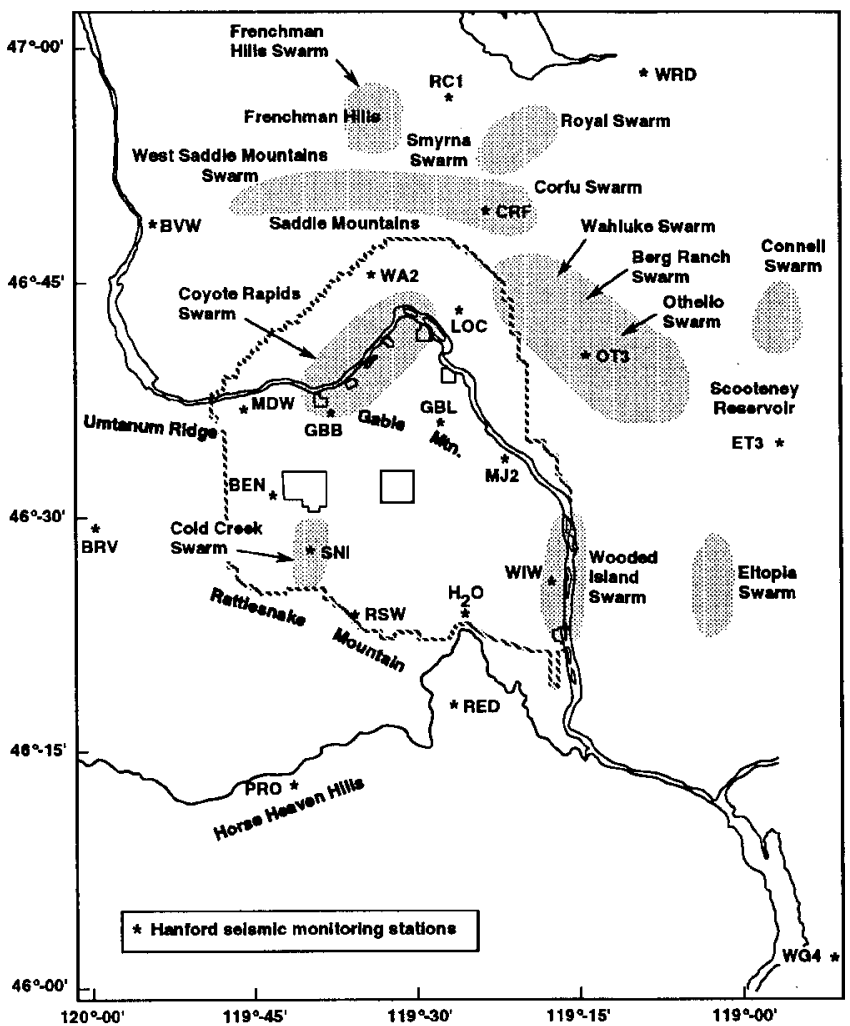

$\begin{array}{lll}\text { BEN } & =\text { Benson Ranch } \\ \text { BRV } & =\text { Black Rock Valley } \\ \text { BVW } & =\text { Beverly } \\ \text { CRF } & =\text { Corfu } \\ \text { ET3 } & =\text { Eltopla Three } \\ \text { GBB } & =\text { Gable Butte } \\ \text { GBL } & =\text { Gable Mountain } \\ \text { H}_{2} 0 & =\text { Water } \\ \text { LOC } & =\text { Locke loland } \\ \text { MOW } & =\text { Midway } \\ \text { MJ2 } & =\text { May Junction Two }\end{array}$

$\begin{array}{lll}\text { OT3 } & = & \text { Othello Three } \\ \text { PRO } & = & \text { Prosser } \\ \text { RC1 } & = & \text { Royal Clty One } \\ \text { RED } & = & \text { Red Mountain } \\ \text { RSW } & = & \text { Rattlesnake Mountain } \\ \text { SNI } & = & \text { Snlvely Ranch } \\ \text { WA2 } & = & \text { Wahluke Slope } \\ \text { WG4 } & = & \text { Wallula Gap Four } \\ \text { WIW } & = & \text { Wooded loland } \\ \text { WRD } & =\text { Warden }\end{array}$


Figure 1-30. Earthquakes at the Hanford Site 1990 through 1995.
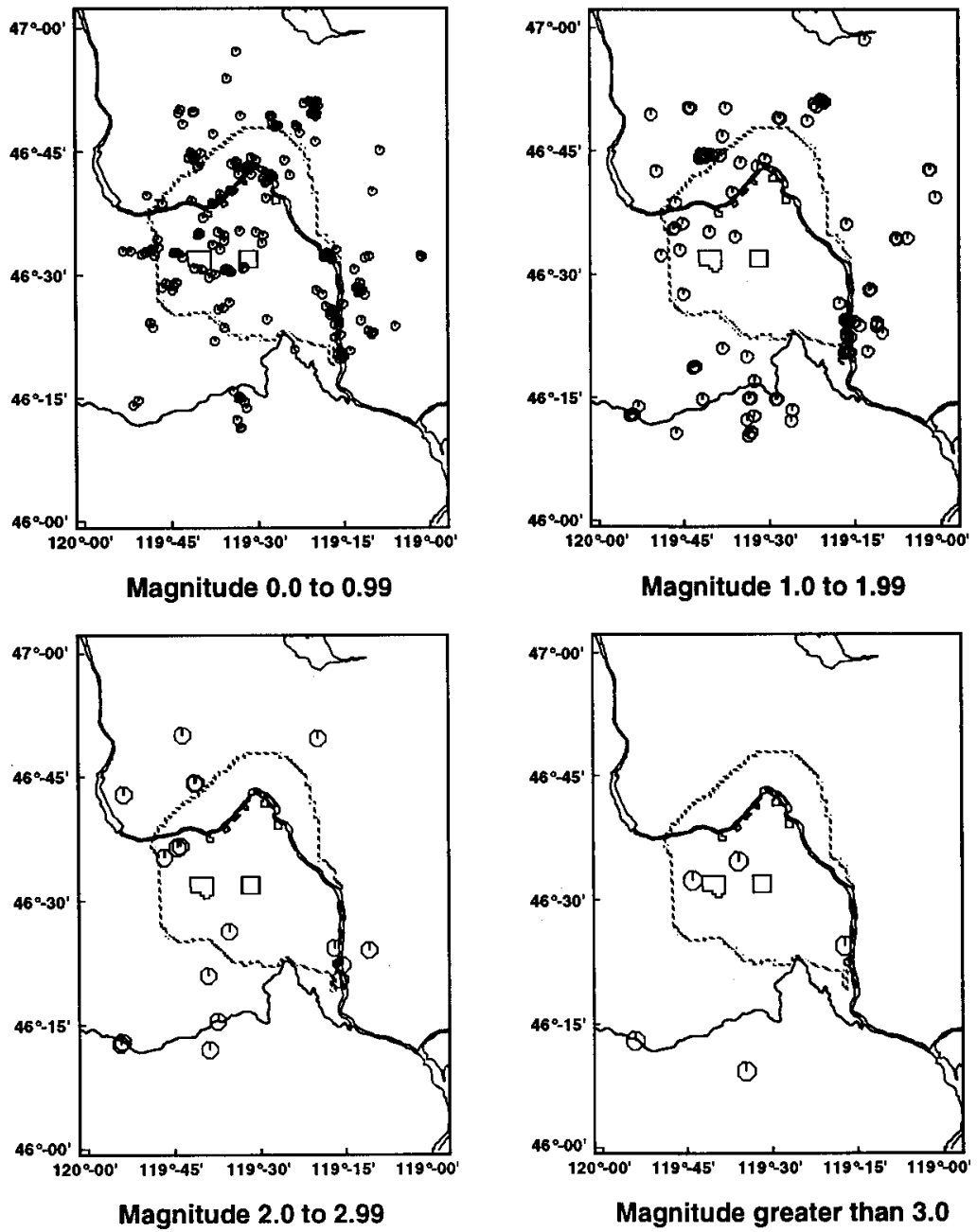

7G96030009.41A

CSB-1 
Figure 1-31. Top of Basalt Structure Contour Maps for 200 Areas.

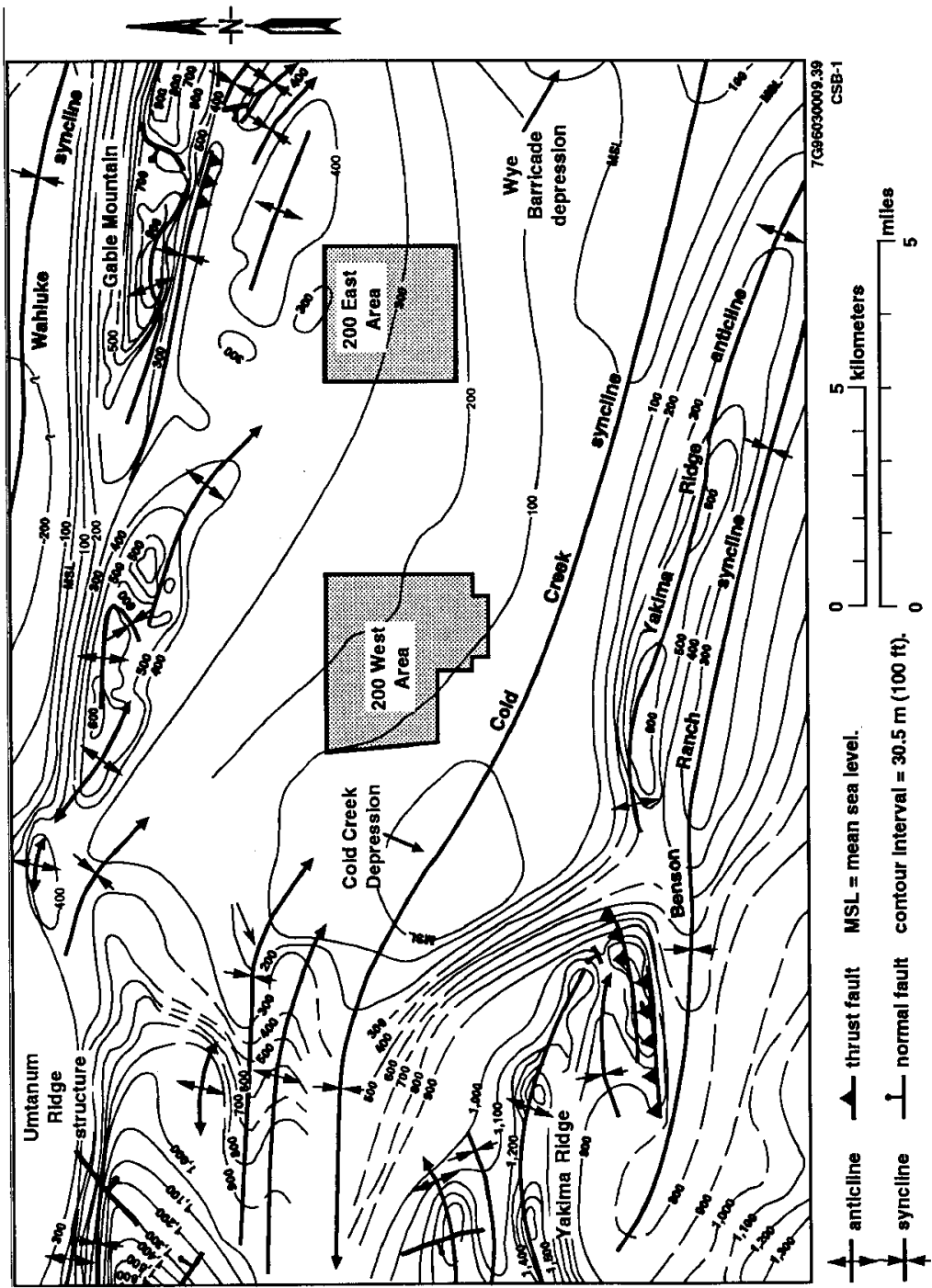


Figure 1-32. Seismic Hazard Curves for the Canister Storage Building Location.

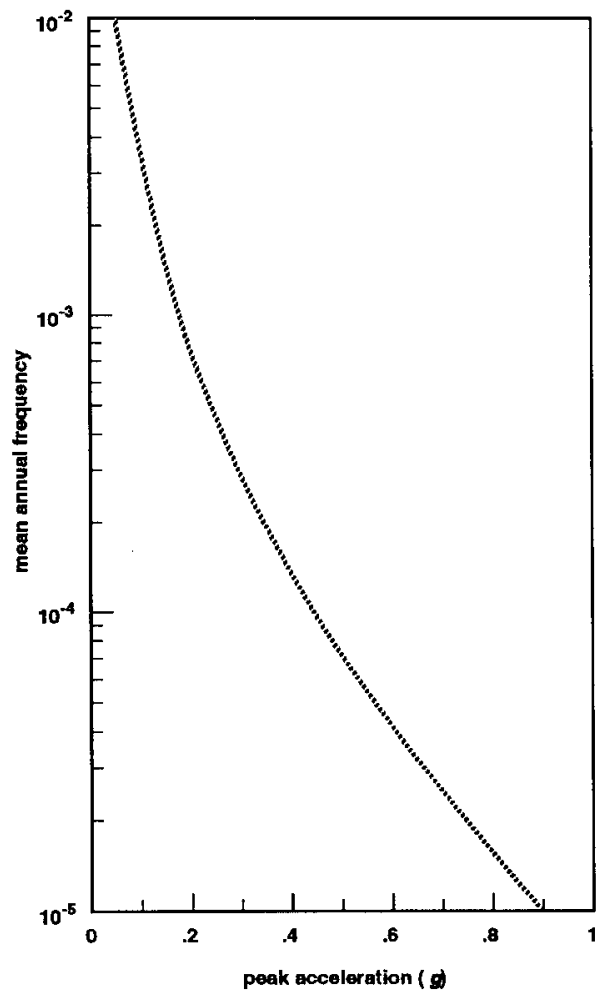

7990030009.45 CSB-1 
Figure 1-33. Contribution of the Various Folds to the Mean Hazard from the Yakima Fold.

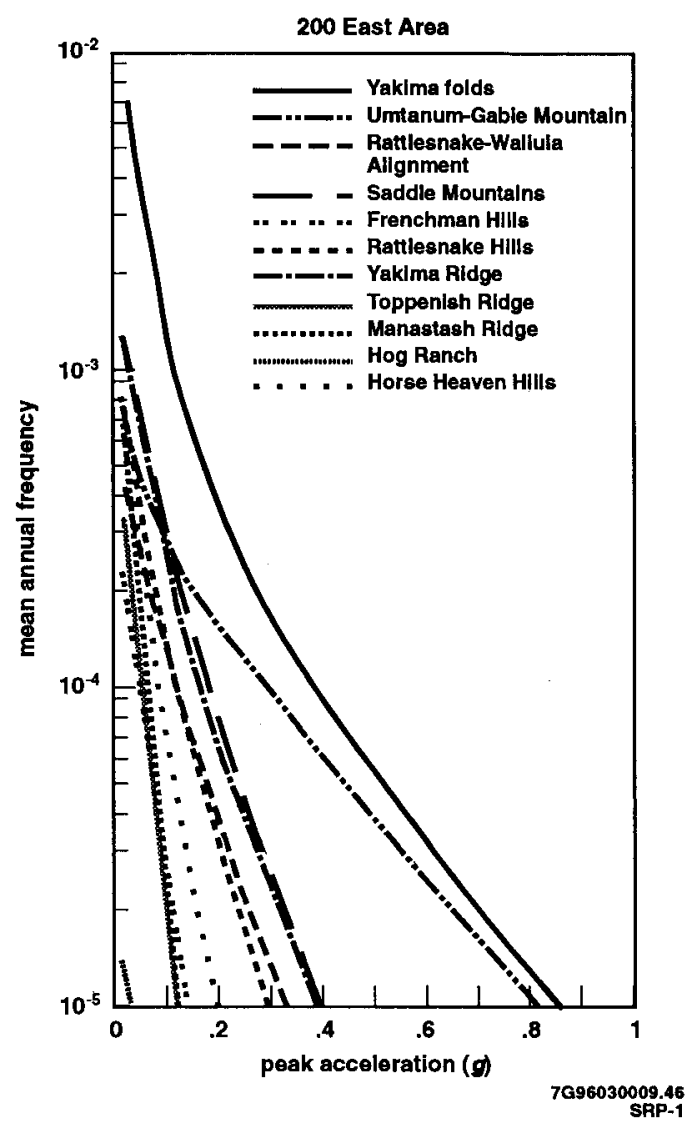


HNF-SD-SNF-RPT-004 REV 6

Figure 1-34. Contributions of the Crustal and Cascadia to the Mean Hazard at the 200 East Area.

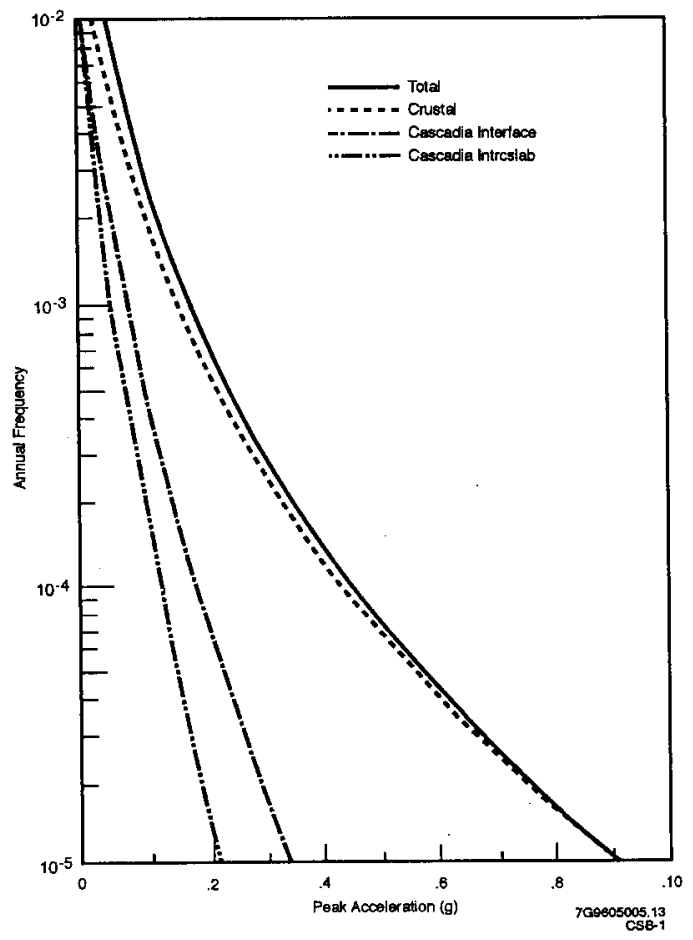


Figure 1-35. Contributions of the Three Crustal Sources to the Mean Hazard from Crustal Sources at the 200 East Area.

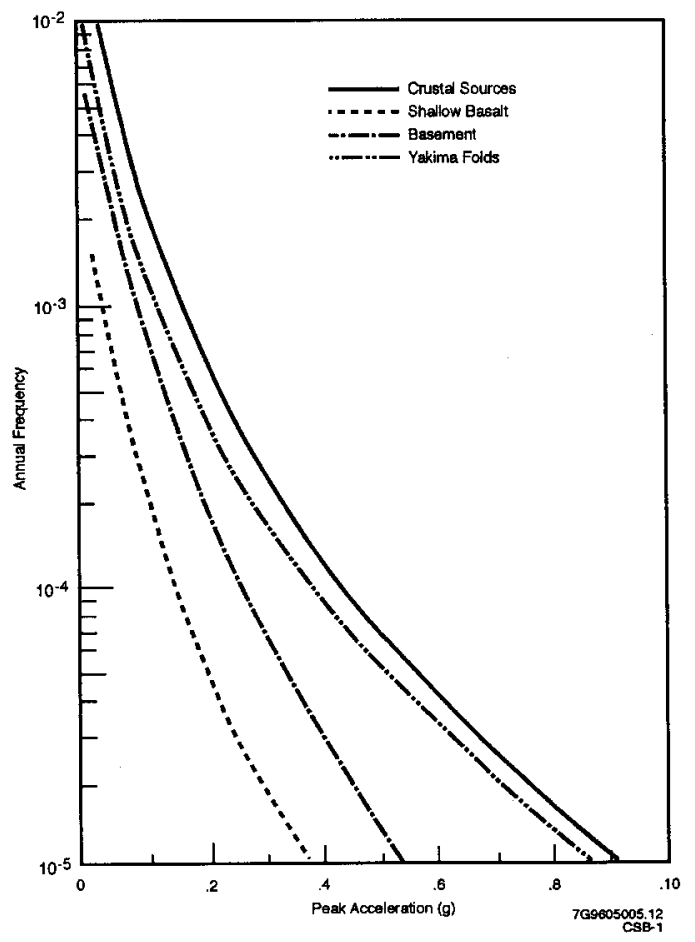


Figure 1-36. Canister Storage Building Response Spectra Compared to the Performance Category 3 Response Spectra.

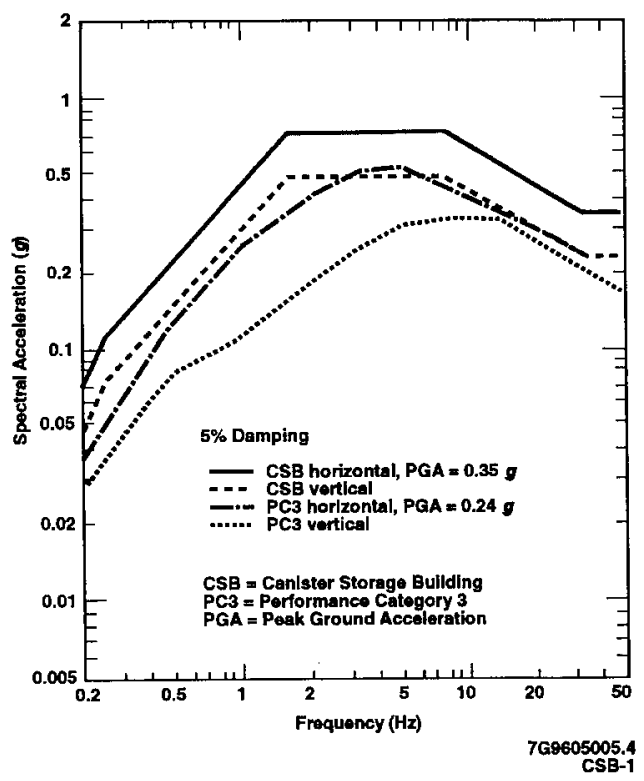


Figure 1-37. Cascade Range Volcanic Ash Hazard.

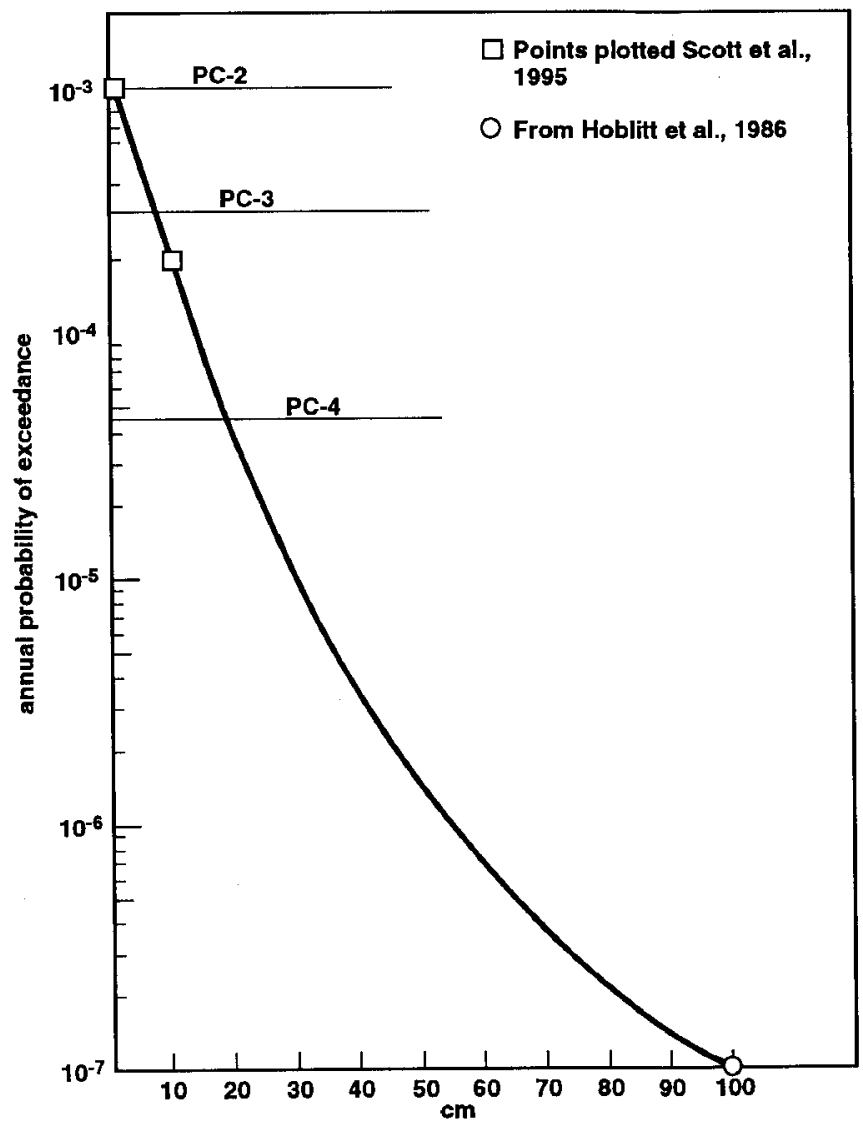

To convert centimeters to inches, multiply by 0.3937 .

Hoblitt, R. P., C. D. MIller, and W. E. Scott, 1987, Volcanle Hezarde with Regard to Sting Nuclear-Power Plantw in the Packife Northwed Open-File Report 87-297, U.S. Geological Survey, Cascades Volcano Observatory, Vancouver, Wahington.

Scott, W. E., R. E. Iverson, M. Vallance, W. James, and W. Hildreth, 1995, Volcano Hazards in the Wount Adams Region, Washington, Open-File Report 95-492, U.S. Geological Survey, Washington, D. C. 
Figure 1-38. Log of Borings: Boring VP-15.

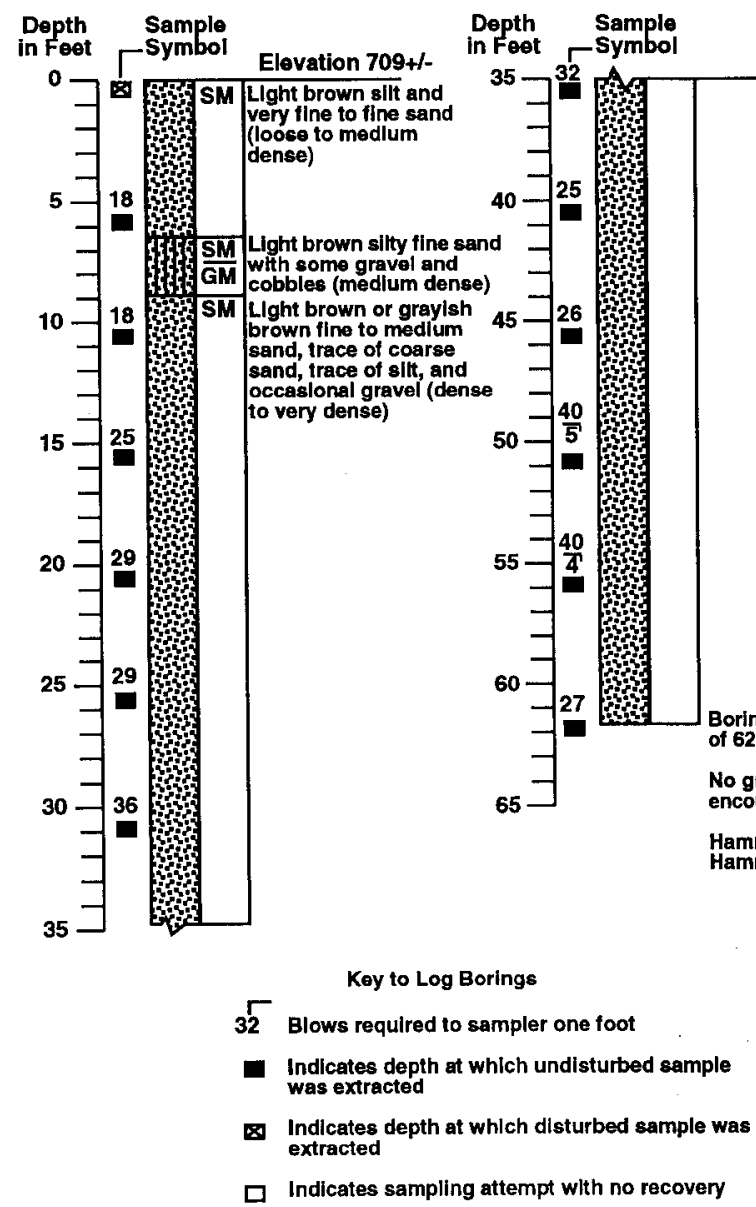


Figure 1-39. Cross Section B - B': Subsurface Profile.

in

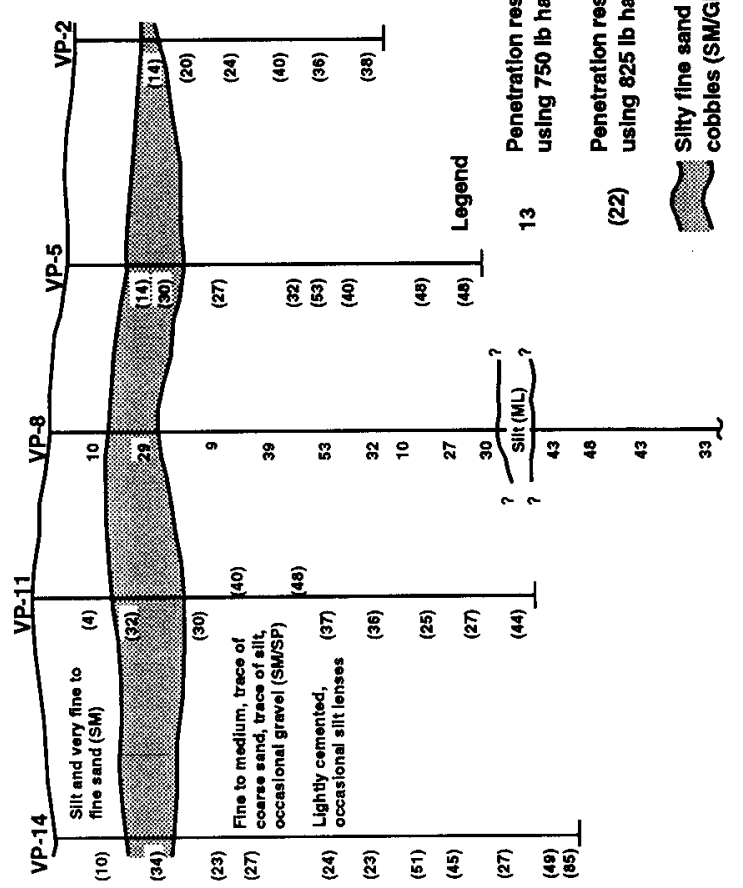

$\mathbf{m}$

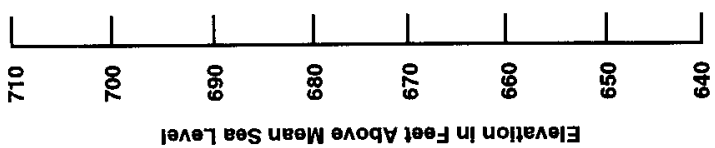

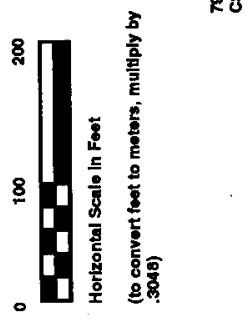
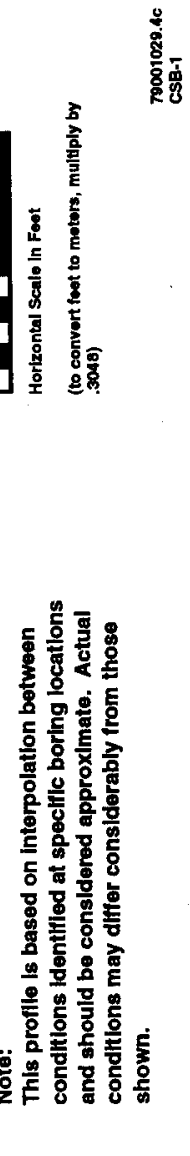
Figure 1-40. Dynamic Soil Properties of the Canister Storage Building Site.

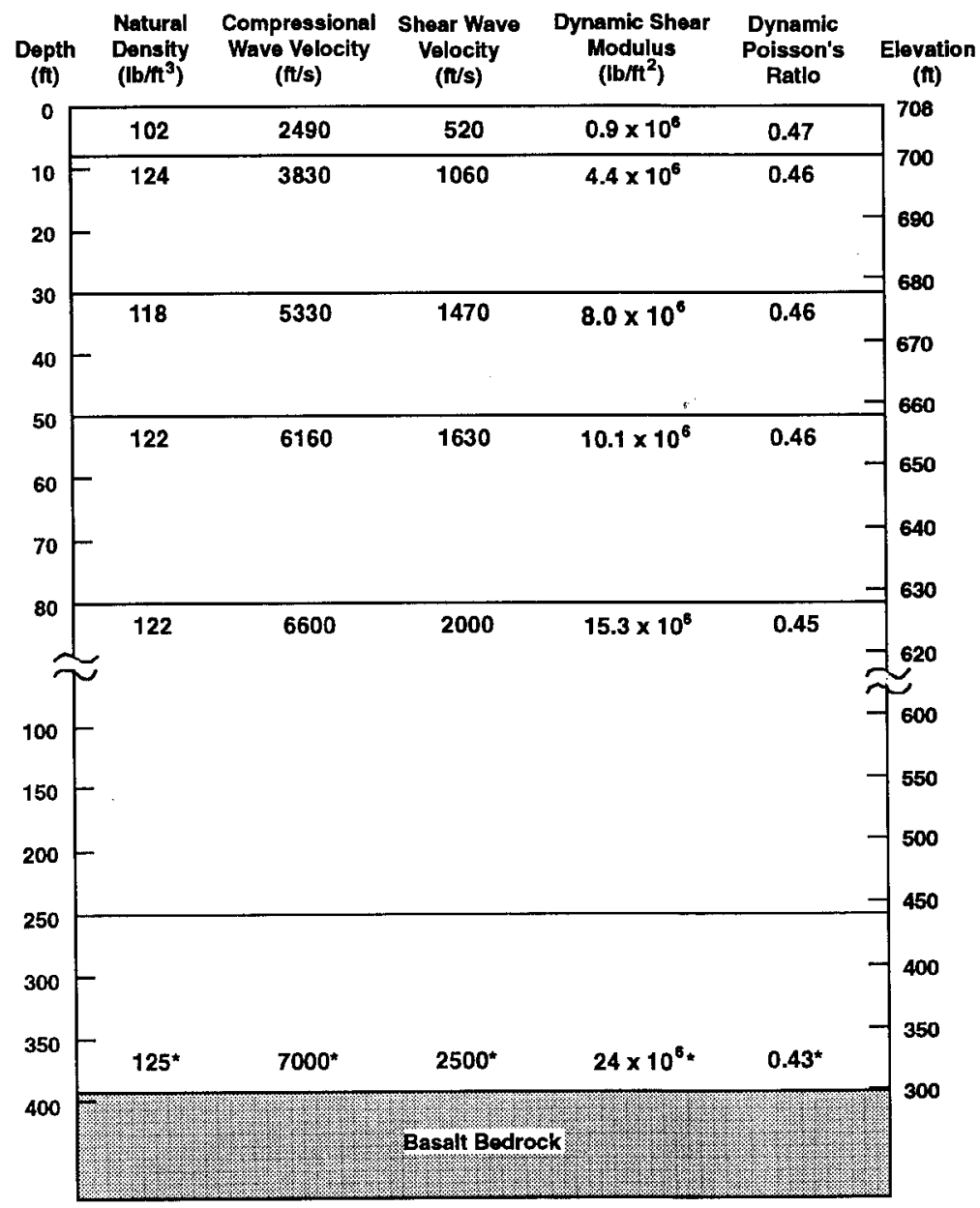

- Estimated using data from previous investigations. 
HNF-SD-SNF-RPT-004 REV 6

Figure 1-41. Federa1 Airways and Instrument Approaches and Departures.

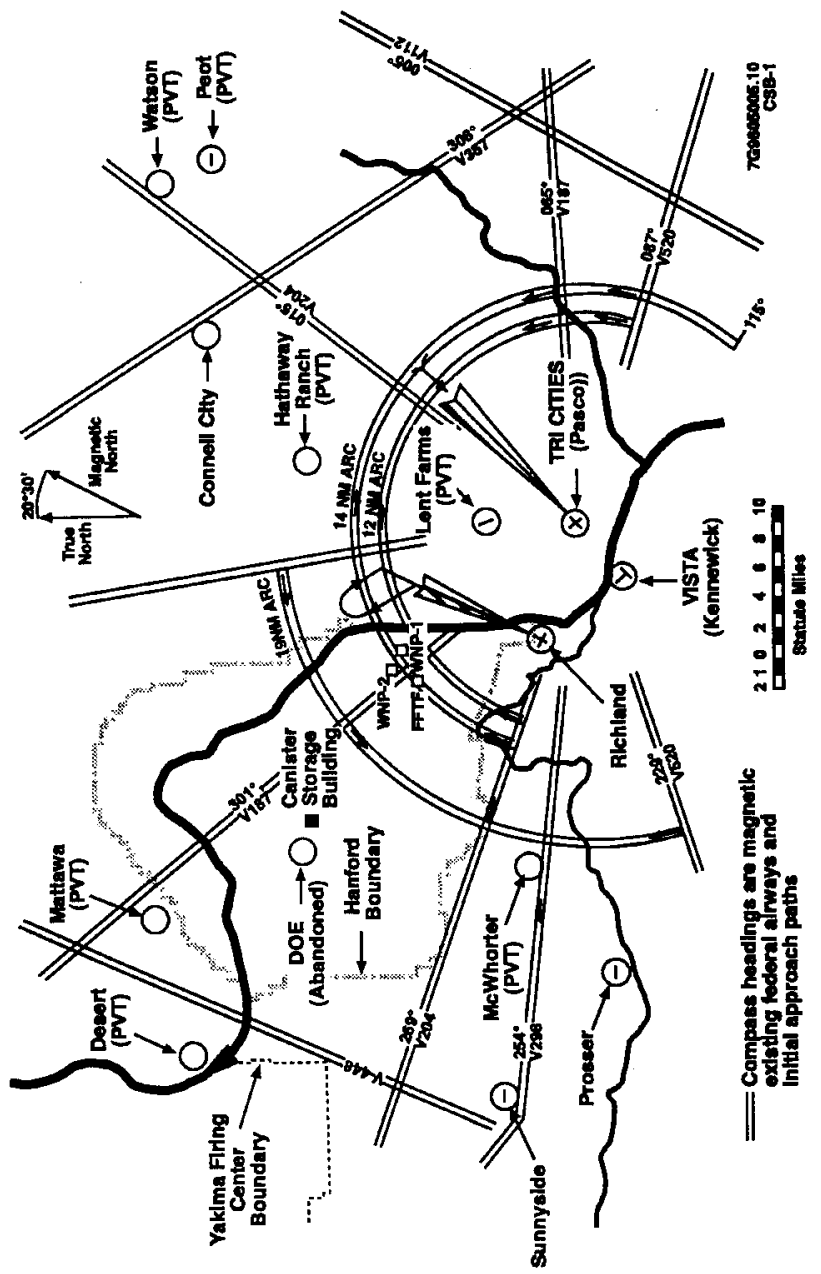


Figure 1-42. The Location of Yakima Training Center with Respect to the Hanford Site.

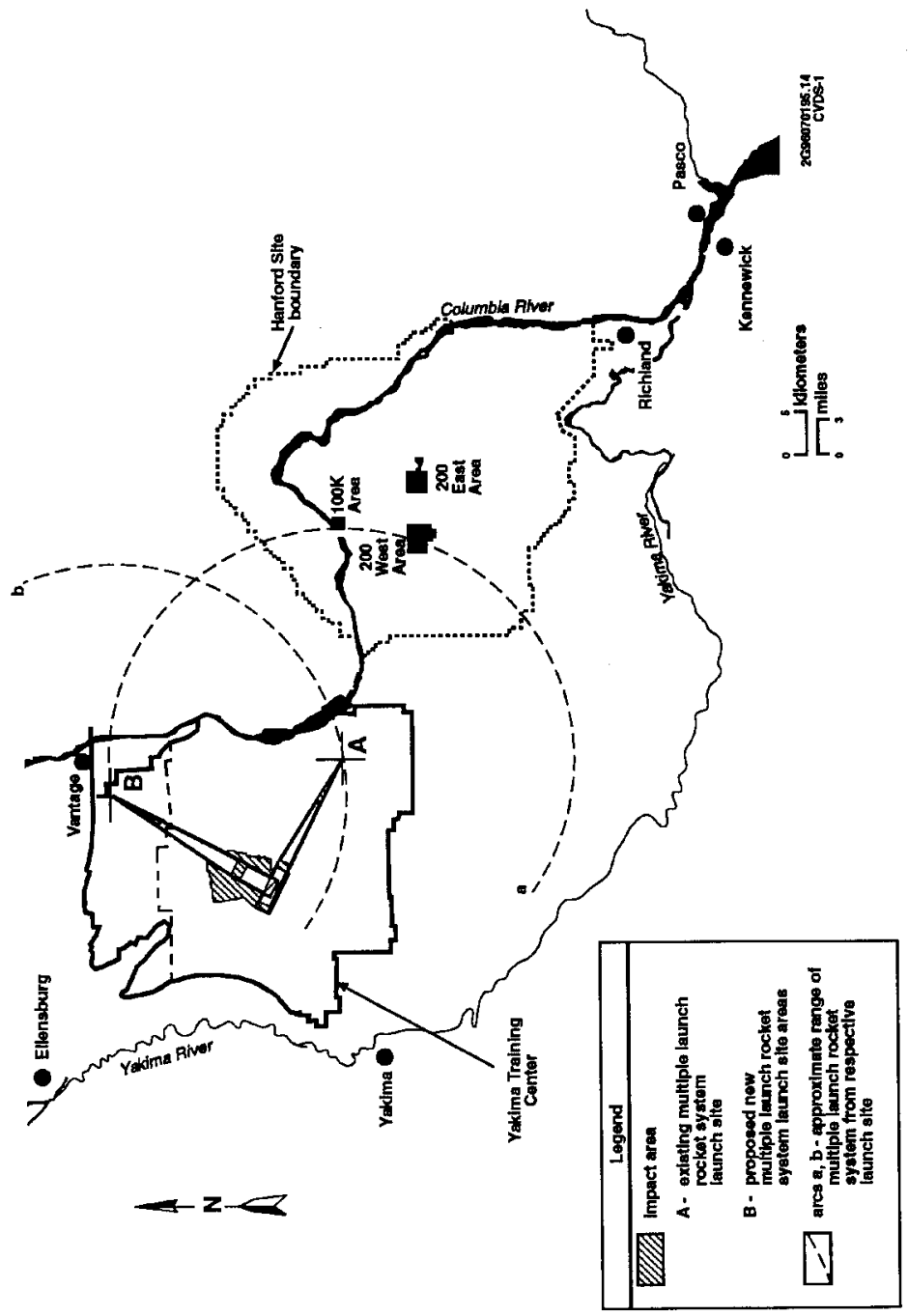




\subsection{FACILITY DESCRIPTION}

\subsection{INTRODUCTION}

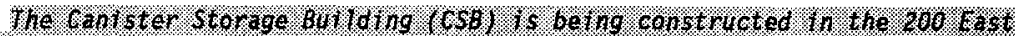

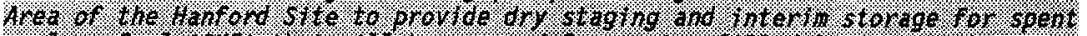

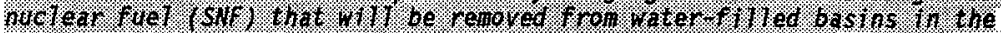

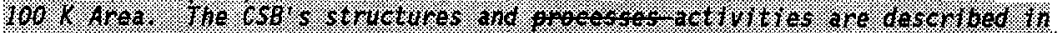

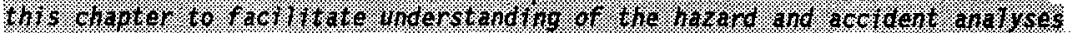

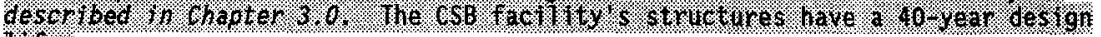
Hire.

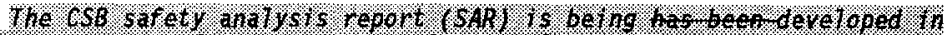

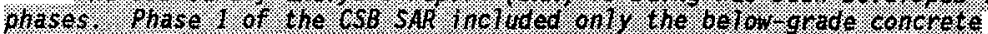

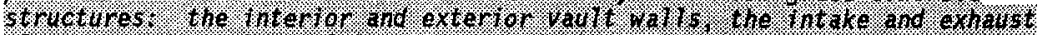

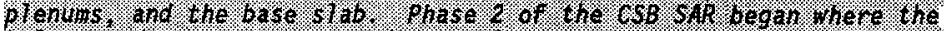

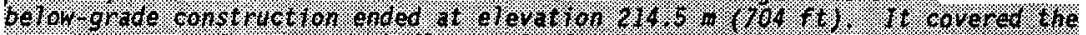

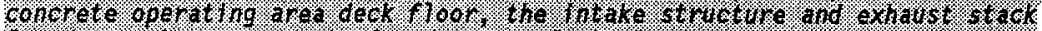

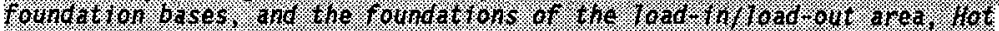

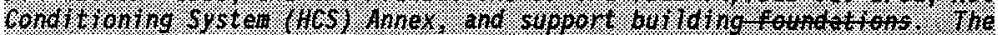

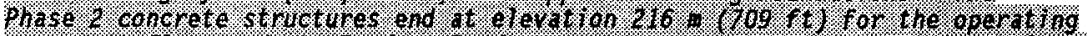

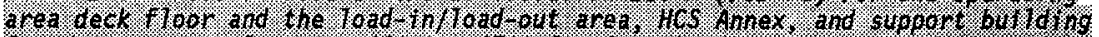

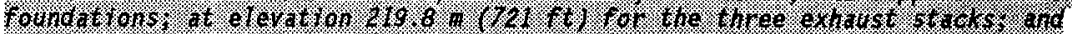

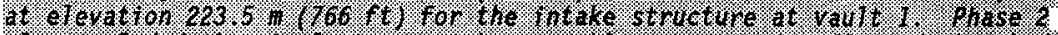

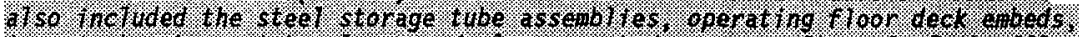

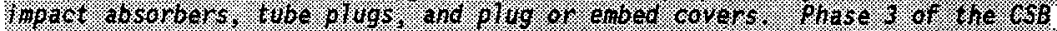

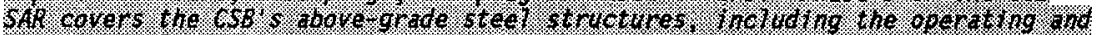

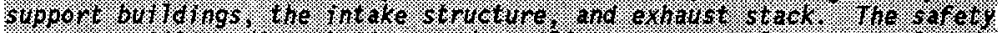

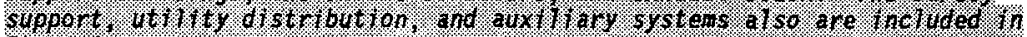
Phos 8 .

\subsection{REQUIREMENTS}

This section lists the design codes, standards, regulations, and 0.S. Bepartment of Energy (DOE) orders that are required for establishing the safety basis of the facility. The intent is to provide only the requirements that are specific for this chapter and pertinent to the safety basis.

\subsubsection{U.S. Department of Energy 0rders and Standards}

The following DOE rule, orders, and standard are applicable to the safety basis for the facility.

- 10 CFR 835, "Occupational Radiation Protection," Code of Federal Regulations. The shielding requirements for the CSB shall meet the ALARA (as-10w-as-reasonably-achievable) guidelines established in this document. The overall source term is derived from the radionuclide composition of the SNF contained in a nominal multicanister overpack (MCO); however, local shielding is provided for a single maximum MCO (Swenson 1996, Table 3.2.2.1.2.2-1). 
- DOE Order 6430.1A, 1989, General Design Criteria. The main reference standards and guides for facility design are presented in Division 13, "Special Facilities." Section 1320, "Irradiated Fissile Material Storage Facilities," contains additional requirements for irradiated fissile material storage facilities. In particular, paragraph 1320-4, "Special Design Features," requires that the passive cooling air system that ensures an acceptable temperature for the stored material be designed as a safety-class system.

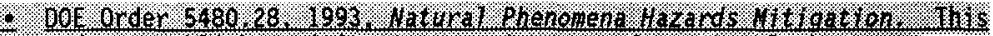

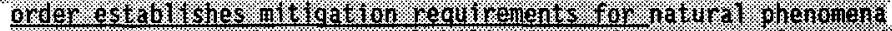

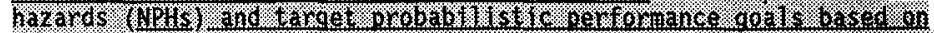

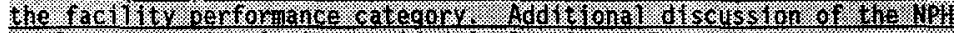

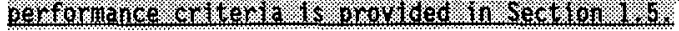

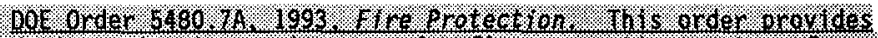

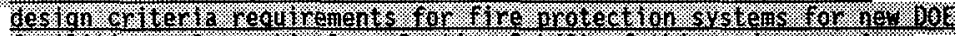

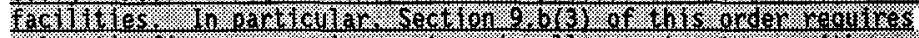

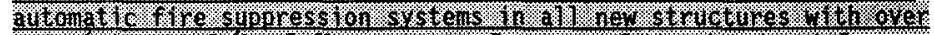

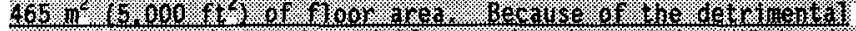

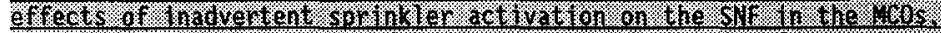

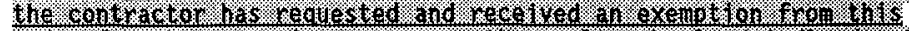

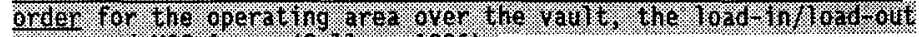

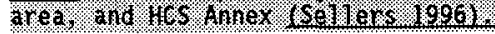

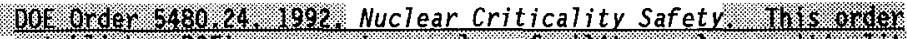

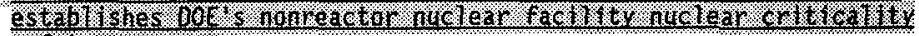

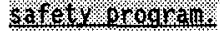

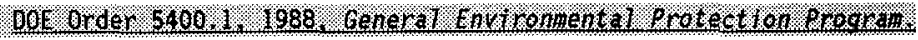

- DOE-RL-HPS-SDC-4.1, 1993, Standard Architectural-Civil Design Criteria, Design Loads for Facilities. This Hanford Site plant standard provides criteria for the design of the CSB. Section 3.1 and Section 3.3 of this standard provide structural design criteria

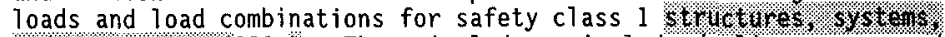
and components (SSCS). These include nominal dead, 1 ive, snow, and soil loads; normal operating loads; and NPH loads for extreme wind, earthquake, ashfall, and flood.

\subsubsection{U.S. Nuclear Regulatory Commission Rules and Regulations}

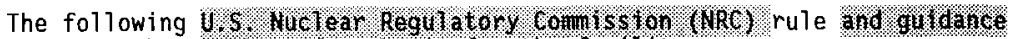
are is applicable to the safety basis for the facility.

- 10 CFR 72, "Licensing Requirements for the Independent Storage of Spent Nuclear Fuel and High-Level Radioactive Waste, "Subpart F, "General Design Criteria," and Subpart H, "Physical Protection," Code of Federal Regulations. This rule provides general design criteria for a spent fuel storage facility. Selected sections of the rule have been invoked by the Regulatory Requirements Team as a means to comply with NRC equivalency criteria. These criteria are 
given in WHC-SD-SNF-DB-003, Spent Nuclear Fuel Project Path Forward, Additional NRC Requirements (Garvin 1996a). An evaluation of the application of $\mathrm{NRC}$ equivalency requirements to the CSB is given in

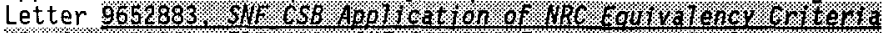
Wa Z 1 (Bedelf 1996$)$.

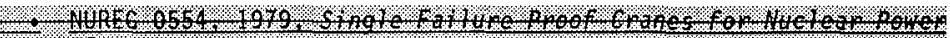
D.t.t. 2 .

\subsubsection{Industry Consensus Standards and Other Documentation}

The following doe and industry standardsare is applicable to the safety basis for the facility.

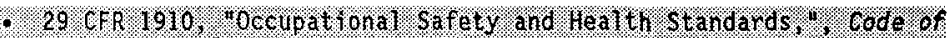
Federat Requlations.

- ANSI/ANS-57.9-1992, 1992, Design Criteria for an Independent Spent Fuel Storage Installation (Dry Type). This standard includes requirements for the design of major buildings and structures, including physical security features for hodependent spent fure storage instrillations. (ISFS Is).

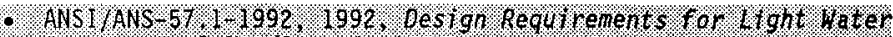

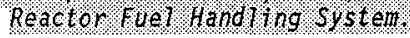

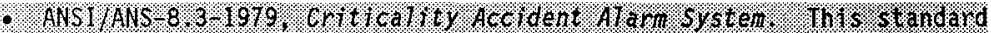

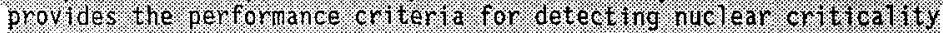
accidents.

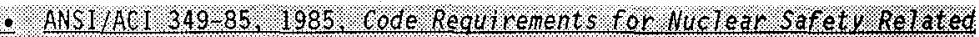

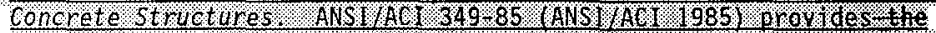

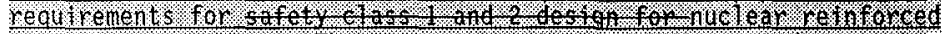

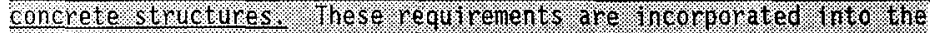

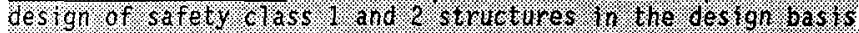

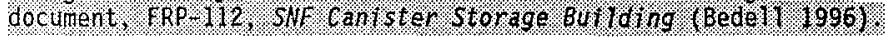

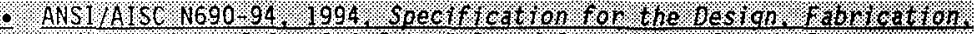

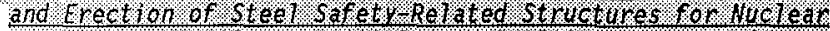

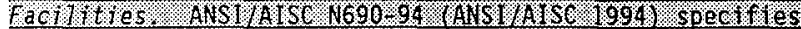

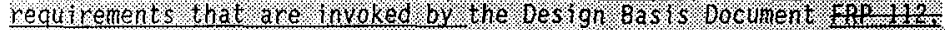

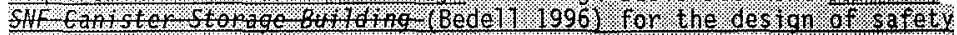

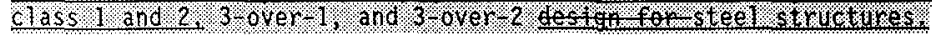

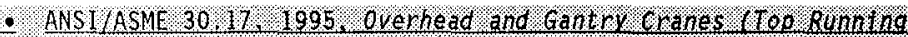

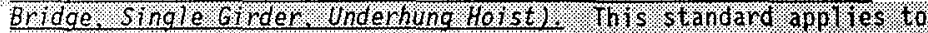
the const ruct ton, operat ton, inspect ton, and mo niterance of pouler-

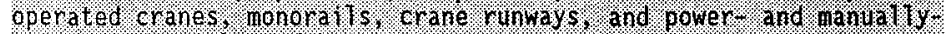
operated derroks and holsts: 


$$
\text { HNF-SD-SNF-RPT-004 REV } 6
$$

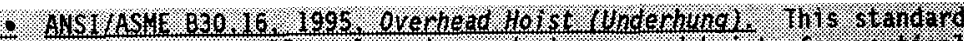

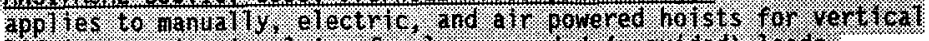

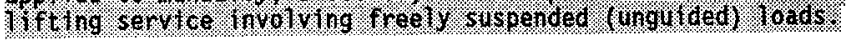

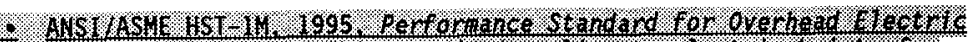

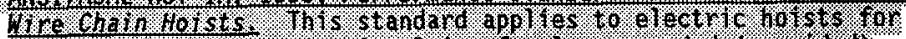

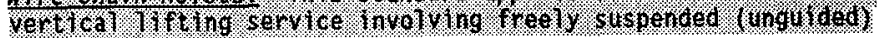
10005

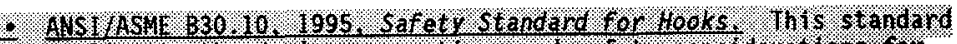

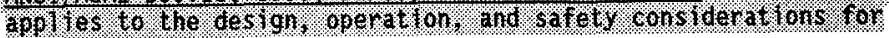
Kriting . $100 \mathrm{ks}$ :

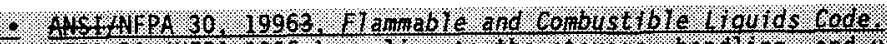

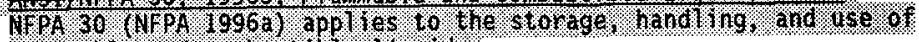

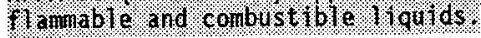

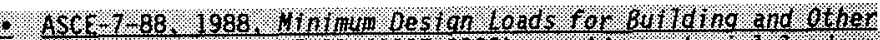

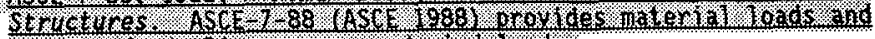

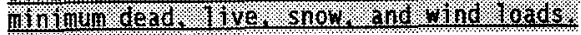

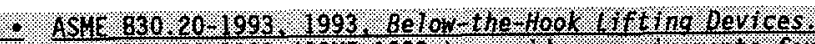

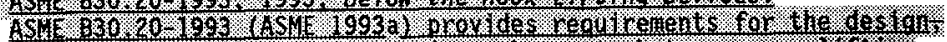

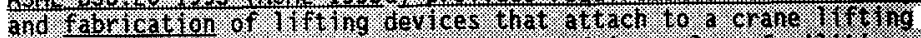

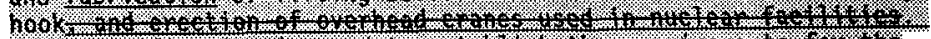

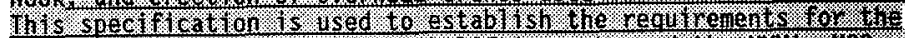

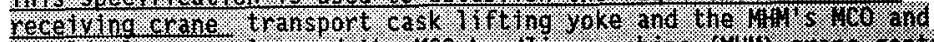

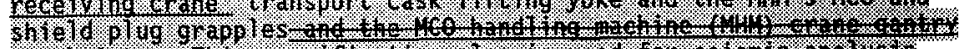

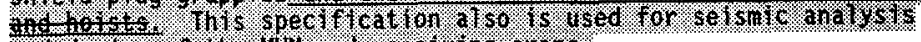

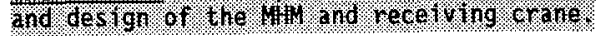

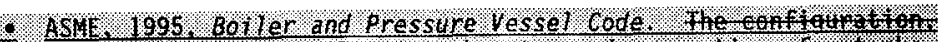

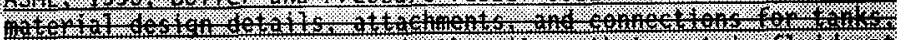

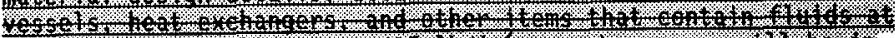

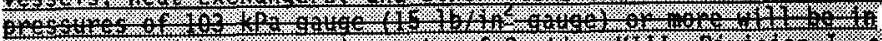

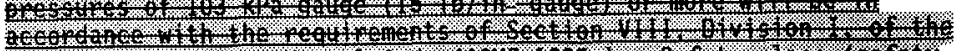

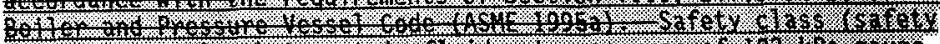

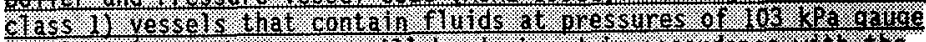

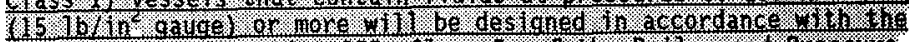

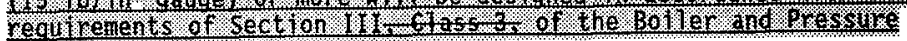
Sosed 6ode

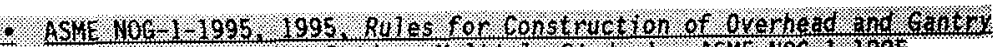

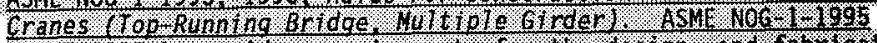

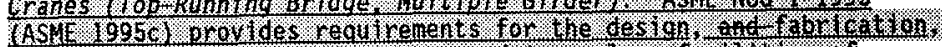

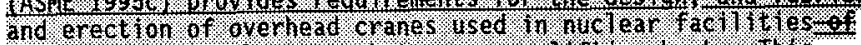

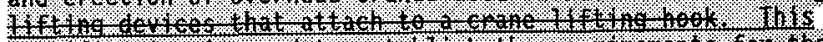

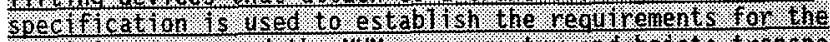

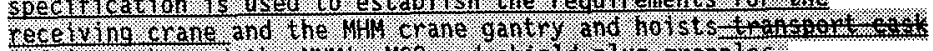

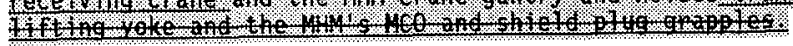

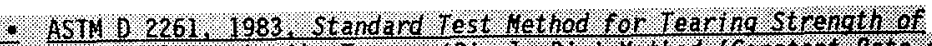

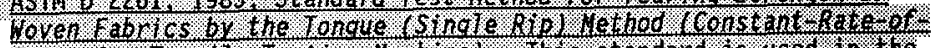

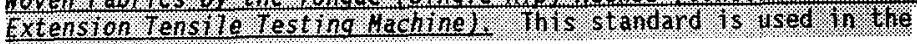




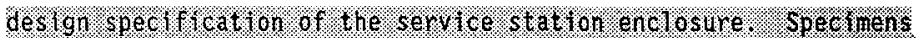

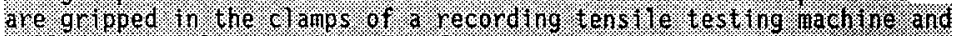

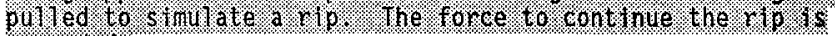
recorded

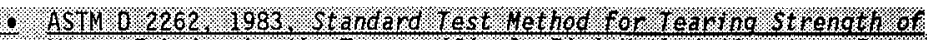

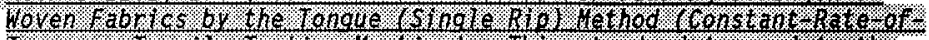

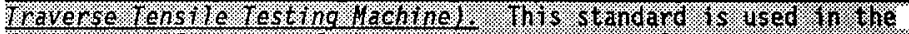

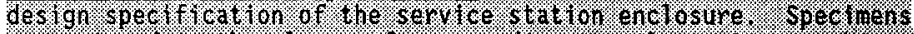

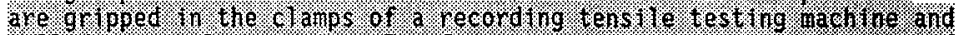

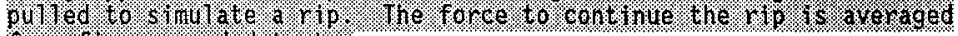
from flye recorded tests:

- ASTI. 1055. 1992, standard Gulde for Hadted sy stem surface

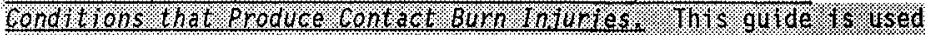

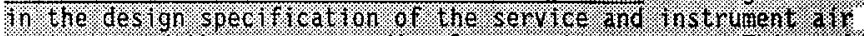

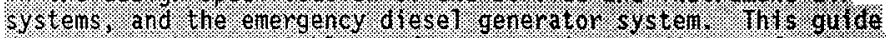
determines the acceptable surf ace operat ho condit tons for weated

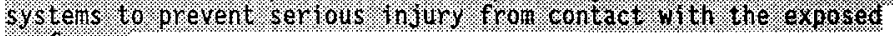
surerest

\subsubsection{Contractor Requirements}

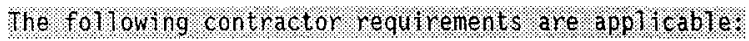

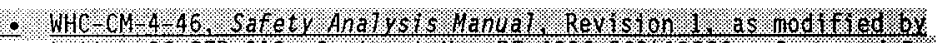

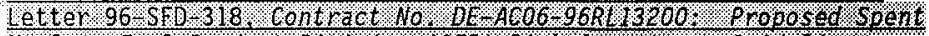

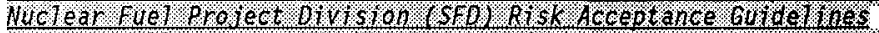

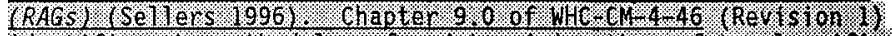

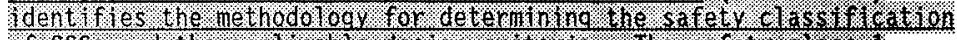

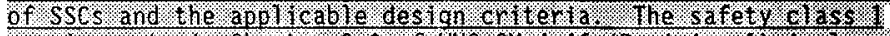

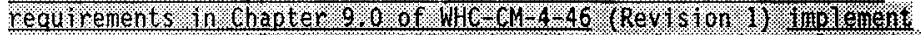

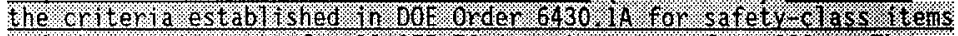

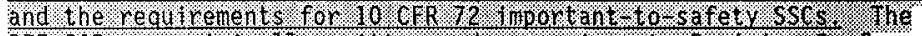

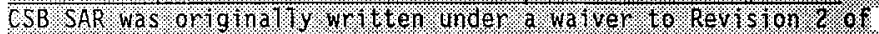

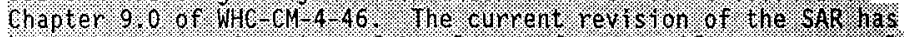

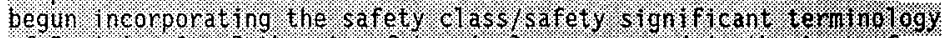

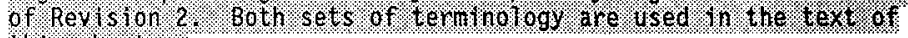
tho chapter

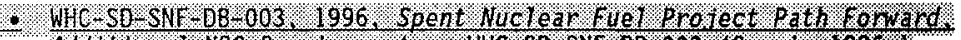

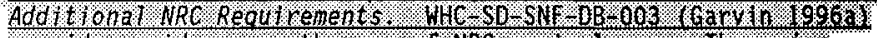

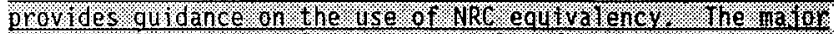

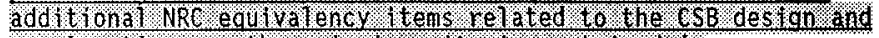
construction are the selsmil crlterla contained In

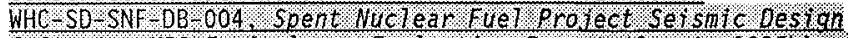

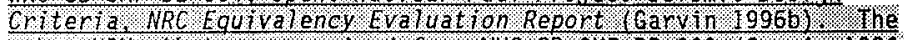

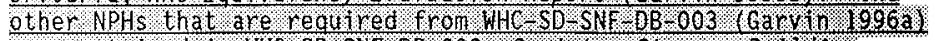

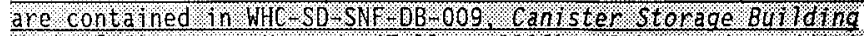

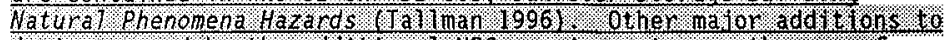
des lon caused by the add t tonal NGC requirenents are the use ol

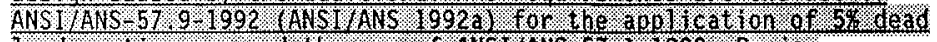

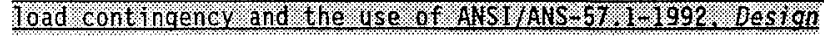




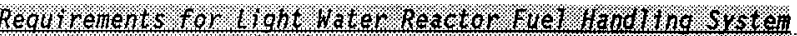

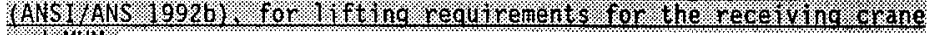
and $\mathrm{MHO}$

- WHC-SD-SNF-DB-004, 1996, Spent Nuclear Fuel Project Seismic Design Criteria, NRC Equivalency Evaluation Report. WHC-SD-SNF-DB-004 (Garvin 1996b) provides seismic design criteria.

- WHC-SD-SNF-DB-009, 1996, Canister Storage Building Natura7 Phenomena Hazards. WHC-SD-SNF-DB-009 (Tal1man 1996) supplements previous

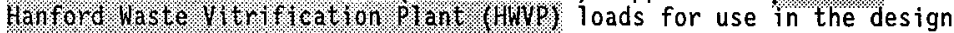
and construction of the CSB. With the exception of seismic criteria, the compliance to both NRC and DOE requirements is accomplished with this document. The supplenert tal loads are orose

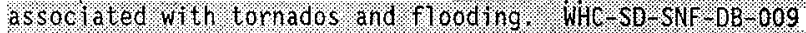

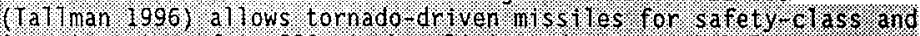

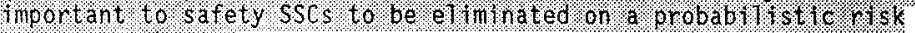
as ses sment bas is.

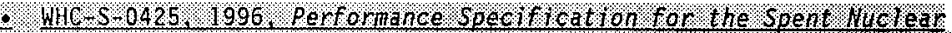

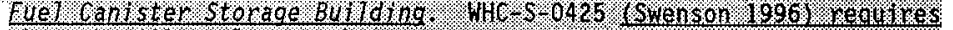

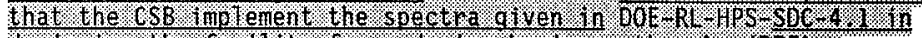

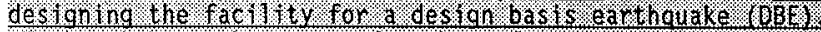

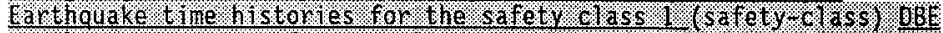

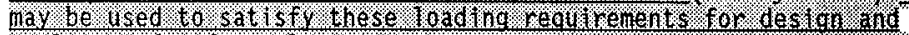

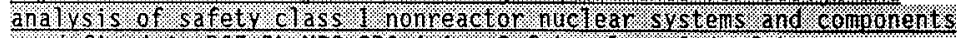

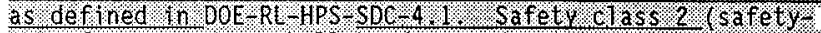

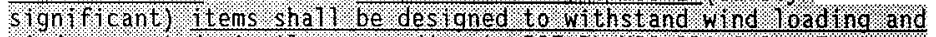

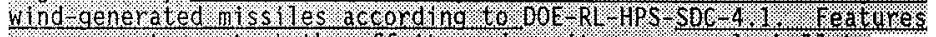

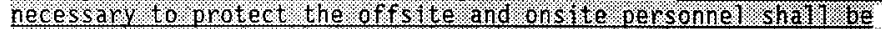

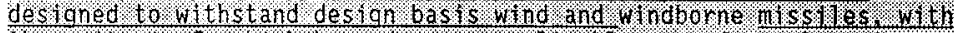

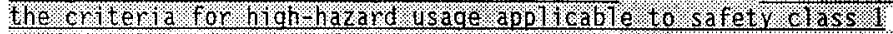
(safety-class) jtems and nocerale bazard usace applicable to safely

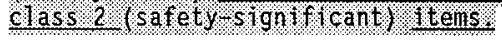

\subsection{FACIITT Y OVERVIEW}

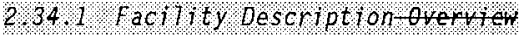

The SNF CSB consists of a steel operat Who area shelter, wholo encloses the load-in/load-out area and the HCS Annex, and three equaTly sized below-grade concrete vauits covered by a concrete operating deck. Support functions and equipment are housed in the steel support building located at the north side of the operations building. Only the northernmost vault (vault 1) is equipped with steel tubes for staging and storage of the MCOs. The storage tubes are supported from the foundation base slab of the vault and are accessed through tube plugs in the operating deck. The tube plugs provide

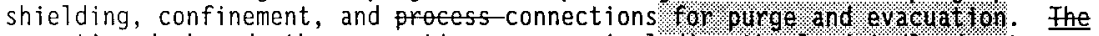
operating deck and other operations areas, including the load inlload out area and HCS Annex, will be enclosed in a steel building. The MCO storage vault (vault 1) is cooled by natural convection through whe obove, grade. ded daled

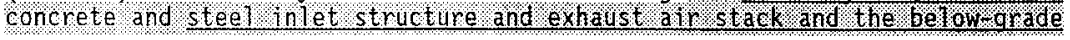




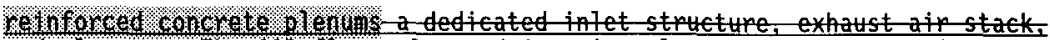
and plemens. The CSB floor plan and interior elevations are shown in Figure 2-1, sheets 1 through 3 .

Mo 100 Is-MCOs are received into a trailen-twak vestibule on the nordelwest side of the CSB where the transport cask, contallating ond. unlatched from the trailer. A gantry-type receiving crane is used to transfer the casks from the transporter trailer to a below-grade service station pit in the load-in/load-out area located at the north end of the operating area. After the eask $M C O$ has anpivet at the CSB, but before the cask 7 id is removed, the pressure in the cask annulus is tested. If a high pressure is detected, the cask can be evatuted using a tempory connection to the service station purge and vent system and returned to the Cold Vaeum Orying System (CVOS) for reentification. This enstres workep safety during removal of the cask lid. Following cask lid removal, process lines are attached to the Mco process ports to measure $M C O$ pressure. If necessary the $M C O$ is evacuated to a vacum and refilled with inert $g a s$. If the $M C O$ is received with the pressure relief valves and/on rupture disk blanked off, the blank-will be removed and the valve -177 be tested after the $M C O$ is evacuated and refilled. This step ensures-worker safety and prevents the service area confinement tent from being subjected to pressures greater than design pressure. The rupture disk blank is then removed and the MCO readied for movement into the MCO handing machine (HH). MCOS are-1We HCO is. removed from the casks and are-either placed into givertical steel tubes housed in the vault the deck by or moved directly to the HCS Annex on the south side of the CSB operating area. The MHM will also be- 1 s used to transfer the

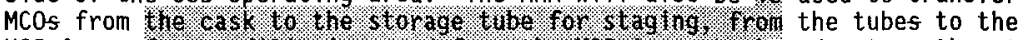

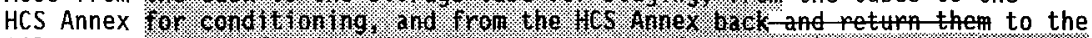

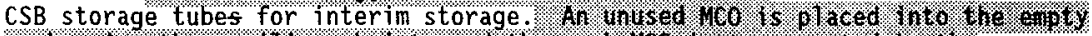

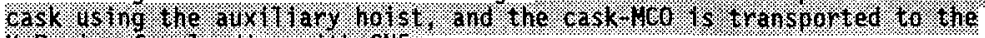

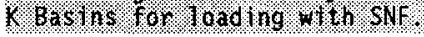

[The folfowing has been moved to the introduction] The portion of the SAF CSB that is covered by this document is referped to as Phase 2 of the CSB SAR. Phase 1 of the CSB SAR ineluded only the below grade concrete strutures: the interior and exteriop vautt walls, the intake and exhaust Penums, the base stab (se figures 22 an 23). Phase 2 of the CSB SAR begins where the below grade construction ends at elevition $214.5 \mathrm{~m}$ (704 ft). It covers concrete structures and steel struetures as described below.

The following has ben the the introduction] The to structures coved by Phase 2 of the CSB SAR are the operat ing area deck floor, intake strueture and exhaust stack foundation bases, the load in/load out area, the HCS Annex, and the suppont building fortion. The concrete strutures end at elevation $216 \mathrm{~m}-(709 \mathrm{ft})$ for the operating area deck floor, toad in/toad out area, HCS Annex, and support building foundation; at elevation $219.8 \mathrm{~m}(721 \mathrm{ft})$ fop the three exhaust stacks; and at elevation $223.5 \mathrm{~m}$ (756 ft) for the intake structure at vault 1. The concrete operating area deck floop coletely entoses the below grade vaut at the $216 \mathrm{~m}$ (709 ft) level. [The following has been moved to section 2.4.2] The operating area deck floor is bound to the nonth by the lod in/lould area (trailer vestibule and $M C O$ sepvice station) and support building foundations, and to the south by the HCS Annex. [The following is coved in 
Section 2.4 .2$]$ The perimeter of the operating area deck has a $1 \mathrm{~m}(3-\mathrm{ft})$ high curb on top of which rests the steel shelter.

[The following has been moved to the introduction] The steel structures eovered by Phase 2 of the CSB SAR include the carbon stee storage tube asemblies (including bellows), operating floor deck-mbeds, tube base assemblies, impact absorbers, tube plugs and plug op embed covers. The storage tube plug and bellows are discussed in section 2.4.3] The storage tube plug is a composite carbon steel and concrete compont. The bellows portion of the storage tube assemblies is stainless steel. The following information has been moved to Section 2.4.3] Storage tubes are located in the operating floor by the floor embels and supported from the basemat by a tube base assembly. Each of the 220 standard storage tube assemblies in vault 1 will include two impact absorbers (one at the bottom of the storage tube, the other in between the two MCOst, a-tube base, and a tube plug. Each storage tube focation will receive a plug orer plate. In vautts 2 and 3 the operating floor embed locations will not include storage tube assemblies. Embed covers will be placed at the floor level in these openings unt a future mission is identified that requires utilization of these openings:

[The foltowing has been to setion 2.3 .3 \} The sufety classification of the CSB vault-structure is covered on pages 37 and 3 - 8 of WHE SQ HWV PSE OO1, Hanford Waste Vitrification Plant Ganister Storage Building Preliminary Safety Analysis Report Addendum (WHC 1992), Which designated all of the strutures contained in the below grade structure as safety class 1. Portions of the vault that were completed prior to suspension of the HWWP project in 1993 were-reviewed, appored, reepted, and incorporated into the present design. These include the base stab and intions of the walls. The curpent SAF CSB ratlt is struturally similap to the HWVP CSB vault with a few exceptions. These differences are discussed below.

The foltowing has been moved to section 2.3.3] Each of the three vatt areas is now physically separate-instead of sharing common intake and exhatrst plentms, wich was the case for the original HWV CSB. The interiop walls have been extended the full east west length of the vaults including the intake and exhatst plentms. Separation of the valt-areas allows the storage tubes to be installed in vaults 2 and 3 at a later date. The separation of the valt-areas also impoves the convective coling. The heat louldensity for one vault containing SAF MCOS is less than it would have been with the vitrified high level waste canisters. Lower vattl temperatures allowed elimination of the requirement for insulating the concrete in vault 1 as was the case in the HWVP CSB. This is diseussed further in section 2.4.5.

The following has ben to section 2.3 .3 ] The below grate vaut changed from the HWVP concept as a result of the SAF Project mission. The major change to the concrete deck is an increase in the number of intake structures and exhaust stack bases. The-stack bases for vaults 2 and 3 will be-apped unt il neded to support futuremissions. Vaults 2 and 3 are also similar to the HWWP design in that $25 \mathrm{~cm}(10 \mathrm{in})$ - of insulating concrete is provided to the deck and exhaust plenum ceiling, and $15 \mathrm{~cm}$ (6 in.) to the interior surfaces of the-below grade- vault walls. 
The following has been moved to section 2.3.37 figure 22 shows supface Irains in the basemat that connect to a sump located at the noptheast cornep. These drains, as well as the stoped basemat floor and sump, remain from the original construction of the HWWP basemat. This system of surface-drains and sump has no identified puppose in the SNF CSB mission.

[The following has been moved to section 2.3.3] [xtension of the interior walls-to-create separate-valt areas achieves physical separation of valt 1 from vaults 2 and 3 . This modification contributes to reducing the radiation streaming around and scattering up through the air intake strutture. With partial interior walls in the HWV design this radiation streaning and seattering were mitigated through the use of a set of heary concrete touvers. The separate vattes and reduced source term in the SNF-ESB design allow for removal of the louvers from the design. The architect engineer thertook high level waste canister studies (with a somewhat lower specified source for the high level waste glass canisters than the- HWP canisters and found that the concrete louvers were not-needed to meet the exposure criteria. The main reason for this is that the CSB vaut intet and exhatst plentms have been redesigned from the original HWV configuration. The redesign features separate plentms for each watt and a wall in front of the plentms in erch vallt, which tends to mitigate the direct scattering of radiation from the stored canisters. Doctmentation of the shielding andysis can be found in Appendix A of Letter FRF 034, Canister Storage Building (CSB) High Leve) Waste (HEW) Implementation Study (jacobs 1996b). This design revision redues the construction complexity and results in savings as compared to the HWVP CSB.

the following information has been moved to section 2.3.3] Fully isolating vautt 1 from vaults 2 and 3 provides sufficient shielding to permit personnel to install storage tubes in valts 2 and 3 at a future time-while vault 1 is opepating. Shielding analysis conservatively assumes that vault 1

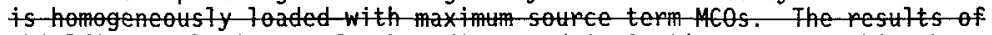
shielding analysis are further discussed in section 2.4.5. This change eliminates the need to completely fumish all three vauts with tubes and plugs before placing MCOs in vault 1 of the CSB. Extension of the interion walls provides for increased-flexibility, as compared with the HWVP CSB design, and results in a significant near tem construction time and cost savings as well as a capital cost deferpal until missions-are approved for the othep two vatts.

\section{4 .3 Facility Mission}

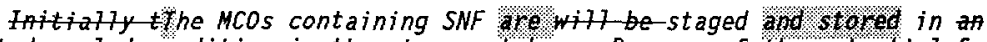
inerted sealed condition in the storage tubes. Because of the potential for hydrogen generation and buildup from both radiolytic and chemical reactions of the bound and free water in the MCO after cold vacuum drying onoliol hol

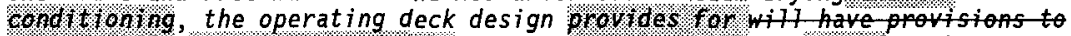

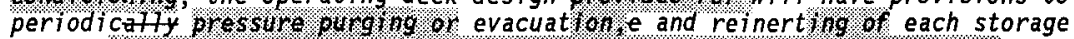

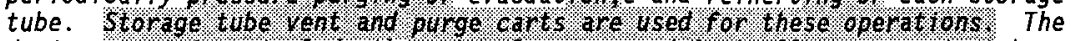
design provisions include the tube plug covers (which allow access to tube plug service connections), service connections in the tube plugs, and electrical power out lets in the floor. Eventually the MCOs will be processed in the HGS. AnAEX. Ctrpent planing calls for the HCOs to be stored in a seated configuration upon completion of HCS procesing. 
Vault 1 contallis will contain-220 storage tubes, each capable of staging or storing two MCOs. Six additional lubes fore available to accommodate overpacked MCOs. Each standard storage tube will-contains both a bottom and an intermediate impact absorber to mitigate the consequences of a

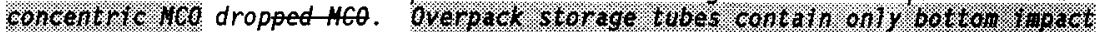
dosoroars. The storage tubes are safety class 1, and atom with the impact absorbers, they are designed to withstand all credible DBAs discussed in Section 3.4.2 of this document ineluting dropping of MEOs. The botrom impact

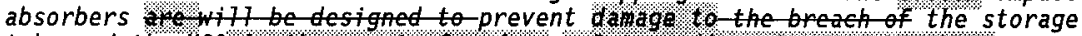

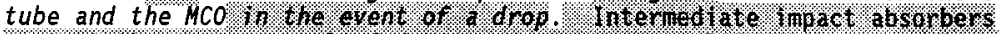

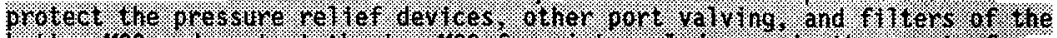

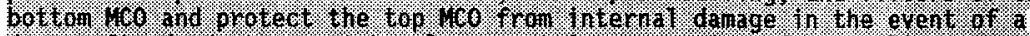

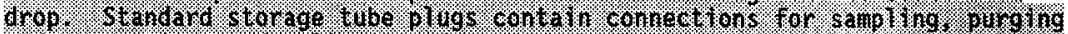

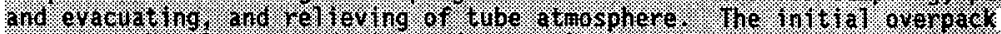

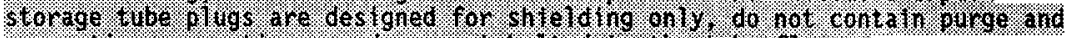

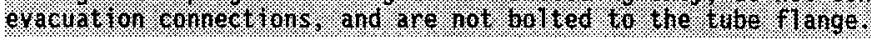

\subsubsection{Site Grading and Storm Drains}

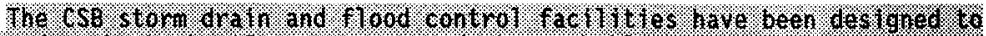

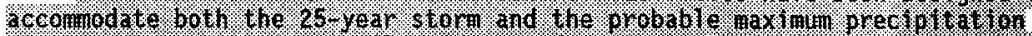

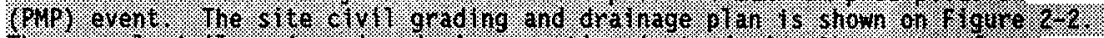

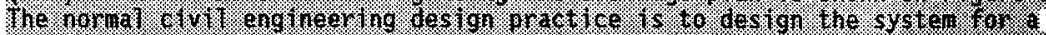

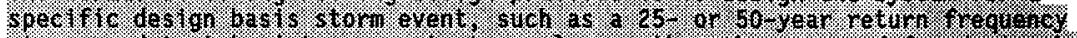

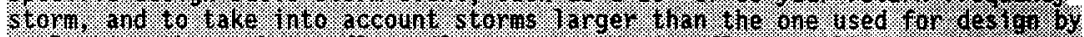

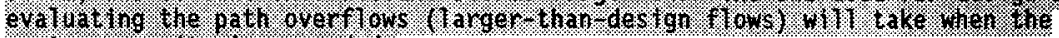
systen capacty 1 is. exceded

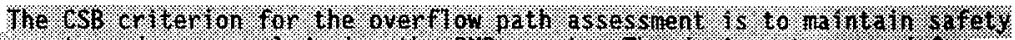

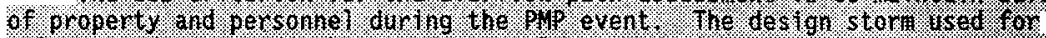

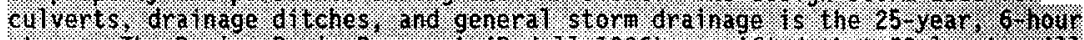

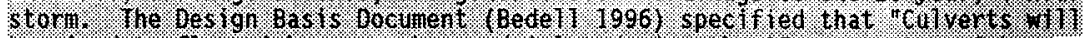

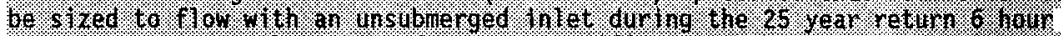

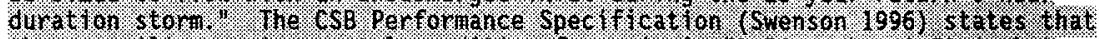

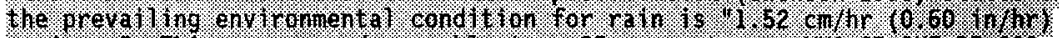

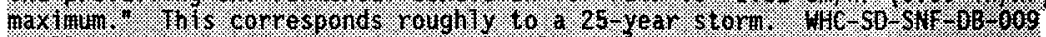

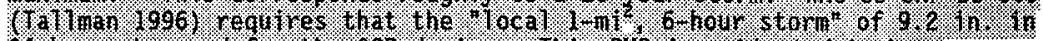

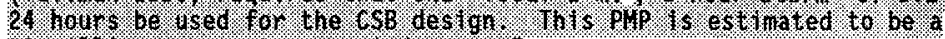

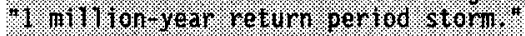

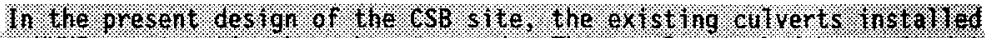

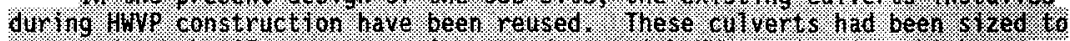

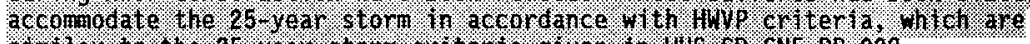

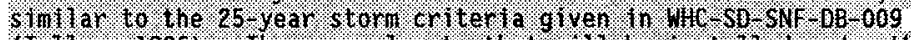

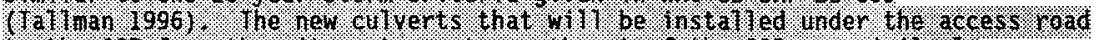

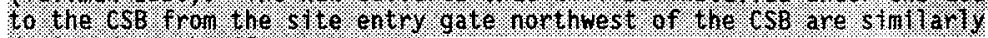
des roned to the 25 yedr storn.

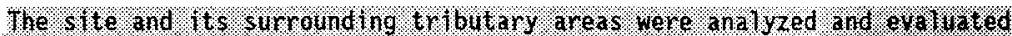

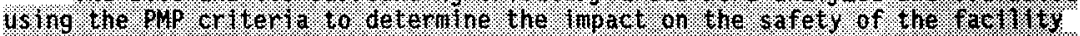

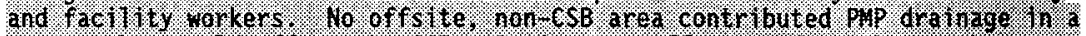

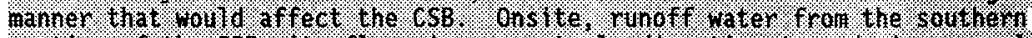

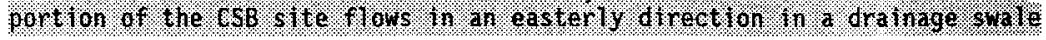




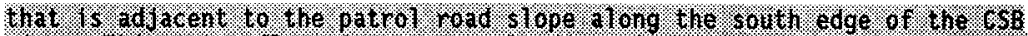

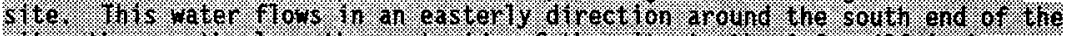

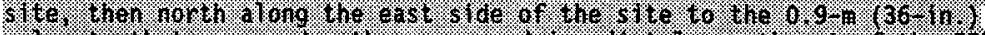

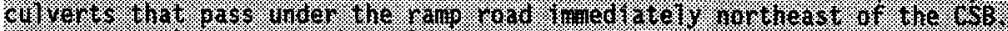

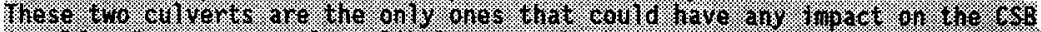
H

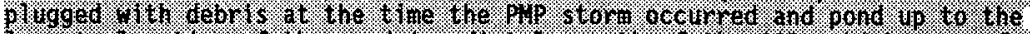

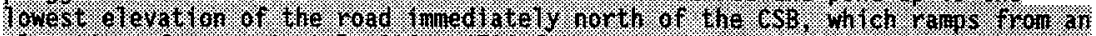

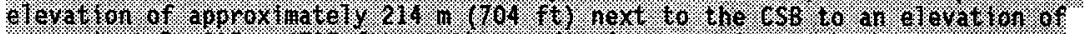

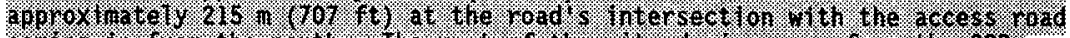

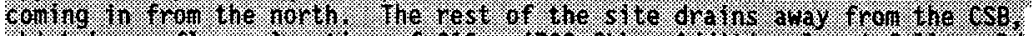

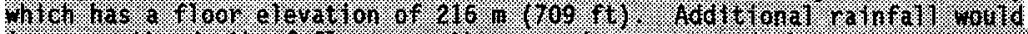

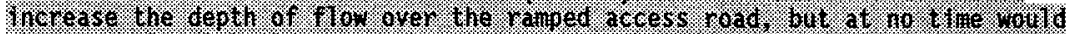

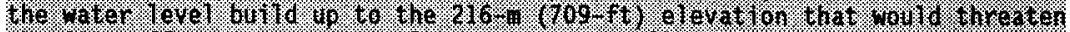

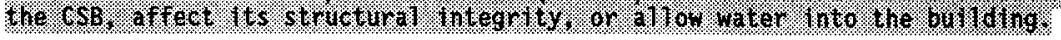

\subsection{Facility Modifications to Hanford Waste Vitrification Plant Canister Storage Building}

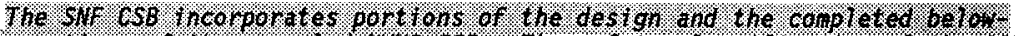

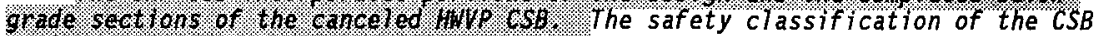
vault structure is covered on pages 3-7 and 3-8 of WHC-SD-HWV-PSE-001, Hanford Waste Vitrification Plant Canister Storage Building Preliminary Safety Analysis Report Addendum (WHC 1992), which designated all of the structures contained in the below-grade structure as safety class 1 . Portions of the vault that were completed prior to suspension of the HWVP project in 1993 were reviewed, approved, accepted, and incorporated into the present design. These include the base slab and portions of the wal7s. The current SNF CSB vault is structurally similar to the HWVP CSB vault with a few exceptions. These differences are discussed below.

The conversion of the CSB from the HWVP mission to the current SNF mission resulted in two structural revisions made possible by the lower radiation source term and lower heat load associated with the SNF MCOS as compared with the HWVP canisters. One is the removal of the intake plenum louvers in all three vaults. The other is the deletion of insulating concrete on the interior walls and underside of the operating deck in vault 1 .

The below-grade vault changed from the HWVP concept as a result of the SNF Project mission. The major change to the concrete deck is an increase in the number of intake structures and exhaust stack bases. The stack bases for vaults 2 and 3 will be capped unt $i l$ needed to support future missions. Vaults 2 and 3 are also similar to the HWVP design in that $25 \mathrm{~cm}$ (10 in.) of insulating concrete is provided to the deck and exhaust plenum ceiling, and $15 \mathrm{~cm}$ ( $6 \mathrm{in.})$ to the interior surfaces of the below-grade vault walls.

The CSB design for the HWVP mission had partial-length, below-grade interior walls and common intake and exhaust plenums. The shf eurrent-CSB configuration, as shown in Figures $2=3$ and $2-422$ and 23 , extends the below-grade walls to isolate the individual vaults and creates individual intake and exhaust plenums for each vault. This in the deletion of the intake shielding louvers. 
Extension of the interior walls to ereate sepanate valt areas zehieves physical sepation of vallt 1 from-vatts 2 and 3. This modification contributes to reducing-vedoces the radiation streaming around and scattering up through the air intake structure. With patial interion why in the HWP design this radiation streaming and scattering were mitigated throwg the use of a set of heary concrete lowrers. The separateraute and reduced souree tem in the SAF CSB design allow for removal of the louvers from the desigh. The archite engineep un hook high level waste canister studies fwith-a somewhat lower specified source for the high level waste glass canisters than

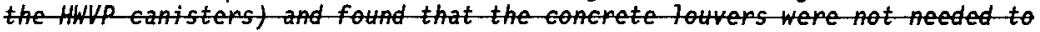
meet the exposure critenia. The main reason for this is that the CSB vatit inlet and exhoust plentms have been resigned from the original HWW configuration. The redesign $\mathbf{a} / \mathrm{so}$. features separate plenums for each vault and a wall in front of the plenums in each vault, which to mitigates the direct scattering of radiation from the stored canisters. For documentation of the shielding analysis, ses. Canister Storage Building (CSB) High Level Waste (HLW) Implementation Study (Jacobs 19966). This design revision reduces the construction complexity and results in savings as compared to the HWVP CSB.

Fully isolating vault 1 from vaults 2 and 3 provides sufficient shielding to permit personnel to install storage tubes in vaults 2 and 3 at a future time-while valt 1 is operating. Shielding andysis conservatively asstmes that valt 1 is homogeneously loaded with maximum souree tem MCOS. The results of shielding andysis are fupther disetsed in setion 2.4.5. This change eliminates the need to completely furnish all three vaults with tubes and plugs before olating HCOS in vault 1 of the CSB. Extension of the interion walls provides for increased flexibility, as compared with the HWlp ESB design, and results in a significant near term-construction time and cost savings as well as a capital cost deferpal unt il missions are approved for the other two vatts.

Each of the three valt-areas is now physically separate instead of shaning comm intake and exhat plentms, which was the ease for the oniginal HWVP CSB. The interior walls have been extended the full east west length of the-valts including the intake platems. Separation of the vault areas allows the storage tubes to be installed in vaults 2 and 3 at a later date. The separation of the vault areas also improves the convective cooling. The heat load density for one vault containing SNF MCOs is less than it would have been with the vitrified high-level waste canisters. Lower vault temperatures allowed elimination of the requirement for insulating the concrete in vault 1 as was the in ESP.

The total activity for one $M C O$ is given as $309,883 \mathrm{Ci}$ versus $891,000 \mathrm{Ci}$ $\left(5.4 \times 10^{\frac{3}{2}} \mathrm{Ci} / \mathrm{ga} 7 \times 165 \mathrm{gal}\right)$ for a vitrified waste canister. This information can be obtained from Tab7e 3.2.2.1.2.2-1 of WHC-S-0425 (Swenson 1996) and

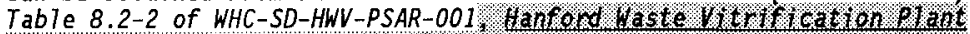

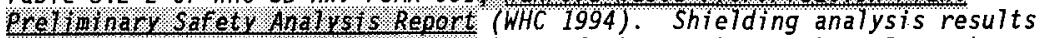
indicate that the dose rate at the base of the intake stack is less than $5.0 \times 10^{-4} \mathrm{mSv} / \mathrm{h}(0.05 \mathrm{mrem} / \mathrm{h})$, and in the adjoining below-grade vault, the dose rate is less than $4.0 \times 10^{-3} \mathrm{mSv} / \mathrm{h}(0.4 \mathrm{mrem} / \mathrm{h})$ (Sienko 1996).

On page 3-32 of WHC-SD-HWV-PSE-001 (WHC 1992), the heat loads for the HWVP canisters in the three vaults are given as 800 canisters at $0.4 \mathrm{~kW}$ and 
1,200 canisters at $1 \mathrm{~kW}$ for a total CSB heat load of $1,520 \mathrm{~kW}(507 \mathrm{~kW}$ per vault). In Section 3.2.2.1.2.2 of WHC-S-0425 (Swenson 1996), the SNF MCO heat load for one vault is given as $80 \%$ at $401396 \mathrm{~W}$ and $20 \%$ at $852 \mathrm{~W}$ for a total of $192 \mathrm{~kW}$ for $390 \mathrm{MCOS}$. Based on these conservative assumptions, results of the

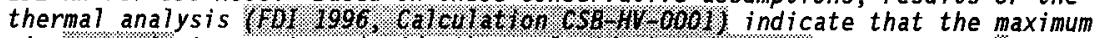

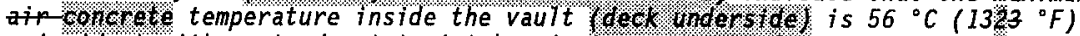
coincident with a steady state intake air temperature of $46^{\circ} \mathrm{C}\left(115^{\circ} \mathrm{F}\right)$. This result is below the ANSI/ACI 349-8590 (ANSI/ACI 1990) limit of $65^{\circ} \mathrm{C}\left(150^{\circ} \mathrm{F}\right.$ )

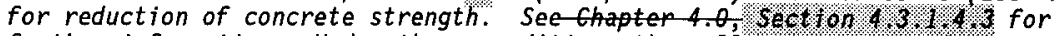
further information. Under these conditions the wal7 temperature of the MCO

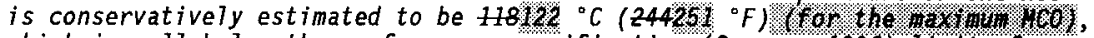
which is well below the performance specification (Swenson 1996) Timit of $132{ }^{\circ} \mathrm{C}\left(270{ }^{\circ} \mathrm{F}\right)$ wall temperature required to ensure $\mathrm{K}$.

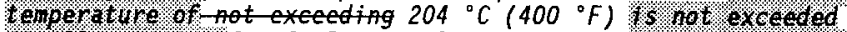

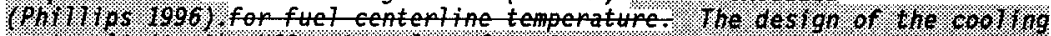

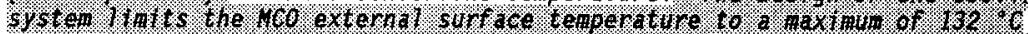

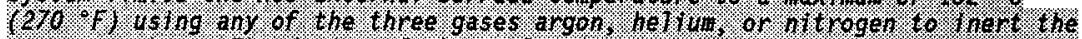

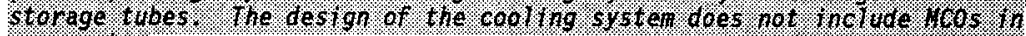
20.0.0.5

The below-grade portion of the HWVP CSB was designed to carry the loads associated with a large, wheeled, shielded canister transporter that was to be used for the HWVP mission. The SNI . heavy crane, the MHM, is used to transport the MCOS. The MHM is designed to ride on steel rails that run north to south and are located at the 216.1-m (709-ft, 0-in.) floor elevation. Anchor bolts are will be-installed in the deck at the east and west sides of the operating floor for the installation of

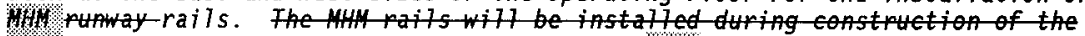
operating area superstructure. The MHM rails irewill be installed in trenches that foun north to south and cut across the receiving crane rails. The receiving crane rails $u_{\text {a }}$ will be installed in trenches that run east to west in the northernmost portion of the operating floor. The reinforced concrete construction of that northernmost portion of the operating floor holudes $k$ as the load-in/load-out areatis included in this phase 2 of the CSB SAR. The receiving crane rails will be installed during construction of the operating ared supentureture. Special rail crossover components called "frogs" are will be provided in the locations where the MHM nuay rails cross the receiving crane way-rails. Details of the MHM and

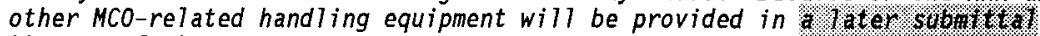
3 of the CSB SAR.

\footnotetext{
BOE Onder 6430.14 , Setion $1300-3.2^{2}$, considers safety class items-as those whose failure would result in exposures exeeding DOE 5400 series. Iimits for the public at the site polary or prest point of public-acess. For the Hanford Site's 200 Area, this distance is $15,000 \mathrm{~m}(9.3 \mathrm{mi})$. The Aegulatory Requirements Team's application of NRC equivalency has pesulted in the requirement to identify-SSCS that should be designated as important to safety in with 10 CFR 72, seetion 72.3, as implement though Section 72.106 (Garvin 1996a). Once SSCs "important to safety" have been identified, the requirements for safety elass 1 SSCs are imposed on them as

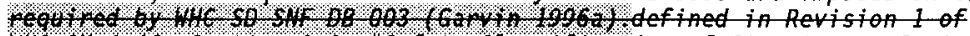
HC CH 4 46, section 9.0, "Safety Classification of strutures, systems and Components."
} 
The facility design has been evaluated for the natural phemalls 7isted on Table 123 of Section 1.5, "Aatural Phenomena Threats." NPH wind toads associated with a reactor design bisis tornato were evaluated using the tonnado wind loud from lable 123 , given as $322 \mathrm{~km} / \mathrm{h}(200 \mathrm{mi} / \mathrm{h})$ total, versus the SAC 4.1 wind 70at of $145 \mathrm{~km} / \mathrm{h}(90 \mathrm{mi} / \mathrm{h})$ (DOE Rt 1993). This higher wind toad on the operating area superstructure and support building was incorporated into the appropriate andysis and load combination for the operating deck and below grade vault (FDI 1996, Galeulations CSB-S 0023, ESB S OQ25, and CSB S OO26).

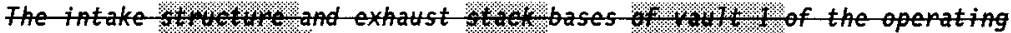
deck structure were re. we. designed to withstand tomado wind lows to meet the NAC tornado eriterita for-reators as diseussed in section 1.4.1.1.4. The analysis and design of the superstrueture for tornato generated missiles-is discussed further in Section 4.3 .4 .4 .

The architect engineer has performed a review of the penformance requirements and design eniteria imposed by ANSI/ANS 57.91992 (ANSI/ANS 1992\%). Section 6.17.1.1 of ANSI/ANS 57.9 -1992 requipes that the most adverse dead load loating contion be increased by $5 \%$ from the estimated $\forall a$ lue. The effects of an increase in the dead load have been included in the ESB design. The substructure walls, piers, an bust continuto provide the strength needed to meet the criteria. The major difference between the ESB a the of AASI/ANS 57.9 1992 (ANSI/AHS 1992) is that in ANSI /ANS 57.9 1992 transportation package washdown, decontamination facilities, and safety-elass electrial powen fop instrumentation, lighting, commications, and physical security systems are assumed to be necessary.

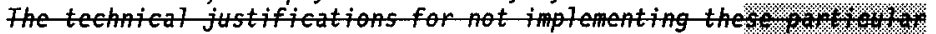
requirements demonstrated that nuclear safety of the faellity wivas not

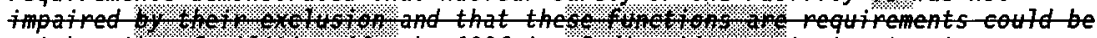
met by other facilities (Jacobs $1996 \mathrm{a}$ ). Radioative waste treatment facilities are not included in the CSB design becuse the rolume of radioactive-waste expected to be gener from ASB operations is very small and does not require an onsite dedicated rudioutive waste treatment facility. tiquid nadioactive waste from the CSB can be shipped by truck to the Effluent Ireatment Facility in the-200 East Area. Emegency commications equment is not provided as part of the CSB design because no dedicated emergency commication center is required: stch comunications will be hand through systems that interface with the central Alarm Station. Iwo independent w/2,

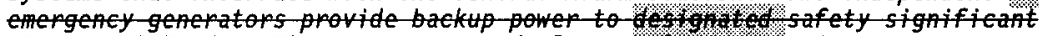
electrical lods. The generators and electrical distribution system are

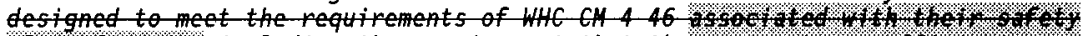
6.7. redundancy to power safety significant louls if one of its components fails to operate.

16.1. 17,1 . Figure 2.322 shows sumface drains in the basemat that connect to a sump located at the northeast comer. These drains, as well as the s7opd basmat floor and sump, remain from the original construction of the HWVP basemat. This system of surface drains and sump has no identified

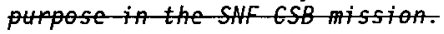


A readiness for construction task foree of key oroject panticipants identified open issues that ne to be adressed before the restart of construction. These issues are document in Report Ho. 951108001 , Ganisten Storage Building Construetion Aestant Aladiness Assessment (Ares 1996). One of the requirements was to document the acceptability of the existing basemat before the restmption of ESB constrution. Detailed inspections and evaluations of the aceptability of the existing basemat foudation penformed and documente including a neview of the adequacy and completeness of the construction quality assurance records. The review is further discussed in Section 14.6.5.1.4.

The architect engineer prepared a statent of wonk document for the constrution magent organization to use as guidance for the inspetion walkdown and repont. This the the repont would contain sufficient information for the architect engineer to adequately evaluate the aceeptability of the existing basemat. Detailed instrutions to prepare-the existing concete for the resumption of construction were provided on the architect engineer's construetion drawings and speifiens.

Following the submittal of the archit engineer's statement of work for the inspection walkdow, the construction management organization performed a detailed inspection of the below grade vault basenat and partially completed walls (Istam 1996). The pesults were categorized and submitted by the construction manaement organization for disposition by the athitet enginer. Caterory 1,2 , and 3 deficiencies are-from CSB constrution-errors. Environment affected deficiencies are in category-4. To date all ategory 1 , $z$, and 3 deficiencies have been disposition. Categony 4 deficiencies dealing with rebar, nust stains, and basemat embed surface nust have been dispositioned (Hontimen 1996). Deficiencies dealing with-couplens have been dispositioned. The information on disposition is contained in RFI:PH T3 OOI, Engineering Assessment Inspetion (FOI 1996a).

\subsection{F4OTUII STRUGTORE}

\subsubsection{Facility Description}

\subsection{Z.1 Below-Grade Reinforced Concrete Structures}

As shown in Figures $2 \% 3$ and $22422_{2} 2$, the CSB consists of a below-grade reinforced concrete structure, with approximate dimensions of $55 \mathrm{~m} \times 51 \mathrm{~m} \times 15 \mathrm{~m}$ deep (181 ft $\times 166 \mathrm{ft} \times 48 \mathrm{ft}$ deep). The dimensions of the floor plan encompassing the load-in/load-out area, operating area, and HCS Annex are approximately $70 \mathrm{~m} \times 42 \mathrm{~m}(230 \mathrm{ft} \times 137 \mathrm{ft})$. The operating floor $1 \mathrm{~s}$

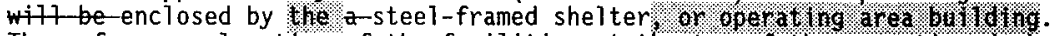
The reference elevation of the facilities at the top of the operating deck is

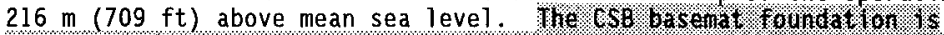

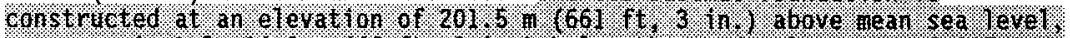
01. 108. (6). The basemat is nominaliy $1.7 \mathrm{~m}$ ( $5 \mathrm{ft}, 6$ in.) thick; its surface elevation is $203.2 \mathrm{~m}$ (666 ft, $9 \mathrm{in}$ ). The distance from the basemat floor to the underside of the operating deck is $11.4 \mathrm{~m}(37 \mathrm{ft}, 3 \mathrm{in.})$. The exterior 
walls and air inlet and outlet plenums are $1.4 \mathrm{~m}(4 \mathrm{ft}, 6 \mathrm{in}$.) thick. Interior partition walls between vaults are $0.9 \mathrm{~m}(3 \mathrm{ft})$ thick.

This material has been moved to Section-4.3.1.4.J The-CSB basemat foundation is constructed at an elevation of $201.5 \mathrm{~m}$ (661 $\mathrm{ft}, 3$ - in.) above mean sea level, 01 approximately $14.2 \mathrm{~m}$ (46 ft, $\mathrm{f}$ in, ) below tox grde

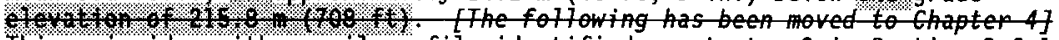
This coincides with a soil profite identified as stratum 3 in section 3.6 .1 .9 of WHC SO HWV PSAR OO1, Hanford Waste Vitrification Plant Preliminary Safety Analysis Repont (HIIC 1994). This layer exhibits light cementation and is typically in a dense to very dense condition. The formation extends to a depth of approximately $76 \mathrm{~m}(250 \mathrm{ft})$ below grade. Geotechnical investigations reponted in WHC SO HWV PSAR 001 (WHC 1994) Charet the soil properties at the elevation of interest as having high-strength and low compressibility. Stratum 3 has a vertical-static sugademodulus value of $8.1 \times 10^{4}-\mathrm{kN} / \mathrm{m}^{3}$

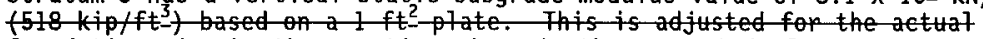
foundation size by the quation given in the geotechieal repont (Dames and Moore-1989).

The mass of the portion of the CSB above the basemat or foundation slab

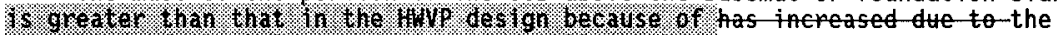
extension of the below-grade interior walls. The weight of the canisters in the storage tubes has also increased from $6,300 \mathrm{~kg}(13,900 \mathrm{lb})$ with vitrified waste (three canisters), to $17,240 \mathrm{~kg}(38,000 \mathrm{lb})$ with SNF (two MCOs). [fhis material has ben moved to seetion-4.3.1.4.J The live loading associat with canister transport equipment has doubled from the HWV design, but the new loading is a live load along the east and west exteriop vault walls versus that of the HWV transponter travel ling orep the full deck. The strutulul toading to the foundation, assuming all vallts fully loaded with SNF, is well within the allowble soil bearing values. Betails of the analysis of the adequacy of the soil to carry the anticipated foundation loading are doctmented in CSB S 0023 (FOI 19960). The soil bearing pressumes beneath the vault are less than $3.8 \times 10^{5} \mathrm{~N} / \mathrm{m}^{2}-\left(8 \mathrm{kip} / \mathrm{ft}^{2}\right)$, which is well within the ulowble bearing capacity of $6.7 \times 10^{5} \mathrm{~N} / \mathrm{m}^{2}-\left(14.0 \mathrm{kip} / \mathrm{ft}^{2}\right)$. The factor of safety against sliding during a design basis eapthquake (DBE) event is appoximately 1.8 (CSB $S 0024)$.

Only vault 1, the northernmost vault, will be provided with carbon steel storage tubes and an individual intake structure and exhaust stack at this time. This will expedite the receipt of MCOs containing SNF. Storage tubes and shield plugs are not provided for the other two vaults. The intake structures and exhaust stacks for the other two vaults wili not be constructed at this time, except the exhaust stack bases for vaults 2 and 3 .

The below-grade walls and basemat carry the loads associated with handling and transporting the $M C O$ (i.e., the transporter with cask, receiving crane, and the MHM). As described further in Section 3.4, "Accident Analysis," the below-grade portion of the CSB has been determined to be salety:

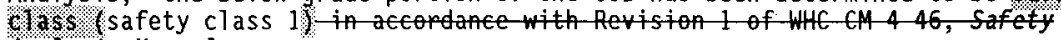
Analysis Manual.

The CSB subsurface structure provides shielding for the inlet and outlet plenums and for possible future work in adjacent vaults or for excavation next to the vaults. The SNF CSB subsurface structure design includes $1.4-\mathrm{m}-$ 
(4-ft, 6-in.-) thick reinforced concrete exterior walls and 0.9-m(3-ft, 0 -in.) thick reinforced concrete interior walls. These wall thicknesses are the same as in the original HWVP CSB design. The subsurface structure with $0.9-\mathrm{m}-(3-\mathrm{ft}, 0-i n$.$) thick interior walls provides shielding$ from the source term associated with SNF storage. This source term is substantially less than the source term that would have been present in the HWVP CSB, as discussed in Section 2.3.34.5.

The exterior walls of the subsurface structure were designed to meet the criteria given in Title 10, Code of Federal Regulations, Part 835, "Occupational Radiation Protection" (10 CFR 835), for uncontrolled access. The radiation field at the exterior surface of the below-grade vault areas when loaded with HWVP CSB sources was calculated to be $1.0 \times 10^{-3} \mathrm{mSv} / \mathrm{h}$ $(0.1 \mathrm{mrem} / \mathrm{h})$. This makes future sol to 3 for installation of additional vaults, such as for high level waste, if desired.

Shielding calculations have assumed that each MCO contains the maximum activity value associated with Mark IV (MKIV) fuel listed in Fab7e 3.2.2.1.2.2 1 and described in Section 3.2.2.1.6 of WHC-S-0425, Perforate Specifieation for the Spent Nuelear Fuel Canister Storage Building (Swenson 1996, Sect.ton 3.2.2.1.6 and Tab7. 3.2.2.1.2.2.1). The shielding calculations indicate that the radiation field at the intake stack base will be less than $5.0 \times 10^{-4} \mathrm{mSv} / \mathrm{h}(0.05 \mathrm{mrem} / \mathrm{h})$ (Stenko 1096$)$, of which less than $1 \%$ is attributed to neutron scatter for SNF as the source term. Originally, the interior walls were designed for structural purposes only; shielding calculations now show that the FIII- i ength SHT GSB walls they-provide shielding from the SNF" for workers in the presently unused vaults 2 and 3. Interior radiation levels in the presently unused vaults will be about $4.0 \times 10^{-3} \mathrm{mSv} / \mathrm{h}(0.4 \mathrm{mrem} / \mathrm{h})$ at the wall surface plane (within $1 \mathrm{~cm}$ $[0.4 \mathrm{in.}])$. Because of the large source configuration, the dose rate inside adjacent vaults (e.g., vault 2 ) does not decrease very rapidly with distance, remaining at about $4.0 \times 10^{-3} \mathrm{mSv} / \mathrm{h}(0.4 \mathrm{mrem} / \mathrm{h})$ for the first meter or so away from the interior wall of vault 2 that is shared with vault 1 . Heating of the concrete by the radiation field inside the vault has been estimated to be insignificant at approximately $\left(2 \times 10^{-8} \mathrm{Btu} / \mathrm{h} / \mathrm{ft}^{2}\right)$. Neutrons and gammas Wf fect from the spontaneous fission of californium were. was not included in the shielding calculations or concrete heating calculations because their

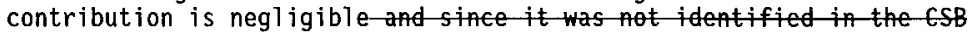
Performance specification source term.

\subsubsection{At-Grade Reinforced Concrete Structures}

The operating deck is a $1.5-\mathrm{m}-(5-\mathrm{ft}-)$ thick reinforced concrete structure that forms the at-grade portion of the CSB. The operating deck is shown in $\mathrm{plan}$ view on Figure $2.52-4$. The dimensions of the operating deck are approximately $70 \mathrm{~m}(230 \mathrm{ft})$ north-south by $42 \mathrm{~m}(137 \mathrm{ft})$ east-west. The operating area deck floor is bounded to the north by the load-in/load-out area (Tuck traifer-vestibule and MCO service station) and support building foundations, and to the south by the HCS Annex Toundot:on. The operating deck structure contains numerous through-thickness steel sleeves (embeds) that receive the storage tubes and tube plugs for both the standard MCO and overpack MCO locations in vault 1 , and that provide a location for the tube plug cover plates in vault 1 or deck embed cover plates in vaults 2 and 3. 
These embeds are offset and arranged at a center-to-center distance of $1.42 \mathrm{~m}$ (4 ft, $8 \mathrm{in.)}$ east to west and $1.37 \mathrm{~m}$ (4 ft, $6 \mathrm{in.)}$ north to south, as shown in Figure $2=52-4$.

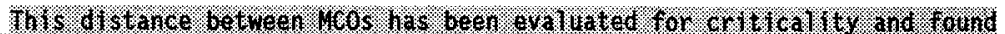

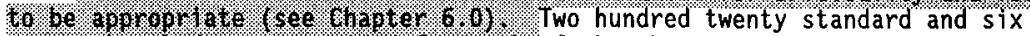
overpack embeds are provided for each of the three vauits. Each of the standard embeds is stepped down from a diameter of $1.07 \mathrm{~m}$ ( $3 \mathrm{ft}, 6 \mathrm{in}$.) at the

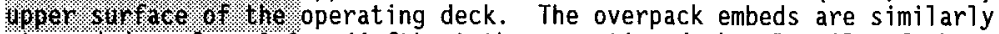
stepped down from $1.2 \mathrm{~m}(4 \mathrm{ft})$ at the operating deck. Details of the standard tube, embed, and plug at the deck level are shown on Figure $2-62-5.10009$.

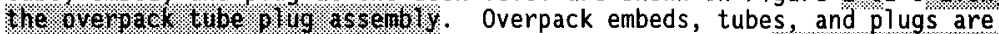

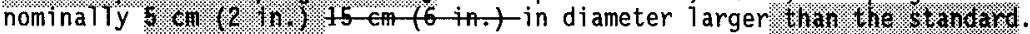

Each vault to accommodate a rectangular intake structure, $3.3 \mathrm{~m} \times 4.9 \mathrm{~m} \times 0.6 \mathrm{~m}$ thick (10 ft, $8 \mathrm{in} . \times 16 \mathrm{ft} \times 2 \mathrm{ft}$ thick) and a circular exhaust stack foundation $3.5 \mathrm{~m}$ ( $11 \mathrm{ft}, 6 \mathrm{in}$ ) in diameter and $1.4 \mathrm{~m} \mathrm{(4} \mathrm{ft,} 6 \mathrm{in}$.) thick. Each of the three exhaust stack bases is furnished with $4457-\mathrm{mm}$ (2.25-in.) diameter anchor bolts to which the steel exhaust stacks will be fastened. The intake structure and exhaust stack bases are designed for the safety class-NPHS tods given in Table 1-23.

The HCS Annex is an extension to the south of the operating deck. It: foundat. on $_{\text {an }}$ is a reinforced concrete structure that houses process moduie mounting plates and seven process pits for HCS equipment. The dimensions of the HCS Annex fourdot ton are $10.7 \mathrm{~m}$ (35 ft, $3 \mathrm{in.}$ ) by $42.3 \mathrm{~m}$ (138 ft, $11 \mathrm{in}$.) by $1.5 \mathrm{~m}(5 \mathrm{ft})$ thick; the reinforced concrete $\mathrm{slab}$ is supported at grade. A loading-staging vestibule is located on the west side of the HCS Annex for egress and ingress of HCS equipment. The dimensions of the loading-staging vestibule foundat on are $7.6 \mathrm{~m}$ (24 ft, $11 \mathrm{in.)}$ by $8.3 \mathrm{~m}(27 \mathrm{ft}, 4 \mathrm{in.}$ ). An outer and inner door in the loading-staging vestibule serve as an air-lock for area ventilation confinement.

The load-in/load-out area is an extension to the north of the operating deck. It houses an MCO service station 9 thes and 1 ines and provides trenches and anchor bolts for receiving crane, service stallor enclosilu tent, and tent gantry rails. The load-in/load-out area's reinforced concrete slab is $42.2 \mathrm{~m}$ (138 ft, $4 \mathrm{in}$.) by $9.1 \mathrm{~m}$ ( $29 \mathrm{ft}, 9.5 \mathrm{in}$.) by $1.5 \mathrm{~m}$ (5 ft) thick supported at grade. A truck vestibule forms an extension to the west of the load-in/load-out area. The dimensions of the truck vestibule stals are $13.0 \mathrm{~m}$

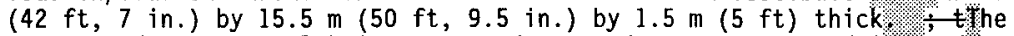
reinforced concrete slab is supported at grade. An outer and inner door in the truck vestibule serve as an air-lock for operating area ventilation

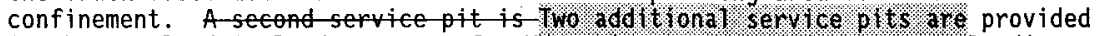
in the CSB load-in/load-out area for MHM maintenance and future transloading

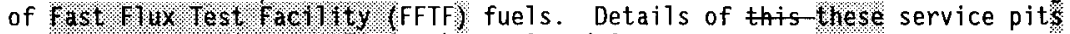
can be seen on Figure $2.72-6$, sheets 1 and 2 .

Surrounding the operating area on the south, east, and west is a $1.3-\mathrm{m}$ (4-ft, 4-in.) thick by $1.0-\mathrm{m}(3-\mathrm{ft})$ high concrete perimeter curb. The curb is $0.6 \mathrm{~m}(2 \mathrm{ft})$ wide and $2.4 \mathrm{~m}(8 \mathrm{ft})$ high at the north wall of the $10 \mathrm{ad}-\mathrm{in} / 1 \mathrm{oad}-$ out area for shielding of support building personnel from the MCO transport cask. Doors are will be-provided for personnel traffic through this shield 
wall. The other portions of the perimeter tub are required to provide shielding. The operating area steel superstructure 3 s. witl be-attached to anchor bolts set at column locations throughout this perimeter curb.

\subsubsection{Steel Structures}

Storage tubes are located in the operating floor by the floor embeds and supported from the basemat by a tube base assembly. Each of the 220 standard storage tube assemblies in vault 1 will include two impact absorbers (one at the bottom of the storage tube, the other in between the two MCOs), a tube base, and a tube plug. Each storage tube location will receive a plug cover plate. In vaults 2 and 3 the operating floor embed locations will not include storage tube assemblies. Embed covers will be placed at the floor level in these embed openings until a future mission is identified that requires utilization of these openings.

The storage tubes are restrained from lateral movement at the basemat by the tube base assemblies into which they are inserted. These are shown on Figure 2.827 . The tube base assemblies are carbon steel, welded structures designed to the requirements of ANSI/AISC N690-94 (ANSI/AISC 1994). They are affixed to embedded plates in the basemat slab. The tube base assemblies are designed with cooling passages to ensure that the temperature at the basemat slab will not exceed the $66^{\circ} \mathrm{C}\left(150{ }^{\circ} \mathrm{F}\right)$ concrete temperature limit. The basemat slab embeds serve as alignment and horizontal seismic restraint points for the storage tube base assemblies. The basemat slab embeds were designed

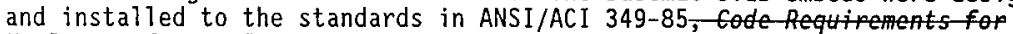
Auclear safety Related conerete-Structures (ANSI/ACI 1985), and were part of the existing HWVP CSB construction.

The standard and overpack storage tubes a 7 so-are provided with a

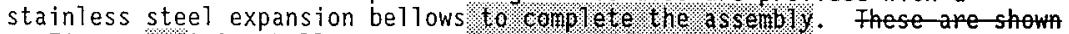
on Figure- 2.928 . Bellows permit unrestricted thermat growth of the storage tube, accommodate differential movement of the operating deck in relation to the basemat slab, and seal the operating area from the vault. Floe standard

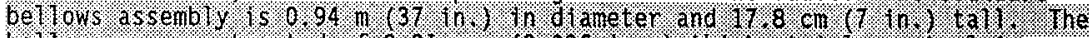

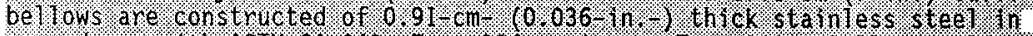

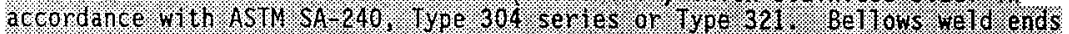

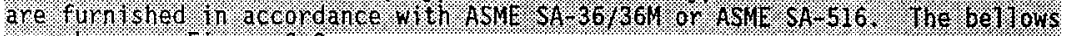
are shown on l $19 \mathrm{gue}$. 29

The standard storage tubes, which are 12.1-m- (39-ft, 7-in.-) 1ong, are carbon steel pipes, $0.7 \mathrm{~m}$ (28 in.) in diameter, closed at the bottom. Whan

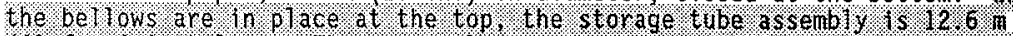

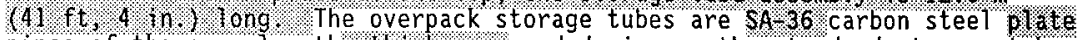
pipes of the same length, thl ckness. and design as the standard storage tubes but $0.8676 \mathrm{~m}$ ( $3430 \mathrm{in.}$.) in diameter. Overpack storage tube assemblies are provided in vault 1 for potential future use. These standard and overolde storage tabe as sembll les. are safety class. (safety class 1) and storage tubes are designed and fabricated to the requirements of the Boiler and Pressure Vessel Code (ASME 1995a), Section VHII, Division-1) as rood f red by the

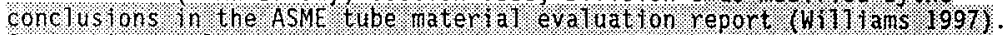
Supporting analyses are in accordance with. ANSI/AISC N690 94 , Specifieation for the Design, Fabrication, and Erection of Steel Safety Related-Structures for Nuclear-Facilities (ANSI/AISC-1934). Bellows assemblies are designed to 


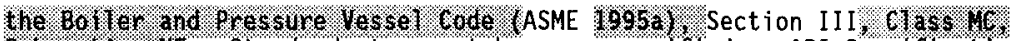

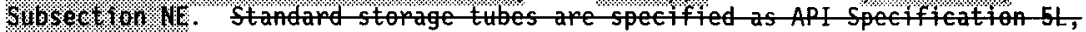
Spee if teation for tine Ripe (API 1995), Grode BCS material with a wall

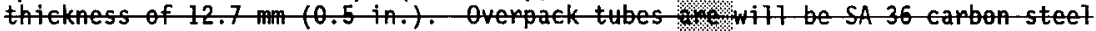
plate of the same thiekness. Ongoing evaluations are expected to show that this material is equivalent to ASTM A 36 by a commercial grade dedication

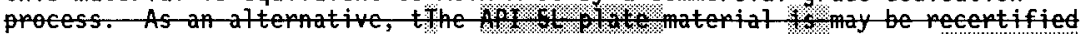
by the tube manufacturer to $\mathrm{SA} 36$, an aeceptable ASHE code matepial \% .

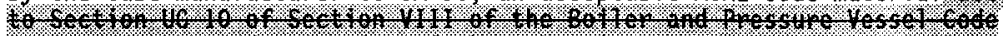

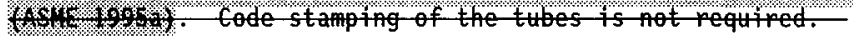

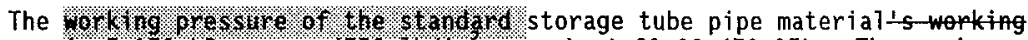
pressure is $5,170 \mathrm{kPa}$ gauge $\left(750 \mathrm{~Tb} / \mathrm{in}^{2}\right.$ gauge) at $21{ }^{\circ} \mathrm{C}\left(70{ }^{\circ} \mathrm{F}\right)$. The maximum

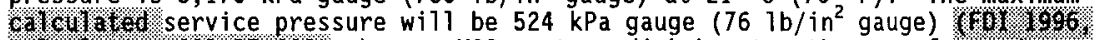

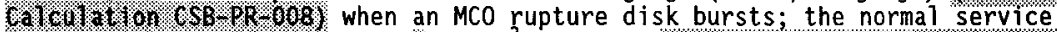

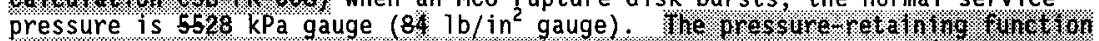

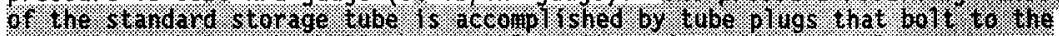

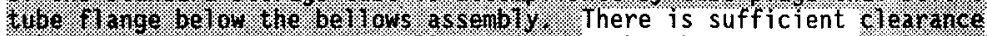
toleranee between the tube hat thand impact absorbers to prevent 1ateral loads

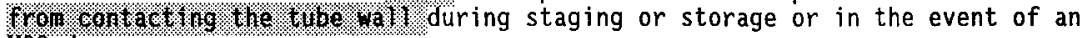
MCO drop.

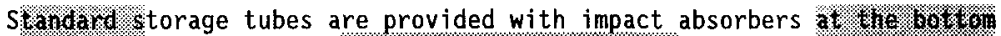

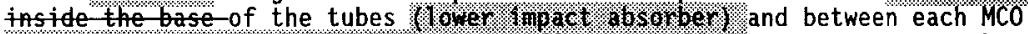

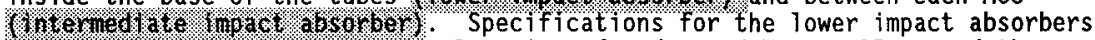
require that they $11 \mathrm{mit}$ the deceleration of a dropped $M C O$ to $35 \mathrm{~g}$, and the radial load on the storage tube to $3,450 \mathrm{kPa}$ gauge (500 $1 \mathrm{~b} / \mathrm{in}^{2}$ gauge) or less. To account for uncertainties in the final MCO design, the storage tube impact absorber has been designed assuming a maximum $M C O$ weight of $9,120 \mathrm{~kg}$ $(20,1007 \mathrm{~b})$ as compared with the maximum value of $8,869 \mathrm{~kg}(19,512 \mathrm{lb}) \mathrm{given}$ in WHC-S-0425 (Swenson 1996, Table 3.2.2.1.2.2-2). In specifying the lower impact absorber, the results contained in Letter SCS-W-96-576, Drop Analysis of Multi-Canister Overpack in Canister Storage Building (Hyde 1996z) were used. The report (Hyde 1996z) indicates that the impact absorbers should be designed to Timit the MCO deceleration to $35 \mathrm{~g}$. Further analysis shows that an intermediate impact absorber is required between MCOs to prevent local damage to the 60 shield plug top and to protect the Mco mechanical seal from damage. The design of the intermediate absorber bottom will need to accommodate the MCO venting and pressure relief functions. In the event of an overpressurization, the released gas would travel to the annulus between the MCO and storage tube. The bottom impact absorber is specified to limit its sideward thrust on the storage tube during deformation to that of the tube's working pressure. The bottom and intermediate impact absorbers are shown on Figure 2.102 9. Impact absorbers for standard and overpack storage tubes are shown on flgure 29 .

\footnotetext{
the following has been to section -4.3.5.4.7 Analyses have show that the $M C O$ shell when fully loaded will not yield when exposed to accelerations betow $150 \mathrm{~g}$ and will not butle (become wable) thit the aecelerations reach $700 \mathrm{~g}$ (Hyde 1996b). By review of the analysis results, it is apparent that the $M C O$ wall does not expal to values greater than $1.3 \mathrm{~cm}$ $(0.5$ in.) unt il exposed to more than $300 \mathrm{~g}$. Analysis of the postulated $M c 0$ drops into the storage tubes shows that the accelerations on the MCO when 40 into the CSB storage tube with impact absorbers is well below $100 \mathrm{~g}$
} 


\section{(Hyde 1996). Thus the MCO witl not-impose any lateral loads on the storage tube.}

The standard tube plug assembly provides radiation shielding, holds gas pressure in the storage tube, and allows access to the tube interior for gas inerting, gas pressure monitoring, pressure relief, and high-effockency

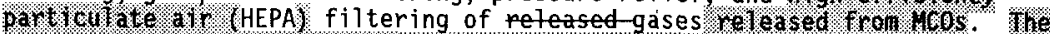

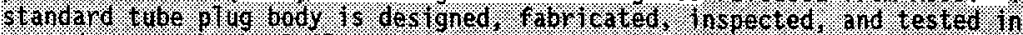

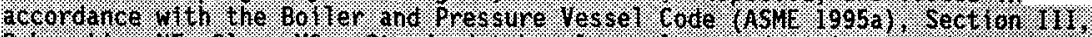

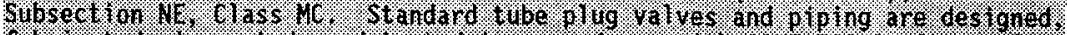

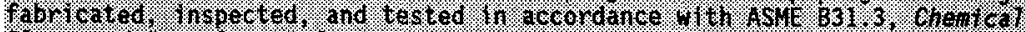

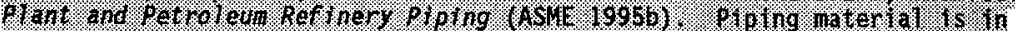

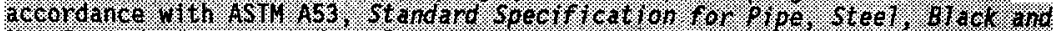

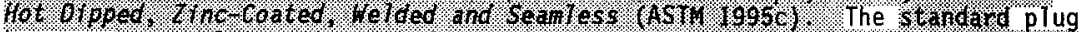

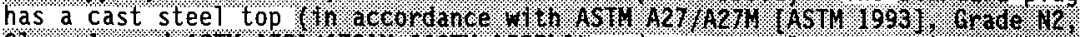

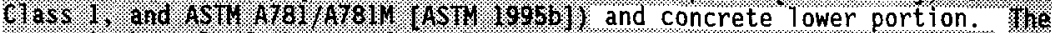

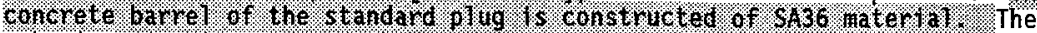
tube interior is accessed through two 5 -cm $(2-i n$.) holes drifled into the casting that connect to two $3.8-\mathrm{cm}-(1.5-i n .-)$ diameter tubes. CThe-following has and section $4.3 .5 .4 .5 \mathrm{All}$ structural welds on the plug are full penetration welds and will withstand a $2.9-m(9.5$ ft) drop of the plug onto the storage tube.

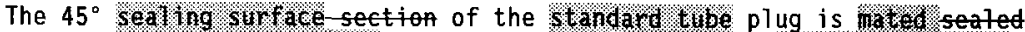

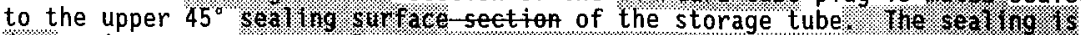

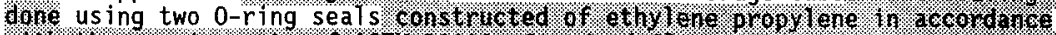

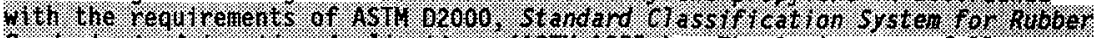

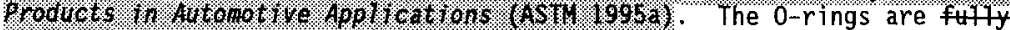

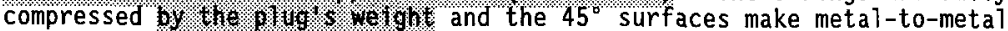
contact-that attentates radiation-exposure the 0 rings. The 0 -ring seals are tested by pressurizing between the seals through a built-in test connectorion located 1 . the olug. The uplift force on the plug, caused by gas pressure, is held by the weight of the plug and eight hand-tightened hold down clamps that connect 10 . 6 fle by bolts on to the $45^{\circ}$ upper section of the tube.

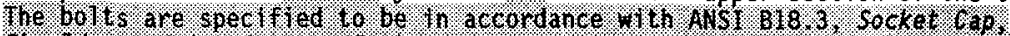

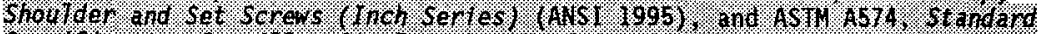

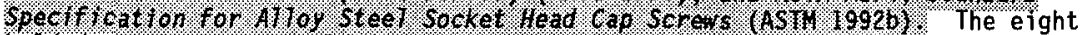
hold down clamps are held in position by retaining points on the clamp tips that grip the bolt heads and the engagement of the clamp screws in a $0.3 \mathrm{em}$ $(0.125$ in.) retaining groove machined into the top surface of the plug. The clamps are connected by steel cable to a flat steel 1 ing-plate to ensure that a]l the clamps are removed before the plua $M C O$ is lifted by the MHM. The plate rests on the plug's lifting lug and will not allow the plug grapple to engage the lug until the hold down clamp ardo ring plate assembly (solosor. are

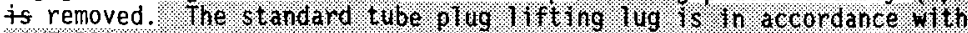
ASUE $630.20-1993$ (ASHE. 1993.$)$

Standard tube plugs are shown on Figure $2.62-5$. The dose rate estimate, based on the Monte Carlo, three-dimensional geometry MCNP-4A code's streaming and scattering calculations (Breismeister 1993), is about $2.0 \mathrm{mSv} / \mathrm{h}$ $(200 \mathrm{mrem} / \mathrm{h})$ near the top of the plug-tube gap (top of the bottom straight plug section). At the surface of the operating deck, the upper limit of the dose rate caused by the radiation from this gap is less than $2.0 \times 10^{-3} \mathrm{mSv} / \mathrm{h}$

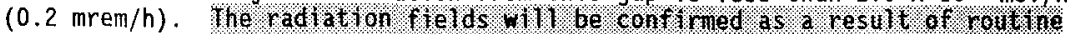




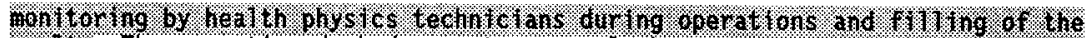
Voult: The operating deck dose rate can only be approximated, based on the anatys is performed, since the complicated geometry and low dose rate make it difficult to achieve adequate Monte Carlo statistics for a precise answer. This analysis was performed on the (low concrete and steel composite plug. Details of the shielding analysis can be found in calculation number CSB-SH-2002, Floor Plug/Deck Interface Analys is (Kidd 1996a). Overpack storage tube plugs were similarly analyzed. Additional caleulations ape performed with the new-1.0 MPa gatge (150 ib/int-gatge) plug design. Only minor changes in dose pates are expected since the source tems are the sameThe results will be inclued in the next phase.

The tube plug leak rate will be tested each time the tube is refilled with inert gas, using the same criteria as for construction acceptance. The current tube plug acceptance specification includes a test procedure to verify that the leak rate through the double seal is less than $1 \times 10^{-4}$ standard $\mathrm{cm}^{3} / \mathrm{s}\left(3.5 \times 10^{-9}\right.$ standard $\left.\mathrm{ft}^{3} / \mathrm{sec}\right)$ at a test pressure of $27 \mathrm{kPa}$ gauge (4 lb/in $n^{2}$ gauge). This test pressure ensures retention of inerting gas in the tubes during normal operations. Since this test measures leakage from the middle (out through both seals at once), the in-service leakage rate through one seal at a time will be lower (one-fourth on average). This leakage rate was chosen to minimize the release of contamination from the tube in the event of a burst MCO rupture disk.

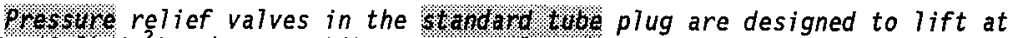
$62 \mathrm{kPa}\left(9 \mathrm{lb} / \mathrm{in}^{2}\right)$, thus providing a means for the inerted storage tubes to maintain a norma? operating pressure of $7 \mathrm{kPa}$ to $28 \mathrm{kPa}$ gauge $\left(1\right.$ to $4 \mathrm{lb} / \mathrm{in}^{2}$

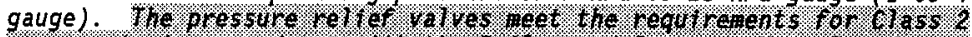

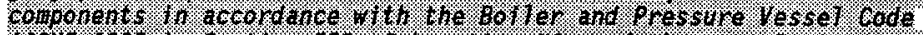

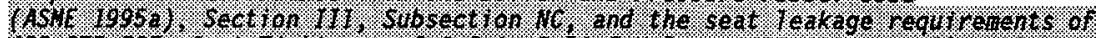

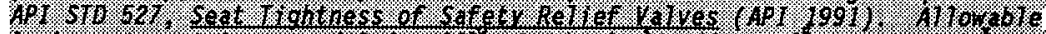

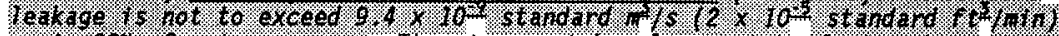

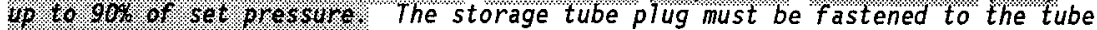
to prevent the plug from lifting at the tube system design pressure of $524 \mathrm{kPa}$ (76 $\left.7 b / i n^{2}\right)$ gauge. The approximate weight of the standard size storage tube plug is 2,406 kg $(5,300 \mathrm{lb})$. During an MCO overpressurization accident as described in Section 3.4.2.1, the MCO pressure will reach $1.0 \mathrm{MPa}\left(150 \mathrm{lb} / \mathrm{in}^{2}\right.$ gauge) above the tube pressure before the MCO rupture disk bursts and arteases

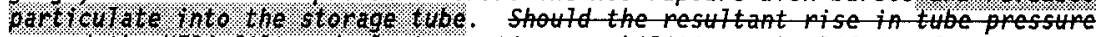
exeed the HEPA filtered plug's venting capabilities, the lifting forces on the tube plug could result in the relecse of unfiltered stokage tube gases past the seals and into the operating area. The design of the storage tube plug seals, relief valves, HEPA filters and lock down devices, as described in Section 4.3.5.2, mitigates against this release.

A start cask pedestal is provided in the MCO service-station load-

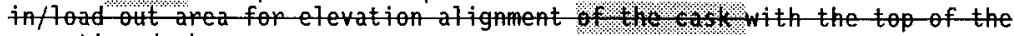
operating decks.

Tube plug covers protect the tube plug connections and devices and fit flush with the operating deck. They are 76.2-mm- (3-in.-) thick carbon steel disks provided with lifting lugs and a concentric inspection port for tube servicing operations and tube pressure monitoring. The deck embed covers in vaults 2 and 3 are $12.7-\mathrm{mm}-(0.5-i n .-)$ thick carbon steel plates designed with 
tube steel reinforcement and with gaskets at deck embed contact surfaces. They provide for personnel safety and maintain a level floor surface. Both the plug and embed covers are shown on Figure $2.112-10$.

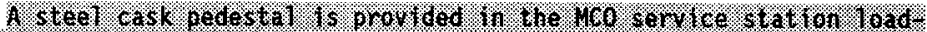

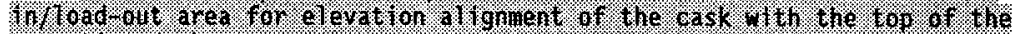

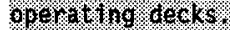

2.4.2.4 Hobile Containment Sepvice Tent and Gantry Crane. [This setion has ored section 2.5.1.27 The mobile containment service tent is wheeled and travels on rails in the load in/load out area of the CSB. Positive restraints are provided betwen the base of the tent and the support rail to prevent the tent from lifting up or moving off the rail during a seismic event and resulting in a potential los of function.

The mbile containment service tent will be staged in an area adjacent to and to the east of the $H C O$ senvice station. The tent will be-staged over the $4 C O$ seprice station pit after receiving a transpont cask load with an $M C O$. The tent will be pushed manually away from the MCO sepvice station pit after the senvicing of the MCO has been completed and the shielding hateh assembly has been placed over the pit.

The mobile containment service tent is equipped with a HEPA filtered exhaust unit with a built in standby exhaust fan. One fan is in standby while the other is in operation. The exhatst-system will maintain a negative $125-\mathrm{Pz}_{2}$ (0.5 in. water gauge) pressure within the tent enclosure during the servicing operations. The exhaust unit discharges to the operating apea exhaust stack. on a loss of nomal-power, the emergency generatop system will provide power to the mobile containment service tent exhaust system.

The tent and the filtered exhaust system form the confinement envelope for the zone 2 ventilation area around the $M C O$ sepvice station. The confinement atmosphere is suporte by mataining a $125 \mathrm{~Pa}-(0.5$ in. water gauge) negative pressure inside the tent. To achieve and maintain this negative presure, the tent is seated to the floor, and the openings and joints in the material of the tent are designed to efficiently maintain the seat.

The tent material is a fire resistant nuteap grade fabric with a specific weight of $425 \mathrm{~g} / \mathrm{m}^{2}-\left(180 \mathrm{oz} / \mathrm{yd}^{2}-\mathrm{m}\right.$ minimum. The tent material meets of exceeds all the requirements of $14 \mathrm{IL} C 4306 \mathrm{G}$, Cloth and Strip, taminated or Eorted, Hinyl Hylon or Polyester High Strength, Flexible (HIt 1989), Type-I specifications. The tent material is also in accordance with AFPA 701, Stand Hethods of Fire Tests for flame Resistant Textiles and Films (NFPA 1996); Chapter 12, and has a maximum tearing strength that is in

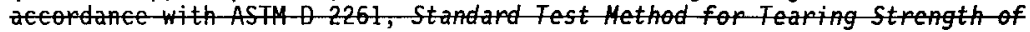
Woven Fabrics by the Iongute (Single Rip) Hethod (Constant Rate of Extension Fensile Testing Machine) (ASTH 1983a), and ASTH Q 2262, Standand Test-Hethod for Tearing Strength of Woven Fabrics by the Tongue (Single Rip) Hethod (Constant Rate of Traverse- Tensile Testing Nachine) (ASTM 19836).

The tent is equipped with a lighting system to provide an illumination level of not less than $757 \times(70$ footeandle) for a distance of $2.7 \mathrm{~m}(9 \mathrm{ft})$ from the top of the $M C O$. The tent has enough capacity to house the cask lid, 
the shield ring, the shield hatch assembly, the 5 ton gantry-crane and hoist, and the storage rack. The tent is equipped with service steves, $7.6 \mathrm{-m}$ (3-in.) diameter miniment to bring senvices into the tent as needed to support ventilation, to supply power, and to intro tools.

The 5 ton motorized-gantry-crane has an undephung electrical wire rope hoist. The erat dos $2.4 \mathrm{~m}-(8 \mathrm{ft})$ in total height and has a maximum 1 ift of $4.6 \mathrm{~m}(15 \mathrm{ft})$. The underhung electrieal wire rope hoist is equippe with brakes, and stops, and a free rotating hook. The wheels of the gantry erane are designed to withstand a minimum loading of $2,270 \mathrm{~kg}$ $(5,000,7 b)$ en and are with locking devices to prevent movement while in use. The gantry crane has an acceleration control, and its travelling speed does not exced $10.7 \mathrm{~m} / \mathrm{min}(35 \mathrm{ft} / \mathrm{min})$. The wire rope hoist has a lift speed of $3.0 \mathrm{~m} / \mathrm{min}(10 \mathrm{ft} / \mathrm{min})$ maximum, and the motorized trolley has $27.6 \mathrm{~m} / \mathrm{min}(25 \mathrm{ft} / \mathrm{min})$ maximum-sped.

The $M C O$-service station gantry erane and hoist ape designed in accopdance with ANSI/ASME B30.10, Safety Standand for Hooks (ANSI/ASME 1995d), ANSI/ASME B30.16, Oremead Hoist (Underhung) (ANSI/ASNE 19956), ANSI/ASME 30.17, overhead and Gantry Cranes (Top Running Bridge, Single Girder, Underhung Hoist) (ANSI/ASME 1995a), and ANSI/ASME HST IM, Performes stand for overhead Electric Wire Chain Hoists (ANSI/ASME 1995C).

2.4.2.5 Mutticanistep Overpack Handling Machine. [This section has been moved to section 2.5.1.5] The 4444 as provided by foster whe len Envirommentat Corporation is a fully shielded machine whose purpose is to remove MCOs from the service station pit in the receiving area of the CSB, place the HCOS in the vautt-storage tubes (having finst remored and subsequently replaced the storage tube $p 7$ tug), and transfer and retrieve $M C O$ s to and from the hot conditioning orens. The $M H M$ can be used to reverse the opepation and remove the MCOS from the rault and, in addition, can handle the storage tube impact absopbers.

The $14+14$ consists of two main units that operate simultaneousty as a single machine: the gantry crane system and the shieldedturet system. The gantry crane system is a 125 ton capacity, equal leg gantry with a top running trolley. The erane system includes the trolley and control panel, girders, end ties, wheel trucks, and seismic clamps. The shielded turret system inclutes the cask body, MCO hoist, ventilation system, shield olug hoist, television navigation cameras, shield skint, and turntable.

The MHAl-gantry crane system is mounted on pails that run north south in

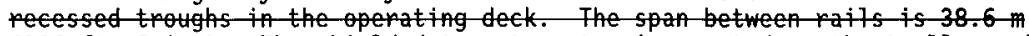
(126- ft, 8 in.). The shielded turnet system is mounted on the trolley, which wans in the east west difection. The cask trolley an travel-31.6-m 1103 ft, 10 in.) east west and $58.05 \mathrm{~m}$ (190 ft, 6 in.) north south (see Figures 211 and 2 12). Specifications for the gantry and main trolley systems requipe that they be designed and fabricated to meet the requirements or ASME HOG 1 1995, Rutes for Construction of Orerhed and Gutry Granes (Top Runing Bnidge, Multiple Girder) (ASME-1995b), Type 1, and NUREG 0554,

Single-failupe-proof cranes for Nuclear Power Plants-(NRC 1979). 


$$
\text { HNF-SD-SNF-RPT-004 REV } 6
$$

The -HHA gantry and trolley and the CSB - support structures are designed with seismic restraints that will prevent dage to an $M C O$ if a seismic event were to oceur during handling.

The MHI controls are provided with east west and nopth south motion interlocks with the cask motion. The interloks are designed to prevent damage to the HCOs during handling if a seismic event or MHA trolley control system failure were to-oecur. The MHAl main girders are located at a height of $2.75 \mathrm{~m}(9 \mathrm{ft})$ bove the operating deck to clear the $M C O$ service station, the tube rent and purge carts, and the HCS proces enclosures.

The turpet consists of a rotating upper assembly and a stationary bottom nose assembly. A retractable shield skirt mounted to and concentric with the nose assembly is lowered to complete the shielding when the MHA is engaged with a storage tube or wen the shield hatch is positioned over the MCO service-station pit. The skirt is connected to a nose tube and is sealed with elastomeric $\theta$ rings to the opating station where it is positioned (storage tube op seprice station).

When the MHM is located over the MCO service-station and the shield-skint is lowered and seated, the turpet is rotated into position to remove the center shield plate. The center shield plate is removed with the MHI's shield plug grapple and hoist. The turpet is then rotated to position the carity over the operating station, and the HCO is removed using the MCO hoist and grapple. After the $M C O$ has been raised to the transporting position, the turpet is again rotated, and the center shield plate is replaced in the shield hatch. The shield skint is paised and locked into position, and the lllly then transports the $M C O$ to the designated storage tube.

Hpon appival at the stopage tube station, the shield skipt is lowered into place and sealed to insure proper confinement and shielding. The turpet is rotated to position the shield plug cavity over the storage tube, and the shield plug is removed using the shield plug grapple and hoist. When the shield is in its stored position, the turpet is rotated to align the cavity over the storage tube and the $M C O$ is lowered into position using the $M C O$ grapple and hoist. After the $M C O$ is in place, the turret is again rotated to position the tube plug and it is re inserted into the tube opening. The shield skirt is then raised and the MHA taken to a designated staging op storage position. MCO retrieval and replacement operations are capried out in a similar manner for transfer of $M C O$ s to and from the HCS ovens.

The dose criterion "shielding goal" for the 1444 is $2.0 \times 10^{-3}-\mathrm{mSV} / \mathrm{h}$

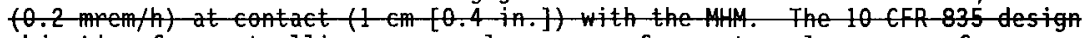
objective for controlling personnel exposure from external sources of cadiation in areas of contintous octpational to maintain exposure levels below an average of 0.5 mrem ( 5 microsieverts) per hour and as far below this average as is reasonably achievable. The $2.0 \times 10^{-3} \mathrm{mSV} / \mathrm{h}(0.2 \mathrm{mrem} / \mathrm{h})$ at contact goal considers the possibility of muttiple other sourees associated wh the CSB.

The stant-angle concrete path and the gap between-the-Mill and deck surface needs to be taken into account when estimating the dose rate at the floor surface of the operating deck. The dose rate including streaming shoutd be less than the shielding goal of $2.0 * 10^{-3}-\mathrm{mSv} / \mathrm{h} .(0.2 \mathrm{mrem} / \mathrm{h})$. The dose 
pate-was reduced by atding an extend shield gate skirt that extends at least $91 \mathrm{~cm}$ (36 in.) beyond the edge of the floor embed. Based on the pretiminary specification seoping shielding analysis (Kidl 1996b), this distance-is judged to be adequate. In addition, the MHllteck gap radiation streaming was

mitigated by the use of a steel below deck insert into the embed on the bottom of the shield gate that blocks the direct line of sight radiation as the $M C \theta$ is withdrawn into, or out of, the Hllll (there is approximate $1 \mathrm{y} 13 \mathrm{~cm}$ [5 in.] of steel blocking the path in addition to the very narrow and extended gap based on the extended-skirt described above).

The ain from the MHM carity is monitored by a tritium montor, which-atso

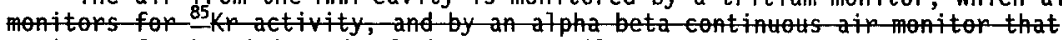
monitors for breakthrough of the MHM ventilation system's HEPA filters. The pobes are located adjucent to the exhatst of the MHH ventilation system.

2.4.2.6 Reeiving Erane. [This section has ben to section 2.5.1.1] The receiving crane is a 60 ton capacity gantry crane-with 60 ton main and one 10 ton auxiliary wire pope hoist supported on a top punning troltey (Figure 2.13). The erane operates in a chemically clean indoop enviroment in the 10 inflod out area of the CSB. The erane is atipped with a shielded operatop station together with remote accessories such as a powered rotating hook, local control panels, and a radio controlled operator station. The various tasks performed with the receiving erane are mainly associated-with off loading $M C O$ shipping casks in preparation for the MCO's transfer to the storage-rattit.

The reciving erane gantry has a span of $8.4 \mathrm{~m}(27 \mathrm{ft}, 6$ in.) and can travel $50 \mathrm{~m}(164 \mathrm{ft})$ in an east west direction. The crane runs on rumway rails that are reses and flush with the operating flook. The rumay travel of the receiving crane intersects with that of the HAl, which is atso a gantry crane system. The intersecting punay pails are coplanar and therefore have been provided with movale pail sections that match the bridge wheels on both exanes. The limits of gantry travel are established by brige stops that have been accommodated in the east and west building walls. These stops are designed to be contacted by bume mount on the gantry trucks to absorb the energy of a kinetic impact.

The receiving crane is considered de coupled from the runway-raits fe.g., no mechanical pail clampst. tateral displacement is restrained by the Wheel flanges and longitudinal displacement is restrained by the crane-wheel brakes during a seismic octurene. The receiving erane is stable against overturning during a seismic occurpence with a safety factor of 1.1 , in accopdance with ASHE NOG I (ASME 19956).

The receiving erane is provided with a hook coverage capability that extends beyond the CSB load in/load out area. The maximum hook elevation of the main hoist hook is based on the need to lift a transpontation cask containing FFFF fuel from the roud truck.

The receiving crane system is designed, fabricated, manufactured, inspect and tested in accordance with the requirements of AWREG 0554 (NAC 1979); CMAA Specification No. 70, Specifications for Top RuAning-Bridge and Gantry Type Nultiple Girder Electuic Orerhad Traveling Cranes (CMAA 1994); ASME B30.20, Below the Hook Lifting Devices (ASME 1993); and 
ASHE NOG I (ASME 1995b), TYpe I with the exeeption of NOG 5420(a) (reeving is in a with CMAA Specificution 10.70 [CMAA 1994$]$ ), and NOG 5428.1 (a) single hook is used rather than a double hook).

The receiving erane is expected to receive some radiation exposure when the shipping eask is being moved. Based on an analysis of the side expostre to the receiving crane, a maximum rate of about $11 \mathrm{~mm} / \mathrm{h}$ is obtained, on about $4 \times 10^{3}$ - Rad for a 40 year 7 ifetime total integrated dose. This is a conservative value beatse it is unlikely that the receiving crane will experience a 40 year continuous work schedule.

The receiving crane has a shielded operator-station mounted on the north bridge truck. The shielding is $9 \mathrm{~cm}(3.5$ in.) thick earben steel with viewing windows that have a shielding equivalency of $9 \mathrm{~cm}(3.5 \mathrm{in}$.) of iron or 1 Hel photons by a fator of 50 .

The reciving crane, including its load blocks, will not be expose to temperatures, pressures, op chemicals that would require special design considerations.

2.4.2.7 Tube-Vent and Purge-Carts, fThis section has ben to Section 3.5.1.6] The tube rent and purge cant (Figure 2 14) is designed to menitor storage tube gas pressure and composition, evacuate air, pressurize and dilute tube gas with inert gas, and provide for controlled venting of gases emitted from the MCOs. The gases are monitored and vented to the operating area through-HEPA filters on the cart. The cart also can maintain and replenish the inert gas atmosphere in the storage tubes. An inert pressurized atmesphere is maintained in the tubes, which contain staged HCOs, to prevent an accumulation of explosive mixtures of hydrogen and oxygen.Periodic tube renting also keps the pressure from rising high enough to activate the relief values in the plug.

The cart is connected to process piping on each tube plug. The process piping-allows monitoring and purging of the twbe atmosphere without remoring the plug. The air in the accessed tube is evactated using the vactum pump, and the inert atmosphere is supplied-from high pressure inert gas bottles on the cart. Pressurization with inert gas is controlled through a pressure regulator, and overpressurization of the tube is prevent by a relief valve. A restrictive flow path from cart to tube also makes rapid overpressurization tnlikely. The inent gas presstre in the tube-is left slightly positive after inerting, and hydrogen, periodically relieved from the $M C O$, gradtrally increases the pressure within the twbe.

The schedute fop venting, purging, and inerting the tubes is detemined from initial operating experience. The interval between scheduled visits is set so the hydrogen-concentration will be below $4 \%$ (the lower flamability Iimit for pure hydrogen in air). Temperature variations in the valut will affect the tube pressures; therefore pressure is not a sensitive indication of hydrogen concentration. Instead, the hydrogen concentration is measured each time the cart makes a schedule visit to a tube. The meastrement result is ts to adjust the schedute as necessary. Should the hydrogen concentration exeed $4 \%$, the tube gas will be diluted to below $4 \%$ before using the vacum pump. The cart includes a function to automatically dilute pressurized gas that is higher than $4 \%$ hydrogen with inert gas as the pressure is vented from 
the tubes through the cart afd into the operating area. Severat cants will be required in order to meet the contemplated schedute when vault l staging eapacity is reached. One cart will be reserved as a spare-duning nomal operatios.

The eurrently conceived pations scenario assmes that when gas generation from the first $M C O$ in a tube has declined to very low rates, a sond $M C O$ is the tube; the purging and inerting proses is red at that time. Periodically (tp to 18 times pep day), the tubes will be vented throug the cant system and peinepted at the oniginal-slightly positive tube pressure. Tubes that contain only sealed MCOS, or no MCOS, do not require sepvicing by the tube vent and purge cart. The operating philosophy witl be developed to accommodate actuat conditions expected after the MCO design and hydrogen-generation molling are complete.

During the time the cart is being used to perform venting, purging, and inerting, the portion of the conected system that is between the cart mounted HEPA filters and the tube atmosphere fills the same secondary confinement role as the-storage tubes. Under wecident eonditions this confinement provides mitigation-of radionuclide releases from-the MCOs-

2.4.2.8-Emergency Biesel Generators. [This section has been moved to Section-2.8.1.2] The emergency generator system is housed in the suppot building at the north end of the CSB. The system is composed of two identicat and redundant mits, each rated at $100 \mathrm{~kW}$ output (3 phase, $480 \mathrm{~K}$ ) and powered by a $V 6$ turbocharged diesel engine with aip starter. The engine generator sets are positioned on vibration isolators to minimize transmission of vibration. The system has been designed in accordance with Engine Oniven

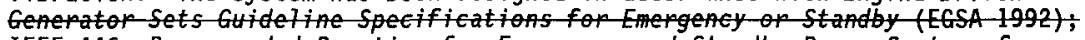
IEEE 446. Recommended Practice-for Emergency and standby Power Systems for Industrial and Comeral Applications (IEEE 1987); NFPA 70, National Electrical Code (NFPA 1993); and NFPA 110, Standard for Emergency and Standby Power Systems (AFPA 1996).

The two thits-are tocated in different rooms separated by a 2 hour firewall in accordance with ANSI/NFPA-30, Flammate and Combust ible liquids Eode (ANSI/ANFPA 1993). Erch rom houses the diesel generator set; a $190 \pm$

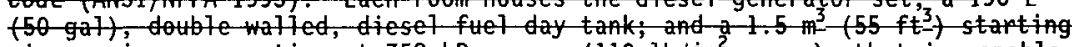
air receiver, operating at $758 \mathrm{kPa}$ gatge $\left(110.1 \mathrm{~b} / \mathrm{in}^{2}\right.$-gathe), that is cupable of providing six consecutive starts of the diesel generator. Each room also houses an automatic transfer switch that will initiate the startup of the tiesel thit on sensing a loss of offsite power.

When a loss of offsite power occurs, each of the automatic transfer switches-will send a start signal to its dedicated generator, power the emergency busses, and thus transfer the safety-class 2 loads to its generator within 15 seconds of the occurrence. The autematic transfer-switeh is programed in such a manner that after two unsucessful starting attempts, it will activate the second emergency generator to start and carny the safety elass 2 tods. The gentor will come to speed within 6 seconds of peceiving the signal to start. The two altomatic transfer switches atso are programed in stlch a way that one is a lead and will receive the starting signal first, and if for some reason it fails to operate, the second transfer switeh will take over and initiate-the-stanting procedure. 
Each generator will have a load bank penmanently installed on the exhatst side of the engine radiator, on the generator skid extension on the north side of the diesel engine. This $100 \mathrm{~kW}$ load bank will allow-genatop loa testing as ned.

Rotating-quiphent exposed to the outside contact is protected by metallic guards to prevent contact. The protection provided is in aceordace with OSHA Instruction Standard 1-12,14, fuads for Rotating Equipment (OSHA 1978). Hot surfaces of $49^{\circ} \mathrm{C}\left(120^{\circ} \mathrm{F}\right)$ or more exposed to hum reach are insulate to prevent buns. This is in aceordance with ASTMU C1055, Standard Guide for Heated-System-Surface Conditions that Produce Cont Buph Injunies (ASTM 1992).

Fwo $1,900 \mathrm{~L}(500 \mathrm{gal})$ diesel fuel storage tanks ane focated outside the nopth wall of the support building at a distance of $3-\mathrm{m}(10 \mathrm{ft})$. Each tank is a double walled, instlated, aboveground tank with a leak detection system. Overfill protection compantments can contain up to $95 \mathrm{~L}-25 \mathrm{ga} 7)$ - of overfill. When full each tank contains enough fuel to pun one diesel generatop unit for 48 houps at full power. Each tank has a positive displacement pump-mounted on the top of the tank. This pump is to react to the level controt on the 1901 $(50$ gal) day tank and keep the day tank filled with diesel fuel. The top of the storage tank is equipped with a walkway and ladders for acess and maintenance. The two diesel fuel storage tanks are to be filled by a dispenser nozzle from a diesel fuel truck.

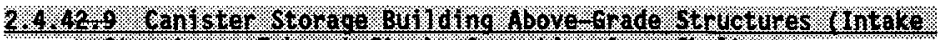

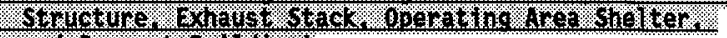

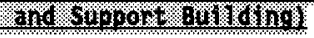

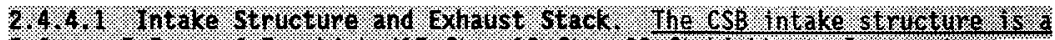

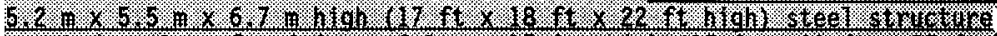

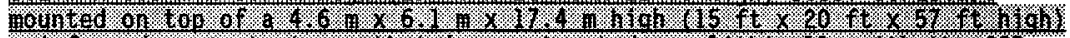

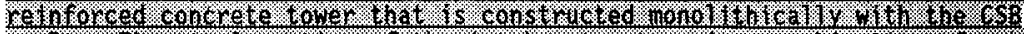

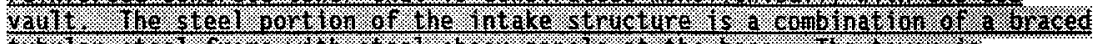

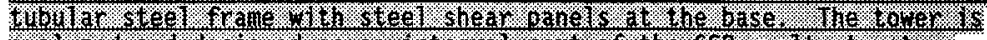

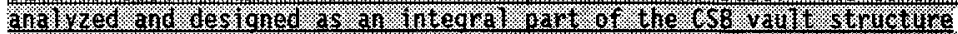

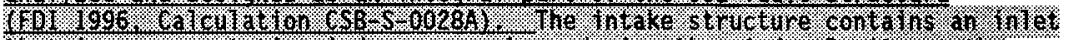

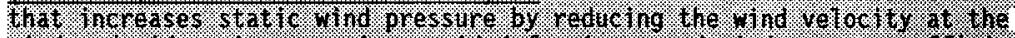

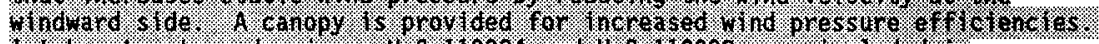

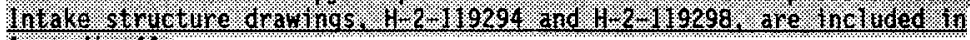

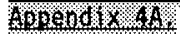

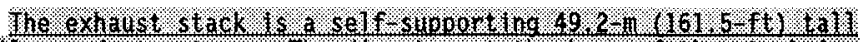

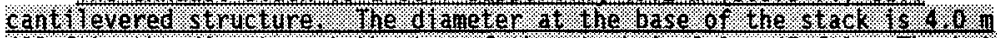

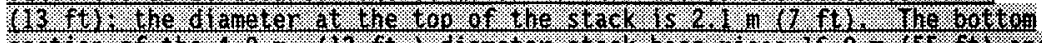

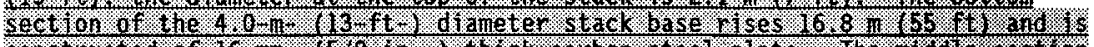

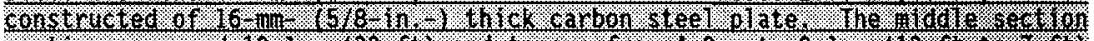

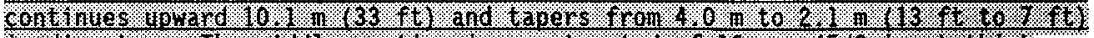

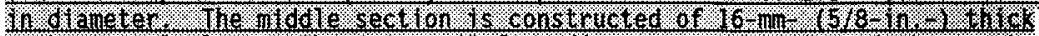

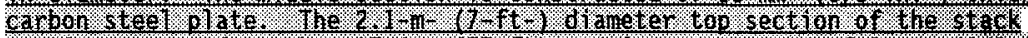

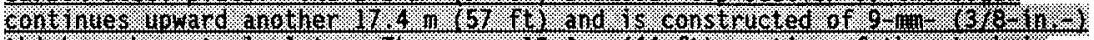

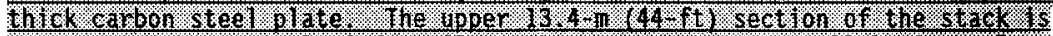

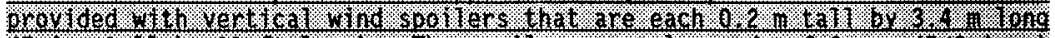

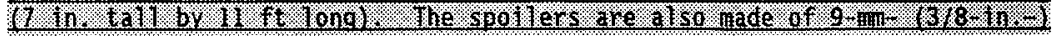




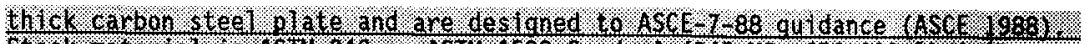

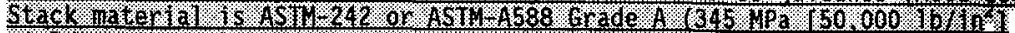

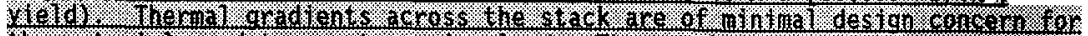

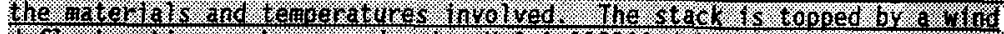

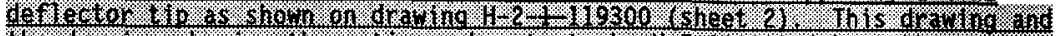

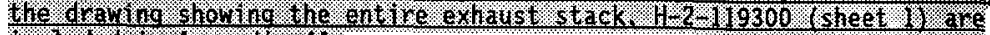

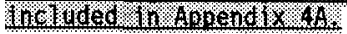

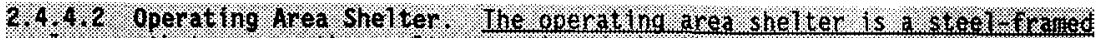

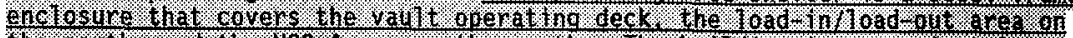

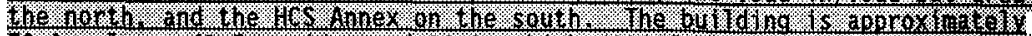

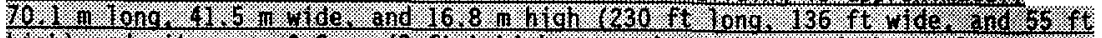

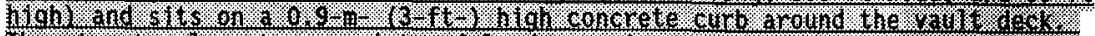

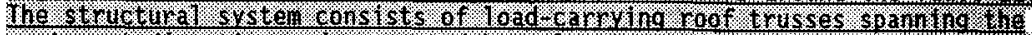

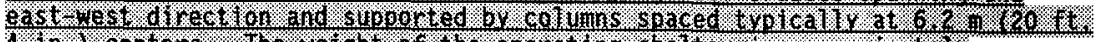

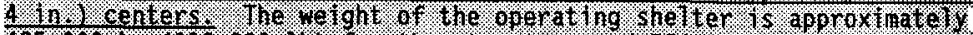

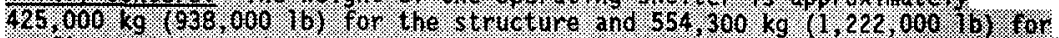

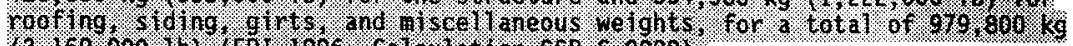

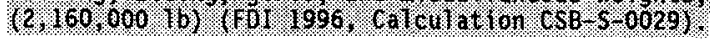

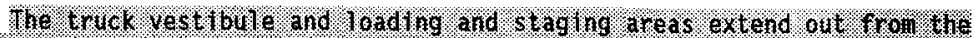

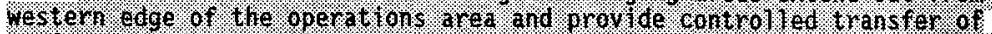

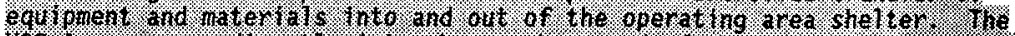

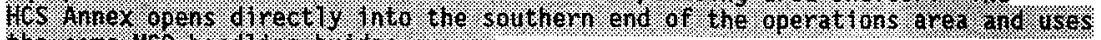

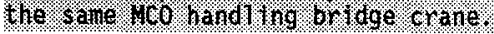

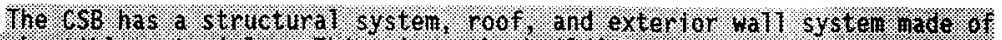

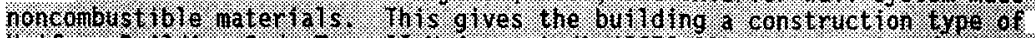

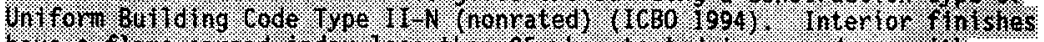

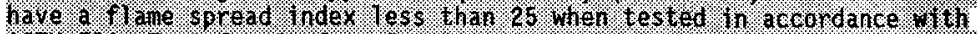

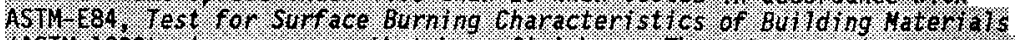

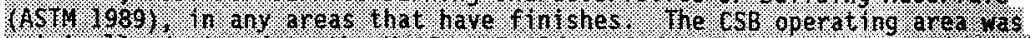

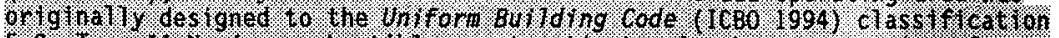

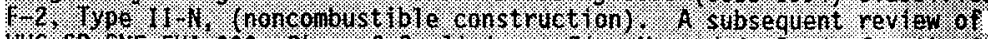

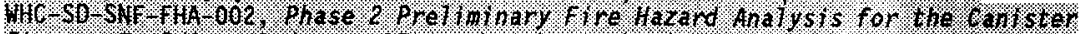

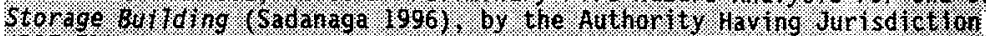

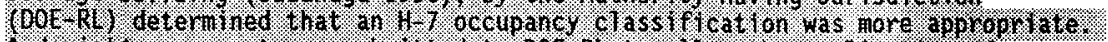

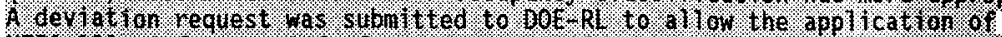

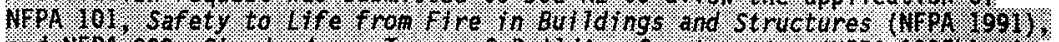

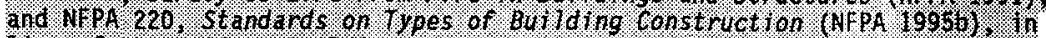

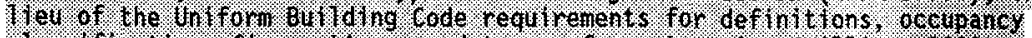

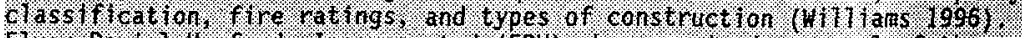

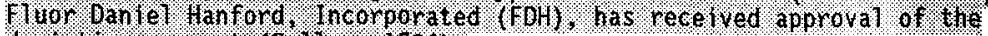

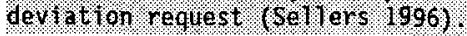

The roof systel. provides an imperv lous weathemproof barr ler over the

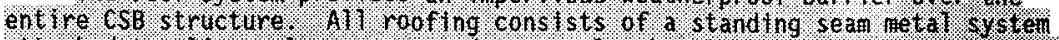

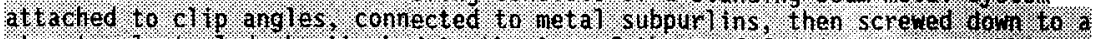

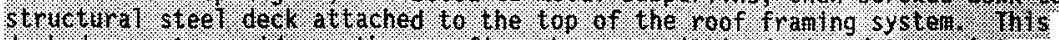
deck does not provioe weather proof ing, however, it is des gned to rest st

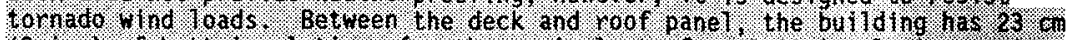

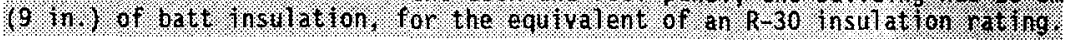




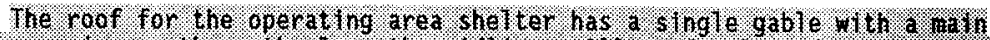

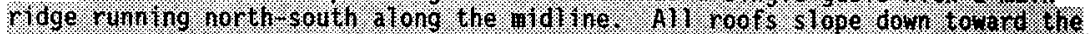

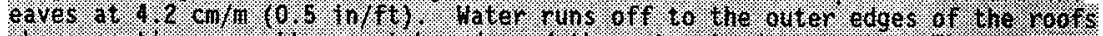

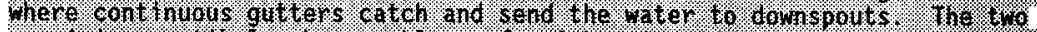

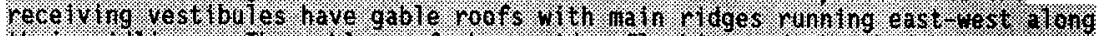

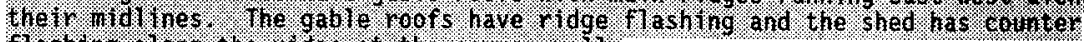
flashing along the , rigge at the cominon wath.

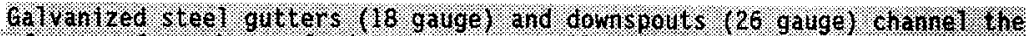

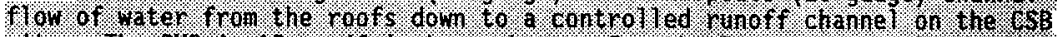

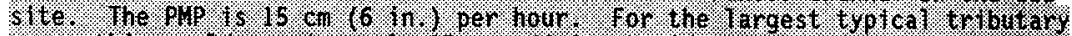

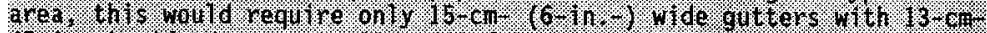

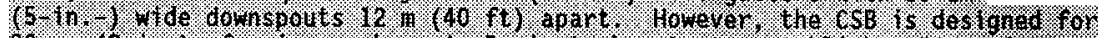

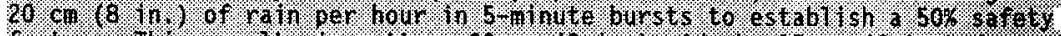

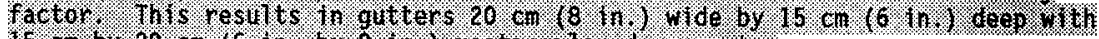

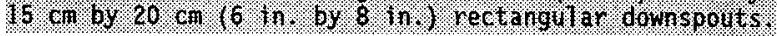

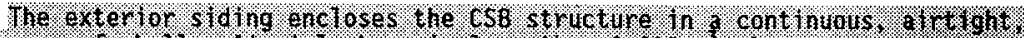

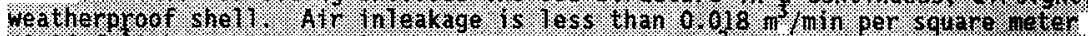

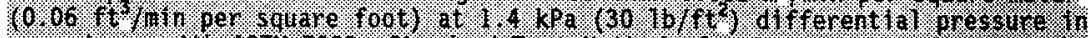

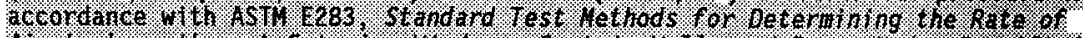

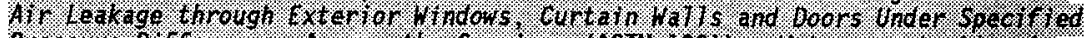

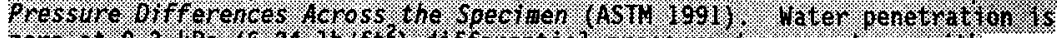

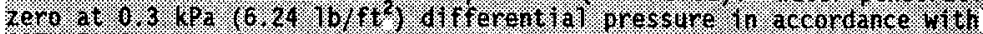

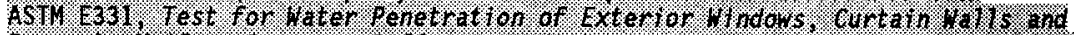

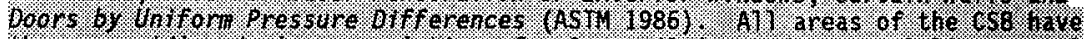

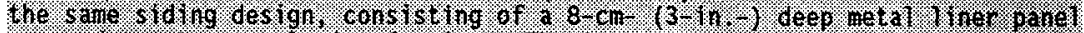

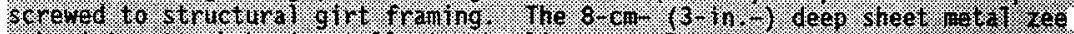

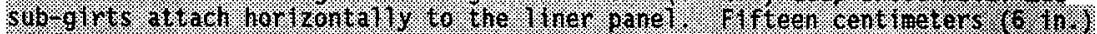

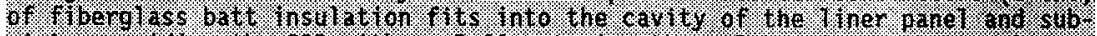

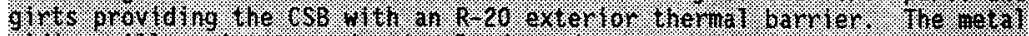

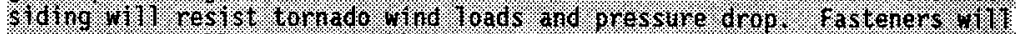

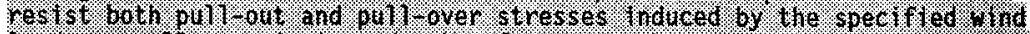

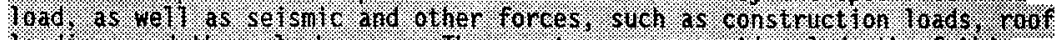

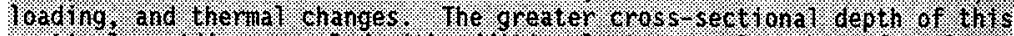

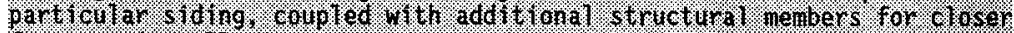

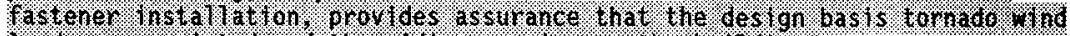

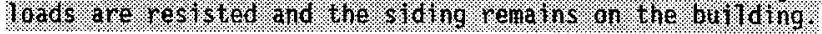

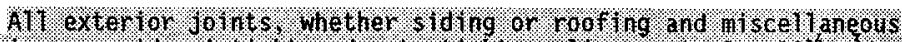

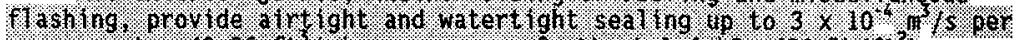

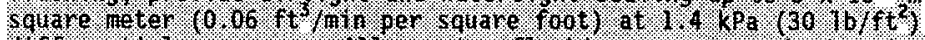

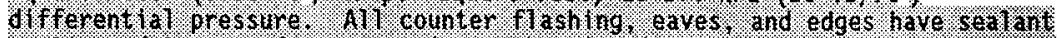

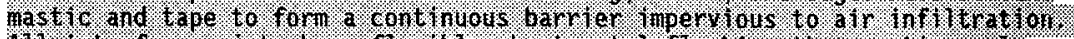

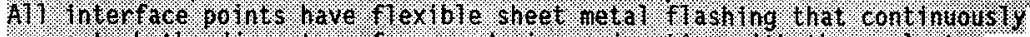

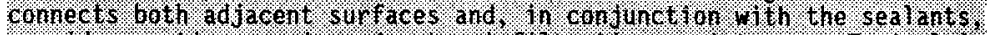

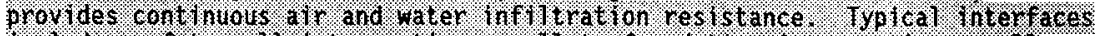

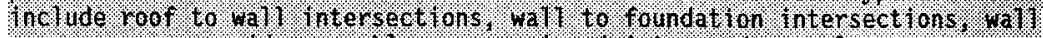
conners, eaves, ridges, gables, expans on jolnts, and reveals.

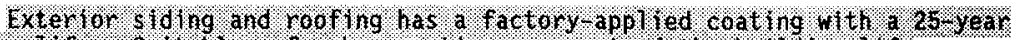

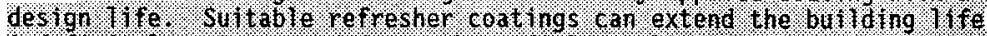

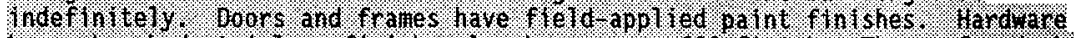

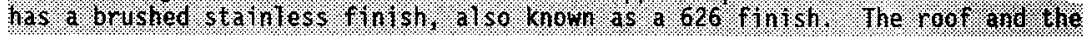




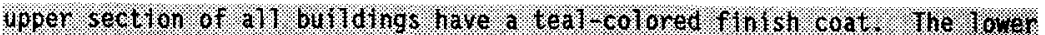

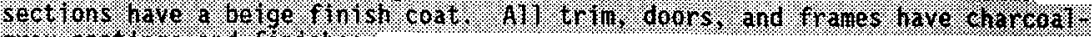

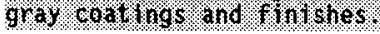

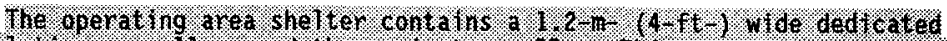

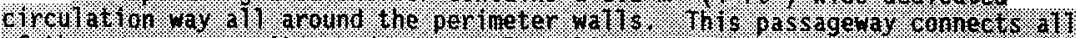

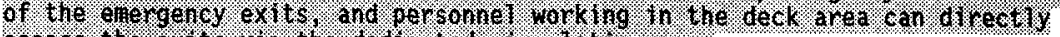

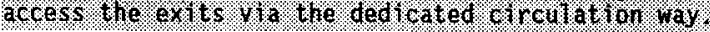

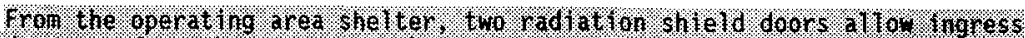

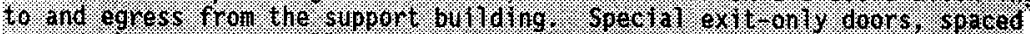

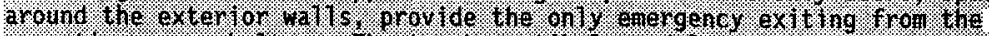

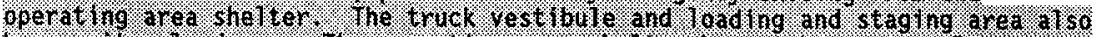

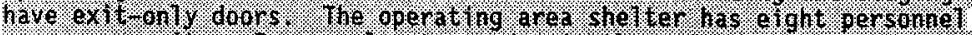

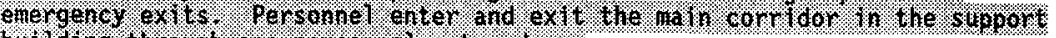
builoligg through one gersonnet entry ogor:

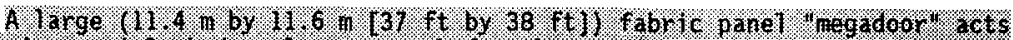

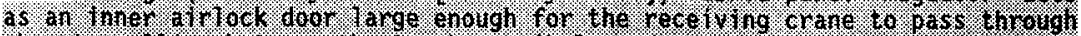

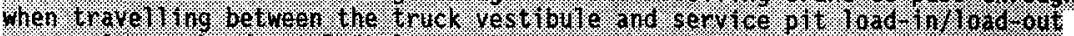

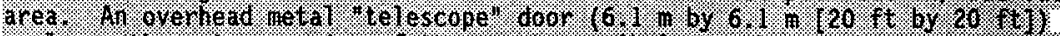

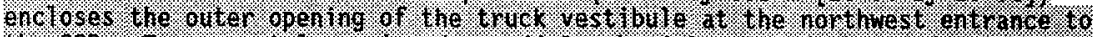

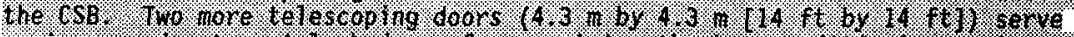

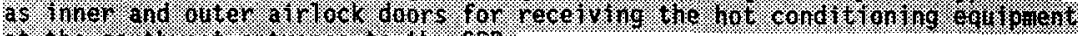

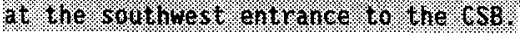

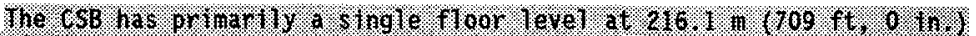

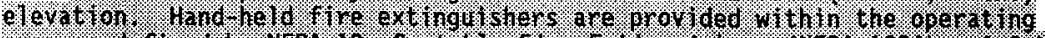

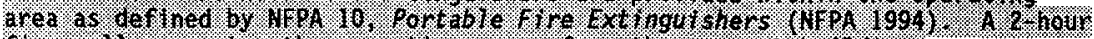

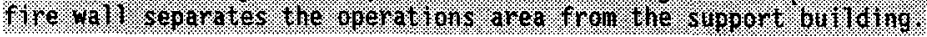

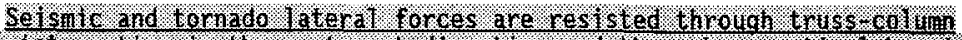

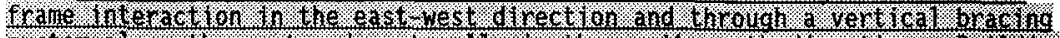

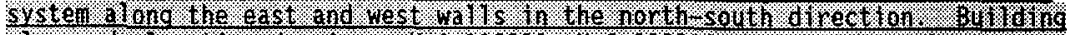

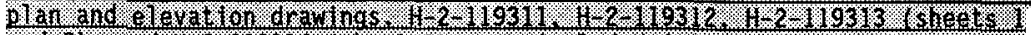

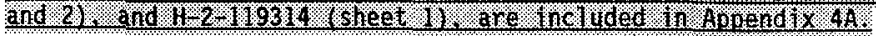

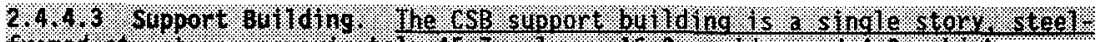

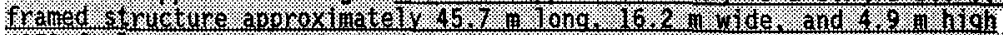

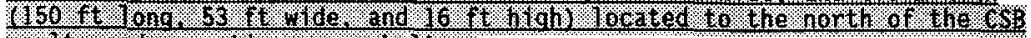

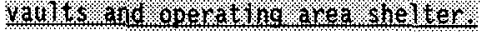

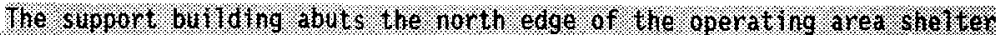

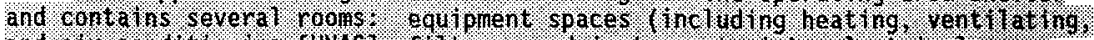

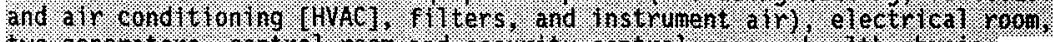

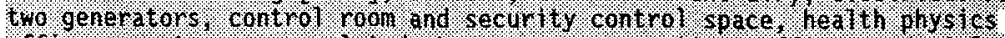

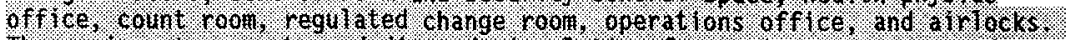

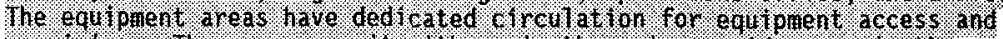

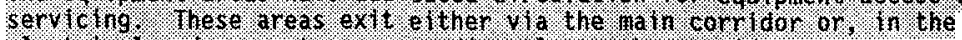

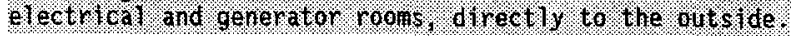

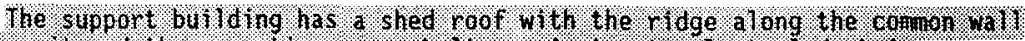

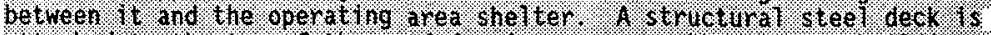

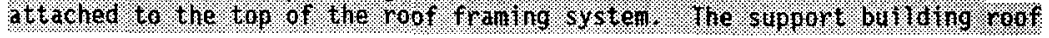




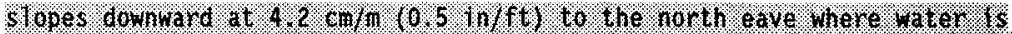

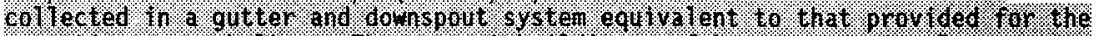

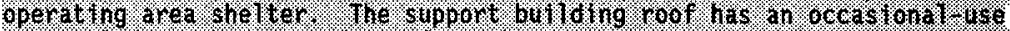

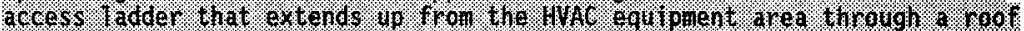

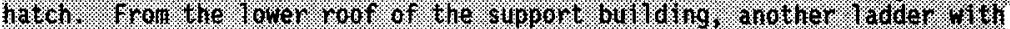
safety cage extends up to the high roor of the operathing area shater.

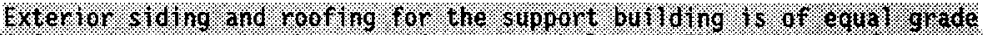

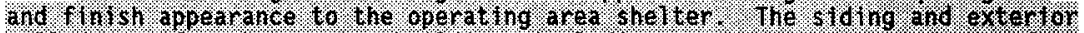

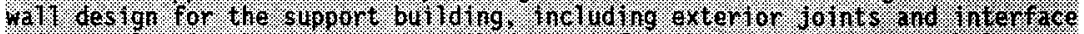

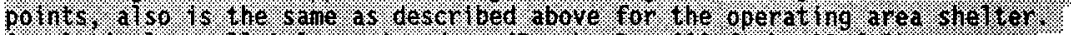

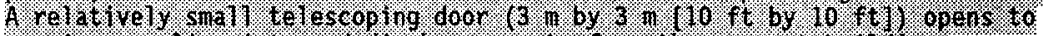

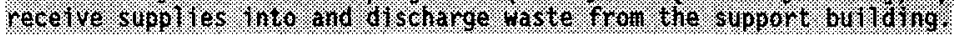

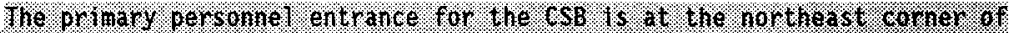

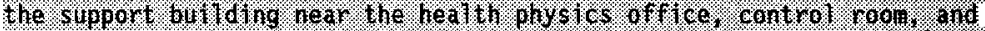

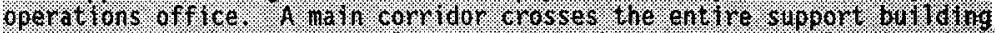

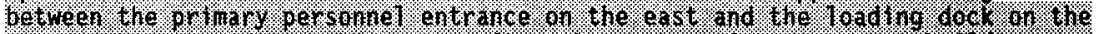

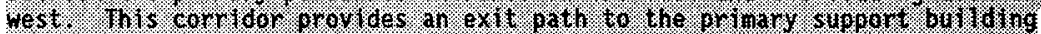

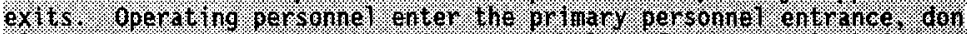

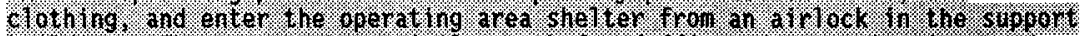

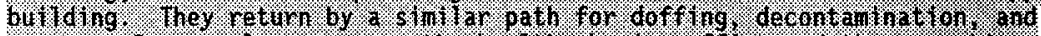

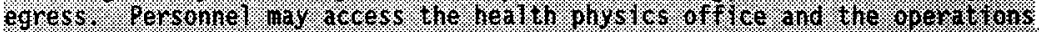

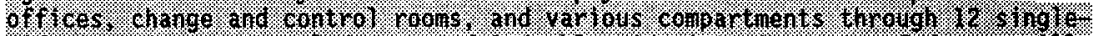

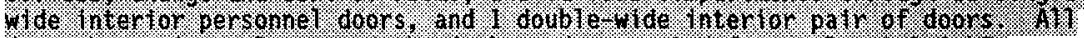

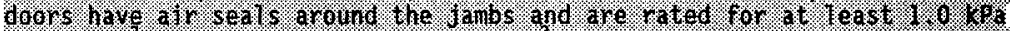

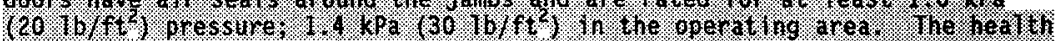

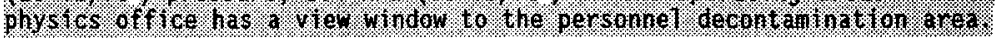

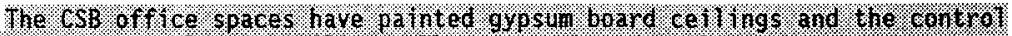

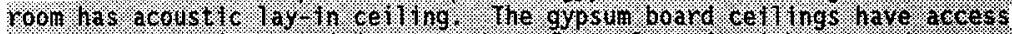

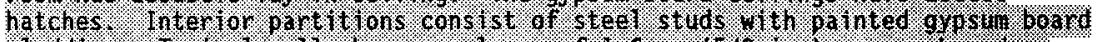

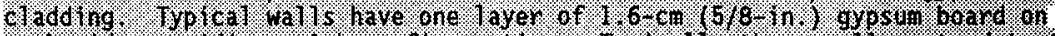

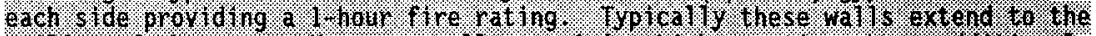

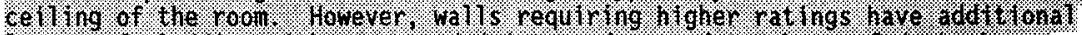

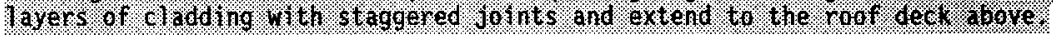

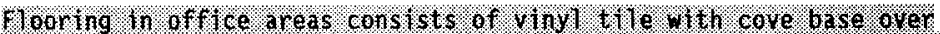

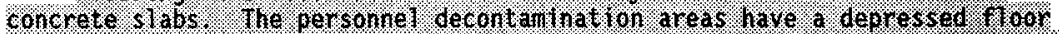

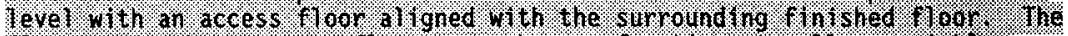

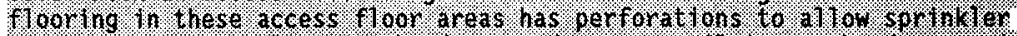

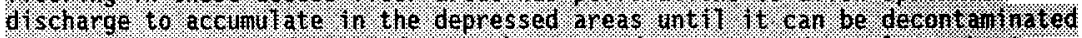

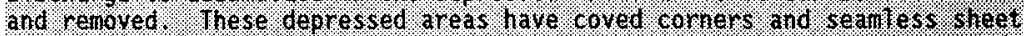

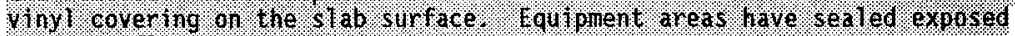
concrete $100 \mathrm{ss}$.

Entry 10 the electrical roon is. through one tal s exterior doubla doo.

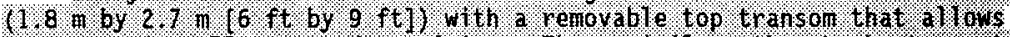

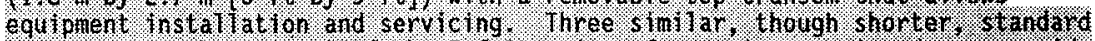

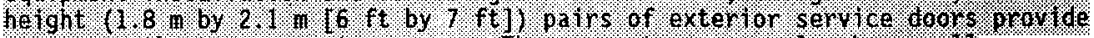
access 10 the two generator rooms, The generator roons al so have wath

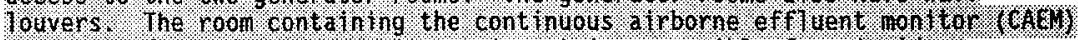

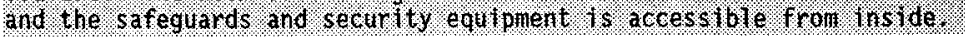




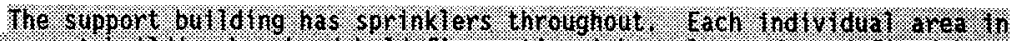

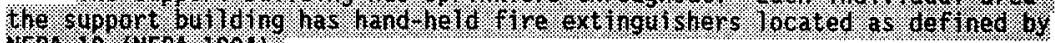

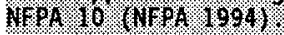

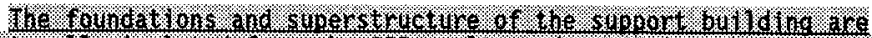

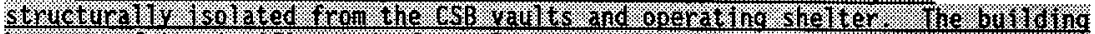

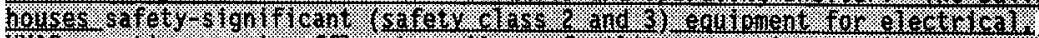

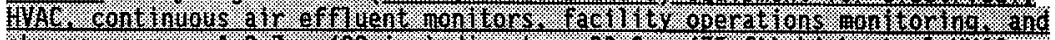

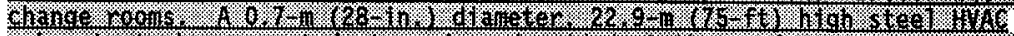

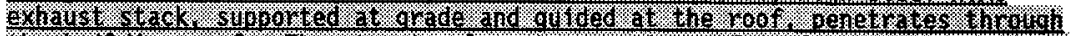

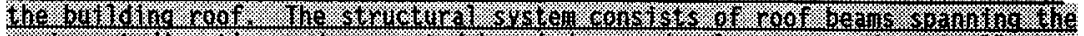

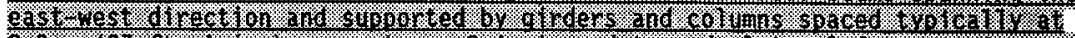

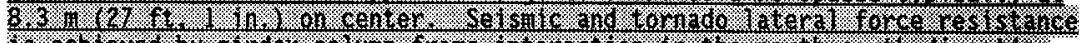

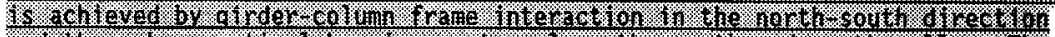

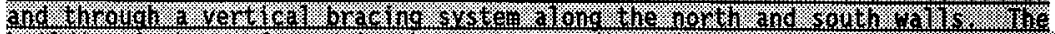

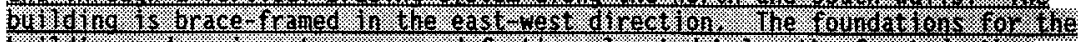

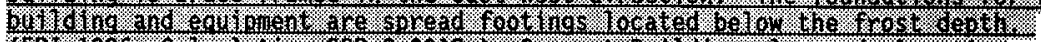

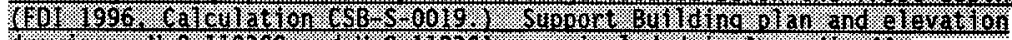

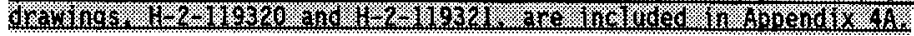

\subsubsection{Facility Mission}

[This section has been moved to Section 2.3.1] Vault 1 will contain-220 storage tubes, exch cupable of staging op stoping two MCOs. Six additional locations are available to accomodate overpacked MCOs. Each standard storage tube-wi77 contain both a bottom and an intermediate impact absorber to mitigate the consequences of a dropped $M C O$. The storage tubes are safety elass 1 , and along with the impact absorbers, they are designed to withstand all enedible DBAs discussed in Section 3.4 .2 of this document including dropping of MCOS. The impact absorbers will be designed to prevent the breach of the-storage tube and the $\mathrm{MCO}$.

Initially the MCOs containing-SNF will be staged in an inepted seated condition-in the storage tubes. Because of the fotential for hyogen generation and buildup from both radiolytic and chemical reactions of the bound and free water in the $M C O$ after cold vatum drying, the operating deck design will have provisions to periodically evacuate and reinert each storage tube. The design provisions include the tube plug covers (which allow-aceess to tube plug service connections), sepvice connections in the tube plugs, and efectrical power outlets in the floor. Eventwally the-MCOs-will be processed in the HCS Annex. Current planning calls for the MCOs to be-stored in a sealed configuration upon completion of HCS processing.

\subsubsection{Facility Design Assumptions}

The following was moved to Section 2.4.1] Shielding calculations have assumed that each $M C O$ contains the maximum activity value associated with Mark IV (HKIV) fuel listed in Table 3.2.2.1.2.2 I and described in Section 3.2.2.1.6 of WHC $S 0425$, Penformes Specifiction for the spent Auclear Fuel Canistep Storage-Building (Swenson 1996). (The following information is overed in Section 2.3.3] Vautt thermal analyses have assumed that $20 \%$ of the MCOs contain the maximum heat-value associated with MKIV fuel 
and $80 \%$ contain the areage value, as directed by the design athority in WHC S 0425 (Swenson 1996), Section 3.2.2.1.2.2, "Design Feed," and Fable 3.2.2.1.2.2 2, "MCO Geneal Attributes." The following information is in Section 2.5.2] Evaluations of hydrogen generation pates and HCO pressunization were based on WHC SQ SHF. II O29, NUIt; Canister Overpack (HCO) Pressurization Analysis (Bergsman 1996).

The following information has been moved to section 2.5.1] The presence of water in an $\mathrm{HCO}$ will incease the pate of hydrogen generation and the pate at which $\mathrm{ACO}$ pressure increases. The hydrogen pressure control strutegy includes the following steps:

- Cold vacum drying to remove all of the free water, significantly peducing the reaction rate

- Independent testing to confirm that the fuel is dry by measuring the pate at which the pressure increases white the ful (MCO) is heated to $75^{\circ} \mathrm{C}\left(167^{\circ} \mathrm{F}\right)$

-. Selection of an appropriate nomal condition of transpopt time (TBO)

- Verification that the pressure and temperature within the MCO does not exced technical safety requipement (TSR) values priop to ESB ipt

- Hot conditioning to decompose any residual free watep and decompose hydrates and hydrides prior to long term interim storge.

The following has been moved to section 2.5.1] Hydrogen generated in the SNF contained in the MCOS is assme to presturize the MCO fand periodically release from the MCOs) and cause a pise in the storage tube prestre. The $\mathrm{H}_{2}$ generation is caused by coprosion, ratiolys is of water, and by decomposition of hydrides and hydrates in the SNF within the MCOS.-

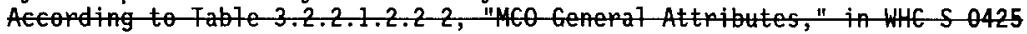
(Swenson 1996), the quantity of water present in an $M C 0$ is $1.8 \mathrm{~kg}$ (4 $\mathrm{lb}$ ). This is based on the conservative assumption that $1.8 \mathrm{~kg}(4 \mathrm{lb})$ is the maximum expected amount, with $0.45 \mathrm{~kg}(1-1 \mathrm{~b})$ being the arepage.

The following has to setion 2.4 .37 To recount for tncertainties in the final $M C O$ design, the storage tube impact absorber has been designed assuming a maximum $M C \theta$ weight of $9,120-\mathrm{kg}(20,100-1 \mathrm{~b})$ as compared with the maximum value of $8,869 \mathrm{~kg}(19,512 \mathrm{lb})$ given in fable 3.2 .2 .1 .2 .2 2 of WHE 50425 (Swenson 1996)-

HThe folfowing has to section 2.4.3] In specifying the lower impact absorber, the results contained in Lettep SCS $W-96-576$, Orop Analysis of $\mathrm{Nulti}$ Canister overpack in Canister Storage Building (Hyde 19962) were used. The report (Hyde 1996a) indicates that the impact absorbers shoutd be designe to limit the MCO-deceleration to 35 9. Funther analysis shows that an-intermediate impact absorber is required between MCOs to prevent local damage to the shield plug top and to protect the mechanical seal from damage. The design of the intermediate absopber bottom will need to accomolate the HCO venting and pressure relief functions. In the event of an oreppesurization, the released gas would travel to the annulus between the 
MCO and storage tube. The bottom impact absopber is specified to limit its sideward thrust on the storage during deformation to that of the tube's working pressure. The bottom and intermediate impact absorbers are shown on Figure 29 .

The following has been moved to section 2.4 .3 T The tube plug leak rate will be tested each time the tube is refilled with inept gas, using the same eriteria as for constrution aceptance. The curpent tube plug acceptance specification includes a test procedure to verify that the leak rate through the double-seat is less than $1 \times 10^{-4}$-standard em $\mathrm{m}^{3}\left(3.5 \times 10^{-9}\right.$ standard $\mathrm{ft} / \mathrm{sec}$ ) at a test pressure of $27 \mathrm{kPa}$ gatge $\left(4 \mathrm{lb} / \mathrm{in}^{2}-\mathrm{gauge}\right)$. This test pressure enstres retention of inerting gas int the tubes during nomat opepations. Since this test measures leakage from the middle (out through both seals at once), the in service leakage rate through one seal at a time will be lower (one fourth on average). This leakage rate was chosen to minimize-the release of contamination from the tube in the-event of a bupst MCO pupture disk. Relief valves-in the plug are designed to lift at $62 \mathrm{kPa}$ $\left(9-1 \mathrm{~b} / \mathrm{in}^{2}\right)$, thus providing a means for the inepted storage tubes to mathtain a nomal operating pressure of $7 \mathrm{kPa}$ to $28 \mathrm{kPa}$ gauge (1 to $4-1 \mathrm{~b} / \mathrm{in}^{2}$ gauge). The storage tube plug must be fastened to the tube to prevent the plug from 7 ifting at the tube system design pressure of $524 \mathrm{kPa}\left(76-1 \mathrm{~b} / \mathrm{in}^{2}\right)$ gauge. The appoximate weight of the standar size storage tube-plug is $2,406 \mathrm{~kg}$ $(5,300-1 b)$. Buring an $\mathrm{HCO}$ overpressunization accident as deseribed in Section 3.4.2.1, the MCO presture will reach $1.0 \mathrm{MPa}\left(150-1 \mathrm{~b} / \mathrm{in}^{2}\right.$-gatige) above the tube pressure before the MCO pupture disk bursts. Should the resultant pise in tube pressure exced the HEPA filtered plug's renting capabilities, the lifting forces on the tube plug could result in the release of unfiltered storage tube gases past the seals and into the operating area. The design of the storage tube plug-seals, relief valves, HEPA filters and lock down devices, as deseribed in section 4.3.5.2, mitigates against this release.

\subsubsection{Facility Modifications to Hanford Waste Vitrification plant Canistep Storage Building}

This section has ben to section 2.3.3] The conversion of the CSB from the HWVP mission to the curpent SNF mission resulted in two structural pevisions-made possible by the lower radiation source term and lower heat load associated with the SAF MCOS as compared with the HWVP-canisters. One is the removal of the intake plenum-lowers in all three ratts. The other is the deletion of insulating concrete on the interion walls and underside of the operating deck in vatt 1 .

The total activity for one- $M C 0$ is given as $309,883 C_{i}$ rensts $891,000 \mathrm{C}$ i $\left(5.4 *-10^{3}-\mathrm{Ci} / \mathrm{gal} * 165 \mathrm{ga}\right)$ for a vitrified waste eanister. This information tan be butined from Table 3.2 .2 .1 .2 .21 of WHE $S-0425$ (Swenson 1996) and Fab 8.2 2 of WHC SO HWV PSAR 001 (WHC 1994). Shielding andlys is results indicate that the dose rate at the base of the intake stack is less than $5.0 \times 10^{-4} \mathrm{mSr} / \mathrm{h}(0.05 \mathrm{mrem} / \mathrm{h})$, and in the adjoining below grade valt, the dose rate is less than $4.0-10^{-3}-\mathrm{mSv} / \mathrm{h}(0.4 \mathrm{mrem} / \mathrm{h})$ (Sienko 1996).

On page 3-32 of the WHC SO HWH PSE OO1 (WHC 1992), the heat loads for the HWW canisters in the three vatlts are given as 800 canisters at $0.4 \mathrm{~kW}$ and 1,200 canisters at $1 \mathrm{~kW}$ for a total CSB heat foad of $1,520 \mathrm{~kW}(507 \mathrm{~kW}$ per 
vault). In Section 3.2.2.1.2.2 of WHC $S 0425$ (Swenson 1996), the SAF MCO heat tou for watt is given as $80 \%$ at $401 \mathrm{~W}$ and $20 \%$ at $852 \mathrm{~W}$ fop a total of $192 \mathrm{~kW}$ for $390 \mathrm{MCOS}$. Based on these conseprative assumptions, results of the thermal andysis indicate that the maximum air temperature inside the vaut is $56^{\circ} \mathrm{C}\left(133^{\circ} \mathrm{F}\right)$ coincident-with a steady state intake dip temperature of $46^{\circ} \mathrm{C}$ $\left(115^{\circ} \mathrm{F}\right)$. This pestlt is below the ANSI/ACI 349 90 (ANSI/ACI 1990) $1 \mathrm{imit}$ of $65^{\circ} \mathrm{C}$ ( $\left.150^{\circ} \mathrm{F}\right)$ for reduction of concrete strength. See Chapter 4.0 for funther information. Unter these conditions the wall temperature of the MCO is conservatively estimated to be $118^{\circ} \mathrm{C}$ ( $\left.244^{\circ} \mathrm{F}\right)$, wh is well below the performance specification (Swenson 1996) 7 imit- of $132{ }^{\circ} \mathrm{C}$ (270 ${ }^{\circ} \mathrm{F}$ ) wall temperature required to ensure not exceeding 204 of $(400$ of $)$ for fuet centerline temperature.

The CSB design for the HWV mission had partial length, below grade interionwalls and commen intake and exhaust plenums. The current CSB configuration, as shown-in figures 22 and 23 , extends the below grade walls to isolate the individual vallts and creates individual intake and exhaust plenums for each vautt. This sign hange atso aided in the deletion of the intake shielding louvers.

The below grade portion of the HWVP CSB was designed to carpy the loads associated with a large, wheled, shielded eanister transpopter that was to be Used for the HWVP mission. The current CSB configuration assumes a large heary crane, the MAM, is Used to transpont the MCOS. The MHA is designed to ride on steel rails that wun nopth to south and are-located at the $216.1 \mathrm{~m}$ (709 ft; 0 in.) floor elevation. Anchor bolts will be installed in the deck at the east and west sides of the operating floor for the installation of punway rails. The MHM-rails will be installed during construction of the operating area supenstructure. The MHAl rails will be installed in trenches that will run north to south and cut across the receiving crane rails. The iving exane rails will be installed-in trenches that run east to west in the northernmest portion of the operating floor. The reinfored concrete construction of that nonthernmest portion of the operating floor known as the load in/load out area is included in this Phase 2 of the CSB SAR. The peceiving crane rails will be installed during construction of the operating area supepstructure. Special rail erossover compents called "frogs" will be provided in the locations where the MHll punway pails cross the receiving erane rumay rails. Details of the MHIM and other MCO related handing a will be provided in Phase 3 of the CSB SAR.

BOE Order $6430.1 \mathrm{~A}$, Section $1300-3.2$, considers safety class items as those whose failure would result in exposures exceding DOE 5400 sepies 7 imits for the public at the Site boundary or nearest point of public acess. For the Hanford site's 200 Area, this distance is $15,000 \mathrm{~m}(9.3 \mathrm{mi})$. The Regulatory Requirements Team's application of NRC equivalency has resulted in the requirement to ident ify $S S C$ s that should be designated as important to safety in aceordance with 10 CFR 72 , Section 72.3 , as implemented through fection 72.106 (Garvin 1996a). Once SSCs "impontant to safety" have been identified, the requirements for safety class 1 SSCs are imposed on them as defined in Rerision 1 of WHC 4H-46, section 9.0, "Safety Classification of Structures, Systems and Components."

The facility design has been evaluated fop the natural hemena loads listed on Table 123 of section 1.5, "Hatural Phenemena Threats." NPH wind 
toads associated with a reactor design basis tornado were-evaluated using the tornado wind load from Table 123 , given as $322 \mathrm{~km} / \mathrm{h}(200 \mathrm{mi} / \mathrm{h})$ total, versts the SDC 4.1 wind load of $145 \mathrm{~km} / \mathrm{h}(90 \mathrm{mi} / \mathrm{h})$ (DOE RL 1993). This higher wind toad on the operating area stperstructure and support butiding was incorporated into the appropriate analys is and load combination for the operating deck and below grade vallt (FDI 1996b, Caleulations CSB S 0023, ESB S 0025, CSB S 0026).

The intake and exhaust bases of the operating deck structure wepe pesigned to withstand torna wind loads to meet the NRC torna eriteria for reactors as discussed in Section 1,4,1,1,4. The analys is and design of the superstructure formorna generate missiles is disetused-further in Section $4.3 \cdot 4 \cdot 4$.

The architect engineer has performed a review of the performance pequirements and design eriteriz imposed by ANSI/ANS 57.91992 (ANSI/ANS 1992). Section-6.17.1.1 of ANSI/ANS 57.9.1992 requires that the most adverse dead load loading condition be increased by $5 \%$ from the stimated value. The effects of an increase in the deat load have been included in the ESB design. The stbstructure walls, piers, and basemat cont intle to provide the strength needed to meet the criteria. The major difference between the CSB and the generic requirements of ANSI/ANS 57.9 1992 (ANSI/ANS 1992) is that in ANS1/ANS 57.9 1992 transpoptation package washdown, ontamination facilities, and safety class electrical power for instrumentation, lighting, commications, and physical secupity systems are assumed to be necesary. The technicul justifications for not implementing the requirements demenstrated that nutelear-safety of the facility was not impaired and that the requirements could be met by other facilities (Jacobs 1996a). Radioactive waste treatment facilities are not included in the CSB design becuse the volume of radioactive waste expected to be generated from CSB openations is vay small and does not pequire an onsite dedicated padioactive waste treatment facility. Liquid radioactive wate from the CSB can be shipped by truck to the Effluent freatment Facility in the 200 East Area. Emergency communications equipment is not provided as papt of the CSB design becuse no dedicatemergency commication center is required: such communications will be handled through systems that interface with the Central Alarm Station. Fwo independent emergency generators provide backup power to safety significant electrical loads. The generators and electrical distribution system are designed to meet the requirements of WHC CM $4-46$ incluting the requirement that the system have sufficient redundancy to power safety significant touts if one of its coments fails to

\subsubsection{Construction Restart Issues}

[This section has been moved to section 2.3.4] A readiness for construction task force of key project participants identified open isstres that needed to be addressed before the restart of construction. These-isstes are documented in Report Ho. 951108001 , Cantiter Storat Butlding Construction Restant Readiness Assessment (Ares 1996). One of the requirements was to doement the acceptability of the existing basemat before the resumption of CSB construction. Betailed inspections and evaluations of the acceptability of the existing basemat foundation were pepfomed and documented, including a review of the adequacy and completeness of the 
construction quality assurance records. The peview is further discussed-in Section 14.5.5.1.4.

The architect-engineen prepared a statement of work document for the construction management organization to use as guidance for the inspection walkewn and report. This ensured that the report would antain sufficient information for the arehitect engineer to adequately evaluate the acceptability of the existing basemat. Detailed instructions to prepare the existing concrete for the resumption of constrution were provided on the architect engineep's construction drawings and specifications.

Following the submittal of the arehitect engineep's statement of work for the inspection walk tow, the constrution management organization performed a detailed inspection of the below grade vault basemat and partially completed walls (Istam 1996). The results were categorized and submited by the construction management organization for disposition by the architect engineer. Category 1,2 , and 3 deficiencies are from CSB construction errops. Enviroment affect defieiencies are in eategory 4. To date-a77 category 1, $z$, and 3 deficiencies have been dispositioned. Category 4 deficiencies dealing with rebar, rust-stains, and basemat embed sunface rust have been dispositioned (Montimer 1996). Deficiencies dealing with coupleps have been dispositioned. The information on tisposition is cont ined-in RFI:PY T3-001, Engineering Assessment Inspection (FQI 1996a).

\subsection{PROCESS DESCRIPTION}

\subsubsection{Baseline Operations}

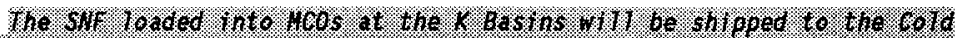

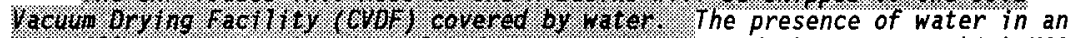
MCO wAl-increases the rate of hydrogen generation and the rate at which $\mathrm{MCO}$ pressure increases. The hydrogen pressure control strategy includes the following steps:

- Cold vacuum drying to remove all of the free water, significantly reducing the reaction rate

- Testing at the owof to confirm that the fuel is dry by measuring the rate at which the pressure increases while the fuel (MCO) is heated to $75{ }^{\circ} \mathrm{C}\left(167^{\circ} \mathrm{F}\right)$

- Selection of an appropriate normal-condition-of-transport time

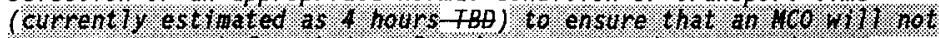

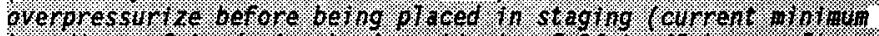

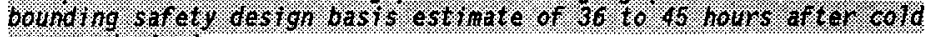

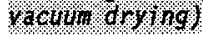

- Verification that the pressure and temperture within the HCo does not exceed t $x$ gedtof technical safety requirement (TSR) values priop to CSB reetpt

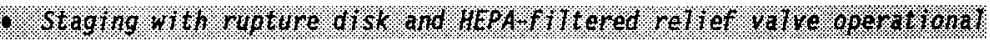


HNF-SD-SNF-RPT-004 REV 6

- Hot conditioning to decompose any residual free water and decompose hydrates and hydrides prior to long-term interim storage

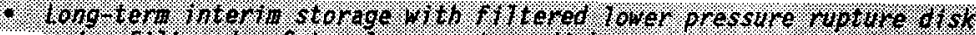

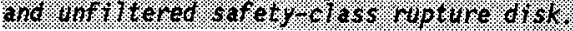

The MCO is shipped from the CVDFS to the CSB inside the cask in a seated

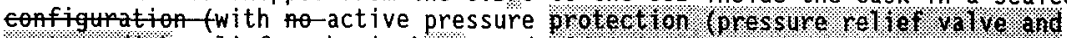
ropure olsk relief manism). transportation and receiving at the CSB reduce the potential for significant

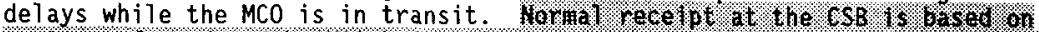

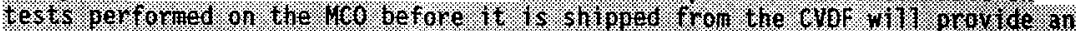

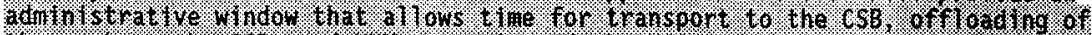

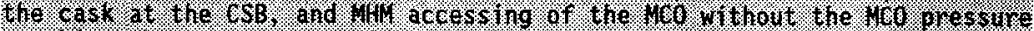

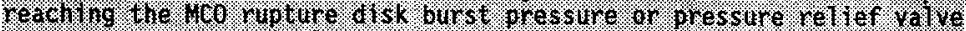
9.6-sure Upon arrival at the CSB, the cask containing the MCO is unloaded

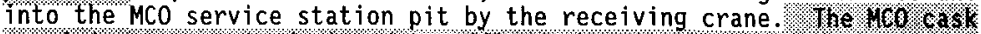

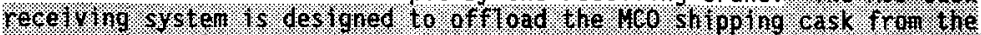

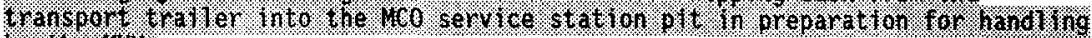
by the thet

Once the cask is inside the pit, the gas inside the cask is checked for excessive pressure, which would indicate excessive temperature or gas leakage

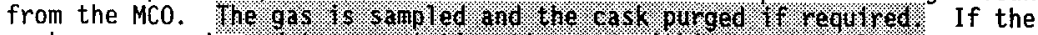

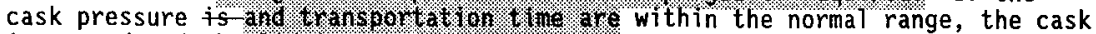
is vented and the Tid is removed to prepare the MCO for seatestaging. Preparation consists of pemoving the flange-covers from the MCO rupture-disk and relief valve ports. The HCO must be vented before removing these covers in opder to prevent accidental damage to a pressumizedpture disk duning matlal operations. After the covers are-removed, the vent connection is used to test for leakage from the rupture disk op relief valve. The final steps in preparation are pepestrization of the $M C O$ with inert gas to $21 \mathrm{kPa}$ gauge (3 lo/in'-gauge) and reinstallation of the process vent connection cover. A service station portable ventilation enclosure provides secondary

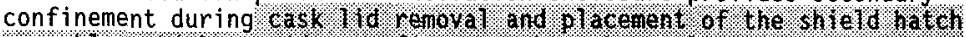

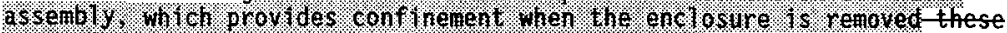
operations. Onee reinenting operations are completed, The MCO is removed from

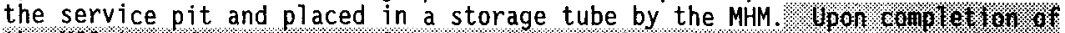

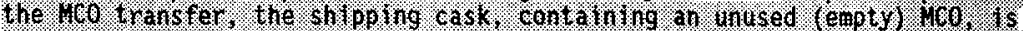

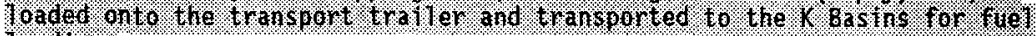
10 a. 1109.

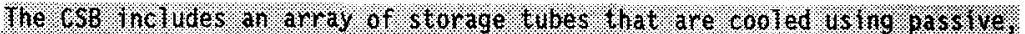

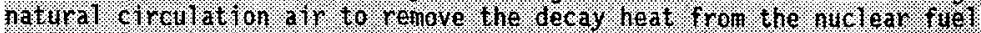

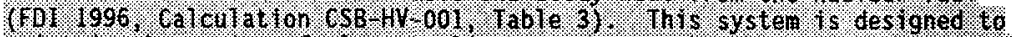

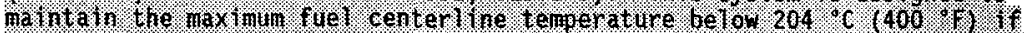

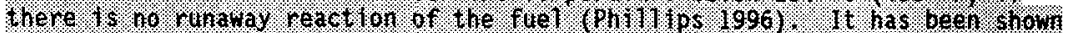

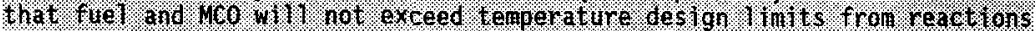

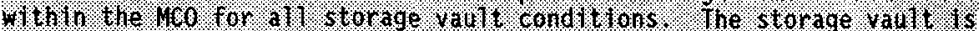

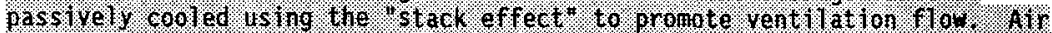

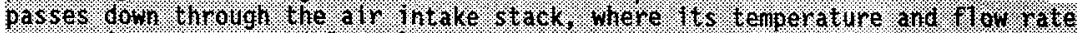

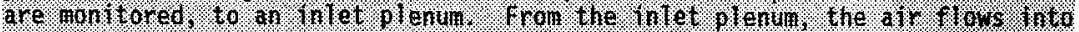

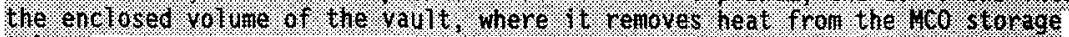
yoes. 
Hydrogen generated in the SAF contained in the MCOS is zssumed to pressurize the $M C O$ (and periodically release from the $N G O s$ ) and callse a rise in the storage tube pressure. The $H_{3}$ generation is caused by conposion, radiolysis of water, and by decompostion of hydnides and hydrates in the SNF within the HCOS. According to Table 3.2.2.1.2.2.2, "NCO Genenal Attributes," in WIIC $S 0425$ (Swenson 1996), the quatity of water prest in an $N C 0$ is $1.8 \mathrm{~kg}(4 \mathrm{lb})$. This is based on the conservative assumption that $1.8 \mathrm{~kg}$ $(4-1 b)$ is the maximum expected amount, with $0.45 \mathrm{~kg}(1 \mathrm{lb})$ being the areage.

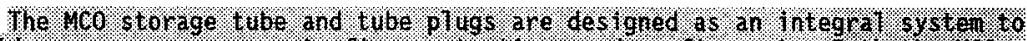

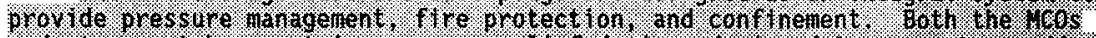

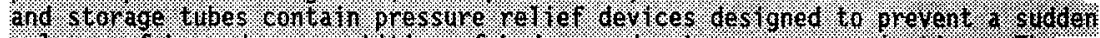

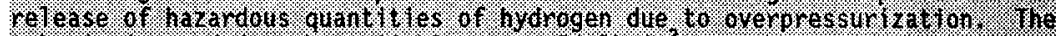

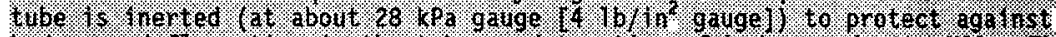

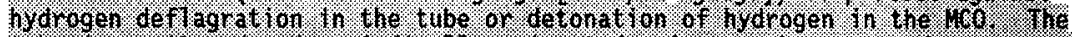

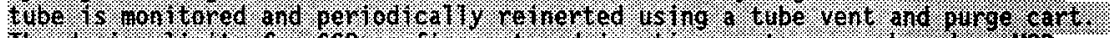

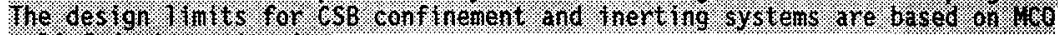

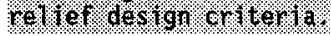

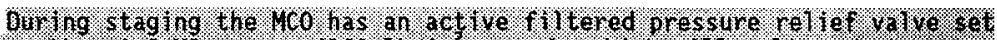

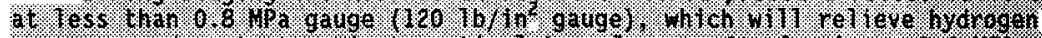

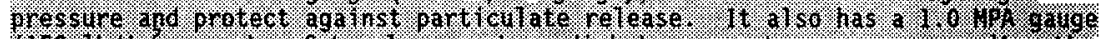

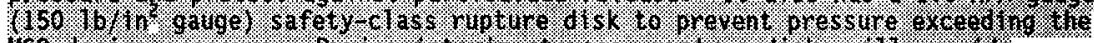

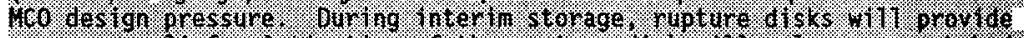

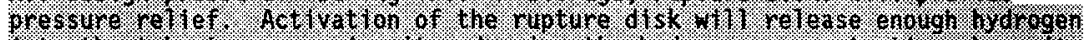

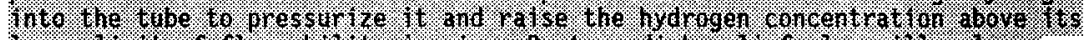

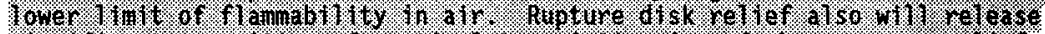
s.

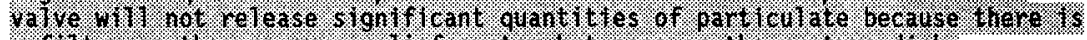

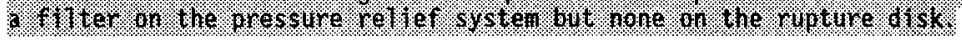

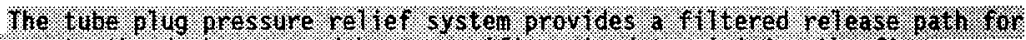

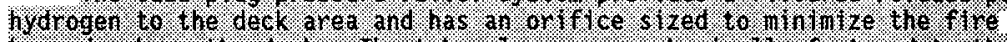

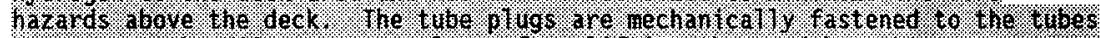

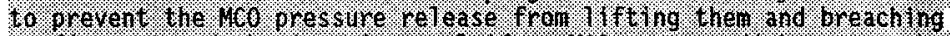

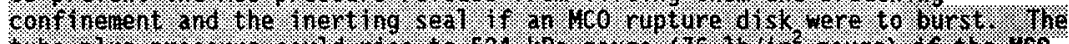

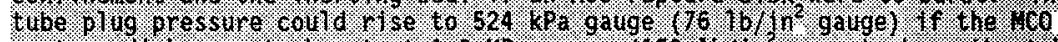

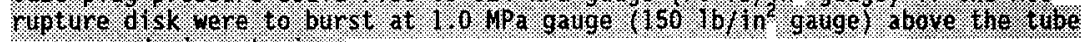

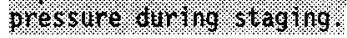

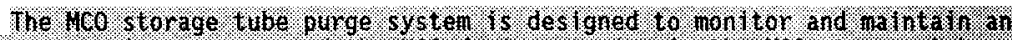

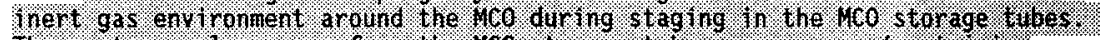

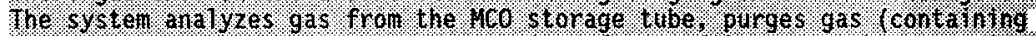

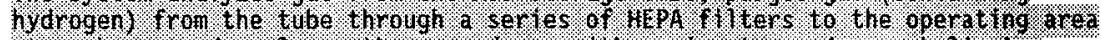

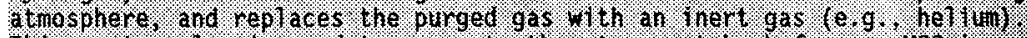

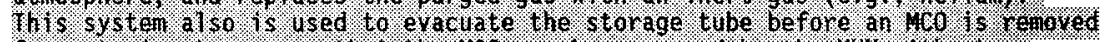

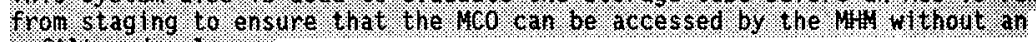
wh Thered retease

The tube o lugs have double seals 10 conthol 1 mert gas out leakage ragas

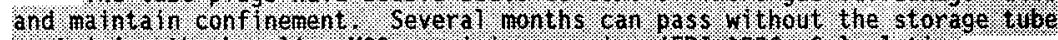

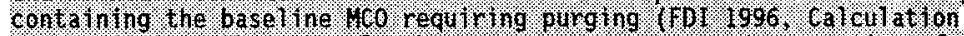

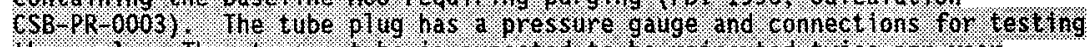
The seats. The storage tube is expected to be relinerted. twice per year 


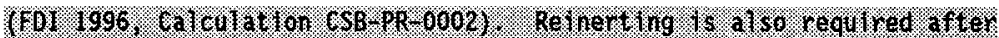

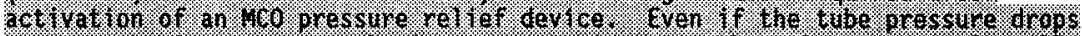

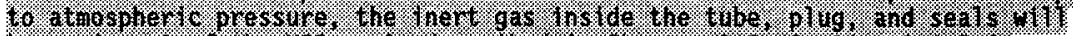

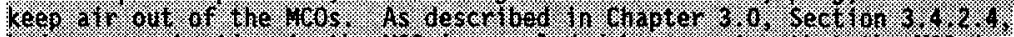

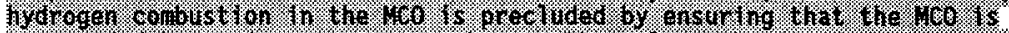

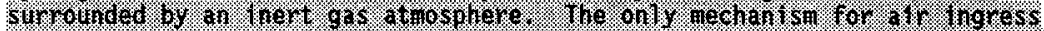

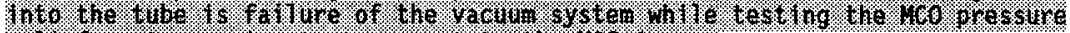

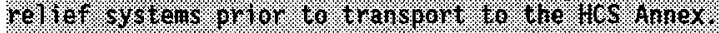

The MHM contains an on-board filtered ventilation system that provides

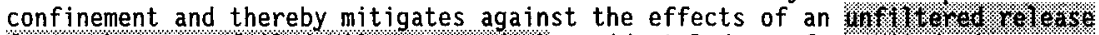

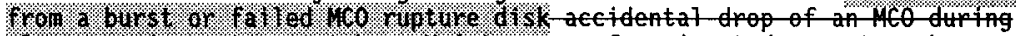
platement in a storage tube. Maintenance of an inerted gas atmosphere surrounding the MCO during transport from the service station to the storage tube or HCS process module will be ensured by the inert gas system on the MHM. During staging of the MCOs, the storage tube is pressurized with inerting gas by the tube vent and purge carts to a slightly positive pressure. The MCO is not vented during staging and has an active pressure relief valve set at something less than $1.0 \mathrm{MPa}$ gatlge $\left(150 \mathrm{Hb} / \mathrm{in}^{2}-g a u g e\right)$ and a $1.0 \mathrm{MPa}$ gatuge $1350-1 \mathrm{~b} / \mathrm{in}^{2}-\mathrm{gauge}$ ) rupture disk to prevent pressure exeeding the $M c 0$ design pressure. During interim storage the $M C O$ wi7l have only the pupture disk for pressture relief.

At the end of staging, the MHM is used to transport the MCO to the HCS Annex for hot conditioning. Before the MHM can remove the tube plug and pick up the MCO, the tube plug, which is locked down, must be manualiy unlocked by loosening and removing the tube plug clamps from the tube bolts. Before the clamps are removed, the pressure gauge in the tube plug is examined to ensure that an MCO rupture disk has not failed and pressurized the tube. Thes Eat flexible hose is attached to the tube plug purge connection, and the pressure on the tube is evacuated to approximately $14 \mathrm{kPa}$ absolute ( $83 \mathrm{kPa}$ vacuum) (2 lb/in ${ }^{2}$ absolute [12 1b/in vacuum]). This evacuation will cause any MCO with a pressure near $1.0 \mathrm{MPa}$ gauge $\left(150 \mathrm{lb} / \mathrm{in}^{2}\right.$ gauge [pressure greater

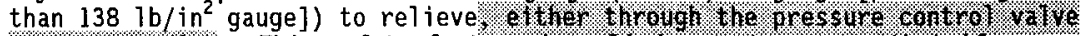
6r waparie. orst. This safety feature is relied upon to ensure that if an MCO's HEPA-fittered relief valve line is plugged, the MCO's rupture disk does not fail after tube plug clamp removal and before MHM movement of the plug and actuation of the MHM floor seal. This feature also provides for worker safety and allows time for MHM transport of MCOs into the HCS process pits with reduced likelihood of MCO rupture disk failure in the MHM. Tube overpressurization caused by relief valve opening will be confined to the tube and to the tube vent and purge cart evacuation system. The MCO's Wet Ket vorke o. 0 will be sealed at the HCS Annex before being placed in interim storage.

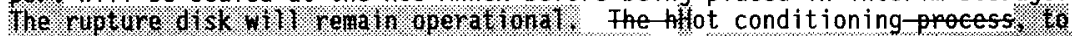

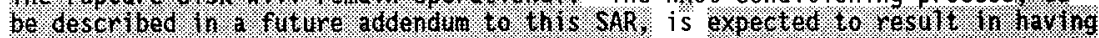
relied to have insufficient residual water, hydrates, and hydrides in the fuel and particulate to pressurize the $M C O$ beyond its design pressure over a

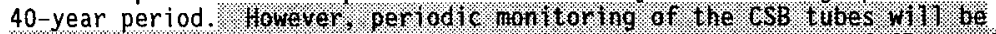

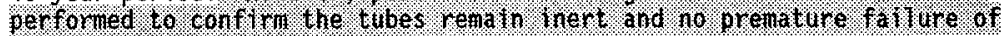
ripture odtsks hos occurred.

All standard storage tubes contain bottom and intermediate impact

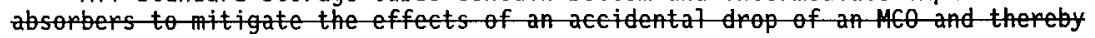


matatain the integrity of the $M C O$-(including the rupture disk) and the storage tube.

7.6.1.1.2.4.2.6 Receiving Crane. The receiving crane is a 60-ton-capacity gantry crane with one 60-ton main and one 10-ton auxiliary wire rope hoist supported on a top-running trolley (Figure 3.12213 ). The crane operates in a and 7 clean indoor environment in the load-in/load-out area of the CSB. The crane is equipped with a shielded operator station together with remote accessories such as a powered rotating hook, local control panels, and a radio-controlled operator station. The various tasks performed with the receiving crane are mainly associated with off-loading MCO shipping casks in preparation for the MCO's transfer to the storage vault.

The receiving crane gantry has a span of $8.4 \mathrm{~m}$ (27 ft, $6 \mathrm{in}$.) and can trave7 $50 \mathrm{~m}$ (164 ft) in an east-west direction. The crane runs on runway rails that are recessed and flush with the operating floor. The runway travel of the receiving crane intersects with that of the MHM, which is also a gantry crane system. The intersecting runway rails are coplanar and therefore have been provided with movable rail sections (frogs). that match the bridge wheels on both cranes. The limits of gantry travel are established by bridge stops that have been accommodated in the east and west building walls. These stops are designed to be contacted by bumpers mounted on the gantry trucks to absorb the energy of a kinetic impact.

EThe following has been moved to section-4.4.5.4.I The receiving crane

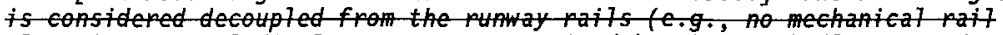
elamps). Lateral displacement is restrained by the wheel flanges and fongitudinal displacement is restrained by the erane wheel brakes during $a$ seismic occurrence. The receiving crane is stable against overturning during a seismic oeturence with a safety factor of 1.1 , in zecolan with ASHE HOG 1 (ASME 19956).

The receiving crane is provided with a hook coverage capability that extends beyond the CSB load-in/load-out area. The maximum hook elevation of

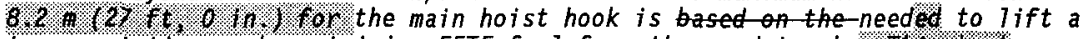
transportation cask containing FFTF fuel from the road truck. W $161 \%$. $100 \%$

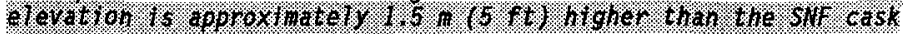

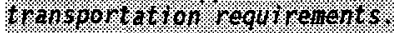

This paraph has been-moved to section-4.4.5.2.] The reciving ane system is designed, fabricated, manufactured, inspected and tested in

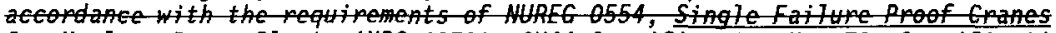
for Nuelear Power Plants (NAG 1979), CMAA Specification No. 70, Specifications

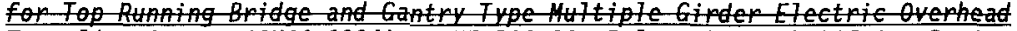
Fraveling Cranes (CMAA 1994), ASME B30.20, Below the Hook Lift ing Devices (ASHE 1993); and ASHE AOG 1, 1998 (ASHE 19956), Type I with the exeption of HOG $5420(a)$ (reeving is in accordance with CMAA Specification No. 70 [CHAA 19947 ), and NOG 5428.1 fa single hook is used rather than a double

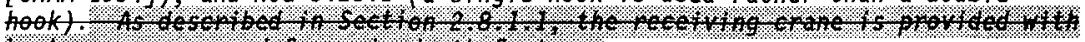

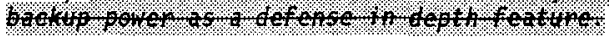

The receiving crane is expected to receive some radiation exposure when the shipping cask is being moved. Based on an analysis of the side exposure to the receiving crane, a maximum rate of about $11 \mathrm{mrem} / \mathrm{h}$ is obtained, or 
about $4 \times 10^{3}$ Rad for a 40-year lifetime total integrated dose. This is a conservative value because it is unlikely that the receiving crane will experience a 40-year continuous work schedule.

The receiving crane has a shielded operator station mounted on the north bridge truck. The shielding is 9-cm- (3.5-in.-) thick carbon steel with viewing windows that have a shielding equivalency of $9 \mathrm{~cm}(3.5 \mathrm{in}$.$) of iron or$

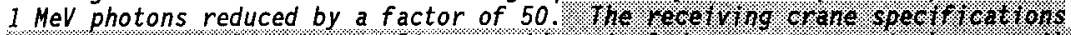

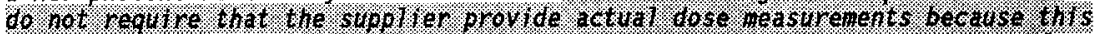

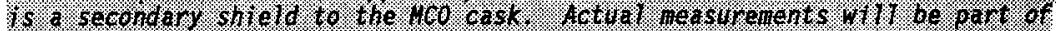

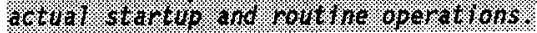

The receiving crane, including its load blocks, will not be exposed to temperatures, pressures, or chemicals that would require special design

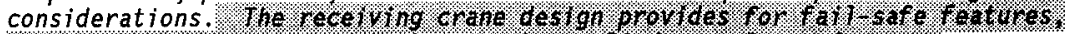

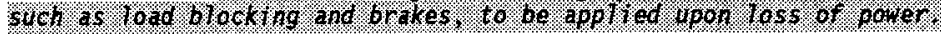

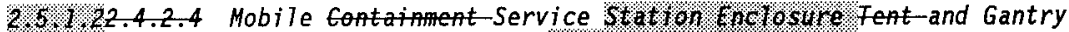

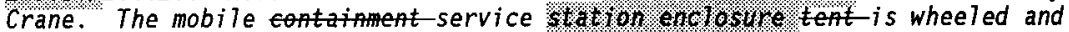
travels on rails in the load-in/load-out area of the CSB. Positive restraints are provided between the base of the enelosure tent-and the support rail to prevent the enclosume from lifting up or moving off the rail during a seismic event and resulting in a potential loss of function.

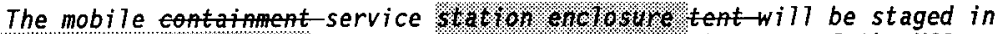

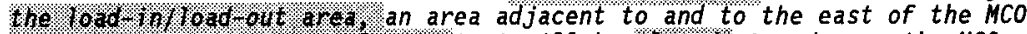
service station. The enclosure tent will be B occod staged over the $M C O$ service station pit after wing transport cask loaded with an MCO

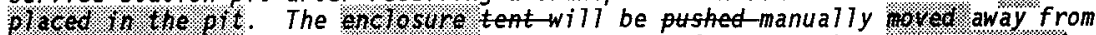
the MCO service station pit after the sepricing of the-MCO has been or eford for $5 \% 19109$ completed and the shielding hatch assembly has been placed over

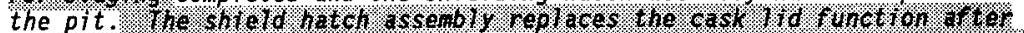

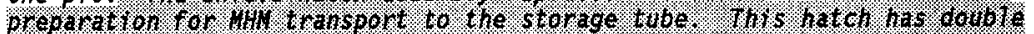

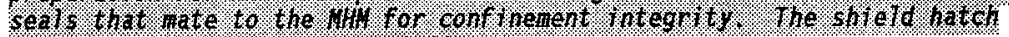

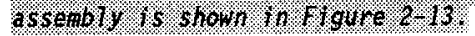

The mobile contanent-service stollon enclosure tent-is equipped with a HEPA-filtered exhaust unit with a built-in standby exhaust fan. One $f$ an is in standby while the other is in operation. The exhaust system will maintain a

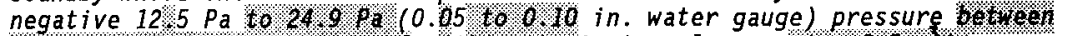

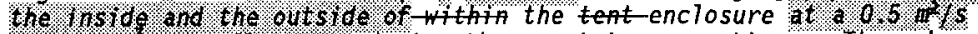

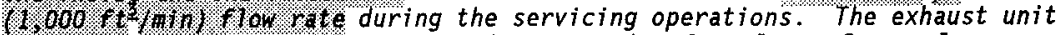
discharges to the operating area exhaust stack. On a loss of normal power, the emergency generator system will provide power to the mobile ontaiment service $10 t 10 n$ enclosure tent exhaust system.

The enclosure and the filtered exhaust system form the confinement envelope for the zone 2 ventilation area around the $M C O$ service station. The confinement atmosphere is supported by maintaining a 12.5-Pa $10.24 \%$ \% \% (0.05-in. to 0.10 .17 . water gauge) negative pressure inside the eno 10 sura tent. To achieve and maintain this negative pressure, the enctosule tent is sealed to the floor, and the openings and joints in the material of the enclosure t-are designed to efficiently maintain the seal. 
The enclosure tent-material is a fire-resistant nuclear grade fabric-with

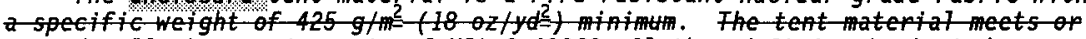
exeeds a 77 the requimements of MIL $C 43066$, Cloth and Strip, taminated op Goated, Vinyl Mylon op Polyestep High Strength, flexible (NIL 1989), Fype-I speifications. The enclosure tent material is also-in accordance with NFPA 701 , Standard Methods of Fire Tests for Flame-Resistant Textiles and Films (NFPA 1996\%), Chapter 12, and has a maximum tearing strength that is in accordance with ASTM $D$ 2261, Standard Test Method for Tearing Strength of Woven Fabrics by the Tonque (Single Rip) Method (Constant-Rate-of-Extension Tensile Testing Machine) (ASTM 1983a), and ASTM D 2262, Standard Test Method for Tearing Strength of Woven Fabrics by the Tonque (Single Rip) Method (Constant-Rate-of-Traverse Tensile Testing Machine) (ASTM 1983b).

The roclosure to is equipped with a lighting system to provide an illumination level of not less than $7581 \times$ ( 70 footcandle) for a distance of

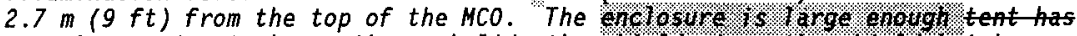
engh capacity to house the cask lid, the shield ring, the shield hatch assembly, the 5-ton gantry crane and hoist, and the storage rack. The enclosture tent-is equipped with service sleeves, 7.6-cm- (3-in.-) diameter minimum, to bring services into the grolosume tent as needed to support ventilation, to supply power, and to introduce tools.

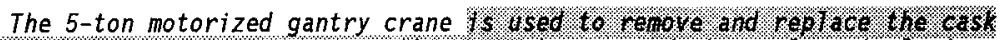

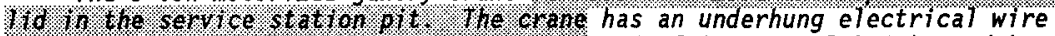
rope hoist. The crane does not exceed $2.4 \mathrm{~m}(8 \mathrm{ft})$ in total height and has

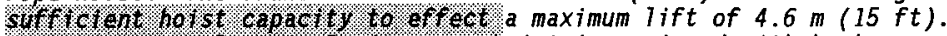
The underhung electrical wire rope hoist is equipped with brakes, end stops, and a free rotating hook. The wheels of the gantry crane are designed to withstand a minimum loading of $2,270 \mathrm{~kg}(5,000 \mathrm{lb})$ each and are provided with locking devices to prevent movement while in use. The gantry crane has an acceleration control, and its travelling speed does not exceed $10.7 \mathrm{~m} / \mathrm{min}$ (35 ft/min). The wire rope hoist has a lift speed of $3.0 \mathrm{~m} / \mathrm{min}(10 \mathrm{ft} / \mathrm{min})$ maximum, and the motorized trolley has a $7.6 \mathrm{~m} / \mathrm{min}(25 \mathrm{ft} / \mathrm{min})$ maximum speed.

The MCO service station gantry crane and hoist are designed in accordance with ANSI/ASME B30.10, Safety Standard for Hooks (ANSI/ASME 1995d), ANSI/ASME B30.16, Overhead Hoist (Underhung) (ANSI/ASME 1995b), ANSI/ASME 30.17, Overhead and Gantry Cranes (Top Running Bridge, Single Girder. Underhung Hoist) (ANSI/ASME 1995a), and ANSI/ASME HST-1M, Performance Standard for Overhead Electric Wire Chain Hoists (ANSI/ASME 1995c).

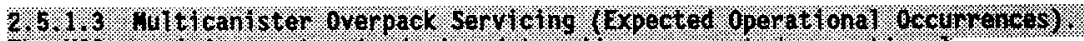

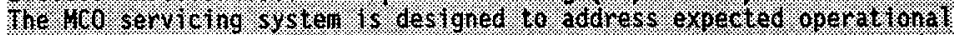

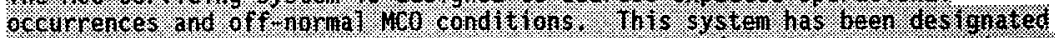

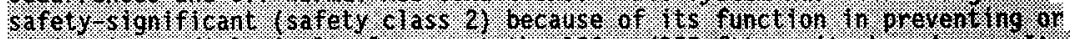

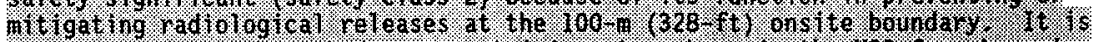

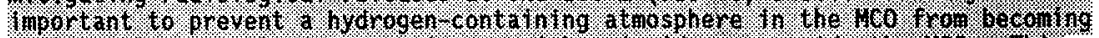

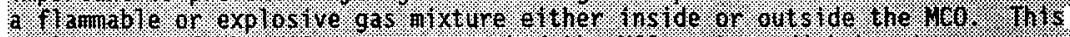

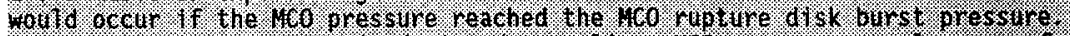

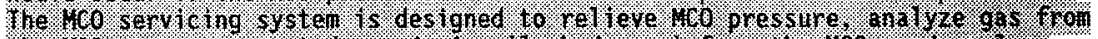

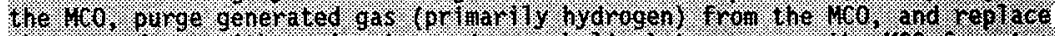

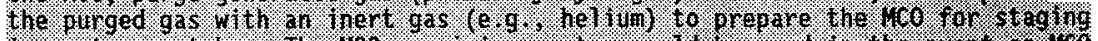

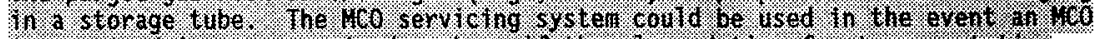

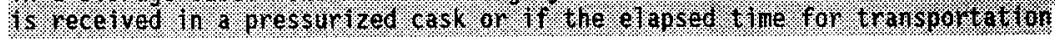




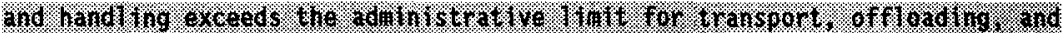

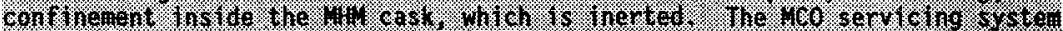

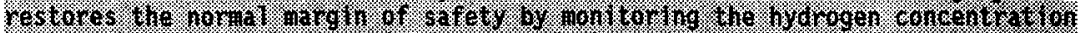

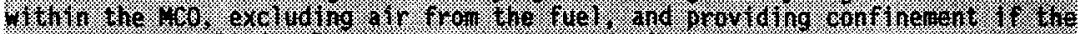

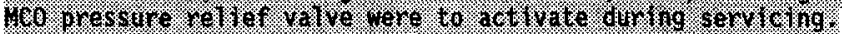

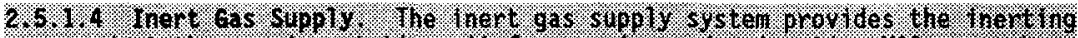

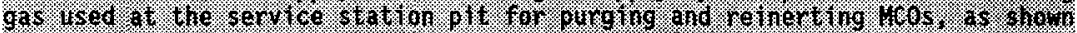

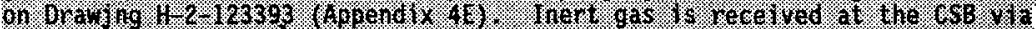

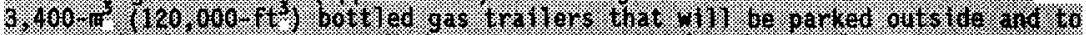

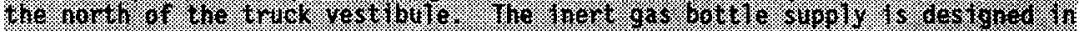

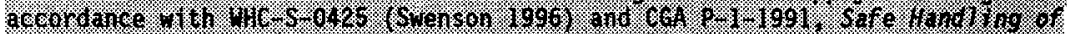

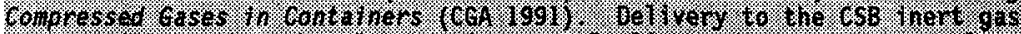

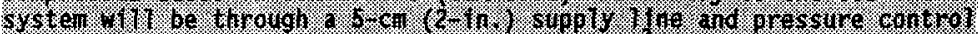

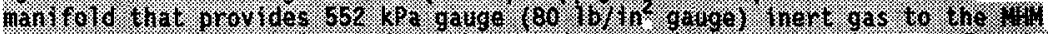

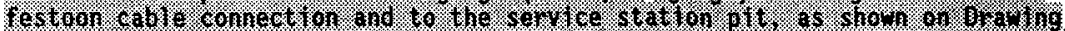

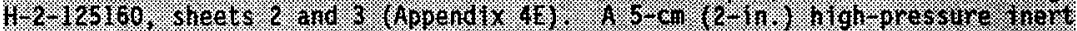

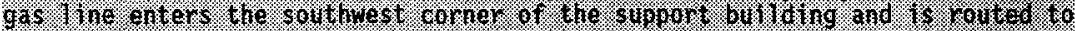

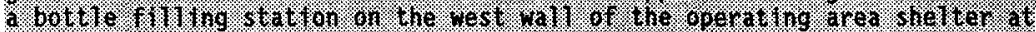

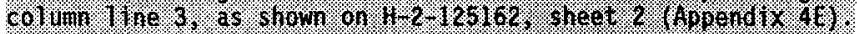

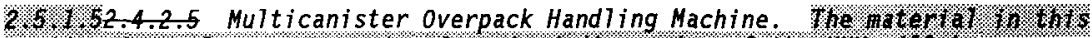

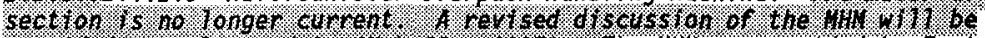

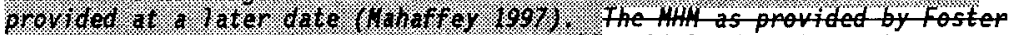
Wheeter Invtronmental Corporation-7s a fulfy shielded machine whose purpose is to remove HCOs from the service station pit in the reciving ared of the $6 S B$, place the HCOs in the vallt storage tubes (having first removed and

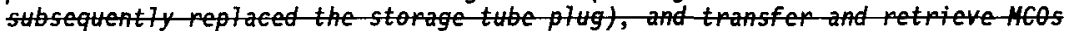
to and from the hot conditioning ovens. The HIII can be used to reverse the operation and remove the NCos from the valt and, in addition, can handle the storage tube impact absorbers.

The HIH consists of two main units that opate simultansily as a single matine. the gantry erane system-and the shielded turret system. The gantry crane system is a 125 ton capacity, equal leg gantry with a top running trolley. The crane system ineludes the trolley and control panel, ginders, end ties, whel trucks, and seismic elamps. The shielded turret system includes the eask body, HCO hoist, ventilation system, shield plug hoist, television navigation cameras, shield skipt, and turntable.

The NHA gantry crane-system is mounted on rails that run nonth south in recessed troughs in the operating deck. The span between rails is $38.6-\mathrm{m}$ $(126 \mathrm{ft}, 6$ in.). The shielded turpet system is mounted on the trolley, which funs in the east west dipection. The cask trolley can trave $31.6 \mathrm{~m}$ (103 ft,

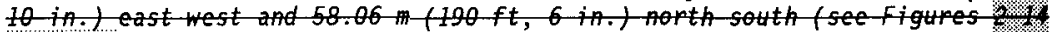

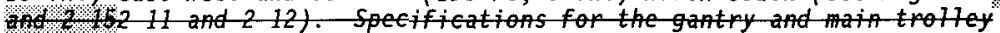
systems require that they be designed and fabricated to meet the requirements or ASHE NOG 1 1995, Rutes for Construction of Orerhead and fratry cranes (Top Runing Bride, Multiple Ginter) (ASHE 19956), Type 1, and NUREG 0554, single Failure Proof - Cranes-for Nucleam Power Plants (NRC 1979). 
The-1114 gantry and trolley and the CSB support structures are designed with seismic restraints that will prevent damage to an $N C O$ if a seismic event were to during handing.

The-1111 controls are provided with east west and nonth south motion interlocks with the cask motion. The interlocks an losigned to prevent dame to the MCOS during handling if a seismic event or MHII trolley control system failure were to occur. The NHM main giladers are located at a height of $2.75 \mathrm{~m}(9 \mathrm{ft})$ above the operting deck to elear the $H C O$ service station, the tube vent and purge carts, and the HCS process enclosures.

The turret consists of a rotating upper assembly and a stationary bottom nose asembly. A retrat able shield skint mothed to and concentric with the nose assembly is lowered to complete the shielding when the HHI is ongaged with a storage tube or when the shield hateh is positioned over the HCO senvice station pit. The skint is connected to a nose tube and is sealed with elast onic o nings to the operating station where it is positioned (storage tube or service station).

When the MHA is located over the HCO service station and the shield skint is fowered and sealed, the turpet is rotated into postion to pemove the center shield plate. The center shield plate is removed with the MHI's shield plug graple and hoist. The turnet is then rotated to position the cavity over the operating station, and the $M C O$ is removed Using the $N C O$ hoist and grapple. After the MCO ho ben raised to the transponting position, the turpet is again rotated, and the center shield plate is replaced in the shield hateh. The shield skint is rased and loked into postion, and the HII then transports the HEQ to the designated storage tube.

Upon arrival at the storage tube station, the shield skirt is lowered into place and sealed to insure proper confinement and shielding. The turpet is rotated to position the shield plug cavity over the storage tube, and the shiefd plug is removed using the shield plug graple and hoist. When the shield is in its stored position, the turret is rotated to atign the carity over the storage tube and the $N$ Co is lowered into position using the $H C O$ grapple and hoist, After the $M C O$ is in place, the turret is again rotated to position the tulug al it is pe inserted into the tube opening. The shield skipt is then raised and the MHI taken to a designated staging op storage position. MGO retrieval and replanent opertions-are carpied out in a similar manner for transfer of MCOS to and from the HCS OVens.

The dose eniterion "shielding goal" for the HHW is $2.0 * 10^{-3}-\mathrm{mSV} / \mathrm{h}$ $(0.2$ mrem/h) at contact $(1 \mathrm{em}[0.4 \mathrm{in}$.$] ) with the 1111$. The 10 CFR 835 desigh objetive for controlling personnel exposure from external soures of cadiation in areas of cont inuous occupational ocupancy $(2,000 \mathrm{~h} / \mathrm{ym})$ is to maintain expostre levels below an average of 0.5 mrem (5 mictosieverts) per hour and as far below this average as is reasonably achievabie. The $2.0 \times 10^{-3}-\mathrm{mSv} / \mathrm{h}(0.2 \mathrm{mrem} / \mathrm{h})$ at contat gorl considers the possibility of multiple other sources associated with the CSB.

The slant angle concrete path and the gap between the MHM and deck sthface neds to be taken into wecount wen estimating the dose rate at the floor surface of the operating deck. The dose rate including streaming should be less than the shielding goal of $2.0 \times 10^{-3}-\mathrm{ms} / \mathrm{h}(0.2 \mathrm{mrem} / \mathrm{h})$. The dose 


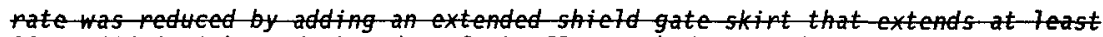
$91 \mathrm{~cm}$ (36 in.) beyond the edge of the floor embet. Based on the prefininary specification soping shielding analysis (Kidd-1996), this distance is judged to be adequate. In addition, the MHI deck gap radiation streaming was mitigated by the tse of a steel below deck insert into the embed on the bottom of the shield gate that blocks the direct line of sight radiation as the $M C O$ is withdran into, or out of, the HHI (there is approximately $13 \mathrm{~cm}[5$ in.] of steel blocking the path in addition to the very nampow and exted gas based

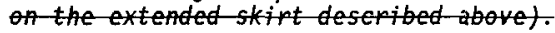

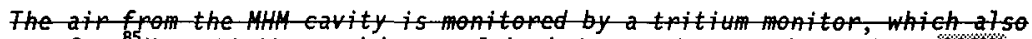
monitors for $\stackrel{85}{=} \mathrm{Kr}$ activity, and by an alpha beta continuous air monitor (1) that mitors for breakthrough of the-MHI ventilation system's HEPA filters: The probes are located adjacent to the exhaust of the MHM ventilation system.

2. 5. 1.62.4.2.7 Tube Vent and Purge Carts. The tube vent and purge cart (Figure 2.162 14) is designed to monitor storage tube gas pressure and composition, evacuate $106 \mathrm{c}$. 2 tmosoliere aip, pressurize and dilute tube gas with inert gas, and provide for controlled venting of storage tube gases emitted from the MCOS. The gases are monitored and vented to the operating area through HEPA filters on the cart. The cart also can maintain and replenish the inert gas atmosphere in the storage tubes. An inert pressurized atmosphere is maintained in the tubes, which contain staged MCOs, to prevent an accumulation of explosive mixtures of hydrogen and oxygen. Periodic tube venting also keeps the pressure from rising high enough to activate the relief

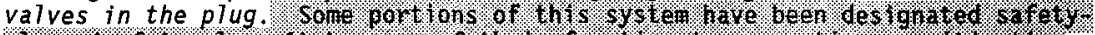

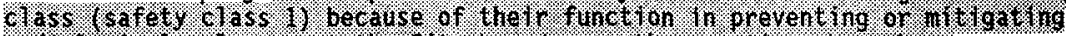

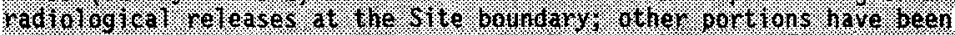

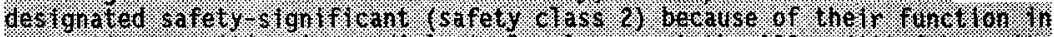

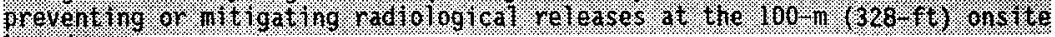

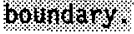

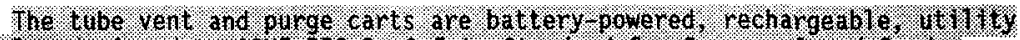

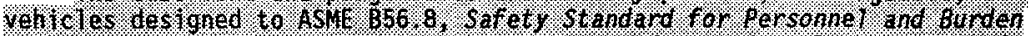

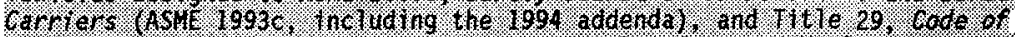

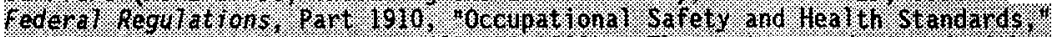

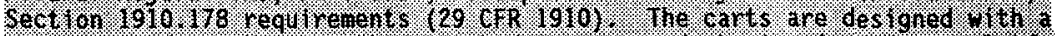

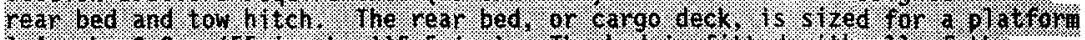

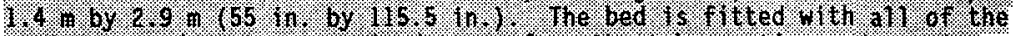

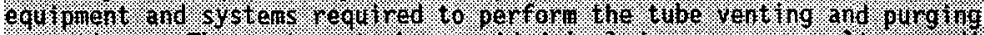

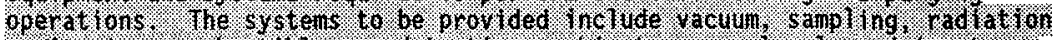

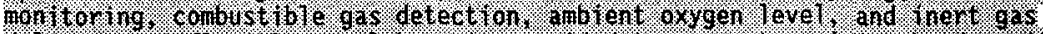

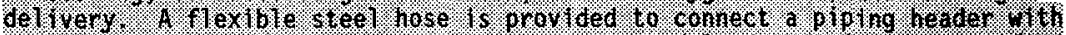

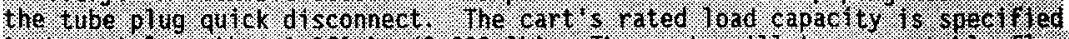

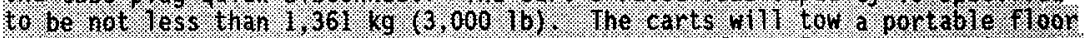

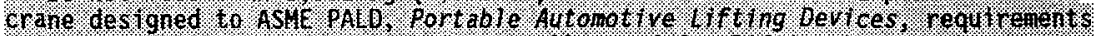

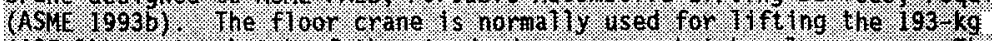

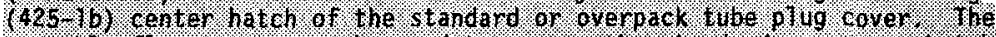

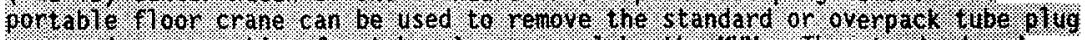

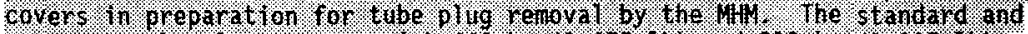

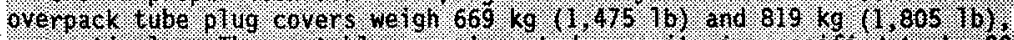

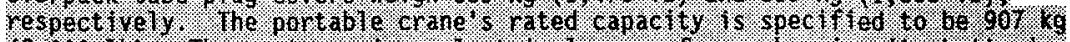

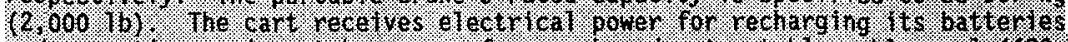

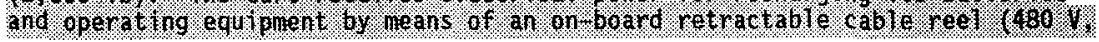




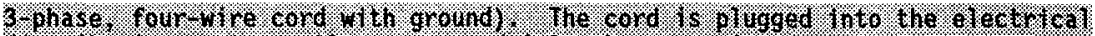

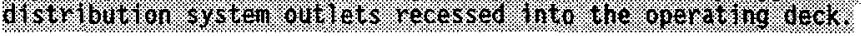

The cart is connected to piping on each tube plug. The piping allows monitoring and purging of the tube atmosphere without removing

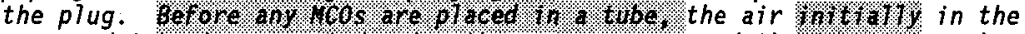
accessed tube is evacuated using the vacuum pump, and the inert atmosphere is supplied from high-pressure inert gas bottles on the cart. Pressurization with inert gas is controlled through a pressure regulator, and overpressurization of the tube is prevented by a relief valve. A restrictive flow path from cart to tube al so makes rapid overpressurization unlikely. The inert gas pressure in the tube is left slightly positive after inerting, and

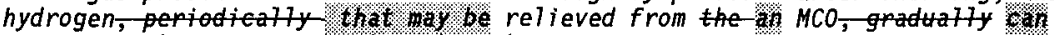
increases the pressure within the tube.

The sehedule for venting, punging, and inerting the tubs is determined

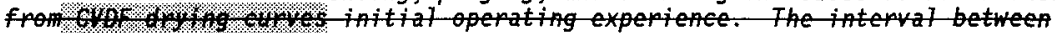
scheduted ristes is set so the hydrogen concentration will be below $4 \%$ (the tower flambility limit for pure hydrogen in ain). Temperature variations in the valt will affect the tube pressures; therefore presture is not a sensitive indication of hydrogen concentration. Instead, the hydrogen conentration is meastred each time the cant makes a scheduled visit to a tube. The measurement result is used to adjust the schedule as necessany. Shouf the hydrogen concentration exced $4 \%$, the twe gas will be difuted to below $4 \%$ before using the vaum pump. The cant includes a function to Whatily atomatically-dilute pressurized gas that is higher than $4 \%$ hydrogen with inert gas as the pressure is vented from the tubes through the cant and into the openating ared. Several earts will be required in onder to meet the contemplated schedule when vallt 1 staging capacity is reached. One antwill be reserved as a spare duning nomal operations.

The cuprently conceived operations-sechanio assumes that when gas generation from the finst $M G O$ in a tube has declined to reny low rates, a second HCO is alded to the tube; the purging and inerting process is repeated at that time. Periodically (up to 18 times per day), the tubes will be vented through the cat system and reinerted at the oniginal stight ly positive tube

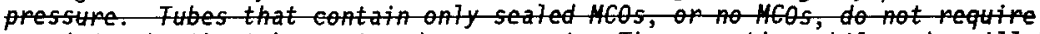
servicing by the tube vent ad purge cant. The operating phitosophy will be developed to accomodate atual conditions expected after the Hco design and hydrogen generation moding are

During the time the cart is being used to perform venting, purging, and inerting, the portion of the connected system that is between the cart-mounted HEPA filters and the tube atmosphere fills the same secondary confinement role as the storage tubes. Under accident conditions this confinement provides mitigation of radionuclide releases from the MCOs.

\subsubsection{Staging Operations}

The SNF contained in the MCO generates hydrogen gas from the exothermic reaction of free water with uranium metal and from radiolys is of bound and free water. Hydrogen can accumulate in a storage tube if a pressure relief device on an seated MCO actuates or leaks. Although the storage tube is 
inerted, it is assumed that-the tube plug seals permit very slight loss of storage tube atmosphere to the operating area. To limit the concentration of

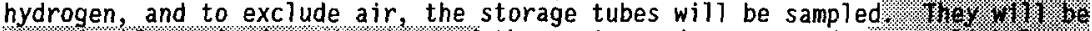

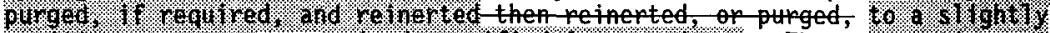

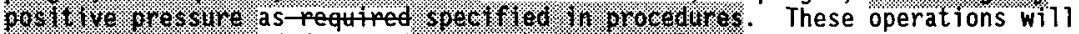
be performed as needed depending on observed valt temperature tube pressure measurements during staging. Tube vent and purge carts are provided to facilitate these hydrogen-related storage tube operations. If the tube pressure is too low, inert gas will be added to reach $28 \mathrm{kPa}$ gauge $\left(4 \mathrm{~b} / \mathrm{in}^{2}\right.$ gauge). If the tube pressure is too high, the tubes will be purged of

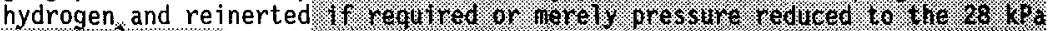

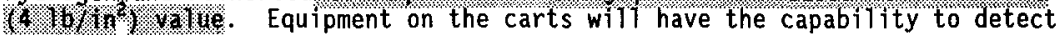
airborne radioactivity and dangerous concentrations of hydrogen in a gas sample from the tube. Upon determining that the tube atmosphere is acceptable for purging, the carts will evacuate the storage tube and exhaust filtered storage tube atmosphere into the operating area through HEPA filters. If the

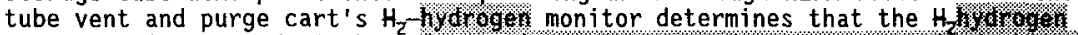

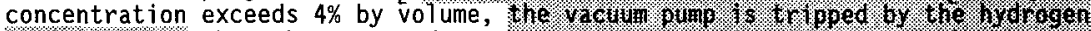
Won 100.5 . and the tube vent and purge procedure requires that the tube be purged by repeated pressurization with an inert gas (helium). The diluted gas will be vented to the operating area. The storage tube then will be reinerted to $28 \mathrm{kPa}$ gauge (4 $\mathrm{lb} / \mathrm{in}^{2}$ gauge) pressure.

The amount of sludge and water in an $M C 0$ not only affects the potential eonsequences of an accident but also affects the frequency of tube purging. The CSB was designed for a maximum hydrogen generation rate of $0.4 \mathrm{~g} / \mathrm{s}$ and a maximum generated quant ity of $1.1 \mathrm{~kg}(2.4 \mathrm{7b})$ of hydrogen per MCO. Recent preliminary studies of gas generation in $14 C 0$ s (Bergsman 1996) have estimated the amount of radiolytic hydrogen and oxygen produced in vented staging after

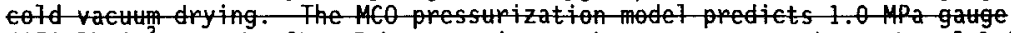
$\left(150 \mathrm{lb} / \mathrm{in}^{2}-\right.$ gauge) after 5 hours and a maximum gas generation rate of $0.4 \mathrm{~g} / \mathrm{s}$ of hydrogen based on a maximum fuel corrosion inventory of $160 \mathrm{~kg}(353-1 \mathrm{~b})$, a watep inventopy of $6 \%$, and $800,000 \mathrm{~cm}^{2}-(124,000$ in -2 - sunface area. The presurization lel predicts $379-\mathrm{kPa}$ absolute ( 55 - $1 \mathrm{~b} / \mathrm{in}^{2}$ absolute) after 90 hours using a high nominal case $\left(155 \mathrm{~kg}[342-\mathrm{b}], 6 \%\right.$ water, $80,000 \mathrm{~cm} \mathrm{c}^{2}$ $\left[12,400\right.$ in $\left.{ }^{2} f\right)$. The expected gas generation will be- less. The maximum quantity of water is $1.1 \mathrm{~kg}(2.4-7 \mathrm{~b})$ corpesponding to the bound water with $160 \mathrm{~kg}(353-\mathrm{lb})$ of corposion prots with $6 \%$ water by mass.

The hydrogen generation calculations included a calculation of the hydrogen generated by padiolysis of water and decomposition of hydrides or hydrates. The rate of hudrogen generation by this means is less than $3.7 \times 10^{-3}-\mathrm{m}^{3}-\mathrm{yr}-(0.13 \mathrm{ft}-\mathrm{fyr})$ based on $1.8 \mathrm{~kg}(4 \mathrm{lb})$ of water avaitable for falysis. If the cold racum trying press works as intended (negligible free water in the $M C O$ after processing), the rate of radiolysis and chemical decomposition of hydrides or hydrates will determine the frequency of tube purging in the ESB.

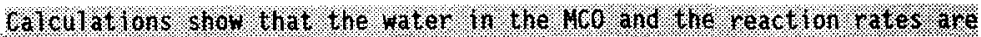

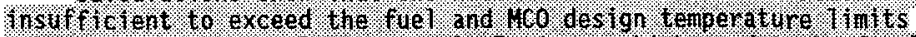

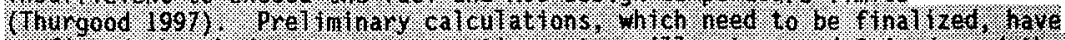

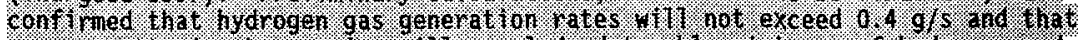

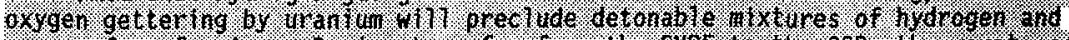

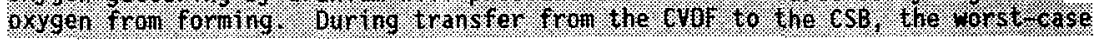




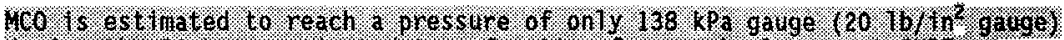

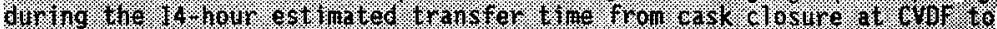

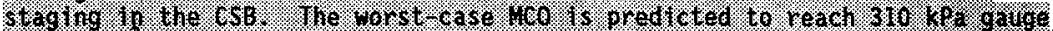

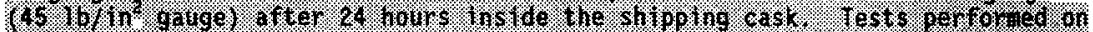

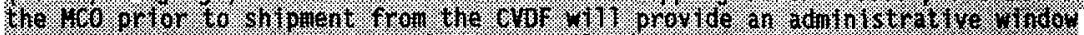

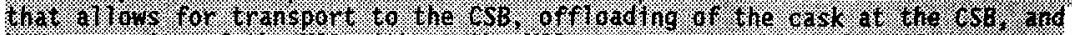

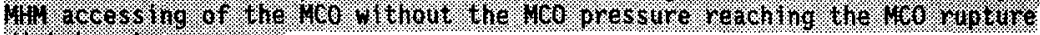

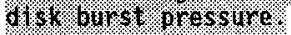

The temperature of the vault is not controlled, and therefore depends on

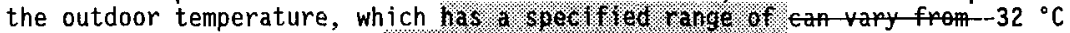
to $46^{\circ} \mathrm{C}\left(-27^{\circ} \mathrm{F}\right.$ to $\left.115^{\circ} \mathrm{F}\right)$ / (Swenson 1996 ). Ho brittie-fratures of occur, even at $32^{\circ} \mathrm{C}(27.7)$, becattse the carbon steel material is very low in carbon (API 5 L is $\leftarrow 0.008 \%$ carbon: A 36 is $\leftarrow 0.2 \%$ capon). The temperatures in a tube and in the MCOs contained in it depend on the temperature of the vault at that location and on the heat produced by the

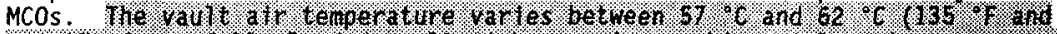

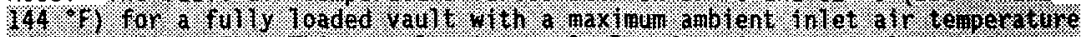

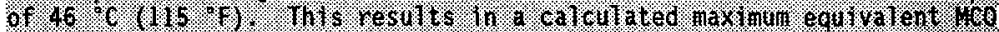

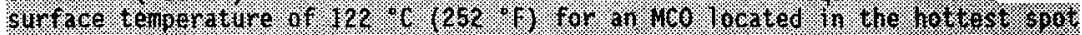

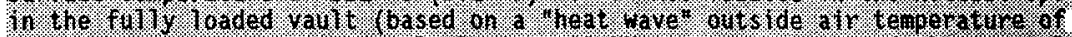

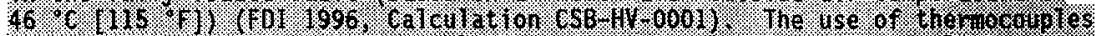

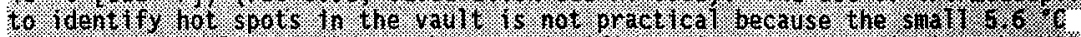

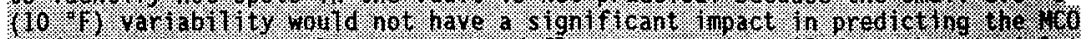

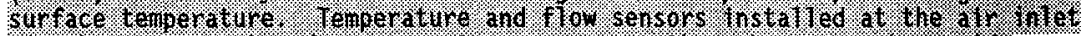

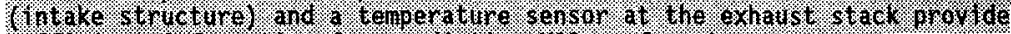

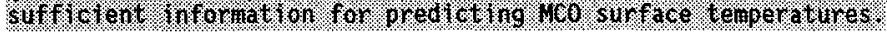

Seasonal temperature changes in a tube can alter the tube pressure up to

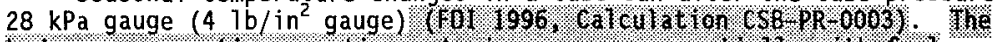

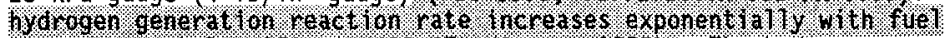

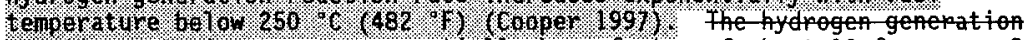
peastion rate incerases exponentially by a factor of a 10 for every $30^{\circ} \mathrm{C}$ (50 50 f) increase in fuet temperature.

This creates a concern that several MCOs will become active if the vault suddenly warms up after a period of cold weather. Based on best currently available hydrogen generation information ( (orenz 1997 ), the foum the tube vent and purge carts (the-turo operating and one spare) may not besufficient to can purge the tubes fast enough to prevent releases of 1 me

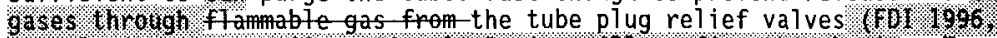

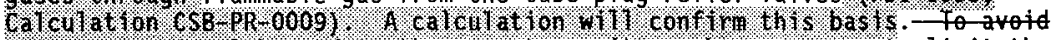
this occupational hazard to the operators, it may be neessary to 7 imit the Aumer of potentially active $M C O$ s that are loaded in cold weather. The

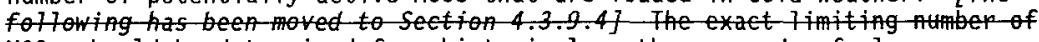
HCOs should be determined from historical weather records, fuel characterization tata, and hydrogen generation readings-taken from initial CSB operating experience. Additional carts could also be procured if required at a later date. 


\subsubsection{Interla Storage operations}

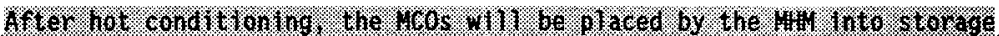

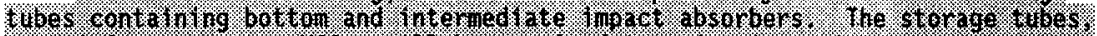

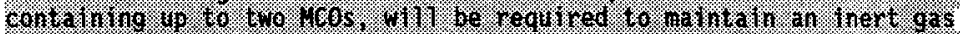

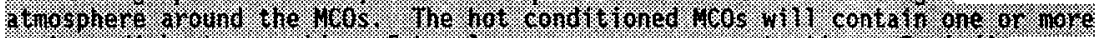

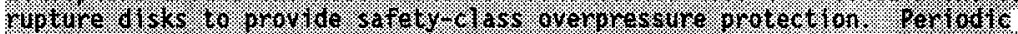

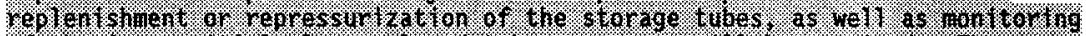

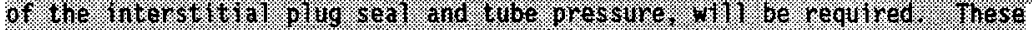
eperat lons can continue to be perfarmed by the tube yent and purge carts.

\subsection{CONFINEMENT SYSTEMS}

\subsubsection{Confinement During Staging Operations}

Because some of the fuel $\mathrm{cladding}$ is not intact, the primary confinement feature for the SNF at the CSB consists of the stainless-steel MCOs. Initially, the MCOS to be stored in the CSB will have undergone sing

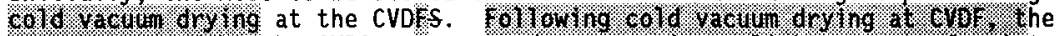
MCOs by the CVOS assumed to contain a slight amount of moisture that will contribute to some radiolytic, but mostly corrosion-induced hydrogen gas generation. The MCOS will be sed oressure-nanaged and can relieve through a HEPA-filtered relief valve located atop the MCO elostre head-Sirig/:

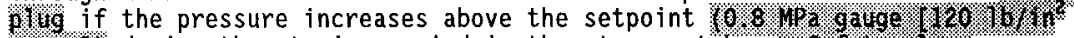
gavge) during the staging period in the storage tubes. Safety-dos.

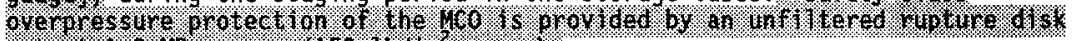
set at $1.0 \mathrm{mpa}$ gauge $\left(150,1 \mathrm{~b} / 1 \mathrm{i}^{2}\right.$. $\left.9 \mathrm{auge}\right)$.

2.6.1.1 Multicanister Overpack Servicing. MCO servict thy incl was row tral

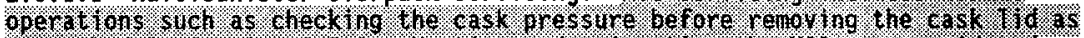

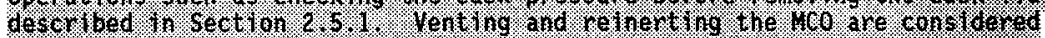

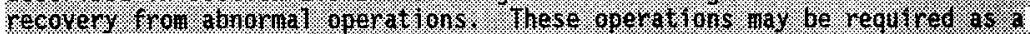

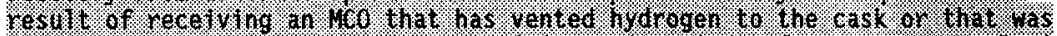
recelved after explration of its acnin strat vo windon for transport During HCo venting and reinerting serviciling operations in the MCO service station, air will flow from the operating area through the service station enclosure's HEPA filtration system. Confinement is provided by the enclosure's ventilation system from the time the MCO cask is plaead in the serwice station oll until the shield hatch assembly is in place. During the brief time that the service station enclosure is moved out of the way of the MHM (101 1986. Calculation CSB PP -00II). the a shield hateh assembly. A burst $14 C 0$ rupture disk event is not eredible during this short period of time. After the MCO has been evactated and purged, the rate of gas generation necsary to quickly burst the disk is consedible (Pajunen et al. 19XX).

During MCO handling by the MHM, air flowing from the operating area or from the storage tube will flow into the MHM cask space where it will be diluted by an inert gas. Inert gas is manifolded inta the bottom of the cask and exhausted through the on-board HEPA filtration system. Confinement in the storage tube is maintained by the MHM's on-board, HEPA-filtered, exhaust ventilation system during MCO handling. 
2.6.1.2 Staging. The secondary confinement system during MCO staging consists of the storage tube and 6 tube 3 luas. The MCOs have a pressure relief valve (setpoint less than $0.8 \mathrm{MPa}$ gauge [120 1b/in ${ }^{2}$ gauge]) and rupture disk (1.0 $\mathrm{MPa}$ gauge [150 lb/in ${ }^{2}$ gauge]) to control pressure. The storage tubes are initially inerted and evacuated to the operating area through testable HEPA filters located on the tube vent and purge carts. The tube vent and purge carts are used to check, evacuate, and recharge the inerting gas in the storage tubes as needed. If the pressure inside of a tube rises above $62 \mathrm{kPa}$ gauge ( $9 \mathrm{lb} / \mathrm{in}^{2}$ gauge), the tubes will begin to vent to the operating area through a relief valve and HEPA filter in the tube plugs (Nal 1906 . see Calculation CSB-PR-0003). The tube plug design includes a tube seat leak test tap and a direct reading tube pressure gauge. Excess hydrogen generation in the $\mathrm{MCO}$ and pressure relief is the primary cause for a rise in pressure inside the tube. Other effects, such as gas volume expansion or water vapor expansion, are considered minor. The storage tube and the tube plug are sarely.coss (safety class 1 ) and have been designed to remain intact and functionat when subjected to a DBE.

\subsubsection{Confinement During Hot Conditioning and Mtertim Storage Operations}

The Hot conditioning is designed to react 7 -bound water, hydrides, and hydrates in the SNF and remove the hydrogen, oxygen, and any unbound water from the MCO. The process also-is designed to passivate the

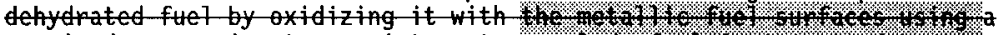
premixed oxygen inert gas mixture to preclude fuel ignition and hydrogen Hot conditioning will take place in ovens that are located in six process pits below the HCS Annex operating deck. Confinement is provided by

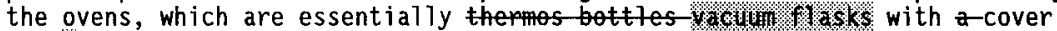
rings that allows hot air to be blown through the annular space between the

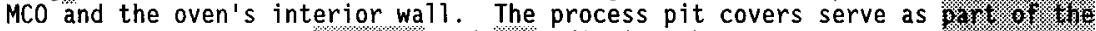
secondary confinement bouldary and as radiation shields. The covers are designed as two parts (plug within a cover) to allow the MHM to move the MCO, while maintaining the double confinement of the SNF, using the same procedure as is used in the rest of the CSB. Other systems in the HCS that are similar to those in the CSB are the impact absorber at the bottom of each pit, which would prevent catastrophic failure of an MCO if it were dropped to the bottom of the pit, and the MHM guidance system and interlocks, which prevent the MHM from colliding with or damaging the process enclosure or MCO. Process lines that connect the oven with the loo conollowlong equipment (air cleaning, inert gas purge system, heaters and fans) run below floor level in a trench. A thick steel plate covers the trench to provide shielding from any potential particulate or condensed volatile radioactive materials in the 1ines. The exhausts will pass through air-cleaning equipment before being discharged from the facility through a stack. A portable process enclosure will be provided for shielding, for making and breaking MCO connections remotely and for changing air-cleaning traps and filters. The enclosure will be ventilated so that it prides matraths secondary confinement while the MCO's top is exposed and while the MCO's ports are manipulated. The finat closure of the $M C Q$ will be made by welding a cover piece on the $M C O$ white the $M C O$ is in the oven after hot conditioning has been completed. Welding the cover piece on the $M C O$ after hot conditioning seals off the pressure derice so that only the rupture disk is available for pressure relief. 


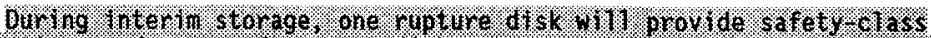

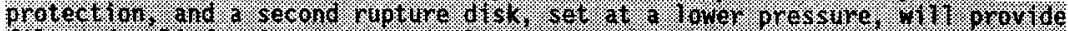

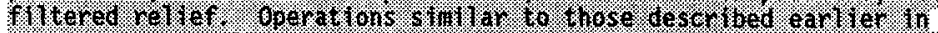

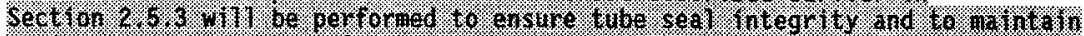

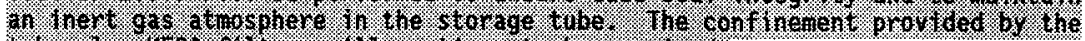

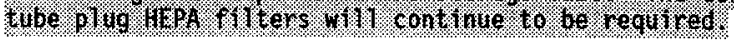

\subsection{SAFETY SUPPORT SYSTEMS}

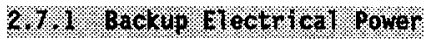

As described in Section 2.8.12.4.2.8, the design of the CSB electrical

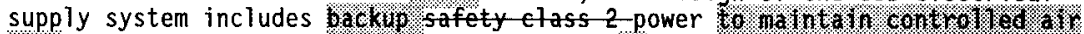
fo\% to the MCO service station and MHM-and 160 in-deck $480 \mathrm{~V}$ power outlets used for operating the MCO vent and purge cart equipment, as well as auxiliary loads assocjated with the bas un eower emengency-generators and

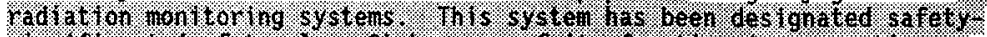

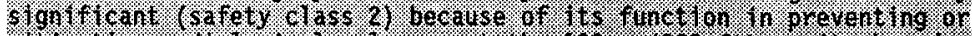

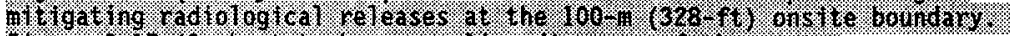

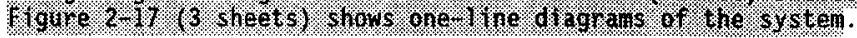

The backivesafety class 2 emergency power system has two independent

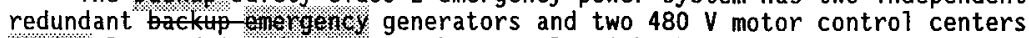
(10.5) located inside the CSB that comply with the-single-failure and

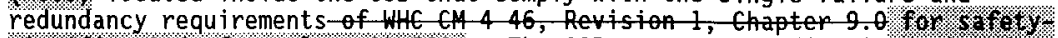

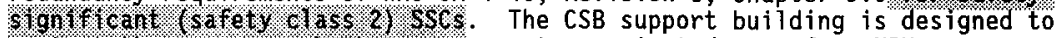
protect the emergency bodkut power system against damage from NPHs, as

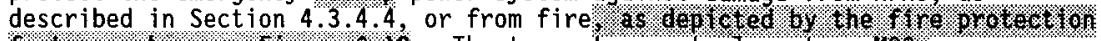

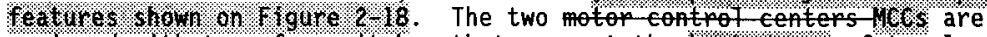
equipped with transfer switches that connect the 1/doked . up safety class 2

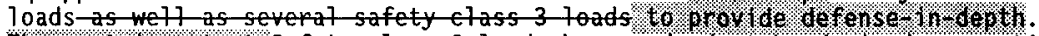
The most 1 in protant safety elass $2-10 a d s$ have redundant hard-wired connections to viluer both motor control centers. by either motor control center $/ \mathrm{c}$ via the $480 \mathrm{~V}$ floor out 1 ets. Each backup power system is protected by independent fire barriers, detectors, and suppression systems. The system is designed to prevent failure of one system, structure, or component from causing cascading failure of anoortant. safety elass 2 loads. The system is designed to power all knowtant safety-class 2 loads from either generator as described in the architect-engineer's File 106.151, Failure Modes and Effects Analysis: Emergency Power System

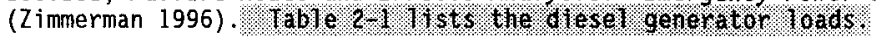

\section{$2.2 . \% 1$ re protection}

The safety support functions of the $C S B$ are provided by backup electricat power and fire protection and monitoring systems. The design of the CSB ant DOE Order 5480.7A, Fire Protection, requirement for a fully sprinkled building Sel\%ers. 1996). WHC-SD-SNF-FHA-002, Fire Hazard Analysis for the Canister

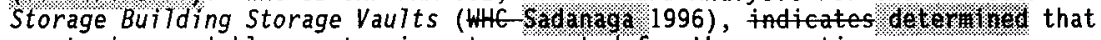
a wet pipe sprinkler system is not warranted for the operating area. 


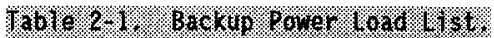

\begin{tabular}{|c|c|c|}
\hline 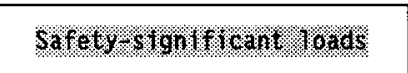 & 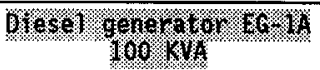 & 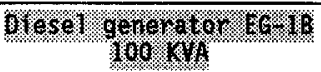 \\
\hline \multicolumn{3}{|l|}{ Safefy y.4s: } \\
\hline 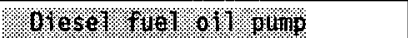 & 10.88 & $0 \%$ \\
\hline 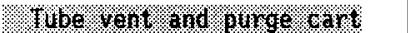 & 12.60 & $1 \mathrm{rou}$ \\
\hline Wro went and guroes cart & 12.00 & 12.00 \\
\hline 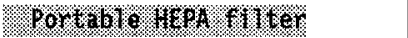 & $2.0 \%$ & 207 \\
\hline 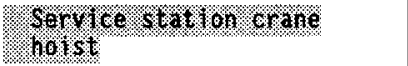 & 6.06 & 0.00 \\
\hline (४⿻) & 3. 61. & 60.81 \\
\hline \multicolumn{3}{|l|}{ 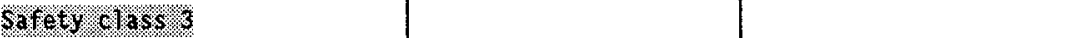 } \\
\hline 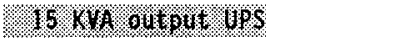 & $18 . / 15$ & \% \\
\hline 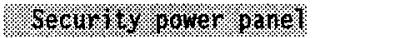 & 15.69 & \% \\
\hline Pane & M & $30 \%$ \\
\hline 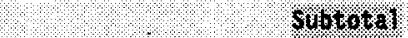 & 66.76 & 63.89 \\
\hline 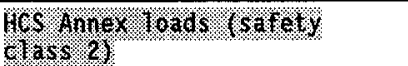 & 30.60 & $30 \% 0$ \\
\hline 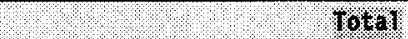 & 96.76 & 93.61 \\
\hline
\end{tabular}

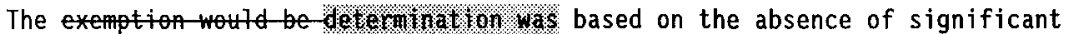
existing combustible loading, the control of transient combustible loading, the minimal benefit of a sprinkler system, and the reduced potential for moisture entering the storage tubes and possibly overpresturizing thestorage tube.

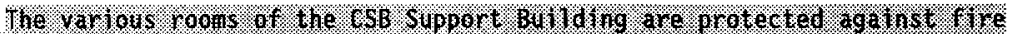

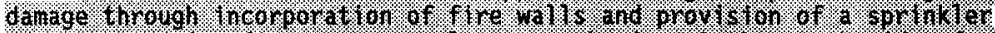

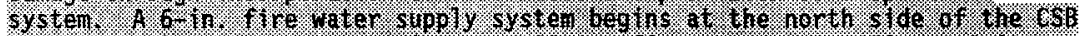

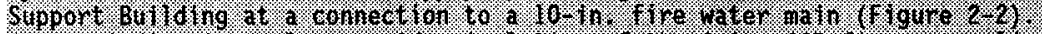

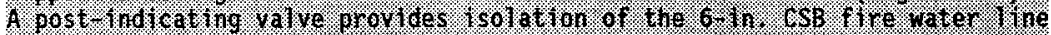

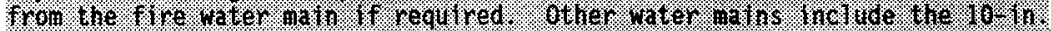

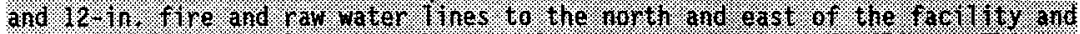

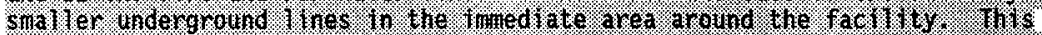

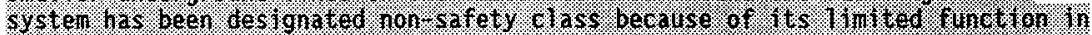

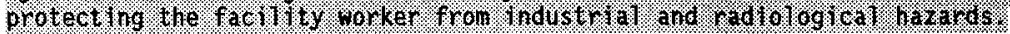




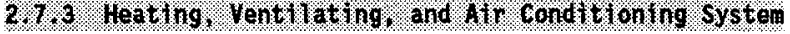

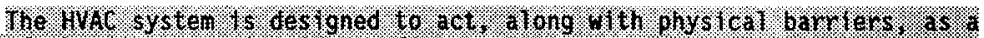

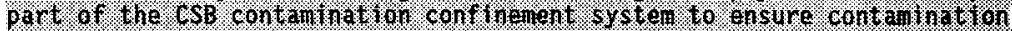

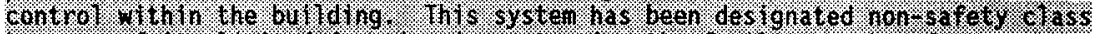

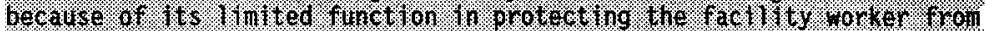

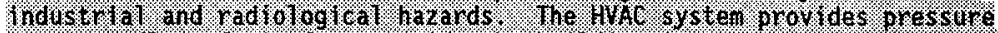

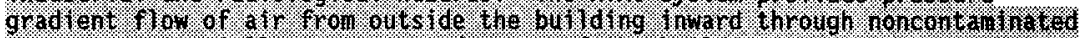

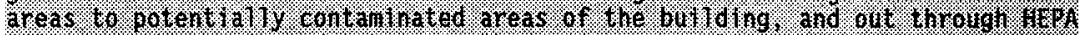

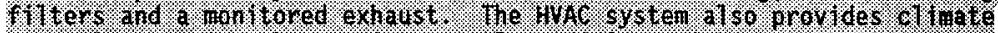

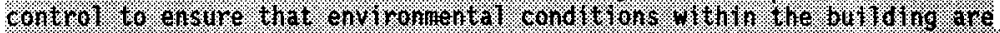

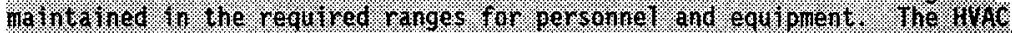

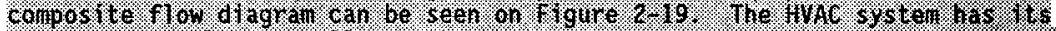

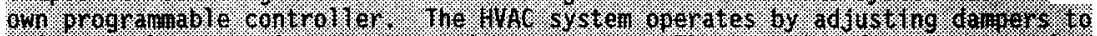

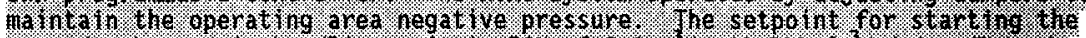

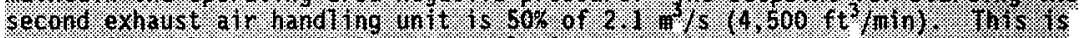

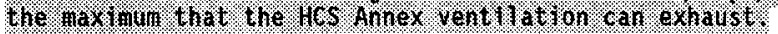

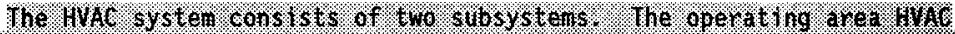

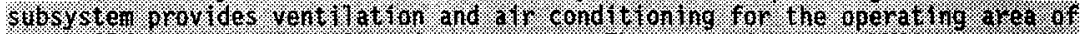

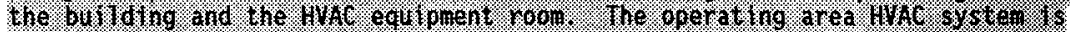

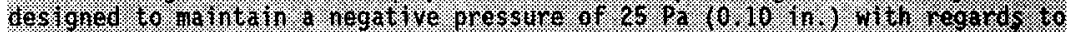

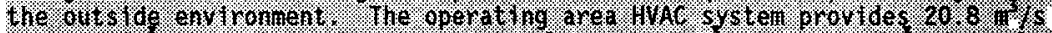

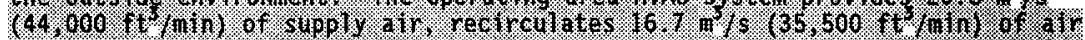

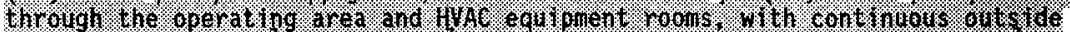

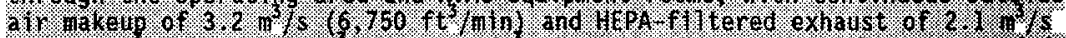

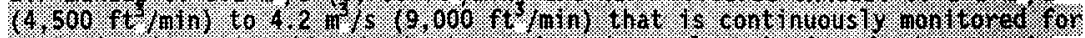

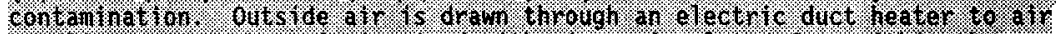

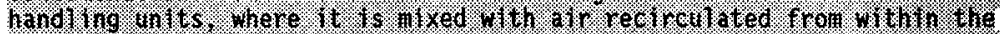

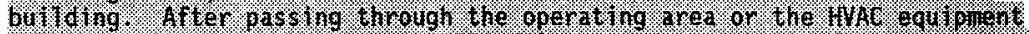

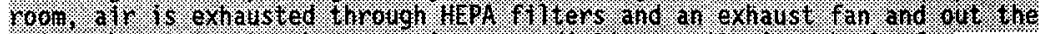

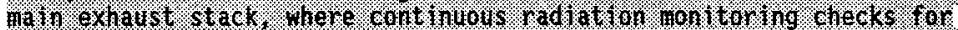

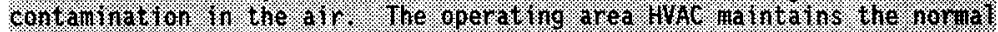

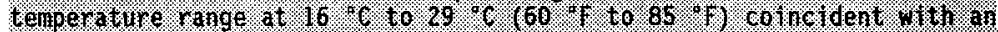

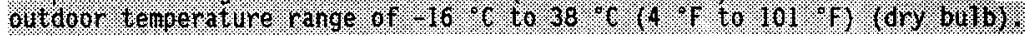

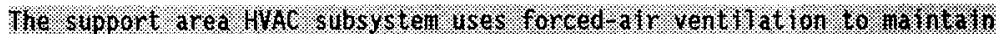

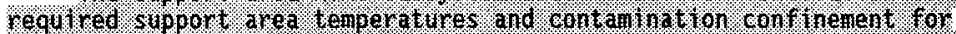

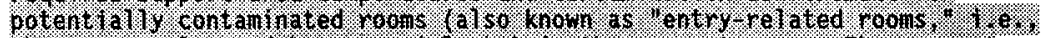

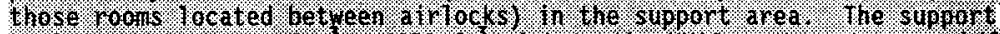

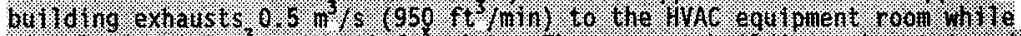

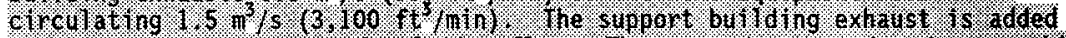

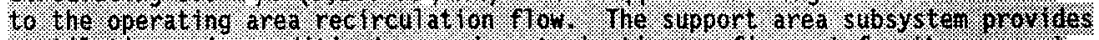

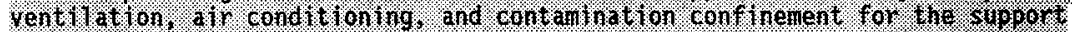

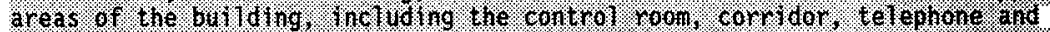

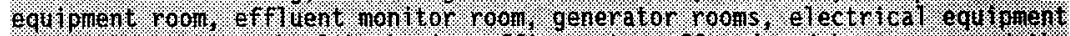

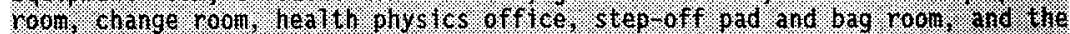

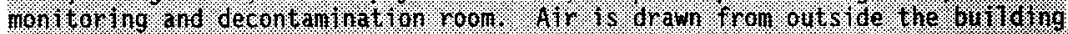

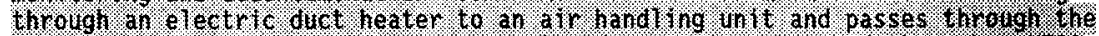

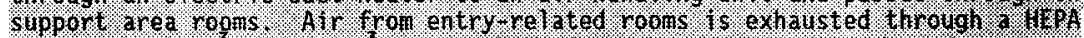

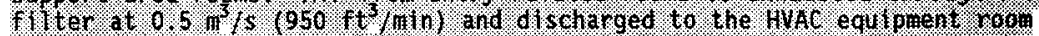

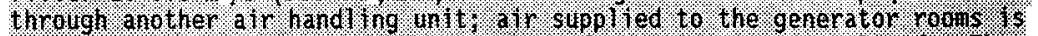

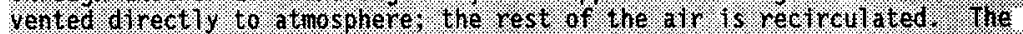

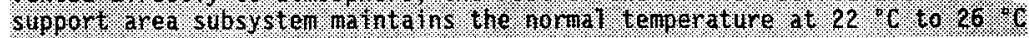




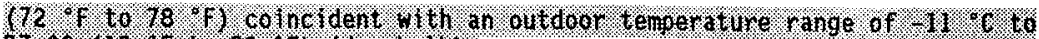

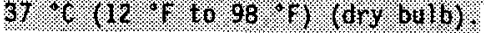

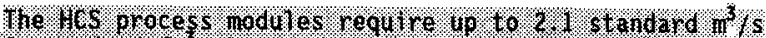

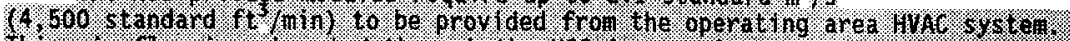

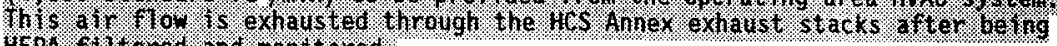

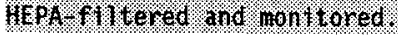

\subsection{4 . Health Protection system}

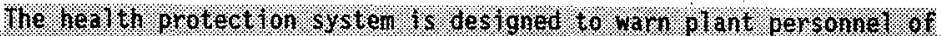

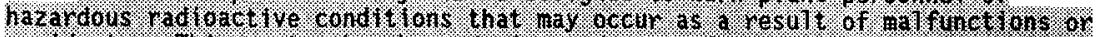

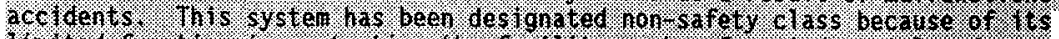

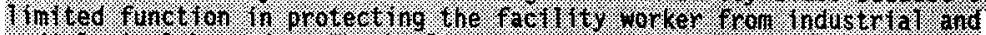

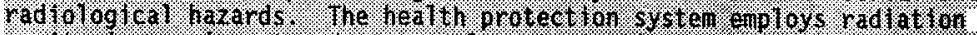

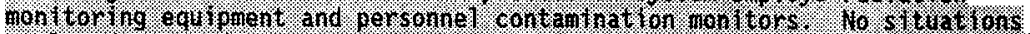

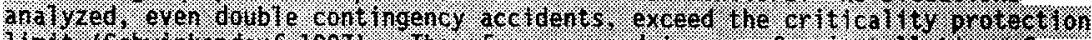

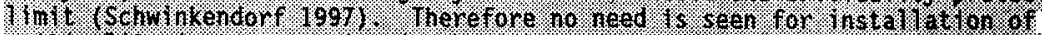

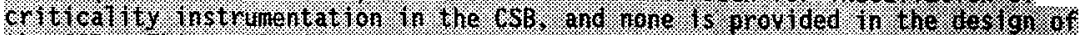

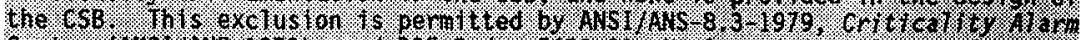

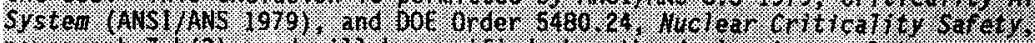

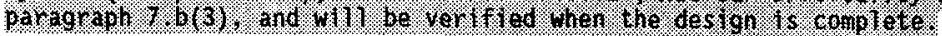

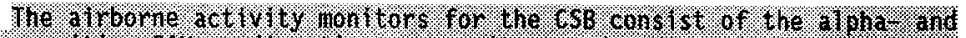

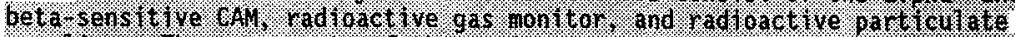

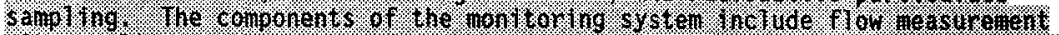

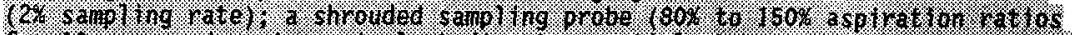

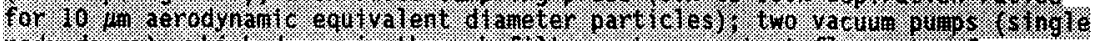

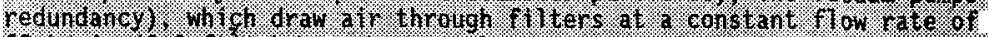

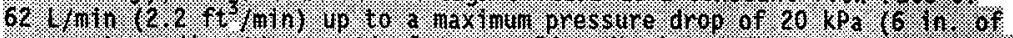

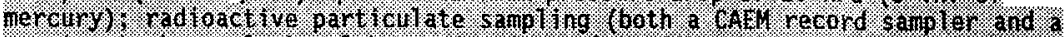

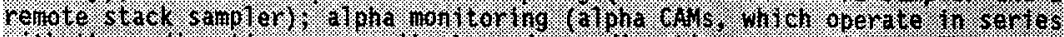

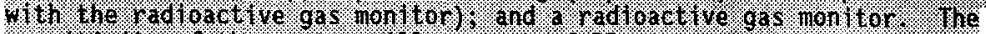

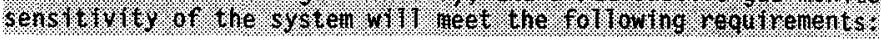

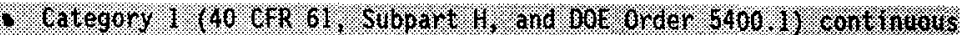

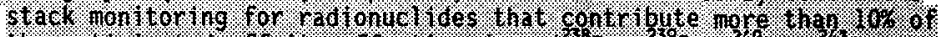

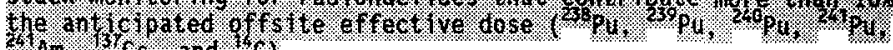

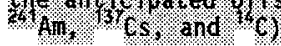

- Constant a ir montorling of alpha and noble gases

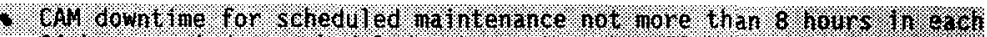

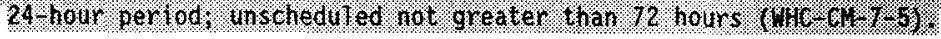

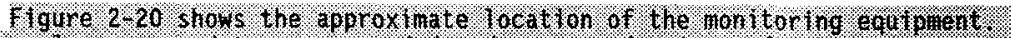
personnel exposura data are recorded and processed us ino a factithy.

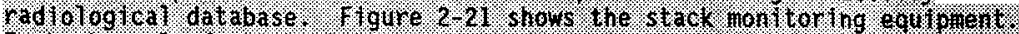

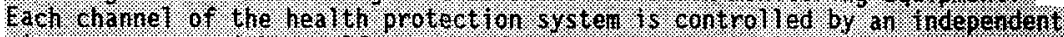

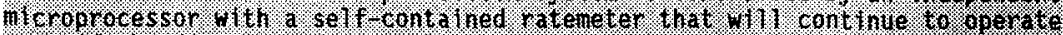

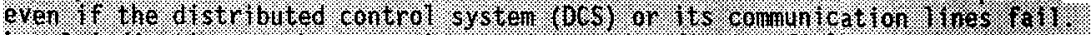
Local indications such as count rate data and radtathon ffeld interswtiles will be avallable from each chamel. If alorn conditions exist. there whl be 


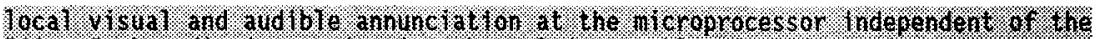

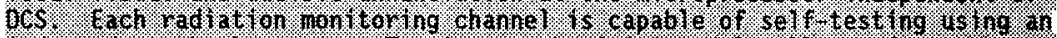

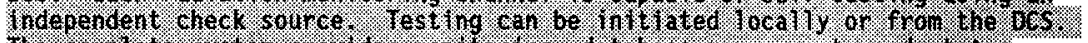

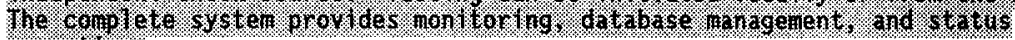
1epor $\$ 110$.

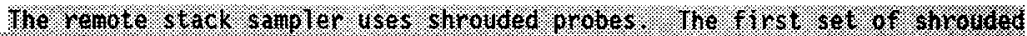

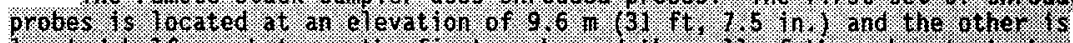

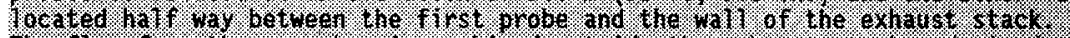

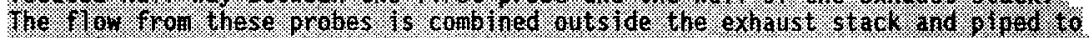

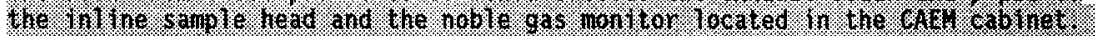

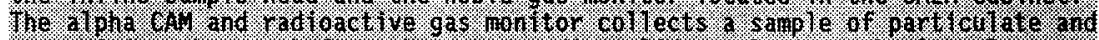

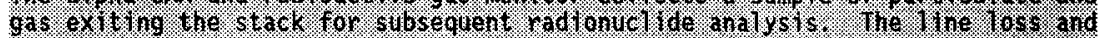

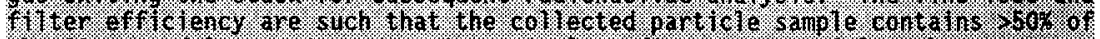

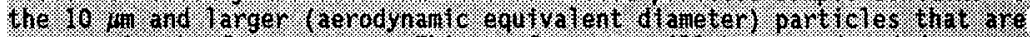

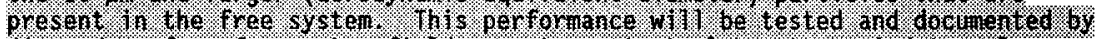

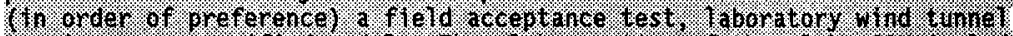

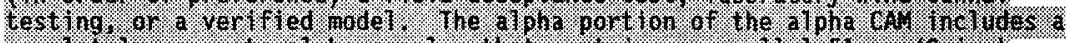

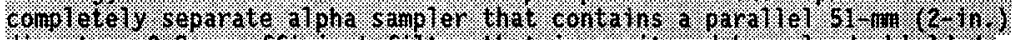

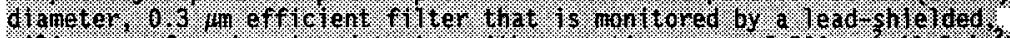

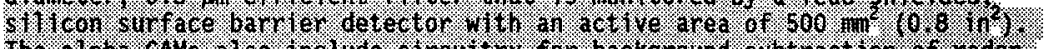

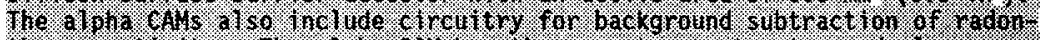

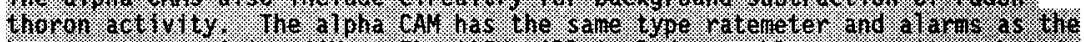

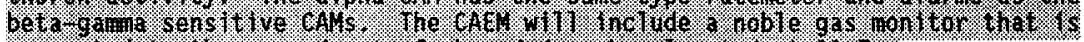

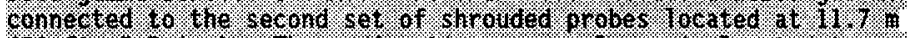

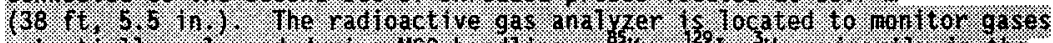

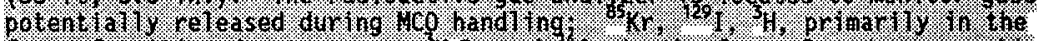

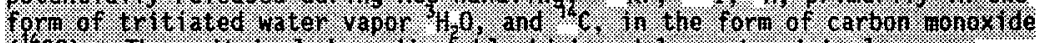

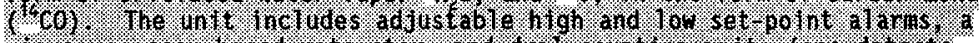

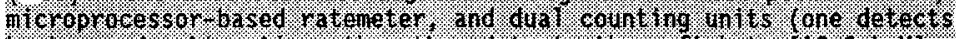

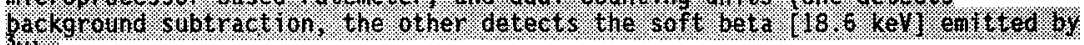
31.

\section{8. UTITV BISTRMBTION SYSTEWS}

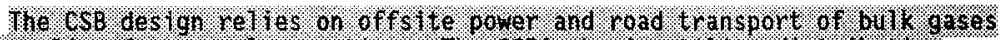

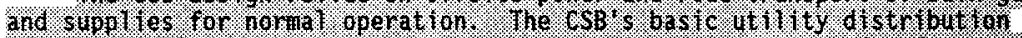

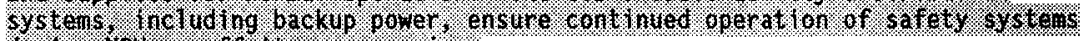

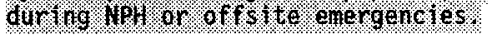

\subsubsection{Backup Electrlcal Power and Generators}

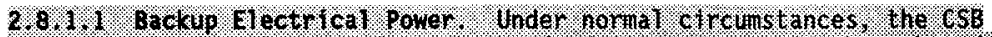

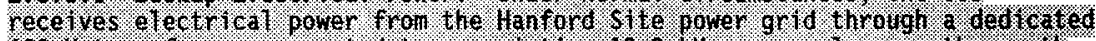

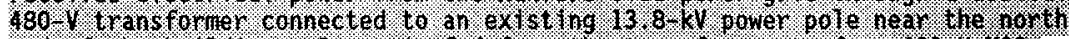

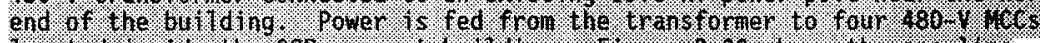

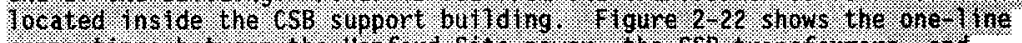

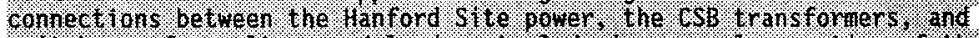

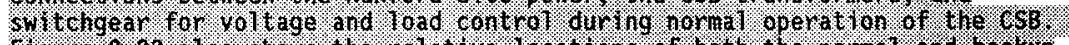

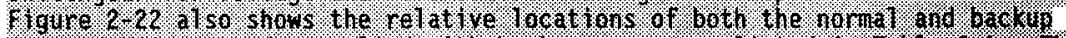

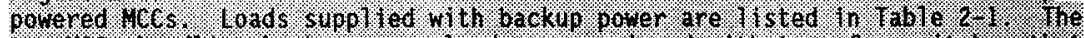

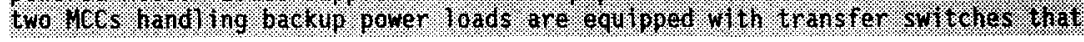




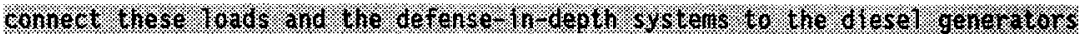

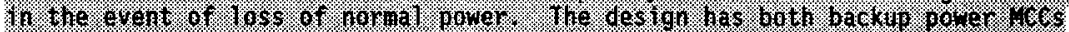

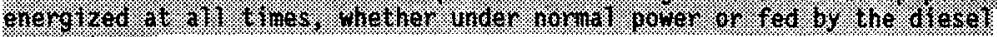
gencr $180 \%$.

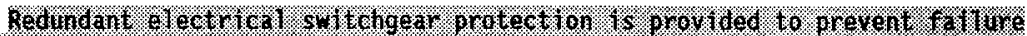

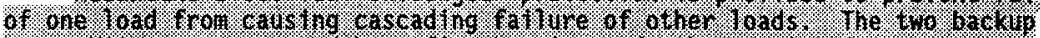

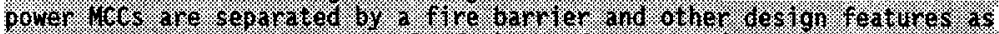

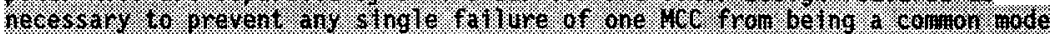

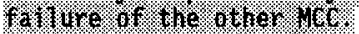

2.8. $124-2.8$ Emergency Diesel Generators. The emergency generator system is

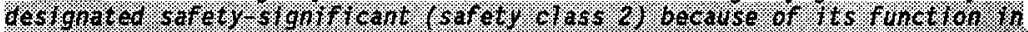

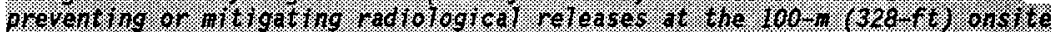
$6000 \% 0 \%$. 15 . housed in the support building at the north end of the CSB. The system is composed of two identical and redundant units, each rated at 100-164kh output (3-phase, $480 \mathrm{~V}$ ) and powered by a V-6 turbocharged diesel engine with air starter. The engine generator sets are positioned on vibration isolators to minimize transmission of vibration. The system has been designed in accordance with Engine Driven Generator Sets Guideline Specifications for Emerqency or Standby (EGSA 1992); IEEE 446, Recommended Practice for Emergency and Standby Power Systems for Industrial and Commercial Applications (IEEE 1987); NFPA 70, National Electrica7 Code (NFPA 1993); and NFPA 110, Standard for Emergency and Standby Power Systems (NFPA 1996\%).

The two units are located in different rooms separated by a 2-hour firewall in accordance with ANSI NFPA 30, Flammable and Combustible Liquids Code (AASIHNPA 19960\%). Each room houses the diesel generator set; a 190-L (50-gal), double-walled, diesel fuel day tank; and a $1.5 \mathrm{~m}^{3}$ (55 $\mathrm{ft}^{3}$ ) starting air receiver, operating at $758 \mathrm{kPa}$ gauge $\left(110 \mathrm{lb} / \mathrm{in}^{2}\right.$ gauge), that is capable of providing si* erght consecutive starts of the diesel generator. Each room also houses an automatic transfer switch that will initiate the startup of the diesel unit on sensing a loss of offsite power.

When a loss of offsite power occurs, each of the tho automatic transfer switches will send a start signal to its dedicated generator. 1 he ganerforoo

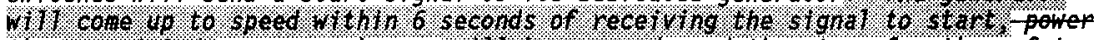

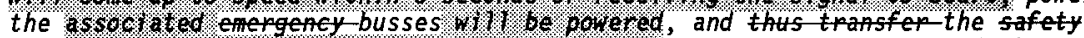
eTass 2 loads troos terded. 10 . Whe to its generator within 15 seconds of the occurrence. The automatic transfer switch is programed in such a manem that after two unstrecesful starting attempts, it will ativate the second emergency generator to stant and carny the 6 astowowafety elass 2 loals. The generator will come up to sped within 6 seconds of receiving the signal to stapt. The two automatic transfer switches a 750 are programed in such a way that one is a 7 ad and will receive the stanting signal first, and if for some reason it fails to operate, the second transfer switch will take over and initiate the starting procedure.

Each generator will have a load bank permanently installed on the exhaust side of the engine radiator, on the generator skid extension on the north side of the diesel engine. This 100-kW load bank will allow generator load testing

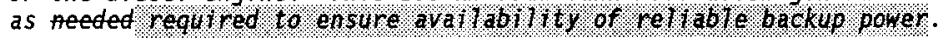


Rotating equipment exposed to operator w contact is protected by metallic guards to prevent contact. The protection provided is in accordance with OSHA Instruction Standard 1-12-14, Guards for Rotating Equipment (OSHA 1978). Hot surfaces of $49^{\circ} \mathrm{C}\left(120^{\circ} \mathrm{F}\right)$ or more What one 10.085\%16\% - exposed to human reach are insulated to prevent burns. This is in accordance with ASTM C1055, Standard Guide for Heated System Surface Conditions that Produce Contact Burn Injuries (ASTM 1992\%).

Two 1,900-L (500-gal) diesel fuel storage tanks are located outside the north wall of the support building at a distance of $3 \mathrm{~m}(10 \mathrm{ft})$. Each tank is a double-walled, insulated, above-ground tank with a leak detection system.

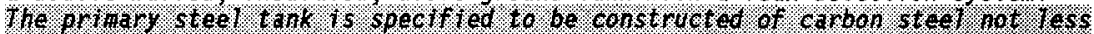
than: 0.5 . chit $17.18 \%$.

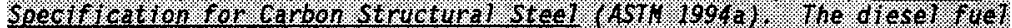

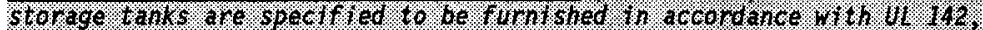

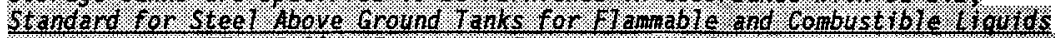

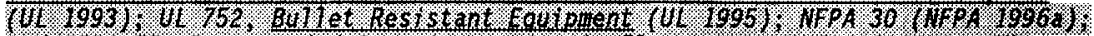

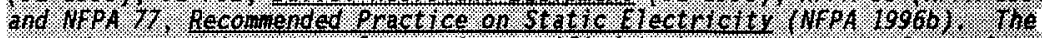

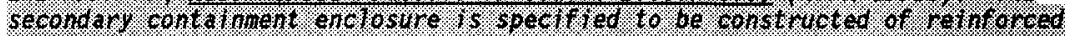

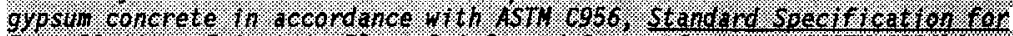

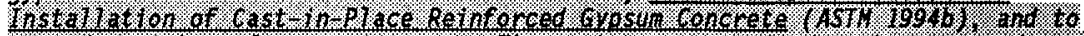

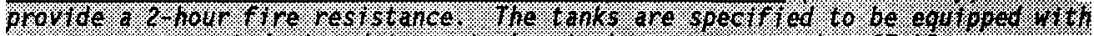

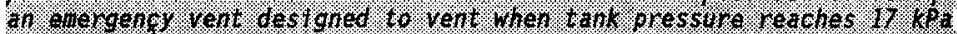

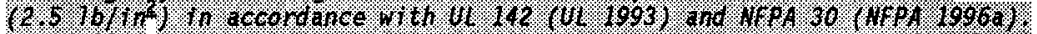
Overfilt protection compartments can contain to- $95 \%$ : -2 (2/.5 gat) of

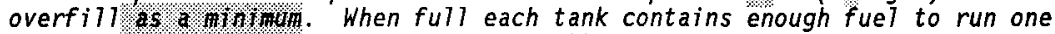
diesel generator unit for 48 hours at full power. Each tank has a positive displacement pump mounted on the top of the tank. This pump is $50.4 \%$ to reat to the level control on the 190-L (50-gal) day tank and keeps the day tank filled with diesel fuel. The top of the storage tank is equipped with a walkway and ladders for access and maintenance. The two diesel fuel storage $t a n k s$ are to be filled by a standurd fuel hose and dispenser nozzle from a

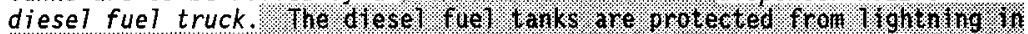

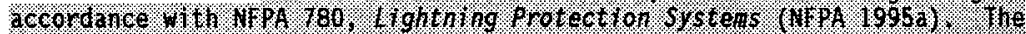

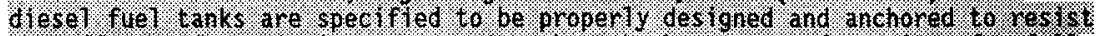

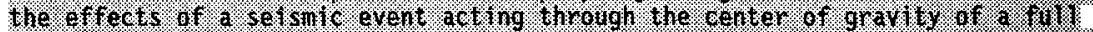

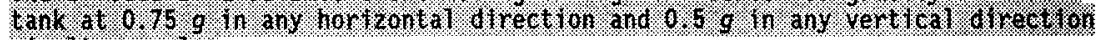
stoult aneous 1 \%

\subsubsection{Distributed Control System}

The DCS is designed to serve as the central monitoring system for CSB

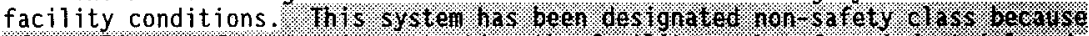

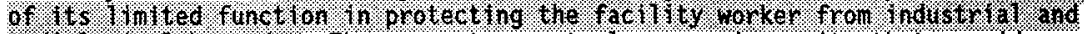
radologlcal. hazards. There are two central processing units that provide redundant data collection from instrumentation and monitoring systems located throughout the facility. The DCS collects data from a separate HVAC programale compter, which is used to monitor ain temperatures in the storage vault and to perform calculations on heat removal in the vault. Components in the field (e.g., instruments, actuators, sensors) are connected to the DCS at remote termination unit cabinets and data multiplexers that are located throughout the facility. Beduated orstrocessing units will be added later as the primary controllers for hot conditioning and to provide 
signal conditioning and communications with operator workstations in the HCS Annex. These fedicated dith processing units may share a cabinet with the remote termination units. The multiplexers concentrate serial data from the health physics instruments and transmit the data to the operator workstations. A data highway links all components of the DCS together. Printers in the control room allow for the printing of hardcopy listings of alarms, control actions, and other reports by operator request. The DCS also provides access to the Hanford Local Area Network (HLAN) through a separate HLAN server. The iES is showir on f I grre 2 - 23 .

\subsubsection{Instrument and Plant Air System}

The CSB instrument and plant air system consists of two two-stage oilfree rotary screw compresşors operating in lead-lag fashion to deliver a minimum of 5.7 standard $\mathrm{m}^{3} / \mathrm{min}\left(200\right.$ standard $\left.\mathrm{ft}^{3} / \mathrm{min}\right)$ of compressed air at $862 \mathrm{kPa}$ gauge (125 $\mathrm{lb} / \mathrm{in}^{2}$ gauge). The air passes through a coalescing prefilter, a heatless desiccant air dryer, and a particulate afterfilter before it resides in a 9,690-L $(2,560-$ gal $)$ air receiver to provide air on demand to the diesel air-start tanks, the MHM festoon supply, and the instrument and plant air utility stations, as shown on Drawings $\mathrm{H}-2-123392$,

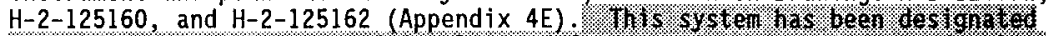

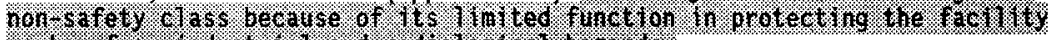

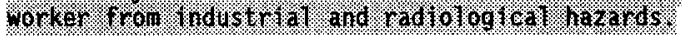

\subsubsection{Liquid Waste Collection}

The liquid waste collection system is designed to collect water condensate from the HVAC air handling unit's cooling coils and from the instrument air compressors, and and to pride for transfe of the waste condensate to drums that can be transported to the Treated Effluent Disposal Facility. ITis syster. has been

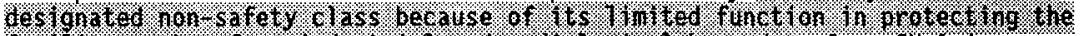

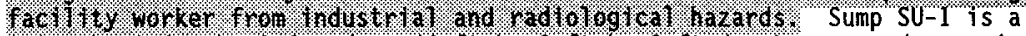
$1.2 \mathrm{~m}$ by $0.6 \mathrm{~m}$ by $0.6 \mathrm{~m}$ deep $(4 \mathrm{ft}$ by $2 \mathrm{ft}$ by $2 \mathrm{ft}$ deep) recessed area in the support building floor between the air handling units, as shown on Drawings $\mathrm{H}-2-123395$ and $\mathrm{H}-2-129416$ (Appendix 4E). A second sump $0.6 \mathrm{~m}$ square by $0.6 \mathrm{~m}$ deep ( $2 \mathrm{ft}$ square $2 \mathrm{ft}$ deep) is located between the instrument and plant air compressors, as shown on Drawing H-2-125160 (Appendix 4E). The liquid waste collection system is not a floor drain or fire suppression water catchment. HVAC condensate drains to the liquid collection sump from drip pans located in the HVAC equipment room. The system is designed to collect condensate at approximately $3.8 \mathrm{~L} / \mathrm{h}(1 \mathrm{gal} / \mathrm{h})$ for 8 hours per day. An alarm is activated on the DCS when the level sensor in the sump indicates that the water level has reached $30.5 \mathrm{~cm}$ (12 in.), approximately $208 \mathrm{~L}$ (55 gal).An operator empties the sump into a $208 \mathrm{~L}$ ( 55 -gal) drum using a portable air operated pump by first placing the pump's stution hose into the stmp and then connecting an air hose between the pump motor and the nearby utility station. This poss cont intes unt the pump is unable to lower the level any-farther and the alarm has cleared, or unt il the drum is full. The contents of the full barrels are then tested for radiological and chemical contamination.When the contents are released for disposal, the barrels are shipped to a facility from which the contents can be trasfored to the Treated Effluent 
Disposal Facility. SNF Operations will be responsible for detemining disposition of barat contents that test orep limits for ratiological or chemical contamination and cannot be released for disposal.

\subsubsection{Potable Tater}

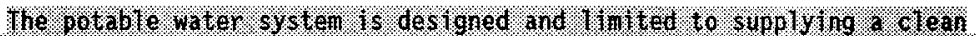

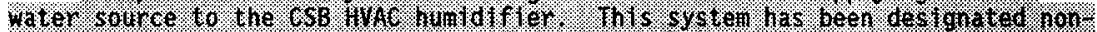

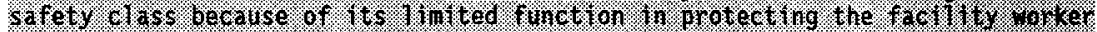

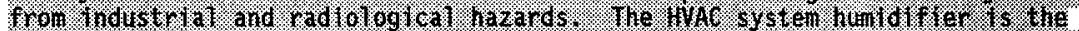

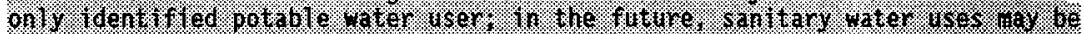

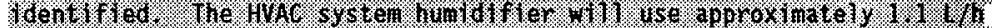

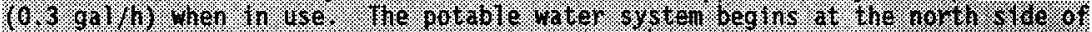

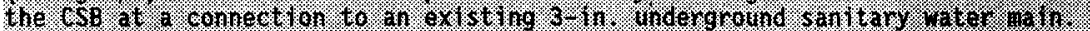

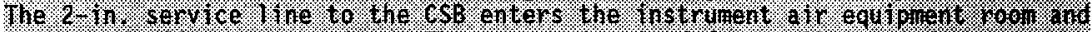

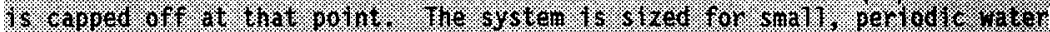

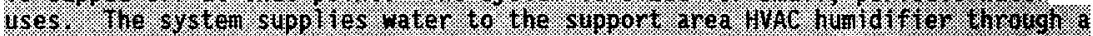

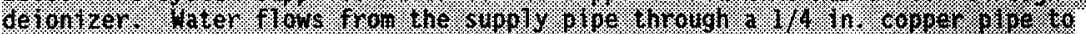

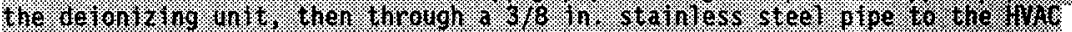

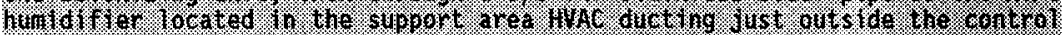

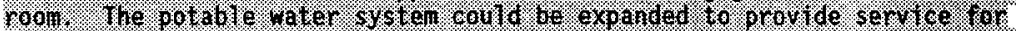

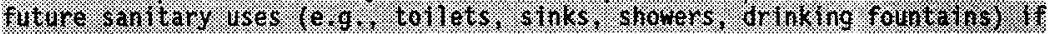
reavirect:

\subsection{AUMULRY SYSTIIS}

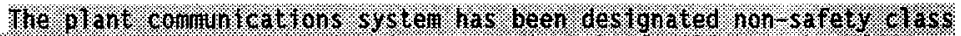

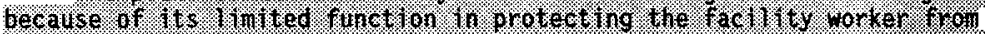

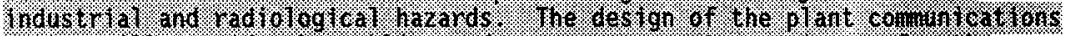

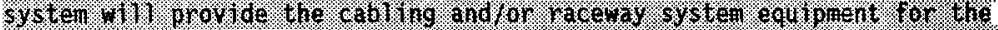

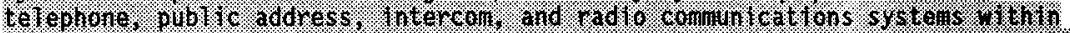

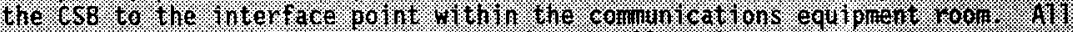

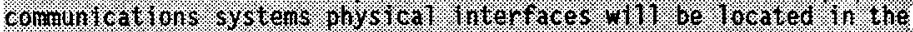

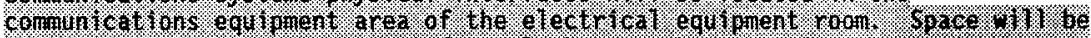

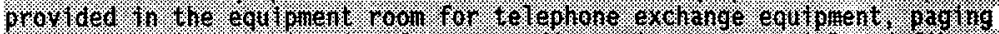

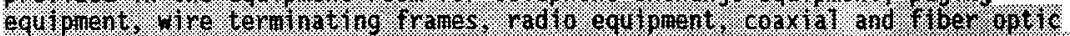

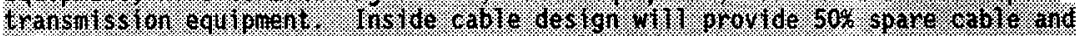

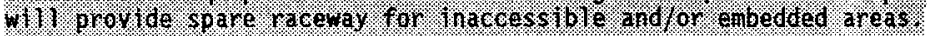

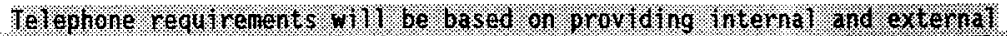

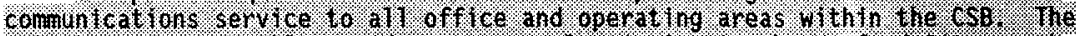

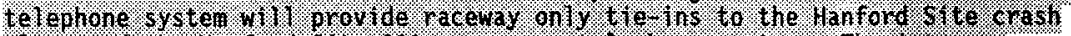

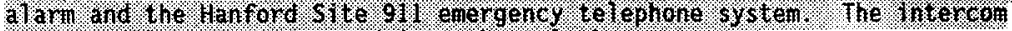

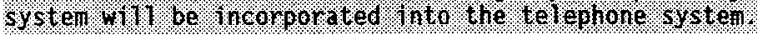

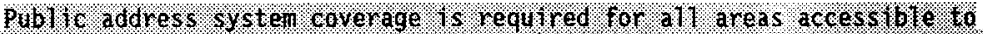

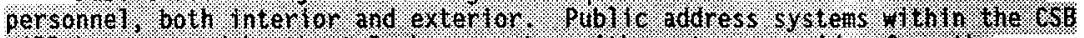

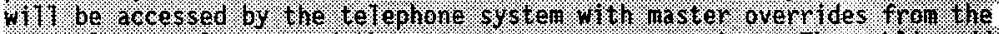

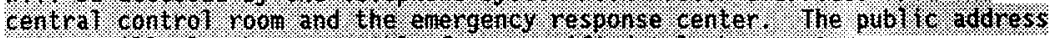

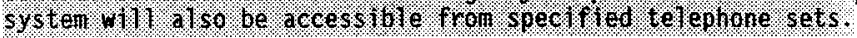




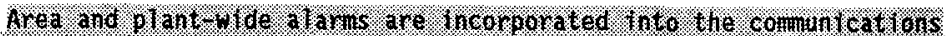

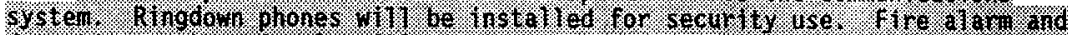

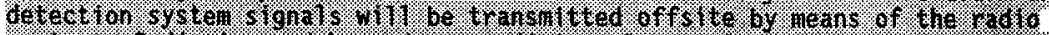

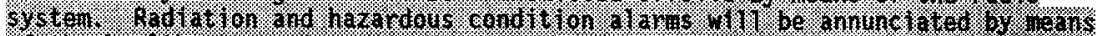

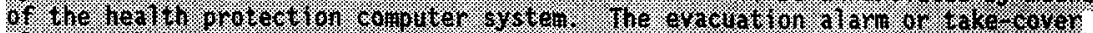

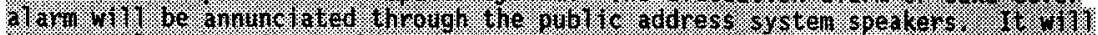

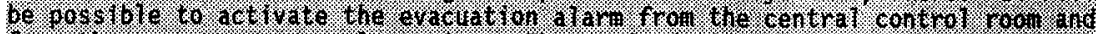

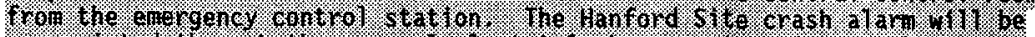

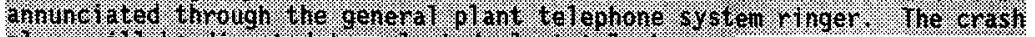

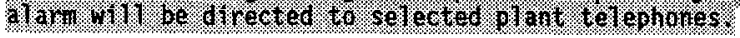

MT areras of \%

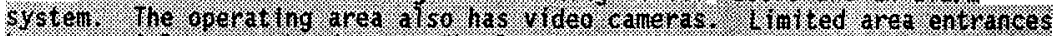

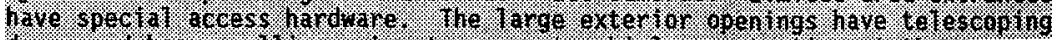

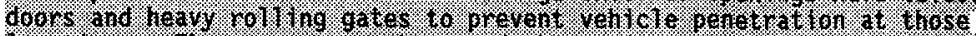

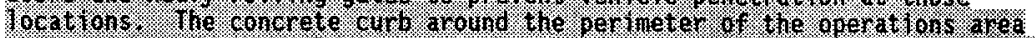

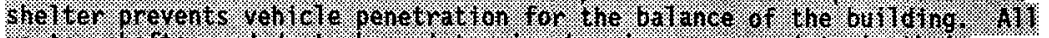

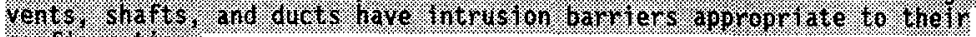
conf curatron:

\subsection{REFERENCES}

10 CFR 72, "Licensing Requirements for the Independent Storage of Spent Nuclear Fuel and High-Level Radioactive Waste," Code of Federal Regulations, as amended.

10 CFR 835, "Occupational Radiation Protection," Code of Federal Regulations, as amended.

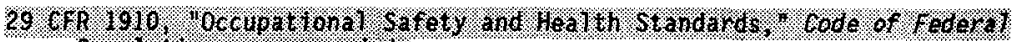

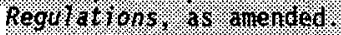

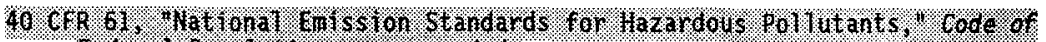

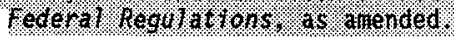

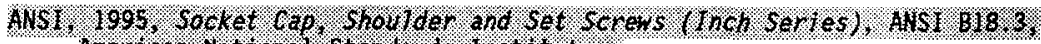

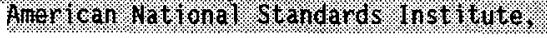

ANSI/ACI, 1985, Code Requirements for Nuclear Safety Related Concrete Structures, ANSI/ACI 349-85, American Concrete Institute, Detroit, Michigan.

ANSI/AISC, 1994, Specification for the Design, Fabrication, and Erection of Steel Safety-Related Structures for Nuclear Facilities, ANSI/AISC N690-94, American Institute of Steel Construction, Chicago, Illinois.

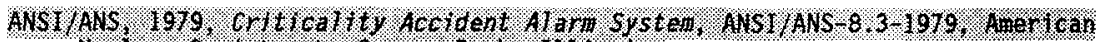

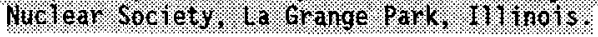

${ }^{1}$ Medeco is a trademark of Medeco, Incorporated. 
ANSI/ANS, 1992\%, Design Criteria for an Independent Spent Fuel Storage Installation (Dry Type), ANSI/ANS-57.9-1992, American Nuclear Society, La Grange Park, Illinois.

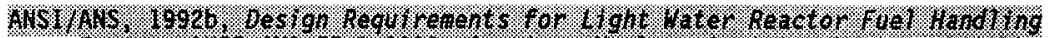

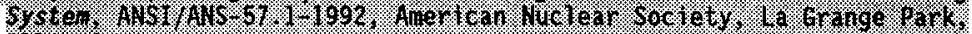
MYUts.

ANSI/ASME, 1995a, Overhead and Gantry Cranes (Top Running Bridge, Single Girder, Underhung Hoist), ANSI/ASME 30.17, American Society of Mechanical Engineers, New York, New York.

ANSI/ASME, 1995b, Overhead Hoist (Underhung), ANSI/ASME B30.16, American Society of Mechanical Engineers, New York, New York.

ANSI/ASME, 1995c, Performance Standard for Overhead Electric Wire Chain Hoists, ANSI/ASME HST-1M, American Society of Mechanical Engineers, New York, New York.

ANSI/ASME, 1995d, Safety Standard for Hooks, ANSI/ASME B30.10, American Society of Mechanical Engineers, New York, New York.

ANSI/AFPA, 1993, Flamable and Combustible Liquids code, ANSI/AFPA 30, National Fire Protection Association, Quincy, Massachusetts.

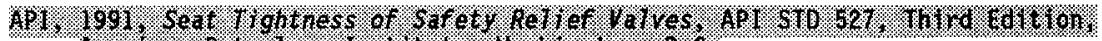

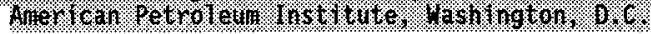

API, 1995, Specification for time Pipe, API Specification-5L, American Petroleum Institute, Washington, D.C.

Ares, 1996, Canister Storage Building Construction Restant Readiness Assessment, Repont No. 951108 -001, Ares Corporation, Richland, Hashington.

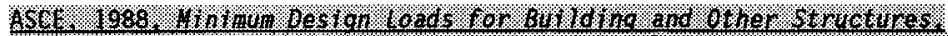

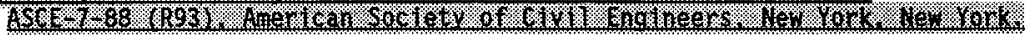

ASME, 1993柿, Below-the-Hook Lifting Devices, ASME B30.20-1993, American Society of Mechanical Engineers, New York, New York.

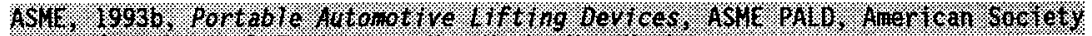

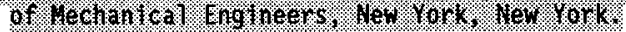

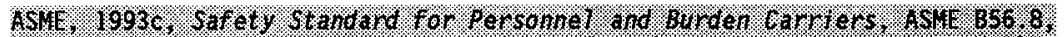

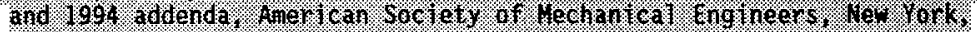
1e* Iort:

ASME, 1995a, Boiler and Pressure Vessel Code, Section III, Division 1, Subsection NB, "Rules for Construction of Nuclear Power Plant Components," American Society of Mechanical Engineers, New York, New York. 


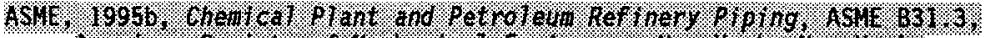

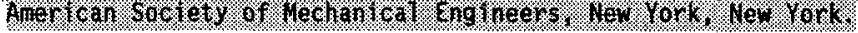

ASME, 1995eb, Rules for Construction of Overhead and Gantry Cranes (TopRunning Bridge, Multiple Girder), ASME NOG-1-1995, American Society of Mechanical Engineers, New York, New York.

ASTM, 1983a, Standard Test Method for Tearing Strength of Woven Fabrics by the Tongue (Single Rip) Method (Constant-Rate-of-Extension Tensile Testing Machine), ASTM D 226l, American Society for Testing and Materials, Philadelphia, Pennsylvania.

ASTM, 1983b, Standard Test Hethod for Tearing Strength of Woven Fabrics by the Tongue (Single Rip) Method (Constant-Rate-of-Traverse Tensile Testing Machine), ASTM D 2262, American Society for Testing and Materials, Philadelphia, Pennsyivania.

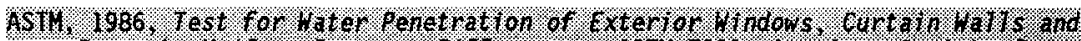

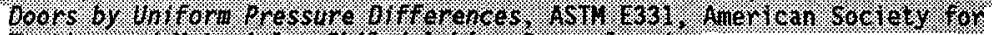

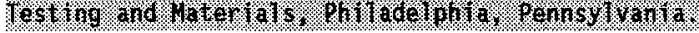

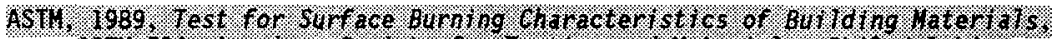

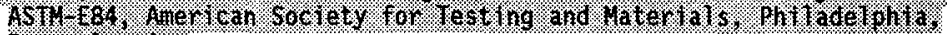

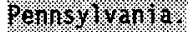

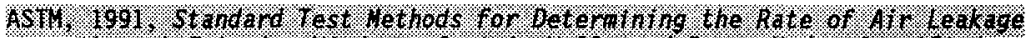

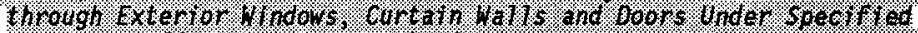

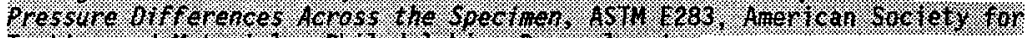

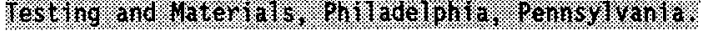

ASTM, 1992;, Standard Guide for Heated System Surface Conditions that Produce Contact Burn Injuries, ASTM C1055, American Society for Testing and Materials.

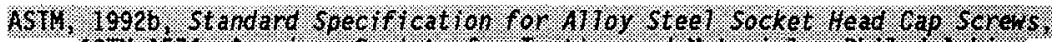

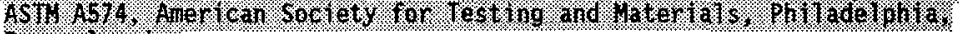

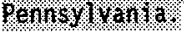

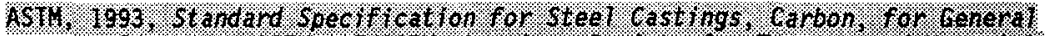

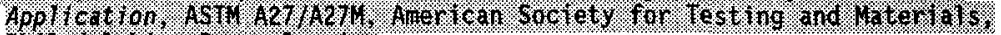

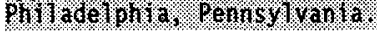

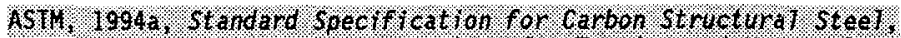

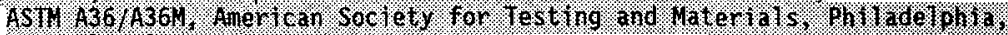
Pen Instrot.

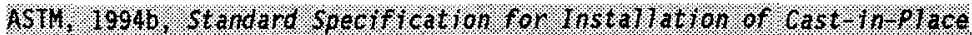

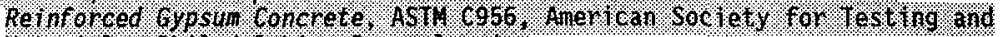

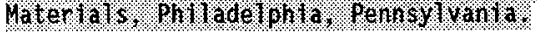

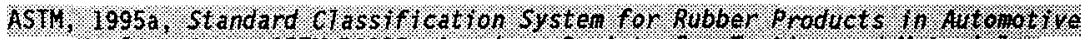

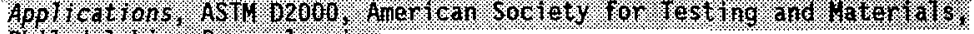

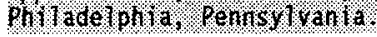




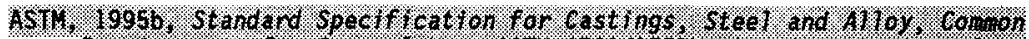

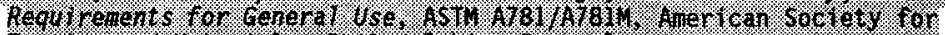

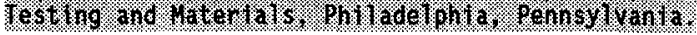

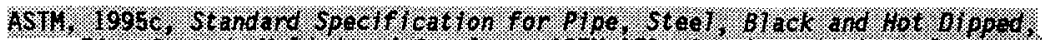

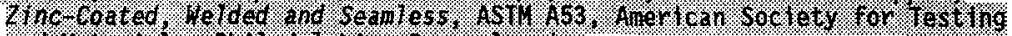

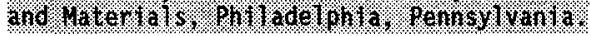

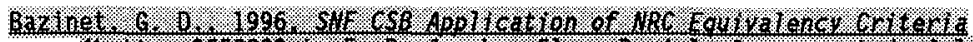

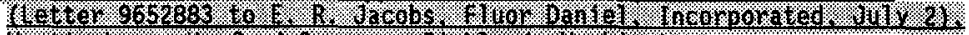

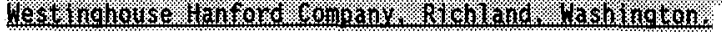

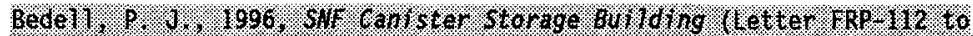

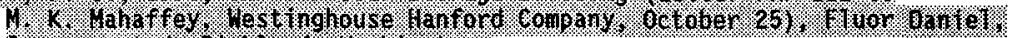

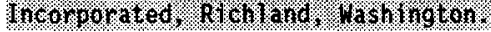

Bede17, P. J., 1996, SAF CSB ARC EquivalenCy Evaluation thetter FOF 012 to M. K. Mahaffey, Duke Engineering and Senvices Hanford, Incopopated, November 21), F7uor Daniel, Incorporated, Richland, Washington:

Bergsman, K. H., 1996, Multi- Ganister Orerpak (H60) Pressupization Ana7ysis; WHC SO SNF TI 029, Rer. O, West inghouse Hanford Company, Richland, Washington.

Breismeister, J. F., editor, 1993, MCNP - A General Monte Carlo N-Particle Transport Code, Version 4A, LA-12625, Los Alamos National Laboratory, Los Alamos, New Mexico.

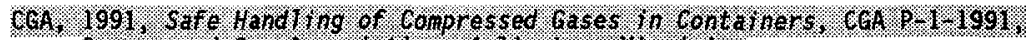

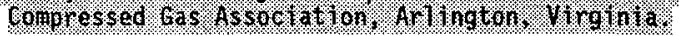

CMAA, 1994, Specifications for Top Running Bridge and Gantry Type Multiple Girder Electric Overhead Traveling Cranes, Specification No. 70, Crane Manufacturers Association of America, Pittsburgh, Pennsylvania.

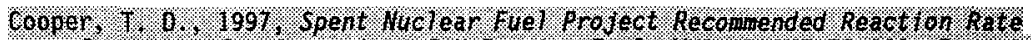

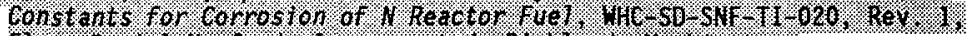

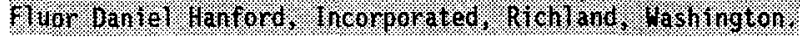

Bames and Hoore, 1989, fropt of Geothical Investigations for the proposed Hanford Waste Vitrification Plant, Hanford Washington, Report 10805385016 and stpplate date 24,1991 , 1992, Dames and Moore, Seattle, Washington.

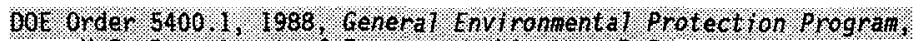

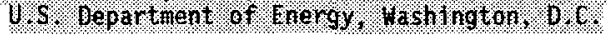

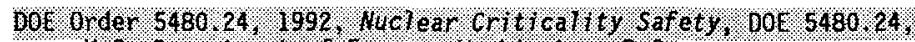

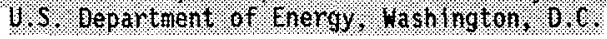

DOE Order 5480.28, 1998. Natural Phenomena Hazards Mitigation, U.S. Department of Energy, Washington, D.C. 
DOE Order 5480.7A, 1993, Fire Protection, U.S. Department of Energy, Washington, D.C.

DOE Order 6430.1A, 1989, General Design Criteria, U.S. Department of Energy, Washington, D.C.

DOE-RL, 1993, Standard Architectural-Civil Design Criteria, Design Loads for Facilities, DOE-RL-HPS-SDC-4.1, Rev. 12, U.S. Department of Energy, Richland Operations office, Richland, Washington.

EGSA, 1992, Engine Driven Generator Sets Guideline Specifications for Emergency or Standby, Electrical Generating Systems Association,

FQI, 19962, Engineering Assessment Inspection (RFI:PH T3-001 to Westinghouse Hanford Company, Mareh 19), Rev. 1, fluor Baniel, Incopoted, Richland, Washington.

FDI, 1996b, Design Calculations for the SNF Canister Storage Building Project, Fluor Daniel, Incorporated, Richland, Washington.

Garvin, L. J., 1996a, Spent Nuclear Fuel Project Path Forward, Additional NRC Requirements, WHC-SD-SNF-DB-003, Rev. 1, Westinghouse Hanford Company, Richland, Washington.

Garvin, L. J., 1996b, Spent Nuclear Fuel Project Seismic Design Criteria, NRC Equivalency Evaluation Report, WHC-SD-SNF-DB-004, Rev. 2, Westinghouse Hanford Company, Richland, Washington.

Hyde, L. L., 1996a, Drop Analysis of Multi-Canister Overpack in Canister Storage Building (Transmittal Letter SCS-W-96-576 to L. H. Goldmann, Westinghouse Hanford Company, January 17), ICF Kaiser Hanford Company, Richland, Washington.

Hyde, L.t., 1996b, Nulti Canister Overpack Drop Analysis (tetter SCS -W $96-549$ to L. H. Goldmann, Westinghouse Hanfoud Company, January -9), ICF-Kaiser Hanford fompan, Richlant, Washington.

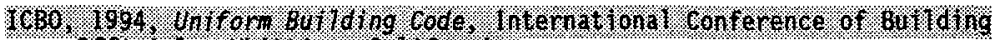

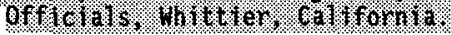

IEEE, 1987, Recommended Practice for Emergency and Standby Power Systems for Industrial and Commercial Applications, IEEE 446, Institute of Electrical and Electronics Engineers, Piscataway, New Jersey.

Istam, M.-A., 1996, Inspection of Canister Storage Building (CSB) Construction (ICF Kaiser Hanford Company Interoffice Memorandm to M. K. Mahaffey, Hestinghouse Hanford Company, March 1), ICF Kaiser Hanford-Company, Richland, Washington.

Jacobs, E. R., 1996a, AASI-57.9 (Transmittal Letter FRF 2792 to 14. K. Mahaffey, Westinghouse-Hanford Company, May 15), Fluop Daniel, theoporated, Richland, Washington. 
Jacobs, E. R., 1996b, Canister Storage Building (CSB) High Level Waste (HLW) Implementation Study (Letter FRF-034 to J. J. Jones, Westinghouse Hanford Company, May 13), Fluor Daniel, Incorporated, Richland, Washington.

Jacobs, E. R., 1996e, CSB Substructure Reanalysis (Pransmittal Letter FRF 2783 to M. K. Mahaffey, West inghouse Hanford Company, Apri7 24), Fluor Daniel, Incorporated, Richland, Washington.

Kidd, C. C., 1996a, Floor Plug/Deck Interface Analysis, Calculation CSB-SH-2002, Fluor Danie1, Incorporated, Richland, Washington.

Kidd, $C . C ., 1996 b, N C O$ Handling Machine/Portable Shield Gate, Galculation GSB SH 1004, Fluop Qaniel, Incorporated, Richland, Washington.

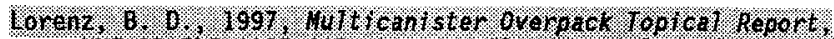

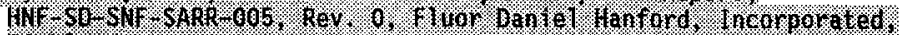

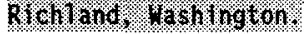

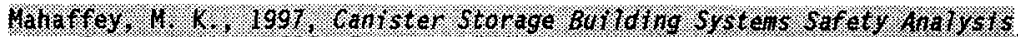

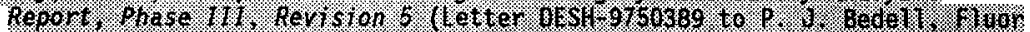

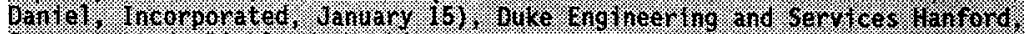

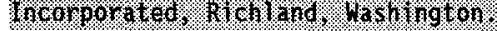

MH, 1989., Cloth and Strip, Laminated on Couted, Vinyl Nylon or Polyester High Strength, Flexible, HIt C 43066, U.S. Depantment of Defense, Washington, D.C.

Hortimer, d. H., 1996, RFI 034 Concpete Forming and Placement of Rebar Eurtains/RFI 036 Existing Rebar of CSB (Transmittal No. W 379017 to E. R. Jacobs, Fluor Baniel, Incopporated, April 15), ICF Kaiser-Hanford Eompany, Richland, Washington.

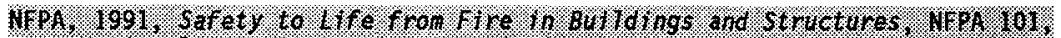

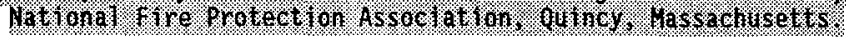

NFPA, 1993, National Electrical Code, NFPA 70, National Fire Protection Association, Quincy, Massachusetts.

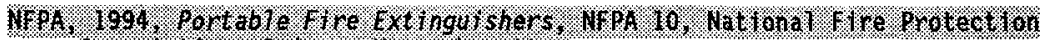

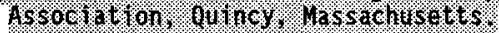

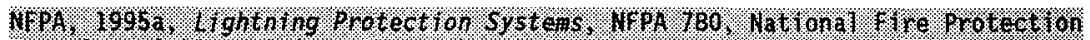

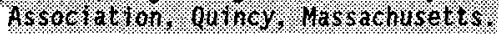

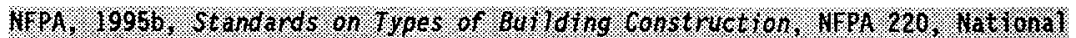

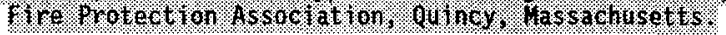

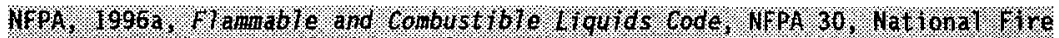

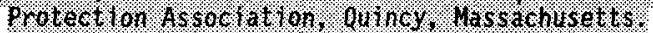

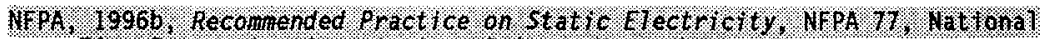

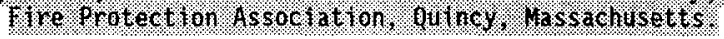


NFPA, 1996\%, Standard for Emergency and Standby Power Systems, NFPA 110, National Fire Protection Association, Quincy, Massachusetts.

NFPA, 1996ä, Standard Methods of Fire Tests for Flame-Resistant Textiles and Films, NFPA 701, National Fire Protection Association, Quincy, Massachusetts.

ARC, 1979, Single Failure Proof Cranes for Nuclear Power Plants, AllREG 0554, U.S. Nullear Regutatopy Commission, Washington, D.C.

OSHA, 1978, Guards for Rotating Equipment, OSHA Instruction Standard 1-12-14, Occupational Safety and Health Administration, Washington, D.C.

Pajunen, A. L., R. G. Cowan, L. D. Muhlestein, and B. B. Groth, A Arobabilistic Assesment of Fuel Particulate Contents of a Hulti Canister Orenpack, WHC SQ-SNF RPT 013, ReV. 0, Westinghouse Hanford Company. Aichland, Washington.

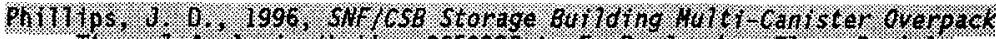

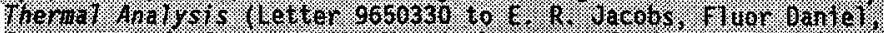

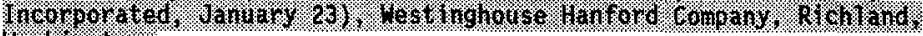
W. sing 10 n.

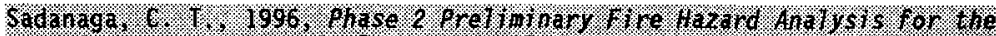

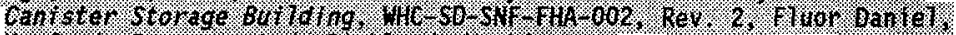

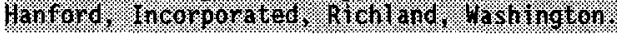

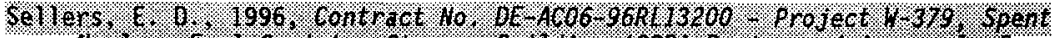

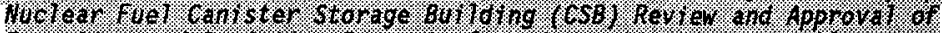

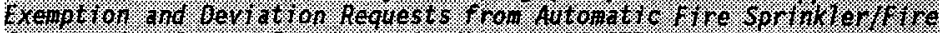

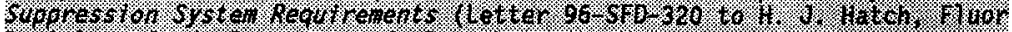

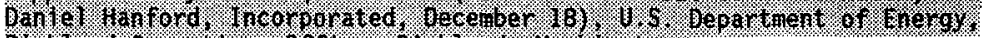

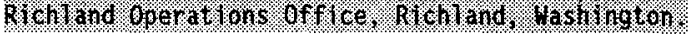

Sienko, F. L., 1996, Bulk Shielding for the Vault Release (Phase I) of the Canister Storage Building (CSB), Calculation CSB-SH-1002, FTuor Danie1, Incorporated, Richland, Washington.

Swenson, C. E., 1996, Performance Specification for the Spent Nuclear Fuel Canister Storage Building, WHC-S-0425, Rev. 2, Westinghouse Hanford Company, Richland, Washington.

Tallman, A. M., 1996, Canister Storage Building Natural Phenomena Hazards, WHC-SD-SNF-DB-009, Rev. 4, Westinghouse Hanford Company, Richland, Washington.

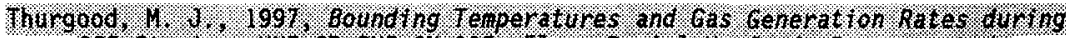

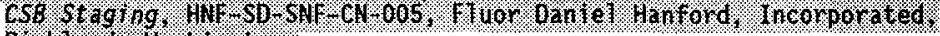

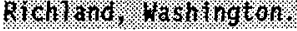

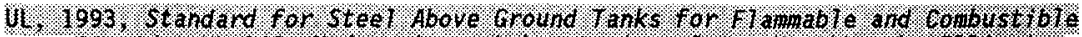

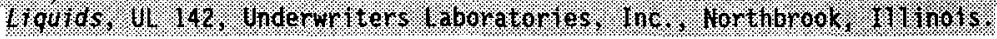




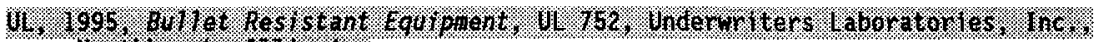

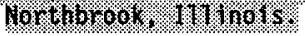

WHC, 1992, Hanford Waste Vitrification Plant Canister Storage Building Preliminary Safety Analysis Report Addendum, WHC-SD-HWV-PSE-001, Rev. OA, Westinghouse Hanford Company, Richland, Washington.

WHC, 1994, Hanford Waste Vitrification Plant Preliminary Safety Analysis Report, WHC-SD-HWV-PSAR-001, Rev. 1, Westinghouse Hanford Company, Richland, Washington.

WHC, 1996, Fipe Hazand Analysis for the Ganisten Storage Building Storat Vautts, WHC SD SNF FHA OO2, Rev. O, Westinghouse Hanford Company, Richland, Washington.

WHC-CM-4-46, 1995, Safety Analysis Manual, Rev. 1, Westinghouse Hanford Company, Richland, Washington.

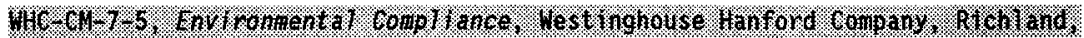
Howhorton:

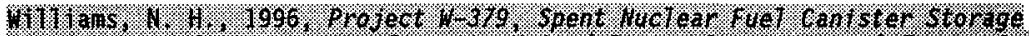

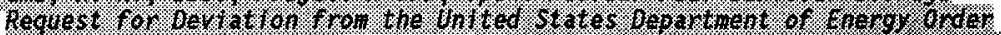

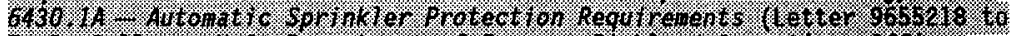

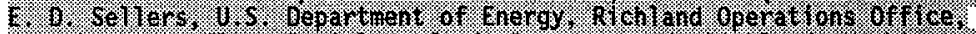

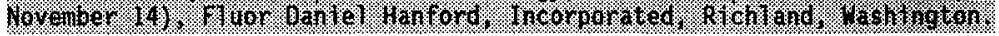

Zimmerman, R. D., 1996, Failure Modes and Effects Analysis: Emergency Power System, File 106.151, Fluor Danie1, Incorporated, Richland, Washington. 


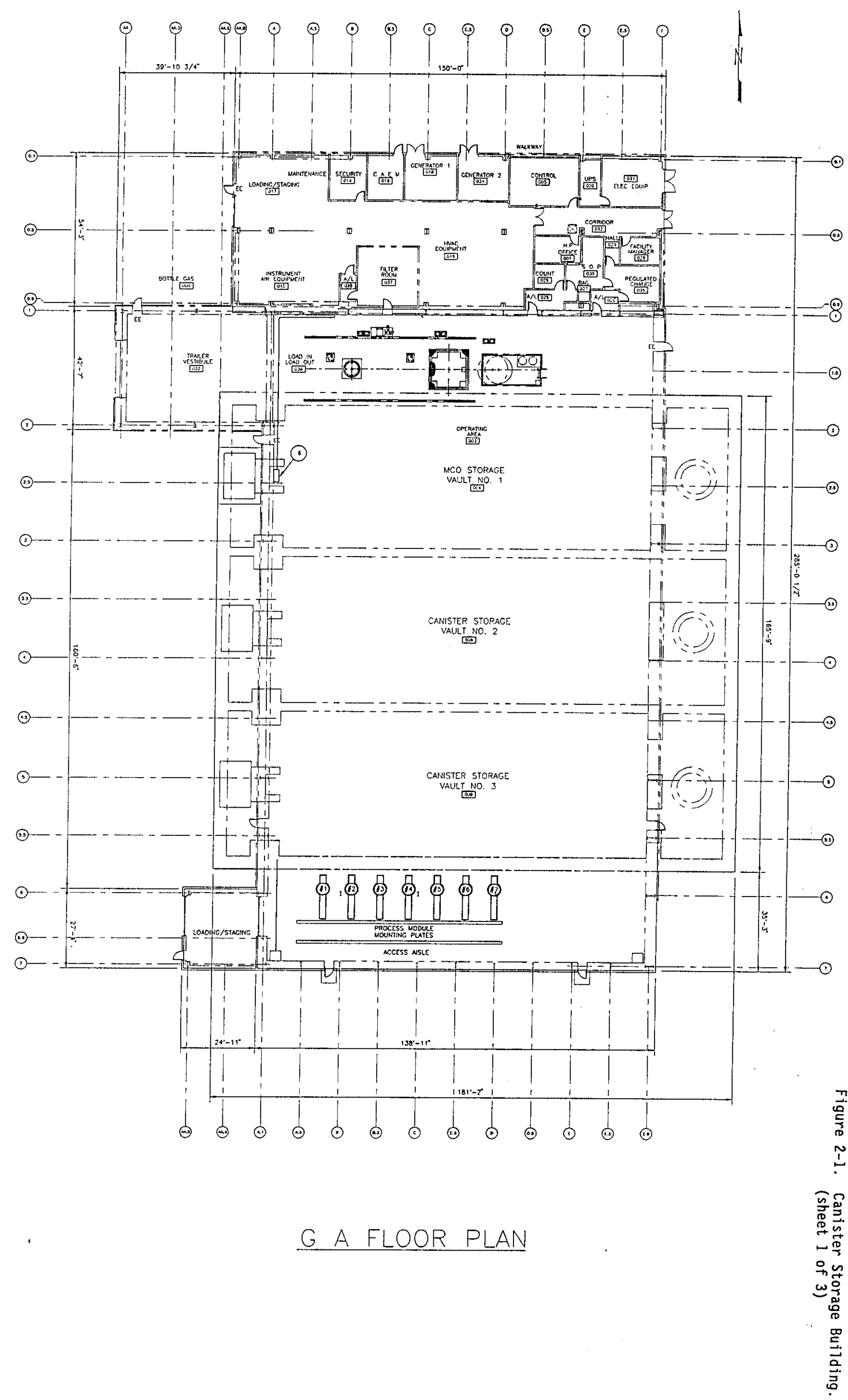




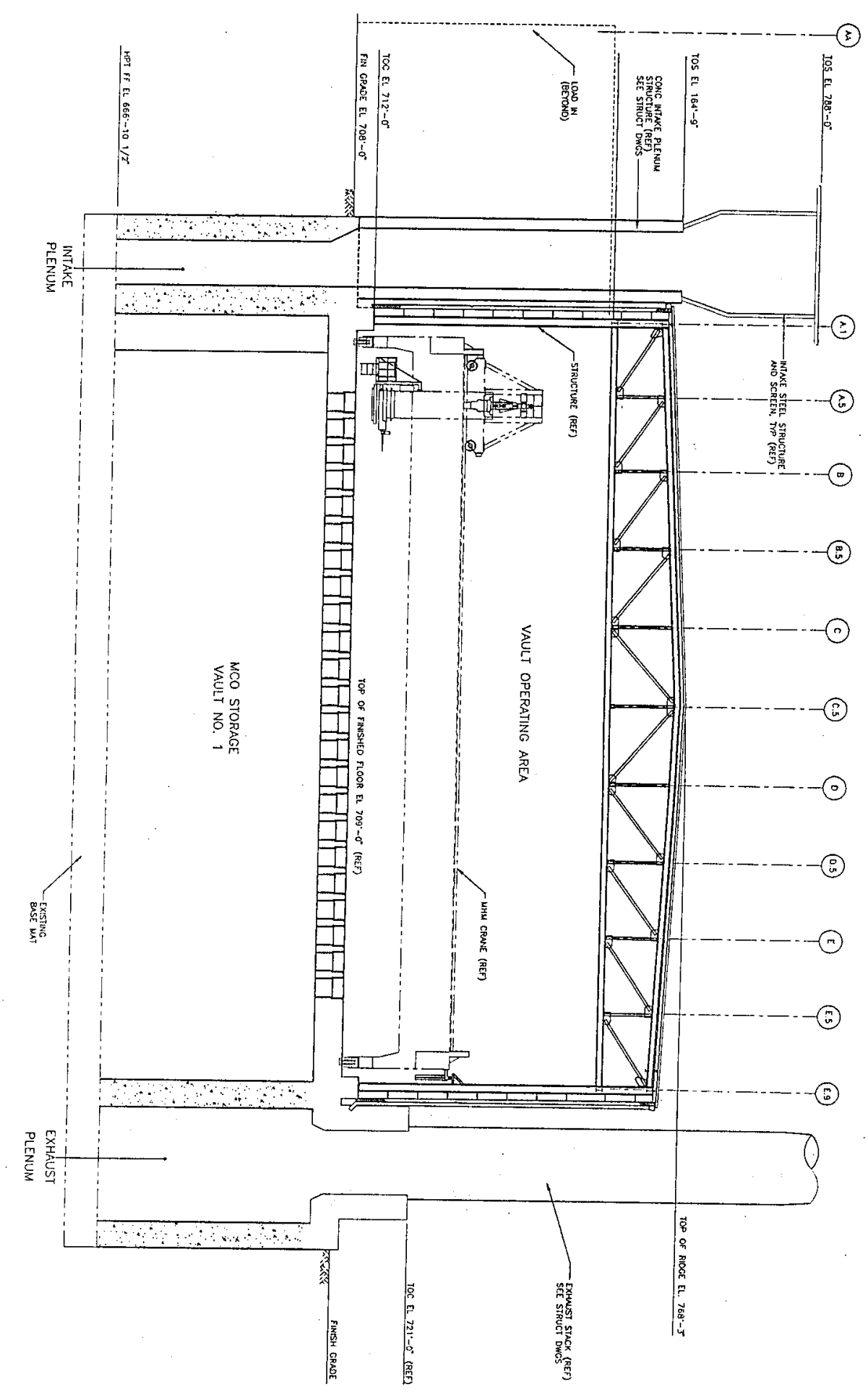

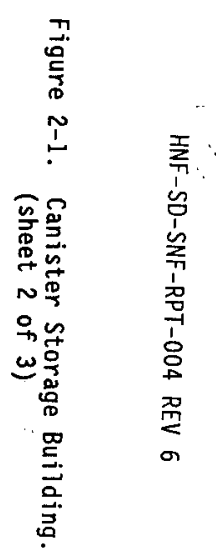




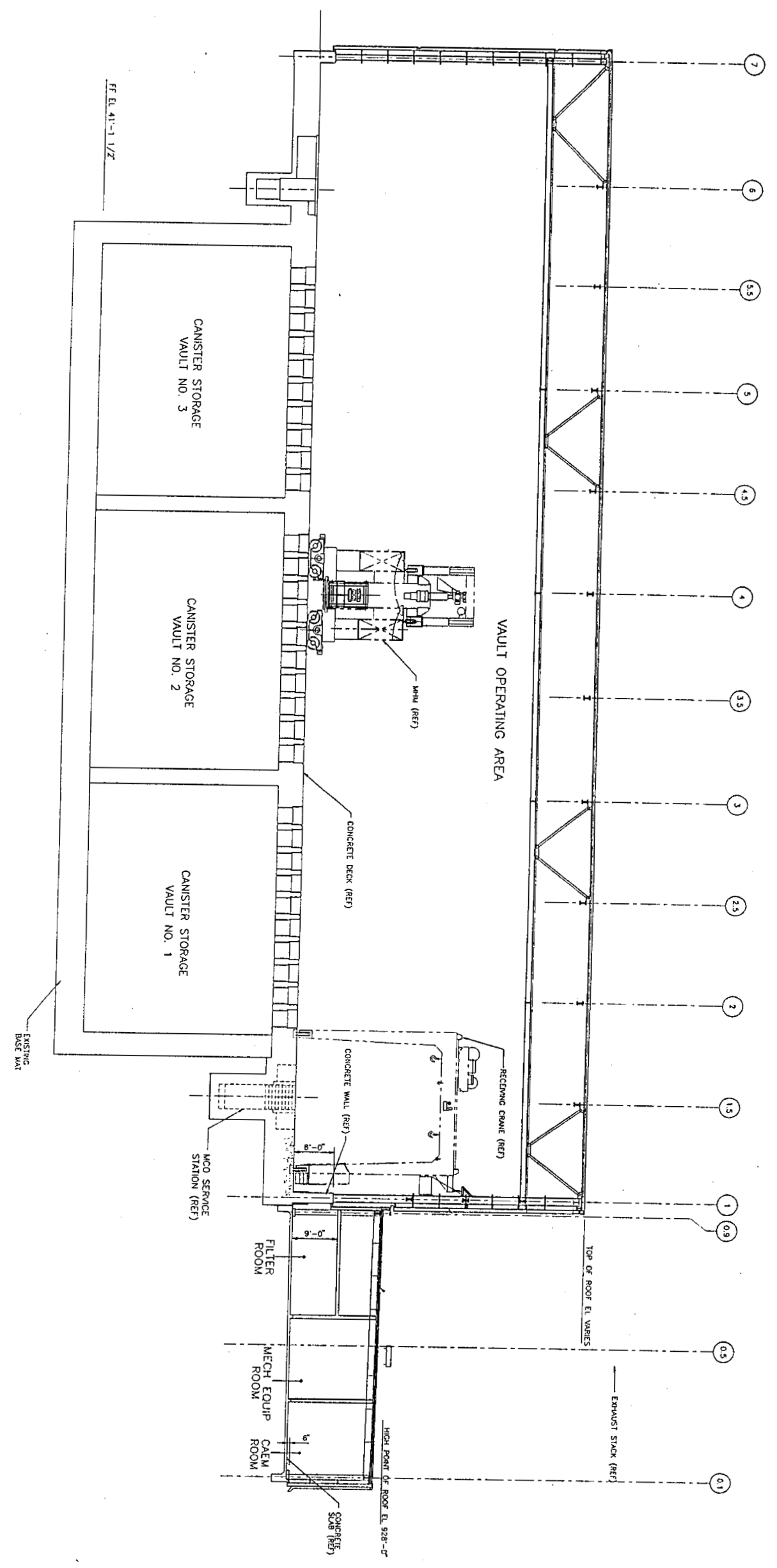

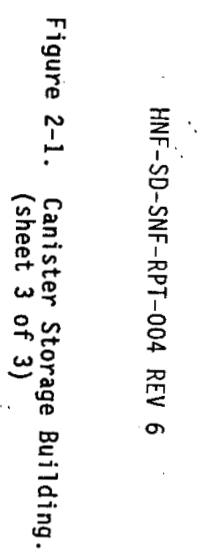




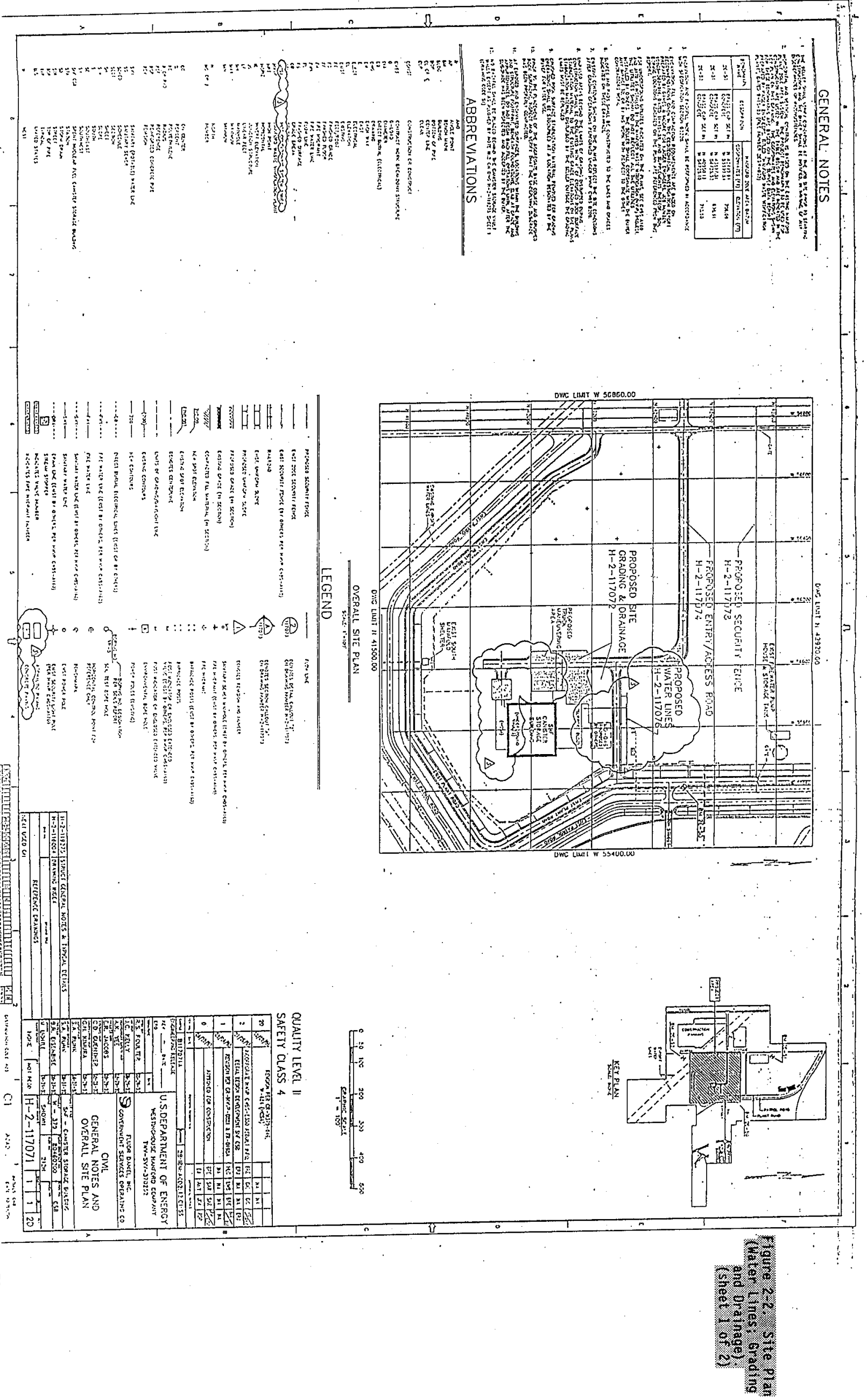









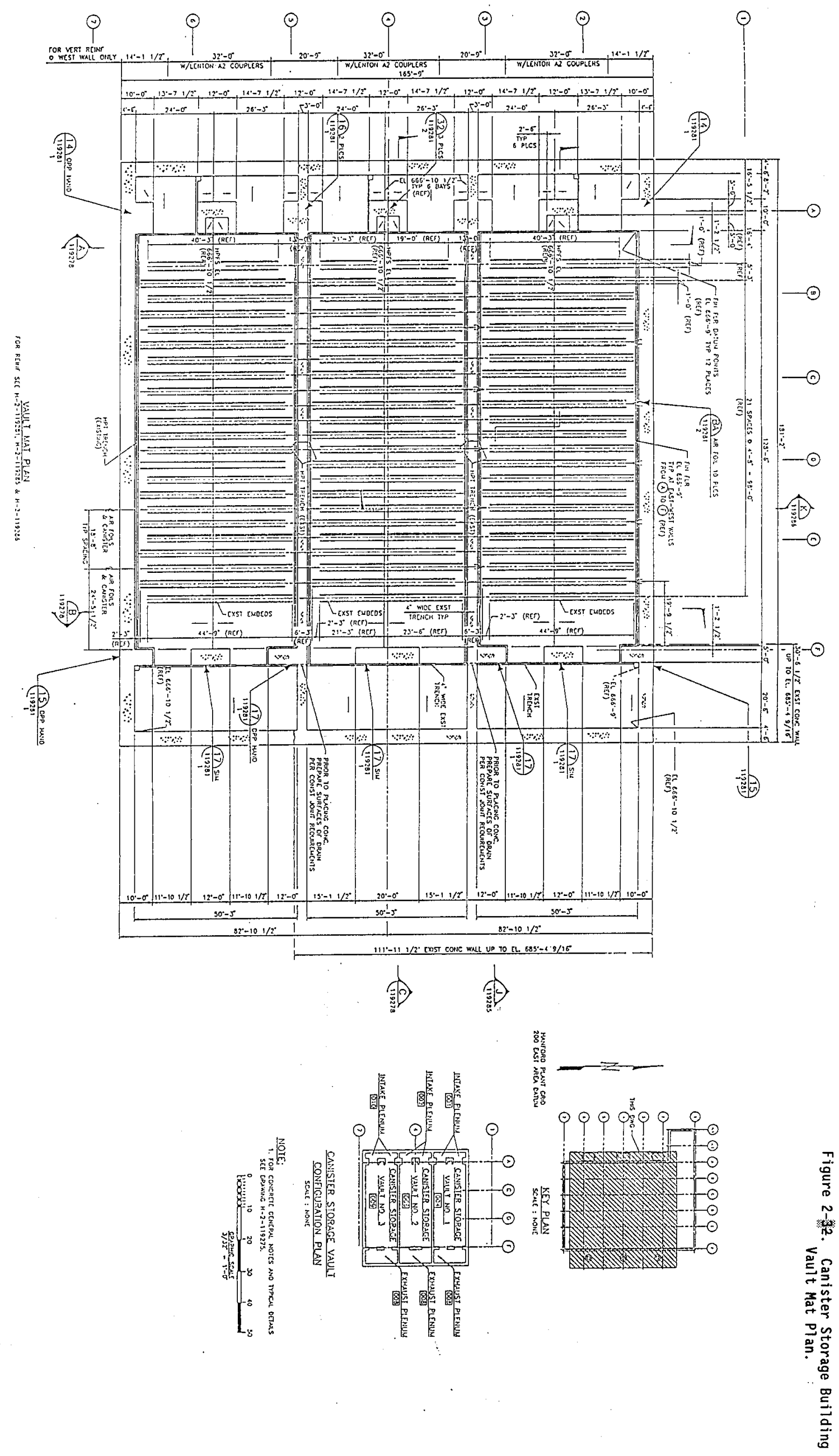




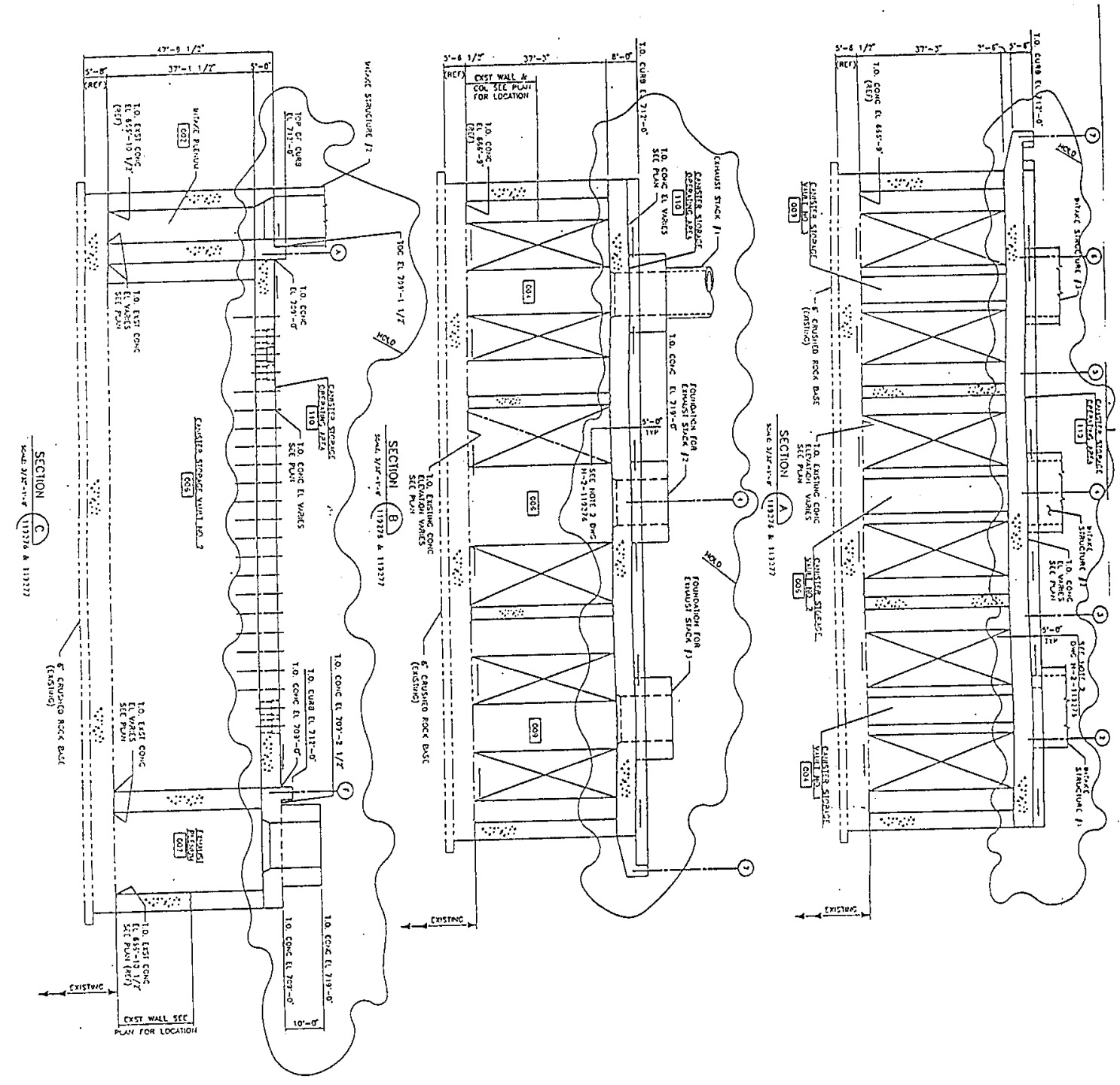

$\pi$
$\stackrel{\Lambda}{\omega}$
$\stackrel{N}{N}$
$\vdots$
$\vdots$

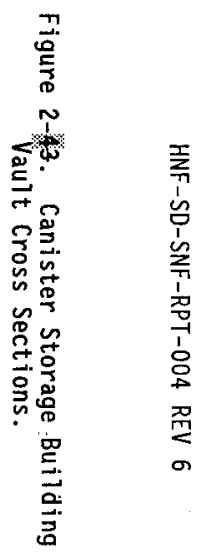



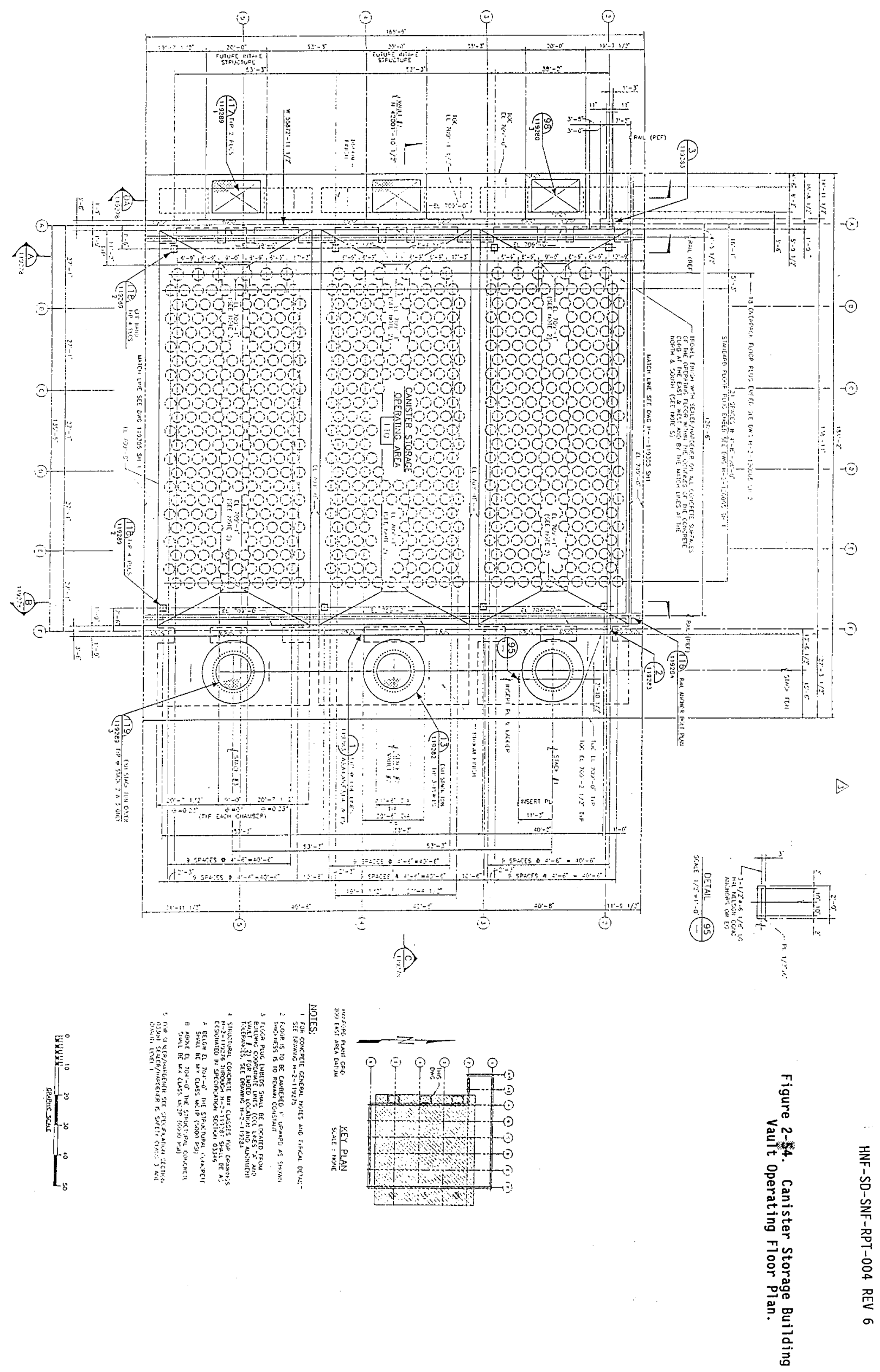


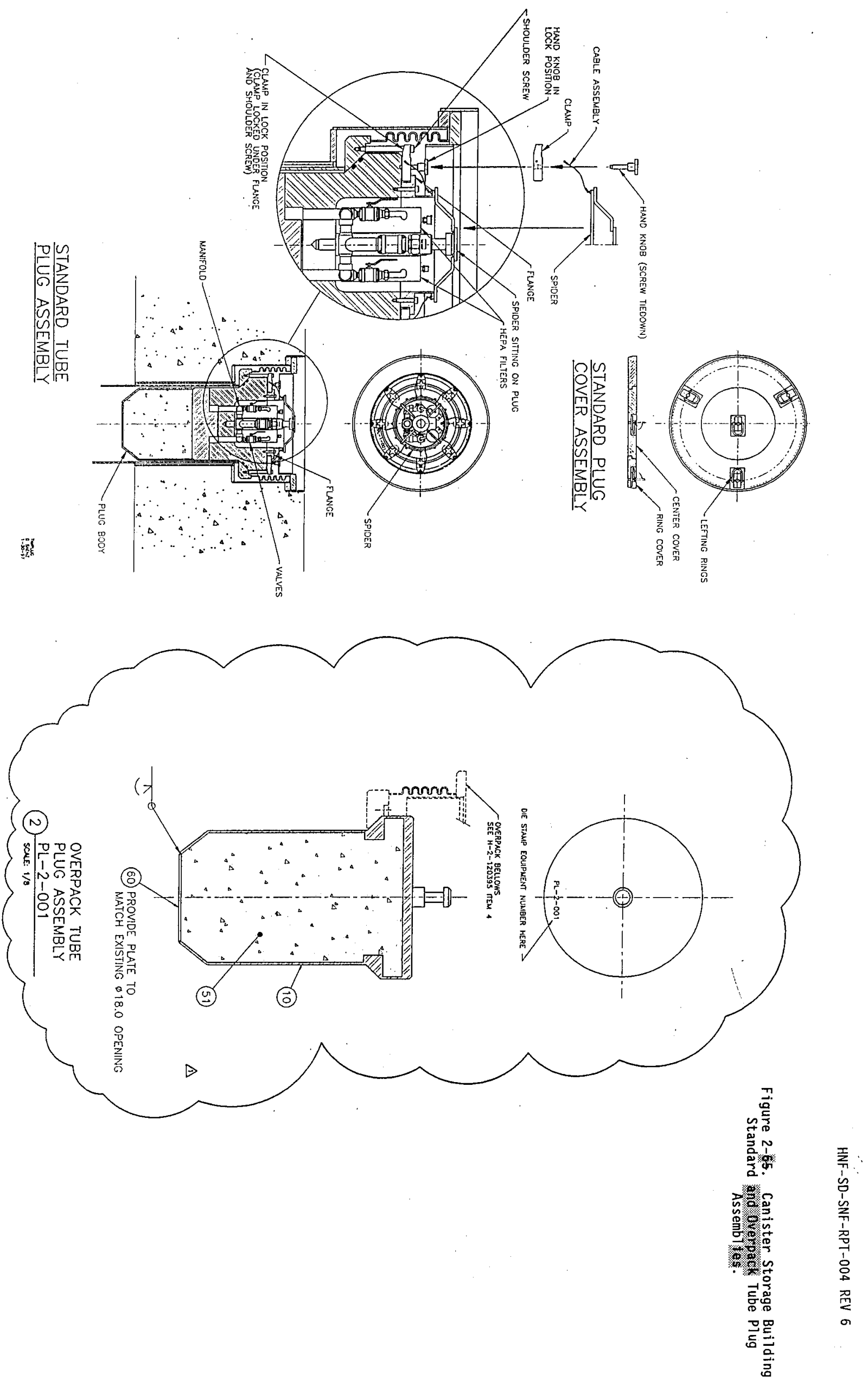




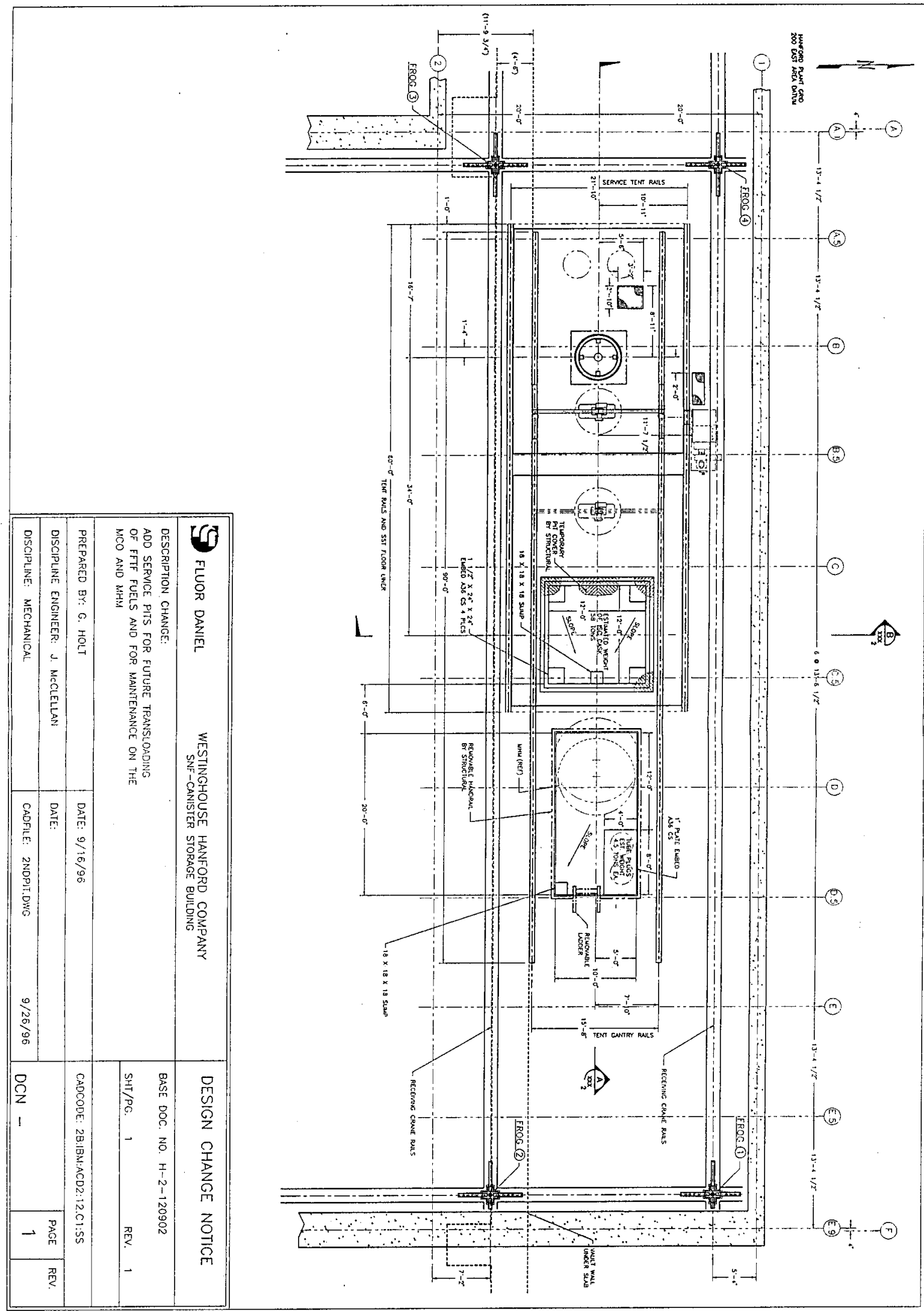

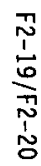

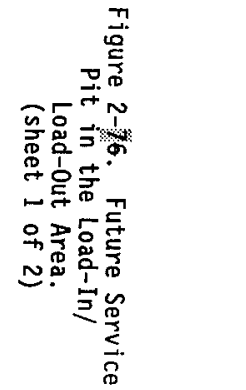




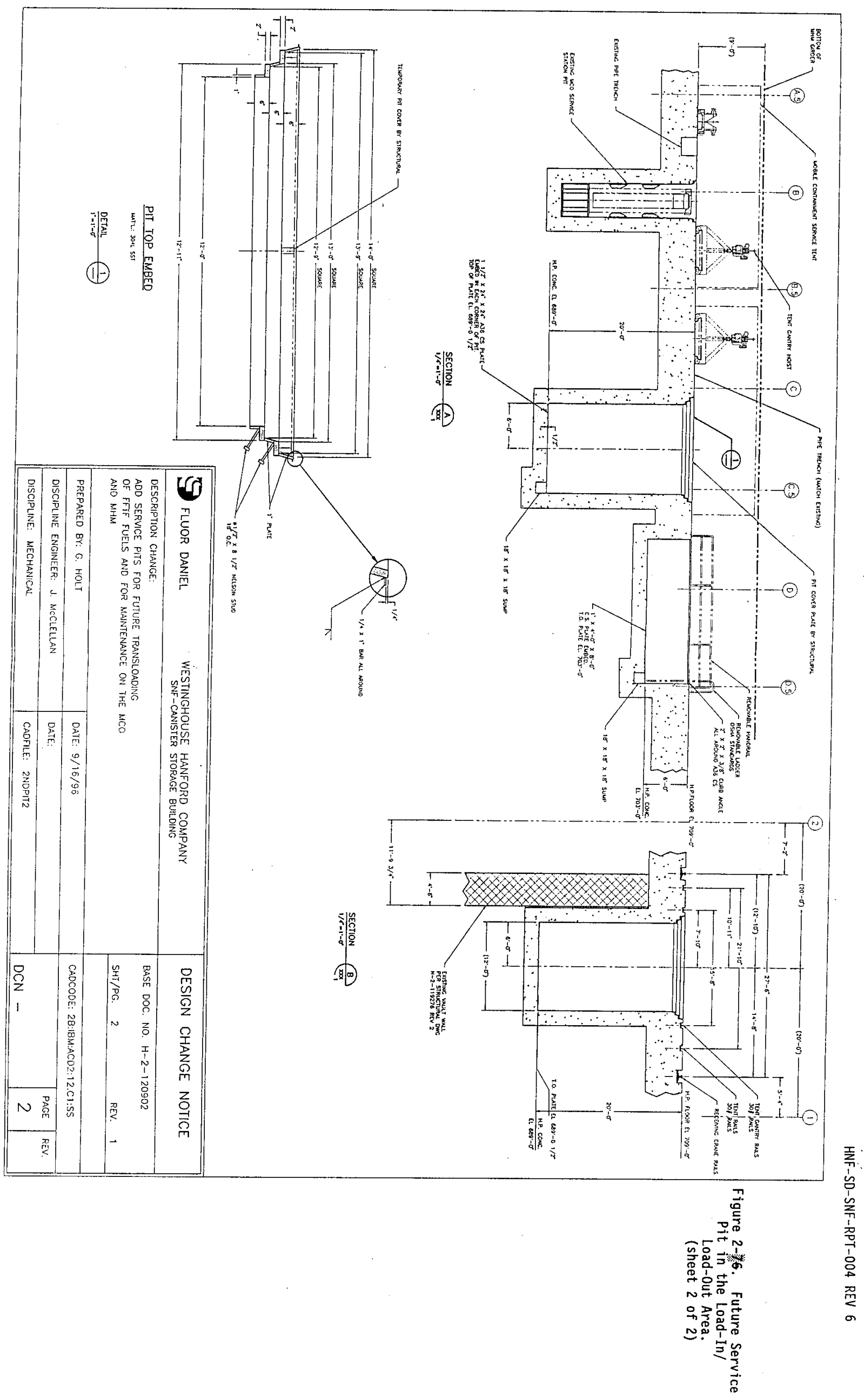



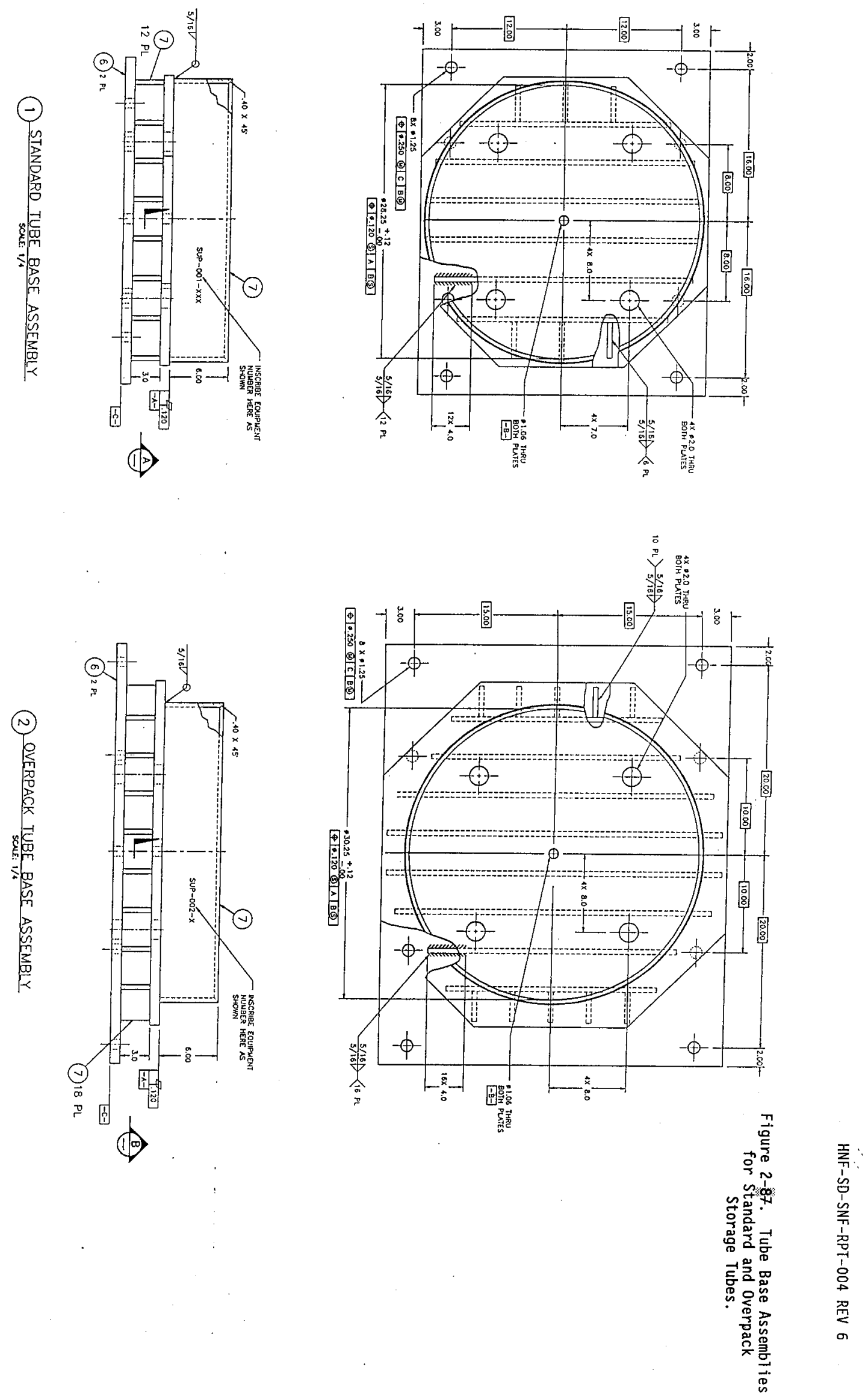




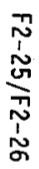

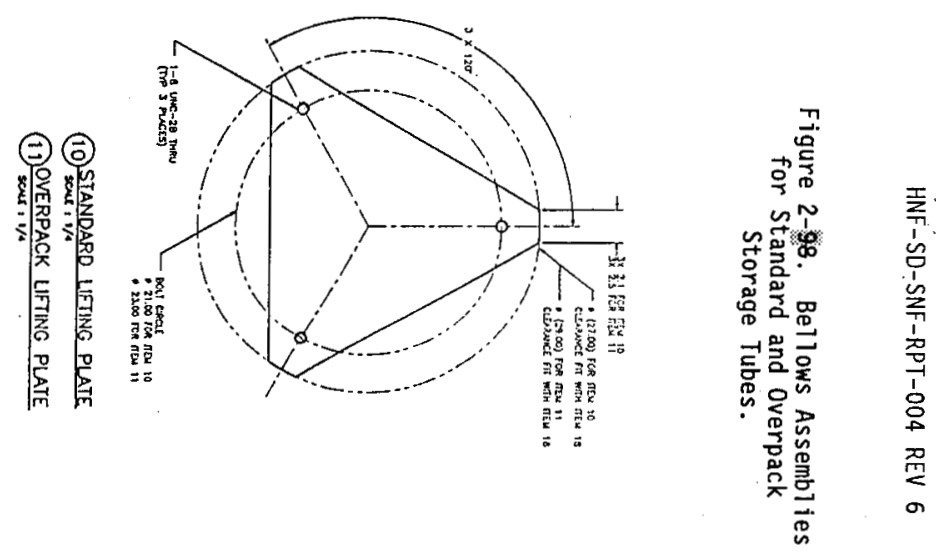




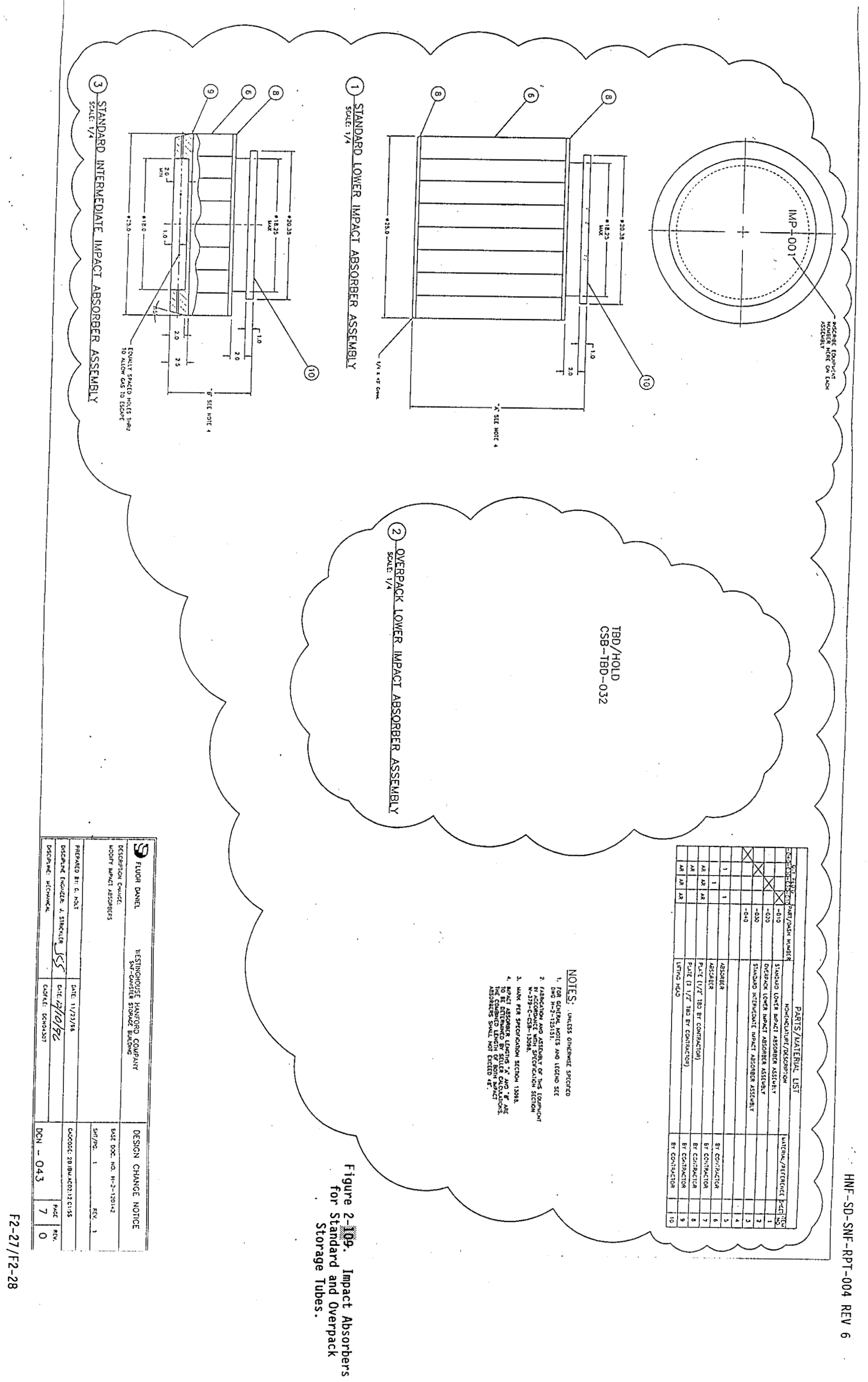



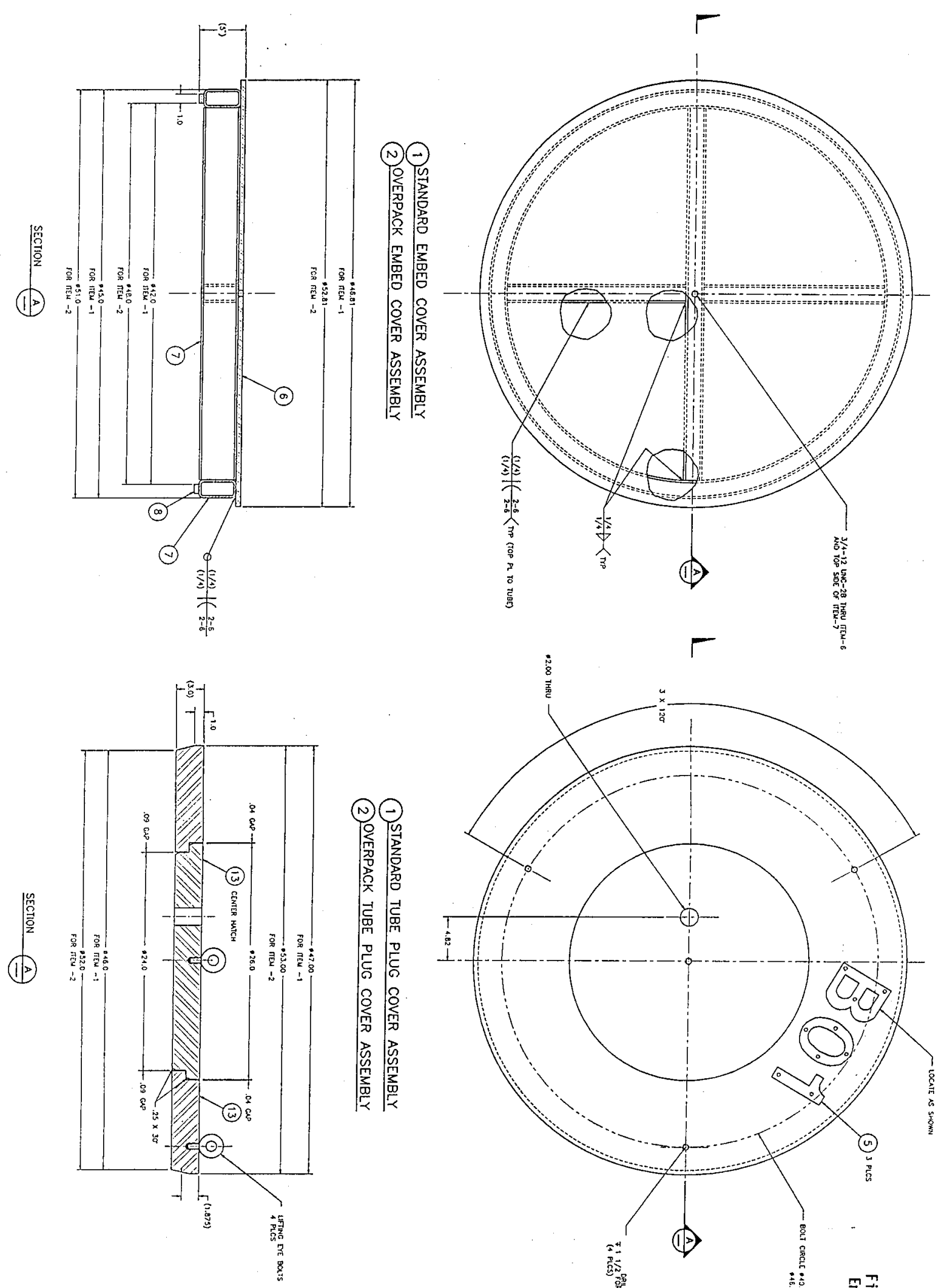

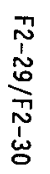

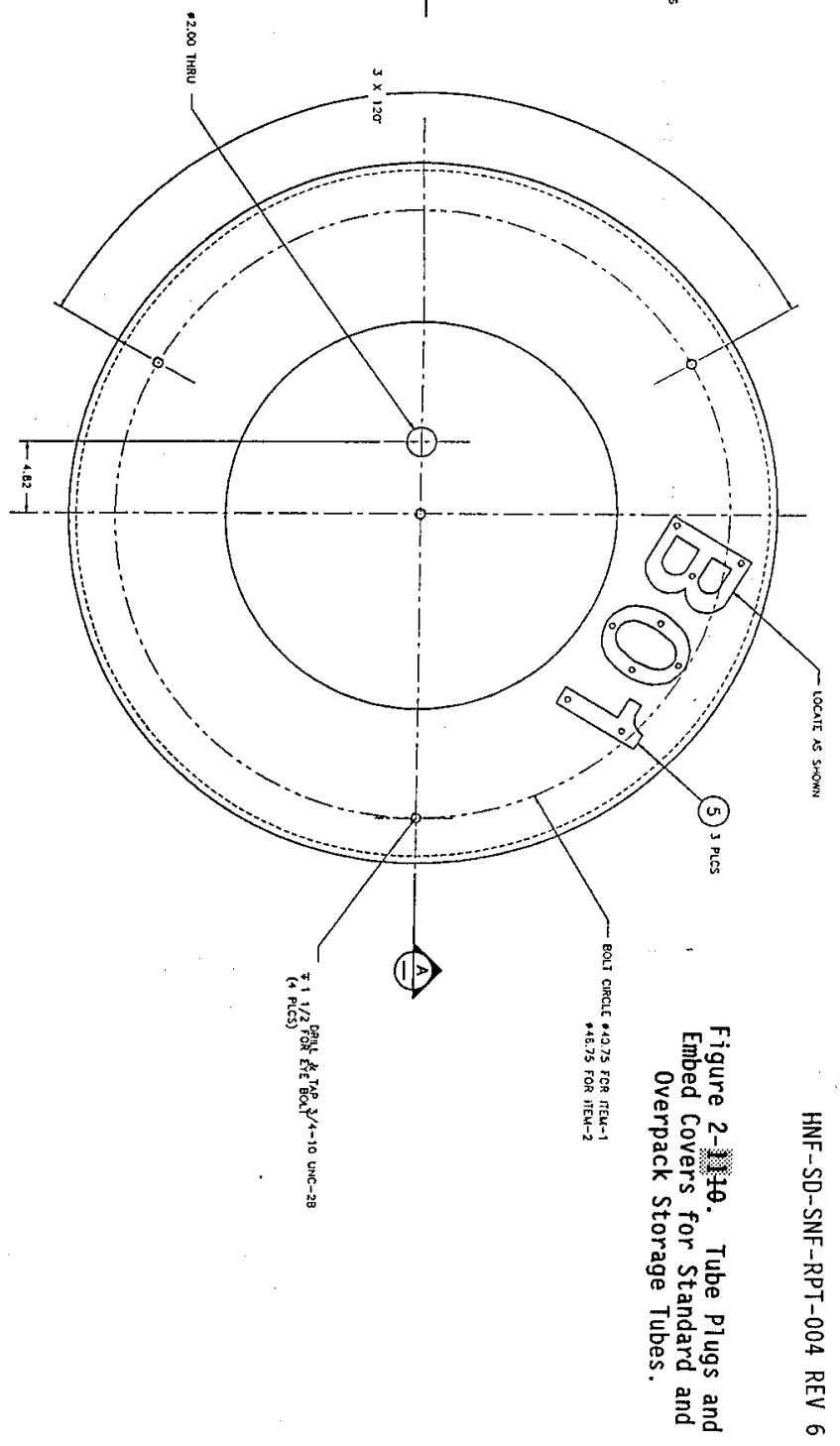


Figure 2-1213. Canister Storage Building Receiving Crane.

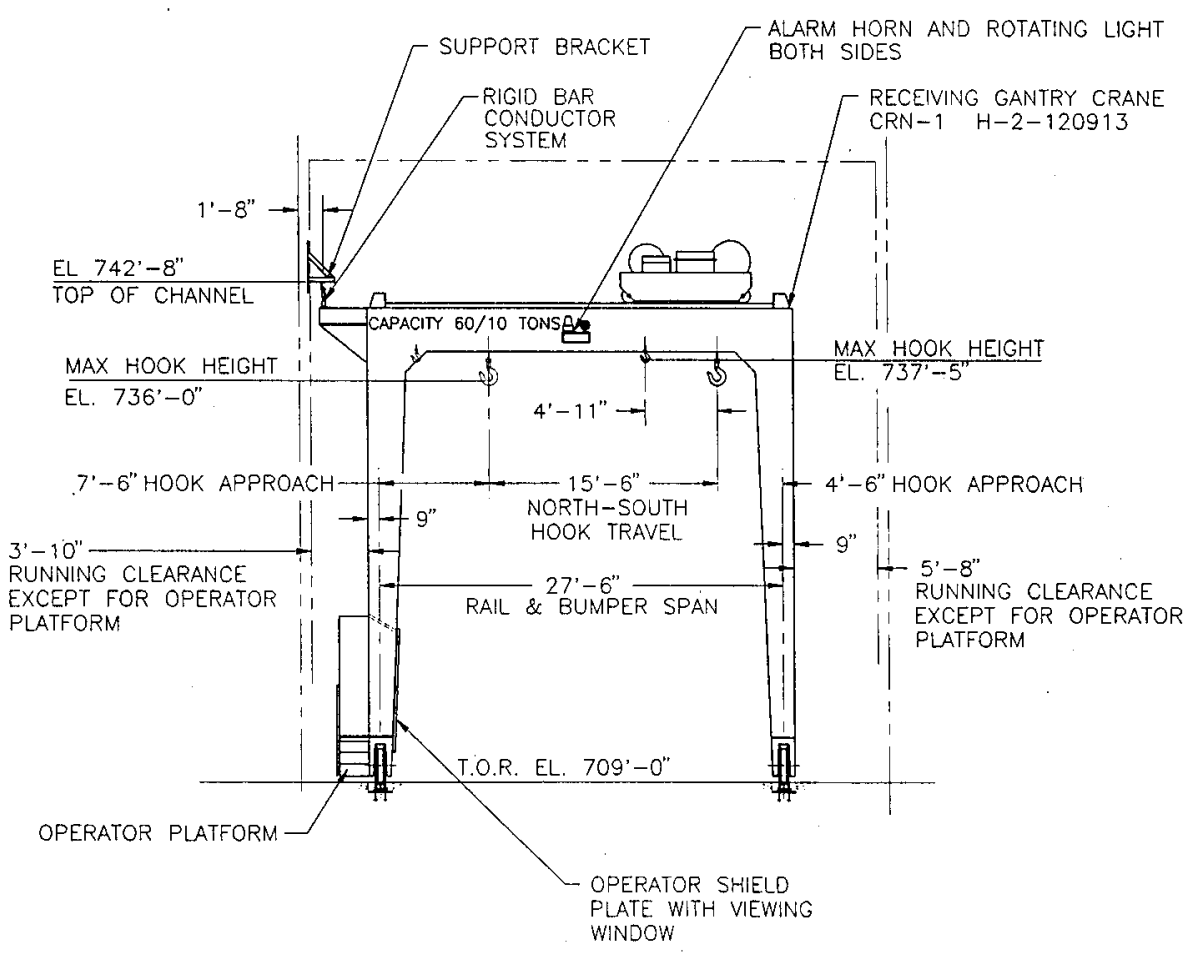


HNF-SD-SNF-RPT-004 REV 6

This page intentionally left blank. 


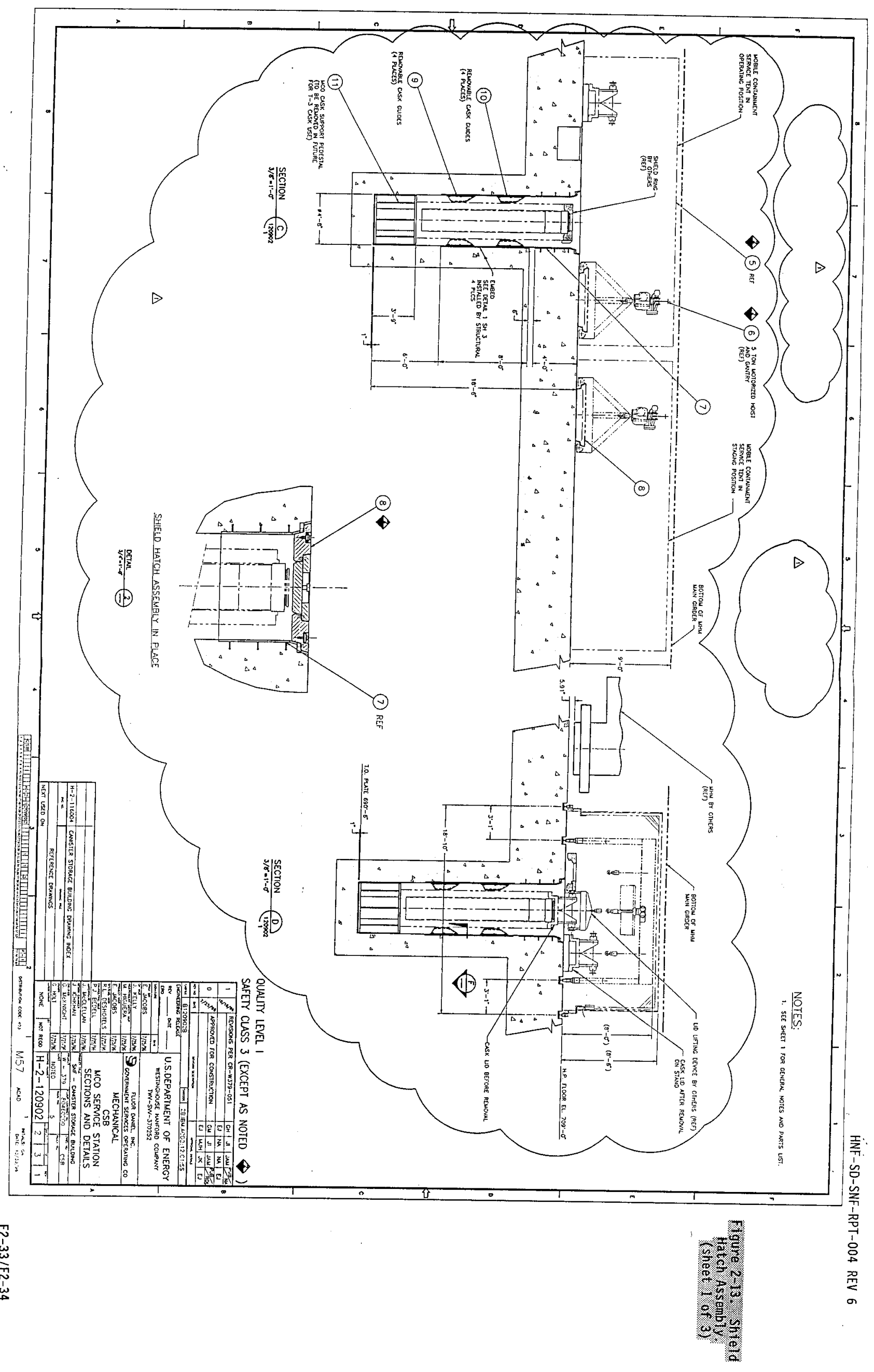



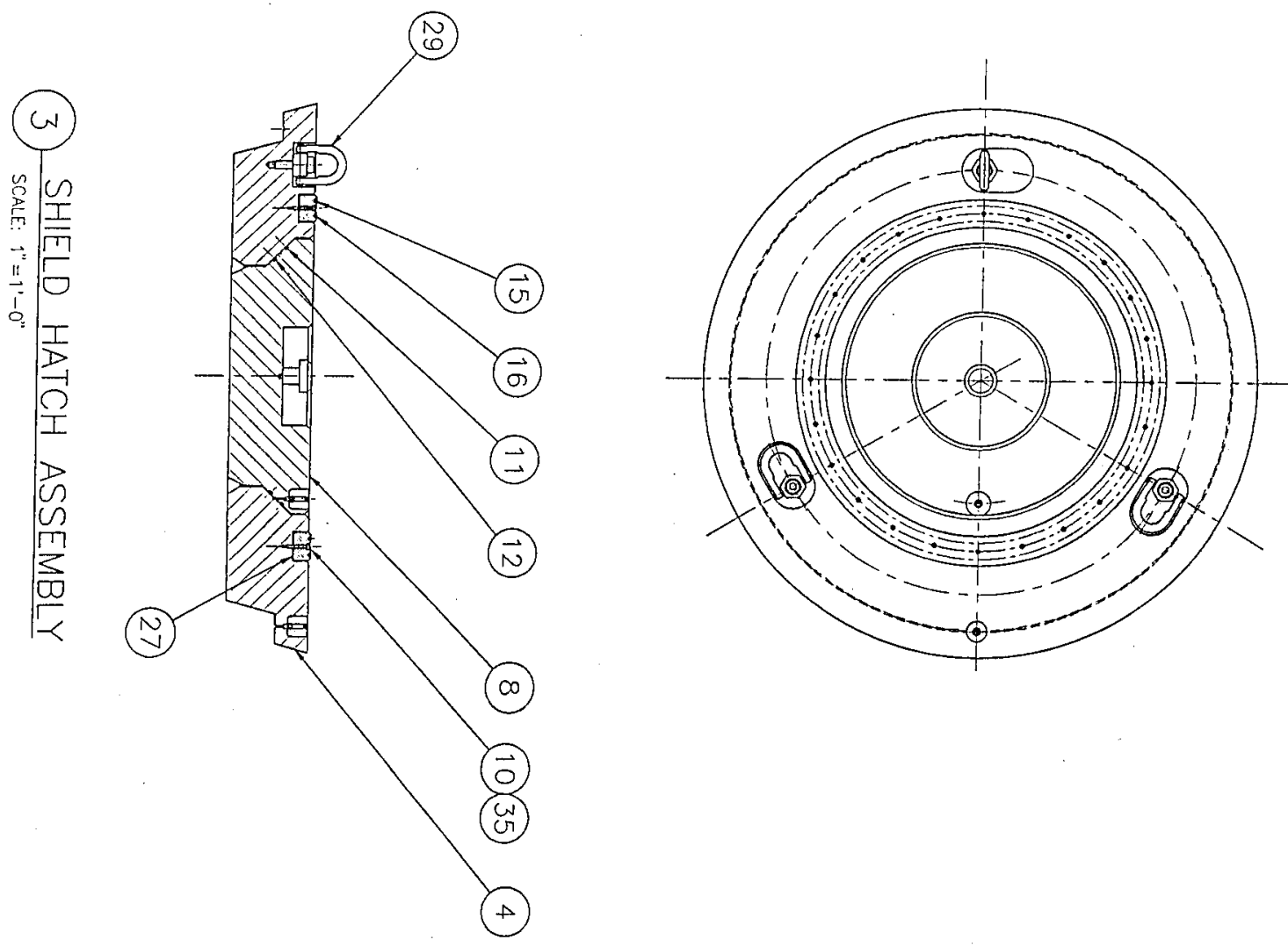

WNN

wnzopornun

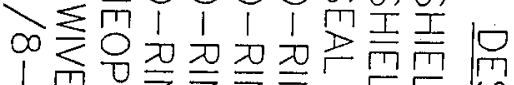

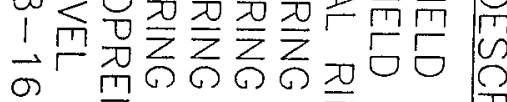

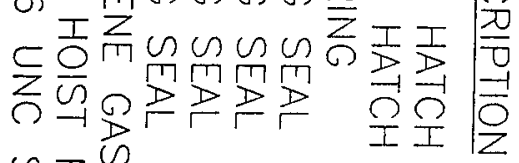

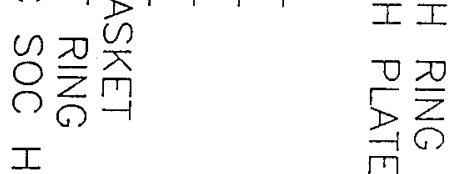

I

8

$\stackrel{\Omega}{\Omega}$ 


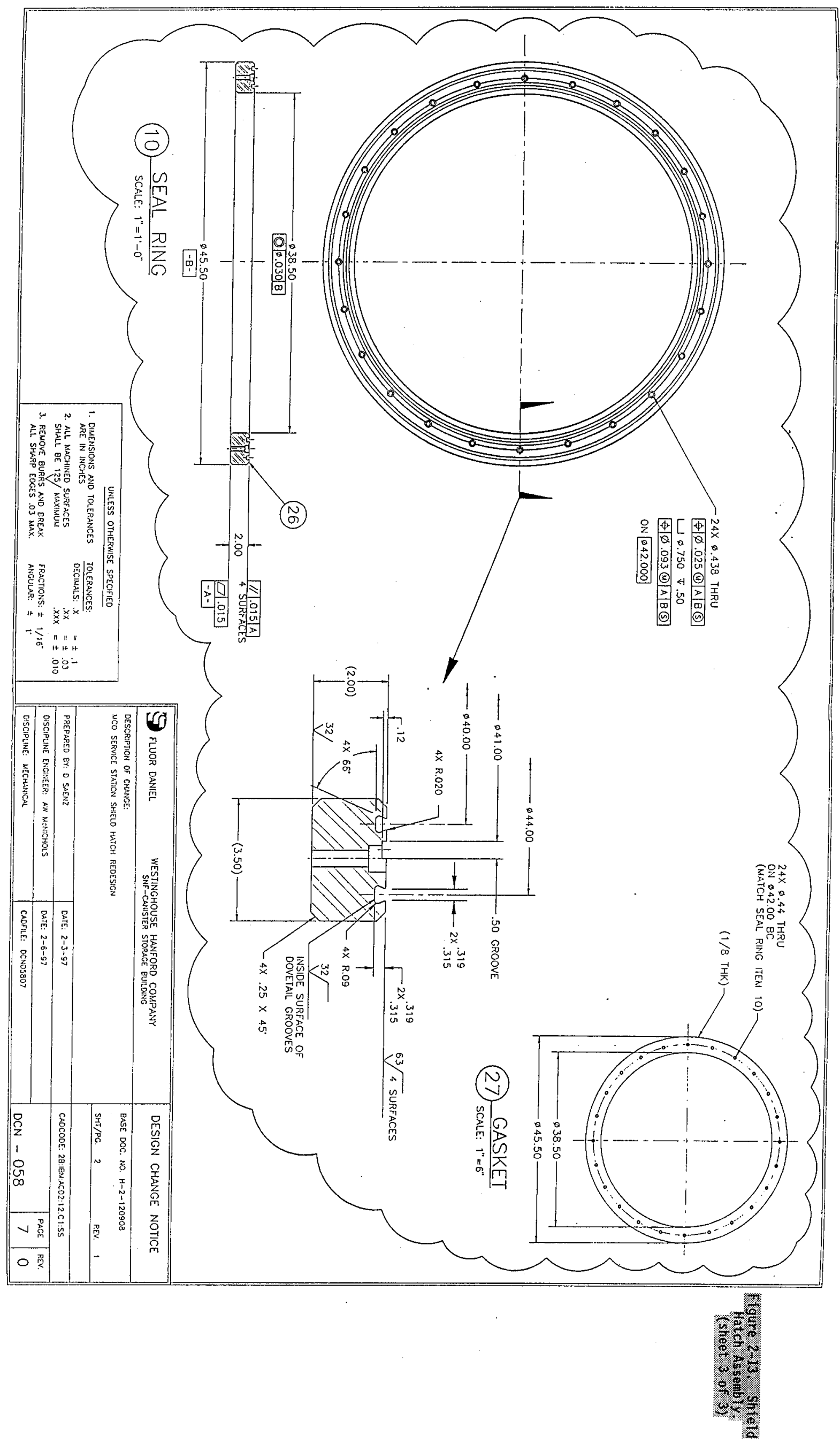

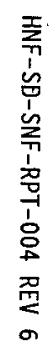




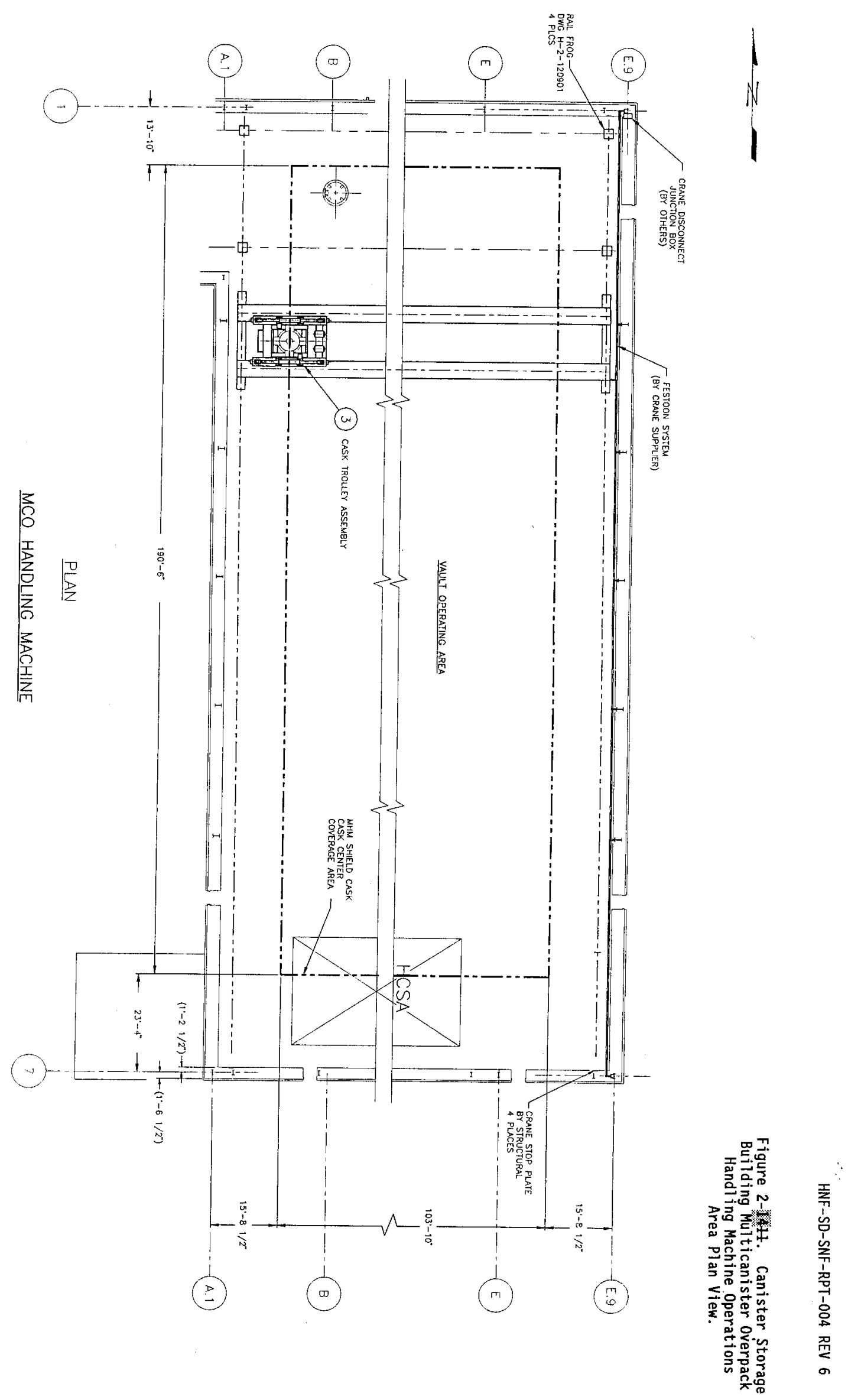




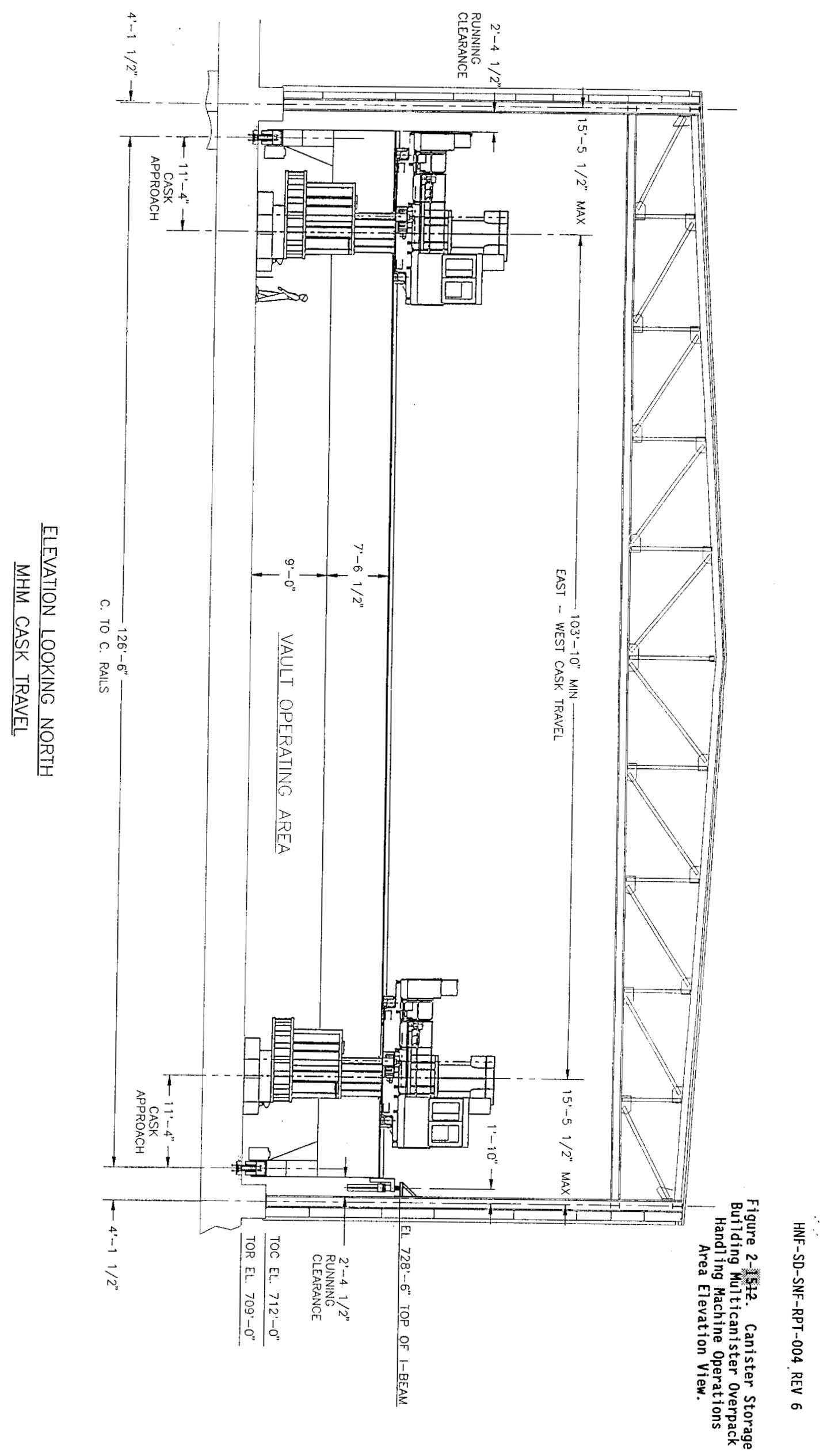



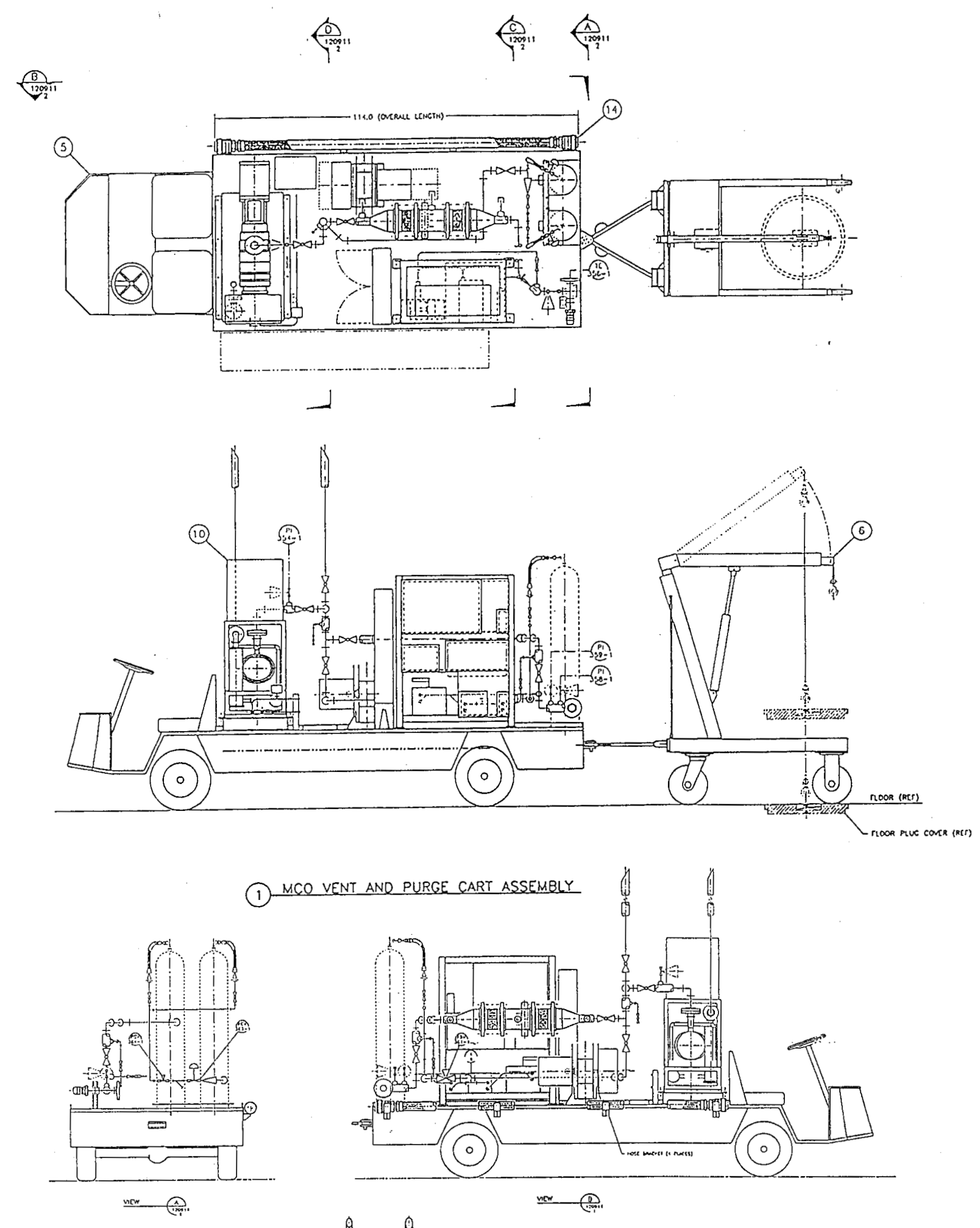

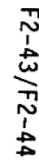

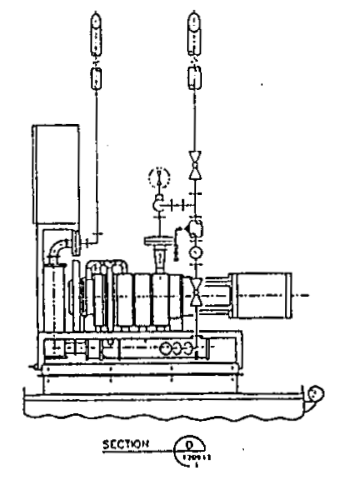

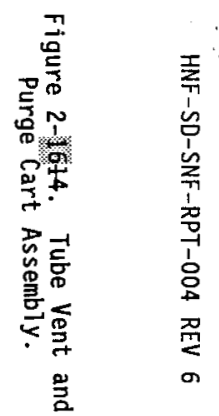



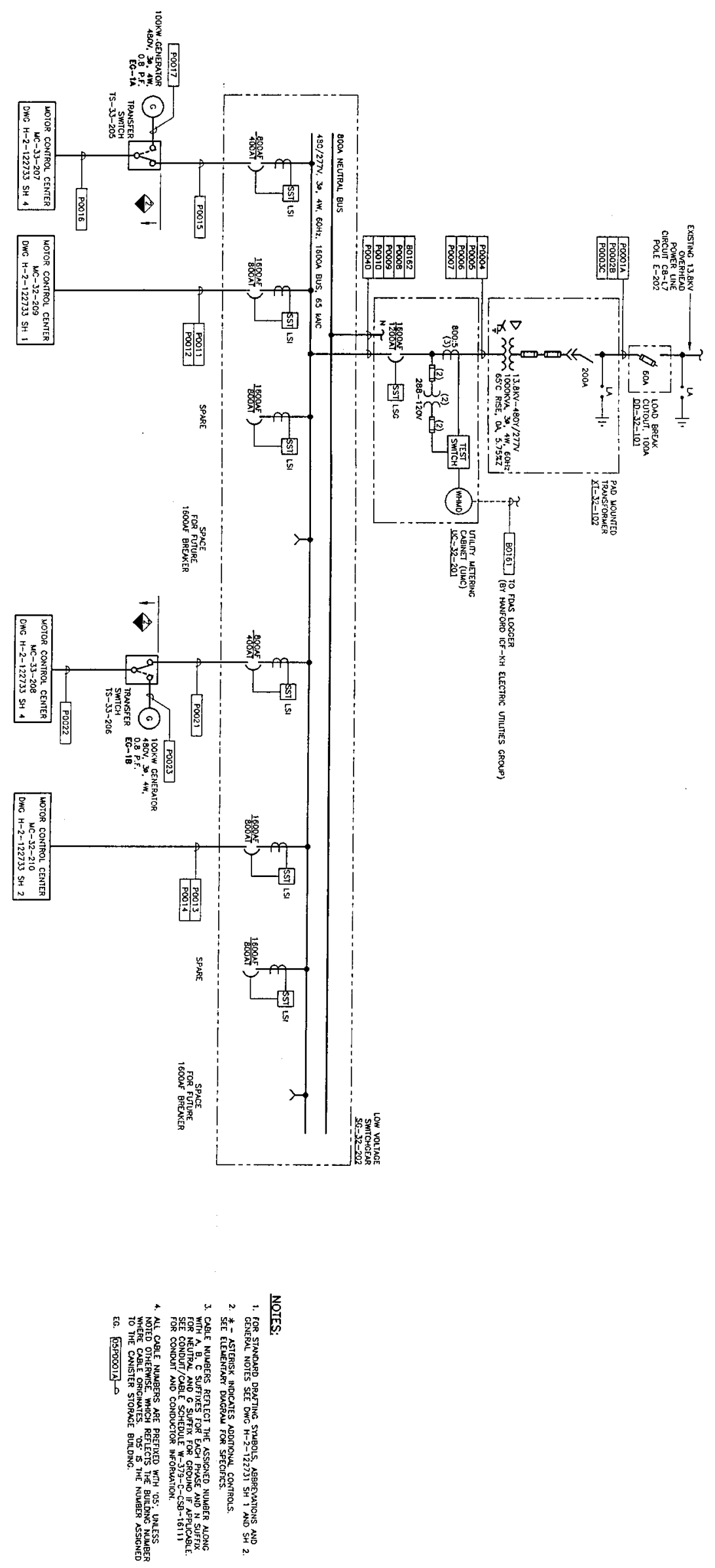


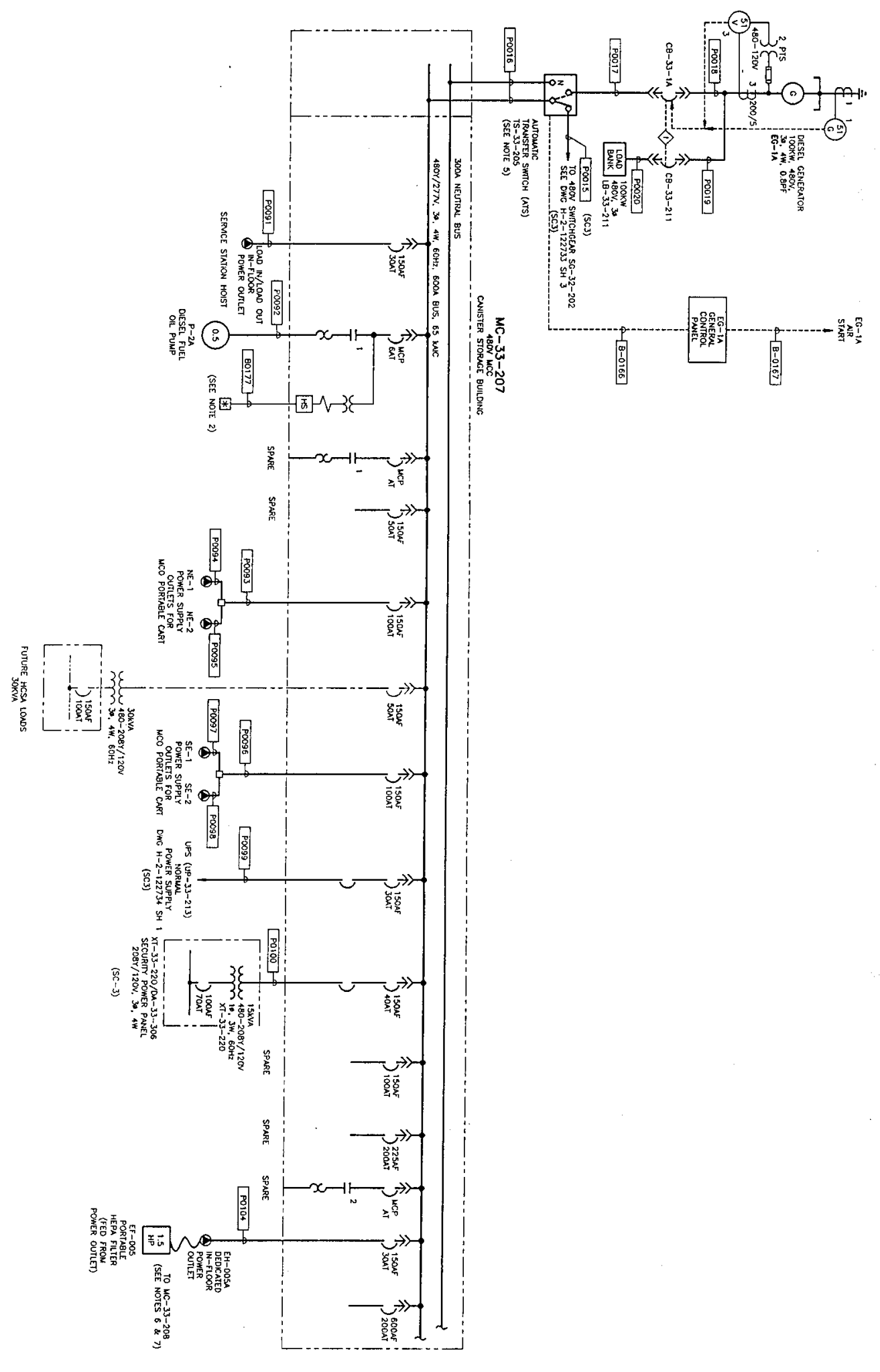

$\pi$
1
$\vdots$
$\vdots$
$⿱ \pi$
1
1
$\infty$
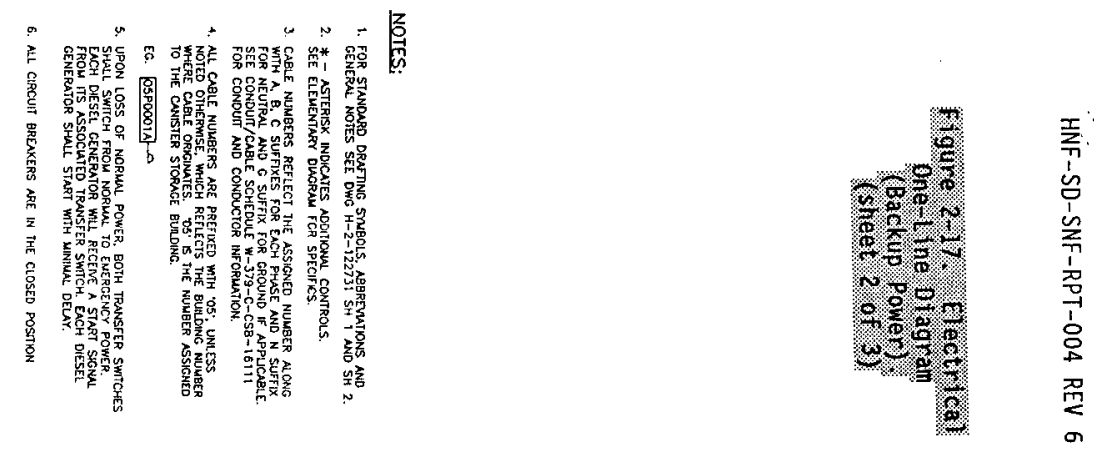


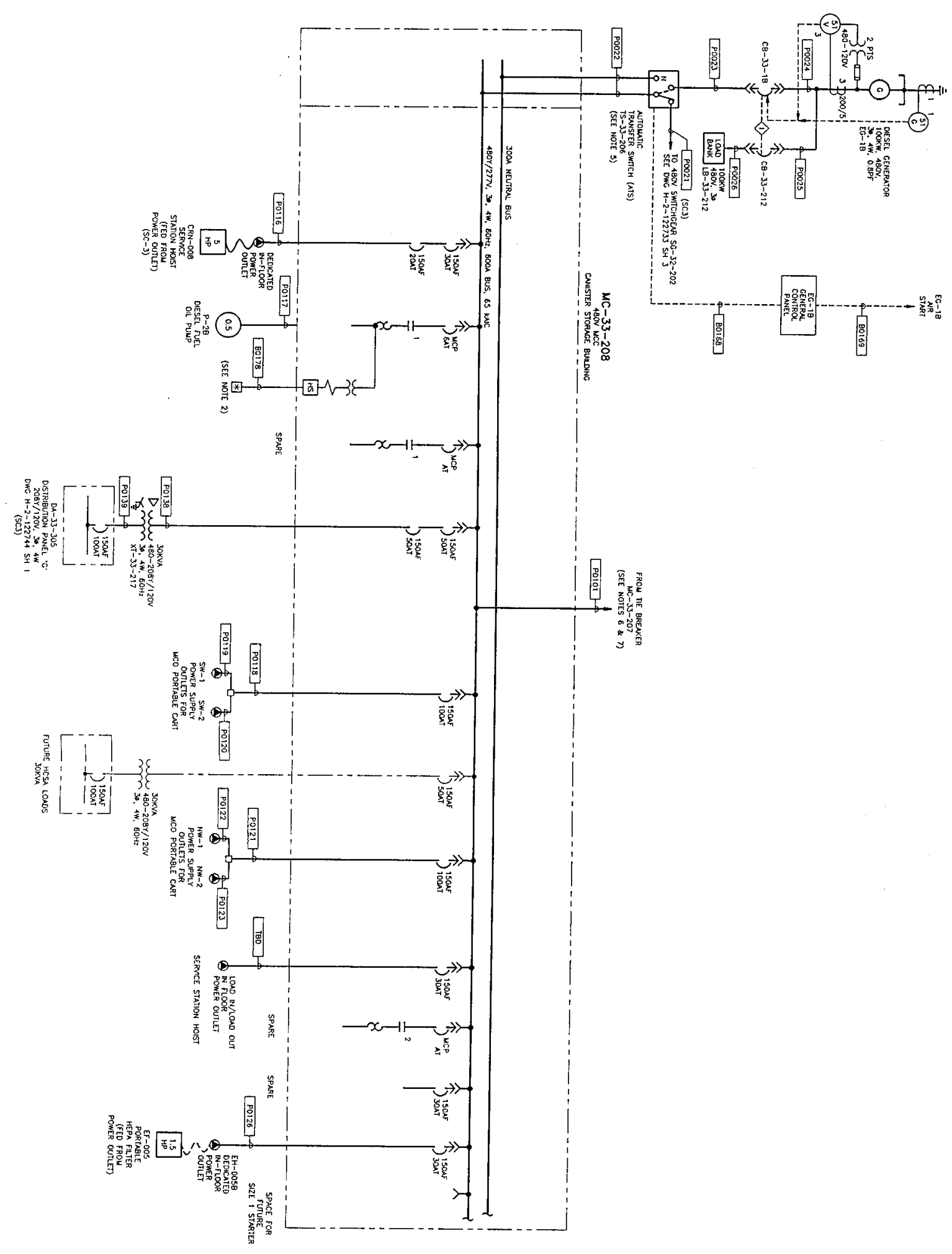




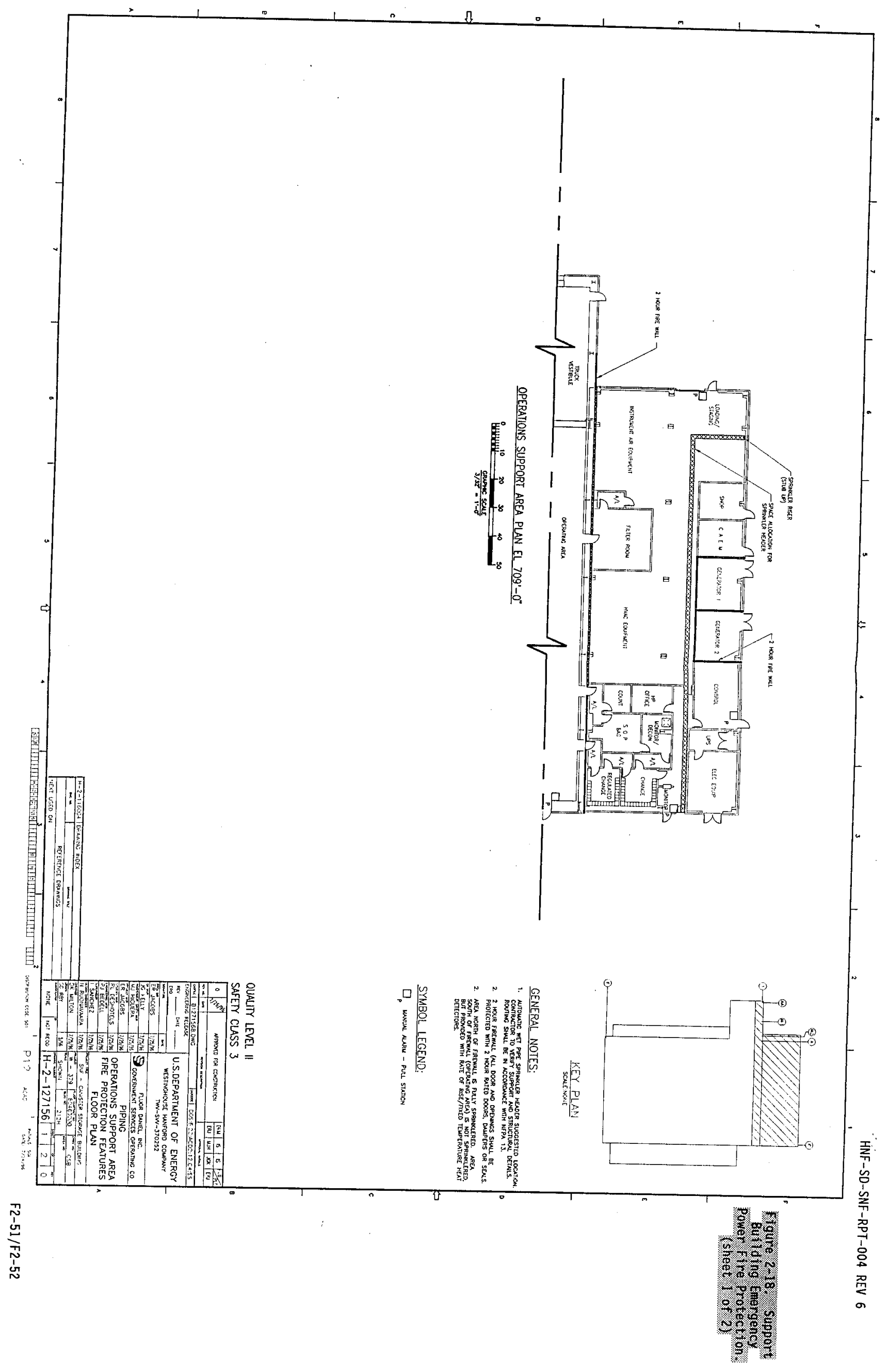




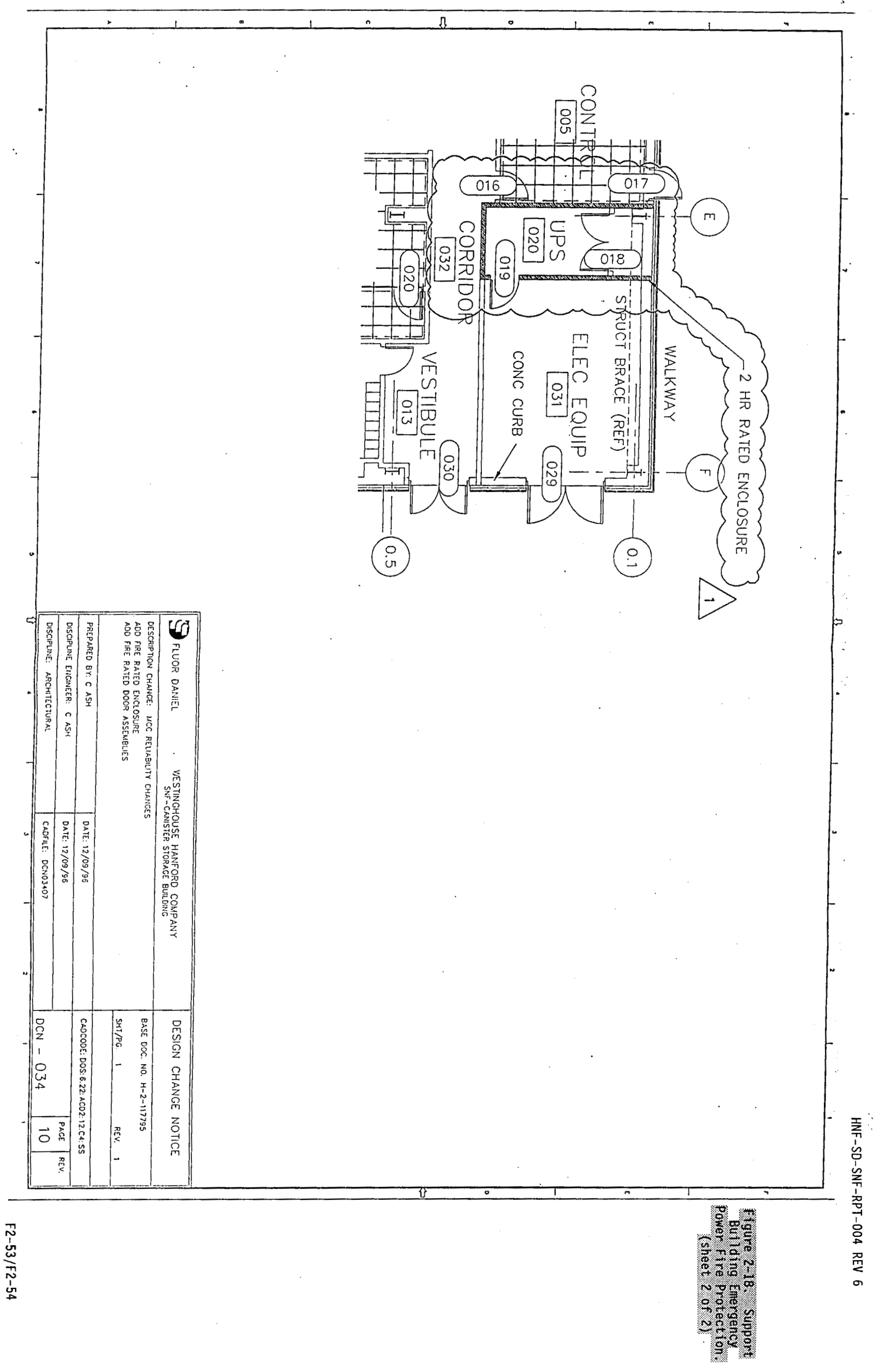




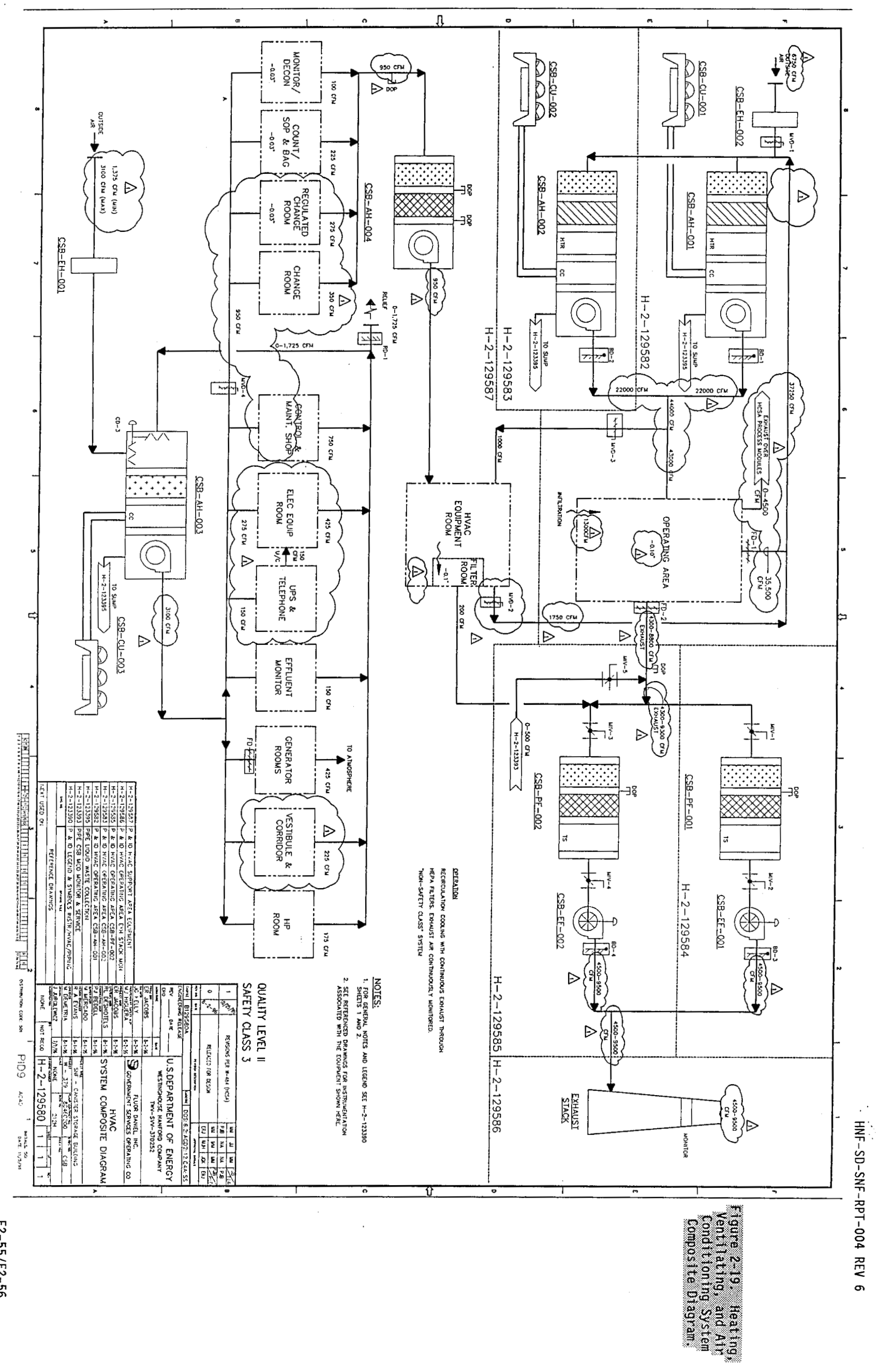




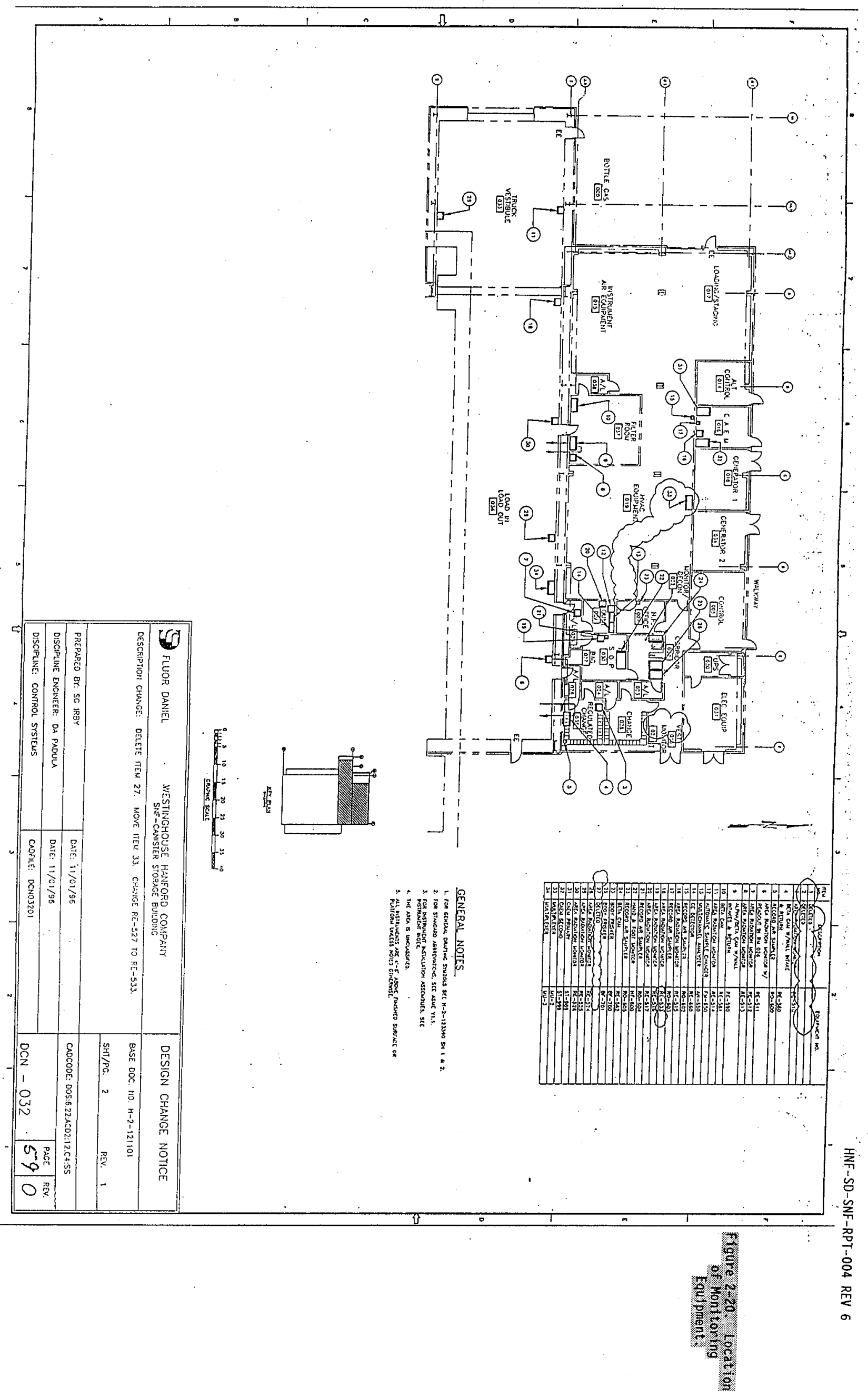




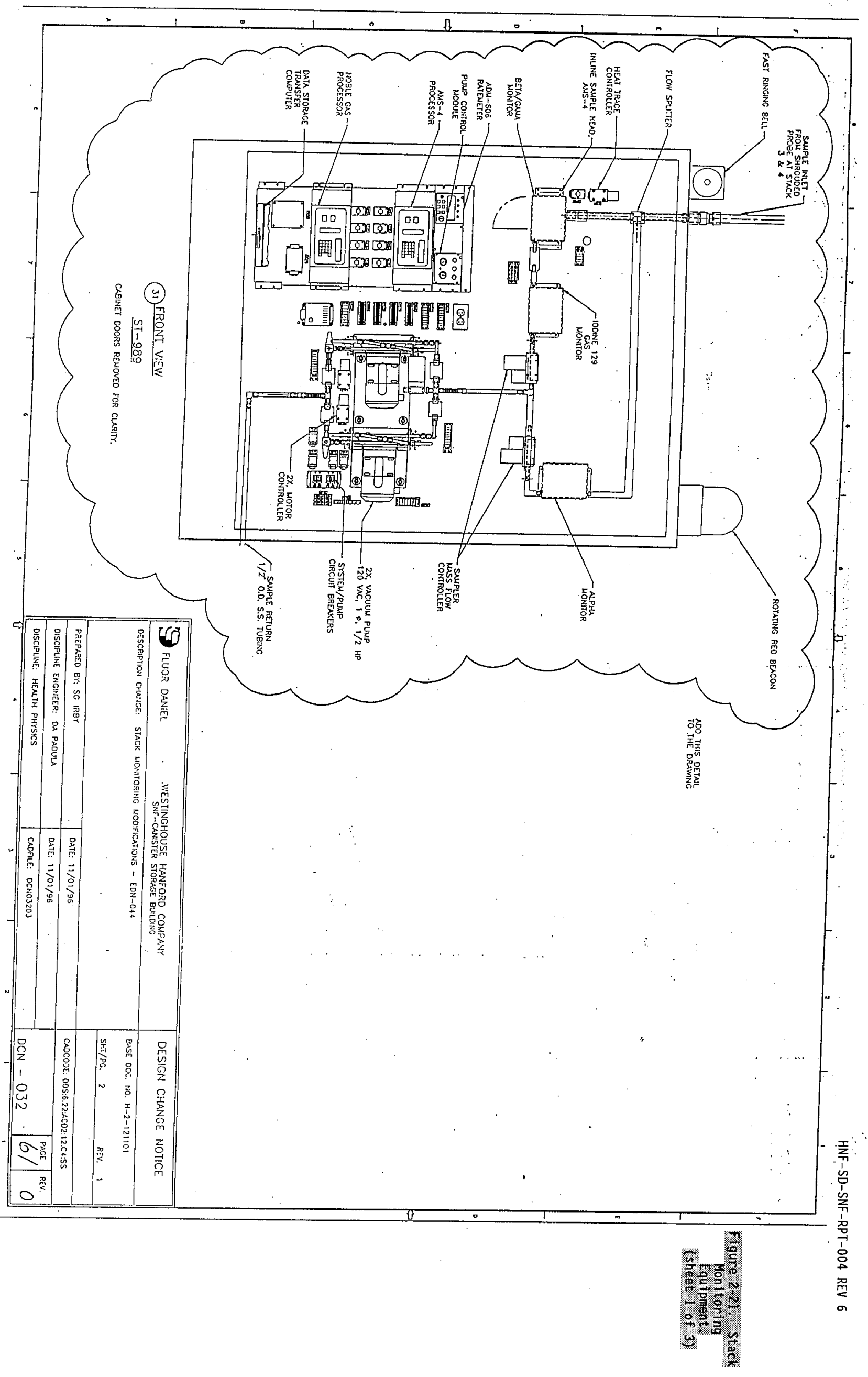




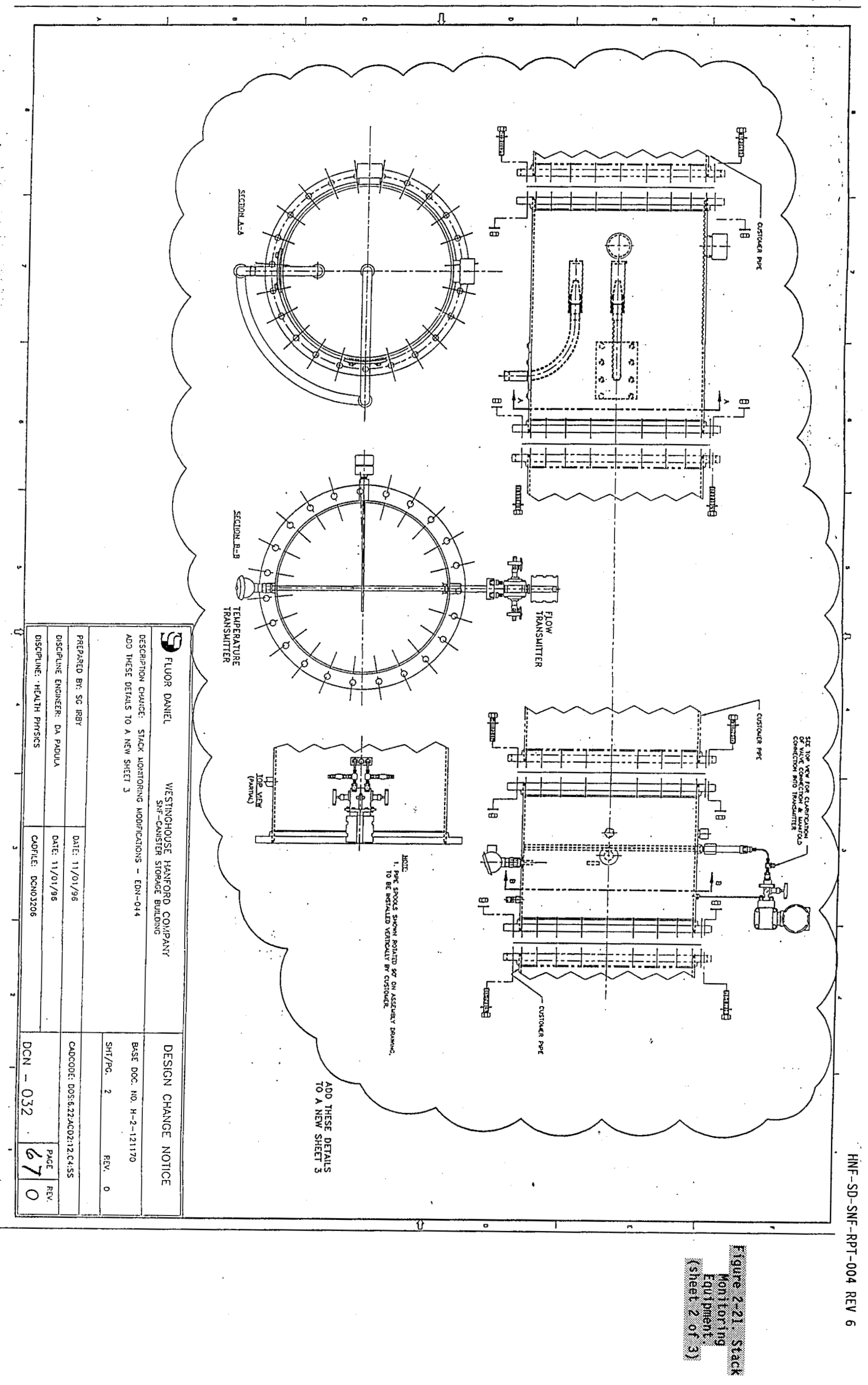




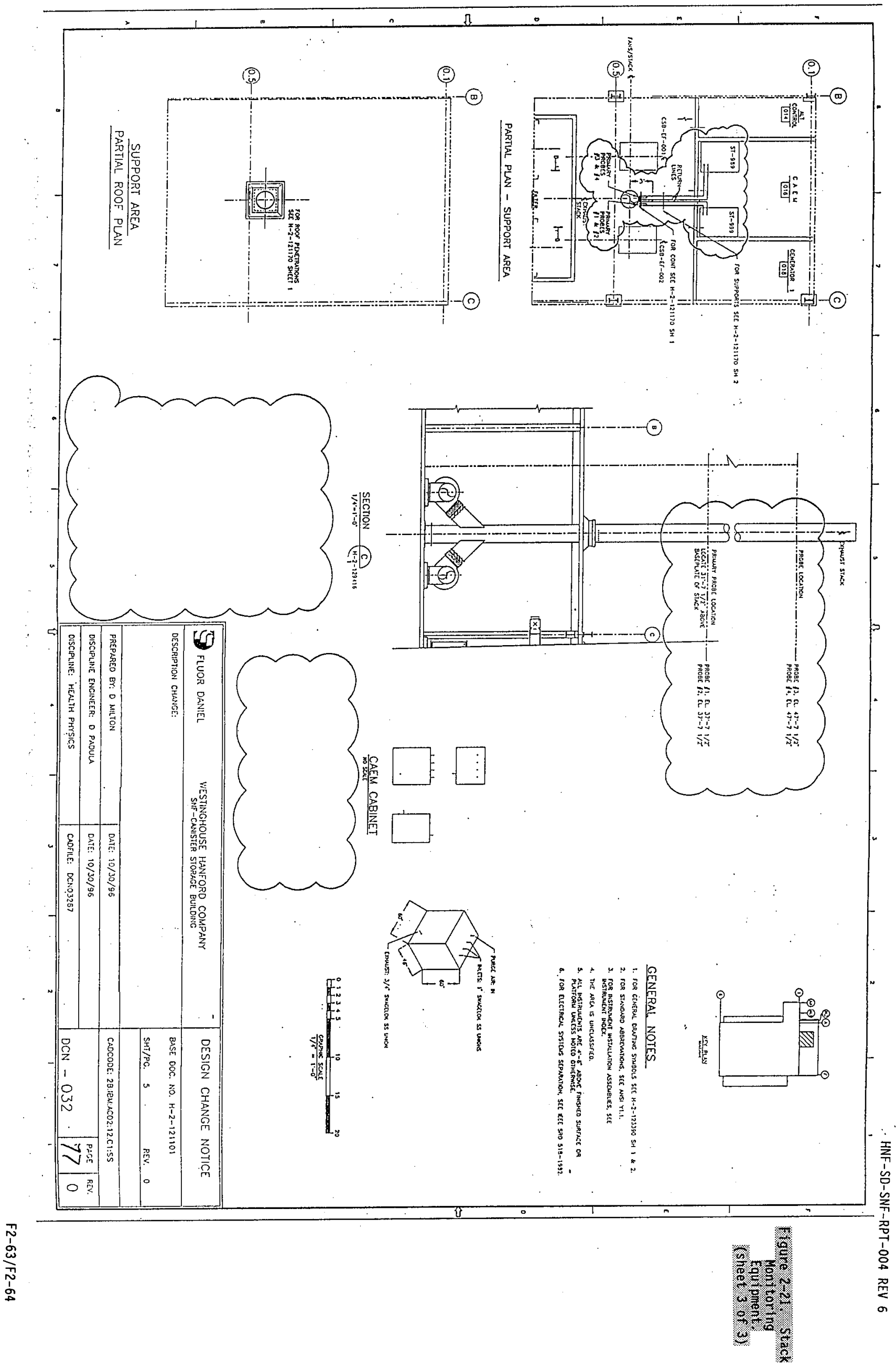




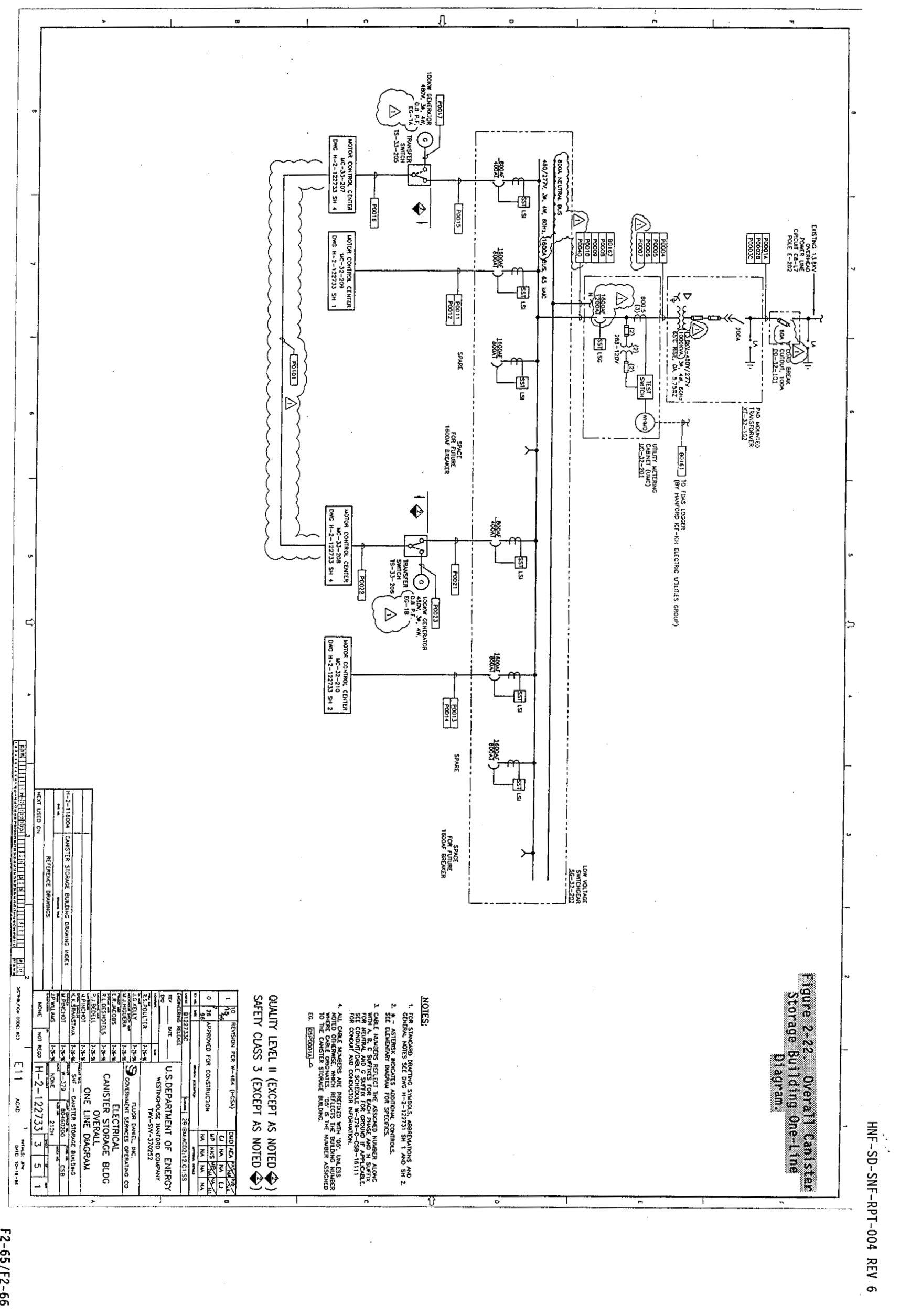




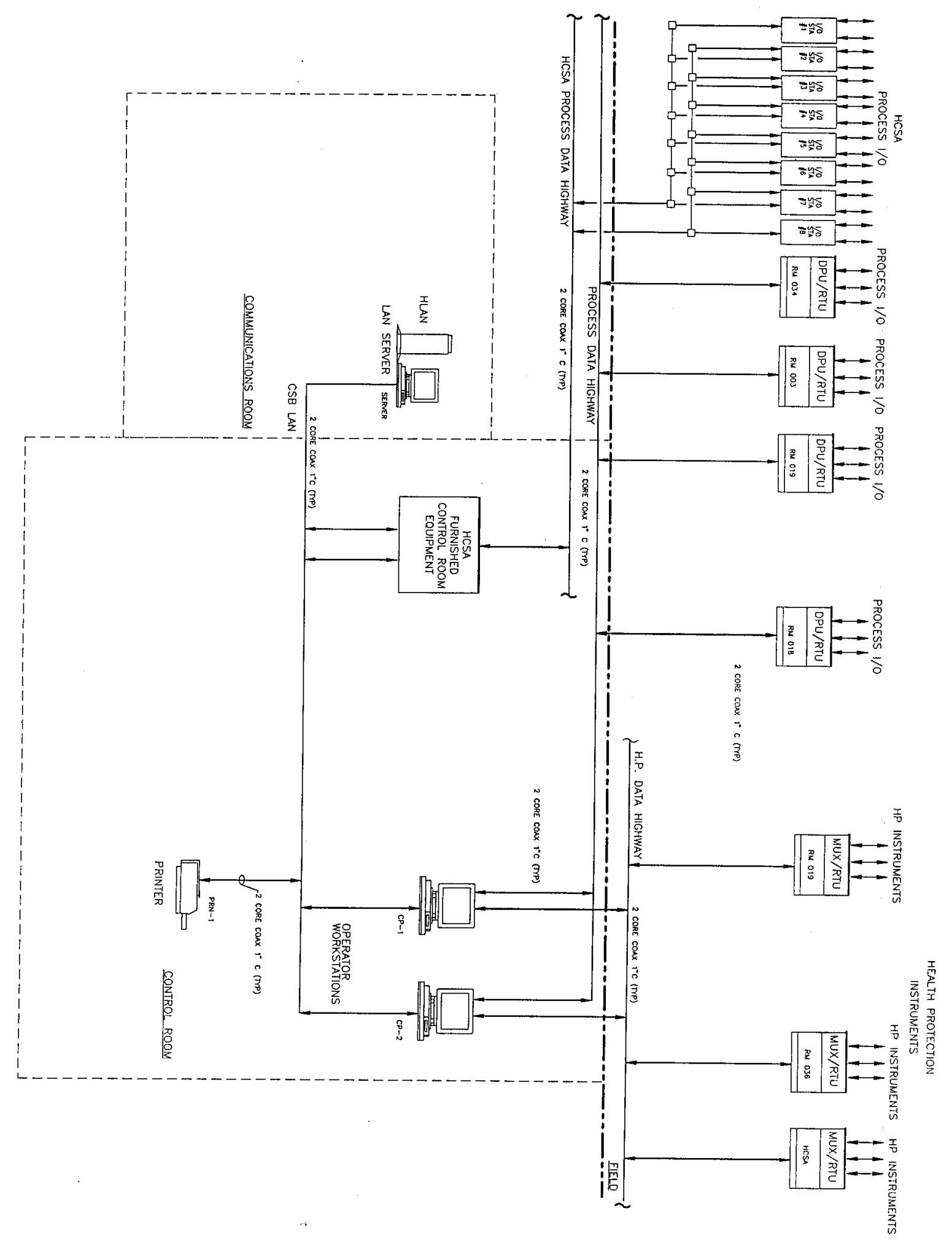

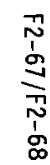
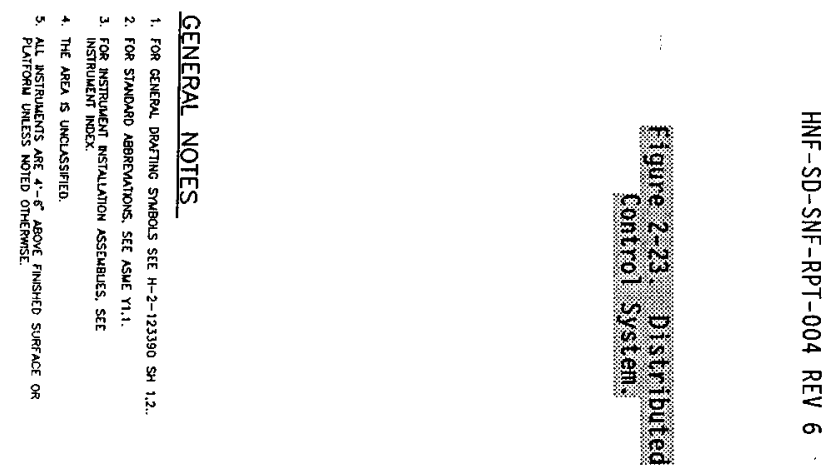
HNF-SD-SNF-RPT-004 REV 6

\subsection{HAZARD AND ACCIDENT ANALYSES}

\subsection{INTRODUCTION}

This chapter summarizes the hazard and accident analyses performed to support the CSB design and initial construction activities. The methods used to identify CSB hazards and select accident scenarios for analysis are described in Section 3.3. The analyses of the selected accidents are presented in Section 3.4, with emphas is on the identification of SSCs required for accident prevention and mitigation. The potential impacts of these SSCS on the design of the CSB structure and systems, including the HCS Annex structure are discussed. The hazard category classification of the facility is presented in Section 3.3.2.2 with the conclusion presented that the CSB is a hazard category 2 facility. Dose assessments to operating personnel and the public during normal operations and anticipated operational occurrences will be provided in Chapter 7.0 of the flnot. SAR.

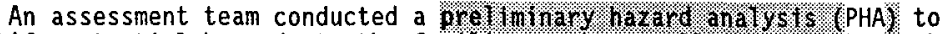
identify potential hazards to the facility worker, collocated worker, the public, and the environment. Potential events considered ranged from normal operation through beyond design basis accidents. Accidents for consideration of consequence analyses were grouped as follows:

- Release of MCO gases under pressure during handling, staging, or interim storage

- Single MCO obrigae-fatlure during handling

- Multiple MCO-failures during handling

- Hydrogen gas combustion

- Multiple MCO-tube failures during temporay-staging or interim storage

- Beyond design basis svents - acidents.

The PHA also identified off-normal conditions for consideration of defense-indepth features for the protection of the workers, environment, and the public.

The results of the subsequent accident consequence analyses identify the need for both safety-class and safety-significant accident prevention and

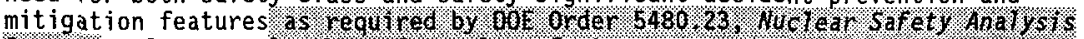
Reorols. In general, the safety-class features are required to protect the environment or the offsite receptor and the safety-significant features are

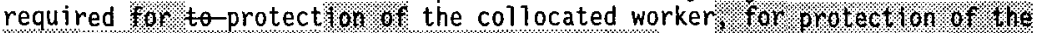
fach W wo ker, or to prov de defense in depth. As a general rule, according to DOE-STD-3009-94, Preparation Guide for U.S. Department of Energy Nonreactor Nuclear Facility Safety Analysis Reports, safety-significant SSC designations for worker safety are limited to those SSCS whose failure is estimated to result in an acute worker fatality or serious injury to the worker. ${ }^{2}$ In

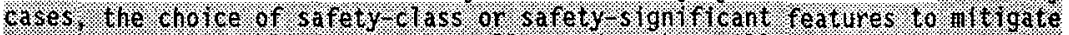

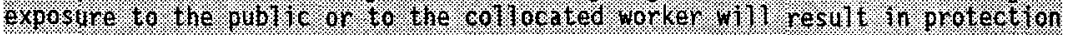




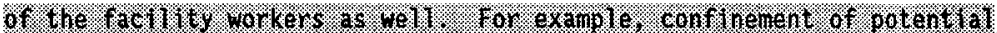

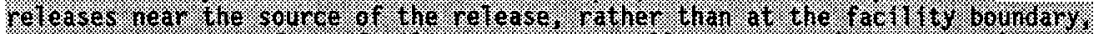

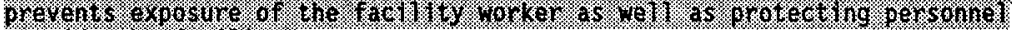
outs res

The location of the offsite receptor and the bases for this location are discussed in Section 1.3. The collocated worker is assumed to be located at $100 \mathrm{~m}(328 \mathrm{ft})$ from the CSB release point.

The accident analysis is augmented by a formal design review process-and independent safety review to ensure that the safety-related design requirements have been correctly identified, interpreted, and applied to the design. This is described in Section 17.4.1 as suggested by DOE-STD-3009-94. The appropriate design requirements, with identified options, have been established through the safety classifications based on the analyses presented in this chapter. A configuration management plan that follows the design process has been implemented (WHC 1995). The plan ensures that the safety-class SSCs are maintained and that any open items are tracked and closed. Additional detail on this configuration management plan and other aspects of its implementation are discussed in Section 17.4.2.

The final SAR will define the safety basis of the facility, document the logic of its derivation, demonstrate adherence to the safety basis, and

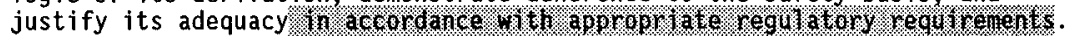
Chapter 3.0 of the finaT SAR wilT include the results of the safety analyses that identify the dominant contributors to the risk of the facility so that these vulnerabilities can be managed.

\subsection{REQUIREMENTS}

This section lists the design codes, standards, regulations, and DOE orders that are required for establishing the safety bas is for the CSB. Only the requirements that are specific for Chapter 3.0 and that pertain to the hazard and accident analysis are provided.

\subsubsection{U.S. Department of Energy Orders and Standards}

The following DOE orders and standards are applicable to the safety analysis.

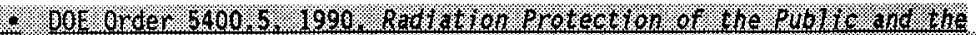

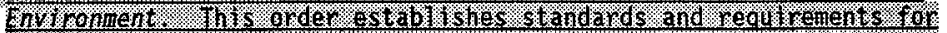

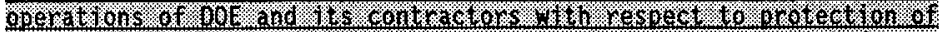

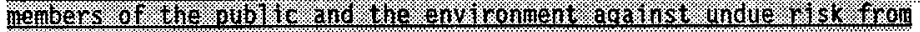
10.0161010

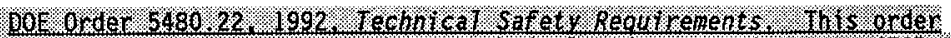

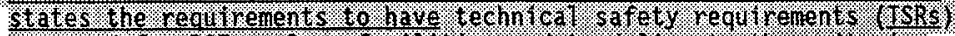

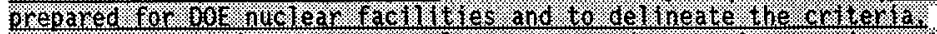

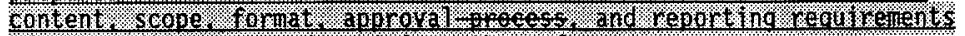

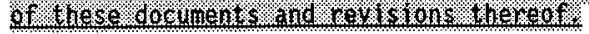


- DOE Order 5480.23, 1992, Nuclear Safety Analysis Reports. II DOE Order 5480.23, Section 8.8.(3). (k) sets the requirement for analysis, and Attachment 1 to the order includes guidance to meet this requirement.

- DOE Order 6430.1A, 1989, General Design Criteria. This Order provides requirements for the identification of safety-class items.

- DOE-STD-1027-92, 1992, Hazard Categorization and Accident Analysis Techniques for Compliance with DOE Order 5480.23, Nuclear Safety Analysis Reports. This standard establishes guidance for the preparation and review of hazard categorization and hazards and accident analyses techniques as required by DOE Order 5480.23. Of particular importance to Chapter 3.0 is the guidance relative to the hazard categorization methodology and the hazards and accident analyses techniques appropriate to the graded approach required by the-Bot order 8480.23 .

- DOE-STD-3009-94, 1994, Preparation Guide for U.S. Department of Energy Nonreactor Nuclear Facility Safety Analysis Reports. This standard supplements DOE Order 5480.23 by providing guidance specific to nonreactor nuclear facilities. In this regard, the standard provides more detailed information on the performance of hazards and accident analyses for hazard category 2 and 3 facilities. The standard also establishes additional requirements for the establishment of defense in depth and the identification of safety-significant SSCs.

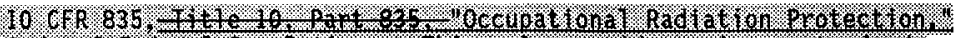

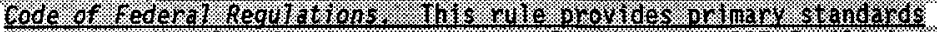

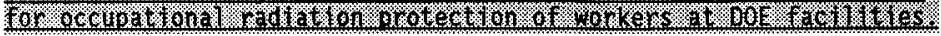

\subsubsection{U.S. Nuclear Regulatory Commission Rules and Guidance}

In Memorandum EM-36-3.1.6.7, Concurrence with K-Basins Spent Nuclear Fuel Project Policy on Nuclear Safety Requirements (Grumbly 1995), DOE established the requirement for new SNF Project facilities to achieve "nuclear safety equivalency" to comparable NRC-licensed facilities. The SNF Project identified the NRC requirements that were needed in addition to existing and applicable DOE requirements to establish nuclear safety equivalency. These NRC requirements and the nethed used to ident ify them are documented in WHC-SD-SNF-DB-003, Spent Nuclear Fuel Project Path Forward, Additional NRC Requirements (Garvin 1996) and in WHC-SD-SNF-DB-009, Canister Storage Building Natural Phenomena Hazards (Tallman 1996). These documents establish the design requirements to be met for the CSB to achieve this equivalency.

The following NRC rules and guidance were considered in the development of WHC-SD-SNF-DB-003 (Garvin 1996) and WHC-SD-SNF-DB-009 (Tallman 1996) and have particular significance to Chapter 3.0.

- 10 CR 12. Tit7e 10, Part 72, "Licensing Requirements for the Independent Storage of Spent Nuclear Fuel and High-Level Radioactive Waste," Code of Federal Regulations (10 CFR 72). This rule is used 
for the 1icensing of ISFSIs. Section 72.3, "Definitions," provides the definition of SSCs that should be considered as "important to

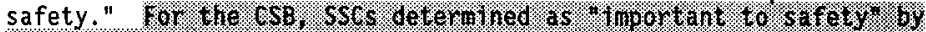

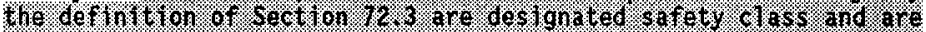

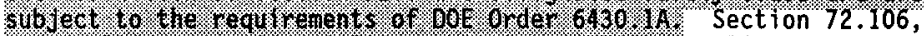
"Controlled Area of an ISFSI or MRS, establishes a 1imit of $50 \mathrm{mSV}$ ( 5 rem) at the controlled area boundary for any gesogn.

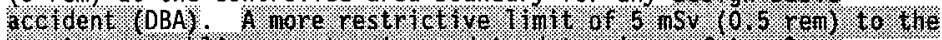

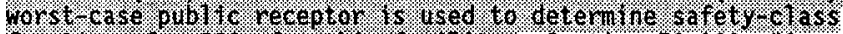

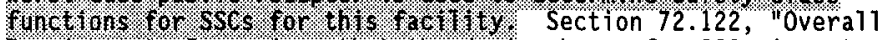
Requirements, " requires that the design bases for SSCS important to safety must reflect appropriate combinations of the effects of normal and accident conditions, and the effects of natural phenomena. Section 72.24, "Content of Application: Technical Information," provides requirements in $72.24(\mathrm{~m})$ for the analyses of accidents and natural phenomena events that may result in a dose at the controlled area boundary.

- NRC Regulatory Guide 3.48, Standard Format and Content for the Safety Analysis Report for an Independent Spent Fuel Storage Installation or Monitored Retrievable Storage Installation (Dry Storage) (NRC 1989). This guide establishes the format and content for materials license applications for ISFSIs, including the requirements for a chapter on accident analyses. For such a chapter, Regulatory Guide 3.48 states that ANSI/ANS-57.9-1984, Design Criteria for an Independent Spent Fuel Storage Installation (Dry Storage Type), defines four categories of design events that provide a means of establishing design requirements to satisfy operational and safety criteria. This standard was reissued in 1992 as ANSI/ANS-57.9-1992 and retitled Design Criteria for an Independent Spent Fuel Storage Installation (Dry Type) (ANSI/ANS 1992a).

- NRC Regulatory Guide 3.60, Design of an Independent Spent Fuel Storage Installation (Dry Storage) (NRC 1987), adopts, with qualification, ANSI/ANS-57.9-1984 as acceptable for use in the design of an ISFSI that uses a dry environment as the mode of storage for SNF. of the nine qualifications made by the NRC staff on the use of the standard, one relates to the content of Chapter 3.0 of this SAR. The staff points out that Section 2.8 of the standard defines a new term, "important to confinement features, " to classify SSCS with regard to the degree of their importance to safety. The staff requires that the definition of the term "important to safety" provided in 10 CFR 72.3 should be used instead of "important to confinement features."

As mentioned above, ANSI/ANS-57.9-1984 was reissued and retitled in 1992. Section 2, "Definitions," defines design event categories that are to be used to evaluate the radiological protection provided by the facility. Design events I and II cover normal and off-normal events. These events are usually addressed by summarizing analyses that confirm the SSCs are appropriately designed to accommodate the events without challenge to the design. Design events III and IV cover a range of postulated accident events for which radiological 


$$
\text { HNF-SD-SNF-RPT-004 REV } 6
$$

calculations are performed to confirm that onsite and offsite doses are within acceptable 1 imits as defined in 10 CFR 72 .

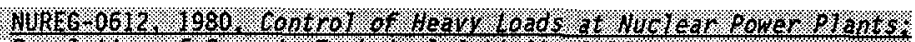

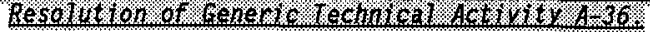

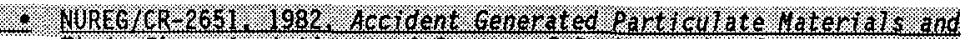

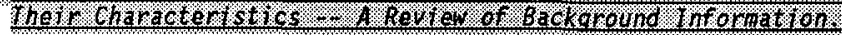

\subsubsection{Industry Consensus Standards and other Doctinentartion}

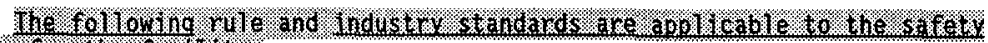

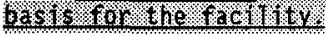

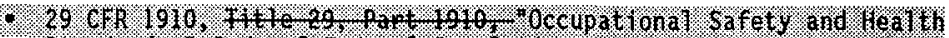
Standards." code of Federal Regulat ions.

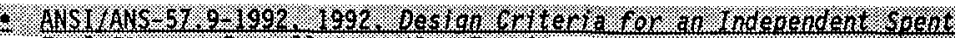

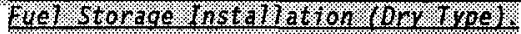

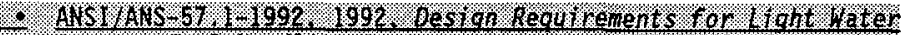

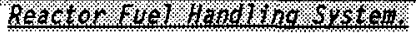

\subsubsection{Ianford Site Requil rements}

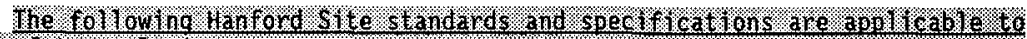
Me. Saretr analysis.

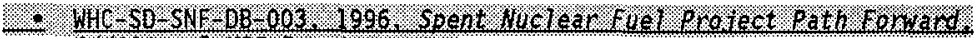
ACd T Tona THE Requirenents.

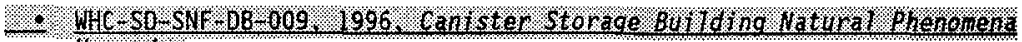
Eazards.

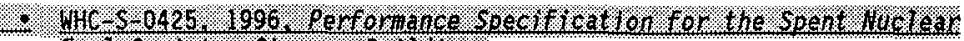

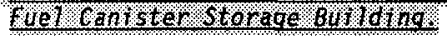

\subsection{HAZARD ANALYSIS}

This section describes the hazard identification and evaluation performed for the CSB.

\subsubsection{Methodology}

This subsection presents the methodology used to identify and characterize CSB hazards. It also presents the methodology used to evaluate the identified accidents. The results of the application of this methodology to the CSB are presented in Section 3.3.2. 
3.3.1.1 Hazards Identification. Hazard identification is the process of highlighting material, system, process, and facility characteristics with the potential to initiate accidents having undesirable consequences. For the CSB, this would be undesirable consequences to the workers, public or environment. The hazard identification methodology considers the following characteristics of hazards:

- Inherent physical, radiological, or chemical characteristics that have the potential to cause harm to people, property, or the environment

- Combinations of hazardous material, an operating environment, and planned and unplanned events that can result in an accident.

To identify hazards associated with the CSB, a PHA, bosect. on conceptufu desugro. was performed by anteam that included individuals knowledgeable of accident analyses, chemical syslens and facility operations. As the CSB design evolved, the assesment-BIf team was reconvened, as necessary, to examine the effect of design-and process changes, and to revise the PHA as appropriate. The main contributors to the PHA team, and their qualifications, are listed alphabetically in Table 3A-2, Appendix 3A. The PHA is an initial effort directed at the requirements of DOE Order 5480.23 and its implementing standard, DOE-STD-3009-94, for a systematic, rigorous technique for identifying the range of potential hazards posed by the operation of the facility. The PHA supports current CSB safety analysis and design activities. PHA pes othep hazard evaluation techniques will be applied to support the hazards

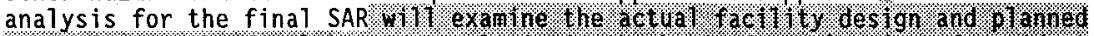

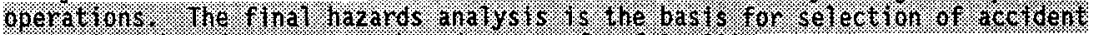

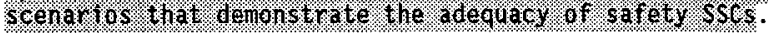

The PHA consisted of identifying the various operational steps to be conducted within the CSB. The main operational steps are

- Cask receiving

- MCO servicing

- MCO handling

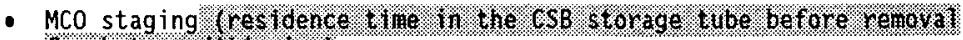
Hor hot ( cond (Woring)

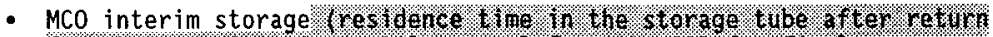

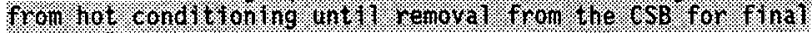
Oisposil).

Each step was subdivided into specific activities, as provided in Appendix $3 A$. For each activity, the potential hazards were identified along with the potential causes and consequences of the hazard. The hazards were further evaluated by establishing accident initiators and sequences, potential targets or consequences, and potential mitigating features (engineered and

administrative), and by qualitatively estimating the severity of each accident 
and its likelihood. The completed PHA and a discussion of its development are provided in Appendix $3 A$.

The effects of natural phenomena and external hazards on the CSB can include confinement systems. These are reflected in the PHA (Appendix 3A, Table 3A-1) in the following manner.

- Process-Parameter changes initiated by natural phenomena and external events are often the same type as changes that may be initiated by equipment failures or operator error.

- In some cases, external events can add hazardous material to the system (e.g., a radionuclide release from a nearby facility) possibly initiating accidents.

- The common-cause failure of several non-safety-class structural features of the CSB that have not been designed for a particular severe natural phenomenon may be more challenging than the failures considered individually.

For the first two cases, the natural and external phenomena are included in the "Causes" column of the PHA form (Appendix 3A, Table 3A-1). The third case is included in Appendix 3A, Table 3A-1, as "Accident/system, Mten hinuto. $60 . f . "$

3.3.1.2 Hazard Evaluation. The PHA team used the following "S" rankings to assign qualitative levels of severity to the hazard consequences. Unless noted otherwise in Appendix $3 A$, Table $3 A-1$, the severity assignments were made with the assumption that the accident was unmitigated. As such, these assignments are not true indications of the potential consequences of the accident to the worker, the public, or the environment.

So No effect outside the CSB confinement systems and no safety concerns for the facility worker, the collocated worker, or members of the general public

Sl Potential industrial injury, radiological dose consequences, or chemical exposure to the facility worker; limited environmental discharge of hazardous material outside the facility

S2 Potential significant radiological dose consequences or chemical exposure to the collocated worker; significant environmental discharge of hazardous material within the Hanford Site boundary

S3 Potential significant radiological dose consequences or chemical exposure to the offsite receptor; environmental discharge of hazardous material outside the Hanford Site boundary or to the groundwater.

In assigning these severity levels the PHA team had the benefit of preliminary safety evaluations that had been completed for the CSB (Brehm 1995a and 1995b). These preliminary safety evaluations included 
quantitative estimates of the exposures to the collocated worker and the offsite receptor.

The assignment of the likelihoods were qualitative, consensus estimates of the frequency of the initiating event. An alphanumeric system was used to designate the frequency (events/year) by the following "F" rankings:

F1 Anticipated event (the event can be expected to occur regularly during the course of the activity: $>10^{-2}$ to $\leq 10^{\circ}$ )

F2 Unlikely event (the event is not expected to occur regularly during the course of the activity but may occur sometime during the operating 7 ife of the CSB: $>10^{-4}$ to $\leq 10^{-2}$ )

F3 Extremely unlikely event (the event is credible but not expected to occur during the operating life of the $\mathrm{CSB}:>10^{-6}$ to $\leq 10^{-4}$ )

F4 Beyond extremely unlikely event (the event is not considered "credible": $\leq 10^{-6}$ ).

The upper bound for the $F 1$ classification is 1.0 . This differs from 18

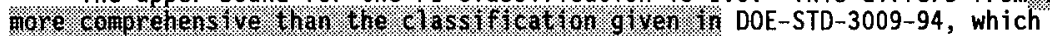
defines the upper bound as 0.1 and thereby does not account for events from $1.0 / \mathrm{yr}$ to $0.1 / \mathrm{yr}$.

The initiating events can be internal or external events. External events include severe natural phenomena, range fires, and hazards from nearby facilities. In most cases, the internal events dominate the frequency assignment.

The selection of accidents for quantitative analysis was performed by a

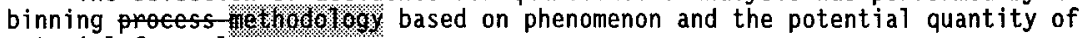
material for release.

DOE-STD-3009-94 suggests a matrix approach in which only "unacceptable accidents" (moderate to high consequences, unlikely to extremely unlikely frequency) should be identified. For the binning of the CSB hazards, only those hazards ranked as categories S2 and $\$ 3$ were considered to be sufficiently significant to require consideration for additional analysis. The selection of the $S 2$ and $S 3$ events was made independent of the frequency assignment, that is, independent of the " $F$ " ranking.

The worst-case accident in each major grouping served as a representative and bounding scenario for that set of accident types. The worst-case accidents are evaluated in detail in Section 3.4. The major groupings are as follows.

- Release of MCO gases under pressure during handling, staging, or interim storage

- Single-MCO damage-fatlure during handling

-.Multiple-MCO failures during handing 
- Hydrogen gas combustion

- Multiple MCO-tube failures during -staging or interim storage

- Beyond design basis everts

The specific accidents included in each group are provided in Section 3.3.2.3.5.

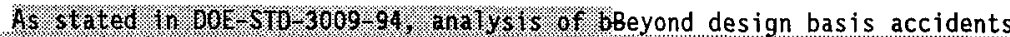

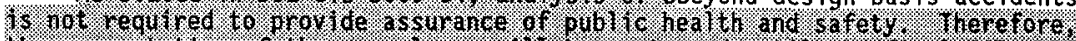

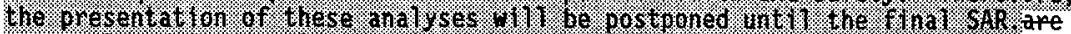
not analyzed in detail in this isste of thapter 3.0 . They whtl be adressed in the-finat SAR as suggested by Section 3.4 .3 Of DOE STD 3009 -94.

Section 3.2.2 discusses implementation of NRC nuclear safety equivalency for the CSB. An element of that equivalency is ANSI/ANS-57.9-1992 (ANSI/ANS 1992a). This standard presents the following set of events for consideration in the design and accident analyses for an ISFSI:

Design event I Expected to occur regularly or frequently in the eapse-course of normal operation

Design event II Can be expected to occur with moderate frequency or on the order of once during a calendar year of operation

Design event III Infrequent events that could reasonably be expected to occur during the lifetime of the installation

Design event IV Postulated because their consequences may result in the maximum potential impact on the immediate environs.

This chapter is limited to consideration of off-normal and accident conditions. As design event I occurrences are associated with normal operation, they are not addressed in this chapter except for identifying hazards to the facility worker. Hazards to the facility worker during normal, off-normal, and accident conditions are addressed in Section 3.3.2.3.3. Protection of the facility worker for normal and off-normal events will be addressed in Chapters 7.0 and 8.0 of the SAR as required by DOE-STD-3009-94. The loadings the CSB will experience during design event I conditions

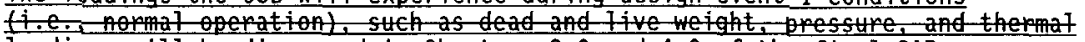
loaditg. will be discussed in chapters 2.0 and 4.0 of the finat SAR as sugested by DOE STO 3009 94. Similar loadings for the MCOS will be discussed in the MCO Topical Report.

Design event II, III, and IV occurrences are identified by the hazard identification thodology discussed in Section 3.3.1.1. Consequence analyses for design event II, III, and IV hazards are performed as discussed in Section 3.3.1.2. 


\subsubsection{Hazard Analysis Results}

3.3.2.1 Hazard Identification. The results of the PHA activity are provided in Appendix 3A, Table 3A-1. Table 3A-1 presents, for each hazard, its form

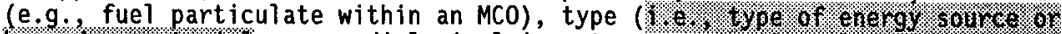
Gazarcous onaterrale.g., ratogical inventony op missite), location (e.g., pressure relief in the service station), and total quantity (e.g., the contents of one MCO). The form-type, and total quantity are presented in the "Inventory at risk" column. The location of the hazard is presented in the "Accident/system" column. Quantitative information on the hazard is presented in Section 3.4 for those hazards for which consequence analyses were performed. The "Potential Hazard" anos "uassesi columns of Table 3A-1, Appendix $3 A$, provides information on the Iype. of energy sownce. or material tsed by - ir esent. In the CSB facility that may generate-const, tutue the hazard. The "Coment" Mentrolsol column provides information on sources of energy that may exacerbate an accident resulting from the hazard.

The CSB has one main inventory of hazardous material: the radionuclide contents of the MCOS. The CSB does not include any chemical as discussed in Section 3.3.2.3.4.

As the CSB does not have an operating history, major hazards that have resulted from the facility operation cannot be summarized as suggested by DOE-STD-3009-94. However, the CSB is similar to facilities issued materials 1 icenses under 10 CFR 72, so the 10 CFR 72 dockets including notices of violations issued and reporteding under 10 CFR 72.75, "Reporting Requirements for Specific Events and Conditions," were reviewed. The results of this review are presented in Table $3-1$. This table also addresses events at DOE facilities similar to the CSB.

3.3.2.2 Hazard Classification. The CSB has been assigned a hazard category of 2 in accordance with DOE-STD-1027-92. The hazards category for the CSB was derived in WHC-SD-SNF-HC-007, Hazard Category Analysis for the Canister Storage Building (Kummerer 1995). That document was prepared in accordance with the requirements of DOE Order 5480.23 and DOE-STD-1027-92. This hazard classification assignment for the CSB has been approved by DOE

(Sellers 19966). In accordance with DOE-STD-1027-92, the final hazard category of the CSB will be based on the hazard analysis presented in the final SAR.

The initial hazard category was determined by identifying the facility radioactive materials inventory at risk for release, unmitigated by any safety features. The bounding scenario for release of material from the CSB was taken to be a beyond design basis seismic event that collapsed the operating floor. All the MCOs broke open during the event. The release from these MCOs was a resuspension over a 24-hour period of the fine particulate material within an MCO. It was also assumed that $1 \%$ of the MCOs (four) had not been adequately dried, or adequate $y$-vented, contained hydrogen gas buildup from radiolysis and corrosion. These MCOs experienced a sudden venting, releasing the fine particulate material with the MCO gases. 


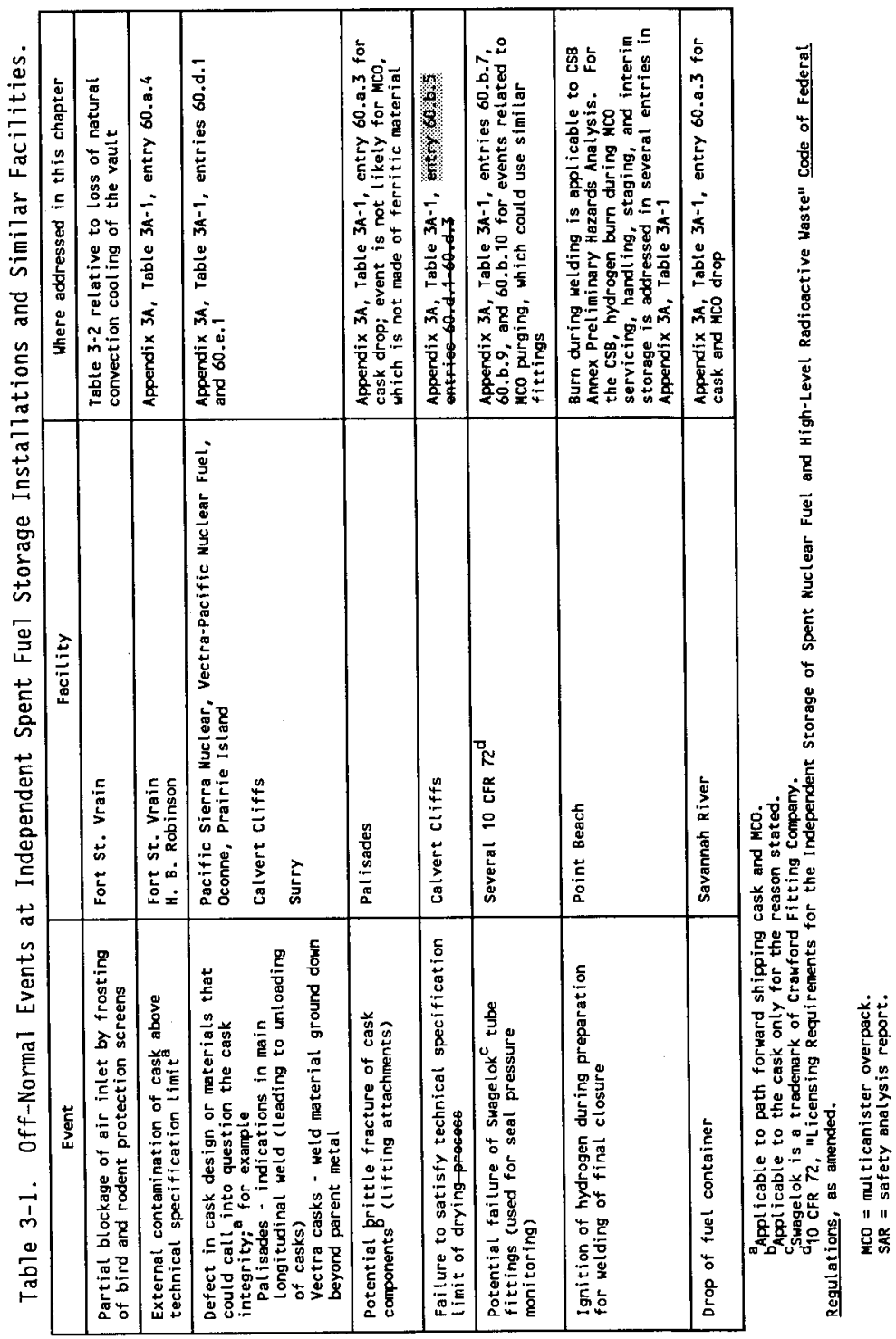


The inventory at risk for release in this event was the total assumed quantity of particulate material in the MCOs. For the $386 \mathrm{MCOs}$ from which resuspension of particulates was the only release mechanism, $6.5 \mathrm{~kg}$ (14 $1 \mathrm{~b})$

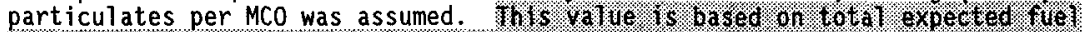

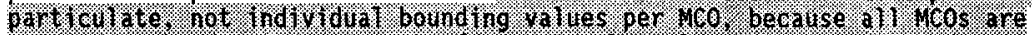
assuined to. 6e- datiaget: for the four MCOs that also experienced sudden venting, an upper value of $13.0 \mathrm{~kg}(29 \mathrm{lb})$ particulates per MCO was assumed. This value was chosen to account for additional particulate that could form in MCOs that were not properly treated before shipping.

The total inventory at risk for release was

$$
(386 \mathrm{MCOs} \times 6.5 \mathrm{~kg}+4 \mathrm{MCOS} \times 13.0 \mathrm{~kg}) \times \frac{1,000 \mathrm{~g}}{\mathrm{~kg}}=2.56 \times 10^{6} \mathrm{~g}
$$

(Kummerer 1995). It was assumed that the particulate material at risk for release had the same radionuclide content as the fuel. Using these assumptions, the sum of ratios to the hazard category 2 threshold quantities of DOE-STD-1027-92 was 19.0. If the sum of the ratios exceeds 1.0 , the facility is designated hazard category 2 .

During the time since the hazard category analysis was performed, estimates of the total expected particulate inventory of an MCO have been reassessed (Pajunen and Cowan 1996). The expected

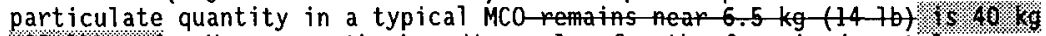
(88. 16 ) and. Hewerer, the bounding value for the four thatequately Pressurvzed MCOs is now $300 \mathrm{~kg}(660 \mathrm{lb})$. If the four MCOs that experienced sudden venting are assumed to contain $300 \mathrm{~kg}(660 \mathrm{lb})$ particulate, the inventory at risk for release is increased to $3.7 \times 10-1,1 \% \times 10 \% \mathrm{~g}$ and the ratio to hazard category 2 threshold values increases to 27 . 20 . The increase does not change the hazard category 2 designation.

The descrlotrous above did not rely on segmentation of the radionuclide inventory.

3.3.2.3 Hazard Evaluation. The PHA described in Sections 3.3.1.1, 3.3.1.2, and 3.3.2.1, in addition to identifying the potential hazards, also characterized the identified hazards in the context of the actual proct res: to be used in the CSB. For example, while the MCO is being serviced in the service station ("Accident/system, 60.b" in Appendix 3A, Table 3A-1), a number of hazards may put the $M C O$ radionuclide inventory at risk. These hazards are listed in the table and include dropping the cask 1 id, inadvertent release of the MCO atmosphere, and errors in the purging operation. The "Safety features" columns include suggestions for prevention and mitigation features, both engineered and administrative.

The accident groupings provided in Section 3.3.1.1 provide systematic evaluation of the accidents based upon common phenomena. The qualitative severity of assignments of the hazard consequences described in Section 3.3.1.2 consider the potential impact of the hazard on the environment.

DOE-STD-3009-94 suggests discussion of specific topics of concern relative to the accident analyses. During the completion of the analyses 
discussed in Section 3.4, key assumptions were made that will need to be confirmed before the CSB design and SAR safety analyses are finalized. These are presented in Table 3-2 as concerns requiring resolution.

Some of the items in Table 3-2 indicate plans for using data from fuel and particulate characterization efforts. The schedule for acquiring these data is given in WHC-SD-SNF-PLN-012, Spent Nuclear Fuel Project Integrated Safety Management Plan (Daschke 1996).

3.3.2.3.1 Planned Design and Operational Safety Improvements. According to DOE-STD-3009-94, this section is to discuss planned improvements for an existing facility. As the CSB is a new facility, this specific requirement is not meaningful for this SAR.

The CSB definitive design is currently evolving in paralle] with the hazards evaluation. The accident analyses discussed in Section 3.4 have identified the need for safety-class and safety-significant prevention and mitigatroning features for several postulated accidents. As the definitive design progresses, the architect-engineer will evaluate these requirements and recommend the most cost-effective options. The acceptance of the recommendations will be closely coordinated with the CSB safety analysis group.

3.3.2.3.2 Defense in Depth. This section summarizes the plans to address the significant aspects of defense in depth. Defense in depth consists of multiple features (equipment and administrative) applied to accident prevention or mitigation to a degree proportional to the hazard risk (i.e., likelihood and consequence). This provides for an increased level of protection by providing additional barriers that, while not used specifically within the accident analyses to prevent or mitigate, serve to (1) reduce the number of challenges to the safety-class systems identified within the accident analysis, (2) mitigate releases upon barrier failure, or (3) ensure the safety of the facility is not unduly dependent upon the existence of a particular barrier. For example, where an MCO is designed to withstand all anticipated drops without confinement failure, the design of a crane system that reduces the likelihood of an MCO drop is an implementation of defense in depth. The crane function would not be taken credit for in the analysis (and therefore would not require designation as safety class) although it serves to reduce the likelihood of events that challenge the safety function of the MCO barrier.

Defense in depth also includes administrative programs that ensure features continue to be available for accident prevention or mitigation and that promulgate a particular set of safety practices.

CSB hazards that are not characteristic of industrial safety hazards are associated with the uncontrolled dispersion of radionuclides from an MCO. Because this hazard may result in effects at a distance from the CSB (either to the offsite receptor or the collocated worker) and can also cause exposure to the facility worker, the defense-in-depth items that protect the individuals at a distance also protect the facility worker. This section discusses the defense-in-depth items for the collocated worker and the offsite receptor with the implicit assumption that these also apply to the facility worker. Section 3.3.2.3.3 addresses defense-in-depth considerations for accidents that affect only the facility worker. 
HNF-SD-SNF-RPT-004 REV 6

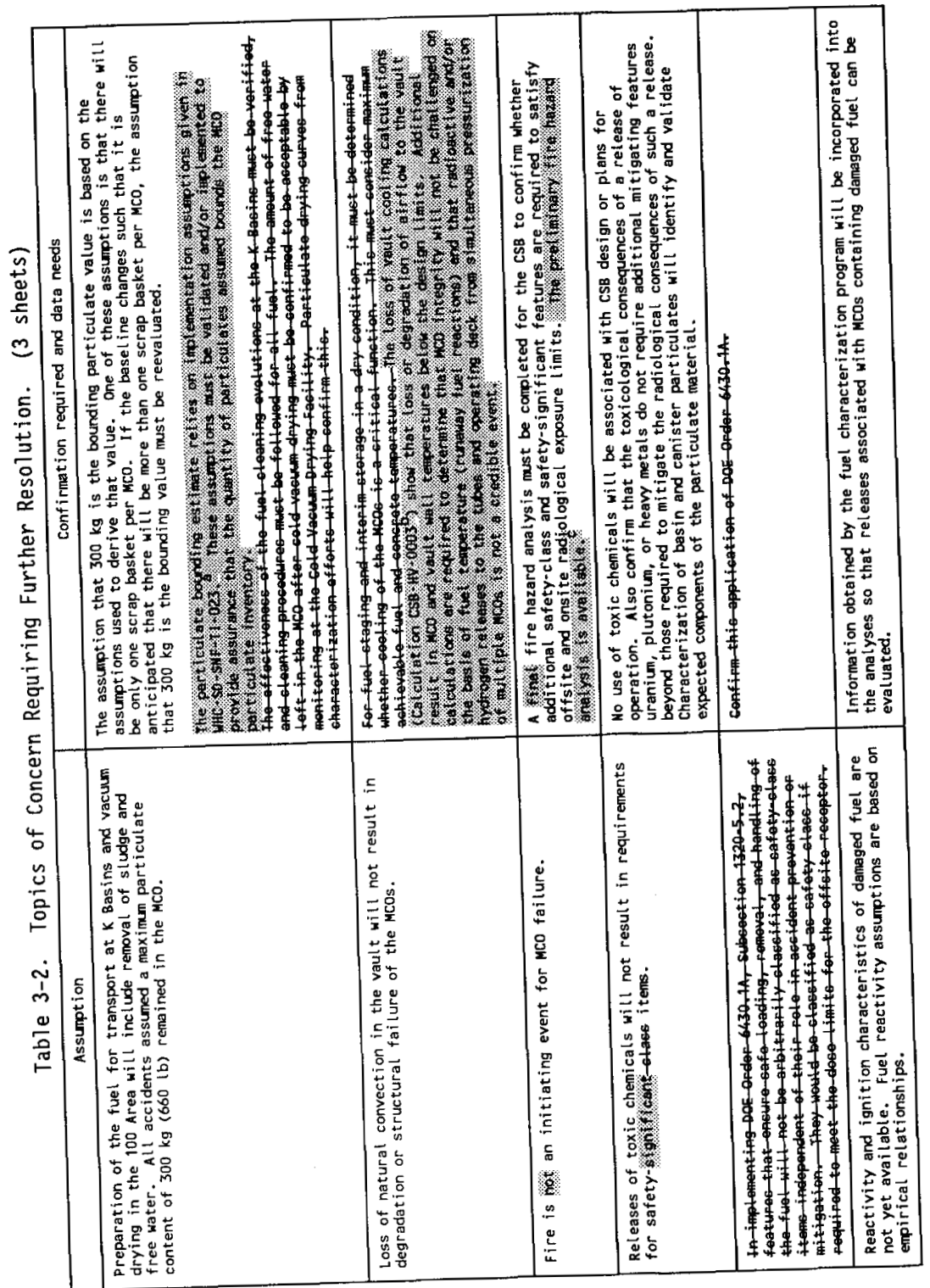


HNF-SD-SNF-RPT-004 REV 6

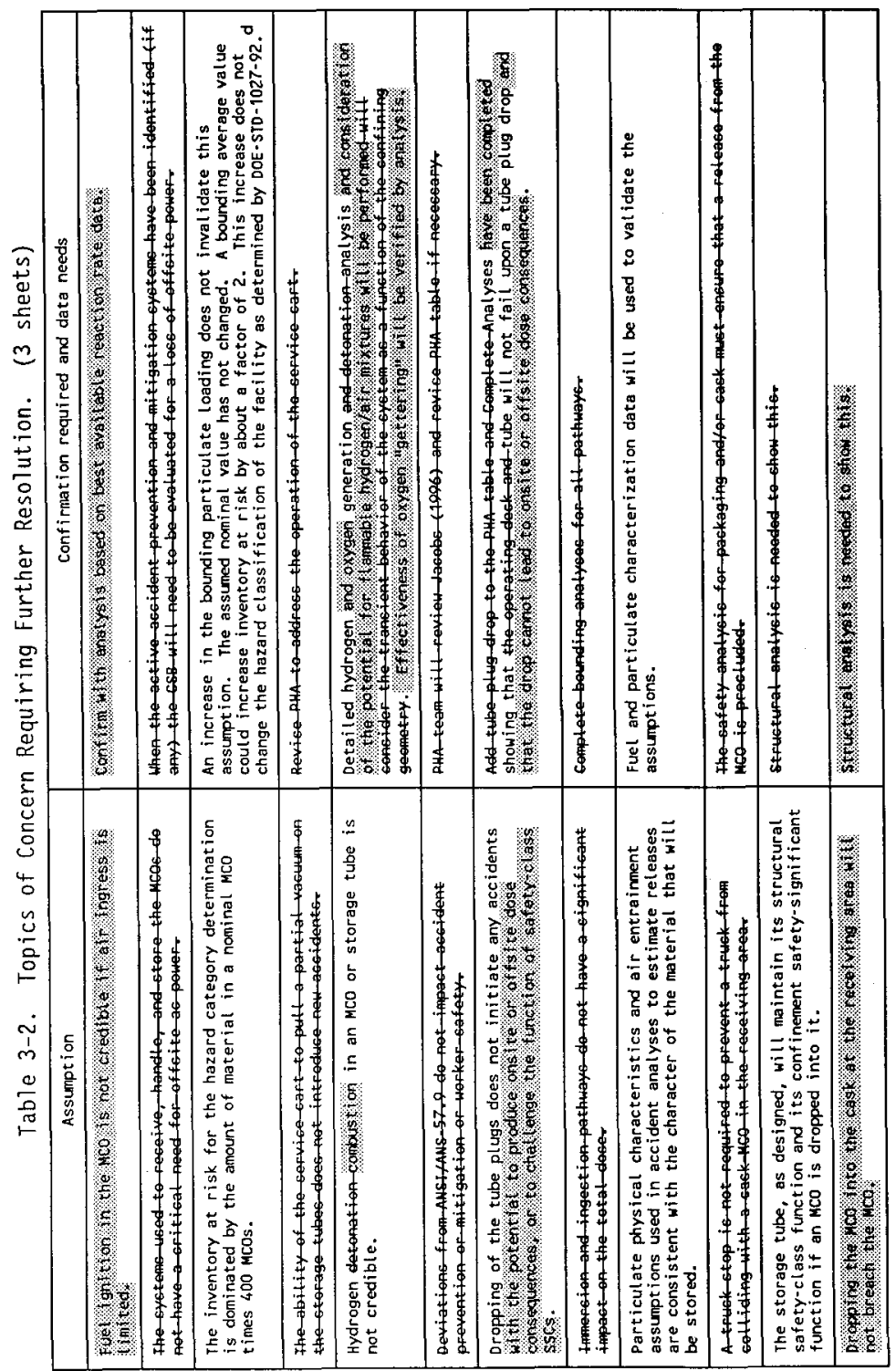


HNF-SD-SNF-RPT-004 REV 6

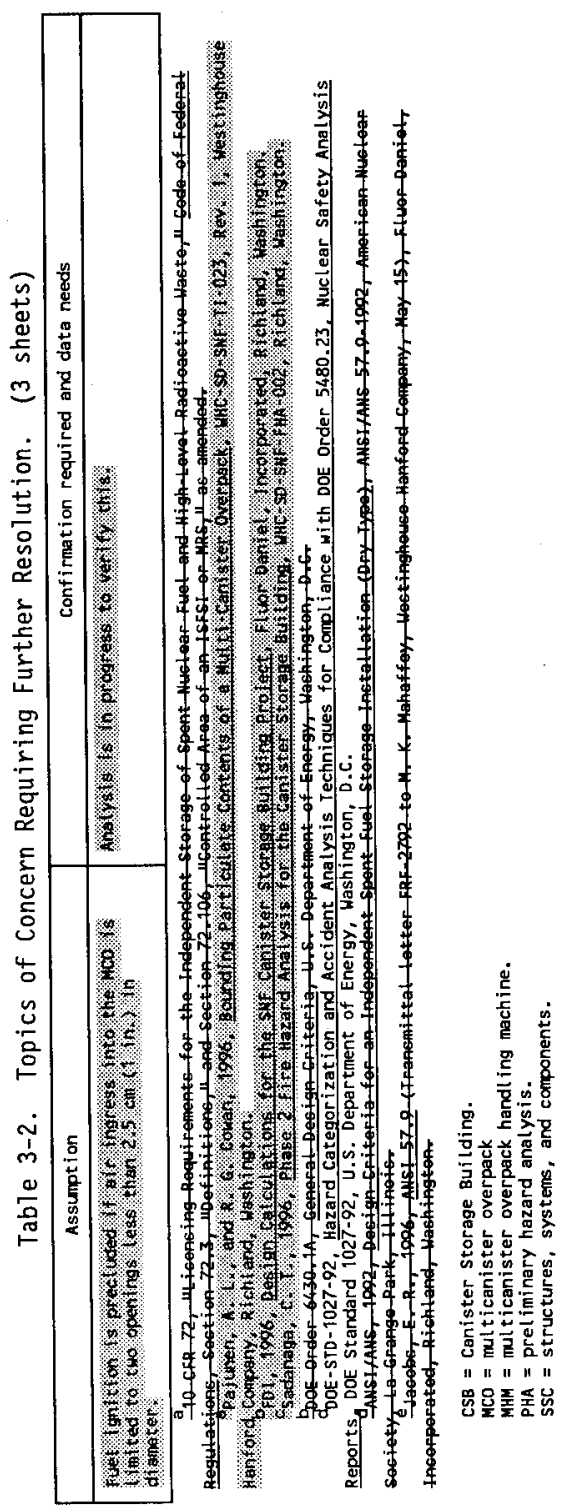


During the performance of the PHA, options were identified for establishing defense in depth for each hazard. These options are noted in Appendix 3A, Table 3A-1, in the two columns included under "Safety features." Both engineered and administrative features are suggested. Table 3-3 shows the approach that will be used in the final SAR to address defense in depth for accidents that have the potential to affect the collocated worker and the offsite receptor.

The defense-in-depth administrative and engineered features 1 isted in

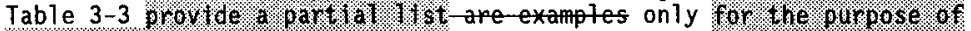
Vhlustrathig the aporoach, with the exception of reference to the hitos as the primary bappier against a radiontelide release and the service area ventilation enclosure, MCO storage tubes and MHA4 as the secondary barriers.

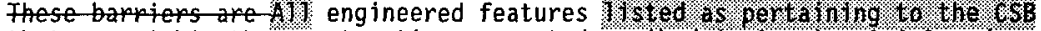
that are within the construction request described in section 2.4 .1 and are

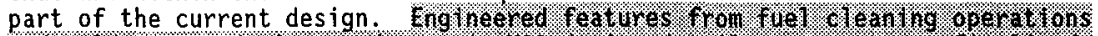

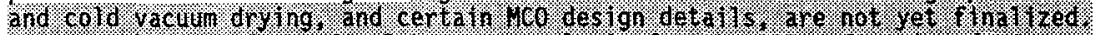

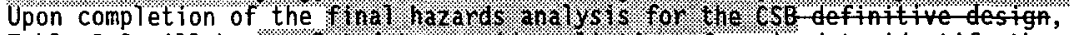
Table 3-3 will be congluted 10 provlos a. W st wing of revised to identify the tocation of additionat information on the 1 ingor tant engineered defense-indepth features disetssed in the SAR. Before requesting DOE approval for operating authorization of the CSB, Table 3-3 will be revised again to ceser the line lypes. of provide-reference to specific procedures and training that provlde inflement the administrative defense-in-depth features.

Safety Classification. DOE-STD-3009-94 requires that this section address the identification of safety-significant SSCs that relate to the prevention of uncontrolled release of hazardous material. To present a complete description of the safety classification fors used for the CSB, all of its elements are described here. Safety classification for CSB SSCs is developed by considering the requirements found in DOE Order 6430.1A and DOE-STD-3009-94.

In addition, the application of NRC nuclear safety equivalency discussed in Section 3.2 .2 has resulted in requirements that impact safety classification, as documented in WHC-SD-SNF-DB-003 (Garvin 1996). These safety classification requirements were derived from 10 CFR 72 .

DOE Order 6430.1A defines safety-class items in Section 1300-3.2, "Safety Class Items":

Safety class items are systems, components, and structures, including portions of process systems, whose failure could adversely affect the environment or the safety and health of the public.

Specifically, safety class items are those systems, components, and structures with the following characteristics:

- Those whose failure would produce exposure consequences that would exceed the guidelines in Section 1300-1.4, Guidance on Limiting Exposure of the Public, at the site boundary or nearest point of public access

- Those required to maintain operating parameters within the safety 1 imits specified in the operating safety requirements during normal operations and anticipated operational occurrences 
HNF-SD-SNF-RPT-004 REV 6

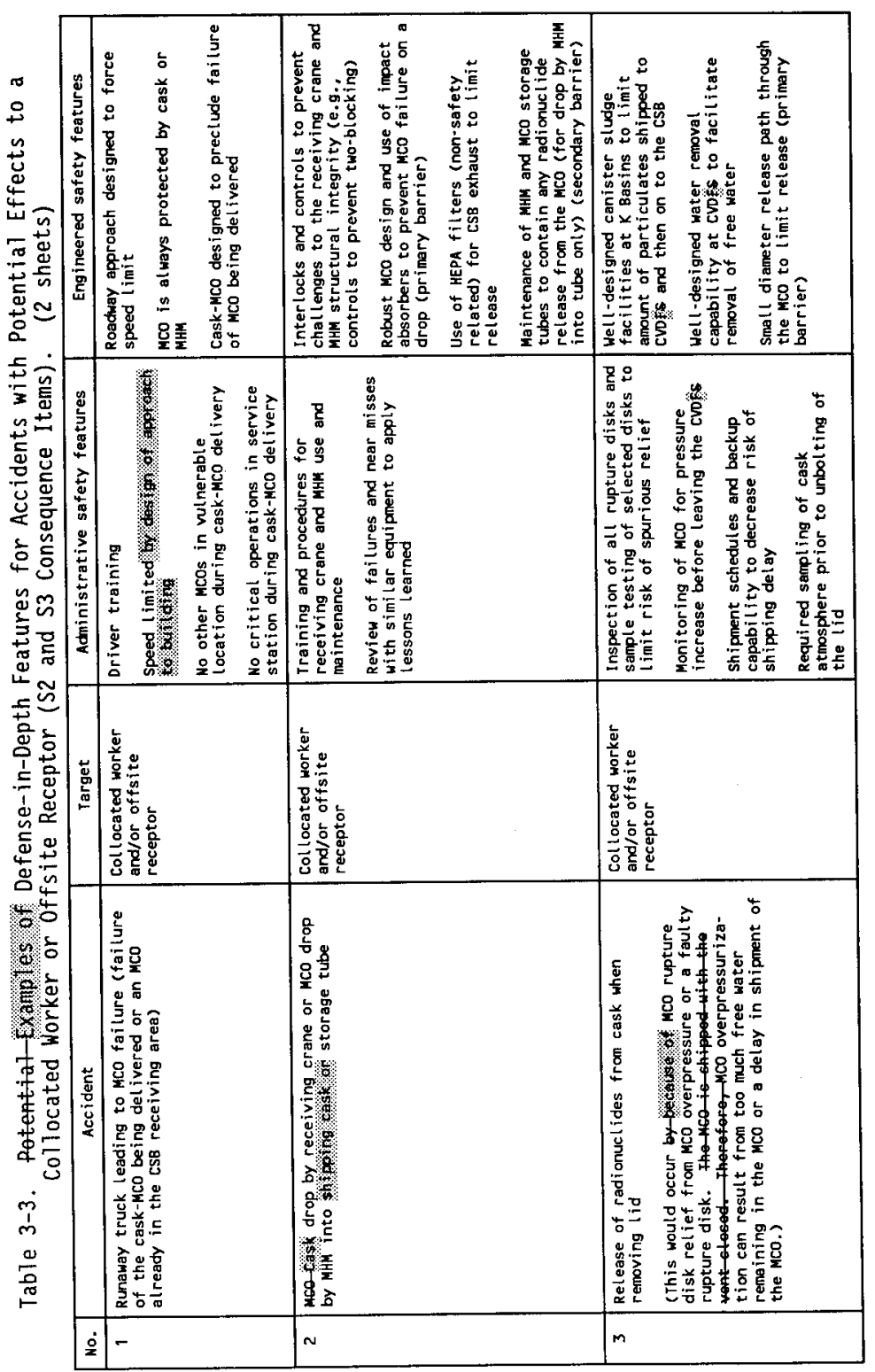




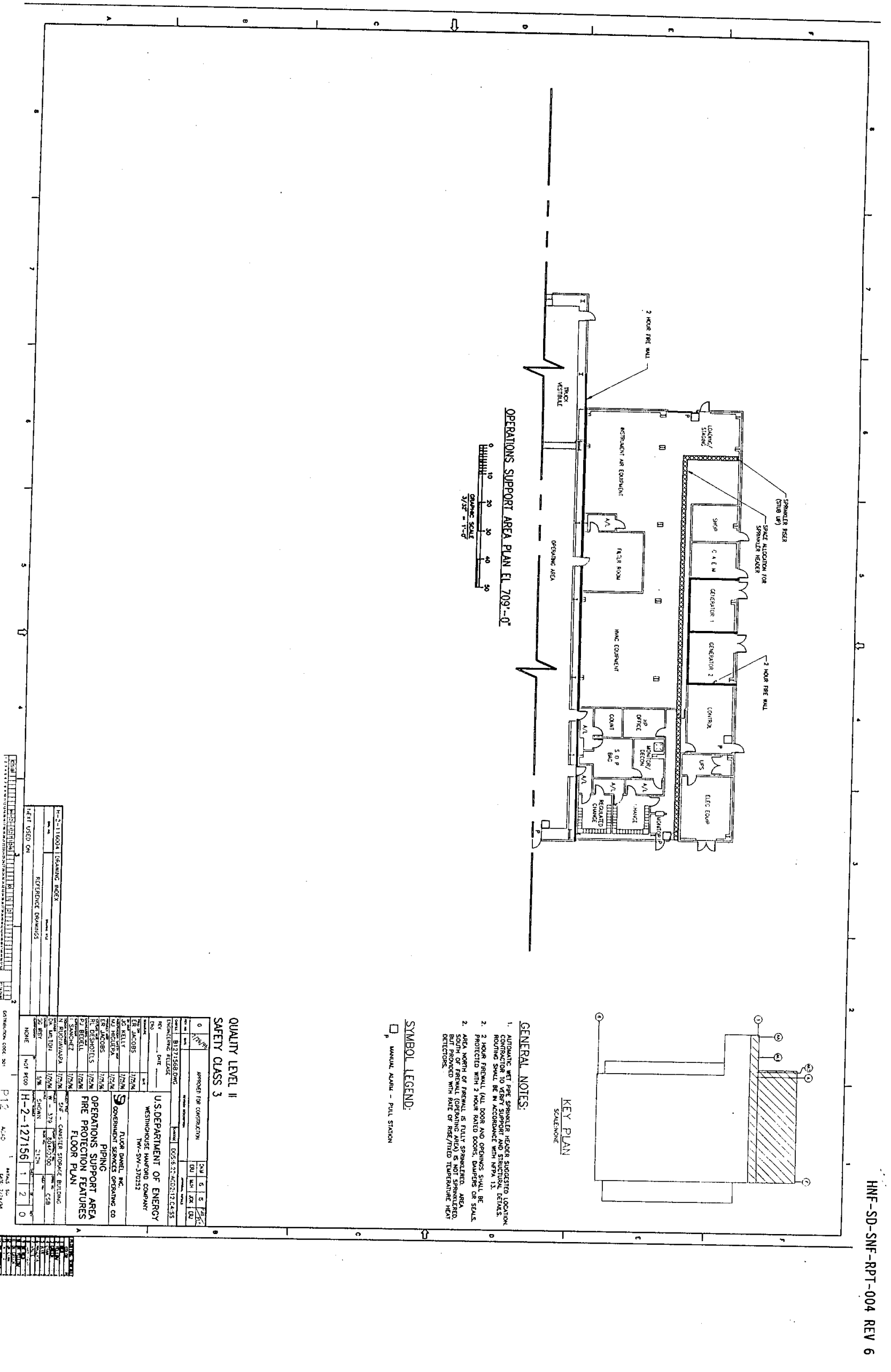




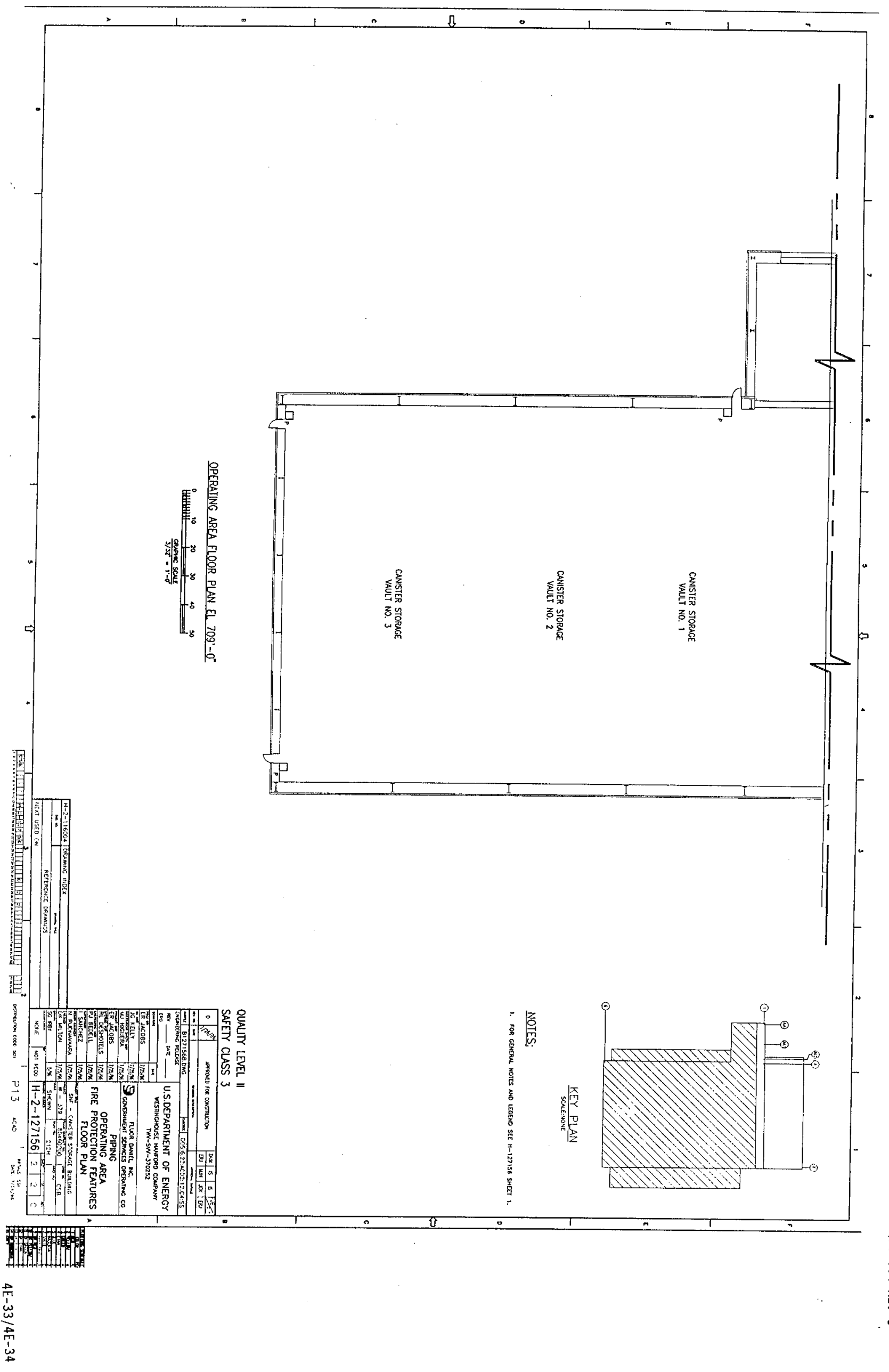

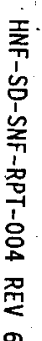




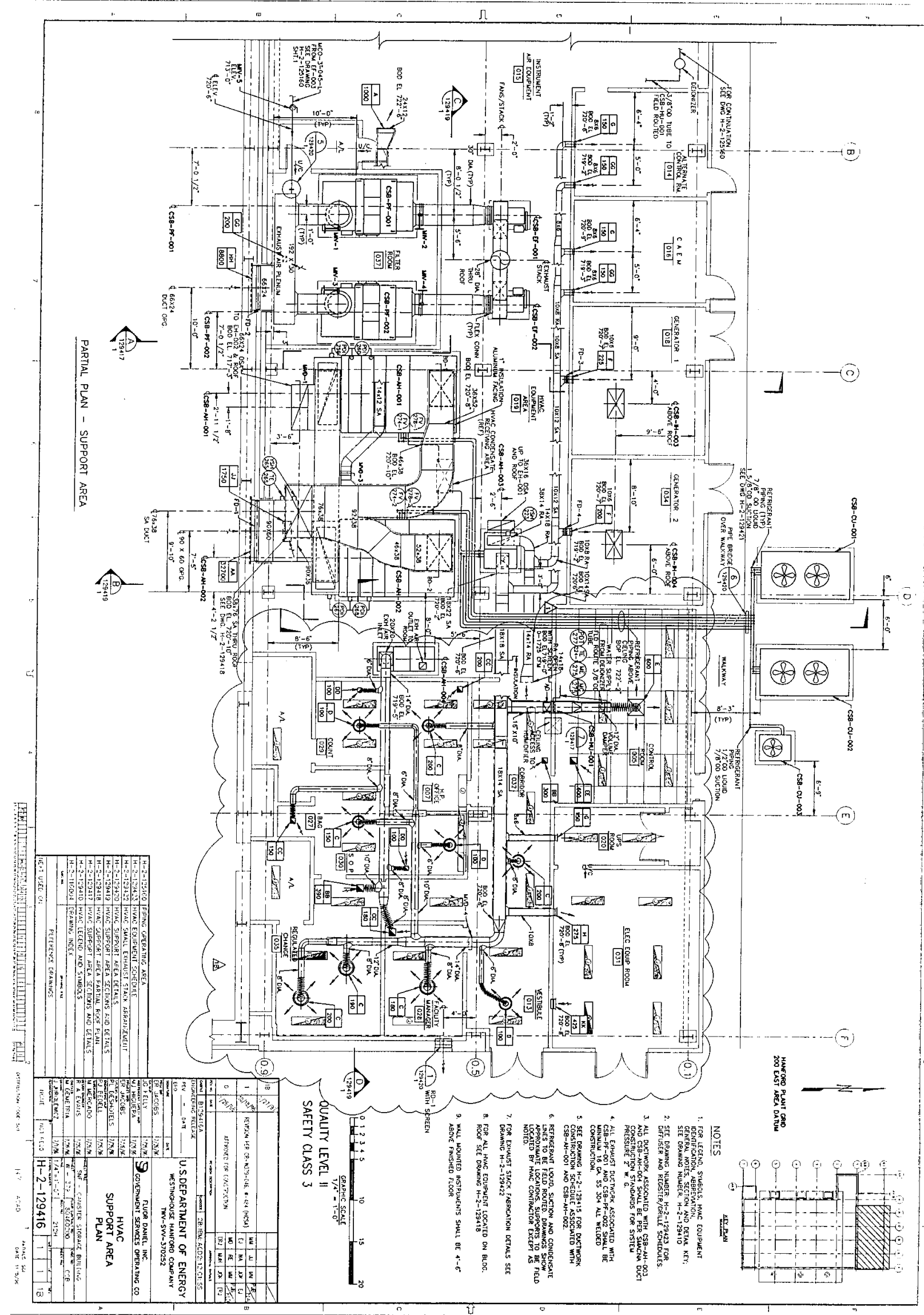

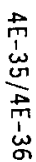


HNF-SD-SNF-RPT-004 REV 6

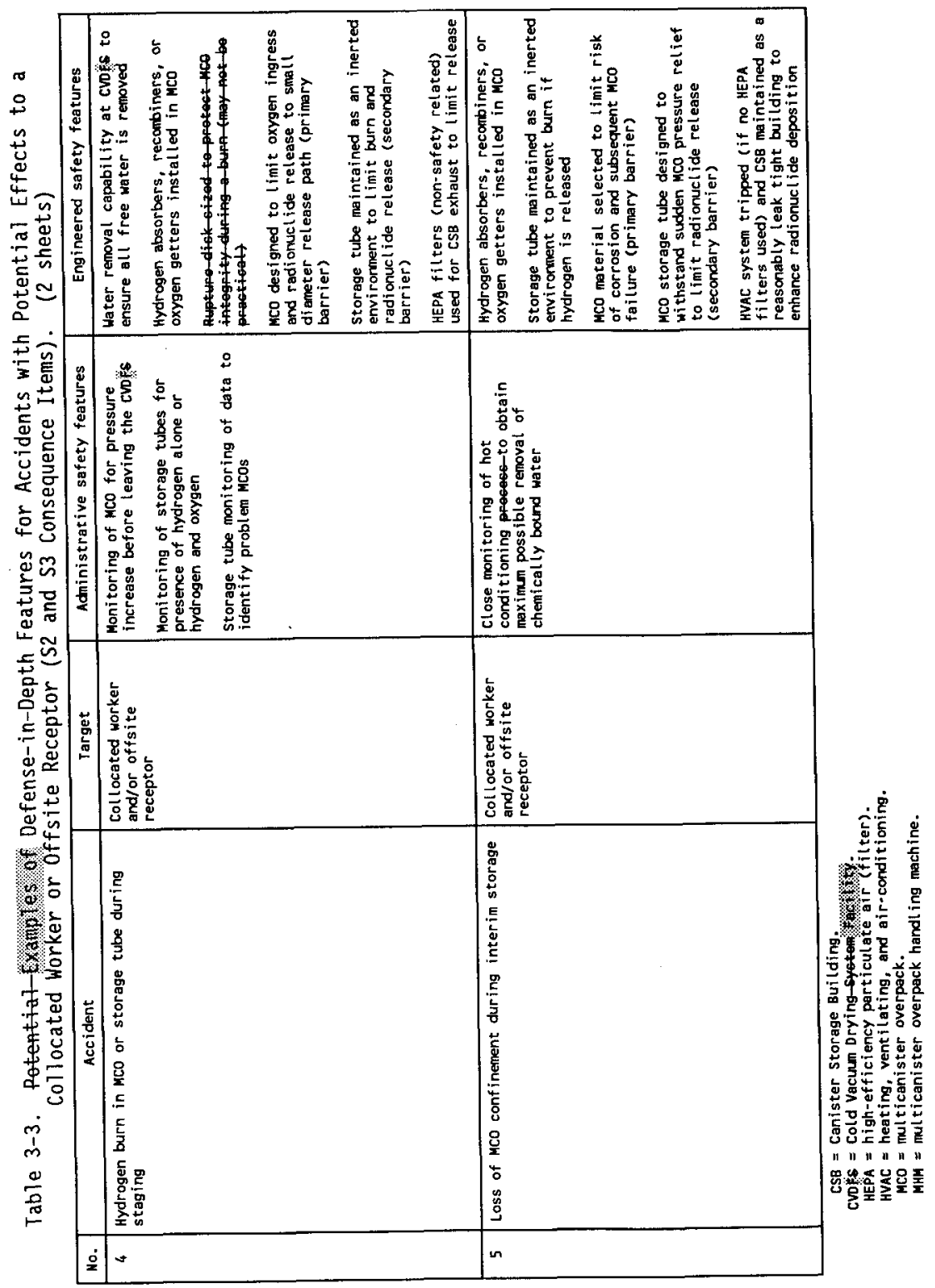


- Those required for nuclear criticality safety

- Those required to monitor the release of radioactive materials to the environment during and after a DBA

- Those required to achieve and maintain the facility in a safe shutdown condition

- Those that control the safety class items described above.

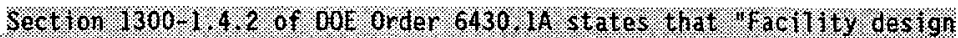

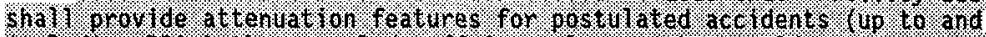

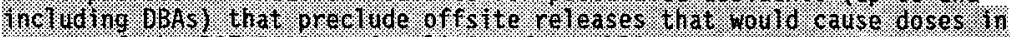

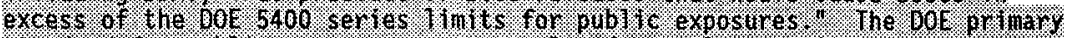
standard for publite exposures as a result of rormal operat ions is gilen in

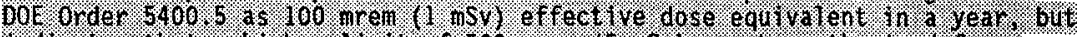

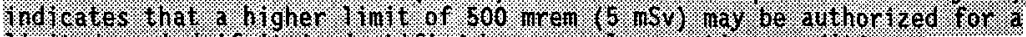

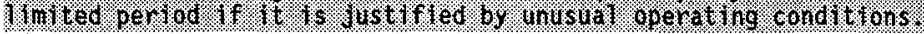

For the purpose of asstgring safety- Ch ass attenual tor features for the

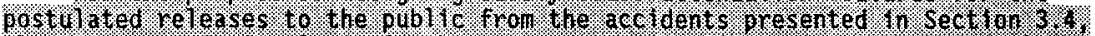

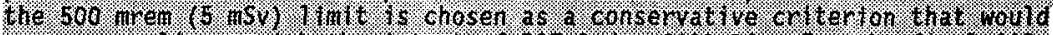

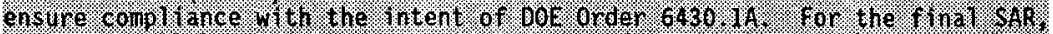

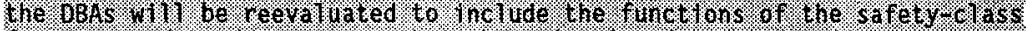
features and to denonstrate that the er.terta of bet Order 6430 . 14 are net: For the CSB, the naximuip dose pubthe recepter was follad to be at the reak

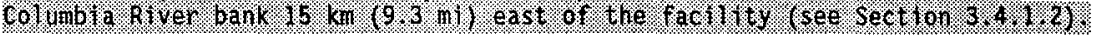

Section $1300-1.4$ of $D 0 E$ Order 6430.1A and the other orders referenced in this section do not contain quant itative guidelines for the identification of safety class SSCS. These guidelines are provided in, WHC CM-4 46, Safety Analysis Mantral, Section 7.0, "Risk," Revision 4, and-are sumatin Fable-3-4.

Because of uneertainties at this stage of the CSB design-and operation, all-dose assesments are performed to the "anticipated" eniteria provided in Table 3-4. For the final SAR, the complete risk acceptance guidelines will be appliet.

\section{Fab7e-3-4. Radiological Risk Guidelines:}

\begin{tabular}{|c|c|c|c|}
\hline \multirow{2}{*}{$\begin{array}{l}\text { Event frequency } \\
\text { category }\end{array}$} & \multirow{2}{*}{$\begin{array}{c}\text { Event frequency } \\
\left(y x^{-1}-\right)\end{array}$} & \multicolumn{2}{|c|}{$\begin{array}{c}\text { Effective dose equivalent } \\
\text { (AnSh) }\end{array}$} \\
\hline & & Onsite & $\theta$ ffsite \\
\hline Anticipated & $>10^{-2}-$ to $-10^{0}$ & -50 & -5 \\
\hline Hntikely & $710^{-4}-t 0 \leq 10^{-2}$ & -250 & -50 \\
\hline Extremely unlikely & $710^{-6}-10 \leq 10^{-4}$ & 1,000 & $50 *$ \\
\hline
\end{tabular}

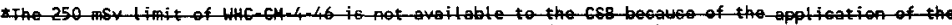

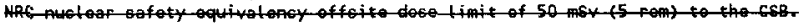


In addition to the general criteria listed above for the identification of safety-class items, DOE Order 6430.1 A contains the following specific requirement in Section 1320, "Irradiated Fissile Material Storage Facilities":

\begin{abstract}
Special design features shail be considered to ensure safe loading, removal, and handling of IFM [irradiated fissile material]. These systems and equipment shali be designed as safety-class items and shall protect against the dropping of shipping casks, IFM assemblies, and other items on the stored IFM.
\end{abstract}

The requirement has been interpreted to require safety-class items for the movement of SNF assemblies and equipment over SNF in unprotected storage. This does not occur in the CSB where the fuel, that being moved and that in staging or interim storage, is always contained in an MCO.

DOE-STD-3009-94, Section 3.4.2.X.4, "Comparison to Guidelines, " requires that receptor dose/exposure for the accident sequence be compared to the evaluation guidelines; however, quantitative guidelines are not provided. DOE-STD-3009-94 defines safety-significant SSCs as

Structures, systems, and components not designated as safety-class SSCs but whose preventive or mitigative function is a major contributor to defense in depth (i.e., prevention of uncontrolled material releases) and/or worker safety as determined from hazard analysis.

As a general rule of thumb, safety-significant SSC designations based on worker safety are limited to those systems, structures, or components whose failure is estimated to result in an acute worker fatality or serious injuries to workers. Serious injuries, as used in this definition, refers to medical treatment for immediately life-threatening or permanently disabling injuries (e.g., loss of eye, loss of $1 \mathrm{imb}$ ) from other than standard industrial hazards. It specifically excludes potential latent efforts (e.g., potential carcinogenic effects of radiological exposure or uptake).

The general rule of thumb cited above is not an Evaluation Guideline. It is a lower threshold of concern for which safety-significant SSC designation may be warranted, not a quantitative criteria. Estimates of worker consequences for the purpose of safety-significant SSC designation are not intended to require detailed analytical modeling. Considerations should be based on engineering judgement of possible effects and the potential added value of safetysignificant SSC designation.

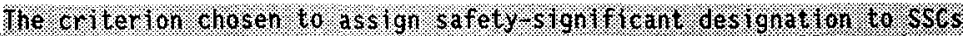

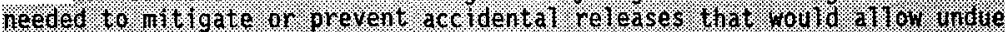

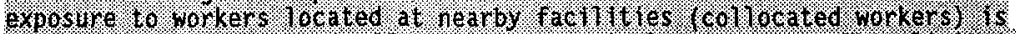

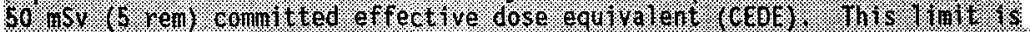

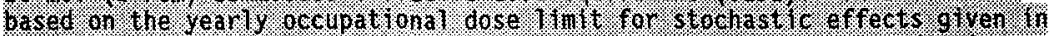

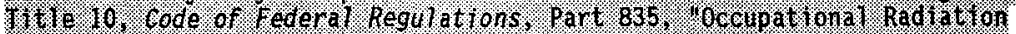




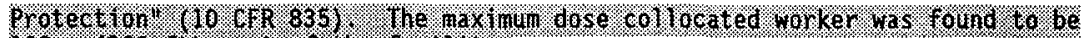

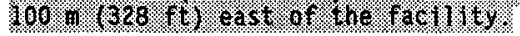

NRC nuclear safety equivalency requirements for ISFSIs define SSCS important to safety in broad terms (Garvin 1996). For ISFSI application, NRC requirements are established in 10 CFR 72.3, which defines SSCs important to safety as those that perform one or more of the following functions:

1. Maintain the conditions required to store spent fuel or high-level radioactive waste safely

2. Prevent damage to the spent fuel or the high-level radioactive waste container during handling and storage

3. Provide reasonable assurance that spent fuel or high-level radioactive waste can be received, handled, packaged, stored, and retrieved without undue risk to the health and safety of the public.

Relative to this aspect of NRC nuclear safety equivalency, the following SNF Project position has been established (Garvin 1996).

For the CSB only, - . identify structures, systems and components (SSCS) 'important to safety' in accordance with Section 72.3, as implemented through Section 72.106. Once SSCs 'important to safety' have been identified, impose the requirements for safety class 1 SSCS. . as defined in WHC CH 4-46, Safety Analysis Hat, Setton 9.0, Revision 1, Safety-Elassification-of Structures, Systems This includes the loaded MCO once it is received at the CSB.

SSCs required to support or safeguard the safety-class function of a safety-class SSC are also safety class. Therefore, the storage tubes, operating deck, vault structure, and intake and exhaust stacks for vault cooling are all safety class.

Thus, identification of SSCs important to safety for the three functions contained in 10 CFR 72.3 is by application of the $50 \mathrm{mSv}$ ( $5 \mathrm{rem}$ ) dose $1 \mathrm{imit}$ provided in 10 CFR 72.106. For example, if failure of a piece of equipment required to receive, handle, package, store, or retrieve SNF will result in a dose that exceeds $50 \mathrm{mSv}(5 \mathrm{rem})$ at the controlled area boundary, then that

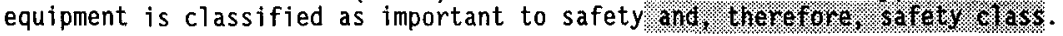

The requirements for safety class 1 SSCs in the quote from WHC-SD-SNF-DB-003 (Garvin 1996) refer to such items as industry consensus standards and codes, redundancy, reliability, and environmental qualification.

Technical Safety Requirements. The determination of TSRs will be accomplished in accordance with the requirement of DOE Order 5480.22, Technical Safety Requirements.

3.3.2.3.3 Worker Safety. Worker safety for the CSB is assured by a combination of confinement and shielding features and institutional practices. The main radiological hazard of the CSB is the fuel particulate material contained in the MCOS. For MCO receiving and purging operations, an enclosure 
is placed over and around the cask-MCO to protect the workers from exposure during normal and off-normal conditions. While the MCOs are in staging or interim storage, the storage tube and plug serve to provide this protection. The MHM and the MHM-deck fioor seal provide protection during MCO handling operations. Chapter 7.0 of the SAR will provide more detail on radiation protection for the worker, as required-by-DOE-STB $3009-94$.

Table 3-45 provides otential examples. of defense-in-depth items that-may provide protection for normal and off-normal operation and accident conditions that affect only facility workers. This table is provided as an example of how this issue will be addressed in this chapter of the final SAR the items listed may not be available or cost effective for the CSB as it is to be operated. The consequence column of the table is used to highlight features that may be provided to prevent or mitigate a significant worker exposure to hazardous materials with the potential to cause a serious injury.

The hazards listed in Table 3-45 are based on the completed PHA form in Appendix 3A. The PHA study specifically ranked various hazards according to

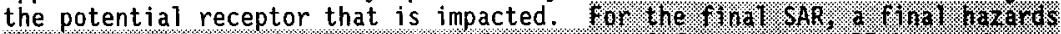

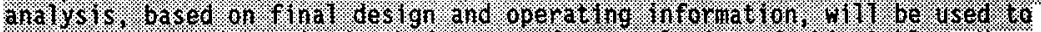

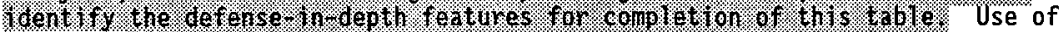
the PHA study $102010 \mathrm{~s}$. Nollos/s to ident ify worker safety concerns and potential accidents satisfies the process safety management guidelines in Title 29, Code of Federal Regulations, Part 1910; "Occupational Safety and Health Standards" (29 CFR 1910), Section 1910.119, "Process Safety Management of Highly Hazardous Chemicals, "relative to evaluating hazards of a Process safety management is an integrated approach to hazard identification and risk management. This method of assessing facility worker hazards is also consistent with the guidance provided in DOE-STD-3009-94.

Table 3-45 identifies the CSB worker hazards according to various operations and proposed engineered and administrative barriers that could be in place to control possible exposure to the identified hazards. This identification follows the safety management process and the guidance of DOE-STD-3009-94. Engineered barriers are design features (e.g., cover blocks, ventilation system) that prevent or mitigate the exposure of the facility worker to hazards. Administrative barriers are procedures and programs designed to prevent and mitigate exposure of the facility worker to hazards. It should be noted that safety-class or safety. sagrafleant SSCs designed to protect the collocated worker and public will also provide protection for the facility worker. - Fop the actidents addressed in Section 3.4.2, no credit is taken for operator action fop accident mitigation and, as stch, no operatop tose assessment is made.

3.3.2.3.4 Environmental Protection. The external hazards associated with CSB operation all involve the potential release of radionuclides. The release pathway for these radionuclides is only via the air to the boundaries and receptors discussed in Section 1.3.1.3. None of the accidents identified by the PHA involve radiological releases to the ground or groundwater. The MCO will be drained and the fuel dried at the CVDFs to remove water before shipping to the CSB. Therefore, the potential for liquid releases to the ground during receiving, handling, staging, or interim storage does not exist. 
HNF-SD-SNF-RPT-004 REV 6

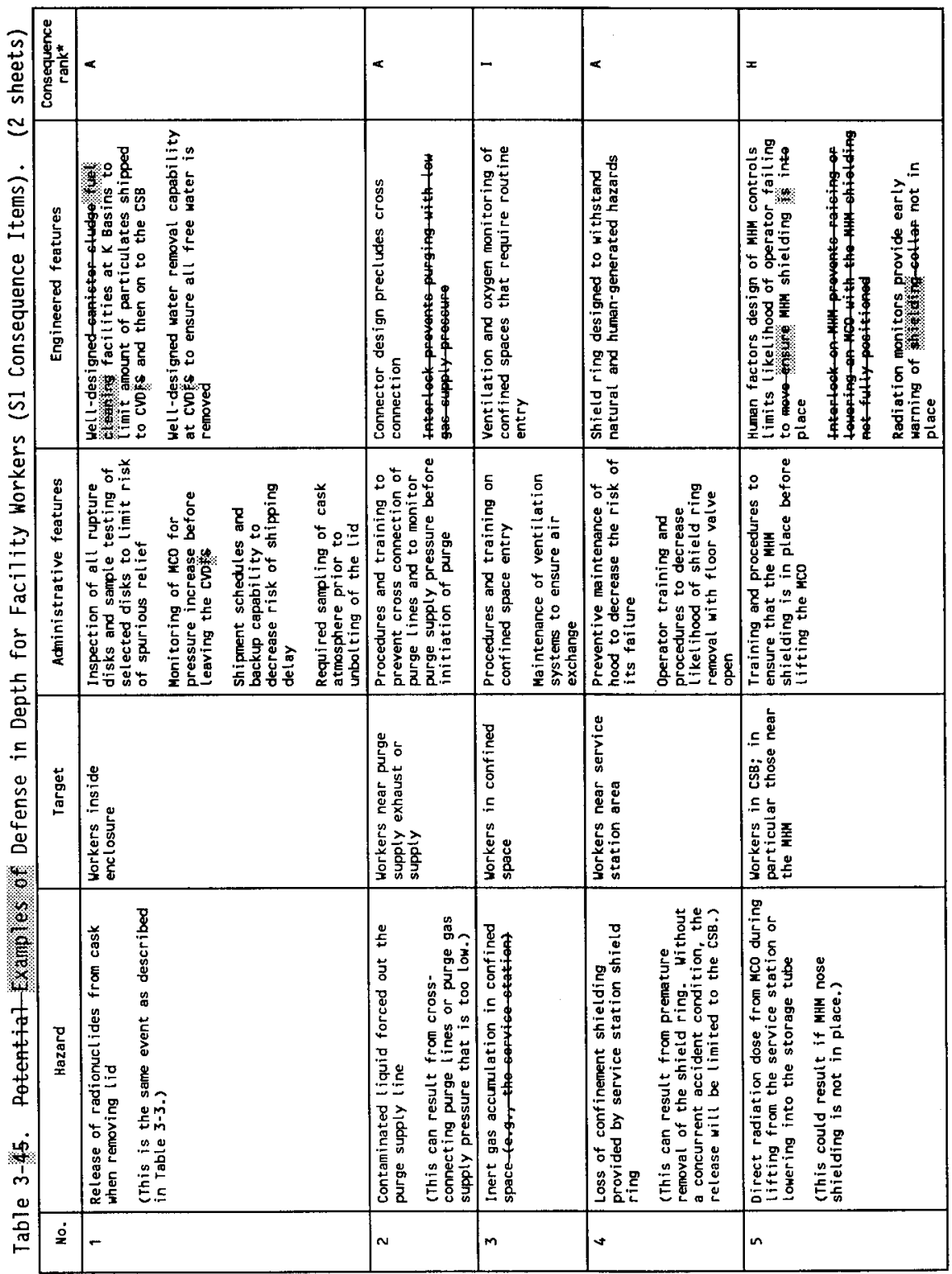


HNF-SD-SNF-RPT-004 REV 6

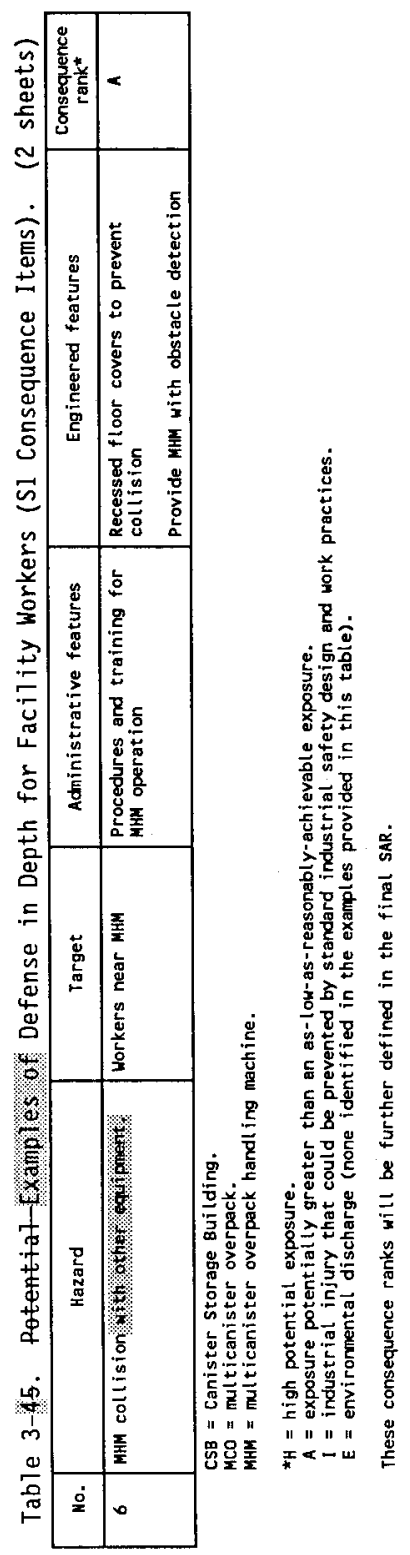


Based on the CSB design and operating information currentiy available, no use of toxic chemicals has been identified. The risk of toxic chemical exposure will need to be considered as more detailed information on each phase of the process is developed. This is listed in Table $3-2$ as an item to be tracked.

Potential consequences, including offsite releases, and required prevention and mitigation features are discussed in Section 3.4.2. Implementation of the prevention and mitigation features will prevent large releases that could have significant environmental impact.

The project features that protect the collocated worker and public against radiological exposure also serve to prevent and mitigate radiological release to the environment. In addition, there are Fluop Daniel Hanford,

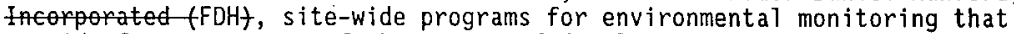
provide for assessment of the impact of facility releases. Normal CSB operational activities are expected to have a minor impact on the local and regional environment. Expected environmental impacts include the following:

- Increased noise levels from trucks in the 200 East Area during the cask-MCO receiving phase

- Increased levels of vehicle exhaust to the atmosphere, which will be very limited during the interim storage phase

- Air emissions of water vapor, hydrogen, and smajl amounts of

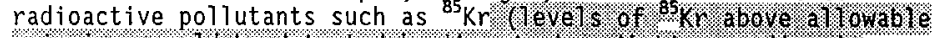
ents stons woutd be detedted by the stact rad d at won nontrors)

The CSB will be designed and operated to maintain CSB facility worker, collocated worker, and offsite public exposures to all known hazards to levels as low as reasonably achievable and well below regulated levels.

3.3.2.3.5 Accident Selection. Accident analysis criteria require that a set of accidents be quantitatively analyzed. The results of this analysis demonstrate compliance with the risk acceptance criteria identified in fection-3.3.2.3.2 and justify the choice of safety-class and safetysignificant SSCS. The accident selection methodology is described in Section 3.3.1.2.

This section documents the results of the accident selection activity. The initial screening criterion used was that all 52 and 53 accidents be chosen as candidate accidents. The selection of the S2 and S3 events was made independently of the frequency assignment, that is, independently of the " $F$ " ranking. From this list, the accidents were grouped by phenomenon based on the potentia? quantity of radioactive material available for release to the facility from the event (the numbers preceding each entry refer to corresponding entries in Appendix $3 A$, Table $3 A-1)$.

- Releases of MCO gases under pressure during handling, staging, or interim storage

A pressurized release could potentially whll involve the MCO atmosphere and the inventory of particulate material in the $M C 0$. 
PHA 60.b.23 MCO pressurized release during shipping cask-sampling pressure testing in the service station

PHA 60.b.34 Pressurized release during unbolting of shipping cask Tid

PHA 60.b.45 Pressurized release from MCO resulting from damage caused by dropped shipping cask lid; op shielding

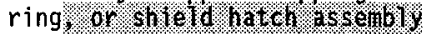

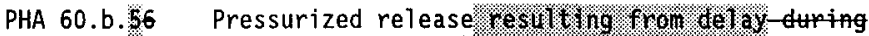
thbolting of $\mathrm{MCO}$ flanges

PHA 60.b.\%8 Pressurized release caused by MCO overpressurization by inert gas during purging

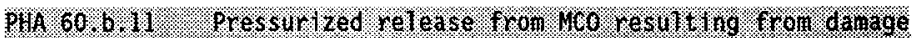

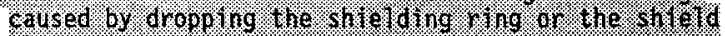
1409

PHA 60.C.10 Release of unfiltered MCO contents through pressure relief device or due to MCO failure during MCO handling

PHA 60.d.1 Release of unfiltered MCO contents through pressure relief device during $M C O$ staging

PHA 60.e.1 Release of unfiltered MCO contents through pressure relief device or due to MCO failure during MCO interim storage

- Single-MCO Ganage-Failupe during Handling

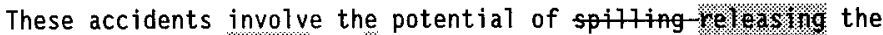
contents of one or 1 wo MCOS into the building.

PHA 60.a.1 Damage to MCO in service station caused by runaway transport vehicle

PHA 60.a.2 Shipping cask-MCO tipover or drop from transport trailer

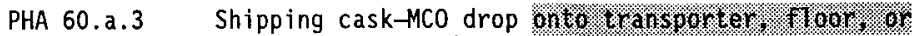
into service station

PHA 60.c.2 MCO drop to 1 to shipping cask-without impact absorber

PHA 60.C.4 Shearing of an MCO during handling

PHA 60.c.5 MCO drop onto operating area floor or storage tube plug

PHA 60.c.6 MCO drop into empty storage tube 


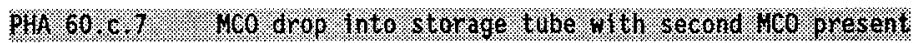

PHA 60.c.8 Tube plug drop into storage tube with MCO in place

- Multiple MCO Fatiures during Handling

This recident involves the potential-to spill the contents of two

MCOS inte the building.

PHA 60.C.7 MCO drop into storage tube with second MCO present

- Hydrogen Gas Combustion

Chemical and radiolytic hydrogen production, and subsequent mixing with oxygen-containing atmospheres, could lead to combustion events that would release MCO gases and particulates and potentially entrain greater amounts of particulates than would be the case with a simple depressurization.

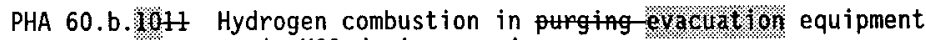
or in MCO during purging

PHA 60.c.9 Hydrogen combustion in MHM caused by hydrogen release from $\mathrm{MCO}$

PHA 60.d.2 Hydrogen combustion in MCO during staging

PHA 60.d.3 Hydrogen combustion in storage tube during staging

PHA 60.e.2 Hydrogen combustion in MCO during interim storage

PHA 60.e.3 Hydrogen combustion in storage tube during interim storage

- Multiple MCO-tube Failures during For Interim Storage

This accident involves the potential for release of atmosphere and entrained particles from multiple MCOs.

PHA 60.e.1 Loss of MCO integrity during interim storage caused by loss of convective cooling

- Beyond Design Basis Events

Beyond design basis events are to be included in a future revision to this chapter.

PHA 60.e.1 MCO structural failure

PHA 60.d.1 MCO structural failure or rupture disk relief

PHA 60.f Structural failure of the CSB or SSCS within the CSB. 
An accident scenario from each of the accident groups identified by the PHA was selected for analysis. This was done by choosing the scenario judged to bound the potential releases from the group to represent the group. In most cases, this selection was based on an assessment of the energy driving the release. For instance, for MCO overpressure accidents, pressure high enough to rupture the rupture disk would provide greater releases, both in quantity of particulate released and the fraction of the particulate that is respirable, than would releases occurring at lower pressures.

Following the analysis of the representative and bounding scenarios, safety-class design features to mitigate or prevent the release were identified. Then the list was reexamined to judge whether any of the remaining scenarios could challenge a different barrier or require different SSCS to mitigate or prevent the release. For the preliminary accident analyses presented. II. Whese phased. SARs, no additional consequence analysis \%or the. remining scenstios was performed. Rather, it was assumed that the

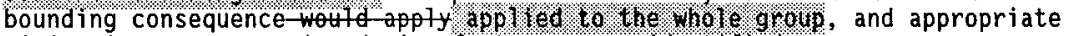
mitigative or preventive design features were identified.

\subsection{ACCIDENT ANALYSIS}

This section presents the format the hodorogy used to develop the potential accidents identified in Section 3.3 .

\subsubsection{Methodology}

3.4.1.1 Source Term. The bounding source term used for the accident analysis was based on data for the fuel in the $K$ East and $K$ West Basins given in WHC-SD-SNF-TI-009, 105-K Basin Material Design Basis Feed Description for Spent Nuclear Fuel Project Facilities (Willis 1995). That document defines an inventory for safety analysis considering inventories of MKIV, Mark IA (MKIA), and single-pass reactor (SPR) fuel in $K$ Basins. High-burnup MKIV fue 1 , the fuel type that results in the highest estimated dose to people exposed to the material, was selected as the bounding inventory from the radiological dose perspective. Nuclear accountability records gave the basis for the quantity, exposure variation, and decay time variation of the stored fuel. The radionuclide inventory was estimated from these data. Spent fuel and sludge

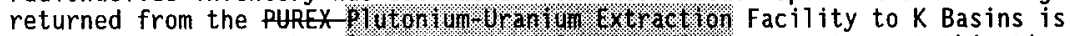
not included in the baseline for assessing bounding source term at this time.

The assumed radioactive inventory of the $M C O$ is the inventory associated with 270 high-burnup MKIV fuel assemblies. The MCO will contain finely divided particulate material associated with the fuel. This includes particulates left on fuel surfaces and in crevices after fuel washing and racking into the MCO, with expected increases in oxidation products following cold vacuum drying, staging, and hot conditioning.

The particulate inventory of the MCO dominates the airborne release. It is expected to be similar in makeup, and radionuclide content, to the sludge found in the canisters in the $K$ Basins. Because the canister sludge has not yet been characterized, the analyses assume that the available particulate material contains the same radionuclide content as the fuel. 
The total amount of fuel oxide in an $M C O$ is greater than the total amount of particulate available for release since some fraction of the oxide adheres to the metal surface. The fuel will go through cleaning intended to remove loose particulates before it is loaded into the MCO. However, some oxide may remain beneath cladding, on some fuel surfaces, and within fuel assembly flow channels. Subsequent to loading the SNF into the MCO, the quantity of particulate matter is expected to increase, because of additional fuel oxidation by residual water in the $M C O$, until all of the residual water in the $\mathrm{MCO}$ is consumed. This oxidation will continue, possibly into the

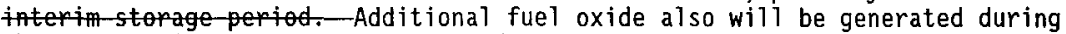
the-passivation process-(Pajunen and Cowan 1996).

A bounding value for the mass of particulate in the MCO after hot

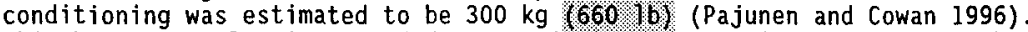
This bounding value is intended to provide a conservative estimate of the MCO's maximum particulate inventory in support of desion safety analyses.

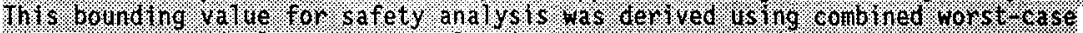

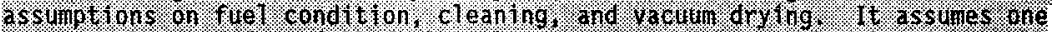

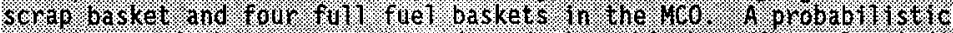

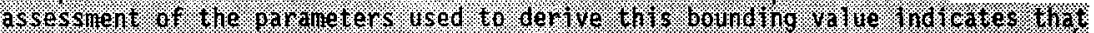

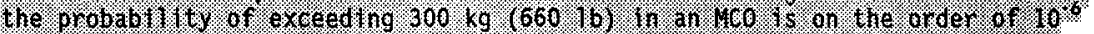
(Padunen ef al. 1996) for the purpose of the accident analyses presented in Section 3.4.2, the bounding value of $300 \mathrm{~kg}(660.1 \mathrm{~g})$ is used throughout, without regard to the postulated to occur. - Sufficient conservatism is ineluted in the bases that analyses using this estimate will define safety constraints that will not need to be supported by a direct measure of the particulate inventory in each MCO during system operation.

Efforts have been made to minimize any operating-constraints associated with arguing the conservatism of the bound. fo be consistent with the bounding particulate estimates, the analysis includes the following selected assumptions and constraints for operations.

- The analysis is limited to a consideration of $N$ Retor-fuel: SPR fuel will need to be evaluated as a special case.

. The inventory of elements and scrap baskets-must be controlled consistent-with the assumptions-

- Cleaning by a qualified system must be performed on all fuel.

- Fuel and seap basket queuing is limited to-30-days before recleaning will berequired.

- Cold vacum drying should be produrally controlled to limit-oxide generation.

-A transport time constraint-must be observed.

- The water inventory of MCOs-entering staging is assumed to colfolely with fuel, generating particulate (the MCO watep inventory entering staging at the CSB is based on achieving 
particulate water content of less than 10 wto at the conclusion-of eold ractum drying).

- The hot conditioning process must be procedurally-controlled to pestrict oxidation.

$\rightarrow$ No additional particulate generation-is-assumed to occur during interim storage, which is consistent with seated storage.

The SNF is primarily uranium metal, which is known to have toxicological effects. Plutonium and other heavy metals are present in smaller quantities. It is not expected that the toxicological consequences of the release of these substances would require mitigating features beyond those required by the radiological doses.

No routine chemical processes will be conducted within the CSB. Purging and backfilling the MCOs will involve the use of an inert gas. Some chemicals, such as those used for equipment decontamination, may be used occasionally (wtlc 1995). However, there are no chemical inventories of concern for safety analysis considerations.

3.4.1.2 Consequence Analysis. Radiological inhalation dose consequences for each accident analyzed are based on

- Mass of material available for release

- Airborne release fraction (ARF) and respirable fraction (RF)

- Dose conversion factors

- Atmospheric dispersion of airborne particles

- Duration of exposure

- Breathing rates.

The radiological dose to a maximum receptor of interest is typically determined by using the following equation:

$$
D=M \times \frac{X}{Q} \times R \times C
$$

where

$$
D=\text { Dose }(S v)
$$

$\begin{aligned} M & =\text { Mass of Sespl Mable material released }(\mathrm{g}) \\ X / Q & =\text { Time-integrated atmospheric dispersion coefficient }\left(\mathrm{s} / \mathrm{m}^{3}\right)\end{aligned}$

$\mathrm{R}=$ Breathing rate $\left(\mathrm{m}^{3} / \mathrm{s}\right)$

$C=$ Dose per unit respirable radioactive material inhaled (Sv/g).

The quantity of respirabie material released (M) is determined by the specific accident scenario.

The atmospheric dispersion coefficient $(X / Q)$ is based on specific release conditions (e.g., ground level or elevated, long or short duration) and the receptor's distance from the release. The atmospheric dispersion coefficient is the time-integrated normalized air concentration at the receptor's 
location. The coefficient represents the dilution of an airborne contaminant caused by atmospheric mixing and turbulence. AII X/Q values for these analyses have been generated using the GXQ computer program (Hey 1993a and Hey 1993b).

Table 3-56 contains the $X / Q$ values used to determine onsite and offsite consequences. Section 1.4.1.1.8 provides additional information on the calculation of the $X / Q$ values. The basis for defining the location of the onsite and offsite receptors is provided in Section 1.3.1.3.

Table 3-56. Atmospheric Dispersion Coefficients Used in Accident Analyses for the Canister Storage Building.

\begin{tabular}{|c|c|c|c|}
\hline \multirow{2}{*}{$\begin{array}{l}\text { Receptor location } \\
\text { description }\end{array}$} & \multicolumn{3}{|c|}{$\begin{array}{c}\mathrm{X} / \mathrm{Q} \\
\text { point source }\left(\mathrm{s} / \mathrm{m}^{3}\right)\end{array}$} \\
\hline & $\begin{array}{l}\text { Without plume } \\
\text { meander, } \\
\text { without stack }\end{array}$ & $\begin{array}{l}\text { With plume } \\
\text { meander, } \\
\text { without stack }\end{array}$ & $\begin{array}{c}\text { Stack release } \\
\text { (one fan at } \\
5.66 \mathrm{~m}^{3} / \mathrm{s} \text { ) }\end{array}$ \\
\hline $\begin{array}{l}\text { Onsite } \\
(100 \mathrm{~m} \mathrm{E})\end{array}$ & $3.41 \mathrm{E}-02$ & $1.13 \mathrm{E}-02$ & $\begin{array}{l}4.18 \mathrm{E}-0.5 \\
(230 \mathrm{~m} \mathrm{~W})\end{array}$ \\
\hline $\begin{array}{c}\text { Hanford Site boundary } \\
(18.3 \mathrm{~km} \mathrm{E})\end{array}$ & $1.32 \mathrm{E}-05$ & $1.11 \mathrm{E}-05$ & 7.14 E-06 \\
\hline Near riverbank $(15.0 \mathrm{~km} \mathrm{E})$ & $1.96 \mathrm{E}-05$ & $1.55 \mathrm{E}-05$ & $8.31 \mathrm{E}-06$ \\
\hline
\end{tabular}

Values of $X / Q$ were calculated for various distances from the release in the full range of compass directions. For these analyses, the worst-case meteorology (windspeed and direction) for the Hanford Site was used to determine the location at the Site boundary where the maximum doses would occur. The same approach was used to determine the direction of the maximum doses at $100 \mathrm{~m}$ (328 ft) for the collocated worker (onsite receptor).

For calculation of offsite releases, values of $X / Q$ were calculated for a receptor in the highest dose direction at the Hanford Site boundary and for a maximum dose receptor at the Columbia River to the east and at Highway 240 to the west. The maximum offsite receptor for the Site boundary was found to be at a location $18.3 \mathrm{~km}(11.3 \mathrm{mi})$ east of the CSB. The maximum offsite receptor at the near river boundary $15 \mathrm{~km}(9.3 \mathrm{mi})$ east of the facility was found to be more limiting than one at Highway 240 . This is the case even though Highway 240 is closer to the facility. The maximum onsite (100 m [328 ft]) receptor was east of the facility for the ground-level release.

Table 3-36 also reports $X / Q$ values for an elevated release with operating deck ventilation airflow to enhance the elevation of the release point. The accidents analyzed in this document do not credit mitigation of the release through this building ventilation. The values are preserved here for potential use in analyzing mitigating features of the design. 
Correction to the $X / Q$ may be taken for building wake effects if the accident does not change the building configuration. To provide conservatism in the analysis, none of the accidents analyzed in this document use building wake effect corrections. Correction for plume meander is credited for ground releases assumed to occur during neutral or stable atmospheric conditions with windspeeds less than $6 \mathrm{~m} / \mathrm{s}(19.7 \mathrm{ft} / \mathrm{s})$ and with release times greater than 1 hour.

The breathing rate (R) depends on activity factors and exposure duration. All accidents analyzed assume 8-hour exposure (the duration of a typical working shift) to the onsite receptor and 24-hour exposure to the offsite receptor. It is assumed that within one day's time, emergency measures will have caused evacuation of offsite areas affected by the accident. Therefore, the breathing rate used is the acute, light activity rate given in Reference Man: Anatomical, Physiological, and Metabolic Characteristics (ICRP 1975). Its value is $3.3 \times 10^{-4} \mathrm{~m}^{3} / \mathrm{s}$.

The dose per unit material inhaled (C) is the value for the total comitted-effective dose equivalent-CEDEF. The relative contribution of each nuclide to the total composite dose was calculated using the GENII computer code (Napier et a7. 1988). The CEDE for a 50-year dose commitment period was calculated using the code's worst-case solubilities library (Huang 1996). This is the most conservative dose conversion factor library used by GENII.

The major radiation exposure pathway for the identified accidents is inhalation of radioactive material. Dose contributions from the submersion and groundshine pathways were calculated and found to be negligible with respect to the total dose 100 ang $1996 \%$ for the radionucldes of interest (Hey 1995). Doses from groundshithe are also-expected to be negligible becuse most of the radionuclides of interest are alpha emitters. Therefore, the dose from groundshine and submersion are not included in the radiological dose calculations.

Potential-doses from the ingestion pathwa are not considered-because DOE, state, and federal emergency preparedness plans 1 imit ingestion of contaminated food in the event of an accident. DOE/RL-94-02, Hanford Emergency Response Plan (DOE-RL 1995), governs emergency response for all Hanford Site facilities. Specific emergency plans for the CSB will be covered

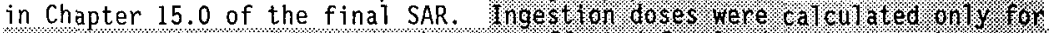

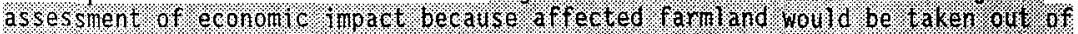

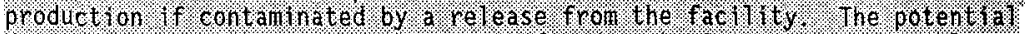
doses from the ingest on pathway were found 10 be 1 . 6 . thes the tor thl 7 hil 10 t ion $00 \mathrm{se}$. The primary determinant of exposure from the ingestion pathway, however, is the effectiveness of public health measures (i.e., interdiction) rather than the severity of the accident itself. Merefore.

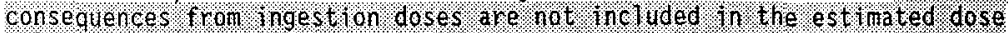

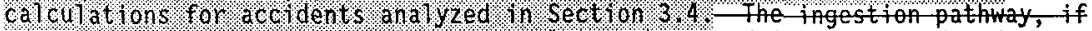
it oceurs, is a relatively slow to develop pathway and is not considered an immediate threat-to an-exposed population-in the same-sense as the inhalation pathway. 
Table 3-67 shows the results of the radiological analysis of the high burnup MKIV fuel and the corresponding CEDE per gram of respirable release.

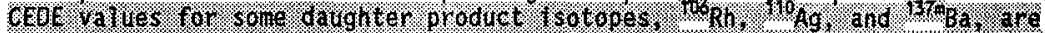

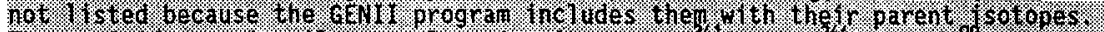

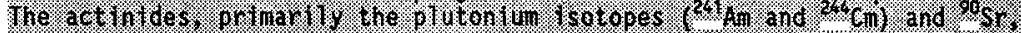

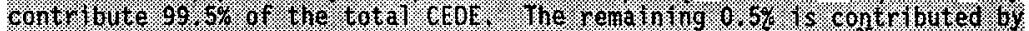

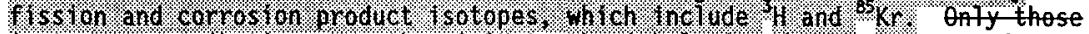
isotopes contributing mope than $0.1 \%$ to the inhatation dose are reported, except for the gases- $\mathrm{H}$ and- $85 \mathrm{Kr}$. Those two isotopes are included because their-1fie release pathways and release fractions of the gos seous 1 sol ofes can be significantly different from the isotopes onimaty of transported. whth the solids-matrix. Isotopes of plutonium, $241 \mathrm{Am}, 244 \mathrm{Am}$, and 90 Sp constitute $99.6 \%$ of the total inhatation dose. The relative contribution

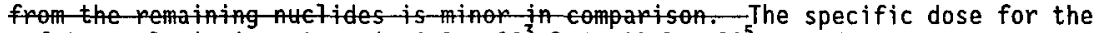
safety analysis inventory is $4.3 \times 10^{3} \mathrm{~Sv} / \mathrm{g}\left(4.3 \times 10^{5} \mathrm{rem} / \mathrm{g}\right)$.

\subsubsection{Frequency Estimates. Specific data for estimating accident}

frequencies are not avajlable at this stage of the design. Therefore, the accident consequences are evaluated solely against the deterministic guidelines discussed in Section 3.3.2.3.2 for the identification of safetyclass and safety-significant SSCS. This approach is more limiting than the risk-based approach that allows higher dose consequences for accident sequences judged to be of sufficiently low estimated frequency.

\subsubsection{Risk Guidelines. The radiological consequences of the accidents,} unmitigated by any safety features, were determined and compared to the criteria listed in Table 3-78. By the guidelines of DOE-STD-3009-94, analys is of unmitigated scenarios may take credit for reduction of releases by passive design features (e.g., buildings) that may be assumed to remain in place during and after the accident. In many of the accident scenarios presented in Section 3.4.2, no credit is taken for such passive features and therefore additional conservatism is incorporated in the results. For the final SAR analyses, holdup in the building and other passive structures will be considered where appropriate.

The criteria for identifying safety-class SSCs implement the guidance of DOE Order 6430.1A, Section 1300-1.4, "Guidance on Limiting Exposure of the Public," and are consistent with the graded approach to safety required by DOE Order 5480.23. They are more limiting than the 10 CFR 72.106 limit of $50 \mathrm{mSv}(5 \mathrm{rem})$ at the controlled area boundary (see Section 1.3.1.3).

3.4.1.5 Safety-Class Structures, Systems, and Components. For each accident scenario, the airborne radiological dose calculated using the methods described was compared to the appropriate acceptance guideline limit. If the radiological dose for the unmitigated case exceeded the guideline, mitigating safety features, with appropriate safety-class designation, were suggested. The dose consequences will be recalculated for the final SAR, taking appropriate credit for the mitigating safety features, 10 addit on 10 . Whe reduet on of releases by passive dest gn features, to verify that the mitigated doses satisfy the guidelines. 


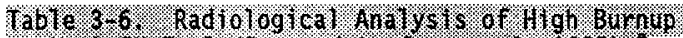

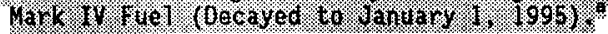

\begin{tabular}{|c|c|c|c|c|c|}
\hline Wor & $\mathrm{How}+\mathrm{H}$ & 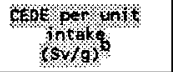 & Wo & \%oloty & $\begin{array}{c}\text { ofoe } \\
\text { Whotot }\end{array}$ \\
\hline \multicolumn{6}{|c|}{ 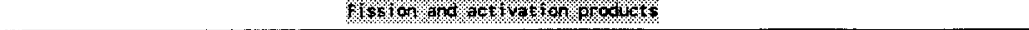 } \\
\hline 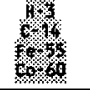 & 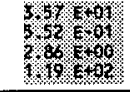 & 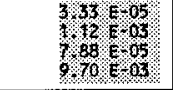 & 3614 & 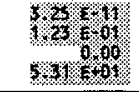 & 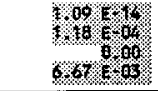 \\
\hline 16\% & 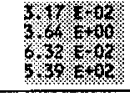 & $\begin{array}{l}10 \% \text { Enot } \\
600 \mathrm{KO} \\
60 \% \mathrm{KO} \\
60 \%\end{array}$ & 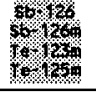 & 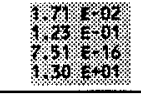 & 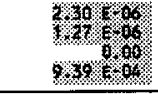 \\
\hline $\begin{array}{l}400 \\
1 \% 9\end{array}$ & $78 \%$ \%or & $\frac{60 \%}{6 \% 00}$ & 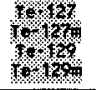 & 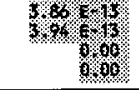 & $\begin{array}{l}\text { owo } \\
0 \% \\
0 \%\end{array}$ \\
\hline $\begin{array}{l}74 \% \\
40 \% \\
4 \%\end{array}$ & 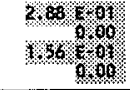 & $\begin{array}{r}909 \mathrm{E} 00 \\
485 \% 00 \\
0.00\end{array}$ & 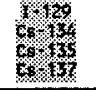 & 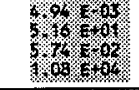 & 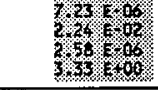 \\
\hline 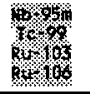 & 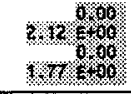 & $\begin{array}{l}1.00 \% \\
6.48600\end{array}$ & 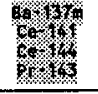 & 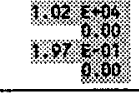 & 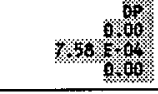 \\
\hline 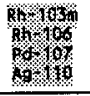 & 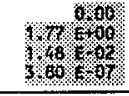 & $\begin{array}{r}0 \% 0 \% \\
\%, 1 \mathrm{fog} \\
0 p\end{array}$ & 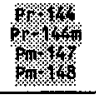 & 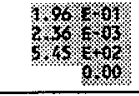 & 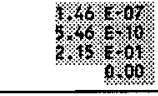 \\
\hline 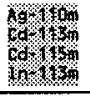 & 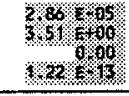 & $\begin{array}{r}10 \% \mathrm{eq} \\
0,00 \\
000\end{array}$ & 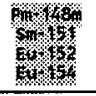 & 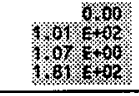 & 300\% \\
\hline 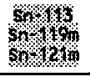 & $\begin{array}{l}1.2 \\
382 \\
68\end{array}$ & $\begin{array}{l}130 \mathrm{E}+1 \\
255 \mathrm{t}=9 \\
758 \mathrm{t}\end{array}$ & 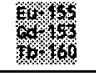 & 3.3. & 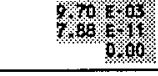 \\
\hline \multicolumn{4}{|c|}{ 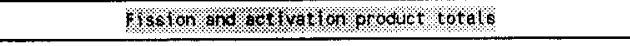 } & $38 \times 1+48$ & $2126 \times 1$ \\
\hline \multicolumn{6}{|c|}{$8.610 \%$} \\
\hline 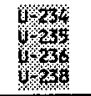 & 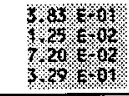 & $\begin{array}{l}515 \mathrm{E} 01 \\
1.61 \% 02 \\
3.04, \% 02\end{array}$ & 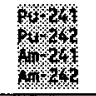 & 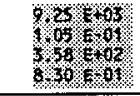 & 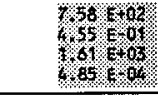 \\
\hline 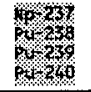 & 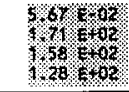 & $\begin{array}{l}366 \mathrm{E} 001 \\
6.67 \mathrm{E} \\
6.97 \mathrm{E}+02 \\
5.76+02\end{array}$ & $\frac{1}{40 \%}$ & 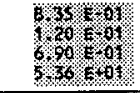 & 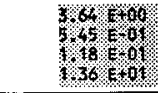 \\
\hline \multicolumn{4}{|c|}{ HodrJo $\alpha d u L$} & $100<0 \%$ & 833,08 \\
\hline
\end{tabular}

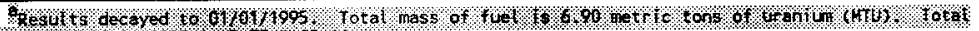

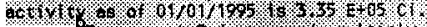

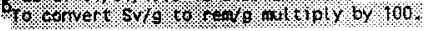

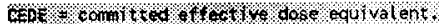

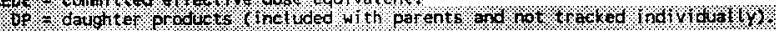

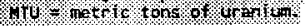


Fable 3-7. Radiological Analysis of High Bumup Mark IV Fuel (Deeaye to Jantary 1, 1995).

\begin{tabular}{|c|c|c|}
\hline Radiontulite & $\begin{array}{l}\text { Aetivity } \\
\text { (Ci/MTU) }\end{array}$ & $\begin{array}{c}\text { EED pep unit intake } \\
\mathrm{sV} / \mathrm{g}(\mathrm{rem} / \mathrm{g})\end{array}$ \\
\hline$-3 H$ & $3.57 \quad E+01$ & $3.3-E .05(3.3-E-03)$ \\
\hline$-85 \mathrm{kn}$ & $5.39-102$ & $3.0 \leq 05-(3.0 \leq 03)$ \\
\hline$-905 p$ & $7.84-5103$ & $1.6-E 101-(1.6-[103)$ \\
\hline 907 & $7.84-5103$ & $7.0-01 \quad(7.0-101)$ \\
\hline${ }^{137} \in \mathrm{s}$ & $1.08 \cdot E+04$ & $3.3 E 100(3.3-E+02)$ \\
\hline${ }^{238} \mathrm{Pu}$ & $1.71 E+02$ & $6.7 \quad[102(6.7 \quad E 104)$ \\
\hline$\stackrel{239}{-P H}$ & $1.58-E+02$ & $7.0-102(7.0-104)$ \\
\hline $240 p_{4}$ & $1.28 E 102$ & $5.8-102(5.8-104)$ \\
\hline${ }^{241} \mathrm{P}_{\mathrm{H}}$ & $9.25-E+03$ & $7.6-E+02(7.6-E 104)$ \\
\hline${ }^{241} \mathrm{Am}$ & $3.58-E+0 z$ & $1.6-E_{103}\left(1.6 E_{105}\right)$ \\
\hline${ }^{244} \mathrm{Em}$ & $5.35 E+00$ & $1.4-E+01 \quad(1.4-E+03)$ \\
\hline Fotal & & $4.3-E+03-(4.3-E+05)$ \\
\hline
\end{tabular}

$1.0 \mathrm{C1}=3.1 \times 1010$

CEPE - eamitted affect ive dose equivatent. MFU - metfic tong of ufaniumr

Table 3-78. Safety Classification Criteria.

\begin{tabular}{|l|c|}
\hline & $\begin{array}{c}50-6 \text { - } \\
\text { dose equivalent }\end{array}$ \\
\hline Offsite guideline & $0.005 \mathrm{~Sv}(0.5 \mathrm{rem})$ \\
\hline Onsite guideline & $0.05 \mathrm{~Sv}(5.0 \mathrm{rem})$ \\
\hline
\end{tabular}

\subsubsection{Design Basis Accidents}

This section discusses the representative accidents analyzed from each of the major groupings and the accidents initiated by human-caused external events or natural phenomena. The MCO has - a $\%$ roviloses a confinement function

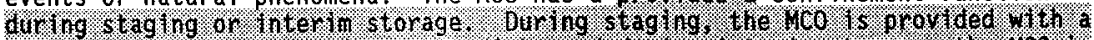

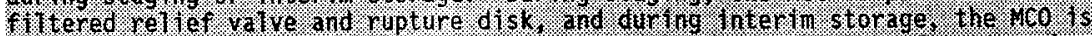
providod With a ripture $\mathrm{d}$ isk. When it is vented and a contarmment function when 7t is seated. In the following discussion of actidents, when the MCO-may exist in either mode, its function is referred to is "confinement/ contument." 


\subsubsection{Release of Multicanister Overpack Gases Under Pressure during} Handling, Staging, or Interim Storage. Pressurization of the MCO to the design limit of its gip IIre. $6 /$ sk unfiltered pressure petief device is an

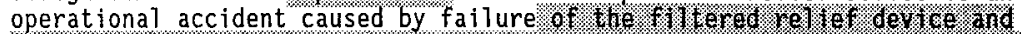

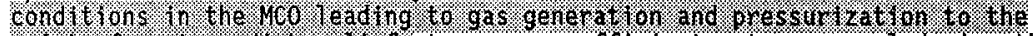

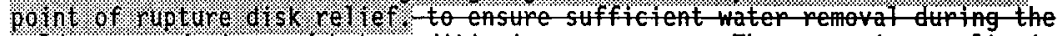
cold vacum drying and hot conditioning processes. The scenario results in a pressurized release from the $\mathrm{MCO}$.

\subsection{Scenario Development. MCOs arrive at the CSB seded and}

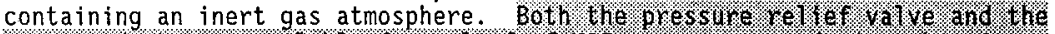

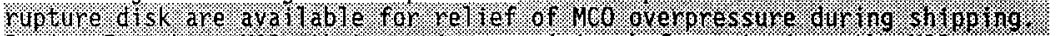

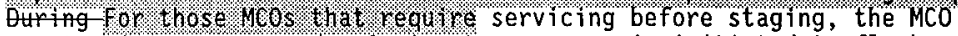
penetrations are opened. An inert gas purge is initiated to flush out unwanted gases that may have formed during shipping. There is a potential for accumulation of hydrogen as a result of radiolytic or chemical reactions of residual water with the fuel during shipping, staging, or interim storage

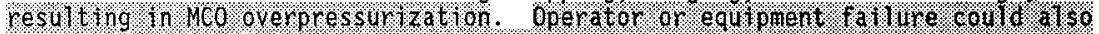

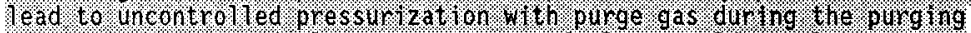
operat on operator failure or equipment failure coutd restlt in MCO overpressurization.

The excessive pressure from either purging or hydrogen generation may

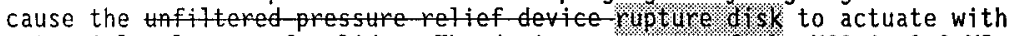
potential releases of solids. The design pressure of the MCO is $1.0 \mathrm{MPa}$ gauge (150 1b/in gauge). For the purpose of this analysis, it is assumed that the

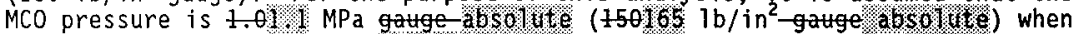
the pressure relief dovice dure dis actuates. This would allow MCO gases with suspended particulate to vent. For the purpose of this analysis, no mitigation of the release is assumed. The release is vented to the environment.

The basis for choosing this scenario to bound the class of MCO overpressurization accidents in the CSB is that the release is a direct

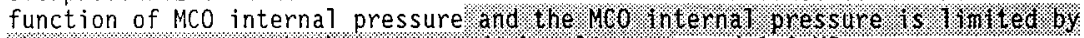
the pressure at whlch the rupture dist. re tieves, and 1.0 MPa gauge $(1507 \mathrm{~b} / \mathrm{in}-\mathrm{g}$ guge) is the highest pressure the MCO-wi77-eredibly reach-under Eurrent design assumptions. The MCO could achieve this internal pressure during transport, handling in the MHM, staging, or interim storage. Following are the assumptions for this choice.

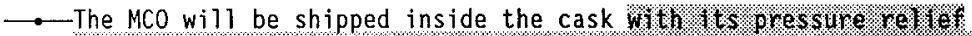

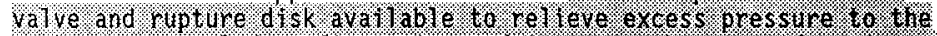

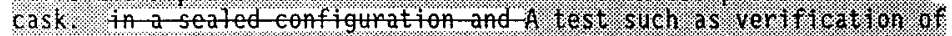

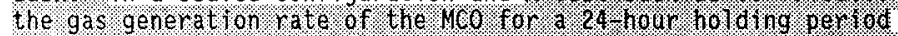

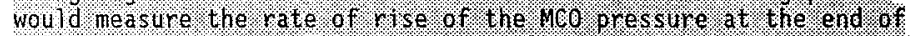

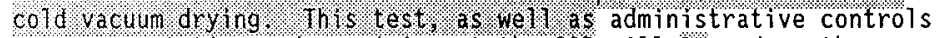
on transportation and receiving at the CSB will

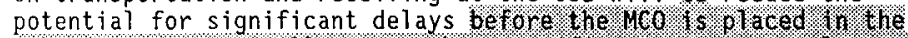

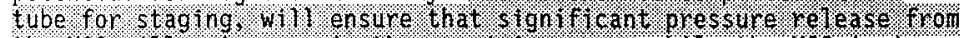

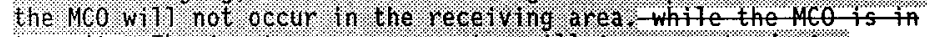

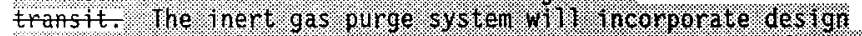

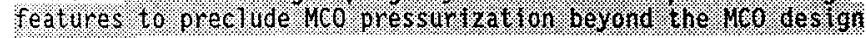
pressuret 
- - The MCO is not vented during staging. . 1 , 60 s and has an active pressure relief valve set at something less than $1.0 \mathrm{MPa}$ gatuge

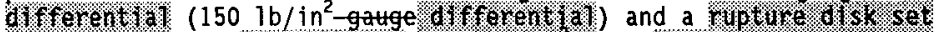

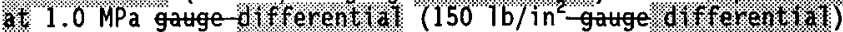
pupture disk-to prevent pressure exceeding the MCO design pressure. During interim storage the MCO will have only the rupture disk for pressure relief.

$\rightarrow$ The inert gas purge system will incorporate design features to preclude $M C O$ pressurization beyond 1.0 MPa gauge (150 lb/in-gattge).

3.4.2.1.2 Source Term Analysis. The inventory at risk is the $300 \mathrm{~kg}$ (660 1b) of particulate material in the MCO available for release. A particulate release fraction for an MCO blowdown from 1.01 . I MPa gage absolitie ( $1501651 \mathrm{~b} / \mathrm{in}^{2}$ guge absolate) to atmospheric pressure was estimated (Kumeree and. Plys 1996). Resuspension rate parameters for fuel assembly baskets and a scrap basket in the MCO were estimated using calculated flow velocities through the fuel baskets and experimental data for particulate resuspension. Calculation of the mass flow from the MCO breach during the blowdown provided the basis for estimating flow velocities over the fuel surfaces and estimating the duration of the event.

An MCO will contain five or six baskets of SNF stacked one above the other. The baskets have perforated plate bottoms designed to allow drainage of water during cold vacuum drying and to facilitate gas flows during oforit Vaculuiduryolng processing. Most of the baskets will contain whole fuel assembites resting vertically on their ends, arranged in a hexagonal matrix. There will be yo 1054 fuel assemblies in a fuel basket.

Some baskets will hold broken fuel pieces, and scrap, ranging in size from sections of a fuel element down to $0.6-\mathrm{cm}(0.25-i n$.$) pieces. In these scrap$ baskets the fuel pieces will be randomly distributed and are modeled as a bed of rubble. The and ys ss assumes. that there will be, at most, one scrap basket in an $\mathrm{MCO}$.

The standard equations for compressible flow and choked flow were employed in a simple computer simulation to calculate the flow behavior during the blowdown. The following key MCO assumptions were used in the analysis.

- The area of the MCO rupture disk orifice was taken to be $3.2 \times 10^{-5} \mathrm{~m}^{2}$, corresponding to a $0.25-i n$.-diameter hole. The flow loss coefficient for the opening was 1.27 , to account for a sudden contraction, friction losses, abrupt turns, and a sudden expansion.

- The MCO gas was assumed to be hydrogen, and the MCO free volume was assunted 10 be $1.0 \mathrm{~m}^{3}$.

- The temperature of the MCO gas was taken to be $75{ }^{\circ} \mathrm{C}$ throughout the event.

An additional calculation was made to test the effect of the higher initial temperatures that would be expected after staging in the CSB. Increasing the temperature to $250{ }^{\circ} \mathrm{C}$ showed insignificant effects on the gas velocities and blowdown time. In addition, gas at higher temperature has 
lower density and would entrain fewer particles as it flows past the fuel. Therefore, the conclusions and assumptions incorporated in the analysis remain valid and conservative.

The standard compressible flow equation (Daily and Harleman 1966) gives

$$
W=\frac{A}{\sqrt{K}}\left[\gamma P \rho\left(\frac{2}{y+1}\right)^{\frac{y+1}{y-1}}\right]^{0.5}
$$

where

$$
\begin{aligned}
& W=\text { mass flow rate }(\mathrm{kg} / \mathrm{s}) \\
& A=\text { flow area }\left(3.2 \times 10^{-5} \mathrm{~m}^{2}\right) \\
& K=\text { loss coefficient }(1.27) \\
& \rho=\text { density of the gas }\left(\mathrm{kg} / \mathrm{m}^{3}\right) \\
& \mathrm{P}=\text { gas pressure }(\mathrm{Pa}) \\
& Y=\text { ratio of specific heats for a gas }(1.4 \text { for diatomic gases, } 1.667 \text { for } \\
& \text { monatomic gases). }
\end{aligned}
$$

During the blowdown, pressure and gas density change with time.

The maximum free stream velocity past the fuel was calculated from the mass flow rate.

$$
V_{\text {MAX }}=\frac{W}{\rho A_{f}}
$$

where

$A_{f}=$ the flow area through a cross section of a fuel basket $\left(0.14 \mathrm{~m}^{2}\right.$ [224 $\left.\mathrm{in}^{2}\right]$ ).

$A_{f}$ was taken as the difference between the cross-sectional area of the $\mathrm{MCO}$ and the total cross-sectional areas of 54 fuel assemblies. This equation applies to the upper portion of fuel loaded in the uppermost position. The free stream velocity is zero at the bottom of the MCO and increases 1 inearly along the height of the MCO.

The gas velocity through the interstices in the scrap basket was estimated by observing that the free stream flow would be further restricted by passing through the smaller cross-sectional area available in the scrap basket. Using a void fraction, e, of 0.5 for the scrap, and assuming the maximum free stream velocity from the fuel basket for the gas as it enters the scrap basket, the interstitial velocity in the scrap basket, $V_{i}$, is given by 


$$
V_{i}=\frac{V_{\text {MAX }}}{e}
$$

The maximum possible interstitial velocity corresponds to a scrap basket in the uppermost position in the MCO. The maximum free stream velocity in a fuel basket was found to be $0.16 \mathrm{~m} / \mathrm{s}$. MCO blowdown for this case was estimated based on the calculated blowdown period for a 500-L gas volume provided in WHC-SD-WM-CN-079, MCO Blowdown Release Fraction (Kummerer and Plys 1996). Using a ratio of the new volume $(1,000 \mathrm{~L})$ to the original volume $(500 \mathrm{~L})$, the blowdown was estimated to be approximately 110 seconds. For this analys is, a $10 \%$ uncertainty factor was applied and the particulate release was determined on the basis of a 120-second MCO blowdown period. WHC-SD-WM-CN-079 (Kummerer and Plys 1996) also shows MCO pressure, gas temperature, and gas velocity transients during blowdown.

Data from measurements of particle resuspension rates in low air flow over surfaces were examined to provide a resuspension parameter for the fuel surfaces and the scrap basket. Report SR-0980-5, Experimental Studies of Resuspension and Weathering of Deposited Aerosol Particles (Reynolds and Slinn 1979), measured resuspension of ZnS particles from a surface in horizontal flows between 2 and $8 \mathrm{~m} / \mathrm{s}$. The particle mean diameter was $3 \mu \mathrm{m}$, and the particulate mass concentration on the surface was $10^{-3} \mathrm{~g} / \mathrm{cm}^{2}$.

The relationship derived from the data gives the following

$$
\wedge=7.4 \times 10^{-10} \mathrm{U}_{\infty}^{3.08}
$$

where

$$
\begin{aligned}
& \hat{\Lambda}=\text { resuspension rate parameter }(1 / \mathrm{s}) \\
& \hat{U}_{\infty}=\text { free stream velocity }(\mathrm{m} / \mathrm{s}) .
\end{aligned}
$$

The resuspension rate parameter, $\wedge$, was calculated from measured experimental parameters and is defined as follows:

$$
\Lambda=\frac{M}{X A_{s} t}
$$

where

$$
\begin{aligned}
M & =\text { resuspended mass } \\
A_{s} & =\text { surface area } \\
X & =\text { particulate mass concentration on the surface } \\
t & =\text { time the surface is exposed to the airflow. }
\end{aligned}
$$

The maximum air velocity of interest in the MCO is well below the flows used in the experiments. Extrapolating the experimentally derived relationship for $\wedge$ to the calculated MCO flow velocities gives 


$$
\begin{aligned}
\Lambda & =7.4 \times 10^{-10}(0.16)^{3.08} \\
& =2.6 \times 10^{-12} / \mathrm{s}
\end{aligned}
$$

Using the experimentally derived resuspension rates, the ARF can be estimated by multiplying the resuspension parameter by the duration of blowdown. It is conservatively assumed that $\Lambda=10^{-6} / \mathrm{s}$.

$$
\begin{aligned}
\text { ARF } & =\wedge t \\
& =\frac{10^{-6}}{\mathrm{~s}} \times 120 \mathrm{~s} \\
& =1.2 \times 10^{-4} .
\end{aligned}
$$

This approach represents a departure from the pressurized powder models presented in DOE-HDBK-3010-94, Airborne Release Fractions/Rates and Respirable Fractions/Rates for Nonreactor Nuclear Facilities (Mishima 1994). It is an attempt to provide a model that more closely represents the physical configuration of the MCO system while still providing adequate conservatism. Key uncertainties involved in the approach, and conservative assumptions used to address them, include the following.

- Uniformiy distributed flow across the MCO cross section is assumed. Flow splits would be likely to cause higher flows at the periphery with lower velocities through the fuel baskets so that entrained particulate would be lower than assumed by the analysis. Additional conservatism is provided by increasing the asstmed ARF to-U.

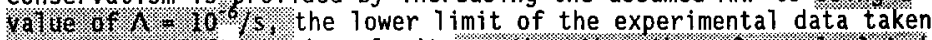

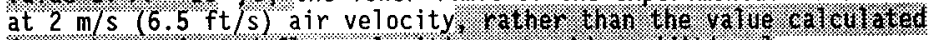

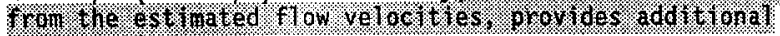
conservats.s.

- The data are reasonable for a scrap basket with 6-cm-diameter particles that resemble gravel. The resuspension parameter is likely to be much higher for a smooth surface. However, surfaces in the MCO bearing corrosion products are expected to be rough. Data from "Initial Correlation of Particle Resuspension Rates as a Function of Surface Roughness Height" (Sehmel and Simpson 1975) show that an increase of about three orders of magnitude could be expected for smooth surfaces, but the low end of the data still corresponds to a velocity of $2 \mathrm{~m} / \mathrm{s}$ or greater, so a value of $10^{-6} / \mathrm{s}$ is taken to bound the case.

- At present, no quantitative assumption can be made about the expected particle mass concentration, $x$, on the fuel surfaces. However, concentrations greater than the $10^{-3} \mathrm{~g} / \mathrm{cm}^{2}$ experimental condition are anticipated. Greater values of $X$ would give lower

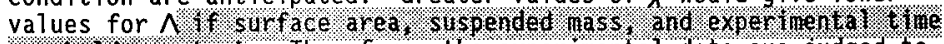
are fido constant. Therefore, the experimental data are judged to bound the SNF from the standpoint of surface particle mass concentrations. 
- The expected MCO particulate may display different suspension characteristics than the material used to generate the experimental data. As characterization data on fuel particulate become available, the conservatism of using these data will be-confirmed revoluated.

The RF is conservatively taken to be 1.0 because the experimental data are based on particles largely in the respirable range. Additional conservatism is introduced into the calculation by neglecting redeposit of particles by impaction caused by turns and bends in the gas-particle flow path, particularly as the flow passes through the scrap basket.

With the maximum particulate loading of $300 \mathrm{~kg}(660 \mathrm{lb})$ per MCO on arrival at the CSB, the estimated inventory released is

$$
\left(1.2 \times 10^{-4}\right)(300 \mathrm{~kg})=3.6 \times 10^{-2} \mathrm{~kg} \text {. }
$$

3.4.2.1.3 Consequence Analysis. The released source term was used to determine the radiological doses to the onsite and offsite receptors. The following assumptions were used to determine radiological consequences to human receptors.

- The release is caused by pressure in the $M C O$.

- Only exposure effects resulting from inhalation are evaluated. As indicated in Section 3.4.1.2, submersion and direct radiation doses provide an insignificant contribution to the total dose, and interdiction limits the exposure from the ingestion pathway.

- The values of $X / Q$ for the selected receptor location are those given in Table 3-56 for ground-leve? releases without plume meander.

- The dose per unit of respirable radjoactive material inhaled is the total given in Table $3-67\left(4.3 \times 10^{3} \mathrm{~Sv} / \mathrm{g}\left[4.3 \times 10^{5} \mathrm{rem} / \mathrm{g}\right]\right)$.

The unmitigated effective dose equivalent for the onsite receptor that results from the depressurization of an MCO during handling can be calculated using the equation in Section 3.4.1.2.

$$
\begin{aligned}
D & =M \times \frac{X}{Q} \times R \times C \\
& =\left(3.6 \times 10^{-2} \mathrm{~kg}\right)(1,000 \mathrm{~g} / \mathrm{kg})\left(3.41 \times 10^{-2} \frac{\mathrm{s}}{\mathrm{m}^{3}}\right)\left(3.3 \times 10^{-4} \frac{\mathrm{m}^{3}}{\mathrm{~s}}\right)\left(4.3 \times 10^{3} \frac{\mathrm{Sv}}{\mathrm{g}}\right) \\
& =1.8 \mathrm{~Sv}(180 \mathrm{rem}) .
\end{aligned}
$$

Dose consequences calculated in the same manner for other selected receptors are given in the Table $3-89$. 
Table 3-89. Unmitigated Dose Consequences for Multicanister Overpack Overpressurization during Handling.

\begin{tabular}{|c|c|c|c|}
\hline \multirow{2}{*}{ Receptor location } & \multicolumn{2}{|c|}{$\begin{array}{c}\text { Point source, without stack or } \\
\text { plume meander }\end{array}$} & \multirow{2}{*}{$\begin{array}{c}\text { Guidelines } \\
\text { Sv (rem) }\end{array}$} \\
\cline { 2 - 3 } & $\begin{array}{c}\mathrm{X} / Q^{3} \\
\left(\mathrm{~s} / \mathrm{m}^{3}\right)\end{array}$ & $\begin{array}{c}\text { CEDE } \\
\text { Sv (rem) }\end{array}$ & \\
\hline $\begin{array}{c}\text { Onsite } \\
(100 \mathrm{~m} \mathrm{E})\end{array}$ & $3.41 \mathrm{E}-02$ & $\begin{array}{c}1.8 \\
(180)\end{array}$ & $\begin{array}{c}5.0 \mathrm{E}-02 \\
(5.0)\end{array}$ \\
\hline $\begin{array}{c}\text { Hanford Site boundary } \\
(18.3 \mathrm{~km} \mathrm{E})\end{array}$ & $1.32 \mathrm{E}-05$ & $\begin{array}{c}7.0 \mathrm{E}-04 \\
(0.07)\end{array}$ & $\begin{array}{c}5.0 \mathrm{E}-03 \\
(0.5)\end{array}$ \\
\hline $\begin{array}{c}\text { Near riverbank } \\
(15.0 \mathrm{~km} \mathrm{E)}\end{array}$ & $1.96 \mathrm{E}-05$ & $1.0 \mathrm{E}-03$ & $5.0 \mathrm{E}-03$ \\
$(0.1)$ & $(0.5)$ \\
\hline
\end{tabular}

CEDE $=$ cormitted effective dose equivalent.

3.4.2.1.4 Comparison to Guidelines. If this accident is not mitigated or prevented by designed safety features, the radiological dose consequence to the onsite receptor $100 \mathrm{~m}(328 \mathrm{ft})$ east of the facility is $1.8 \mathrm{~Sv}$ (180 rem). The dose to the offsite receptor at the Hanford Site boundary is $7.0 \times 10^{-4}$ Sv $(0.07 \mathrm{rem})$; and at the near river bank it is $1.0 \times 10^{-3} \mathrm{~Sv}(0.1 \mathrm{rem})$. The dose to the onsite receptor exceeds the guidelines discussed in

Section 3.3.2.3.2. This mandates mitigative or preventive design features designated safety significant.

Either the filtered ventilation enclosure in the service area will be shown to be capable of confining the pressurized releases when the cask 1 id is removed and when the flanges are removed from the MCO pressure relief devices

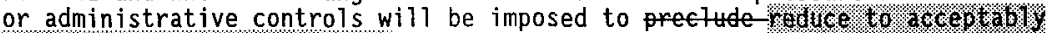

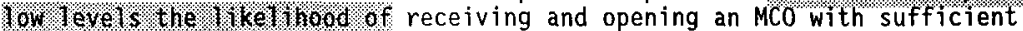
internal pressure to challenge the enclosure confinement function. These controls would include verification of the gas generation rate of the MCO from the 24-hour holding period at the CVDFs fity combined with control of shipping time and conditions covered in the safety analys is report for packaging. The confinement features of the MHM, the storage tube, and the vent and purge cart are designated safety-significant. The dose reduction factors for these mitigation options depend on the final design.

\subsection{Summary of Safety-Class Structures, Systems, and Components} and Technical Safety Requirement Controls. Reduction of the risk from a pressurized release from the $\mathrm{MCO}$ requires safety-significant confinement around the $\mathrm{MCO}$ at all times during receiving operations, handling, staging, and interim storage. Alternately,-For the receiving area, an alternate approach $1 \mathrm{~s} .0$ provade administrative controls that would may be necessary to ensure MCOs opened in the receiving pit are not pressurized beyond the capability of the enclosure to contain the release.

A key assumption in estimating the dose consequences of the pressurized release is that the particulate inventory of the MCO when it enters the CSB is

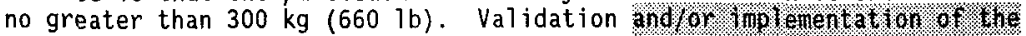




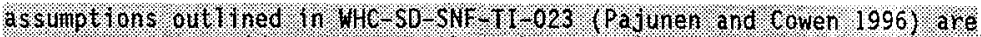

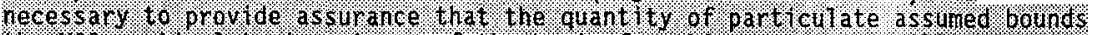
the MCO particulate inventory, of the basts for this assumption will pequire admintstrative controls for the fuel washing operation at- $K$ Basins, and poess contipol at the GVDS.

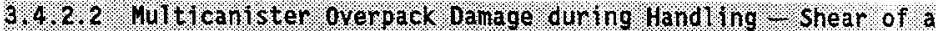

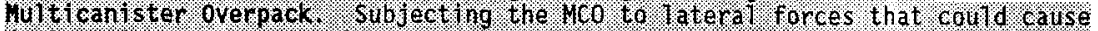

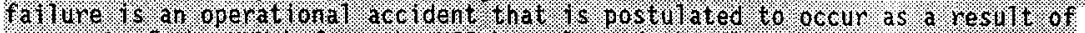

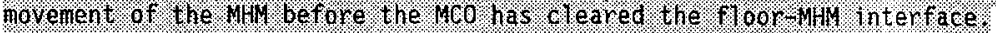

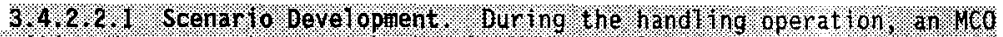

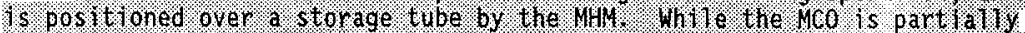

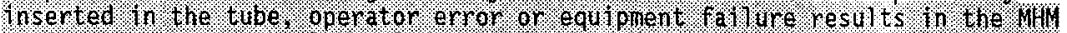

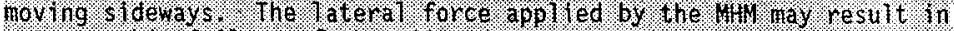

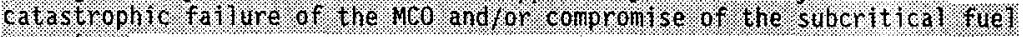
geonet thy.

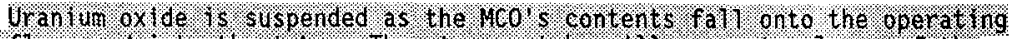

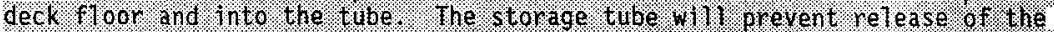

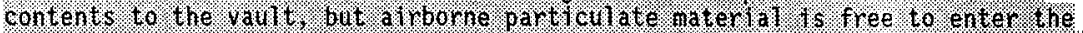

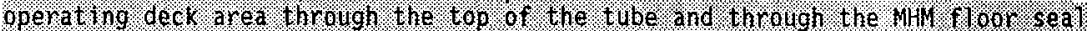

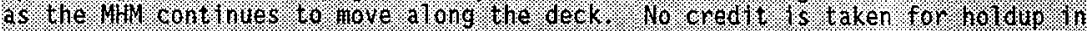

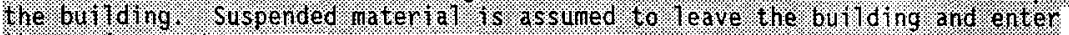
the environient.

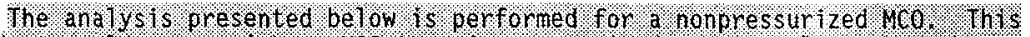
accident could occur with an nco that is pressurtiged to any value up tor the

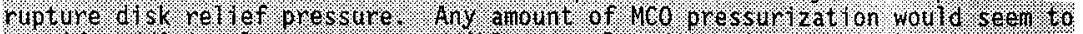

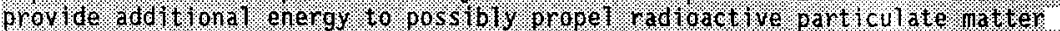

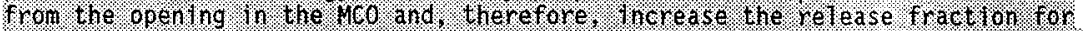

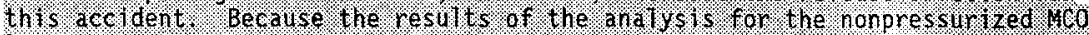

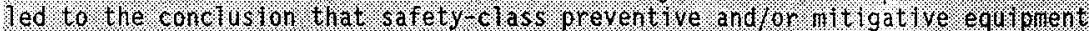

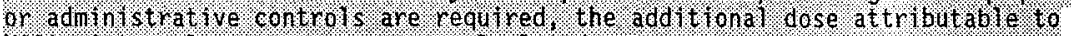
MeO s internat pressure was not calculated:

3.4 .2 .2 .2 Source Tern. Analysts. Informat 1 on and as sumpt ions used to deternine the andunt of nater lat reteased. are os foll ows.

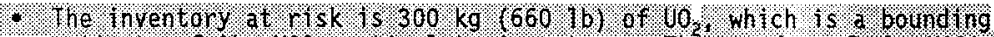

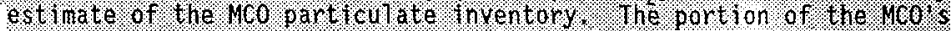

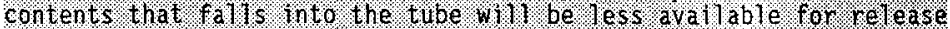
than that whtch falts on the operating deck. Therefore, for cal cul lating the nax imum release, it. is as sumed that the full contents of the MCO are spllied onto the operatting deck.

- The ARF for the fallong contents is determined using informat ton

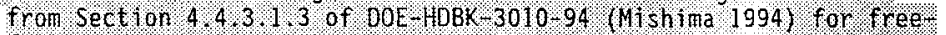
fall powder spl1/s. The average sp 17 l helght is taken to be from the center of mass of the MCO when pos t toned 19 the MHM such that the botton of the MCO just extends into the storage Lube. The average sp 17 , height is therefore est triated to be about one tha ff of

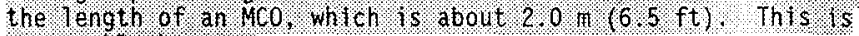
reasonable because 


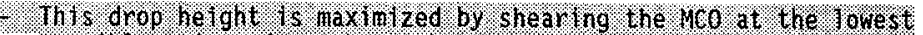

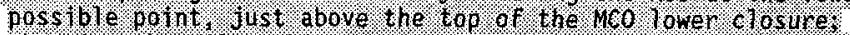

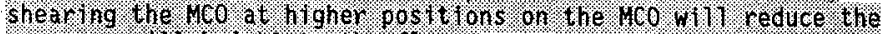
average spolt 1 ielght to the 1100 t.

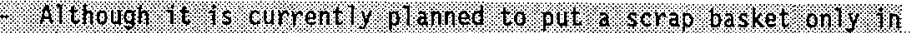

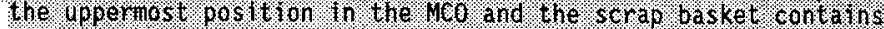

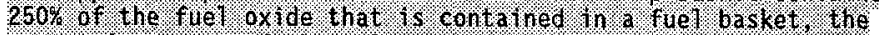

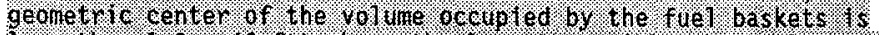

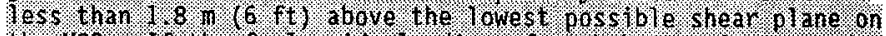

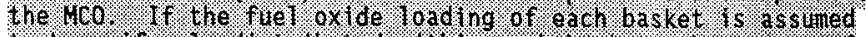

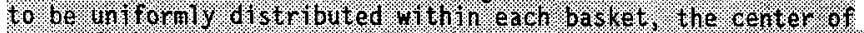
has s. of the ox de 1 skewed 10 the top of the 1460 because of the

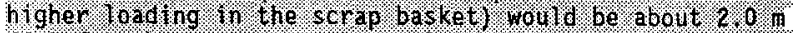

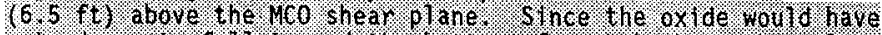

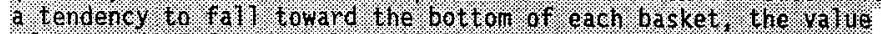

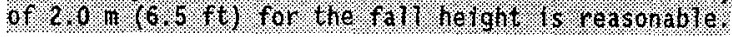

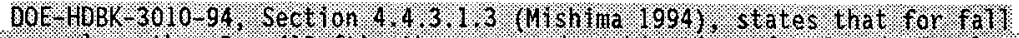

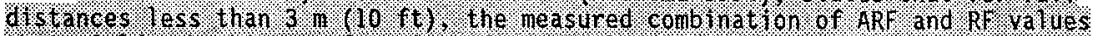

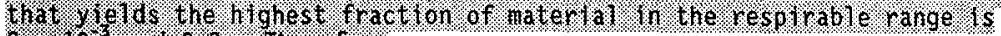
$2.10 \%$ and 0.3 . Inerefore

$$
\text { (AR)(Br) }=\left(2.0 .10^{\circ}\right)(0.3)=6.0 \times 10^{\circ}
$$

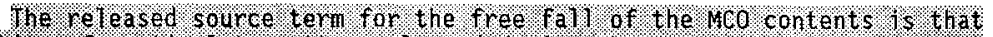

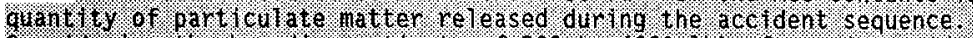

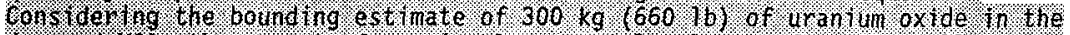

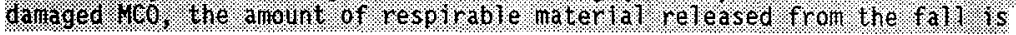

$$
\text { ARF } * \mathrm{RF} \times \mathrm{Y}:=\left(6.0 \times 10^{-6}\right)(300 \mathrm{~kg})(1.000 .9 / \mathrm{kg})=180 \mathrm{9} \text {. }
$$

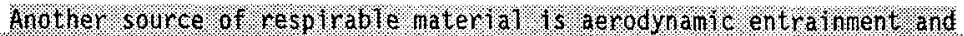
resuspension of part trates, that are ly ing on the deck to lowing the 160 shear

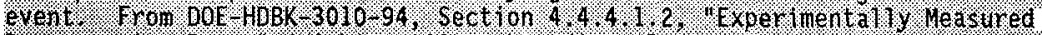

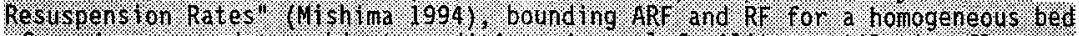

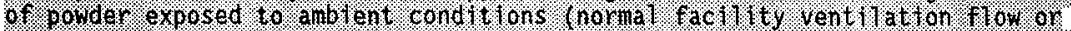

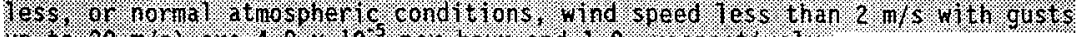

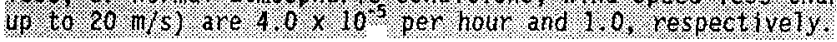

for the offstle receptor. 2. 24 hour exposure per $10 d$ ls assumed. Ihe amolnt of l respirable natertat released in 24 . hours 15 .

$$
\left(4.0 \times 10^{\circ} \mathrm{h}\right)(24 \mathrm{~h})(300 \mathrm{~kg})(1,000 . \mathrm{g} / \mathrm{kg})=288 \mathrm{~g} .
$$

For the ons 1 te receptor. the exposure period 15 g hours, the durath on of a. stardard shlft. The anount of respl rable naterlat released in 8 hours. is

$$
(2889) / 3=96.9 \text {. }
$$

The assumpt on that lhe MCo part lculate of a f rnely dwalded powder in

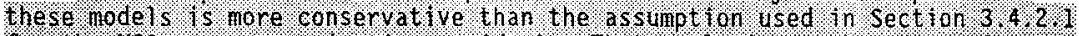
for the Mlo overpressumizat tor accldent. That anatysts. was based on ald

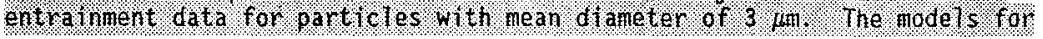




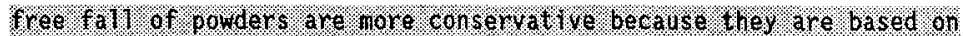

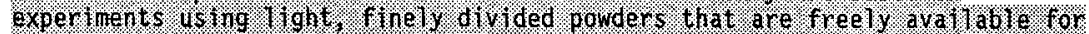

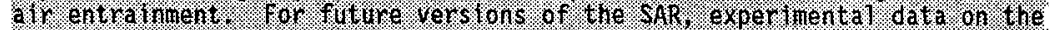

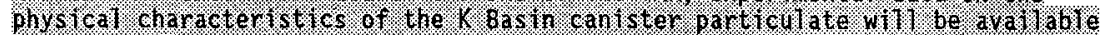

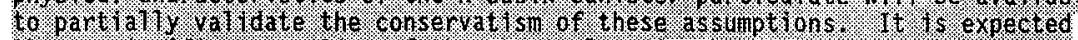

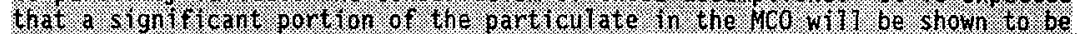

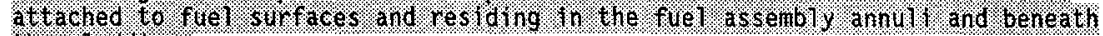
the c tadding

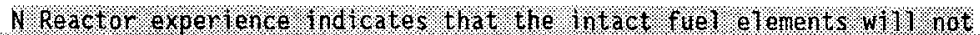

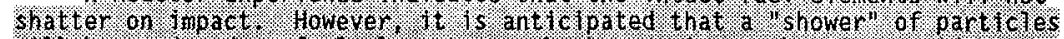

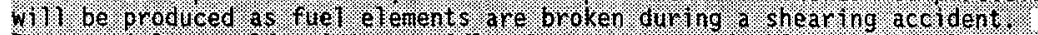

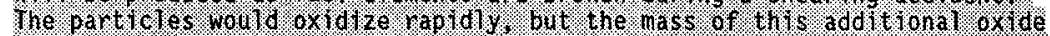

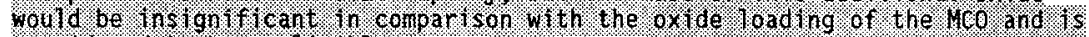
constdered 10 be regl 1916 te.

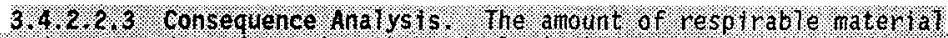

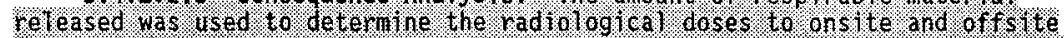

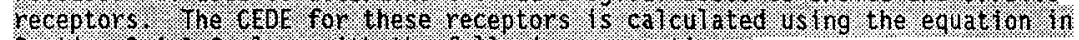

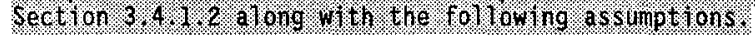

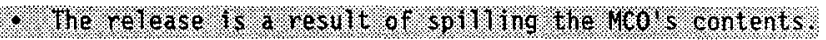

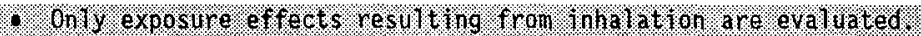

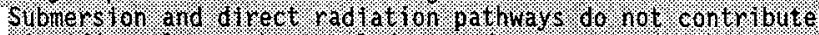

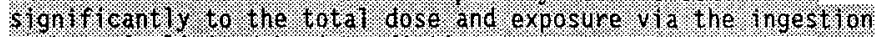

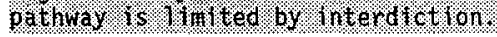

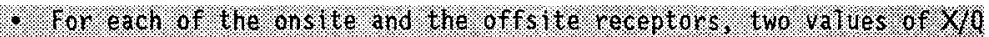

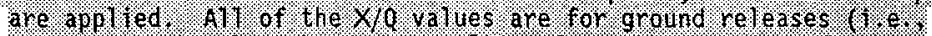

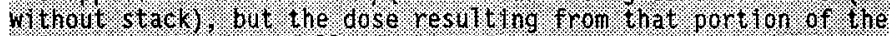

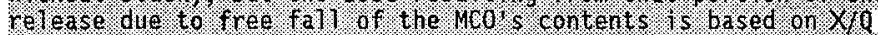

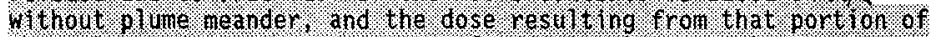

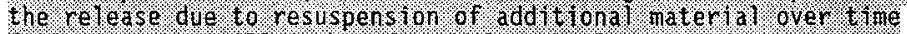
following the spoll. is based on $\times 10$ with or lune neander.

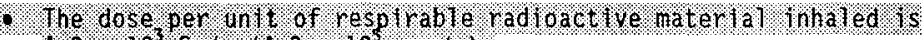
$4.3 \times 10^{3} .51 / \mathrm{g}:(4,3 \times 10$. $\mathrm{rem} / \mathrm{g})$

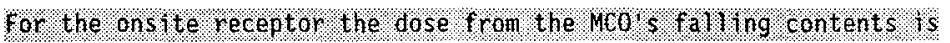

$$
\begin{aligned}
& \mathrm{D}=\mathrm{M} \times \frac{X}{\mathrm{Q}} \times \mathrm{R} \times \mathrm{C}
\end{aligned}
$$

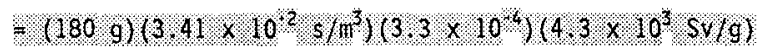

$$
\begin{aligned}
& \text { - } 8.7 \text {. } 5 \text { V }(870.12 \mathrm{er})
\end{aligned}
$$

ard the dose from resuspenston of parthcllate from the 400 s spl 7 ed conterls: 1s: 
$\mathrm{D}=\mathrm{M} \times \frac{X}{Q} \times \mathrm{R} \times \mathrm{C}$

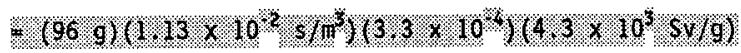

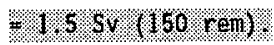

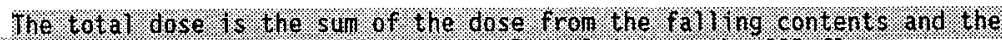

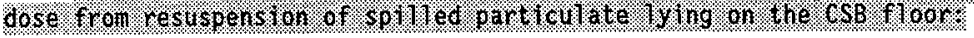

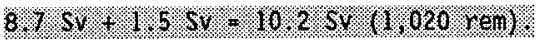

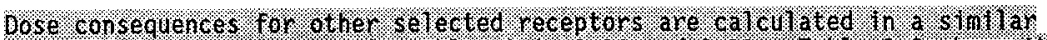

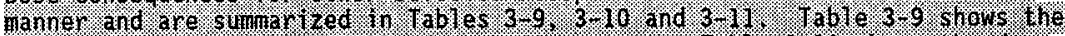

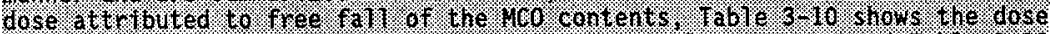

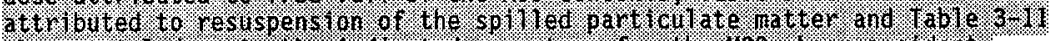

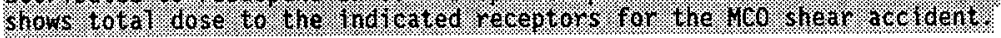

3.4 .2 .2 Single Hulticanister overpack failupe during Handling tateral

Forces. Subjecting the MCO to lateral forces that could cause failure is an operational accident caused by movement of the MHAl before the MCO has cleared the floor MHIH interface. The accident is elassified as confinement contaiment failure.

3.4.2.2.1 Scenario Development. During the handling operation, an MCO is positioned orer a storage tube by the MHM. While the MCO is partially inserted in the tube, operator eprop or equipment failure results in the MHH moving sidews. The lateral force applied by the MHAM results in catastrophic failure of the $\mathrm{MCO}$.

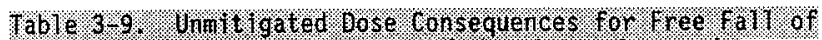

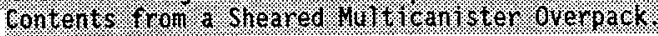

\begin{tabular}{|c|c|c|}
\hline \multirow{2}{*}{ Beceptor $100 a t / 101$} & \multicolumn{2}{|c|}{ 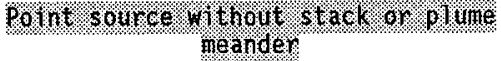 } \\
\hline & $(5 / 2)$ & SV (ren) \\
\hline $000 \% 10$ & $3.41 .6=02$ & $870)$ \\
\hline 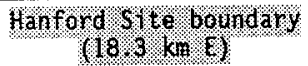 & 162.05 & $(0.0034)$ \\
\hline 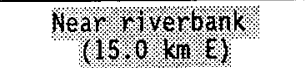 & 1.96 V 005 & 0.0050 \\
\hline
\end{tabular}

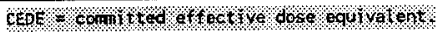




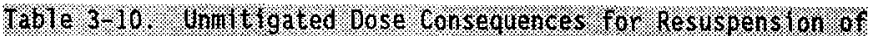

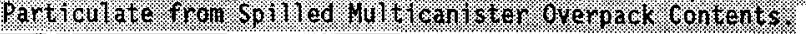

\begin{tabular}{|c|c|c|}
\hline \multirow{2}{*}{ 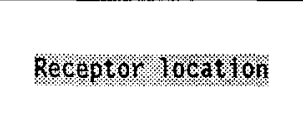 } & \multicolumn{2}{|c|}{ 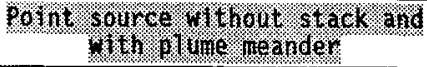 } \\
\hline & $8 \%$ & 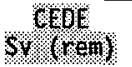 \\
\hline Ons 100 ne & $1.13=1=02$ & 150 \\
\hline Hanford St te boundary & $1.11 .6-0.5$ & 10.6945 \\
\hline Near r. Werlatil & $1,55.1=05$ & 0.0063 \\
\hline
\end{tabular}

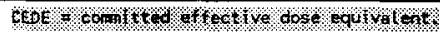

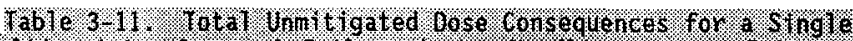

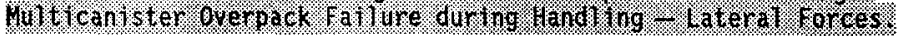

\begin{tabular}{|c|c|c|}
\hline Receptor Incat 101 & $5 \%$ Wen & 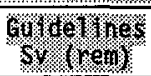 \\
\hline Ons 100 nte & (10.020 & 50.02 \\
\hline Hanford s/le boundary & 0.008 & $10.5 \%$ \\
\hline $\begin{array}{l}\text { Mear r weroank } \\
(150 \text { orm }\end{array}$ & $0.1 \%$ & 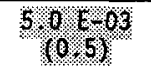 \\
\hline
\end{tabular}

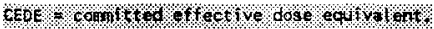

Uranium-oxide is suspended as the $\mathrm{MCO}^{\prime}$ s contents fall onto the operating teck floor and into the tube. The storage tube will prevent retease of the contents to the rault, but airborne particulate material is free to enter the operating deck area through the top of the tube. No eredit is taken for holdup in the building. Stspended material is assumed to leave the building and enter the enviroment.

The analysis presented below is performe for a nenpressurized MCO. This accident could occur with an $\mathrm{ACO}$ that is pressurized to any value up to the

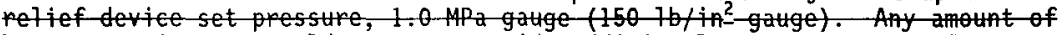
MCO pressurization would seem to provide additional-energy to possibly propel radioactive particulate matter from the opening in the MCO and, therefore, increase the release fraction for this accident. Because the results of the analysis for the nonpressurized $M C O$ led to the conclusion that safety class preventive and/or mitigative equipment or administrative controls are required, the additional dose attributable-to $H C O$ internal presstre was not ealeulated. 
3.4.2.2.2 Source-Tem-Analysis. Information and assumptions used to determine the amount of material released are as follows:

- The inventory at risk is $300 \mathrm{~kg}(660 \mathrm{lb})$ of $-10_{2}$, which is a bounding estimate of the $\mathrm{MCO}$ particulate inventory. The portion of the $M C O$ contents that falls into the tube will be less arailable for pelease than that wich falls on the operating deck. Therefore, for ealculating the maximum release, it is assumed that the full contents of the $M C Q$ are-spilled onte the operating deck.

C. The ARF for the falling contents is determined using the Ballinger model described in DOE HOBK 3010 94. (Mishima 1994), for free falt powder spills. The average-spill height is taken to be from the center of mass of the MCO when positioned in the MHM stuch that the bottom of the $M C O$ just extends into the storage tube. The average spill height is therefore about one half of the length of an $M C O$ which is about $2.0-\mathrm{m}(6.5-\mathrm{ft})$.

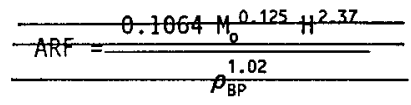

Where

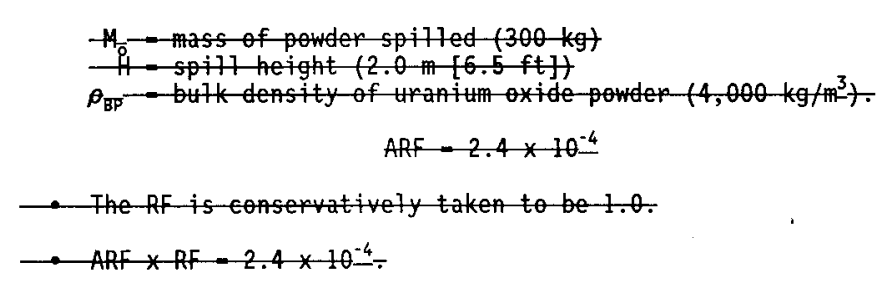

The released source term for the free fall of the $M c 0$ conten is that quantity of particulate matter released during the accident sequence. Considering the bounding estimate of $300 \mathrm{~kg}(660-7 \mathrm{~b})$ of uranium oxide in the damaged $M C 0$, the amount of respirable materiat released from the fall is

$$
\text { ARF } * \text { RF } * M_{0}=\left(2.4 \times 10^{-4}\right)(300-\mathrm{kg})(1,000-\mathrm{g} / \mathrm{kg})-72 \mathrm{~g} .
$$

Another source of respirable material is aerodynamic entrainment and pesuspension of panticles that are lying on the deck following the $M C O$ shear event. From DOE HOBK-3010 94, Section 4.4.4.1.2, "Experimentally Heasured Resuspension Rates" (Mishima 1994), buting ARF a RF for a homogens bed of powder expos to ambient conditions (nomal process facility ventilation flow or less, or normal atmospheric conditions, wind speed less than $2 \mathrm{~m} / \mathrm{s}$ with gusts up to $20 \mathrm{~m} / \mathrm{s}$ ) are-4.0 $410^{-5}$ per hour and 1.0 , respectively.

For the offsite receptor; a 24 hour exposure period is assumed. The amount of respirable material released in 24 hours is 


$$
\left(4.0-10^{-5} / \mathrm{hr}\right)(24 \mathrm{hr})(300 \mathrm{~kg})(1,000-\mathrm{g} / \mathrm{kg})-288 \mathrm{~g} .
$$

For the onsite receptor, the exposure period is \& houp, the duration of a standard shift. The amount of pespirable-material released in 8 hours is

$$
288-9 / 3-96-9 .
$$

The assumption that the MCO panticulate-is a finely divided powder in these-models is more conservat ive than the assumption used in Section 3.4 .2 .1 for the $M C O$ overpressurization accident. That analysis was based on ait entrainment data for particles with mean diameter of $3 \mathrm{\mu m}$. The models for free $f a 7 l$ of powders are more conservative because they are based on experiments using light, finely divided powders that are freely arailable-for aip entrainment. For future versions of the SAR, experimental dats on the physical characteristies of the $K$ Basin canister particulate will be arailable to pantially validate the conservatism of these assumptions. It is expected that a-significant portion of the particulate in the MCO will be shown to be attached to fuel strfaces and residing in the fuel asembly annuli and beneath the cladding.

N Reactor experience indicates that the intact fuel elements will not shatter on impact. However, it is anticipated that a "showerl of partictes will be produced as fuel elements are broken during a shearing aceident. The particles wuld oxidize rapidly, but the mass of this ditional oxide would be insignificant in comparison with the oxide loating of the MCO and is considered to be negligible.

3.4 .2 .2 .3 Consequence Analysis. The amount of respirable material peleas, ealeulated in Section 3.4 .2 .2 .2 , was used to determine the adiological doses to onsite and offsite receptors. The unmitigated effective tose equivalent for these receptors is calculated using the equation given in Section 3.4 .1 .2

$$
\theta-M \times[X / Q] \times R \times C
$$

atong with the following assumptions.

$\rightarrow$ The release is a result of spilling the MCO contents:

-. Onfy-expstre effects restlting from inhalation are-evaluated. As indicated in section 3.4 .1 .2 , submersion and direct radiation pathways do not contribute significantly to the total dose, and exposure $v i$ the ingestion pathwy is limited by interdiction.

$\rightarrow$ The values of $x / Q$ used in this analysis are given in Table $3-6$. For each of the onsite and off site receptors, two values of $X / Q$ are applied. All of the $X / Q$ values are for ground releases fi.e. without stack), but the dose resulting from that portion of the pelease caused by free fall of the $M C O$ contents is based on $x / Q$ without-plume ander, and the dose resulting from that portion of the release callsed by restspension of additional materiat over-time following the spill is based on $X / Q$ with plume-meander. 
- The dose pep unit of respirable radioactive matepial inhaled is the total given in Table $37(4.3 * 10 * 3-\mathrm{Sv} / 9[4.3 * 10 * 45 \mathrm{rem} / \mathrm{g}])$.

For the onsite receptor

- The dose from-the falling MCO contents is

$$
\begin{aligned}
& {[72-g][3.41-10 * 2 \mathrm{~s} / \mathrm{m} * * 3][3.3 \times 10 * *-4][4.3-10 * * 3 \mathrm{sv} / \mathrm{g}]} \\
& -3.5 \mathrm{sv}(350 \mathrm{rem})
\end{aligned}
$$

- The dose from resuspension of particulates from the spilled MCO contents is

$$
\begin{aligned}
& {[92 \mathrm{~g}][1.13 \times 10 * 2 \mathrm{~s} / \mathrm{m} * * 3][3.3 \times 10 * 4-4][4.3 \times 10 * * 3-\mathrm{sv} / \mathrm{g}]} \\
& =1.5 \mathrm{SV}(150 \mathrm{rem})
\end{aligned}
$$

$\rightarrow$ The total dose is the sum of the dose from falling MCO contents and the dose from resuspension of spilled particulates lying on the CSB floor

$$
\begin{aligned}
& =3.5 \mathrm{~Sv}(350 \mathrm{rem})+1.5 \mathrm{St}(150 \mathrm{rem}) \\
& =5.0 \mathrm{~Sv}(500 \mathrm{rem}) .
\end{aligned}
$$

Bose consequences for other seiected receptops are calculated in a similar manner and are-summarized in Tables $-3-10,-3-11$, and $3-12$. Table 3 10 shows the dose attributed to free fall of the $M C O$ contents, Table 311 shows the

\begin{tabular}{|c|c|c|}
\hline \multirow{2}{*}{ Receptor location } & \multicolumn{2}{|c|}{ Point source without stack or } \\
\hline & $\begin{array}{c}x / 0 \\
t s / m^{3}+t\end{array}$ & So (remt \\
\hline $\begin{array}{l}\text { Onsite } \\
(100 \text { m } E)\end{array}$ & $3.41 E 02$ & $\frac{3.5}{(350)}$ \\
\hline $\begin{array}{c}\text { Hanford site butary } \\
(18.3-\mathrm{km} E)\end{array}$ & $1.32 E-05$ & $\begin{array}{l}0.0013- \\
(0.13)\end{array}$ \\
\hline Hear piverbank $(15.0 \mathrm{~km} \mathrm{E})$ & 1.96 E. 05 & $\begin{array}{l}0.0020 \\
(0.20)\end{array}$ \\
\hline
\end{tabular}
dose attributed to resuspension of the spilled particulate matter, and Fable-3-12 shows total dose to the indicated peeptors for the HCO shear aceident.

Fable 3-10. Unmitigated Dose Consequences for Free Fall of contents From a Sheared Multicanister Orenpack.

EDE- offective-doso equivalent. 
Fable 3 11. Unmitiguted Dose Consequences for Resuspension of

Particulates from Spilled Multicanister Qrepack Contents.

\begin{tabular}{|c|c|c|}
\hline \multirow{2}{*}{ Receptor location } & \multicolumn{2}{|c|}{$\begin{array}{c}\text { Point-source-without stack-and } \\
\text { with plume-meander }\end{array}$} \\
\hline & $\begin{array}{l}x / \theta^{3} \\
\left(s / m^{3}\right)\end{array}$ & $\begin{array}{c}\text { EQE } \\
\text { SV (rem) }\end{array}$ \\
\hline $\begin{array}{l}\text { Onsite } \\
(100 \mathrm{mE})\end{array}$ & $1.13-02$ & $\begin{array}{l}1.5 \\
+150)\end{array}$ \\
\hline $\begin{array}{c}\text { Hanford Site-boundary } \\
(18.3 \mathrm{~km} E)\end{array}$ & $1.11 E-05$ & $\begin{array}{l}0.0045 \\
(0.45)\end{array}$ \\
\hline $\begin{array}{l}\text { Hear riverbank } \\
(15.0 \mathrm{~km} E)\end{array}$ & $\pm .55-\mathrm{E}-05$ & $\begin{array}{l}0.0063 \\
(0.63)\end{array}$ \\
\hline
\end{tabular}

EDE- Offocivo do

Fable 3-12. Total Unmitigated Dose Consequences for a Single Hulticanister Overpack Failure during Handling Lateral forces.

\begin{tabular}{|c|c|c|c|}
\hline \multirow{2}{*}{ Receptor location } & \multicolumn{2}{|c|}{ Fotal EQE } & \multirow{2}{*}{$\begin{array}{l}\text { Guideline } \\
\text { St (rem) }\end{array}$} \\
\hline & St & (rem) & \\
\hline $\begin{array}{l}\text { Onsite } \\
(100-m-E)\end{array}$ & 5.0 & $(500)$ & $\begin{array}{c}5.0-5-02 \\
(5.0)\end{array}$ \\
\hline $\begin{array}{c}\text { Hanford Site boundary } \\
(18.3 \mathrm{~km}-\mathrm{E})\end{array}$ & 0.006 & $(0.6)$ & $\begin{array}{c}5.0 .5-03 \\
(0.5)\end{array}$ \\
\hline $\begin{array}{l}\text { Hear riverbank } \\
(15.0 \mathrm{~km}-\mathrm{E})\end{array}$ & 0.008 & $(0.8)$ & $\begin{array}{c}5.0 . E-03 \\
(0.5)\end{array}$ \\
\hline
\end{tabular}

EDE - offective-dosomequivatent.

3.4.2.2.4 Comparison to Guidelines. If this accident is not mitigated or prevented by designed safety features, the radiological dose consequence to the onsite receptor $100 \mathrm{~m}(328 \mathrm{ft})$ east of the facility is $5.010 \%$. Sv (500\%.020 rem). The onsite dose exceeds the guidelines discussed in Section 3.3 .2 .3 .2 . The dose to the offsite receptor at the riverbank is $0.0080 .01 \mathrm{SV}(0.8)$ I rem). This exceeds the guideline $\left(5.0 \times 10^{-3} \mathrm{SV}\right.$ $[0.5 \mathrm{rem}])$ for safety-class mitigation or prevention of the release.

It is anticipated that the reliability of systems and controls designed to protect the confinement/containment function of the $M C O$ will be shown te duce the frequency of this event-sufficiently that risk accept guidelines are met for both-onsite and offsite receptors.

3.4.2.2.5 Summary of Safety-Class Structures, Systems, and Components and Technical Safety Requirement Controls. If conservative analysis does not

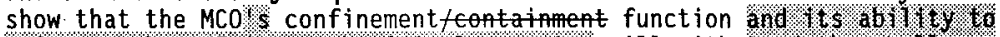

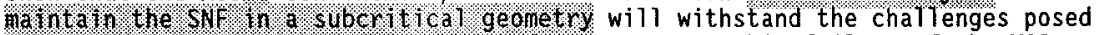
by this class of accidents, the risk from a catastrophic failure of the MCO while being placed in the tube must be reduced by exther mithos were op prevention of the event. 
Safety-class interlocks and keys to prevent MHM sideways movement while the MCO is partially inserted into a storage tube, and design of the receiving area combined with TSR administrative controls that prevent a vehicle colliding with the MCO in the service area are effective preventive features. To prevent MCO shearing during a seismic event, a safety-class brake or locking device on the MHM witl be-1s provided-opit will be stat a design basis seismic event-will not callse MCO-shear.

A key assumption in estimating the dose consequences of the release is that the particulate inventory of the MCO after the hot conditioning ofoess

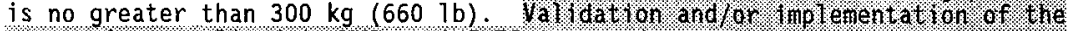

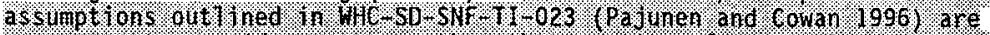

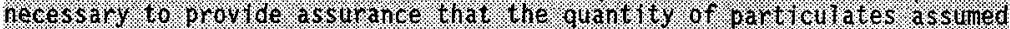
bounds the 160 part wathate inventory. The effectiveness of the fued cteaning evolutions at the $K$ basths must be venified, and cleaning procedures must be followed for all fuel. The amount of free water left in the $M C O$ after cold

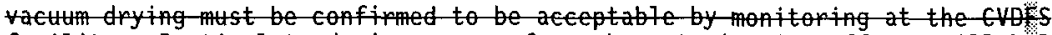
facility. Particulate drying curves from characterization efforts will help eonfinm this.

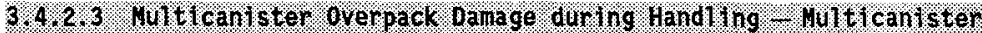

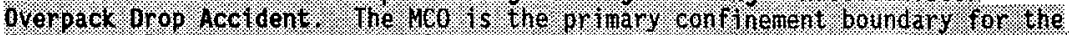

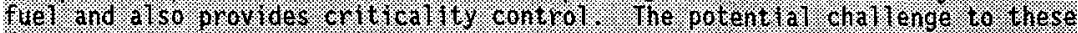

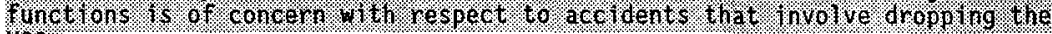
40.

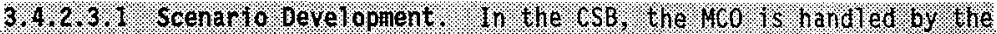

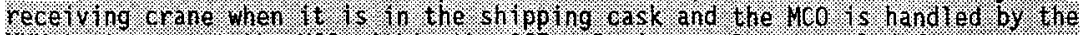

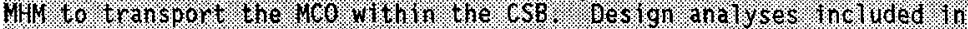

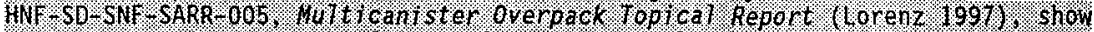

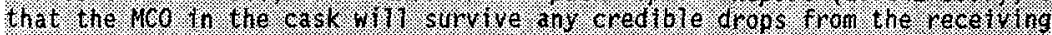

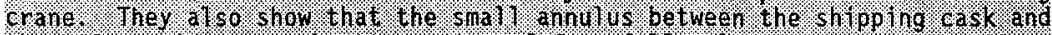

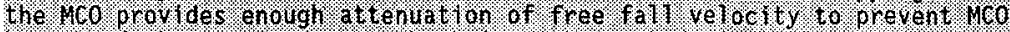

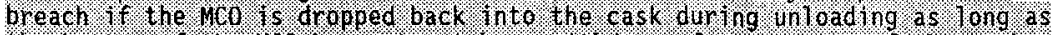

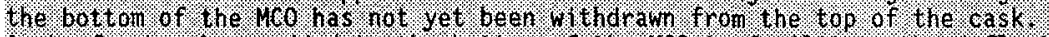

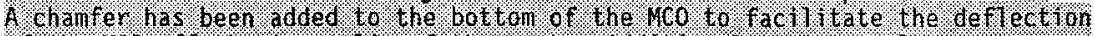

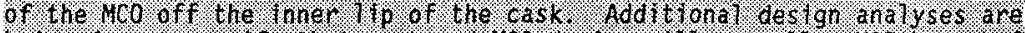
being done to verify. that cass and 400 destgn. 1111 not a $110 \%$ Meg breach for any drop r rom the Ulm.

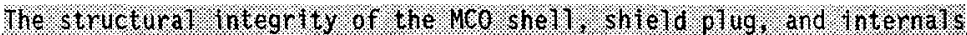

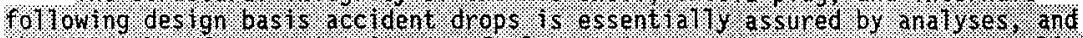

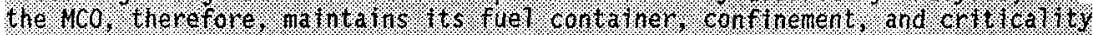

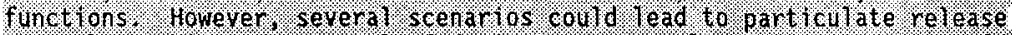

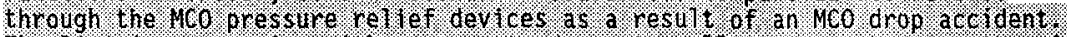

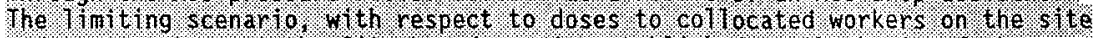
and to receptors at the shte boundary, is established on the bas ts of the

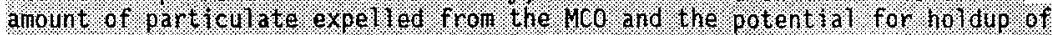
Whe part iculate nateriat as It trave ts to. the receptors.

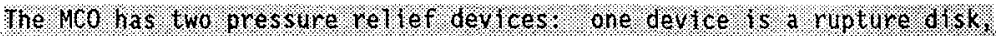

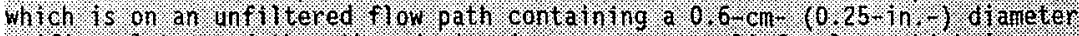

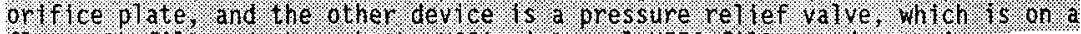

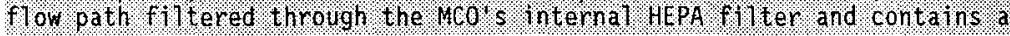




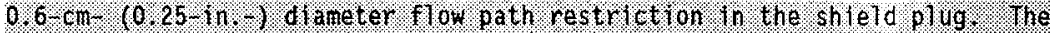

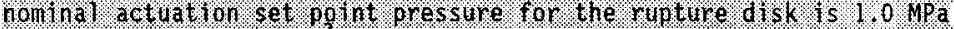

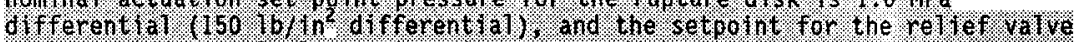

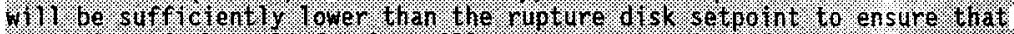

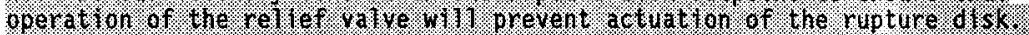

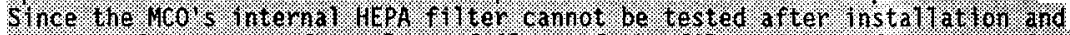

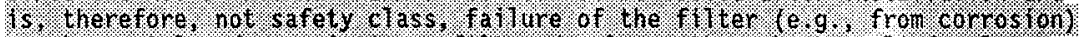

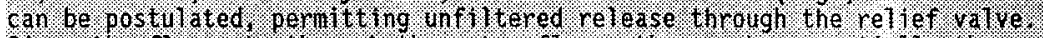

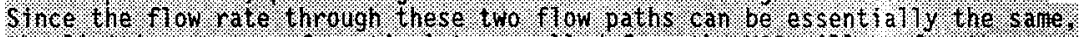

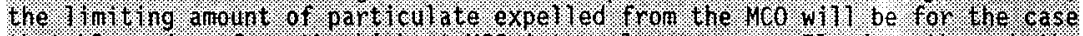

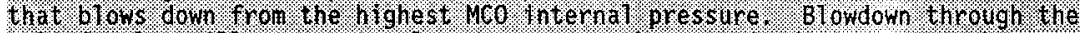

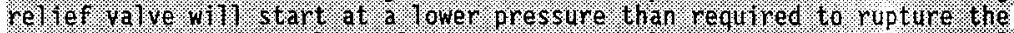

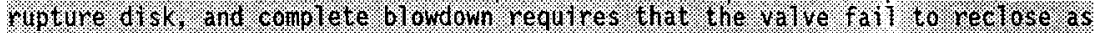

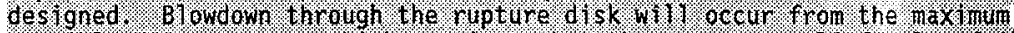

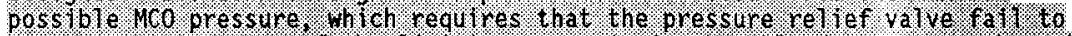

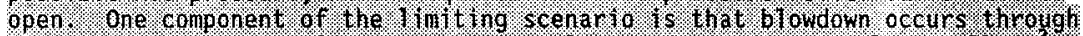

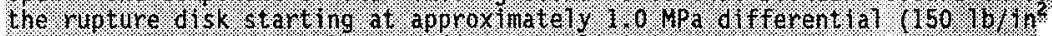

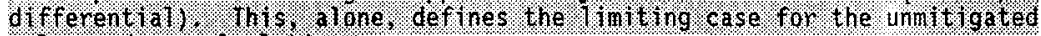
retease dose calcultw10n.

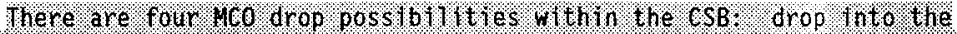

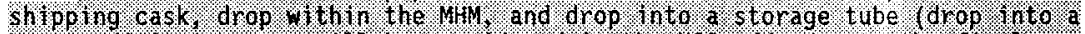

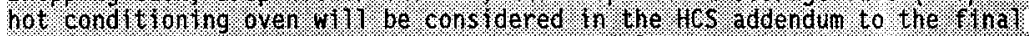

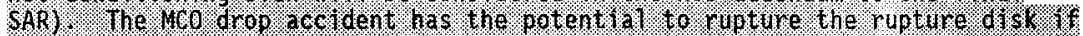

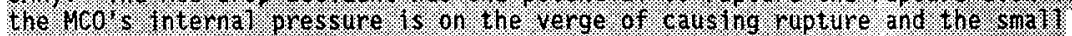

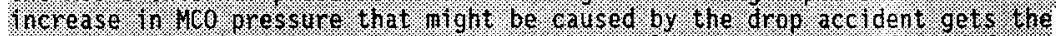

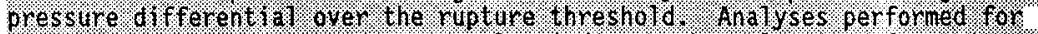

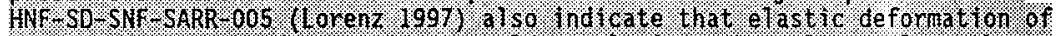

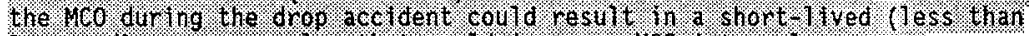

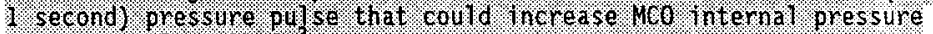

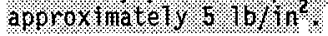

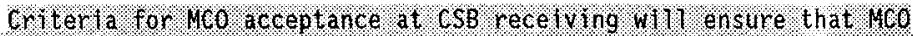

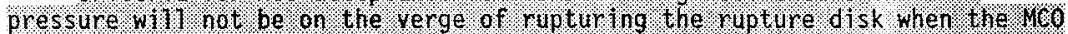

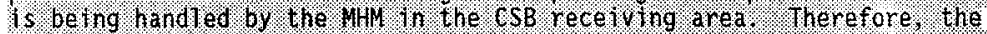

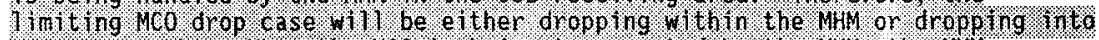

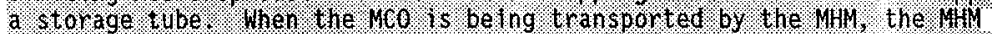

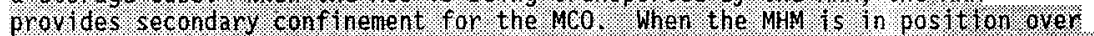

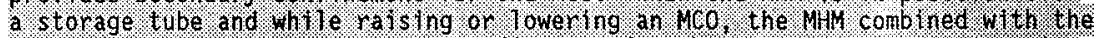
storage tube prov des secondary conf inement for the MCo s contents. As suming: that the decontaminat $\mathrm{won}$ factor a soct ated with secondary conf i nement. decreases. as the conf henent pressure during the acclont increases. Whe

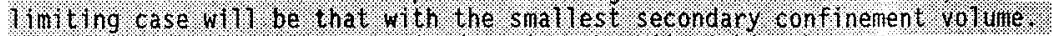

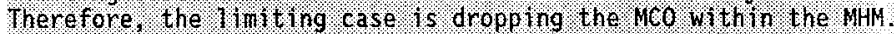

\subsubsection{Multicanistep Overpack Fallure during Handling-Crane Drop. Aropping the cask $H C O$ from the receiving erane or dropping the $M C O$ from the MHA into the shipping cask; into a tube, or onto the operating deck floor are operational accidents caused by - human error op equipment failure. The accident is elassified as a confinement/containment failure.}

Design analyses to be included in the MCO Topical Report show that the MCO in the cask will survive any credible drops from the receiving crane. They also show that the-small annulus-between the shipping cask and the MCO 
provides enough attentution of free fall velocity to prevent $M C O$ breach if the $\mathrm{MCO}$ is dropped back into the cask during unloading as long as the botom of the HCO has not yet eleaped the top of the cask. Adtitional design analysis is being done to verify that eask and MCO design will not allow MCO breach if the $\mathrm{HCO}$ is dropped from its highest position in the MHM. The $\mathrm{MHA}$ will be designed to preclude dropping the $M C O$ to the operating area floop by providing a barpier beneath the $M C O$ whenever it is being moved by the MHA. Therefore, the bounding $M C O$ drop accident involves a drop into the storage tube.

3.4.2.3.1 Seenapio Development, In the- $4 C O$ drop aceident, an unvented $\mathrm{MCO}$ with on internal presstre near the rupture-disk set point is drop by the 14MI. As a consequence of the drop, the safety class rupture disk-puptures or the non safety elass relief valve opens. The drop atso produces accelerations on the fuel causing particulate matter to be shaken from the fuel and-suspended in the $14 C O$ gas space. This particulate laden gas is then expelled from the $M C O$ to the MHM, which may be connected to a storage tube, and then petersed to the environment. The flow rate from the MCO is limited by $20.635 \mathrm{~cm}(0.25 \mathrm{in}$. $)$ diameter orifice plate. The particulate matter is the radiontelide source term used for the dose-aleulations. The resulting onsite dose consequence is $1.45 \mathrm{SV}(145 \mathrm{rem})$ and the offsite dose consequence is $0.83 \mathrm{mSV}(0.083 \mathrm{rem})$.

An $M C O$ is vented and purged with inerting gas at the CSB receiving station before either being placed in a storge tube for staging on moved directly to a furnace in the hat conditioning facility. Following hot conditionifig, an $M C O$ is purged and backfilled with inerting gas at 1 atm absolute pressure just-prior to return to the storage tube for interim storage.

If an MCO is staged before hot conditioning, it can be instaging for several years and the internat presstre will inceuse because of the production of gases from fuel corrosion and radiolysis. During staging, MCOs are not vent? they have an active pressure relief valve with an ative safety class rupture disk to back up the relief valve. The onty possible

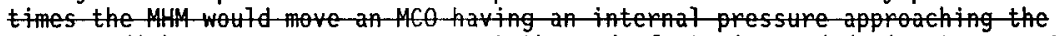
pupture disk rupture pressure are at the end of staging and during transport by the MHH if an abnomma? condition causes the MCO to be kept in the MHA for an unustally long time. During interim storage, the MCOs will not be handled, with the possible exception of retrieving an $M C O$ that has ruptured a rupture disk. In this case, only one pressunized $\mathrm{MCO}$ would be in the storage tube-

\section{the $M C O$ :}

The following possible relief mechanisms would vent unfiltered gas from

- The MCO is pressurized to just under the pelief vatre opening prestre, the drop accident causes the relief valve to open, the relief valve fails to reseat, and corposion has caused the HEPA filter in the $M C O$ to open to the extent that it does not filter the escaping-gas

a. The relief valve has failed-elosed and allowed the Mco's internat pressure to increase to a value just below the rupture disk rupture set point. 
BHowdown of the MCO through either of these two paths would be reay similar inasmuch as each path contains a $0.635 \mathrm{~cm}(0.25 \mathrm{inh}$. $)$ diameter restriction, but blowdown would start at a higher pressure for the case of the pupture disk rupturing. The higher pressure cuse will result in a higher soupe tem? therefore the rest of this accident discussion is in terms of pupturing the pupture disk.

A dropped $\mathrm{MCO}$ with internal pressure near the nupture disk set point ereates a dose consequence hazard only if the accident results in rupture of the rupture disksimutaneous with the $M C O$ coming to a sudden stop, after the fall, in the $M A M M$ or the storage tube. If the $M C O$ is dropped into a storage tube-and the rupture disk ruptures, the gases within the $M c 0$ will cany

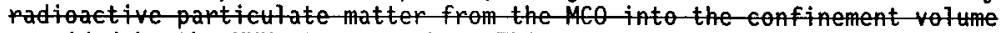
provided by the MHIM storage tube. This MHII storage tube-volume is vented to the CSB through a HEPA filter. A leak in the seal between the MHI and the top of the storage tube could provide a pathway for contaminants to bypass the filter and enter the CSB wich could then leak airborne-contaminants to the environment.

An $M C O$ can be dropped into a-storage tube already containing anow $M C O$ in the bottom position, or it can be-dropped into an empty-storage tube. If the drop occurs into a storage tube that already contains an $M C O$, the ensuing 14144 tube pressure will be higher than if the drop oceurs in a tube that does not contain another MCO because the confinement volume-is larger with onfy-one HCO, and the elevation of the MCO release path will be closep to the elevation of the MHIM storage-tube-interface where-a leak to the CSB could Occur. Based on presurization of the MHII and the elevation of the release point, it is conservative to assume that the $M C O$ drop occurs in a storage tube that already contrias an $4 C O$ in the bottom position.

Increasing prestre in the $M C Q$ to a watte appoling but not exeding the pupture disk rupture pressure requires severat off normal conditions. Finst, the dropped $M C O$ must contain a sufficient quantity of water to produce gases from radiolysis and chemical reactions to-increase the MCO internat pressure to about 1.1-MPa $\left(1657 \mathrm{~b} / \mathrm{in}_{2}^{2}\right.$ absolute). During staging, the. HCO is equipped with the $1.0 \mathrm{MPa}\left(150 \mathrm{lb} / \mathrm{in}^{2}\right.$ absolute) rupture disk and a relief

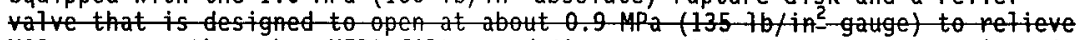
MCO pressure through a HEPA filter and then reseat (reseat pressure unknown). Increasing the $M C O$ pressure to the rupture disk pressure, therefore, requires failure of the pressure relief valve to open.

In addition, impact limiters both above and below the bottom $\mathrm{MCO}$ will peduce impact forces on the bottom $M C O$ and protect the pressure relief valve

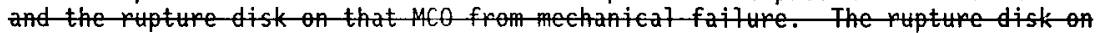
the bottom $M C O$ in the staging tube is assumed to withstand the effects of the droppe $\mathrm{MCO}$ and neither rupture becuse of internal pressure nor breach because of mechanical failure as a consequence of the aceident. Rupturing of a pupture disk would require that the $\mathrm{MCO}^{\prime}$ 's internal pressure be near the mupture disk setpoint differential pressure of $1.0 \mathrm{MPa}\left(150\right.$. $\mathrm{b} / \mathrm{in}^{2}$-absolute). Achieving MCO internal pressure of this magnitude-requires that a sufficient quantity of gas be generated to increase the differential pressure to $1.0-14 P_{a}$ $\left(150 \mathrm{7b} / \mathrm{in}^{2}+\right.$ and that the pressure relief valve fatiure to open. The

probability of two such MCOs residing in the same storage tube and being 
involved in the accidental drop-of an $M C 0$ is sufficiently remote that it can be disregarded.

3.4.2.3.2 Source Term Analysis. Because the bottom MCO does not-nuture as a consequence of dropping another $M C O$ - top of it, the dose consequences of the $M C O$ drop accident are-the result of release of particulate matter from just one MCO, pressurized to approximately $1.1-M P a-(165-1 b /$ in 2 absolute), with the contained fuel jostled simultaneously with the pupture of the pupture disk. This accident also is possible for the sitution where the MCO is droped within the 14144 while being transported within the CSB. For this ease, the particulate release from the $\mathrm{MCO}$ is assume to be the same as droping the HCO into a storage tube since the effect of jostling the-fuel for a drop of a few feet op tens of feet cannot be differentiated. However, the confinement wolume of the $\mathrm{MHH}$ is less than the confinement volume involved in dropping an $M C O$ into a storage tube (the combination of the MHM and the storage tube). consequently, pressure in the confinement volume-will be higher for the "114m only" confinement, resulting in a reduction of the amount of particulate holup (of radioactive material from plateout and settling) for the smaller confinement volume. Holdup in confinement is not considered in the andyses for the MCO drop acident (at this time), but on the basis of the above argument, it-is intuitively obvious that the limiting MCO drop aceident, with pespect to particulate released from the MHM, is the ease-where the MCO is dropper within the MHA.

Anothep factor that must be considered is the potential for leakage at the seal between the MHIM and-the storage tube or the-MHA turret seal. The MHIM is continutusty vented to the $C S B$ through a duct with a safety significant HEPA filter; inert purge-gas is continuously fed into the-MHA. Because the confinement volume for the drop within the MHA4 is smaller, the confinement pressure witl be higher, the particulate concentration will be higher, the probability of plugging the HEPA filter and/or blowing the HEPA filter - out, and the probability of falling-the-seal (assuming that the design presure for both seats is the same) is greater for the case of dropping the MCo within the MHHA.

The bBlowdown of the dropped MCO proceeds in a manner similar to that of an overpressurized $\mathrm{MCO}$, but the effects of jarring the fuel in the dropped $\mathrm{MCO}$ must be taken into account in estimating the release from the dropped $M C O$. DOE-HDBK-3010-94, Subsection 4.4.3.3.1, "Vibration Shock" (Mishima 1994), identifies a bounding value for ARF of 0.001 for the suspension of powder-7ike surface contamination by shock-vibration. Experiments discussed in DOE-HDBK-3010-94, Subsection 4.4.3.3.2, "Large Falling Object Impact or Induced Air Turbulence" (Mishima 1994), involving the suspension of powders into flowing air caused by impact of large pieces of debris on plywood also indicated a maximum ARF of 0.001. DOE-HDBK-3010-94 (Mishima 1994) also states that particles comprising surface contamination are assumed to be more widely dispersed and not as agglomerated as "thick" layers of particles that represent powders. Therefore, for "clumps/piles" of powder, the bounding value for the RF is 0.1 (Mishima 1994, Subsection 4.4.3.3.1) because of the difficulty of deagglomerating powders.

An RF of 0.1 in this case is still-a conservative RF-value for the Mce particulate-because of the inherent difficulty of removing some of the particulategron tre ruel. This difficulty is indicated in the description of 
assumptions used in the bounding particulate calculation (Wibog 1964)

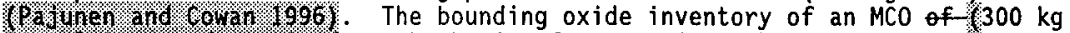
$[660 \mathrm{~Tb}]$ ) was determined on the basis of assumptions that particulate could theoretically remain in several locations on fuel assemblies, evelie after

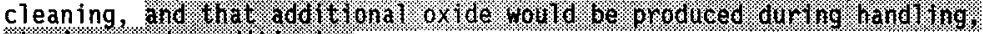

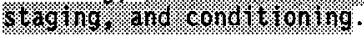

- Panticulate could remain at the end of an assembly whe the unamim metal has corroded away leaving a-cladding shell filled with fuet particulate. (The end-eaps of the-fuel elements in this caleutation had to be asstmed to be in place; this is a description of a "defectivel fuel element. If more oxide was generuted, the end cup would have been displaced, and the fuel element would have been elassified as "ball and put into a serap basket-)

- Panticulate could remain-in a general copposion layer covering the exterior surfaces of the assembly. (This is a $50 \mathrm{~mm}$ thick layer of oxide that has been observed to be sustained un unimmetal without spalling. Note that this panticulate layep is assumed to coat the major exterior assembly surfaces even though the majority of the exterion of most assemblies will consist of the Zircaloy 2 etading.)

- Particulate could remain in pockets in the form of blisters under the cladding. (This inventory of particulate is material enclosed by essentially unbroken-eladoing.)

- Particulate could remain as a build up plug in the assembly flow channel regions. (This panticulate is packed so tightly that it could not be removed by the eleaning process and was not shaken toose during handling.)

It can be seen that the The majority of the particulate that survived the fuel cleaning (i.e., remained with the fuel) and is presumed to be in the bounding $\mathrm{MCO}$ before hot conditioning will be occluded under the cladding and not readily available for release as fine particles. Therefore, an ARF of 0.001 with an RF of 0.1 is considered conservative for the MCO drop accident. With material at risk (MAR) of $300 \mathrm{~kg}(660 \mathrm{lb})$ oranium oxide inventory of as sulied 10 . 60 . 10 an $\mathrm{MCO}$, the amount of released respirable

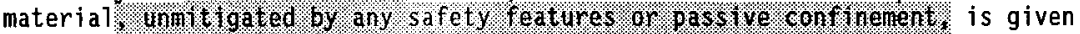
by the following equation.

$$
\begin{aligned}
& \text { Respirable material released from the } M C 0=\text { (MAR) (ARF) (RF) } \\
& \quad=(300 \mathrm{~kg})(0.001)(0.1) \\
& =0.030 \mathrm{~kg} \\
& \quad=30 \mathrm{~g} \text { of respirable material released. }
\end{aligned}
$$

This $30 \mathrm{~g}$ of respirable particulate will be released into the MHM 01 Mus storage tube confinement. At the time of the MCO drop, the-fHAM confinement is being purged with an inerting gas. The presence of the Millos HEPA filter and the assumption of the design leak rate for the MHM seals bould provide for some additional holdup in MHM confinement. 
3.4.2.3.3 Consequence Analysis. The following conditions are necessary for this accident to occur.

- The MCO being moved contains enough water to result in internal

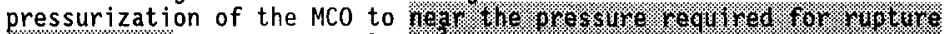

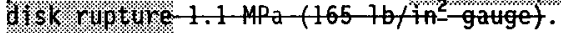

- The pressure relief valve for this MCO has failed to open, or the pressure relief valve fails open and the HEPA filter is corroded to the extent that it permits the flow of unfiltered gas.

- The MCO is dropped while being handled in the MHM.

- The effect of dropping an MCO increases the MCO pressure because of distortion of the MCO and/or stresses the rupture disk sufficiently to cause rupture of the rupture disk.

With the assumption of no holdup of particulate in the MHM or in the CSB, the onsite and offsite dose consequences are calculated from the following equation.

$$
\mathrm{D}=\mathrm{M} \times \frac{X}{\mathrm{Q}} \times \mathrm{R} \times \mathrm{C}
$$

where

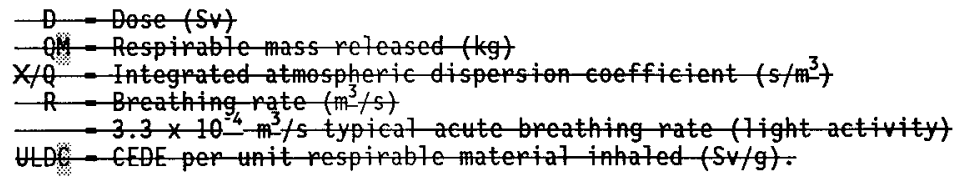

For the-onsite receptor: $00100 \mathrm{cted}$ worker

$$
\begin{aligned}
D(\mathrm{~Sv}) & =(30 \mathrm{~g})\left(0.0341 \mathrm{~s} / \mathrm{m}^{3}\right)\left(3.3 \times 10^{-4} \mathrm{~m}^{3} / \mathrm{s}\right)(4,300 \mathrm{~Sv} / \mathrm{g}) \\
& =1.45 \mathrm{~Sv} \\
& =145 \mathrm{rem} .
\end{aligned}
$$

For a receptor at the Hanford Site boundary

$$
\begin{aligned}
D(\mathrm{~Sv}) & =(30 \mathrm{~g})\left(1.32 \times 10^{-5} \mathrm{~s} / \mathrm{m}^{3}\right)\left(3.3 \times 10^{-4} \mathrm{~m}^{3} / \mathrm{s}\right)(4,300 \mathrm{~Sv} / \mathrm{g}) \\
& =0.56 \mathrm{mSv} \\
& =0.056 \mathrm{rem} .
\end{aligned}
$$

For a receptor at the near riverbank

$$
\begin{aligned}
D(S v) & =(30 \mathrm{~g})\left(1.96 \times 10^{-5} \mathrm{~s} / \mathrm{m}^{3}\right)\left(3.3 \times 10^{-4} \mathrm{~m}^{3} / \mathrm{s}\right)(4,300 \mathrm{~Sv} / \mathrm{g}) \\
& =0.83 \mathrm{mSv} \\
& =0.083 \mathrm{rem} .
\end{aligned}
$$

Dose consequences calculated for this accident are given in Table 3-12+3. 
Table 3-1213. Unmitigated Dose Consequences for Failure of a Multicanister Overpacks during Handling.

\begin{tabular}{|c|c|c|c|}
\hline \multirow{2}{*}{ Receptor location } & \multicolumn{2}{|c|}{ Point source, without stack } & \multirow{2}{*}{$\begin{array}{c}\text { Guidelines } \\
\text { Sv (rem) }\end{array}$} \\
\cline { 2 - 3 } & $\begin{array}{c}\text { X/Q without } \\
\text { plume meander } \\
\left(\mathrm{s} / \mathrm{m}^{3}\right)\end{array}$ & $\begin{array}{c}\text { Total GEDE } \\
\text { Sv (rem) }\end{array}$ & $\begin{array}{c}5.0 \mathrm{E}-02 \\
(5.0)\end{array}$ \\
\hline $\begin{array}{c}\text { Onsite } \\
(100 \mathrm{~m} \mathrm{E})\end{array}$ & $3.41 \mathrm{E}-02$ & $\begin{array}{c}1.45 \\
(145)\end{array}$ & $\begin{array}{c}5.0 \mathrm{E}-03 \\
(0.5)\end{array}$ \\
\hline $\begin{array}{c}\text { Hanford Site boundary } \\
\text { (18.3 km E) }\end{array}$ & $1.32 \mathrm{E}-05$ & $\begin{array}{c}5.6 \mathrm{E}-04 \\
(5.6 \mathrm{E}-02)\end{array}$ & $\begin{array}{c}8.0 \mathrm{E}-03 \\
(0.5)\end{array}$ \\
\hline $\begin{array}{c}\text { Near riverbank } \\
(15.0 \mathrm{~km} \mathrm{E)}\end{array}$ & $1.96 \mathrm{E}-05$ & $(8.3 \mathrm{E}-02)$ & \\
\hline
\end{tabular}

CEDE = ominthof effective dose equivalent.

The total release calculated for the dropped $M C O(300 \mathrm{~g})$ is conservative because it is based on the flowing MCO gas simply entraining, or sweeping up, the particulate matter. This particulate, however, must then be transported upward, within the MCO, for distances ranging from a few inches to more than $4 \mathrm{~m}$ (13 ft), to a $2.5-\mathrm{cm}-(1.0-i n .-)$ diameter port in the MCO shield plug that has right angle bends and a $0.635-\mathrm{cm}-(0.25-\mathrm{in.-})$ diameter orifice. The particulate matter is assumed, in the above calculation, to be carried along this path out of the MCO. No credit was taken for deentrainment or agglomeration and sedimentation of the particulate-

The storage tube and/or MHM confinement volume is a passive confinement system that is vented through a HEPA filter and has a mechanical seal at the bottom of the MHM Euruet. This confinement system must be in place during an MCO drop accident (the MCO is dropped by the MHM) and any leakage that bypasses the HEPA filter is expected to be less than one percent. Therefore, any release from the MCO can be expected to be further reduced by a factor of 100 because of holdup in the secondary confinement. The particulate is released from the MHM into the CSB atmosphere where dilution and further sedimentation take place before the material leaks out of the building to the environment.

3.4.2.3.4 Comparison to Guidelines. If this accident is not mitigated or prevented by designed safety features, the radiological dose consequence to the onsite receptor $100 \mathrm{~m}(328 \mathrm{ft}$ ) east of the facility is $1.45 \mathrm{~Sv}$ (145 rem). The dose to the offsite receptor at the Hanford Site boundary is $5.6 \times 10^{-4} \mathrm{SV}$ $\left(5.6 \times 10^{-2} \mathrm{rem}\right)$; and at the near riverbank it is $8.3 \times 10^{-4} \mathrm{SV}$

$\left(8.3 \times 10^{-2} \mathrm{rem}\right)$. This dose exceeds that provided in Section 3.3.2.3.2. for the onsite receptor. This warrants safety-significant features to mitigate or prevent the release.

Section 3.3.2.3.2 discusses application of risk-based assessment of accident consequences. If the estimated frequency of the event sequence of the accident can be shown to be low enough, an adequate safety margin relative to the risk acceptance guidelines could be shown. This risk-based approach to 
accident analysis is not being applied at this stage of CSB design. However, an assessment of the estimated frequency of crane drops is given here to provide insight into the credibility of the scenario.

Cranes and hoists for the CSB are to conform to the codes and standards addressed in Section 2. 5. $-2 \cdot 4 \cdot 2$. The NRC equivalency review, WHC-SD-SNF-DB-003 (Garvin 1996), has identified ANSI/ANS-57.1-1992, Design Requirements for Light Water Reactor Fuel Handling System (ANSI/ANS 1992b), as a design requirement. In addition, as the design of the CSB and its and shipping cask progresses, consideration will be given to specific features that can be included in the handling equipment to decrease the risk of crane failure that could lead to uncontrolled lowering of an MCO or shipping cask. Training and procedures for use of the handling equipment also will be augmented.

However, even with such steps taken to decrease the risk of failure of the $\mathrm{MCO}$ and cask handling equipment, this postulated event must be analyzed as a credible event. The risk of crane failure for a crane used in nuclear applications to which improved procedures and training have been applied is from $1.0 \times 10^{-5}$ to $1.5 \times 10^{-4} \mathrm{per} 1 \mathrm{ift}$ (NRC 1980). Bur no norna o operat tons

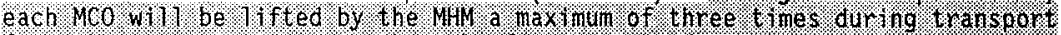

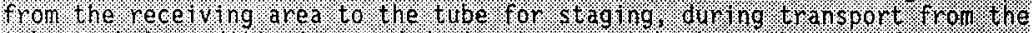

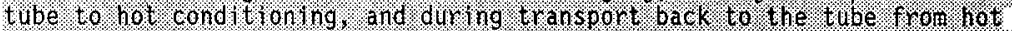

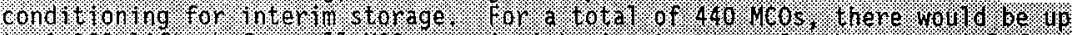

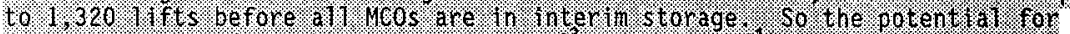

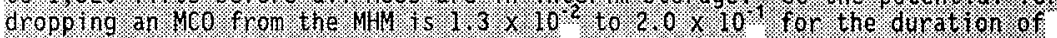

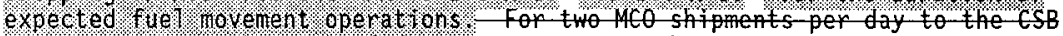
(Swenson 1996), the pisk-of dropping an MCO op shipping cask is from $0.73 *$ $10^{-2}-t 0-1.1-10^{-1}-$ per-yeur. While careful design, training, and procedure considerations may significantly reduce this risk, it is not expected that they would reduce the risk to less than $1 \times 10^{-6}$ per year, the level at which the event could be considered as "beyond extremely unlikely," thereby requiring no analysis.

3.4.2.3.5 Safety-Class Structures, Systems, and Components and Technical Safety Requirements Controls. Reduction of the risk from an MCO release following a drop by the MHM requires safety-significant confinement around the MCO at all times while the MCO is being moved by the MuM. This would require safety-significant design of the MHM, the storage tube and the MHM-tube interface seal for confinement of the release.

Because the $M C O$ is designated safety class for its confinement containment-function, it will be designed to sustuin credible drops from handling equipment without catastrophic failure. The MCO design must be shown to-resist-breaching if another $M C O$ - is dropped-upon it with the-bottom-impact absorber in place. The impact absorber is designated safety class.

The tube also is credited for a safety-class function to protect the MCO. Therefore, the tube design must also be shown to withstand, without breaching, the uncontrolled drop of an MCO into it.

The MCO has a safety-class function for containment-conflinement of the SNF. Safety-class features are incorporated into the CSB design to maintain this function during credible accidents. Design analysis, to be-included in 


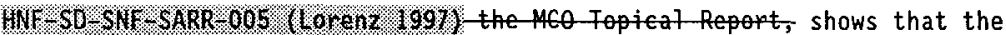
impact +imiter-absover at the bottom of the tube will prevent catastrophic failure both of an MCO dropped to the bottom of the tube and of both MCOs if one is dropped into the tube with another already in place. The impact fimiter-asovoer at the bottom of the tube must therefore be designated safety class for protection of the structural integrity of the MCO.

A second impact 7 imiter bos orrer will be placed between the two MCOs. This impact Fimiter asoorber is needed to protect the functioning of the

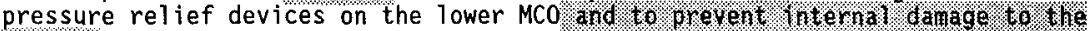
too. IICO. The unfiltered pressure relief path provides a safety-class function to protect the MCO from catastrophic failure from excessive internal pressure. Therefore, the impact 7imiter alsorber between the MCOs provides a safetyclass function insofar as it protects against failure of the unfiltered pressure relief device to relieve MCO internal pressure.

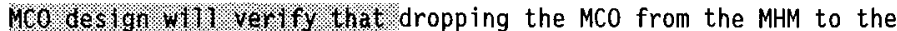

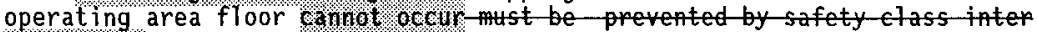

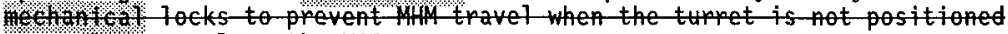
properfy to enelose the $\mathrm{HCO}$.

3.4.2.4 Hydrogen Gas Combustion. The MCO destign, and the-CSB designs and processes will incorporate design features to reduce the potential for hydrogen combustion events in the CSB to the "beyond extremely unlikely" frequency category defined in DOE-STD-3009-94. Hydrogen combustion inside the MCO must be prevented to protect the safety-class functions of the MCO for containment of fuel-contsinging the furel and for mantolumg the fuel in a configuration that is shown to not support nuclear criticatity.

Hydrogen gas will be produced in the MCO from the corrosion of uranium, radiolys is of water, and degradation of uranium hydride. The primary source of hydrogen in the MCO is water, which may be present as free water, water of hydration associated with oxides, or water that is chemically adsorbed on surfaces. Both fuel cleaning before packing into the MCO and the-cold vacuum drying are designed to limit the available water in the MCO before-it the WoO is shipped to the CSB. The-Hot conditioning additional water and hydrogen before the fuel is placed in interim storage.

The amount of water that remains in the MCO following cold vacuum drying and, to a lesser extent, following hot conditioning cannot be-quantified accurately determined. Therefore, it must be assumed that hydrogen concentrations in the MCO atmosphere will increase during staging and again during interim storage. To avoid the potential for hydrogen combustion, the design must be shown to prevent the presence of oxygen in the MCO atmosphere in quantities that would support a sustained combustion reaction.

In add twon to fydrogen, oxygen gas will be produced in the MCO by radiolysis of water. To prevent the MCO atmosphere from attaining a flammable mixture of hydrogen and oxygen, it will be shown by analys is that the oxygen gas will be removed from the atmosphere by reaction with the fuel surface available in the MCO, or by compounds or substrates added to the MCO for that purpose. 
Hydrogen combustion events in the CSB have been postulated to ocou

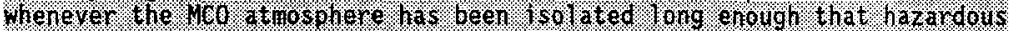

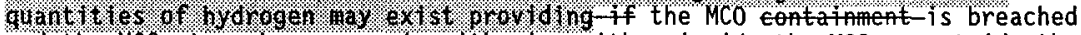
and the MCO atmosphere can mix with air, either inside the MCO or outside the MCO in the service enclosure, the MHM, op the tube. Prevention of flammable mixtures will be accomplished by during receiving and by maintaining inert atmospheres around the MCO Whing.

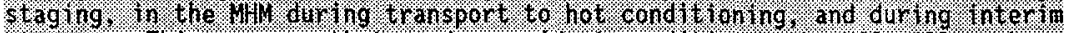
Storage. This ensures that, under accident conditions, the MCO wi17 exchange gases only with an environment deficient in oxygen. . ortteel ta for ocoeptange

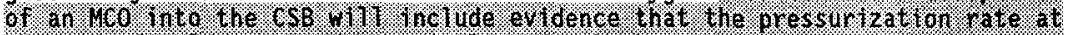

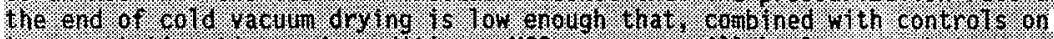

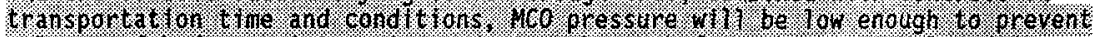

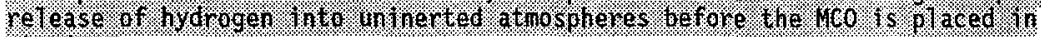
strating.

CSB systems to ensure dequate purging with inert gas during servicing, and maintenance of inert atmosphere during handling, staging, and interim

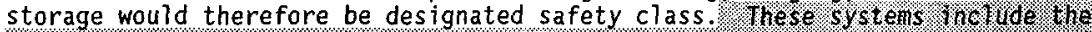

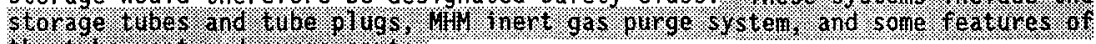

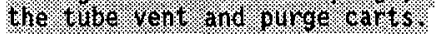

\subsubsection{Multiple Multicanister Overpack-Tube Failures during Staging or} Interoli Storage. The CSB storage vault will be designed in such a way that naturat air circulation will maintain MCO temperatures low enough to prevent failure. Unacceptably high temperatures could result in pressurization, and subsequent breach, of the MCOs from gas expansion and accelerated gas generation from chemical reactions.

3.4.2.5.1 Scenario Development. Debris from high winds, or snow, frost, or ashfall accumulations, plug the inlet or outlet to the vault cooling plenums, or. Also, an external fire (e.g., range fire) impacts natural circulation cooling. The natural airflow is hampered or completely stopped. The MCOs begin to heat up and may reach a temperature at which chemical reactions of the fuel are accelerated. The product gases of the reactions, as well as the temperature increase, cause increased internal pressure in the vessel. Eventually one or more MCOs relieve pressure through the pressure

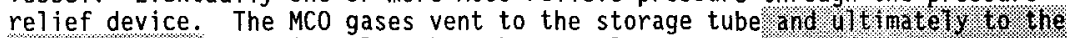
0pera Ung derk. Wtimately, the tube may also pressurize and breach, feleasing the gases to the vault.

3.4.2.5.2 Source Term Development. This is an accident scenario in which a single event could lead to releases from multiple Mcos. During staging, the MCOS will be provided with a filtered pressure relief valve that will allow excess MCO gases to be released to the storage tubes. Both MCO and tube will be filled initially with inert gas. The MCOs will contain bound water that would be released at elevated temperatures, as well as residual free water that would vaporize. The water reacting with the fuel would increase temperatures further.

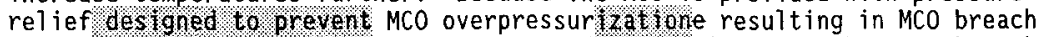
would not oectr. However, the gases would pressurize the tube and the tube

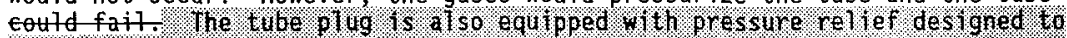

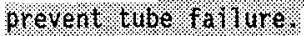


During interim storage, the fuel in the MCO will be covered with an inert

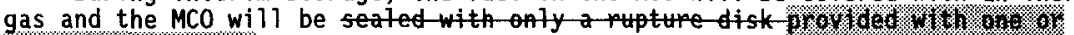

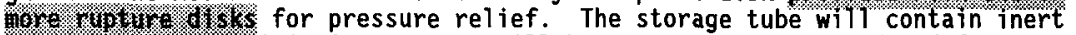
gas. The Hot conditioning will have removed both bound and free water and covered free metal surfaces with a nonpeactive-oxide-layer. Therefore, the potential for accelerating chemical reactions is less during the interim storage phase.

An additional hazard from extended loss of cooling is the heatup of the vault walls to a temperature that would compromise their structural strength.

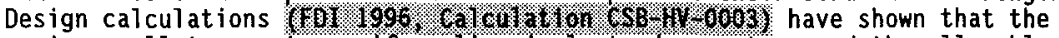
maximum wall temperature, if cooling is lost, does not exceed the allowable limit for structural concrete.

The rate of MCO temperature increase and the maximum 1 fo fuet temperature

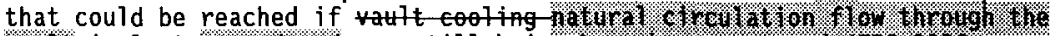

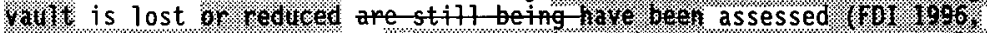

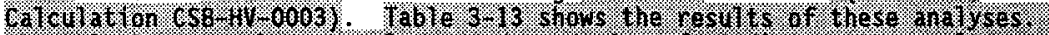

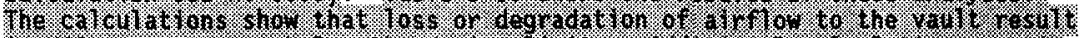

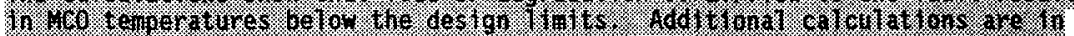

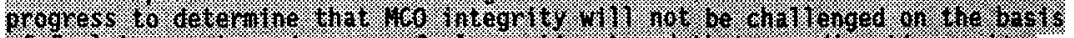

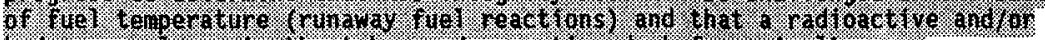

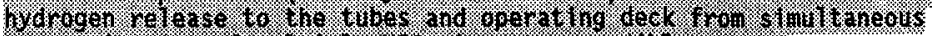

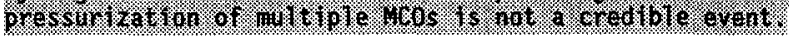

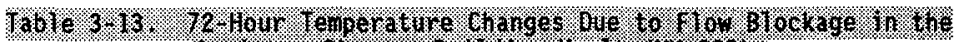

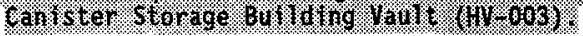

\begin{tabular}{|c|c|c|c|c|}
\hline & Hementraturat & W\%or & 100\% & 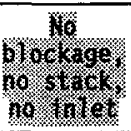 \\
\hline 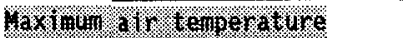 & $45 \%$ & $164 \%$ & $34 \%$ & H6 \\
\hline 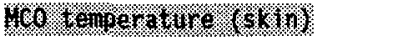 & $25 \%$ & $26 \% \%$ & 328 & $26 \%$ \% \\
\hline 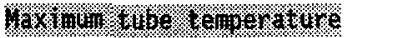 & $204 \%$ & $3 \% 10$ & 200 & 36 - \\
\hline 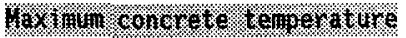 & 30.4 & $15 \%$ & 228 & \% \\
\hline
\end{tabular}

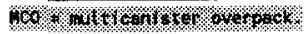

If it is detemine that fuel temperatures could exeet $300^{\circ} \mathrm{C}$ (572-if) if passive cooling is lost, controls to ensure that adequa natural ventilation flow is maintaine will be established. This measure- of sensitivity of the $M C O$ - cooling to natural circulation flow will atso allow for an assessment of the sensitivity of $M C O$ cooling to range fires. Tho of the of of

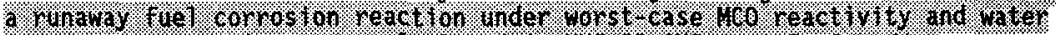

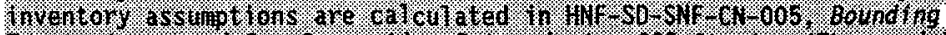

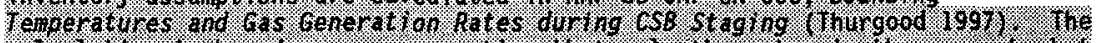

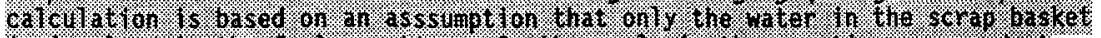

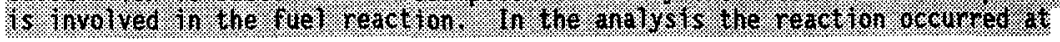




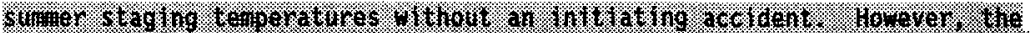

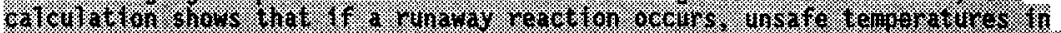
W.

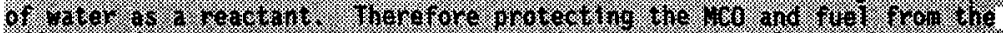

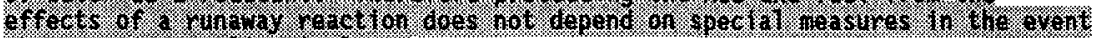
W.t.

\subsubsection{Beyond Design Basis Accidents}

Those events that are beyond the current design basis of the facility are not analyzed in detail at this time. They will be addressed in the final SAR as required by Section 3.4.3 of DOE-STD-3009-94. These beyond design basis accidents may include, but are not limited to, (1) spontaneous breach of an MCO during staging or interim storage, (2) fuel ignition events, (3) hydrogen combustion events, (4) collapse of the building's superstructure as a result of human-generated external events (e.g., crash of a light airplane) or natural phenomena (e.g., tornado and tornado-generated missiles, high winds, earthquake, or snow or ashfall loading of the roof), (5) potential failure of multiple MCOs (e.g., as a result of a seismic event), and (6) failure of identified safety-class accident prevention and mitigation features.

The MCO safety-class design must preclude the potential for rupture of the MCO under normal staging and interim storage conditions. The potential for MCO breach caused by internal pressure from chemically generated gases has been discussed in Section 3.4.2.1. Functioning of safety-class SSCs designed to protect the confinement fontainment function of the MCO throughout the toses will prevent placing a damaged MCO in staging or interim storage.

The potential for fuel ignition, or runaway fuel oxidation, will be precluded by pessesign. This will be accomplished by limiting access of

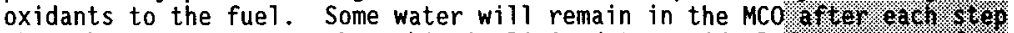
but this is 1 imited to residual free water after cold vacuum drying and the bound water associated with the oxides. After hot

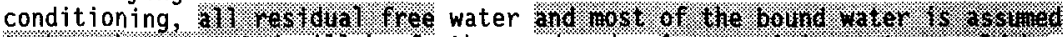

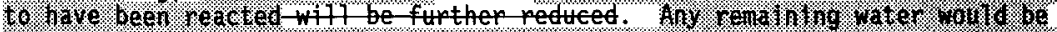

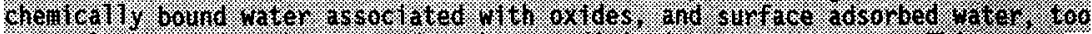

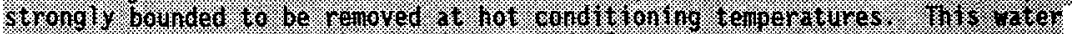

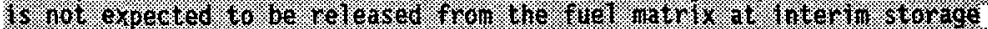

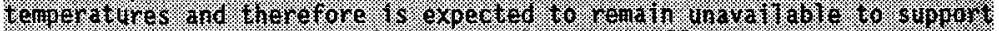

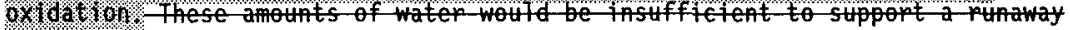
tertion.

Uranium fuel will theoretically burn in ambient air at room temperatures, because of the presence of hydrides. Limiting air availability to the fuel precludes the air-fuel reaction. The primary design feature to limit air availability to the fuel is the $M C O$, and commitment to protect the $M C 0$ confinementfont function except for rupture disk relief and potential breach of -1 ines. Preliminary analysis indicates that air ingress through small penetrations (maximum of two 2.5-cm [1-in.] penetrations), will

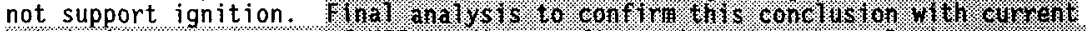

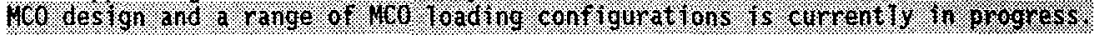


Maintaining an inert atmosphere in the MCO and in the MHM and tube contributes additional assurance that enough oxidant to support fuel burning will not be present.

The vault, tubes, and operating deck floor are designed to withstand all the design basis external loading from human-generated or natural phenomenon events. Superstructure collapse from these events would therefore affect only those MCOs (one or two) in the servicing area or in the MHM at the time of the event. The safety-class SSCs that mitigate or prevent releases from the building, discussed in the other accidents, would presumably also be damaged by the building's collapse. If collapse of the superstructure while MCOs are in service or being handled above the operating deck could result in exceeding offsite dose limits, the structure must also be designed to safety-class standards.

\subsubsection{Safety-Class Design Features}

The accident analyses identified requirements for safety-class or safetysignificant mitigation or prevention of MCO overpressur/wathe events, and all MCO failure events. SSCs to mitigate or prevent the accidents have been suggested.

In the case of MCO overpressurkfortoge, the service station ventilation enclosure, the MHM, the storage tube, and MHM-tube interface seal be

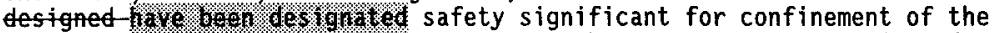
overpressure release. The storage tube, the MHM, and MHM-tube interface seal must also be safety significant for mitigation of crane drop events.

MCO failure events a prevented by safety-class systems to protect the confinement function of the MCO. Interlocks on the MHM to prevent applying force to the MCO while it is partway in the tube, an MHM brake or locking device to prevent $M C O$ shear during a seismic event, and impact absorbers at the bottom of the tube

Design features put in $\mathrm{place}$ to prevent a hydrogen deflagration in the service area, tube, or MHM need to be safety class. Releases from a hydrogen deflagration event in the service area would be-are prevented by a safety-

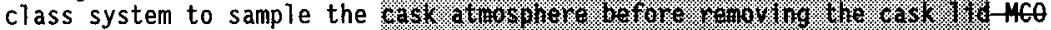
atmosphere before removing the ffCo flanges. Deflagrat ion in the MHM or tube We prevented by safety-class MHM and tube inerting systems.

Safety-class and safety-significant design features identified by the accident analyses are summarized in Table 3-14.

\subsection{REFERENCES}

10 CFR 72, "Licensing Requirements for the Independent Storage of Spent Nuclear Fuel and High-Level Radioactive Waste," Code of Federal Regulations, as amended.

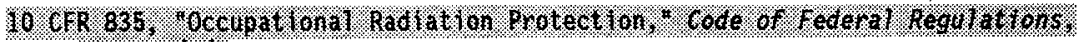
as anended. 
Table 3-14. Preliminary tist-of-Safety-Class and Safety-Significant Structures, Systems, and Components Required by Accident Analysis for the Canister Storage Building. (2 sheets)

\begin{tabular}{|c|c|c|c|}
\hline $\begin{array}{c}\text { Structure, system or } \\
\text { component }\end{array}$ & Safety function & Referenced accident analysis & $\begin{array}{c}\text { Safety } \\
\text { classification }\end{array}$ \\
\hline HCO & Confinoment of fotoeoes & 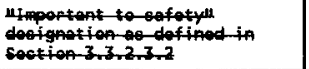 & Sefoty otoses \\
\hline $\begin{array}{l}\text { Service station } \\
\text { ventilation enclosure }\end{array}$ & $\begin{array}{l}\text { Maintain a negative pressure } \\
\text { with respect to the } \\
\text { surrounding atmosphere for } \\
\text { confinement of releases }\end{array}$ & $\begin{array}{l}\text { 3.4.2.1 Release of Mco Gases } \\
\text { Under Pressure during } \\
\text { Handl ing, Staging, or Interim } \\
\text { Storage }\end{array}$ & $\begin{array}{l}\text { Safety } \\
\text { significant }\end{array}$ \\
\hline $\begin{array}{l}\text { Storage tubes and tube } \\
\text { plugs }\end{array}$ & Conf inerrent of releases & 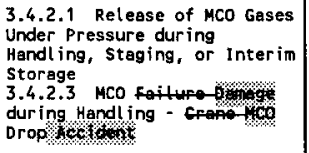 & $\begin{array}{c}\text { Safety } \\
\text { significant }\end{array}$ \\
\hline & 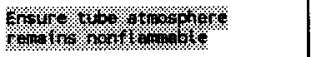 & 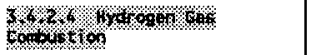 & Kyow \\
\hline & Protection of MCO & 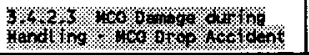 & Safety class \\
\hline МHМ & Conf ine of releases & 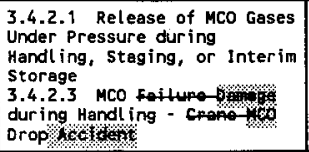 & $\begin{array}{l}\text { Safety } \\
\text { significant }\end{array}$ \\
\hline MHM-tube seal & Confinement of releases & $\begin{array}{l}3.4 .2 .1 \text { Release of MCO Gases } \\
\text { Under Pressure during } \\
\text { Handling, Staging, or Interim } \\
\text { Storage } \\
3.4 .2 .3 \text { MCO } \\
\text { during Handling - } \\
\text { Drop } 4-0 \% \text { ot }\end{array}$ & $\begin{array}{l}\text { Safety } \\
\text { significant }\end{array}$ \\
\hline MHM inert gas purge & $\begin{array}{l}\text { Ensure the MHM atmosphere } \\
\text { remains nonflammable }\end{array}$ & $\begin{array}{l}3.4 .2 .4 \text { Hydrogen Gas } \\
\text { Combustion }\end{array}$ & Safety class \\
\hline MHM interlocks & 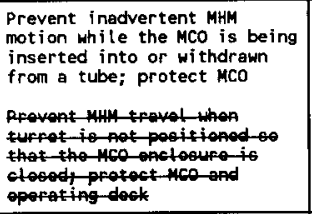 & 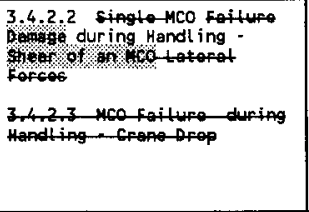 & $\begin{array}{l}\text { Safety class } \\
\text { sofaty }\end{array}$ \\
\hline $\begin{array}{l}\text { MHM brake or locking } \\
\text { device }\end{array}$ & $\begin{array}{l}\text { Prevent mco shearing during a } \\
\text { seismic event }\end{array}$ & 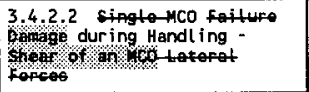 & Safety class \\
\hline $\begin{array}{l}\text { Impact absorber at } \\
\text { bottom of tube }\end{array}$ & $\begin{array}{l}\text { Prevent catastrophic failure } \\
\text { of MCO if MCO is dropped to } \\
\text { the botton of the tube; } \\
\text { protect MCO confinement } \\
\text { function } \\
\text { Prevent failure of both MCOs } \\
\text { if one MCO is dropped on } \\
\text { another; protect MCO }\end{array}$ & 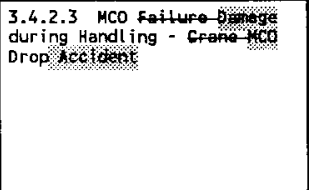 & Safety class \\
\hline
\end{tabular}


Table 3-14. Preliminary tist of Safety-Class and Safety-Significant Structures, Systems, and Components Required by Accident Analys is for the Canister Storage Building. (2 sheets)

\begin{tabular}{|c|c|c|c|}
\hline $\begin{array}{l}\text { structure, system or } \\
\text { component }\end{array}$ & Safety function & Referenced accident anslys is & $\begin{array}{c}\text { Safety } \\
\text { classification }\end{array}$ \\
\hline $\begin{array}{l}\text { Impsct absorber between } \\
\text { NCOs }\end{array}$ & $\begin{array}{l}\text { Protect against failure of } \\
\text { the unfiltered pressure } \\
\text { relief path on the bottom Mco } \\
\text { to relieve MCO internat } \\
\text { pressure }\end{array}$ & 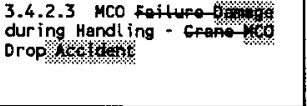 & Safety class \\
\hline $\begin{array}{l}\text { Tube vent and purge } \\
\text { carts }\end{array}$ & $\begin{array}{l}\text { Ensure the tube atmosphere } \\
\text { remains nonf lammable } \\
\text { Conf inement of releases }\end{array}$ & 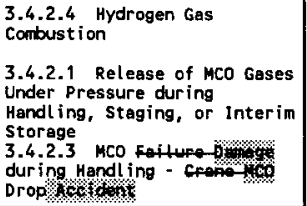 & $\begin{array}{l}\text { Safety class } \\
\text { Safety } \\
\text { significant }\end{array}$ \\
\hline 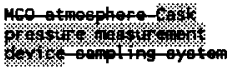 & $\begin{array}{l}\text { Ensure a flammable condit ion } \\
\text { is not created when cask lid } \\
\text { is removed Hco flanges }\end{array}$ & $\begin{array}{l}3.4 .2 .4 \text { Hydrogen Gas } \\
\text { Combustion }\end{array}$ & Safety class \\
\hline
\end{tabular}

MCO = multicanister overpack.

MHM = multicanister overpack handling machine. 
29 CFR 1910, "Occupational Safety and Health Standards, "Code of Federal Regulations, as amended.

ANSI/ANS, 1992a, Design Criteria for an Independent Spent Fuel Storage Installation (Dry Type), ANSI/ANS-57.9-1992, American Nuclear Society, La Grange Park, Illinois.

ANSI/ANS 1992b, Design Requirements for Light Water Reactor Fuel Handling System, ANSI/ANS-57.1-1992, American Nuclear Society, La Grange Park, Illinois.

Brehm, J. R., 1995a, Spent Nuclear Fuel Project Canister Storage Building Preliminary Safety Evaluation, WHC-SD-SNF-PSE-002, Rev. 0, Westinghouse Hanford Company, Richland, Washington.

Brehm, J. R., 1995b, Spent Nuclear Fuel Project Path Forward Preliminary Safety Evaluation, WHC-SD-SNF-PSE-001, Rev. 0, Westinghouse Hanford Company, Richland, Washington.

Daily, J. W., and D. R. F. Harleman, 1966, Fluid Dynamics, Addison-Wesley Publishing Company, Reading, Massachusetts.

Daschke, K. D., 1996, Spent Nuclear Fuel Project Integrated Safety Management Plan, WHC-SD-SNF-PLN-012. Rev. 1, West inghouse Hanford Company, Richland, Washington.

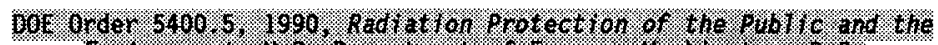

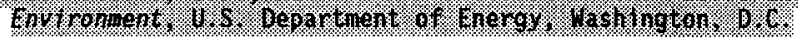

DOE Order 5480.22, 1992\% Technical Safety Requirements, U.S. Department of Energy, Washington, D.C.

DOE Order 5480.23, 1982 Nuclear Safety Analysis Reports, U.S. Department of Energy, Washington, D.C.

DOE Order 6430.1A, 989 \% General Design Criteria, U.S. Department of Energy, Washington, D.C.

DOE-RL, 1995, Hanford Emergency Response Plan, DOE/RL-94-02, U.S. Department of Energy, Richland Operations Office, Richland, Washington.

DOE-STD-1027-92, Hazard Categorization and Accident Analysis Techniques for Compliance with DOE Order 5480.23, Nuclear Safety Analysis Reports, DOE Standard 1027-92, U.S. Department of Energy, Washington, D.C.

DOE-STD-3009-94, Preparation Guide for U.S. Department of Energy Nonreactor Nuclear Facility Safety Analysis Reports, DOE Standard 3009-94, U.S. Department of Energy, Washington, D.C.

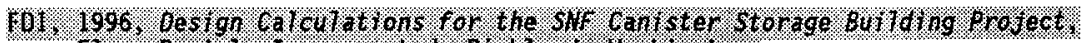

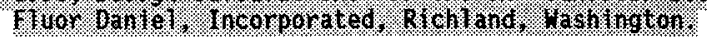


Garvin, L. J., 1996, Spent Nuclear Fuel Project Path Forward, Additional NRC Requirements, WHC-SD-SNF-DB-003, Rev. 2, Westinghouse Hanford Company, Richland, Washington.

Grumbly, T. P., 1995, Concurrence with the K-Basins Spent Nuclear Fuel Project Policy on Nuclear Safety Requirements (Memorandum EM-36-3.1.6.7 to

Manager, U.S. Department of Energy, Richland Operations Office, July 20), U.S. Department of Energy, Washington, D.C.

Hey, B. E., 1993a, GXQ Program Users' Guide, WHC-SD-GN-SWD-30002, Rev. 1, Westinghouse Hanford Company, Richland, Washington.

Hey, B. E., 1993b, GXQ Program Verification and Validation, WHC-SD-GN-SWD-30003, Rev. 0, Westinghouse Hanford Company, Richland, Washington.

Hey, B. E., 1995, Revision 1 to Supponting Caleulations for K Basin ISB (Internal Memo 80150 BEH 94 003 RI to J. R. Brehm, June 12), West inghouse Hanfor Company, Richland, Washington.

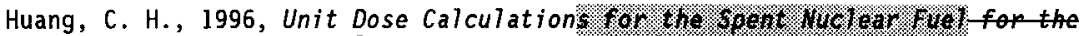

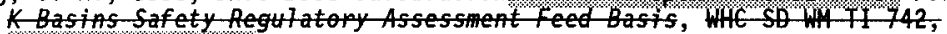
W6. S0.... O. 001. Rev. 0, Westinghouse Hanford Company, Richland, Washington.

ICRP, 1975, Reference Man: Anatomical, Physiological, and Metabolic Characteristics, Publication 23, International Commission on Radiological Protection, Elmsford, New York.

Kummerer, M., 1995, Hazard Category Analysis for the Canister Storage Building, WHC-SD-SNF-HC-007, Rev. 0, Westinghouse Hanford Company, Richland, Washington.

Kummerer, M., and M. Plys, 1996, MCO Blowdown Release Fraction, WHC-SD-WM-CN-079, Rev. 0, Fluor Daniels Northwest, Richland, Washington.

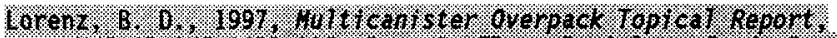

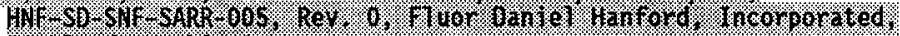

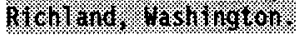

Mishima, J., 1994, Airborne Release Fractions/Rates and Respirable Fractions/Rates for Nonreactor Nuclear Facilities, DOE-HDBK-3010-94, U.S. Department of Energy, Washington, D.C.

Napier, B. A., R. A. Peloquin, J. V. Ramsde17, and D. L. Strenge, 1988, GENII - The Hanford Environmental Radiation Dosimetry Software System, Vol. 1, PNL-6584, Pacific Northwest Laboratory, Richland, Washington.

NRC, 1980, Control of Heavy Loads at Nuclear Power Plants; Resolution of Generic Technical Activity A-36, NUREG-0612, U.S. Nuclear Regulatory Commission, Washington, D. C. 
NRC, 1982, Accident Generated Particulate Materials and Their Characteristics -- A Review of Background Information, NUREG/CR-2651, U.S. Nuclear Regulatory Commission, Washington, D.C.

NRC, 1987, Design of an Independent Spent Fuel Storage Installation (Dry Storage), Regulatory Guide 3.60, U.S. Nuclear Regulatory Commission, Washington, D.C.

NRC, 1989, Standard Format and Content for the Safety Analysis Report for an Independent Spent Fuel Storage Installation or Monitored Retrievable Storage Insta7lation (Dry Storage), Regulatory Guide 3.48, U.S. Nuclear Regulatory Commission, Washington, D.C.

Pajunen, A. L., and R. G. Cowan, 1996, Bounding Particulate Contents of a Multi-Canjster Overpack, WHC-SD-SNF-TI-023, Rev. 1, Westinghouse Hanford Company, Richland, Washington.

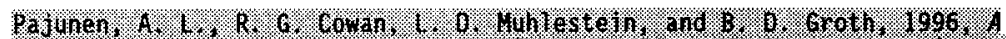

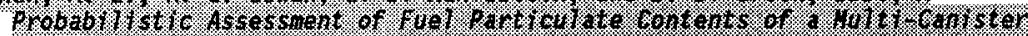

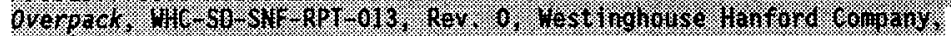

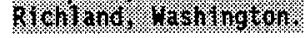

Reynolds, B. W., and W. G. N. Slinn, 1979, Experimental Studies of Resuspension and Weathering of Deposited Aerosol Particles, Report SR-0980-5, Oregon State University, Corvallis, Oregon.

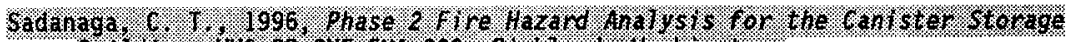

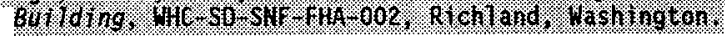

Sehme1, G. A., and C. L. Simpson, 1975, "Initial Correlation of Particle Resuspension Rates as a Function of Surface Roughness Height, "Pacific Northwest Laboratory Annual Report for 1974 to the USAEC Division of Biomedical and Environmental Research, BNWL-1950, Battelle Pacific Northwest Laboratories, Richland, Washington.

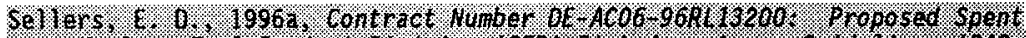

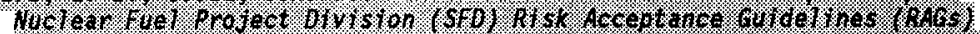

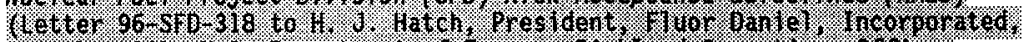

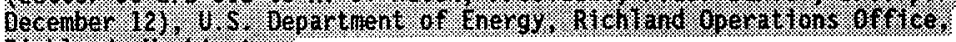

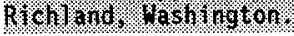

Sellers, E. D., 1996b, Hazard Category for the Spent Nuclear Fuel Project Canister Storage Building (CSB) (Letter 95-SFD-250 to President, Westinghouse Hanford Company, January 10), U.S. Department of Energy, Richland Operations Office, Richland, Washington.

Swenson, C.E., 1996, Perfomane Specifieution for the spent Nuclear fuet Eanister Storage Building, WHC S 0425 , Rev. O, Westinghouse Hanford Eompany, Richtand, Washington.

Tallman, A. M., 1996, Canister Storage Building Natural Phenomena Hazards, WHC-SD-SNF-DB-009, Rev. 4, Westinghouse Hanford Company, Richland, Washington. 


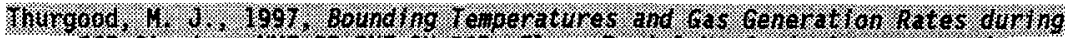

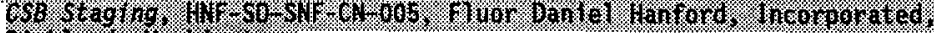

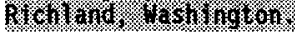

WHC, 1995, Spent Nuclear Fuel Project Configuration Management Plan, WHC-SD-SNF-CM-001, Rev. 0, Westinghouse Hanford Company, Richland, Washington.

WHC CI4 4-46, Safety Analysis Manual, Rev. 1, Westinghouse Hanford Company, Richland, Washington.

Hiborg, J. E., 1996, Fuel Corrosion Product Inventony Safety Approach, WHC SO SAF ER 013, ReV. O, Westinghouse Hanford Company, Richland, Hashington.

Willis, W. L., 1995, 105-K Basin Material Design Basis Feed Description for Spent Nuclear Fuel Project Facilities, WHC-SD-SNF-TI-009, Rev. 0, Westinghouse Hanford Company, Richland, Washington. 
HNF-SD-SNF-RPT-004 REV 6

\subsection{SAFETY STRUCTURES, SYSTEMS, AND CONPONENTS}

\section{1. WTROBUOTON}

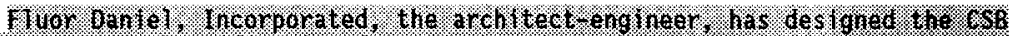

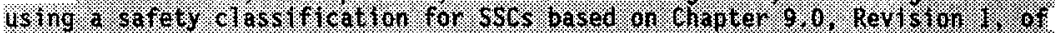

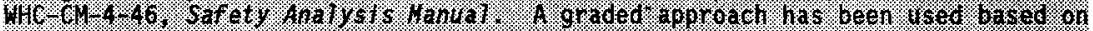

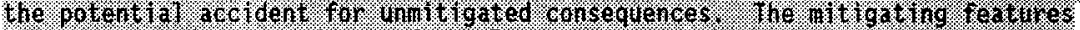

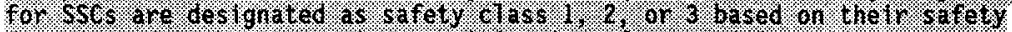

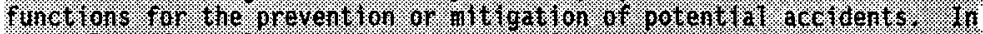

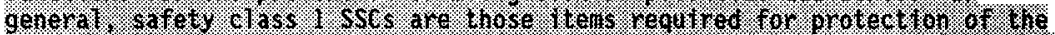

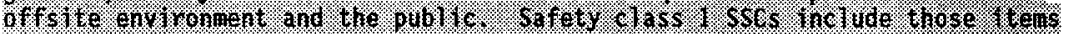

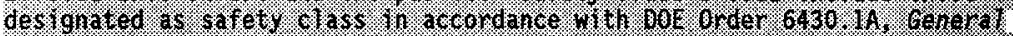

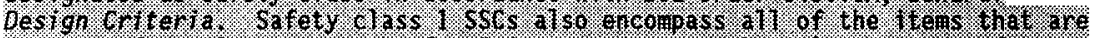

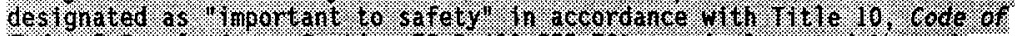

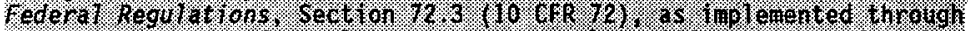

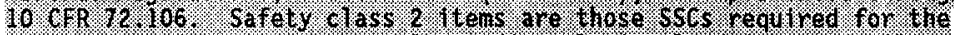

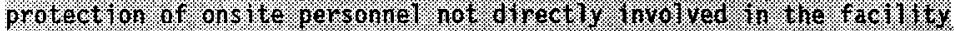

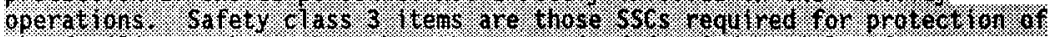

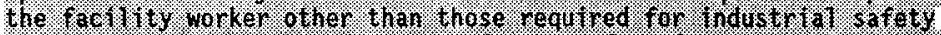

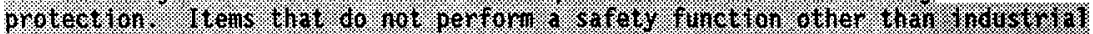

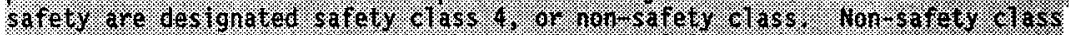
16. a .

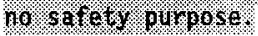

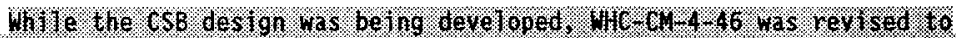

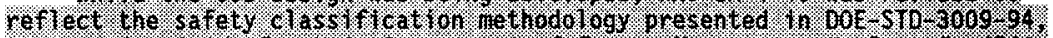

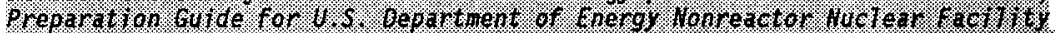

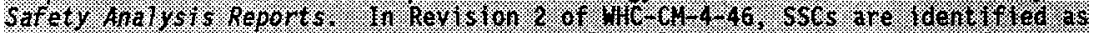

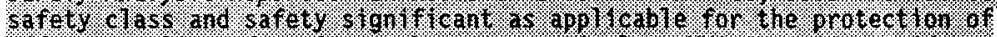

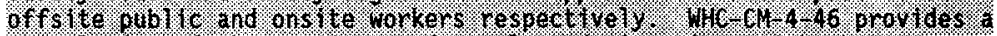

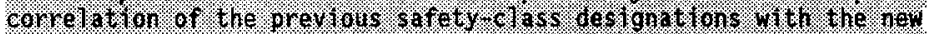

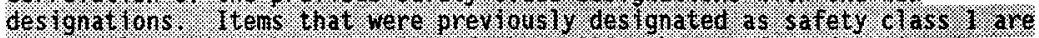

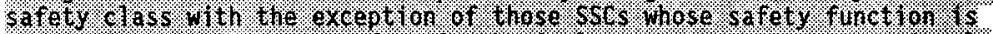

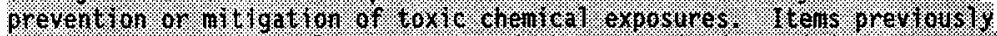

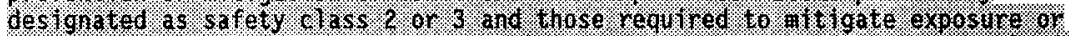

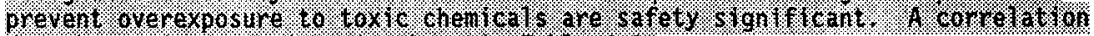

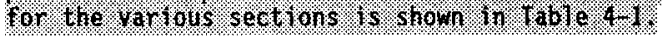

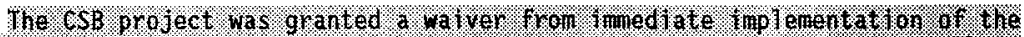

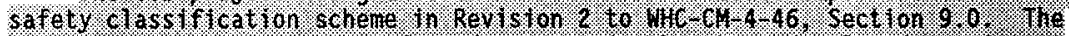

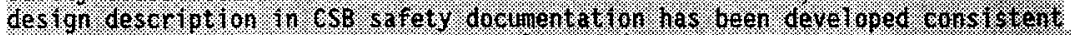

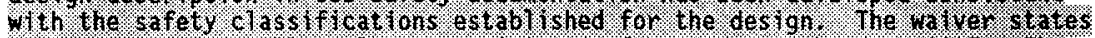

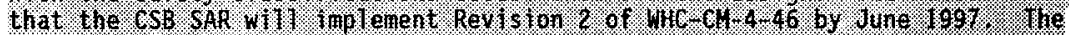

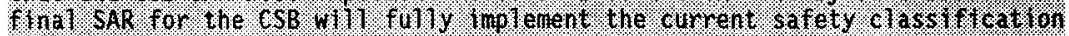
destonat tons:

\subsection{REQUIREMENTS}

This section lists the design codes, standards, regulations, and DOE orders that are required for establishing the safety basis of the facility. The intent is to provide only the requirements that are specific for this chapter and pertinent to the safety basis. 


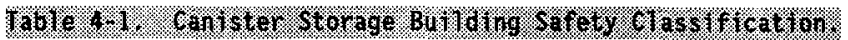

\begin{tabular}{|c|c|c|c|}
\hline $600.0 \%=646 \%$ & 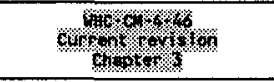 & 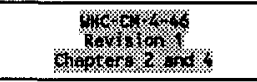 & of $6 \%$ \\
\hline 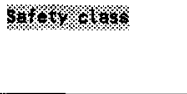 & 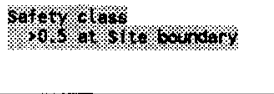 & 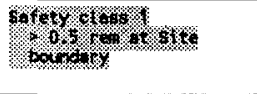 & 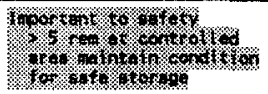 \\
\hline 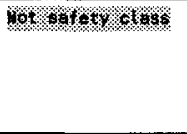 & 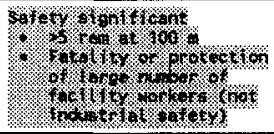 & 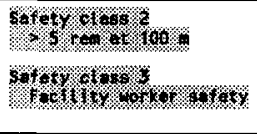 & 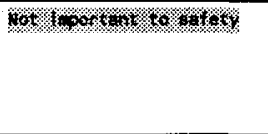 \\
\hline 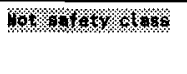 & 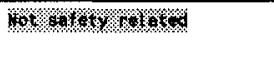 & 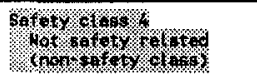 & 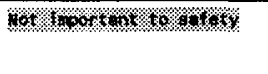 \\
\hline
\end{tabular}

\%. 0 \% / . 3. 10.97 .

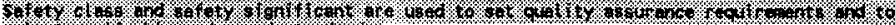

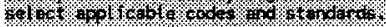

\subsubsection{U.S. Department of Energy Orders and Standards}

The following DOE orders and standards are applicable to the safety basis for the facility.

- DOE Order 6430.1A, 1989, Genera7 Design Criteria. Division 1300-3, "Safety Class Criteria," provides design, fabrication, and testing standards for safety-class items.

- DOE Order 5480.28, 1993, Natura7 Phenomena Hazards Mitigation. This order establishes mitigation requirements for NPHs and target probabilistic performance goals based on the facility performance category. Additional discussion of the NPH performance criteria is provided in Section 1.5.

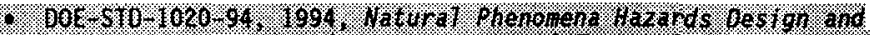

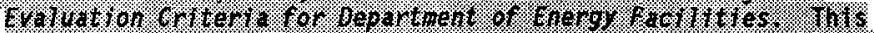

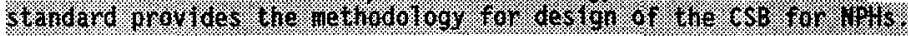

- DOE-RL-HPS-SDC-4.1, Revision 12, 1993, Standard Architectural-Civil Design Criteria, Design Loads for Facilities. This Hanford Site plant standard provides criteria for the design of the below-grade portion of the CSB. This document is invoked by WHC-S-0425, Performance Specification for the Spent Nuclear Fuel Canister Storage Building (Swenson 1996). Section 3.1 and Section 3.3 of this standard provide structural design criteria loads and load combinations for safety class 1 SSCs. These include nominal [sic] dead, live, snow, and soil loads; normal operating loads; and natural phenomena loading of extreme wind, earthquake, ashfall, and flood. The facility design has been evaluated for applicable natural phenomena loads listed on Table 1-23 of Section 1.5, "Natural Phenomena Threats," for the SSCs impacted. These loads are 
higher than 006-2.-WPS.SDC-4.1 loads, particularly those associated with tornado wind and PMP effects. For example, the tornado wind speed from Table 1-23 is given as $322 \mathrm{~km} / \mathrm{h}(200 \mathrm{mi} / \mathrm{h})$ total, versus

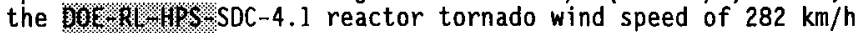
$(175 \mathrm{mi} / \mathrm{h})$. This higher wind speed on the superstructure transmits higher loads to the below-grade portion of the CSB.

\subsubsection{U.S. Nuclear Regulatory Commission Rules and Guidance}

The following NRC rule and guidance is applicable to the safety basis for the facility.

- 10 CFR 72, "Licensing Requirements for the Independent Storage of Spent Nuclear Fuel and High-Level Radioactive Waste," Code of Federal Regulations. The design bases for items identified as important to safety must reflect appropriate combinations of the effects of normal and accident conditions and the effects of natural phenomena. This is implemented by the application of the design criteria for safety-class items in DOE Order 6430.1A to those items identified as important to safety. Applying NRC equivalency requires that SSCS important to safety be jdentified in accordance with 10 CFR 72.3, as implemented through 10 CFR 72.106. Once SSCs important to safety have been identified, the requirements of

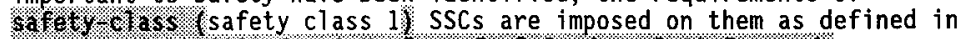

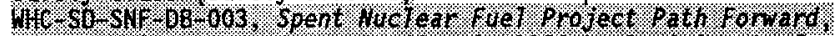

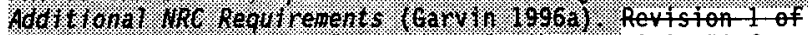
HIC CM 4-46, Safety Analysts Hand, Chapter 9.0, "Safety Classification of Structures, Systems, and Components." Additional discussion of the NRC criteria for mitigation of natural phenomena is provided in Section 1.2.3. An evaluation of the application of

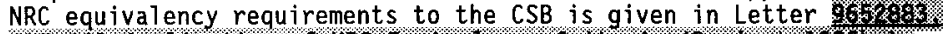

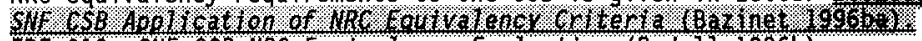

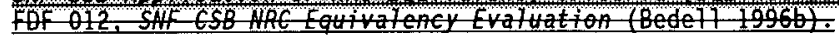

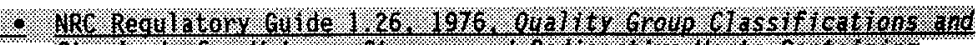

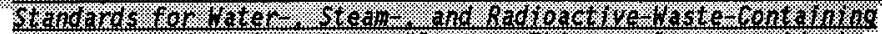

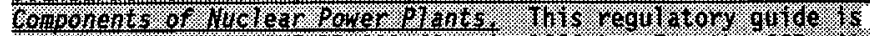

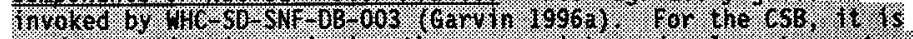

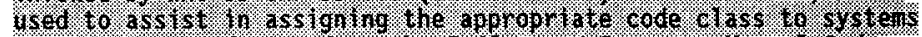

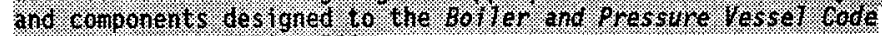

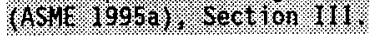

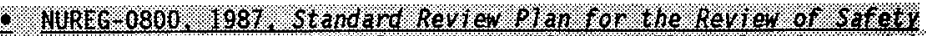

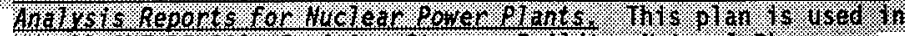

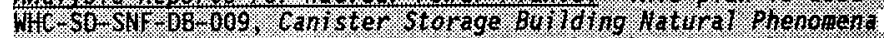

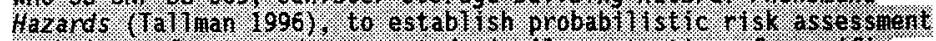

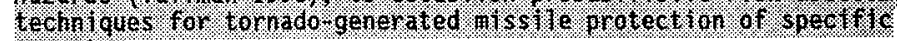
targets. 


\subsubsection{Industry Consensus Standards and Other Documentation}

The following industry standard is applicable to the safety basis for the facility.

- ANSI/ANS-57.9-1992, 1992, Design Criteria for an Independent Spent Fuel Storage Installation (Dry Type). The standard includes requirements for the design of major buildings and structures including physical security and safety features for ISFSIs. The architect engineer has anfomed as asesment of-ANSI/ANS-57.9-1992 (1) 11/10.5. 6022) requirements that are not included in the CSB designihave been ossessed. A complete list and justification is provided in letter FRF-2792, ANSI 57.9 (Jacobs 1996a). The $5 \%$ dead load contingency has been included in the design of the CSB.

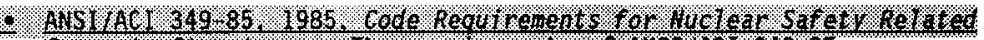

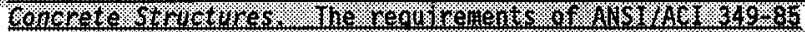

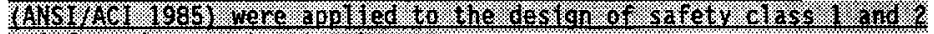

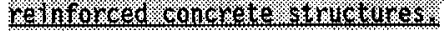

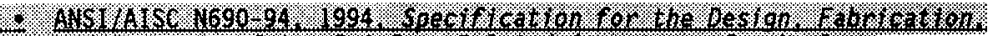

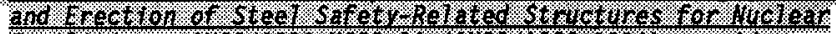

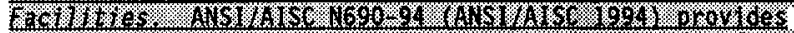

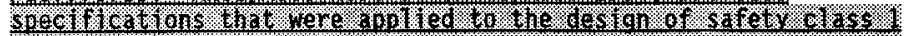

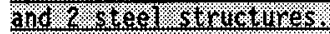

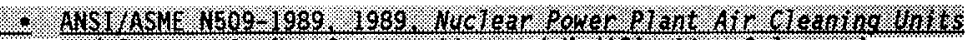

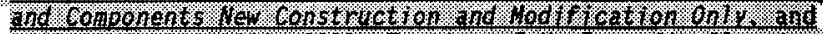

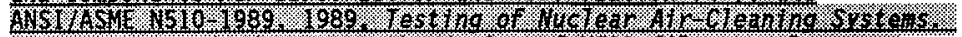

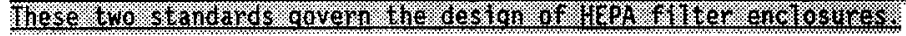

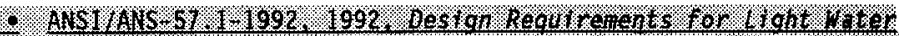

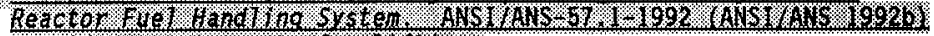

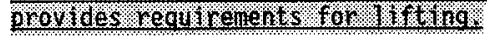

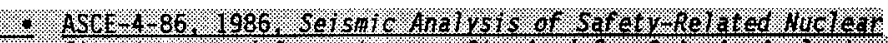

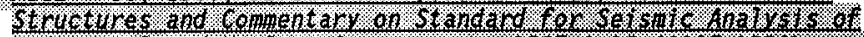

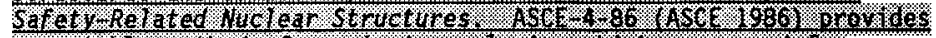

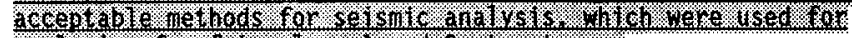

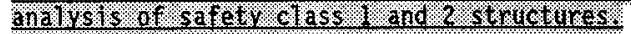

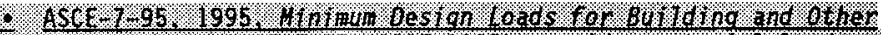

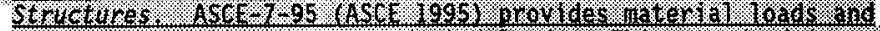

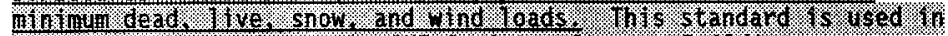

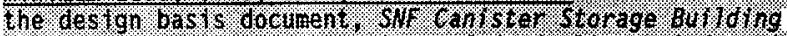

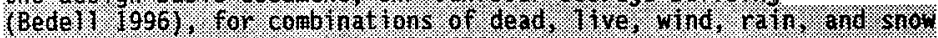

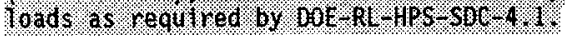

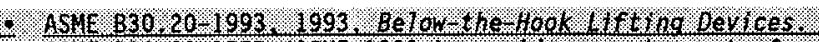

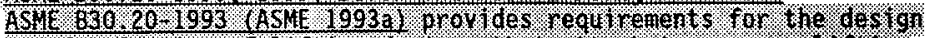

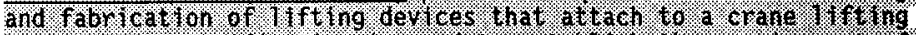

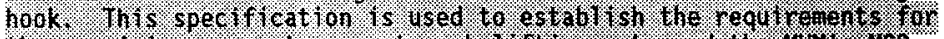

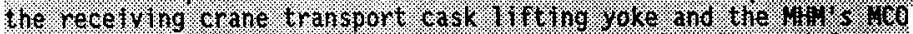

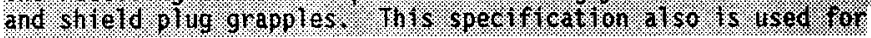




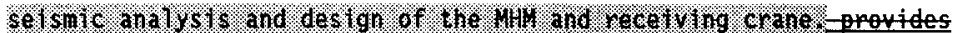
reaufrements for the destan, fabrication, and erection of overhead exanes used in nuelear facilities. This specification is used to establish the requirements for the receiving erane and the-Mll crane gantry hoists.

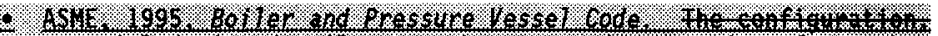

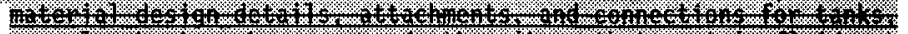
W

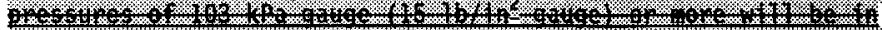

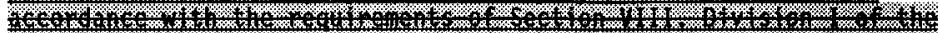

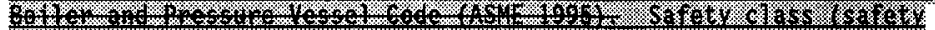

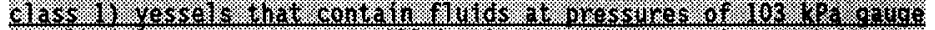

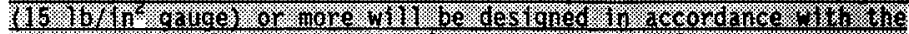

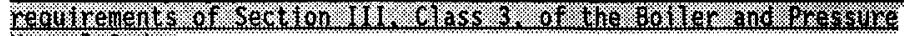
10.s. Code.

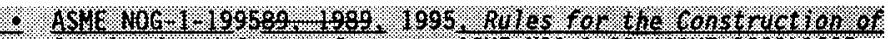

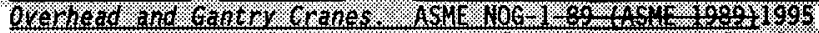

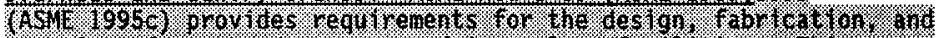

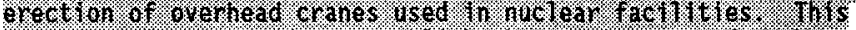

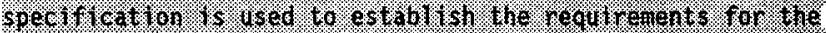

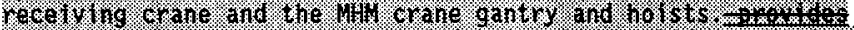

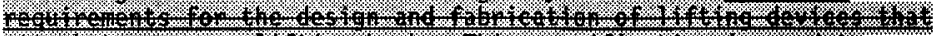

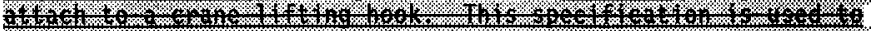

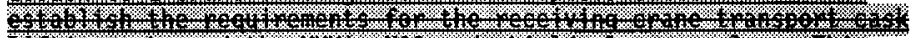

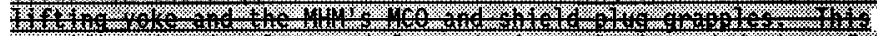
H 1.1\%6\%

\subsubsection{Hanford Site Requirements}

The following Hanford Site standards are applicable to the safety analysis.

- WHC-CM-4-46, Safety Analysis Manual, Revision 1, as noodf Ileo of

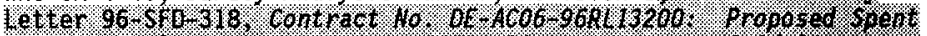

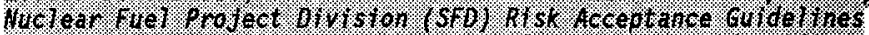

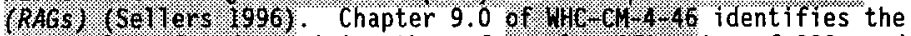
methodology for determining the safety classification of SSCS and the applicable design criteria. The safety class 1 requirements in Chapter 9.0 of WHC-CM-4-46 implement the criteria established in DOE Order $6430.1 \mathrm{~A}$ for safety-class items and the requirements for

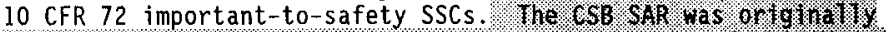

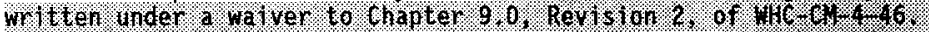

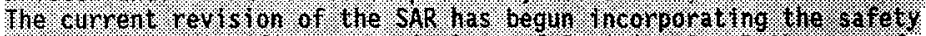

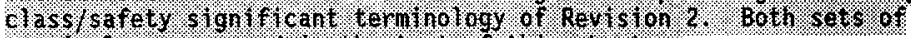
terminology ore used in the text of this ohadter.

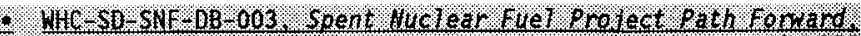

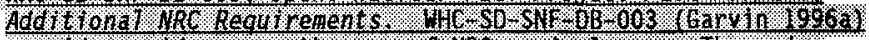

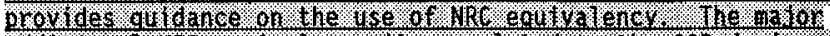

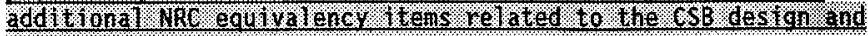




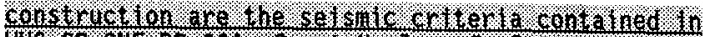

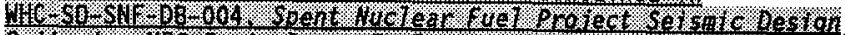

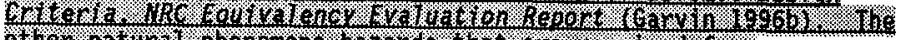

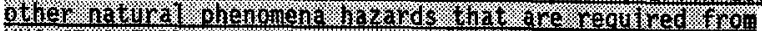

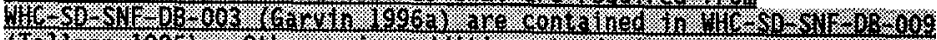

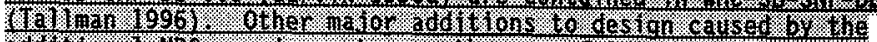

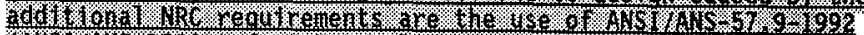

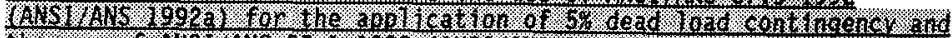

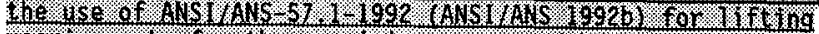

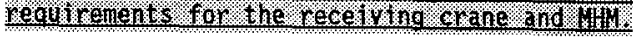

- WHC-SD-SNF-DB-004, 1996, Spent Nuclear Fuel Project Seismic Design Criteria, NRC Equivalency Evaluation Report. WHC-SD-SNF-DB-004

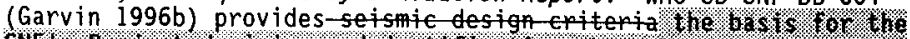

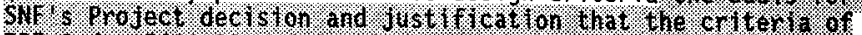

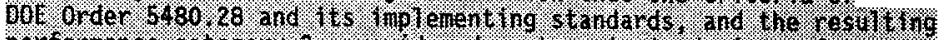

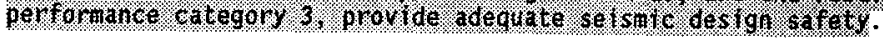

- WHC-SD-SNF-DB-009, 1996, Canister Storage Building Natural Phenomena Hazards. WHC-SD-SNF-DB-009 (Tallman 1996) supplements loads for use in the design and construction of the CSB. With the exception of seismic criteria, the compliance to both NRC and DOE requirements is accomplished with this document.

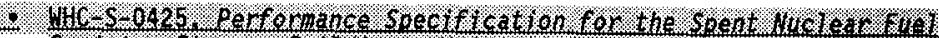

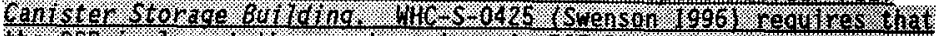

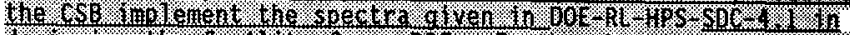

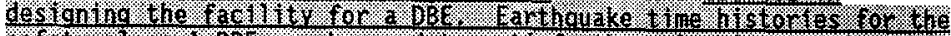

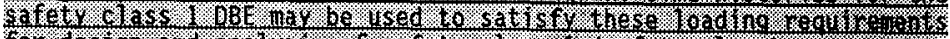

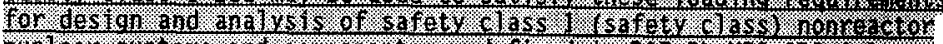

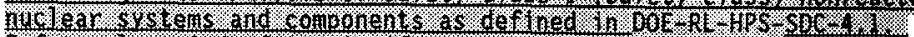

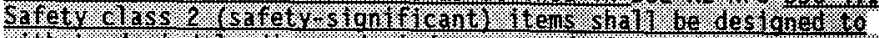

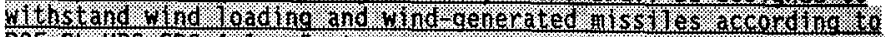

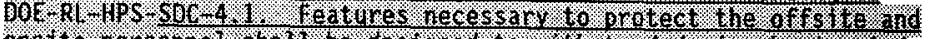

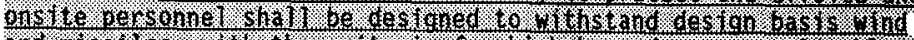

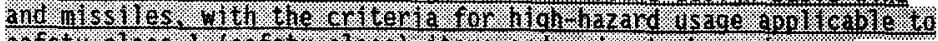

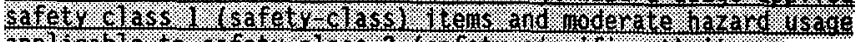

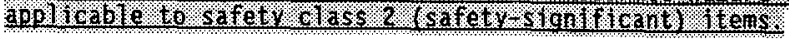

\subsection{OLlur Daniel. Incorporated, Requirements}

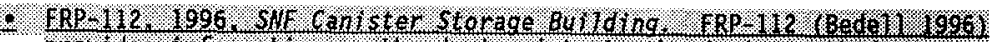

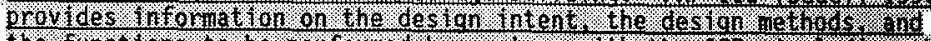

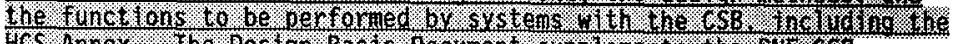

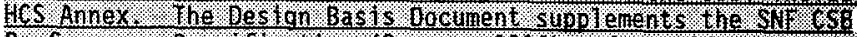

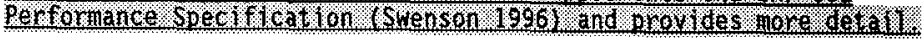

\subsection{SAFETY-CLASS STRUCTURES, SYSTEMS, AND COMPONENTS}

The safety-class (safety. class. 1) SSCs for below-grade and at-grade reinforced concrete structures are described in Sections 4.3.1 through 4.3. 3 to provide an understanding of the safety function and the suitability of the 
safety analysis inputs and assumptions. These safety-class (safaty SSCs prevent and mitigate the potential offsite overexposures as a consequence of the postulated accidents summarized in Chapter 3.0. The safety-class

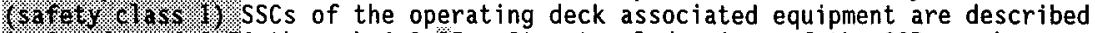
in Sections 4.3.34 through 4.3.35. Structural drawings of the CSB can be found in Appendix 4A.

The safety-class (satety cI ass. W. SSCs are summarized in Table 4-2t for the below-grade and at-grade reinforced concrete structures and in TabTe 4-3z

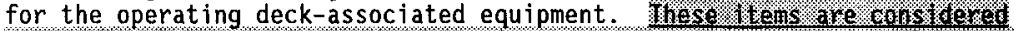

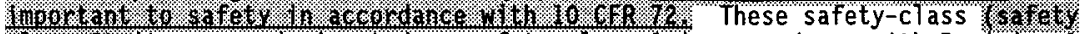

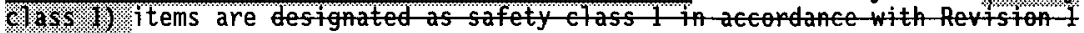
of IHC CH4-46, Safety Ana7ysis Mantua?. WHC CM-4-46 requires that safety elass 1 SSEs be-designed to the criteria of DOE Order $6430.1 \mathrm{~A}$ and DOE-RL-HPS-SDC-4.1 for loads that apply to the postulated accident criteria.

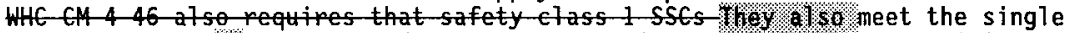
failure criteriouta of DOE Order 6430.1A, Section 1300-3.3. The remaining subsections provide details that expand upon the summary presentation in the table.

\subsubsection{Canister Storage Building Subsurface Structure}

4.3.1.1 Safety Function. The CSB wh-contains MCOs in the below-grade space described in Chapter 2.0 as CSB vault 1. Catastrophic failure of a single MCO

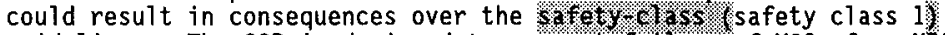

guidelines. The CSB is designed to prevent failure of MCOs from NRC equivalency design criteria NPH and DBA events and to maintain the MCOs below the design fuel centerline temperature. The potential consequences of an unmitigated release from the inventory at risk in the CSB were evaluated in Section 5.3 of WHC-SD-SNF-HC-007, Hazard Category Analysis for the Canister Storage Building (Kummerer 1995). Breach of a significant number of the MCOs

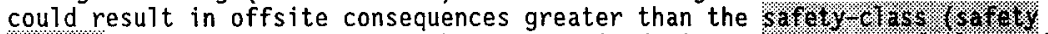
C1.5s. I) guideline. The CSB substructure is designed to prevent faflure of

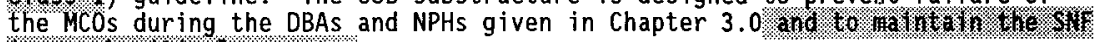

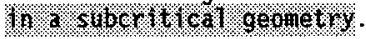

4.3.1.2 System Description. The concrete base slab, exterior and interior walls, and air intake and exhaust plenums are safe $x$. oross. (safety class 1 ) features of the CSB. These items provide protection from all applicable NPH and DBA events for the 220 tubes containing MCOs in vault 1 (and for the 6 overpack tubes that may eventually contain overpacked MCOs) and ovide-are-air

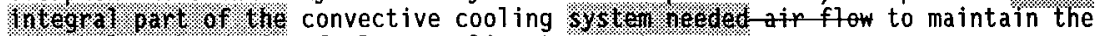
MCOs below the design fuel centerline temperature.

4.3.1.3 Functional Requirements. The reinforced concrete structures have been designed to withstand all applicable NPH and DBA events to the extent required to ensure that the $\mathrm{MCOS}$ and the storage tubes are not damaged. The applicable NPH and DBA events are the natural phenomena established for safely ctoss (safety class 1) SSCs as discussed in Section 1.5. 
Table 4-2t. Safety-Class Structures, Systems, and Components of the Below-Grade and At-Grade Reinforced Concrete Portion of the Canister Storage Building.

\begin{tabular}{|c|c|c|c|}
\hline Safety-class SSC & Safety function & Functional requirements & $\begin{array}{l}\text { Performance criteris } \\
\text { (TSR epplicability) }\end{array}$ \\
\hline $\begin{array}{l}\text { Subsurface structure } \\
\text { (concrete walls and } \\
\text { base slab) }\end{array}$ & $\begin{array}{l}\text { Prevent common cause } \\
\text { failure of multiple MCOs }\end{array}$ & $\begin{array}{l}\text { Withstand applicable NPHs and } \\
\text { OBAs to extent required to } \\
\text { prevent multiple HCO failures }\end{array}$ & Yox \\
\hline $\begin{array}{l}\text { Air intake and exhaust } \\
\text { plenums }\end{array}$ & $\begin{array}{l}\text { Provide enclosure for } \\
\text { convective cooling of } \\
\text { MCOs }\end{array}$ & $\begin{array}{l}\text { Prevent overheating and } \\
\text { faiture of multiple Mcos }\end{array}$ & 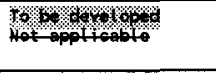 \\
\hline $\begin{array}{l}\text { Carbon steel base slab } \\
\text { embeds }\end{array}$ & $\begin{array}{l}\text { Provide anchor point for } \\
\text { seismic restraints for } \\
\text { tubes }\end{array}$ & $\begin{array}{l}\text { Prevent failure of one or } \\
\text { more tubes and failure of one } \\
\text { or more MCOs }\end{array}$ & Not applicable \\
\hline $\begin{array}{l}\text { Operating deck } \\
\text { structure }\end{array}$ & 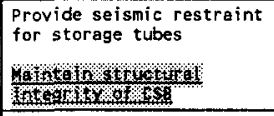 & $\begin{array}{l}\text { Prevent failure of one or } \\
\text { more storage tubes and } \\
\text { failure of one or more MCOs } \\
\text { during all applicable NPH and } \\
\text { DBA events }\end{array}$ & Not applicable \\
\hline $\begin{array}{l}\text { Intake structure and } \\
\text { exhaust stack bases }\end{array}$ & $\begin{array}{l}\text { Provide cool ing passages } \\
\text { to intake and exhaust } \\
\text { plenums for MCo } \\
\text { convective cooling; } \\
\text { provide attachment of } \\
\text { exhaust stack and intake } \\
\text { structure inlet cruciform }\end{array}$ & $\begin{array}{l}\text { Prevent loss of convective } \\
\text { cooling air flow; prevent } \\
\text { overheating and failure of } \\
\text { multiple MCOs }\end{array}$ & 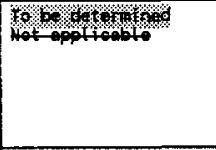 \\
\hline $\begin{array}{l}\text { Hot Conditioning System } \\
\text { Annex }\end{array}$ & 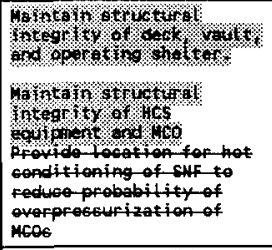 & 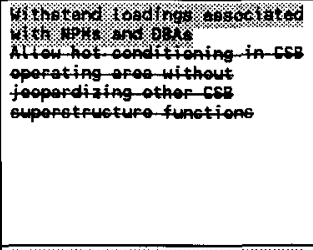 & 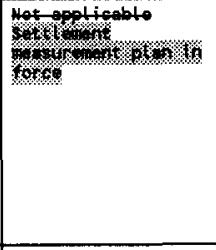 \\
\hline Load-in/load-out area & 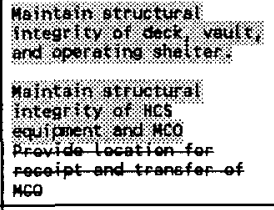 & 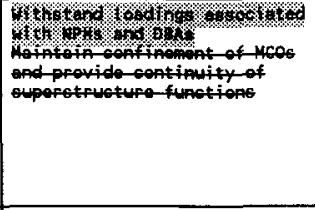 & 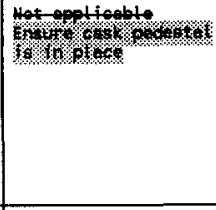 \\
\hline 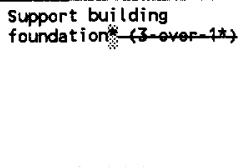 & $\begin{array}{l}\text { Provide safe location for } \\
\text { CSB operation and support }\end{array}$ & 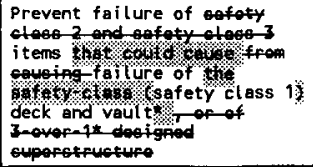 & Not epplicable \\
\hline
\end{tabular}

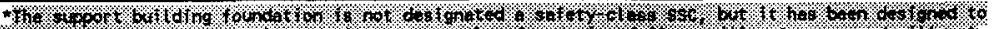

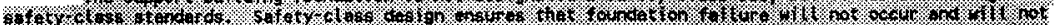
0.7.

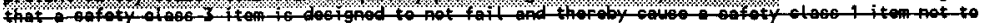

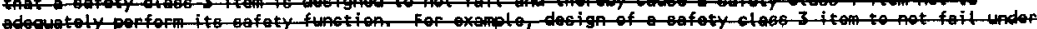

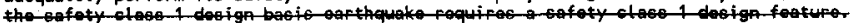

CSB = Canister Storage Building.

$\mathrm{DBA}=$ design basis accident.

MCO = multicanister overpack.

MPH = natural phenomena hazard.

SSC = structure, system, and component.

TSR = technical safety requirement. 
Table 4-3zz. Safety-Class Structures, Systems, and Components of the Canister Storage Building Operating Deck.

\begin{tabular}{|c|c|c|c|}
\hline Safety-class SSC & Safety function & Functional requirements & $\begin{array}{l}\text { Performance criteria } \\
\text { (TSR eppl icability) }\end{array}$ \\
\hline Tube vent and purge cart & 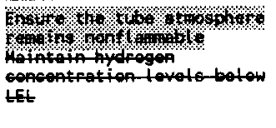 & 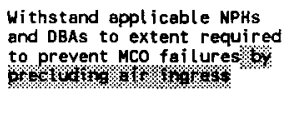 & 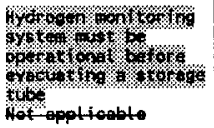 \\
\hline 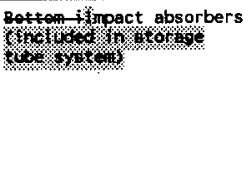 & 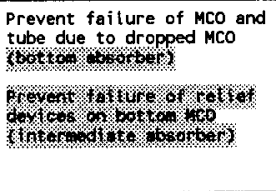 & $\begin{array}{l}\text { Absorb energy from drop of a } \\
\text { single MCO onto bottom of } \\
\text { empty tube (bottom absorber) } \\
\text { or onto second MCO } \\
\text { (intermediate absorber) }\end{array}$ & 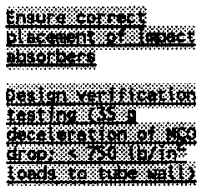 \\
\hline 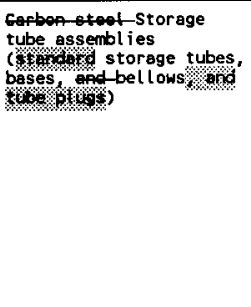 & $\begin{array}{l}\text { Prevent common cause } \\
\text { failure of an MCO }\end{array}$ & $\begin{array}{l}\text { Withstand applicable NPHs } \\
\text { and DBAs to the extent } \\
\text { required to prevent MCo } \\
\text { failure }\end{array}$ & 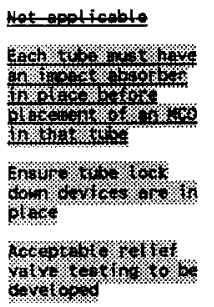 \\
\hline & 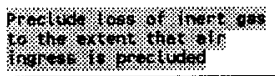 & whor & 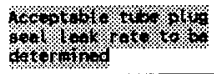 \\
\hline 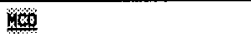 & Wot & 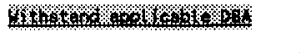 & 1060\% $\%$ \% \\
\hline
\end{tabular}

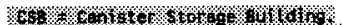

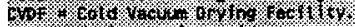

$\mathrm{BBA}=$ design besis accident.

LEt - tovor oxplosivo Limit.

MCO $=$ multicanister overpack.

NPH = natural phenomena hazard.

SSC = structure, system, and component

TSR = technical safety requi rement .
}

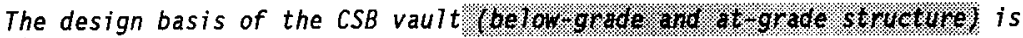
as follows:

- Heinforced ecncrete dead load, includes insulating concrete in vautts 2 and 3

- Live load on deck, $488 \mathrm{~kg} / \mathrm{m}^{2}$ (100 $\left.\mathrm{lb} / \mathrm{ft}^{2}\right)$ plus purge carts' load

- All three exhaust stacks, insulating concrete on the vault 2 and 3 stacks 
- All three air-intake structures, steel and concrete portions:

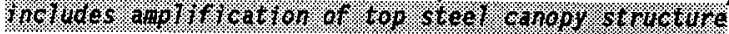

- Steel standard (220) and overpack (6) plugs $(3,850 \mathrm{~kg}[8,500 \mathrm{lb}])$, dead load supported by tube, seismic horizontal forces at deck, vertical at basemat

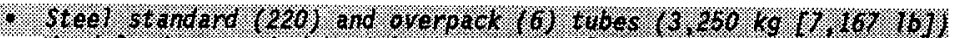

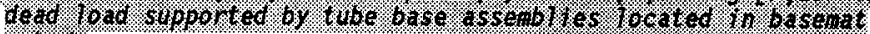
entads

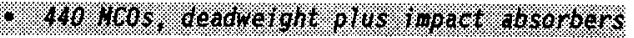

- MHM 7oad, $4.5 \times 10^{5} \mathrm{~kg}\left(1 \times 10^{6} \mathrm{7b}\right)$, includes $10 \%$ contingency

- MCO cask transporter weight, 47,200 kg (104,000 7b) live load in load-in/load-out truck vestibule

- Receiving crane, $149,687 \mathrm{~kg}(330,000 \mathrm{lb})$ in load-in/load-out area (includes $54,432 \mathrm{~kg}[120,000 \mathrm{lb}]$ lift load)

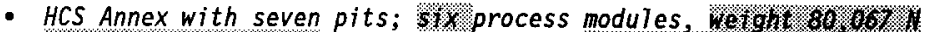

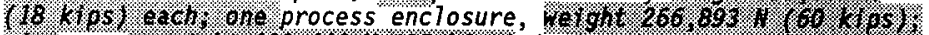

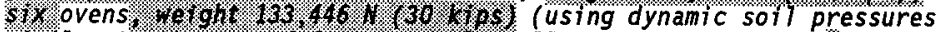
similar to those used for the vault walls); MHM (live load)

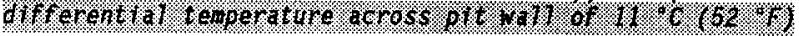

- Operating shelter stwetw. - Fotght as reconfigured for tornado loads, 980 kg: (2. 60.10 .6 . includes dead load, live load, tornado Wind, seismic loads; $5 \%$ dead load contingency in operating she7ter in accordance with ANSI/ANS-57.9-1992 (ANSI/ANS 1992a); $24 \mathrm{~kg} / \mathrm{m}^{2}$ (5 $\left.\mathrm{lb} / \mathrm{ft}^{2}\right)$ dead load cont hogene for fireproofing operating area ceiling

- Soil pressure (at-rest) and surcharge load, $9.6 \mathrm{kPa}\left(200 \mathrm{lb} / \mathrm{ft}^{\underline{2}}\right)$

- Thermal operating loads from $192 \mathrm{~kW}$ heat load (FDI 1996c, Calculations CSB-S-0002 and CSB-S-0003)

- $8,800 \mathrm{~kg}(19,400 \mathrm{lb})$ MCO concentric drop, $13.4 \mathrm{~m}$ (44 ft) into storage tube, impact absorber $66 \mathrm{~cm}$ (26 in.) diameter, $82.7 \mathrm{MPa}$ $\left(12,000 \mathrm{lb} / \mathrm{in}^{2}\right)$

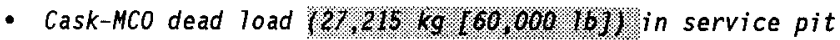

- Future service pits (FFTF cask $\% 00000$ 61, MHM maintenance) in load-in/load-out area

- DBE response spectral analysis with input motion at top of competent 7 ayer $(2.4 \mathrm{~m}[8 \mathrm{ft}]$ from surface) and dynamic soil shear modulus variation of 1.5 and 1 over 1.5 times the best estimate value with confirmatory analysis using $C_{\underline{v}}=1.0$

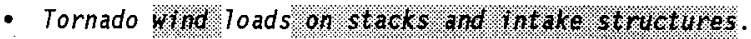


4.3.1.4 System Evaluation. The CSB below-grade and at-grade structures are designed to withstand the DOE-designated natural phenomena specified in Section 1.5. The CSB basemat foundation coincides with a soil profile identified as stratum 3 in Section 3.6.1.9 of WHC-SD-HWV-PSAR-001, Hanford Waste Vitrification Plant Preliminary Safety Analysis Report (WHC 1994). This layer exhibits light cementation and is typically in a dense to very dense condition. The formation extends to a depth of approximately $76 \mathrm{~m}$ (250 ft) below grade. Geotechnical investigations reported in WHC-SD-HWV-PSAR-001 (WHC 1994) characterized the soil properties at the elevation of interest as having high strength and low compressibility. Stratum 3 has a vertical static subgrade modulus value of $8.1 \times 10^{4} \mathrm{kN} / \mathrm{m}^{3}$ (518 kip/ft3 $)$ based on a 1-ft $\mathrm{ft}^{2} \mathrm{plate}$. This is adjusted for the actual foundation size by the equation given in the geotechnical report (Dames and Moore 1989).

The structural loading to the foundation, assuming a 77 vaults fully loaded with SNF, is well within the allowable soil bearing values. Details of the analysis of the adequacy of the soil to carry the anticipated foundation loading are documented in Calculation CSB-S-0023 (FDI 1996c). The soil-bearing pressures beneath the vault are less than $3.8 \times 10^{5} \mathrm{~N} / \mathrm{m}^{2}$ ( $\left.8 \mathrm{kip} / \mathrm{ft}^{2}\right)$, which is well within the allowable bearing capacity of $6.7 \times 10^{5} \mathrm{~N} / \mathrm{m}^{2}\left(14.0 \mathrm{kip} / \mathrm{ft}^{2}\right)$. The factor of safety against sliding during a $D B E$ event is approximately 1.8 as determined in Calculation CSB-S-0024 (FDI 1996c). Further soil compaction and settling and vault sliding analyses were performed because of the cantilever on soil design of the HCS Annex. These analyses are documented in FDT-011, Deck Cantilever Settlement and Vault Sliding Estimates (FDI 1996b), which included a report prepared by Dames and Moore. The report concludes that only negligible settlement will occur in the compacted soils around the CSB and under the HCS Annex and that vault wall pressures during a $D B E$ are adequately considered.

Additional natural phenomena requirements are associated with NRC equivalency: notably, tornado hazards, ashfall, and increased PMP amounts as listed on Table 1-23. The CSB's superstructure is non-safety class (18) 0.8. . 1 . Under the HWVP CSB mission, the building's superstructure was not required to be hardened to protect any interior equipment from NPHs or DBAs imposed by NRC equivalency. Under the SNF CSB criteria, the structure was designed to prevent damage to safety-class equipment under the NPH design loads (e.g., ashfall, PMP, and tornado wind) criteria selected by the Regulatory heaumeneinls Team as being NRC equivalent. The weight and wind loads of a tornado-resistant superstructure (including the extension over the HCS Annex) were evaluated along with the $5 \%$ increase in dead weight load required by ANSI/ANS-57.9-1992 (ANSI/ANS 1992\%). Structural design information follows.

4.3.1.4.1 Soil Structure Interaction. Several steps were used to determine the effects of soil-structure interaction (SSI) on the seismic response of the SNF CSB. Initially, parametric studies were conducted to evaluate the seismic response of the site soils and to determine the level of the soil stress-strain properties for the given level of input ground motion. This was accomplished by finite element methods using the SHAKE computer code analysis. One-dimensional models of the soil properties were developed and equivalent linear soil properties compatible with the strains developed in each layer. These properties were then used in the next step as an initial estimate of soil properties used in the SSI analysis. The SSI was defined by 
finite element methods using the FLUSH computer code (Lysmer et a1. 1975) anatysis.

Two-dimensional models of the soil and structure were developed and gross motion SSI responses for the structure and loads in the below grade walls and basemat were assessed. These results served as verification of the 3-D dynamic (SAP90 [CSI 1995]) model that included the SNF CSB underground vault with surrounding soil and a massive soil column representing "free field." The outer perimeter nodes of the soil elements surrounding the vault were slaved to the elements of the massive soil column thus simulating the transmitting boundary as in the FLUSH (Lysmer et a1. 1975) analysis. This forced the outer perimeter boundaries of the soil surrounding the vautt to move with the free field. This analysis approach provided a one-step pross gettio. to account for SSI effects and yielded three-dimensional shear and moment force distributions over the underground vault structure. The 3-D analysis used input (response spectra and time histories) at the bottom of the vault generated from the free field ground motions acting at the top of the competent layer, deconvoluted to the bottom of the vault using the SHAKE program.

Uncertainty in the accurate prediction of dynamic soil properties was accounted for by employing a parametric analysis using a range of soil dynamic shear moduli values. The range of soil dynamic shear moduli was bounded by the best estimate dynamic shear modulus $\times 1.5$, the best estimate dynamic modulus / 1.5, and the best estimate shear modulus $x 1.0$ (ASCE 1986). Confirmatory analyses for soil dynamic shear moduli ranging from 2 and 0.5 times the best estimate were also done. Strain-dependent soil shear modulus and damping values were used in SSI analysis.

The SAP90 computer program (CSI 1995) in itself is not normally used to account for SSI. However, forcing boundaries of soil elements, constructed with appropriate properties, to conform to the free field motion for the surface and below provided soil pressures and response spectra that were consistent with the FLUSH (Lysmer et al. 1975) analysis values. It is on this basis that the SAP9O computer model is deemed reasonable and the analysis results appropriate. The comparison results were documented in Letter FRF-092, DOE SAR Team Review Request for Structural Analysis (Jacobs 1996b).

4.3.1.4.2 Time Histories. ABB Impell Corporation was a subcontractor to the architect-engineer on the HWVP Project. They provided the artificial earthquake time history that was used in the design of the HWVP CSB and is being used in the SNF CSB Project. Seismic Acceleration Time Histories in Support of Fluor Daniel, Inc. (Salmon et a1. 1990) indicates that a single synthetic time history was created to simulate the DBE. The resulting time history is shown to meet NRC acceptance criteria for a single design time history (NRC 1987). All important ground motion characteristics, including check for power spectral density content, were included in the developed time history.

4.3.1.4.3 Asymetric Loading Effects on the Substructure. The seismic analysis considered all three vaults to be filled with MCOs and all three intake structures and exhaust stacks to be in place. In addition to all the actual above-grade eccentricities (e.g., MHM, superstructure, and receiving 
crane), the model included a $5 \%$ accidental eccentricity. A dominant feature of these below-grade vaults is the participation of the soil mass in the wall flexure and in-plane shears. Since the stored SNF, intake structures, and exhaust stacks account for less than $1 \%$ of the total seismic model mass (soil, structure, and stored fuel) and approximately $32 \%$ of the vault structure and stored fuel system, it was judged that the effective eccentricity was small and that the governing configuration for seismic analysis would be the condition in which all three vaults are full and all three intake and exhaust structures in place. A two-dimensional, l-ft strip model of the vault-deck section was evaluated for the skip gravity and temperature loads. The results of the analysis confirmed that the demand in moments and shears did not exceed the capacity (Jacobs 1996b).

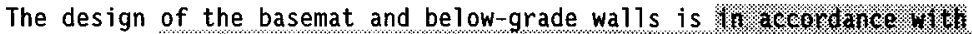

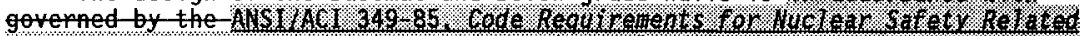

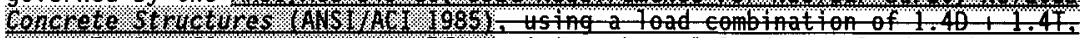
Where I stanffies operatsing seff straining themal loads. A load combination of $1.4 \mathrm{Q}+1.2 \mathrm{~T}$ (ASCE 1995) is more appropriate when considering the thermal 7 oads caused by extreme-maximum $\left(115^{\circ} \mathrm{F}\right)$ and minimm $(27$ if $)$ temperatures whose duration is 6 hours. The high temperature condition governs the exterior face reinforcing and the low temperature the interior face reinforcing. Table 4-43 gives the demand to capacity ratios and

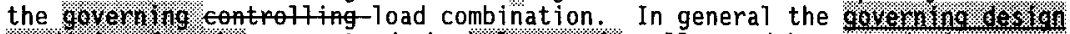

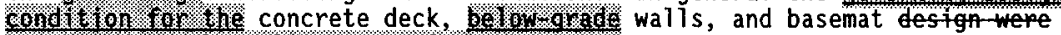

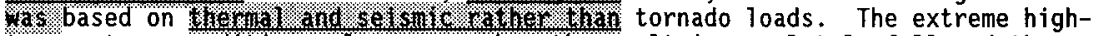
temperature condition only occurs when the vault is completely full and the extreme low-temperature condition occurs only when the vault is completely empty. Any thermal skip loading of the vault (e.g., all tubes in one or two vaults full of heat-source material, but not all three vaults 10 aded) relaxes the self-straining thermal stresses in the vault structure and reduces thermal demand. Based on this reasoning, it was judged that the governing condition for the design of the basemat and below-grade walls was either all the vautts full with high temperature inlet air or all vaults empty with 10 w temperature inlet air. Therefore, the designs of the basemat and below-grade walls are bounded by the two extreme conditions and are not governed by a checkerboard loading pattern because of the dominance of thermal loads.

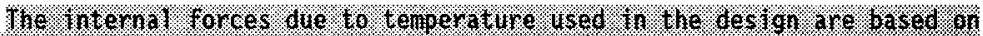

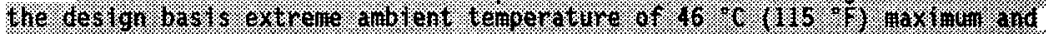

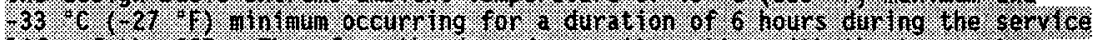

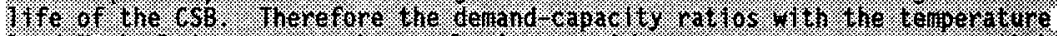

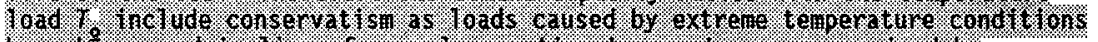

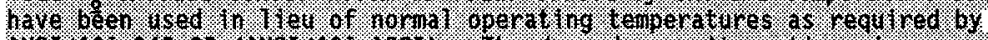

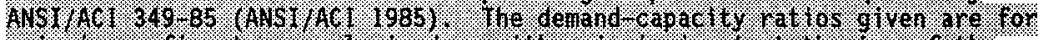

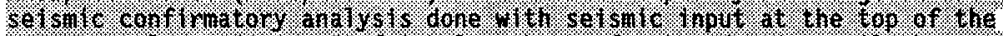

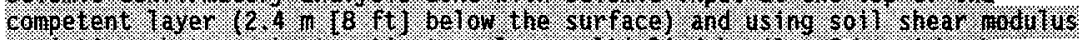

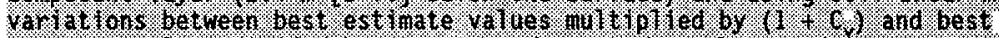

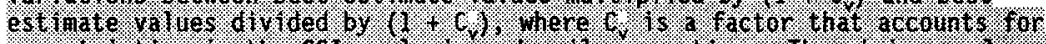

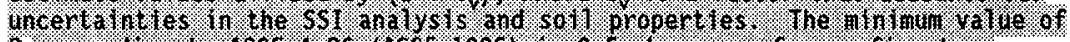

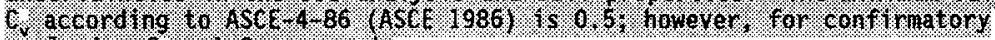

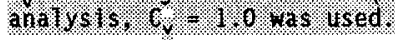




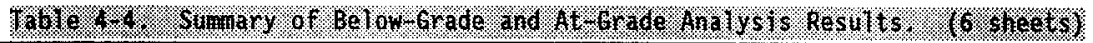

\begin{tabular}{|c|c|c|c|}
\hline & $4+16$ & $\alpha_{10}$ & 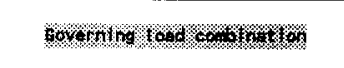 \\
\hline \multicolumn{4}{|c|}{ 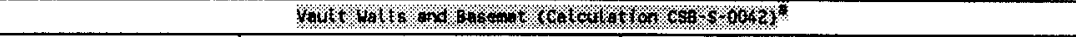 } \\
\hline \multirow[t]{6}{*}{ 10.6\% } & 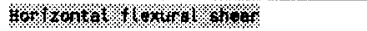 & 9.8 & 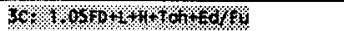 \\
\hline & 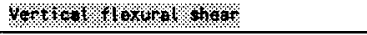 & OH & 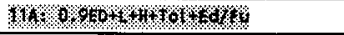 \\
\hline & 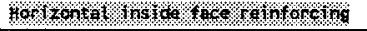 & 988 & 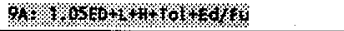 \\
\hline & 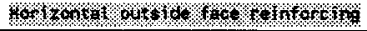 & Mos & 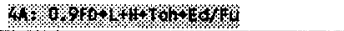 \\
\hline & 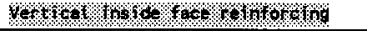 & 策盟 & 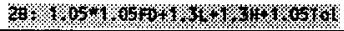 \\
\hline & 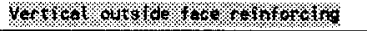 & 0.0 & 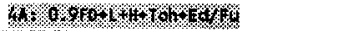 \\
\hline \multirow[t]{6}{*}{ Hox } & 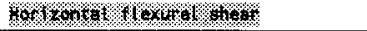 & 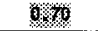 & 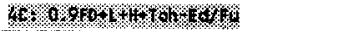 \\
\hline & 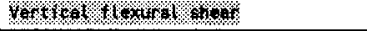 & $0 \times$ & 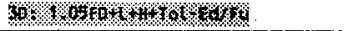 \\
\hline & 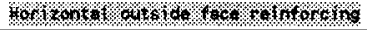 & 0 & 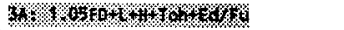 \\
\hline & 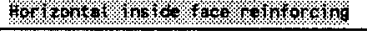 & 0.8 & 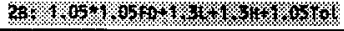 \\
\hline & 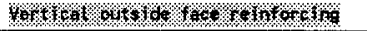 & 嘈姆 & 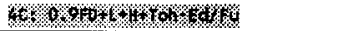 \\
\hline & 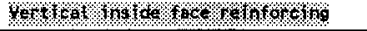 & 的 & 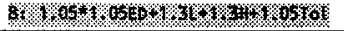 \\
\hline \multirow[t]{6}{*}{ W $\alpha+1+\alpha$} & 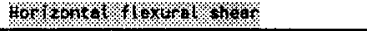 & $0 \%$ & 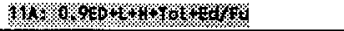 \\
\hline & 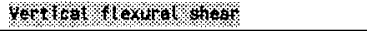 & 96\% & 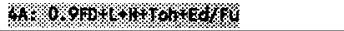 \\
\hline & 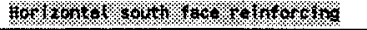 & $0 \%$ & 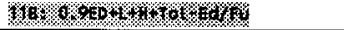 \\
\hline & 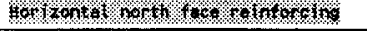 & 0. & 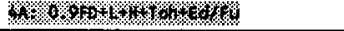 \\
\hline & 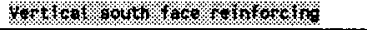 & 60 & 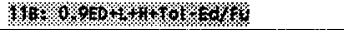 \\
\hline & 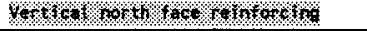 & 60 & 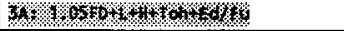 \\
\hline \multirow[t]{6}{*}{ \% } & 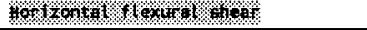 & 98 & 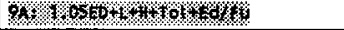 \\
\hline & 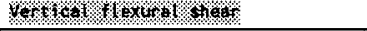 & 6 & 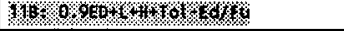 \\
\hline & 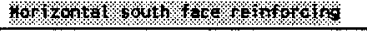 & \% & 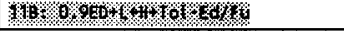 \\
\hline & 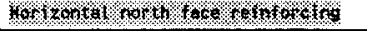 & $6 \%$ & $10 x+y 5=x+4$ \\
\hline & 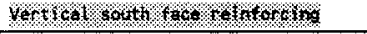 & $0 \%$ & 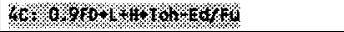 \\
\hline & 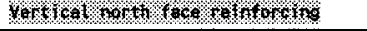 & $0 \%$ & 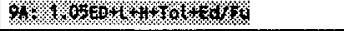 \\
\hline \multirow[t]{6}{*}{$3040 \times 14$} & 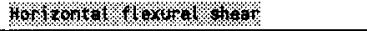 & 068 & 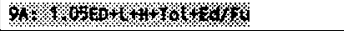 \\
\hline & 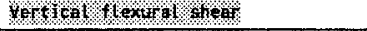 & $0 \%$ & 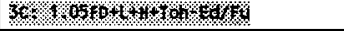 \\
\hline & 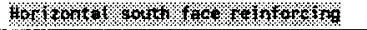 & 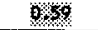 & 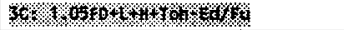 \\
\hline & 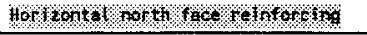 & $0 \%$ & 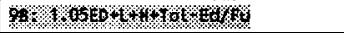 \\
\hline & 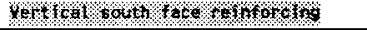 & $0 \%$ & 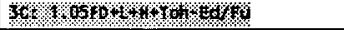 \\
\hline & 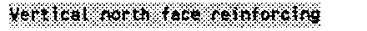 & 90 & $680000 \times 1 \% 4 \% 0 \% 4 \%$ \\
\hline \multirow[t]{6}{*}{ 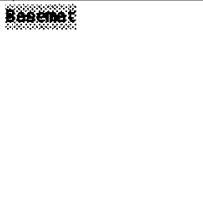 } & 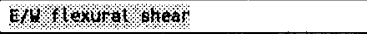 & 980 & $30 \%<0080 \% 2+10 \%=6 \% \%$ \\
\hline & 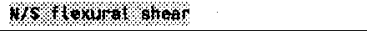 & $\$ \%$ & 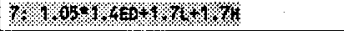 \\
\hline & E 400 roportro & 98 & 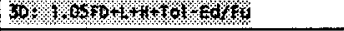 \\
\hline & 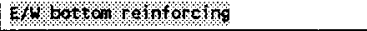 & 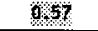 & $34 \%, 05 \% 0 \%<+10 \%<0 \%$ \\
\hline & HStoprenfororna & 082 & 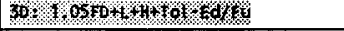 \\
\hline & 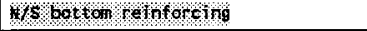 & 085 & $40 / 0 \% 90+1+101 \% / 40$ \\
\hline
\end{tabular}




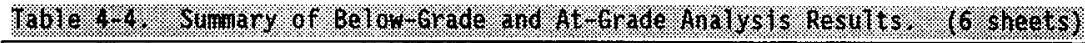

\begin{tabular}{|c|c|c|c|}
\hline & Bog & 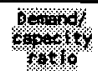 & 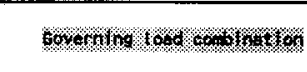 \\
\hline \multicolumn{4}{|c|}{ 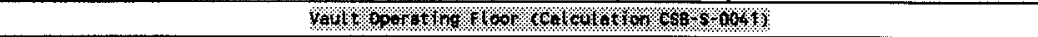 } \\
\hline \multirow{6}{*}{ 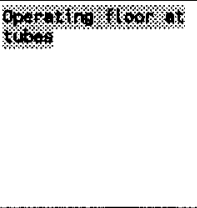 } & 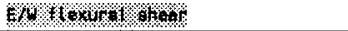 & 01 & $000000 \%$ \\
\hline & 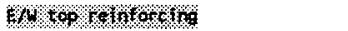 & 48 & $10050 * 1 \%+\% 01 \%=6 \%$ \\
\hline & Wowtuow $\alpha \%$ or & \% & $1080 \% \%+1 \% \%$ ot $-4 \%$ \\
\hline & 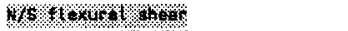 & Qpe & 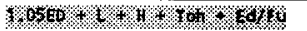 \\
\hline & 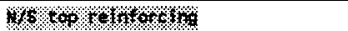 & O6 & 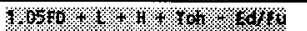 \\
\hline & 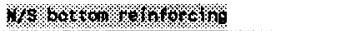 & \% & 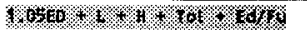 \\
\hline \multirow{6}{*}{$6 \%$} & 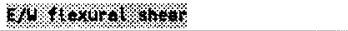 & Q84 & 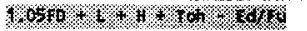 \\
\hline & 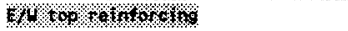 & (6) & 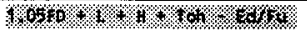 \\
\hline & 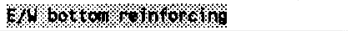 & \% & 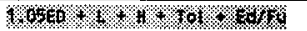 \\
\hline & 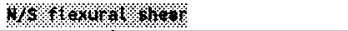 & $6 \%$ & 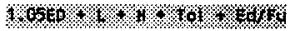 \\
\hline & 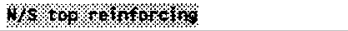 & $\$$ & 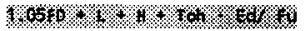 \\
\hline & 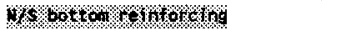 & $\% 8$ & 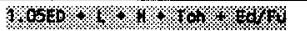 \\
\hline \multirow{6}{*}{$606 \%$ ox $6 \%$} & 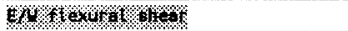 & $0 \%$ & 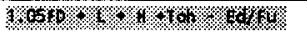 \\
\hline & 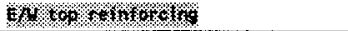 & $0 \%$ & 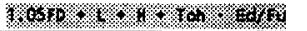 \\
\hline & $6 \% 60+1 \% \% \% \%$ & $0 \%$ & $30 \% 6 \%$ \% \\
\hline & 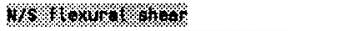 & $6 \%$ & 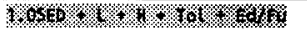 \\
\hline & 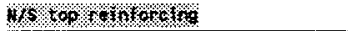 & 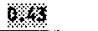 & 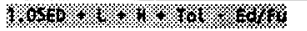 \\
\hline & W & $6 \%$ & 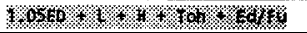 \\
\hline \multirow{6}{*}{ 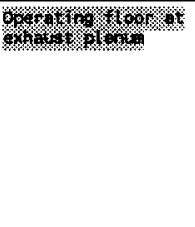 } & 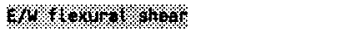 & 08 & 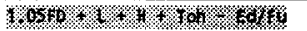 \\
\hline & 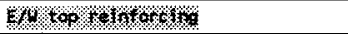 & 68 & 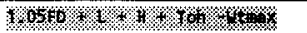 \\
\hline & 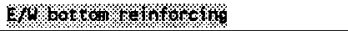 & 60 & 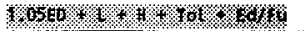 \\
\hline & 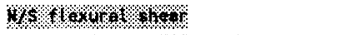 & $6 \%$ & 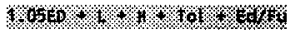 \\
\hline & $48<0,20140 \%<+$ & 00 & 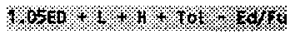 \\
\hline & 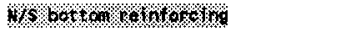 & 48 & 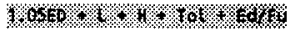 \\
\hline \multicolumn{4}{|c|}{ 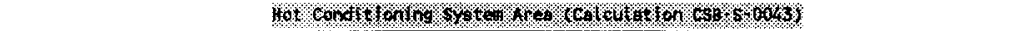 } \\
\hline \multicolumn{4}{|l|}{ 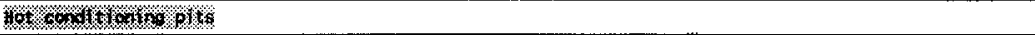 } \\
\hline \multirow[t]{7}{*}{ WO } & 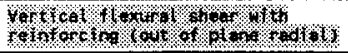 & 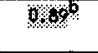 & 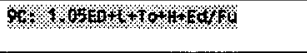 \\
\hline & 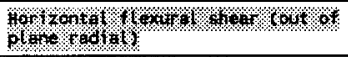 & $\mathrm{Hec}^{\mathrm{c}}$ & $320 \% 180000$ \\
\hline & 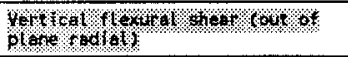 & 28 & $90 \% 0500+1044040 \%$ \\
\hline & 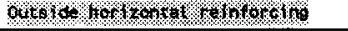 & 68 & 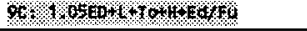 \\
\hline & 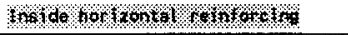 & 00 & 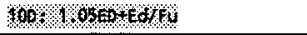 \\
\hline & 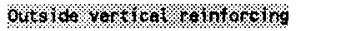 & $0 \%$ & $00 \% 0 \%+10+4+48$ \\
\hline & 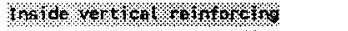 & 007 & $3090 / 00 \%+8 / 8 \mathrm{~s}$ \\
\hline
\end{tabular}




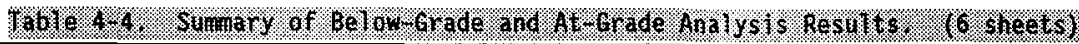

\begin{tabular}{|c|c|c|c|}
\hline & 8000 & $\frac{1}{5 \%}$ & 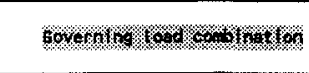 \\
\hline \multirow[t]{6}{*}{ \% $6 \%$ \% } & 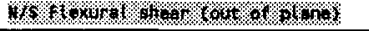 & Q6 & 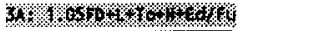 \\
\hline & 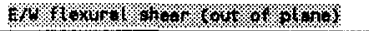 & 68 & 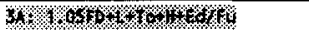 \\
\hline & 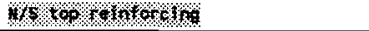 & $2 \%$ & $310 / 6501 \times 10 \% \times 40$ \\
\hline & 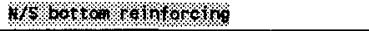 & 88 & 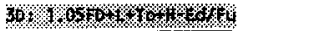 \\
\hline & Woropotronotro & 02 & 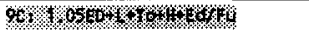 \\
\hline & 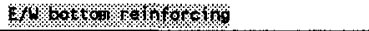 & $0 \%$ & 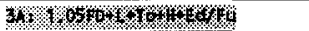 \\
\hline \multirow[t]{6}{*}{ 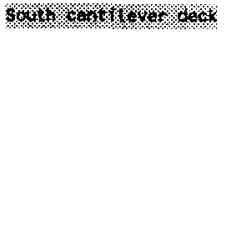 } & 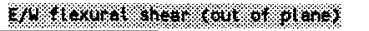 & $0 \% 6$ & $0 \%, 0200 \% 3 \%$ \\
\hline & 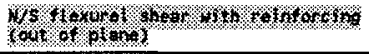 & $6 \%$ & 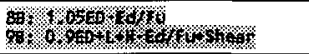 \\
\hline & 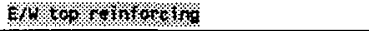 & $6 \%$ & 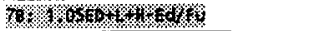 \\
\hline & 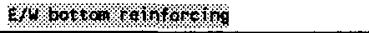 & $6 \%$ & 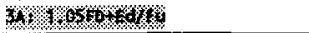 \\
\hline & 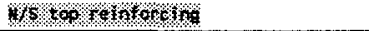 & $\$ \%$ & 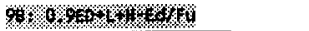 \\
\hline & 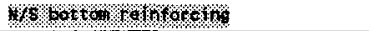 & Q\% & 3\%oxorom \\
\hline \multicolumn{4}{|c|}{ 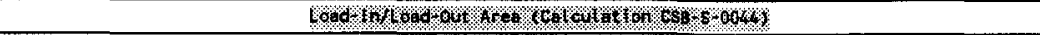 } \\
\hline \multicolumn{4}{|l|}{ 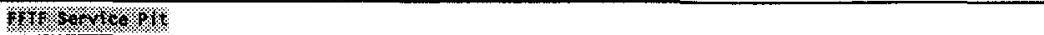 } \\
\hline \multirow[t]{2}{*}{ 酷8 } & 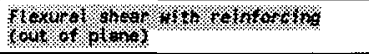 & $6 \%$ & $2040 \times 100$ \\
\hline & 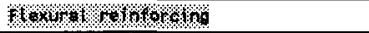 & $8 \times$ & $10 \% 50 \% 1,1+4$ \\
\hline \multirow[t]{2}{*}{ 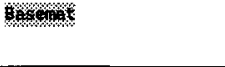 } & 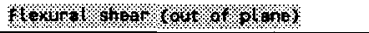 & $0 \%$ & $10050 \% 4018$ \\
\hline & 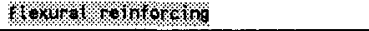 & 0.2 & $10560 \times 408$ \\
\hline \multicolumn{4}{|l|}{$090 \%$ s } \\
\hline \multirow[t]{2}{*}{ WE } & 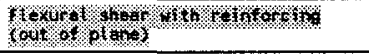 & 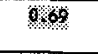 & $3100608 \%$ \\
\hline & 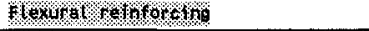 & $0 \%$ & $40 \% 0810 \% 20 \%$ \\
\hline \multirow[t]{6}{*}{ 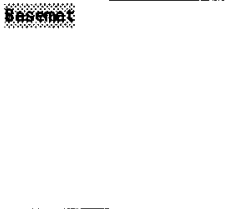 } & 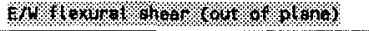 & 000 & $10 \% 0 \% 80 \%$ mo \\
\hline & 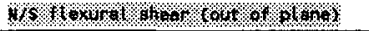 & $0 \%$ & 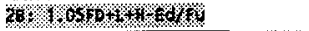 \\
\hline & 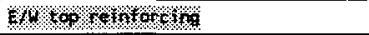 & $0 \%$ & 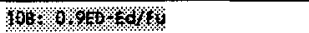 \\
\hline & Wootoonoforoons & $0 \%$ & 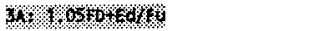 \\
\hline & $168 \times 0 \%+14+48$ & 60 & 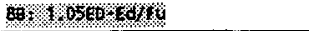 \\
\hline & 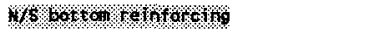 & 642 & 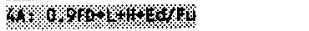 \\
\hline \multicolumn{4}{|l|}{$46 \% \% \% \%$} \\
\hline \multirow[t]{7}{*}{ 6/6 } & 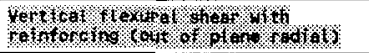 & $0 \%$ & $9 \times 10050 \times 1,041404 \%$ \\
\hline & 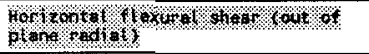 & $08 \%$ & 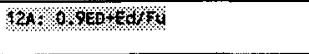 \\
\hline & 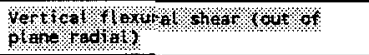 & 007 & 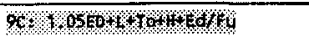 \\
\hline & 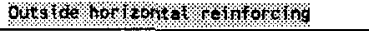 & $0 \% 8$ & 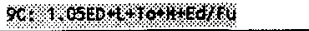 \\
\hline & 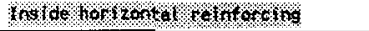 & $0 \% 1$ & 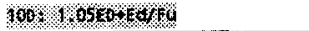 \\
\hline & 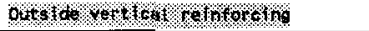 & $0 \% 2$ & 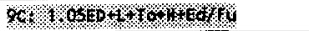 \\
\hline & 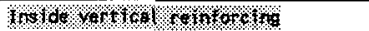 & $6 \%$ & $100 \% 1 \% 9 \% 0 \% 1 \% / \%$ \\
\hline
\end{tabular}




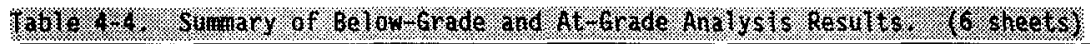

\begin{tabular}{|c|c|c|c|}
\hline \multicolumn{2}{|r|}{80109} & \multirow{2}{*}{$\frac{1 \%}{6 \%}$} & \multirow{2}{*}{ 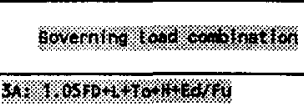 } \\
\hline \multirow[t]{6}{*}{ Hentot } & 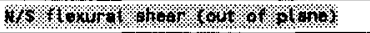 & & \\
\hline & 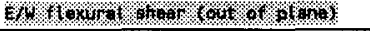 & $0 \%$ & 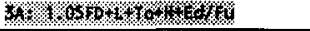 \\
\hline & 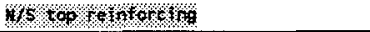 & $0 \%$ & 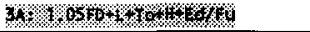 \\
\hline & $4 \% 60 t+\%$ roptortho & $08 \%$ & 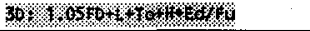 \\
\hline & $1 / 0<0,1 / 1 / 0, \alpha)$ & 012 & 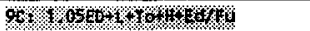 \\
\hline & 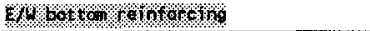 & $0 \%$ & 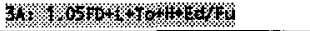 \\
\hline \multirow[t]{6}{*}{ 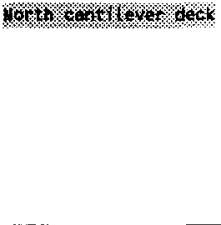 } & 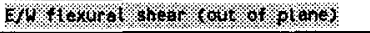 & $6 \%$ & $1010 \% 000 \% \% 40$ \\
\hline & 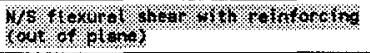 & $0 \%$ & 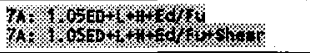 \\
\hline & $1 W 10 p / 4000 \% 1$ & 088 & $10000000+4$ \\
\hline & 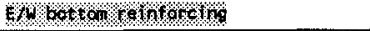 & 661 & $30 / 10 \%+\%=\alpha \%$ \\
\hline & Wroprolnor on & $0 \% 6$ & 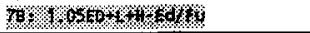 \\
\hline & 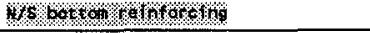 & $6 \%$ & 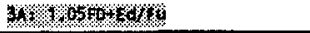 \\
\hline \multicolumn{4}{|c|}{ 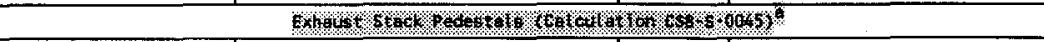 } \\
\hline \multirow[t]{6}{*}{ 6) } & 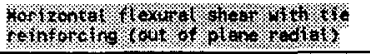 & $6 \%$ & 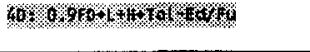 \\
\hline & 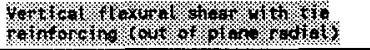 & $0 \%$ & $16 \% 0 \% 0+1+40 \%$ \\
\hline & 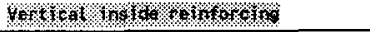 & 965 & 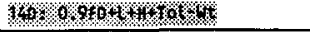 \\
\hline & 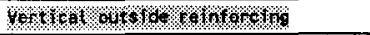 & 08 & 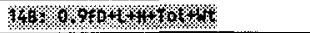 \\
\hline & 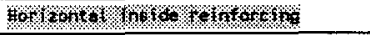 & $9 \%$ & 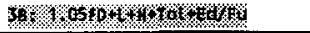 \\
\hline & 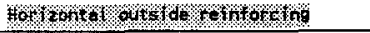 & 8 & 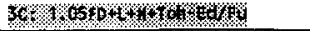 \\
\hline \multicolumn{4}{|c|}{ 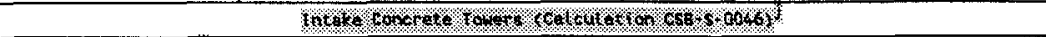 } \\
\hline \multirow[t]{6}{*}{ W } & 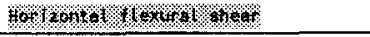 & $0 \%$ & $100 \% 0 \% 00 \%-20 \%$ \\
\hline & 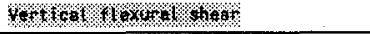 & $0 \%$ & 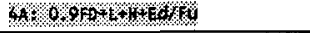 \\
\hline & 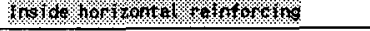 & 08 & 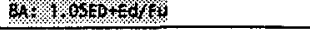 \\
\hline & 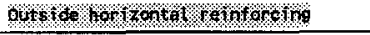 & $0 \times 20$ & $3 \% 1,0,0+0 \%$ \\
\hline & 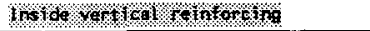 & 9.8 & $58081 \times<8$ \\
\hline & 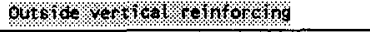 & 08 & $5 \% 0 \% \% \& \&$ \\
\hline \multicolumn{2}{|c|}{ 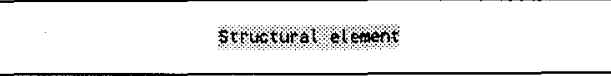 } & 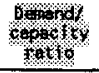 & 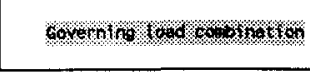 \\
\hline $60 \% 6010$ & 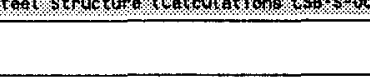 & $\frac{2485}{686}$ & 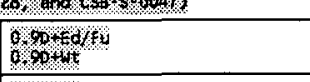 \\
\hline 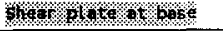 & & 82 & 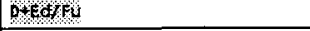 \\
\hline 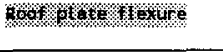 & & $\begin{array}{l}822 \\
0.30\end{array}$ & $0.5 \times 4$ \\
\hline $60 x_{10}$ & & 92 & $0+5+4$ \\
\hline 46os & & 96 & $0+5+4$ \\
\hline
\end{tabular}




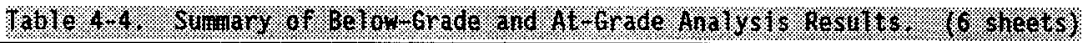

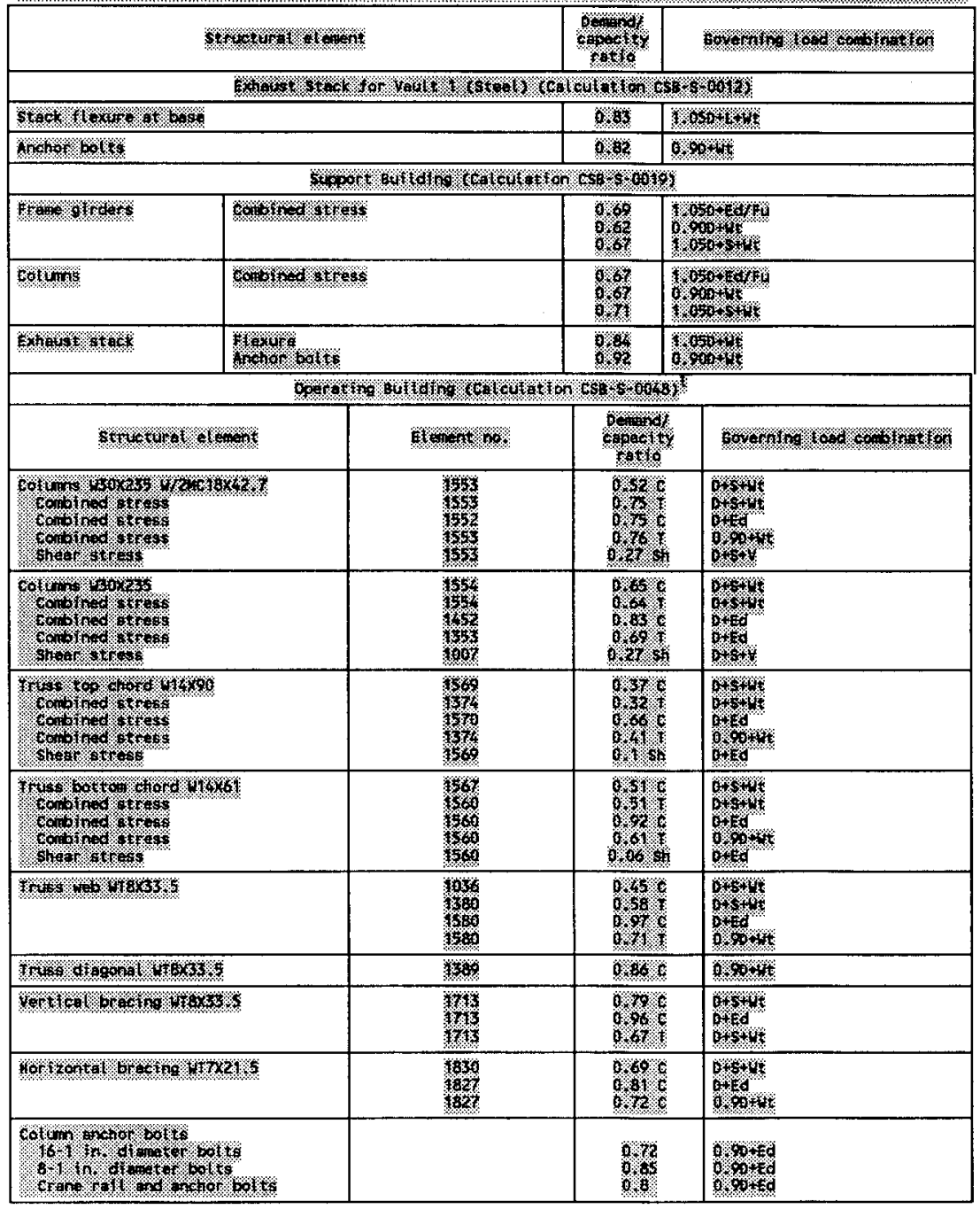




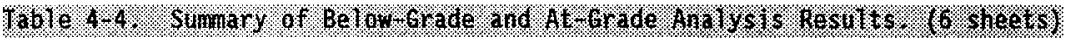

\begin{tabular}{|c|c|c|c|}
\hline \multicolumn{4}{|c|}{ 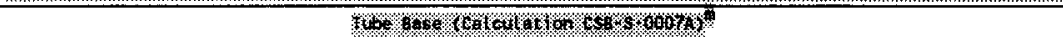 } \\
\hline \multicolumn{2}{|c|}{ 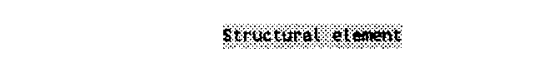 } & Wow & 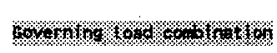 \\
\hline 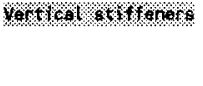 & 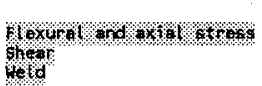 & 0 & 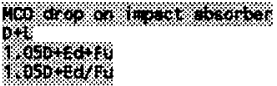 \\
\hline Hoododotus & Soncrete onber,ent & $6 \%$ & X) \\
\hline Bus & 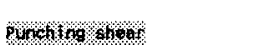 & 04 & 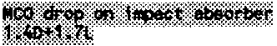 \\
\hline
\end{tabular}
61040

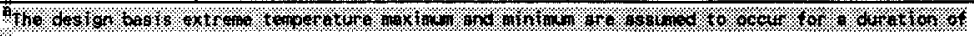

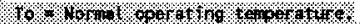

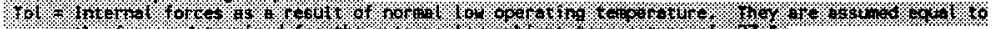

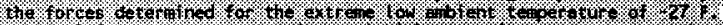

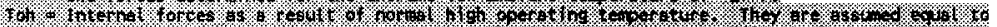

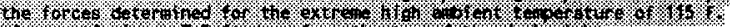

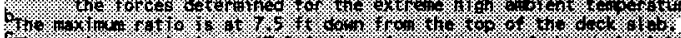

Cf 1 .

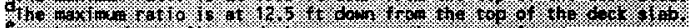

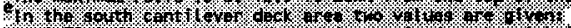

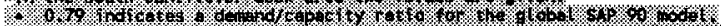

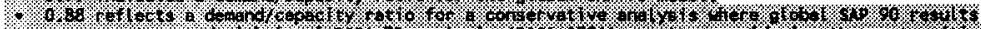
\%

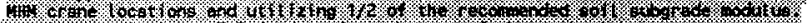

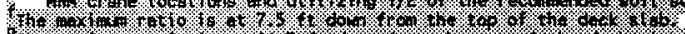

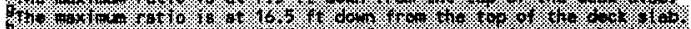

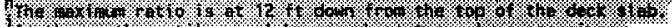

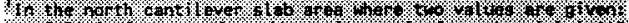

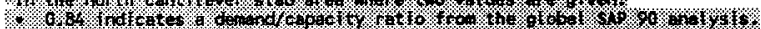

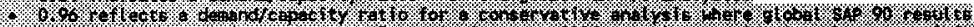
4.

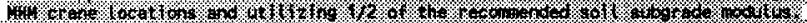

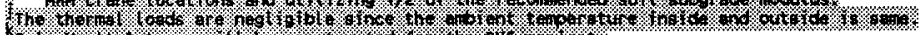

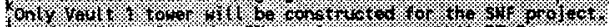

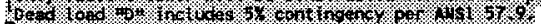

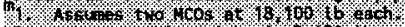

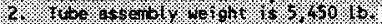

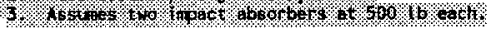

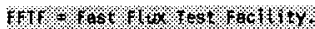

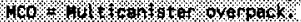

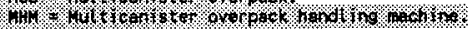

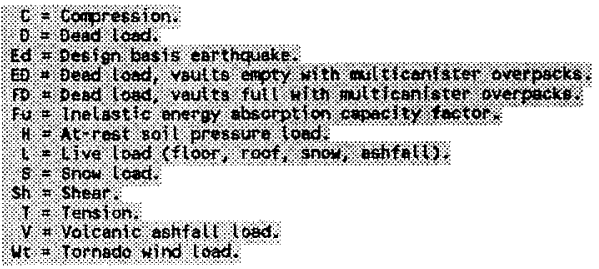


Fab7e-43. Stmmary of Below Grade-and At GadeAnalysis Results. (3-sheets)

\begin{tabular}{|c|c|c|c|}
\hline \multicolumn{2}{|c|}{ Etement } & $\begin{array}{c}\text { DomendFopocity } \\
\text { fotio }\end{array}$ & Geverning-oendition \\
\hline \multicolumn{4}{|c|}{ Vault (Calculation CSE-5-0025ㄱ) } \\
\hline \multirow[t]{6}{*}{ Baso-mat } & Nes-top poinforcing & 0.94 & $1.40 \mathrm{E}+1.4 \mathrm{~T} \mathrm{ET}$ \\
\hline & Hes betem-foiffopeing & 0.70 & $1.40 \mathrm{~F}+1.4 \mathrm{~T}_{\mathrm{En}}$ \\
\hline & $H-5-f$ thed & 0.67 & $\stackrel{D}{F}_{F}+L+T_{E T}+H-E d / F_{\bar{U}}$ \\
\hline & E-W top-roinforcing & 0.80 & $1.40_{E}+1.4 T_{E T}$ \\
\hline & E-W bottom-roinforsing & 0.69 & $1.4 \mathrm{D} F+1.4 \mathrm{~T}_{\mathrm{EK}}$ \\
\hline & E-H-flowat thoof & 0.38 & $\underline{\mathrm{D}}_{\mathrm{F}}+\mathrm{L}+\mathrm{T}_{\mathrm{E}} \mathrm{T}+\mathrm{H}-\mathrm{Ed} / \mathrm{E}_{\overline{\mathrm{U}}}$ \\
\hline \multirow{6}{*}{ 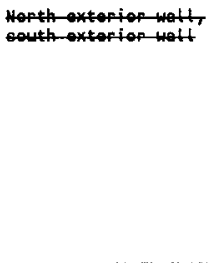 } & Wortical aut ido-roinforeing & 0.76 & $1.4 \mathrm{D}_{\mathrm{F}}+1.4 \mathrm{~T}_{\mathrm{EH}}$ \\
\hline & Verticol inside reinforcing & 0.87 & $1.05 D_{F}+1.3 L+1.05 T_{E T}+1.34$ \\
\hline & Worticel flaxul of hoef & 0.70 & $\underline{D}_{F}+L+T_{E K}+H+E d / F_{\vec{U}}$ \\
\hline & Horizontel auteide-roinforeing & ast & $1.4 \mathrm{D}_{\mathrm{F}}+1.4 \mathrm{~T}_{\mathrm{EF}}$ \\
\hline & Horizontol ingido-roinforeing & $\frac{1.03}{(0.87) \stackrel{c}{=}}$ & 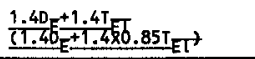 \\
\hline & Horizental flowal of & 0.34 & $\underline{D}_{F}+L+T_{E F}+H+E d / F_{\bar{U}}$ \\
\hline \multirow[t]{4}{*}{ Interion wetts } & Vorticol coinforing & 0 9.95 & $1.4 D_{E}+1.4 \mathrm{~T}_{E \pi}$ \\
\hline & Vorticel flow of ehear & 0.22 & $1.4 \mathrm{D}_{\mathrm{E}}+1.4 \mathrm{I} \mathrm{ET}$ \\
\hline & Horizontal roinforoing & 0.95 & $1.4 \mathrm{D}_{\mathrm{E}}+1.4 \mathrm{~T} \mathrm{ET}$ \\
\hline & Horizontel floxufet thoef & 0.32 & $\underline{1.4 D_{F}} F+1.4 \mathrm{I}_{\mathrm{E}}$ \\
\hline \multirow[t]{6}{*}{ Eaot-axtapiop wall } & vorticol-outcido-roinforcing & 0.68 & $1.4 \mathrm{D}_{\mathrm{F}} \mathrm{F}+1.4 \mathrm{I} \mathrm{E}$ \\
\hline & Vortieal insido-roinforeing & 0.94 & $1.4 D_{E}+1.4 \mathrm{I}_{\mathrm{ET}}$ \\
\hline & Wortical flextral choof & 0.52 & $\underline{D}_{F}+\mathrm{L}+\mathrm{T}_{\mathrm{ET}}+\mathrm{H}-\mathrm{Ed} / \mathrm{F}_{\overline{\mathrm{U}}}$ \\
\hline & Horizentel outeide-poinforeing & 0.93 & $1.4 \mathrm{D} F+1.4 \mathrm{I}_{\mathrm{Eh}}$ \\
\hline & Horizontal incide-roinforoing & $\frac{1.05}{30.895}$ & 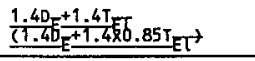 \\
\hline & Horizentel floxifal sheer & 0.05 & $\underline{D}_{F}+L+I_{E}+H-E d / F_{\bar{u}}$ \\
\hline \multirow[t]{6}{*}{ Woet-axteriop watt } & Woptial auteide-roinforcing & 0.77 & $1.4 \mathrm{D} F+1.4 \mathrm{~T} \mathrm{EK}$ \\
\hline & Vertical ingido-roinforcing & $\frac{1.04}{(0.80)}$ & $\frac{1.40}{(1.40} \mathrm{E}_{\mathrm{E}}^{+1.4 \mathrm{~T}} \mathrm{E} \mathrm{KO} .85 \mathrm{~T} \mathrm{~T}_{\mathrm{ET}} \mathrm{T}$ \\
\hline & Woficel floxufal shoar & 0.66 & $\stackrel{D}{F}_{F}+L+T_{E T}+H+E d / F_{\bar{U}}$ \\
\hline & Horizontoutcido roinforcing & $\frac{1.05}{(0.935)}$ & $\frac{1.40}{(1.4 \mathrm{E}} \mathrm{F}^{+1.4 \mathrm{~T}} \mathrm{~T}^{+1.4 \times 0.85 \mathrm{~T}_{E T}}$ \\
\hline & Horizontal inside-roinforeing & $\frac{1.14}{(0.92)^{c}}$ & 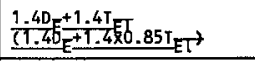 \\
\hline & Hofizontal floxufal oheaf & 0.67 & $D_{F}+L+T E F+H+E d / F_{\bar{u}}$ \\
\hline
\end{tabular}


Fable-4 3.- Sumary of Below Gade and At Grade Analysis Results. (3-sheets)

\begin{tabular}{|c|c|c|c|}
\hline \multicolumn{2}{|c|}{ Etement } & $\begin{array}{c}\text { Domandsepacity } \\
\text { potio }\end{array}$ & Gorerning-oendition \\
\hline \multicolumn{4}{|c|}{ operating Floor (Calculation CSB-5-0014, CSB-5-0026, and CSB-5-0026x-s? } \\
\hline \multirow{6}{*}{$\begin{array}{l}\text { Opopating-floof ovef } \\
\text { tubes (CSB-5-0026 }\end{array}$} & Hes-top-poinforcing & 0.84 & $1.4 \mathrm{D}_{\mathrm{E}}+1.4 \mathrm{~T}_{\mathrm{EK}}$ \\
\hline & Hof botom rainforcing & 0.77 & $1.4 D_{E}+1.4 T_{E T}$ \\
\hline & H-8-ftox at hoor & 0.70 & $\underline{D}_{F}+L+T_{E T}+H+E d / F_{\bar{u}}$ \\
\hline & E-W-top-roinforcing & 0.92 & $1.4 \mathrm{D}_{\mathrm{E}}+1.4 \mathrm{~T} \mathrm{ET}$ \\
\hline & E-w bottem roinforing & 0.04 & $1.4 \mathrm{D}_{\mathrm{E}}+1.4 \mathrm{~T}_{\mathrm{ET}}$ \\
\hline & E-4 floxwat-6hop & 0.35 & $\underline{D}_{F}+T_{E T}+H-E d / F_{\bar{U}}$ \\
\hline \multirow{2}{*}{$\begin{array}{l}\text { Opofating ftoof, autside, } \\
\text { tube region (CSB-S-002b }\end{array}$} & Iwo-way ghodfram HHW toading & 0.67 & $\underline{D}_{F}+E_{\mathrm{d}} / F_{\bar{U}}$ \\
\hline & floxurat hoaf & 0.82 & $\underline{D}_{F}+\mathrm{L}+\mathrm{T} \mathrm{EK}_{\mathrm{K}}+\mathrm{H}-\mathrm{Ed} / \mathrm{F}_{\overline{\mathrm{U}}}$ \\
\hline \multirow{6}{*}{$\begin{array}{l}\text { HCS-AAmOX-doek } \\
\text { TCSB-S-00LBA }\end{array}$} & N-s-top-roinforeing & 0.80 & $1.05 \mathrm{D}+\mathrm{L}+\mathrm{H}+\mathrm{Ed} / \mathrm{F}_{\overline{\mathrm{u}}}$ \\
\hline & W-A bottom-foinforcing & 0.90 & $1.05 \mathrm{D}+\mathrm{L}+\mathrm{H}+\mathrm{Ed} / \mathrm{F}_{\overline{\mathrm{H}}}$ \\
\hline & W-s-floxurat ghoaf & 0.99 & $1.05 \mathrm{D}+\mathrm{L}+\mathrm{H}+\mathrm{Ed} / \mathrm{F}_{\overline{\mathrm{U}}}$ \\
\hline & E-W-top-roinforoing & 0.74 & $1.05 \mathrm{D}+\mathrm{L}+\mathrm{H}+\mathrm{Ed} / \mathrm{F}_{\bar{U}}$ \\
\hline & E-Hbottom-roinforcing & 0.60 & $1.05 \mathrm{D}+\mathrm{L}+\mathrm{H}+\mathrm{Ed} / \mathrm{F}_{\bar{U}}$ \\
\hline & E-H floxurat thos & 0.97 & $1.05 \mathrm{D}+\mathrm{L}+\mathrm{H}+\mathrm{Ed} / \mathrm{F}_{\bar{U}}$ \\
\hline \multirow{6}{*}{$\begin{array}{l}\text { tood-infload-out-dock } \\
\text { fCSB-S-0014) }\end{array}$} & $H-s$ top-roinforcing & 0.72 & $1.05 \mathrm{D}+\mathrm{L}+\mathrm{H}+\mathrm{Ed} / \mathrm{F}_{\overline{\mathrm{u}}}$ \\
\hline & H-c bottom roinforoing & 0.04 & $1.05 \mathrm{D}+\mathrm{L}+\mathrm{H}+\mathrm{Ed} / \mathrm{F}_{\overline{\mathrm{U}}}$ \\
\hline & Hef floxufot of & 0.78 & $1.05 \mathrm{D}+\mathrm{L}+\mathrm{H}+\mathrm{Ed} / \mathrm{F}_{\overline{\mathrm{U}}}$ \\
\hline & Ealt top roinforcing & 0.7 & $1.470+1.74+1.74$ \\
\hline & E-W-bottem-roinforoing & 0.99 & $1.05 \mathrm{D}+\mathrm{L}+\mathrm{H}+\mathrm{Ed} / F_{\bar{U}}$ \\
\hline & EWftowathof & 0.54 & $1.05+L+H+E d / F_{\bar{U}}$ \\
\hline \multicolumn{4}{|c|}{ support Buldaing (Calculation CSB-s-0019?9) } \\
\hline \multirow[t]{2}{*}{ 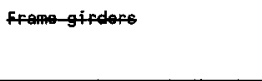 } & combinad-os & 0.62 & $\underline{0.90+W_{t}}$ \\
\hline & Shoof & 0.20 & $\underline{0.90+W t}$ \\
\hline \multirow[t]{2}{*}{ Gotuma } & Cembined-etrose & 0.67 & $\underline{0.90+H_{t}}$ \\
\hline & Shen & 0.17 & $0.90+4 t$ \\
\hline \multirow[t]{2}{*}{ foundation } & soil boafing & 0.64 & $0.90+\mathrm{H}_{\mathrm{t}}$ \\
\hline & stability & 0.93 & $\underline{0.90+w_{t}}$ \\
\hline \multicolumn{4}{|c|}{ Operating Area Butcing (Calculation CSB-s-0uzg 9 -) } \\
\hline \multirow[t]{2}{*}{ Gotuma $+130 \times 235$} & Combined-etrest & 0.89 & $\underline{0+E_{a}}$ \\
\hline & Shear & 0.26 & $0+8+4$ \\
\hline
\end{tabular}


Fab7e-43. Summary of Betow Grade-and At GradeAnalysis Results. (3 sheets)

\begin{tabular}{|c|c|c|c|c|}
\hline \multicolumn{3}{|c|}{ Etement } & $\begin{array}{c}\text { Demandfoepecity } \\
\text { fotio }\end{array}$ & Governing-oendition \\
\hline \multirow[t]{2}{*}{ columan-130 $235+4 c 18 \times 12.7$} & \multicolumn{2}{|l|}{ Gombinod otrose } & 0.82 & $\underline{D+E_{a}}$ \\
\hline & \multicolumn{2}{|l|}{ shen } & 0.27 & $D+c+v$ \\
\hline \multirow[t]{2}{*}{ Frusetop } & \multicolumn{2}{|l|}{ combined-oraces } & 0.80 & $\underline{D+E_{\bar{Z}}}$ \\
\hline & \multicolumn{2}{|l|}{ shoof } & 0.45 & $\underline{D+E_{a}}$ \\
\hline \multirow[t]{2}{*}{ Irues-botton-hord } & \multicolumn{2}{|l|}{ Cembined-atfose } & 0.99 & $\underline{D+E_{\partial}}$ \\
\hline & \multicolumn{2}{|l|}{ Shos } & 0.05 & $\underline{\mathrm{D}+\mathrm{E}_{\mathrm{a}}}$ \\
\hline \multicolumn{3}{|l|}{ 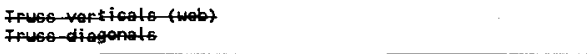 } & 0.84 & $\frac{\mathrm{D}+\mathrm{E}_{\mathrm{B}}}{0.9 \mathrm{D}+\mathrm{H}}$ \\
\hline \multicolumn{3}{|l|}{ Vorticel bracing } & 0.90 & $\underline{\mathrm{D}+\mathrm{E}_{\boldsymbol{Z}}}$ \\
\hline \multicolumn{3}{|l|}{ Horizental braoing } & 0.86 & $\underline{\mathrm{D}+\mathrm{E}_{\mathrm{d}}}$ \\
\hline \multicolumn{5}{|c|}{ Soit Bearing Pressures at Basemat (Calculation CSB-s-0023, } \\
\hline \multicolumn{2}{|c|}{ toation } & \multicolumn{2}{|c|}{$\begin{array}{c}\text { Moximm-pregsure } \\
\text { Tkips/ft? }\end{array}$} & $\begin{array}{l}\text { Pinimun pressure } \\
\text { (kips/ft } \rightarrow \text { ) }\end{array}$ \\
\hline \multicolumn{2}{|c|}{ Horth-and-outh-oxterior wath and } & \multicolumn{2}{|c|}{$7.73\left(\mathrm{D}_{\mathrm{F}}+\mathrm{L}+\mathrm{H}+\mathrm{E}_{\mathrm{d}} \mathrm{T}\right.$} & $0.93\left(0, E+E_{\partial}\right)$ \\
\hline \multicolumn{2}{|c|}{ Horth and-eouth oxterior hall center } & \multicolumn{2}{|c|}{ 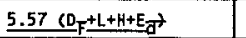 } & $2.32\left(O_{E}+E_{Z}{ }^{7}\right.$ \\
\hline \multicolumn{2}{|c|}{ Eaet and-woet oxtorior watt-contor } & \multicolumn{2}{|c|}{$6.49\left(\mathrm{D}_{F}+\mathrm{L}+\mathrm{H}+\mathrm{E}_{\mathrm{g}} \mathrm{J}\right.$} & $1.90\left(D_{E}+E_{d^{2}}\right.$ \\
\hline \multicolumn{2}{|l|}{ Vault I conter } & \multicolumn{2}{|c|}{$4.79\left(\mathrm{D}_{\mathrm{F}}+\mathrm{L}+\mathrm{H}+\mathrm{E}_{\mathrm{d}}\right)$} & $1.76\left(D_{E}+E_{g}+\right.$ \\
\hline \multicolumn{2}{|l|}{ Voult 2 conter } & \multicolumn{2}{|c|}{$4.67\left(\mathrm{D}_{\mathrm{F}}+\mathrm{L}+\mathrm{H}+\mathrm{E}_{\mathrm{d}}\right)$} & $1.61\left(0_{E}+E_{d^{\prime}}\right.$ \\
\hline \multicolumn{2}{|l|}{ Interiof woll center } & \multicolumn{2}{|c|}{$5.42\left(\mathrm{D} F+L+H+E_{\mathrm{g}} \overrightarrow{ }\right.$} & $1.52\left(D_{F}+E_{-}\right)$ \\
\hline
\end{tabular}

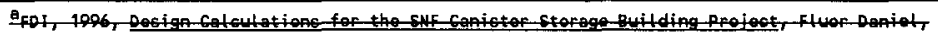

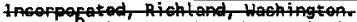

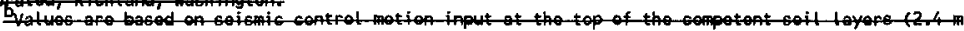
(8-4t) botow the durfacol

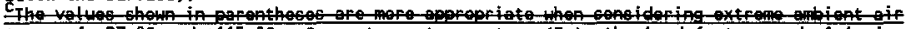
temperatures of $-27^{\circ} \mathrm{F}$ and $+115^{\circ} \mathrm{F}$. For extreme temperature (T/2) tho load-factor-woed 1.2 is

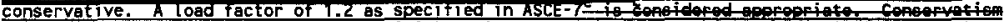

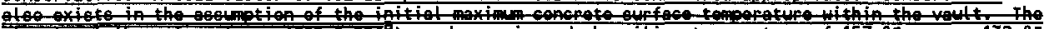

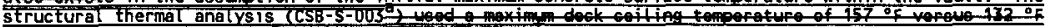
calculated by the vault cooling analys is (CSB-HV-000 t)

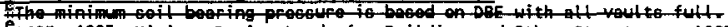

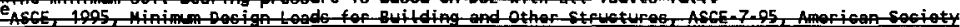

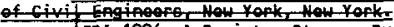

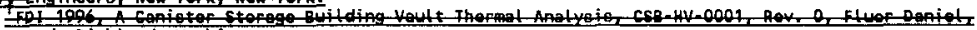

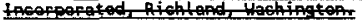

HES- Hot- Conditioning-syotem

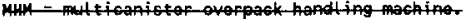

DF - Doed load, valts ompty of mutticanioter-orefpacke

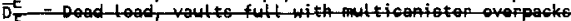

$\overline{0}$ - Doad toad

$t=t$ ivo-toad (floof, roof, saow, oshfatl)

H-mitarest soil prosesure lood

S_ - Snow toad

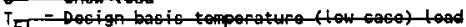

TET - Desigh-bacio-tempepatufo-(high osed load

ET - Dosign bosis enftheluke

If - Fofande-wind laad

$\bar{\psi} \mathrm{t}$ - voleanio achfall load 


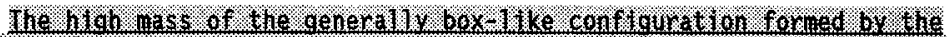

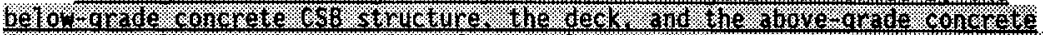

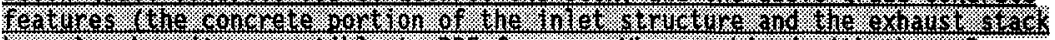

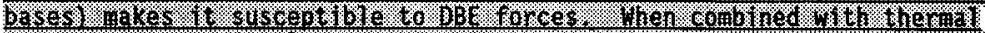

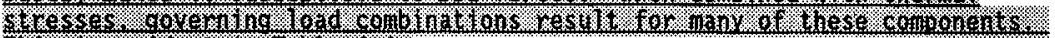

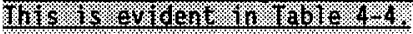

He derk has beer desianed to provide an adeguate safect nargan tor

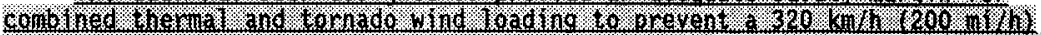

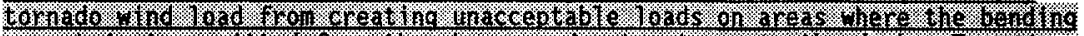

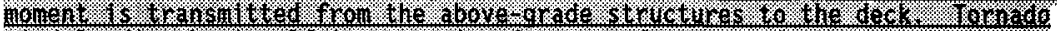

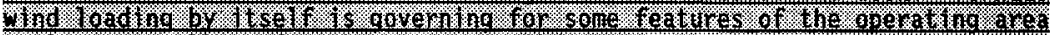

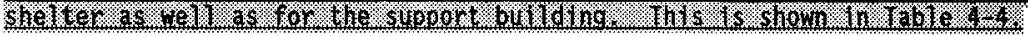

4.3.1.4.4 Mode1ing of the Deck, Superstructure, Ventilation Stacks, and the Multicanister Overpack Handling Machine - Effects on the Substructure. As severe as tornado loading may be, the forces transmitted to the below-grade structure are well below the forces transmitted by seismic forces. Calculations indicate that the below-grade design controlling values of soil pressures, member stresses, displacements, or other parameters are not affected by tornado wind (wt) loads. None of the governing conditions given in Table 4-43 for bellow orade items. (the substructure) were based on tornado wind loads. The weight of the MHM is included in the seismic calculation that affects the seismic response of the CSB below-grade and at-grade structures. The design also includes evaluations of the deck and related structures, such as the stacks and inlets for tornado wind effects as well as the $5 \%$ dead load increases required by ANSI/ANS-57.9-1992 (ANSI/ANS 1992a). The designs were modified as appropriate to accommodate those loads before releases for construction of the below-grade and at-grade reinforced concrete structures.

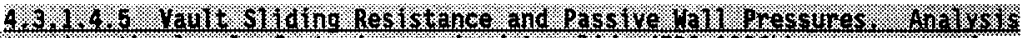

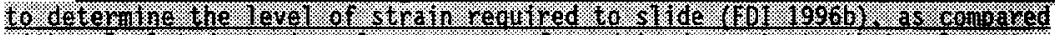

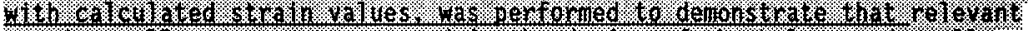

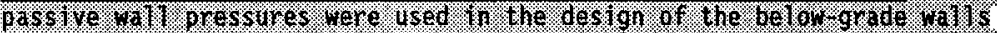

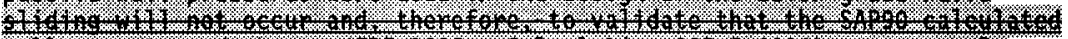

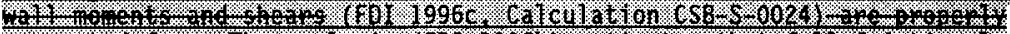

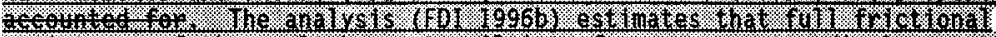

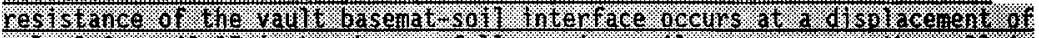

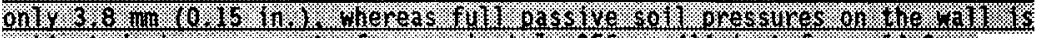

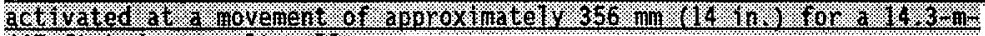

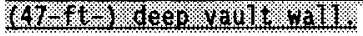

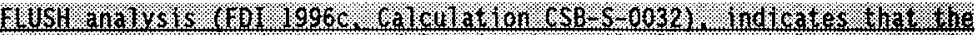
maximem shear strath and shear nodulis in the soll elements below the WaUth

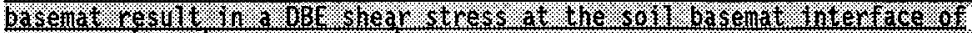

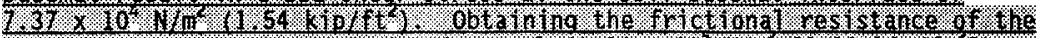

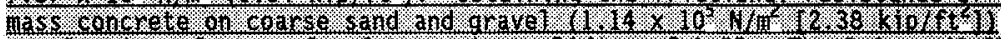

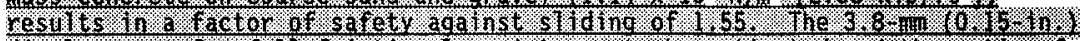

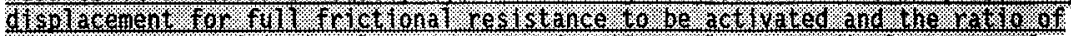
shear stress to frictional resistance of 0.65 resultis ith a displacelent on

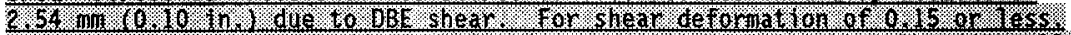

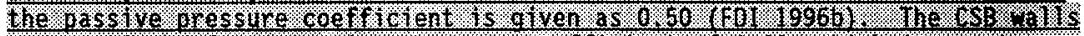

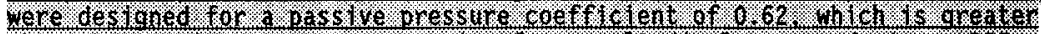

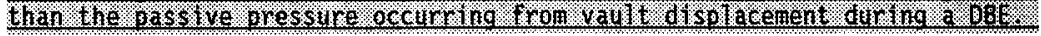




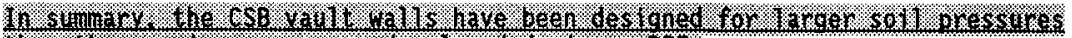

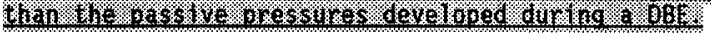

4.3.1.5 Controls (Technical Safety Requirements). TSRs are not applicable

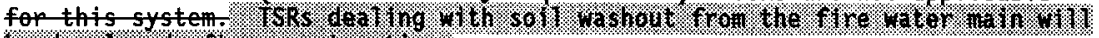
Wo. deveroged at 64 .

\subsubsection{Air Intake and Exhaust Plenums}

4.3.2.1 Safety Function. The CSB will-contains MCOS in the below-grade space described in Chapter 2.0 as CSB vault 1 . The CSB is designed to prevent failure of MCOs. Catastrophic failure of a single MCO could result in consequences over the safety-class guidelines. The potential consequences of an unmitigated release from the inventory at risk in the CSB were evaluated in Section 5.3 of WHC-SD-SNF-HC-007 (Kummerer 1995). Failure of a significant number of the MCOs could result in offsite consequences greater than the sofety. Woss. (safety class 1) guideline. The MCOs must be protected against overheating (fuel centerline temperature greater than $204{ }^{\circ} \mathrm{C}\left[400{ }^{\circ} \mathrm{F}\right]$ ) that could resuit in reactions with the fuel or compromise the structural integrity of the MCO. The air intake and exhaust plenums are integral features of natural convection cooling.

4.3.2.2 System Description. The below-grade concrete structure forms the major portion of the natural convection cooling design for the CSB. Design of the natural convection cooling features is based upon two-dimensional thermal analysis using two-dimensional modeling software and assuming the maximum design air inlet temperature of $115^{\circ} \mathrm{F}$. Results of the vault thermal analysis indicate that the maximum air temperature inside the vault is less than the $65^{\circ} \mathrm{C}\left(150^{\circ} \mathrm{F}\right)$ concrete 1 imitation in ANSI/ACI 349-85, Appendix A (ANSI/ACI 1985). See Figure 4-1 for more temperature profiles. Detailed design calculations have not addressed solar heat gain and wind effects because they are of minor importance. The underground storage vault is not affected by solar heat. The exhaust stack and the air intake being exposed to the same incidence of instantaneous solar exposure has a negligible though positive effect on the thermal analysis. This is because of the slight increase in density differential created by the stack effect. The analysis did not include this effect and has considered this a part of the safety factor in the calculation. Appendix G of CSB-HV-0001, A Canister Storage Building Vault Thermal Analysis (FDI 1996a), provides the wind tunnel test results for the CSB. Adding the deflector at the top of the exhaust stack and

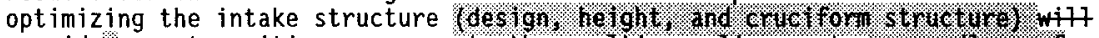
provides a net positive pressure to the vaut's cooling system resactos os of wind direction. The current intake structure configuration with canopy and cruciform wif creates a positive wind pressure effect at the intake under any wind condition.

4.3.2.3 Functional Requirements. The air intake and exhaust plenums withstand a11 applicable NPHs OBA to the extent required to ensure that cooling is maintained to the MCOs. The MCO wall temperature is to be kept at less than $132{ }^{\circ} \mathrm{C}\left(270{ }^{\circ} \mathrm{F}\right)$ to protect the

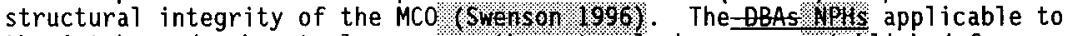
the intake and exhaust plenums are the naturat phenomena establ ished for 


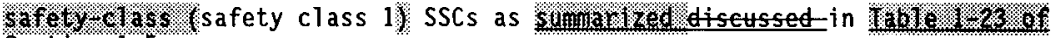
Section 1.5 .

The air inlet and exhaust plenums are. will be-designed to withstand the DOE-designated natural phenomena specified in Section 1.5. Additional natural phenomena requirements are associated with NRC equivalency. Notably, tornado hazards and suspended ashfall were added, and PMP amounts increased.

4.3.2.4 System Evaluation. The above-grade structures that rest on the

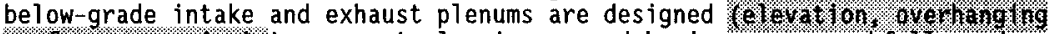

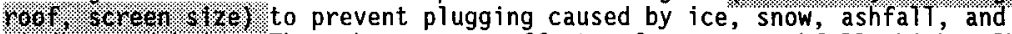
windborne debris. The substructure effects of greater ashfall, higher PMP, tornado wind loading, and pressure changes upon the SNF CSB air intake and exhaust plenums were evaluated and included in the operating deck design.

Structural design information for the current design is provided in Section 4.3.1.4.

4.3.2.5 Controls (Technical Safety Requirements). TSRs are not applicable

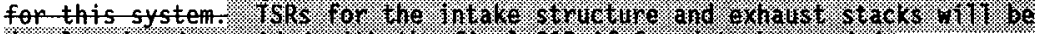

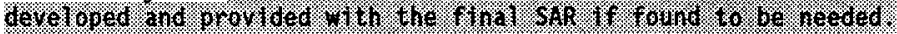

\subsubsection{Carbon Steel Base Slab Embeds}

4.3.3.1 Safety Function. The 220 tubes (and 6 overpack tubes) of vault 1 bxe - seismically restrained through the use of tube base assemblies that bolt to carbon steel embeds in the base slab of the CSB. In vault 1 these embeds will-serve the safety function of maintaining horizontal stability of the tubes containing MCOs during a DBE. The embeds are present in vaults 2 and 3 for future use. Their safety function for future use has not been evaluated.

4.3.3.2 System Description. Two rows of carbon steel embed strips are located under each row of tubes as shown in Figure 4-2. The embeds 71 -serve as the welding plates for threaded weld studs to which the tube base assemblies are. will be-bolted. The tube base assemblies are itl-not affixed to the tubes but will restrain the tubes. Each completed alignment fixture wi7-consists of a $2.5-\mathrm{cm}$ (1-in.) carbon steel plate bolted to the embed strips in four places and topped by a short (about $15 \mathrm{~cm}$ [6 in.] tal1), right-circular cylinder of $1.3-\mathrm{cm}(0.5-i n$.$) thick carbon steel of a diameter$ slightly larger than the tube and welded to the plate. The tubes witi-rest on top of the carbon steel $p l a t e s$ and are seismically restrained within the 15-cm- (6-in.-) tall cylindrical band.

4.3.3.3 Functional Requirements. The embeds in vault 1 must remain in place during the DBE to provide horizontal stabilization of the tubes. Functional requirements for embeds in the base slab areas of vaults 2 and 3 were based on seismic loading for the HWVP CSB mission and will require reevaluation for future uses.

4.3.3.4 System Evaluation. The carbon steel embeds for vault 1 are evaluated for the DBE specified in Section 1.5 based on the seismic loading from the storage tubes and the MCOS, which contain SNF and weigh up to 
$9,090 \mathrm{~kg}(20,000 \mathrm{lb})$. Embed-tube interface design will-accommodates the current DBE for tubes loaded with MCOs. The embeds and tube base assemblies work in concert to restrain the storage tube at the basemat elevation. Seismic analysis and design of the embeds was performed to ANSI/ACI 349-85

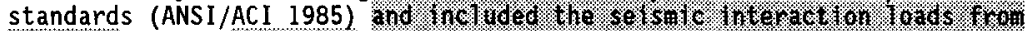

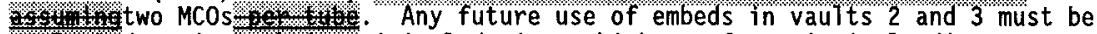
evaTuated against their original design, which was for seismic loading associated with the HWVP CSB mission.

\subsubsection{Controls (Technical Safety Requirements). TSRs are not applicable} for this system.

\subsubsection{Canister Storage Building At-Grade Structures}

The at-grade reinforced concrete structures are the operating area deck, the HCS Annex, the load-in/load-out area, and the support building foundation.

4.3.4.1 Safety Function. As an integral part of the CSB vault, the operating area deck shares the design functions of the vault. Those functions are to maintain the MCOs in a subcritical geometry, to ensure the functionality of the natural convection cooling system, and to protect the staged and stored

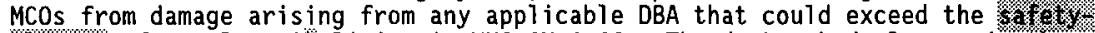
4.5s. (safety class 1) 1imits - in WHC CH-4-46. The deck embed sleeves in the operating area deck provide a finished surface for resting the storage tube's bellows assembly. A $1.3-\mathrm{m}$ (4-ft, 4-in.) wide by $0.9-\mathrm{m}(3-\mathrm{ft}$ ) high curb borders the operating floor area (operating deck, HCS Annex, and load-in/loadout areas) on the east, west, and south. The curb's height is increased to $2.4 \mathrm{~m}(8 \mathrm{ft})$ at the north end to meet shielding requirements $\mathrm{f}_{\mathrm{s}} \mathrm{s}$.

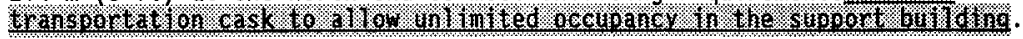

4.3.4.2 System Description. The at-grade reinforced concrete structures have overall dimensions of $86.9 \mathrm{~m}$ by $57.7 \mathrm{~m}$ ( $285 \mathrm{ft}, 0.5 \mathrm{in}$. by $189 \mathrm{ft}, 5.5 \mathrm{in}$.). The operating area deck is a $1.5-\mathrm{m}-(5-\mathrm{ft}-0-\mathrm{in.}$.$) thick reinforced concrete$ structure. The deck is $55.2 \mathrm{~m}$ by $50.5 \mathrm{~m}(181 \mathrm{ft}, 2$ in. by $165 \mathrm{ft}, 9$ in. $)$.

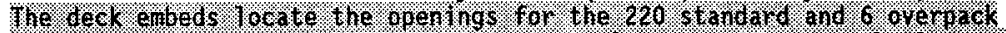

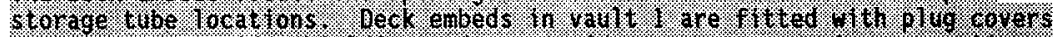

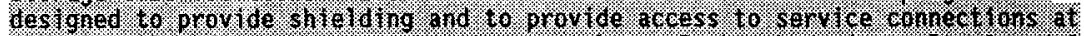

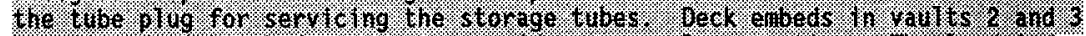

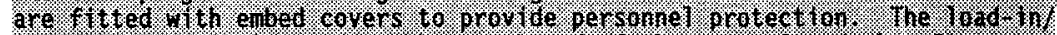

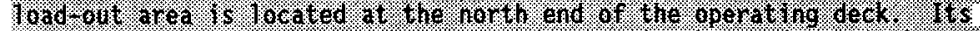

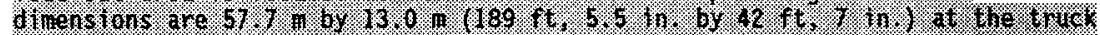

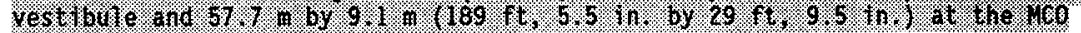
server. 510100

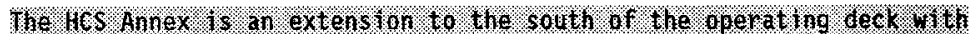

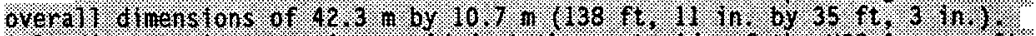

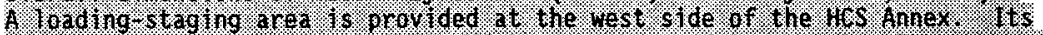

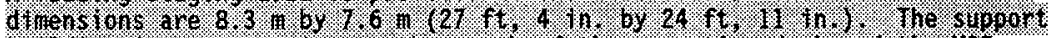

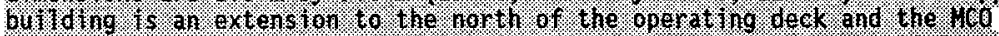

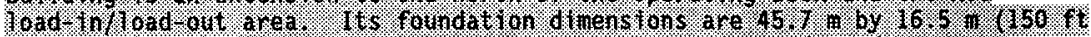

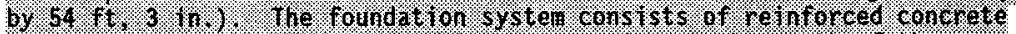

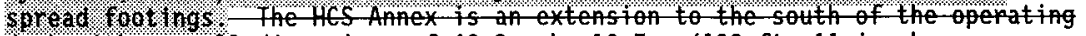
deck with overall dimensions of $42.3 \mathrm{~m}$ by $10.7 \mathrm{~m}$ (138-ft, 11 in. by 
$35 \mathrm{ft}, 3$-in.). The load infload out area's dimensions are $57.7 \mathrm{~m}$ by $13.0 \mathrm{~m}$ (189 $\mathrm{ft}, 5.5 \mathrm{in}$. by $42 \mathrm{ft}, 7 \mathrm{in}$ ) at the truck vestibute and $57.7 \mathrm{~m}$ by $9.1 \mathrm{~m}$ (189 ft, 5.5 in. by 29 ft, 9.5 in.) at the $M C O$ service station. The control bulding foundation dimensions are $-45.7 \mathrm{~m}$ by $16.5 \mathrm{~m}$ (150 $\mathrm{ft}$ by $54 \mathrm{ft}, 3$ in.). A loading staging area-is provided at the west side of the HCS Annex. Its dimensions are $8.3 \mathrm{~m}$ by $7.5 \mathrm{~m}-(27 \mathrm{ft}, 4$ in. by $24 \mathrm{ft}, 11$ in. $)$.

The deck embeds- locate the openings for the 220 standard and 6 overpack

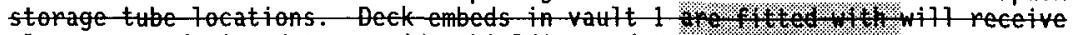
plug covers designed to provide shielding and to provide access to service connetions at the tube plug for servicing the starage tubes. Deck embeds in

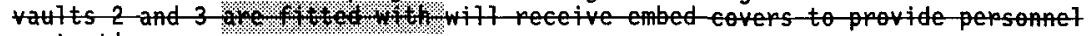
protection.

The support building is a-steel framed structure appoximately-45.7-mby $16.5-\mathrm{m}$ by $4.9 \mathrm{~m}$ ( $150 \mathrm{ft}$ by $54 \mathrm{ft}$ by $16 \mathrm{ft}$ ) high enclosed by insulated metal siding and a pof deck. The structure is moment frame in the north south direction and braced frame in the east west dipection. The steel framing, poof deck, and siding are designed to pesist wind pressures from a $322 \mathrm{~km} / \mathrm{h}$

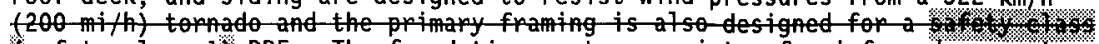
(safety ctass 1 ) DBE. The foundation system consists of reinforced concrete spread footings: The demand tapacity ratios of the primary structurat elements are given in Table 4.43 .

4.3.4.3 Functional Requirements. The operating deck acts together with the vault walls and basemat to support the loads associated with the MHM, the

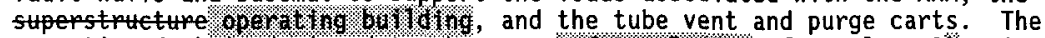

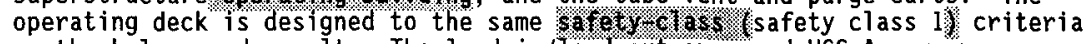
as the below-grade vault. The load-in/load-out area and HCS Annex are

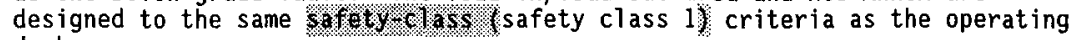
deck.

The operating shelter design basis is as follows:

- Roof dead load, includes $5 \%$ contingency plus $24 \mathrm{~kg} / \mathrm{m}^{2}\left(5 \mathrm{lb} / \mathrm{ft}^{2}\right)$ fireproofing at ceiling for a total of $107 \mathrm{~kg} / \mathrm{m}^{2}\left(22 \mathrm{lb} / \mathrm{ft}^{2}\right)$

- Snow load at ground level, $98 \mathrm{~kg} / \mathrm{m}^{2}\left(20 \mathrm{lb} / \mathrm{ft}^{2}\right)$; roof snow load, considering drifts at low roofs

- Roof live load, $90 \mathrm{~kg} / \mathrm{m}^{2}\left(207 \mathrm{~b} / \mathrm{ft}^{\underline{2}}\right)$

- Volcanic ashfall, $/ 17, \mathrm{~kg} / \mathrm{m}^{2}\left(247 \mathrm{~b} / \mathrm{ft}^{2}\right)$ ground load and ashfall roof drift

- Siding dead load calculated to be $39 \mathrm{~kg} / \mathrm{m}^{2}\left(8 \mathrm{lb} / \mathrm{ft}^{2}\right)$; however, $59 \mathrm{~kg} / \mathrm{m}^{2}\left(12 \mathrm{lb} / \mathrm{ft}^{2}\right)$ used in design

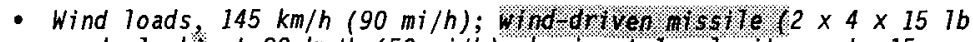
wood plank) at $80 \mathrm{~km} / \mathrm{h}(50 \mathrm{mi} / \mathrm{h})$, horizontal velocity up to $15 \mathrm{~m}$ (50 ft) high, vertical velocity equal to two-thirds horizontal 
- Seismic load, horizontal response spectra of $0.35 \mathrm{~g}$ ("free field" used in Calculation CSB-S-0029); vertical is two-thirds of horizontal spectra; confirmatory analysis (FDI 1996c, Calculation CSB-S-0048) used in-structure response spectra at deck level based on seismic input at top of competent layer and soil properties at mean, mean $\times 2$, and mean $\times 1 / 2$

- Tornado loads

- Wind, $322 \mathrm{~km} / \mathrm{h}(200 \mathrm{mi} / \mathrm{h})$

- Pressure drop, $6.2 \mathrm{kPa}\left(0.97 \mathrm{~b} / \mathrm{in}^{2}\right)$.

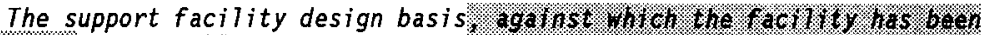
evorufuef is as follows:

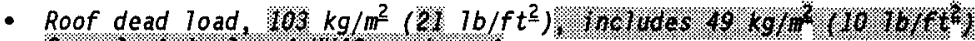
\%or .

- hoof live load, $98 \mathrm{~kg} / \mathrm{m}^{2}\left(20 \mathrm{lb} / \mathrm{ft}^{2}\right)$

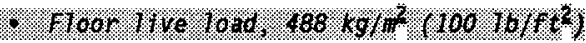

- Roof snow load based on ground-level snow load of $98 \mathrm{~kg} / \mathrm{m}^{2}$ (20 $\left.7 \mathrm{~b} / \mathrm{ft}^{2}\right)$ plus drift

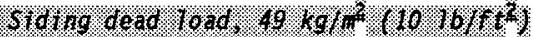

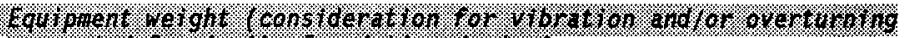

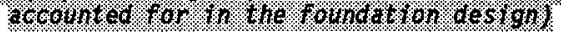

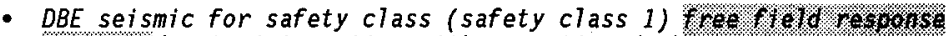
so.ct 6 . due to interaction with operating deck

- Tornado loads, wind $320 \mathrm{~km} / \mathrm{h}(200 \mathrm{mi} / \mathrm{h})$

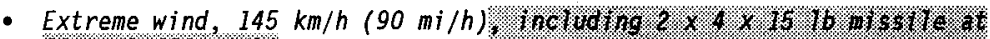
$80.6 \% 16 \cdot 150.616 \%)$

4.3.4.4 System Evaluation. The CSB low grade reinforced concrete structures have been designed for all applicable loads and load combinations as defined in the SNF CSB Detailed Design Basis Document, Section 10 (Bedell 1996z). The loads include normal loads, severe and extreme environmental loads, natural phenomena loads, and any DBAs identified by

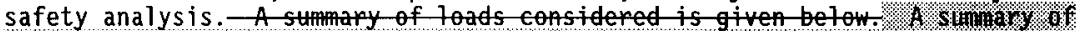

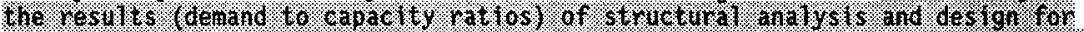

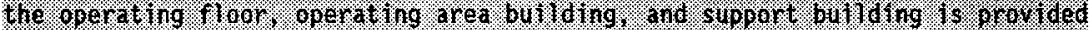
17. 6 . $61.0 .4 \%$ :

4.3.4.4.1 0perating Deck. The operating deck has been designed using an isotropic plate model with a reduced modulus of elasticity derived from a comparison of the natural frequencies of a beam (grillage) model and a plate element model. The operating deck has been designed to perform at the temperatures expected from the below-grade storage of MCOs. The design analysis results, as shown on Figure 4-3, indicate that for a fully loaded 
vault, the highest calculated concrete temperature on the operating floor surface is $41^{\circ} \mathrm{C}\left(106^{\circ} \mathrm{F}\right)$, coincident with a site ambient temperature of $46^{\circ} \mathrm{C}$ $\left(115^{\circ} \mathrm{F}\right)$. The highest calculated temperature for the operating floor deck slab (vault side) is $51{ }^{\circ} \mathrm{C}\left(132{ }^{\circ} \mathrm{F}\right)$. This temperature occurs at the underside of the deck $s 7 a b$ next to the storage tube. These temperature values were obtained from Appendix $E$ of CSB-HV-0001 (FDI 1996a). The operating pressure range for the gas in the tube during staging or interim storage is $6.9 \mathrm{kPa}$ gauge ( $1.0 \mathrm{lb} / \mathrm{in}^{2}$ gauge) to $\mathrm{K} 4 \mathrm{kPa}$ gauge (t6 $\mathrm{lb} / \mathrm{in}^{2}$ gauge). The storage tubes are only at vacuum while being purged by a service cart, a time period that is too short to impact heat transfer and temperature profiles in the deck. Thermal analysis has been performed with all three candidate inerting gases (helium, nitrogen, and argon) (FDI 1996a).

The deck addition for the HCS Annex has been analyzed and designed as integral with the vault for all loads. Soil springs for the compacted stratum 1 were used. Any imported soil used as backfill is consistent with the stratum 1 soils. Dames and Moore, a geotechnical engineering company, estimated the total and differential settlement expected between the vault and the north and south cantilevers during different stages of construction and operation. Estimates of expected settlement are provided in FDT-011, Deck Cantilever Settlement and Vault Sliding Estimates (FDI 1996b).

The geotechnical predicted settlement values (FDI 1996b) were compared with the settlement values computed by the structural analysis (FDI 1996c, Calculation CSB-S-0026A). The differential settlements computed by the structural analysis were found to be generally larger than in the geotechnical analysis. The maximum anticipated differential settlement is on the order of $2.5 \mathrm{~mm}(0.10 \mathrm{in.})$ across the 9.1 to $10.7 \mathrm{~m}$ (30 to $35 \mathrm{ft})$ of the south cantilever deck. Although the predicted differential settlements are small, a crack control joint at the interface with the vault's north and south walls has been included in the design.

The cantilever soil springs used in the structural analysis model were based on an initial vertical coefficient of $150 \mathrm{pci}$ (pounds per cubic inch) and adjusted for the plan dimensions of the basemat to $29 \mathrm{pci}$. The vault basemat soil springs were based on an initial vertical coefficient of 300 pci and adjusted for $p 7$ an dimensions to $74 \mathrm{pci}$. $A$ review of the fill material used and the compaction results suggests that the coefficient of subgrade reaction for the overhang soil springs would be $25 \%$ higher than values previously given for stratum 1 soils and used in the design (FDI 1996c, Calculation CSB-S-0026A). The design has this additional conservatism.

The quality of backfill material being used and the field compaction tests conducted to date have been reviewed and found to meet or exceed the project specification requirements (FOI 1996b). To account for uncertainty in the execution of construction, settlement measurements at the north and south vault walls and at the edges of the north and south deck cantilevers will be taken and evaluated after construction and during operation.

Specific tornado wind loads were developed for the intake and exhaust stacks to evaluate their impact on the vault deck. Structural calculations are documented in CSB-S-0012 for exhaust stack, CSB-S-0028 and CSB-S-0028A for intake structure, and CSB-S-0026 for deck design (FDI 1996C). 
Using NRC-accepted tornado missile probability methodology provided by the design authority (Bazinet 1996c), the architect-engineer completed a probabilistic risk analysis of tornado-wind-driven missiles becoming credible impact loads for the CSB assuming no resistance provided by the superstructure. Further adjustments to the probabilistic risk analyses were made using a survey of the site for potential missiles (Beary 1996a and $1996 \mathrm{~b})$. The revised estimated frequency of $4 \times 10^{-9}$ for a missile strike on the CSB is well below the NRC criterion of $1 \times 10^{-6}$ (Jacobs 1996d). Therefore, the CSB is not subject to missile impacts, and the structures are designed for the tornado wind and atmospheric pressure change.

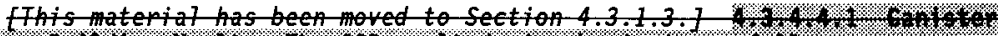

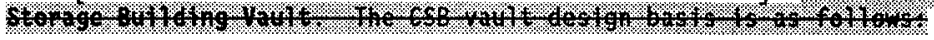

$\rightarrow$ Deat load, includes insulating concrete in vaults 2 and 3

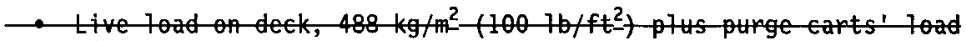

$\rightarrow$ - All-three-exhaust stacks, insulating-enerete on the vault 2 and 3 stacks

-.All three-air intake structures, steel and concrete portions

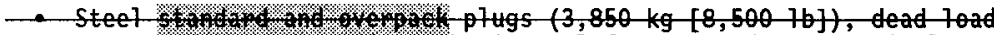
supported by tube, setsmic hopizontal fores-at deck, vertical at basemat

- MIH4 10ad, $4.5 \times 10^{5}-\mathrm{kg}\left(1-10^{6}-16\right)$, ineludes $10 \%$ contingency

- MCO cask transporter weight, $47,200 \mathrm{~kg}(104,000 \mathrm{lb})$ live load in toad inflowt truck vestibule

$\rightarrow$ Receiving crane, $149,687 \mathrm{~kg}(330,000 \mathrm{lb})$ in load in/loat out area (includes $54,432 \mathrm{~kg}[120,000-7 \mathrm{~b}] \mathrm{lift}$ load)

- HES Annex with seven pits, process modutes, process enclosupe ovens

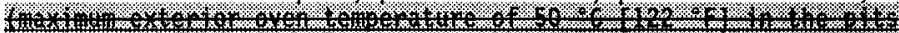
\%

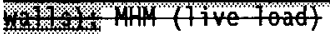

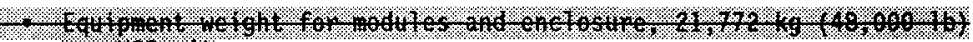
$90.210 .0 \%$

-.-Operating-shelter reconfigured for tornado loads, includes dead tout, live low, tornadowit, seismic lows

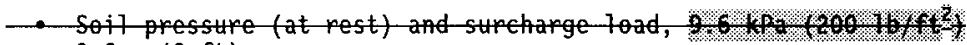
$0.6-\mathrm{m}$ (2 ft)

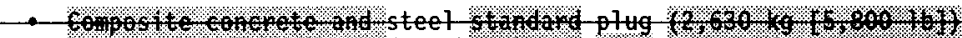
$(3,850 \mathrm{~kg}[8,500 \mathrm{lb}])$, drop height $2.7,2.0 \mathrm{~m}(9 . \mathrm{s}, \mathrm{ft})$ impret on storatue 


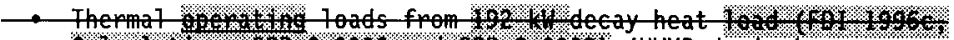

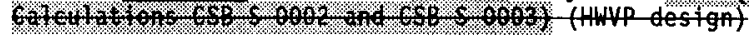

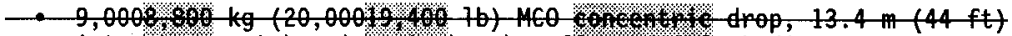
into storage tube, impact absorber $66^{-\mathrm{cm}}(26 \mathrm{in}$ ) diameter, $82.7 \mathrm{MPa}$ $\left(12,000-10+\operatorname{tin}^{2}-t\right.$

- Cask MCO dead loat, $49,900 \mathrm{~kg}(110,000-76)$ in service pit

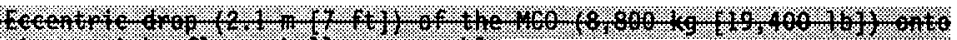

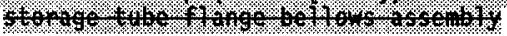

-.. 5\% dead load contingency in operating shelter in accordance with ANSI/ANS 57.9 1992 (ANSI/ANS 1992.2)

- $24 \mathrm{~kg} / \mathrm{m}^{2}-\left(5-1 b / \mathrm{ft}^{2}-\mathrm{dead}\right.$ load for fireproofing operating area eeiling

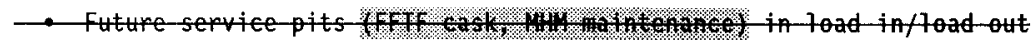
area

- DBE response-spectral analysis with input motion at top of competent 7 yyer $(2.4 m[8 \mathrm{ft}]$ from strface) andyamic soil shear modulus variation of 1.5 and 1 over 1.5 times the best estimate ralue, ow

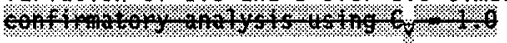

. Tornato torats.

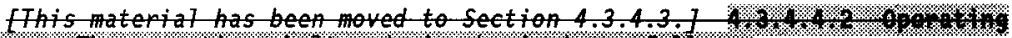

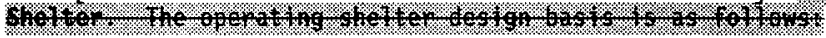

$\rightarrow$ Roof dead load, includes $5 \%$ contingency $p l u s-24 \mathrm{~kg} / \mathrm{m}^{2}-15 \mathrm{lb} / \mathrm{ft}^{2}-\mathrm{t}$

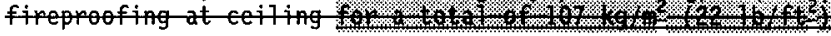

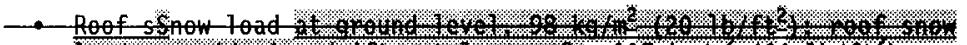

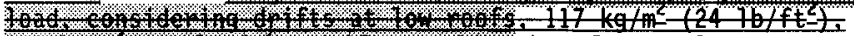

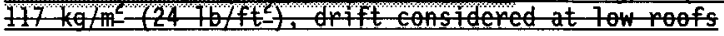

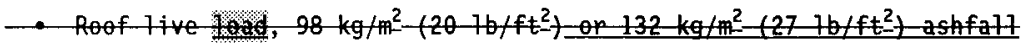

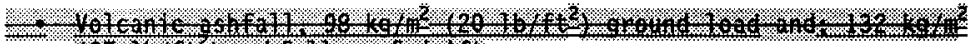

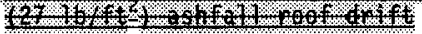

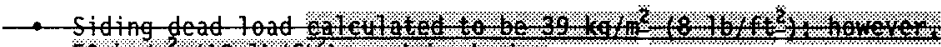

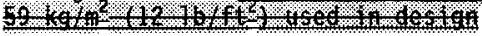

$\rightarrow$ Extreme wind $145 \mathrm{~km} / \mathrm{h}(90 \mathrm{mi} / \mathrm{h}), 2 \times 4 \times 151 \mathrm{~b}$ plank missile at $80 \mathrm{~km} / \mathrm{h}(50 \mathrm{mi} / \mathrm{h})$, horizontal velocity $4 \mathrm{p}-$ to $15 \mathrm{~m}$ (50 ft)-high, vetical velocity equal to two thids hopizontal

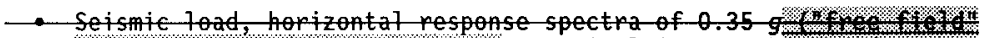

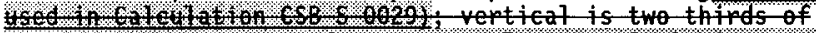

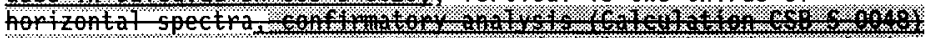

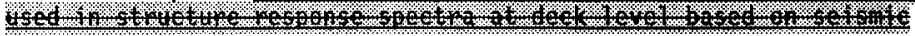




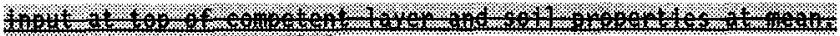

2.2.

- Torndo toads

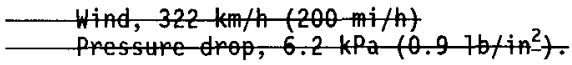

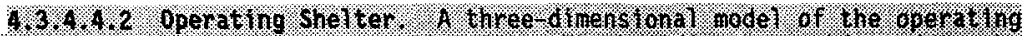

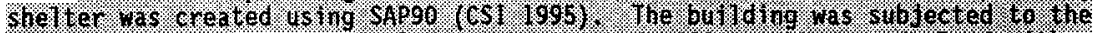

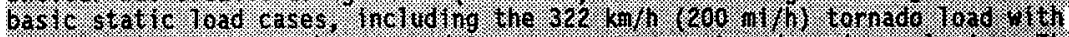

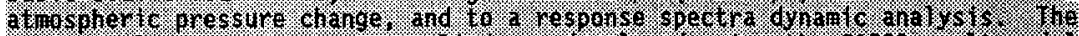

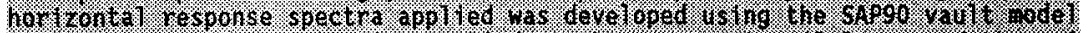

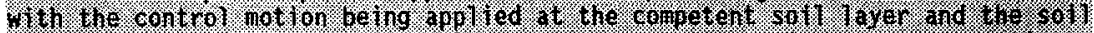

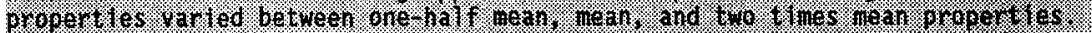

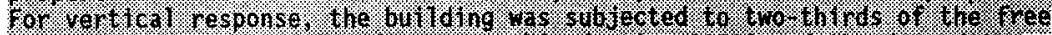

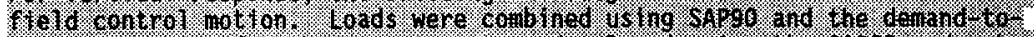

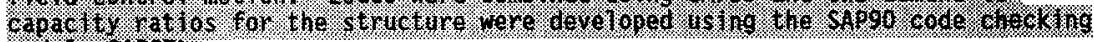
1.0.1.

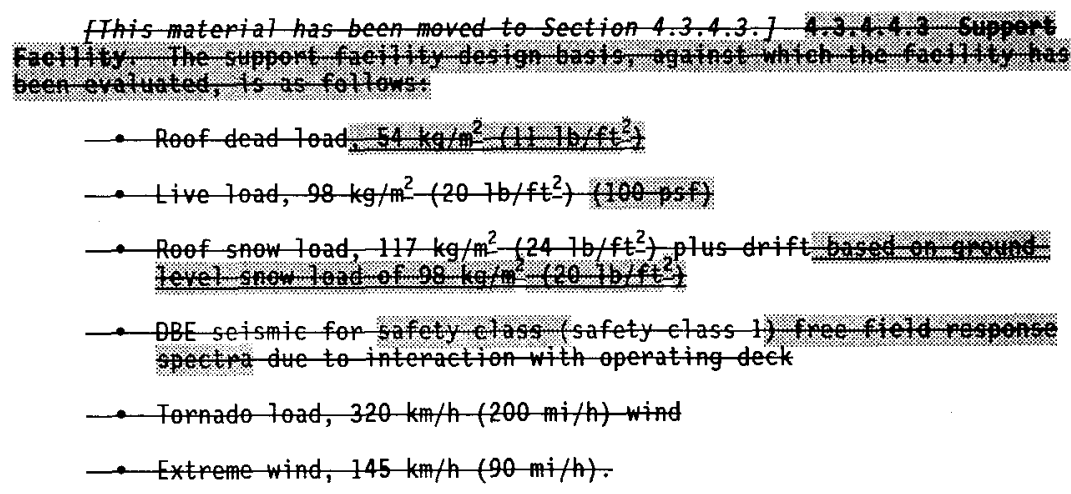

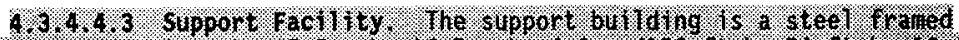

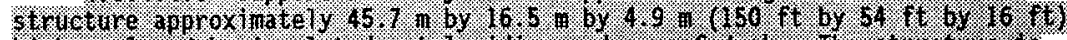

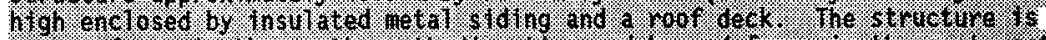

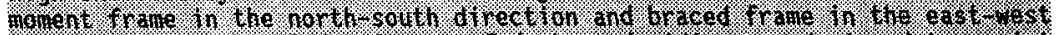

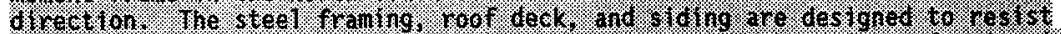

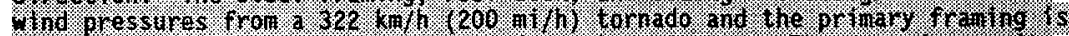

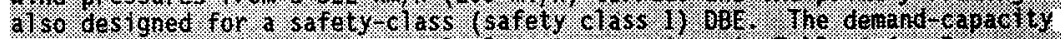

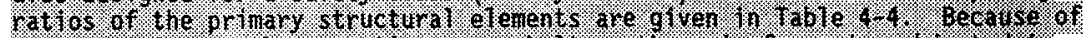

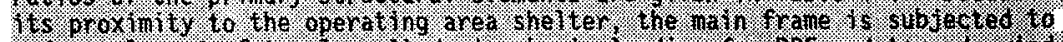

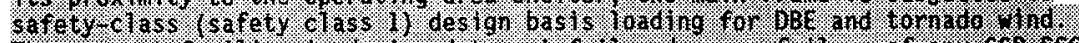

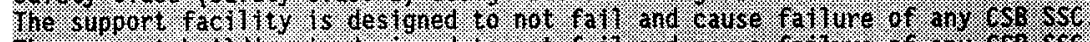

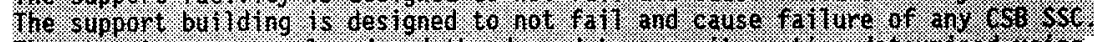

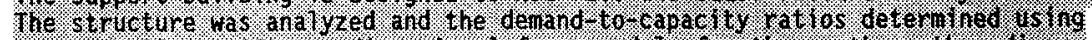

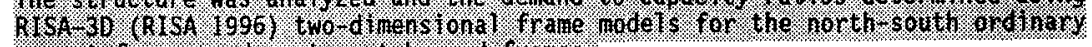

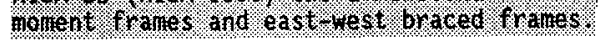




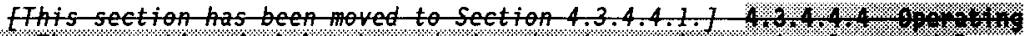

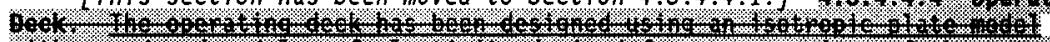

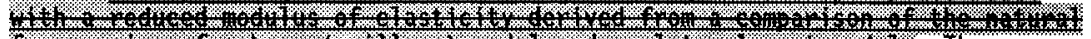

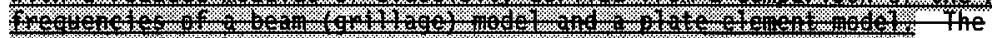
operating deck has been designed to perform at the temperatures expect from the below grade storage of $M C O$ s. At present The design analysis results, as

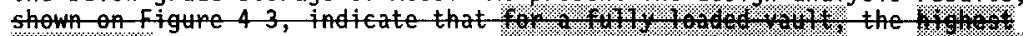

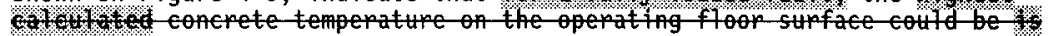
$41^{\circ} \mathrm{C}\left(106^{\circ} \mathrm{F}\right)$, coincident with a site ambient temperature of $46^{\circ} \mathrm{C}\left(115^{\circ} \mathrm{F}\right)$. The highest calculated temperature for the operating floor deck stab o. ox (10.) is $51^{\circ} \mathrm{C}\left(132^{\circ} \mathrm{F}\right)$. This temperature oecurs at the underside of the deck stab next to the storage tube. These temperature values were obtained from Appendix $E$ of CSB HV 0001 (FDI 1996a). The operating pressupe range for the gas in the tube during staging op interim storage is 6.9 kPa gattge $\left(1.0 \mathrm{lb} / \mathrm{in}^{2}-\mathrm{gatge}\right)$ to $524 \mathrm{kP}$ gatuge (76 $7 \mathrm{~b} / \mathrm{in} 2 \mathrm{gauge}$ ). The storage tubes op HCOS are only at ractum while being purged by a service cart, a $t$ ime period that is too short to impact heat transfer and temperature profiles in the deck. Thermal analysis has been performed with all three candidate inerting gases (helium, nitrogen, and argon) (FOI 1996a). The selected themal andysis temperature $\left(69^{\circ} \mathrm{C}\left[157^{\circ} \mathrm{F}\right]\right)$ for structura] envelos the results of the thermat andiysis.

A stmmary of the results (demando capacity ratios) of stutural analysis and design-for the vault, operating floor, operating area building, and suppont butlding is provided in Table $4-43$.

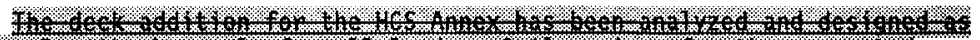

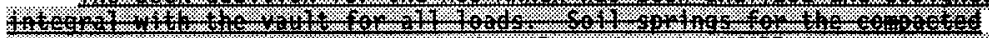

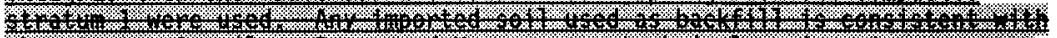

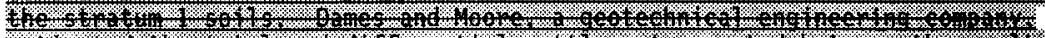

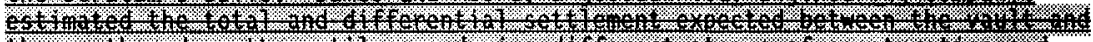

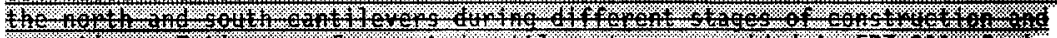

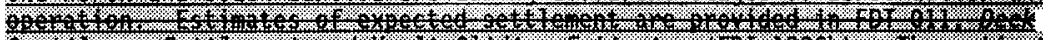

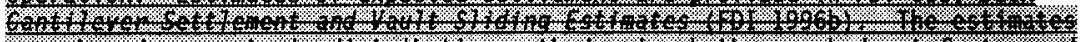

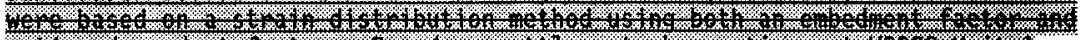

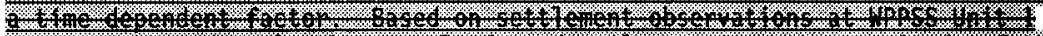

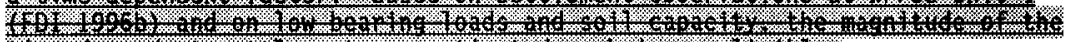

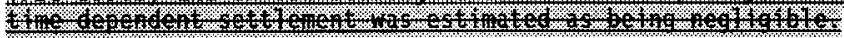

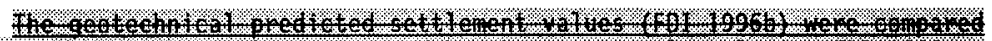

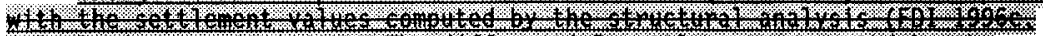

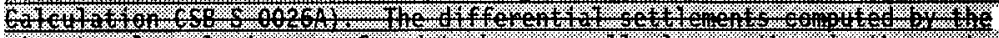

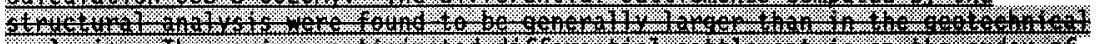

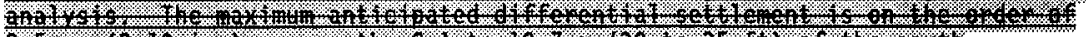
2.r.

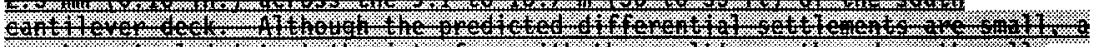

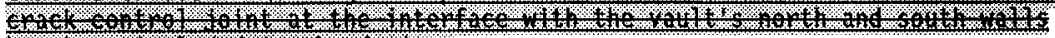

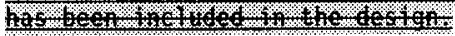

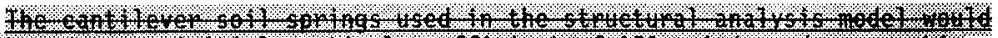

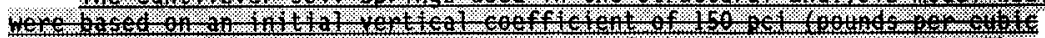

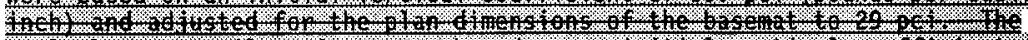

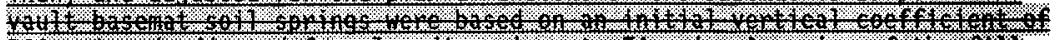

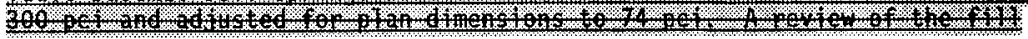




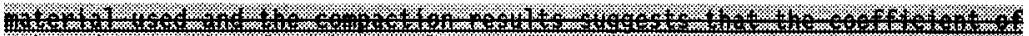

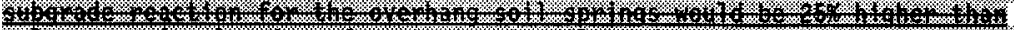

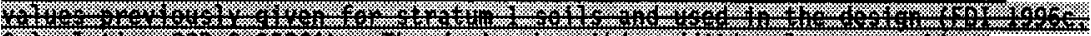

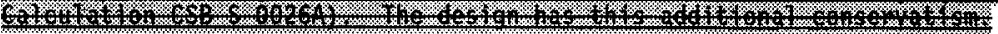

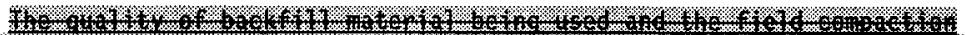

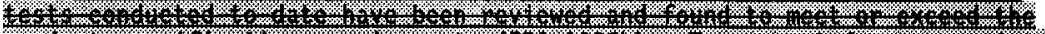

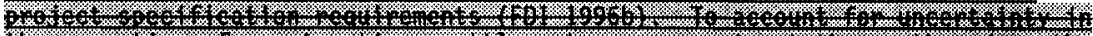
3.1.

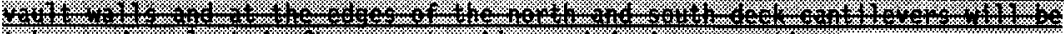

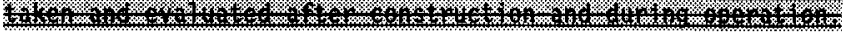

Specific tomado wind loads we developed fop the intake and exhaust stacks to evaluate their impact on the vault deck. Table-4-4 provides ealeulated increases as a ratio (tornado/SNF CSB) of the magnitule of change that tornado loads-impose. As a result, the stack and intake structure (steel and concrete) have been strengthened for the increased demands and areas of deck around them have been reinforced. Structural caleulations are documented in CSB S 0012 for exhatst stack, CSB S 0028 and CSB S 0028A for intake structure, and CSB S 0026 for deck design (FDI 1996ed).

Fable-4-4. Stmmany of Results and Companison of Analyses! Spent- Nulear Fuel Canister Storage Building Load Demand Versus Tornado toads.

\begin{tabular}{|c|c|c|c|c|c|}
\hline \multirow[t]{2}{*}{ Item } & \multicolumn{2}{|c|}{ SAF CSB loads } & \multicolumn{2}{|c|}{ Fornado loads } & \multirow{2}{*}{$\begin{array}{l}\text { Increase due } \\
\text { to tornade } \\
\text { toading }\end{array}$} \\
\hline & toad case & $(k, k, f t)$ & toad ease & $(k,-k, f t)$ & \\
\hline $\begin{array}{l}\text { Exhaust } \\
\text { stack }\end{array}$ & Hind & $H_{w}=8,8 z$ & Fornado & $\begin{array}{l}V_{t}=159 \\
H t=13,700\end{array}$ & $\begin{array}{l}1.94 \\
1.71\end{array}$ \\
\hline $\begin{array}{l}\text { Intake } \\
\text { struture }\end{array}$ & Wind & $\begin{array}{l}v_{w}=33.7 \\
H_{w}=1,432\end{array}$ & Tornado & $\begin{array}{l}V_{t}=236 \\
4 t=-, 520\end{array}$ & $\begin{array}{l}7.0 \\
6.65\end{array}$ \\
\hline
\end{tabular}

NOFE, Wind speod for wind is $145 \mathrm{~km} / \mathrm{h}-(90 \mathrm{mi} / \mathrm{h})$ wind-speod-for tornodo tooding is $322 \mathrm{~km} / \mathrm{h}$

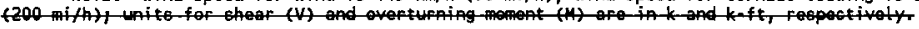

6so- Conitor Storage-Building. SNF - Epent-Auclear fuol.

Using NAC aceepted tornado missile probability methodology-provided by the design authority (Bazinet 1996/3), the architect engineer completed a probabilistic risk analysis of tornado-wind driven missiles bening credible impact loads for the CSB assuming no resistance provided by the superstructure. Further adjustments to the probubilistic risk andyses were made using a survey of the site for potential missites (Beary 1996a and 1996b). The revised estimat frequey of $4 \times 10^{-9}$ for 2 missile strike on the CSB is well below the NRC -eriterion of $1 \times 10^{-6}$ (Jacobs 19964). Therefore, the $C S B$ is not subject tomissile impats, and the structures are designed for the tornado wind and atmespheric pressure change-

4.3.4.5 Controls (Technical Safety Requirements). TSRs are not applicable for this system. 


\subsubsection{Storage Tube, Bellows Assembly, Tube Plugs, Impact Absorbers, and Tube Base Assemblies}

4.3.5.1 Safety Function. The storage tube and tube plugs form the secondary

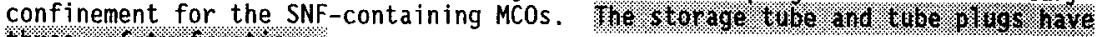
the restery wotwons.

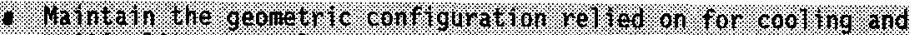
cr. 1 (c)

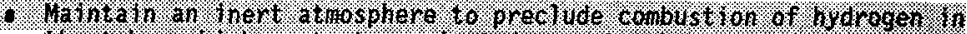

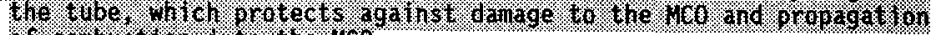

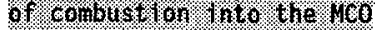

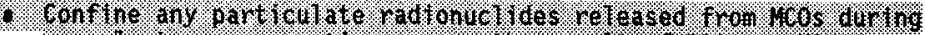

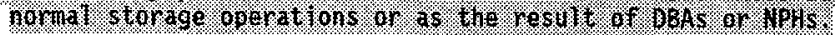

The storage tube also provides the confinement boundary between the vault and the MCO. The bellows isolates the operating area atmosphere from the vault's natural convection cooling and allows for the thermal expansion of the storage tube. The tube plug seals against the tube to prevent the egress of the storage tube's inert atmosphere and the ingress of oxygen, as well as to contain releases from the MCO (see Figures 4-4.n.6.46). The tube plug also provides shielding for the operators. The bottom and intemediate-impact

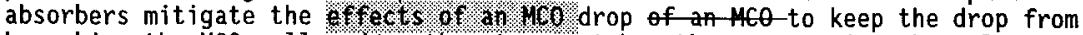
breaching the MCO wall and/or the storage tube, thus preventing the release of radionuclides into the vault atmosphere, which is cooled by natural convection

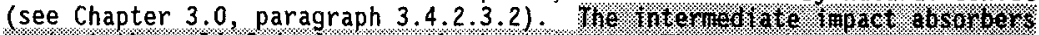

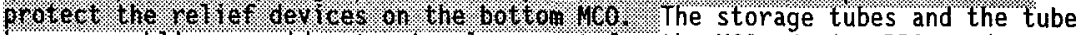
base assemblies provide structural support for the MCOs during DBAs and a geometric array for cooling and criticality oreventoron controt. Tube base assemblies are provided with cooling passages to ensure that the storage tube does not overheat the concrete floor of the vault's basemat.

4.3.5.2 System Description. The storage tubes are $0.013 \mathrm{~m}(0.5 \mathrm{in}$.) thick and $12.6 \mathrm{~m}$ (41 ft, $4 \mathrm{in.)}$ long. The 220 standard tubes have an outside diameter of $0.7 \mathrm{~m}$ (28 in.) and the 6 overpack tubes have an outside diameter

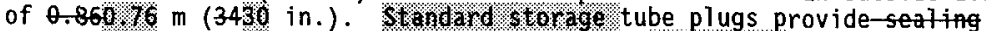

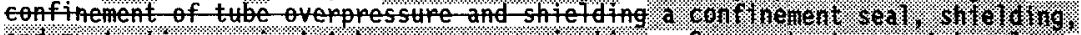

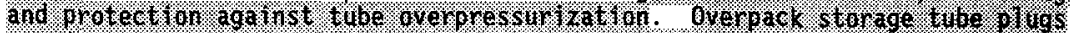

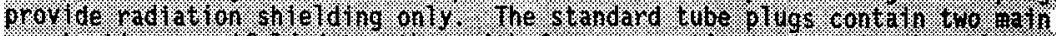

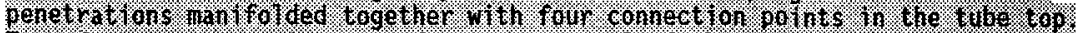

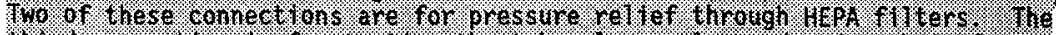

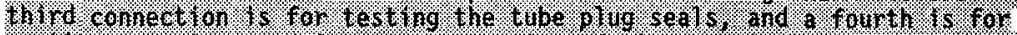

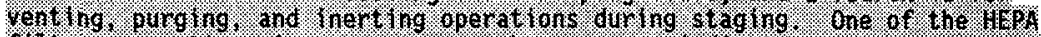

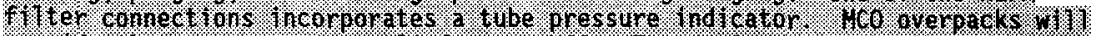

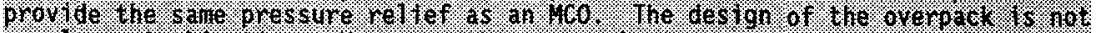

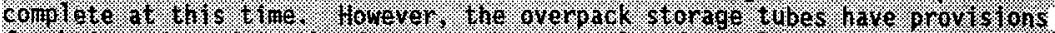

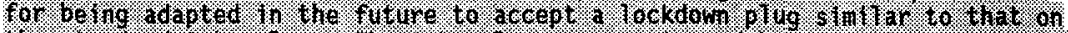

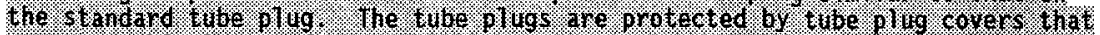

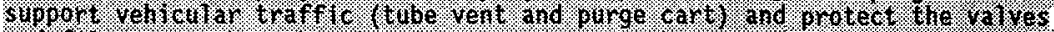

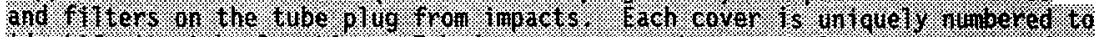

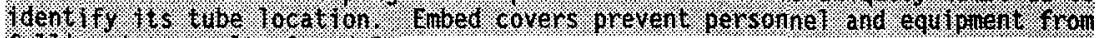

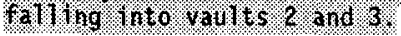




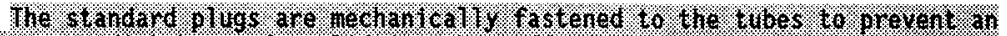

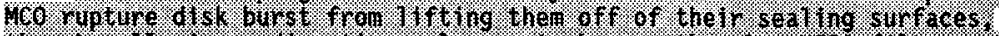

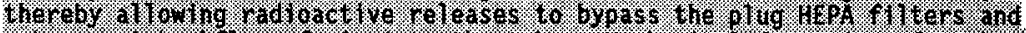

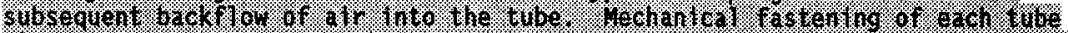

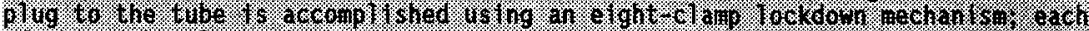

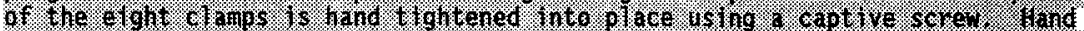

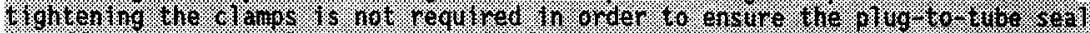

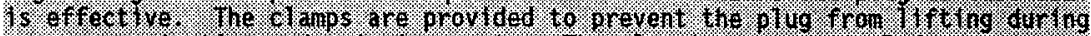

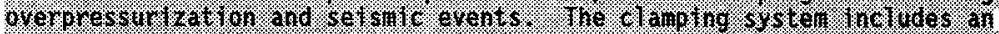

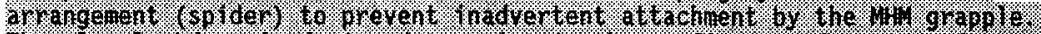

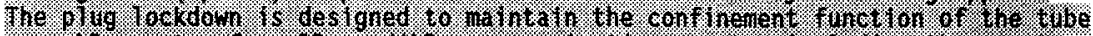

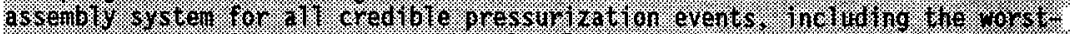

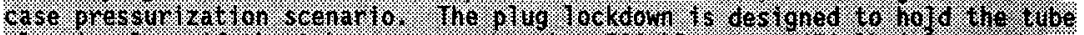

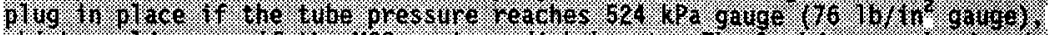

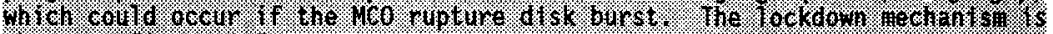

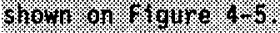

Impact absorbers are provided at the base of all storage tubes (1000

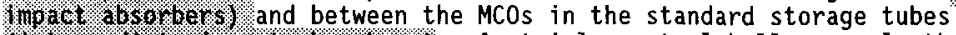

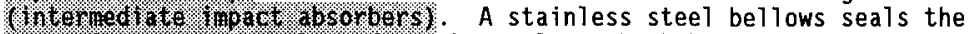
operating area atmosphere from the vault. The bellows allows the storage tube to expand vertically. Tube base assemblies locate and attach the base of the storage tubes to the vault basemat. Storage tube center-to-center distances are the same as the embed dimensions, which are provided in Section 2.4 .2 and shown on Figure 4-2. Released fabrication drawings for these components can be found in Appendix 4B.

4.3.5.3 Functional Requirements. The bottom impact absorbers protect the MCO from exceeding its structural integrity during an accidental drop from heights up to $13.4 \mathrm{~m}$ (44 ft) by limiting its deceleration to $35 \mathrm{~g}$. Bottom impact absorbers also are required to protect the storage tube from exceeding the pipe wall material working strength of $5,170 \mathrm{kPa}\left(7501 \mathrm{~b} / \mathrm{in}^{2}\right)$ during an $\mathrm{MCO}$ drop. Intermediate impact absorbers are provided to protect the pressure relief devices located atop the MCO shield plug and to ensure a gap through which the release of the lower MCO can be relieved.

The bellows are designed to accommodate the calculated storage tube expansion of $0.01 \mathrm{~m}\left(0.432 \mathrm{in}\right.$.) at $-7{ }^{\circ} \mathrm{C}$ through $66^{\circ} \mathrm{C}\left(20^{\circ} \mathrm{F}\right.$ through $\left.150^{\circ} \mathrm{F}\right)$. The architect-engineer has specified a maximum axial compression of

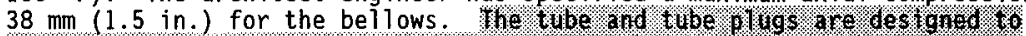

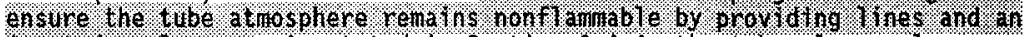
1nented enciosure, As stated in Section 2.4.4, the tube plug seals are specified to provide a leak rate less than $1 \times 10^{-4} \mathrm{std} \mathrm{cm}^{3} / \mathrm{s}\left(3.5 \times 10^{-9} \mathrm{std}\right.$

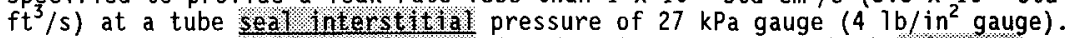

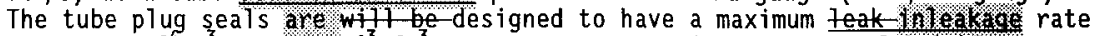
of $2.3 \times 10^{-4} \mathrm{~m}^{3} / \mathrm{s}\left(8 \times 10^{-3} \mathrm{ft}^{3} / \mathrm{s}\right)$ at a storage tube pressure of $1.3 \mathrm{kPa}$ (10 torr) relative to the operating area. Tube plugs are bolted to the storage tube and are designed to provide for $0.5 \mathrm{MPa}$ gauge (76 $1 \mathrm{~b} / \mathrm{in}^{2}$ gauge) pressure containment of a burst MCO rupture disk. Calculations using the MCO volume of $1.0 \mathrm{~m}^{3}\left(35 \mathrm{ft}^{3}\right)$ indicate that $0.5 \mathrm{MPa}$ gauge (76 $1 \mathrm{~b} / \mathrm{in}^{2}$ gauge) would be the resultant pressure in a storage tube. The storage tube, base assemblies, and slab embeds provide lateral restraint of the MCOs. Storage tube and plug requirements are as follows. 
- Design basis MCO (see also Baz/net 1996 a)

- Unvented MCO with 1.0 MPa gauge (150 lb/in ${ }^{2}$ gauge) rupture disk

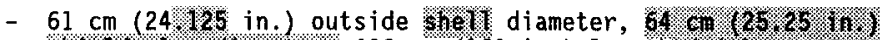

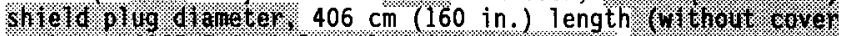
(ap). or $(165.6 \mathrm{n}$.) 1 ength (with cover cap)

- Internal gas volume $0.5 \mathrm{~m}^{3}\left(17.9 \mathrm{ft}^{3}\right)$ minimum, $1.0 \mathrm{~m}^{3}\left(35.3 \mathrm{ft}^{3}\right)$ maximum

- Hydrogen generation rate $0.4 \mathrm{~g} / \mathrm{s}$ (10 standard $\mathrm{ft}^{3} / \mathrm{min}$ ) maximum

- Hydrogen generation quantity $1.1 \mathrm{~kg}$ (1.203 lb-moles)

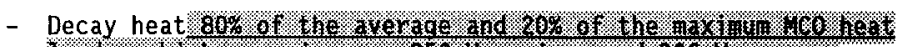

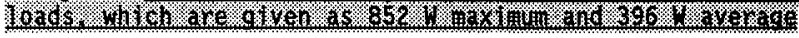

- Helium tube fill gas at $7 \mathrm{kPa}$ to $28 \mathrm{kPa}$ gauge (1 to $4 \mathrm{lb} / \mathrm{in}^{2}$ gauge) normal pressure

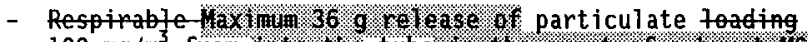
$100 \mathrm{mg} / \mathrm{m}^{3}$ - from into the tube in the evert of a birst ice Kotuc: orlow

- Design basis impact absorbers (Bazinet 1997)

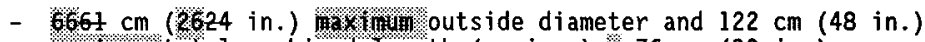
maxulum total combined Tength-(maximum) $76 \mathrm{~cm}$ (30 in.)

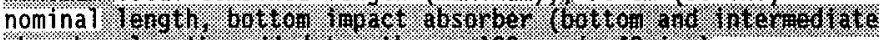

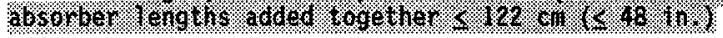

- Tube volume

- $68.4 \mathrm{~cm}$ (26.93 in.) inner diameter, minimum

- $11.1 \mathrm{~m}(36.375 \mathrm{ft})$ minimum clear length when empty with plug in place

- Trive design pressure

- Ful1 vacuum at $96^{\circ} \mathrm{C}\left(205^{\circ} \mathrm{F}\right)$

- $525 \mathrm{kPa}$ gauge (76 $\mathrm{Ib} / \mathrm{in}^{2}$ gauge) at $149^{\circ} \mathrm{C}\left(300^{\circ} \mathrm{F}\right)$

- Plug relief set pressure

- $62 \mathrm{kPa}$ gauge (9 $\mathrm{lb} / \mathrm{in}^{2}$ gauge) for primary relief valve

- $76 \mathrm{kPa}$ gauge (11 $\mathrm{lb} / \mathrm{in}^{2}$ gauge) for back-up relief valve 
- Sized for $0.3 \mathrm{~m}^{3} / \mathrm{min}$ (10 standard $\mathrm{ft}^{3} / \mathrm{min}$ ) minimum flow at $483 \mathrm{kPa}$ gauge $\left(70 \mathrm{lb} /\right.$ in $^{2}$ gauge) tube pressure (Circle Seal ${ }^{1}$ mode 7 s 500-1M-9 and 500-1M-11 are acceptable)

- HEPA filters

- HEPA efficiency $\% 9897 \%$. at full relief valve flow

- $0.3 \mathrm{~m}^{3} / \mathrm{min}$ (10 standard $\mathrm{ft}^{3} / \mathrm{min}$ ) minimum flow each at less than $1.7 \mathrm{MPa}$ (7 in. of water [clean])

- 1.3 grams minimum particulate capacity each

\section{worf anmoble atnosphere}

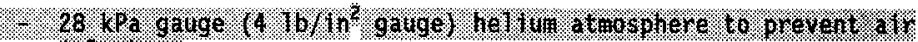
Inleakage

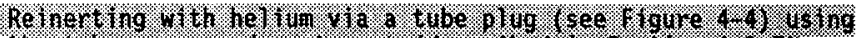

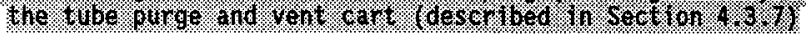

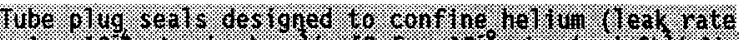

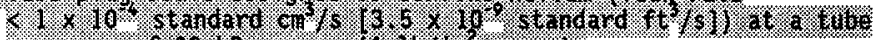

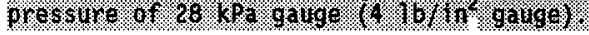

4.3.5.4 System Evaluation. The storage tube and base assemblies (which attach to the $s 1 \mathrm{ab}$ embeds) are designed to provide adequate restraint of the MCOs during all DBAs, including seismic. The storage tubes and bellows, tube base assemblies, plugs, and impact absorbers are classified safole - Class

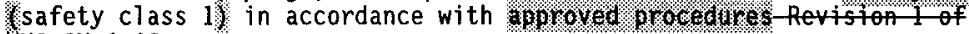
WHC CM-4-46.

The sondard storage tube and tube plug are designed to Boiler and Pressure Vessel Code (ASME 1995\%), Section $\forall I I I$, Division 1, Subsect

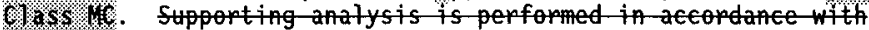
ANSIFISC N690 94, Specification for the Design, Fabrication, and Erection of Stel Safety Related Strutures for Auteleap Fatities (ANSI/AISC 1994). The storage tube bellows are designed folb wated to ASME Section III, Division 1,

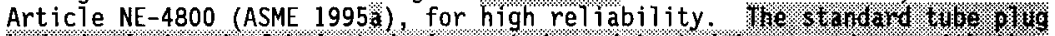

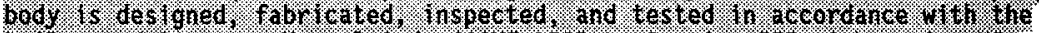

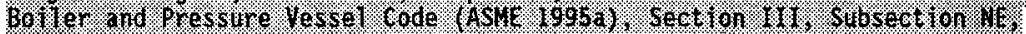

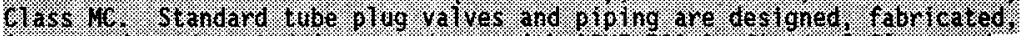

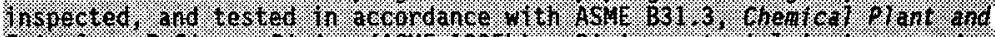

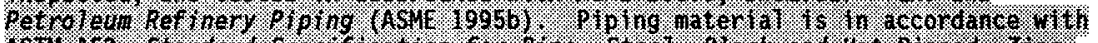

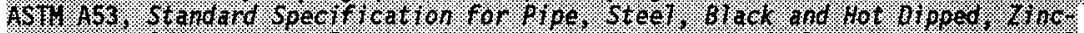

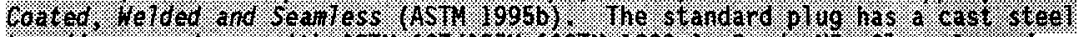

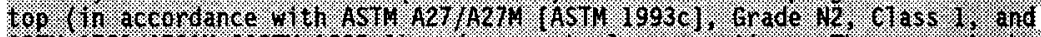

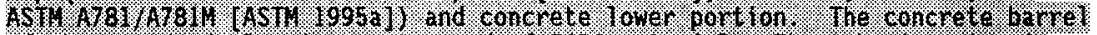

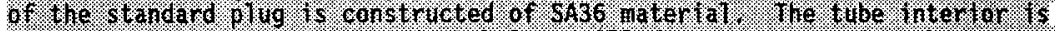

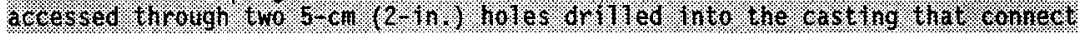

${ }^{1}$ Circle Seal is a trademark of James-Pond-Clark. 


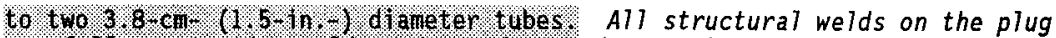
are futt penetration welds and are designed to withstand a $2.9-m(9.5-f t)$ drop of the plug onto the storage tube. The storage tube plug lifting lug is designed in accopdance with ASME B30.20 1993, Below the Hook Lifting Devices (ASHE 1993a). The tube base assemblies are designed to ANSI/AISC N690-94 (ANSI/AISC 1994).

The storage tube impact absorbers are specified to be drop tested to prove their ability to protect the MCO during a drop accident so os 100 . 10

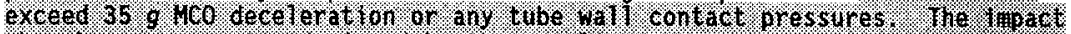

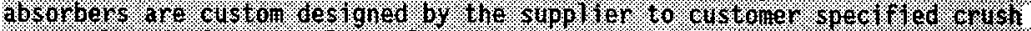

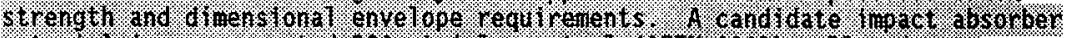

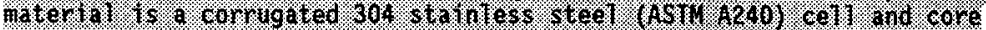
conf $1 \mathrm{gu}$.

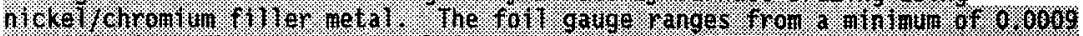

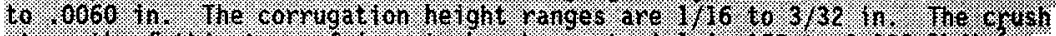

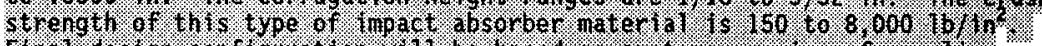

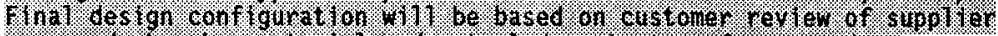

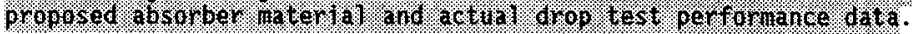

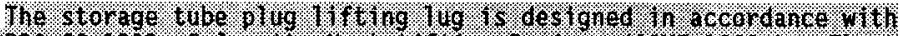

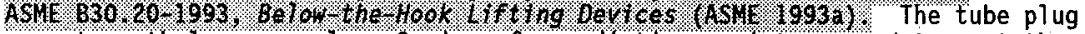
uses two ethylene propylene 0-rings for radiation resistance and to meet the leak rate requirement stated in Section 4.3.5.3. The 0-rings have a service temperature range of $-54{ }^{\circ} \mathrm{C}$ to $149{ }^{\circ} \mathrm{C}\left(-65^{\circ} \mathrm{F}\right.$ to $\left.300{ }^{\circ} \mathrm{F}\right)$ and a resistance of $1 \times 10^{7}$ rad of gamma radiation (onker ogla. The tube plug seals are exposed

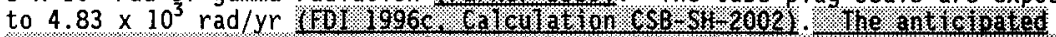

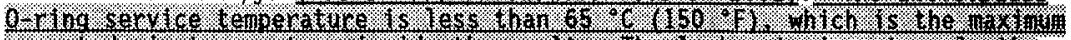

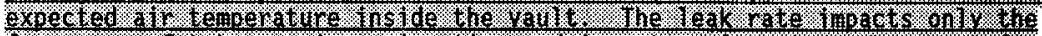

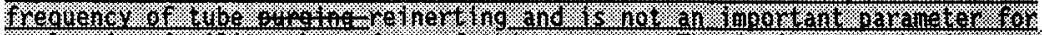

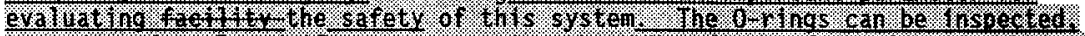

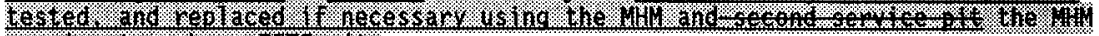

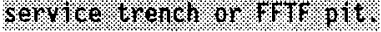

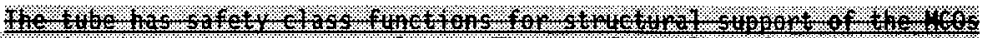

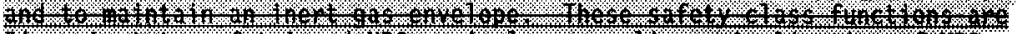

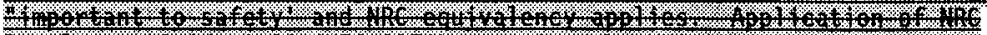

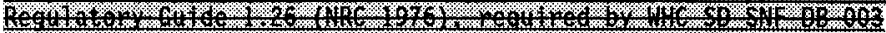

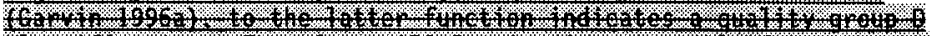

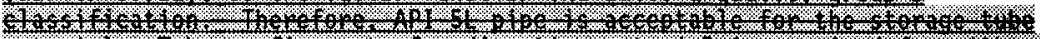

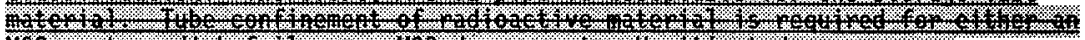

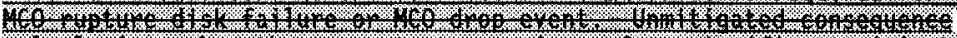

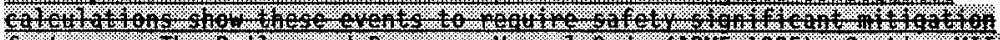

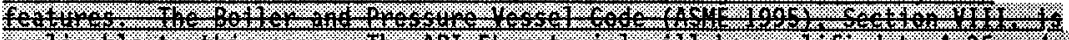

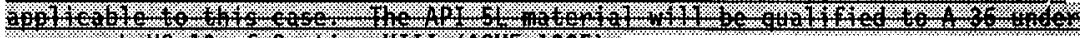

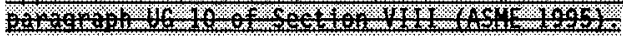

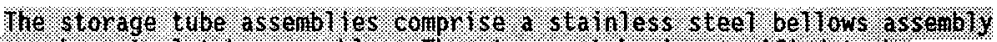

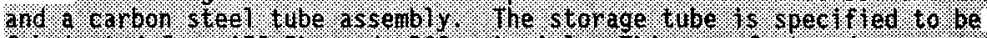

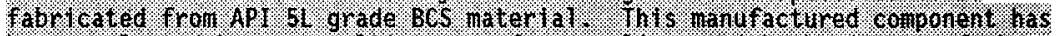

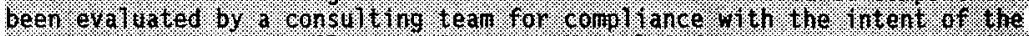

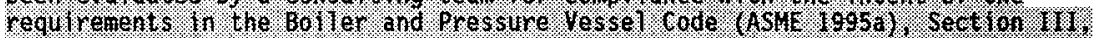

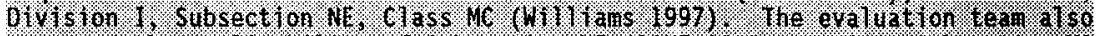

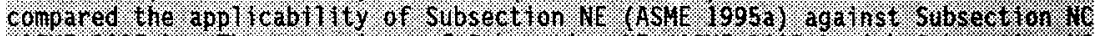

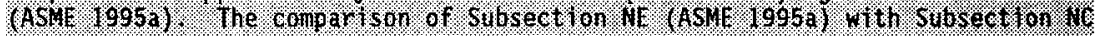




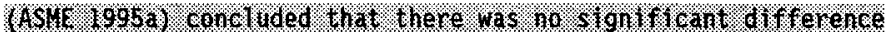

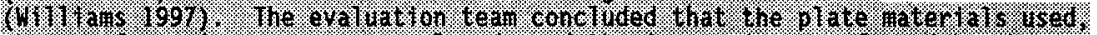

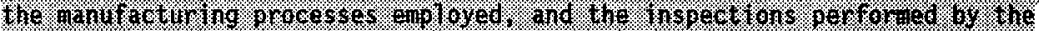

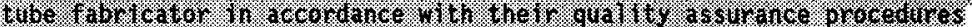

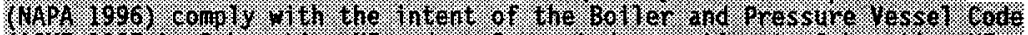

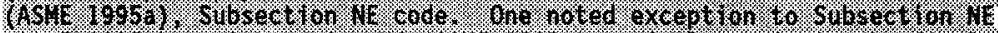

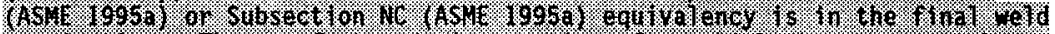

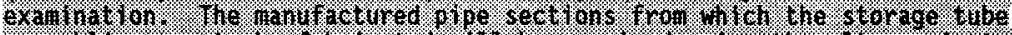

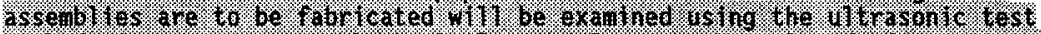

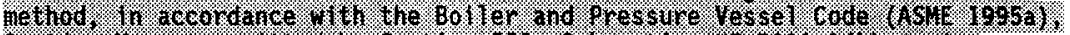

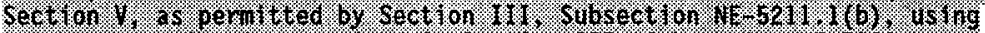

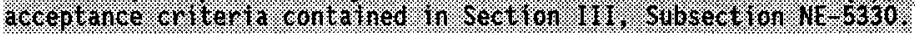

The material properties of candidate tube materials are listed in

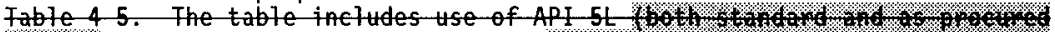

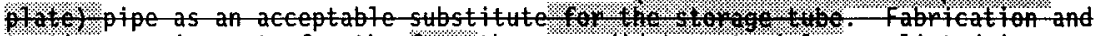
testing pequirements for the four, three eandidate materials are 7 isted in

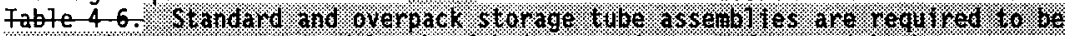

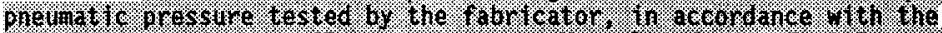

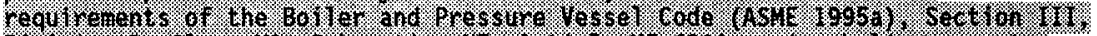

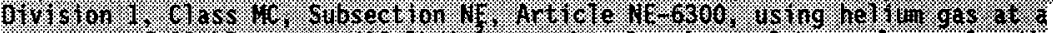

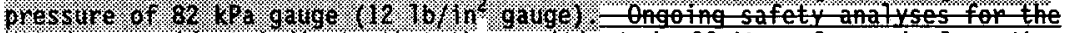
HCO drop accident indicate that the mnititated offsite release is less than 0.5 rem. The reduction in risk from a pressurized retease from an HCO onty pequires a safety significant function, as shown in section 3.4.2.1. Project eriteria require that the tube material be compatible with ASAE section VIII (ASHE 1995). Existing API $5 \mathrm{~L}$ material cun be recertified by the manufacturep or-qual ified by a commercial quade item dedication process.

Fable 45. Storage-Tube-Material Properties.

\begin{tabular}{|c|c|c|c|c|}
\hline Property & 6A-677 Gfodo-0660 & $\begin{array}{c}\text { Ra-36 } \\
\text { SAltede }\end{array}$ & Apt & $\begin{array}{l}\text { MAPA Pipe } \\
\text { (API St? } \\
\text { eubmitted-doto }\end{array}$ \\
\hline Fiold-strongth & $2-32 \mathrm{kgi}$ & $=36-k c i$ & $=35-k g i$ & $39.8-44.5-k e i$ \\
\hline foncilo- otfongth & $60-30-k 0 i$ & $58-80-k e i$ & $2-60$ kei & $57.5-62$ - ket \\
\hline Carben & $\leftrightarrow 0.21 \%$ & $<0.25 \%$ & $\leftarrow 0.27 \%$ & $0.06-0.09 \%$ \\
\hline Manganose & $0.60-1.20 \%$ & Hot contrallod & $<-1.15 \%$ & $0.43-0.56 \%$ \\
\hline Phosphorus & $40.035 \%$ & $40.040 x$ & $40.030 \%$ & $0.002-0.007 x$ \\
\hline Sutfun & $40.035 \%$ & $\leftarrow 0.050 \%$ & $<0.030 \%$ & $0.004-0.006 \%$ \\
\hline silticen & $0.15=0.40 \%$ & $\leftarrow 0.40 \%$ & Hot controlled & $0.22-0.277$ \\
\hline
\end{tabular}

6SQ - Canietor stofago-Buitding 
Fab7e-46. Storage-Tube-Fabrication and Testing.

\begin{tabular}{|c|c|c|c|c|}
\hline & SA-671-Grada-cc60 & $\begin{array}{c}\text { Rollad plate } \\
\text { SA-36 }\end{array}$ & Api5L & $\operatorname{css}$ \\
\hline $\begin{array}{l}\text { Weld foiroumierential } \\
\text { end longitudinell }\end{array}$ & Doublo weldod full & Doublemeldod full & $\begin{array}{l}\text { Full-penetretion butt-mey be } \\
\text { double-weldad }\end{array}$ & Strolohtrenpa, doublo \\
\hline Welder qualifioution & ASME $1 X *$ & ASME-1X- & Alot-oontrolled & Ifolentiontified \\
\hline Dlametor toleriace & Diroumforenos & $=1 \%$ & \pm 106 & $+0.75 \%-0.25 \%$ \\
\hline Out al rawadoces & \pm 10 & 10 & \pm 10 & $=0256$ \\
\hline Aligament & 4148 in in 10 at & 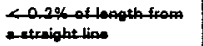 & 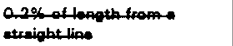 & 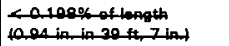 \\
\hline Thiokneas & 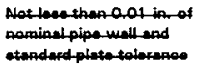 & 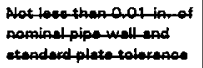 & 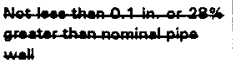 & 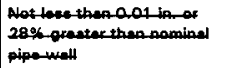 \\
\hline Braduat inepection & took -rediography & 1000 _radiogrephy & $100 \%$-rediography & 10006 -adiography \\
\hline Produos toeting & 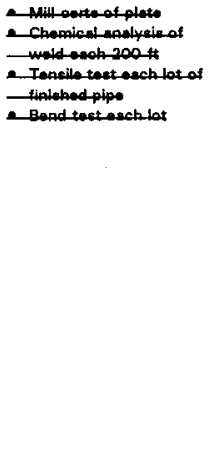 & - Mill-oefte of plats & 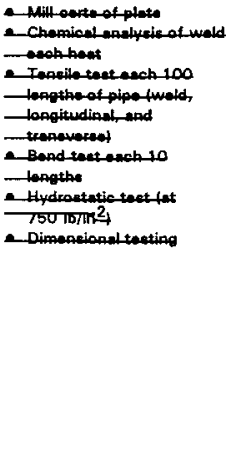 & 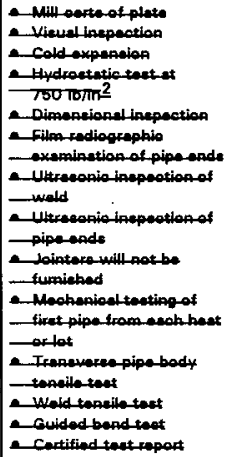 \\
\hline
\end{tabular}

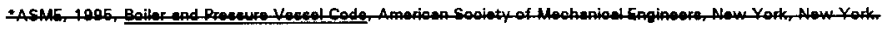




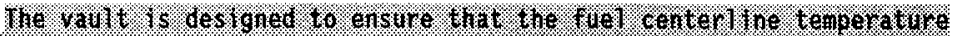

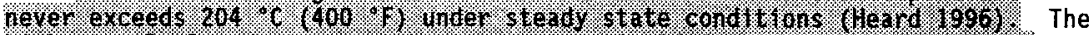

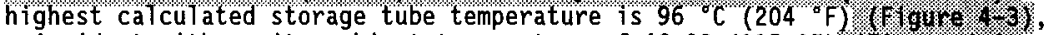

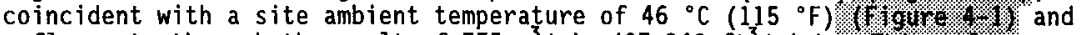
a flow rate through the vault of $775 \mathrm{~m}^{3} / \mathrm{min}\left(27,340 \mathrm{ft}^{3} / \mathrm{min}\right)$. This value,

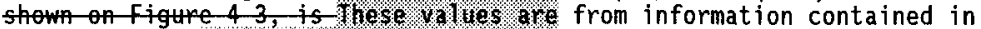
Appendix $\mathrm{E}$ of Oalculatwon. CSB-HV-0001 (FDI 1996a). Other temperature values of interest can be found on Figure 4-3. The cooling passages in the tube base assemblies provide thermal isolation of the concrete vault basemat and of the steel embeds from the storage tube to ensure that the concrete's temperature limit of $66^{\circ} \mathrm{C}\left(150^{\circ} \mathrm{F}\right)$ is not exceeded.

After cold vacuum drying, residual water will not be readily released from the MCO. There will be gradual chemical reactions of hydrides and radiolysis of bound water. Periodic storage tube purging and venting is expected to maintain the storage tube atmosphere below saturation and thereby eliminate corrosion from condensation on the carbon steel tube surfaces. The reader is asked to refer to WHC-SD-SNF-TI-029, Multi-Canister Overpack (MCO) Pressurization Analysis (Bubsan. Bergsman-1996), Section 2.3, which states, "The vacuum drying process operating at $50^{\circ} \mathrm{C}$ and 0.5 tor is designed to effectively remove all free water." Any water that is generated in the CSB by decomposition of hydrates at higher temperatures will quickly react with the excess uranium metal present, as discussed in Sections 4.2.2 through 4.2.4

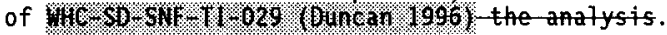

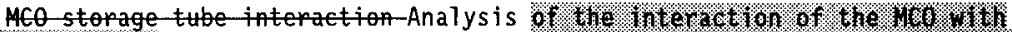

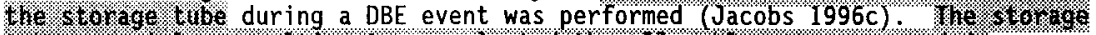

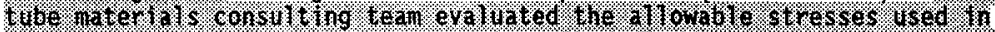

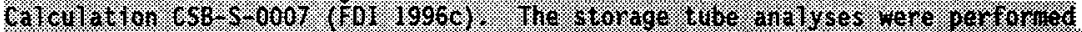

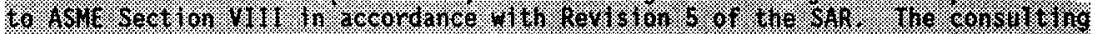

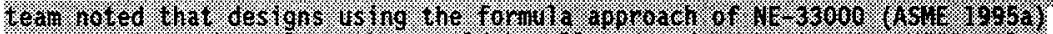

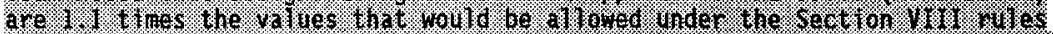

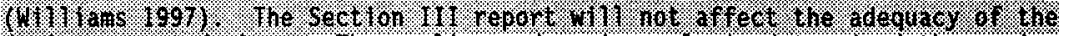

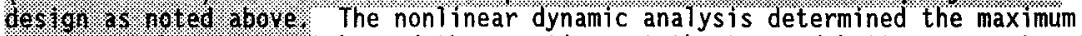
stress in the storage tube and the reactions at the top and bottom supports of the tube.

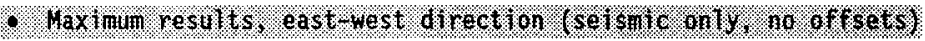

Bending stress in tube, 10.9 kst (Hide 9 (see f f gure 2I])

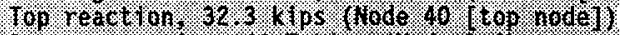

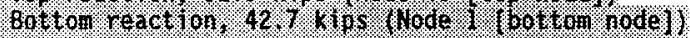

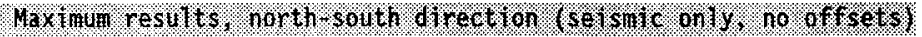

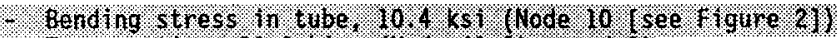

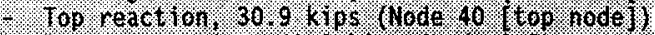

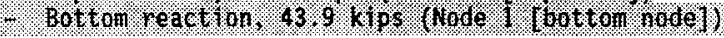

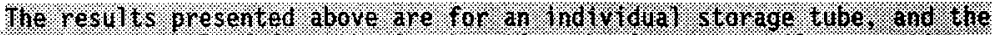

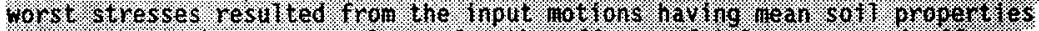

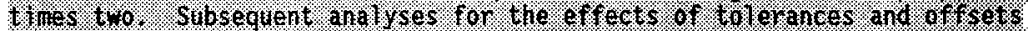

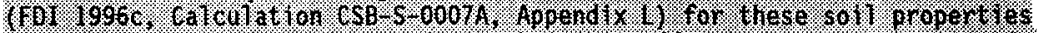

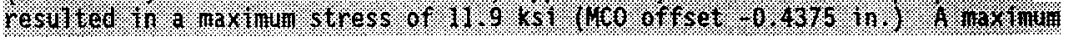




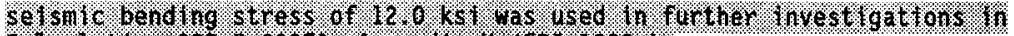

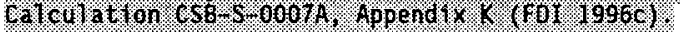

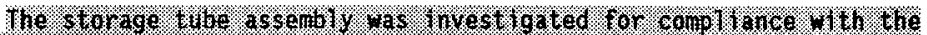

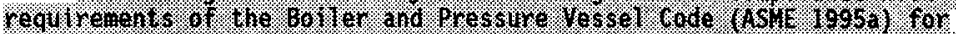

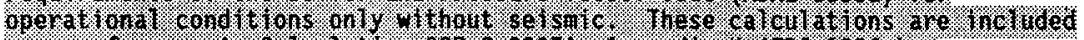

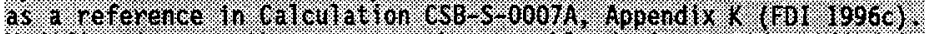

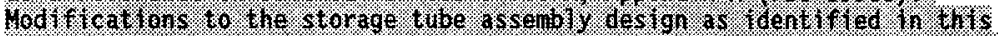

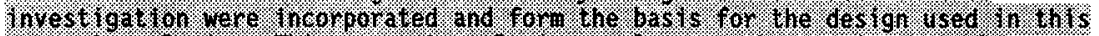

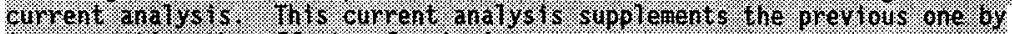

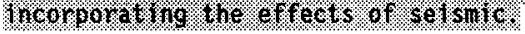

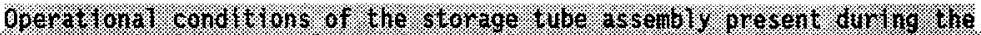

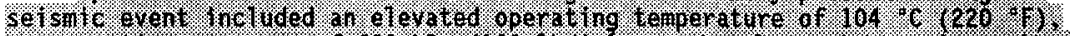

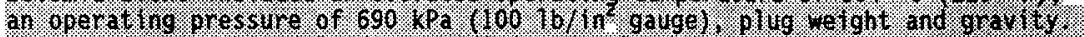

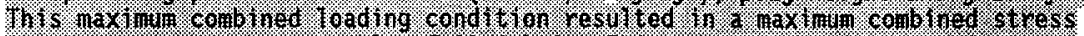

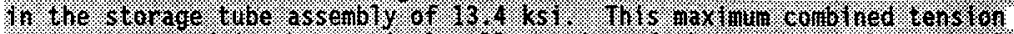

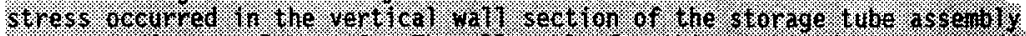

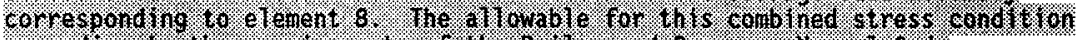

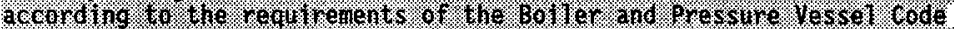

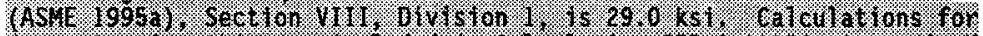

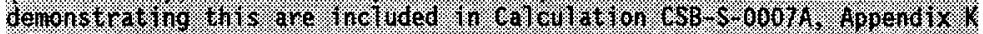
1901.0.6.

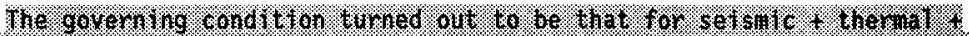

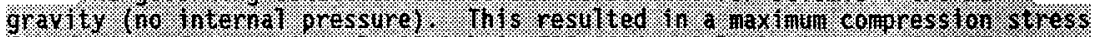

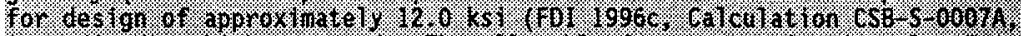

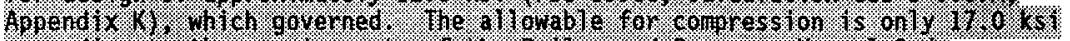

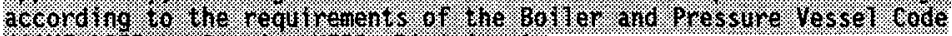

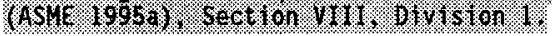

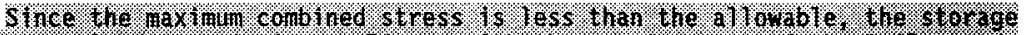

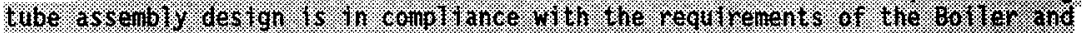

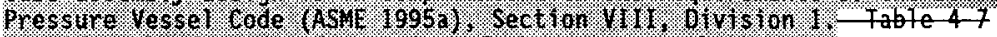
provides the demand and capacity of the stopage tube.

Fable-47. Storage Fube Demand and Capacity Ratios.

\begin{tabular}{|c|c|c|c|}
\hline tocation & Demand & Eapacity & $\begin{array}{c}\text { Bemad/capacity } \\
\text { patio }\end{array}$ \\
\hline $\begin{array}{l}\text { Fuending } \\
\text { (between } \mathrm{MCOS})\end{array}$ & $14.8 \mathrm{ksi}$ & $32.6 \mathrm{kst}$ & 0.45 \\
\hline Fop reaction & $36.7 \mathrm{kip}$ & 129 kips & 0.28 \\
\hline Bottom reaction & $44.2 \mathrm{kip}$ & $83.2 \mathrm{kip}$ & 0.53 \\
\hline
\end{tabular}

$M 60-$ multicanister ovorpack.

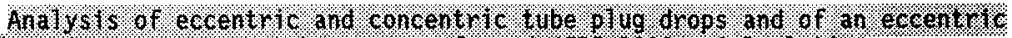

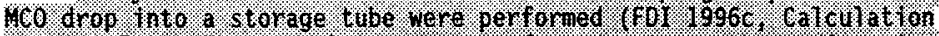

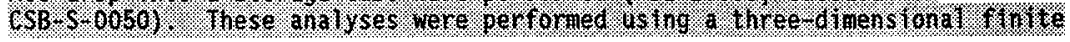




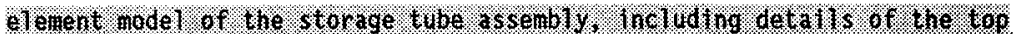

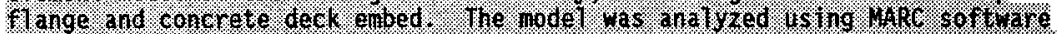

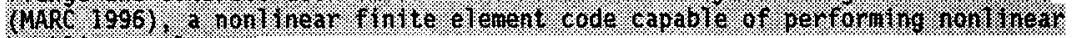
bueking and $y s e s$.

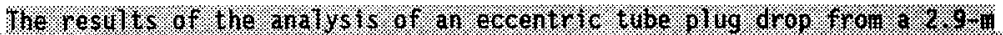

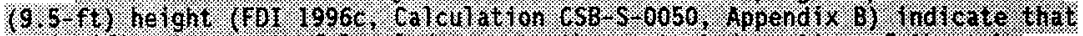

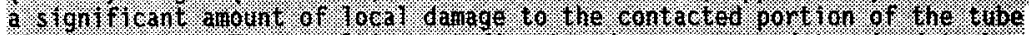

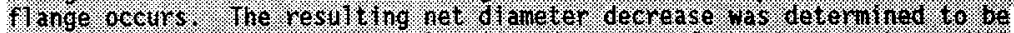

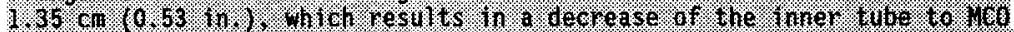

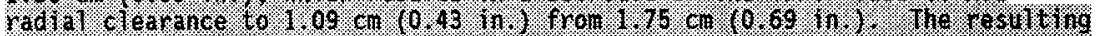

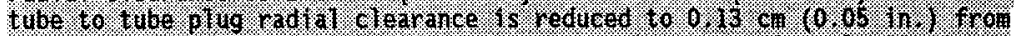

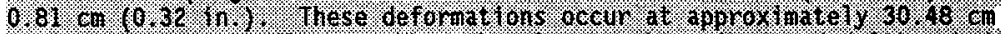

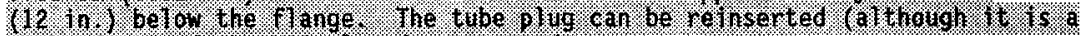

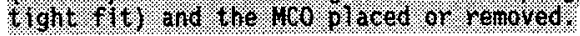

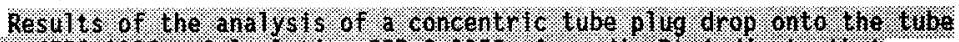

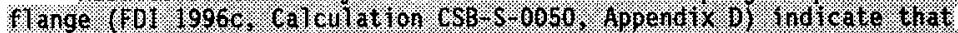

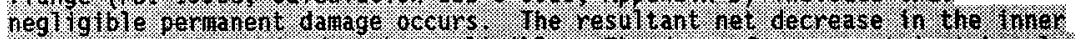

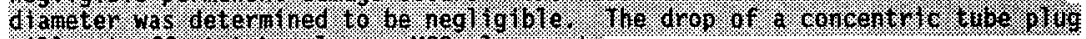
H) $10 \mathrm{t}$. $\mathrm{ffect}$.

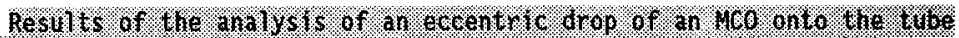

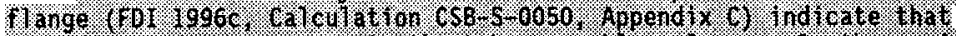

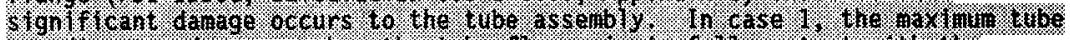

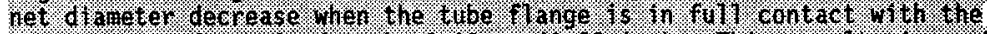

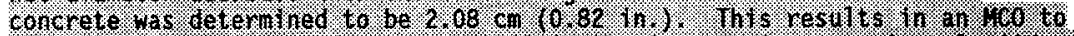

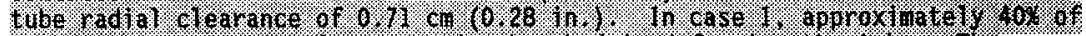

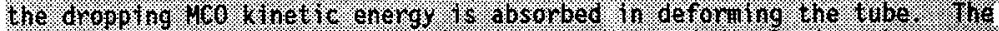

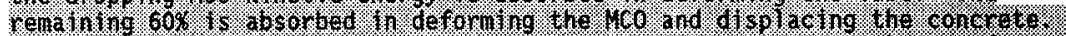

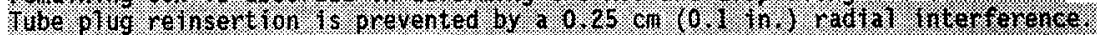

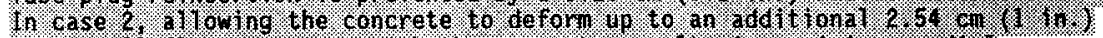

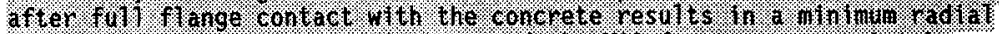

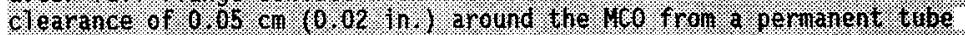

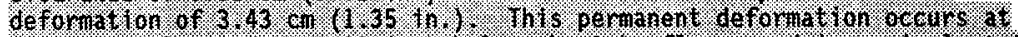

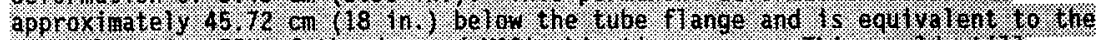

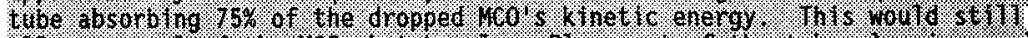

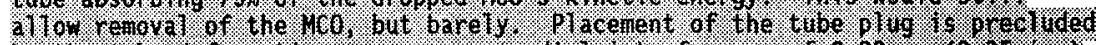

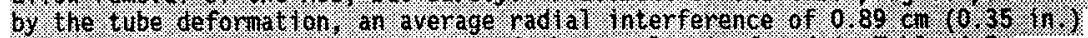

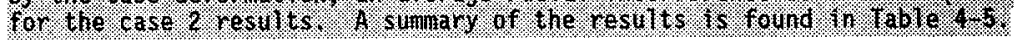

Analyses of concentro. MCO drops. have shown that the MCO shell when fully loaded will not yield when exposed to accelerations below $150 \mathrm{~g}$ and will not buckle (become unstable) until the accelerations reach $700 \mathrm{~g}$ (Hyde 1996). By review of the analysis results, it is apparent that the $M C O$ wall does not expand to values greater than $1.3 \mathrm{~cm}(0.5 \mathrm{in.})$ until exposed to more than $300 \mathrm{~g}$. Analysis of the postulated MCO drops into the storage tubes shows that the accelerations on the MCO when dropped into the CSB storage tube with impact absorbers is well below $100 \mathrm{~g}$ (Hyde 1996). Thus the MCO will not impose any lateral loads on the storage tube because of wall deformation resulting from a drop. 


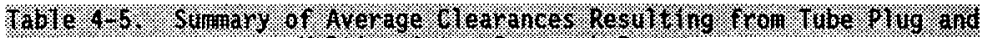

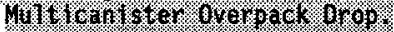

\begin{tabular}{|c|c|c|c|}
\hline \multirow{2}{*}{ Arop cise } & \multirow{2}{*}{ 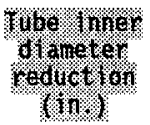 } & \multicolumn{2}{|c|}{ 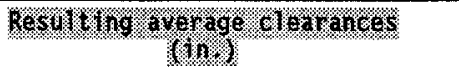 } \\
\hline & & MeO & 9ug \\
\hline Grdianloged condrt thon & & 3.69 & 10.32 \\
\hline 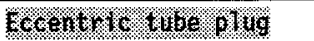 & 0.53 & 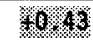 & 10.05 \\
\hline 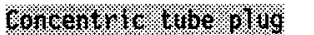 & nII & 60.53 & $\% 0.32$ \\
\hline 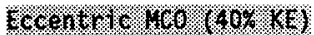 & 6.8\% & 0.28 & I. (17ter) \\
\hline 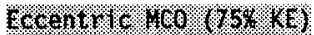 & 1.35 & 10.82 & 35 (Interforonce) \\
\hline
\end{tabular}

\%

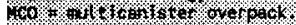

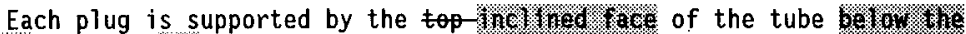
holows (Figure 10.210 ). If moisture were present, the area where the steel plug rests on the steel tube could rust together and potentially prevent plug removal; moisture and rust, however, have been prevented by the building design. During building construction, the contractor is responsible for preventing rust or other damage to the polished sealing surfaces on the tubes and plugs (see note on Drawing H-2-120394, DCN-029, sheet 5 [Appendix 4B]). The corrosion protection applied to the tube and plug sealing surfaces will not be removed until the building superstructure and heating, ventilating, and ind HVACF system are complete. This precaution is necessary mostly to ensure the necessary leak-tightness fylaty of the seals. The presence of rust or grit wil-prevents proper sealing. The superstructure roof and walls are specially-essenvlyluly leak-proof, designed to withstand the NRC-equivalent design basis tornado or rainfal1. No systems or equipment in the operating area contain water or can deliver water by accident into the operating area. Furthermore, after the tubes are installed, water is not required for construction, startup, or maintenance in the operating area.

Moisture from the air cannot condense on a surface unless the temperature of the surface is at or below the dew point of the air. Since dew point measurements were begun in 1946, the dew point at the Hanford Site has exceeded $13{ }^{\circ} \mathrm{C}\left(55^{\circ} \mathrm{F}\right)$ for only a few hours during one month of July, and has never exceeded $21^{\circ} \mathrm{C}\left(70^{\circ} \mathrm{F}\right)$ (Stone et al. 1983). Once the HVAC system is

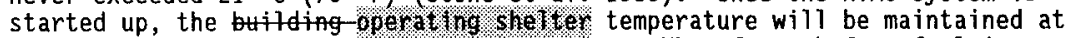
an average of $22^{\circ} \mathrm{C}\left( \pm 6^{\circ} \mathrm{C}\right)\left(72^{\circ} \mathrm{F}\left[ \pm 12^{\circ} \mathrm{F}\right]\right)$. Therefore, before fuel is loaded into the vault, the operating deck temperature will average $22^{\circ} \mathrm{C}$ $\left(72^{\circ} \mathrm{F}\right)$, which is well above the recorded maximum dew point. After fuel is loaded, the decay heat from the MCOs will warm the deck above $24^{\circ} \mathrm{C}\left(75^{\circ} \mathrm{F}\right)$ but below $66^{\circ} \mathrm{C}\left(150^{\circ} \mathrm{F}\right)$. In the relatively dry climate at the site, it is unlikely that the amount of corrosion that will occur will prevent plug removal. 


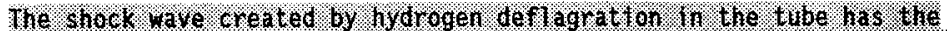

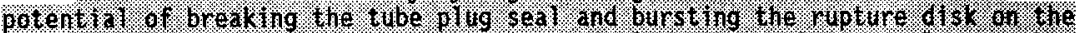

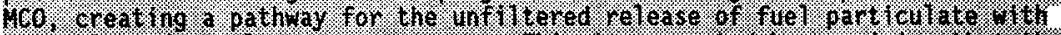

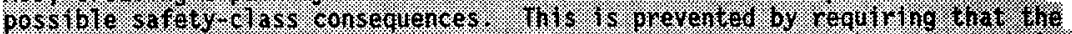

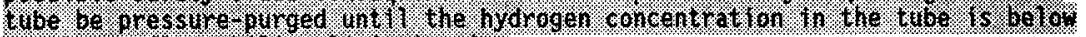

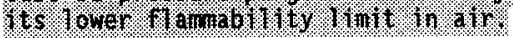

4.3.5.5 Controls (Technical Safety Requirements). Meeting to maintain the MCO pressume below its $1.0 \mathrm{MPa}$ gauge $\left(150 \mathrm{lb} / \mathrm{in}^{2}-\right.$ gauge) design pressure and the ability of the vaut design to keep the fuel temperature low enough to prevent spontaneous decomposition depends on factors outside- the ESB. The hydrogen generation rate inside the $14 C 0$ relates directly to the quantity of free water and to the chemical composition of fuel and crud and to the tube sepvice intervals. These futors are controlled by $K$ Basin fuel washing or sorting and $M C O$ loading and CVOS process of water remova?.?

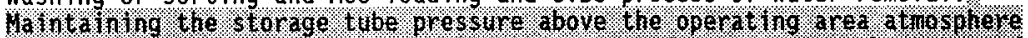

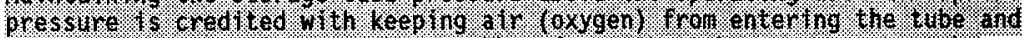

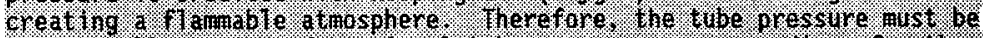

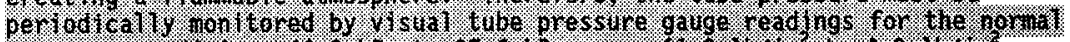

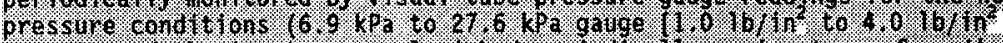



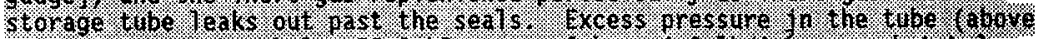

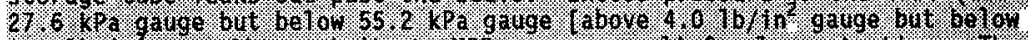

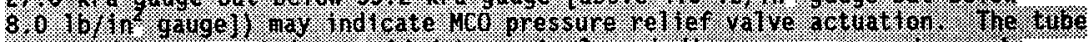

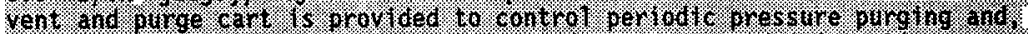

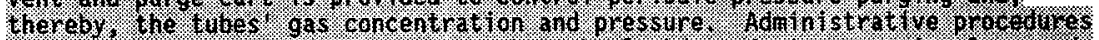

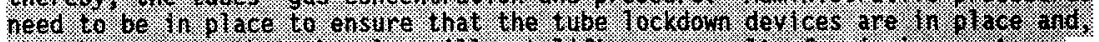

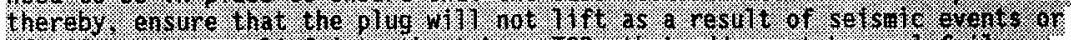

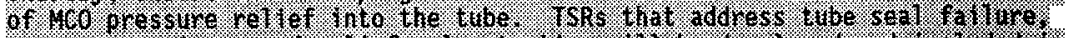

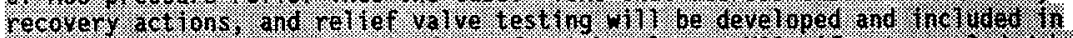

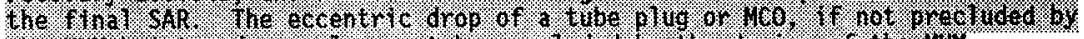

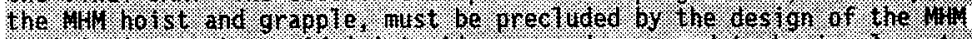

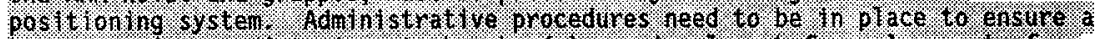

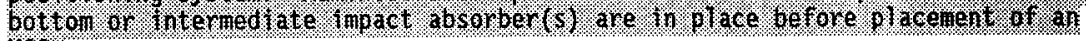
M60.

\subsubsection{Tanister Storage Builloing Above-Grade Structures I Intake. Structure, Exhaust Stack and boerating area Sholted}

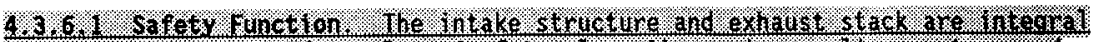

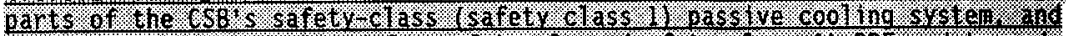

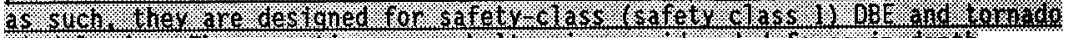

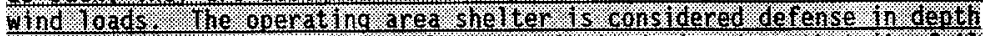

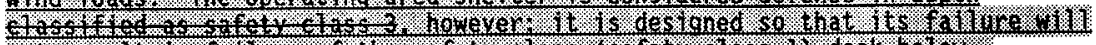

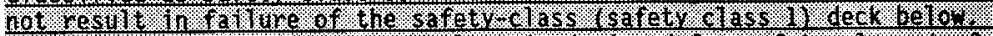

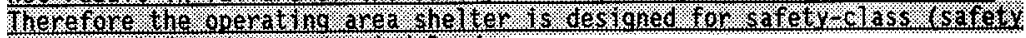

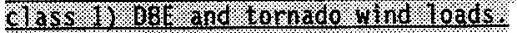

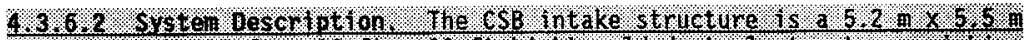

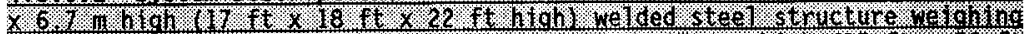

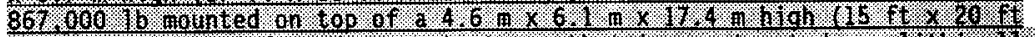

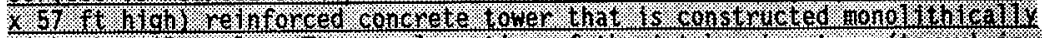

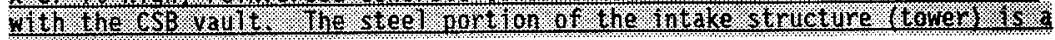




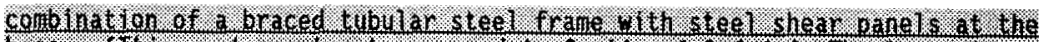

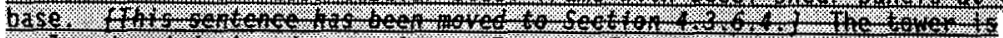

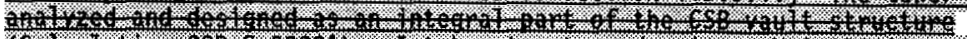

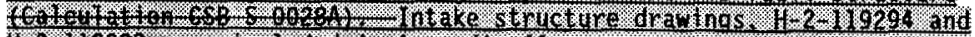

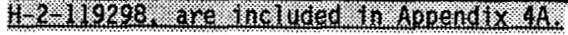

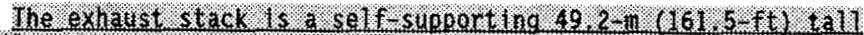

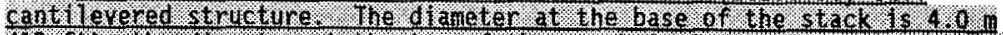

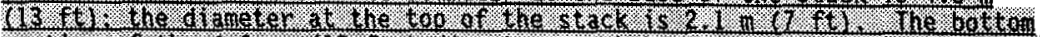

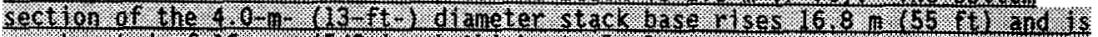

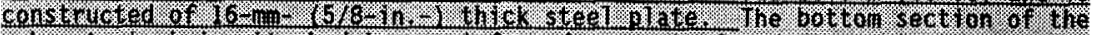

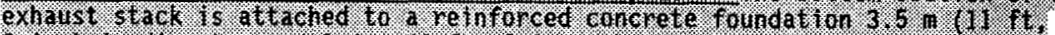

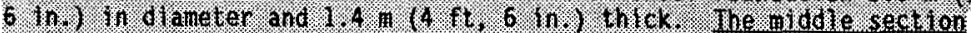

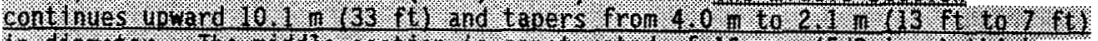

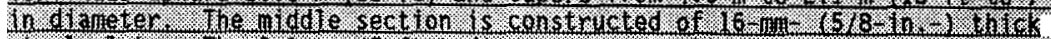

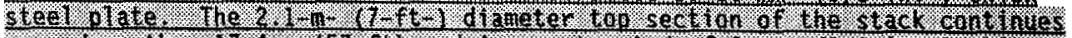

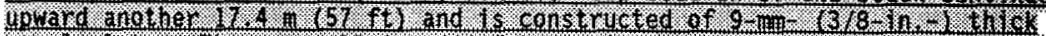

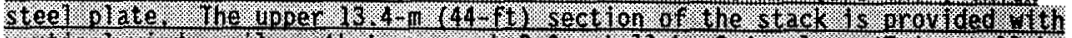

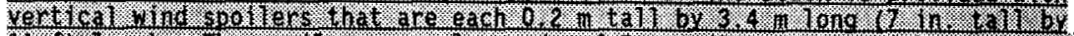

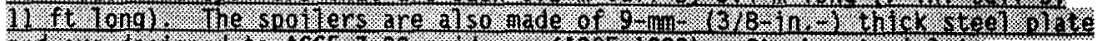

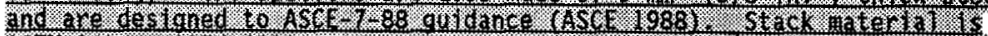

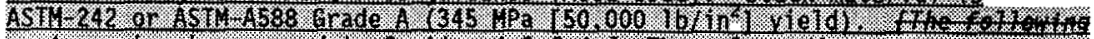

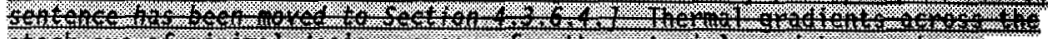
S)

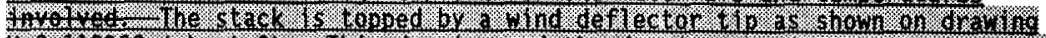

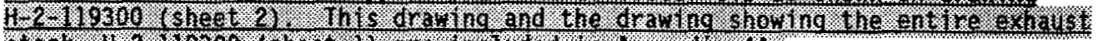

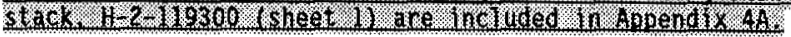

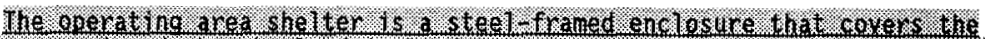

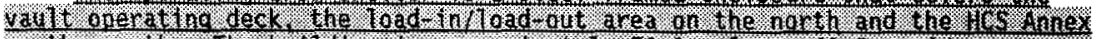

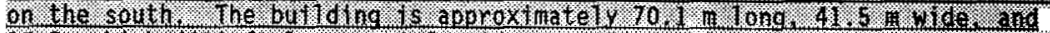

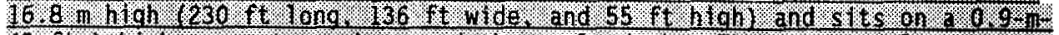

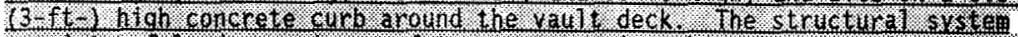

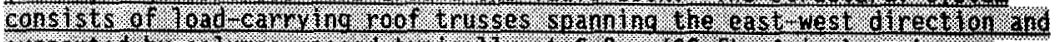

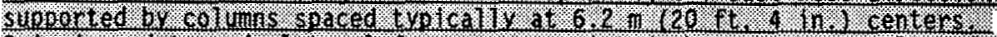

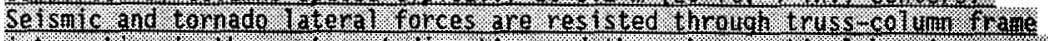

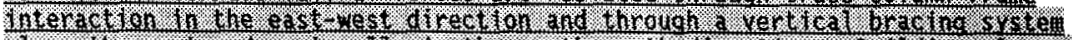

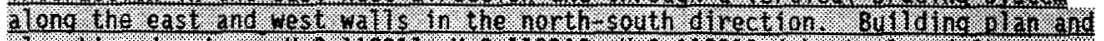

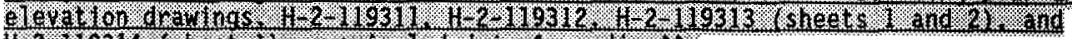

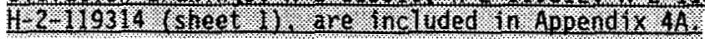

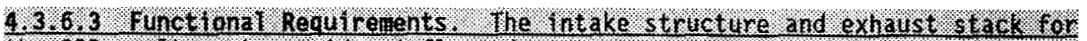

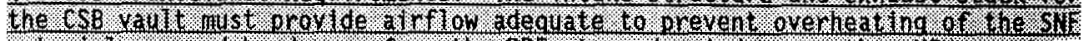

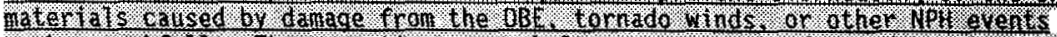

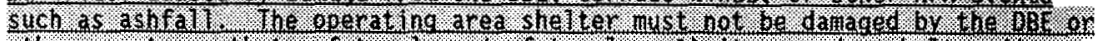

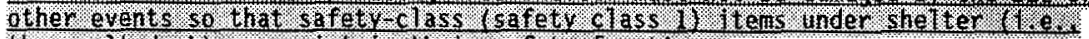

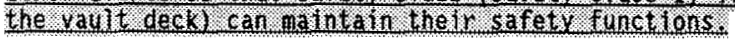

Operating shelter design basis loads are given in Section 4.3.4.3.

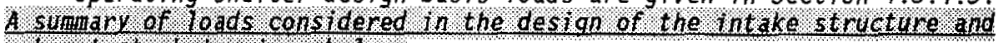

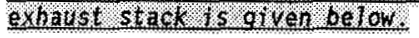

4. Intake structure 
HNF-SD-SNF-RPT-004 REV 6

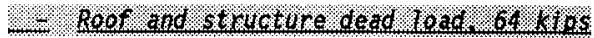

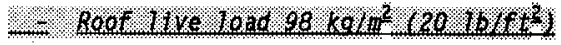

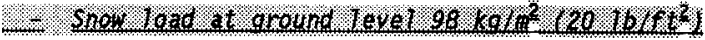

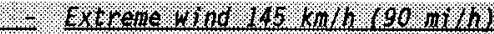

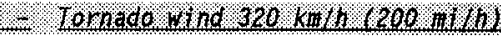

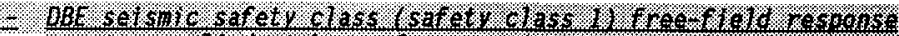

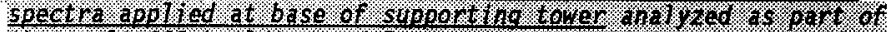

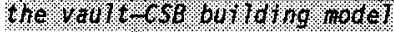

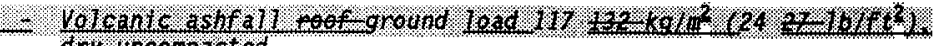
drit incompictied.

1. $1 \times$ haust stack

-1. St uature dedod 100 d

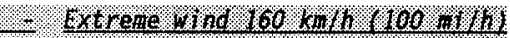

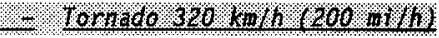

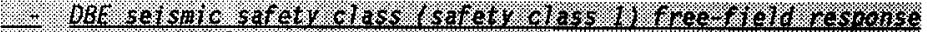

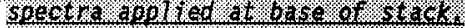

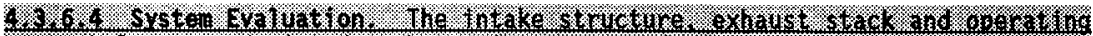

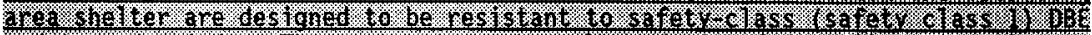

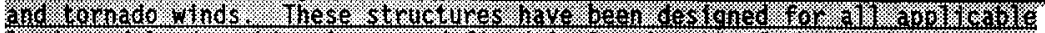

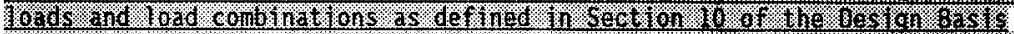

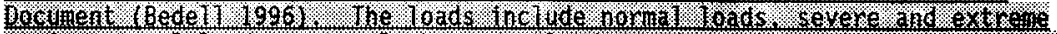

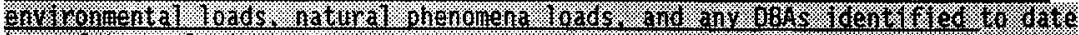

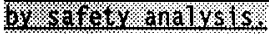

The tower is analyzed and designed as an integral part of the CSB vau7t

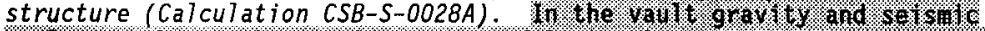

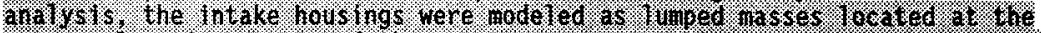

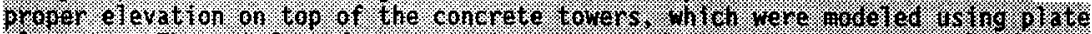

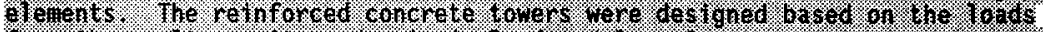

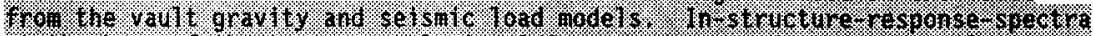

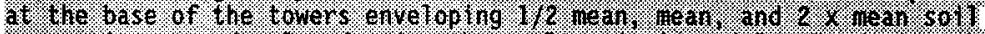

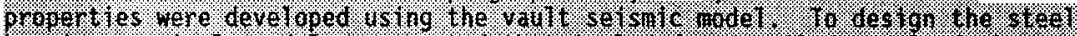

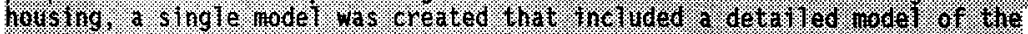

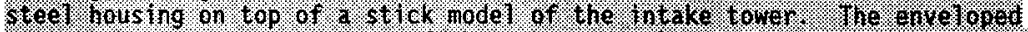

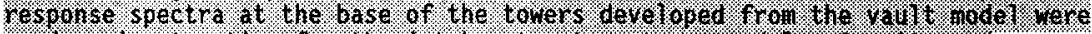

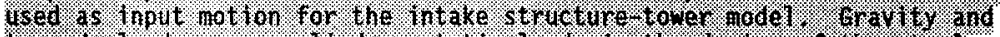

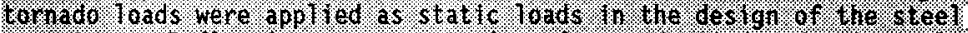

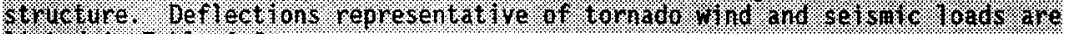
3ted 101010.6 . 
Tab1e 4-6. Deflections at Top of Intake Structure and Exhaust Stack:

\begin{tabular}{|c|c|c|c|c|c|c|c|c|}
\hline & \multicolumn{3}{|c|}{$18 \% 2010.0117 \%$} & \multicolumn{5}{|c|}{ 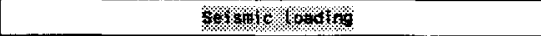 } \\
\hline & Es/ro & 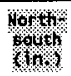 & $y_{11} / 10 \%$ & 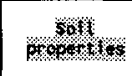 & 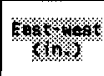 & 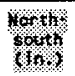 & $6 \%$ & Krot \\
\hline Mrofos suretiure & 0.04 & 0.02 & $0 \%$ & \multirow{2}{*}{ 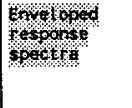 } & 618 & 009 & 100 & 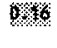 \\
\hline morow of oturt & 0.10 & 0.07 & 00 & & 0.25 & 0.68 & a.eo & 6.1. \\
\hline \multirow{3}{*}{ 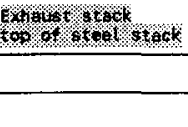 } & 357 & $8 \times 2$ & 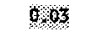 & 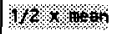 & 68 & 28 & 0.03 & 20 \\
\hline & & & & Hes & $5 \% 3$ & 583 & $000 \%$ & r. \\
\hline & & & & $2 \times$ noph & 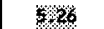 & 5.3 & $6 \times 10$ & \%o \\
\hline
\end{tabular}

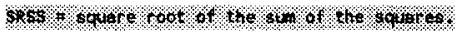

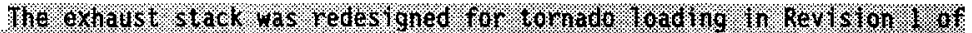

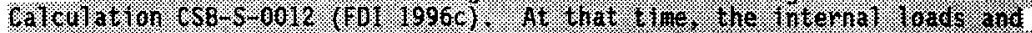

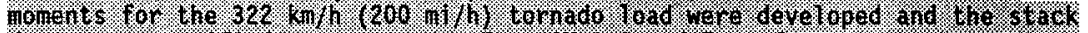

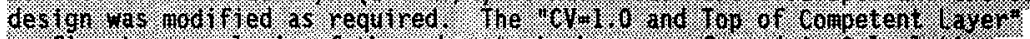

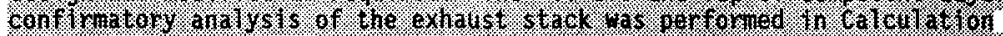

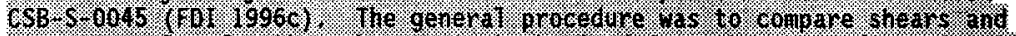

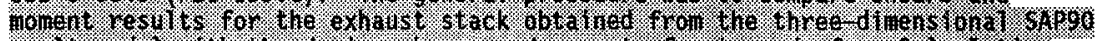

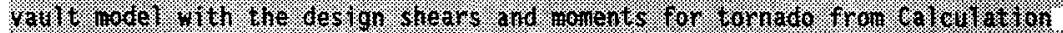

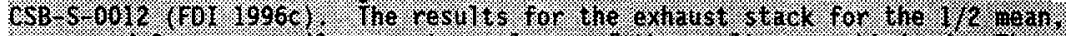

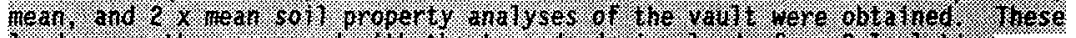

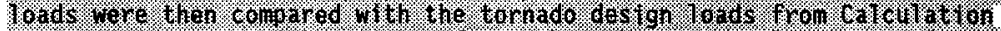

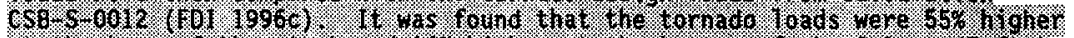

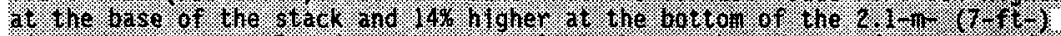

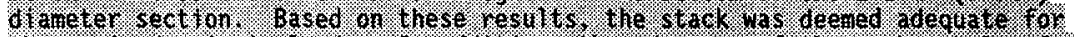

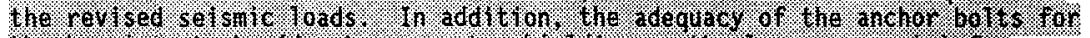

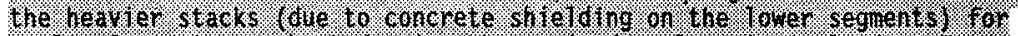

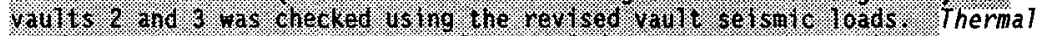
gradients across the stack are of minimal design concern for the materials and temperatures involved.

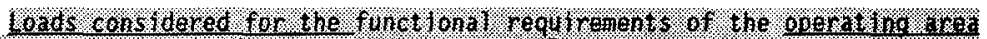

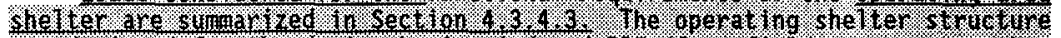

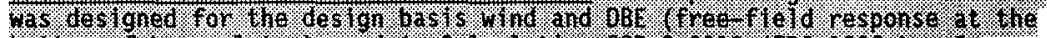

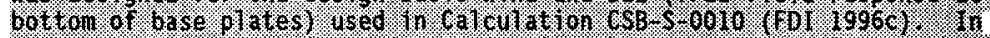

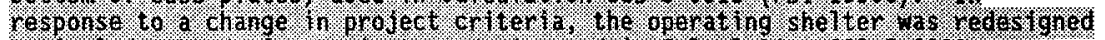

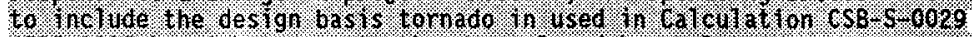

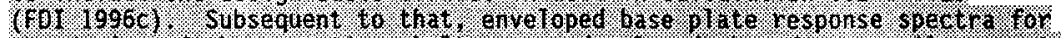

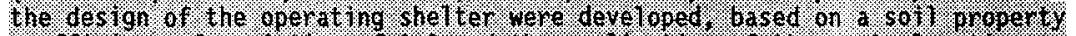

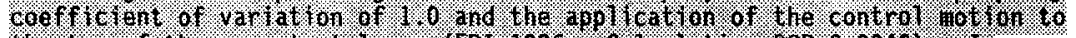

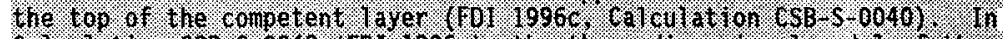

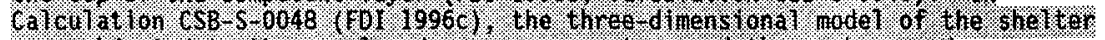

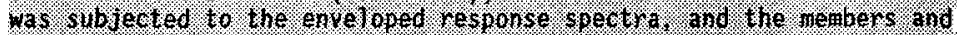

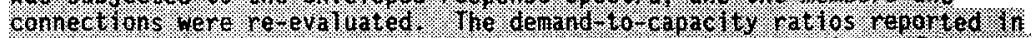

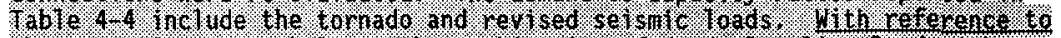

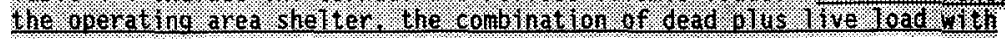




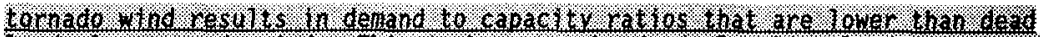

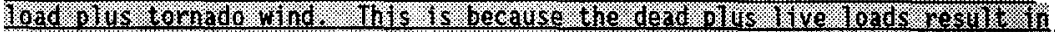

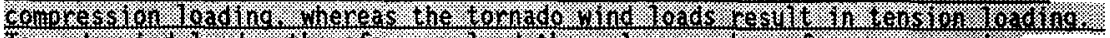

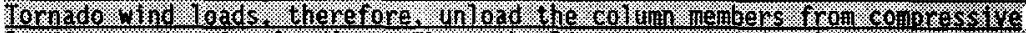

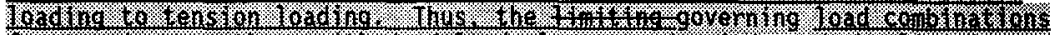

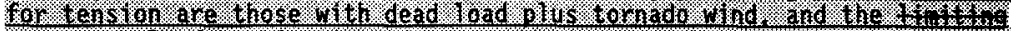

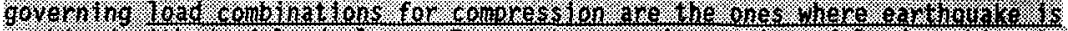

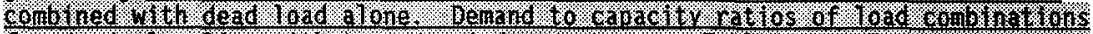

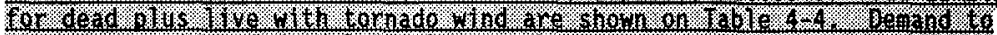

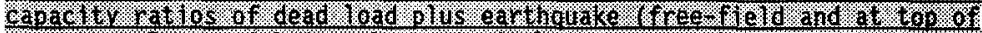

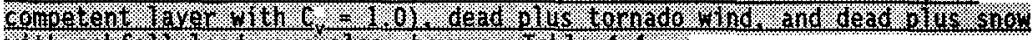

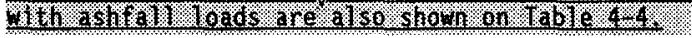

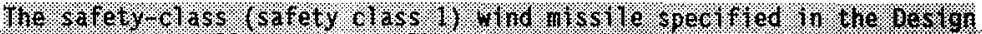

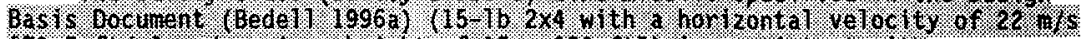

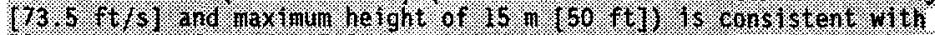

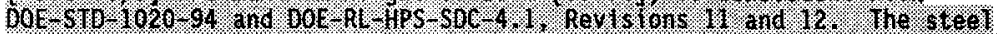

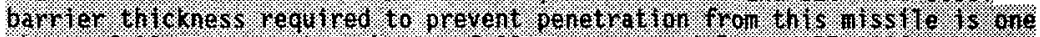

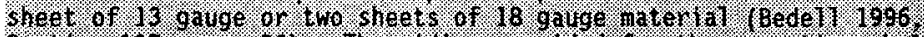

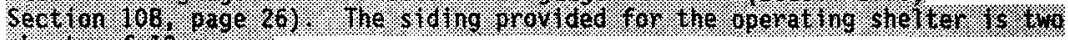
shert: of 18.0 .949 :

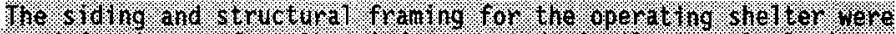

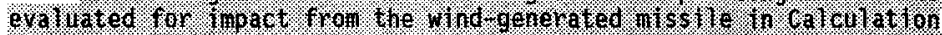

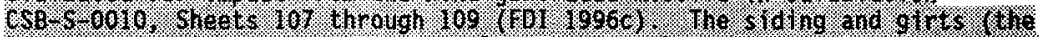

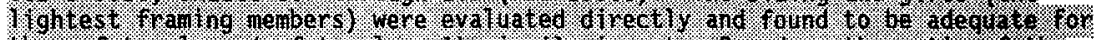

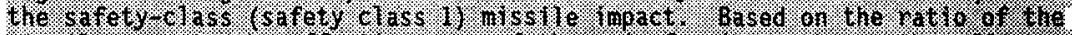

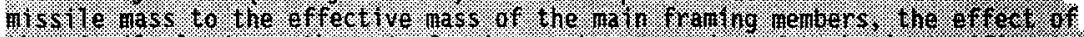

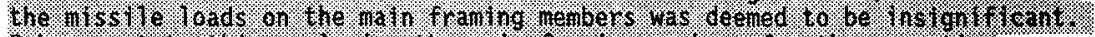

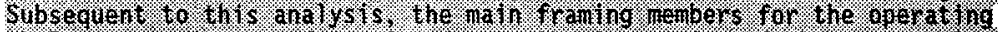

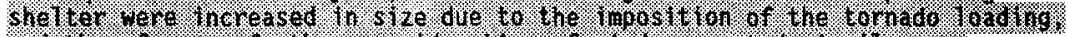

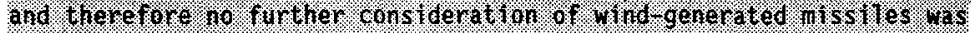

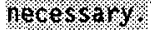

[This material has been moved to Section 4.3.6.3.] operating shelter design basis loads are given in section-4.3.4.3. A

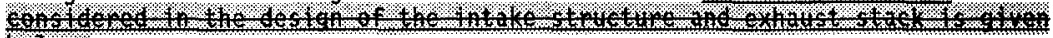
6010\%

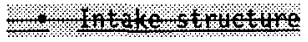

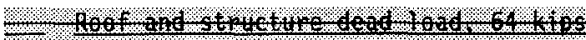

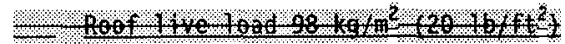

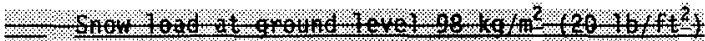

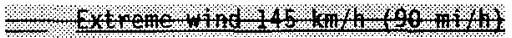

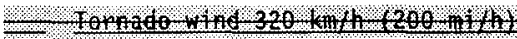

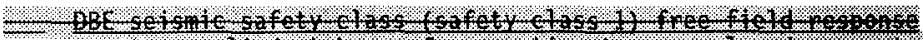

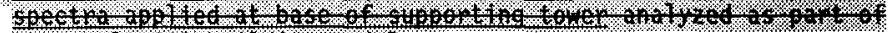

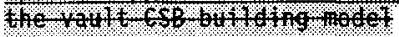

RPT -004.4 
HNF-SD-SNF-RPT-004 REV 6

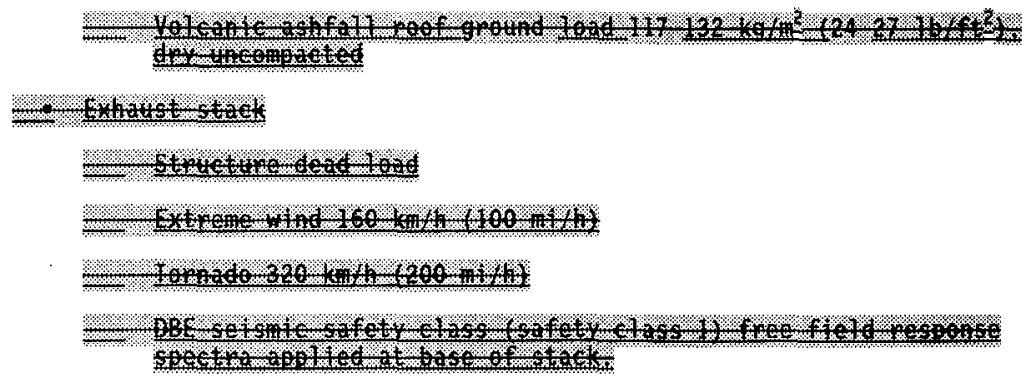

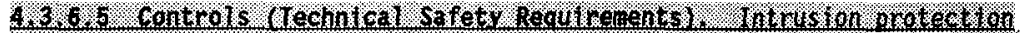

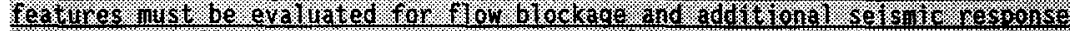

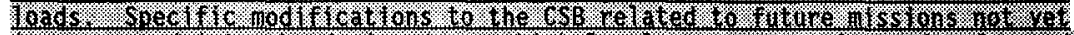

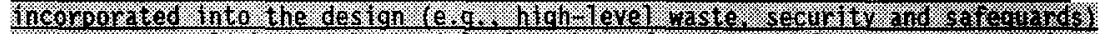

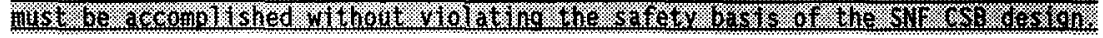

\section{3. \% Tube Vent and Purge Cart}

4.3.7.1. Safety function. The tube vent and purge cart provides the saretch

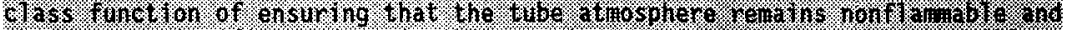

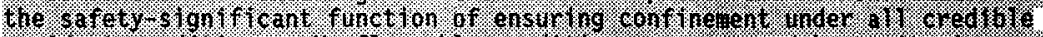

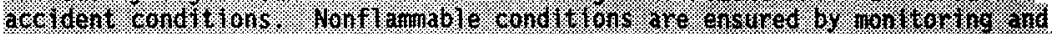

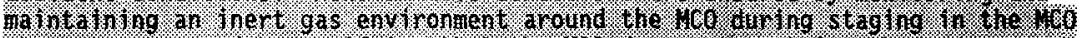

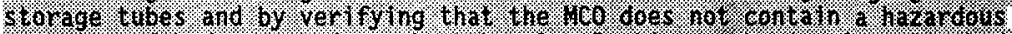

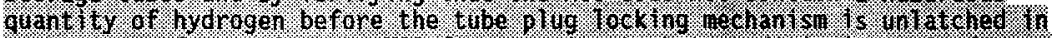

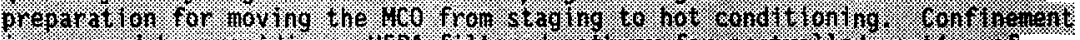

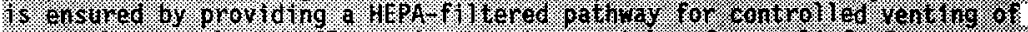

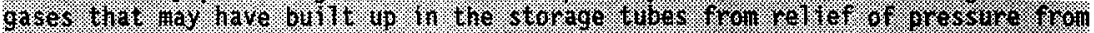

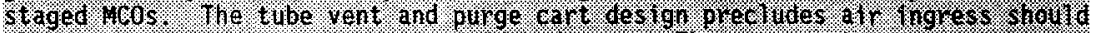

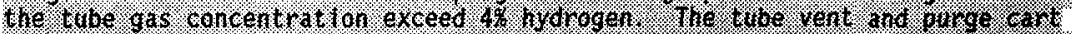

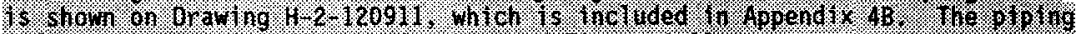
and instrumentation diagrati is shown of I tgure $4-13$.

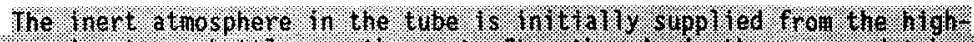
pressure inert gas bottles on the eart arter the ait it the acessed twe Is

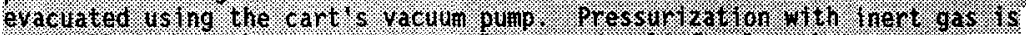

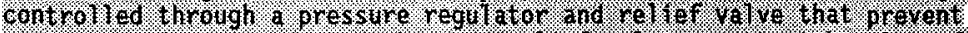

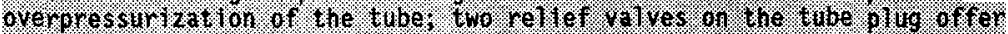
Fedundant protect ion. When linerting is i inished, the tube pressure is

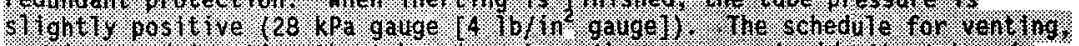
purging and nerting the lubes is set so the pressure listide the twies is

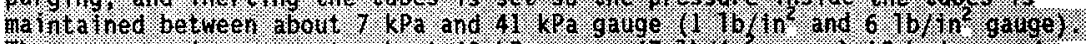

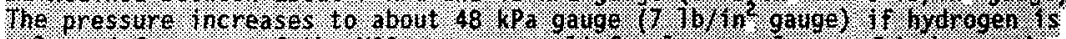

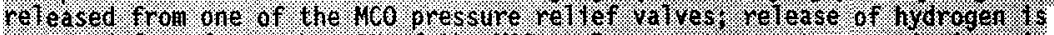

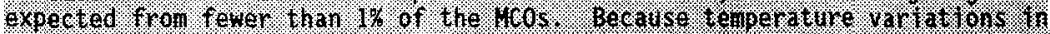

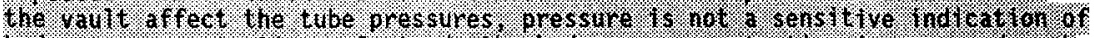
hydrogen concentration. Instead, the hydrogen contentrat lon is measured each

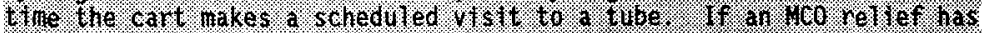
occurred. the hydrogen concentration in the twbe nay exceed $4 \%$. In this 


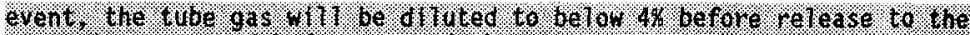
operating area and before use of the vacuun punp. Tubes used for storiege of

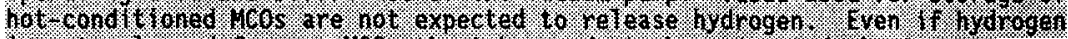

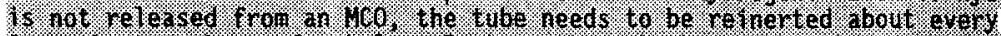

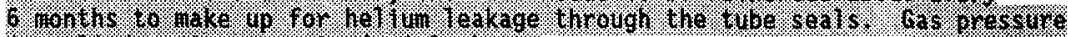
ts religed on to prevent alr Mieakage.

The cart?s a acuum puing is used to reduce the pressure in the tibe before Whatching the plig to enstree that a sudden retease from the Meo through the

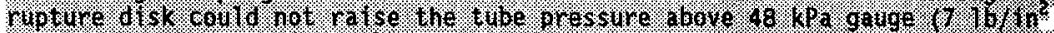

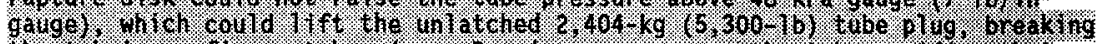

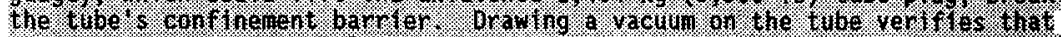

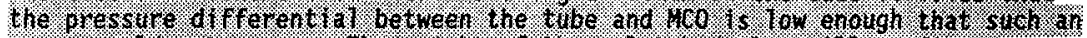
event contil not accur. The velght of the untatched plug with conth the a

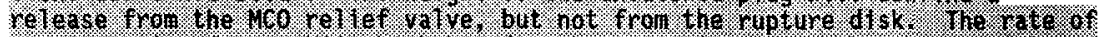

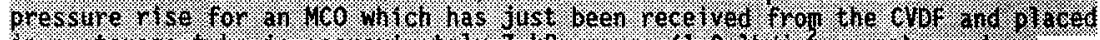

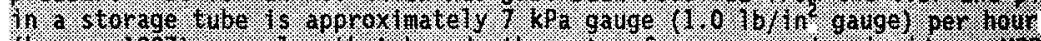

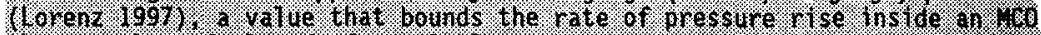

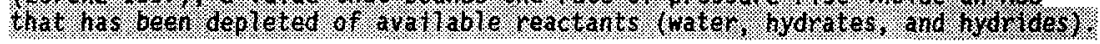

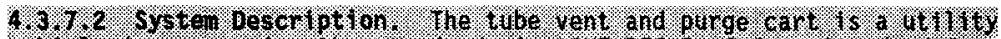

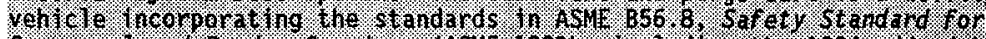

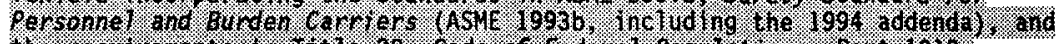

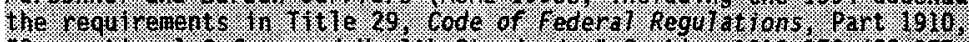

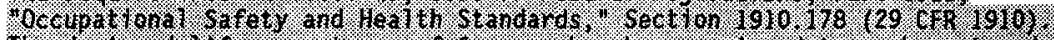

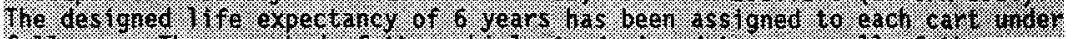

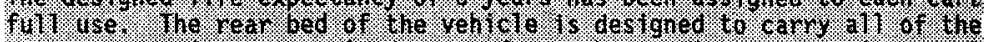
necessary equipuent required to perform tibe tent ng. evacuation sampling,

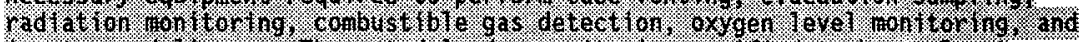

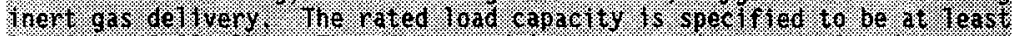

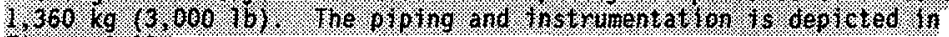
Figuro 4.13 .

With the eart in pos thion at the Med tube the lube aceess cever remervert and extermat power comnected to the cart, the deslgh flow path of gases beghts With the counaet ion and al ligment of the purge cant (satety class. I and 2 )

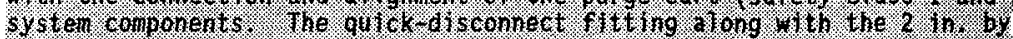

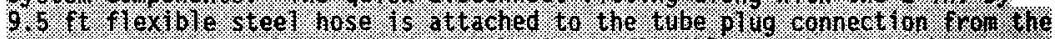

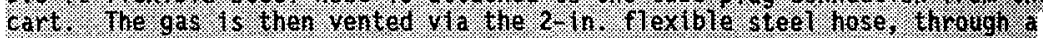

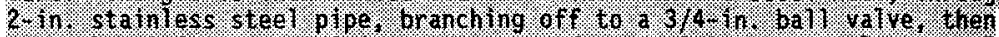

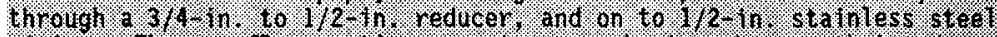

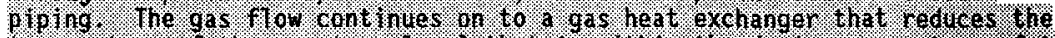
temperature of the gas to 4 level that 15 withith the desion paraneters of the gas aralyzers. Gas flow continues from the leat exchanger through a 1/2 1 .

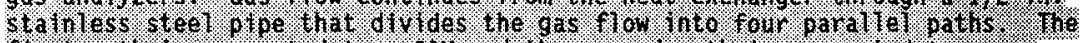
first path is connected to a CAM and the second path is comnected to a gas.

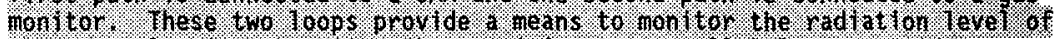

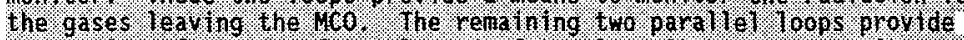

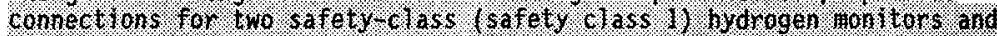

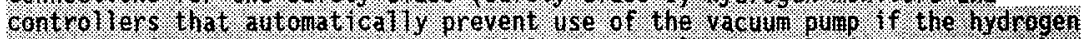

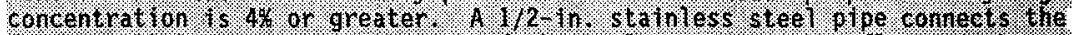
four paralle? downstream exhausts of the analyzers through a flow stheh, to: a

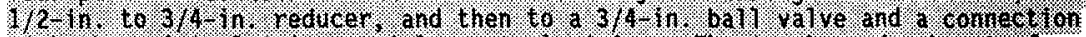
With the original 2 in. stainless steel plping. The intake and exhaust of 


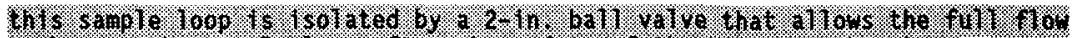

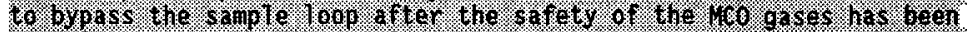

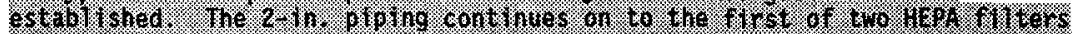

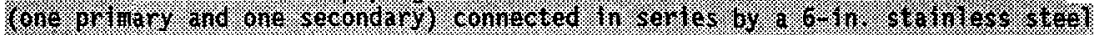
1.

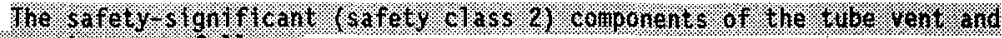
purge cart are as. followst

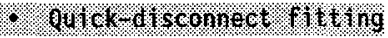

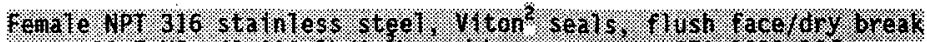

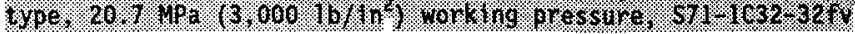

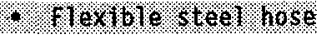

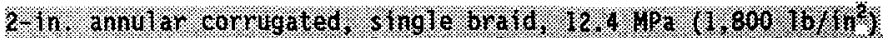

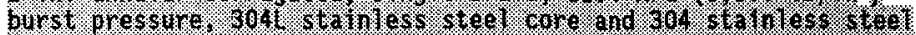

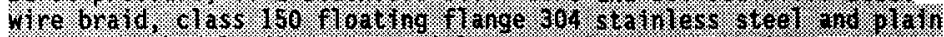

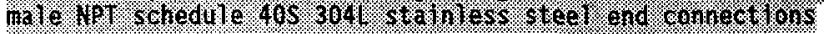

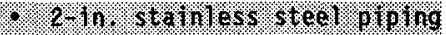

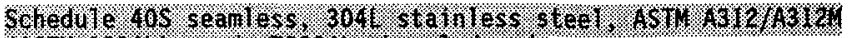

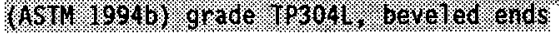

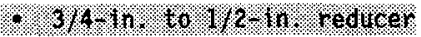

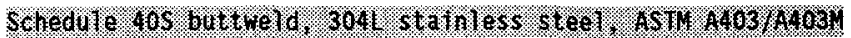

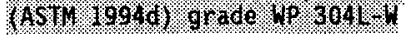

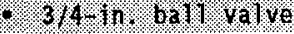

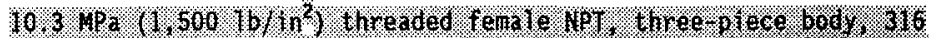

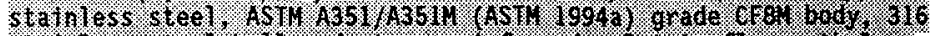

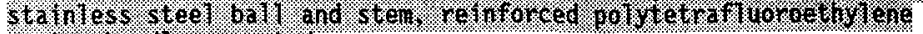
s.ats. hanuto 002 rated

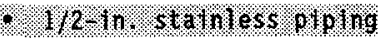

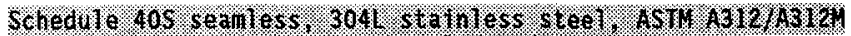

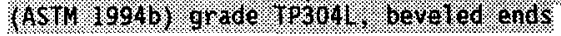

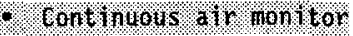

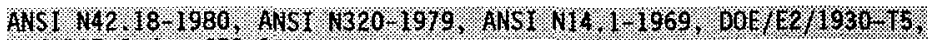
and vot 0. 0.8er $653.1 \mathrm{~s}$

\footnotetext{
${ }^{2}$ Viton is a trademark of E. I. du Pont de Nemours and Company.
} 
HNF-SD-SNF-RPT-004 REV 6

- Gas non 10 .

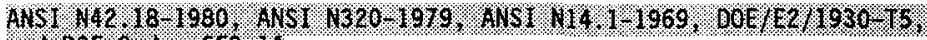
and 100 . Oyer 653 . of

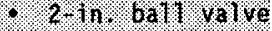

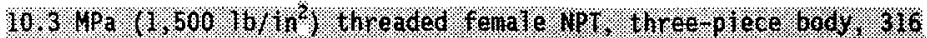

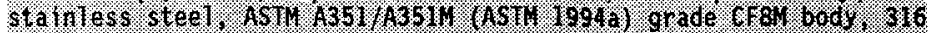

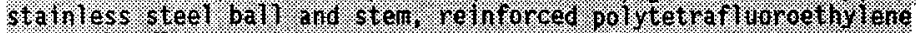
seat - intive operated

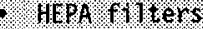

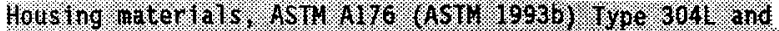

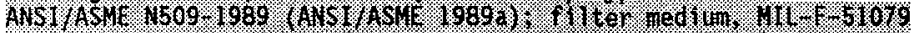

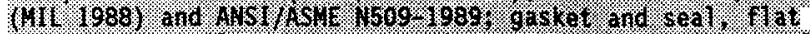

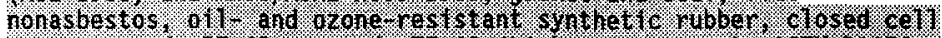

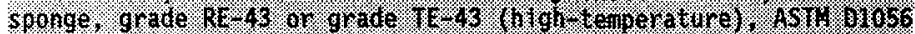
(ASTH. 1991$)$

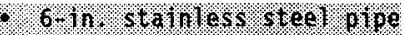

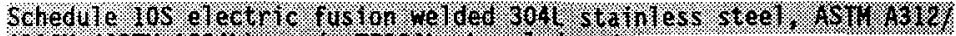

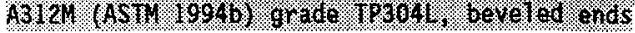

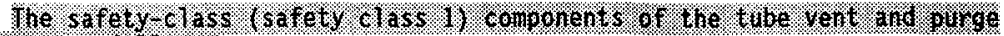
art. are as . 104 . ows?

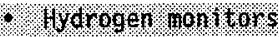

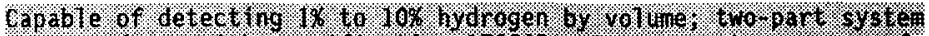

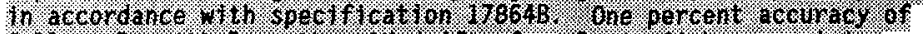

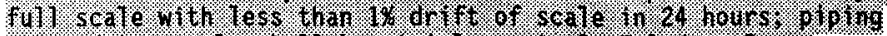

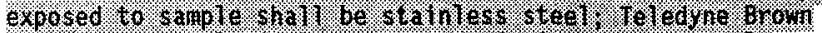

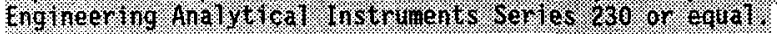

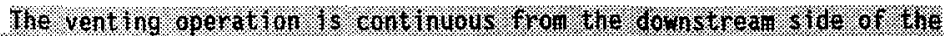

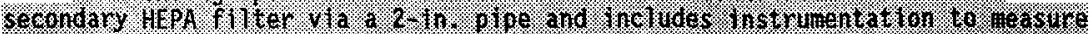

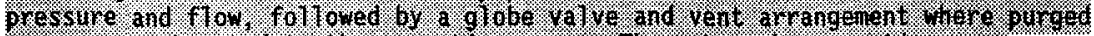

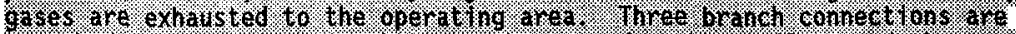

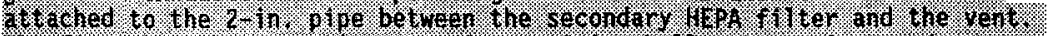

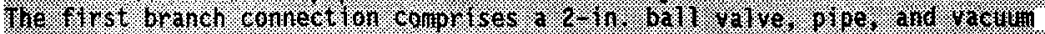

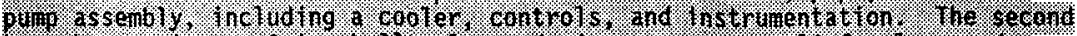

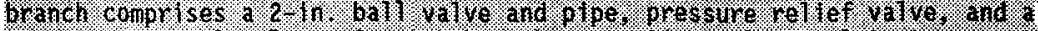

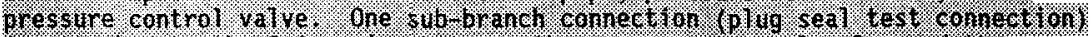

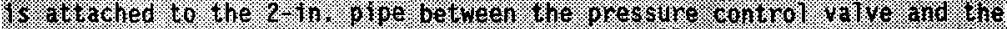

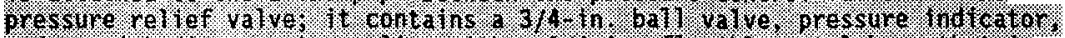

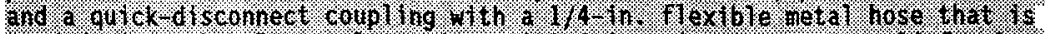

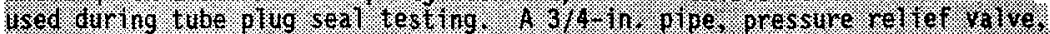

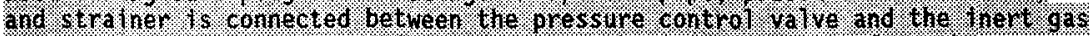

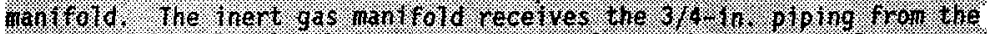

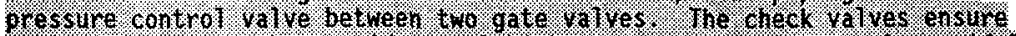

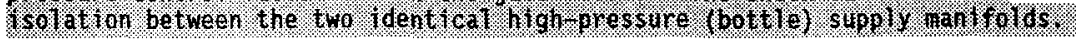




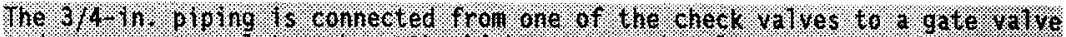

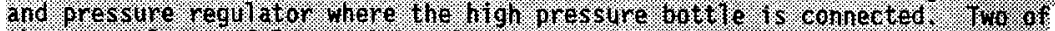

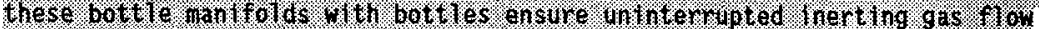

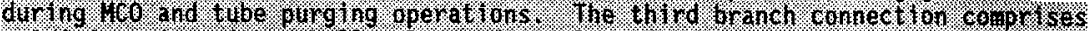

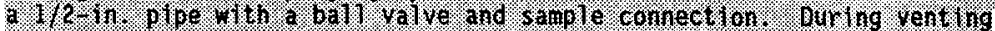

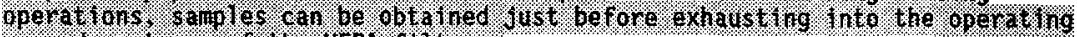

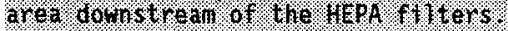

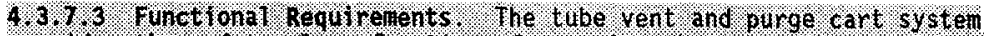
provides. the safely. e tass. funct o or of ensuring that the tube atmosplere

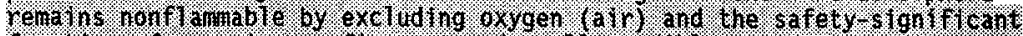

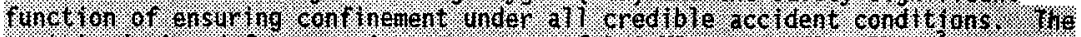

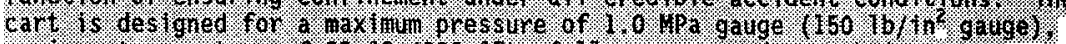

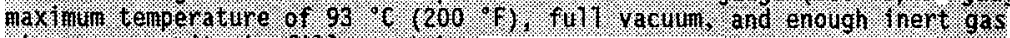

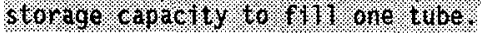

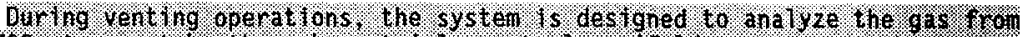

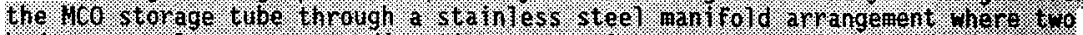

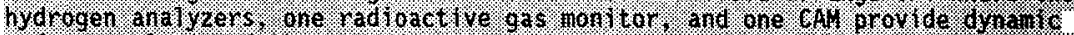

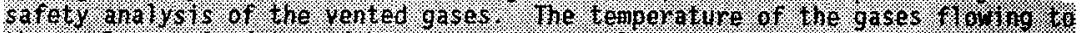

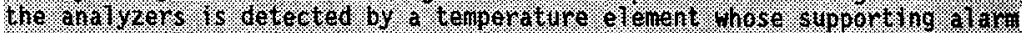

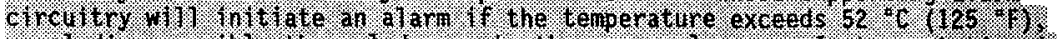

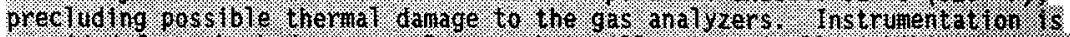

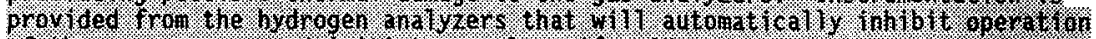

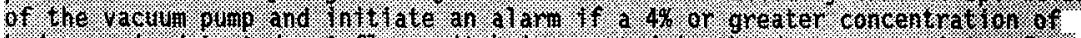

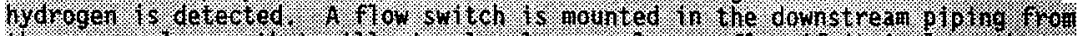

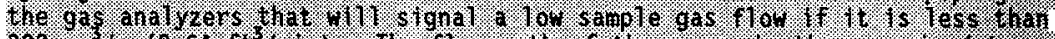

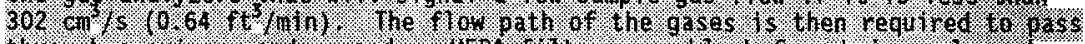

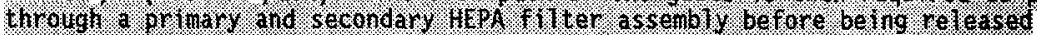

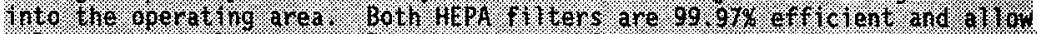

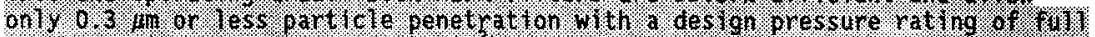

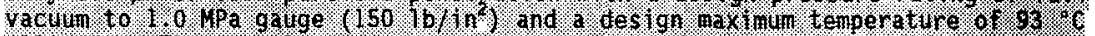

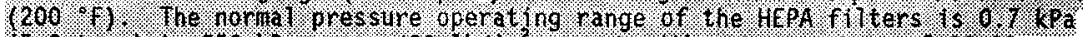

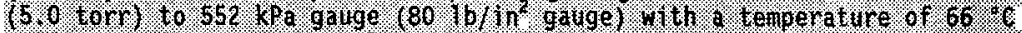

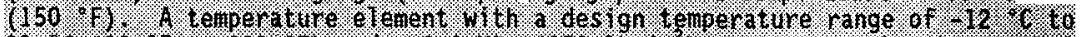

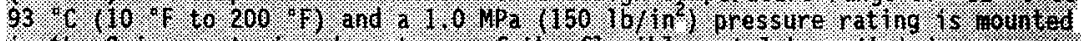

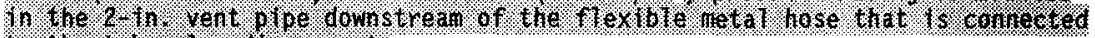
to. the tube plig. of sconnect.

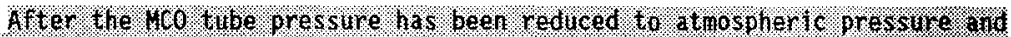

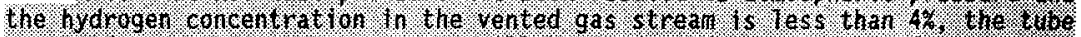

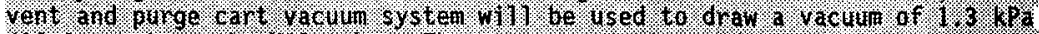

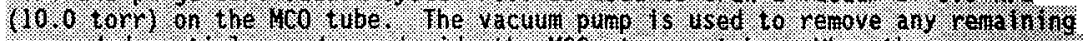

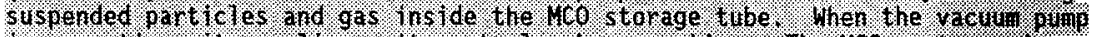

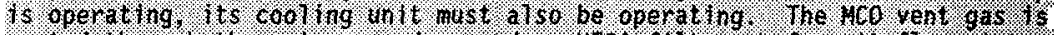

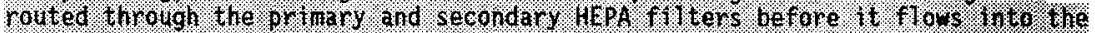

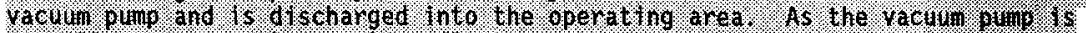

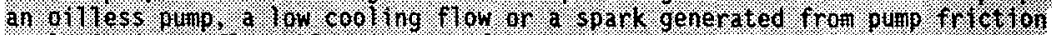

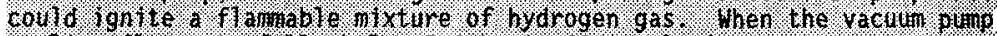

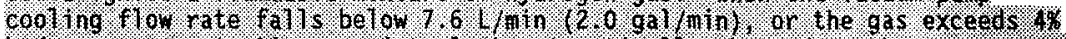

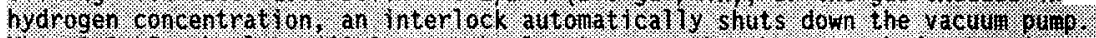

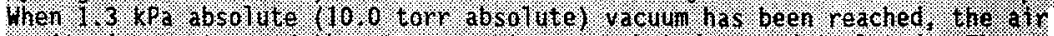

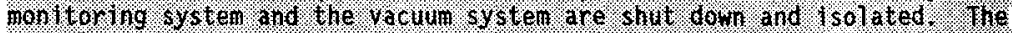

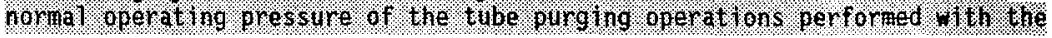




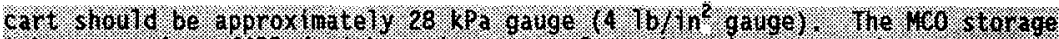

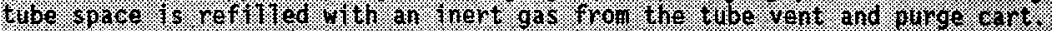

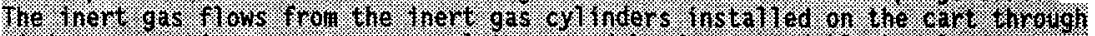

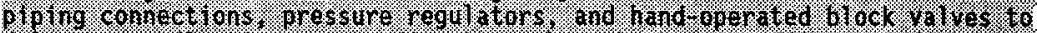

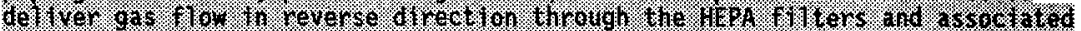

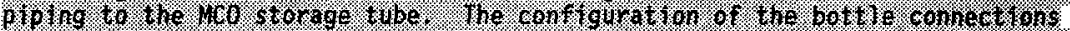

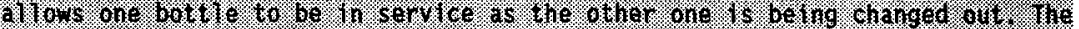

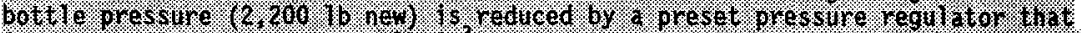

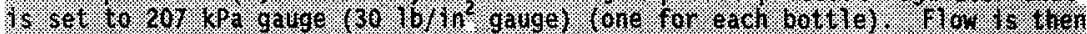

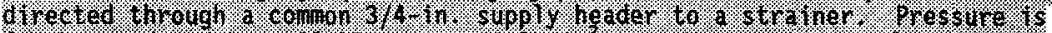

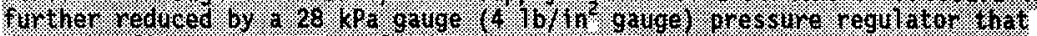

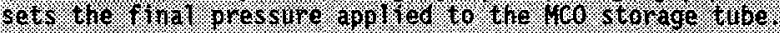

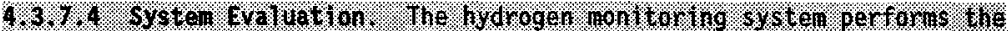

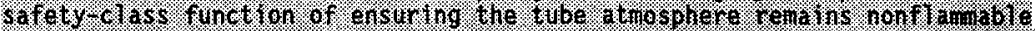

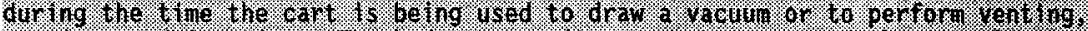

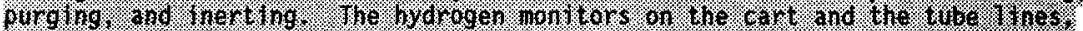

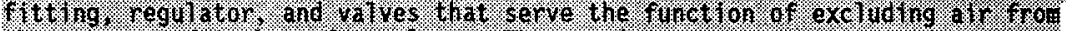

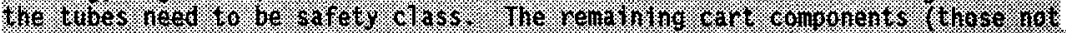

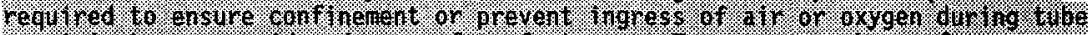

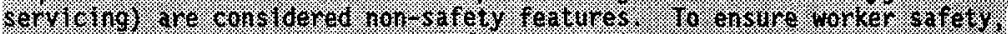

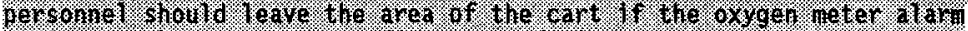

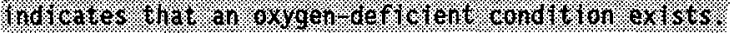

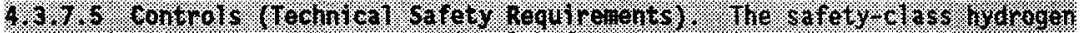

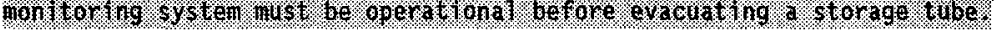

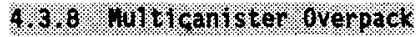

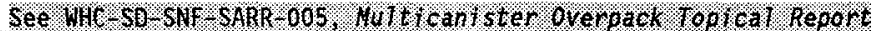

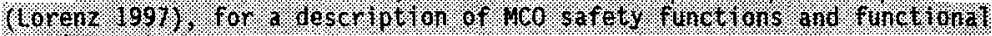

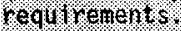

\subsection{SAFETY-SIGNIFICANT STRUCTURES, SYSTEMS, AND COMPONENTS}

The safety-significant SSCs are summarized in Table 4-78. These items

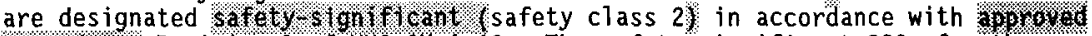
procedwes Reviston 1- Of WHC CM 4-46. The safety-significant SSCs for the operating deck and its associated mechanical equipment are described in

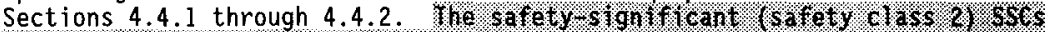

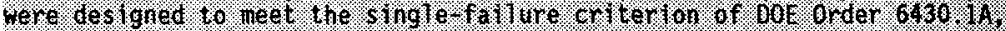
Section 1 300.3. 3. Safety signifieant SSES determined to be safety elass 3

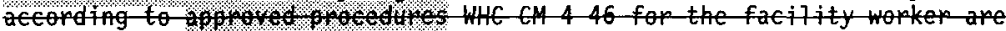
included in chapter 2.0 . 
Table 4-78. Safety-Significant Structures, Systems, and Components for the Canister Storage Building. (2 sheets)

\begin{tabular}{|c|c|c|c|}
\hline $\begin{array}{c}\text { Safety-significant } \\
\text { SSC }\end{array}$ & Safety function & Functional requirements & $\begin{array}{l}\text { Performence criteria } \\
\text { (TSR applicability) }\end{array}$ \\
\hline $\begin{array}{l}\text { Tube vent and purge } \\
\text { cart }\end{array}$ & $\begin{array}{l}\text { Provide secondary } \\
\text { confinement for one or } \\
\text { two MCOs } \\
\text { Provide confinement from } \\
\text { overpressurization of MCO }\end{array}$ & 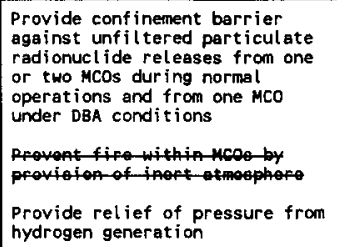 & 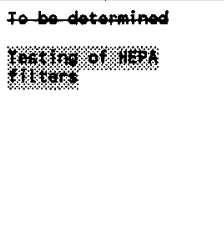 \\
\hline nMM & 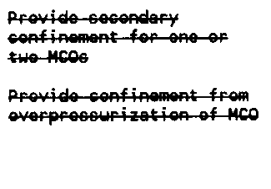 & 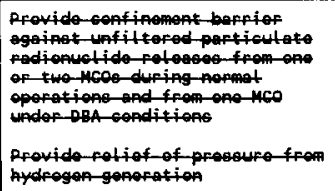 & To-bo-dotorminad \\
\hline Rortablo ohiold-goton & 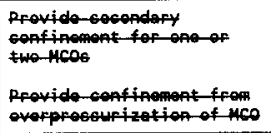 & 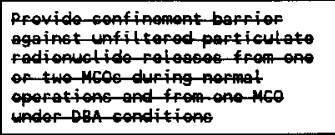 & Io-bo-doterminod \\
\hline 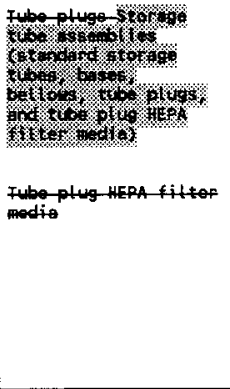 & $\begin{array}{l}\text { Provide confinement of } \\
\text { MCO releases to the } \\
\text { storage tube; prevent } \\
\text { ingress of operating air } \\
\text { to the tube } \\
\text { Mitigate the onsite } \\
\text { release of particulate } \\
\text { from an MCo caused by } \\
\text { overpressurization }\end{array}$ & 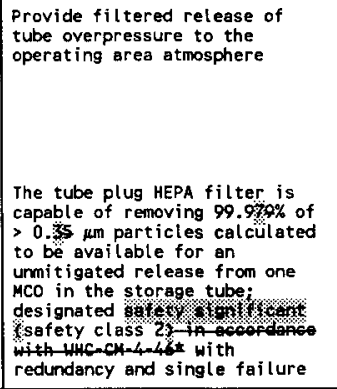 & 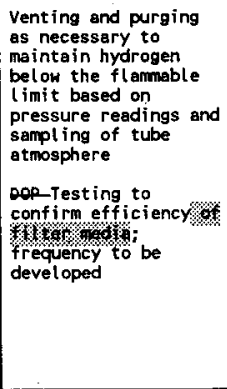 \\
\hline Plug flacki & 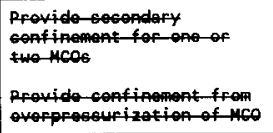 & 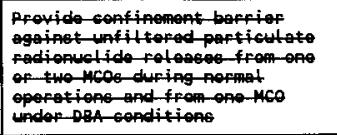 & fo-bo-detaninod \\
\hline $\begin{array}{l}\text { Byody-Emergency } \\
\text { power syster } \\
\text { (generators, } \\
\text { electrical } \\
\text { distribution) }\end{array}$ & 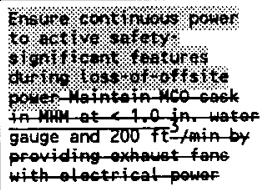 & 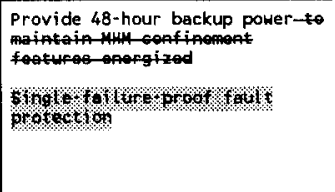 & 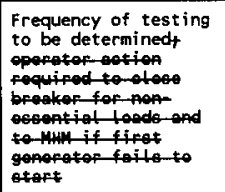 \\
\hline
\end{tabular}


Table 4-78. Safety-Significant Structures, Systems, and Components for the Canister Storage Building. (2 sheets)

\begin{tabular}{|c|c|c|c|}
\hline $\begin{array}{c}\text { Safety-significant } \\
\text { SSC }\end{array}$ & Safety function & Functional requirements & $\begin{array}{l}\text { Performance criteria } \\
\text { (TSR applicability) }\end{array}$ \\
\hline 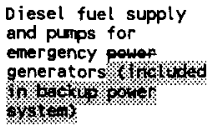 & $\begin{array}{l}\text { Provide fuel for } 48 \text { hours } \\
\text { of generator operation }\end{array}$ & $\begin{array}{l}\text { Maintain fuel supply to at } \\
\text { least one of two generators for } \\
48 \text { hours }\end{array}$ & $\begin{array}{l}\text { Frequency of testing } \\
\text { to be determined }\end{array}$ \\
\hline 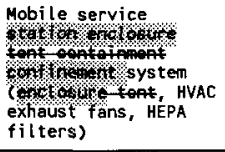 & $\begin{array}{l}\text { Maintain secondary } \\
\text { confinement of MCO while } \\
\text { in service pit with cask } \\
\text { lid off and during } \\
\text { servicing operations; } \\
\text { mitigate against burst } \\
\text { MCO when cask tid off }\end{array}$ & 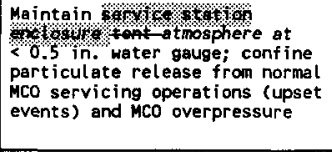 & $\begin{array}{l}\text { oop-iesting of HEPA } \\
\text { filters; } \\
\text { functional ity checks } \\
\text { of blowers }\end{array}$ \\
\hline Receiving crane & Prevent drop of MCO cask & $\begin{array}{l}\text { Withstand DBE with load without } \\
\text { tipoing over }\end{array}$ & $\begin{array}{l}\text { Limits on height of } \\
\text { load above deck to } \\
\text { prevent swing and Mco } \\
\text { contact during sling } \\
\text { failure }\end{array}$ \\
\hline $\begin{array}{l}\text { MCO service station } \\
\text { gantry crane }\end{array}$ & 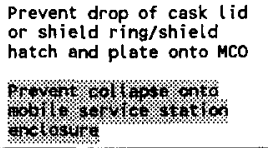 & 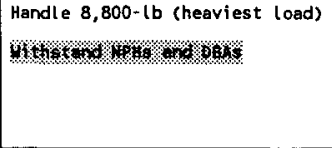 & To be determined \\
\hline 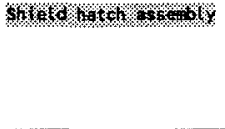 & 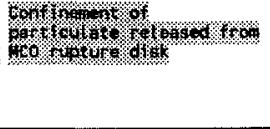 & 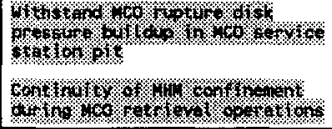 & Wo\% \% \% $\%$ \\
\hline SW & 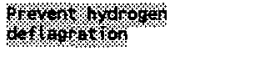 & 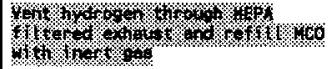 & $16 \%=0 \%$ og \\
\hline
\end{tabular}

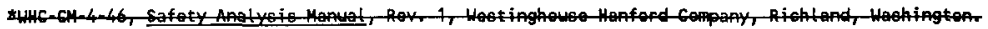

$D B A=$ design basis accident.

DBE = design basis earthquake.

DOR = diocty

HEPA = high-efficiency particulate air (filter).

HVAC = heating, vent $i$ lating, and air cond $i$ t ioning.

$M C O=$ multicanister overpack.

MHM = multicanister overpack handling machine.

SSC = structure, system, and component.

$T S R=$ technical safety requirement.

\subsubsection{Tube Plug Filter Media}

4.4.1.1 Safety Function. The tube plug HEPA filter media are required to

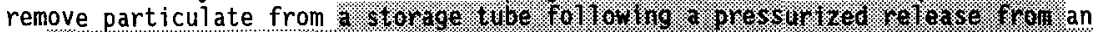

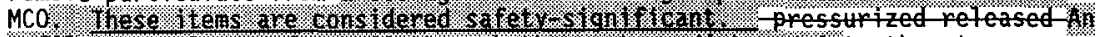

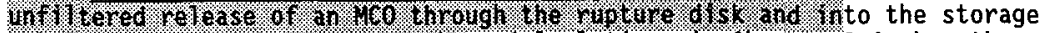

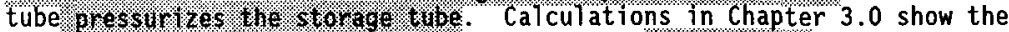
unmitigated dose of a pressurized $4 C 0$-release rool an 140 containing $300 \mathrm{~kg}$ (660 ib) of particulate to-exceeds the WHC CM-4-46-1) for onsite dose (Selvers. 1996 ). The filter media are required to be designed 
to meet Safoty. silonifleant (safety class 2 ) (safety-significant) requirements

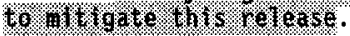

4.4.1.2 System Description. The tube plug HEPA filter media are contained within a metal canister located upstream of the tube plug relief valves. They are depicted on Figures 6 - and $6-5$. The filter media housing is threaded to the tube plug relief valve.

4.4.1.3 Functional Requirements. The tube plug HEPA filter media are required to remove sufficient particulate to mitigate the onsite consequences of a pressurized MCO release. This is accomplished by specifying $99.97 \%$ of $>0.3 \mu \mathrm{m}$ removal of particulate $25-$ state 3.0 and a minimum capacity of $1.3 \mathrm{~g}$.

4.4.1.4 System Evaluation. The tube plug HEPA filter media are required to remove sufficient particulate to mitigate the onsite consequences of a pressurized MCO release. This is accomplished by specifying $99.97 \%$ of $>0.3 \mu \mathrm{m}_{3}$ removal of $\sim 1.3 \mathrm{~g}$ (based on a respirable particulate loading of $100 \mathrm{mg} / \mathrm{m}^{3}$ in the tube) of particulate as stated in Section 4.3.5.3. The tube plug HEPA filters are specified to comply with ANSI/ASME N509-3989, Nuclear Power Plant Air Cleaning Units and Components New Construction and Modification Only (ANSI/ASME 1989a).

4.4.1.5 Controls (Technical Safety Requirements). Frequent-dioctyl phthatate aerosor. Gar Wenge testing will verify capability of HEPA filtration for the tube plug HEPA filter media. The testing of HEPA filters is specified to comply with ANSI/ASME N510-1989, Testing of Nuclear Air-Cleaning Systems (ANSI/ASME 1989b).

\subsubsection{Multicanister Overpack Handling Machine}

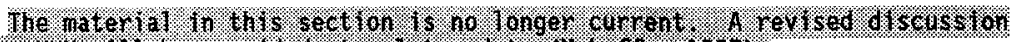

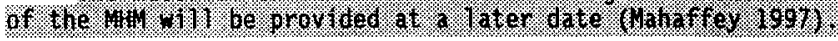

4.4.2.1 Safety Function. The MHH is Used to remove-an MCO from the transfer eask and place it in a storage tube. The primary function of the Mllly is to transport the $M C O$ within the CSB without incident and to maintain an inerted confinement atmospere around the $M C O$ during these handling operations. MCO retrieval and replacement operations are similarly carried out fop transfer of $M C O$ s to and from the HCS. The tube vent and purge carts will purge the tube in order to restore the hydrogen concentration in a storage tube to below the lower explosive 7 imit in the event of abnomal hydrogen generation from an $M C 0$. The carts are diseussed in section 4.4 .4 of this document.

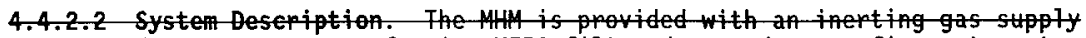
system and emergency power for its HEPA filtered secondary confinement system and radiation monitors. The anchitect-engineer prepared-specifications for the MHH equipment that require safety class interlocks designed to prevent inadventent operations, which cold cause the breach of an MCO. The principal interlocks for this function are associated with the safety class seismit pestraints that inhibit trolley and gantry movement. The-AHAl as provided by 
Foster Wheelep Environment Corporation incopporates atl the requirements of these specifications.

The shield hatch-provides the interface surface fop the MHM's shielded turet nose assembly at the $M C O$ service station. The shielded turpet nose assembly provides secondapy confinement for the $M c 0$ during the transfer operation when the center shield plate is removed from the shield hatch assembly.

A makeup ring is inserted into the selected storage tube to raise the machine interface at the storage tube to the MHll charge face level. When the MHA4 is located over the tube, the lowering of the shield skirt extends the nose ring to seat on top of the makeup ring. The shield turet nose assembly provides secondary conf inement for the $M C O$ during the transfer operation when the striele plug is remolfrom the storage tuber

The doctmented shielding andyses (Kid 1996) based on the arehitect engineer's conceptual design show that the sides of the shielding enclosure ned to be $28 \mathrm{~cm}(11 \mathrm{in}$.$) of steel inside 10 \mathrm{~cm}(4 \mathrm{in}$.) of borated polyethylene inside an outer $2.5 \mathrm{~cm}(1 \mathrm{in})$ ) of steel. This-shield configuration is provided in the shield gate specification and associated drawings. It is assumed that the vendor supplied design will meet all pequirements in these documents. Final confinmatony shielding analyses-will be done after final design is complete. The current design approach fop the MHAl incoporates the functions of the shield gate and plug flask, which were the architect-engineer's conceptul design, within the vendor's advanced conceptut design for the-HHM.

The- HIM ventilation system is designed with redund The system consists of a pain of HEPA filtered exhaust fans, one of which is designated the standby unit while the other unit is in operation. The interion of the 14114 cask will be at a negative pressure of 250 Pa (1.0 in. water gatrge) refative-to the operating area. The fan flow ate is based on a minimum indued velocity of $61 \mathrm{~m} / \mathrm{min}-(200 \mathrm{ft} / \mathrm{min})$ to prevent buek diffusion of particulate contamination in vertical and horizontal ducts and flow passages. Each system consists of an exhaust fan, HEPA filter, back draft valve, dioctyl phthalate-test ports, vactum-switch, andwaning light. Erch exhaustsystem is independent of the other. Upon the loss of vacum, the standby fan will start automatically and a red-waning-7ight will-illminate. During loss of nommal power, the ventilation system will be switched to emergency power. The MIII rentilation system will be in cont intls operation whenever the HHI is moved away from its parking position. The machine will be interlocked so that no task tan be performed without the ventilation-system being functional. Air will be drawn in via the nose-of the machine and shield skint. The infiltrating air, combining with inent gas within the MHM, will flow up orer the $M C O$, out through a tapping in the cask above the $M C O$, across the rotate drag ehain, through a flexible pipe to a ventilation cubicle on the trolley and will be discharged vertieally upwards from a stack pipe protruding from the top of the bicle.

4.4.2.3. Functional Requirements. An inert gas flow of $1.42-\mathrm{m}^{3} \mathrm{mmin}$ (50-ft- $\mathrm{fmin}$ ) is required to maintain a safe atmos with the MHA considering restricted difution from air in leakage and projected maximum hydrogen evolution. 
The MHH's ventilation system-is base on a minimum in welly of $61 \mathrm{~m} / \mathrm{min}(200 \mathrm{ft} / \mathrm{min})$ to prevent back-diffusion of particulate-contamination in vertical and horizontal duets and flow pasages. The system consists of a fan. HEPA filter, back draft valve, dioctyl phthalate test ports, vacuum switch, and warning light. Each fan system-will be indentent of the other. one-fan system will be operated while the second fan system will be used as a standby unit. Upon the loss of fan vactum, the standby fan will stant attomatically and a red warning light will illuminate. Buring loss of nomal power the ventilation system will be switched to emergency power. The MHAl's ventifation system will be in cont intlous operation whenever the MHAl is moved away from its parking position. The machine will be interlocked so that no task can be performed without the ventilation system being functional. Aip will be drawn in via the nose of the machine and shield skipt, up over the $M C O$, out through a tapping in the cask above the $M C O$, across the potatedrag chain through a flexible pipe to a ventilation cubicle on the trolley and [discharged vertically upwards from- a stack pipe protruding from the top of the eubiete.

4.4.2.4 system Evaluation. The tube plug is engaged by the grapple of the shield plug hoist on the MHM. The grapple has electrical and mechanical interlocks that prevent its opening inadvertently. If a plug were to drop, it would not contact the tube assembly until reaching the chamfered suface, as the MIII guides it past the top flange above the bellows section. The chamfered surface may be damaged and receivemino deformation if the plug strikes it a glancing blow rather than falling eleanly into the tube. The plug will eventually rest in its seated position. The plug and tube will not fait al though the seal may be unserviceable. Ealeulations (Fluor 1996) show that strutetural yielding of the componts will not octur if the plug is dropped into the tube from a maximum height of approximately $3.0-m-(10-f t)$. During tube plug removal ppertions, the volume of the uninerted atmosphere-in the space above the tube-plug mixes with the inerted volume of gas in the storage twbe. The results of preliminary analyses indicate that there is no flammability hazard as long as the hydrogen concentration-in the inered storage tube atmosphere is below $6 \%$ at the time the plug is removed.

The 1444 atmosphere is required to be-inented during-MCO transpont operations. The HHH can supply $1.42 \mathrm{~m}^{3} \mathrm{mmin}$ ( $50 \mathrm{ft}^{3} \mathrm{fmin}$ ) of inert gas to the eask body to dilute aip in leakage. This stpply of inert gas wl be sufficient to stay below the hydrogen flammability limit of $20 \%$ aip in inert gas (see Ordin $[1970]$ ). The system is sized to prevent exeding this value with-up to $0.17 \mathrm{~m}^{3} \mathrm{~min}$ (6 $\left.\mathrm{ft}^{3}-\mathrm{fmin}\right)$ of aip in 7 eakage.

Conceptul mechanical space allocation drawings are provided in Figures $4-65$ through 498 . These depiet the arehitet engineen's conceptuat design for miscellaneous pieces of $M C O$ and transpontation cask handling equipment. Atso bepicted in Figure 4109 is a to HCO

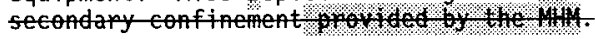

The-estimates of trolley bridge and bridge building intepface seismic toads were obtained using the representative geometry for the proposed machine design in conjunction with the response spectra from specification WHCS 0468 , Specification for Hulti Canister oreack (HCO) Hand ling Hache, section 3.2.4 (WHC 1996) and ANSYS runs. The results of both trolley centrat and trolley offset cases are presented in Appendi*-4C for the $50 \%$ tesign. 
Static 70 dis self weight downards, dyamic load is seismic only and ean be plus or minus. For the bridge, static minus dynamic provides the minimum load on the end truck pivot pins. Static plus dynamic provides the maximum pivot pin load for the bridge and the maximum individual wheel loads for the trolley. The pesults also provide "along the wail" and "right angles to the pail" loads and at the interface between the-bridge and building; these are estimat to be 200 tons and 300 tons, respectively. It is est imat that these figures should be within $15 \%$ of theip final values. The mathematicat molel used assumes that the bridge and trolley are restrained with laterat seismic restraints and rail beakes as required by specification WHC $S-0468$, Section 3.2.1.4d (WHC 1996). No connection has been assumed between the machine nose and the vault charge face. Refer to Appendix-4C for the latest results pertaining to the $2.7 \mathrm{~m}$ (9-ft) high girders.

The architect engineep used the $2.0 \times 10^{-3} \mathrm{mSv} / \mathrm{h}(0.2 \mathrm{mrem} / \mathrm{h})$ dose rate goal with a fallock to $5.0 \times 10^{-3}-\mathrm{mSv} / \mathrm{h}-(0.5 \mathrm{mrem} / \mathrm{h})$ as a design objective. These dose rate eriteria applied to all locations in the vicinity of the MHI, including the operator stution, during nomal Mco handling.

The dose pate at the floor surface of the operating deck because of both the slant angle concrete path and the gap between the MHI and deck sumface, will be less than $2.0 \times 10^{-3}-\mathrm{mSv} / \mathrm{h}-(0.2$ mrem/h). The stant distance was-made adequate by recommending an extended shield gate-skint that extends at least $91 \mathrm{~cm}(36$ in.) beyond the edge of the floom embed. This configuration is based on the preliminary specification scoping shielding andysis (Kidd 1996). Refer to Appendix 40 for the preliminary results of the MHH cask-shielding analysis.

4.4.2.5 Controls (Technical Safety Requirements). TSRs for the MAll will addres the $M C O$ pelated confinement and inepting features of the cask. including transport time from the CVOFs and HCO reinerting in the service station. These TSRs will be developed when MCO hydrogen generation rates are better undertood.

\subsubsection{Backup. Emergency-Power. $5 y$ s toe}

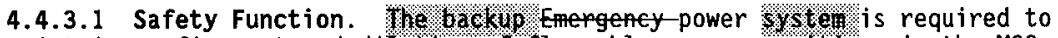
maintain confinement and diTution of flammable gas compositions in the MCO environment during a design basis loss of power event (loss of site power from

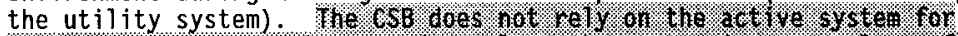

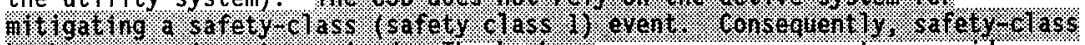

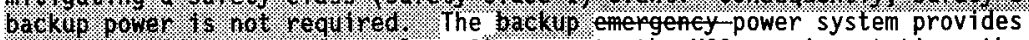

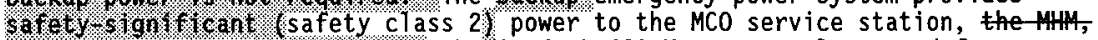

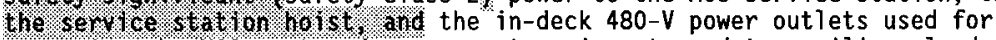
operating the MCO vent and purge cart equipment, and to auxiliary loads

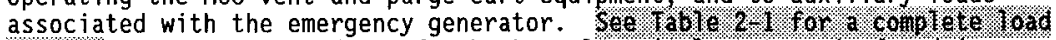
1.5. . Hanford Site guidance for backup electrical systems is found in

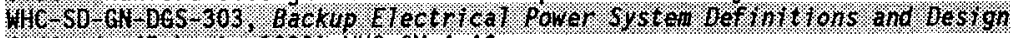
$6 \%$ \% \% (Roserts. 19901 - WHE CHA $4-46$.

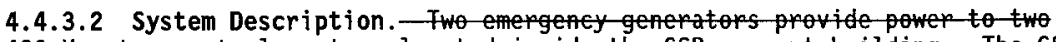
$480-1$ motor control centers located inside the CSB support building. The CSB support building is designed to protect the emergency power system-against 
damage from-safety class z and safety class 1 NPHs as 7 isted in

section 4.3.4.4. The two-motor control centers are equipped with transfep switches that (1) disconnect the low voltage power and utility power system; (2) send a stant signal to the genenators; and (3) connect the safety class 2 and 3 loads and onnected safety etass 3 tods. The safety-elass 3 touds are the receiving erane, the main CSB operating area HVAC exhaust fans, the HVAC stack effluent air sampling system, and the uninterpuptible power supply system. Safety class 2 electrical switchgeap protection is provided to prevent failure of one load from causing caseading failupes of other loads. The MHH4 is supplied with emergeney power via a festoon cable. The MHA provides its own independent emergency battery power to back up the operation of the safety elass 2 electrical systems (exhat fans and monitons) on the MHAl in the event of faiture of the festooned cable system for 4 hours. IIIS

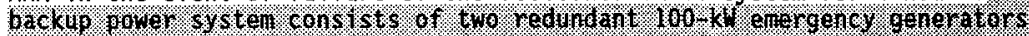

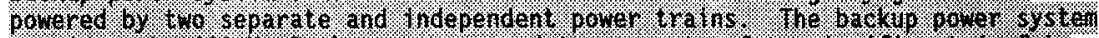

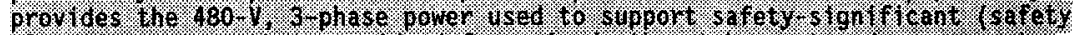

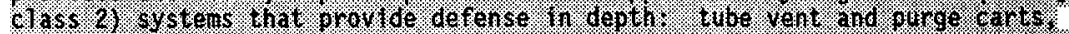

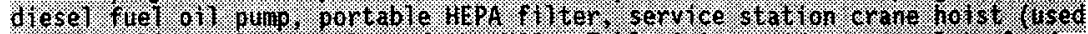

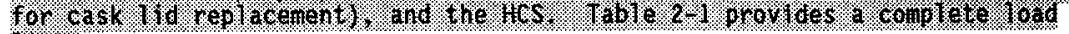
1.5 1 .

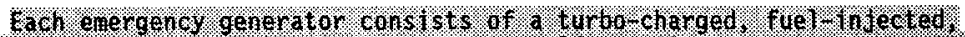

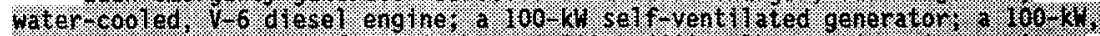

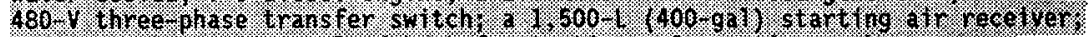

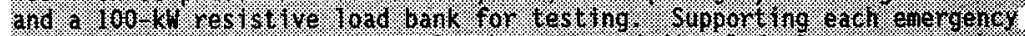

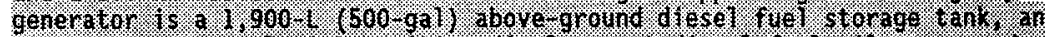

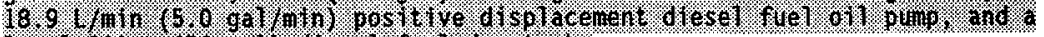

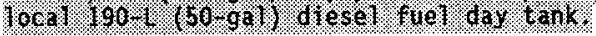

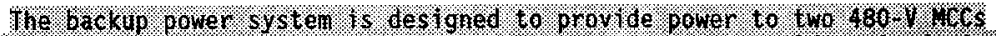

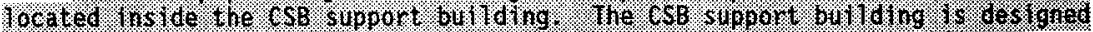

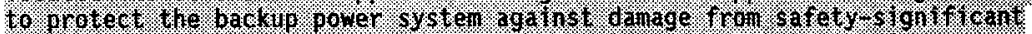

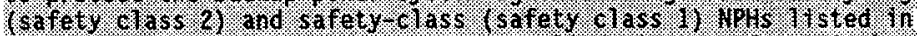

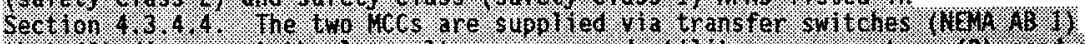

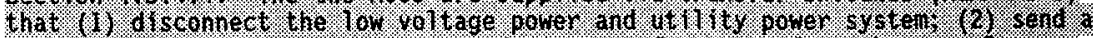

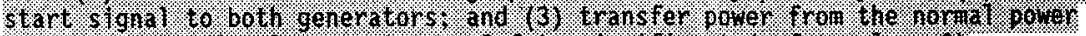

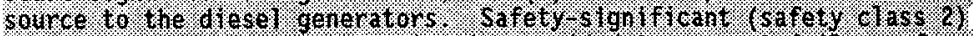

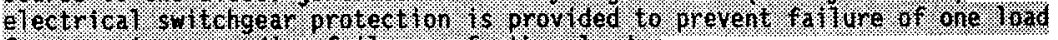

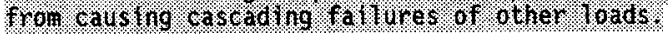

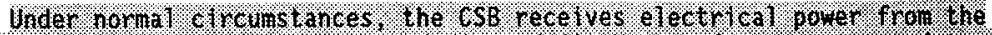

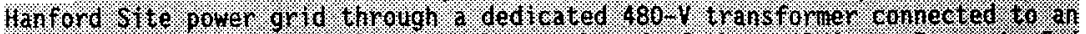

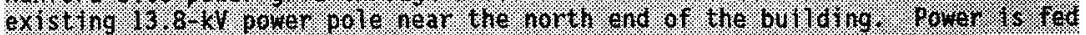

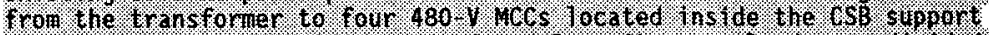

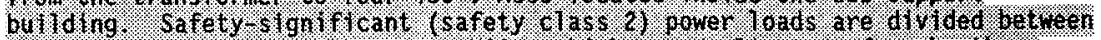

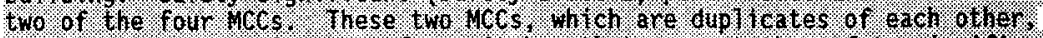

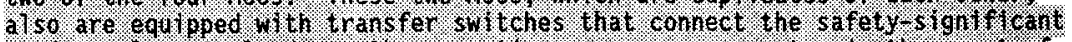

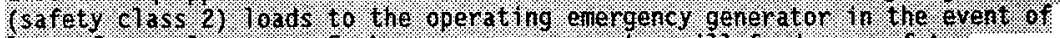

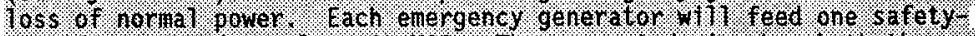

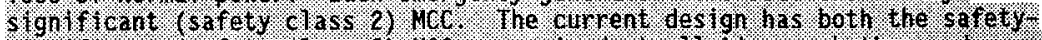

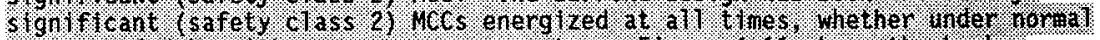

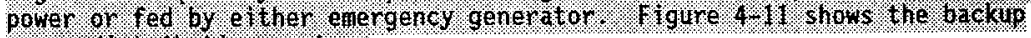

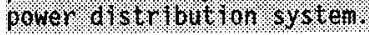




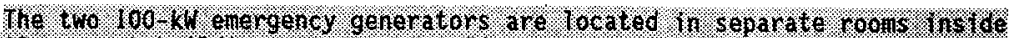

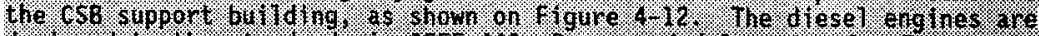

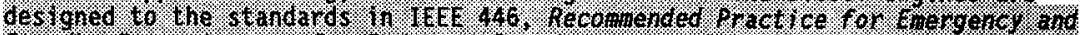

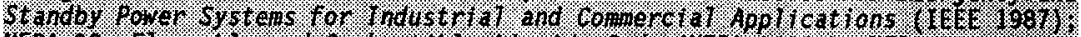

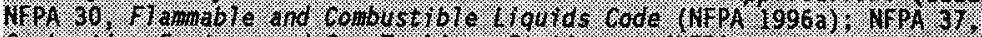

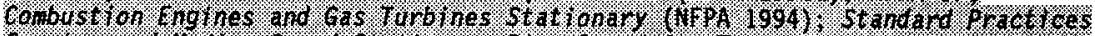

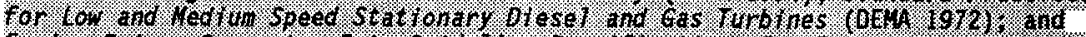

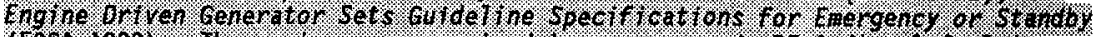

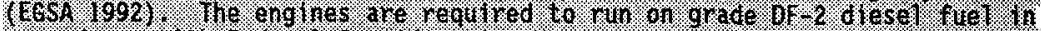

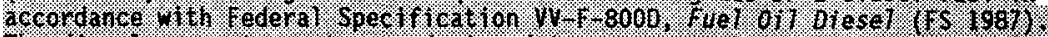

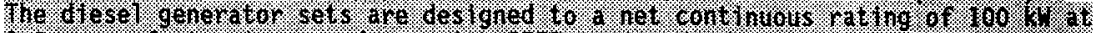

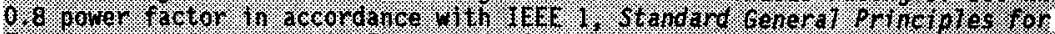

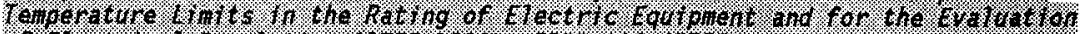

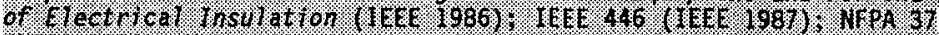

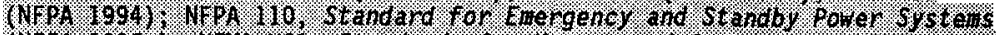

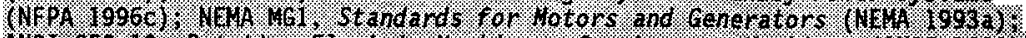

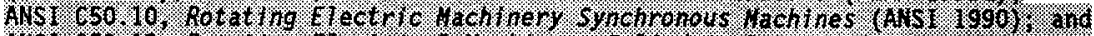

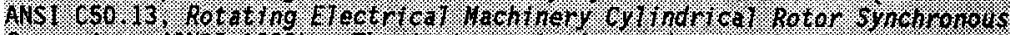

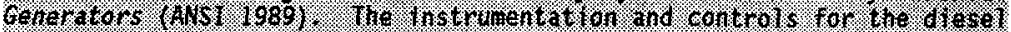

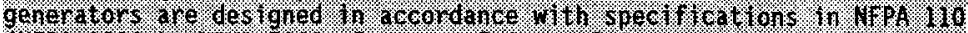

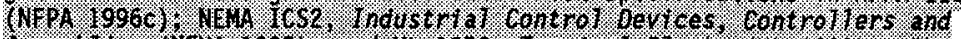

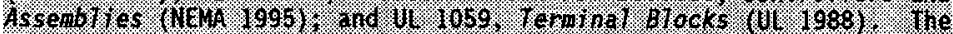

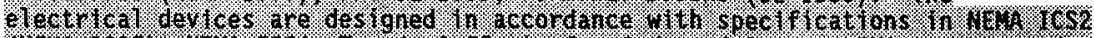

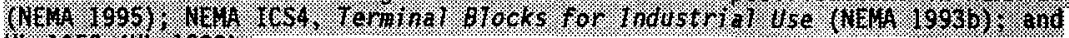
$4.1059 .6(1988)$

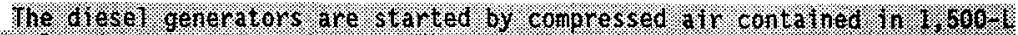

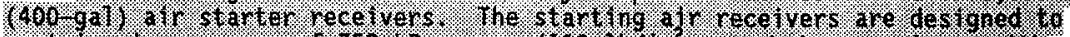

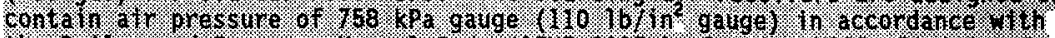

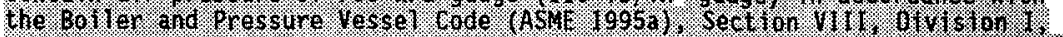

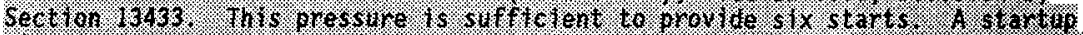

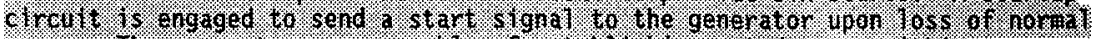

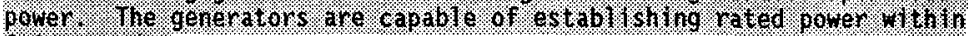
6.6. seones.

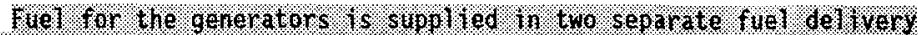

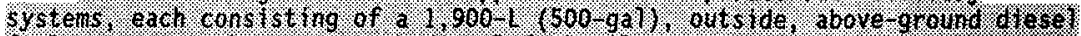

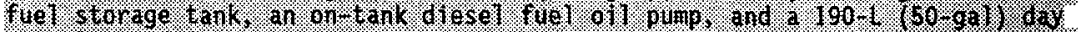

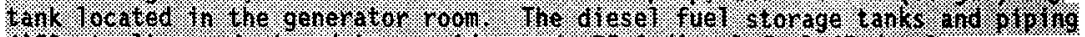

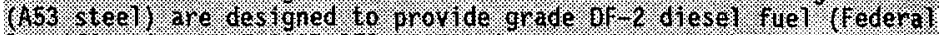

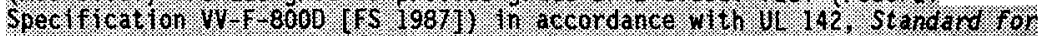

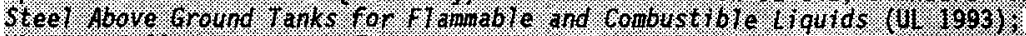

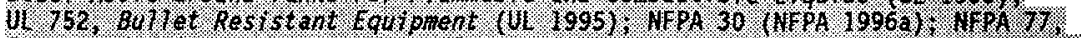

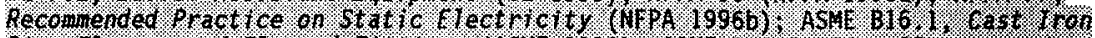

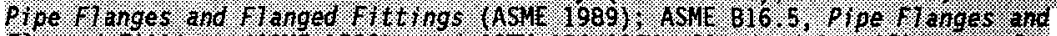

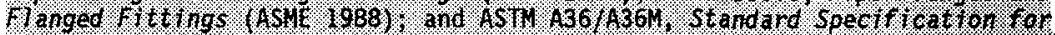

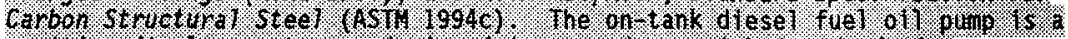

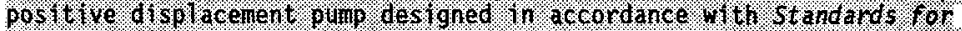

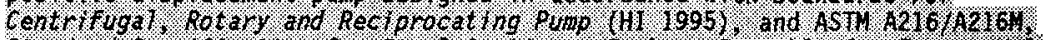

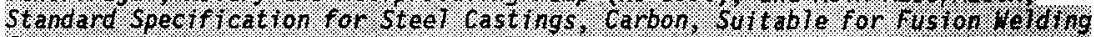

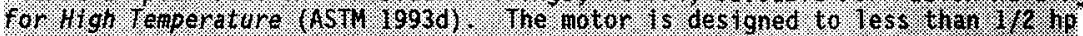

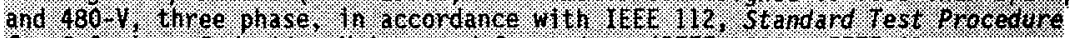

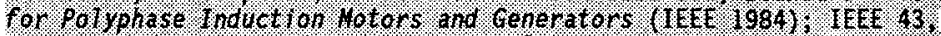

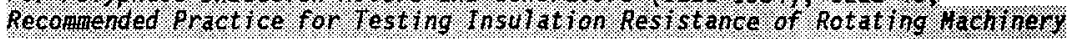




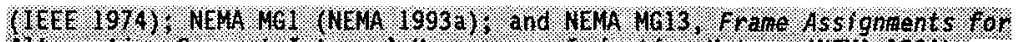

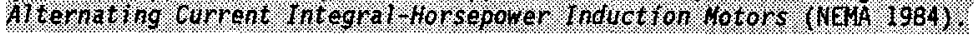

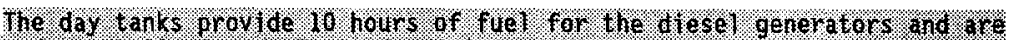

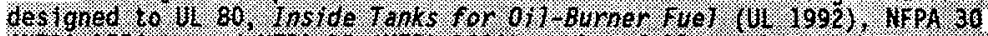

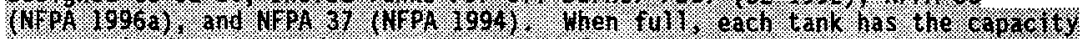

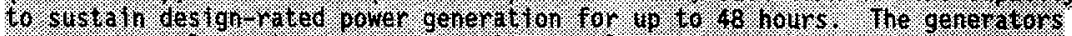

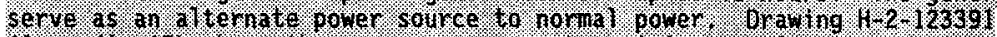

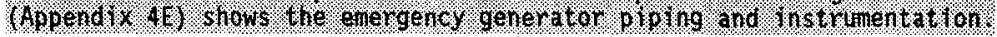

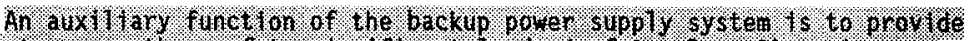

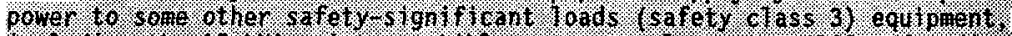

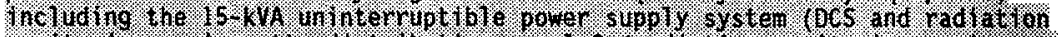

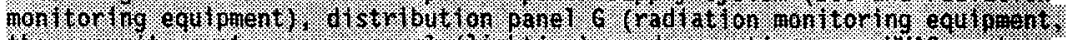

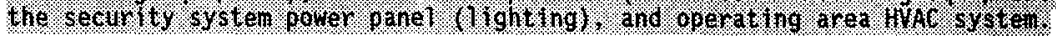

4.4.3.3 Functional Requirements. The design basis loss of power event is given as a total loss of normal power for a maximum of 48 hours in Section 3.2 .2 .1 .3 .2 of the CSB Performanes Specification (Swenson 1996).. Safety class 2 emergency power is designed to the single failure proof

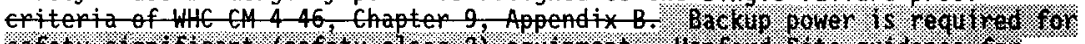

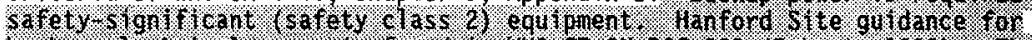

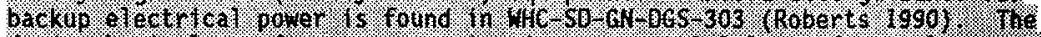

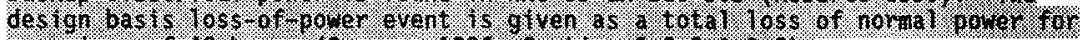

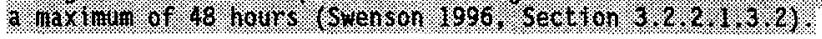

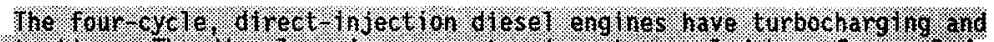

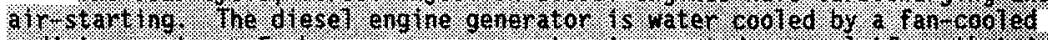

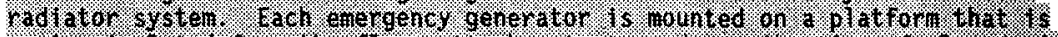

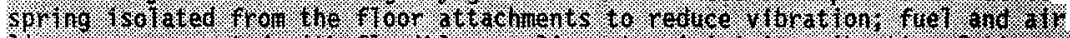

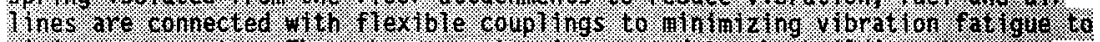

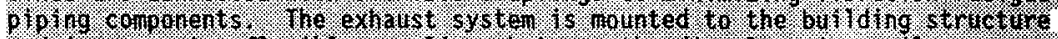

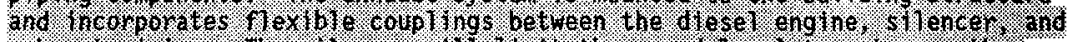

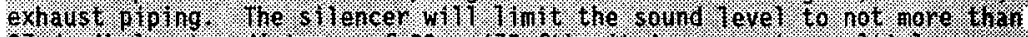

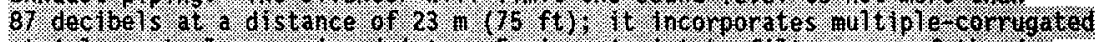

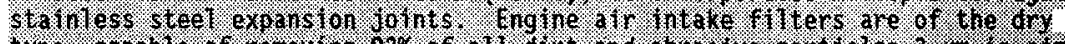

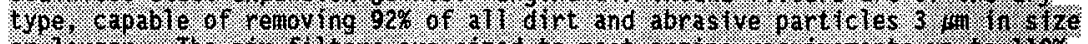

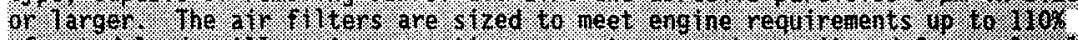

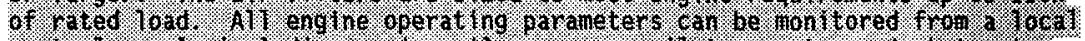

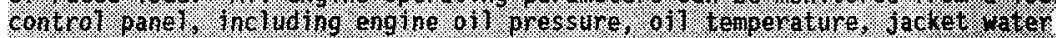

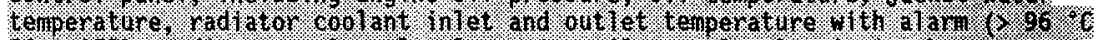

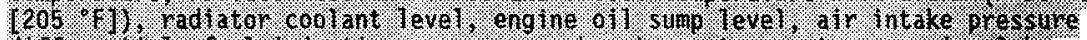

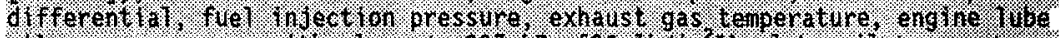

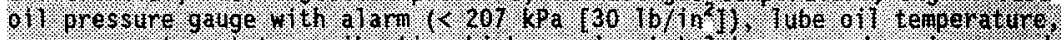

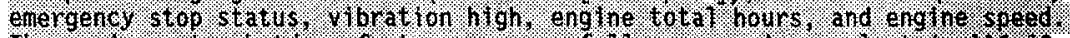

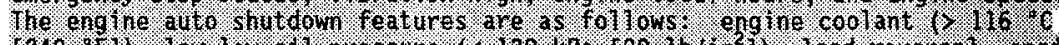

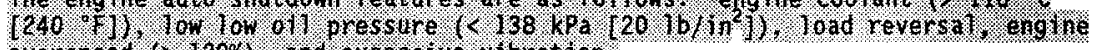

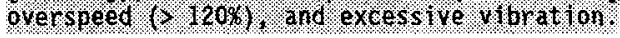

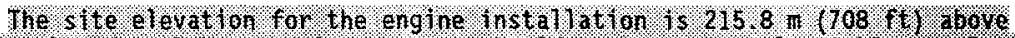

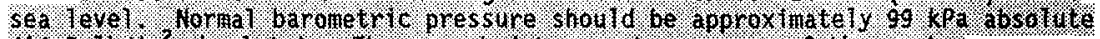

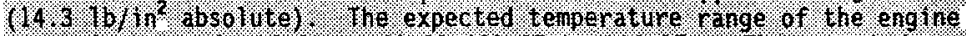

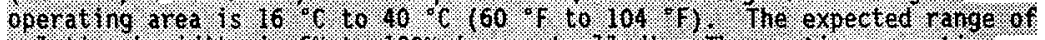

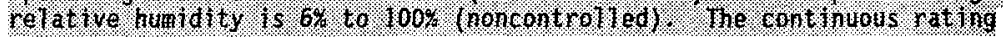




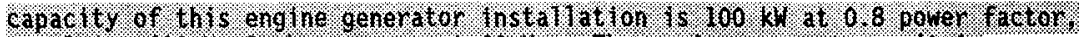

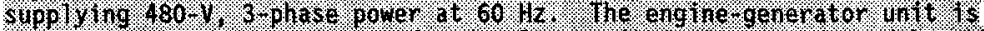

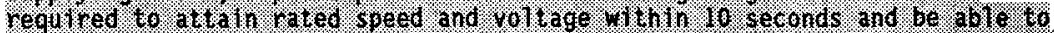

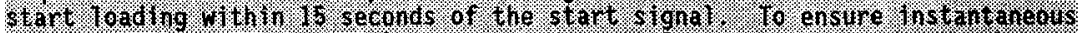

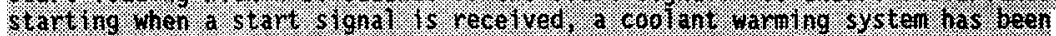

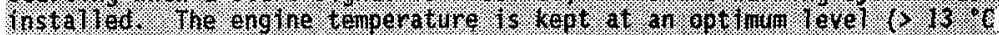

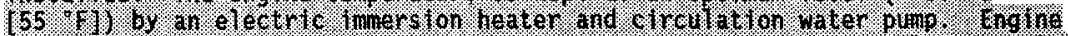

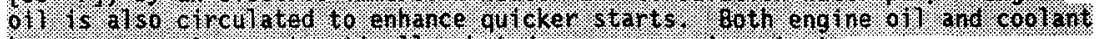

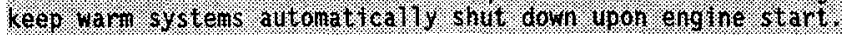

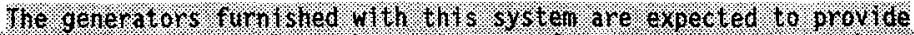

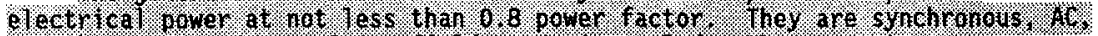

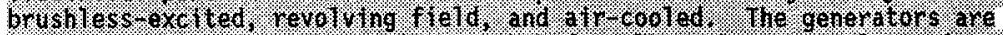

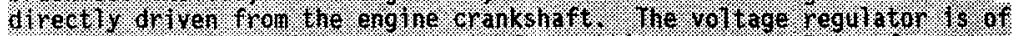

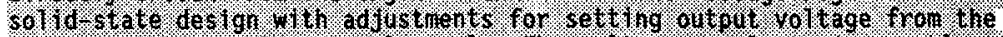

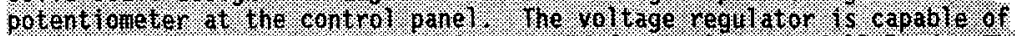

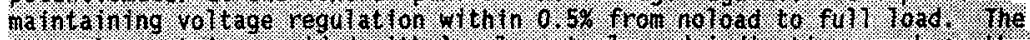

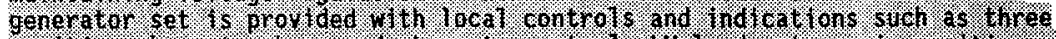

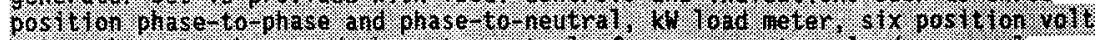

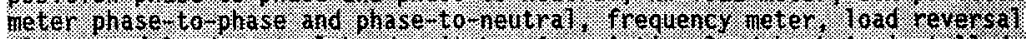

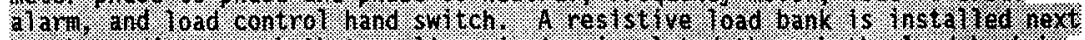

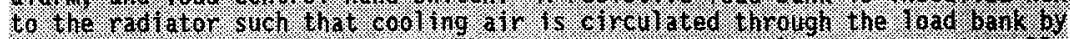

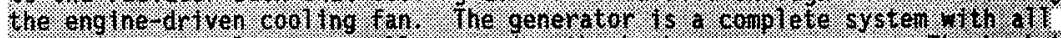

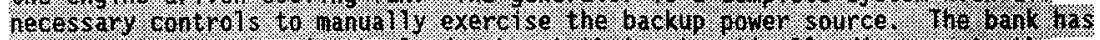

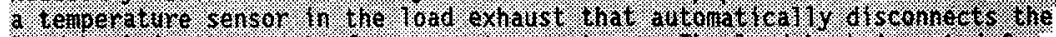

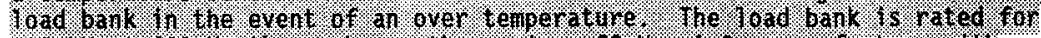

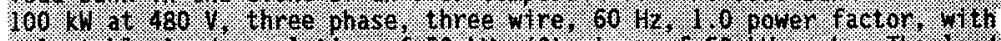

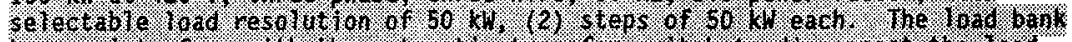

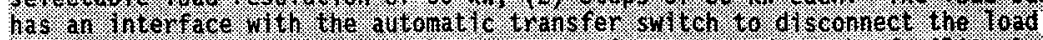

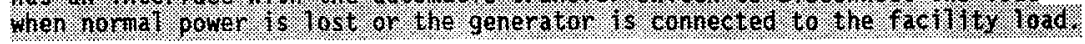

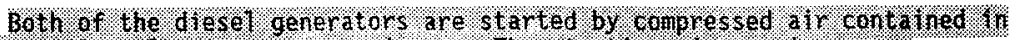

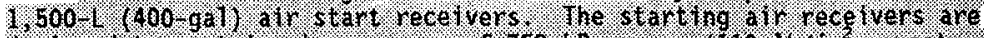

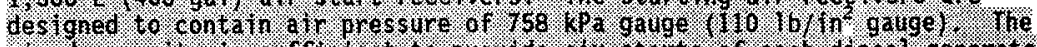

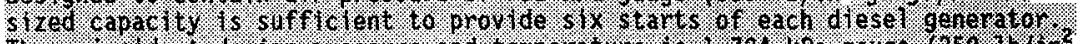

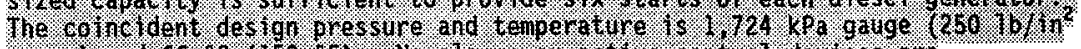

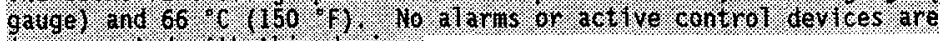

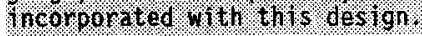

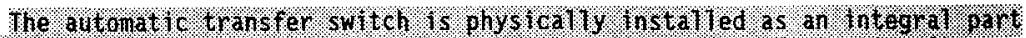

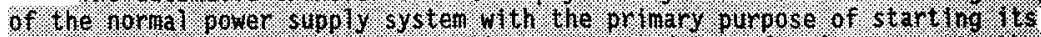

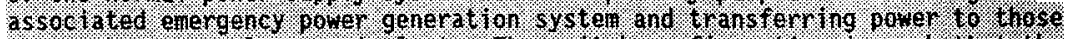

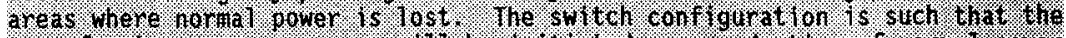

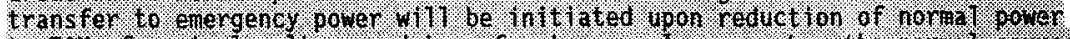

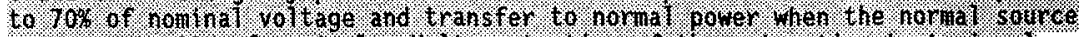

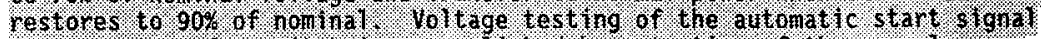

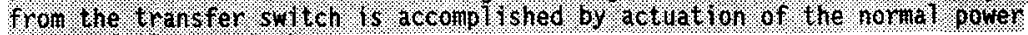

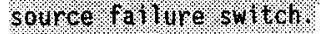

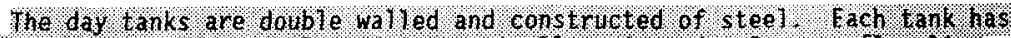

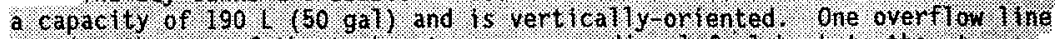
ex thing the top of the tant returns excess diesel f get t back to the storage

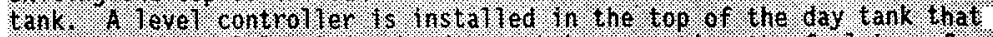

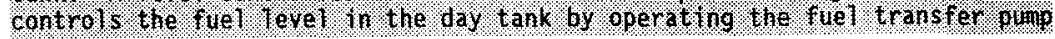




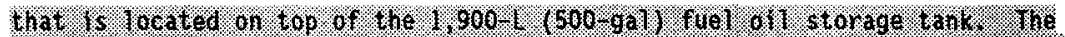

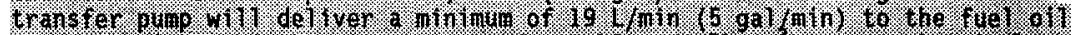

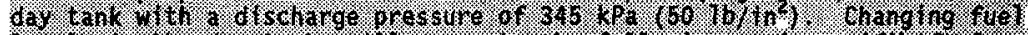

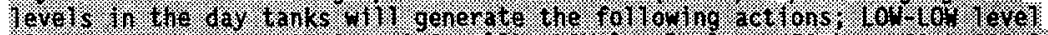

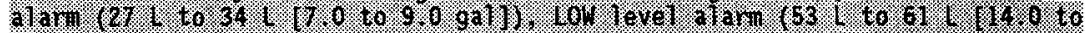

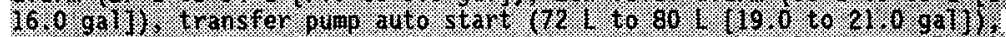

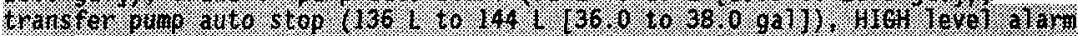

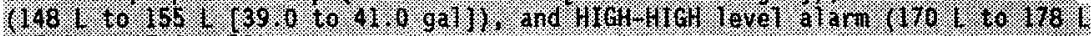

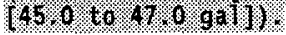

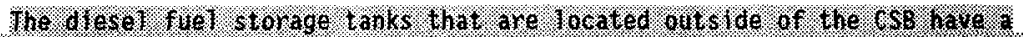

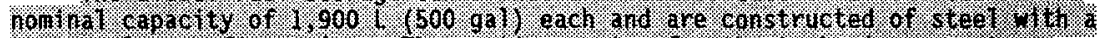

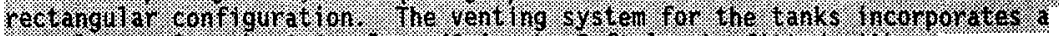

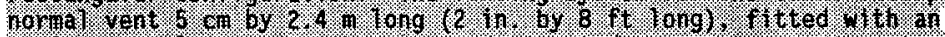

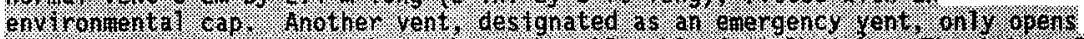

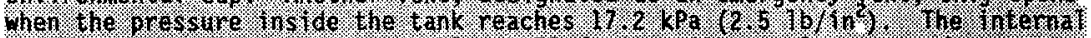

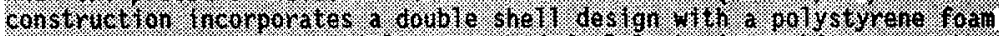

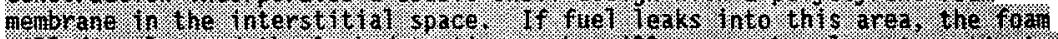

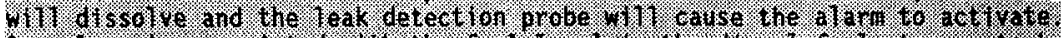

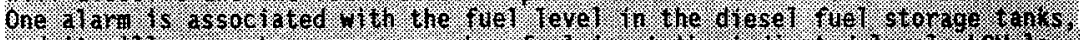

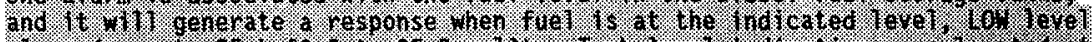

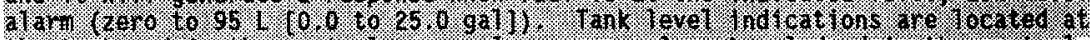

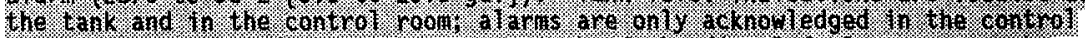

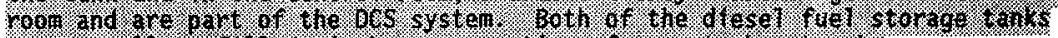

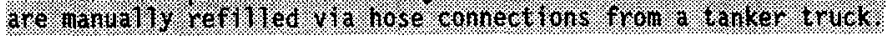

4.4.3.4 System Evaluation. A failure modes and effects analys is was prepared

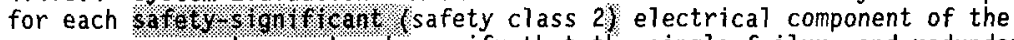
emergency generator system to verify that the single-failure and redundancy

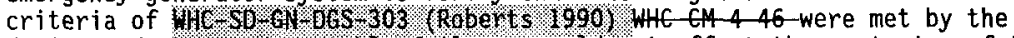
design and that undetectable failures could not affect the system's safety functions (2 /mmerman $1996 \%$. The failure of each component of the system was evaluated, including consideration of how that component might fail and the effect of each failure on the safety functions of the system load and CSB facility.

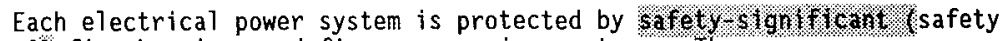
class $2 \mathrm{~J}$ fire barriers and fire suppression systems. The emergency power system includes fire stops, seals, and fire-resistant conduit. The electrical room is constructed with fire barriers, detectors, and fire sprinklers. Consequently loss of both backup emergency-power systems caused by failure of the fire suppression system is not considered credible. The outside diesel fuel supply tanks are electrically grounded and protected by the site fire department. Each diesel generator room is protected by a fire water sprinkler system.

File 106.151, Failure Modes and Effects Analysis: Emergency Power System (Zimmerman 1996), established that the design met all of the single component

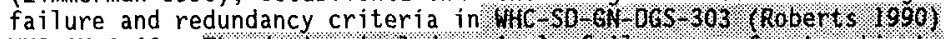

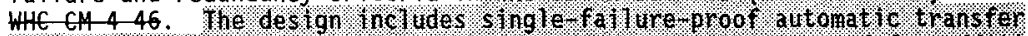

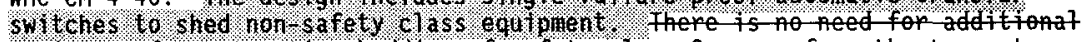
equipment for autematic sheditng of safety-elass 3-power from the two motor conter centers that are supplied by the emergency generators. 
4.4.3.5 Controls (Technical Safety Requirements). The design of the emengency generators is such that upon a loss of offsite power-signal, the generator (Ef IA) connected to the roc motor control center bus poweping the MHAl festoon cable receives the start signal. After two stapting attempts, the stapt signal is sent to EG 1B. The operator shall elose the tie breaker

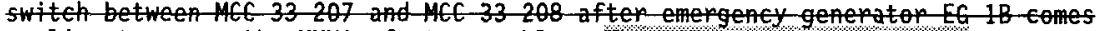

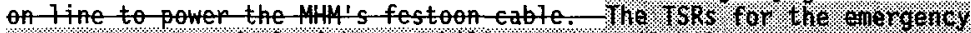

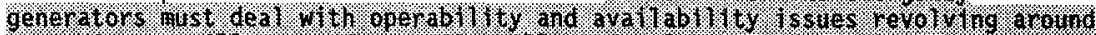

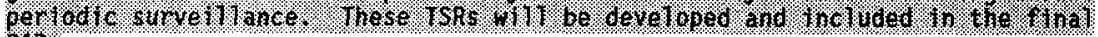
SAR.

\subsubsection{Tube Vent and Purge Carts}

4.4.4.1 Safety Function. Storage tube vent and purge carts provide confinement when connected to the storage tube plug. The tube vent and purge carts provide a means to periodically evacuate the storage tubes of hydrogen and to sample the gas stream for concentrations of radioactivity. This precludes the buildup of hydrogen above the $4 \%$ lower flammability limit. See

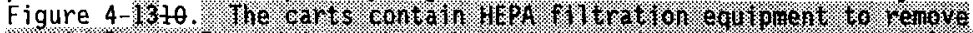

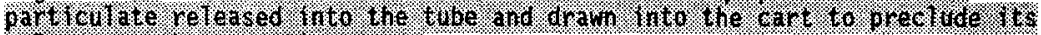

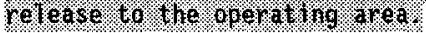

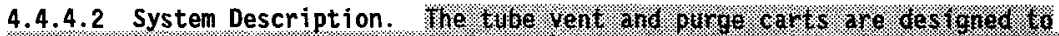

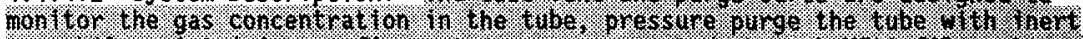

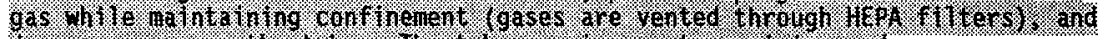

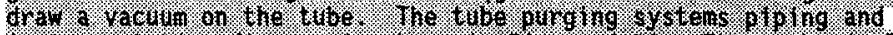

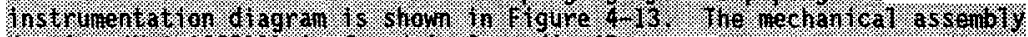

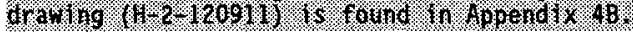

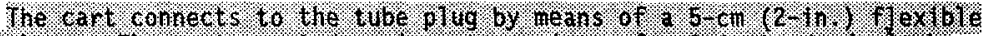

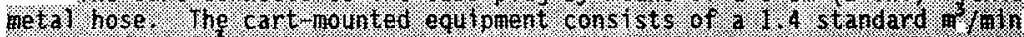

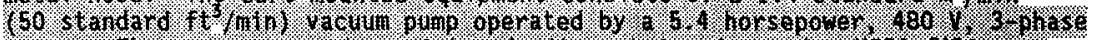

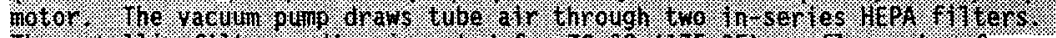

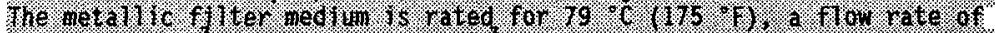

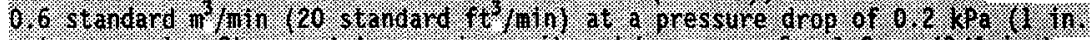

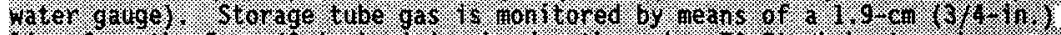

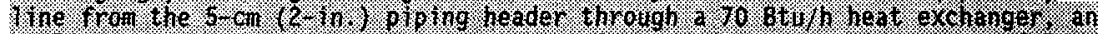

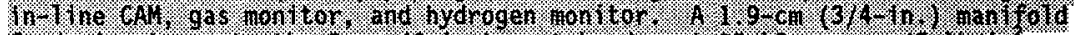

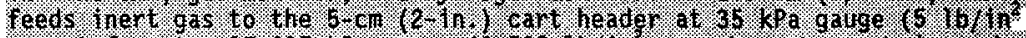

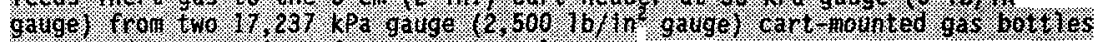
connected 10 a ser. $1 \mathrm{es}$. of . Bressure regut o tors.

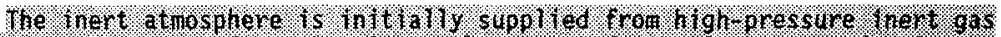

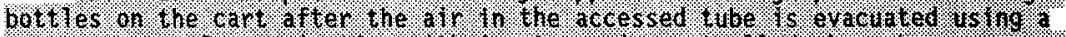

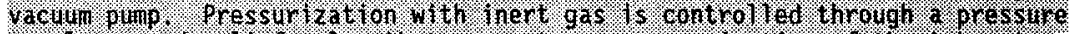

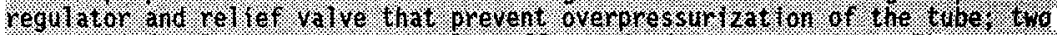

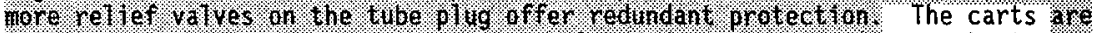
wht be-equipped with a vacuum pump capable of drawing the storage tube to $1.3 \mathrm{kPa}$ (10 torr) at the maximum tube gas temperature of $80^{\circ} \mathrm{C}\left(175^{\circ} \mathrm{F}\right)$. They can will he the callity-todect airborne radioactivity and dangerous hydrogen concentrations in a sample tube. 


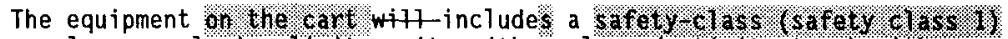
hydrogen lower-explosive-limit monitor (thermal conductivity type) with an

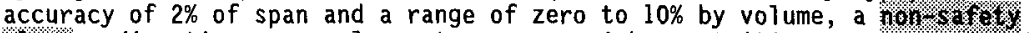
C10ss radioactive gas analyzer to measure airborne tritium concentration in an

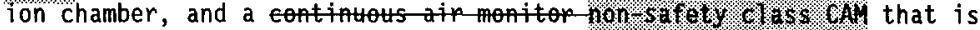
sensitive to beta-gamma in a low radiation field and contains an alpha detector. The hon safety class vacuum pumps are prevented from operating if the hydrogen concentration reaches $4 \%$ by volume. A mixture of $6 \%$ hydrogen in

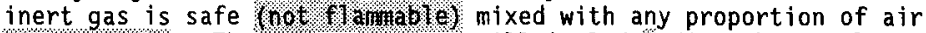
(0)197.970). The cart equipment wit7 includes

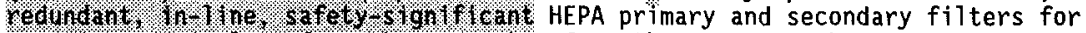
removing particulate from the gas taken from the storage tube.

The carts are battery powered for motion. The equipment is powered

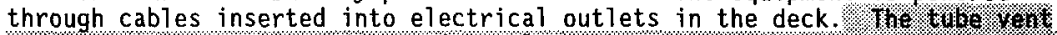

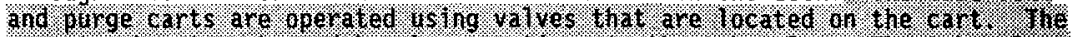

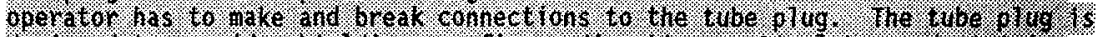

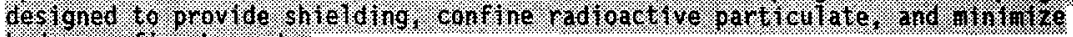
1.drogen fire hatatds.

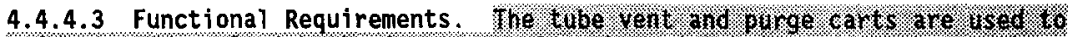

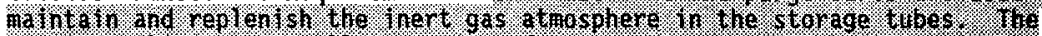

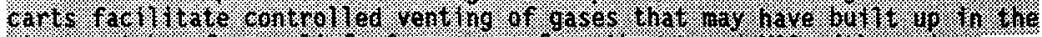

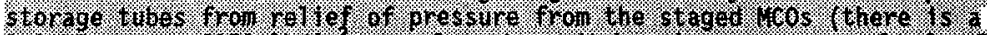

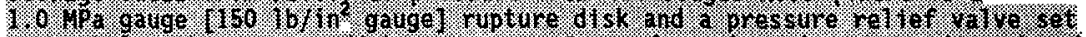

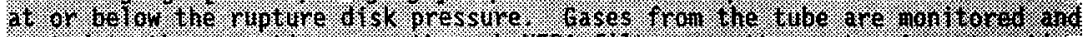

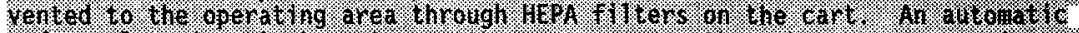

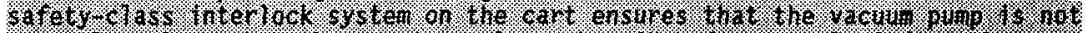

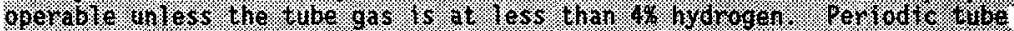

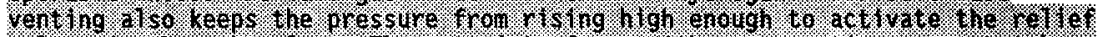

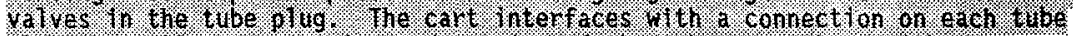

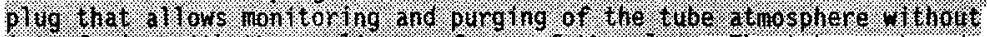

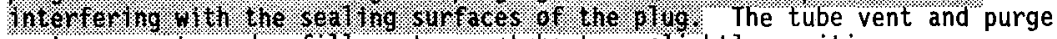
carts evacuate and refill a storage tube to a slightly positive pressure immediately preceding tube plug removal. Equipment on the storage tube vent and purge carts can detect airborne radioactivity and hydrogen concentrations and provide HEPA filtration of the sampled volume before release to the operating area atmosphere. The equipment can will be-apable-of drawing the $79{ }^{\circ} \mathrm{C}\left(175^{\circ} \mathrm{F}\right)$ (maximum gas temperature) storage tube atmosphere to $1.3 \mathrm{kPa}$ (10 torr). The cart equipment will-draws an $80^{\circ} \mathrm{C}\left(175^{\circ} \mathrm{F}\right)$ sample, passex it through the monitors listed above, and vents it to the operating area through two stages of HEPA filters. Connections to the storage tube are made using quick-disconnect fittings atop the storage tube plug. A towable hoist is provided to remove the center access plate in the storage tube plug cover. Figure 4-1310 represents a diagram of piping, instruments, and equipment required by the tube vent and purge carts to service the storage tubes.

4.4.4.4 System Evaluation. Failure of the confinement and inerting features of the cart during a DBA could result in release of radioactivity if the DBA could result in radionuclides being released from the MCOs. Offsite consequences may occur if cart failure after a DBA results in a detonable concentration of hydrogen. 


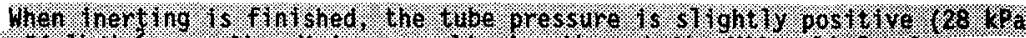

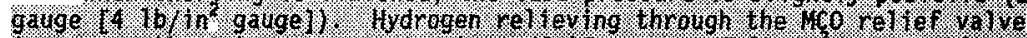

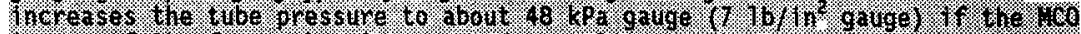

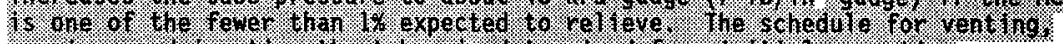

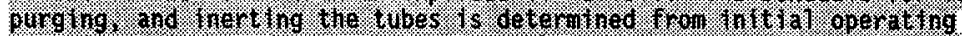

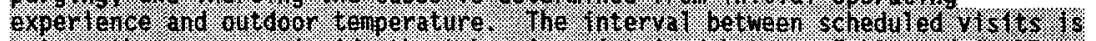

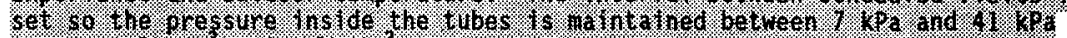

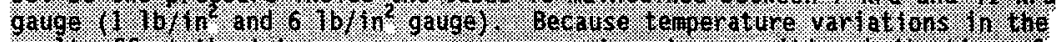

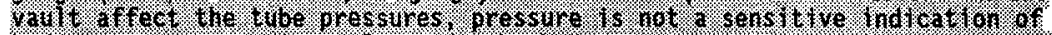

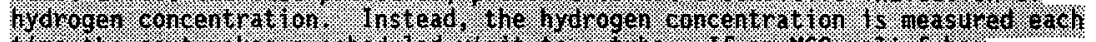

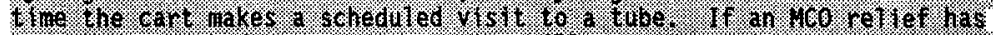

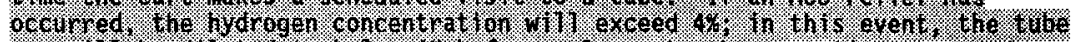

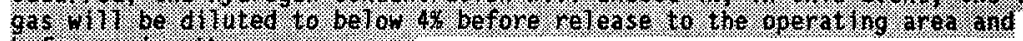

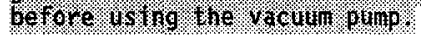

If during the evacuation of a storage tube containing an MCO at just below the rupture disk set pressure, the rupture disk's pressure is reached, then the MCO will vent unfiltered particulate into the storage tube. This release 1 wil be-captured by the tube vent and purge cart's iargerthan-tube-plug HEPA filter.

As stated in Section 2.5.2, the frequency of storage tube purging is affected by the amount of sludge in an MCO because of the accompanying hydrogen gas generation. Recent preliminary studies of hydrogen gas

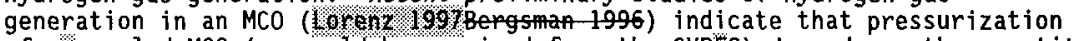
of an seated MCO (as would be received from the CVD:S) depends on the quantity of water in the $M C O$, its temperature, and the time elapsed since sealing. For

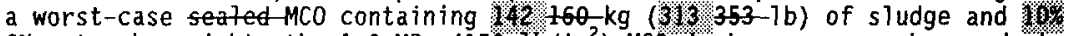
$6 \%$ water by weight, the $1.0 \mathrm{MPa}\left(150 \mathrm{Hb} / \mathrm{in}^{2}\right) \mathrm{MCO}$ design pressure is reached

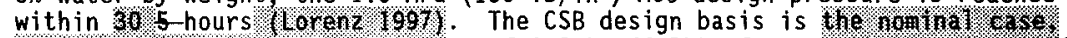

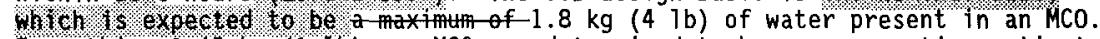
From this, $0.45 \mathrm{~kg}$ (1 $1 \mathrm{~b}$ ) per $M C O$ was determined to be a conservative estimate of the average free water present and was used to determine the number of tube vent and purge carts required. Eighteen purges are required to remove $0.45 \mathrm{~kg}$

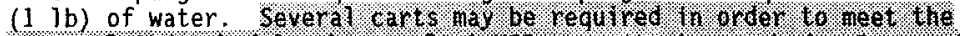

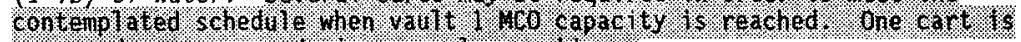

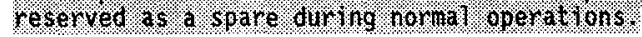

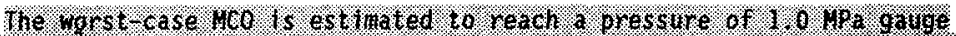

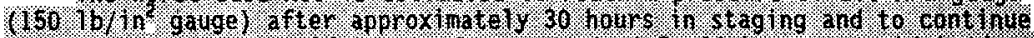

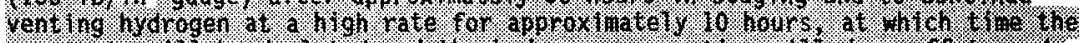

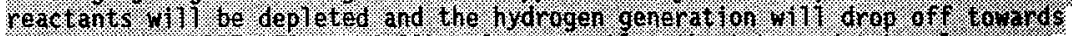

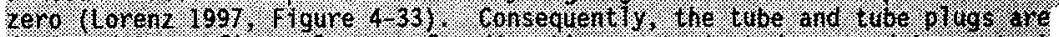

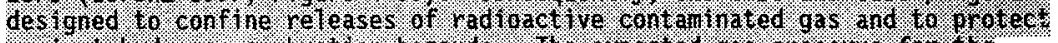

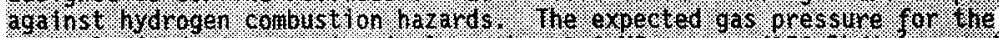

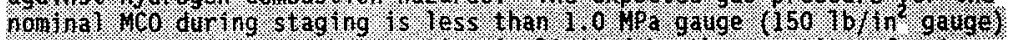

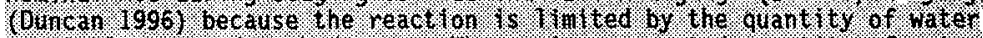

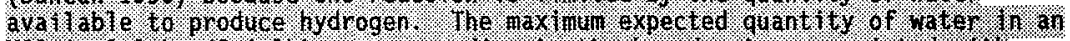

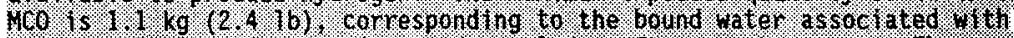

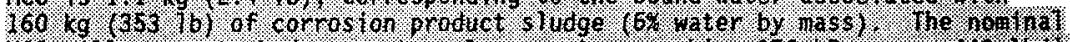

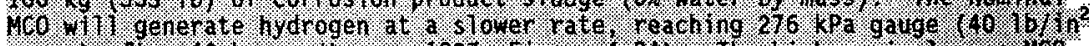

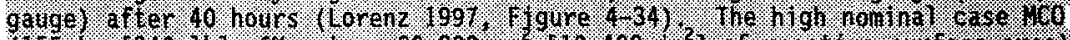

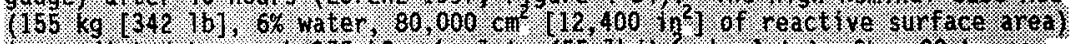

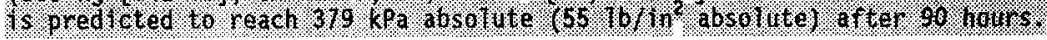




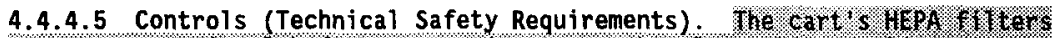

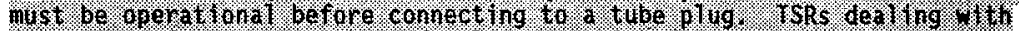

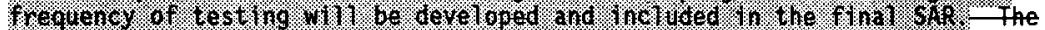
tube vent and purge cants provide the means to maintain the TSRs fop hydrogen generation and inepted atmesphere requirements for the vented MCOs. These FSRs will be develope after hydrogen evolution values are obtainet.

\subsubsection{Reeelving Crane}

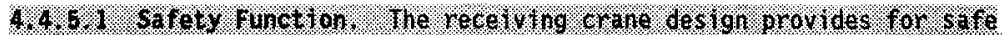

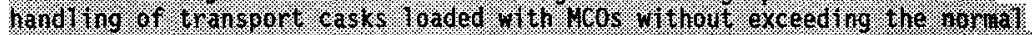

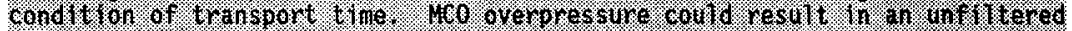

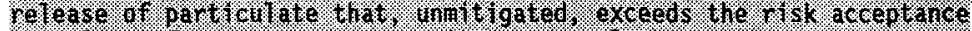

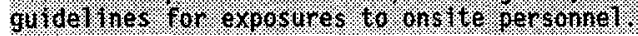

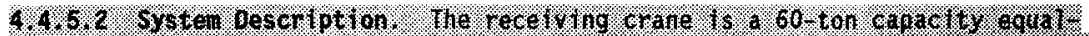

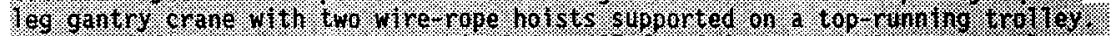

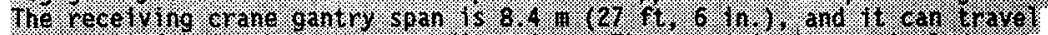

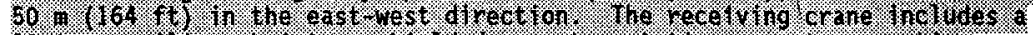

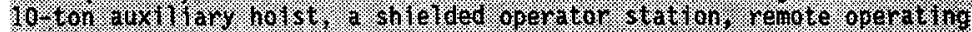

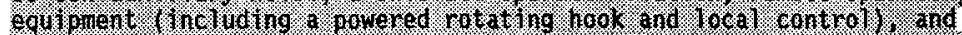

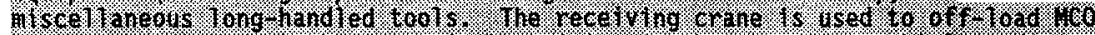

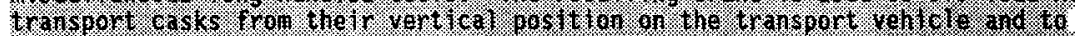

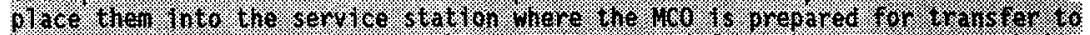

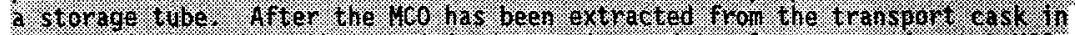

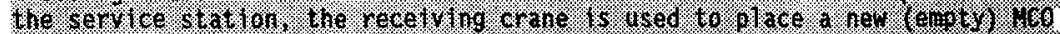

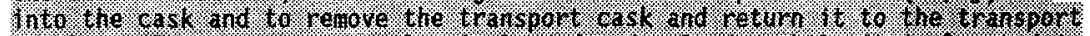

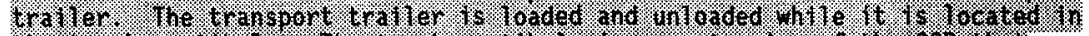

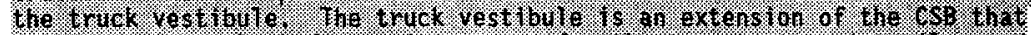

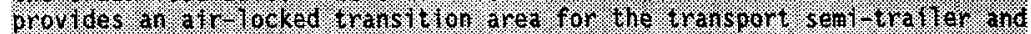

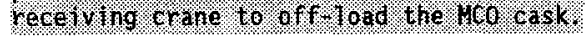

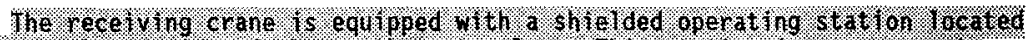

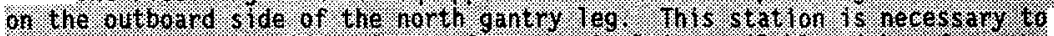

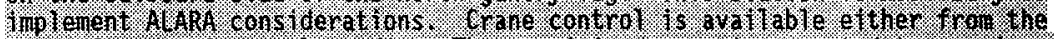

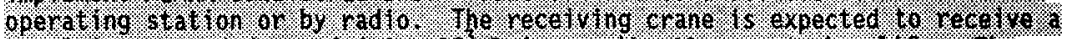

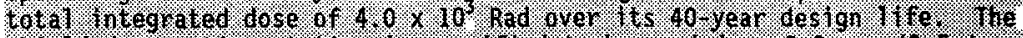

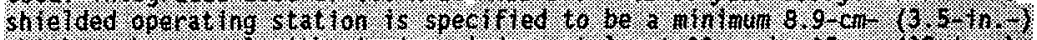

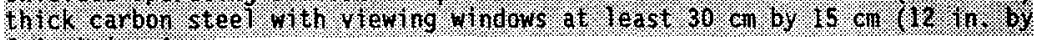
$6.11,1,1 \%, 210 \%$

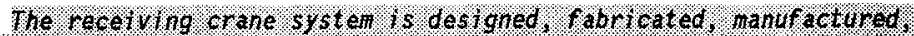

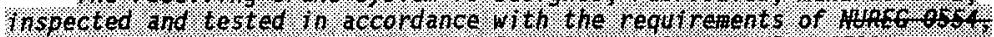

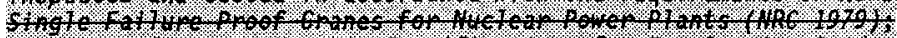

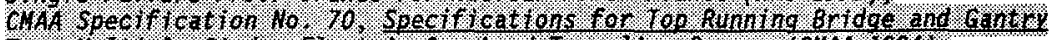

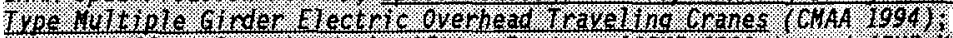

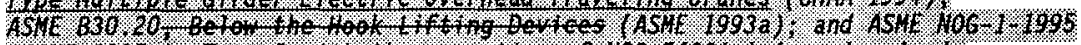

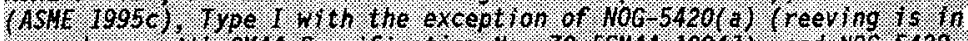

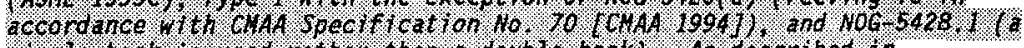

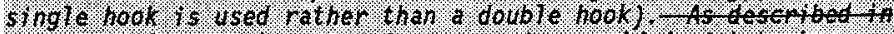

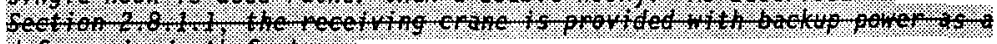

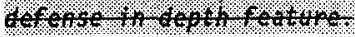




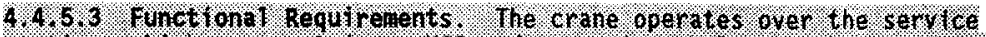

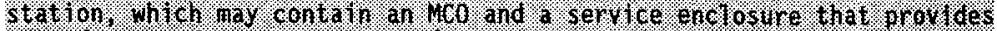

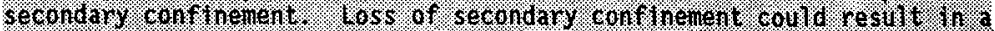

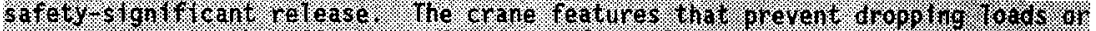

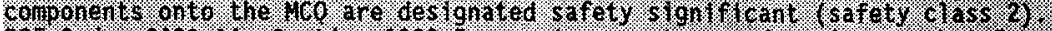

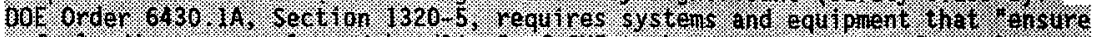

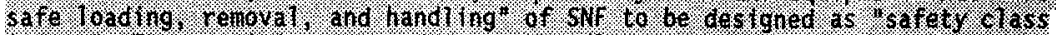

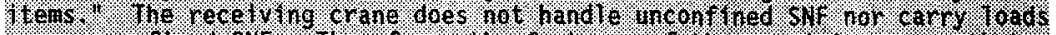

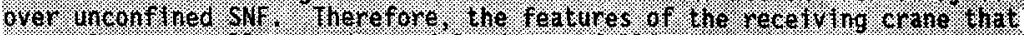

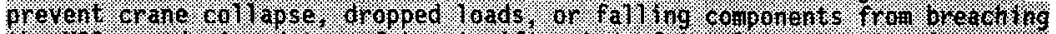

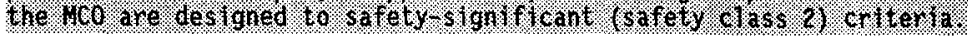

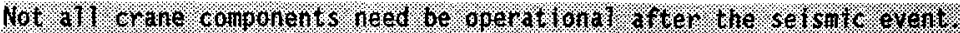

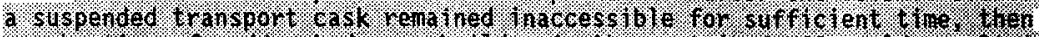

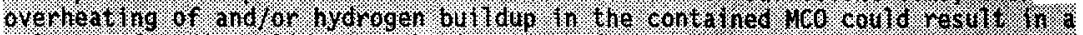

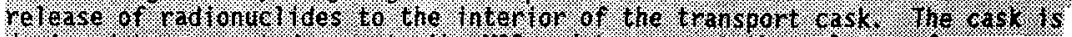

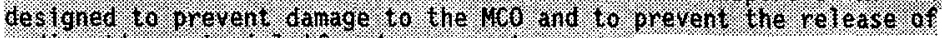

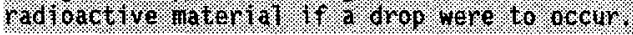

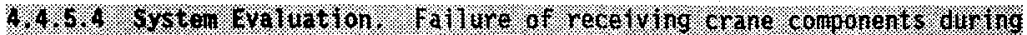

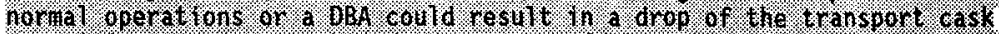

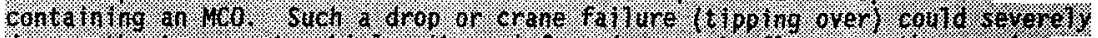

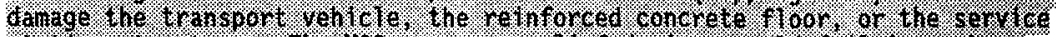

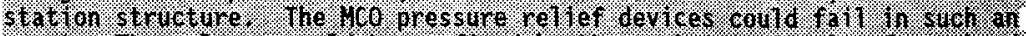

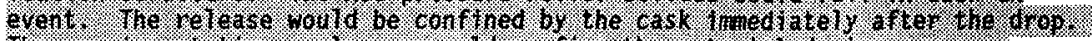

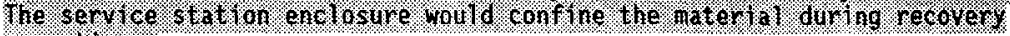
operatorons.

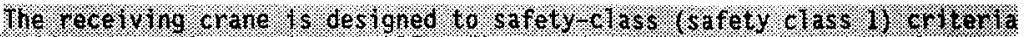

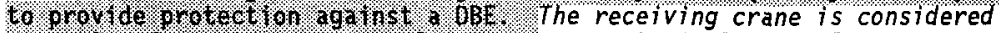
decoupled from the runway raits (e.g., no mechanical rail clamps). Lateral displacement is restrained by the wheel flanges and longitudinal displacement is restrained by the crane wheel brakes during a seismic occurrence. The receiving crane is stable against overturning during a seismic occurrence with a safety factor of 1.1, in accordance with ASME NOG-1-1995 (ASME 1995c). Results of the stability analysis performed by the manufacturer of the receiving crane indicate that the minimum safety factor against overturning for the extreme environmental load conditions is 1.64 about the $x$ axis (transverse horizontal), and 1.1 about the $z$ axis (transverse longitudinal).

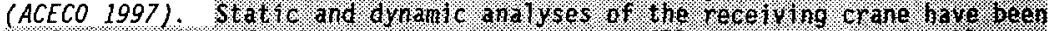

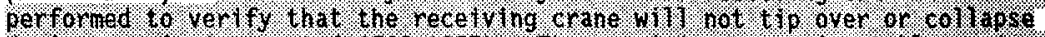

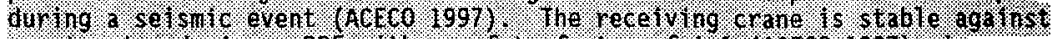

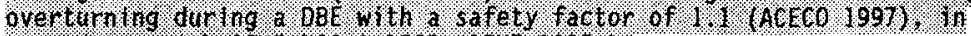

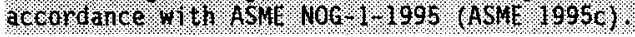

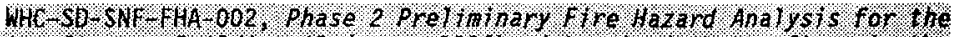

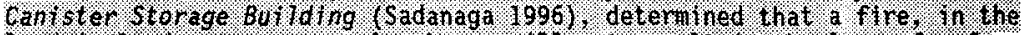

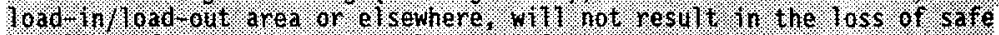

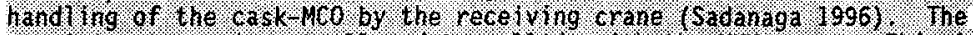

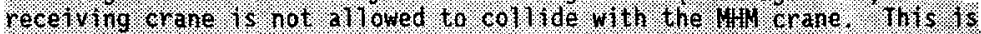

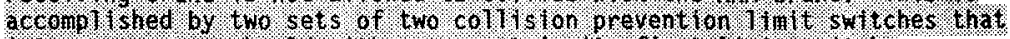

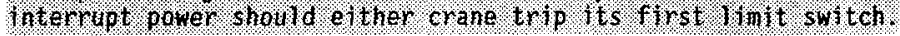




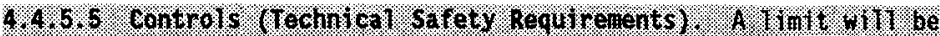

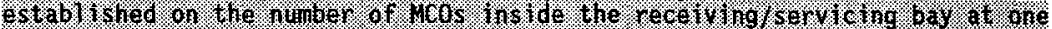

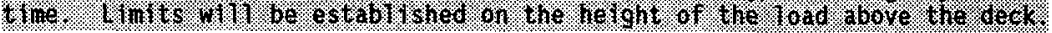

\subsubsection{Service Stition - Ventilatt on Enelosure}

4. 4.6.) Safety Function. The service statt on enclosure malntains a regafive pressure with respect to the sumounding atmosphere for cont hement of reteases.

4.4.6.2 systen bescription. The service station enctosure and portable llePA flther are located in the 100 recelving and servich hy area of the CSB.

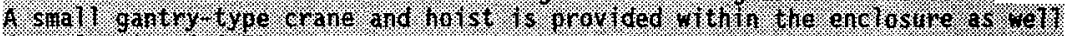
(see Section 4.4 .5$)$.

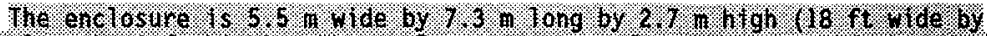

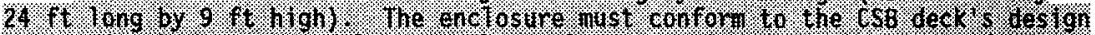

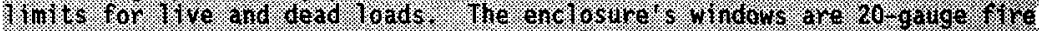

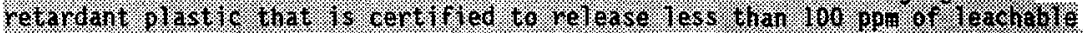

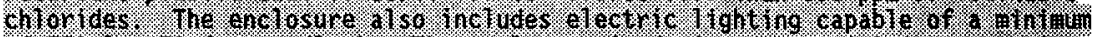

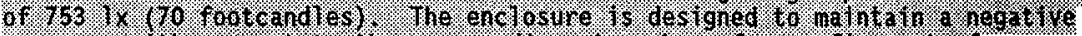

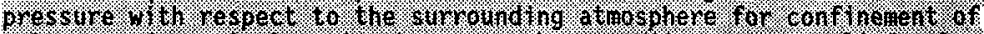

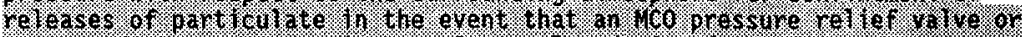

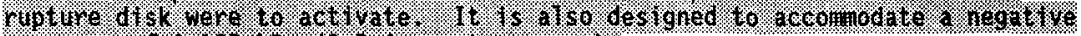

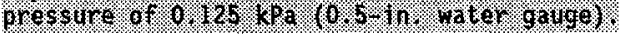

The enclosure contalins the following auxh t ary equ ponent:

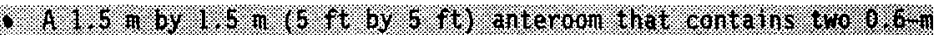

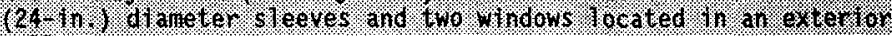
wa11

- TWo dogrs. one along a ste wall and the other between the gort anea

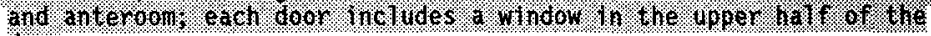
coor

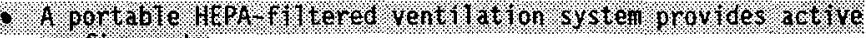
conf thement.

The portable vertillatlon systeil is located on the north side of the emclosire. This venth ation system consists of a pref liter a stamiess steel

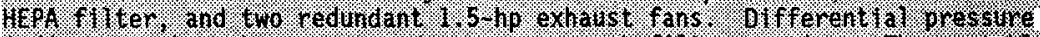

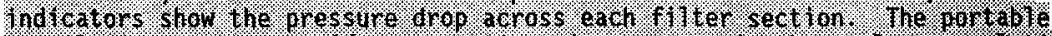

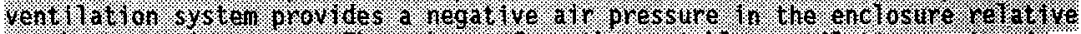
to the operat ing area. The exhaust from the portable rentillation systee is inantored for radtonuclitos before it is released nto the operathing area ith stream.

4.4.6.3. Funct horal Requirements. The service station enclosure prov doss.

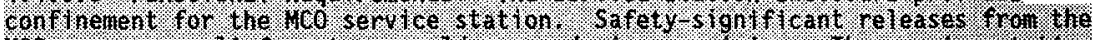

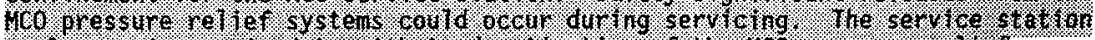
enclosure 15 requtred to withstand act vation of the 160 pressure tel ief systems: 


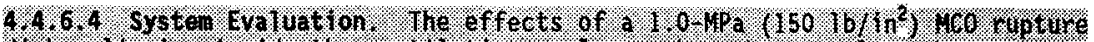

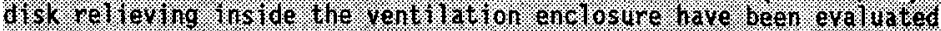

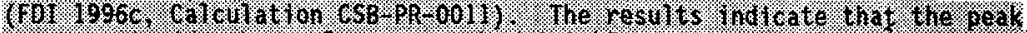

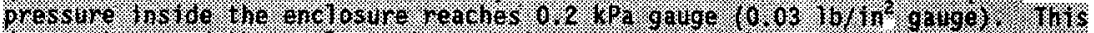

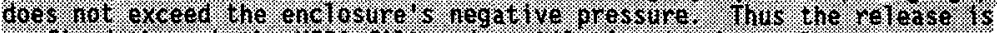

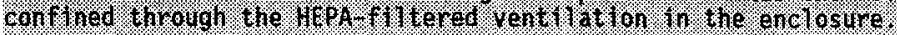

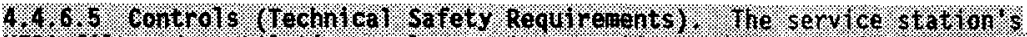

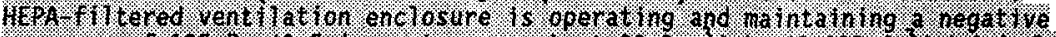

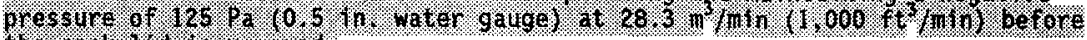

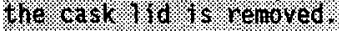

\section{4. Tे Service Station - Shield Hatch Issembly and Shield RIng}

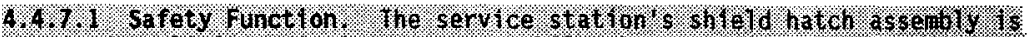

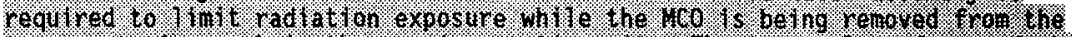

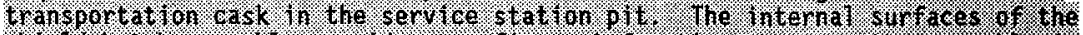

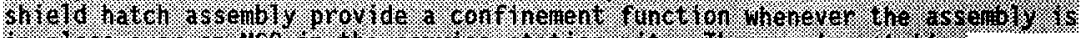

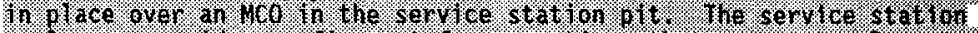

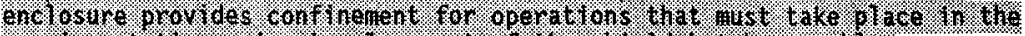

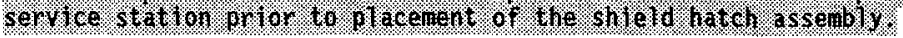

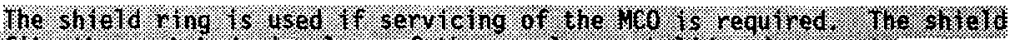

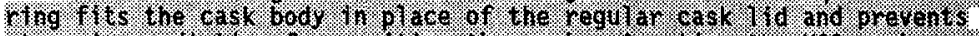

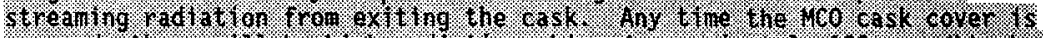

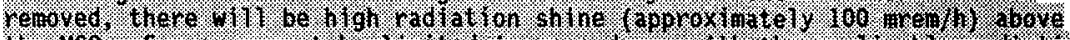

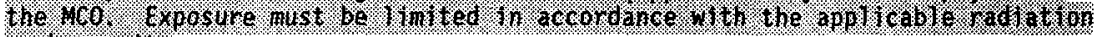

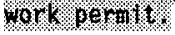

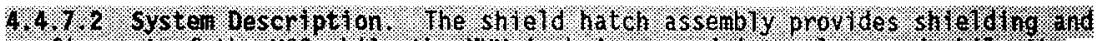

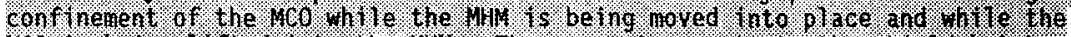

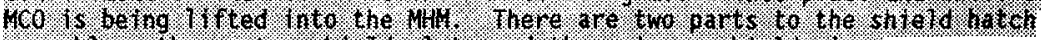

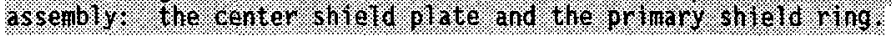

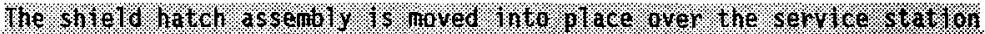

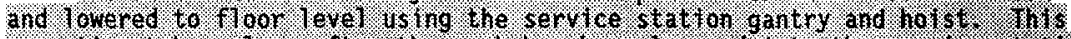

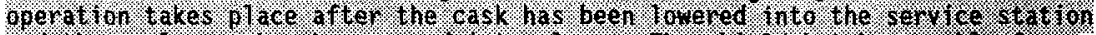

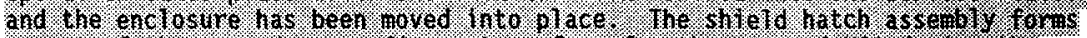

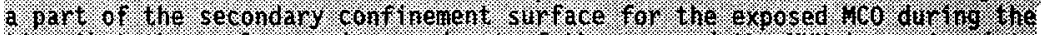

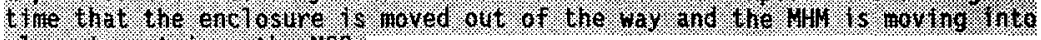

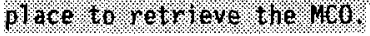

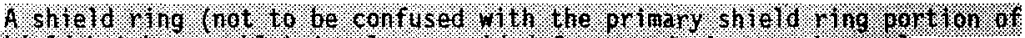

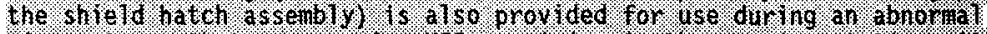

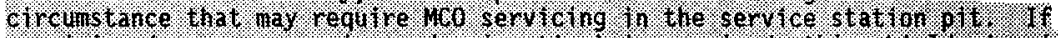

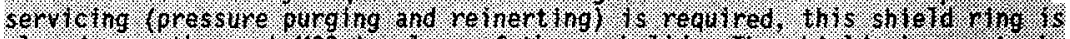

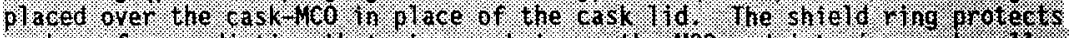

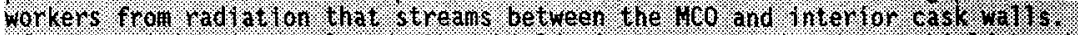

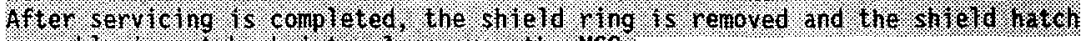

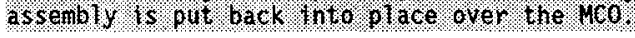

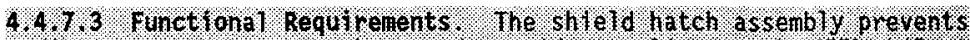

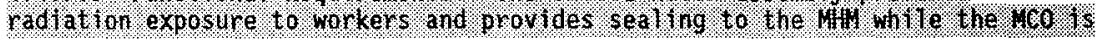




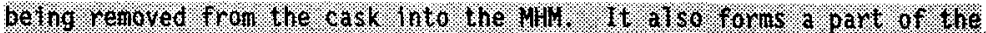

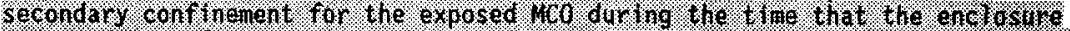

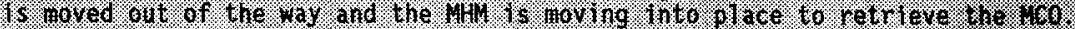

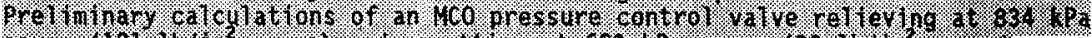

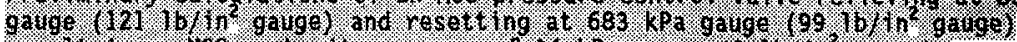

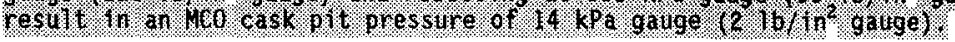

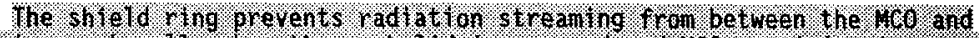

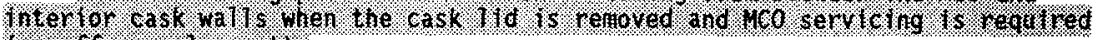
(an or f noreat event)

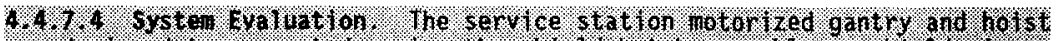

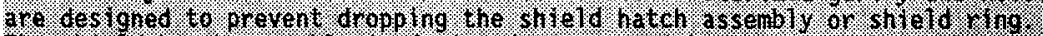

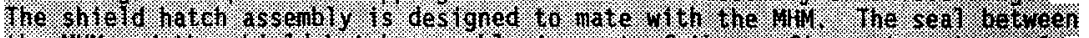

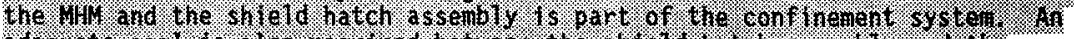

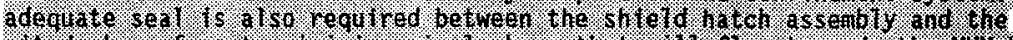

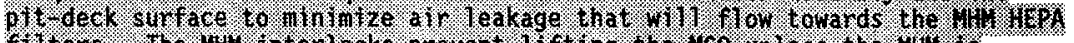

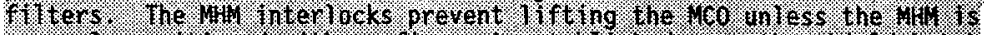

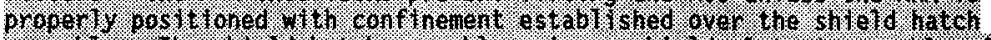

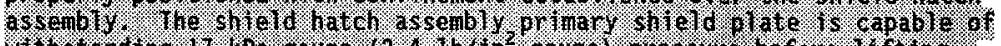

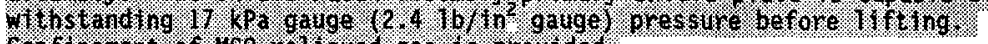

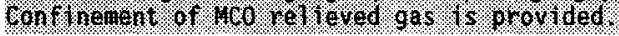

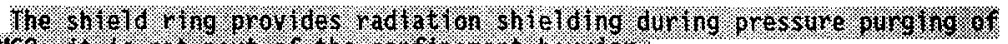

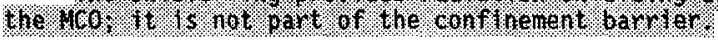

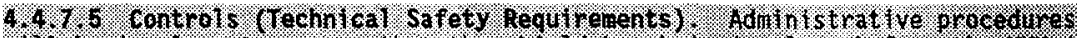

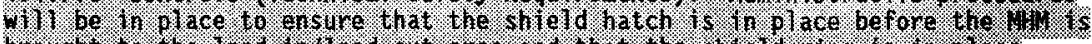

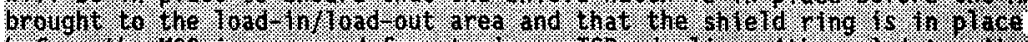

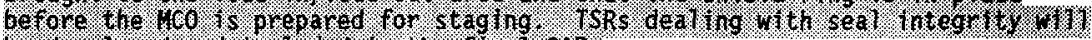

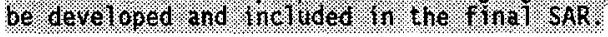

\title{
4.4.8. Fultican ster. overpack servicing systed
}

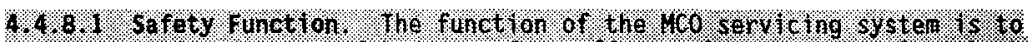

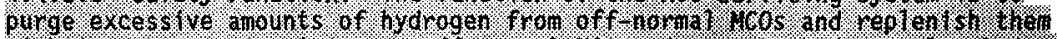

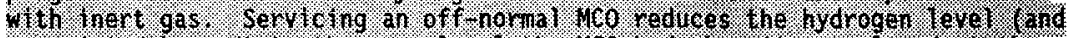

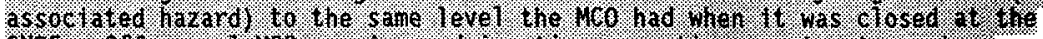

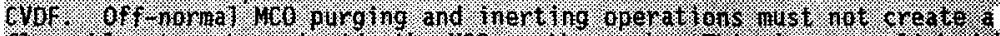

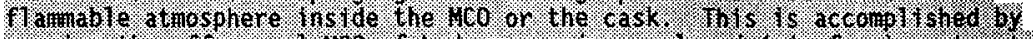

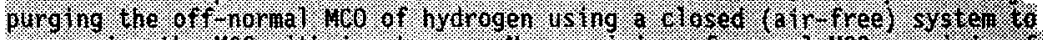

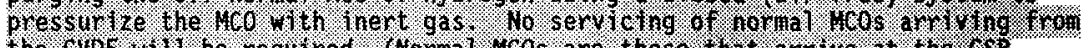

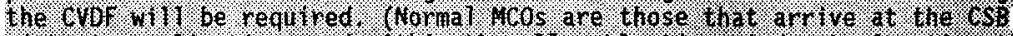

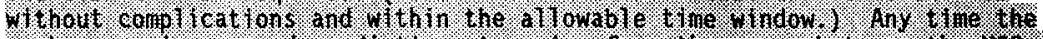

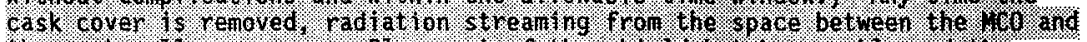

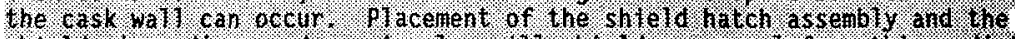

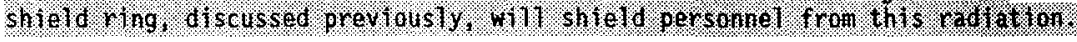

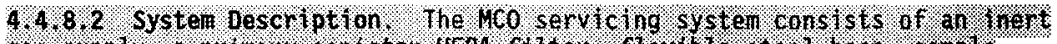

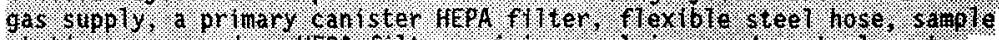

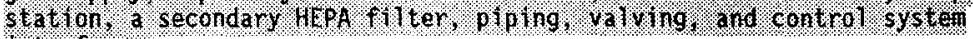
Jinterfoces. 


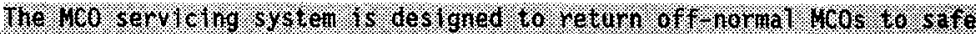

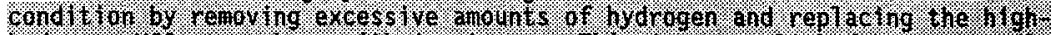

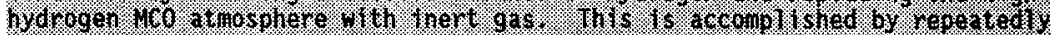

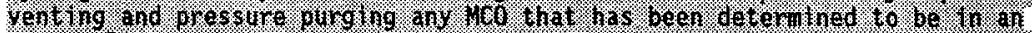

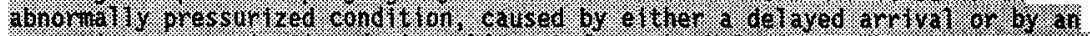

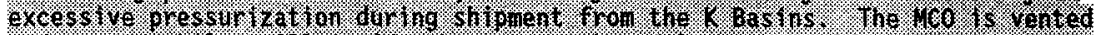

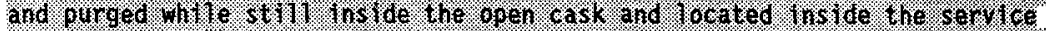

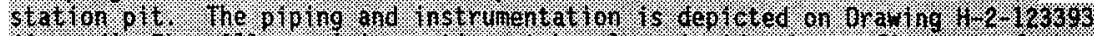

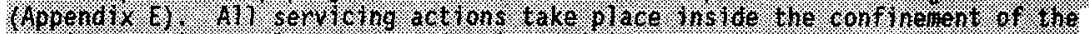

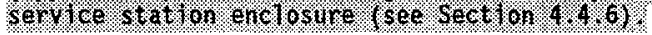

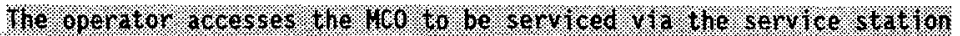

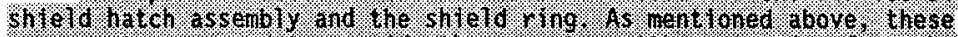

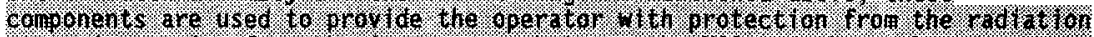

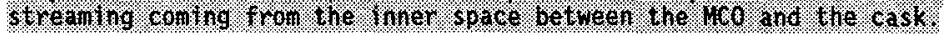

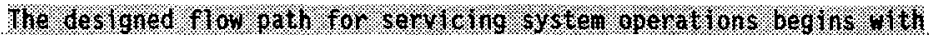

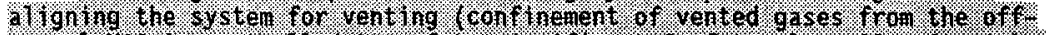

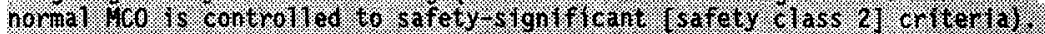

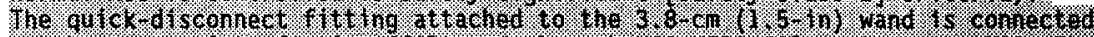

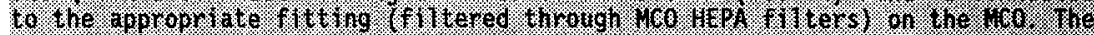

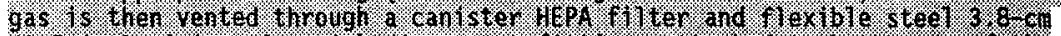

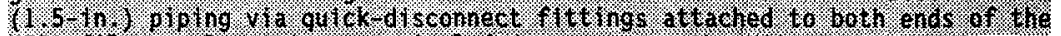

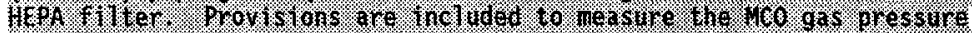

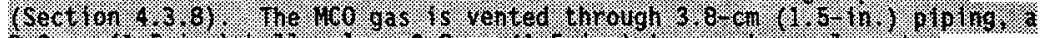

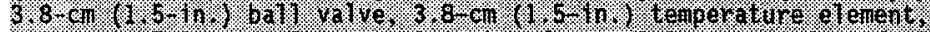

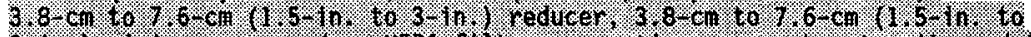

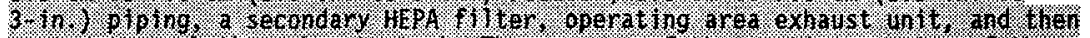

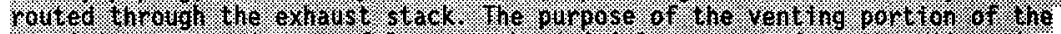

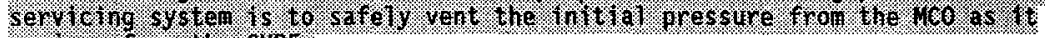
arrotes

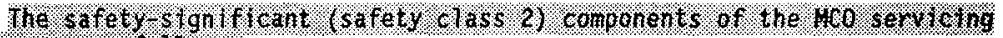
Syenoreas. follous\%

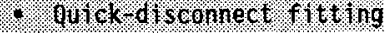

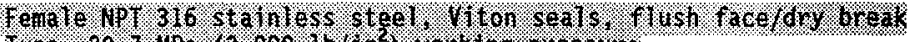

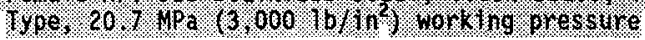

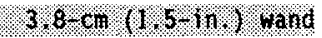

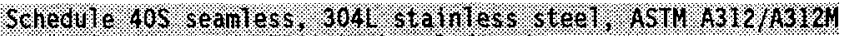

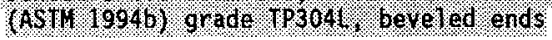

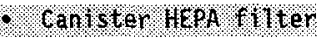

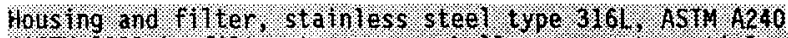

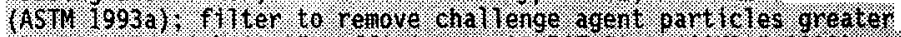

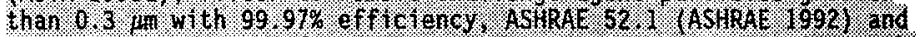

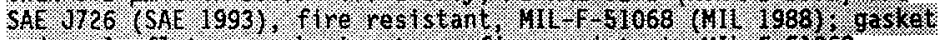

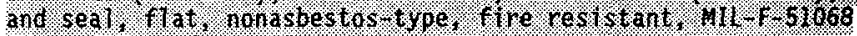
WU. 19881 , and 4 . 585 


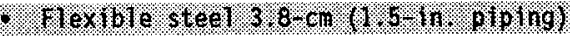

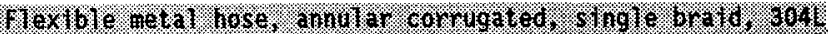

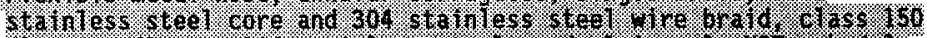

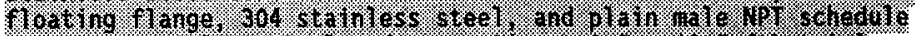

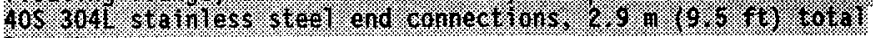
1.ength

\section{- 0ulck-d scornect (wand)}

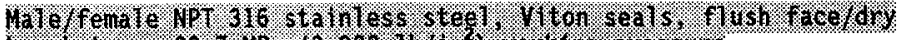

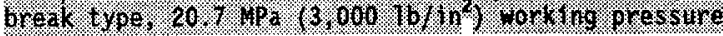

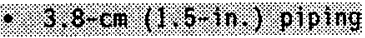

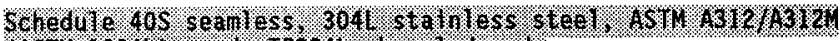
(ASTI 19946) grade TP304L. beveled endis

\section{*. 3.8-er (1.8- $\mathrm{n}$.) temperature}

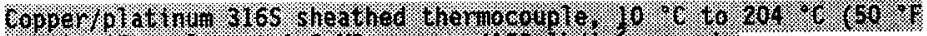

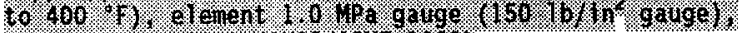

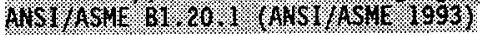

\section{8.-en (1.5- .h. ) reducer}

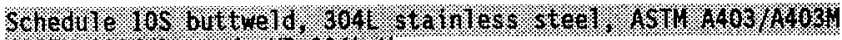

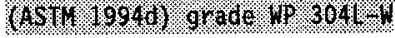

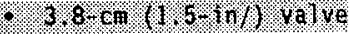

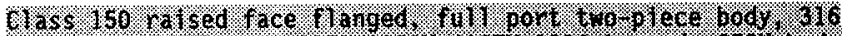

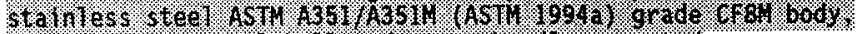
316 staintess steel ball and sten, handle operated

\section{1.6 ch proing}

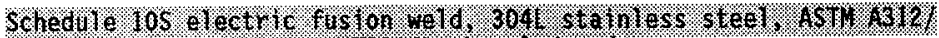
A3124. (AST) 9994) grade TP304L, beveled ends

\section{- Secondary MEPA fIIter}

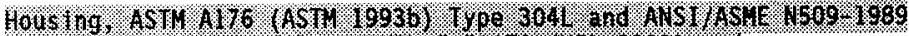

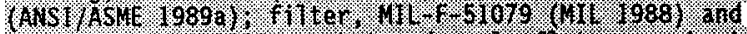

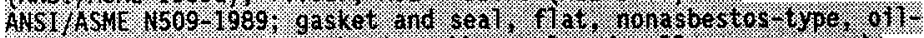

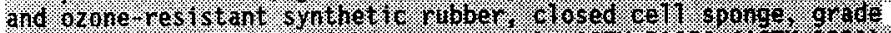

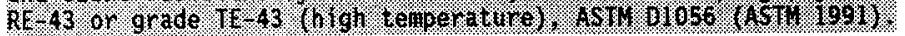

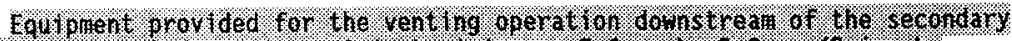

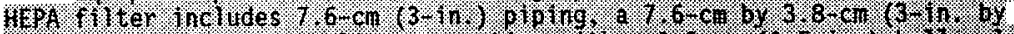

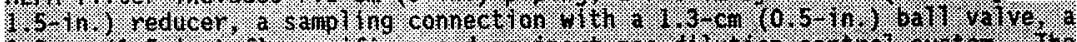

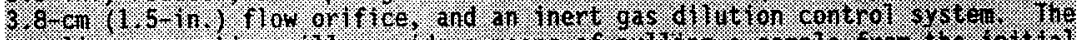

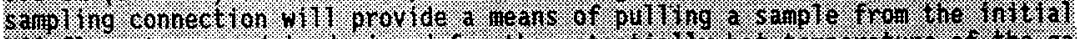

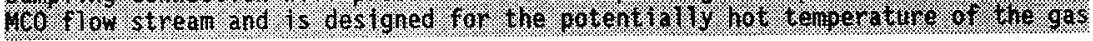




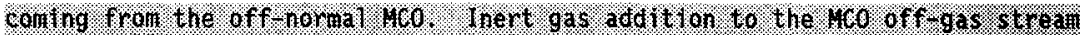

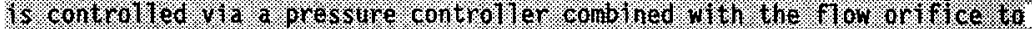

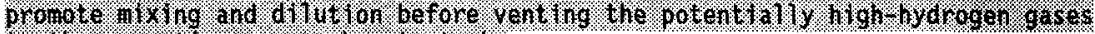

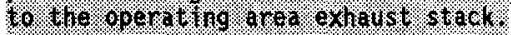

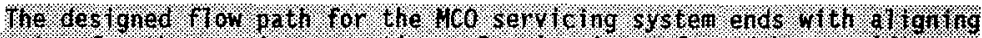

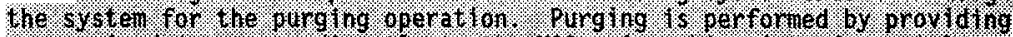

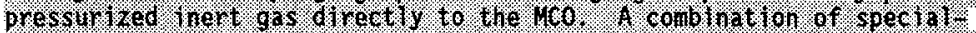

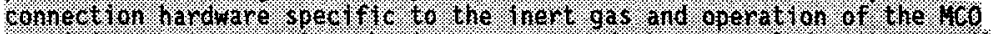

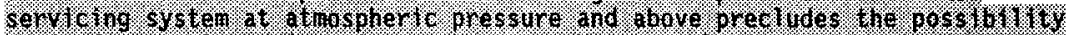

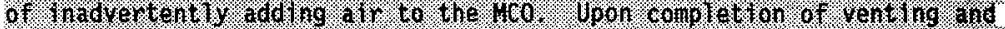

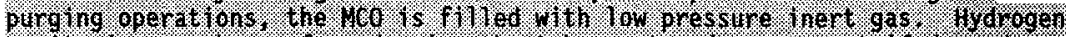

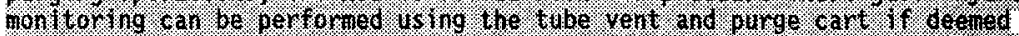

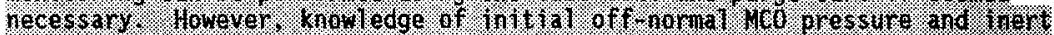

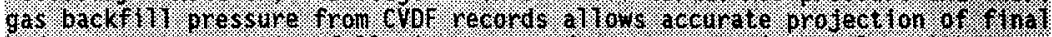

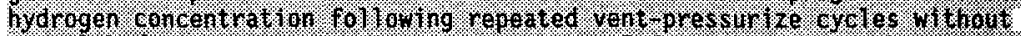

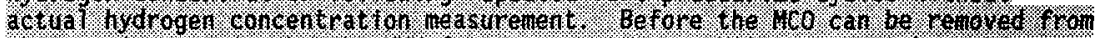

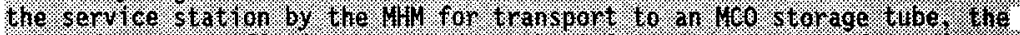

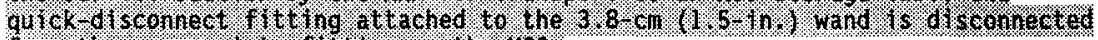

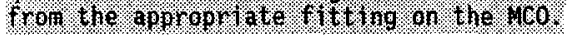

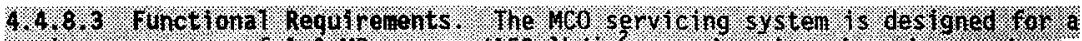

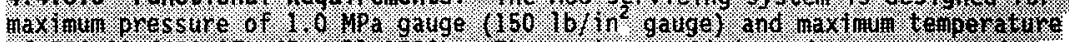

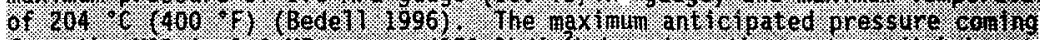

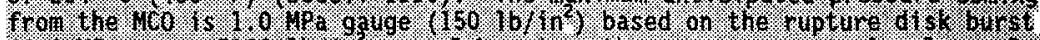

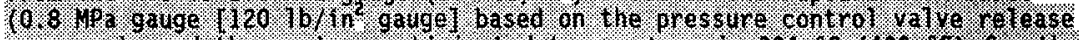

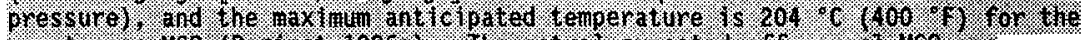

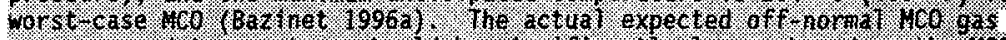

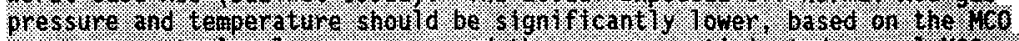

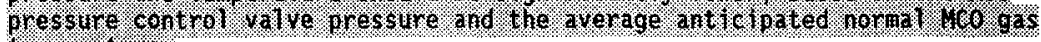

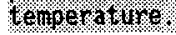

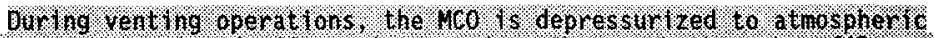

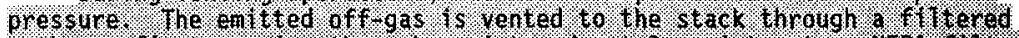

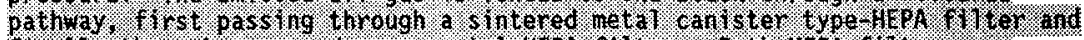

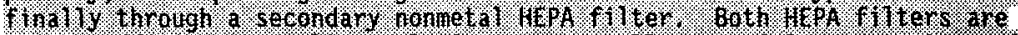

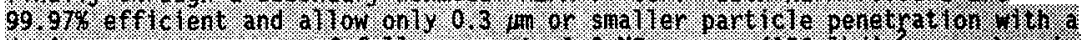

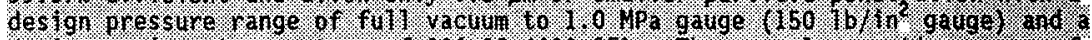

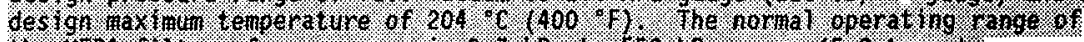

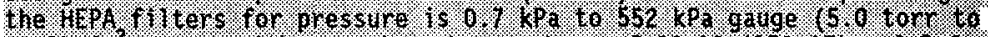

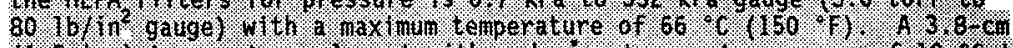

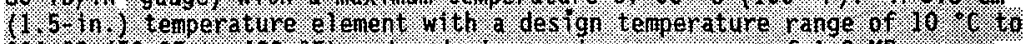

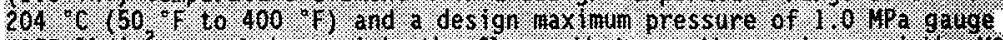

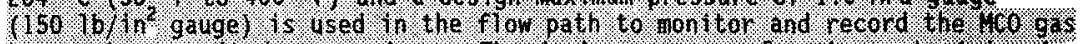

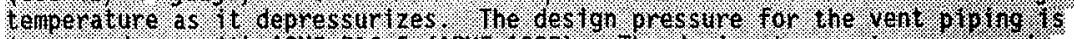

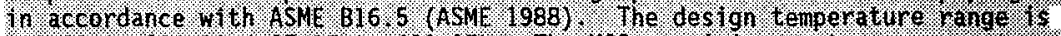

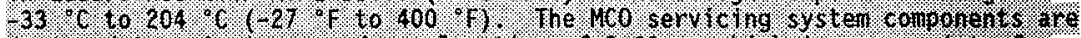

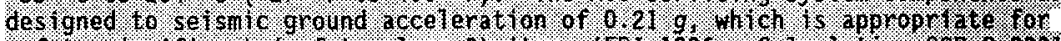

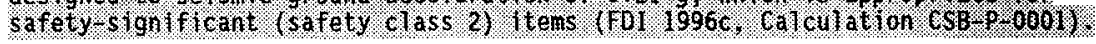

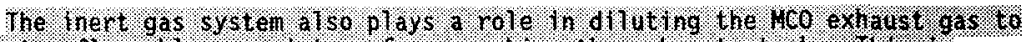

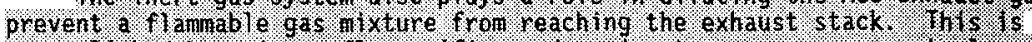

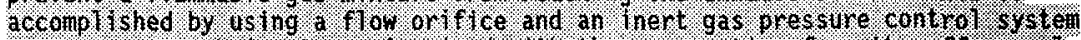

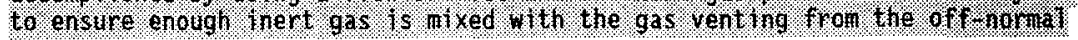




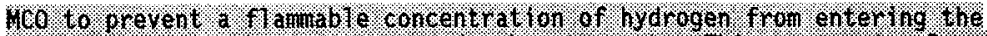

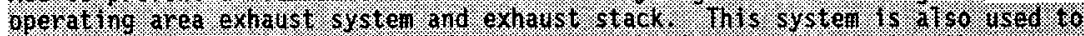

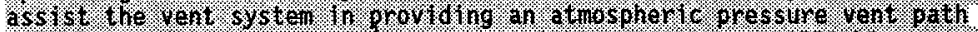

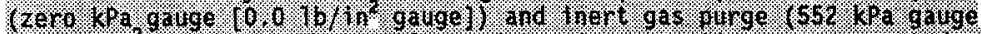

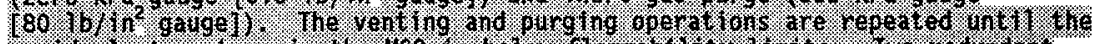

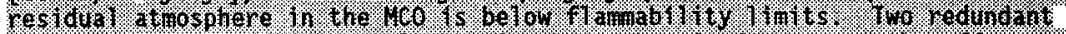

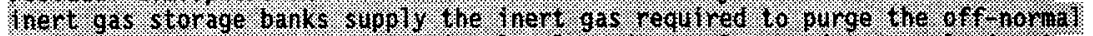

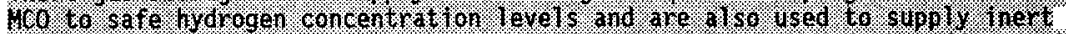

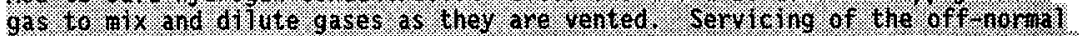

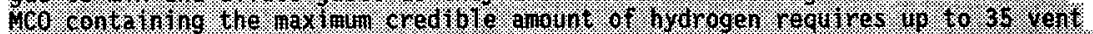

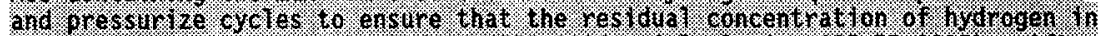

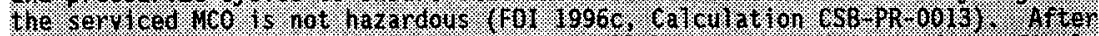

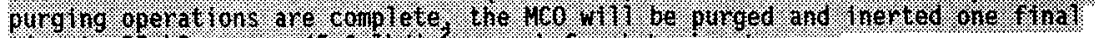

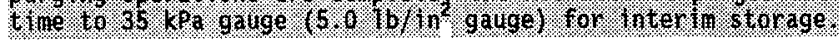

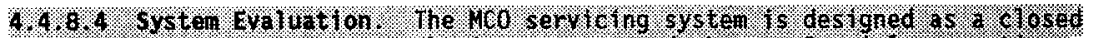

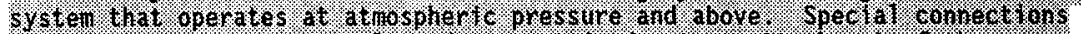

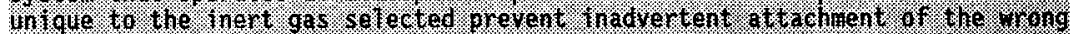

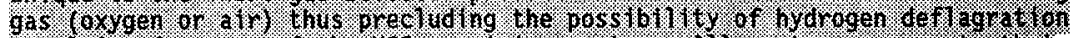

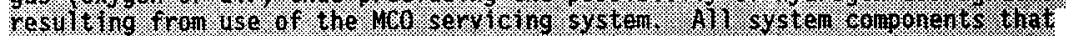

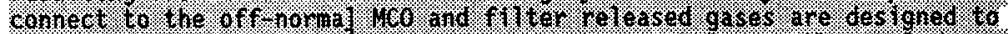

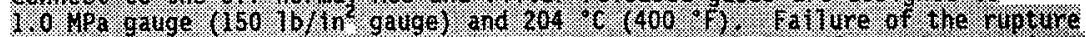

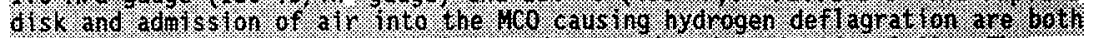

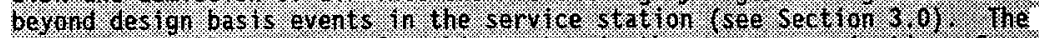

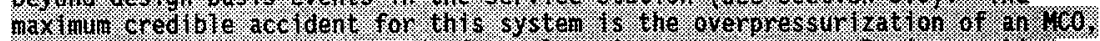

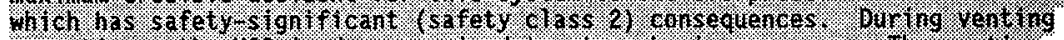

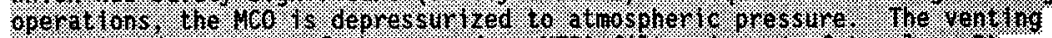

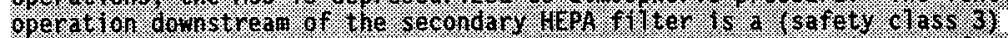

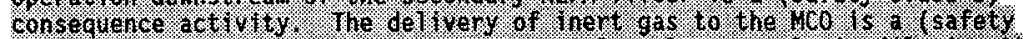

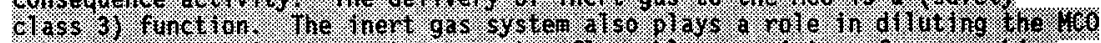

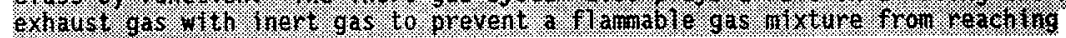
Ho. oxiaust stack.

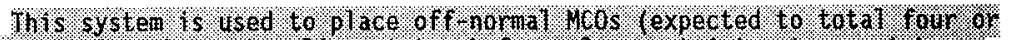

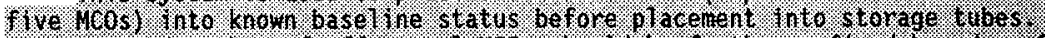

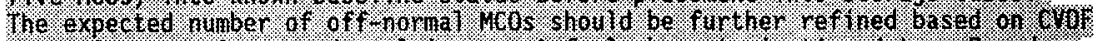

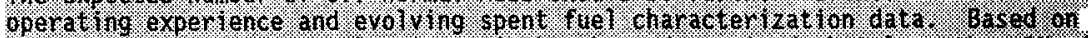

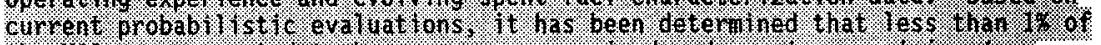

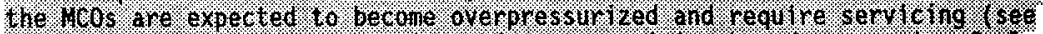

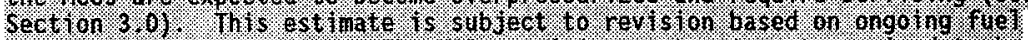

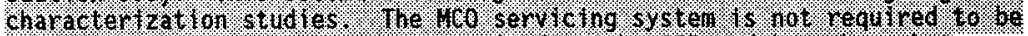

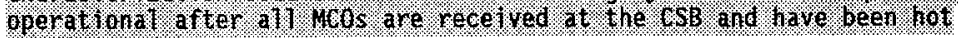
condl 10 ed

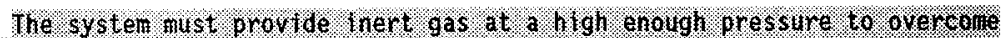

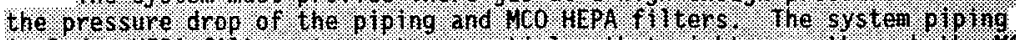

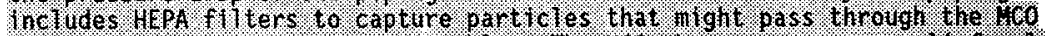

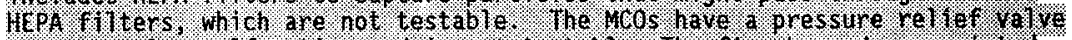

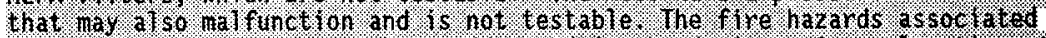

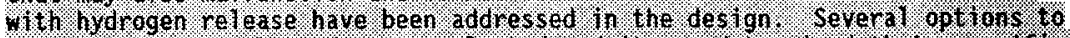

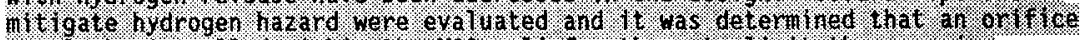

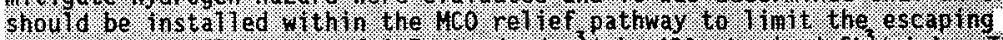

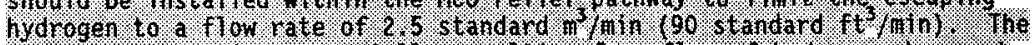

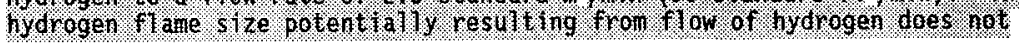




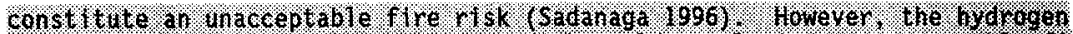

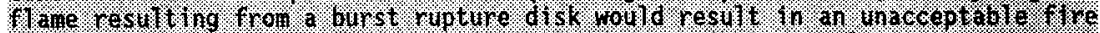

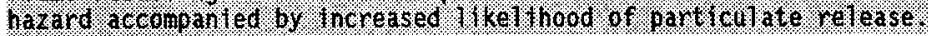

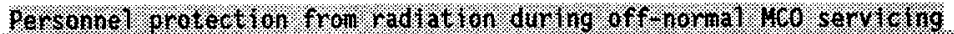

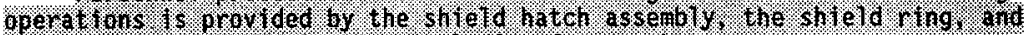

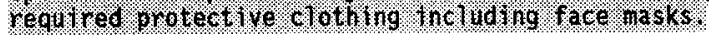

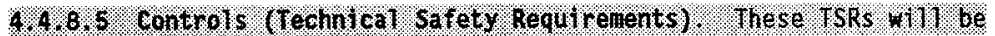
developed and provided 19 . the throt. SAR.

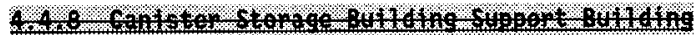

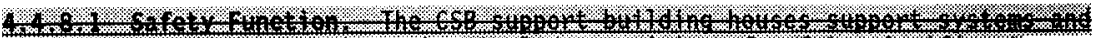

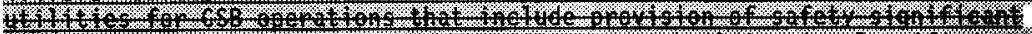

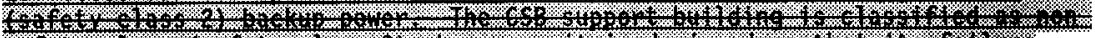

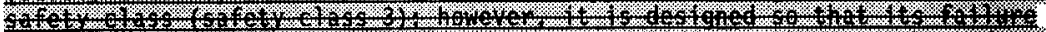

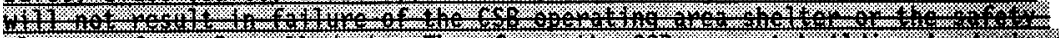

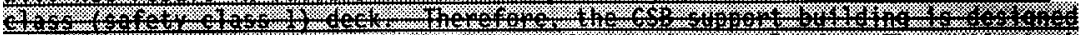

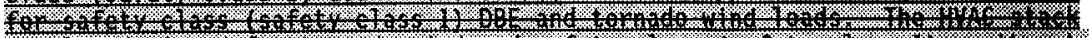

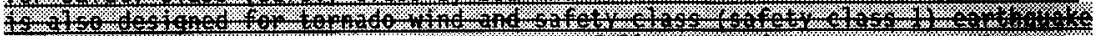

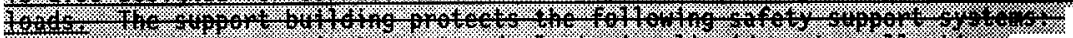

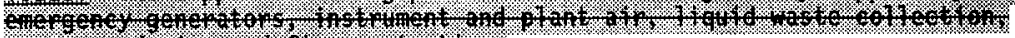

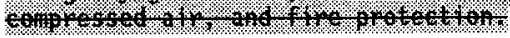

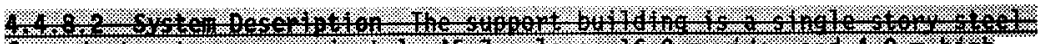
W.

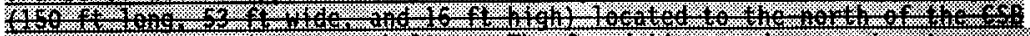
3.7.

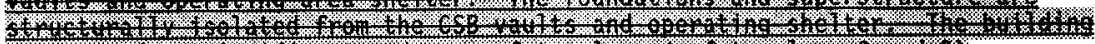

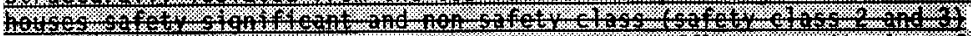

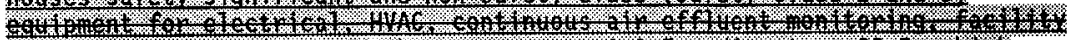

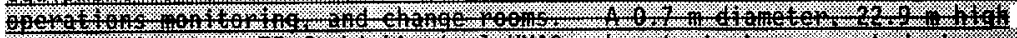
128.

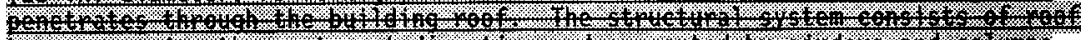

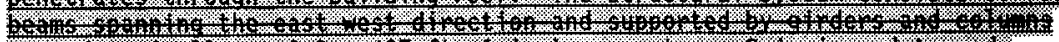

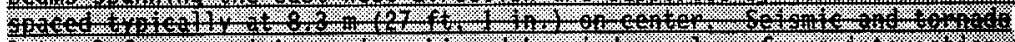

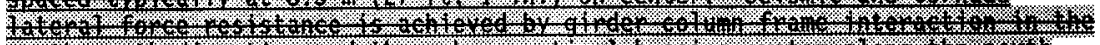

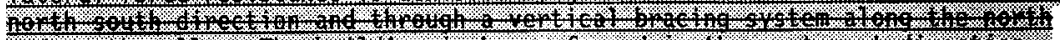

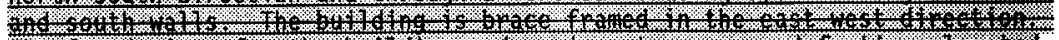

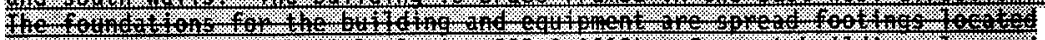

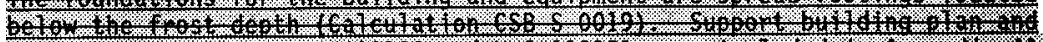

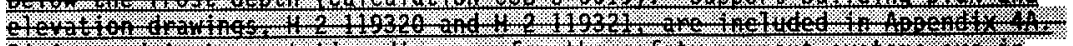

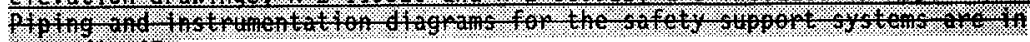
Hentw.

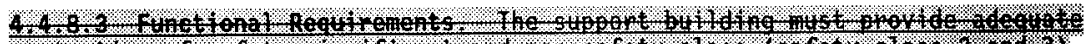

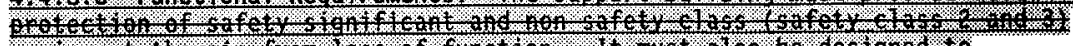

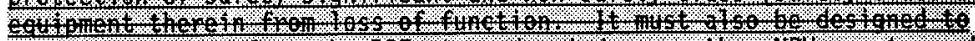

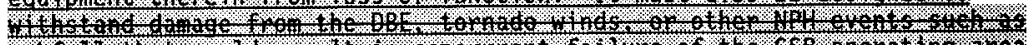
Q7f(f)

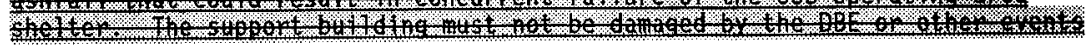




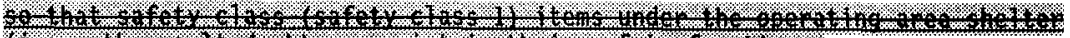

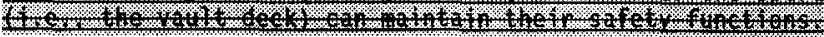

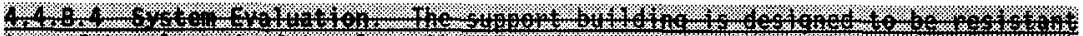

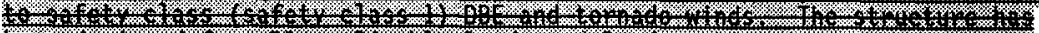

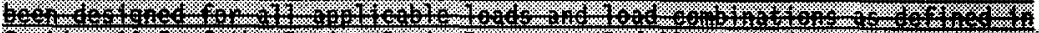

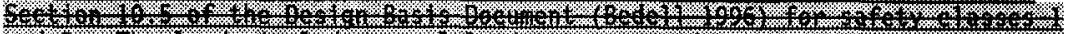

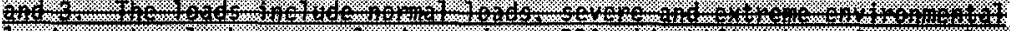

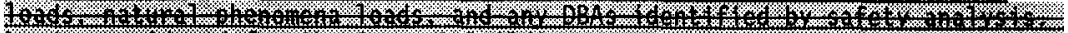

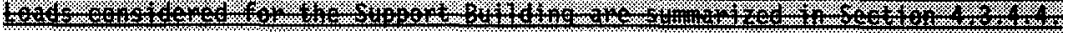

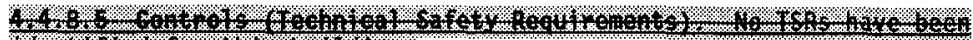

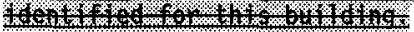

\subsection{REFERENCES}

10 CFR 72, "Licensing Requirements for the Independent Storage of Spent Nuclear Fuel and High-Level Radioactive Waste," Code of Federal Regulations, as amended.

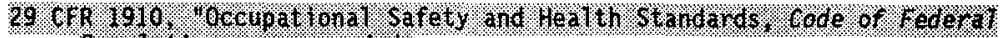

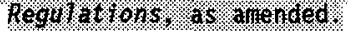

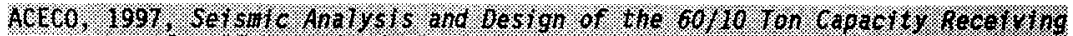

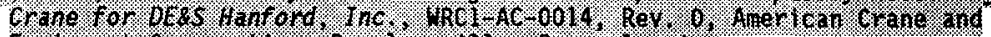

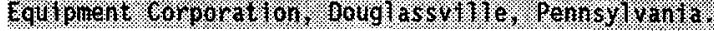

ACI, 1995. Building Code Requirements for Structural Concrete (ACE 318 95) and comentary (ACE 318 Q 25), ACI 318/318R. Amemican Concrete Inst itute. Detroit. Michigan.

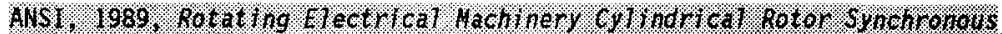

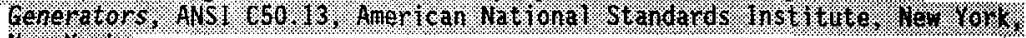
Ne. Wort.

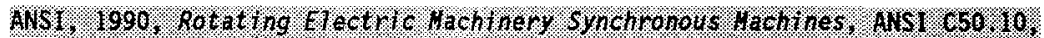

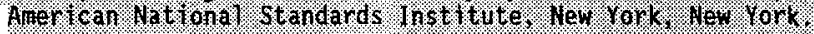

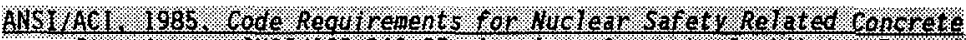

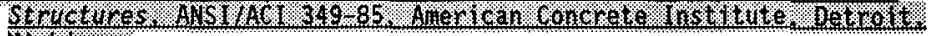

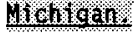

ANSI/AISC, 1994, Specification for the Design, Fabrication, and Erection of Steel Safety-Related Structures for Nuclear Facilities, ANSI/AISC N690-94, American Institute of Steel Construction, Chicago, Illinois.

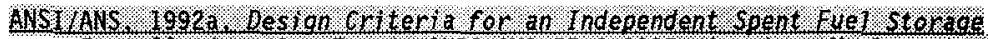

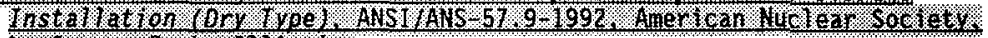

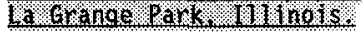




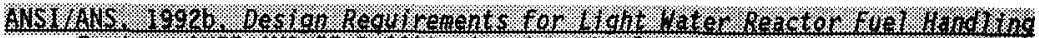

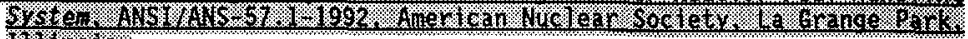

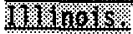

ANSI/ASME, 1989a, Nuclear Power Plant Air Cleaning Units and Components New Construction and Modification Only, ANSI/ASME N509-1989, American Society of Mechanical Engineers, New York, New York.

ANSI/ASME, 1989b, Testing of Nuclear Air-Cleaning Systems, ANSI/ASME N510-1989, American Society of Mechanical Engineers, New York, New York.

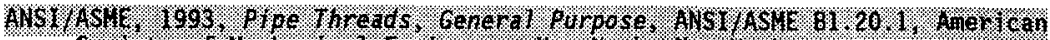

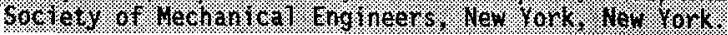

ASCE, 1986, Seismic Analysis of Safety-Related Nuclear Structures and Commentary on Standard for Seismic Analysis of Safety-Related Nuclear Structures, ASCE-4-86, American Society of Civil Engineers, New York, New York.

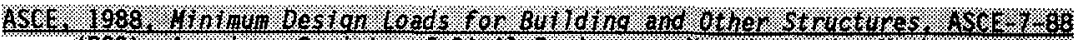

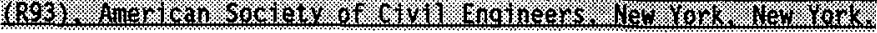

ASCE, 1995, Minimum Design Loads for Building and Other Structures, ASCE-7-95, American Society of Civil Engineers, New York, New York.

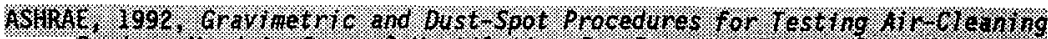

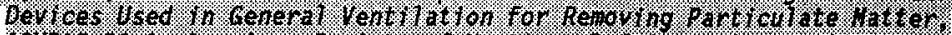

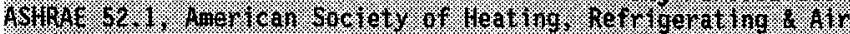

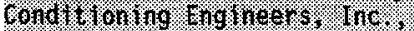

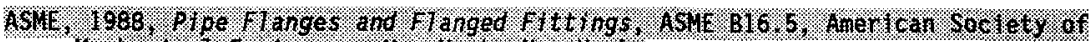

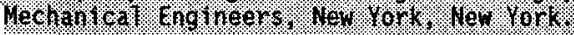

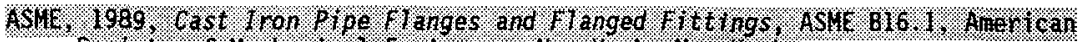

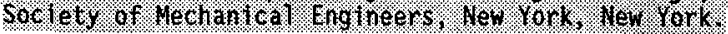

ASME, 1993a, Below-the-Hook Lifting Devices, ASME B30.20-1993, American Society of Mechanical Engineers, New York, New York.

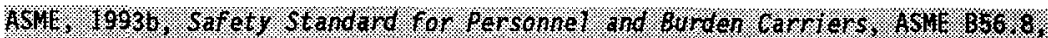

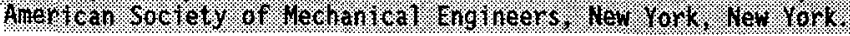

ASME, 1995\%, Boiler and Pressure Vessel Code, American Society of Mechanical Engineers, New York, New York.

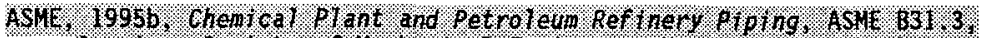

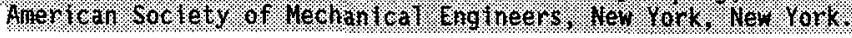

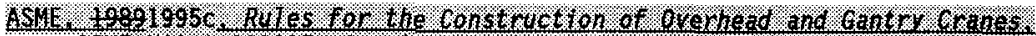

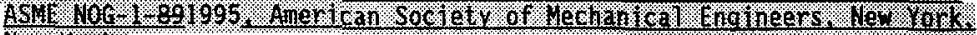
Ney Wir.: 


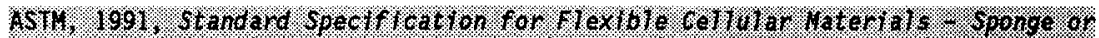

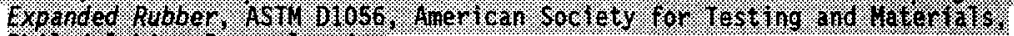

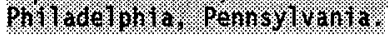

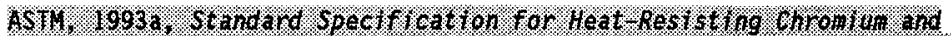

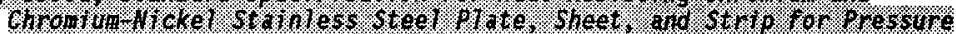

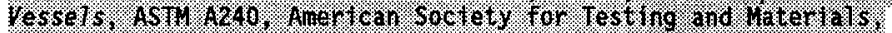

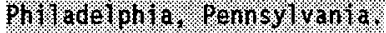

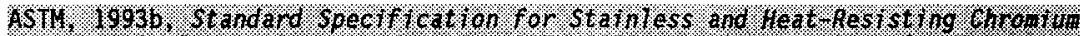

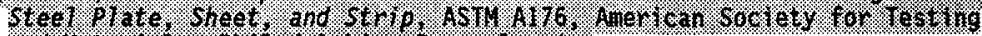

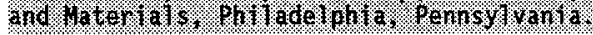

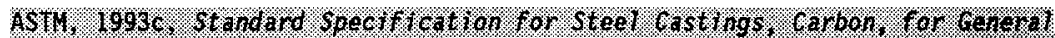

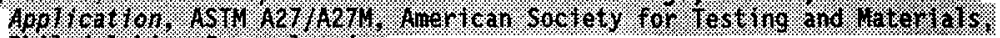

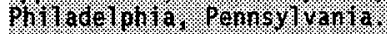

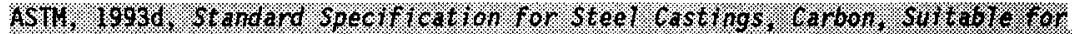

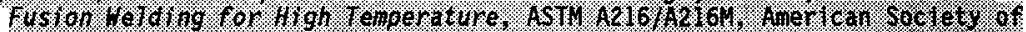

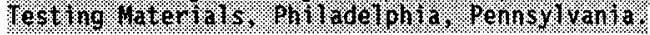

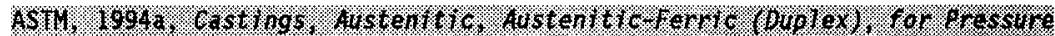

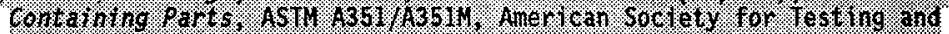

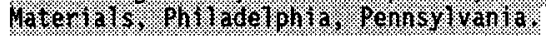

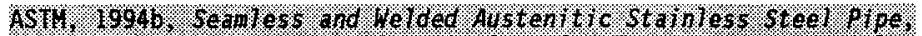

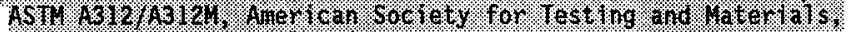

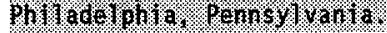

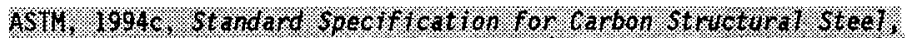

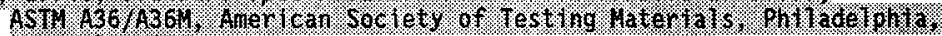

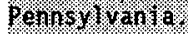

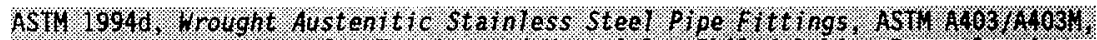

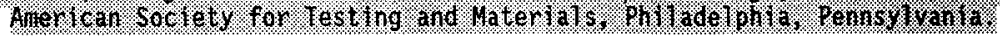

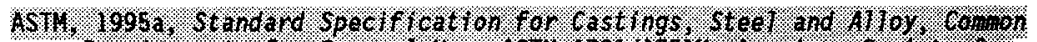

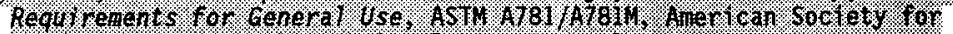

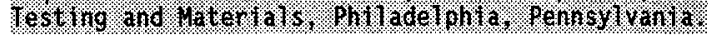

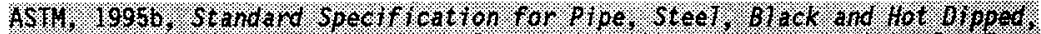

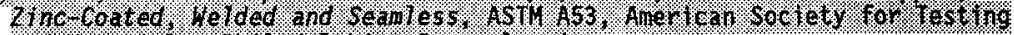

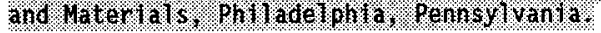

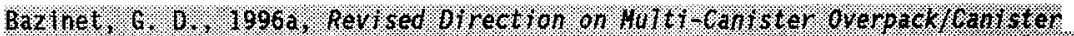

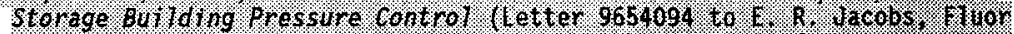

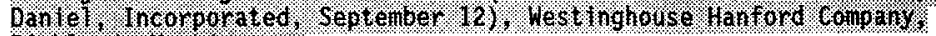
Futrond. vasnington.

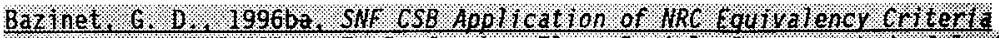

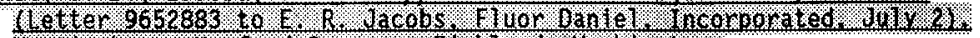

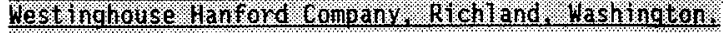


Bazinet, G. D., 199606, Spent Nuclear Fuel/Canister Storage Building-Tornado Strategy Implementation Plan (Letter 9652531 to E. R. Jacobs, Fluor Daniel, Incorporated, June 5), Westinghouse Hanford Company, Richland, Washington.

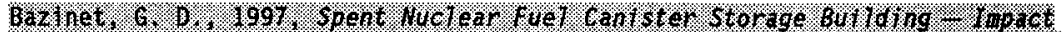

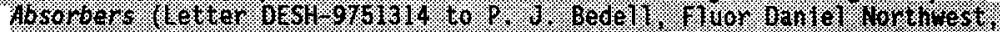

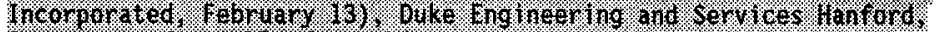

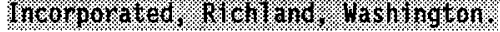

Beary, M. M., 1996b, Task Order 07, WHC Contract No. MRV-SBW-482901. Ana7ysis of Tornado/Tornado Missile Risk to New SNFP Facility; Initial Report (Letter 96-0133.MMB to R. Bradshaw, Westinghouse Hanford Company, July 8), Science Applications International Corporation.

Beary, M. M., 1996a, Errata: Tab7e 4. Analysis of Tornado/Tornado Missile Risk to New SNFP Facility (Letter 075MMB.96 to R. Bradshaw, Westinghouse Hanford Company, September 17), Science Applications International Corporation.

Bedel1, P. J., 1996r, SNF Canister Storage Building (Letter FRP-112 to M. K. Mahaffey, Westinghouse Hanford Company, October 25), Fluor Danie1, Incorporated, Richl and, Washington.

Bedel1. P. J.. 1996b. SAF CSB NAC Equivalency Evaluation (tetter FOF 012 to 4. K. Mahaffey, Quke Engineering and Services Hanford. Incorouta Hovember 21). Fluor Daniel. Incorporated, Richland, Washington.

CSI, 1995, SAP90, A Series of Computer Programs for Finite Element Analysis of Structures, Version 5.5, Computers and Structures, Incorporated, Berkeley, California.

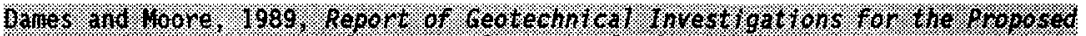

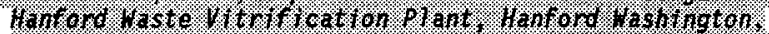

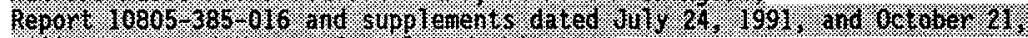

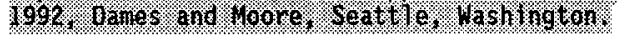

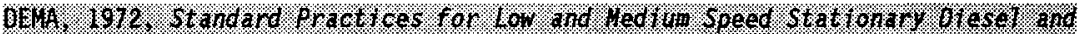

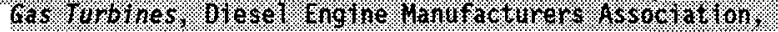

DOE Order 5480.28, 1993, Natural Phenomena Hazards Mitigation, U.S. Department of Energy, Washington, D.C.

DOE Order 6430.1A, 1989, General Design Criteria, U.S. Department of Energy, Washington, D.C.

DOE-RL-HPS-SDC-4.1, 1993, Standard Architectural-Civil Design Criteria, Design Loads for Facilities, Revision 12, U.S. Department of Energy, Richland Operations Office, Richland, Washington.

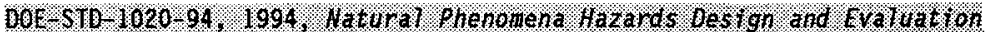

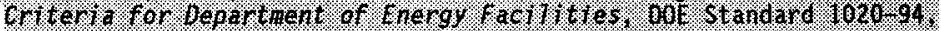

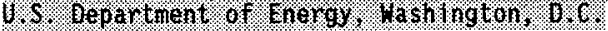




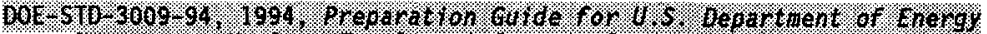

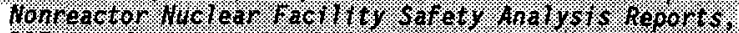

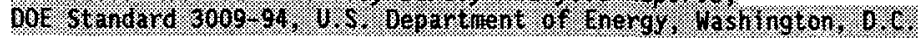

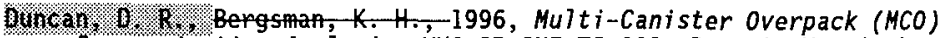
Pressurization Analysis, WHC-SD-SNF-TI-029, Rev. 0, Westinghouse Hanford Company, Richland, Washington.

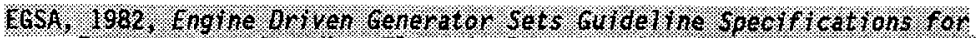

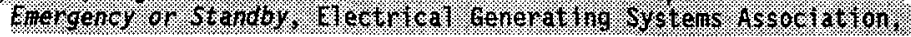

FDI, 1996a, A Canister Storage Building Vault Therma7 Analysis, CSB-HV-0001, Rev. 0, Fluor Daniel, Incorporated, Richland, Washington.

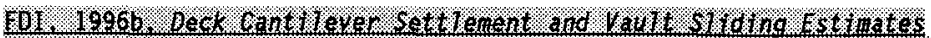

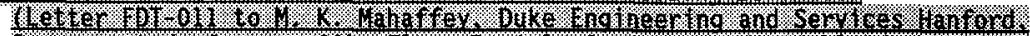

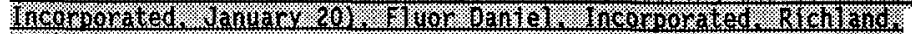
Wa Singuter.

FDI, 1996e日e, Design Calculations for the SNF Canister Storage Building Project, Fluor Daniel, Incorporated, Richland, Washington.

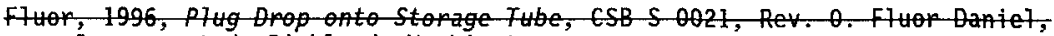
incorporated, Richland, Washington.

15. $198 \%$ \%

Garvin, L. J., 1996a, Spent Nuclear Fuel Project Path Forward, Additional NRC Requirements, WHC-SD-SNF-DB-003, Rev. 2, Westinghouse Hanford Company, Richland, Washington.

Garvin, L. J., 1996b, Spent Nuclear Fuel Project Seismic Design Criteria, NRC Equivalency Evaluation Report, WHC-SD-SNF-DB-004, Rev. 2, Westinghouse Hanford Company, Richland, Washington.

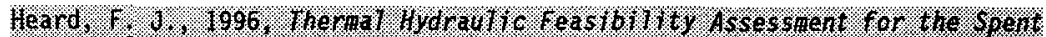

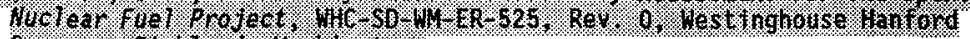

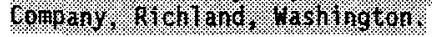

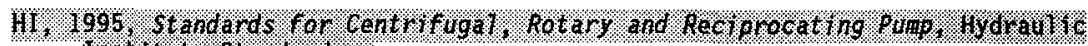
Hot torte 5 tandands.

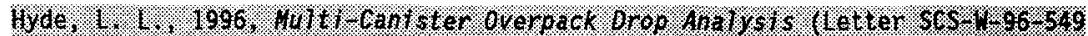

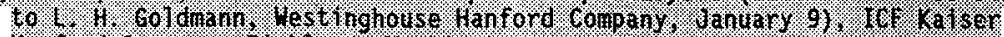

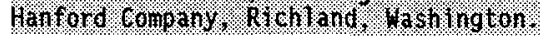

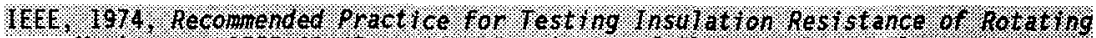

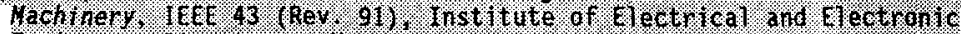

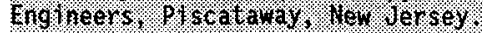

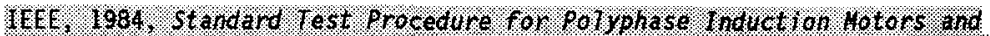

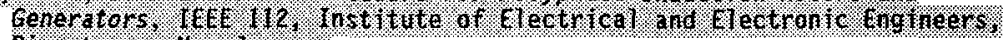

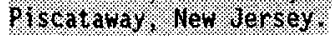




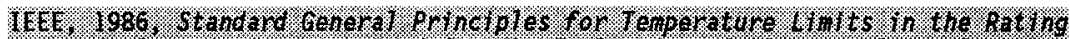

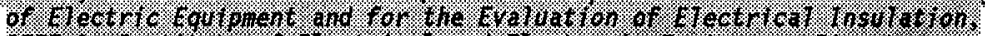

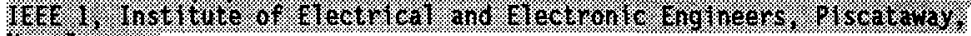
18.

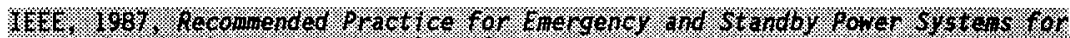

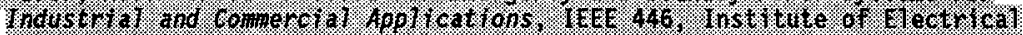

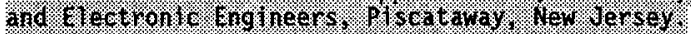

Jacobs, E. R., 1996a, ANSI 57.9 (Transmitta1 Letter FRF-2792 to M. K. Mahaffey, Westinghouse Hanford Company, May 15), Fluor Daniel, Incorporated, Richland, Washington.

Jacobs, E. R., 1996b, DOE SAR Team Review Request for Structural Analysis (Letter FRF-092 to M. K. Mahaffey, Westinghouse Hanford Company, October 2), Fluor Danie1, Incorporated, Richland, Washington.

Jacobs, E. R., 1996c, Response to Action Items on the MCO Drop Analysis from the VTC with DNFSB (Letter FRF-2876 to M. K. Mahaffey, Westinghouse Hanford Company, October 7), Fluor Danie1, Incorporated, Richland, Washington.

Jacobs, E. R., 1996d, SNF CSB Revised Tornado Strategy Implementation Plan and Probabilistic Risk Analysis (Letter FRF-2875 to M. K. Mahaffey, Westinghouse Hanford Company, September 25), Fluor Daniel, Incorporated, Richland, Washington.

Kidd, C. C., 1996, M60 Handling Machine/Pontable Shield Gate, Caleutation ESB SH 1004, Fluor Baniel, Ineorporated, Richland, Washington.

Kummerer, M., 1995, Hazard Category Analysis for the Canister Storage Building, WHC-SD-SNF-HC-007 Rev. 0, Westinghouse Hanford Company, Richland, Washington.

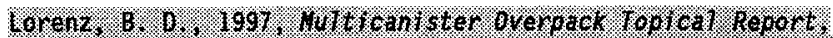

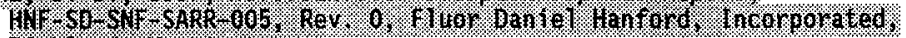

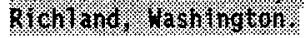

Lysmer, J., T. Udaka, C. Tsai, and H. B. Seed, 1975, FLUSH: A Computer Program for Approximate 3-D Analysis of Soil-Structure Interaction Problems, EERC 75-30, University of California, Berkeley, California.

Mahaffey, M. K.. 1996, Ganister Storage-Building-Fube Material Eva7uation. WHC SQ SNF TA 014, ReV. O. Draft, Westinghouse Hanford Company, Richland, Washington.

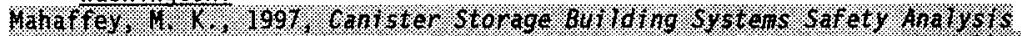

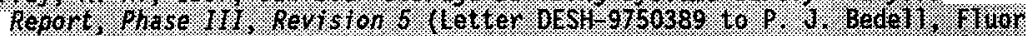

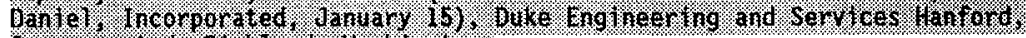

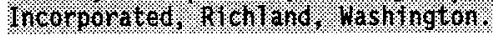

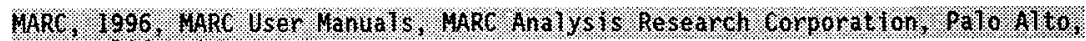

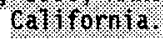




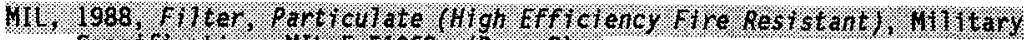

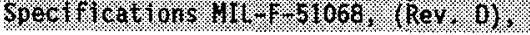

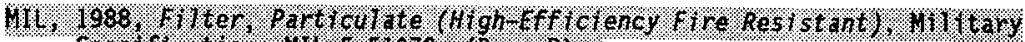

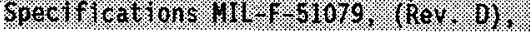

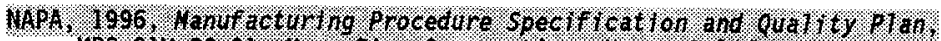

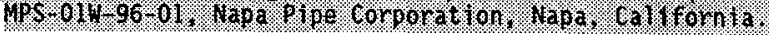

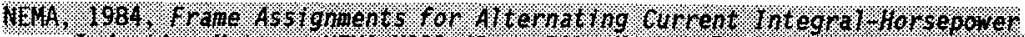

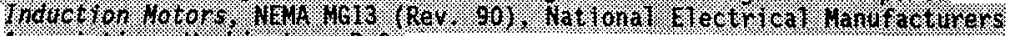

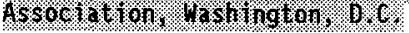

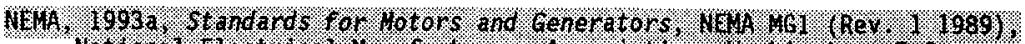

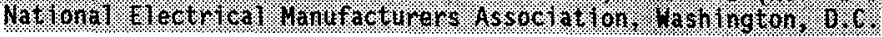

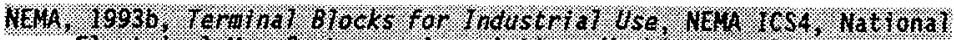

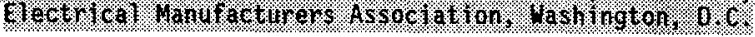

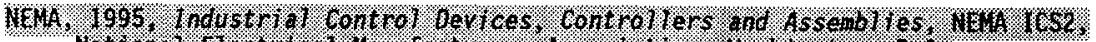

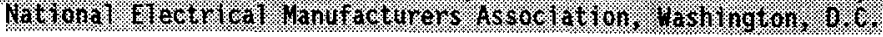

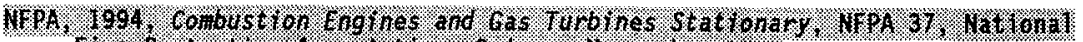

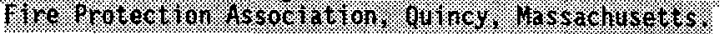

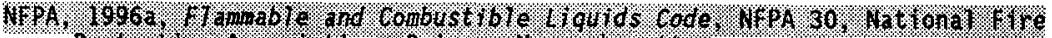

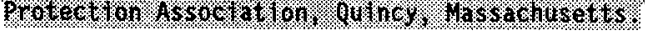

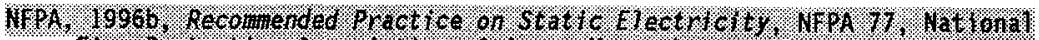

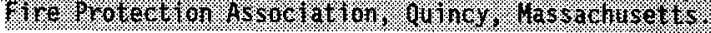

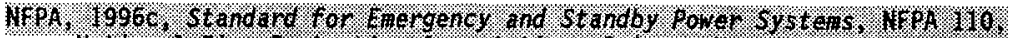

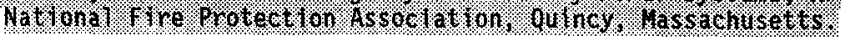

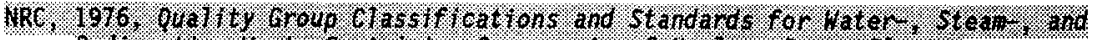

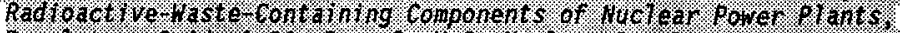

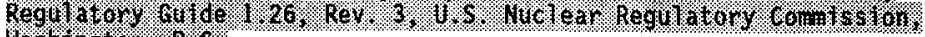

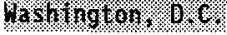

NRC, 1987, Standard Review Plan for the Review of Safety Analysis Reports for Nuclear Power Plants, NUREG-0800, U.S. Nuclear Regulatory Commission, Washington, D.C.

Ordin, P. M., 1970, Hydrogen Safety Handbook, National Aeronautics and Space Administration, Washington, D.C.

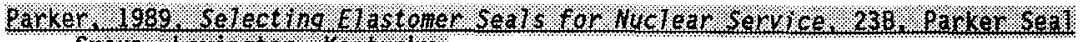
Group. Lexinclon, Kentucky.

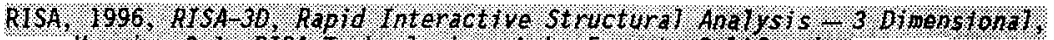

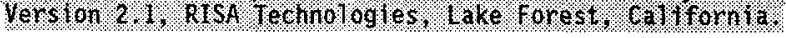




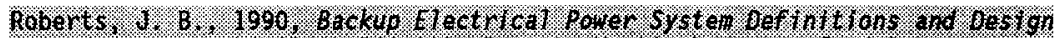

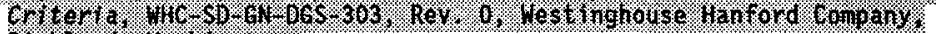

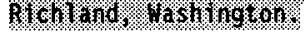

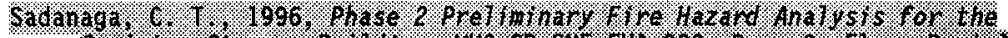

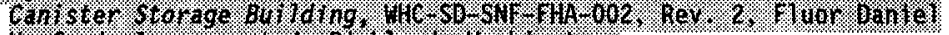

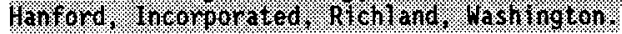

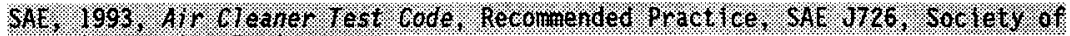

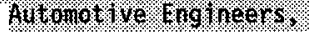

Salmon, M. W., S. A. Short, S. Lu, and R. P. Kennedy, 1990, Seismic Acceleration Time Histories in Support of Fluor Daniel, Inc. Project HWVP-845734, ABB-IMPELL6510-001-1359, Rev. 1, ABB-Impe 11 Corporation, Mission Viejo, California.

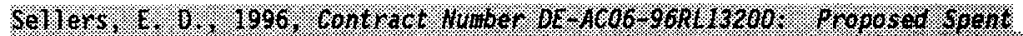

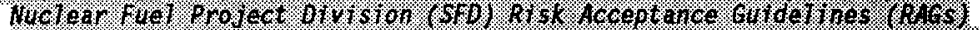

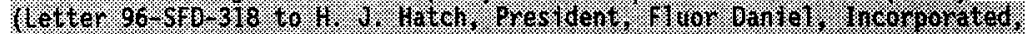

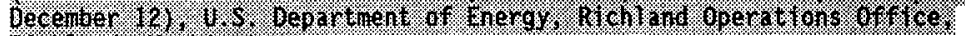

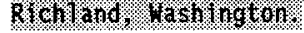

Stone, W. A., J. M. Thorp, O. P. Gifford, and D. J. Hoitink, 1983, Climatological Summary for the Hanford Site, PNL-4266, Pacific Northwest Laboratory, Richland, Washington.

Swenson, C. E., 1996, Performance Specification for the Spent Nuclear Fuel Canister Storage Building, WHC-S-0425, Rev. 2, Westinghouse Hanford Company, Richland, Washington.

Tallman, A. M., 1996, Canister Storage Building Natural Phenomena Hazards, WHC-SD-SNF-DB-009, Rev. 4, West inghouse Hanford Company, Richland, Washington.

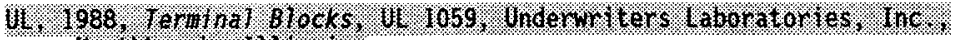

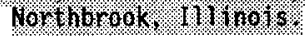

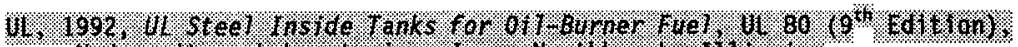

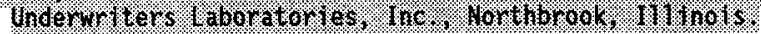

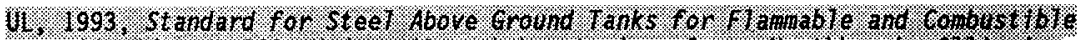

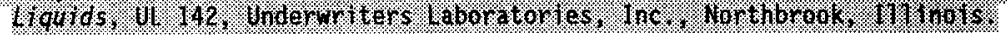

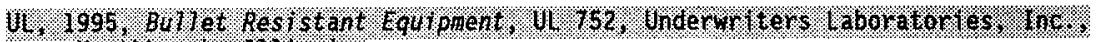

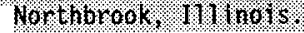

WHC-CM-4-46, 1995, Safety Ana7ys is Manua7, Rev. 1, Westinghouse Hanford Company, Richland, Washington.

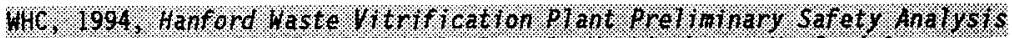

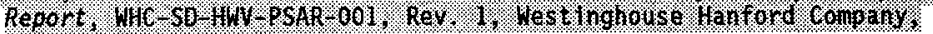

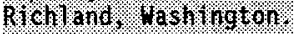




\section{HNF-SD-SNF-RPT-004 REV 6}

WHC, 1996, Specification for Hult; Canistep-Oreppack (H60) Handling Hachine, WHC S 0468, Rev, 2 , Westinghtuse-Hanford Company, Richtand, Washington.

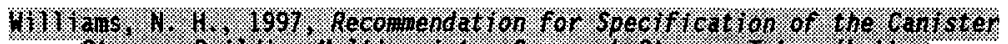

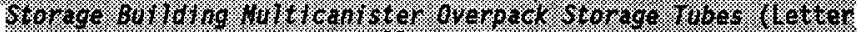

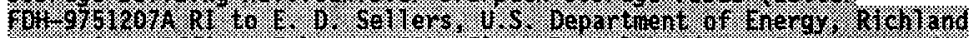

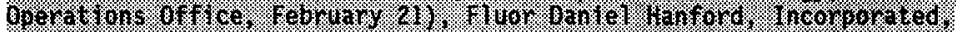

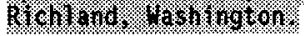

Zimmerman, R. D., 1996, Failure Modes and Effects Analysis: Emergency Power System, File 106.151, Fluor Danie1, Incorporated, Richland, Washington. 
HNF-SD-SNF-RPT-004 REV 6

This page intentionally left blank. 
HNF-SD-SNF-RPT-004 REV 6

Figure 4-1. Air Temperature Profile.

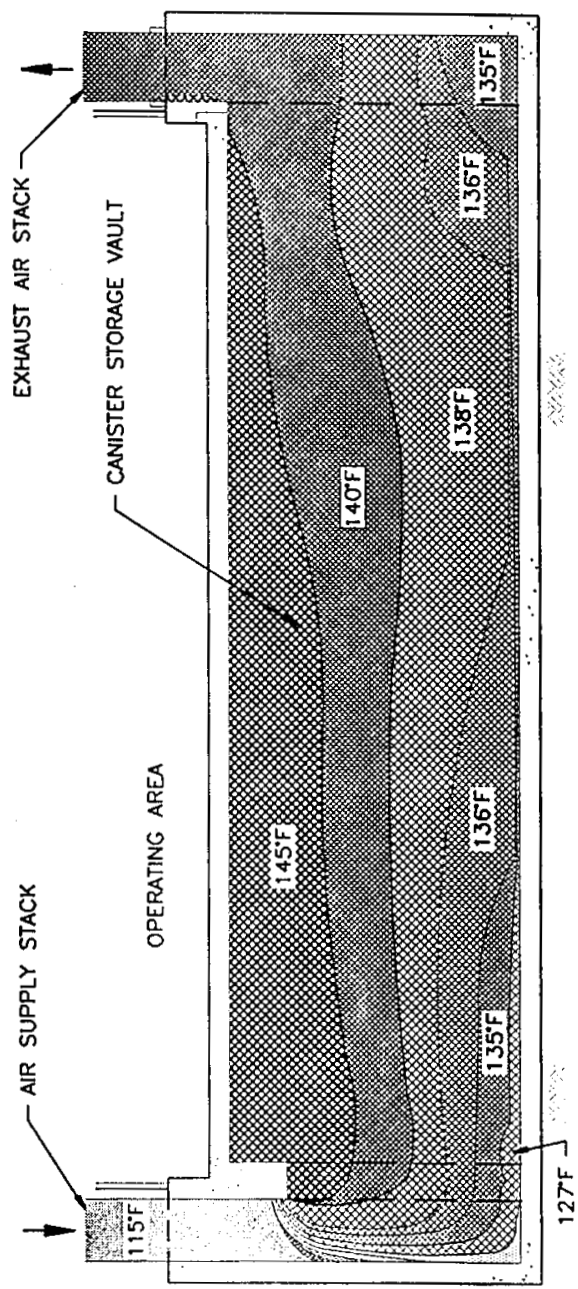


HNF-SD-SNF-RPT-004 REV 6

This page intentionally left blank. 
HNF-SD-SNF-RPT-004 REV 6

APPENDIX IA

STRUCTURAL FEATURES OF THE COLUMBIA BASIN 